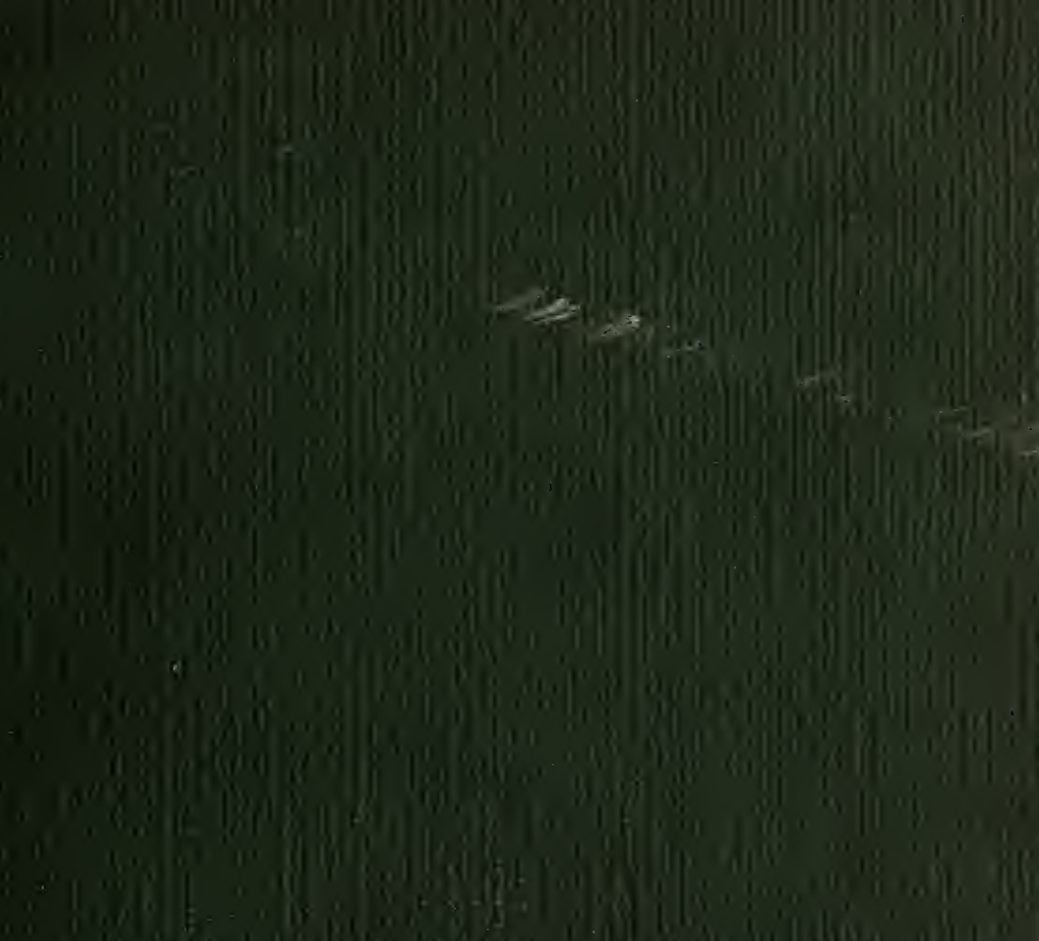
[10

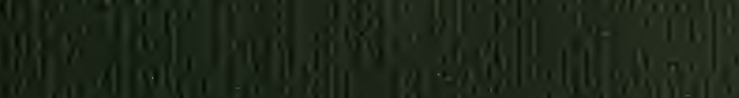
6. lo In| 


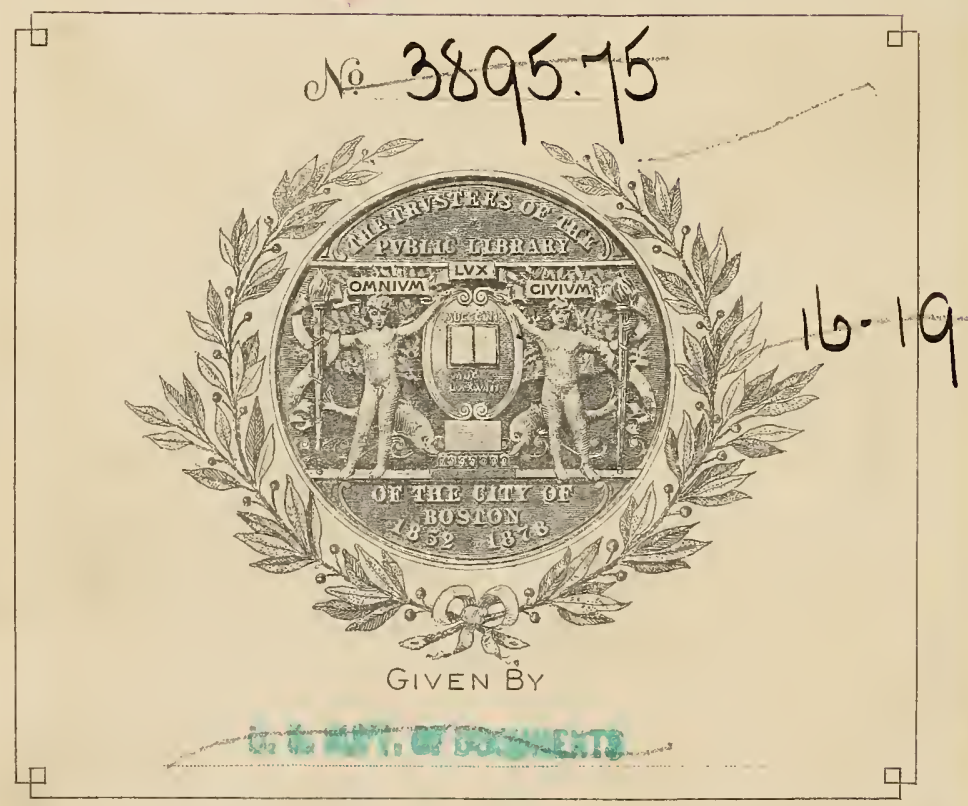

$$
\begin{aligned}
& 3 \\
& i)
\end{aligned}
$$


etanjecto

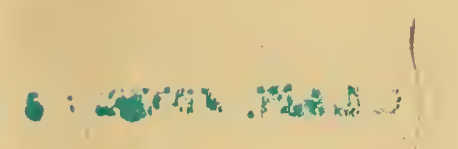



Technical Series, No. 16, Part I.

U. S. DEPARTMENT OF AGRICULTURE, BUREAU OF ENTOMOLOGX.

L. O. HOWARD, Entomologist and Chief of Bureau.

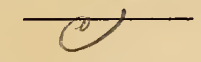

PAPERS ON COCCIDE OR SCALE INSECTS.

\section{THE NATIONAL \\ COLLECTION OF COCCIDÆ.

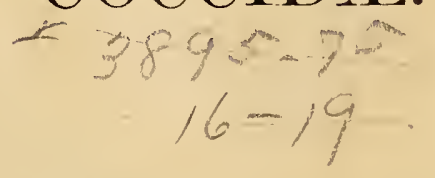

By C. L. MARLATT, M. S.,

Entomologist and Assistant Chief of Bureau.

Issued April 23, 1908.

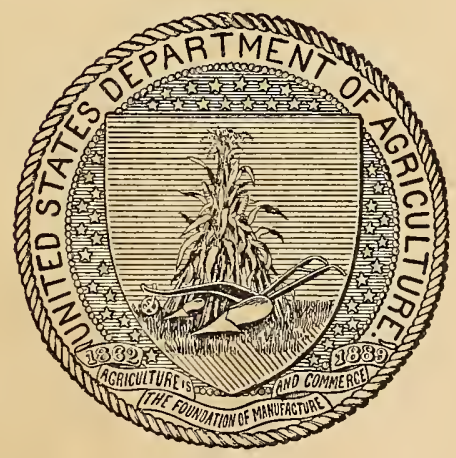

WASHINGTON:

GOVERNMENT PRINTING OFFICE。

1908. 


$$
\frac{409=}{3}
$$

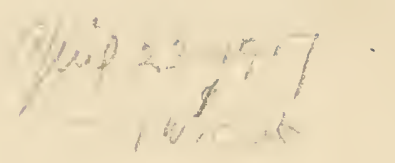

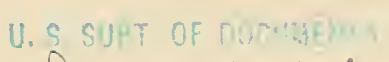
guare 23,100 


\section{CONTENTS.}

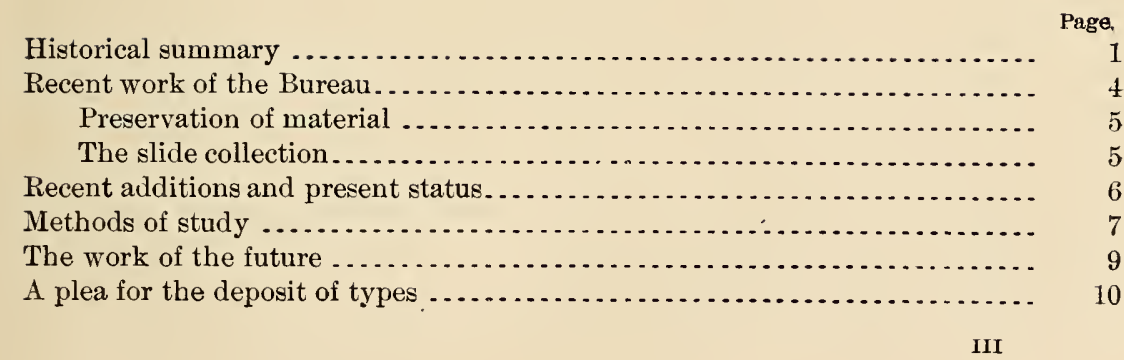


Digitized by the Internet Archive in 2010 with funding from Boston Public Library 


\title{
PAPERS ON COCCIDE OR SCALE INSECTS.
}

\section{THE NATIONAL COLLECTION OF COCCIDÆ.}

\author{
By C. L. Marlatt, M. S., \\ Entomologist and Assistant Chief of Bureau.
}

The collection of scale insects or Coccidæ, accumulated chiefly through the agency of the Bureau of Entomology of the U. S. Department of Agriculture and forming a part of the national collection of insects, is undoubtedly the most valuable and complete in existence. This has come from the early interest of the Bureau in the subject through the work of Prof. J. H. Comstock, and as a result of the generosity of many of the describers of new species of later years in depositing types or cotypes in the National Collection. It may not be out of place, therefore, to give a brief historical summary of the National Collection of Coccidæ, together with a description of its present condition, an account of the methods of installation and preservation of material, and a numerical statement of species and types represented.

\section{HISTORICAL SUIMIMARY.}

The knowledge in America of this important group of insects was very scant prior to 1880 . During that year Prof. J. Henry Comstock, then Entomologist of the Department of Agriculture, in the course of an investigation of the insects injurious to orange trees, begun the previous year, noted that the greater part of the insect injury to citrus fruits was due to scale insects. This led him to make, during 1880, a particular study of the family Coccidæ, broadening the inquiry to include the study of all scale insects affecting cultivated plants in the United States. Professor Comstock personally collected many southern species in a trip through Florida in January and February, 1880, and during the following summer spent three months in the fruitgrowing sections of California and Utah investigating the subject and 
collecting scale insects. He was assisted also by several of his colleagues in the office, notably Dr. L. O. Howard and Mr. Theo. Pergande. The results of this work appeared as Part II of his Annual Report for 1880 , in a paper on scale insects, which included descriptions of most of the Coccidre then in the collection of the U.S. Department of Agriculture, lack of space preventing the description of all the species which had been collected up to that time. Some 45 species are listed and described in this report, more than half of which were new to science. Previous to this only about 30 species had been described by American writers, the majority of which are to be credited to Dr. Asa Fitch. Most of the species referred to in Comstock's report were figured, and these figures mark the beginning of really careful scientific drawings of Coccidre, and have since been standard illustrations of the species concerned.

Doctor Howard, while assisting Professor Comstock in the study of Coccida, took up particularly the subject of the chalcidid parasites of these insects, and presented as Part III of Professor Comstock's report a paper entitled "Report on the Parasites of the Coccidr in the Collection of this Department." This was the beginning of Doctor Howard's work on chalcidid parasites and led to his becoming the world's authority on the subject. How little was known of these parasites previous to the publication of this paper is shown by the fact that, with four or fire exceptions, the species described and figured were new to science.

Professor Comstock retired from the position of Entomologist in 1881, but published in Professor Riley's Report for that year a short illustrated article on Lac Insects, describing three new species. He also gave a brief article on methods of controlling scale insects. A much more important article on remedies for scale insects of the orange, by Mr. H. G. Hubbard, is published in the same report. In this paper some very good work is recorded and some of the more important modern methods of control are given first exploitation.

Professor Comstock's report on Coccidæ in the Department Report of 1880, as already indicated, was incomplete and did not include all of the species collected. His final paper occupied the principal portion of the Second Report of the Department of Entomology of the Cornell University Experiment Station, published in 1883. This paper is a brief monograph of the subfamily Diaspinæ as represented in the fauna of North America, together with notes on species not at that time observed in the United States. Several new species are described in this report, and the latter concludes with a list of the American nondiaspine scale insects.

This practically concluded Professor Comstock's work on Coc. cidæ, and for a long period thereafter the systematic study of this important group of insects practically ceased in this country. The 
Department Collection contained types or cotypes representing practically all of Comstock's work, and examples of the known species collected by him, and Mr. Theo. Pergande undertook, during the years following 1880 , to identify the material which was sent to the Department by comparison with named material in the collection. Mr. Pergande's work during this period was of great value to the Bureau and to the entomologists in this country, but necessarily much that came in could not be identified, and there was a large accumulation of unnamed material representing in part old species and in part species new to science.

Mr. H. G. Hubbard, who has already been referred to as having published an important paper on remedies for Coccidæ in the Annual Report of the Department for 1881, continued his investigation of orange insects and the means of controlling them, at Crescent City, Fla., as an agent of the Department of Agriculture, and published in 1885 his excellent report entitled "Insects Affecting the Orange." 'This represented nearly four years' study and experiment, and dealt very largely with the common scale enemies of the orange. Mr. Hubbard's interest in scale insects, aroused in this study, continued, although he published nothing noteworthy afterwards on the subject. It was, however, his intention to bring out a new and thoroughly revised edition of his Orange Insects, and to take up in connection with it a study of the classification of Coccidx; but his untimely death prevented the accomplishment of this task.

About 1891 Prof. T. D. A. Cockerell began to collect and study the Coccidx of Jamaica, where he was then stationed. For some years much of his material came to this office for determination, but in a short time he became familiar with the subject, and ultimately the world's best authority in the group, and for a period of several years much of the new material coming to the Department was sent to him for determination and description. Professor Cockerell had in the meantime accepted a position in the New Mexico Agricultural College, and his collections and descriptions of Coccidæ were enriched by the inclusion of many new southwestern species as well as by material which came to him from all quarters of the world. Very fortunately his close cooperation and sympathy with the Burean of Entomology and interest in the National Collection led him to deposit his types in Washington, thus very greatly enriching the local collection. Professor Cockerell, while diminishing very much his activity in this group in later years, has retained his interest. During his most active decade his publications on Coccida were voluminous, much exceeding the work of any other investigators in this field with the possible exception of Signoret and Maskell. In connection with this Bureau he published several papers, notably his bulletin on the 
San Jose scale and its nearest allies, ${ }^{a}$ and, through the Smithsonian Institution, papers on the food plants of scale insects, ${ }^{b}$ directions for collecting and preserving scale insects, ${ }^{c}$ and geographical distribution of scale insects. ${ }^{d}$

\section{RECENT WORK OF THE BUREAU.}

The resumption of active study of Coccida in connection with the Department of Agriculture began in the early nineties, partly as a result of the interest aroused by the San Jose scale and the necessity of being able to determine at once and authoritatively all material which was coming in supposedly representing this new and dangerous species. It proved, in other words, impracticable to be dependent for such determinations on specialists at a distance. Mr. Pergande, who had had charge of the coccid collections, had his time so fully taken up with other lines of investigation, notably the subjects of A phididæ and Formicidæ, that he could not keep up with the rapidly increasing collection and literature in Coccidæ. To meet the need and following the incentive of an old interest the writer therefore took as his special field in systematic entomology the subject of Coccidæ. A season spent in studying orange insects in southern California accentuated his interest in the subject, and general charge of the Department collections in this family was assumed by him in 1900 , and a thorough reorganization of the collection and notes was then begun. Before this work had progressed very far it was interrupted for more than a year by a trip to the Orient, in which, however, the scale insects were the special object of study and collection.

During the twenty years which had elapsed since the work of Comstock, a great mass of material had accumulated, most of it preserved under very bad conditions, and more than half of it unidentified. It was no small undertaking to bring all this mass into order, and in this work the writer was assisted during a number of years by Messrs. J. Kotinsky and E. R. Sasscer.

The enormous increase in the number of scale insects, and the amount of technical work necessary to determine the validity of species and to identify new material, made it early evident that it would be impossible for the writer to keep the whole subject as his own. field, and in January, 1905, Mr. J. G. Sanders was appointed an assistant in the Bureau and became the writer's colleague in the study of Coccidx, the important field of the nondiaspine scale insects, together with the collections and notes, being turned over to him unreservedly. Mr. Sanders is also charged with the very important

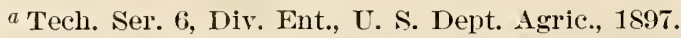

${ }^{b}$ Proc. U. S. Nat. Ius., XIX, No 1122, pp. 725-785, 1897.

${ }^{e}$ Bul. 39, Part L, U. S. Nat. Mus., 1897.

${ }^{a}$ Proc. U. S. Nat. Mus., XVII, No. 1026, pp. 615-625, 1895. 
inspection and quarantine work of the new importations made by the Department, and in this field has detected and prevented the introduction of a number of new scale insects which probably would have made very destructive records if established in this country.

PRESERVATION OF MATERIAL.

The first effort was to arrange for the proper preservation of the type and other material, and a modification of the system followed by Green was adopted-namely, the inclosing of material in strongly made pasteboard boxes, following a definite unit of length and breadth, 3 by 2 inches, so that they can be arranged in five columns in the standard insect drawer which has been in use in the U. S. National Museum ; ${ }^{a}$ these boxes vary in depth, however, to accomodate different quantities of material. All type and valuable material, in fact all material not in large quantity, is further protected by being first folded in squares of lens paper to retain any loose scales or insects. By this system the bulk of the collection was enormously reduced and loss of valuable specimens obviated. This system presents also the great convenience that additions may be made with the same facility as in a card catalogue.

Special card labels suitable to the nature of the collection were secured from the Library Bureau. These are of different colors to indicate respectively the genus, the valid species and varieties, and the typical material of the species reduced to synonymy.

THE SLIDE COLLECTION.

The slide preparations of the different species had become very extensive, and now comprise fully 10,000 slides, relating to more than a thousand species. A new system of storage for slide material was devised, following the plan of the ordinary card catalogue cabinet. $^{b}$ The older systems of slide storage had proved to be very unsatisfactory for so large a collection representing so many different species. None of the older systems was sufficiently elastic or allowed easy systematic classification, but required card indexes and the consultation of many different slide boxes to get together material representing a single subject. This led the writer to devise a cabinet in which the slides could be filed on the card index plan. To enable a slide to be thus stored a special envelope or jacket is provided for each slide. This jacket is made of strong manila paper and but little larger than the standard slide size (slide 1 by 3 inches, jacket $1 \frac{1}{4}$ by $3 \frac{1}{4}$ inches), affords an opportunity for sufficient labeling, and

$a$ The insect drawers since then adopted by the National Museum, and intended for pinned insects, are somewhat shallower than those first used.

${ }^{b}$ See Science, Dec. 30, 1904, p. 925. 
can be filed exactly as an index card. The cabinet follows the general plan of a library card index, is of five drawers of three partitions each, and holds upward of 2,000 slides. Guide cards were devised to correspond with the slide envelope, and have on their lower edge an extended lip perforated for the countersunk retaining rod which runs just below the level of the slides. This rod holds the guide cards and gives additional security to the slides, which remain steadily in place by their own weight. Each cabinet is arranged with a lock which fastens all five drawers. The latter have the retaining device so that there is no danger of pulling them entirely out and spilling their contents. The envelopes, however, give such protection to the slides that the latter will not break even from falling some distance, and, furthermore, they protect the slides entirely from dust. The slide cabinets, envelopes, and guide cards are all made by the Library Bureau at very reasonable cost. The slide jackets cost about $\$ 2$ a thousand, and the cabinets are but little more expensive than the ordinary index case.

This system of storing slides allows for additions indefinitely in exact classification, with as minnte and accurate subdivisions as may be necessary. It has now been in use some five years and has given complete satisfaction. The work of consulting the slides and handling the material is reduced at least two-thirds, and consultation is so easy that it increases the usefulness of the slide collection many times.

The cabinet described here in some detail is suitable for dry balsam mounts, and in the preparation of slides of Coccidæ the mount, as soon as prepared, is dried over an alcohol flame for a few seconds, when it can be put at once into the jacket. 'In any case where the slide can not be thus dried it must be laid in a horizontal position until the balsam has become thoroughly hardened. Once thoroughly dried, the intense heat of Washington summers does not result in any softening or attachment of the slide to the inclosing jacket.

A card catalogne has been made of all the material which has come to the Department, and the accumulated notes have been systematically arranged so that they are available for instant reference. This work has been done whenever time was available, and has often been interrupted for weeks or months together, but has now resulted in the collection, notes, and records being in exceptional order and in shape for study by the specialist with the greatest economy of time.

\section{RECENT ADDITIONS AND PRESENT STATUS.}

The deposit of the types of Professor Cockerell's new species represent the most important additions since Comstock's time. Following this commendable example, most of the other workers in this group 
in this country have given their types, or at least cotypes, to the National Collection. Among this material are the species described by Newell, King, Sanders, Tinsley, Johnson, Townsend, Cooley, Coleman, and Woglum. Cotypes of the greater number of Green's oriental species have also been most kindly presented by him to the National Collection, making a large and very valuable addition. Cotypical or authentic material representing many of the new species of other foreign workers in the family has been received in exchange or by gift, including a considerable percentage of Maskell's species and those of later students, notably Hempel.

The collection now includes, besides much unidentified material, representatives of 1,072 species of Coccidx, of which 816 are types or cotypes. Of these 366 belong to the subfamily Diaspinæ, with 293 types; and 706 to the non-diaspine scales, with 523 types. The described Coccidx of the world now reach a total of nearly 1,600 , but of these, from the critical studies which have been in progress now for sereral year's, it seems likely that at least one-third will fall as synonyms, leaving perhaps a thousand valid species. A corresponding proportion of the type and other material in the National Collection of Coccida will fall as synonyms. Nevertheless, the figures given indicate a collection of extraordinary richness and value in its accumulation of species and types. In working out synonymy the type specimens of the synonyms, together with the material referred to these synonyms by the describers or later workers of authority, are kept together, so that they can be easily referred to should any question arise as to their status.

\section{METHODS OF STUDY.}

A very large amount of laborious preliminary work has been done which makes no showing, but in the course of this work those who are actively conducting it have gained such a familiarity with the subject and so broad an acquaintance with the different genera that it should now be possible for them to monograph the material far more satisfactorily and accurately than ever before. The opportunity now had for comparison of types leads necessarily to the discovery of a large amount of synonymy, and the task of weighing and definitely ascertaining the status of older work is now in progress and represents the most difficult part of the undertaking, although a necessary preliminary to the description of new species and the monographing of genera.

In attempting to make determinations from published descriptions the inadequacy of the characterizations was at once felt, through no fault, however, of the early describers, who followed the customary methods of the time, just as the descriptions of this day may similarly 
prove to be inadequate fifty years from now. The principal difficulty, however, was that many structural features of the insect were not mentioned in the descriptions, and hence a systematic arrangement from descriptions was impossible, or, if attempted, very faulty. To give a standard for comparisons of descriptions, the writer has drawn up a scheme to be followed which has proved to be a great convenience. It at least insures that no important character is omitted, and the discussion of the different parts in regular order allows an easy comparison of the same characters for different species. Card blanks have been prepared, and following the printed indications the descriptions can be made very readily in abbreviated form and elaborated as fully as necessary for publication. These cards, being of the same size ( 5 by 8 inches) as the standard note card adopted by the Bureau, are filed as a permanent record. The card illustrated below is designed especially for the diaspine scale insects. Some modification of this card is necessary for the nondiaspine species, and Mr. Sanders has worked out such a modification, also illustrated. It is hoped that the describers of new species of scale insects will follow the order indicated on these cards, so that all future descriptions may be readily compared.

\section{Order folloned in describing Diaspine.}

Name :

Female scale: (Size, shape, density, convexity, color, pellicles, ventral scale, situation, etc.).

MaLe scale: (Do.) Male insect: (Unimportant).

Adult Female: (Shape, size, color, chitinization, anterior and marginal characters, stigmatic pores-if present, relationship).

Anal Plate: (Shape, size, color, chitinization, etc.).

Lobe: (No., size, shape, chitinization, position, etc.).

Lateral TEeTH: (Anterior to lobes and plates).

Incisions : (i. e., notches between lobes).

Paraphyses: (Chitinous thickenings at base of lobes and sometimes marginal beyond lobes).

Plates: (No., character, situation).

SPINEs: (Position same for all species, as a rule unimportant).

Anal opening: (Size, shape, position). Genttal opening: (Unimportant).

Paragenitals : (No., massed or scattering, etc.).

Dorsal PoRes: (No., size, distribution, etc.).

BASAL THICKEnings: (Transverse, broken, rod-like elevations near base of plate-dorsal).

Ventral THICKENINGS: (Broad areas of slight chitinization extending from tip and longitudinal ridges laterad of vaginal opening).

TrPe: (Dept. No., U. S. Nat. Mus. No., host, locality, coll., date).

NoTE: (Prominent distinguishing characters, relationships, etc.). 
Order followed in describing non-diaspine coccide.

Name:

MaLE: (Scale or puparium; adult, emergence).

Female: (Size, shape, color, markings, secretion, maturity, reproduction).

Derar (ClEARED) : (Character, size, outline, color, chitinization, pilosity, color in $\mathrm{KOH})$.

ANTENN.E: (Location, segments, measurements in $\mu$, formula, hairs).

LEgs : (Location, development, pilosity, coxa, trochanter, femur, tibia, tarsus, claw, digitules).

Spiracles: (Location, character, pores).

PoRes: (Character, simple or compound; arrangement, dorsal, ventral).

Spines-marginal: (Character, length, arrangement). Spiracular: (Character, length, arrangement).

HYPOPYGIAL : (Character, number, arrangement). SURFACE : (Character, length, arrangement).

ANal Plates: (Shape, size, character, location).

Seta-Fringe: (Number, location, length). Subapical: (Number, location, length).

APICAL: (Number, location, length).

Thickenings: (Character, location).

ANAL RING: (Shape, character, number of hairs).

TyPe: (Host, locality, date, collector).

Note: (Prominent distinguishing characters, peculiarities, relationships, etc.).

THE WORK OF THE FUTURE.

It is the intention of the writer and of his colleagues in the study of this family to work out the synonymy of described material which has accumulated, to prepare synoptic tables of the different genera, and describe the species which seem to be new to science. These papers will be issued from time to time as parts of the present bulletin and of later bulletins of the Technical Series of this Bureau.

The catalogue and bibliography of Coccidæ, started in such a comprehensive and thoroughgoing manner by Mrs. Fernald, will be continued in biennial supplements by Mr. J. G. Sanders, one such supplement having already been issued. ${ }^{a}$

One of the great difficulties in the study of Coccidæ has been the inaccessibility of the types of Maskell's many new species, especially as the descriptions and figures were in most cases inadequate. It is a pleasure, therefore, to be able to announce that, through the courtesy of Mr. T. IT. Kirk. the Department is to be allowed to make a critical examination and study of all of Maskell's types and other material, which are now making their long journey from IVellington, New Zealand, to Washington for this purpose.

The field of Coccidre is a very large one, and there is plenty of room in it for a consiclerable number of students, and the National Collec-

a Tech. Ser. No. 12, Part I, Bur. Ent., U. S. Dept. Agriculture. 1906. 
tion is open to anyone who wishes to study or consult it. A good deal of exchange material of value has been accumulated, and exchanges for species not represented in the Department Collection will be gladly made.

\section{A PLEA FOR THE DEPOSIT OF TYPES.}

- The Coccidæ present special difficulties in the way of determination on account of their small size and the necessity of making careful microscopic preparations. Furthermore, it is not very practicable to determine material from descriptions only, and it is necessary in most cases to hare type, or accurately identified material, for the purpose of comparison. With Coccidx, therefore, more than with other groups of insects, it seems necessary to hare some central depot for the deposit of types; where authoritative identifications may be made. It is hoped and urged, therefore, that all American describers of new species will adopt the course of placing type or cotype material in the National Collection. where it will be carefully preserved and be a railable for study at any time. 


Technical Series, No. 16, Part II.

U. S. DEPARTMENT OF AGRICULTURE, BUREAU OF HITOMOLOGY.

L. O. HOWARD, Entomologist and Chief of Bureau.

\title{
PAPERS ON COCCIDE OR SCALE INSECTS.
}

\section{NEW SPECIES OF}

\section{DIASPINE SCALE INSECTS.}

\author{
By C. L. MARLATT, M. S.,
}

Entomologist and Assistant Chief of Bureaz.

ISSUED AUGUST 5., 1908.

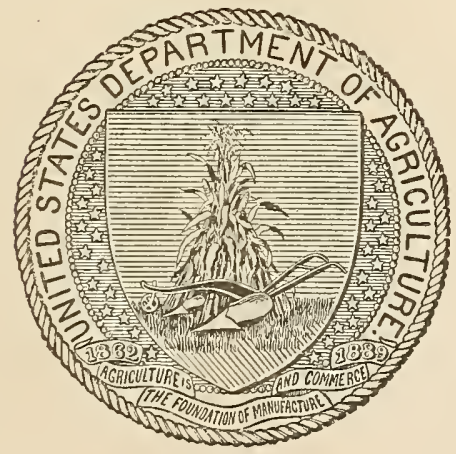

WASHINGTON:

GOVERNMENT PRINTING OFFICE. 
Introductory

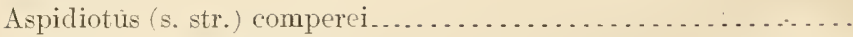

Aspidiotus (s. str.) meyeri

Aspicliotus (Aonidiella) cocotiphagus

Aspidiotus (Diaspidiotus) africanus.

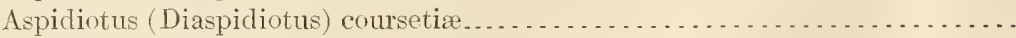

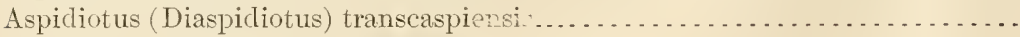

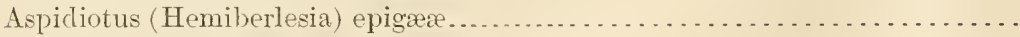

Aspidiotus (Hemiberlesia) mitchelli..............................

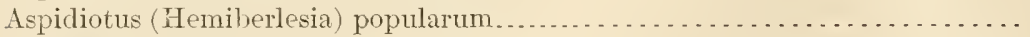

Aonidia juniperi . . . . . . . . . . . . . . . . . . . . . . . . . . . . .

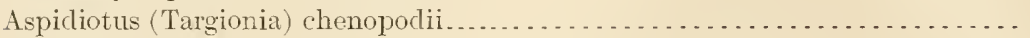

Chionaspis micropori . . . . . . . . . . . . . . . . . . . . . . . . . . . . .

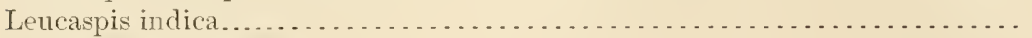

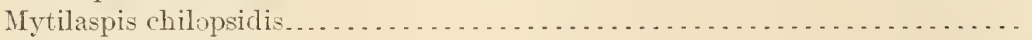

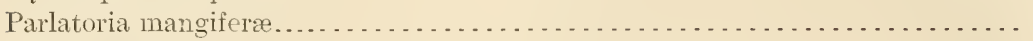

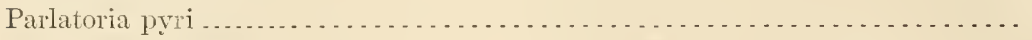

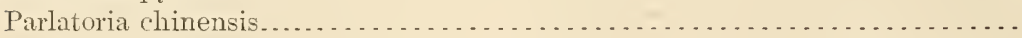

\section{ILLUSTRATIONS.}

Plate I. Fig. 1.-Aspidiotus (s. str.) comperci. Fig. 2.-Aspidiotus (s. str.)

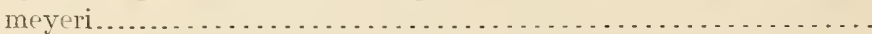

II. Fig. 1.-Aspidiotus (Aonidiella) cocotiphagus. Fig. 2.-Aspidiotus (Aonidiella) cocotiphagus............................

Page.

III. Fig. 1.-Aspidiotus (Diaspidiotus) africanus. Fig. 2.-Aspidiotus

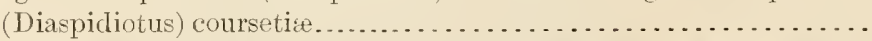

IV. Fig. 1.-Aspidiotus (Diaspidiotus) transcaspiensis. Fig. 2.-Aspidi-

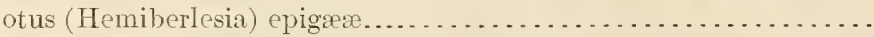

V. Fig. 1.-Aspidiotus (Hemiberlesia) mitchelli. Fig. 2.-Aspidiotus

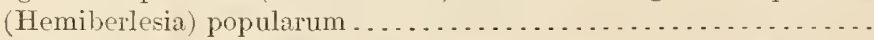

VI. Fig. 1.--Aonidia juniperi. Fig. 2.-Aspidiotus (Targionia) cheno-

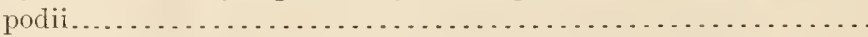

VII. Fig. 1.-Chionaspis micropori. Fig. 2.-Leucaspis indica.........

VIII. Fig. 1.-Mytilaspis chilopsidis. Fig. 2.-Parlatoria mangiferæ. . . . .

IX. Fig. 1.-Parlatoria pyri. Fig. 2.-Parlatoria chinensis ........... . 


\title{
PAPERS ON COCCLD E OR SCALE INSECTS.
}

\section{NEW SPECIES OF DIASPINE SCALE INSECTS.}

\author{
By C. L. Martatt, M. S., \\ Entomologist and Assistant Chief of Bureau.
}

\section{INTRODUCTORY.}

The species described below as new to science are mostly insects of potential economic importance, as indicated by place of origin and host plants. The facts concerning each of these species in these particulars are given in the notes accompanying the descriptions.

Of the seventeen species listed, four are apparently native to this continent, and the rest are foreign. Of the latter, five species have been found on living plants recently imported from foreign countries. Two of these, Leucaspis indica and Parlatoria mangiferæ, attack mango. The former is established in mango plantings in Florida and Porto Rico, and the latter is found more or less generally infesting the mango nursery stock in the Department greenhouses. A vigorous effort is being made to exterminate both of these scale insects. Parlatoria pyri infested cuttings of apple and soft pear imported from Manchuria, and might easily become a pest second only to the San Jose scale in importance. All of the infested cuttings were burned, and the entire stock was thoroughly fumigated. Parlatoria chinensis infested Xanthoxylon, Thuja, and Zizyphus sp. imported from China, and is closely related to pyri. Both of these Parlatorias were collected by the writer in China in 1901. Aspidiotus meyeri infested an Abies imported from the region of Peking, China. The rest of the foreign material came to the Department for determination from various collectors as dry, dead specimens, and the danger of the introduction of these species is a future one. Of the latter, the ones presenting the greatest danger to this country are Aspidiotus cocotiphagus, which in Cuba infests the cocoanut and trifoliate orange, and is doubtless capable of developing a wide range of food plants, and Aspidiotus africanus, which is making in South Africa a reputation very similar to that of the San Jose scale in this country. 
Credit is due Mr. J. G. Sanders, of this Bureau, who made the photomicrographs of the anal plates of the species described in this paper. While it does not seem possible to get a photograph which will show satisfactorily all the structural characters of the anal plate, these photographs are still very helpful as supplementing the text, and give a general pictorial effect which it is impossible to convey by description.

\section{ASPIDIOTUS (s. str.) COMPEREI n. sit.}

(Plate I, fig. 1.)

Scale of female: About $1 \mathrm{~mm}$. in diameter, strongly curven, nearly circular. Exuviæ covered, but covering secretion easily rubus uf exposing the lemon-yellow to brown exuviæ. Secretion covering the larval exuvia sometimes more dense and adherent, thus sometimes giving the scale an annulated appearance due to the second exuvia showing through the section surrounding the larval skin. Secretionary supplement normally white, sometimes slightly yellowed. Ventral scale inconsiderable.

Scale of male: About one-half the size of the female scale, and of the normal oval shape.

Adult female: In balsam mount, nearly circular and hyaline, with a diameter of about $0.8 \mathrm{~mm}$; ; anal. plate broad, rounded, about $0.2 \mathrm{~mm}$. long by $0.3 \mathrm{~mm}$. broad, for the most part hyaline, apical third very slightly suffused or chitinized; three pairs of very small, narrow, subequal lobes; median lobes rectangular and more heavily chitinized than laterals, and with chitinization, not sharply limited, extending into the pygidium something more than a lobe's length; lateral lobes with distinct outer shoulder and somewhat constricted at base, hyaline; a projection is sometimes seen at some distance anterior to the third lobe having the appearance of a rudimentary fourth lobe; incisions shallow, given a truncate appearance by the occurrence of marginal pores; paraphyses wanting; plates about lobe length, inconspicuous, apparently two median, two in first. incision, and three in second incision, with some additional rudimentary piates beyond second lateral incision; spines normal; anal opening oval, very large, larger than the two median lobes together, remote from tip, near center of the segment; paragenitals represented only by the anterior lateral groups, which consist of from 1 to 4 (usually 2) glands; dorsal glands small and rather numerous, limited to the apical third of the margin of the segment; basal thickenings wanting; ventral thickenings not present as a divaricating: band from the tip, but represented by the uniform chitinous suffusion of the apical third of the segment. 


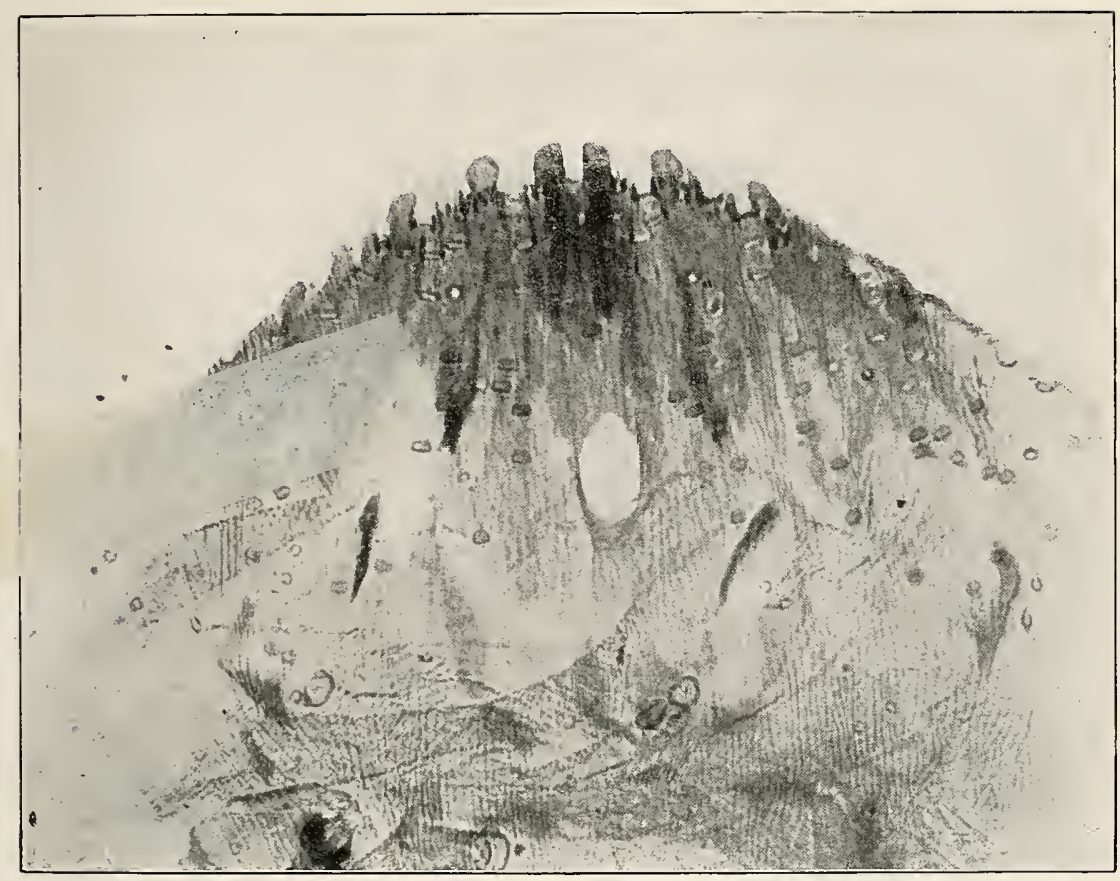

FIG. 1.-ASPIDIOTUS (S. STR.) COMPEREI.

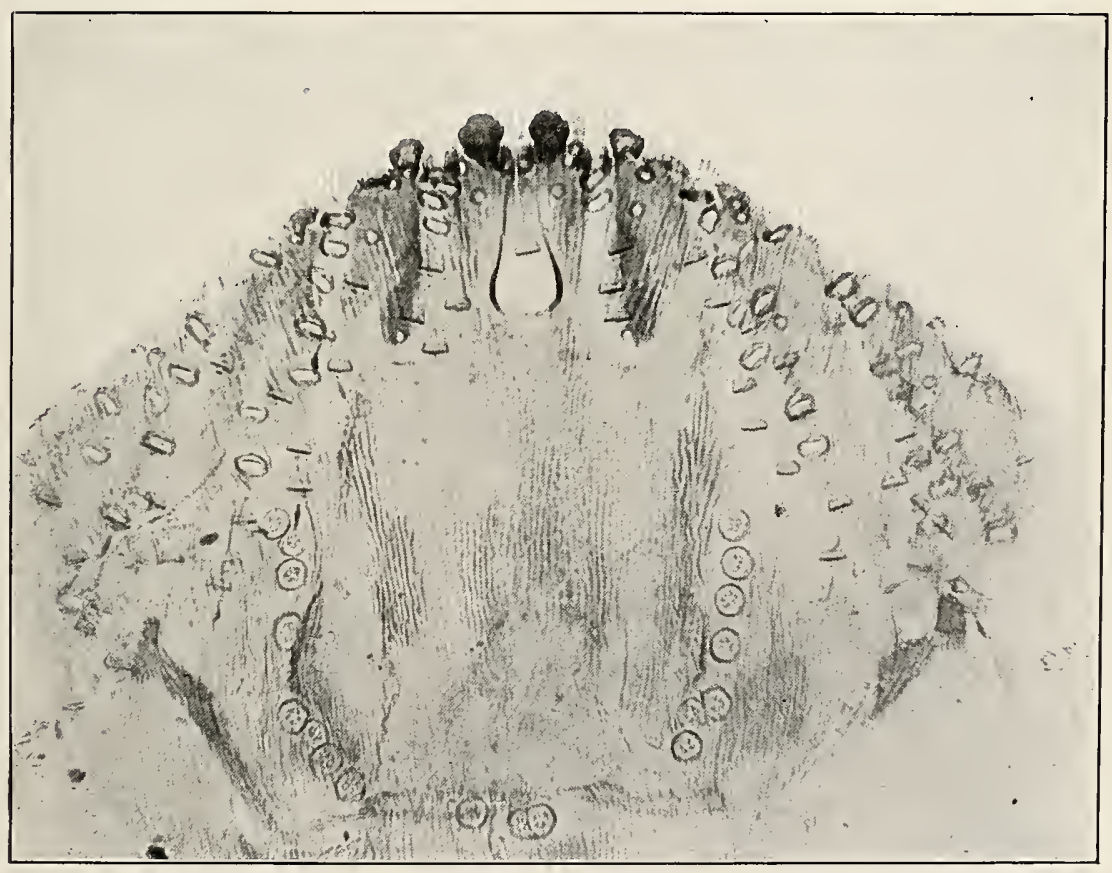

FIG. 2.-ASPIDIOTUS (S. STR.) MEYERI.

ANAL PLATES OF NEW SCALE INSECTS. 

Type.-Bureau of Entomology No. 14129. On Hake sp. and an undetermined plant. Raventhorpe, West Australia, collected by George Compere (Nos. 968 and 990), received at the Department February, 1902.

Note.-This species in scale characteristics and large anal orifice reminds one of Aspidiotus camellix Sign.; in its pygidial characters it is more like $A$. destructor Sign. It differs distinctly, however, from both of these species, as indicated in the description. It occurs massed rather thickly on the smaller twigs of the two food plants. It does not seem to coincide with any of the species described by Maskell, aithough, when Maskell's types are examined, it may fall to one of his species.

ASPIDIOTUS (s. str.) MEYERI n. sp.

(Plate I, fig. 2.)

Scale of female: Elongate oval, 1.5 to $2 \mathrm{~mm}$. (or more) in length; very convex; exurvix subcentral; larval secretion whitish except as obscured by extraneous matter; main or subsequent secretion dull resinous brown; larval secretion and exuvia easily lost, exposing the large, bright orange colored second exuvia; scale adhering very loosely to the leaf and easily dislodged, leaving the insect exposed; inner surface of scale covered with snow-white secretion which entirely conceals the exuviæ.

Scale of male: Not certainly identified, but apparently the same general type as female, except as to size and number of exuviæ.

Adult female: Long, oval, distinctly robust or convex, 0.7 to $0.9 \mathrm{~mm}$. broad by 1 to $1.4 \mathrm{~mm}$. long; hyaline in balsam mount; anal plate broad, rounded, in general hyaline, $0.32 \mathrm{~mm}$. broad by $0.20 \mathrm{~mm}$. long; two pairs of simple normal lobes, median largest and most chitinized, $0.012 \mathrm{~mm}$. in diameter; both lobes with two minute shoulders, often worn, and shoulders obscure; some distance beyond the second lobe is a very low, rudimentary, lobular projection, with difficulty distinguished, terminating in a nipple or pointed tip; lateral teeth wanting; incisions moderate, normal; paraphyses practically wanting; plates lower than lobes, broad, many-branched; $2,2,3$, and, following the rudimentary lateral lobe, 4 or 5 narrow, branched plates; spines very short and inconspicuous; anal opening large, circular, $0.2 \mathrm{~mm}$. in diameter, larger than a single median lobe and about two lobes distant from base of lobes; paragenitals in five groups, $2-4,3-3,3-4$; dorsal pores large and conspicuous, in rows counting from the center as follows: $3-4,5-7,6-7$, with a few additional pores in obscure rows of 2,3 , or 4 pores each; basal thickenings represented by two narrow median transverse rods, and the 
widely separated oblique lateral thickenings; ventral thickenings normal, but slightly chitinized.

Type.-Bureau of Entomology No. 14137. On Abies sp., imported by F. N. Meyer, for the Bureau of Plant Industry, from Wu Tai Shan, near Peking, China, receired April 21, 1908.

Note.-This insect occurs quite abundantly on the short leares of the Abies. It is closely allied to abietis hrank, but diverges from the latter in some easily recognizable surat foatures. The

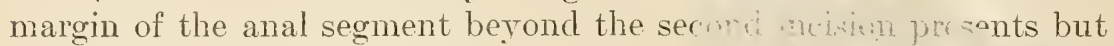
one lobular projection instead of two, as is the crise rith mietis; and, furthermore, in abietis these projections are moie pudued an are finely serrate on the oblique outer margin.

\section{ASPIDIOTUS (AONIDIELIA) COCOTIPHAGUS n. sp.}

(Plate II, figs. 1, 2.)

Scale of female: Subcircular, 1.6 to $2 \mathrm{~mm}$. in diameter; light yeilowish brown, with a very minute central white tubercle; exuriæ central, larval $0.35 \mathrm{~mm}$. in diameter; second stage, $0.75 \mathrm{~mm}$. in diameter.

Scale of male: Similar in color to the female, oval, a little over a millimeter long by $0.7 \mathrm{~mm}$. wide; both male and female secretions moderate, translucent.

Adult female: Subcircular, $1.2 \mathrm{~mm}$. in diameter; the older or spent females with the anal segment usually retracted, giving a kidney shape to the insect as in aurantii; the inflated cephalo-thoracic and abdominal segments, except the anal plate, are also strongly chitinized as in aurantii; anal plate with basal lobules, $0.4 \mathrm{~mm}$. in diameter, but slightly chitinized, rounded; median lobes largest, chitinized, brown, together measuring a little less than $0.04 \mathrm{~mm}$; second and third lobes much smaller; median lobes with two shoulders; innei shoulder of the second and third lobes minute, sometimes absent in the case of the third lobe, outer shoulders distinct; three low, serrated areas beyond third incision, not always apparent; the posterior point, howerer, of the first area chitinized, and sometimes assuming the form of a rudimentary third lateral lobe; incisions normal; paraphyses shorter than lobes, narrow, the one extending from the inner base of the median lobes most prominent; plates in median and first and second lateral incisions respectively $2,2,3$, in length ra ria ble, sometimes slightly exceedng lobes, deeply forked at tips; three broad plates in the third incision, oblique at apex, each terminating at the posterior angle in a long spindle-shaped tail; anal opening about the size of the first lateral lobe and about two lobes' length distant from tip; paragenitals $0-1,3-8,3-5$, scattering; dorsal pores in two prominent rows, extending respectively from the second and third incisions, of 6 to 10 pores each; there are also some scattering lateral pores; basal 


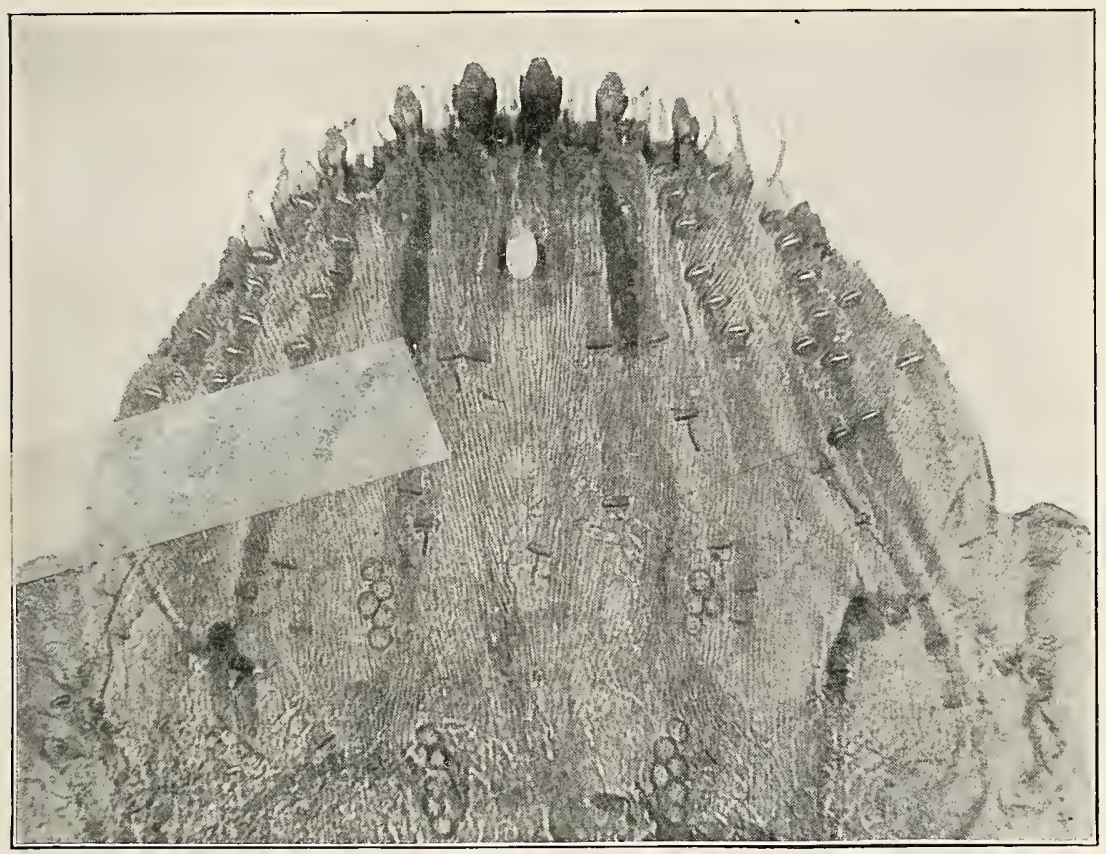

FIG. 1.-ASPIDIOTUS (AONIDIELLA) COCOTIPHAGUS.

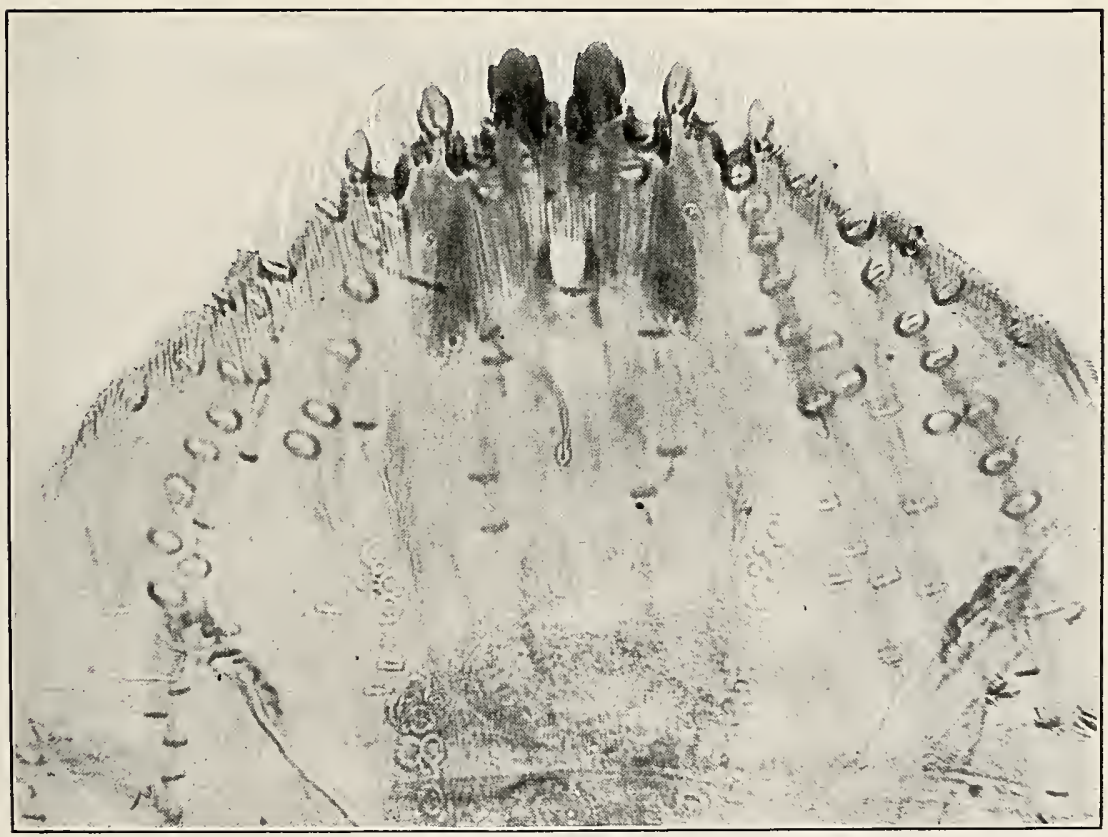

FIG. 2.-AsPidiotUS (AONIDIELLA) COCOTIPHAGUS.

ANAL PLATES OF NEW SCALE INSECTS. 



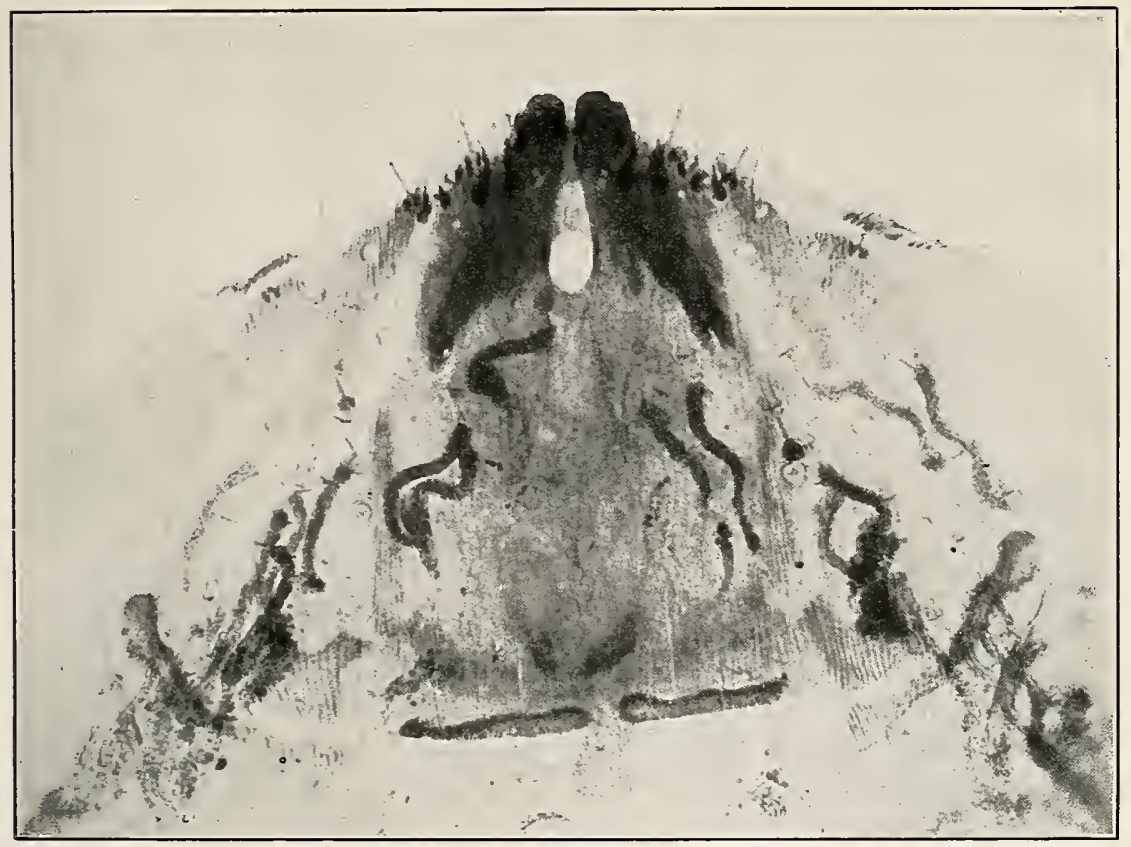

FIG. 1.-ASPIDIOTUS (DIASPIDIOTUS) AFRICANUS.

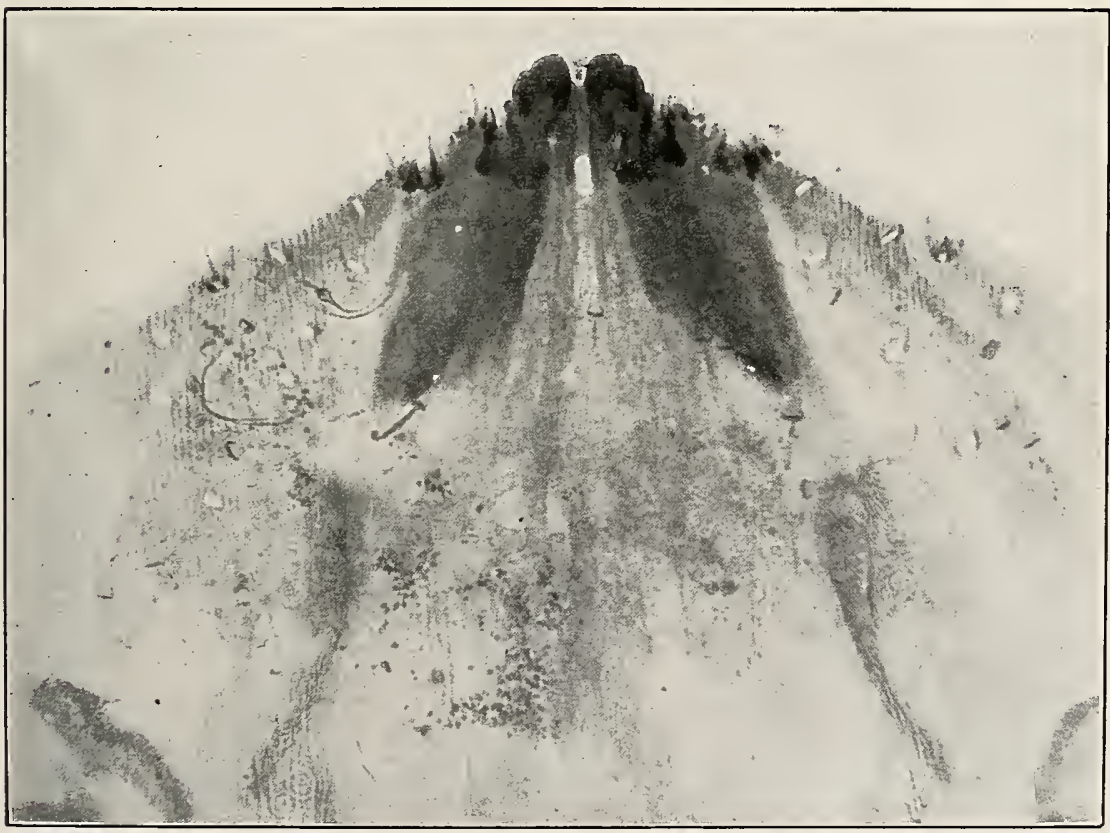

FIG. 2.-ASPIDIOTUS (DIASPIDIOTUS) COURSETIE.

ANAL PLATES OF NEW SCALE INSECTS. 

thickenings slight, two short central rods and a larger lateral rod; ventral thickenings inconspicuous, represented chiefly by a chitinized line on each side below the first lateral incision.

Type.-Bureau of Entomology No. 14136. Massed on the upper surface of the leaves of cocoanut (Cocos nucifera), Santiago de las Tegas, Cuba, collected August, 1904, by Wm. T. Horne, chief of the department of vegetable pathology of the central agricultural experiment station of Cuba. Also on Citrus trifoliata, collected by Mr. Horne, Santiago de las Tegas, Cuba, January 13, 1906.

Note.-This species seems to be an intermediate one between Aspidiofas (Aonidiella) aurantii and Aspidiotus (Chrysomphalus) dictyuspermi. It, however, differs distinctly from both of these species; from aurantii by notable differences in the pores, plates, and the presence of paragenitals, and from dictyospermi in the shape of the adult female and of the anal plate, and in the character and shape of the plates and lobes. In aurantii all the plates are distinctly subbranched and the three broad plates of the third incision have each two prominent apical branches which are distinctly subbranched. In dictyospermi the anal plate is much more produced and with much longer paraphyses, and of the three plates of the third incision the two posterior have long, spindle-shaped branches, the anterior plate two short branches. There is a distinct difference also in the shape of the lobes.

The specific variation in point of length of plates relative to lobes, and size of the lobes, position of the anal opening, etc., is illustrated in the two photographs of the anal segment shown on Plate II. The upper figure is from trpe material on cocoanut and the lower from trifoliate orange.

\section{ASPIDIOTUS (DIASPIDIOTUS) AFRICANUS n. sp.}

(Plate III, fig. 1.)

Scale of fcmale: Dull opaque brown, $1.5 \mathrm{~mm}$. in diameter; circular, moderately convex, with fairly prominent central nipple, and slightly annulated as in perniciosus; when rubbed, resinous exuviæ appear, and when old and massed the ashen appearance of perniciosus is presented.

Scale of male: About $1 \mathrm{~mm}$. long, of normal type.

Adult female: $1 \mathrm{~mm}$. long, oval. Anal plate $0.32 \mathrm{~mm}$. broad at base by $0.2 \mathrm{~mm}$. long, normal, not produced. Median lobes like those of ancylus, slightly converging toward tip; inner notch practically wanting; lateral lobes wanting or rudimentary, as in the case of ancylus; two distinct lateral incisions; paraphyses of first incision heavy, subequal, inner slightly largest; paraphyses of second incision much smaller; minute but distinct paraphyses also are seen at the inner base of the median lobes; plates minute, inconspicuous: spines 
rather strongly developed; anal opening circular, near tip; paragenitals often wanting: if present, represented by from 1 to 3 glands only; dorsal pores few, scattering; transverse basal thickenings well developed, laterals separated from the central line and robust; apical ventral chitinization rather strongly developed, brown; ventral longitudinal ridges feebly developed.

Type.-Bureau of Entomology No. 14121.

Material studied: Original lot from Bloemfrum. South Africa, December, 1907 , from the Hon. W. J. Palmer Airoctom a f rriculture, Orange River Colony. Food plants represu thos, Schinus molle, fig (two samples), almond, a.t! th. Il: material was abundantly parasitized, but none of the parasi a obtainable for identification. Specimens on Gleditsia triacantiw a followed in description, except as to note on paragenitals.

Additional lot from Charles P. Lounsbury, government entomologist, Cape Colony, with letter of January 29, 1908, representing material on pear, Hex River, Cape Colony; Kieffer pear, Prospect Farm, Komgha (east of Cape Colony); fig, Paarl, Cape Colony, and fig and privet from Bloemfontein.

The original lot, received through the Hon. W. J. Palmer, was submitted under the supposition that the insect might prove to be the San Jose scale (Aspidiotus perniciosus Comst.), and with the request that an authoritative determination be cabled to Bloemfontein. The insect proved to be entirely distinct from perniciosus, and evidently an undescribed species native to South Africa. The general appearance of the scale and insect is strikingly close to the San Jose scale. Even the anal plate bears a close resemblance to the San Jose scale, but lacks the second pair of lobes and presents some other minor differences. In the specimens examined of the first lot paragenitals also seemed to be entirely wanting, although later, in the case of three specimens, scattering pores were found, in some instances rudimentary.

The fact that the insect is distinct from the San Jose scale was cabled to Mr. Palmer, and a letter giving details was sent. Before the receipt of this cablegram the entomologists of South Africa, viz, Mr. Charles P. Lounsbury, Cape Colony; Claude Fuller, Natal; C. IT. Howard, Transtaal, and H. Neethling, biologist, Orange River Colony, had held a conference at Bloemfontein and arrived at the conclusion that the South African insect was distinct from perniciosus.

The original information given by Mr. Palmer concerning the food habits of this insect is as follows:

In the first place the worst infestations met with thus far occur on the mimosa (Acacia horrida), acacia (Robinia pseudacacia), pepper (Schinus molle), and fig; whereas pear. pecan, and apple trees growing in the worst infested spots have either not been attacked at all, or only to a very shight extent. The distribution over such a large area as it has already spread shows that it must have occurred here for a period of at 
least several years, but, in spite of careful search, no tree has been found so badly attacked that its life is threatened; no tree has been found to have actually succumbed to its attack.

The scale is apparently kept in check by an insect enemy, although up to the present no parasites have actually heen discovered. In other countries where the scale has become established, it can hardly be said to be kept down by its parasites.

In letter of February 3, 190s, transmitting the report of the conference of entomologists at Bloemfontein, Mr. Neethling states that since the discovery of the insect it has become very destructive to some cultivatar pian a tably the fig and privet. The list of plants which i' l... Lenf fonct infest, given in the report referred to, includes the

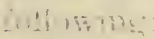

Abundantly infested.

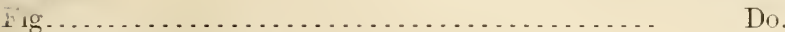

Honey locust (Gleditsia iriaranthos) ............ Do. Do.

Pepper (Schinus molle . . . . . . . . . . . . . . . . . . Do.

Apricot............................... Sparsely infested.

Quince............................... Do.

Apple .................................. Very rarely and sparsely infester.

Acacia horrida............................ More or less abundantly infested.

Robinia pseudacacia....................... . Sparsely infested.

Rhus $\mathrm{sp}$.................................. Do.

Mr. Lounsbury's communication of January 29, with accompanying specimens, gives further interesting information relative to the insect, and considerably extends its range in South Africa, as already noted. He adds two new food plants for Bloemfontein, namely, willow and poplar. He had also found, in the material which he had studied, particularly in that from South Africa and more rarely in some of the Bloemfontein samples, scattering paragenitals. Following his suggestion the writer gave a second and most careful scrutiny to all the material, with the results in the matter of paragenitals and other features indicated in the concluding notes descriptive of all the material. Mr. Lounsbury states:

I have known the occurrence on the pear for some years and suspect that the infestation went with nursery stock sent out years ago by a certain nurseryman. But we have failed to find the scale on his place and have come to think that it might have been imported by hin with French stocks before the days when we fumigated such and that it has since been eliminated. In our notes we have entered the species as "near ancylus" and "near perniciosus," but the possibility of it being the one at Bloemfontein incorrectly identified as perniciosus did not occur to me until I received material of the latter. I have not seen the species away from orchards or habitations, but some Orange River Colony material was found on Rhus and mimosa (native plants) under circumstances suggestive of its being indigenous. The pear occurrence at Komgha (east of Cape Colony) was on a few trees in one orchard, and cutting them out seems to have proved eradicative. A few branches were heavily incrusted. The one at Hex Rivel (only 125 miles from here) is also in one orchard only, so far as I know, and here some dozens of trees show the injury by the death of inside wood and spotting of fruit. I can not compare the species with perniciosus for perniciousness. 
The fact that this insect occurs on native plants, as indicated by Mr. Lounsbury, and also that it is rather abundantly parasitized, further emphasizes the probability that it is an indigenous species. Some descriptive notes of the different lots of material follow:

Original material received from W. J. Palmer, Bloemfontein (letter of November 4, 1907):

(1) On Cheditsia triacanthos: Type of description.

(2) On Schinus molle (pepper tree): Typical, except for a slightly more prominent development of dorsal pores, and a much lighter coloring of the scale secretion. Then occurring on this food plant the scale is light yellowish brown, almost buff, but otherwise normal. Such variation in coloring is sometimes seen in the San Jose scale, and may be due purely to the food plant.

(3) On fig: Typical, save for a single anterior lateral circumgenital gland in two females out of eight examined.

(4) On almond: Typical, save for two rudimentary glands in one specimen. These glands in the specimens on fig and almond were not noted in the first examination.

(5) On quince: Typical.

Material received from Charles P. Lounsbury (letter of Jamuary 29, 1908):

(1) On pear, Hex River, Cape Colony, November 17, 1907, three females: Typical, except that they show scattering paragenitals, as follows:

$\begin{array}{ccccccc}0 & 0 & 0 & 0 & 0 & 0 & 0 \\ 2-1 & 0-0 & 0-1 & 1-2 & 3-2 & 1-1 & 0-0 \\ 1-2 & 1-1 & 1-0 & 1-1 & 1-1 & 1-1 & 0-0\end{array}$

Scales reddish brown, with nipple and ring as in perniciosus; when rubbed, exposing exuvia as in perniciosus.

(2) On Kieffer pear, Prospect Farm, Komgha (east of Cape Colony), September, 1905: Scale similar to last, but with central nipple and ring less prominent; pygidium rather produced or triangular; dorsal pores numerous and prominent, arranged in two or more irregular rows on each side, the first extending from the second incision. Paragenitals:

$\begin{array}{ccccc}0 & 0 & 1 & 0 & 0 \\ 2-3 & 2-4 & 2-2 & 2-1 & 1-1 \\ 2-2 & 2-2 & 2-2 & 2-2 & 1-2\end{array}$

(3) On fig, Paarl, Cape Colony, November 8, 1907; 11 females examined: Typical in character of dorsal pores. Paragenitals absent or very few. Color of scales modified by the reddish-brown superficial layers of the bark which are carried over the scale; evidently 
approximating the color of the scales of the other specimens. Paragenitals:

$\begin{array}{lcccc}0-0 \text { (two specimens). } & & 0 & 0 & 0 \\ 0-0 & & 2-1 & 1-0 & 0-1 \text { (three specimens). } \\ & & 2-1 & 0-0 & 0-0 \\ 0 & 0 & & 0 \\ & 1-1 & 1-0 & & 1-1 \text { (two specimens). } \\ 1-0 & 1-3 & & 1-1\end{array}$

(4) On fig. Bluemfontein, November 29, 1907: Substantially typical, one specimen out of six exhibiting two paragenital glands, namely, one each of posterior laterals; with the other five specimens no glands present. Mounted material only.

(5) On privet, Bloemfontein, October, 1907: Typical, except for the presence of scattering paragenitals as follows:

$\begin{array}{cc}0 & 0 \\ 1-2 & 3-3 \\ 1-1 & -2-2\end{array}$

Slide mount only, showing two females.

All of this material evidently belongs to the same species. The five lots originally studied show practically no paragenital glands, also general uniformity in dorsal pores, except in the case of specimens on pepper tree.

In all the later material received from Mr. Lounsbury scattering paragenital glands are found in most of the individuals examined. The specimens on fig from Cape Colony and Bloemfontein show a general absence of these glands, or, if present, represented mostly by single glands. In the case of the other food plants, both from Cape Colony and from Bloemfontein, the paragenitals are very scattering, with one or more groups often entirely wanting. Taking the reasonable supposition that all this material represents the same speciesand there seems to be no occasion to doubt this judgment-we have evidently a case of a species either in a transition stage, in the matter of the presence or absence of paragenitals, or slightly variable in this feature. The paragenital glands are developed only in the adult stage of the female, and it has long been the belief of the writer that they can not be given very much specific importance. They are always subject to considerable variation, and future studies may prove that, in certain instances where species have been separated chiefly on the presence or absence of these glands, the separation is not justified, as possibly illustrated in the case of latanix and camellix. In the matter of dorsal pores, the specimens on Kieffer pear, Cape Colony, show a rather unusual derelopment, and the pygidium in the examples studied is rather more produced or triangular; otherwise the agreement is close. Some slight variation in the number of dor- 
sal pores is seen in other specimens, notably in the case of the pepper specimens already referred to. This greater development in the number of dorsal pores is not a character of great importance, and much variation in this respect is seen in other species. The abundance of dorsal pores seems to be governed to some extent by climatic conditions, a marked increase being often noted in specimens from arïl districts.

The discovery of scattering paragenitals brir this species into close relationship with the ancylus native to in imerica, and places it in a group of species hitherto especial . hiusciefse of the New World. It is interesting to note also that a laced $3,+$ a mues more strongly chitinized species, lacking paragenitals, has be pcently received from Transcaspian Russia. We know too lith of the scale-insect fauna of Asia and Africa to be able to generalize as iw what types of species are likely to be met with.

\section{ASPIDIOTUS (DIASPIDIOTUS) COURSETIE n. sp.}

(Plate III, fig. 2.)

Scale of female: $1.5 \mathrm{~mm}$. in diameter, nearly circular, of medium density, depressed; color grayish, more or less soiled by adhering extraneous matter; exuviæ sublateral, covered.

Scale of male: Similar, of normal shape.

Adult female: Length less than $1 \mathrm{~mm}$., of normal peg-top shape, not chitinized; anal plate slightly more chitinized than body except for lobes and apical and basal thickenings; median lobes only present; laterals obsolete as in ancylus; outer shoulder of median lobes prominent, inner shoulder minute, sometimes practically wanting; paraphyses of two incisions beyond lobes strongly developed; inner paraphyses of first incision terminating in a distinct oval knob lying at right angles to the line of the thickening; spines normal, fairly long; anal opening very minute and in line with the knobbed terminals of the inner paraphyses of first incision. Paragenitals: Anterior laterals, 1-3; posterior laterals, 0-1; dorsal pores few in number, inconspicuous; transverse basal thickenings of dorsal surface in three parts, consisting of a long, straight central line, sometimes broken at middle, and two stronger lateral thickenings in the form of a double curve. The ventral apical divaricating chitinized bands broad and undivided.

Type-Bureau of Entomology No. 14002. On Coursetia glandulosa, Hermosillo, Nexico; collected by Albert Koebele April 23 and 24, 1897 (Koebele No. type material, 1713).

Note.-This species is closely allied to Aspidiotus subsimilis Ckll. The latter differs in having a more produced pygidium and tobes, the latter without inner shoulder, anus midway of first thickening, paragenitals absent, and in minor characters. This species is scarcely more than a variety of subsimilis. 
ASPIDIOTUS (DIASPIDIOTUS) TRANSCASPIENSIS n. sp.

(Plate IV, fig. 1.)

Scale of female: $1.5 \mathrm{~mm}$. in diameter, subcircular, of a rellowish or buff color. Exuviæ orange, exposed when rubbed or old.

Scale of male: Of normal oval shape, similar in color to the female. Adult female: Broad, oval, $1 \mathrm{~mm}$. in length; anal plate broad, rounded; median lobes only represented; laterals wanting or rudimentary as in the case of ancylus; median lobes strongly chitinized, with very deep outer notch forming a rather distinct lobule; inner notch wanting; the two lateral incisions shallow, broad, and with very heavy, robust, bordering paraphyses or thickenings; paraphyses of first incision particularly large, especially the inner one; of second incision, much smaller; plates inconspicuous; spines not especially developed, normal; anal opening near tip, very minute; paragenitals wanting; dorsal pores few, inconspicuous, scattering; median line of basal thickenings subhyaline, inconspicuous; laterals narrow, well chitinized; two prominent longitudinal thickenings bordering the center of the pygidium; ventral thickenings normal, well chitinized.

Type.-Bureau of Entomology No. 8216. On some old dried bark of Poputus, from Transcaspian Russia, supposed to be from C. Ahnger, of Ashkabad, received November, 1898.

In its rudimentary second and third lobes this species is related to ancylus. The important characters are the strongly chitinized median lobes, with prominent external lobule and the prominent longitudinal thickenings, and the absence of paragenitals. In the latter character it falls with the South African species africanus, which, however, it does not otherwise closely resemble.

\section{ASPIDIOTUS (HEMIBERLESIA) EPIGÆEE n. sp.}

(Plate IV, fig. 2.)

Scale of female: $1.5 \mathrm{~mm}$. in diameter, subcircular, elevated, more or less conical; exuvia covered but showing as a yellowish spot; larval excretion persistent as a central wipple; color gray, often with purplish tinge, more or less annulated with lighter.

Scale of male: Normal shape, otherwise resembling the female.

Adult female: 0.6 to $0.7 \mathrm{~mm}$. wide by $0.9 \mathrm{~mm}$. long; normal peg-top shape, hyaline in balsam mount; anal plate 0.30 to $0.34 \mathrm{~mm}$. in diameter at base, rounded, nearly hyaline; two pairs of well-developed lobes with sometimes a rudimentary third spear-shaped lobe; median lobes much larger than second pair and strongly chitinized, brown, the chitinization ending abruptly at base, not extending into segment except slightly at inner side, giving the base a somewhat irregular oblique termination; median and second pairs of lobes with two subequal small notches; second pair of lobes, and third, if present, 
practically hyaline: median pair of lobes together $0.036 \mathrm{~mm}$. in diameter; incisions normal; paraphyses nearly wanting, represented by mere points of chitinization; plates very little exceeding lobes, not very strongly developed but of the general Hemiberlesia type, two median narrow, two broader first notch, then three broad followed by two or three simple plates, all plates save last being fingered at tips; spines normal; anal opening large, nearly equaling in size one median lobe, one and one-half lobe's length distant from base of median lobes; paragenitals scattering, linearly arranged, $0-1,4-7,4-6$; dorsal pores very few, scattering; basal thickenings not prominent, but slightly chitinized, divaricated ventral thickenings not extending beyond anal opening.

Type.-Bureau of Entomology No. 14135, on the ground laiurel or trailing arbutus (Epigæa repens), Chain Bridge, Ta. (near Washington, D. C.), collected by J. G. Sanders, May 6, 1906. Collected also on the same food plant, Sugar Grove, Ohio, by Bertha C. Hite, and donated by Mr. J. G. Sanders.

Note.-This species is evidently related to latanix of Signoret, but is a smaller species and differs in the notable and peculiar chitinization of the median lobes. It presents considerable variation, some of the smaller or incompletely developed specimens of the last stage of the female showing less chitinization and approaching rather closely in superficial appearance to townsendi, and it might easily be determined as this latter species. Its host-plant and occurrence in woodlands indicate that it is a species native to North America.

\section{ASPIDIOTUS (HEMIBERLESIA) MITCHELLI n. sp.}

(Plate V, fig. 1.)

Scale of female: Length, $1.5 \mathrm{~mm}$.; subcircular to broad oval, strongly convex, and of the general camellix type; secretionary matter rather dense, color dull yellowish, due chiefly to the extraneous matter taken up from the surface; exuvir yellowish brown, near the anterior end usually covered. Ventral scale a distinct white flocculent patch, thinnest at the center.

Scale of male: Similar in general appearance to that of the female, but of the normal elongate shape.

Adult female: Normal top-shaped, $0.75 \mathrm{~mm}$. in diameter; in balsam hyaline; anal plate a little more yellowed than body, broad, not produced; three pairs of lobes; median lobes truncate, not converging, with two lateral shoulders, separated by a lobe's wilth, relatively much smaller than the lobes of camellix; second lobe minute, spearshaped, often with outer lateral shoulder; third lobe narrow, spiniform; thickenings of first and second incisions present, subequal, and 


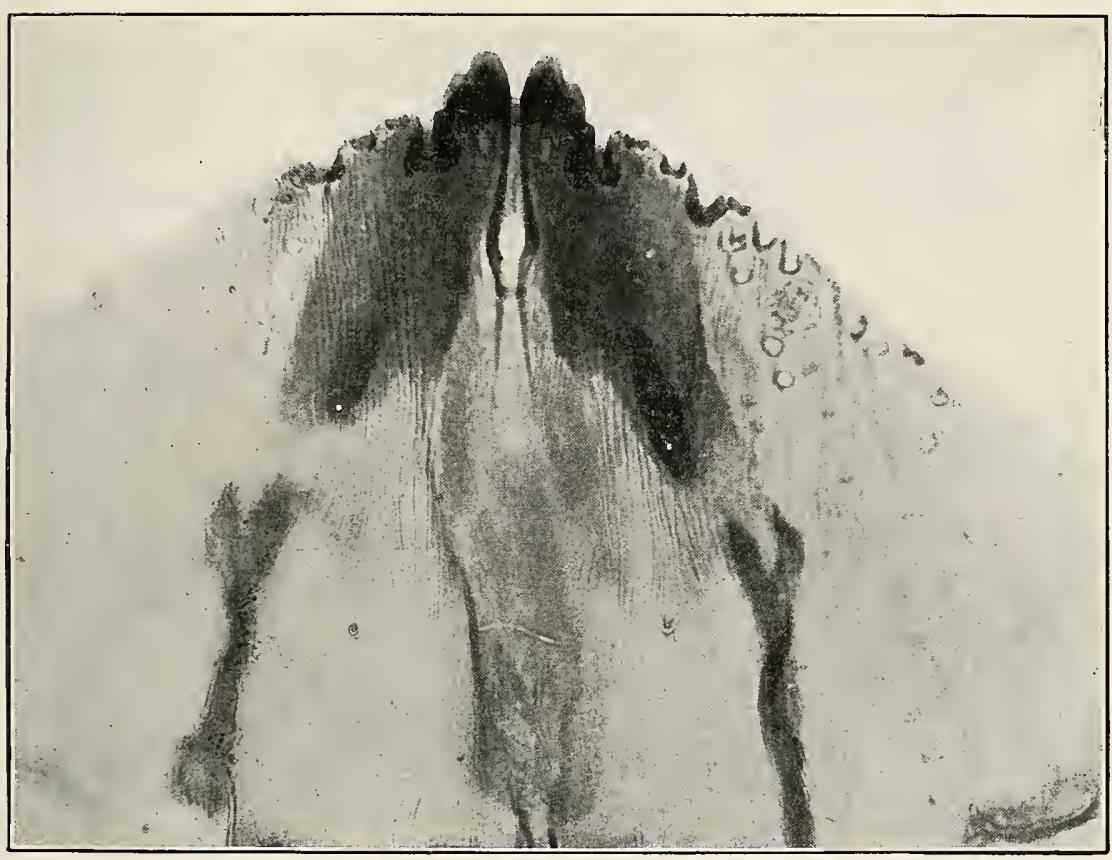

FIG. 1.-ASPIDIOTUS (DIASPIDIOTUS) TRANSCASPIENSIS.

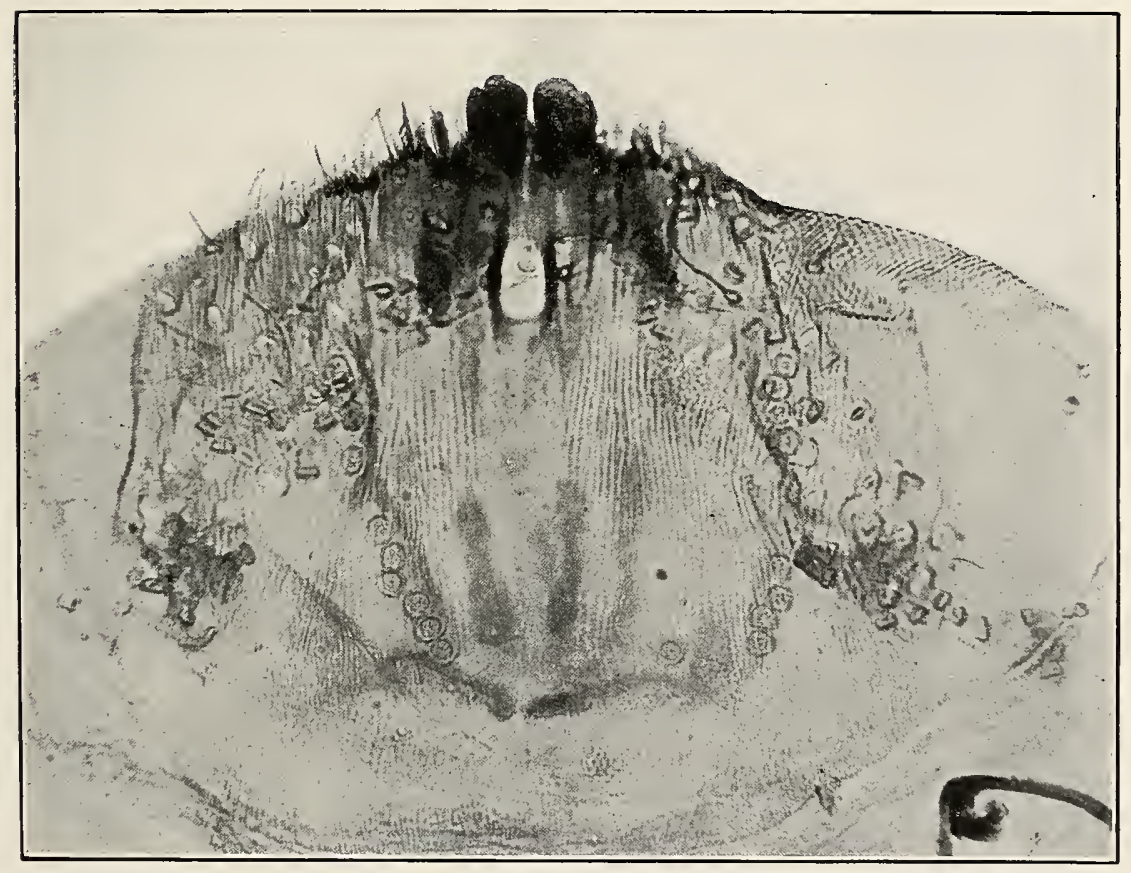

FIG. 2.-ASPIDIOTUS (HEMIBERLESIA) EPIGAF.

ANAL PLATES OF NEW SCALE INSECTS. 
<smiles>C1CC1</smiles> 


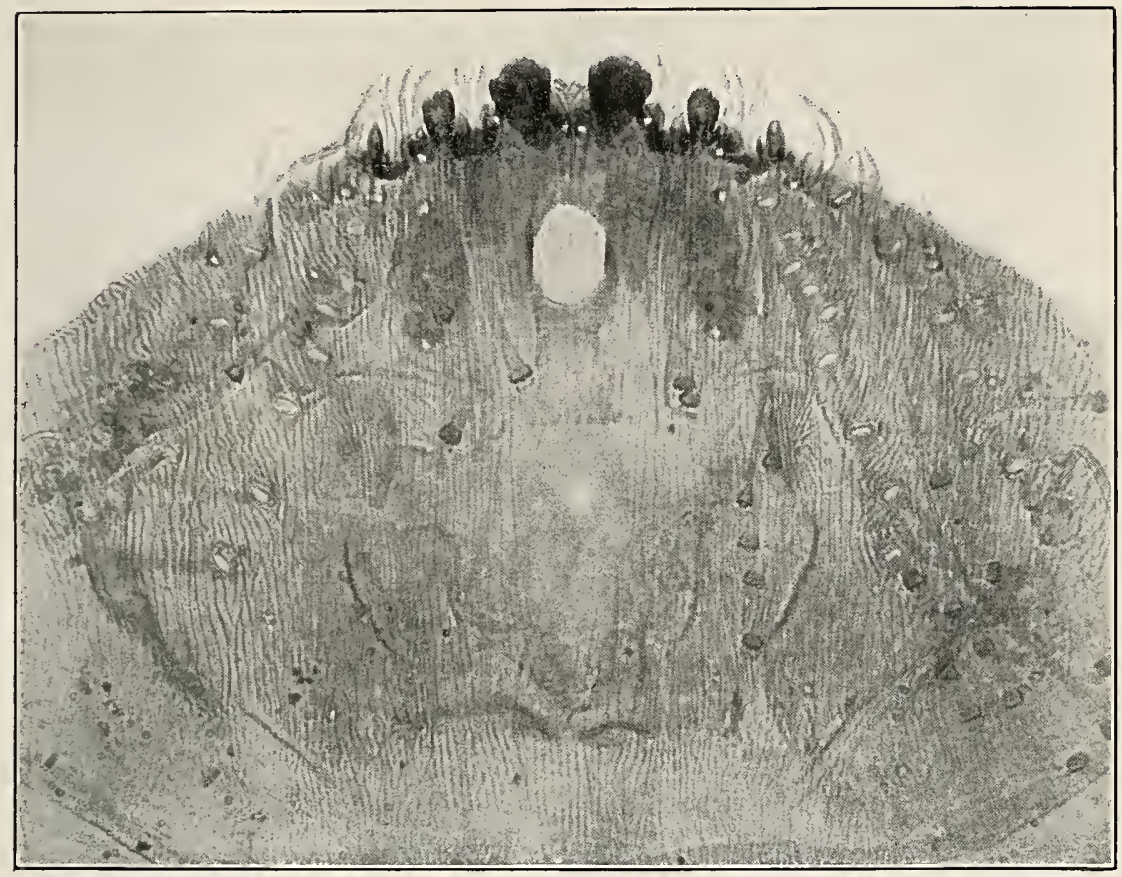

Fig. 1.-ASPIDIOTUS (HEMIBERLESIA) MITCHELLI.

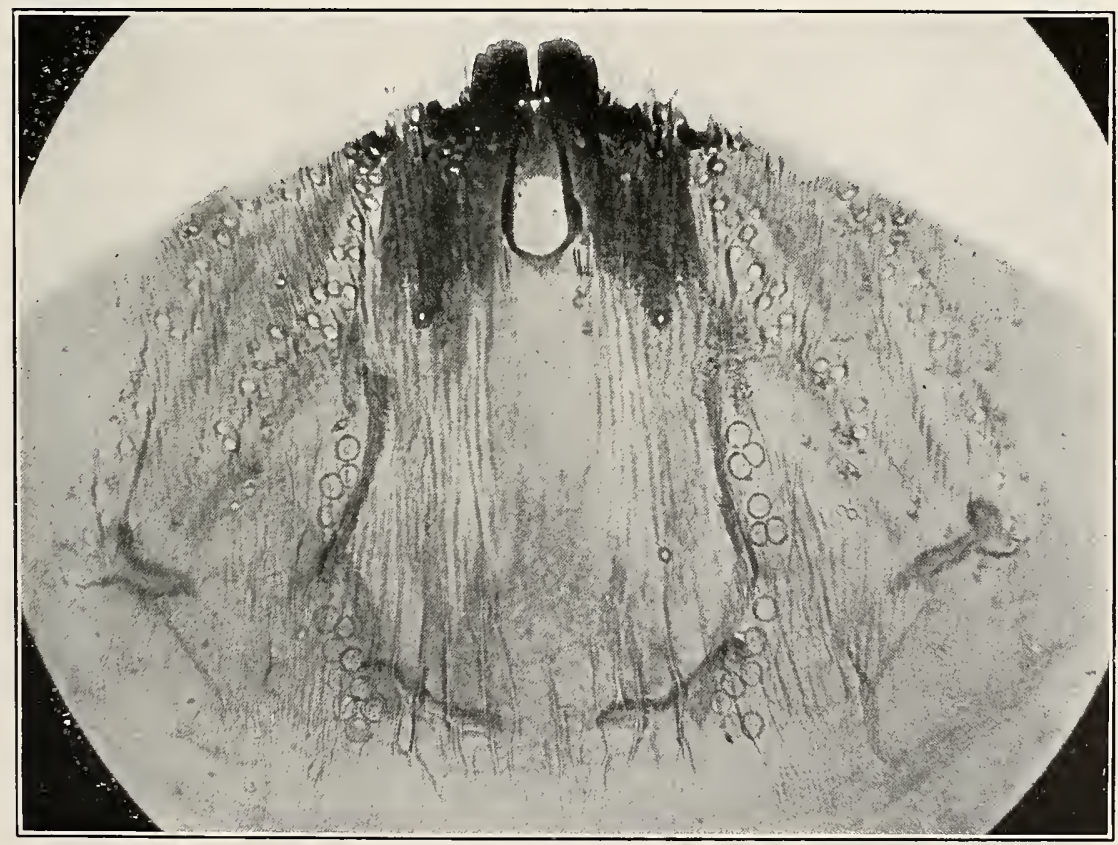

FIG. 2.-ASPIDIOTUS (HEMIBERLESIA) POPULARUM.

ANAL PLATES OF NEW SCALE INSECTS. 

together with lobes a little more yellow than the pygidium, but not strongly chitinized; plates numerous, long, filiform, central ones simply branched; spines short, inconspicuous; basal dorsal thickenings not strongly developed or chitinized; anal opening much larger than median lobes, broad oval, about one lobe's length from tip; paragenital pores wanting; dorsal pores not numerous or conspicuous, but with very long (one-half with of pygidium) internal tubes; ventral thickening of intem tending from median lobes practically wanting.

Tyme Btirw an kn unology No. 7695. On thick, narrow,

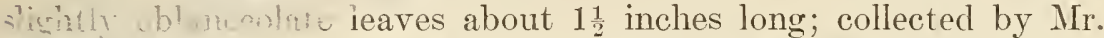
W I cunsbury, at Mitchells Pass, South Africa, January 29,

Note.-This species, in character of scale and last segment, is distinctly a Hemiberlesia. The anal opening is relatively as large as in camellix, but the median lobes are much smaller, and the chitinization of the last segment is clistinctly less than in camellix. The scale occurred scatteringly on both surfaces of the leaves.

\section{ASPIDIOTUS (HEMIBERLESIA) POPULARUM n. sp.}

(Plate V, fig. 2.)

Scale of female: Length, $2 \mathrm{~mm}$; broad oval, of the camellix type; strongly convex; exuvia near the anterior end, dark brown, the larval exuria nearly black, normally covered; secretionary matter yellowish white, very dense.

Scale of male: Length, 1 to $1.5 \mathrm{~mm}$; ; of the normal oval shape, with the larval exuvia showing prominently at one end through scanty secretionary covering.

Adult female: Normal top-shaped, in balsam hyaline; $1.5 \mathrm{~mm}$. in diameter; anal plate broad, rounded, tip slightly more yellowed than the body; median lobes large, close together, slightly converging, and with two distinct lateral shoulders, often lost in old worn specimens; second and third lobes of ancylus type or practically wanting; thickenings of first and second incision prominent, subequal; plates rather short and inconspicuous, doubtless partly lost or reduced by age and use; spines normal; anus very large, broad oval, distinctly larger as a rule than median lobes; paragenitals in four groups, anterior groups $3-9$, posterior groups $3-8$, often nearly continuous; dorsal pores very numerous, chiefly confined to two irregular double lateral rows extending from the second incision, and a third inconspicuous incision; basal dorsal thickening linear, not especially prominent.

Type.-Bureau of Entomology No. 8370. On cottonwood, from Deming, N. Mex., through Prof. T. D. A. Cockerell, February 9, 1897. 
Additional specimens, also on cottonwood, received from Professor Cockerell from Phoenix, Ariz., November 2, 1899.

NoтE.-This species is very closely allied to camellix and latanix. In the possession of paragenital pores it comes nearest to the latter species. It differs notably in the great development of the dorsal pores, which seems to be a common characteristic of scale insects in very dry climates, and in the sparsity and shortness of the plates. It is, furthermore, a rather larger species than either of the two mentioned.

AONIDIA JUNIPERI n. sp.

(Plate VI, fig. 1.)

Scale of female: Thin, whitish, slightly tinged with yellow, $1 \mathrm{~mm}$. in diameter, circular in outline, slightly convex. First exuvia very light yellow, easily lost, showing the much darker second stage as a circular central spot through the opening. Second exuvia very large, dark resinous, almost redelish, strongly chitinized and inclosing the adult female, which can be easily removed through the much thinner and delicate ventral skin of this stage.

Scale of male: Unusually large, oval, as large as the second exuvia of the female. Coloration and texture as in female.

Adult female: A little more than half a millimeter in diameter (0.54), of normal peg-top shape, not elongated nor chitinized. Anal plate, $0.20 \mathrm{~mm}$. broad by $0.14 \mathrm{~mm}$. long; scarcely chitinized, subhyaline; two small apical, nearly contiguous lobes, laterals wanting; lateral teeth wanting save as produced by the indentations containing the large peripheral dorsal pores, which form, especially toward the apex, distinct incisions; paraphyses and plates wanting; spines minute; anal opening remote from tip; paragenitals wanting; dorsal pores represented by a large central pore lying between the base of the apical lobes and five large lateral pores along the periphery of either side; some few other pores present, but inconspicuous; ventral thickening inconspicuous save the uniform slight chitinization of the pygidium.

Type.-Bureau of Entomology No. 14123.

On the fruit of Juniperus sp.; from E. G. Titus, Logan, Utah.

This species belongs to the genus Aonidia, and is ovo-viviparous, the bodies of the females examined being filled with young ready for emergence.

ASPIDIOTUS TARGIONIA) CHENOPODII n. sp.

(Plate VI, fig, 2.)

Scale of female: 1.5 to $2 \mathrm{~mm}$. in diameter, subcircular, convex; light buff in color, the secretion covering the larval exuvia whitish; with the loss of the larval exuvia, the light-orange second exuvia appears 


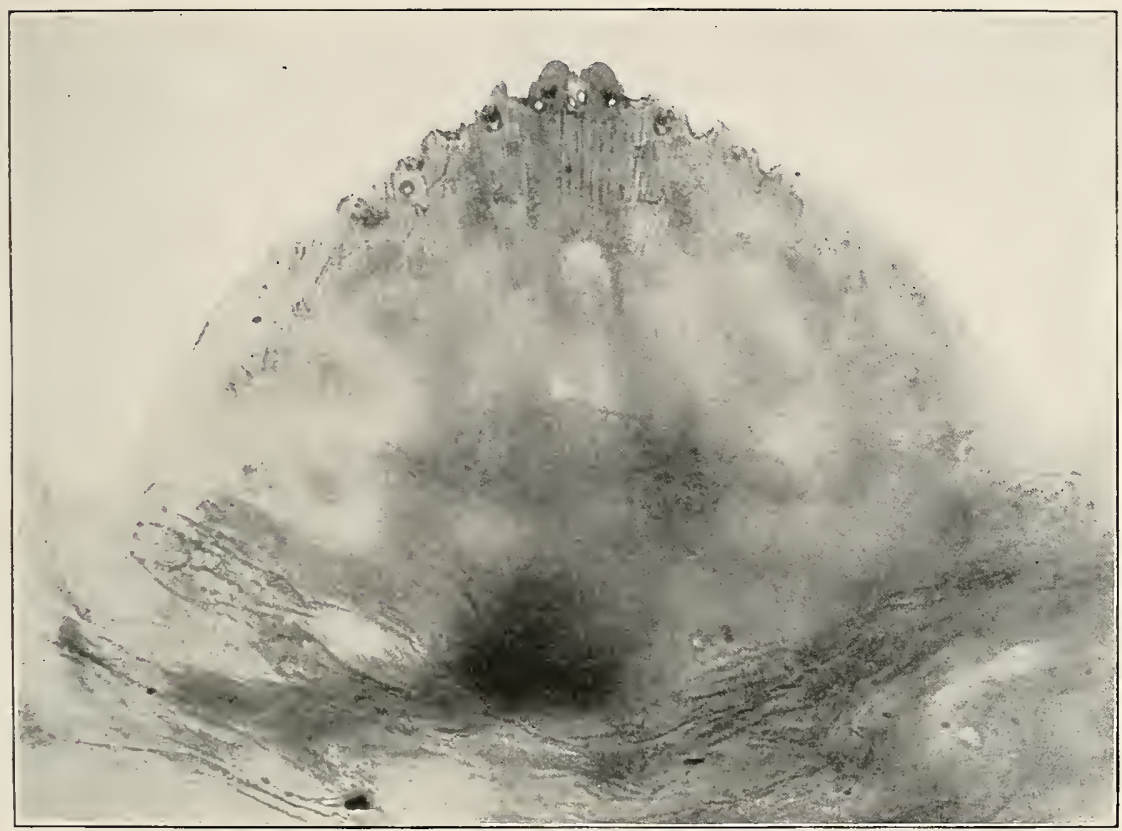

FIG. 1.-AONIDIA JUNIPERI.

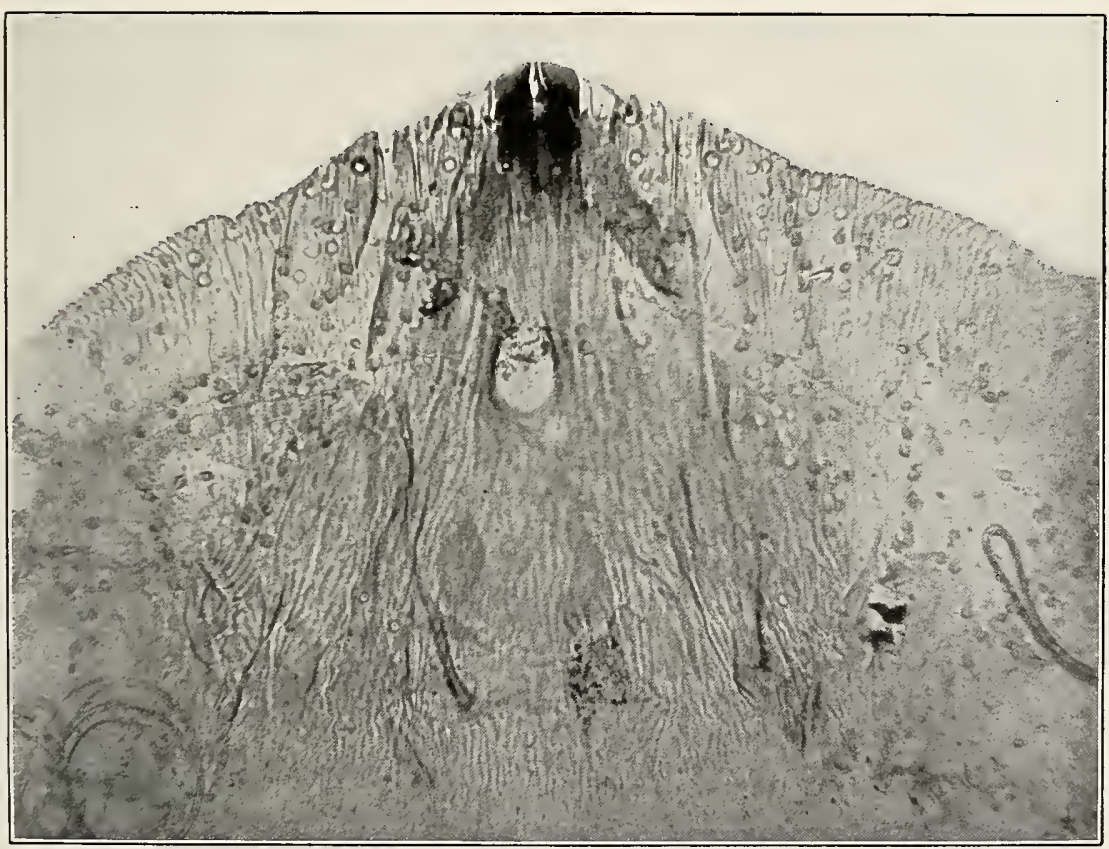

FIG. 2.-ASPIDIOTUS (TARGIONIA) CHENOPODII.

ANAL PLATES OF NEW SCALE INSECTS. 

as a conspicuous spot; ventral scale attached to the bark, white, rather abundant.

Scale of male: Elongate, sides nearly parallel; length $1 \mathrm{~mm}$., sonetimes slightly more; same general characters as the female, except that the lower secretion remains attached to the upper, forming a definite flattish sac or cocoon which easily separates from the plant.

Adult female: Nearly circular, $1.3 \mathrm{~mm}$. wide by $1.5 \mathrm{~mm}$. long in the larger specimens; hyaline, except anal plate; parastigmatic glands wanting. Anal plate about $0.4 \mathrm{~mm}$. in diameter, normally shaped, but slightly chitinized; a single pair of rather contiguous narrow median lobes, chitinized, brown, with a more or less distinct basal chitinized prolongation; lobes oblique at tip, with a produced inner apical angle, closely reproducing the characteristics of the same lobes of dearnessi; second and third lobes represented by mere projections; lateral teeth represented by the projections just referred to, which are homologous with the second and third lobes, and by a minute general serration of the edge of the anal plate; first incision deep and containing two short but easily distinguishable plates; second and third incisions minute; paraphyses wanting; plates, except in first incision, as noted, minute or wanting; spines normal; anal opening large, oval, one-third from tip; paragenitals wanting; dorsal pores minute and inconspicuous; basal thickenings inconspicuous or wanting; ventral thickenings not showing more than the generally suffused chitinization of the anal plate, the longitudinal thickenings distinctly inclosing the oral vaginal area.

Type.-Bureau of Entomology No. 14143. Coolabah, New South Wales, on Chenopodium; collector, J. G. Smith.

NoтE.-This species is very close structurally to dearnessi Ckll., but is much less chitinized. The prominent median lobes are almost exactly like those of dearnessi. The latter species, however, has five prominent lateral projections instead of the two inconspicuous ones exhibited by chenopodii. The dorsal pores of chenopodii are much less conspicuous than in the case of dearnessi; the first incision is deep, the plates in this incision are larger and more distinct, and there are other minor differences which, taken together with the wide separation geographically and the different food plants, perhaps warrant giving a specific name to the New South Wales material.

\section{CHIONASPIS MICROPORI n. sp.}

(Plate VII, fig. 1.)

Scale of female: $2.5 \mathrm{~mm}$. long, of the normal shape, expanding posteriorly, usually more or less curved; secretion white, smooth, and dense; with distinct ventral seale.

Scale of male: About $1 \mathrm{~mm}$. in length, normally shaped, with distinct median carina. 
Adult female (dried specimens): Dark purple, with the eggs or young also dark purple; length 0.9 to $1 \mathrm{~mm}$.; breadth at widest part 0.4 to $0.5 \mathrm{~mm}$., of normal Chionaspis type, tapering anteriorly; body nearly hyaline; parastigmal glands rariable, sometimes as many as 9. Anal plate broader than long, 0.26 by $0.38 \mathrm{~mm}$.; in older specimens distinctly and generally chitinized and brown, nearly hyaline in recently matured females; median lobes touching at base and widlely diraricating toward tips: latter rounded. Inner lobe of first lateral pair one-lialf width of median; outer lobes, same pair, very short and much smaller; second lateral pair represented by the inner lobe only, which is similar to the same lobe of the first lateral pair: outer lobe apparently practically wanting; lateral lobes directed distinctly toward apex of segment; lateral teeth represented only by the projections laterad of the large oblique marginal glands; incisions inconspicuous; paraphyses wanting: plates, including the median, 2, 2, 2, 2, 4-5; spines normal; anal opening one-third or less from base, circular, about the diameter of the first lateral lobe; paragenitals 12-13, 20-29, 18-22; oblique marginal pores 1, 2, 2, 2; dorsal pores small, nearly circular; inner row or group next to paragenitals 7-9; irregular row extending from third incision, more or less in two groups, of some 15 pores altogether: followed by an exterior row of some 12 pores, number of pores, however, variable; basal thickenings inconspicuous or wanting; rentral thickenings the suffused chitinization of the anal plate already noted, slightly hearier below median lobes.

Type--Bureau of Entomology No. 14144. Collected on poplar, probably Populus tremula, at ITu Tai Shan, Shansi. China, by F. X. Neyer. Received February 26, 1908.

\section{LEUCASPIS INDICA n. sp.}

(Plate VII, fig. 2.)

Scale of female: White, elongate, narrow, convex, flattened at tip, easily falling from the insect beneath.

Scale of male: Not noted.

Adult female: Entirely inclosed within the swollen, strongly chitinized second stage, latter 0.5 to $0.6 \mathrm{~mm}$. long, elongate oral, clark reddish brown. Adult female hyaline, elongate, sides subparallel. Anal plate very minute, about $0.1 \mathrm{~mm}$. in diameter, rounded, longitudinally striate. Margin with a series of elongate plate-like processes; lobes, incisions, and paraphyses wanting. The processes referred to are truncate or slightly spatulate at tip, and are of two lengths; the long ones are the second, fifth, and ninth from the center and are homologous to the lobes of other species: between the median long pair is a central short pair, then beyond the first long plate two other short ones, and beyond the second long plate three 


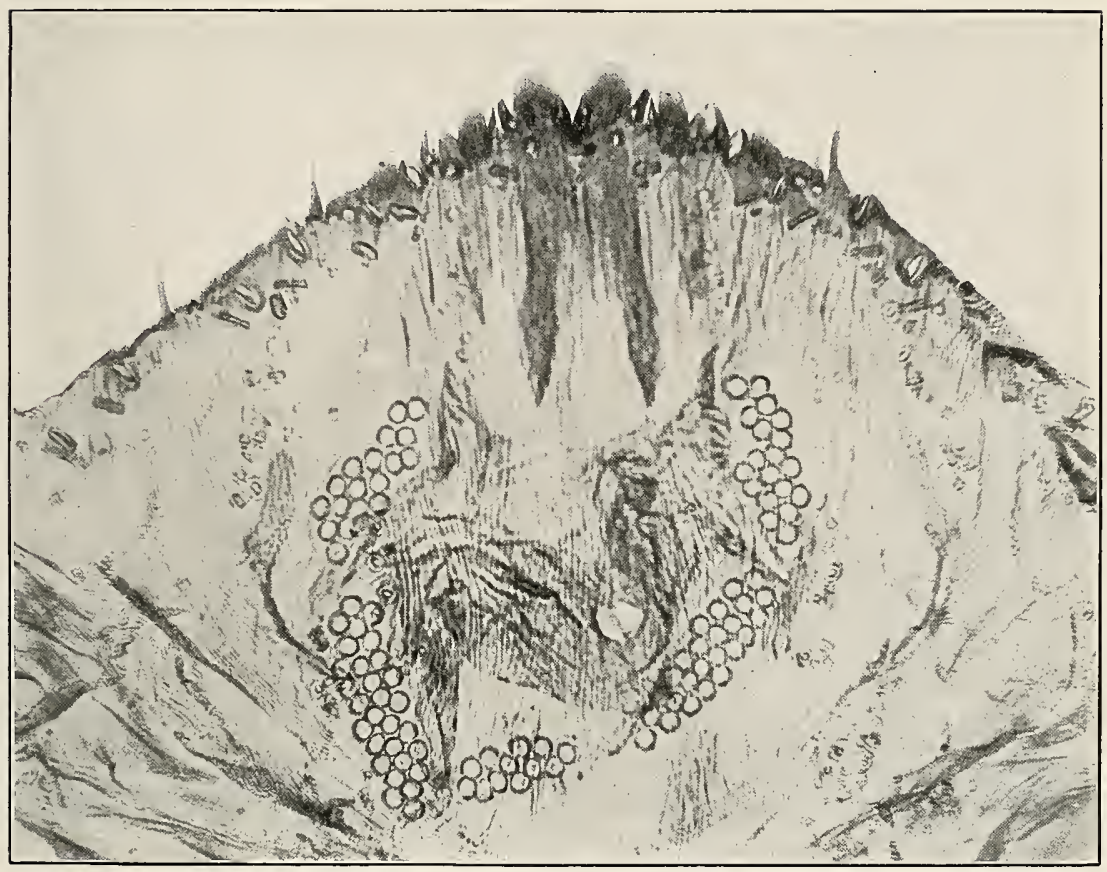

FIG. 1.-CHIONASPIS MICROPORI.

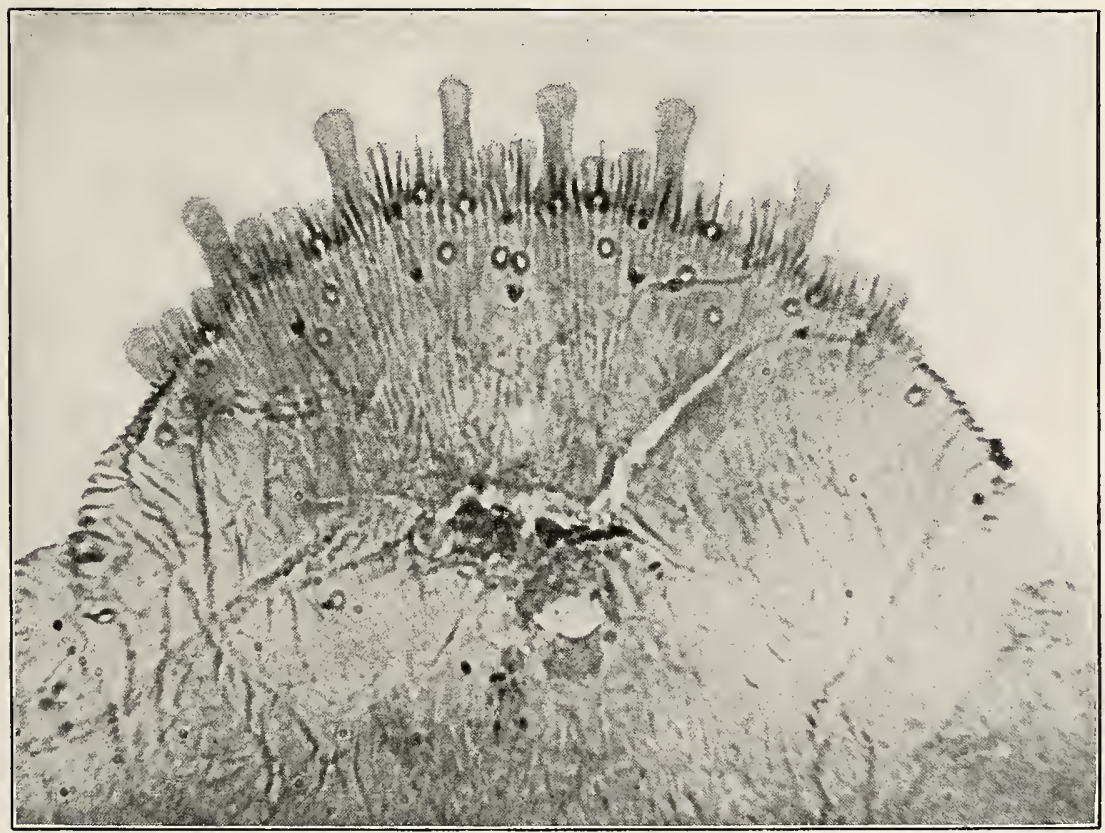

FIG. 2.-LEUCASPIS INDICA. 

short ones, and beyond the third three short ones. The marginal spines are normal, and within these is a submarginal row of short spines; anal opening large, nearer base that tip of segment; paragenitals, dorsal pores, and basal and rentral thickenings wanting.

The 5 or 6 abdominal segments preceding the anal plate are very narrow, rather sharply defined, and covered with cross or longitudinal striæ.

Type.-Bureau of Entomology No. 14125. On mangoes imported from India, at Miami, Fla., collected by Mr. P. J. Wester, of the Subtropical Laboratory and Garden of the Department of Agriculture, and from Mayaguez, P. R., through D. W. May.

NotE.-This mango scale is a very interesting species, apparently undescribech, and evidently imported from India with the original sending of the variety of mango on which it occurs, namely, Seed and Plant Introduction and Distribution No. 7108, the Sundershah. It seems to belong to the genus Leucaspis, but the failure to find the male scale leaves this reference in some little doubt. It is certainly unlike any described species of this genus. It occurs thickly massed in the cracks of the bark, and the reddish inflated skins are the second stage, which include the adult insect in a sort of sac, and look like minute eggs or seeds, the whitish waxy covering adhering very loosely and in many cases having been lost off. It has every appearance of being a serious pest, from the dense infestation exhibited.

\section{MYTILASPIS CHILOPSIDIS n. sp.}

(Plate VIII, fig. 1.)

Scale of female: More than a millimeter in length, narrow, light purplish in color.

Scale of male: Similar, about one-half the size of the female.

Adult female: A little more than a millimeter long, of normal Chionaspis shape, expanding notably posteriorly; anterior and lateral margins smooth, normal. Anal plate much broader than long, and but slightly chitinized. Lobes limited to one prominent median pair. Laterals obsolete or represented by slight tooth-like projections. Margin of pygidium somewhat toothed, caused by the projections over each of the large marginal oval pores. Incisions inconspicuous; paraphyses wanting. Plates: 2 median followed on either side by a group of 4 or 5 , then 2 or 3 ; plates somewhat longer than lobes. Spines normal; anal opening very near base of segment. Paragenitals: Anterior 5; anterior laterals 7 to 10; posterior laterals 7 to 9 (from examination of two females). Large marginal pores occurring in three pairs, two each, with a single pair near the base of the segment. Large scattering circular or slightly oval pores over the general area of the pygidium. Basal thickenings wanting; ventral 
thickenings limited to a slightly chitinized band about twice the width of the median lobes, extending slightly beyond the anal opening.

Type.-Bureau of Entomology No. 7218. Scatteringly infesting a small section of a plant doubtfully identified as Chilopsis linearis; collected by C. H. T. Townsend in Tehuantepec City, Mexico, May 26, 1896 .

Note.-The females of this insect were gravid with young at time of collection. The distinguishing feature is the absence of the lateral lobes in connection with the rather large prominent median pair.

\section{PARLATORIA MANGIFERE n. sp.}

(Plate VIII, fig. 2.)

Scale of female: Moderately dense, dark brown, lighter at the edges, oval in outline, usually with slight apical extension; larral exuria dull greenish. Length $1.5 \mathrm{~mm}$.; breadth 1 to $1.25 \mathrm{~mm}$.

Scale of male: Oval, slightly lighter colored, 1 to $1.3 \mathrm{~mm}$. long by about $0.8 \mathrm{~mm}$. broad. Exuvia more distinctly and purely green than in the case of the female, forming quite a striking contrast with the dull brown of the secretion.

Adult female: $0.65 \mathrm{~mm}$. by $0.75 \mathrm{~mm}$; of normal rounded, peg-top shape; hyaline, save the anal plate. Anal plate $0.45 \mathrm{~mm}$. broad at base by $0.25 \mathrm{~mm}$. long; rounded, rather strongly chitinized throughout median area and marginally; general structure very similar to pergandei. Lobes of the pergandei type, rather more chitinized. Three pairs of lobes with strong outer shoulder, median lobes with minute inner shoulder also; fourth and fifth lobes triangular, terminating in a point as in pergandei; lateral teeth represented by irregular serrations beyond lobes; incisions normal; paraphyses represented by the semilunar chitinization at the base of the lobes, unusually heavy; plates resembling those of pergandei in general, i. e., two narrow central plates, and two narrow plates in the first and three in the second incision, posterior one minute; the third incision bears three broad, triangular plates, serrated on the exterior margin; following the fourth lobe are four or five similar exteriorly serrated plates; spines normal; anal opening narrow, halfway between tip of segment and vaginal orifice; paragenitals wanting; parastigmals represented by a group of 8 to 10 pores on the inner side of each stigma; dorsal pores large and numerous, represented by 5 more or less regular rows of pores on either side of the center; the central row 3 to 4 , the second row 5 to 6 , third 8 , fourth and fifth scattering. Marginal oval pores decreasing in size from tip to base of segment; basal thickenings practically wanting; ventral thickenings represented by a broad suffused chitinization extending from the tip to the base of segment, and more or less along the margin. 


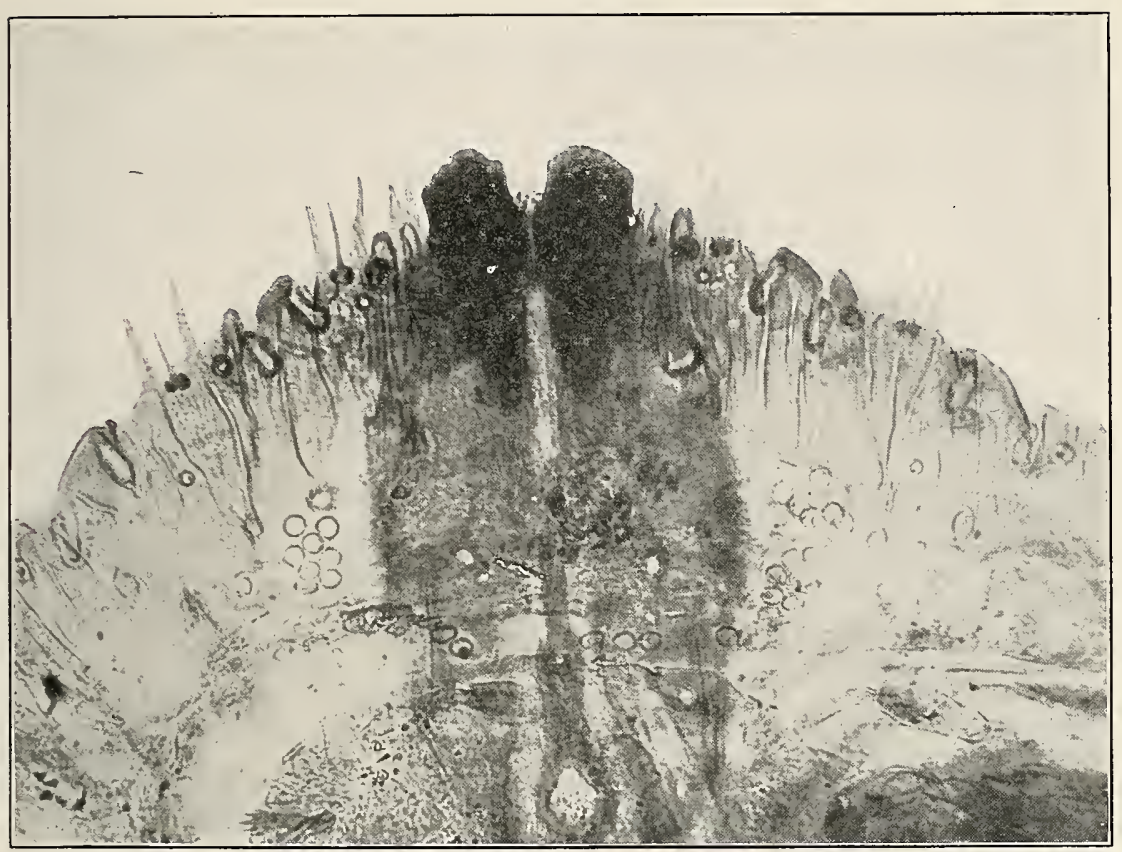

FIG. 1.-MYTILASPIS CHILOPSIDIS.

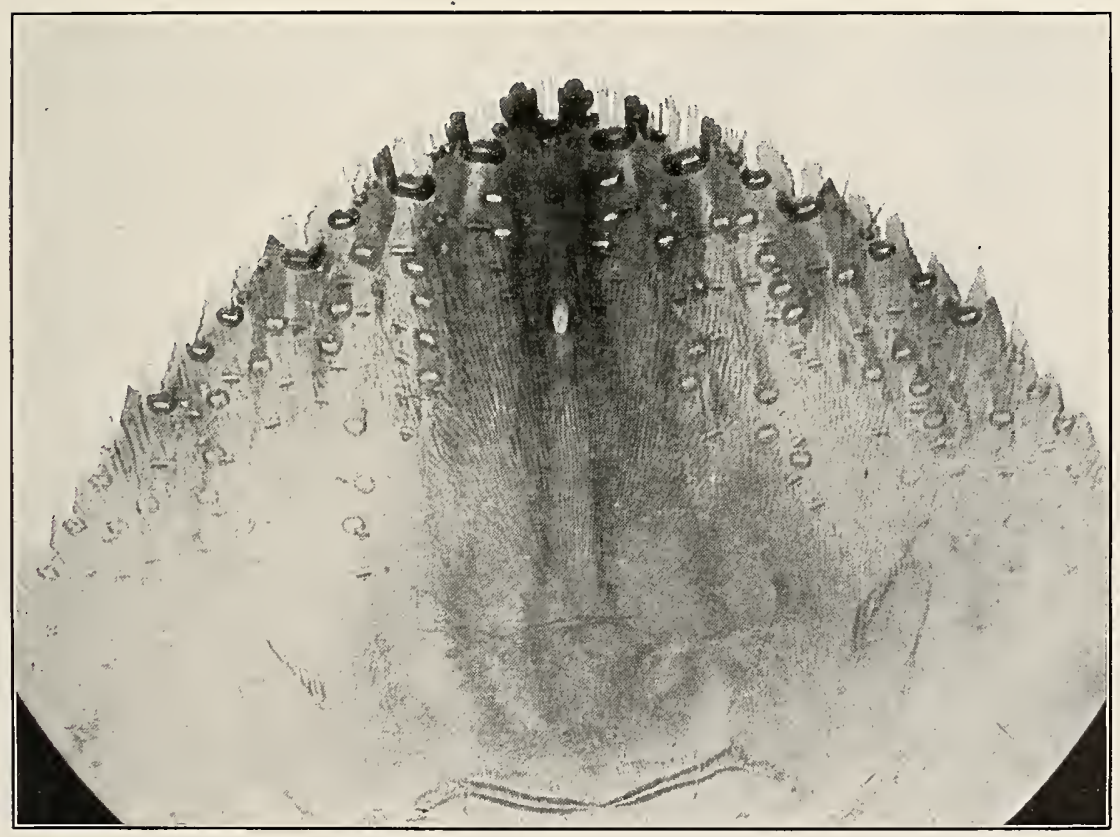

FIG. 2.-PARLATORIA MANGIFERAE.

ANAL PLATES OF NEW SCALE INSECTS. 

Type--Bureau of Entomology No. 14128. On mango; collected in the Department greenhouses, Washington, D. C., January 28, 1908, by J. G. Sanders, in course of quarantine inspections. Dr. L. Reh, of Hamburg, sent this species for determination June 27, 1904, as from Singapore.

NoтЕ - This species is a strongly chitinized pergandei lacking paragenital pores and exhibiting a much greater development of dorsal pores. In this last feature it resembles some of the varieties of pergandei. It is further distinguished by the more produced, tapering, exteriorly serrated lateral plates occurring in the incision posterior to the fourth lobe, and also on the margin of the segment anterior to this lobe. The large number of small parastigmatic pores is also a marked character.

It occurs massed as thickly as may be on the young mango twigs, and evinces the prolificness characteristic of the genus. It is undoubtedly an offshoot of pergandei, and may not deserve more than varietal status.

\section{PARLATORIA PYRI n. sp.}

(Plate IX, fig. 1.)

Scale of female: $1 \mathrm{~mm}$. to $1.25 \mathrm{~mm}$. in length, oval; exuviæ of larval and second stage and supplementary secretion normal to the genus, the secretion, however, usually terminal, but its position varies somewhat as affected by irregularities of the bark, sometimes sublateral and sometimes more or less inclosing the posterior half at least of the second exuvia. Larval exuvia purplish-green; second exuvia dark olive, almost black, more or less overlaid with a grayish secretion; supplement yellowish.

Scale of male: Larval exuvia as in female; supplemental area broad, circular.

Adult female: Of the normal peg-top shape, $0.8 \mathrm{~mm}$. long by 0.6 $\mathrm{mm}$. broad, hyaline. Anal plate distinctly triangular, very slightly chitinized; two pairs of lobes, compressed or close together, the median more than twice the size of the laterals, and both pairs with a deep exterior shoulder; second pair of lobes much lower than median pair; edge of pygidium beyond plates, irregularly obtusely serrated; incisions shallow and inconspicuous; paraphyses wanting, or indicated by a small point of chitinization at inner end of first and second lateral marginal pores; plates short and inconspicuous, not exceeding lobes, and extending a short distance laterally beyond lobes; spines normal; anal opening fairly large, circular, subcentral or nearer base than tip of pygidium. Paragenitals: Anterior group 1 to 4, anterior laterals 8 to 10 , posterior laterals 8 to 12 . The large oval marginal pores characteristic of the genus are present, 5 to 6 on either margin of the anal plate, with one central one between the median lobes, continued 
also, somewhat smatler, on all the abdominal segments, with, on these segments and also to a less extent on the pygidium, numerous smaller oral submarginal pores. Basal and ventral thickenings practically wanting.

Type.-Bureau of Entomology No. 14115. On pear, Chefoo, China, collected October 4,1901 , by the writer. Also infesting cuttings of apple and soft pear, received from the Province of Liaou Yang, Manchuria, through F. N. Meyer (S. P. I. \& D. Nos. apple, 20276, 20280; soft pear, 2024t and 20280). Collected by Mrr. J. G. Sanders in the course of inspection of Department importations, March 21, 1907.

Note.--In the case of the Meyer importations this insect was found very scatteringly present on the cuttings of pear and apple refermed to, principally the former, and was associated with the San Jose scale, which was even more sparsely represented. Curiously enough, also, this new Parlatoria bears a close superficial resemblance in the balsam mounted female to the San Jose scale, and particularly in the shape of the anal segment and of the produced tip, with two pairs of compressed or closely placed lobes, which are almost of the identical size and shape of perniciosus. The plates also are just about the same size and extent as in perniciosus. While distinctly a Parlatoria, this species lacks the abundant and striking: development of the plates which is usually characteristic of the genus. Its occurrence with the San Jose scale and in somewhat greater numbers even than the latter species, and particularly its habitat in the North Temperate region, would indicate, in connection with its host relations, that it has very great possibilities for eril should it gain foothold on this continent. The genus Parlatoria is noted for its enormous powers of multiplication, and the possibilities of damage as seen in the case of the chaft scale (Parlatoria pergandei Comst.) and the date-paln scale (Parlatoria blanchardi Targ.) indicate that this Manchurian Parlatoria might develop into a much more dangerous insect eren than the San Jose scale. While no parasitism was noted in the case of the Parlatoria, some of the San Jose scales associated with it had been parasitized, the parasite, howerer, not being identifiable from the single fragment found, which was, however, referred by Doctor Howard to the genus Aphetinus.

\section{PARLATORIA CHINENSIS, n. sp.}

(Plate IX, fig. 2.)

Scate of female: $1 \mathrm{~mm}$. in diameter or less, subcircular, exuviæ eccentric, dark metallic olive, similar in general characters to $P$. pyri.

Scale of male: Not seen.

Adult female: About $0.6 \mathrm{~mm}$. broad by $0.7 \mathrm{~mm}$. long (probably old gravid female considerably larger): normally shaped. Anal plaie 


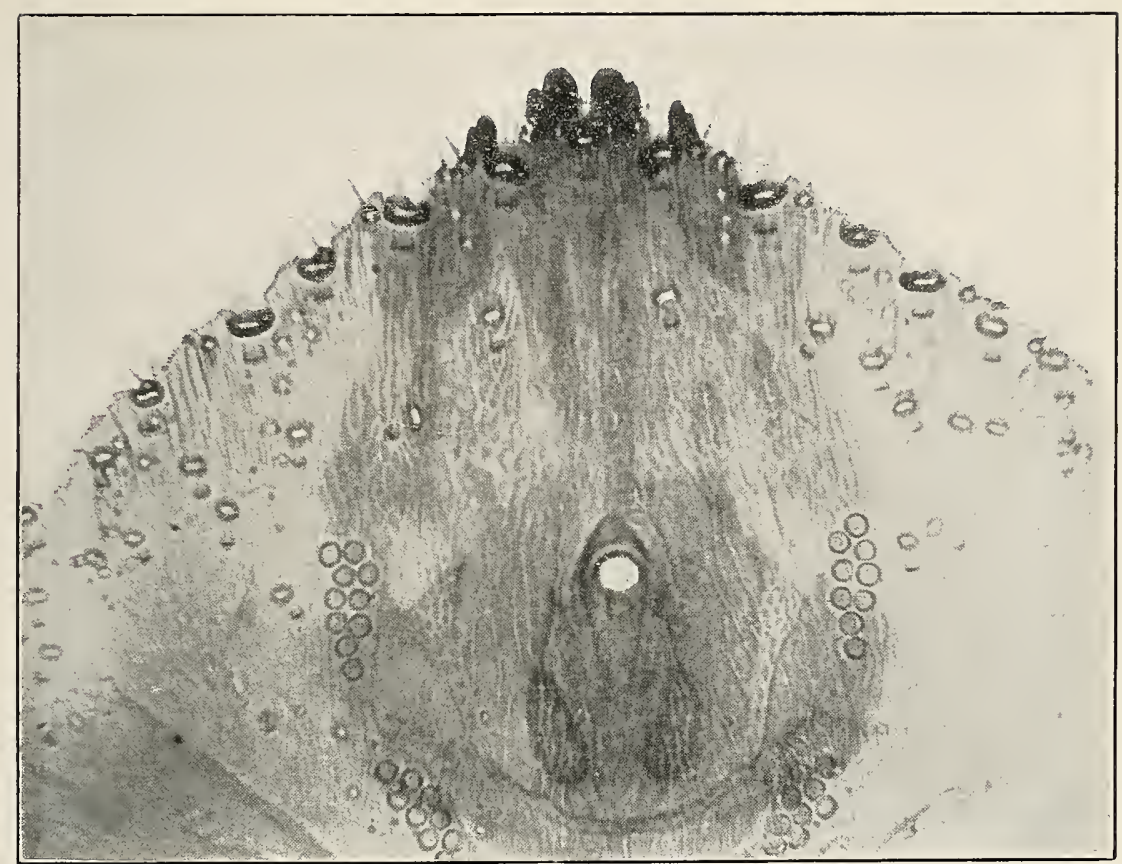

FIG. 1.-PARLATORIA PYRI.

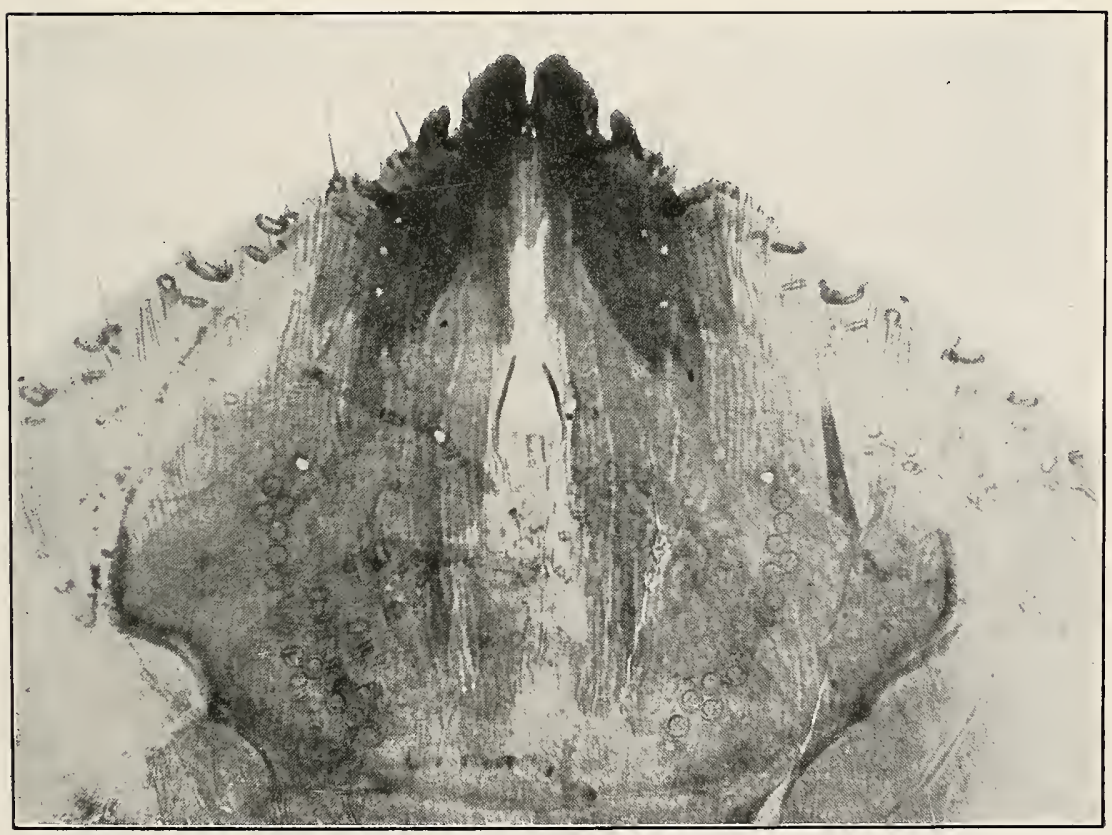

FIG. 2.-PARLATORIA CHINENSIS.

ANAL PLATES OF NEW SCALE INSECTS. 

broad, triangular; width $0.3 \mathrm{~mm}$., lengih $0.21 \mathrm{~mm}$; more chitinized than pyri: lobes in two pairs; median large, each $0.15 \mathrm{~mm}$. broad, obtusely pointed; inner margin with one notch, outer margin oblique, with four or more fine teeth; second lobe much smaller and lower than median, close to the latter, outer margin oblique, with 2 to 4 mimute teeth; incisions normal; paraphyses represented by two rounded, knobbed chitinous processes attached to the inner end of each of the first and second lateral marginal lunar pores, bringing them at or near the outer bases respectively of the median and lateral lobes; plates inconspicuous; between the median lobes and in the first lateral incision two rery short, scarcely discemible simple plates; three slightly longer simple plates occur in the second incision; beyond the second incision no plates easily discernible; spines normal; anal opening subcentral, situated just in front of vaginal opening, equaling in diameter rridth of median lobe; paragenitals in four groujs of about 6 pores each, the anterior group apparently not represented in the specimens examined; basal thickenings a distinct narrow line, oblique lateral portion of same character as central and scarcely separated from latter; rentral thickenings diffused, normal.

Type.-Bureau of Entomology No. 1413S. On crab-apple, Tientsin, China, October 11, 1901 ; collector, C. L. Marlatt.

Note.-This anomalous Parlatoria was first collected by the writer on a small tree, possibly a crab-apple, growing near the railway station at Taira, Japan, August 30, 1901. This tree was thickly infested, and this was the only example of this insect found in Japan. In China the writer collected it at Chefoo on Hibiscus (October 4, 1901), and later, October 11, on crab-apple at Tientsin. The latter lot has been indicated as the type material. What is evidently this insect was also collected by the writer (March 12, 1902), in Cairo, Egypt, on an unknown plant, which it infested in conjunction with Parlatoria affinis Newst. The Egyptian variety differs slightly in the exterior serration of the median lobes, these serrations or notches being reduced to two or three instead of four or more, and the central lobular projection is somewhat larger. The paragenitals also are less abundant, ranging as follows: $0,0-3$, and $1-2$.

The same insect was found on plants imported for the Department of Agriculture by F. N. Meyer, from Peking and northern China, namely, on Xanthoxylon, received May 2, 1907, on Thuja orientalis, received March, 1908, and on jujube, receired April 21, 1908. From these records it is evident that it is a common and widespread species in northern China, and probably will be found to occur throughout eastern Asia. The Egyptian variety may have been a recent importation, or the range of the species may be much wider in the Old World than that indicated.

This insect is remarkably like Parlatoria pyri in general appearance and characters, and is very likely closely related to the latter 
species, perhaps presenting merely a variety. It differs, however, very notably in the character of the median lobes, which in pyri are of the normal Parlatoria type, with a deep prominent outer shoulder on each of the lobes. It also differs from pyri in the presence of the chitinized processes or paraphyses, which in pyri are usually wanting or only faintly indicated, and in the practical absence of the smaller pores, which in pyri are found rather abundantly near the margin of the anal and other segments. The anal plate is a little more heavily chitinized, thus bringing out more prominently the basal and ventral thickenings. It occurred very scatteringly, altogether but four females being secured. Like pyri, the tip, at a superficial glance, reminds one strongly of perniciosus, the effect being produced by the very much smaller, lower, and closely placed second lobes. This species diverges still farther than pyri from the normal Parlatoria characters. The sparsity of plates and the practical absence of the branched plates along the margin of the anal and other segments, and the sparsity of submarginal and marginal pores, are all features which differentiate it from the normal type of Parlatoria. The broad lunar marginal pores of the anal segment, however, are distinctly of the Parlatoria character, and the secretions and exuviæ are distinctly those of Parlatoria. 
TECHNICAL SERIEs, No. 16, PART III.

U. S. DEPARTMENT OF AGRICULTURE, BURFAU OH HNTOMOLOGX.

L. O. HOWARD, Entomologist and Chief of Bureau.

\section{PAPERS ON COCCIDE OR SCALE INSECTS.}

\section{CATALOGUE}

OF

\section{RECENTLY DESCRIBED COCCID E-II.}

By J. G. SANDERS, M. A., Assistant.

IsSued December 22, 1909.

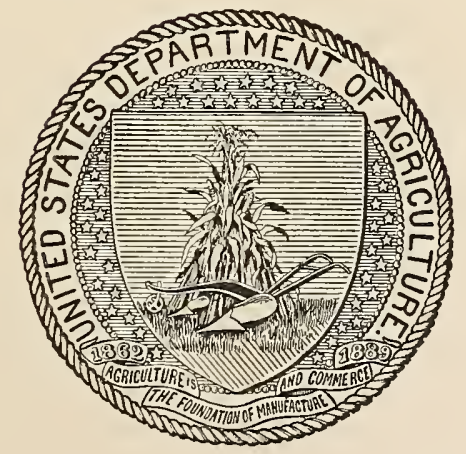

WASHINGTON :

GOVERNMENT PRINTING OFEICE. 


\section{U. S. SLPT OI VOOUEF'T \\ i \\ CONTE N TS.}

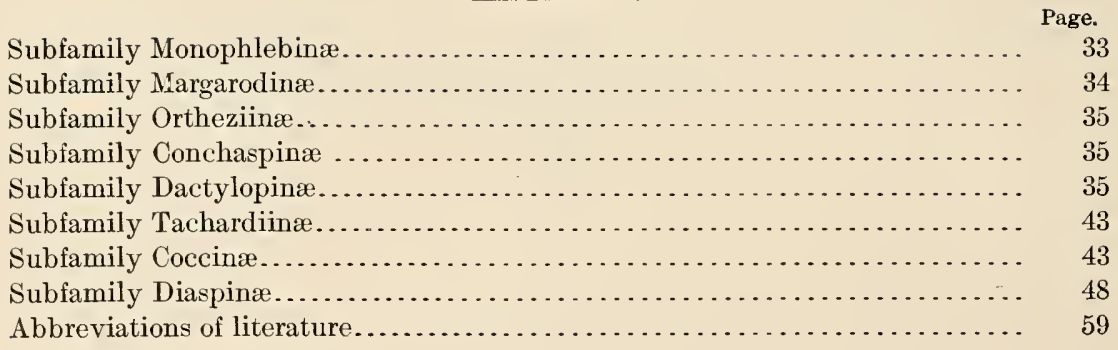




\section{PAPERS ON COCCIDE OR SCALE INSECTS.}

\section{CATALOGUE OF RECENTLY DESCRIBED COCCID AE-II.}

By J. G. Sanders, M. A., Assistant.

The preparation of a catalogue of this character requires great vigilance and constant attention to the voluminous literature of entomology, in order that every reference to Coccidx be noted. Descriptions of new genera and species appear in all conceivable publications in many languages, but the publication of the results of technical entomological research in botanical journals or other periodicals which do not usually treat of entomological subjects can not be too strongly condemned. For decades the publication of names for new species without description, nomina nud $;$, has been decried. Still there are entomologists who indulge in this unfortunate practice, thereby leading to confusion and error.

In this catalogue, the second of the series, ${ }^{a}$ are included references to 24 new genera, 195 new species, and 14 new varieties. The writer believes the list quite complete to March, 1909, and asks the assistance of coworkers in adding references which may have been overlooked.

\section{Subfamily MONOPHLEBIN屁.}

\section{Monophlebus stebbingi octocaudata Green.}

Monophlebus stebbingi var. octocaudata Green, Mem. Dep. Ag. India, II, 2, p. 16 (1908). Maxwell-Lefroy, Mem. Dep. Ag. India, Ir, 7,

Habitat-Lahore, India. p. 111 (1908). Fig.

On mango; Ficus bengalensis; $F$. infectoria; F. religiosa; $F$. glomerata; F. carica; Dalbergia sissu; Artocarpus integrifolia.

\section{Monophlebus tamarindus Green.}

Monophlebus tamarindus Green, Mem. Dep. Ag. India, II, 2, p. 17 (1908).

Habitat-India.

On branches of tamarind.

$a$ The first catalogue of the series was published as Technical Series 12, Pt. I, of this Bureau, and was issued June 5, 1906. 
Palæococcus pulcher Leonardi.

Palæococcus pulcher Leon., Annali di Agr., vir, p. 1 (1907). Fig.

Habitat-Java.

On leaves of Ilex sp.

\section{Palæococcus rosæ australis (Maskell).}

Icerya rosæ var. australis Mask., N. Z. Trans., p. 101 (1893). Fig.

Habitat-Australia.

On Hakea gibbosa.

\section{Palæococcus theobromæ Newstead.}

Palæococcus theobromæ Newst., Jn. Econ. Biol., rn, 4, p. 154 (1908).

Habitat-Calabar, West Africa.

On leaves of cultivated cacao.

\section{Walkeriana cinerea Green.}

Walkeriana cinerea Green (sine descr.), Mem. Dep. Ag. India, II, 2, p. 18 (1908).

Maxwell-Lefroy (sine descr.), Mem. Dep. Ag. India, II, 7, p. 121 (1908).

Habitat-India.

On Acacia arabica; Lawsonia alba.

\section{Icerya minor Green.}

Icerya minor Green, Mem. Dep. Ag. India, II, 2, p. 17 (1908). Fig.

Maxwell-Lefroy, Mem. Dep. Ag. India, rr, 7, p. 118 (1908). Fig.

Leichia festiva Kieffer, Marcellia, vir, p. 163 (1909). Fig.

Habitat-Bengal.

On mango.

a Icerya okadæ Kuwana.

Icerya okadæ Kuwana, Bul. Ag. Exp. Sta. Japan, I, 2, p. 178 (1907). Fig. Ckll., Can. Ent., xur, 2, p. 55 (1909).

Habitat-Japan.

On orange tree (Citrus).

Icerya seychellarum cristata Newstead.

Icerya seychellarum var. cristata Newst., Liverpool Univ. Quart. Jn., III, 6, p. 11 (1908).

Habitat-Madagascar.

\section{Subfamily MARGARODIN坐.}

\section{Margarodes mediterraneus Silvestri.}

Margarodes mediterraneus Silv., Bul. Soc. Ent. Ital., xxxvin, p. 140 (1906). Fig.

Habitat-Italy. Leon., Cherm. Ital., Fasc. Iv, No. 77 (1908).

On roots of Cynodon sp.

Genus MATSUCOCCUS Cockerell. Type, matsumuræ.

Matsucoccus Ckll., Can. Ent., xLI, 2, p. 56 (1909).

To include Xylococcus matsumuræ Kuw., Insect World, Ix, 3, March (1905). Fig.; Sanders, Catalogue Coccidæ (1906); Kuwana, Bul. Ag. Exp. Sta. Japan, 1, 2, p. 209 (1907). Fig.

a This species is a synonym of Icerya seychellarum (Westwood), which had been previously discovered in China, Formosa, etc. 
Genus STEINGELIA Nassonow. Type, gorodetskia.

Steingelia Nassonow, Ann. Mus. Zool. Imp. Acad. Sc. St. Petersbourg, xıII, p. 345 (1908).

Ckll., Can. Ent., XLI, 2, p. 56 (1909).

Steingelia gorodetskia Nassonow.

Steingelia gorodetskia Nassonow, Ann. Mus. Zool. Imp. Acad. Sc. St. Petersbourg, xiII, p. 345 (1908).

Habitat-Fussia. Ckll., Can. Ent., xuI, 2, p. 56 (1909). Fig.

Xylococcus macrocarpæ Coleman.

Xylococcus macrocarpa. Coleman, Jn. N. Y. Ent. Soc., xvi, p. 198 (1908). Fig.

Habitat-California.

On Cupressus macrocarpa.

\section{Subfamily ORTHEZIIN E.}

Orthezia californica Ehrhorn.

Orthezia californica Ehrh., Can. Ent., xxxviII, p. 329 (1906).

Habitat-California.

On Bahia sp.

Orthezia martelli Leonardi.

Orthezia martelli Leon., Bol. Zool. Sc. Sup. Portici, III, p. 150 (1908). Fig.

Habitat-Italy.

On grasses (Graminacer).

\section{Subfamily CONCHASPIN 丑.}

Genus FAGISUGA Lindinger. Type, tritoba.

Fagisuga Lindgr., Zeitschr. f. wiss. Insektenbiol., v, 4, p. 107 (1909).

Fagisuga triloba Lindinger.

Fagisuga triloba Lindgr., Berl. Ent. Zeitschr., Iv, 5, p. 107 (1909). Fig.

Habitat-Chile.

On Nothofagus dombeyi.

\section{Subfamily DACTYLOPIINÆE.}

Asterolecanium lineare Lindinger.

Asterolecanium lineare Lindgr., Jahrb. Hamb. wiss. Anst., xxvi, p. - (1908).

Habitat-Brazil.

On cocoanut.

Asterolecanium miliaris robusta Green.

Asterolecanium miliaris var. robusta Green, Mem. Dep. Ag. India, II, 2, p. 19 (1908). Maxwell-Lefroy, Mem. Dep. Ag. India, II, 7, p. 121 (1908).

Habitat-Bengal.

On stems of bamboo (Dendrocalamus sp.). 


\section{Lecaniodiaspis baculifera Leonardi.}

Lecaniodiaspis baculifera Leon., Annali di Agr., vır, p. 11 (1907). Fig.

Habitat-Java.

On an undetermined plant.

\section{Lecaniodiaspis frenchii Green.}

Lecaniodiaspis frenchii "Green" French (sine descr.), Victorian Nat., xxIII, pp. 184, 240 (1907).

Habitat-Victoria, Australia.

$a$ Genus CERCOCOCCUS Scott. Type eremobius.

Cercococcus Scott, Tr. Linn. Soc. Lond., 2d ser., Ix, 12, p. 455 (1907). Fig.

Cerococcus Green, Ent. Mo. Mag., xix, p. 42 (1908).

\section{Cerococcus eremobius (Scott).}

Cercococcus eremobius Scott, Trans. Linn. Soc. Lond., 2d ser., IX, 12, p. 455 (1907). Fig.

Cerococcus eremobius Green, Ent. Mo. Mag., xıx, p. 42 (1908).

Habitat-Algeria.

On Helianthemum kahiricum.

\section{Cerococcus hibisci Green.}

Cerococcus hibisci Green, Mem. Dep. Ag. India, II, 2, p. 19 (1908). Fig.

Maxwell-Lefroy, Mem. Dep. Ag. India, II, 7, pp. 122, 135 (1908).

Habitat-Bombay, India.

On branches of Hibiscus liliflorus and Gossypium sp.

\section{Solenococcus muratæ (Kuwana).}

Cerococcus muratæ Kuwana, Bul. Ag. Exp. Sta. Japan, I, 2, p. 180 (1907). Fig.

Solenophora muratæ Ckll., Can. Ent., xLI, 2, p. 55 (1909).

Habitat-Japan.

On grape; Viburnum odoratissimum.

\section{Kermes bacciformis Leonardi.}

Kermes bacciformis Leon., Bol. Zool. Sc. Sup. Portici, III, p. 156 (1908). Fig.

Habitat-Italy.

On Quercus suber.

\section{Kermes himalayensis Green.}

Kermes himalayensis Green, Ent. Mo. Mag., xx, p. 1 (1909). Fig.

Habitat-Northern India.

On Quercus incana.

Kermes miyasakii Kuwana.

Kermes miyasakii Kuwana, Bul. Ag. Exp. Sta. Japan, I, 2, p. 181 (1907). Fig.

Habitat-Japan.

On Quercus serrata.

\section{Kermes rattani Ehrhorn.}

Kermes rattani Ehrh., Can. Ent., xxxvin, p. 329 (1906).

Habitat-California.

On Quercus chrysolepis.

a A synonym of Cerococeus, having been described from immature specimens. 
Kermes variegatus corticalis Nassonow.

Kermes variegatus corticalis Nass., Ann. Mus. Zool. Ac. Imp. Sc. St. Petersbourg, xIII, p. 490 (1909). Fig.

Habitat-Russia.

On bark of Quercus sp.

\section{Kermes vastus Kuwana.}

Kermes vastus Kuwana, Bul. Agr. Exp. Sta. Japan, I, 2, p. 181 (1907). Fig.

Habitat-Japan.

On Quercus glandulifera.

Genus ATRIPIICIA Cockerell. Type gallicola.

Atriplicia Ckll., Pr. Ent. Soc. Wash., x, p. 169 (1909).

Atriplicia gallicola Cockerell \& Rohwer.

Atriplicia gallicola Ckll. \& Rohw., Pr. Ent. Soc. Wash., x, p. 169 (1909).

Habitat-Colorado; New Mexico.

On leaves of Atriplex canescens.

\section{Eriococcus bahiæ Ehrhorn.}

Eriococcus bahiæ Ehrh., Can. Ent., xxxvIIr, p. 330 (1906).

Habitat-California.

On roots of Bahia sp.

Eriococcus bezzii Leonardi.

Eriococcus bezzii Leon., Bol. Zool. Sc. Sup. Portici, I, p. 148 (1907). Fig.

Cherm. Ital., Fasc. rv, No. 83 (1908).

Habitat-Italy.

On branches and petioles of Rhododendron ferrugineum.

Eriococcus catalinæ Ehrhorn.

Eriococcus catalinæ Ehrh., Can. Ent., xxxvıI, p. 332 (1906).

Habitat-California.

On Artemisia sp.

Eriococcus howardi Ehrhorn.

Eriococcus howardi Ehrh., Can. Ent., xxxviII, p. 331 (1906).

Habitat-California.

On Quercus sp.

\section{Eriococcus lagerstrœmiæ Kuwana.}

Eriococcus lagerstrœmiæ Kuwana, Bul. Ag. Exp. Sta. Japan, I, 2, p. 182 (1907). Fig. Habitat-Japan.

On Ficus carica; Lagerstrœmia indica.

\section{Eriococcus latialis Leonardi.}

Eriococcus latialis Leon., Bol. Zool. Sc. Sup. Portici, I, p. 144 (1907).

Habitat-Italy.

On an undetermined plant.

Eriococcus quercus gilensis Cockerell.

Eriococcus quercus gilensis Ckll., Pr. Ent. Soc. Wash., x, p. 167 (1909).

Habita1-Arizona.

On Quercus toumeyi. 
Genus LEFROYIA Green. Type castaneæ.

Lefroyia Green, Mem. Dep. Ag. India, II, 2, p. 21 (1908).

\section{Lefroyia castaneæ Green.}

Lefroyia castanex Green, Mem. Dep. Ag. India, II, 2, p. 21. (1908). Fig.

Habitat-Assam.

On smaller branches of Castanea sp.

\section{Stictococcus multispinosus Newstead.}

Stictococcus multispinosus Newst., Jn. Econ. Biol., I, 4, p. 150 (1908).

Habitat-East Africa.

Dactylopius argentinus Dominguez.

Dactylopius argentinus Dominguez, Trab. Mus. Farm. Fac. Cienc. Med., no. 17 (1907).

Dominguez, Bol. Min. Ag., vш, 3, pp. 148, 150 (1907).

Habitat-Argentina.

On Cactaceæ (Opuntia ficus-indica and O. aurantiaca).

Dactylopius ceylonicus (Green).

Coccus cacti var. ceylonicus Green, Ind. Mus. Notes, Iv, 1, p. 7 (1896).

Mask., N. Z. Trans., xxıx, p. 319 (1897).

Coccus indicus Green, Mem. Dep. Ag. India, II, 2, p. 28 (1908). Fig.

Habitat-Ceylon; India.

On Opuntia dillenii.

a Sphærococcus draperi Newstead.

Sphærococcus draperi Newst., Liverpool Univ. Quart. Jn., I, 2, p. 70 (1906); Agr. News West Ind., v, 3, p. - (1906).

Habitat-Egypt.

Draper, Scale Insects of Egypt, p. 12 (1907).

On date palm.

Genus MACROCEROCOCCUS Leonardi. Type, superbus.

Macrocerococcus Leon., Bol. Zool. Sc. Sup. Portici, r, p. 151 (1907).

Macrocerococcus superbus Leonardi.

Macrocerococcus superbus Leon., Bol. Zool. Sc. Sup. Portici, I, p. 152 (1907). Fig.

Marchal, Compt. Rend. Ac. Sci., Paris, CXLIII, 13, p. 872 (1909).

Habitat-Sardinia; Corsica; France.

On stems of an undetermined grass, and on Lepidium draba; Alyssum mediterraneum; Lotus; Fumaria major; Cetarach officinalis; Antirrhinum latifolium.

Phenacoccus cholodkovskyi Marchal.

Phenacoccus cholodkovskyi Marchal, Ann. Soc. Ent. France, Lxxviı, p. 245 (1908). Fig. Habitat-Southern Russia.

On Triticum vulgare.

a This species must be very close to Phœnicococcus marlatti Ckll., a very common pest of the date palm in Algeria, if it is not indeed identical. The description answers very well for the latter species. 


\section{Phenacoccus colemani Ehrhorn.}

Phenacoccus colemani Ehrh., Can. Ent., xxxviII, p. 332 (1906).

Habitat-California.

On Rubus sp.

\section{Phenacoccus formicarum Leonardi.}

Phenacoccus formicarum Leon., Bol. Zool. Sc. Sup. Portici, III, p. 162 (1908). Fig.

Habitat-Italy.

In nest of ants (Pheidole pallidula).

Phenacoccus graminicola Leonardi.

Phenacoccus graminicola Leon., Bol. Zool. Sc. Sup. Portici, III, p. 160 (1908). Fig.

Habitat-Italy.

On grasses (Graminaceæ).

\section{Phenacoccus hirsutus Green.}

Phenacoccus hirsutus Green, Mem. Dep. Ag. India, II, 2, p. 25 (1908). Fig.

Habitat-India; Tasmania.

"On terminal shoots of an undetermined shrub, attended by ants (Cremastogaster rogenhoferi), which had constructed shelters around the colonies of insects."

Phenacoccus iceryoides Green.

Phenacoccus iceryoides Green, Mem. Dep. Ag. India, II, 2, p. 26 (1908).

Maxwell-Lefroy, Mem. Dep. Ag. India, II, 7, p. 129 (1908).

Habitat-Calcutta, Tanjore, Surat, India.

On mango; Boswellia; Capparis horrida.

Phenacoccus insolitus Green.

Phenacoccus insolitus Green, Mem. Dep. Ag. India, 11, 2, p. 26 (1908). Fig.

Habitat-Bengal.

On Sida cordifolia.

\section{$a$ Phenacoccus ramonæ Essig.}

Phenacoccus ramonæ Essig, Pomona Jn. Ent., I, 2, p. 44 (1909). Fig.

Habitat-California.

On roots of black sage (Ramona stachyoides).

Genus COCCURA Sulc. Type, comari Kunow.

Coccura Sulc., Nachrichtsbl. Naturfrsch.-Klubs, Prossnitz, x, 7 pp. (1907); Lindgr., Zeitschr. f. wiss. Insektenbiol., Iv, 12, p. 475 (1908).

A new genus for the reception of Coccus (Phenacoccus) comari Kunow, Ent. Nachrichten, vi, p. 46 (1880).

Ceroputo volynicus Nassonow.

Ceroputo volynicus Nass., Ann. Mus. Zool. Ac. Imp. Sc. St. Petersbourg, XıI, p. 471 (1909). Fig.

Habitat-Russia.

On leaves and stems of Dactylis glomerata.

a This is undoubtedly an immature stage of Ceroputo yuccæ (Coquillett). The lateral patches of spines on each segment, and the incompletely developed 7 -jointed antennæ indicate strongly its connection with the latter species.

12600-No. 16, pt 3-C9-2 
Genus LACHNODIELLA von Ihering. Type, cecropix.

Lachnodiella von Iher. (sine descr.), Bot. Jahrb., Xxxıx, 5, p. 680 (1907).

Lachnodiella cecropiæ von Ihering.

Lachnodiella cecropiæ von Iher. (sine descr.), Bot. Jahrb., xxxıx, 5, p. 680 (1907).

Habitat-Brazil.

On Cecropia adenopus.

\section{Pseudococcus agrifoliæ Essig.}

Pseudococcus agrifoliæ Essig, Pomona Jn. Ent., I, 2, p. 42 (1909). Fig.

Habitat-California.

Beneath bark and in cracks of bark of Quercus agrifolia.

Pseudococcus artemisiæ Essig.

Pseudococcus artemisix Essig, Pomona Jn. Ent., I, 2, p. 38 (1909). Fig.

Habitat-California.

"Under bark of Artemisia californica."

Pseudococcus citri coleorum Marchal.

Pseudococcus citri var. coleorum Marchal, Ann. Soc. Ent. France, Lxxvir, p. 236 (1908).

Habitat-France.

On Coleus.

Pseudococcus coffeæ (Newstead).

Dactylopius n. sp. Newst. (sine descr.), Liverpool Univ. Quart. Jn., I, 2, p. 74 (1906). coffeæ Newst., Jn. Econ. Biol., III, 2, p. 37 (1908). Fig.

Habitat-Java.

On Liberian coffee.

\section{Pseudococcus cupressi Coleman.}

Pseudococcus cupressi Coleman, Jn. N. Y. Ent. Soc., xvi, p. 197 (1908). Fig.

Habitat-California.

On Cupressus macrocarpa.

Pseudococcus (?) cycliger Leonardi.

Pseudococcus cycliger Leon., Bol. Zool. Sc. Sup. Portici, III, p. 168 (1908). Fig.

Habitat-Italy.

In nest of ants (Aphenogaster testaceo-pilosus).

Pseudococcus elongatus Reuter.

a Pseudococcus graminis Reuter, Medd. Soc. Faun. Fenn., p. 66 (1904). elongatus Reuter, Medd. Soc. Faun. Fenn., p. 251 (1904). elongatus Sanders, Catalogue Coccidæ, p. 5 (1906).

Habitat-Finland.

On Phleum pratense; Poa pratensis.

Pseudococcus juniperi Ehrhorn.

Pseudococcus juniperi Ehrh., Can. Ent., xxxvirI, p. 333 (1906).

Habitat-Arizona.

On Juniperus virginiana. 
Pseudococcus longipes Leonardi.

Pseudococcus longipes Leon., Bol. Zool. Sc. Sup. Portici, III, p. 166 (1908). Fig.

Habitat-Italy.

On Alocasia macrorica.

\section{Pseudococcus myrmecarius Leonardi.}

Pseudococcus myrmecarius Leon., Bol. Zool. Sc. Sup. Portici, III, p. 164 (1908). Fig. Habitat-Sardinia.

In nest of ants (Camponotus sp.).

\section{Pseudococcus obscurus Essig.}

Pseudococcus obscurus Essig, Pomona Jn. Ent., I, 2, p. 43 (1909). Fig.

Habitat-California.

"On Opuntia and under the bark of Sambucus glauca."

\section{Pseudococcus saccharifolii (Green).}

Dactylopius saccharifolii Green, Mem. Dep. Ag. India, II, 2, p. 23 (1908).

Maxwell-Lefroy, Mem. Dep. Ag. India, II, 7, p. 124 (1908).

Habitat-Bengal.

Fig.

On leaves of sugar cane.

Pseudococcus (?) takæ (Kuwana).

Dactylopius takæ Kuwana, Bul. Ag. Exp. Sta. Japan, I, 2, p. 184 (1907). Fig.

Pseudococcus takæ Ckll., Can. Ent., Xli, 2, p. 55 (1909).

Habitat-Japan.

On bamboo.

\section{Pseudococcus theæcola (Green).}

Dactylopius thexcola Green, Mem. Dep. Ag. Ind., I, 5, p. 347 (1907). Fig.

Green, Mèm. Dep. Ag. Ind., II, 2, p. 24 (1908).

Habitat-India.

"On roots of tea plants."

\section{Pseudococcus virgatus madagascariensis (Newstead).}

Dactylopius virgatus var. madagascariensis Newst., Liverpool Univ. Quart. Jn., III, 6, p. 9 (1908). Fig.

Habitat-Madagascar.

"On an unknown plant."

Pseudocuccus vovæ Nassonow.

Pseudococcus (Dactylopius) vovæ Nass., Ann. Mus. Zool. Ac. Imp. Sc. St. Petersbourg, x111, p. 484 (1909). Fig.

Habitat-Russia.

On Juniperus communis.

\section{Ripersiella kelloggi Ehrhorn.}

Ripersiella kelloggi Ckll. (sine descr.), Pr. Biol. Soc. Wash., xIv, p. 166 (1901).

Habitat-California.

Ehrh., Can. Ent., xxxvin, p. 334 (1906).

On bunch-grass. 


\section{Ripersia candidata Cockerell.}

Ripersia candidata Ckll., Ann. Mag. N. H. (7), vıI, p. 53 (1901).

"=6-jtd. R. lasii from Massachusetts."-(Ckll. in litt.)

Ripersia donisthorpei Newstead.

Ripersia donisthorpei Newst., Ent. Rec. Jn. Variation, xıx, p. 5 (1907). Fig.

Habitat-England.

In nests of Ponera contracta.

Ripersia formicarii Newstead.

Ripersia formicarii Newst., Ent. Rec. Jn. Variation, xıx, p. 5 (1907). Fig.

Habitat-England.

Associated with Lasius flavus.

\section{Ripersia hypogea Leonardi.}

Ripersia hypogea Leon., Bol. Zool. Sc. Sup. Portici, IlI, p. 176 (1908). Fig.

Habitat-Italy.

Underground.

Ripersia inquilina Leonardi.

Ripersia inquilina Leon., Bol. Zool. Sc. Sup. Portici, III, p. 174 (1908). Fig.

Habitat-Sardinia.

In nest of undetermined ants.

Ripersia japonica Kuwana.

Ripersia japonica Kuwana, Bul. Ag. Exp. Sta. Japan, I, 2, p. 186 (1907). Fig.

Habitat-Japan.

Under sheathing, base of leaf of Miscanthus sp.

Ripersia libera Leonardi.

Ripersia libera Leon., Bol. Zool. Sc. Sup. Portici, II, p. 170 (1908). Fig.

Habitat-Italy.

On an undetermined grass.

\section{Ripersia (?) oryzæ Kuwana.}

Ripersia oryzæ Kuwana, Bul. Ag. Exp. Sta. Japan, I, 2, p. 186 (1907). Fig.

Habitat-Japan.

$$
\text { Ckll., Can. Ent., XuI, 2, p. } 55 \text { (1909). }
$$

On roots of rice (Oryza) and other plants.

Ripersia sardiniæ Leonardi.

Ripersia sardiniæ Leon., Bol. Zool. Sc. Sup. Portici, III, p. 173 (1908). Fig.

Habitat--Sardinia.

In nest of ants (Solenopsis sp.).

Genus MICROCocCUs Leonardi. Type, silvestrii.

Micrococcus Leon., Bol. Zool. Sc. Sup. Portici, I, p. 135 (1907).

Micrococcus silvestrii Leonardi.

Micrococcus silvestrii Leon., Bol. Zool. Sc. Sup. Portici, I, p. 136 (1907). Fig.

Habitat-Sardinia.

In nests of Tapinoma erraticum. 
Micrococcus similis Leonardi.

Micrococcus similis Leon., Bol. Zool. Sc. Sup. Portici, r, p. 143 (1907). Fig.

Habitat-Sardinia.

On roots of a cereal.

Antonina (?) africana Newstead.

Antonina (?) africana Newst. (sine descr.), Liverpool Univ. Quart. Jn., I, 2, pp. 69, 72 (1906).

Habitat-Egypt.

Draper (sine descr.), Scale Ins. of Egypt, p. 11 (1907).

On "sunt" tree (Acacia arabica var. nilotica).

Antonina indica Green.

Antonina indica Green, Mem. Dep. Ag. India, II, 2, p. 27 (1908). Fig.

Habitat-Bengal.

On bases of leaves of "hariali" grass.

Antonina phragmitis Marchal.

Antonina phragmitis Marchal, Compt. Rend. Ac. Sci., Paris, cxurr, 13, p. 872 (1909).

Habitat-France.

On Phragmites gigantea.

\section{Subfamily TACHARDIIN ÆE.}

Tachardia argentina Dominguez.

Tachardia argentina Dominguez (sine descr.), An. Soc. Cient. Argentina, p. 219 (1906).

Fig.

Dominguez (sine descr.), Bol. Min. Ag., vir, 3, pp. 148, 150 (1907).

Habitat-Argentina.

On Acacia cavenia.

Tachardia decorella theæ Green \& Mann.

Tachardia decorella var. theæ Green \& Mann, Mem. Dep. Ag. India, r, 5, p. 348 (1907).

Habitat-India.

Green, Mem. Dep. Ag. India, II, 2, p. 28 (1908).

On tea.

\section{Subfamily COCCIN 2 .}

Ceronema caudata Froggatt.

Ceronema caudata Froggatt, n. sp. - (?).

Froggatt, Australian Insects, p. 376 (1907).

Habitat-New South Wales, Australia.

On "gum-trees."

\section{Pulvinaria antigoni Green.}

Pulvinaria antigoni Green, Tr. Linn. Soc. Lond., xı, 2, pp. 199, 204 (1907). Fig.

Habitat-Seychelles.

On Antigonon.

Pulvinaria burkilli Green.

Pulvinaria burkilli Green, Mem. Dep. Ag. India, II, 2, p. 31 (1908). Fig.

Habitat-India.

On leaves of Croton tiglium. 
Pulvinaria jacksoni Newstead.

Pulvinaria jacksoni Newst., Jn. Econ. Biol., II, 4, p. 155 (1908). Fig.

Habitat-West Africa.

On cacao and Ficus sp.

Pulvinaria kuwacola Kuwana.

Pulvinaria kuwacola Kuwana, Bul. Ag. Exp. Sta. Japan, I, 2, p. 188 (1907). Fig.

Habitat-Japan. Ckll., Can. Ent., xLI, 2, p. 55 (1909).

On mulberry.

Pulvinaria oxientalis Nassonow.

Pulvinaria orientalis Nass., Ann. Mus. Zool. Ac. Imp. Sc. St. Petersbourg, xıII, p. 493 (1909). Fig.

Habitat-Russia.

On branches of Haloxylon ammodendron.

Pulvinaria plucheæ Ehrhorn.

Pulvinaria plucheæ Ehrh., Can. Ent., xxxvıI, p. 334 (1906).

Habitat-California.

On Pluchea sericea.

Genus STOTzIA Marchal. Type, striata.

Stotzia Marchal, Bul. Soc. Ent. Fr., p. 143 (1906).

Stotzia striata Marchal.

Stotzia striata Marchal, Bul. Soc. Ent. Fr., p. 144 (1906).

Habitat-Algeria.

On branches of Ephedra altissima.

Genus EUPHILIPPIA Berlese \& Silvestri. Type, olivina.

Euphilippia Berl. \& Silv., Redia, III, fasc. 2, p. 396 (1905).

Euphilippia olivina Berlese \& Silvestri.

Euphilippia olivina Berl. \& Silv., Redia, III, fasc. 2, p. 398 (1905). Fig.

Habitat-Italy.

On olive.

\section{Ceroplastes africanus senegalensis Marchal.}

Ceroplastes africanus var. senegalensis Marchal, Bul. Soc. Zool. France, xxxiv, p. 68 (1909).

Marchal, Mém. Soc. Zool. France, xxiI, p. 168

Habitat-Senegal. (1909).

On Acacia arabica; $A$. tortilis.

Ceroplastes bussei Newstead.

Ceroplastes bussei Newst. (sine descr.), Liverpool Univ. Quart. Jn., I, 2, pp. 71, 74 (1906).

Habitat-Cameroon, West Africa.

On cacao.

Ceroplastes tenuitectus Green.

Ceroplastes tenuitectus Green, Tr. Linn. Soc. Lond., xII, 2, p. 204 (1907). Fig.

Habitat-Aldabra Isl.

On "bois la fumee." 
Ceroplastes theobromæ Newstead.

Ceroplastes theobromæ Newst. (sine descr.), Liverpool Univ. Quart. Jn., I, 2, pp. 71, 74 (1906).

Newst. (sine descr.), Scale Ins. of Egypt, p. 16 (1907).

Newst., Jn. Econ. Biol., III, 2, p. 38 (1908).

Habitat-Cameroon, West Africa.

On cacao (Theobroma cacao).

\section{Ceroplastes uvariæ Marchal.}

Ceroplastes uvariæ Marchal, Bul. Soc. Zool. France, xxxrv, p. 68 (1909).

Marchal, Mém. Soc. Zool. France, xxII, p. 170 (1909). Fig.

Habitat-French Guinea.

On Uvaria sp. (Anonaceæ).

\section{Ceroplastes vuilleti Marchal.}

Ceroplastes vuilleti Marchal, Bul. Soc. Zool. France, xxxır, p. 68 (1909).

Habitat-Senegal.

Marchal, Mém. Soc. Zool. France, xxIı, p. 165 (1909). Fig.

On Ormosia laxiflora (Leguminosæ).

\section{Ceroplastodes chiton Green.}

Ceroplastodes chiton Green (sine descr.), Mem. Dep. Ag. India, II, 2, p. 32 (1908).

Habitat-India.

On Cajanus indicus.

\section{Coccus gymnospori (Green).}

Lecanium gymnospori Green, Mem. Dep. Ag. India, II, 2, p. 29 (1908). Fig.

Habitat-Indià.

On Gymnosporia montana.

\section{Coccus hesperidum javanensis (Newstead).}

Lecanium (Trechocorys) hesperidum var. africanum Newst. (sine descr.), Liverpool Univ. Quart. Jn., I, 2, p. 74 (1906).

Lecanium hesperidum var. javanensis Newst., Jn. Econ. Biol., III, 2, p. 38 (1908). Fig. Habitat-Java.

On Liberian coffee.

\section{Coccus nicotianæ (Newstead).}

Lecanium nicotianæ Newst., Liverpool Univ. Quart. Jn., III, 6, p. 8 (1908). Fig。 Habitat-Madagascar.

On tobacco.

\section{Coccus tuberculatus Kotinsky.}

Coccus tuberculatus Kotinsky, Pr. Haw. Ent. Soc., I, pt. 5, p. 168 (1908). Fig.

Habitat-Singapore.

On leaves of unknown tree.

Mesolecanium perditulum Cockerell \& Robbins.

Mesolecanium perditulum Ckll. \& Robb., Can. Ent., XLI, p. 150 (1909).

Habitat-Nicaragua.

"On bark of small branches of tree No. 2122"-C. F. Baker coll. 


\section{Akermes montanus (Green).}

Lecanium montanum Green, Mem. Dep. Ag. India, II, 2, p. 30 (1908). Fig.

Habitat-Himalaya Region, India.

On twigs of undetermined shrub.

Genus PALÆOLECANIUM Sulc. Type, bituberculatum.

Palæolecanium Sulc, Ent. Mo. Mag., XIX, p. 36 (1908).

Genus PARTHENOLECANIUM Sulc. Type, coryli.

Parthenolecanium Sulc, Ent. Mo. Mag., xix, p. 36 (1908).

Genus SPHEROIECANIUM Sulc. Type, prunastri.

Sphærolecanium Sulc, Ent. Mo. Mag., xIx, p. 36 (1908).

Globulicoccus n. subgen. of Lecanium auctt. Type, fuscum.

Lindgr., Ent. Blätter, Schwabach, III, 8, p. 113; 9, p. 136 (1907).

Lindgr., Ber. Stat. f. Pflanzensch. Hamb., Ix, p. 7 (1907).

Lecanium cecconi Leonardi.

Eulecanium cecconi Leon., Bol. Zool. Sc. Sup. Portici, III, p. 178 (1908). Fig.

Habitat-Italy.

On Menispermum canadense.

Lecanium glandi (Kuwana).

Lecanium glandi Kuwana, Bul. Ag. Exp. Sta. Japan, I, 2, p. 191 (1907). Fig.

Eulecanium glandi Ckll., Can. Ent., xLI, 2, p. 56 (1909).

Habitat-Japan.

On apple, pear, and other trees.

\section{Lecanium kunoensis (Kuwana).}

Lecanium kunoensis Kuwana, Bul. Ag. Exp. Sta. Japan, I, 2, p. 121 (1907). Fig. Ckll., Can. Ent., Xli, 2, p. 56 (1909).

Habitat-Japan.

On Rharinus japonica; Prunus mume; Pyrus sinensis.

\section{Lecanium pulchrum Marchal.}

Lecanium pulchrum King (sine descr.), Alig. Zeits. f. Ent., viII, p. 410 (1903).

Eulecanium pulchrum Sanders, Catalogue Coccidæ, p. 9 (1906).

Lecanium rubellum Lindgr., Ent. Blätter, Schwabach, iI, 9, p. — (1907).

Lindgr., Ber. Stat. f. Pflanzensch. Hamb., Ix, p. 7 (1907).

pulchrum Marchal, Ann. Soc. Ent. France, LXxviI, p. 304 (1908). Fig.

Habitat-Germany.

On Calluna vulgaris; Ulex europæus; Rosa arvensis; Rubus sp.; Sarothamnus scoparius.

\section{Lecanium sericeum Lindinger.}

Lecanium sericeum Lindgr., Insekten Börse, xxıII, p. 147, Sept. (1906). Fig.

Lecanium (Globulicoccus) sericeum Lindgr., Ent. Blätter, Schwabach, III, 8 and 9 (1907).

Lindgr., Ber. Stat. f. Pflanzensch. Hamb., Ix, p. 7

Habitat-Bavaria. (1907).

On Abies pectinata. 
Paralecanium cocophyilæ Banks.

Paralecanium cocophyllæ Banks, Philippine Jn. Sci., I, 3, pp. 223, 235 (1906). Fig. Habitat-Philippines.

On cocoanut palm.

"Lecanium" montonoæ Newstead.

Lecanium montonoæ Newst. (sine descr.), Liverpool Univ. Quart. Jn., I, 2, p. 69 (1906).

montonoai Lindgr. (sine descr.), Ent. Wochenblatt, xxrv, 5, p. 19 (1907). Habitat-Egypt.

"Lecanium" nishigaharæ Kuwana.

Lecanium nishigaharæ Kuwana, Bul. Ag. Exp. Sta. Japan, I, 2, p. 192 (1907). Fig. Habitat-Japan.

On mulberry (Morus sp.).

Genus HEMILECANIUM Newstead. Type, theobromæ.

Hemilecanium. Newst. (sine descr.), Liverpool Univ. Quart. Jn., I, 2, pp. 71, 74 (1906). Newst., Jn. Econ. Biol., III, 2, p. 39 (1908).

Hemilecanium theobromæ Newstead.

Hemilecanium theobromæ Newst. (sine descr.), Liverpool Univ. Quart. Jn., I, 2, pp. 71,74 (1906).

Newst. (sine descr.), Scale Ins, of Egypt, p. 16 (1907).

Habitat-Cameroon, West Africa.

Newst., Jn. Econ. Biol., III, 2, p. 39 (1908). Fig.

On Theobroma cacao.

\section{${ }^{a}$ Genus HOUARDIA Marchal. Type, troglodytes.}

Houardia Marchal, Compt. Rend. Soc. Biol., Paris, Lxvi, p. 586 (1909).

Houardia troglodytes Marchal.

Houardia troglodytes Marchal, Compt. Rend. Soc. Biol., Paris, LXvi, p. 586 (1909).

Marchal, Bull. Soc. Zool. France, xxxiv, p. 73 (1909).

Marchal, Mém. Soc. Zool. France, xxır, p. 171 (1909). Fig.

Habitat-Senegal.

In tunnels in branches of Balanites (Agialida) xgyptiaca inhabited by ants of the genus Cremastogaster near kneri Mayr.

Lecanopsis mirmecophila Leonardi.

Lecanopsis mirmecophila Leon., Bol. Zool. Sc. Sup. Portici, III, p. 181 (1908). Fig. Habitat-Sardinia.

In nest of ants (Tetramorium cæspitum).

Aclerda biwakoensis Kuwana.

Aclerda (?) biwakoensis Kuwana, Bul. Ag. Exp. Sta. Japan, I, 2, p. 187 (1907). Fig.

Habitat-Japan.

Ckll., Can. Ent., xLI, 2, p. 55 (1909).

On Phragmites communis.

$a$ An unfortunate name, because of its similarity to Howardia Berlese \& Leonardi, a genus of Diaspine Coccidæ. 


\section{Subfamily DIASPINA.}

Chionaspis etrusca Leonardi.

Chionaspis etrusca Leon., Annali di Agr., vın, p. 44 (1908).

Leon., Bol. Zool. Sc. Sup. Portici, III, p. 184 (1908). Fig.

Habitat-Italy.

Leon., Cherm. Ital., iv, No 88 (1908).

On Tamarix sp.

\section{Chionaspis gryphæformis Newstead.}

Chionaspis gryphæformis Newst. (sine descr.), Liverpool Univ. Quart. Jn., 1, 2, p. 71 (1906).

crypheaformis Draper (sine descr.), Scale Ins. of Egypt, p. 15 (1907). Cairo. Habitat-Egypt.

"On four unnamed plants; one a conifer."

\section{Chionaspis inday Banks.}

a Chionaspis candida Banks, Philippine Jn. Sci., I, 3, pp. 222, 232 (1906). Fig.

Chionaspis inday Banks, Philippine Jn. Sci., I, 7, p. 787 (1906).

Habitat-Philippines.

On cocoanut palm.

\section{Chionaspis manni Green.}

Chionaspis manni Watt \& Mann (sine descr.), Pests and Blights of Tea Plant, 2nd ed., p. 309 (1903).

Green, Mem. Dep. Ag. India, I, 5, pp. 342, 344 (1907). Fig.

Mann, Mem. Dep. Ag. India, I, 5, p. 351 (1907).

Habitat-India

Green, Mem. Dep. Ag. India, II, 2, p. 37 (1908).

On tea; Ficus sp.; Solanum melongena.

\section{Chionaspis micropori Marlatt.}

Chionaspis micropori Marlatt, Bul. U. S. Bur. Ent., t. s. 16, pt. 2, p. 25 (1908). Fig. Habitat-Shansi Province, China

On Populus tremula.

\section{Chionaspis vuilleti Marchal.}

Chionaspis vuilleti Marchal (sine descr.), Compt. Rend. Soc. Biol., Lxvi, p. 587 (1909). Marchal, Bul. Soc. Zool. France, xxxıv, p. 69 (1909).

Habitat-Guinea.

Marchal, Mém. Soc. Zool. France, xxır, p. 175 (1909). Fig.

On gum copal (Copaifera guibourtiana?)

\section{Diaspis barberi Green.}

Diaspis barber Green, Mem. Dep. Ag. India, II, 2, p. 35 (1908). Fig.

Habitat-Tanjore, India.

On branches of Loranthus sp.

\section{Diaspis (?) ericicola Marchal.}

Draspis (Adiscodiaspis) ericicola Marchal, Compt. Rend. Ac. Sci., Paris, cxlvin, 13, p. 871 (1909).

Habitat-France.

On Erica arborea. 
Aulacaspis javanensis Newstead.

Aulacaspis (Diaspis) javanensis Newst. (sine descr.), Liverpool Univ. Quart. Jn., I, 2, p. 74 (1906).

Aulacaspis javanensis Newst., Jn. Econ. Biol., III, 2, p. 35 (1908). Fig.

Habitat-Java.

"On various plants."

\section{Aulacaspis penzigi Leonardi.}

Aulacaspis penzigi Leon., Annali di Agr., viI, p. 14 (1907). Fig.

Habitat-Java.

On leaves of Ilex sp.

Aulacaspis tubercularis Newstead.

Aulacaspis (Diaspis) tubercularis Newst., Liverpool Univ. Quart. Jn., I, 2, p. 73 (1906). Aulacaspis cinnamomi Newst., Jn. Econ. Biol., III, 2, p. 34 (1908). Fig.

Habitat-Java.

On Cinnamomum zeylanicum.

Hemichionaspis aspidistræ gossypii Newstead.

Chionaspis (Hemichionaspis) aspidistræ var. gossypı Newst. (sine descr.), Liverpool Univ. Quart. Jn., I, 2, p. 74 (1906). Newst., Jn.Econ.Biol., III, 2, p. 37

Habitat-Java. (1908).

On Gossypium hirsutum.

Hemichionaspis fici Green.

Hemichionaspis fici Green, Mem. Dep. Ag. India, II, 2, p. 37 (1908). Fig.

Habitat-Bengal.

On stems of Ficus glomerata.

\section{Hemichionaspis minima Green.}

Hemichionaspıs minima Green, Mem. Dep. Ag. India, II, 2, p. 38 (1908). Fig.

Habitat-Bengal.

On leaves of "Banian" tree (Ficus sp.).

Hemichionaspis orlandi Leonardi.

Hemichionaspis orlandi Leonardi, Redia, I11, p. 5 (1906). Fig. orlandii Lindgr., Ent. Wochenblatt., xxıv, 5, p. 19 (1907).

Habitat-Brazil.

"Underside of leaves of an undetermined plant."

Pinnaspis javanica Leonardi.

Pinnaspis javanica Leon., Annali di Agr., vir, p. 17 (1907). Fig.

Habitat-Java.

On leaves of Ilex sp.

Pinnaspis rombica Leonardi.

Pinnaspis rombica Leon., Annali di Agr., vır, p. 16 (1907). Fig.

Habitat-Java.

On leaves of Persea sp. 
Genus ACTENASPIS Leonardi. Type, pusilla.

Actenaspis Leon., Annali di Agr., vı, p. 25 (1906). Fig.

A new genus from Leucaspis auctt.

Genus ANAMASPIS Leonardi. Type, loewi.

Anamaspis Leon., Annali di Agr., vı, p. 22 (1906). Fig.

A new genus from Leucaspis auctt.

\section{Leucaspis affinis Leonardi.}

Leucaspis affinis Leon., Annali di Agr., vi, p. 4 (1906). Fig.

Habitat-France.

On Pinus sylvestris.

\section{Leucaspis ephedræ Marchal.}

Leucaspis ephedræ Marchal, Bul. Soc. Zool. France, xxxiv, p. 59 (1909).

Habitat-Algeria.

On Ephcdra corsoniana.

\section{Leucaspis indica Marlatt.}

Leucaspis indica Marlatt, Bul., U. S. Bur. Ent., t. s. 16, Pt. II, p. 26 (1908). Fig.

Habitat-Miami, Fla., and Mayaguez, P. R.; imported from India.

On mango.

\section{Leucaspis pistaciæ Lindinger.}

Leucaspis pistaciæ Lindgr., Jahrb. Hamb. wiss. Anst., xxıı, p. 403 (1906).

Habitat-Cyprus.

On leaves of Pistacia lentiscus.

$a$ Leucodiaspis Sign.<Lindinger, Jahrb. Hamb. wiss. Anst., xxv (1908). Not valid.

Adiscofiorinia (n. g. of Fiorinia), Leonardi, Redia, III, pp. 17, 52 (1906).

Anamefiorinia (n. g. of Fiorinia), Leonardi, Redia, III, pp. 17, 48 (1906).

Trullifiorinia (n. g. of Fiorinia), Leonardi, Redia, III, pp. 17, 41 (1906).

Fiorinia atalantiæ Leonardi.

Fiorinia (Adiscofiorinia) atalantiæ Leon., Redia, 11, p. 54 (1906). Fig.

Habitat-Ceylon.

On Atalantia zeylanica.

a Lindinger resurrects Leucodiaspis Sign. for Leucaspis, and assigns to it all the species formerly known under the latter name, and refers to Leucospis Fab., Syst. Entom., p. 361, Nr. 114 (1775) (Hymenoptera). The latter name has no reference or connection with Leucaspis Targ.-Tozz, a genus of Coccidae erected in 1869. Leucodiaspis credited by Signoret [Ann. Soc. Ent. France, Ix, p. 99 (1869)] to TargioniTozzetti is an error in spelling and of no value.

The following reference to Leucaspis appears in Atti Soc. Ital. di Sci. Nat., xi, p. 734 (1869), which establishes its validity:

\section{"Coccidarum Catalogus Targ.-Tozz.}

"Gen. 22. Leucaspis nob. Gen. n.

"Sp. 1. Leucaspis candida nob. Diaspis candida nob. 1867.

"Sp. 2. Leucaspis Signoreti nob. n.sp. 1868 (a D. Signoreti recepta, Pini sp. incola)." 
Fiorinia diaspiformis Newstead.

Fiorinia diaspiformis Newst. (sine descr.), Liverpool Univ. Quart. Jn., I, 2, p. 74 (1906). diaspitiformis Lindgr. (sine descr.), Ent. Wochenblatt., xxıv, 5, p. 20 (1907). diaspiformis Newst., Jn. Econ. Biol., III, 2, p. 35 (1908). Fig.

Habitat-Java.

On Piper sp.

Fiorinia hirsuta Marchal.

Fiorinia hirsuta Marchal, Bul. Soc. Ent. Fr., p. 145 (1906).

Habitat-Algeria.

On Nephelium longana and other Sapindacex.

\section{Fiorinia juniperi Leonardi.}

Fiorinia juniperi Leon., Redia, I⿰工, p. 39 (1906). Fig.

Habitat-Ceylon.

On Juniperus bermudiana.

Fiorinia macroprocta (Leonardi).

Trullifiorinia macroprocta Leon., Annali di Agr., vir, p. 19 (1907). Fig.

Habitat-Java.

On leaf of Raphis fabelliformis.

Fiorinia odinæ Leonardi.

Fiorinia odinæ Leon., Redia, III, p. 24 (1906). Fig.

Habitat-Ceylon.

On Odina woodice.

Fiorinia rubrolineata Leonardi.

Fiorinia (Trullifiorinia) rubrolineata Leon., Redia, I11, p. 44 (1906). Fig.

Habitat-Ceylon.

On Murraya exotica.

Fiorinia tumida Leonardi.

Fiorinia tumida Leon., Redia, III, p. 38 (1906). Fig.

Habitat-Ceylon.

On Grewia sp.

\section{Aspidiotus africanus Marlatt.}

Aspidiotus (Diaspidiotus) africanus Marlatt, Bul. U. S. Bur. Ent., t. s. 16, Pt. II, p. 15 (1908). Fig.

Habitat-South Africa.

On fig; apricot; almond; apple; quince; pear; privet; honey-locust (Gleditsia triacanthos); Schinus molle; Acacia horrida; Robinia pseudacacia; Rhus sp.

Aspidiotus cecconi (Leonardi).

Hemiberlesia cecconi Leon., Bol. Zool. Sc. Sup. Portici, III, p. 188 (1908). Fig.

Habitat-Sardinia.

On Osirys alba.

Aspidiotus cocotiphagus Marlatt.

Aspidiotus (Aonidiella) cocotiphagus Marlatt, Bul. U. S. Bur. Ent., t. .. 16, Pt. II, p. 14 (1908). Fig.

Habitat-Santiago de las Vegas, Cuba.

On Cocos nucifera: Citrus trifoliata. 
Aspidiotus comperei Marlatt.

Aspidiotus (s. str.) comperei Marlatt, Bul. U. S. Bur. Ent., t. s. 16, Pt. II, p. 12 (1908). Fig.

Habitat-W. Australia.

On Hake sp. and an undetermined plant.

\section{Aspidiotus corticis-pini Lindinger.}

Aspidiotus corticis-pini Lindgr., Jahrb. Hamb. wiss. Anst., xxvı, p. - (1908).

Habitat-Japan.

On Pinus densiflora.

\section{Aspidiotus coursetiæ Marlatt.}

Aspidiotus (Diaspidiotus) coursetix Marlatt, Bul. U. S. Bur. Ent., t. s. 16, Pt. II, p. 20 (1908). Fig.

Habitat-Mexico.

On Coursetia glandulosa.

\section{Aspidiotus densiflora Bremner.}

Aspidiotus densiflora Bremner, Can. Ent., xxxıx, p. 366 (1907). Fig.

Habitat-California.

On leaves of Quercus densiftora.

\section{Aspidiotus eglandulosus Lindinger.}

Aspidiotus eglandulosus Lindgr., Jahrb. Hamb. wiss. Anst., xxvi, p. - (1908).

Lindgr., Ber. Stat. f. Pflanzensch. Hamb., x, p. 10 (1908).

Habitat-Guatemala; Panama.

On Cereus; "auf Kakteen."

\section{Aspidiotus elæidis Marchal.}

Aspidiotus elæidis Marchal (sine descr.) Compt. Rend. Soc. Biol., Lxvi, p. 587 (1909).

Marchal, Bul. Soc. Zool. France, xxxiv, p. 69 (1909).

Marchal, Mém. Soc. Zool. France, xxıI, p. 179 (1909). Fig.

Habitat-Dahomey.

On oil palm (Elæis guineensis).

Aspidiotus epigææ Marlatt.

Aspidiotus (Hemiberlesia) epigææ Marlatt, Bul. U. S. Bur. Ent., t. s. 16, Pt. II, p. 21 (1908). Fig.

Habitat-Virginia; Ohio.

On trailing arbutus (Epigæa repens).

Aspidiotus herculeanus Doane and Hadden.

Aspidiotus herculeanus Doane and Hadden, Can. Ent., XLI, p. 298 (1909). Fig.

Habitat-Society Islands.

On bark of unknown plant.

\section{Aspidiotus labiatarum Marchal.}

Aspidiotus (Evaspidiotus) labiatarum Marchal, Compt. Rend. Ac. Sci., Paris, cxuvir, 13, p. 872 (1909).

Habitat-Corsica.

On Stachys glutinosa and Teucrium capitatum. 


\section{Aspidiotus lectularius Green.}

Aspidiotuslectularius" Green" French (sine descr.), Victorian Nat., xxIII, p. 184 (1907). Habitat-Victoria, Australia.

\section{Aspidiotus meyeri Marlatt.}

Aspidiotus (s. str.) meyeri Marlatt, Bul. U. S. Bur. Ent., t. s. 16, Pt. II, p. 13 (1908). Fig. Habitat-Peking, China.

On Abies sp.

Aspidiotus mitchelli Marlatt.

Aspidiotus (Hemiberlesia) mitchelli Marlatt, Bul. U. S. Bur. Ent., t. s. 16, Pt. II, p. 22 (1908). Fig.

Habitat-Mitchell's Pass, South Africa.

"On thick, narrow, slightly oblanceolate leaves about $1 \frac{1}{2}$ in. long."

Aspidiotus popularum Marlatt.

Aspidiotus (Hemiberlesia) popularum Marlatt, Bul. U. S. Bur. Ent., t. s. 16, Pt. II, p. 23 (1908). Fig.

Habitat-Arizona; New Mexico.

On cottonwood (Populus sp.).

\section{Aspidiotus privignus Lindinger.}

Aspidiotus privignus Lindgr., Zeitschr. f. wiss. Insektenbiol., v, 5, 7 \& 8, p. 151 (1909).

Fig. in No. 5.

Habitat-Italy; Greece.

On Hypericum coris; Thymelæa tarton (?).

Aspidiotus trabuti Marchal.

Aspidiotus (Hemiberlesia) trabuti Marchal, Bul. Soc. Zool. France, xxxıv, p. 59 (1909). Habitat-Algeria.

On Ephedra altissima.

Aspidiotus transcaspiensis Marlatt.

Aspidiotus (Diaspidiotus) transcaspiensis Marlatt, Bul. U. S. Bur. Ent., t. s. 16, Pt. II, p. 21 (1908). Fig.

Habitat-Transcaspian Russia.

On Populus sp.

Aspidiotus vuilleti Marchal.

Aspidiotus (Hemiberlesia) vuilleti Marchal, Compt. Rend. Soc. Biol., Lxvi, p. 587 (1909).

Marchal, Bul. Soc. Zool. France, xxxrv, p. 73 (1909).

Marchal, Mém. Soc. Zool. France, xxII, p. 178

Habitat-Senegal. (1909). Fig.

On branches of Balanites sp.

\section{Aspidiotus yulupæ Bremner.}

Aspidiotus yulupæ Bremner, Can. Ent., xxxıx, p. 367 (1907). Fig.

Habitat-California.

On Quercus lobata. 


\section{Pseudaonidia ferox (Lindinger).}

Selenaspidus ferox Lindgr., Jahrb. Hamb. wiss. Anst., xxvı, pp. 4, 7 (1909). Fig.

Habitat-Gold Coast, West Africa.

On Euphorbiaceæ.

\section{Pseudaonidia gracilis (Lindinger).}

Selenaspidus gracilıs Lindgr., Jahrb. Hamb. wiss. Anst., xxvı, pp. 4, 10 (1909). Fig. Habitat-Kamerun, West Africa.

On leaves of Agelaia fragrans and Tricalysia sp.

\section{Pseudaonidia greeni Marlatt.}

Pseudaonidia greeni Marlatt, Pr. Ent. Soc. Wash., Ix, pp. 135, 138, 140 (1908).

Habitat-Java.

On mangosteen and mango.

\section{Pseudaonidia junctiloba Marlatt.}

Pseudaonidia junctiloba Marlatt, Pr. Ent. Soc. Wash., Ix, pp. 135, 138 (1908).

Habitat-Victoria, Australia.

On Acacia sp.

\section{Pseudaonidia kamerunica (Lindinger).}

Selenaspidus kamerunicus Lindgr., Jahrb. Hamb. wiss. Anst., xxvr, pp. 4, 7 (1909). Fig.

Habitat-Kamerun, West Africa.

On palms.

\section{Pseudaonidia lounsburyi Marlatt.}

Pseudaonidia (Selenaspidus) lounsburyi Marlatt, Pr. Ent. Soc. Wash., 1x, pp. 134, 136, 139 (190S).

Habitat-South Africa.

On Mesembryanthemum edule.

Pseudaonidia magna (Lindinger).

Selenaspidus magnus Lindgr., Jahrb. Hamb. wiss. Anst., xxvı, pp. 4, 9 (1909). Fig. Habitat-A byssinia.

On Euphorbia sp.

\section{Pseudaonidia silvatica (Lindinger).}

Selenaspidus silvaticus Lindgr., Jahrb. Hamb. wiss. Anst., xxvı, pp. 4, 10 (1909). Fig. Habitat-Kamerun, West Africa; Amani, East Africa.

On Anacardiaceæ; Rinorea exappenáiculata; Ficus indica; Bandeiræa speciosa.

Genus FURCASPIS Lindinger. Type, biformis.

Furcaspis Lindgr., Berl. Ent. Zeitschr., L11, pp. 98, 99 (1908).

Includes Furcaspis (Aspidiotus) biformis (Ckll.) and F. (Aspidiotus) capensis (Walk.).

\section{Furcaspis oceanica Lindinger.}

Aspidiotus biformis Lindgr., Ber. Stat. f. Pflanzensch., vi, p. 44 (1904). In part. Furcaspis oceanica Lindgr., Zeitschr. f. wiss. Insektenbiol., v. 5, p. 149 (1909). Fig. in Nos. 7 and 8.

Habitat-Jaluit Islands in Marshall group.

On fruit hulls of cocoanut. 
Chrysomphalus barbusano Lindinger.

Chrysomphalus barbusano Lindgr., Berl. Ent. Zeitschr., LII, p. 101 (1908).

Lindgr., Ber. Stat. f. Pflanzensch. Hamb., p. 8 (1908).

Lindgr., Zeitschr. f. wiss. Insektenbiol., v, 4, p. 105 (1909). Fig.

Habitat-Teneriffe, Canary Islands.

On Phobe barbusano.

\section{Chrysomphalus minutus Kotinsky.}

Chrysomphalus minutus Kotinsky, Pr. Haw. Ent. Soc., I, pt. 5, pp. 170-171 (1908). Fig.

Habitat--Singapore.

On leaf of undetermined plant.

\section{Chrysomphalus propsimus Banks.}

Chrysomphalus propsimus Banks, Philippine Jn. Sci., I, 3, pp. 221, 230 (1906). Fig. Habitat-Philippines.

On leaves of Cocos nucifera.

\section{Chrysomphalus taxus (Leonardi).}

Aonidiella aurantii (Mask.) Berl. \& Leon., Cherm. Ital., Fasc. I, no. 23 (1895). taxus Leon., Redia, IIr, p. 1 (1906). Fig. Leon., Bol. Zool. Sc. Sup. Portici, p. 131 (1907). Fig.

Habitat-Italy.

On Taxus baccata.

\section{Chrysomphalus triglandulosus Green.}

Aspidiotus (Chrysomphalus) triglandulosus Green, Mem. Dep. Ag. India, II, 2, p. 33 (1908). Fig.

Mem. Dep. Ag. India, II, 7, p. 134

Habitat-Bombay. (1908).

On leaves of undetermined tree.

Targionia alni Marchal.

Targionia alni Marchal, Compt. Rend. Ac. Sci., Paris, cxlıI, 13, p. 872 (1909).

Habitat-France.

On Alnus glutinosa.

Targionia chenopodii Marlatt.

Aspidiotus (Targionia) chenopodii Marlatt, BuI. U. S. Bur. Ent., t. s. 16, Pt. II, p. 24 (1908). Fig.

Habitat-Coolabah, New South Wales.

On Chenopodium.

Targionia vitis suberi Leonardi.

Targionia vitis var. suberi Leon., Bol. Lab. Zool. Sc. Sup. Portici, p. 166 (1907). Fig. Habitat-Sardinia.

On Quercus suber.

Odonaspis graminis Bremner.

Odonaspis graminis Bremner, Can. Ent., xxxıx, p. 368 (1907). Fig.

Habitat-California.

On roots of grass. 
Odonaspis ruthæ Ehrhorn.

Odonaspis ruthæ Ehrh. (sine descr.), 2d Bien. Rep. Com. Hort. Cal., p. 26 (1997)

Habitat-Hawaii; California (at quarantine).

On grass.

\section{Pseudoparlatoria chilina Lindinger.}

Pseudoparlatoria chilina Lindgr., Jahrb. Hamb. wiss. Anst., xxvı, p. — (1908).

Habitat-Chile.

On Saxegothæa conspicua.

Aonidia glandulosa Newstead.

Aonidia glandulosa Newst., Draper (sine descr.), Scale Ins. of Egypt, p. 11 (1907).

Habitat-Egypt.

On "sunt" tree (Acacia arabica var. nilotica).

\section{Aonidia juniperi Marlatt.}

Aonidia juniperi Marlatt, Bul. U. S. Bur. Ent., t. s. 16, Pt. II, p. 24 (1908). Fig. Habitat-Utah.

On Juniperus sp.

\section{Aonidia perplexa Green.}

Aonidia perplexa Green, Jn. Bomb. N. H. Soc., xIII, p. 252 (1902). Fig.

Lindgr., Zeitschr. f. wiss. Insektenbiol., v, 4, p. 109 (1909).

Habitat-Ceylon.

On leaves of Mesua ferrea.

Aonidia picea Leonardi.

Aonidia picea Leon., Redia, III, p. 6 (1906). Fig.

Habitat-Spain.

On Billartia officinalis.

\section{Aonidia pinicola Leonardi.}

Aonidia pinicola Leon., Annali di Agr., vi, p. 3 (1906). Fig.

Habitat-Spain.

On Pinus sylvestris.

\section{Gymnaspis clusiæ Lindinger.}

Gymnaspis clusiæ Lindgr., Deutsche Ent. Zeitschr., I, p. 153 (1909). Fig

Habitat-Jamaica.

On leaves of Clusia sp.

Lepidosaphes auriculata (Green).

Mytilaspis auriculata Green, Tr. Linn. Soc. Lond., xII, pt. 2, p. 205 (1907). Fig.

Habitat-Seychelles.

On "croton."

\section{Lepidosaphes beckii oleæ Leonardi.}

Lepidosaphes beckii var. oleæ Leon., Bol. Zool. Sc. Sup. Portici, III, p. 193 (1908). Fig.

Habitat-Sardinia.

On roots of olive.

\section{Lepidosaphes beyeriæ (Green).}

Mytilaspis beyerix "Green" French (sine descr.), Victorian Nat., xxıI, p. 184 (1907).

Habitat-Victoria, Australia. 
Lepidosaphes bicolor Newstead.

Mytilaspis (Lepidosaphes) bicolor Newst. (sine descr.), Liverpool Univ. Quart. Jn., I, 2, pp. 71, 72 (1906).

Newst. (sine descr.), Scale Insects of Egypt, p. 15

Habitat-Egypt. (1907).

"On an unknown plant."

\section{Lepidosaphes chilopsidis (Marlatt).}

Mytilaspis chilopsidis Marlatt, Bul. U. S. Bur. Ent., t. s. 16, Pt. II, p. 27 (1908). Fig. Habitat-Mexico.

On Chilopsis linearis.

Lepidosaphes destefanii Leonardi.

Lepidosaphes destefanii Leon., Bol. Zool. Sc. Sup. Portici, I, p. 167 (1907). Fig.

Habitat-Italy.

On Phillyrea media.

\section{Lepidosaphes ficifoliæ ulmicola Leonardi.}

Lepidosaphes ficifolix var. ulmicola Leon., Bol. Zool. Sc. Sup. Portici, I, p. 168 (1907). Fig.

Habitat-Italy.

On leaves of Ulmus.

Lepidosaphes longula Leonardi.

Lepidosaphes longula Leon., Annali di Agr., viı, p. 20 (1907). Fig.

Habitat-Java.

On leaves of Persea sp.

\section{Lepidosaphes megregori Banks.}

Lepidosaphes megregori Banks, Philippine Jn. Sci., I, 3, pp. 222, 233 (1906). Fig.

Habitat-Philippines.

On leaves of Cocos nucifera.

\section{Lepidosaphes ocellata (Green).}

Mytilaspis ocellata Green, Tr. Linn. Soc. Lond., XII, pt. 2, p. 206 (1907). Fig.

Habitat--Seychelles.

On fronds of Davallia sp.

\section{Lepidosaphes piperis (Green).}

Mytilaspis piperis Green, Mem. Dep. Ag. India, II, 2, p. 34 (1908). Fig.

Habitat-Madras, India.

On young stems of Piper nigrum.

$a$ Lepidosaphes serrifrons (Leonardi).

Mytilaspis serrifrons Leon., Riv. Pat. Veg., vi, pp. 118 (276), 121 (279) (1897). Fig.

Ckll., Bul. Ill. St. Lab. N. H., v, Art. xii, p. 397 (1899).

Habitat-Italy.

Leon., Annali di Agr., v, pp. 45, 48 (1903). Fig.

On Croton undulatum and C. majesticum.

a This species apparently has been omitted in the Fernald catalogue and the writer's first supplementary catalogue (1906). 
Lepidosaphes unicolor Banks.

Lepidosaphes unicolor Banks, Philippine Jn. Sci., I, 3, pp. 222, 234 (1906). Fig.

Habitat-Philippines.

On leaves of Cocos nucifera.

\section{Parlatoria chinensis Marlatt.}

Parlatoria chinensis Marlatt, Bul. U. S. Bur. Ent., t. s. 16, Pt. II, p. 30 (1908). Fig. Habitat-China; Japan; Egypt.

On crab-apple; Hibiscus; Xanthoxylon; Thuja orientalis.

Parlatoria cinerea Doane \& Hadden.

Parlatoria cinerea Doane \& Hadden, Can. Ent., XLI, p. 299 (1909). Fig.

Habitat-Society Islands.

On bark of orange tree and on cultivated vine.

Parlatoria greeni Banks.

Parlatoria greeni Banks, Philippine Jn. Sci., I, 3, pp. 222, 231 (1906). Fig.

Habitat-Philippines.

On leaves of Cocos nucifera.

Parlatoria mangiferæ Marlatt.

Parlatoria mangiferæ Marlatt, Bul. U. S. Bur. Ent., t. s. 16, Pt. II, p. 28 (1908). Fig. Is a synonym of $P$. pseudaspidiotus Lindgr., Insekten Börse, xxII, 33, p. 131 (1905).

\section{Parlatoria pyri Marlatt.}

Parlatoria pyri Marlatt, Bul. U. S. Bur. Ent., t. s. 16, Pt. II, p. 29 (1908). Fig. Habitat-China; Manchuria.

On apple; pear.

\section{CORRECTIONS TO CATALOGUE I (1906).}

Page 2. Icerya colimensis Ckll., Mem. Soc. Cient. Ant. Alz., xvıII, p. 81 (1902). Icerya tonilensis Ckll., Mem. Soc. Cient. Ant. Alz., xvil, p. 80 (1902). Icerya rileyi larreæ Ckll., Mem. Soc. Cient. Ant. Alz., xvıII, p. 82 (1902).

Page 4. Trionymus hordei (Lindeman).

Page 5. Pseudococcus elongatus Reuter, corrected in Catalogue II, p. 40.

Page 10. Chionaspis angusta Green for Ch. angustata .

Page 14. Aspidiotus riveræ Ckll., Ent. News, xvi, p. 161 (1905).

Page 15. Chrysomphalus malleolus Green=Pseudaonidia malleolus (Green). Page 16. Fernaldella for Fernaldiella.

Attention should be called to the fact that Fernaldella Leonardi is preoccupied in Lepidoptera. 


\section{ABBREVIATIONS OF LITERATURE.}

Allg. Zeits. f. Ent.-Allgemeine Zeitschrift für Entomologie.

Agr. News West. Ind.-Agricultural News. West Indies.

An. Soc. Cient. Argentina.-Anales de la Sociedad Cientifica Argentina.

Ann. Soc. Ent. France.-Annales de la Société Entomologique de France.

Annali di Agr.-Annali di Agricoltura. Portici.

Ann. Mag. N. H.-Annals and Magazine of Natural History.

Ann. Mus. Zool. Ac. Imp. Sc. St. Petersbourg.-Annuaire Musée Zoologique Académie

Impériale des Sciences de St. Petersbourg.

Berl. Ent. Zeitschr.-Berliner Entomologische Zeitschrift.

Ber. Stat. f. Pflanzensch. Hamb.-Bericht der Station für Pflanzenschutz, Hamburg.

Bol. Min. Ag.-Boletín del Ministerio de Agricultura. Argentina.

Bol. Zool. Sc. Sup. Portici.-Bollettino del Laboratorio di Zoologia generale e agraria della R. Scuola Superiore d'Agricoltura di Portici.

Bot. Jahrb.-Botanische Jahrbücher.

Bul. Ag. Exp. Sta. Japan.-Bulletin of the Imperial Central Agricultural Experiment Station. Japan.

Bul. Ill. St. Lab. N. H.-Bulletin of the Illinois State Laboratory of Natural History.

Bul. Soc. Ent. Fr.-Bulletin de la Société Entomologique de France.

Bul. Soc. Ent. Ital.-Bulletino della Società Entomologica Italiana.

Bul. Soc. Zool. France.-Bulletin de la Société Zoologique de France.

Bul. U.S. Bur. Ent.t.s. 16, Pt. II.-Bulletin, Technical Series, Bureau of Entomology,

U. S. Department of Agriculture.

Can. Ent.-Canadian Entomologist.

Catalogue Coccidæ.--U. S. Bur. Ent. technical series, Bul. 12, Pt. I (1906).

Cherm. Ital.-Chermotheca Italica.

Compt. Rend. Ac. Sci., Paris.-Comptes rendus hebdomadaires des séances de l'Académie des sciences. Paris.

Compt. Rend. Soc. Biol.—Comptes rendus des seances de la Société de Biologie. Paris.

Deutsche Ent. Zeitschr.-Deutsche Entomologische Zeitschrift.

Ent. Mo. Mag.-The Entomologist's Monthly Magazine.

Ent. Blätter.-Entomologische Blätter, Internationale Monatsschrift für die Biologie der Käfer Europas. Schwabach.

Ent. Rec. Jn. Variation.--The Entomologist's Record and Journal of Variation.

Ent. Wochenblatt.-Entomologisches Wochenblatt (antea Insekten-Börse).

Ind. Mus. Notes.-Indian Museum Notes.

Insekten Börse.-Entomologische Wochenblatt.

Jahrb. Hamb. wiss. Anst.- Jahrbuch der Hamburgischen wissenschaftlichen Anstalten.

Jn. Bomb. N. H. Soc.-Journal of the Bombay Natural History Society. Calcutta.

Jn. Econ. Biol.-The Journal of Economic Biology.

Jn. N. Y. Ent. Soc.-Journal of the New York Entomological Society.

Liverpool Univ. Quart. Jn.--Institute of Commercial Research in the Tropics, Liverpool University, Quarterly Journal.

Medd. Soc. Faun. Fenn.-Meddelanden af Societas pro Fauna et Flora Fennica.

Mem. Dep. Ag. India.-Memoirs of the Department of Agriculture in India.

Mem. Soc. Cient. Ant. Alz.-Memorias y Revista de la Sociedad Científica "Antonio Abzate."

Mém. Soc. Zool. France.-Mémoires de la Société Zoologique de France. 
Nachrichtsbl. Naturfrsch.-Klubs, Prossnitz.-Nachrichtsblatt Naturforscher-Klubs, Prossnitz (Mähren).

N. Z. Trans.-Transactions of the New Zealand Institute.

Pests and Blights of Tea Plant.-The Pests and Blights of the Tea Plant, 2d ed. Watt \& Mann, Calcutta, 1903.

Philippine Jn. Sci.-The Philippine Journal of Science.

Pomona Jn. Ent.-Pomona Journal of Entomology. Claremont, California.

Pr. Biol. Soc. Wash.-Proceedings of the Biological Society of Washington.

Pr. Ent. Soc. Wash.-Proceedings of the Entomological Society of Washington.

Pr. Haw. Ent. Soc.-Proceedings of the Hawaiian Entomological Society.

Redia.-Redia.

Riv. Pat. Veg.-Rivista di Patologia Vegetale.

Scale Ins. of Egypt.-Notes on the Injurious Scale Insects and Mealy Bugs of Egypt. Cairo, 1907.

Trab. Mus. Farm. Fac. Cienc. Med.-Trabajos del Museo de farmacologia de la Facultad de Ciencias Medicas. Buenos Aires, Argentina.

Tr. Linn. Soc. Lond.-Transactions of the Linnæan Society of London.

Victorian Nat.-The Victorian Naturalist.

Zeitschr. f. wiss. Insektenbiol.-Zeitschrift für wissenchaftliche Insektenbiologie. 

Technical Series, No. 16, Part IV.

U. S. DEPARTMENT OF AGRICULTURE, BUREAU OH ENTOMOLOGY.

L. O. HOWARD, Entomologist and Chief of Bureau.

PAPERS ON COCCIDE OR SCALE INSECTS.

\section{CATALOGUE}

OF

\section{RECENTLY DESCRIBED COCCIDE-III.}

By E. R. SASSCER,

Scientific Assistant.

ISSUED June 8, 1911.

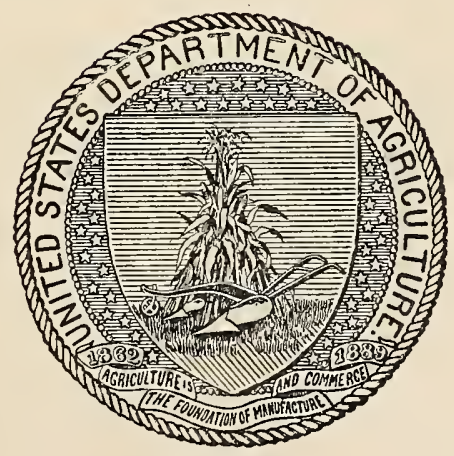

WASHINGTON :

GOVERNMENT PRINTING OFFICE.

1911. 


\section{CONTENTS}

Page.

Subfamily Monophlebinæ............................................. 61

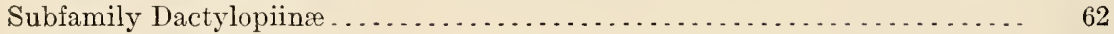

Subfamily Coccinæ. . . . . . . . . .

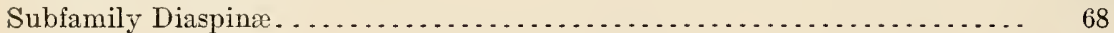

II 


\section{PAPERS ON COCCID E OR SCALE INSECTS.}

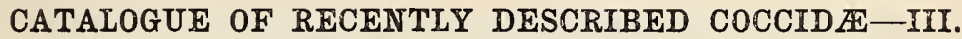

By E. R. SAsscer, Scientific Assistant.

Since the publication, December 22, 1909, of Tech. Ser.16, Part III, "Catalogue of Recently Described Coccidæ-II," by Mr.J. G. Sanders, 3 new subgenera, 98 new species, and 5 new varieties have been recorded by workers on scale insects. In all, some 23 new genera, 9 new subgenera, 430 new species, and 41 new varieties have been recorded from various quarters of the globe since the publication of Mrs. Fernald's valuable contribution in 1903.

Owing to the large amount of literature relating to entomology which is published daily and to the fact that some entomologists describe species in periodicals which do not relate to insect life, it is the earnest request of the writer that all workers on Coccidæe send to the Bureau of Entomology separates of their papers and as far as possible any available material. This list is believed to be fairly complete up to March, 1911, and any corrections or omissions are solicited from coworkers.

In examining the voluminous literature the writer was greatly assisted by Miss Mabel Colcord, librarian of the bureau, and he is equally indebted to Prof. T. D. A. Cockerell for his many valuable suggestions.

All species marked with an asterisk are represented in the National Collection of Coccidæ.

\section{Subfamily INONOPHLEBIN HE:}

\section{Monophlebus sjöstedti Newstead.}

Monophlebus sjöstedti Newst., Kilimandjaro-Míeru Exp., 12 (1 Coccidæ), p. 2 (1908). Fig.

Habitat-Kilimandjaro.

Monophlebus pallidus Newstead.

Monophlebus palliaus Newst., Kilimandjaro-Meru Exp., 12 (1 Coccidæ), p. 3 (1908). Fir.

Habitat-Kilimandjaro.

Walkeriana africana Newstead.

Walkeriana africana Newst., Kilimandjaro-Meru Exp., 12 (1 Coccidæ), p.4 (1908). Fig. Habitat-Kilimandjaro.

On grass.

90515-No. 16-11 


\section{Subfamily DACTYLOPIINE.}

\section{Asterolecanium ceriferum Green.}

Asterolecanium ceriferum Green, Cocc. Ceylon, Iv, p. 324 (1909). Fig.

Habitat-Ceylon.

On leaves of palm.

\section{Asterolecanium ceriferum prominens Green.}

Asterolecanium ceriferum prominens Green, Cocc. Ceylon, Iv, p. 326 (1909). Fig.

Habitat-Ceylon.

On Oxytenanthera thwaitesii.

\section{Asterolecanium coronatum Green.}

* Asterolecanium coronatum Green, Cocc. Ceylon, Iv, p. 327 (1909). Fig.

Habitat-Ceylon.

On Dendrocalamus giganteus and Gigantochloa aspera.

\section{Asterolecanium exiguum Green.}

Asterolecanium exiguum Green, Cocc. Ceylon, rv, p. 315 (1909). Fig.

Habitat-Ceylon.

On under surface of leaves of bamboo.

\section{Asterolecanium flavociliatum Green.}

Asterolecanium flavociliatum Green, Cocc. Ceylon, Iv, p. 322 (1909). Fig.

Habitat-Ceylon.

On Arundinaria sp.

\section{Asterolecanium lanceolatum Green.}

Planchonia miliaris longa Green (part), Ind. Mus. Notes, Iv, p. 5 (1896).

${ }^{1}$ Asterolecanium lineare Green, Cocc. Ceylon, Iv, p. 336 (1909). Fig.

lanceolatum Green, Cocc. Ceylon, IV, preface (1909).

Habitat-Ceylon.

On leaves of Arundinaria sp.

Asterolecanium pasaniæ Kuwana and Cockerell.

Asterolecanium pasaniæ Kuwana and Ckll., Jn. N. Y. Ent. Soc., xvIr, 4, p. 152 (1909). Fig.

Habitat-Japan.

On Pasania cuspidata.

\section{Asterolecanium pudibundum. Green.}

Asterolecanium pudibundum Green, Cocc. Ceylon, Iv, p. 323 (1909). Fis.

Habitat-Ceylon.

On Arundinaria sp.

\section{Asterolecanium pustulans seychellarum Green.}

Asterolecanium pustulans seychellarum Green, Jn. Econ. Biol., v, I, p. 3 (1910). Fig. Habitat--Seychelles Islands.

On Hevea brasiliensis.

1 A. lincare was first proposed for this species, but was subsequently changed by the author to A. lanceolatum, since the former was preoccupied by a species described by Lindinger on coconut palms from Brazil. 


\section{Asterolecanium rubrocomatum G̈reen.}

*Asterolecanium rubrocomatum Green, Cocc. Ceylon, Iv, p. 316 (1909). Fig.

Habitat-Ceylon.

On upper surface of leaves of Bambusa sp.

Asterolecanium tenuissimum Green.

Asterolecanium tenuissimum Green, Cocc. Ceylon, Iv, p. 318 (1909). Fig.

Habitat-Ceylon.

On bamboo, both surfaces of leaves.

\section{Asterolecanium thespesiæ Green.}

*Asterolecanium thespesix Green, Cocc. Ceylon, Ir, p. 331 (1909). Fig.

Habitat-Ceylon.

On Thespesia populnea.

\section{Asterolecanium tumidum Green.}

Asterolecanium tumidum Green, Cocc. Ceylon, Iv, p. 330 (1909). Fig.

Habitat-Ceylon.

On leaves of bamboo.

Asterolecanium udagamæ Green.

Asterolecanium udagamæ Green, Cocc. Ceylon, Iv, p. 319 (1909). Fig.

Habitat-Ceylon.

On leaf of bamboo.

Asterolecanium variolosum minor Leonardi.

Asterolecanium variolosum minor Leonardi (sine descr.), Cherm. Ital., v, No. 107 (1909). Habitat-Italy.

On Quercus sp.

Lecaniodiaspis azadirachtæ Green.

Lecaniodiaspis azadirachtæ Green, Cocc. Ceylon, r, p. 298 (1909). Fig.

Habitat-Ceylon.

On "margosa" (Azadirachta indica).

Lecaniodiaspis malaboda Green.

*Lecaniodiaspis malaboda Green, Coce. Ceylon, rv, p. 300 (1909). Fig.

Habitat-Ceylon.

On "malaboda" (Myristica laurifolia) and Bocagea obliqua.

Cerococcus albospicatus Green.

${ }^{*}$ Cerococcus albospicatus Green, Cocc. Ceylon, rr; p. 308 (1909). Fig.

Habitat-Ceylon.

On bark of Symplocos obtusa.

Cerococcus indicus Green.

Cerococcus indicus Green, Jn. Econ. Biol., r, 1, p. 5 (1910). Fig.

Habitat-India.

On Helicteres isora.

Cerococcus ornatus Green.

Cerococcus ornatus Green, Cocc. Ceylon, Iv, p. 306 (1909). Fig.

Habitat-Ceylon.

On Coffea arabica and Carissa sp. 
Cerococcus roseus Green.

*Cerococcus roseus Green, Cocc. Ceylon, Iv, p. 310 (1909). Fig.

Habitat-Ceylon.

On undetermined tree.

Stictococcus dimorphus Newstead.

Stictococcus dimorphus Newst., Bul. Ent. Res., I, i, p. 63 (1910). Fig.

Habitat-German East Africa.

On cacao pods.

Stictococcus formicarius Newstead.

Stictococcus formicarius Newst., Jn. Econ. Biol., v, 1, p. 19 (1910). Fig.

Habitat-Upper Congo, Africa.

In hollow stems of Barteria fistulosa and Cuviera angolensis attended by Sima spininoda André.

\section{Phenacoccus oleæ Marchal.}

Phenacoccus oleæ Marchal, Bul. Soc. Ent. Fr., No. 13, p. 244 (1910).

Habitat-Tunisie.

On olive attended by a Cremastogaster.

Ceroputo ambigua Fullaway.

Ceroputo ambigua Fullaway, Pr. Haw. Ent. Soc., II, 2, p. 73 (1909).

Fullaway, Pr. Dav. Acad. Sci., xII, p. 223 (1910). Fig.

Habitat-California.

On pickle weed (Salicorria ambigua).

Pseudococcus ananassæ Kuwana.

Dactylopius (Pseudococcus) ananassæ Kuwana, Jn. N. Y. Ent. Soc., XvII, 4, p. 162 (1909). Fig.

Habitat-Japan.

On pineapple.

\section{Pseudococcus bakeri Essig.}

Pseudococcus bakeri Essig, Pom. College Jn. Ent., II, 4, p. 334 (1909). Fig.

Habitat-California.

On elder (Sambucus glauca); walnut (Juglans regia); apple (Pyrus malus); pear

(Pyrus communis).

\section{Pseudococcus boninsis Kuwana.}

Dactylopius (Pseudococcus) boninsis Kurana, Jn. N. Y. Ent. Soc., xvIr, 4, p. 161 (1909). Fig.

Habitat-Japan.

On sugar cane.

Pseudococcus coccineus Newstead.

Dactylopius coccineus Newst., Kilimandjarc-Meru Exp., 12 (1 Coccidæ), p. 8 (1908). Fig.

Habitat-Kilimandjaro.

On Acacia.

Pseudococcus missionum Cockerell.

Pseudococcus missionum Ckll., The Entom., xLII, 563, p. 113 (1910).

Habitat-Argentina.

$\mathrm{On}-$ ? 
Pseudococcus perniciosus Newstead and Willcocks.

Dactylopius perniciosus Newstead and Willcocks, Bul. Ent. Res., 1, 2 (Appendix 1), pp. 138-140, July, 1910. Fig.

Willcocks, Bul. Ent. Res., I, 2, pp. 121-137, July, 1910. Fig.

Habitat-Egypt.

Hughes, Bul. Ent. Res., I, 2, Appendix II, p. 141, July, 1910.

On lebbek (Albizzia lebbek); cotton (Gossypium sp.); Christ's thorn (Zizyphus spinachristi); sunt tree (Acacia arabica).

Ripersia anomala Newstead.

Ripersia anomala Newst., Kilimandjaro-Meru Exp., 12 (1 Coccidæ), p. 9 (1908). Fig.

Habitat-Kilimandjaro.

Under bark accompanied by Pheidole megacephala.

Ripersia agasawarensis Kuwana.

Ripersia agasawarensis Kuwana, Jn. N. Y. Ent. Soc., xvII, 4, p. 161 (1909). Fig.

Habitat-Japan.

On Miscanthus sp.

Ripersia smithii Essig.

Ripersia smithii Essig, Pom. College Jn. Ent., II, 2, p. 218 (1910). Fig.

Habitat-California.

On wild rye (Elymus condensatus).

Ripersiella rhizophilla Fullaway and Kotinsky.

I Ripersiella rhizophilla Fullaway and Kotinsky (sine descr.), Ent. News, xxı, 1, p. 49 (1910).

\section{Pollinia ceylonica Green.}

Pollinia ceylonica Green, Cocc. Ceylon, rv, p. 341 (1909). Fig.

Habitat-Ceylon.

On under surface of undetermined trees in dense jungle.

Ceroplastidia Cockerell, n. subg. of Ceroplastes. Type, bruneri Ckll.

Cockerell, Can. Ent., xLII, 3, p. 76 (1910).

Ceroplastina Cockerell, n. subg. of Ceroplastes. Type, lahillei Ckll.

Cockerell, Can. Ent., xLII, 3, p. 76 (1910).

Ceroplastes ficus Newstead.

Ceroplastes ficus Newst., Bul. Ent. Res., 1, 3, p. 190 (1910). Fig.

Habitat-German East Africa.

On bark-cloth (Ficus sp.).

Ceroplastes lahillei Cockerell.

Ceroplastes (Ceroplastina) lahillei Ckll., Can. Ent., xLII, 3, p. 74 (1910). Fig.

Habitat-Argentina.

Ceroplastes quadrilineatus Newstead.

Ceroplastes quadrilineatus Newstead, Bul. Ent. Res., I, 3, p. 193 (1910). Fig.

Habitat-British East Africa.

On Anona muricata; bark-cloth (Ficus sp.).

1 Reduced to synonym of Geococcus radicum Green by David T. Fullaway, Pr. Haw. Ent. Soc., II, 3, p. 108 (1910). 
Ceroplastes singularis Newstead.

Ceroplastes singularis Newstead, Bul. Ent. Res., I, 3, p. 188 (1910). Fig.

Habitat-British East Africa.

On guava (Psidium guava).

\section{Ceroplastodes chiton Green.}

Ceroplastodes chiton Green (sine descr.), Mem. Dep. Ag. India, II, 2, p. 32 (1908). Sanders, Catalogue Coccidæ-II, p. 45 (1909).

Green, Cocc. Ceylon, rv, p. 287 (1909). Fig.

Habitat-India and Ceylon.

On Cajanus indicus and Cassia sp.

\section{Ceroplastodes virescens Green.}

Ceroplastodes virescens Green, Cocc. Ceylon, rv, p. 288 (1909). Fig.

Habitat-Ceylon.

On terminal shoots of Theobroma cacao.

\section{Subfamily COCCIN EE.}

\section{Ceronema koebeli Green.}

*Ceronema koebeli Green, Cocc. Ceylon, iv, p. 256 (1909). Fig.

Habitat-Ceylon.

On Sapium sebiferum.

\section{Pulvinaria cellulosa Green.}

*Pulvinaria cellulosa Green, Cocc. Ceylon, rv, p. 262 (1909). Fig.

Habitat-Ceylon.

On Citrus sp.

Pulvinaria ixoræ Green.

Pulvinaria ixoræ Green, Cocc. Ceylon, rv, p. 266 (1909). Fig.

Habitat-Ceylon.

On Ixora coccinea.

Pulvinaria occidentalis subalpina Cockerell.

*Pulvinaria occidentalis subalpina Ckll., Jn. Econ. Ent., II, 5, p. 428 (1910).

Habitat-Colorado.

On Betula glandulosa.

Pulvinaria thespesiæ Green.

*Pulvinaria thespesiæ Green, Cocc. Ceylon, iv, p. 259 (1909). Fig.

Habitat-Ceylon.

On "suriya" (Thespesia populnea).

\section{Protopulvinaria longivalvata Green.}

Protopulvinaria longivalvata Green, Cocc. Ceylon, rv, p. 254 (1909). Fis

Habitat-Ceylon.

On leaves of Piper nigrum.

Coccus celtium Kuwana.

Lecanium (Coccus) celtium Kuwana, Jn. N. Y. Ent. Soc., xvII, 4, p. 162 (1909). Fig.

Habitat-Japan.

On Celtis sinensis. 
Coccus fukayai Kuwana.

Lecanium (Coccus) fukayai Kuwana, Jn. N. Y. Ent. Soc., Xvir, 4, p. 154 (1909). Fig. Habitat-Japan.

On vine.

Coccus muiri Kotinsky.

${ }^{1}$ Coccus tuberculatus Kotinsky, Pr. Haw. Ent. Soc., I, 5, p. 168 (1908). Fig.

Sanders, Catalogue Coccidæ-II, p. 45 (1909).

Coccus muiri Kotinsky, Pr. Haw. Ent. Soc., II, 2, p. 37 (1909).

Habitat-Singapore.

On leaves of unknown tree.

\section{Coccus ochnaceæ Kuwana.}

Lecanium (Coccus) ochnaceæ. Kuwana, Jn. N. Y. Ent. Soc., xvil, 4, p. 154 (1909). Fig. Habitat-Japan.

On Eurya ochnacea.

Hemilecanium recurvatum Newstead.

Hemilecanium recurvatum Newst., Jn. Econ. Biol., v, 1, p. 18 (1910). Fig.

Habitat-Upper Congo, Africa.

In hollow stems of Plectronia laurentii De ITild attended by Cremastogaster.

\section{Neolecanium crustuliforme Green.}

Neolecanium crustuliforme Green, Cocc. Ceylon, Iw, p. 252 (1909). Fig.

Habitat-Ceylon.

On small branches of undetermined tree.

Lecanium mori var. somereni Newstead.

Lecanium mori var. somcreni Newst., Bul. Ent. Res., I, 3, p. 187 (1910).

Habitat-British East Africa.

On Morus sp.

Lecanium resinatum Kieffer and Herbst.

Lecanium resinatum Kieffer and Herbst, Centr. f. Bakt. Par. u. Infekt., zweite Abt., xxIII, 1-5, p. 122 (1909).

Habitat-Chile.

On Baccharis rosmarinifolia.

Saissetia pseudonigrum Kuwana.

Lecanium (Saissetia) pseudonigrum Kuwana, Jn. N. Y. Ent. Soc., xvII, 4, p. 162 (1909). Fig.

Habitat-Japan.

On "shirotsugi."

Saissetia sideroxylium Kuwana.

Lecanium (Saissetia) sideroxylium Kuwana, Jn. N. Y. Ent. Soc., xvII, 4, p. 162 (1909). Fig.

Habitat-Japan.

On Sideroxylon ferrugineum.

Aclerda distorta Green.

*Aclerda distorta Green, Cocc. Ceylon, Iv, p. 290 (1909). Fig.

Habitat-Ceylon.

Beneath the ensheathing bases of leaves of Arundinaria sp. 
Takahashia citricola Kuwana.

Takahashia citricola Kuwana, Jn. N. Y. Ent. Soc., xvח, 4, p. 153 (1909). Fig. Habitat-Japan.

On Citrus sp.

\section{Lichtensia japonica Kuwana.}

Lichtensia japonica Kuwana, Jn. N. Y. Ent. Soc., xvı, 4, p. 152 (1909). Fig.

Habitat-Japan.

On Thea japonica.

\section{Inglisia chelonioides Green.}

Inglisia chelonioides Green, Cocc. Ceylon, Iv, p. 283 (1909). Fig.

Habitat-Ceylon.

On Gelonium lanceolatum.

Inglisia conchiformis Newstead.

Inglisia conchiformis Newst., Bul. Ent. Res., I, 3, p. 185 (1910). Fig.

Habitat-West Africa and British East Africa.

On Averrhoa carambola and Harogana madagascariensis.

\section{Subfamily DIASPINÆE.}

Chionaspis dentilobis Newstead.

Chionaspis dentilobis Newst., Bul. Ent. Res., I, 3, p. 195 (1910). Fig.

Habitat-British East Africa.

"On $-? "$

\section{Chionaspis kinshinensis Kuwana.}

Chionaspis linshincnsis Kuwana, Jn. N. Y. Ent. Soc., xvIr, 4, p. 155 (1909). Fig.

Habitat-Japan.

On Quercus sp.

Chionaspis sassceri Cockerell and Robbins.

* Chionaspis sassceri Ckll. and Robb., Jn. N. Y. Ent. Soc., xvil, 3, p. 105 (1909). Fig. Habitat-California.

On orange.

\section{Chionaspis substriata Newstead.}

Chionaspis substriata Newst., Bul. Ent. Res., I, 3, p. 197 (1910). Fig.

Habitat-British East Africa.

On palms.

\section{Diaspis africana Lindinger.}

Diaspis africana Lindgr., Jahrb. Hamb. wiss. Anst., xxv1, p. 22 (1909). Fig.

Habitat-South Africa.

On leaves of Connarum smeathmanni and Syzygium guineense.

\section{Diaspis (?) chionaspiformis Newstead.}

Diaspis (?) chionaspiformis Newst., Bul. Ent. Res., I, 3, p. 198 (1910). Fig.

Habitat-British East Africa.

On an unknown plant.

\section{Diaspis pugionifera Lindinger.}

Diaspis pugionifera Lindgr., Jahrb. Hamb. wiss. Anst., xxvi, p. 24 (1.909). Fig. Habitat--South Africa.

On leaves of Mitragyne macrophylla. 
Diaspis stilosa Lindinger.

Diaspis stilosa Lindgr., Jahrb. Hamb. wiss. Anst., xxvı, p. 25 (1909). Fig.

Habitat-South Africa.

On leaves of Strychnos cinnabarina.

\section{Leucaspis indiæ-orientalis Lindinger.}

${ }^{1}$ Leucodiaspis indix-orientalis Lindgr. (sine descr.), Zeitschr. f. wiss. Insektenbiol., vi, 11, p. 373 (1910).

Habitat-India.

On Pinus sp.

Cryptodiaspis Lindinger, n. subg. of Diaspis. Type, conservans.

Lindinger, Jahrb. Hamb. wiss. Anst., xxvı, p. 26 (1909).

Diaspis conservans Lindinger.

Diaspis (Cryptodiaspis) conservans Lindgr., Jahrb. Hamb. wiss. Anst., xxvi, p. 26 (1909). Fig.

Habitat-South America.

On leaves of Euphorbiaceæ.

Diaspis hamata Lindinger.

Diaspis (Cryptodiaspis) hamata Lindgr., Jahrb. Hamb. wiss. Anst., xxvi, p. 28 (1909).

Fig.

Habitat-South Africa.

On leaves of Macrolobium zenkeri.

Diaspis limuloides Lindinger.

Diaspis (Cryptodiaspis) limuloides Lindgr., Jahrb. Hamb. wiss. Anst., xxvi, p. 30 (1909). Fig.

Habitat-South Africa.

On leaves of Cynometra sp. with Aonidia biafræ Lindgr.

Aspidiotus arctostaphyli Cockerell and Robbins.

Aspidiotus arctostaphyli Ckll. and Robb., Jn. N. Y. Ent. Soc., xvn, 3, p. 104 (1909). Fig.

Habitat-California.

On leaves of Arctostaphylos viscida.

Aspidiotus fissidens Lindinger.

Aspidiotus fissidens Lindgr., Jahrb. Hamb. wiss. Anst., xxvı, p. 14 (1909). Fig.

Habitat-South Africa.

On leaves of Parinarium gabunense and Strychnos cinnabarina.

Aspidiotus mæandrius Lindinger.

Aspidiotus mæandrius Lindgr., Jahrb. Hamb. wiss. Anst., xxvı, p. 15 (1909). Fig.

Habitat-South Africa.

On leaf of Dichapetalum sp.

Aspidiotus mori Herrick.

* Aspidiotus (Diaspidiotus) mori Herrick, Ent. News, xxI, 1, p. 22 (1910). Fig.

Habitat-Texas.

On Morus rubra.

${ }^{1}$ Leucodiaspis is not valid. See Bui. U. S. Bur. Ent., Tech. Ser. 16, Pt. In, p. 50 (1909). 
Aspidiotus pectinatus Lindinger.

Aspidiotus pectinatus Lindgr., Jahrb. Hamb. wiss. Anst., xxvı, p. 43 (1909). Fig. Habitat-South Africa.

On pear.

\section{Aspidiotus replicatus Lindinger.}

Aspidiotus replicatus Lindgr., Jahrb. Hamb. wiss. Anst., xxvi, p. 17 (1909). Fig. Habitat-South Africa.

On leaves of Ehretia cymosa, Illigera pentophylla, Mitragyne macrophylla, and Anacardiaceæ.

\section{Aspidiotus seurati Marchal.}

Aspidiotus (Hemiberlesia) seurati Marchal, Bul. Soc. Ent. Fr., p. 71 (1911).

Habitat--South Algeria.

On Zilla macroptera.

Aspidiotus spiniger Lindinger.

Aspidiotus spiniger Lindgr., Jahrb. Hamb. wiss. Anst., xxvı, p. 19 (1909). Fig.

Habitat-South Africa.

On leaf of Strombosiopsis tetranda.

\section{Aspidiotus undulatus Lindinger.}

Aspidiotus undulatus Lindgr., Jahrb. Hamb. wiss. Anst., xxvi, p. 20 (1909). Fig.

Habitat--South Africa.

On leaves of Acioa pallescens and Strychnos cinnabarina.

Aonidia biafræ Lindinger.

Aonidia biafræ Lindgr., Jahrb. Hamb. wiss. Anst., xxvi, p. 40 (1909). Fig.

Habitat-South Africa.

On leaves of Schotia humboldtioides, Crudia zenkeri, and Cynometra sp.

Aonidia dentata Lindinger.

Aonidia dentata Lindgr., Zeitschr. f. wiss. Insektenbiol., v11, 1, p. 12 (1911). Fig. Habitat-India.

On leaf of Walsura piscidis.

Aonidia spinosissima Lindinger.

Aonidia spinosissima Lindgr., Zeitschr. f. wiss. Insektenbiol., vII, p. 12 (1911). Fig. Habitat-Central India.

On Mimusops hexandra.

Gymnaspis aberemoæ Lindinger.

Gymnaspis aberemoæ Lindgr., Deutsche Ent. Zeitschr., 1v, p. 437 (1910). Fig.

Habitat-Brazil.

On Aberemoa rhizantha.

Chrysomphalus portoricensis Lindinger.

Chrysomphalus (Melanaspis) portoricensis Lindgr., Zeitschr. f. wiss. Insektenbiol., vı, 12, p. 441 (1910). Fig.

Habitat-Venezuela.

On leaf of Bletia sp. 
Targionia celtis Herrick.

${ }^{1}$ Targionia celtis Herrick, Can. Ent., xuII, 11, p. 373 (1910). Fig.

Habitat-Texas.

On Celtis occidentalis.

Targionia vitis arbutus Leonardi.

Targionia vitis arbutus Leon. (sine descr.), Cherm. Ital., v, p. 123 (1909).

Habitat-Italy.

On Arbutus unedo.

Pseudoparlatoria cristata Lindinger.

Pseudoparlatoria cristata Lindgr., Zeitschr. f. wiss. Insektenbiol., viI, p. 10 (1911).

Fig.

Habitat-Brazil.

On leaf of Gnetum leyboldi.

Cryptaspidiotus mediterraneus Lindinger.

Cryptaspidiotus mediterraneus Lindgr. (sine descr.), Zeitschr. f. wiss. Insektenbiol., $\mathrm{VI}, 11$, p. $373(1910)$.

Lindgr., Zeitschr. f. wiss. Insektenbiol., vi, 12, p. 437

Habitat-Algeria.

(1910). Fig.

On leaves of Juniperus phœnicea and Callitris quadrivalvis.

Ischnaspis bipindensis Lindinger.

Ischnaspis bipindensis Lindgr., Jahrb. Hamb. wiss. Anst., xxvI, p. 32 (1909). Fig.

Habitat-South Africa

On leaves of Cyclostemon bipindensis and Strychnos cinnabarina.

Lepidosaphes aberrans Lindinger.

Lepidosaphes aberrans Lindgr., Jahrb. Hamb. wiss. Anst., xxvi, p. 33 (1909). Fig. Habitat-South Africa.

On leaf of Cynometra sp.

Lepidosaphes arii Kuwana.

Mytilaspis (Lepidosaphes) arii Kuwana, Jn. N. Y. Ent. Soc., Xvır, 4, p. 163 (1909).

Fig.

Habitat-Japan.

On Miscanthus sp.

Lepidosaphes buzenensis Kuwana.

Mytilaspis (Lepidosaphes) buzenensis Kuwana, Jn. N. Y. Ent. Soc., xvII, 4, p. 155 (1909). Fig.

Habitat-Japan.

On vine.

\section{Lepidosaphes chitinosus Lindinger.}

Lepidosaphes (Coccomytilus) chitinosus Lindgr., Jahrb. Hamb. wiss. Anst., xxvI, p. 34 (1909). Fig.

Habitat-South Africa.

On Berlinia.

1 Not a valid species; synonym of Targionia cueroensis (Ckll.). 


\section{Lepidosaphes crudiæ Lindinger.}

Lepidosaphes crudix Lindgr., Jahrb. Hamb. wiss. Anst., xxvi, p. 35 (1909). Fig.

Habitat-South Africa.

On leaf of Crudia zenkeri.

Lepidosaphes kamerunensis Lindinger.

Lepidosaphes kamerunensis Lindgr., Jahrb. Hamb. wiss. Anst., xxvi, p. 37 (1909). Fig.

Habitat-South Africa.

On leaves of Loranthus sp.

Lepidosaphes meridionalis Lindinger.

Lepidosaphes meridionalis Lindgr., Jahrb. Hamb. wiss. Anst., xxvı, p. 38 (1909). Fig.

Habitat-South Africa.

On Macrolobium palisoti.

\section{Lepidosaphes tenuior Lindinger.}

Lepidosaphes tenuior Lindgr., Jahrb. Hamb. wiss. Anst., xxvi, p. 40 (1909). Fig.

Habitat-South Africa.

On leaf of Cynometra sp.

Lepidosaphes uniloba Kuwana.

Mytilaspis (Lepidosaphes) uniloba Kuwana, Jn. N. Y. Ent. Soc., xvir, 4, p. 156 (1909). Fig.

Habitat-Japan.

On Osmanthus.

Parlatoria hastata Lindinger.

Parlatoria hastata Lindgr. (sine descr.), Zeitschr. f. wiss. Insektenbiol., vi, 11, p. 375 (1910).

Habitat-Not given.

\section{CORRETIONS TO CATALOGUE II-1909.}

Page 38, instead of lines 9 and 10 under "Stictococcus multispinosus Newstead," read:

Stictococcus multispinosus Newst., Kilimandjaro-Meru Exp., 12 (1 Coccidæ), p. 6 (1908). Fig. Newst., Jn. Econ. Biol., II, 4, p. 150, footnote (1908).

Habitat-Kilimandjaro, East Africa.

Page 38, line 12 from bottom, for cxLIII read cxuviII.

Page 46, line 15, for Lecanium cecconi Leonardi read Lecanium cecconi (Leonardi). Page 46, line 19, for Lecanium glandi (Kuwana) read Lecanium glandi Kuwana.

Page 46, line 24, for Lecanium kunoensis (Kuwana) read Lecanium kunoensis Kuwana.

Page 46, line 13 from bottom. Lecanium rubellum Lindinger on Calluna vulgaris, given as a synonym of Lecanium pulchrum Marchal, has been resurrected as a valid species by Mr. J. G. Sanders.

Page 47, line 18. Hemilecanium theobromæ Newstead=Hemilecanium imbricans Green, on the authority of Green.

Page 55, line 16, for cxlin read cxlviII. 


\section{ABBREVIATIONS OF LTTERATURE.}

Allg. Zeits. f. Ent.-Allgemeine Zeitschrift für Entomologie.

Agr. News West Ind.-Agricultural News. West Indies.

An. Soc. Cient. Argentina.-Anales de la Sociedad Científica Argentina.

Ann. Soc. Ent. France.-Annales de la Société Entomologique de France.

Annali di Agr.-Annali di Agricoltura. Portici.

Ann. Mag. N. H.-Annals and Magazine of Natural History:

Ann. Mus. Zool. Ac. Imp. Sc. St. Petersbourg.-Annuaire Musée Zoologique Académie

Impériale des Sciences de St. Petersbourg.

Berl. Ent. Zeitschr.-Berliner Entomologische Zeitschrift.

Ber. Stat. f. Pflanzensch. Hamb.-Bericht der Station für Pflanzenschutz, Hamburg.

Bol. Min. Ag.-Boletín del Ministerio de Agricultura. Argentina.

Bol. Zool. Sc. Sup. Portici.-Bollettino del Laboratorio di Zoologia generale e agraria della R. Scuola Superiore d 'Agricoltura di Portici.

Bot. Jahrb.-Botanische Jahrbücher.

Bul. Ag. Exp. Sta. Japan.-Bulletin of the Imperial Central Agricultural Experiment Station. Japan.

Bul. Ent. Res.-Bulletin of Entomological Research.

Bul. Ill. St. Lab. N. H.-Bulletin of the Illinois State Laboratory of Natural History.

Bul. Soc. Ent. Fr.-Bulletin de la Société Entomologique de France.

Bul. Soc. Ent. Ital.-Bulletino della Società Entomologica Italiana.

Bul. Soc. Zoo. France.-Bulletin de la Société Zoologique de France.

Bul. U. S. Bur. Ent., t. s.16, Pt. II.-Bulletin, Technical Series, Bureau of Entomology,

U. S. Department of Agriculture.

Can. Ent.-Canadian Entomologist.

Catalogue Coccidæ-I.-U. S. Bur. Ent., technical series, Bul. 12, Pt. I (1906).

Catalogue Coccidæ-II.-U. S. Bur. Ent., technical series, Bul. 16, Pt. III (1909).

Centr. f. Bakt. Par. u. Infekt.-Centralblatt für Bakteriologie und Parasitenkunde und Infektionskrankheiten.

Cherm. Ital.-Chermotheca Italica.

Cocc. Ceylon.-Coccidæ of Ceylon.

Compt. Rend. Ac. Sci., Paris.-Comptes rendus hebdomadaires des séances de l'Académie des sciences. Paris.

Compt. Rend. Soc. Biol.—Comptes rendus des seances de la Société de Biologie. Paris. Deutsche Ent. Zeitschr.--Deutsche Entomologische Zeitschrift.

Ent. Mo. Mag.--The Entomologist's Monthly Magazine.

Ent. Blätter.-Entomologische Blätter, Internationale Monatsschrift für die Biologie der Käfer Europas. Schwabach.

Ent. News.-Entomologicał News.

Ent. Rec. Jn. Variation.-The Entomologist's Record and Jourual of Variation.

Ent. Wochenblatt.-Entomologisches Wochenblatt (antea Insekten-Börse).

Ind. Mus. Notes.-Indian Museum Notes.

Insekten Börse.-Entomologische Wochenblatt.

Jahrb. Hamb. wiss. Anst.--Jahrbuch der Hamburgischen wissenschaftlichen Anstalten.

Jn. Bomb. N. H. Soc.-Journal of the Bombay Natural History Society. Calcutta.

Jn. Econ. Biol.-The Journal of Economic Biology.

Jn. N. Y. Ent. Soc.-Journal of the New York Entomological Society. 
Kilimandjaro-Meru Exp.-Schwedischen Zoologischen Expedition nach Dem Kilimandjaro, Dem Meru und Den Umgebenden Massaisteppen Deutsch-Ostafrikas. Liverpool Univ. Quart. Jn.-Institute of Commercial Research in the Tropics, Liverpool University, Quarterly Journal.

Medd. Soc. Faun. Fenn.-Meddelanden af Societas pro Fauna et Flora Fennica.

Mem. Dep. Ag. India.-Memoirs of the Department of Agriculture in India.

Mem. Soc. Cient. Ant. Alz.-Memorias y Revista de la Sociedad Científica "Antonio Alzate."

Mém. Soc. Zool. France.-Mémoires de la Société Zoologique de France.

Nachrichtsbl. Naturfrsch.-Klubs, Prossnitz.-Nachrichtsblatt Naturforscher-Klubs, Prossnitz (Mähren).

N. Z. Trans.-Transactions of the New Zealand Institute.

Pests and Blights of Tea Plant.-The Pests and Blights of the Tea Plant, 2d ed. Watt \& Mann, Calcutta, 1903.

Philippine Jn. Sci.-The Philippine Journal of Science.

Pomona College Jn. Ent.-Pomona College Journal of Entomology. Claremont, California.

Pr. Biol. Soc. Wash.-Proceedings of the Biological Society of Washington.

Pr. Dav. Acad. Sci.-Proceedings Davenport Academy of Sciences. Davenport, Iowa.

Pr. Ent. Soc. Wash.-Proceedings of the Entomological Society of Washington.

Pr. Haw. Ent. Soc.-Proceedings of the Hawaiian Entomological Society.

Redia.-Redia.

Riv. Pat. Veg.-Rivista di Patologia Vegetale.

Scale Ins. of Egypt.-Notes on the Injurious Scale Insects and Mealy Bugs of Egypt. Cairo, 1907.

The Entom.-The Entomologist.

Trab. Mus. Farm. Fac. Cienc. Med.-Trabajos del Museo de Farmacologia de la Facultad de Ciencias Médicas. Buenos Aires, Argentina.

Tr. Linn. Soc. Lond.-Transactions of the Linnæan Society of London.

Victorian Nat.-The Victorian Naturalist.

Zeitschr. f. wiss. Insektenbiol.-Zeitschrift für wissenchaftliche Insektenbiologie. 
Technical Series, No. 16, Part V.

U. S. DEPARTMENT OF AGRICULTURE, BUREAU OF EN'TOMOLOGY.

L. O. HOWARD, Entomologist and Chief of Bureau.

\section{PAPERS ON COCCIDE OR SCALE INSECTS.}

\section{THE GENUS FIORINIA IN THE UNITED STATES.}

BY E. R. SASSCER, Scientific Assistant.

IssUed DECEMBer 6, 1912.

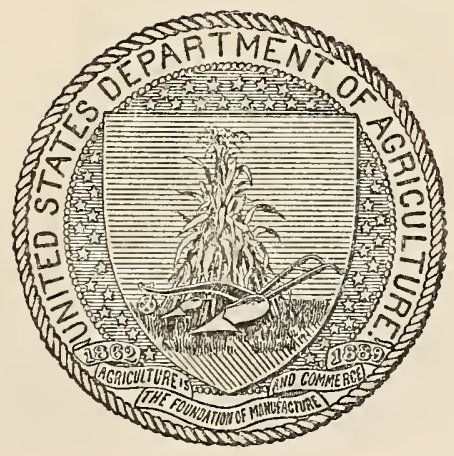

WASHINGTON:

GOVERNMENT PRINTING OFFIOE.

1912. 


\section{2xim}

\section{CONTENTS.}

Page.

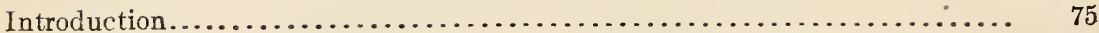

Description of the Genus Fiorinia. . . . . . . . . . . . . . . . . . . . 75

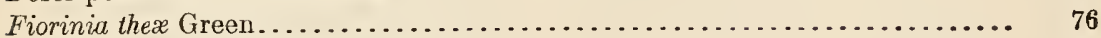

Fiorinia fiorinix Targioni Tozetti.............................. 79

Fiorinia fiorinix minor Maskell . . . . . . . . . . . . . . . . . . . . . . . . . 79

Fiorinia fiorinia japonica Kuwana ............................ 81

\section{ILLEUSTRATIONS.}

PLATES.

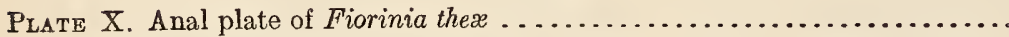

XI. Fig. 1.-Fiorinia ther on leaf of Camellia. Fig. 2.-Fiorinia theæ on leaf of Camellia............................. $\quad 76$

XII. Anal plate of Fiorinia fioriniæ ...................... 80

XIII. Anal plate of Fiorinia fiorinix minor.................. 80

U

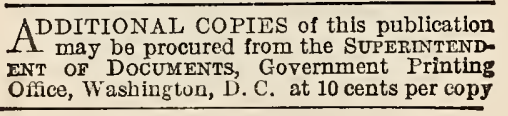




\section{PAPERS ON COCCIDE OR SCALE INSECTS.}

\section{THE GENOS FIORINIA IN THE UNITED STATES.}

By E. R. SASSCER, Scientific Assistant.

\section{INTRODUCTION.}

The genus Fiorinia at the present time consists of some 30 described species and 4 varieties, and of this number there are only 2 species and 1 variety established in this country, viz, Fiorinia fioriniz Targioni Tozetti, $F$. theæ Green, and $F$. fioriniæ japonica Kuwana. Judging from the available records at hand, it is quite evident that the first two coccids mentioned were imported on ornamental plants, and their status in some locations is such as to warrant the use of remedial measures. The last-named variety of fiorinix is a Japanese importation, and while it appears to be established in only one State, it is not infrequently collected at quarantine on imported evergreens.

\section{Fiorinia TARgIonr.}

This genus is characterized by the adult female being smaller, decreasing in size after the second molt, and entirely inclosed in the second larval exuvia; puparium elongate, with first larval exuvia extending beyond the margin. Male scales white, elongate, with or without carinæ, larval exuvia at anterior extremity. Pygidium of adult female (Fiorinia s. str.), possessing well-defined median lobes, and some species exhibiting a small pair on either side; paragenitals normally in five groups, although in some species the median and anterior laterals coalesce, forming an arch.

Leonardi in his paper," "Saggio de Sistematica delle Fiorioniæ" divides Fiorinia sens. lat. into three subgenera, viz, Trullifiorinia (paragenitals and lobes present), Anamefiorinia (paragenitals present, lobes absent), and Adiscofiorinia (paragenitals absent). Fiorinia s. str. is characterized by possessing paragenitals and plates, and the species discussed in this paper come distinctly within this division. 
The following table, based on characters exhibited by the adult female, is offered as a means for separation of the species occurring in the United States.

I. Spatulate protuberance between antennæ present, first pair of lateral lobes represented by serrate thickenings ....................... theæ Green.

II. Spatulate protuberance between antennæ absent, first pair of lateral lobes prominent.

(a) Median and anterior lateral paragenitals usually contiguous, 21-23;

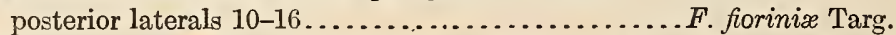

(b) Paragenitals massed and numerous; median 3-11, anterior laterals 16-24, posterior laterals $19-31 . . . . . . . . . . . F$. fioriniæx var. japonica Kuw.

\section{THE TEA SCAIE.}

\section{Fiorinia theæ Green.}

\section{Plates X and XI.}

Fiorinia fioriniæ var. camelliæ Rolfe and Quaintance, Coccidæ Americanæ. Decades i-iii, No. 6 (1898).

Fiorinia the Green, Indian Museum Notes, V, No. 1, p. 3 (1900). Fig.

Fiorinia theæ Stebbing, Insects that affect forestry, No. 1, p. 133 (1902). Fig.

Fiorinia theæ Green, Indian Museum Notes, V, No. 3, p. 102 (1903). Record only.

Fiorinia thex Fernald, Catalogue of the Coccidæ of the world, p. 250 (1903).

Fiorinia thex Watt and Mann, The pests and blights of the tea plant, p. 306, Calcutta, 2d edition (1903). Fig.

Fiorinia theæ Leonardi, Redia, III, p. 28 (1905). Fig. "Saggio di Sistematica Delle Fioriniæ."

Fiorinia theæ Green and Mann, Memoirs of the Department of Agriculture in India, Entomological Series, I, No. 5, pp. 343, 350 (1907). Bibliography and record only. Fiorinia thex Green, Memoirs of the Department of Agriculture in India, Entomological Series, II, No. 2, p. 39 (1908). Record only.

Fiorinia thea Stebbing, Manual of forest zoology for India, p. 165 (1908). Fig.

Fiorinia theæ Lindinger, Zeitschr. f. wiss. Insektenbiol., VII, 4, p. 127 (1911).

Notwithstanding the fact that the tea scale, Fiorinia theæ Green, has been in the National Collection of Coccidæ since 1887 identified as $F$. fioriniz Targ., it was not described until 1900 by Green on tea from Assam and Kangra, India. A thorough study of the material in this collection revealed the fact that all the specimens on Camellia, with the exception of Comstock's type of $F$. camellix, which is now recognized as a synonym of $F$. fiorinix Targ., are the tea scale of Green.

In 1897 Cockerell ${ }^{1}$ recorded what he considered a distinct variety of $F$. fioriniz Targ. on the underside of a leaf of Camellia japonica from Baton Rouge, La., and, judging from his partial description he surely had reference to $F$. theæ Green.

A microscopic study of the material in "Coccidæ Americanæ" (Decades i-iii, No. 6 [1898]), distributed by Rolfs and Quaintance 


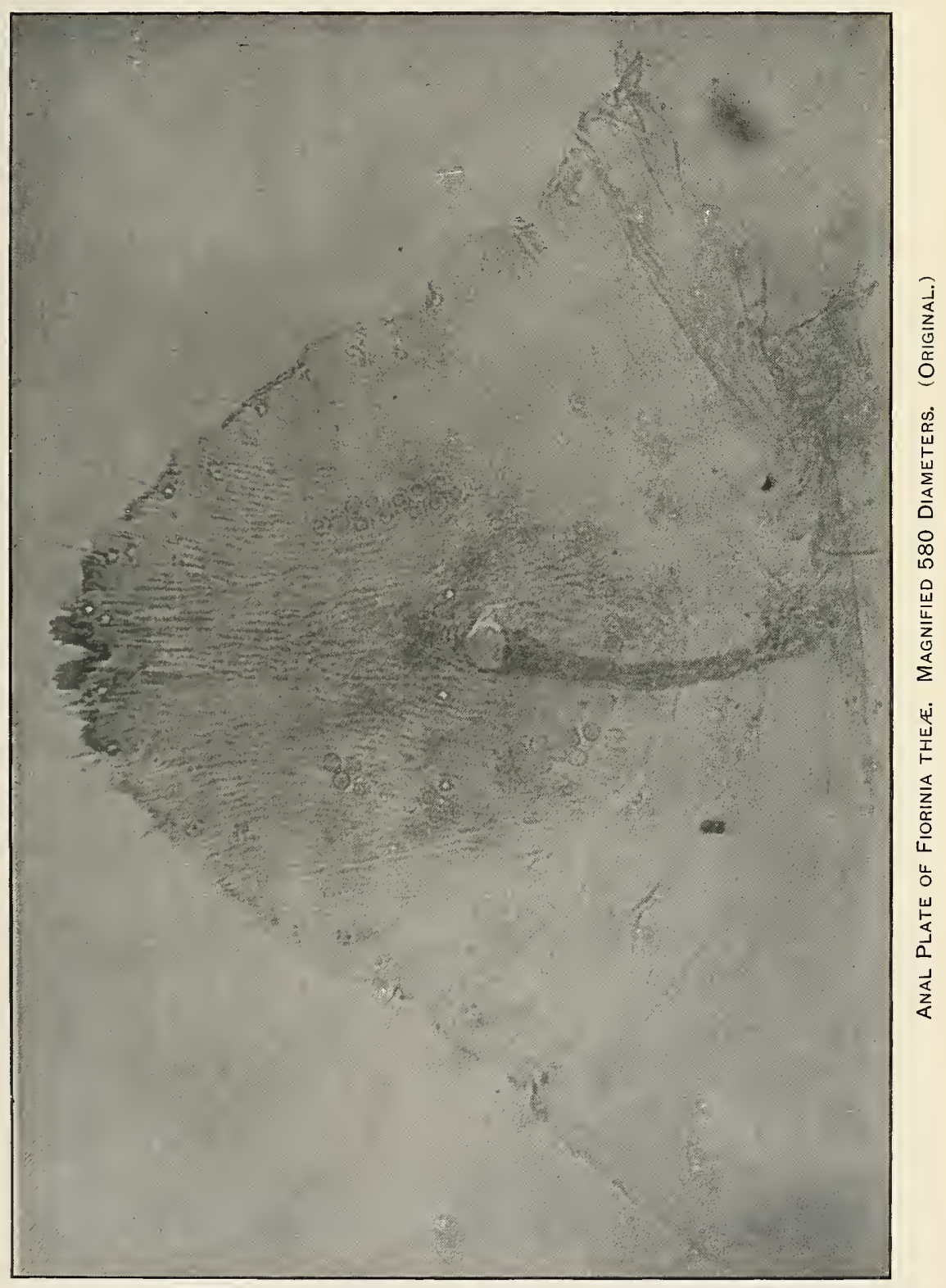




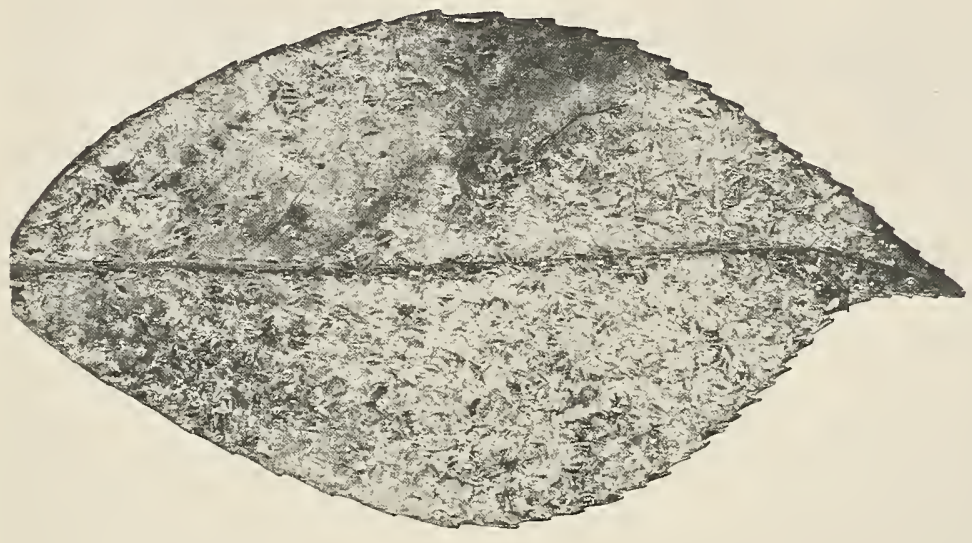

Fig. 1.-Fiorinia the on leaf of Camellia. Twice Enlarged. (Original.)

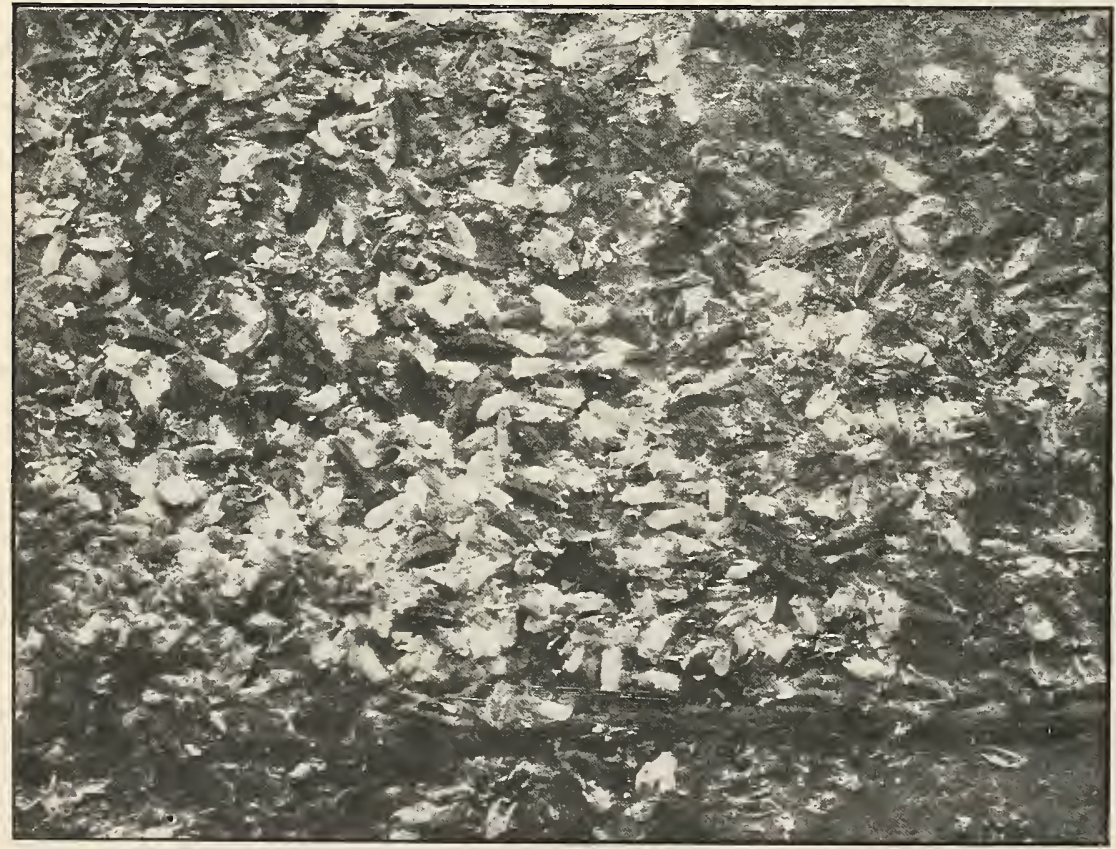

Fig. 2.-Fiorinia thefe on Camellia leaf. Enlarged five Times. (Original.) 
and labeled $F$. fioriniæ var. camelliæx, proves it to be $F$. theæ Green and not a variety.

In March, 1908, Mr. George F. Mitchell, of the Experimental Tea Farm at Summerville, S. C., submitted leaves of tea thickly infested with Fiorinia ther Green and stated that it was becoming a serious enemy of this plant. At the request of Dr. R. H. True, Mr. J. G. Sanders, at that time an agent of the Bureau of Entomology, visited the tea farm and found this scale in abundance on Assam hybrid, Darjeeling, and China teas and camellias grown for ornamental purposes. Mr. Sanders observed that the Darjeeling tea which was grown in moist lowland was frequently covered with a brown fungus, which was apparently parasitic on the scale.

It is the belief of Dr. Charles U. Shepard, who is in charge of the experimental farm, that the tea affords better food than Camellia japonica, and he states that it is seldom if ever that the latter plant is killed by attack of this insect alone.

Since no plants have been introduced from Asiatic regions, all being grown from seed, it is extremely probable that its introduction was through the agency of the camellias, which have been for a number of years greatly in demand as ornamental plants in this country.

According to Watt and Mann ${ }^{1}$ this scale is of common occurrence in both Assam and Kangra, and is the most prevalent of all coccids in the former Province. Mr. Stebbing ${ }^{2}$ records it on the leaves of the olive, Olea glandulifera, in the northwestern Himalayas, frequently causing the leaves to turn yellow and drop off.

Although this insect occurs on both sides of the leaves of tea and Camellia japonica, it is more commonly found on the underside, and if present in sufficient numbers it can be easily detected by yellow markings plainly to be seen on the upper surface.

Fiorinia theæ Green can be readily separated from $F$. fioriniæ Targ. by the larger and darker scale, the presence of a proboscis-like projection between the antennæ which have no stout spines, and in the absence of lateral lobes on the pygidium.

Scale of female.--Elongate, narrow, dark brown in color, usually darker than $F$. fioriniæ, with a distinct dark median longitudinal carina; adult insect entirely inclosed in the hardened exuvia of the second stage, which varies from 1 to $1.24 \mathrm{~mm}$. in length, and does not bear a secretionary margin. Length, 1 to $1.40 \mathrm{~mm}$. Breadth, 0.40 to $0.60 \mathrm{~mm}$.

Scale of male.-Snow-white, sides nearly parallel, usually indistinctly tricarinate, pellicle pale yellow approaching lemon-yellow at extreme posterior tip. When present in large numbers the puparia

1 The Pests and Blights of the Tea Plant (second edition), p. 306 (1903).

2 Manual of Forest Zoology of India, p. 166 (1908). 
are frequently covered with a flocculent secretion given off by the larvæ. Length, 0.80 to $1 \mathrm{~mm}$; breadth, about $0.40 \mathrm{~mm}$.

Eggs: Arranged in double rows inclosed within the second larval exuvia.

Female.1 "Adult female pale yellow, of normal form. Antennæ close together, on anterior margin; each antenna consisting of an irregular tubercle with a single curved bristle on one side. From between the antennæ springs a stout spatulate process which is not chitinous but of the same consistency as the surrounding parts of the body. Margin of thorax and abdomen with a series of minute spinneret ducts opening on to small conical tubercles. Pygidium (Pl. I) with a conspicuous median cleft, on the margin of which are situated the moderately large serrate median lobes. First pair of lateral lobes represented only by small serrate thickenings of the margin; second lateral lobes obsolete." [Although the lateral lobes are wanting in the adult, they are quite prominent on the second larval exuvia and are of the normal $F$. fiorinix type.] "Spines normal, the dorsal series rather long; one pair springing from within the median cleft. Circumgenital glands in five groups; the median and upper lateral groups together forming an almost continuous arch. Median group with four or five orifices; upper laterals, 10 to 13 ; lower laterals, 15 to 18 . A very few circular pores with accompanying ducts, on dorsal surface, near the margin. Length, 0.50 to $0.75 \mathrm{~mm}$."

\section{DISTRIBUTION.}

The tea scale is recorded on Camellias in Alabama, District of Columbia, Florida, Georgia, Louisiana, North Carolina, and South Carolina. It has been collected in Ceylon, Philippine Islands, and India, occurring in the following localities in the latter country: Kangra Valley, Assam, Bashahr State close to Kilta in the Sutlej Valley, Calcutta, and the northwestern Himalayas.

\section{FOOD PLANTS.}

In the United States this scale has only been collected on camellias and tea, but in India it has been recorded on tea, olive (Olea glandulifera), and citrus. In the Philippine Islands it occurs on a species of Caryola, and Mr. R. S. Woglum has collected it on Ostodes in the Royal Botanical Gardens of Peradenyia, Ceylon. Although $F$. ther seems to show a preference to the tea at Summerville, S. C., it appears to be quite a serious pest on the camellias in several of the more Southern States, and is not infrequently found associated with Lepidosaphes lasianthi Green.

1 Owing to the accuracy of Mr. E. E. Green's description of this species it has been deemed wise to give it verbatim. (Indian Museum Notes, 5, No. 1, p. 3 (1900).) 


\section{ENEMIES.}

The following predaceous beetles which have been determined by Mr. E. A. Schwarz, of the Bureau of Entomology, were found by Mr. Sanders preying on the tea scale: Chilocorus bivulnerus Muls., Microweisea misella Lec., and Cybocephalus nigritulus Lec. As stated elsewhere, when on the Darjeeling tea these coccids are frequently covered by a parasitic fungus, which doubtless in a measure is effective in holding this pest in check.

\section{Fioninia fioriniz TARG. \\ Pyates XII and XIII.}

Diaspis foriniæ Targioni, Studii sul. Cocciniglie, p. 14 (1867).

Chermes arecæ Boisduval, Insectologie Agricole, p. 262 (1868).

Fiorinia pellucida Targioni, Catalogue, p. 42 (1868).

Fiorinia camelliæ Comstock, Rep. U. S. Dept. Agr. 1880, p. 329 (1881).

Uhleria fiorinix Comstock, 2nd Rep. Dept. Ent. Cornell Univ., p. 111 (1883).

Fiorinia palmæ Green, Ind. Mus. Notes, IV, p. 5 (1896).

This coccid is a very cosmopolitan species and is of common occurrence on kentias in greenhouses. A complete bibliography of this species is not given, since it has been the subject of numerous papers, many of which, however, are of little value either from a scientific or economic standpoint.

\section{DISCUSSION OF SYNONYMY.}

A thorough study of the material on Kentia belmoreana, Cycas revoluta, and Camellia which was described by Comstock ${ }^{1}$ as Fiorinia camelliz proves this species to be none other than Fiorinia fioriniz Targ. In 1896 Green $^{2}$ described a form known as Fiorinia palmæ, but he later reduced it to synonymy. Leonardi, ${ }^{3}$ in his paper entitled "Saggio di Systematica Delle Fiorinia," reduces Fiorinia fiorinix var. minor Maskell to synonymy, since Maskell in his meager description merely states that it was given varietal rank, owing to its small size. Assuming that the only character of separation was the size of the scale, Leonardi concluded that the difference was too inadequate to justify even varietal rank.

A study of the Maskell material revealed a number of characters which are surely of sufficient importance to allow it to remain as a good variety if not raised to specific rank. As will be seen by examining Plate IV, the median lobes in minor are larger and more chitinized, the marginal pores more numerous, varying from six to seven, and the general shape of the pygidium is different. The material of this variety is very scanty and is on the underside of a leaf which is 
quite hairy, causing the scales to assume various shapes and possibly preventing them from reaching their normal dimensions. In size the pygidium of Fiorinia forinize Targ. and Fiorinia forinix var. minor Mask. compare very favorably.

\section{DISTRIBUTION.}

Fiorinia fioriniz Targ. has a wide range of distribution and is known to occur in the following countries: Algiers, Australia, Barbados, Brazil, Ceylon, China, Egypt, Europe (Belgium and Spain), Jamaica, Japan, Madeira(?), Mauritius, Mexico, New South Wales, Peru, United States (Alabama, California, Colorado, District of Columbia, Hawaiian Islands, Louisiana, Maryland, and Massachusetts), West Africa, and Zanzibar.

\section{FOOD PLANTS.}

The food plants of this insect are numerous, some of the most important of which are the following:

Anthurium acaule, Appolonias canariensis, Aralia, Areca aurea, bamboo, bay, Camellia, Celtis mauritiana, Chamarops humuli, coconut palm, Cupressus, Cycas circinalis, C. revoluta, Dracæna indivisa, ferns, Ficus elastica, Ficus sp., Garcinia sp., Hedera helix, Japanese quince, Kentia belmoreana, $K$. fosteriana, Larix sp., Leptospermum, Licula, Livistona, Persea gratissima, Phœnix canariensis, Phœnix sp., Phormium tenax, Phytelephas macrocarpa, Podocarpus, Strelitzia reginix, tea (Thea japonica).

\section{ENEMIES.}

In studying the slides of the National Collection of Coccidæ one partially mature specimen of the parasite Aspidiotiphagus citrinus Craw was discovered inclosed in the body of an adult insect collected in Washington, D. C., on Chæmerops humuli and the same chalcid has also been reared from material on Persea gratissima from Honolulu, Hawaii. In addition to the above a species of Aspidiotiphagus was reared from this scale on an unknown plant collected at Hongkong by Mr. Kcebele, and he also collected Prospaltella aurantii How. from this coccid on Ficus sp. at Swatow, Canton, China.

Among the fungous enemies of this coccid the redheaded fungus (Sphrrostilbe coccophila) has been recorded ${ }^{1}$ by Mr. John Parkin from Mauritius on infested Camellia.

\section{DESCRIPTION.}

Scale of female.-Elongate, narrow, revealing a distinct median longitudinal ridge; first larval exuvia yellow, small, and extending beyond the margin; second larval exuvia ranging from 1.20 to 1.46 


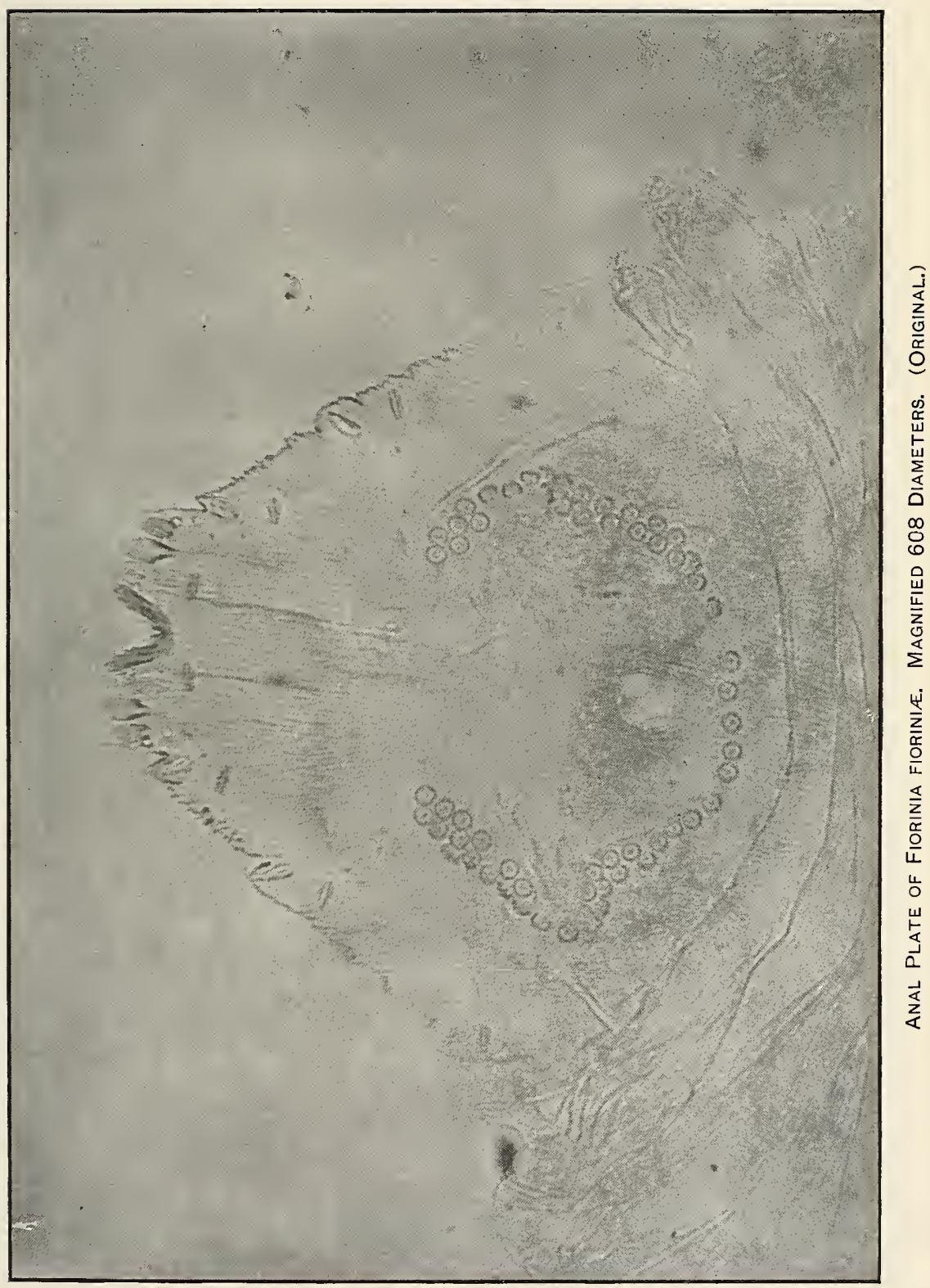




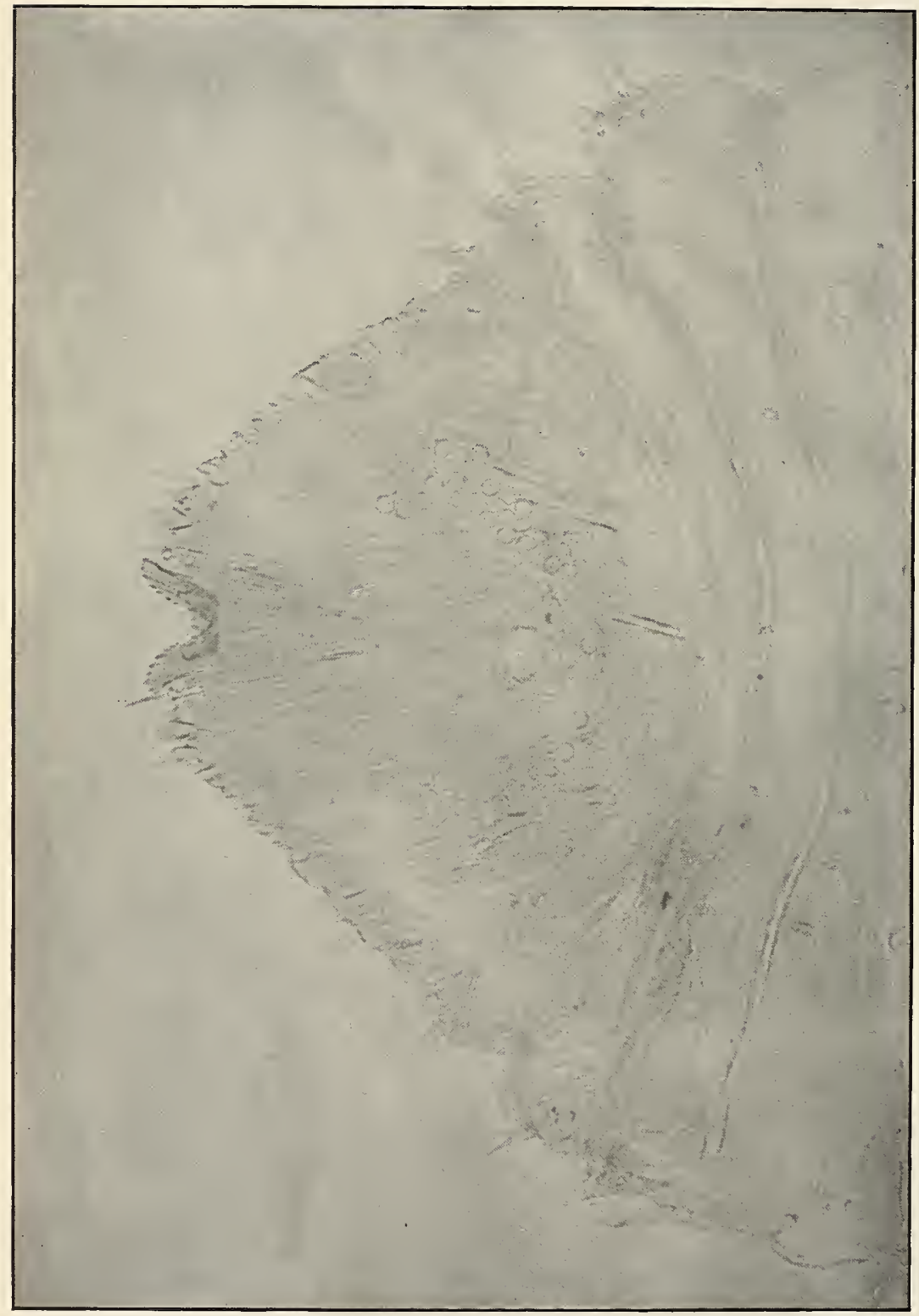

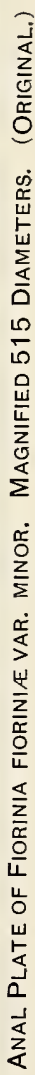


$\mathrm{mm}$. in length and varying from brown to dark brown with frequently a white secretionary margin, and inclosing the adult insect, which is situated in the anterior portion of the scale. Length 1 to $1.25 \mathrm{~mm}$. Breadth about $0.50 \mathrm{~mm}$.

Eggs.-Yellow and arranged in a double row.

Scale of male.-White, tricarinate, larval exuvia pale yellow, Length about $1 \mathrm{~mm}$. Breadth about $0.40 \mathrm{~mm}$.

Female.-Thin and much contracted after oviposition, elongate, possessing rudimentary antennæ, which are apparently two-jointed, the first consisting of a fleshy tubercle, which bears the second joint and a bristle, the second joint occasionally possessing a short lateral branch near the tip; anal plate triangular, 0.187 to $0.204 \mathrm{~mm}$. in width, slightly truncate at tip, median notch distinct and formed by the median lobes, which are oblique and serrated along their entire free edge; second lobes prominent both in second larval exuvia and adult, incised, about twice as long as broad and followed by several indentations; margin of the pygidium exhibiting four rather conspicuous tubular pores; between the median lobes are two short spines; located on the dorsal surface situated along the lateral margin of the median lobe there are two spines, the posterior being the larger, one on the outer lobule of the second lobe and two situated between the second lobe and the penultimate segment; on ventral surface there is a spine corresponding with each dorsal spine, except on the first lobe; laterad of each lobe there is an elongate pore and two between the second lobule and the penultimate segment; anal opening twice the width of one median lobe and far removed from the tip; median and anterior lateral paragenitals contiguous, forming an arch, 21 to 23 , posterior laterals 10 to 16 .

\section{Fiorinia foriniæ japonica Kuw.}

Fiorinia foriniæ japonica Kuwana, Proc. Cal. Acad. Sci. (3), III, p. 79 (1902).

Fiorinia fioriniæ japonica Coleman, Journ. N. Y. Ent. Soc., XI, p. 84 (1903). Record only.

Fiorinia forinix japonica Leonardi, Redia, III, Fasc. 1, p. 36 (1905). Bibliography and description.

Fiorinia forinix japonica Kuwana, Bul. Imp. Cent. Agr. Exp. Sta., Japan, p. 200 (1907). Bibliography and record only.

Fiorinia fioriniz japonica Brick, Sta. f. Pflanzenschutz z. Hamburg, XI, p. 6 (1909). Record only.

Fiorinia fiorinix japonica Brick, Jahrb. Hamb. wiss. Anst., XXVII, p. 505 (1909). Record only.

Fiorinia fiorinix japonica Essig, Pom. Journ. Ent., II, 2, p. 207 (1910). Description and figure.

Fiorinia fioriniæ japonica Lindinger, Zeitschr. f. wiss. Insektenbiol., VII, 4, p. 126 (1911). Record only.

Although this variety of fioriniæ is a native of Japan, it has been introduced into this country on numerous occasions on infested ever- 
greens. In September of 1908 it was collected on Tsuga sp., at Queens, Long Island, by Mr. F. N. Meyer, where it had apparently become established, and subsequently it was collected in New York by Mr. E. P. Felt on Japanese hemlock. In June of 1909 it was collected on the fruit and leaves of Podocarpus elata received by the Bureau of Plant Industry from the Botanical Gardens of New South Wales. Mr. Edward M. Ehrhorn, while horticultural commissioner of California, collected it at quarantine on Podocarpus chinensis and Pinus sp. Mr. Lindinger in a recent paper ${ }^{1}$ records it from the Philippine Islands on Podocarpus nageia and Abies veitchi and Mr. Brick reports it from Japan on Pinus pentaphylla, P. thunbergi, and Tsuga sieboldi.

\section{DESCRIPTION.}

Scale of female.-Fresh female scales frequently covered with a white powdery substance, median carina indistinct and frequently not visible, brown to dark brown, reaching a chestnut brown at the anterior end of the scale; first larval exuvia yellow, about three-fourths of it extending beyond the margin; second larval exuvia 1.80 to 2 $\mathrm{mm}$. in length and from 0.60 to $0.80 \mathrm{~mm}$. in breadth. When collected on T suga sp., it usually occurs on the underside of the leaves, although this does not hold true in the case of the specimens on Podocarpus.

Scale of male.- White, apparently uncarinated, larval exuvia yellow. Length about $1 \mathrm{~mm}$. Breadth about $0.40 \mathrm{~mm}$.

Female.-Thin, pygidium slightly brownish, antennæ rudimentary, apparently two-jointed, the second joint bearing a spine; width of pygidium 0.187 to $0.255 \mathrm{~mm}$., slightly truncate at tip, median lobes serrated along free edge, oblique, forming a distinct notch, second lobes conspicuous in both second larval exuvia and adult, incised, approximately twice as long as broad, six prominent tubular pores on the margin of the pygidium with two very short spines between the median lobes; gland spines simple, long, one laterad of each lobe and one on the margin near the penultimate segment; on the dorsal surface along the lateral margin of the median lobes there are two spines, the posterior being the larger, one on the outer lobule of the second lobe, and two between second lobe and penultimate segment. Anal opening far removed from the tip and twice the width of a median lobe. Paragenitals in five groups, arranged as follows: Median group 3 to 11 , anterior laterals 16 to 24 , posterior laterals 19 to 31 . 


Technical Series, No. 16, PART VI.

U. S. DEPARTMENT OF AGRICULTURE, BUREAU OF EN'TOMOLOGY.

L. O. HOWARD, Entomologist and Chief of Bureau.

\section{PAPERS ON COCCIDE OR SCALE INSECTS.}

\section{CATALOGUE}

OF

\section{RECENTLY DESCRIBED COCCIDE-IV.}

By E. R. SASSCER,

Scientific Assistant.

IsSUED OCTOBER 19, 1912.

WASHINGTON:

GOVERNMENT PRINTING OFFIOE. 



\section{CONTENTS.}

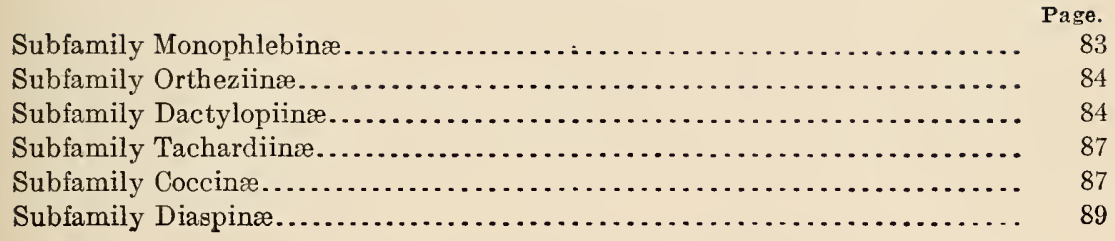





\section{PAPERS ON COCCID E OR SCALE INSECTS.}

\section{CATALOGUE OF RECENTLY DESCRIBED COCCID ZE-IV.}

By E. R. Sasscer, Scientific Assistant.

Since the publication of the "Catalogue of Recently Described Coccidæ-III," 16 new genera, 110 new species, and 4 new varieties have been described in various publications by workers on Coccidæ. This makes a total of 29 new genera, 9 new subgenera, 540 new species, and 45 new varieties recorded since the appearance of Mrs. Fernald's Catalogue in 1903 . The writer believes this list to be fairly complete to March, 1912, and earnestly requests the assistance of coworkers in adding any references that may have escaped his notice.

All species marked with an asterisk are represented in the National Collection of Coccidæ.

\section{Subfamily MONOPHLEBIN 西.}

Monophlebus africanus Newstead.

Monophlebus africanus Newst., Zool. Anthr. Ergeb. westl. zentr. Südafr., v, 1, p. 15 (1912). Fig.

Habitat-Dutch Southwest Africa.

On roots of ! "kxuibes"-plant.

Stigmacoccus zimmermanni Newstead.

Perissopneumon zimmermanni Newst., Mitt. zool. Mus. Berlin, v, 2, p. 157 (1911).

Habitat-German East Africa.

On Manihot glazionii.

Aspidioproctus armatus Newstead.

Aspidioproctus armatus Newst., Mitt. zool. Mus. Berlin, v, 2, p. 160 (1911). Fig.

Habitat-German East Africa.

On Acacia.

Aspidioproctus maximus Newstead.

*Aspidioproctus maximus Newst., Mitt. zool. Mus. Berlin, v, 2, p. 158 (1911). Fig.

Habitat-German East Africa.

On M'sasa tree (Brachystegia randii).

'Sasscer, E. R., 'Catalogue of Recntly Described Coccidæ-III," Tech. Ser. 16, Part IV, Bur. Ent., U. S. Dept. Agr., 1911. 
Icerya longisetosa Newstead.

Icerya longisetosa Newst., Mitt. zool. Mus. Berlin, v, 2, p. 155 (1911). Fig.

Habitat-German East Africa.

On Acacia.

Icerya subandina Leonardi.

Icerya subandina Leon., Bol. Zool. Sc. Sup. Portici, v, p. 238 (1911). Fig.

Habitat-Argentina.

On Bulvesia retana.

Lophococcus mirabilis tricornis Newstead.

Lophococcus mirabilis tricornis Newst., Zool. anthr. Ergeb. westl. zentr. Südafr., v, 1, p. 17 (1912). Fig.

Habitat-Dutch Southwest Africa.

On ?

\section{Subfamily ORTHEZIIN 2 .}

Orthezia varipes Leonardi.

Orthezia varipes Leon., Bol. Zool. Sc. Sup. Portici, v, p. 240 (1911). Fig.

Habitat-Argentina.

On Atriplex lampa.

\section{Subfamily DACTYLOPIIN}

Opisthoscelis (?) prosopidis Kieffer and Jorgensen.

Opisthoscelis prosopidis Kieffer and Jorgensen, Centr. f. Bakt. Par. u. Infekt., xxvii, 2, p. 417 (1910). Fig.

Habitat-Argentina.

In galls of Prosopis adesmioides.

Asterolecanium coffer Newstead.

Asterolecanium coffer Newst., Mitt. zool. Mus. Berlin, v, 2, p. 161 (1911). Fig.

Habitat-German East Africa.

On Coffea arabica.

Lecaniodiaspis africana Newstead.

Antonina (?) africana Newst. (sine descr.), Liverpool Univ., Quart. Jn., i, 2, pp. 69, 72 (1906).

Draper, Scale Insects of Egypt, p. 11 (1907).

Lecaniodiaspis africana Newst., Bul. Ent. Res., ii, 2, p. 100 (1911). Fig.

Habitat-Egypt.

On Acacia arabica and Ficus sp.

Cerococcus andinus Leonardi.

Cerococcus andinus Leon., Bol. Zool. Sc. Sup. Portici, v, p. 245 (1911). Fig.

Habitat-Argentina.

On Tricycla patagonica, T. cacheuta.

Cerococcus badius Leonardi.

Cerococcus badius Leon., Bol. Zool. Sc. Sup. Portici, v, p. 243 (1911). Fig.

Habitat-Argentina.

On Vendtia calycina, Baccharis rosmarinifolia. 
Birchippia americana Leonardi.

Birchippia americana Leon., Bol. Zool. Sc. Sup. Portici, v, p. 246 (1911). Fig.

Habitat-Argentina.

On Larrea divaricata, L. cuneata.

Kermes shastensis Ehrhorn.

Kermes shastensis Ehrh., Can. Ent., xliii, 8, p. 275 (1911).

Habitat-California.

On Quercus chrysolepsis.

Eriococcus diversispinus Leonardi.

Eriococcus diversispinus Leon., Bol. Zool. Sc. Sup. Portici, v, p. 249 (1911). Fig.

Habitat-Argentina.

On Zuccagnia punctata.

Eriococcus eriogoni Ehrhorn.

Eriococcus eriogoni Ehrh., Can. Ent., xliii, 8, p. 276 (1911).

Habitat-Arizona.

On Eriogonum stellatum.

Eriococcus parcispinosus Leonardi.

Eriococcus parcispinosus Leon., Bol. Zool. Sc. Sup. Portici, v, p. 248 (1911). Fig.

Habitat-Argentina.

On Atriplex lampa.

Eriococcus salinus Ehrhorn.

Eriococcus salinus Ehrh., Can. Ent., xliii, 8, p. 276 (1911).

Habitat-California.

On roots of grass (Distichlis sp.?).

Gymnococcus lahillei Leonardi.

Gymnococcus lahillei Leon., Bol. Zool. Sc. Sup. Portici, v, p. 251 (1911). Fig.

Habitat-Argentina.

On Larrea divaricata, L. cuneata.

Cissococcus ? oahuensis Ehrhorn.

Cissococcus? oahuensis Ehrh., Proc. Haw. Ent. Soc., ii, 4, pp. 149, 179 (1912). Fig.

Habitat-Hawaiian Islands.

On Opuhe (Urera sandwichensis).

Sphærococcus cupressi Ehrhorn.

Sphærococcus cupressi Ehrh., Can. Ent., xliii, 8, p. 277 (1911). Fig.

Habitat-California.

"Under dry bark and in crevices on trunk of Cupressus macrocarpa."

Ceroputo koebelei Ehrhorn.

Ceroputo koebelei Ehrh., Can. Ent., xliii, 8, p. 278 (1911). Fig.

Habitat-Arizona.

On Quercus engelmanni. 
Genus LACHNODIELLA von Ihering. Type, cecropiæ.

Lachnodiella von Iher. (sine descr.), Bot. Jahrb., xxxix, 5, p. 680 (1907).

Sanders, Catalogue Coccidæ-II, p. 40 (1909).

Hempel, Rev. Mus. Paul., viii, p. 52 (1911). Descr.

Lachnodiella cecropiæ von Ihering.

Lachnodiella cecropiæ von Iher. (sine descr.), Bot. Jahrb., xxxix, 5, p. 680 (1907).

Sanders, Catalogue Coccidæ-II, p. 40 (1909).

Habitat-Brazil.

Hempel, Rev. Mus. Paul., viii, p. 52 (1911). Descr.

On Cecropia adenopus.

\section{Trionymus californicus Ehrhorn.}

Trionymus californicus Ehrh., Can. Ent., xliii, 8, p. 270 (1911). Fig.

Habitat-California.

On Festuca sp.

Pseudococcus aridorum Lindinger.

Pseudococcus aridorum Lindgr., Jahrb. Hamb. wiss. Anst., xxviii, 3, p. 7 (1911). Fig.

Habitat-Canary Islands.

On Argyranthemum frutescens, Cytisus prolifer var. palmensis, grass, Trifolium panormitanum.

\section{Pseudococcus crotonis Green.}

Dactylopius crotonis Green (sine descr.), Trop. Agr., xxiv, p. 44 (1905).

Pseudococcus crotonis Sanders, Catalogue Coccidæ-I, p. 5 (1906).

Dactylopius crotonis Green, Jn. Econ. Biol., vi, 2, p. 35 (1911). Fig.

Habitat-Ceylon.

On Castilloa elastica, variegated croton (Codiæum variegatum), Terminalia catappa, Erythrina lithosperma.

Pseudococcus ledi Cockerell.

*Pseudococcus ledi Ckll., Ent. News, xxii, 5, p. 217 (1911).

Habitat-New York.

On Ledum grenlandicum.

Pseudococcus mendozinus Leonardi.

Pseudococcus mendozinus Leon., Bol. Zool. Sc. Sup. Portici, v, p. 255 (1911). Fig.

Babitat-A rgentina.

On Hyalis argentea.

Pseudococcus obtusus Newstead.

Dactylopius (Pseudococcus) obtusus Newst., Mitt. zool. Mus. Berlin, v, 2, p. 164 (1911).

Fig.

Habitat-German East Africa.

On Baobabrinde.

Pseudococcus percerosus Leonardi.

Pseudococcus percerosus Leon., Bol. Zool. Sc. Sup. Portici, v, p. 254 (1911). Fig.

Habitat-Argentina.

On Gourliea decorticans.

Genus HELIOCOCCUS Sulc. Type, bohemicus.

Heliococcus Sulc, C̆as. Společ. Ent., ix, 1, p. 39 (1912). 
Heliococcus bohemicus Sulc.

Heliococcus bohemicus Sulc, Čas. Společ. Ent., ix, 1, p. 39 (1912). Fig.

Habitat-Bohemia and Moravia.

On Robinia pseudacacia.

\section{Ripersia grandulifera Newstead.}

Ripersia grandulifera Newst., Zool. anthr. Ergeb. westl. zentr. Südafr., v, 1, p. 17 (1912). Fig.

Habitat-Southwest Africa.

On Adiantum sp.

\section{Subfamily TACHARDIIN Z2.}

Tachardia albizziæ Green.

Tachardia albizzix Green (sine descr.), Ind. Mus. Notes, v, p. 98 (1903).

Tachardia albizziæ Sanders, Catalogue Coccidæ-1, p. 6 (1906).

Tachardia albizziæ Green, Jn. Econ. Biol., vi, 2, p. 32 (1911). Fig. Description.

Habitat-Ceylon.

On Landolphia sp., Albizzia stipulata, Filicium decipiens, Harpullia cupanioides,

Croton lacciferum. Theobroma cacao, Sleichera trijuga.

Tachardia cordaliæ Leonardi.

Tachardia cordalix Leon., Bol. Zool. Sc. Sup. Portici, v, p. 258 (1911). Fig.

Habitat-Argentina.

On Cordalia lineata.

Tachardia longisetosa Newstead.

Tachardia longisetosa Newst., Bul. Ent. Res., ii, 2, p. 102 (1911).

Habitat-Uganda.

On bark-cloth (Fiscus sp.):

Tachardia Iycii Leonardi.

Tachardia lycii Leon., Bol. Zool. Sc. Sup. Portici, v, p. 256 (1911). Fig.

Habitat-Argentina.

On Lycium chilense.

\section{Subfamily COCCIN⿴囗十}

Pulvinaria argentina Leonardi.

Pulvinaria argentina Leon., Bol. Zool. Sc. Sup. Portici, v, p. 260 (1911). Fig.

Habitat-Argentina.

On Lycium chilense, Fabiana denudata.

Pulvinaria plana Lindinger.

Pulvinaria plana Lindgr., Jahrb. Hamb. wiss. Anst., xxviii, 3, p. 34 (1911). Fig.

Habitat-Canary Islands.

On underside of leaves of Laurus canariensis.

Iuzulaspis spinulosa Leonardi.

Luzulaspis spinulosa Leon., Bol. Zool. Sc. Sup. Portici, v, p. 262 (1911). Fig.

Habitat-Argentina.

On Atriplex lampa.

$58242^{\circ}-12-2$ 


\section{Ceroplastes breviseta Leonardi.}

Ceroplastes breviseta Leon., Bol. Zool. Sc. Sup. Portici, v, p. 264 (1911). Fig.

Habitat-Argentina.

On Atriplex lampa.

\section{Ceroplastes galeatus Newstead.}

Ceroplastes galeatus Newst., Bul. Ent. Res., ii, 2, p. 95 (1911). Fig.

Habitat-Uganda.

On?

Ceroplastes irregularis Leonardi.

Ceroplastes irregularis Leon,, Bol. Zool. Sc. Sup. Portici, v, p. 271 (1911). Fig.

Habitat-Argentina.

On Larrea cuneata.

\section{Ceroplastes longiseta Leonardi.}

Ceroplastes longiseta Leon., Bol. Zool. Sc. Sup. Portici, v, p. 268 (1911). Fig.

Habitat-Argentina.

On Fabiana denudata.

Ceroplastes subrotundus Leonardi.

Ceroplastes subrotundus Leon., Bol. Zool. Sc. Sup. Portici, v, p. 266 (1911). Fig.

Habitat-Argentina.

On Cercidium andicolum.

\section{Ceroplastes subsphæricus Newstead.}

Ceroplastes subsphæricus Newst., Mitt. zool. Mus. Berlin, v, 2, p. 166 (1911).

Habitat-German East Africa.

On Albizzia lebbek.

Ceroplastes ugandø Newstead.

Ceroplastes ugandæ Newst., Bul. Ent. Res., ii, 2, p. 94 (1911). Fig.

Habitat-Uganda.

On "Amakebe."

Ceroplastes vinsonioides Newstead.

Ceroplastes vinsonioides Newst., Bul. Ent. Res., ii, 2, p. 96 (1911). Fig.

Habitat-Uganda.

On Coffea.

Ceroplastes gowdeyi Newstead.

Ceroplastes gowdeyi Newst., Bul. Ent. Res., ii, 2, p. 98 (1911). Fig.

Habitat-Uganda.

On African bark-tree (Ficus sp.).

Inglisia castillow Green.

Inglisia castillo:e Green, Jn. Econ. Biol., vi, 2, p. 29 (1911). Fig.

Habitat-Ceylon.

On Castilloa elastica, Grewia microcos, Adenochlæna zeylanica, Solanum sp., Ternonia sp., and tea.

Coccus nyasæ Newstead.

Lecanium nyasæ Newst., Mitt. zool. Mus. Berlin, v, 2, p. 162 (1911). Fig.

Habitat-German East Africa.

On? 
Lecanium elegans Leonardi.

Eulecanium elegans Leon., Bol. zool. Sc. Sup. Portici, v, p. 273 (1911). Fig.

Habitat-Argentina.

On Larrea cuneata, $L$, divaricata.

\section{Lecanium tenuivalvatum Newstead.}

Lecanium tenuivalvatum Newst., Bul. Ent. Res., ii, 2, p. 92 (1911). Fig.

Habitat-Uganda.

On citronella grass.

Lecanium tremæ Newstead.

Lecanium (Eulecanium) tremæ Newst., Mitt. zool. Mus. Berlin, v, 2, p. 162 (1911). Fig.

Lecanium (Eulecanium) tremæ Newst., Bul. Ent. Res., ii, 2, p. 93 (1911).

Habitat-German East Africa.

On Trema guineensis.

Saissetia silvestrii Leonardi.

Saissetia silvestrii Leon., Bol. Zool. Sc. Sup. Portici, v, p. 275 (1911). Fig.

Habitat-Argentina.

On Zuccagnia punctata.

\section{Subfamily DIASPIN As.}

Chionaspis africana Newstead.

Chionaspis africana Newst., Zool. anthr. Ergeb. westl. zentr. Südafr., v, 1, p. 19 (1912). Fig.

Habitat-Southwest Africa.

On?

Chionaspis amaniensis Lindinger.

Chionaspis amaniensis Lindgr., Jahrb. Hamb. wiss. Anst., xxvii, 3, p. 42 (1910). Fig. Habitat-German East Africa.

On underside of an undertermined dicotyledonous leaf.

Chionaspis arthrocnemi Lindinger.

Chionaspis arthrocnemi Lindgr., Zeitschr. f. wiss. Insektenbiol., vii, 11, p. 354 (1911). Fig.

Habitat-Turkey.

On Arthrocnemum macrostachyum.

Chionaspis canariensis Lindinger.

Chionaspis canariensis Lindgr., Jahrb. Hamb. wiss. Anst., xxviii, 3, p. 26 (1911). Fig. Habitat-Canary Islands.

On Plocama pendula, Micromeria ericifolia, M. linki, $M$. teneriff $x$, M. terebinthacea, Micromeria sp., Ruta oreojasme, Salsola longifolia, Cneorum pulverulentum, Cytisus filiper.

Chionaspis cassim Newstead.

Chionaspis cassiæ Newst., Bul. Ent. Res., ii, 2, p. 89 (1911). Fig.

Habitat-Uganda.

On Cassia floribunda.

Chionaspis longispina Newstead.

Chionaspis longispina Newst., Bul. Ent. Res., ii, 2, p. 88 (1911). Fig.

Habitat-Egypt.

On Justicia alba. 
Chionaspis mytilaspiformis Newstead.

Chionaspis mytilaspiformis Newst., Zool. anthr. Ergeb. westl. zentr. Südafr., v, 1, p. 19 (1912). Fig.

Habitat-Southwest Africa.

On Rhus lancea.

Chionaspis nudata Newstead.

Chionaspis nudata Newst., Mitt. zool. Mus. Berlin, v, 2, p. 170 (1911). Fig.

Habitat-German East Africa.

On (?)

\section{Chionaspis subnudata Newstead.}

Chionaspis subnudata Newst., Zool. anthr. Ergeb. westl. zentr. Südafr., v, 1, p. 19 (1912). Fig.

Habitat-Southwest Africa.

On "! obarus."

Diaspis atlantica Lindinger.

Diaspis atlantica Lindgr., Jahrb. Hamb. wiss. Anst., xxviii, 3, p. 28 (1911). Fig.

Habitat-Canary Islands.

On leaf of Juniperus phoenicea.

\section{Diaspis barrancorum lindinger.}

Diaspis barrancorum Lindgr., Jahrb. Hamb. wiss. Anst., xxviii, p. 29 (1911). Fig. Habitat-Canary Islands.

On Euphorbia regis-jubæ.

Diaspis parva Lindinger.

Diaspis parva Lindgr., Jahrb. Hamb. wiss. Anst., xxvii, 3, p. 44 (1910). Fig.

Habitat-German East Africa.

On leaf and twig of Loranthus undulatus var. sagittifolius.

\section{Diaspis regularis Newstead.}

Diaspis regularis Newst., Bul. Ent. Res., ii, 2, p. 86 (1911). Fig.

Habitat-Uganda.

On (?)

\section{Aulacaspis cinnamomi mangiferæ Newstead.}

Diaspis (Aulacaspis) cinnamomi v. mangiferæ Newst., Bul. Ent. Res., ii, 2, p. 86 (1911). Fig.

Habitat-Egypt (imported from Ceylon).

On mango.

Phenacaspis bussii Newstead.

Chionaspis bussii Newst., Mitt. zool. Mus. Berlin, v, 2, p. 171 (1911).

Habitat-German East Africa.

On Macrolobium sp.

Phenacaspis lutea Newstead.

Chionaspis lutea Newst., Mitt. zool. Mus. Berlin, v, 2, p. 169 (1911). Fig.

Habitat-German East Africa.

On forest tree, under fungus.

\section{Phenacaspis tangana lindinger.}

Phenacaspis tangana Lindgr., Jahrb. Hamb. wiss. Anst., xxvii, 3, p. 45 (1910). Fig.

Habitat-German East Africa.

On leaf of Dracæna sp. 
Femichionaspis chionaspiformis Newstead.

Diaspis (?) chionaspiformis Newst., Bul. Ent. Res., i, 3, p. 198 (1910). Fig.

Chionaspis unita Lindgr., Jahrb. Hamb. wiss. Anst., xxvii, 3, p. 43 (1910). Fig.

Hemichionaspis chionaspitiformis Lindgr., Jahrb. Hamb. wiss. Anst., xxvii, Berichtigung (1910).

Diaspis (?) chionaspiformis Sasscer, Catalogue Coccidæ-III, p. 68 (1911).

Habitat-British and German East Africa.

On an unknown plant and Turræa sp.

Crypthemichionaspis Lindinger. Type, nigra.

Crypthemichionaspis Lindgr., ${ }^{1}$ Zeitschr. f. wiss. Insektenbiol., vii, 5, 6, p. 175 (1911).

Crypthemichionaspis nigra Lindinger.

Crypthemichionaspis nigra Lindgr., Zeitschr. f. wiss. Insektenbiol., vii, 5, 6, p. 175 (1911). Fig.

Habitat-South Australia.

On Acacia salicina; Phyllodien.

Leucaspis indiæ-orientalis Lindinger.

Leucaspis indiæ-orientalis Lindgr., Zeitschr. f. wiss. Insektenbiol., vii, 4, p. 127 (1911). Fig.

Habitat-India.

On Pinus kasya.

Fiorinia africana Newstead.

Fiorinia africana Newst., Bul. Ent. Res., ii, 2, p. 90 (1911). Fig.

Habitat-Egypt.

On poplar.

Fiorinia neo-caledonica Lindinger.

Fiorinia neo-caledonica Lindgr., Zeitschr. f. wiss. Insektenbiol., vii, 5-6, p. 176 (1911).

Fig.

Habitat-New Caledonia.

On Bæckia pinifolia.

Fiorinia odinæ multipora Lindinger.

Fiorinia odinæ multipora Lindgr., Zeitschr. f. wiss. Insektenbiol., vii, 4, p. 126 (1911). Habitat-India.

On Taxus wallichiana.

Genus CRYPTA SPIDŨS Lindinger. Type, nucum.

Cryptaspidus Lindgr., Jahrb. Hamb. wiss. Anst., xxvii, 3, p. 43 (1910).

Cryptaspidus nucum Lindinger.

Cryptaspidus nucum Lindgr., Jahrb. Hamb. wiss. Anst., xxvii, 3, p. 43 (1910). Fig. Habitat-Madagascar.

On scales of fruit of Cocos nucifera.

\section{Aonidia glandulosa Newstead.}

Aonidia glandulosa Newst., Draper (sine descr.), Scale Ins. of Egypt, p. 11 (1907).

Sanders, Catalogue Coccidæ-II, p. 56 (1911).

Habitat-Egypt.

Newst., Bul. Ent. Res., ii, 2, p. 103 (1911). Fig.

On "sunt" tree (Acacia arabica). 
Aonidia longa Lindinger.

Aonidia longa Lindgr., Zeitschr. f. wiss. Insektenbiol., vii, 5, 6, p. 172 (1911). Fig. Habitat-New Caledonia.

- On Podocarpus gnidioides.

\section{Aonidia (?) paradoxa Lindinger.}

Aonidia (?) paradoxa Lindgr., Zeitschr. f. wiss. Insektenbiol., vii, 5, 6, p. 173 (1911). Fig.

Habitat-South Australia.

On Casuarina glauca.

\section{Aonidia (?) targioniopsis Lindinger.}

Aonidia (?) targioniopsis Lindgr., Zeitschr. f, wiss. Insektenbiol., vii, 3, p. 86 (1911).

Fig.

Habitat-Burma.

On Miliusa velutina.

\section{Aonidia viridis Lindinger.}

Aonidia viridis Lindgr., Zeitschr. f. wiss. Insektenbiol., vii, 3, p. 86 (1911). Fig. Habitat-India.

On upper side of leaf of Aglaia minutiflora.

\section{Cryptaspidiotus aonidioides Lindinger.}

Cryptaspidiotus aonidioides Lindgr., Jahrb. Hamb. wiss. Anst., xxviii, 3, p. 21 (1911). Fig.

Habitat-Canary Islands.

On leaves of Laurus canariensis, Apollonias canariensis.

Cryptaspidiotus austro-africanus Lindinger.

Cryptaspidiotus austro-africanus Lindgr. (Brick), Jahrb. Hamb. wiss. Anst., xxvii, p. 505 (1910).

Lindgr., Jahrb. Hamb. wiss. Anst., xxvii, 3, p. 41

Habitat-Natal.

(1911). Fig. and description.

On Euphorbia sp.

\section{Aspidiotus argentina Leonardi.}

Aspidiotus (Hemiberlesia) argentina Leon., Bol. Zool. Sc. Sup. Portici, v, p. 277 (1911). Fig.

Habitat-Argentina.

On Ophryoporus andinus.

\section{Aspidiotus bavaricus Lindinger.}

Aspidiotus (Diaspidiotus) bavaricus Lindgr., Zeitschr. f. wiss. Insektenbiol., viii, 1, p. 31 (1912).

Habitat-Bavaria, Prussia, Austria, Norway, England (?), and Portugal (?).

On Calluna vulgaris, Erica tetralix.

\section{Aspidiotus canariensis Lindinger.}

Aspidiotus canariensis Lindgr., Jahrb.Hamb. wiss. Anst., xxviii, 3, p. 12 (1911). Fig.

Habitat-Canary Islands.

On stem and branch of Argyranthemum frutescens. 
Aspidiotus euphorbiæ Newstead.

Aspidiotus (Selenaspidus) euphorbiæ Newst., Zool. anthr. Ergeb. westl. zentr. Südafr., v, 1, p. 18 (1912). Fig.

Habitat-South Africa.

On Euphorbia virosa.

\section{Aspidiotus fissidens pluridentatus Lindinger.}

Aspidiotus fissidens pluridentatus Lindgr., Jahrb. Hamb. wiss. Anst., xxvii, 3, p. 35 (1910).

Habitat-German East Africa, Mozambique.

On leaves of Bosquiea cerasiflora, Sideroxylon inerme, Chrysophyllum stuhlmanii.

Aspidiotus fissus Lindinger.

Aspidiotus fissus Lindgr., Jahrb. Hamb. wiss. Anst., xxvii, 3, p. 35 (1910). Fig.

Habitat-Abyssinia.

On Euphorbia sp.

\section{Aspidiotus furcræicola Lindinger.}

Aspidiotus furcræicola Lindgr., Jahrb. Hamb. wiss. Anst., xxvii, 3, p. 36 (1910). Fig. Habitat-German East Africa.

On underside of leaf of Furcræa gigantia.

Aspidiotus gymnosporiø Lindinger.

Aspidiotus gymnosporiæ Lindgr., Jahrb. Hamb. wiss. Anst., xxviii, 3, p. 13 (1911) Fig.

Habitat-Canary Islands.

On leaf of Gymnosporia cassinoides.

\section{Aspidiotus lauretorum Lindinger.}

Aspidiotus lauretorum Lindgr., Jahrb. Hamb. wiss. Anst., xxviii, 3, p. 15 (1911). Fig.

Habitat-Canary Islands.

On Dracæna draco, Gymnosporia cassinoides, Ilex canariensis, I. platyphylla, Oreodaphne foetens, Picconia excelsa, Smilax canariensis, Hedera helix canariensis, Apollonias canariensis, Heberdenia excelsa, Laurus canariensis, and Lauraceæ.

Aspidiotus mammillaris Lindinger.

Aspidiotus mammillaris Lindgr., Jahrb. Hamb. wiss. Anst., xxvii, 3, p. 37 (1910). Fig.

Habitat-Abyssinia.

On surface of leaves of Aloe eru.

Aspidiotus reticulatus Newstead.

Aspidiotus reticulatus Newst., Zool. anthr. Ergeb. westl. zentr. Südafr., v, 1, p. 17 (1912). Fig.

Habitat-Southwest Africa.

On monocotyledon (?)

Chrysomphalus samoana Lindinger.

Chrysomphalus (Melanaspis) samoana Lindgr., Zeitschr. f. wiss. Insektenbiol., vii, 5, 6, p. 177 (1911). Fig.

Habitat-Island of Samoa.

On Myristica hypargyræa. 
Aspidiotus schultzei Newstead.

Aspidiotus (Selenaspidus) schultzei Newst., Zool. anthr. Ergeb. westl. zentr. Südafr., v, 1, p. 18 (1912). Fig.

Habitat-Southwest Africa.

On succulent plant.

\section{Aspidiotus taorensis Lindinger.}

Aspidiotus taorensis Lindgr., Jahrb. Hamb. wiss. Anst., xxviii, 3, p. 17 (1911). Fig. Habitat-Canary Islands.

On Euphorbia aphylla, E. regis-jubæ.

\section{Aspidiotus tectarius Lindinger.}

Aspidiotus tectarius Lindgr., Jahrb. Hamb. wiss. Anst., xxvi, 3, p. 20 (1909). Fig.

Habitat-South America.

On leaves of Euphorbia sp.

\section{Aspidiotus tinerfensis Lindinger.}

Aspidiotus tinerfensis Lindgr., Jahrb. Hamb. wiss. Anst., xxviii, 3, p. 18 (1911). Fig. Habitat - Canary Islands.

On Draciena draco.

\section{Aspídiotus tsugæ Marlatt.}

Aspidiotus (Diaspidiotus) tswgre Marlatt, Ent. News, xxii, 9, p. 385 (1911). Fig.

Habitat-Japan.

On Japanese hemlock (Tsuga sp.).

\section{Aspidiotus varians Lindinger.}

Aspidiotus varians Lindgr., Jahrb. Hamb. wiss. Anst., xxvii, 3, p. 39 (1911). Fig.

Habitat-German East $\Lambda$ frica, Madagascar.

On leaf and scales oi fruit of Cocos nucifera.

Targionia (?) campylanthi Lindinger.

Targionia (?) campylanthi Lindgr., Jahrb. Hamb. wiss. Anst., xxviii, 3, p. 25 (1911). Fig.

Habitat-Canary Islands.

On Campylanthus solsoloides.

Targionia fabianæ Leonardi.

Targionia fabianx Leon., Bol. Zool. Sc. Sup. Portici, v, p. 278 (1911). Fig.

Habitat-Argentina.

On Fabiana denudata.

Genus PROTARGIONIA Leonardi. Type, larreæ.

Protargionia Leon., Bol. Zool. Sc. Sup. Portici, v, p. 280 (1911).

Protargionia larreæ Leonardi.

Protargionia larreæ Leon., Bol. Zool. Sc. Sup. Portici, v, p. 280 (1911). Fig.

Habitat-Argentina.

On Larrea divaricata, L. cuneata.

\section{Lepidosaphes fasciata Green.}

Lepidosaphes (Mytilaspis) fasciata Green, Jn. Econ. Biol., vi, 2, p. 31 (1911). Fig.

Habitat-Ceylon.

On leaves of Hevea brasiliensis. 
Lepidosaphes travancorensis Lindinger.

Lepidosaphes travancorensis Lindgr., Zeitschr. f. wiss. Insektenbiol., vii, 4, p. 127 (1911). Fig.

Habitat-India.

On underside of leaf of Aglaia minutiflora.

Genus DINASPIS Leonardi. Type, ichesii.

Dinaspis Leon., Bol. Zool. Sc. Sup. Portici, v. p. 282 (1911).

Dinaspis ichesii Leonardi.

Dinaspis ichesii Leon., Bol. Zool. Sc. Sup. Portici, v, p. 282 (1911). Fig.

Habitat-Argentina.

On Ephedra andina.

Dinaspis lahillei Leonardi.

Dinaspis lahillei Leon., Bol. Zool. Sc. Sup. Portici, v, p. 283 (1911). Fig.

Habitat-Argentina.

On Bulvesia retana.

Ischnaspis spathulata Lindinger.

Ischnaspis spathulata Lindgr., Zeitschr. f. wiss. Insektenbiol., vii, 4, p. 127 (1911). Fig.

Habitat-India.

On underside of leaf of Atica obscura.

Parlatoria ephedræ Lindinger.

Parlatoria ephedræ Lindgr., Zeitschr. f. wiss. Insektenbiol., vii, 4, p. 129. Fig.

Habitat-Persia.

On Ephedra intermedia, E. nebiodensis, E. nebiodensis var. procera.

Parlatoria hastata Lindinger.

Parlatoria hastata Lindgr., Zeitschr. f. wiss. Insektenbiol., vii, 4, p. 129 (1911). Fig. Habitat-Borneo.

On leaf of Gnetum scandens.

Cryptoparlatorea uberifera Lindinger.

Cryptoparlatorea uberifera Lindgr., Zeitschr. f. wiss. Insektenbiol., vii, 4, p. 126 (1911). Fig.

Habitat-Philippine Islands.

On leaves of Artocarpus sp. and Mallotus philippinensis.

Cryptoparlatorea parlatoreiodes Lindinger.

Cryptoparlatorea parlatoreiodes Lindgr., Zeitschr. f. wiss. Insektenbiol., vii, 3, p. 89 (1911). Fig.

Habitat-India.

On surface of leaf of Xanthophyllum flavescens.

\section{CORRECTION TO CATALOGUE III-1911.}

On page 66 the heading "Subfamily Coccinæ" should be transferred to page 65 to precede Ceroplastidia, line 17 from bottom. 


\section{ABBREVIATIONS OF LITERATURE.'}

Allg. Zeits. f. Ent.-Allgemeine Zeitschrift für Entomologie.

Agr. News West Ind.-Agricultural News. West Indies.

An. Soc. Cient. Argentina.-Anales de la Sociedad Científica Argentina.

Ann. Soc. Ent. France.-Annales de la Société Entomologique de France.

Annali di Agr.-Annali di Agricoltura. Portici.

Ann. Mag. N. H.-Annals and Magazine of Natural History.

Ann. Mus. Zool. Ac. Imp. Sc. St. Petersbourg.-Annuaire Musée Zoologique Académie

Impériale des Şciences de St. Petersbourg.

Berl. ent. Zeitschr.-Berliner entomologische Zeitschrift.

Ber. Stat. f. Pflanzensch. Hamb.-Bericht der Station für Pflanzenschutz, Hamburg. Boi. Min. Ag.-Boletín del Ministerio de Agricultura. Argentina.

Bol. Zool. Sc. Sup. Portici.-Bollettino del Laboratorio di Zoologia generale e agraria della R. Scuola Superiore d'Agricoltura di Portici.

Bot. Jahrb.-Botanische Jahrbücher.

Bul. Ag. Exp. Sta. Japan.-Bulletin of the Imperial Central Agricultural Experiment Station. Japan.

Bul. Ent. Res.-Bulletin of Entomological Research.

Bul. Ill. St. Lab. N. H.-Bulletin of the Illinois State Laboratory of Natural History.

Bul. Soc. Ent. Fr.-Bulletin de la Société Entomologique de France.

Bul. Soc. Ent. Ital.-Bulletino della Società Entomologica Italiana.

Bul. Soc. Zoo. France.-Bulletin de la Société Zoologique de France.

Bul. U. S. Bur. Ent., t. s. 16, Pt. II.-Bulletin, Technical Series 16, Part II, Bureau of Entomology, U. S. Department of Agriculture.

Can. Ent.-Canadian Entomologist.

Čas. Společ. Entom.-Časopis Česke Společnosti Entomologicke. Acta Societatis Entomologicæ Bohemiæ.

Catalogue Coccidæ-I.-U. S. Dept. Agr., Bur. Ent., technical series, Bul. 12, Pt. I (1906).

Catalogue Coccidæ-II.-U.S. Dept. Agr., Bur. Ent., technical series, Bul. 16, Pt. III (1909).

Catalogue Coccidæ-III.-U. S. Dept. Agr., Bur. Ent., technical series, Bul. 16, Pt. IV (1911).

Centr. f. Bakt. Par. u. Infekt.-Centralblatt für Bakteriologie und Parasitenkunde und Infektionskrankheiten.

Cherm. Ital.-Chermotheca Italica.

Cocc. Ceylon.-Coccidæ of Ceylon.

Compt. Rend. Ac. Sci., Paris.-Comptes rendus hebdomadaires des séances de l'Académie des sciences: Paris.

Compt. Rend. Soc. Biol.-Comptes rendus des séances de la Société de Biologie. Paris. Deutsche ent. Zeitschr.-Deutsche entomologische Zeitschrift.

Ent. Mo. Mag.-The Entomologist's Monthly Magazine.

Ent. Blätter.-Entomologische Blätter, Internationale Monatsschrift für die Biologie der Käfer Europas. Schwabach.

Ent. News.--Entomological News.

Ent. Rec. Jn. Variation.-The Entomologist's Record and Journal of Variation.

Ent. Wochenblatt.-Entomologisches Wochenblatt (antea Insekten-Börse).

Ind. Mus. Notes.-Indian Museum Notes.

Insekten Börse.--Entomologisches Wochenblatt.

Jahrb. Hamb. wiss. Anst.-Jahrbuch der Hamburgischen wissenschaftlichen Anstalten. Jn. Bomb. N. H. Soc.-Journal of the Bombay Natural History Society. Calcutta.

1 This list includes abbreviations of literature used for coecid descriptions referred to in Nos. I, II, III. and IV. 
Jn. Econ. Biol.-The Journal of Economic Biology.

Jn. N. Y. Ent. Soc.-Journal of the New York Entomological Society.

Kilimandjaro-Meru Exp.-Schwedischen zoologischen Expedition nach dem Kilimandjaro, dem Meru und den umgebenden Massaisteppen Deutsch-Ostafrikas.

Liverpool Univ. Quart. Jn.-Institute of Commercial Research in the Tropics, Liverpool University, Quarterly Journal.

Medd. Soc. Faun. Fenn.-Meddelanden af Societas pro Fauna et Flora Fennica.

Mem. Dep. Ag. India.-Memoirs of the Department of Agriculture in India.

Mem. Soc. Cient. Ant. Alz.-Memorias y Revista de la Sociedad Científica "Antonio Alzate."

Mém. Soc. Zool. France.-Mémoires de la Société Zoologique de France.

Mitt. zool. Mus. Berlin.--Mitteilungen aus den zoologischen Museum in Berlin.

Nachrichtsbl. Naturirsch.-Klubs, Prossnitz.-Nachrichtsblatt Naturforscher-Klubs, Prossnitz (Mähren).

N. Z. Trans. - Transactions of the New Zealand Institute.

Pests and Blights of Tea Plants.-The Pests and Blights of the Tea Plant, 2d ed. Watt \& Mann, Calcutta, 1903.

Philippine Jn. Sci.-The Philippine Journal of Science.

Pomona College Jn. Ent.-Pomona College Journal of Entomology. Claremont, California.

Pr. Biol. Soc. Wash.-Proceedings of the Biological Society of Washington.

Pr. Dav. Acad. Sci.--Proceedings Davenport Academy of Sciences. Davenport, Iowa.

Pr. Ent. Soc. Wash.--Proceedings of the Entomological Society of Washington.

Pr. Haw. Ent. Soc.-Proceedings of the Hawaiian Entomological Society.

Redia.-Redia.

Rev. Mus. Paul.--Revista Museu Paulista.

Riv. Pat. Veg.--Rivista di Patologia Vegetale.

Scale Ins. of Egypt.-Notes on the Injurious Scale Insects and Mealy Bugs of Egypt. Cairo, 1907.

The Entom.-The Entomologist.'

Trab. Mus. Farm. Fac. Cienc. Med.-Trabajos del Museo de Farmacologia de la Facultad de Ciencias Médicas. Buenos Aires, Argentina.

Tr. Linn. Soc. Lond.-Transactions of the Linnæan Society of London.

Trop. Agr.-Tropical Agriculturist.

Victorian Nat.- - The Victorian Naturalist.

Zeitschr. f. wiss. Insektenbiol.-Zeitschrift für wissenchaftliche Insektenbiologie.

Zool. anthr. Ergeb. westl. zentr. Südafr.-Zoologische und anthropologische Ergebnisse einer Forschungsreise im westlichen und zentralen Südafrika. 

Technical Series, No. 16, Part VII.

U. S. DEPARTMENT OF AGRICULTURE, BURFAU OF FNTOMOLOGY.

L. O. HOWARD, Entomologist and Chief of Bureau.

\section{PAPERS ON COCCIDE OR SCALE INSECTS.}

\section{AN INDEX TO CATALOGUES OF RECENTLY DESCRIBED COCCIDE}

INCLUDED IN TECHNICAL SERIES NOS. 12 AND 16.

BY

E. R. SASSCER, Scientific Assistant.

ISSUED JANUARY 23, 1913.

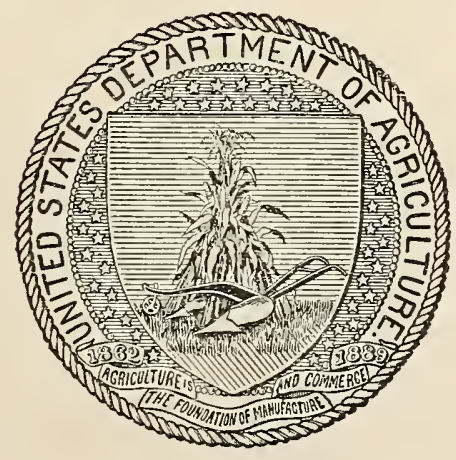

WASHINGTON:

GOVERNMENT PRINTTNG OFFICE. 


\section{men}

BUREAU OF ENTOMOLOGY.

L. O. Howard, Entomologist and Chief of Bureau.

C. L. Marlatt, Entomologist and Acting Chief in Absence of Chief.

R. S. Clifton, Executive Assistant.

W. F. TAstet, Chief Clerk.

F. H. Chittenden, in charge of truck crop and stored product insect investigations.

A. D. HopkINs, in charge of forest insect investigations.

W. D. Hunter, in charge of southern field crop insect investigations.

F. M. WEBSTER, in charge of cereal and forage insect investigations.

A. L. QuaInTANCE, in charge of deciduous fruit insect investigations.

E. F. Phillips, in charge of bee culture.

D. M. RoGERs, in charge of preventing spread of moths, field work.

Rolla P. CuRrie, in charge of editorial work.

MaBel Colcond, in charge of library.

II 


\section{PAPERS ON COCOID E OR SCALE INSECTS.}

\section{AN INDEX TO CATALOGUES OF RECENTLY DESCRIBED COCCIDE INCLUDED IN TECHNICAL SERIES NOS. 12 AND 16.}

By E. R. SAsscer,

Scientific Assistant.

This index of Coccidx includes all those forms contained in the following papers: Technical Series No. 12, Part I, "Catalogue of Recently Described Coccidx"' (1906) and Technical Series No. 16, Part III, "Catalogue of Recently Described Coccidæ-II" (1909), by James G. Sanders; Technical Series No. 16, Part IV, "Catalogue of Recently Described Coccidæ-III" (1911) and Technical Series No. 16, Part VI, "Catalogue of Recently Described Coccidæ-IV" (1912), by E. R. Sasscer. It is thus intended that it shall be an index to all the forms described and published since the issuance of Mrs. Fernald's "Catalogue of Coccilæ" in 1903, making it unnecessary to search through each of the four separate papers to find the desired citation.

\begin{tabular}{|c|c|c|}
\hline INDEX. & $\begin{array}{l}\text { Terhnical } \\
\text { Series No. }\end{array}$ & Page. \\
\hline aberemoæ. & $\cdot 16$ & 70 \\
\hline aberrans...................... & 16 & 71 \\
\hline acaciæ. . . . . . . . . . . . . . & 16 & 91 \\
\hline Aclerda. ................... & 16 & 47,67 \\
\hline Actenaspis. . . . . . . . . . . . . & 16 & 50 \\
\hline Adiscofiorinia. . . . . . . . . . . & 16 & 50 \\
\hline africana, Chionaspis.......... & 16 & 89 \\
\hline africana, Diaspis.............. & 16 & 68 \\
\hline africana, Fiorinia. . . . . . . . . . . . & 16 & 91 \\
\hline 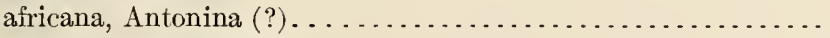 & 16 & 43 \\
\hline africana, Lecaniodiaspis........... & 16 & 84 \\
\hline africana, Walkeriana............. & 16 & 61 \\
\hline africanus, Aspidiotus. . . . . . . . . . & 16 & 51 \\
\hline africanus, Monophlebus........... & 16 & 83 \\
\hline africanus senegalensis. . . . . . . . . & 16 & 44 \\
\hline a asawarensis.................. & 16 & 65 \\
\hline 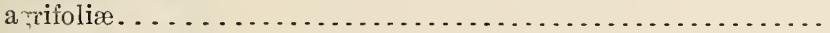 & 16 & 40 \\
\hline 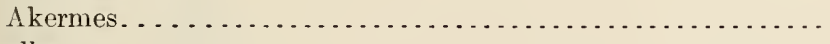 & 16 & 46 \\
\hline alba. . . & 12 & 16 \\
\hline 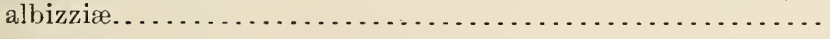 & 12 & 6 \\
\hline & 16 & 87 \\
\hline & 16 & 63 \\
\hline alluaudi...... & 12 & 4 \\
\hline
\end{tabular}


Technical Series No.

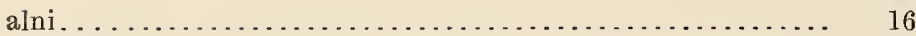

Pagc.

amaniensis..................................... 16

55

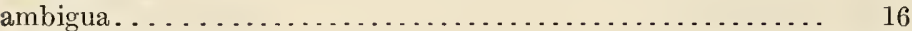

Amelococcus..................................... 12

89

64

americana........................................ 16

4

Anamaspis. . . . . . . . . . . . . . . 16

85

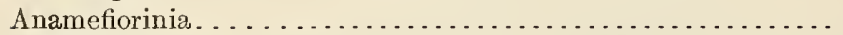

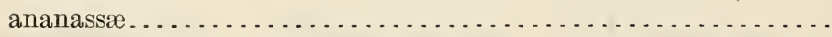

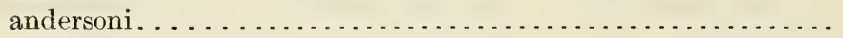

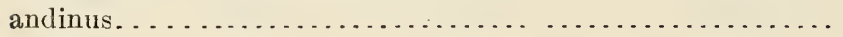

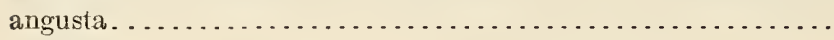

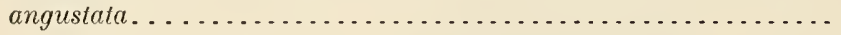

$16 \quad 50$

$16 \quad 64$

$12 \quad 5$

$16 \quad 84$

$16 \quad 58$

$12 \quad 10$

$16 \quad 58$

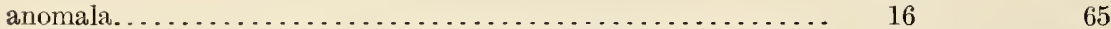

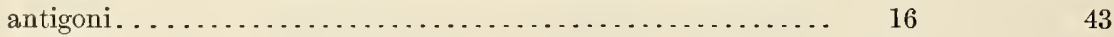

Antonina...................................... 12 5

$16 \quad 43,84$

Aonidia....................................... $12 \quad 16$

$16 \quad 56$

70,91

Aonidiella..................................... 12

15

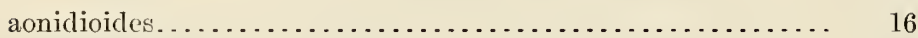

51,55

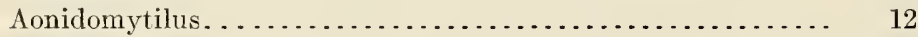

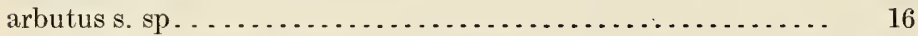

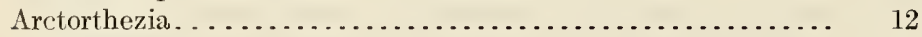

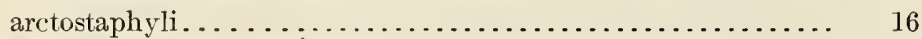

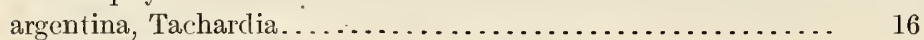

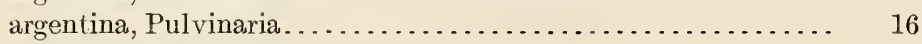

argentina, Aspidiotus. . . . . . . . . . . . . . . . . . . . . . 16

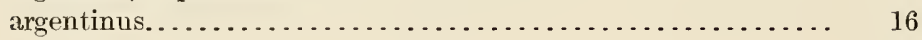

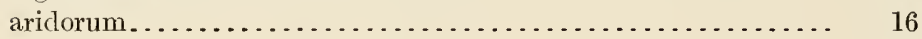

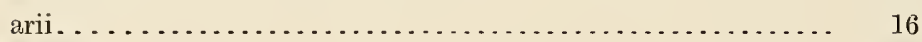

armatus. . . . . . . . . . .

arthrocnemi.................................... 16

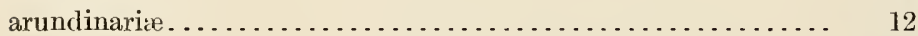

Aspidiotus.... . . . . . . . . . . . . . . . . . . . . . . . . 12

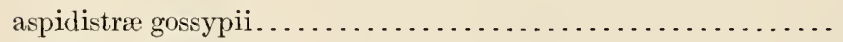

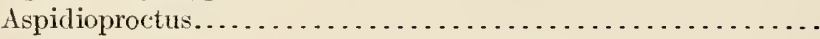

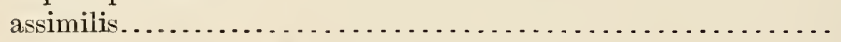

Asterolecanium................................ 12

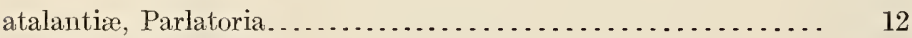

atalantiæ, Fiorinia................................... 16

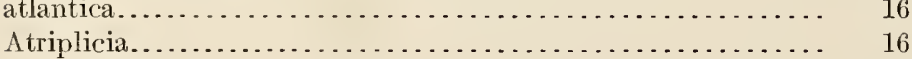

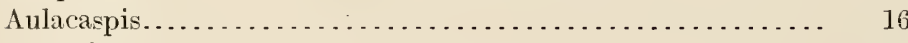

aurantiaca................................... 12

aurantii........................................... 16

$16 \quad 55$

auriculata................................... 16

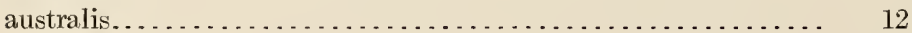

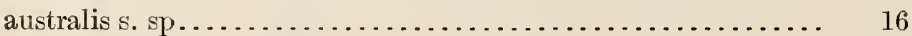




\begin{tabular}{|c|c|c|}
\hline & $\begin{array}{l}\text { Technical } \\
\text { Series No. }\end{array}$ & Page. \\
\hline austro-africanus. & 16 & 92 \\
\hline azadirachtæ... & 16 & 63 \\
\hline bacciformis... & 16 & 36 \\
\hline$\ldots \ldots \ldots \ldots \ldots \ldots \ldots \ldots$, & 16 & 36 \\
\hline badius.......... & 16 & 84 \\
\hline$\ldots \ldots \ldots \ldots \ldots \ldots \ldots \ldots \ldots \ldots \ldots$ & 16 & 37 \\
\hline bakeri.......... & 16 & 64 \\
\hline 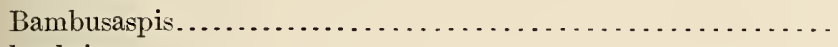 & 12 & 3 \\
\hline banksiæ........... & 12 & 18 \\
\hline 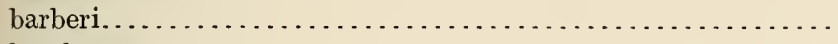 & 16 & 48 \\
\hline$\ldots \ldots \ldots \ldots \ldots \ldots \ldots \ldots \ldots \ldots \ldots \ldots \ldots \ldots$ & 16 & 55 \\
\hline 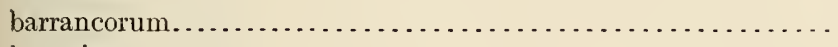 & 16 & 80 \\
\hline 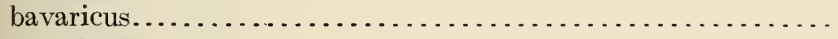 & 16 & 92 \\
\hline beckii oleæ................................ & 16 & 56 \\
\hline 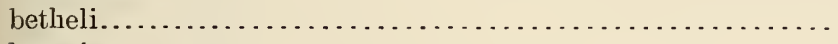 & 12 & 6 \\
\hline 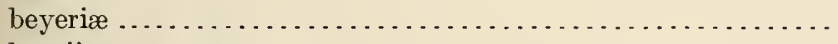 & 16 & 56 \\
\hline 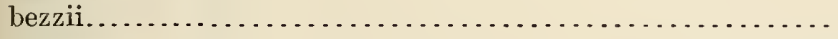 & 16 & 37 \\
\hline 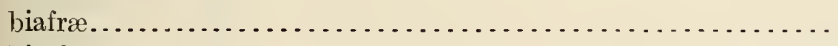 & 16 & 70 \\
\hline 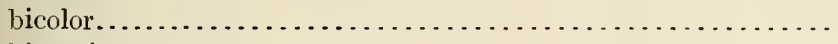 & 16 & 57 \\
\hline 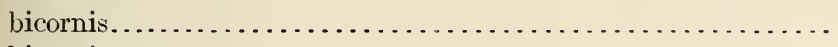 & 12 & 17 \\
\hline 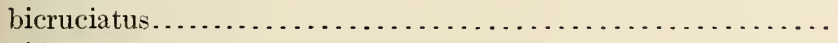 & 12 & 8 \\
\hline 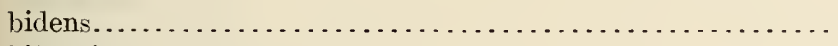 & 12 & 13 \\
\hline 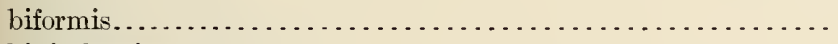 & 16 & 54 \\
\hline 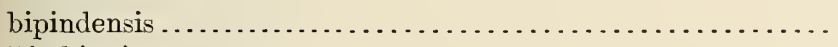 & 16 & 71 \\
\hline 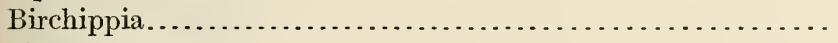 & 16 & 85 \\
\hline 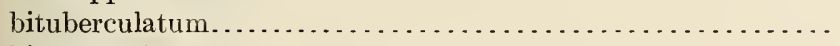 & 16 & 46 \\
\hline 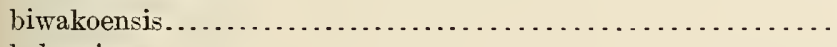 & 16 & 47 \\
\hline 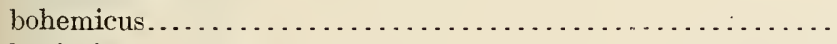 & 16 & 86,87 \\
\hline 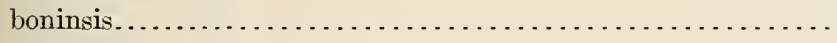 & 16 & 64 \\
\hline 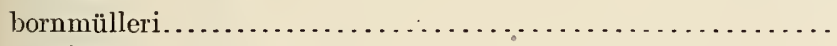 & 12 & 15 \\
\hline 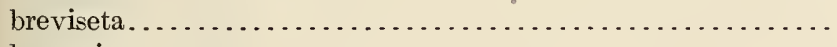 & 16 & 88 \\
\hline 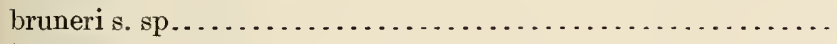 & 12 & 11 \\
\hline 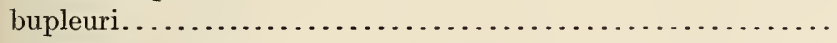 & 12 & 12 \\
\hline 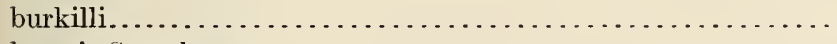 & 16 & 43 \\
\hline bussei, Ceroplastes ............................... & 16 & 44 \\
\hline 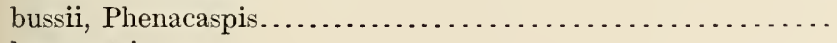 & 16 & 90 \\
\hline 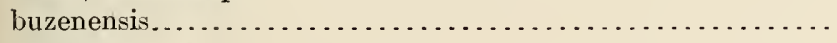 & 16 & 71 \\
\hline 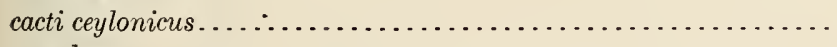 & 16 & 38 \\
\hline 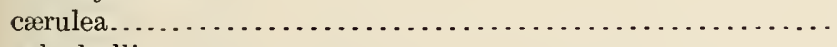 & 12 & 6 \\
\hline 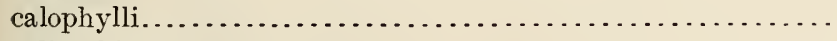 & 12 & 9 \\
\hline 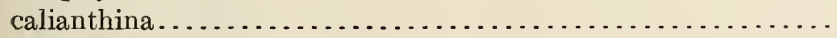 & 12 & 18 \\
\hline 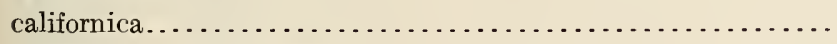 & 16 & 35 \\
\hline 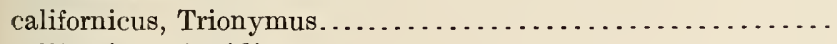 & 16 & 86 \\
\hline 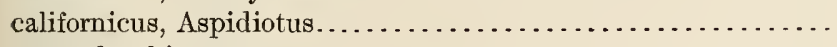 & 12 & 13 \\
\hline 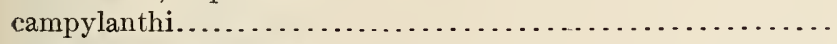 & 16 & 94 \\
\hline canariensis, Chionaspis . . . . . . . . . . . . . . . . . . . . & 16 & 89 \\
\hline 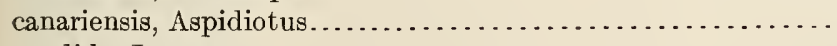 & 16 & 92 \\
\hline 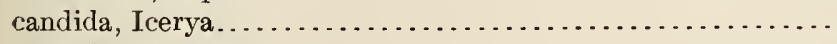 & 12 & 2 \\
\hline 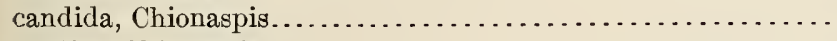 & 12 & 10 \\
\hline 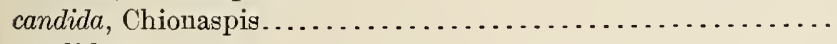 & 16 & 48 \\
\hline 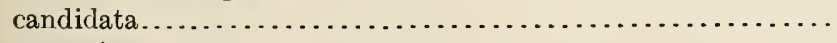 & 16 & 42 \\
\hline 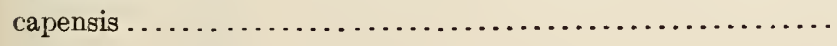 & 12 & 13 \\
\hline & 16 & 54 \\
\hline
\end{tabular}


capparidis

capsulatus.

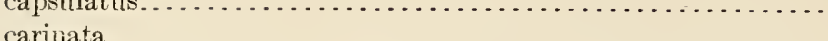

carina

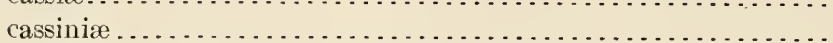

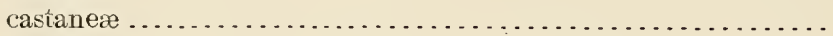

castillox.

catalinæ.

caudata.

cecconi, Aspidiotus.

cecropiæ.

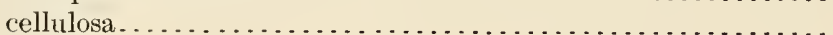

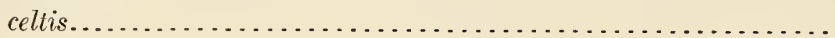

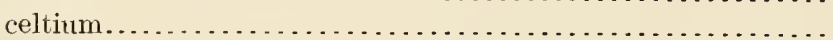

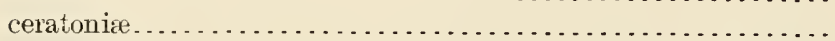

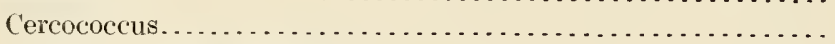

ceriferum prominens, Asterolecanium . . . . . . . . . . . . .

Cerococcus.

Ceronema

Ceroplastes.

Ceroplastidia s.g

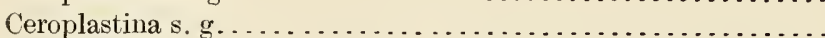

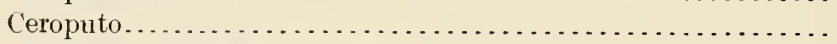

ceylonica, Pollinia... . . . . . . . . . . . . . . . . . . . . .

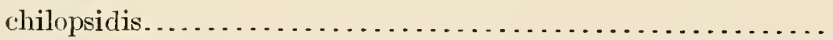

chinensis............................................

chionaspiformis.

chusiæ.

chiton

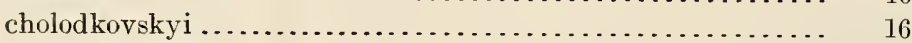

Chrysomphalus...................................... 12

cinerea.

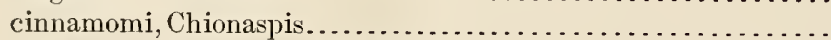

cinnamomi mangiferæ, Aulacaspis....................

Cissococcus (?) ................................... 


\begin{tabular}{|c|c|c|}
\hline \multirow{3}{*}{ 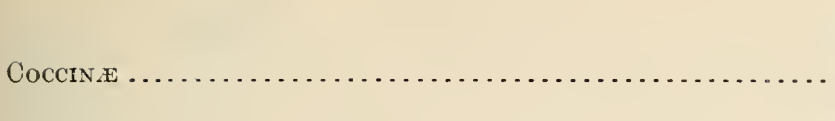 } & \multirow{2}{*}{$\begin{array}{c}\text { Technical } \\
\text { Series No. } \\
12\end{array}$} & \multirow{2}{*}{ Page. } \\
\hline & & \\
\hline & 16 & $43,66,87,95$ \\
\hline coccineus.. & 16 & 64 \\
\hline 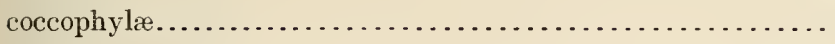 & 16 & 47 \\
\hline (n. & 16 & 39 \\
\hline \multirow{2}{*}{ 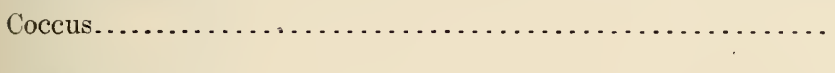 } & 12 & 8 \\
\hline & 16 & $45,67,88$ \\
\hline cockerelli. & 12 & 4 \\
\hline$\ldots \ldots \ldots \ldots \ldots \ldots \ldots \ldots$. & 12 & 16 \\
\hline cocotiphagus.. & 16 & 51 \\
\hline coffeæ.... & 16 & 40,84 \\
\hline 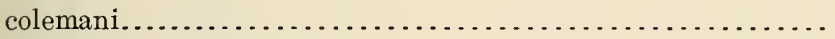 & 16 & 39 \\
\hline 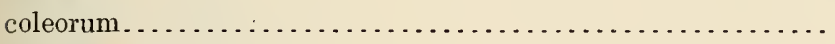 & 16 & 40 \\
\hline \multirow[t]{2}{*}{ 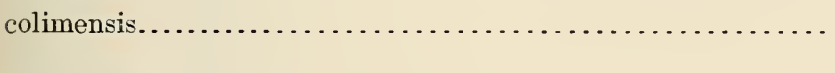 } & 12 & 2 \\
\hline & 16 & 58 \\
\hline coloradensis. & 12 & 7 \\
\hline comari........... & 16 & 39 \\
\hline 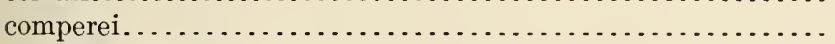 & 16 & 52 \\
\hline \multirow[t]{2}{*}{ 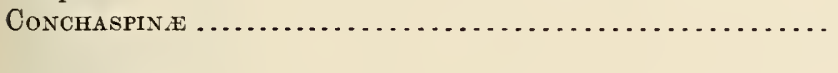 } & 12 & 3 \\
\hline & 16 & 35 \\
\hline Conchaspis & 12 & 3 \\
\hline conchiformis. & 16 & 68 \\
\hline concolor, Physokermes................................. & 12 & 10 \\
\hline concolor, Aonidomytilus................................ & 12 & 16 \\
\hline coniferarum shastæ. & 12 & 13 \\
\hline 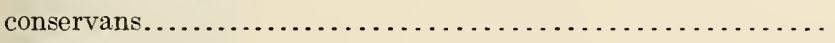 & 16 & 69 \\
\hline cordaliæ & 16 & 87 \\
\hline 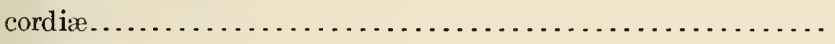 & 12 & 11 \\
\hline 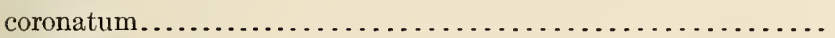 & 16 & 62 \\
\hline 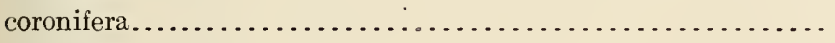 & 12 & 11 \\
\hline 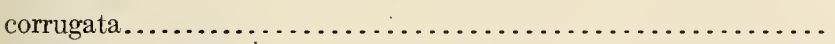 & 12 & 17 \\
\hline${ }^{\prime}$ & 12 & 12 \\
\hline 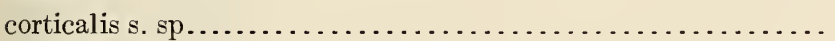 & 16 & 37 \\
\hline corticis-pini & 16 & 52 \\
\hline corticoides s. sp.............. & 12 & 14 \\
\hline 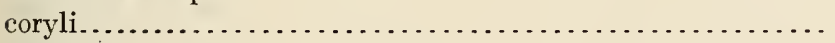 & 16 & 46 \\
\hline coulteri. & 12 & 6 \\
\hline$\ldots \ldots \ldots \ldots \ldots \ldots \ldots \ldots .6$. & 16 & 52 \\
\hline crenulata. & 12 & 16 \\
\hline cristata $\mathrm{s.}$ sp., Icerya............ & 16 & 34 \\
\hline 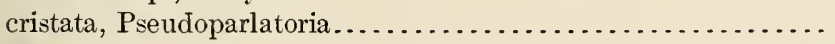 & 16 & 71 \\
\hline \multirow[t]{2}{*}{ 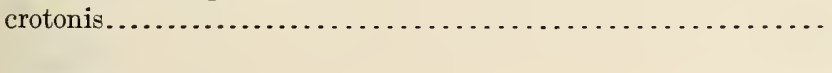 } & 12 & 5 \\
\hline & 16 & 86 \\
\hline crudiæ... & 16 & 72 \\
\hline crustuliforme........ & 16 & 67 \\
\hline cryphæformis........ & 16 & 48 \\
\hline Cryptaspidiotus...... & 16 & 71,92 \\
\hline Cryptaspidus......... & 16 & 91 \\
\hline Crypthemichionaspis.............. & 16 & 91 \\
\hline 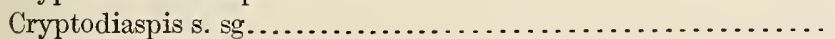 & 16 & 69 \\
\hline \multirow{2}{*}{ 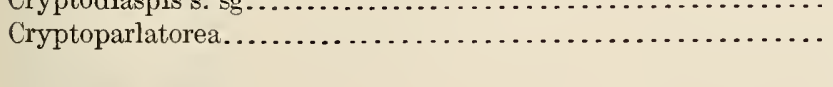 } & 12 & 18 \\
\hline & 16 & 95 \\
\hline Cryptophyllaspis. & 12 & 15 \\
\hline
\end{tabular}


Ctenochiton.

Technical .

cupressi, Pseudococcus............................... 16

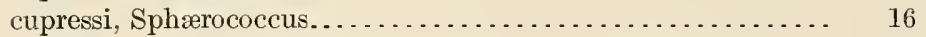

cuculis........................................... 12

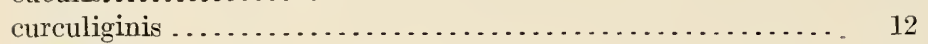

curtisi........................................... 12

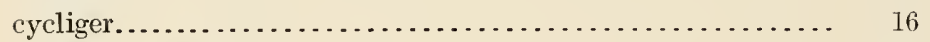

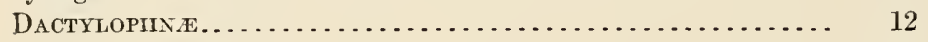

Dactylopius.

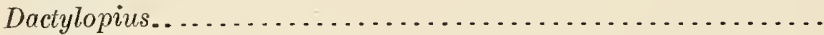

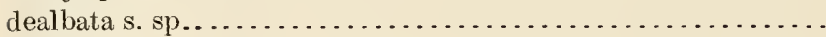

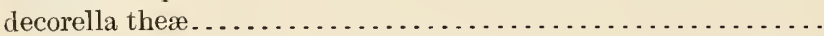

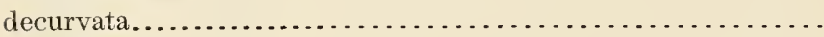

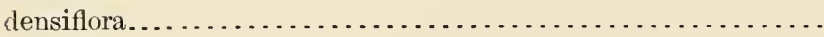

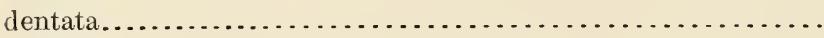

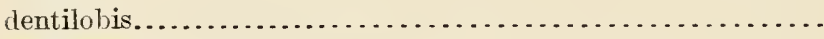

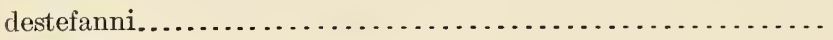

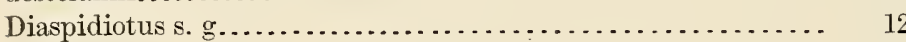

16

12

16

diaspiformis.

DIASPINA.

Diaspis.

dimorphus

Dinaspis.

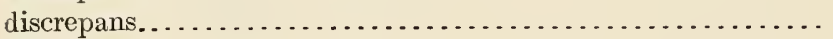

distorta.

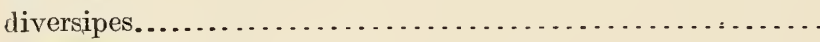

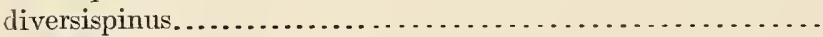

donisthorpei.

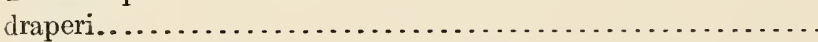

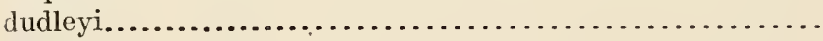

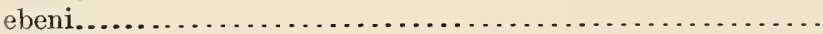

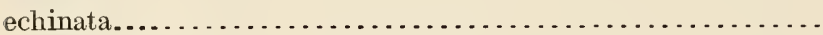

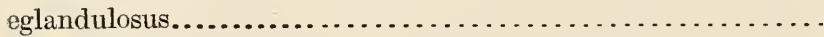

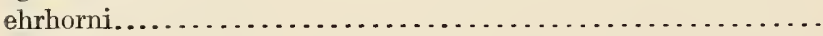

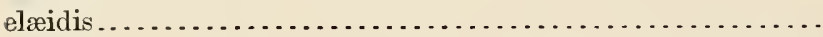

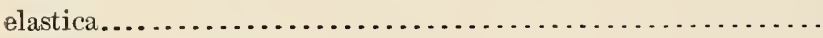

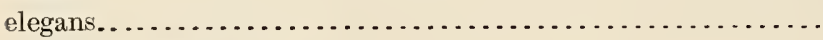

elongatus, Pseudococcus.......................... 12 
Technical

erigoni

Series No.

Eriopelti

etrusca.

Eucalymnatus.................................. 12

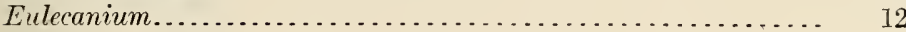

\section{7}

Euparlatoria s. g.................................. 12

Euphilippia...................................... 16

euphorbiæ...................................... 16

Evaspidiotus................................... 12

exiguum

expansum javanicum

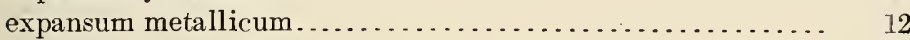

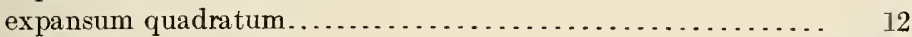

expansum rotundum.............................. 12

fabianæ....................................... 16

Fagisuga

fasciata.

Fernaldella

Fernaldiella.

ferox

festiva

fici, Hemichionaspis

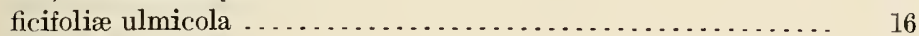

ficifolii.

ficus.

Fiorinia.

fissidens, Aspidiotus

fissidens pluridentatus, Aspidiotus . .

fissus

flavociliatum.

florenciæ

fluminensis.

folsomi

formicarii

formicarius.

formicarum

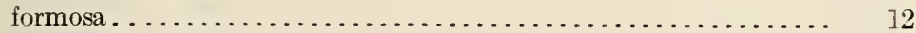

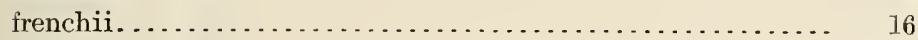

frontalis....................................... 12

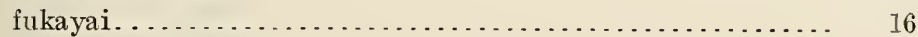

Furcaspis. . . . . . . . . . . . 16

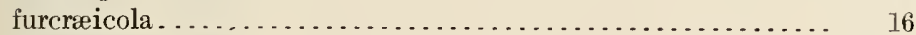

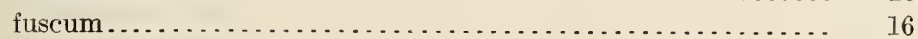

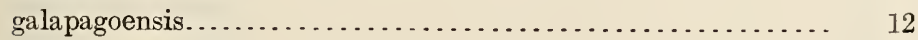

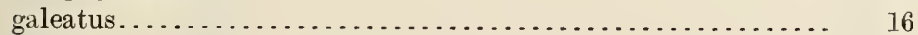


$\begin{array}{rr}\text { Technical } & \text { Series No. } \\ \end{array}$

glandi.

glandulosa

gleditsiæ.

Globulicoccus s. g.................................. 16

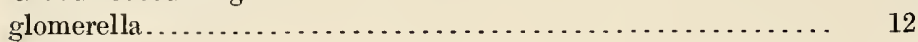

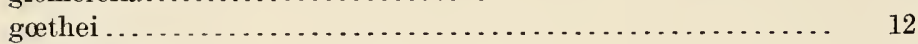

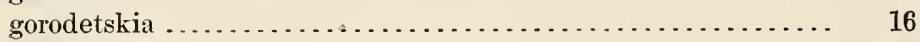

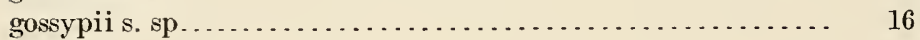

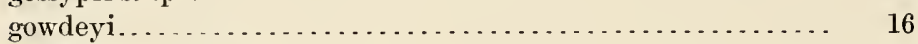

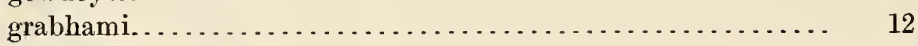

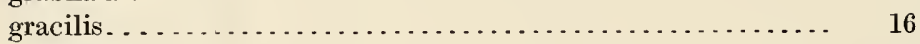

graminicola. . . . . . . . . . . . .

graminis. . . . . . . .

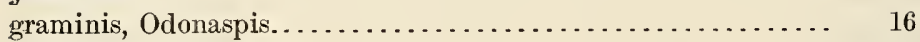

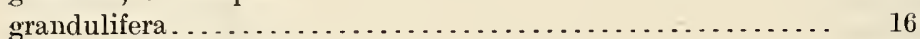

greeni, Asterolecanium.............................. 12

greeni, Pseudaonidia................................ 16

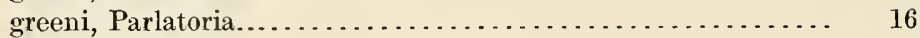

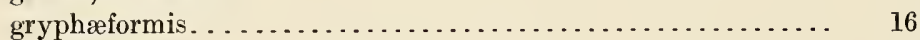

Gymnaspis................................. 12

Gymnococcus.

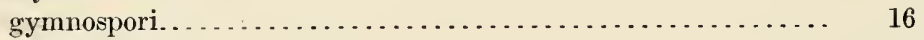

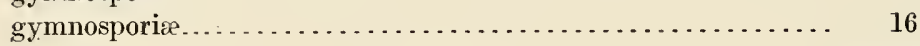

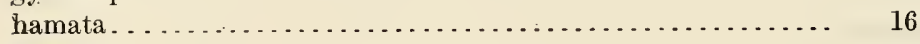

hastata. . . . . . . . . . . . . . . . . . . .

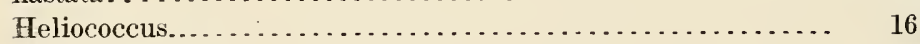

Hemiberlesia s. g................................ 12

Hemichionaspis.

Hemilecanium.

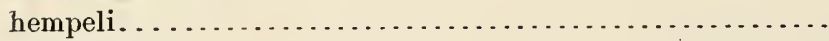

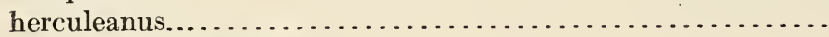

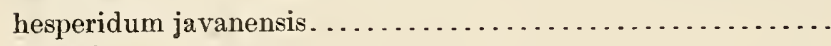

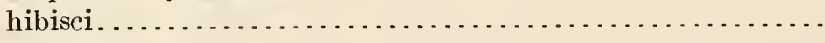

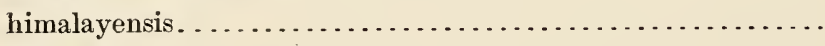

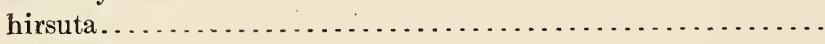

hirsutus. . . . . . . . . . . . . . . . . . . . . . . . . . .

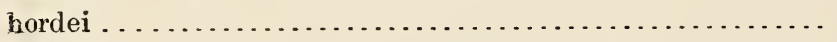

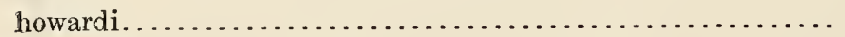

Houardia . . . . . . . . . . . . . . . . . . . . . . . . . . .

Howardia. . . . . . . . . . . . . . . . . . . . .

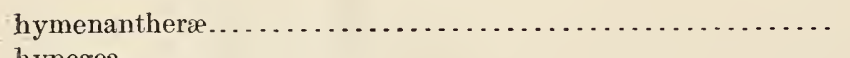

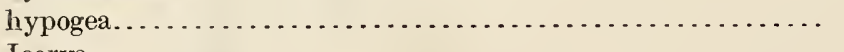

iceryoides................................. 16

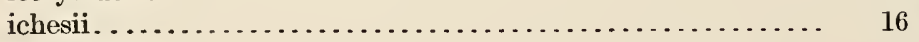

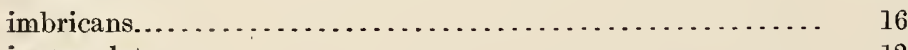

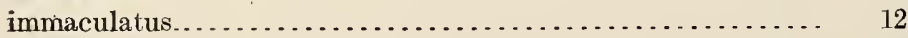


Technical Series No.

inday

indentata.

indiæ-orientalis.

indica, Antonina.

69,91

indica, Leucaspis.

indicus.

inflatum

Inglisia .

innumerabilis betheli

inquilina

insolens.

insolitus

intermedia victoriæ

irregularis

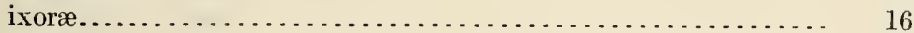

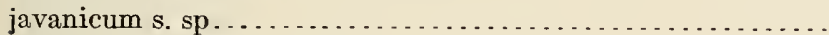

juniperi, Pseudococcus.............................

juniperi, Fiorinia . . . . . . . . . . . . . . . . . . . . . . . . .

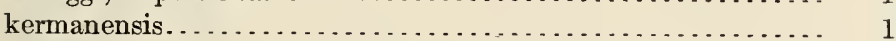

36,85

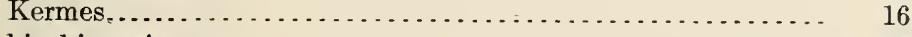

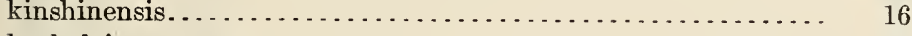

koebeli....................................... 16

kunoensis........................................ 16

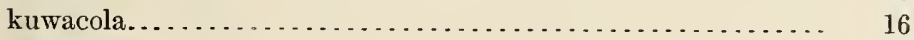

46,72

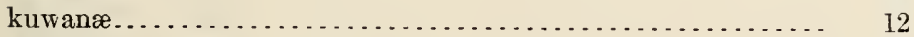

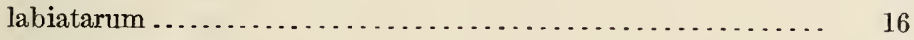

Lachnodiella........................................ 16

40,86

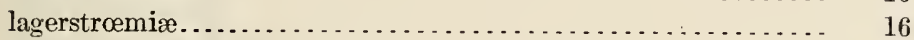

lahillei, Ceroplastes............................... 16

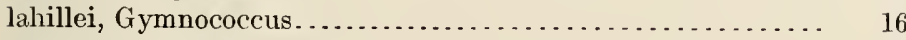

lahillei, Dinaspis.................................. 16

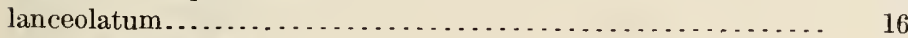

larreæ s. sp., Icerya............................... 12

larreæ, Protargionia................................. 16 
Lecanium

Lecaniodiaspis.

36,84

Lecanopsis.

lectularius.

ledi.

Lefroyia

leonardi.

Lepidosaphes.

Leucaspis.

leucaspis.

Leucodiaspis.

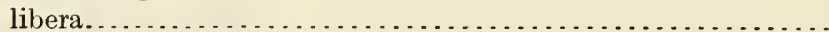

Lichtensia....................................

lidgetti. .

lilacinus

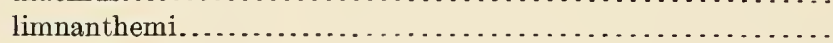

limuloides

lineare...

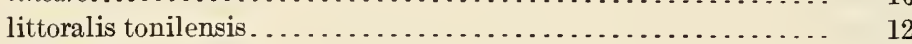

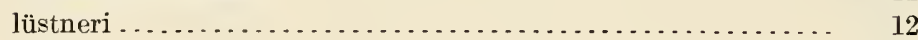

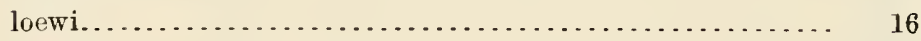

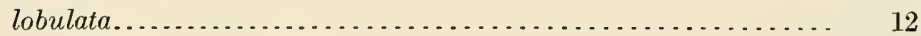

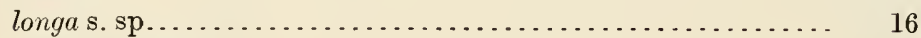

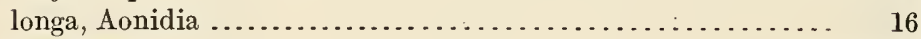

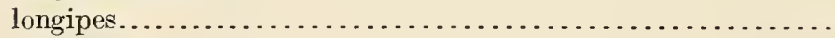

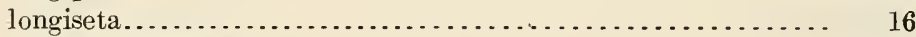

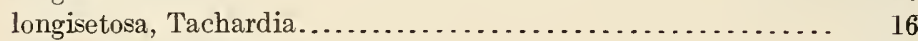

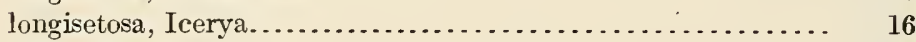

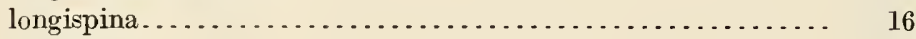

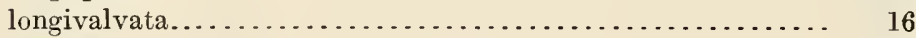

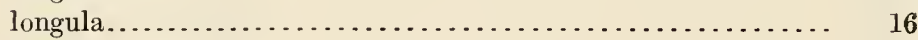

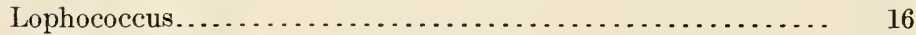

lounsburyi......................................... 16

lutea............................................. 16

Luzulaspis......................................... 16

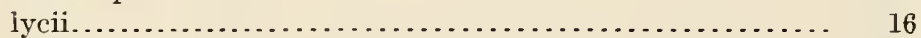

macrocarpæ....................................... 16

Macrocerococcus..................................... 16

macroprocta......................................... 16

madagascariensis s. sp .................................... 16

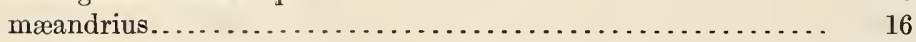

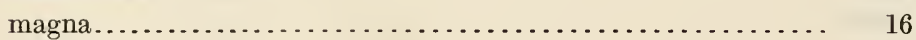

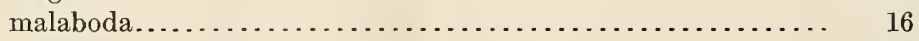

malleolus......................................... 12

mammillaris.................................... 16 
mangiferæ s. sp., Aulacaspis .

Technical

manni.

Page.

Margarodes.

MaRgarodin $E$

marsupialis.

Matsucoccus

matsumuræ.

matumuræ

maxima.

maximus.

mcgregori

83

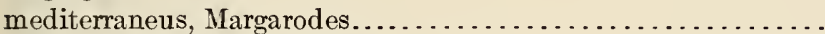

mediterraneus, Cryptaspidiotus..........................

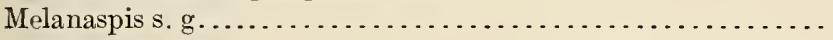

mendozinus.

meridionalis. . . . . . . . . . . . . . . . . . . . . . . . . . .

Mesolecanium

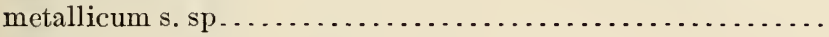

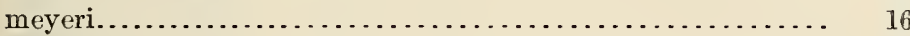

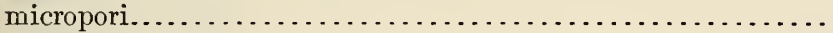

Micrococcus.

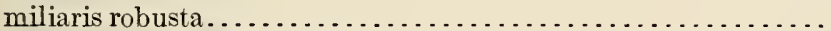

Mimosicerya, n. sec. Icerya........................ 12

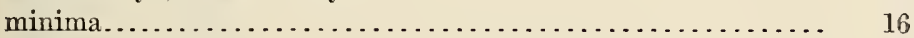

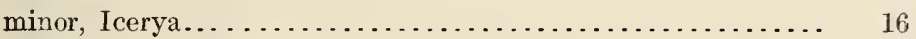

minor s. sp., Asterolecanium..................... 16

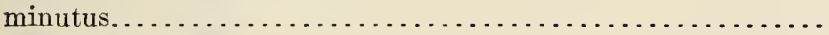

mirabilis tricornis . . . . . . . . . . . . . . . . . . . . . .

mirmecophila.................................. 16

missionum.

Monophlebinet

Monophlebus.

montanus. 
mytilaspiformis.

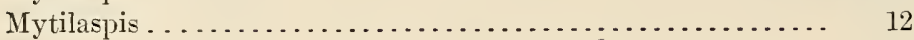

16

Page.

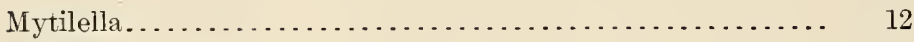

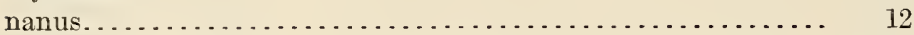

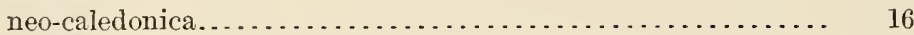

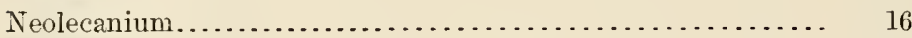

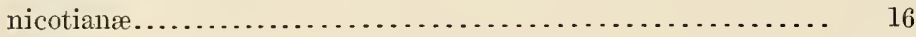

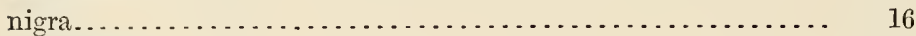

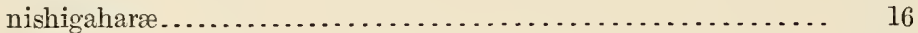

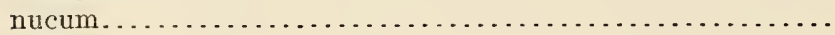

nudata. . . . . . . . . . . . . . . . . . . . . . .

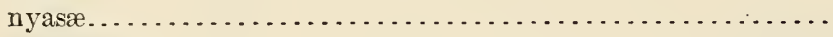

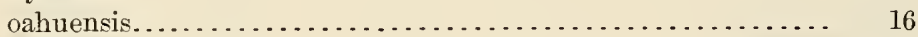

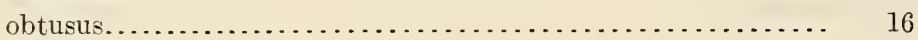

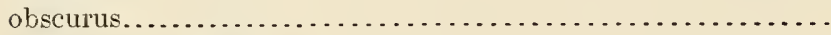

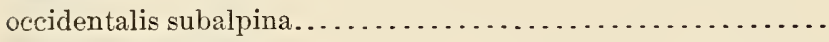

occultus elongatus.............................

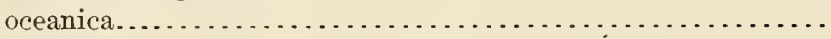

ocellata.

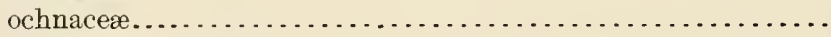

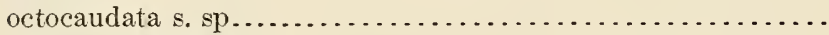

odinæ, Fiorinia..

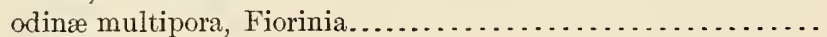

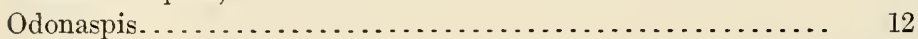

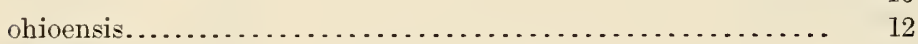

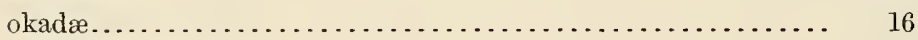

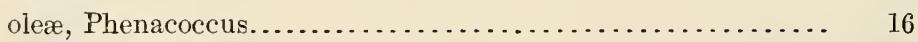

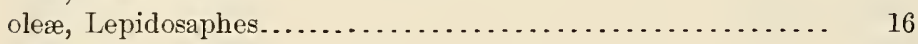

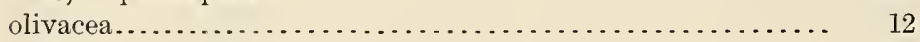

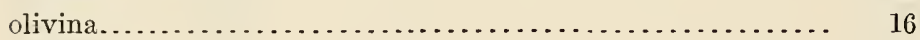

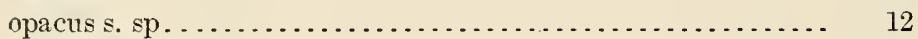

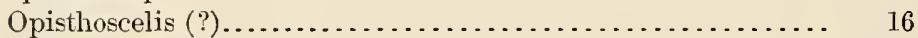

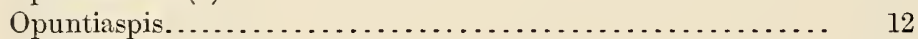

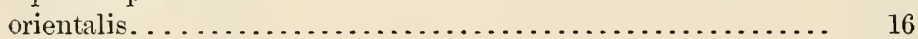

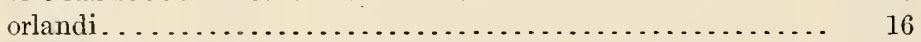

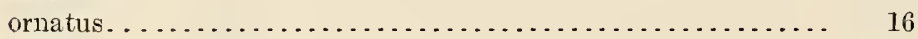

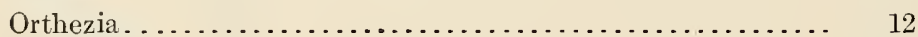

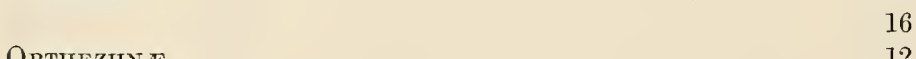

ortholobis brumeri.................................... 12

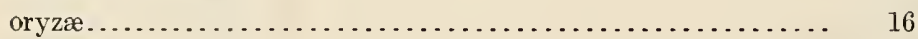

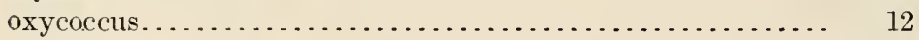

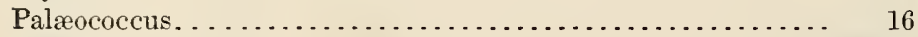

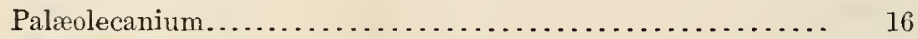

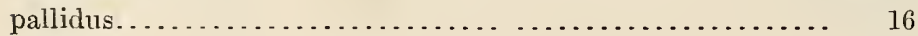

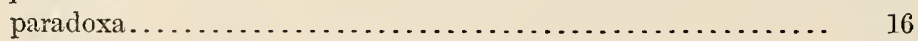

Paralecanium.............................. 12 


\begin{tabular}{|c|c|c|}
\hline \multirow{3}{*}{ Parlatoria.. } & \multirow{2}{*}{$\begin{array}{c}\text { Technical } \\
\text { Series No. } \\
12\end{array}$} & \multirow{2}{*}{$\begin{array}{r}\text { Page. } \\
18\end{array}$} \\
\hline & & \\
\hline & 16 & $58,72,95$ \\
\hline parlatoriæ. & 12 & 18 \\
\hline 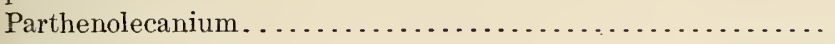 & 16 & 46 \\
\hline parva & 16 & 90 \\
\hline 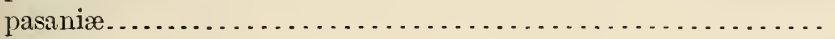 & 16 & 62 \\
\hline 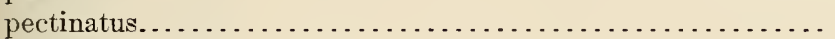 & 16 & 70 \\
\hline 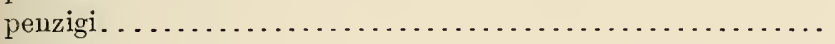 & 16 & 49 \\
\hline perditulum $\ldots \ldots \ldots \ldots \ldots \ldots \ldots \ldots \ldots$ & 16 & 45 \\
\hline 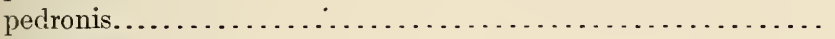 & 12 & 15 \\
\hline 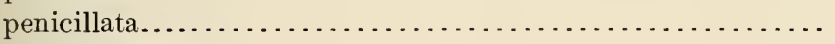 & 12 & 16 \\
\hline 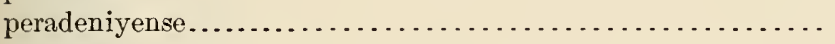 & 12 & 9 \\
\hline 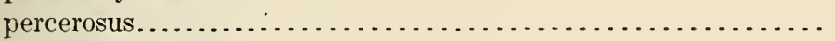 & 16 & 86 \\
\hline 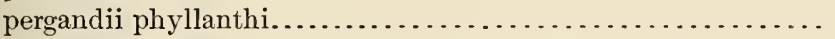 & 12 & 18. \\
\hline 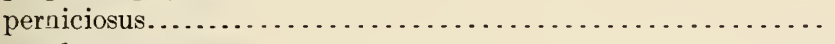 & 16 & 65 \\
\hline 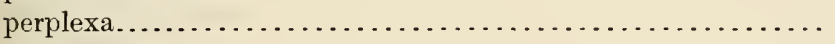 & 16 & 56 \\
\hline \multirow[t]{2}{*}{ 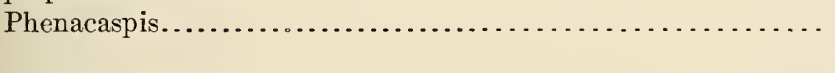 } & 12 & 12 \\
\hline & 16 & 90 \\
\hline Phenacobryum.............. & 12 & 3 \\
\hline \multirow[t]{2}{*}{ 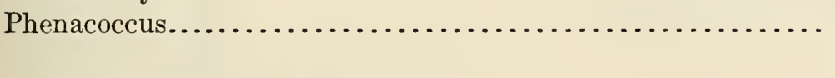 } & 12 & 4 \\
\hline & 16 & 38,64 \\
\hline philippina s. sp. & 12 & 7 \\
\hline phragmitis $\ldots{ }^{\prime}$ & 16 & 43 \\
\hline 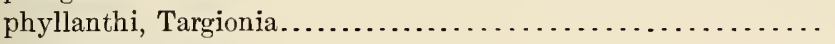 & 12 & 16 \\
\hline 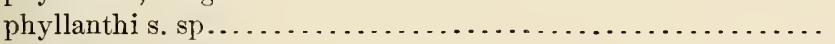 & 12 & 18 \\
\hline 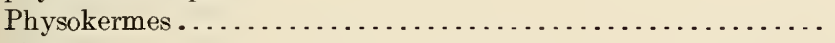 & 12 & 10 \\
\hline 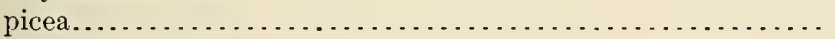 & 16 & 56 \\
\hline 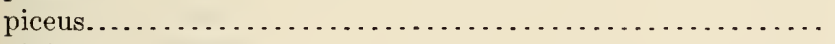 & 12 & 14 \\
\hline pinicola. & 16 & 56 \\
\hline Pinnaspis.. & 16 & 49 \\
\hline piperis........................... & 16 & 57 \\
\hline pisai & 12 & 14 \\
\hline 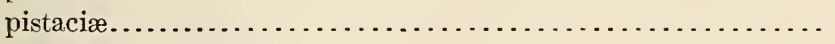 & 16 & 50 \\
\hline plana..... & 16 & 87 \\
\hline 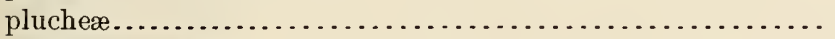 & 16 & 44 \\
\hline 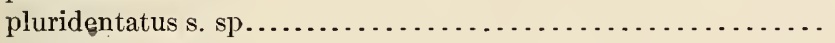 & 16 & 93 \\
\hline 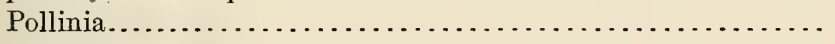 & 16 & 65 \\
\hline polygonata. & 12 & 6 \\
\hline Polyocellaria.......................... & 12 & 2 \\
\hline 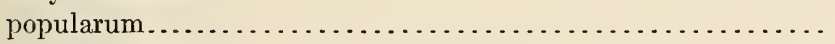 & 16 & 53 \\
\hline 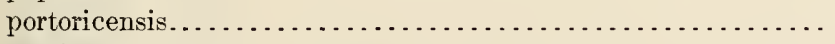 & 16 & 70 \\
\hline privignus. & 16 & 53 \\
\hline prominens s. sp............. & 16 & 62 \\
\hline propsimus......... & 16 & 55 \\
\hline 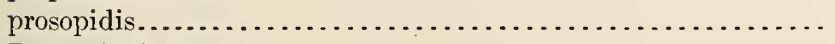 & 16 & 84 \\
\hline 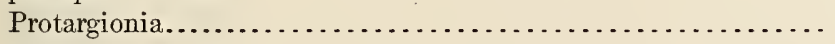 & 16 & 94 \\
\hline proteus....................... & 12 & 18 \\
\hline prunastri...................... & 16 & 46 \\
\hline \multirow[t]{2}{*}{ 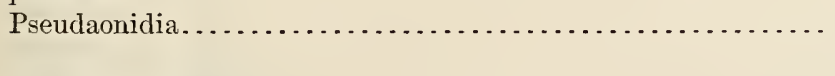 } & 12 & 15 \\
\hline & 16 & 54 \\
\hline pseudaspidiotus.. & 12 & 18 \\
\hline \multirow[t]{2}{*}{ Pseudococcus...................................... } & 12 & $\tilde{3}$ \\
\hline & 16 & $40,58,86$ \\
\hline
\end{tabular}


$\begin{array}{rr} & \text { Technical } \\ \text { Series No. }\end{array}$

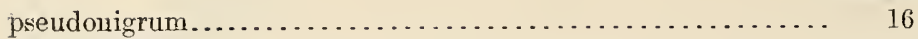

Page.

Pseudoparlatoria................................... 16

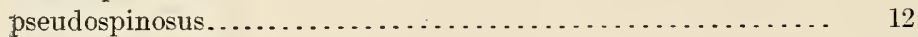

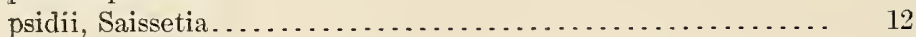

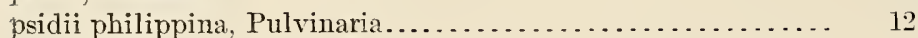

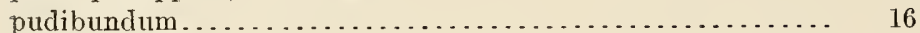

67

56,71

14

10

7

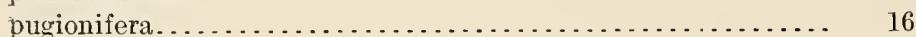

62

68

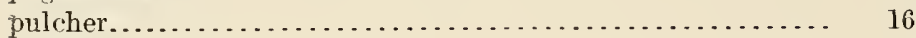

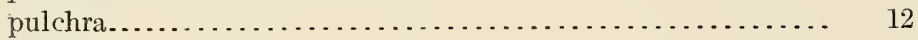

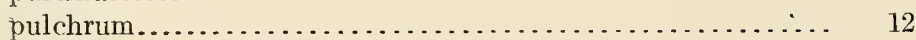

34

16

9

46,72

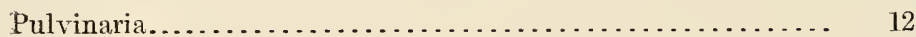

6

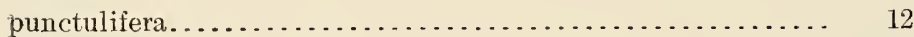

$43,66,87$

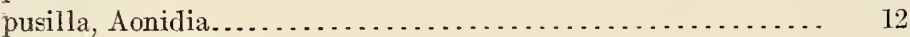

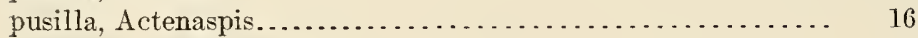

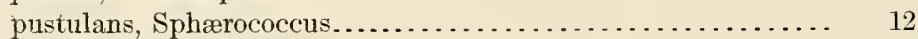

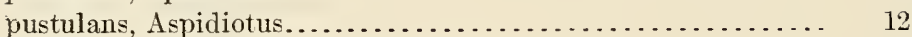

pustulans sambuci, Asterolecanium.................... 12

pustulans seychellarum, Asterolecanium . . . . . . . . . . . . 16

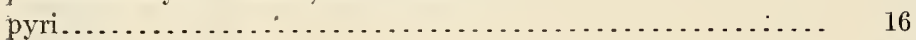

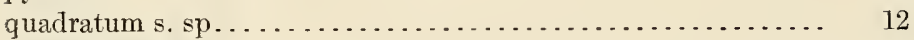

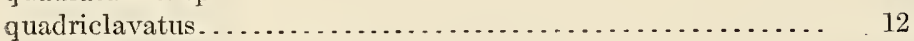

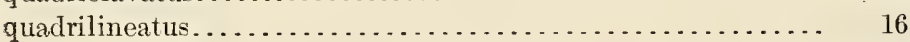

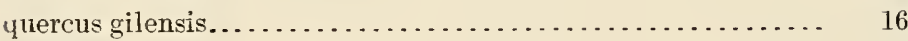

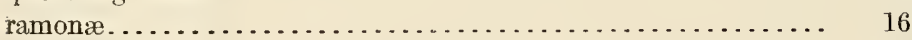

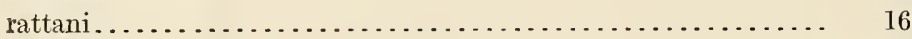

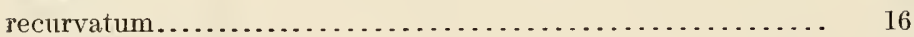

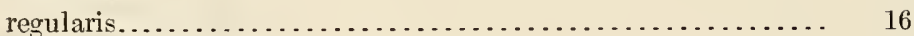

rehi, Asterolecanium................................ 12

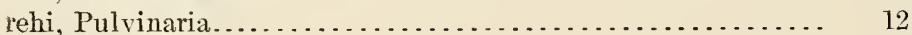

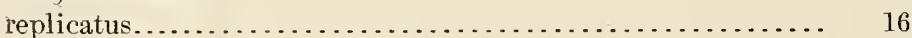

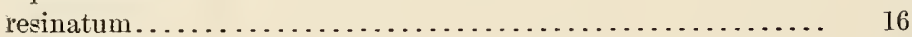

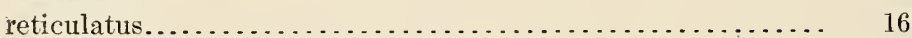

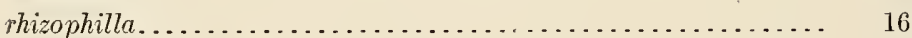

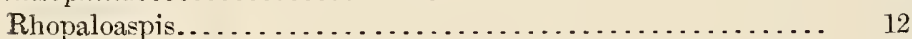

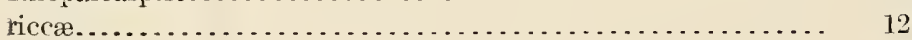

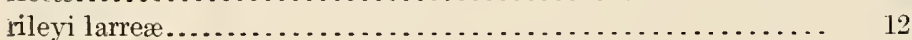

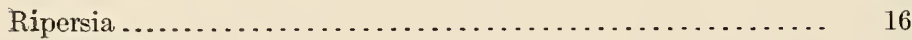

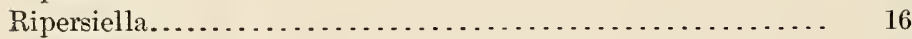

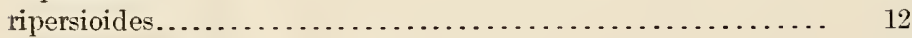

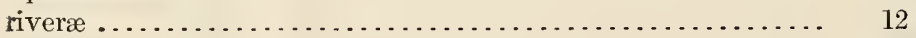

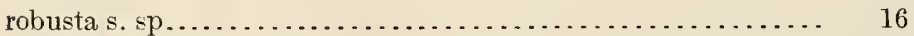

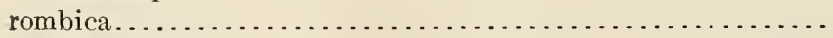

rosæ australis . . . . . . . . . . 16

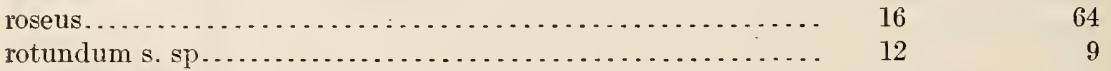

rubellum............................................ $16 \quad 46,72$

rubrocomatum.................................... $16 \quad 63$ 
Technical

Series No.

rubrolineata.

Page.

rubrovittatus

16

51

ruthre.

12

17

16

56

saccharifolii.

41

Saissetia.

salinus.

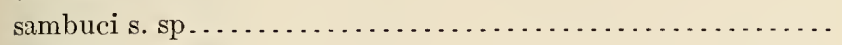

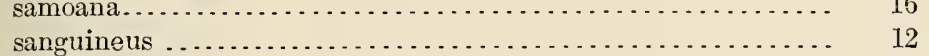

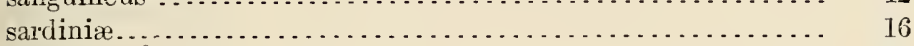

sassceri.

schultzyi .

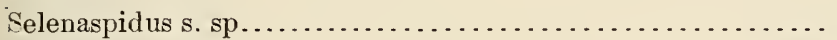

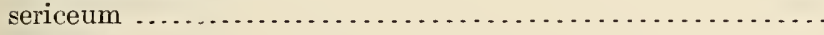

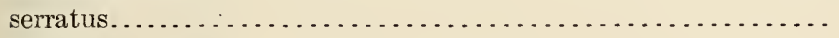

serrifrons........................................ 16

seurati........................................ 16

seychellarum s. sp., Asterolecanium.................... 16

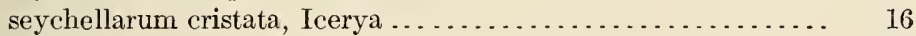

shastæ.............................................. 12

shastensis........................................... 16

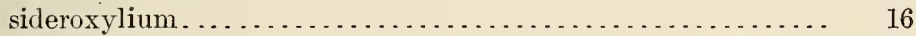

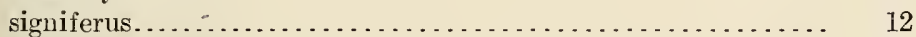

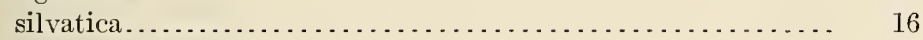

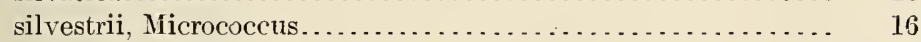

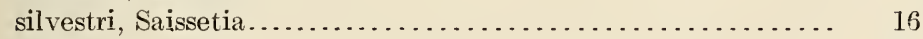

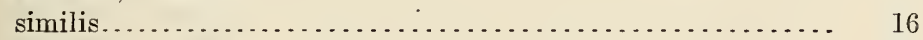

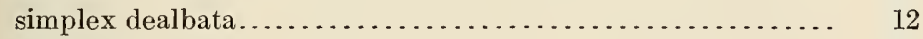

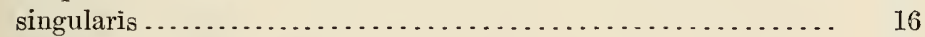

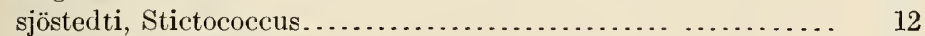

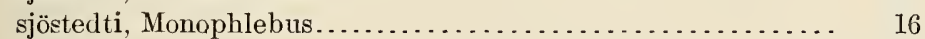

smithii........................................ 16

54,93

46

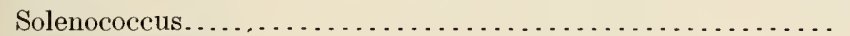

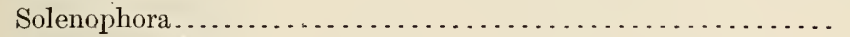

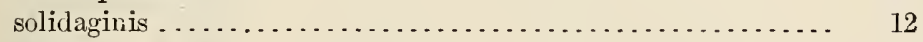

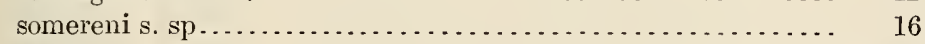

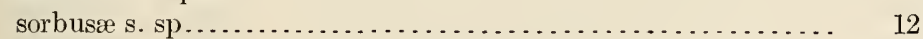

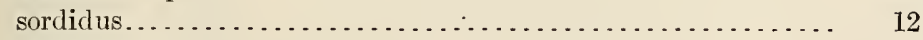

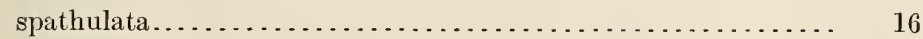

Sphærococcus................................. 12

Sphærolecanium....................................... 16

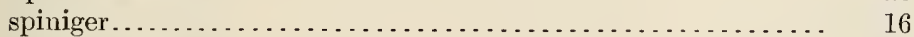

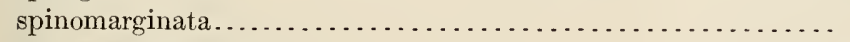

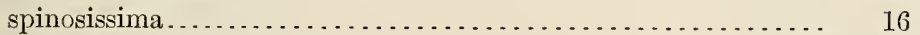

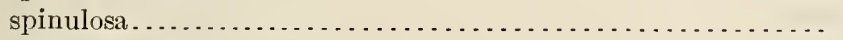

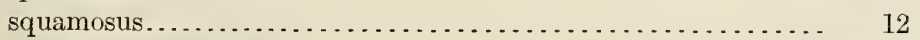

stebbingii mangiferæ................................. 12

stebbingi octocaudata ............................... 16

Steingelia . 
Stictococcus.

Technical Series No.

Stigmacoccus.

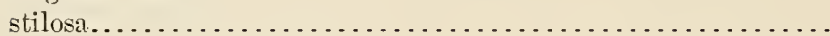

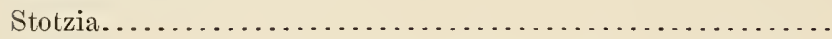

striata. . . . . . . . . . . . . . . . . . . . . . . .

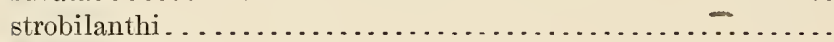

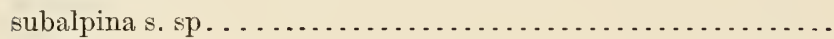

subandina......................................... 16

subcorticalis. . . . . . . . . . . . . . . . . . 12

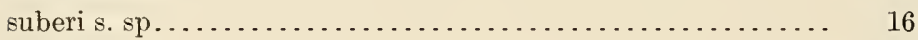

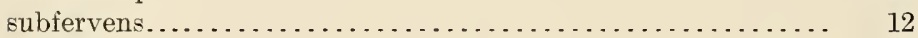

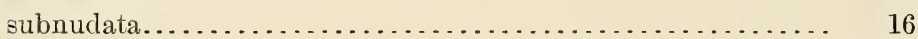

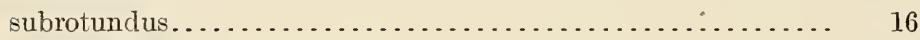

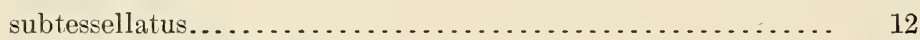

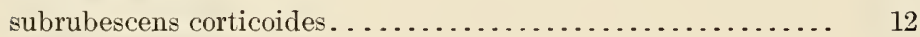

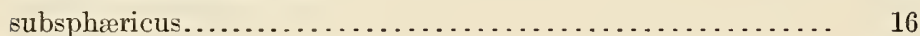

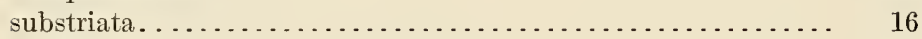

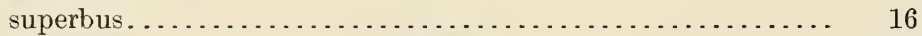

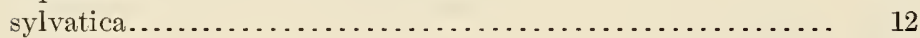

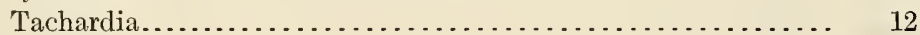

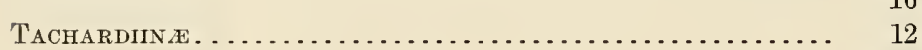

takæ.

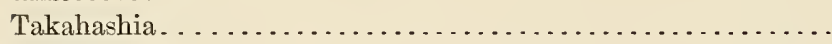

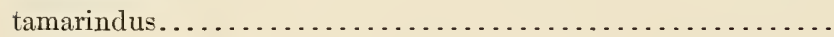

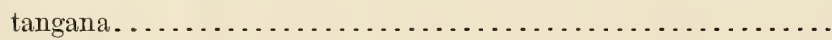

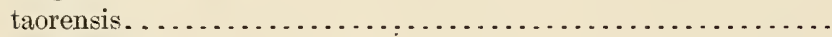

taprobanus. . . . . . . . . . . . . . . . . . . . . . . . .

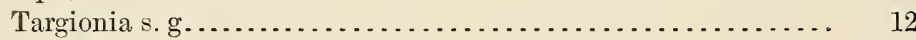

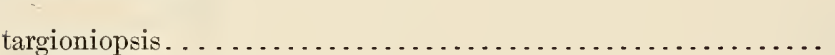

tayabanus, Aspidiotus . . . . . . . . . . . . . . . . . . . .

tayabanus, Pseudococcus.........................

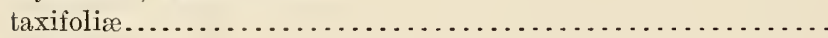

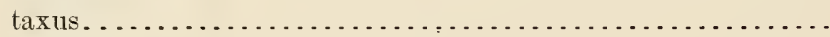

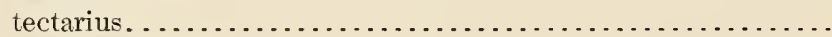

tenebricophilum. . . . . . . . . . . . . . . . . . . . . .

tenuior...................................

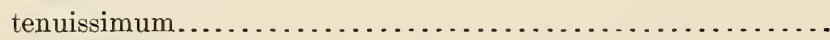

tenuitectus..............................

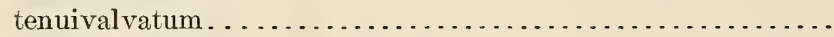

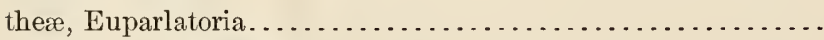

theæ s. sp., Tachardia. . . . . . . . . . . . . . . . . . . . .

theæ ceylonica, Hemichionaspis. . . . . . . . . . . . . . . . .

theacola.

theobromæ, Palæococcus..........................

theobromæ, Ceroplastes..........................

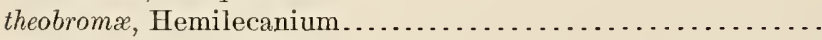

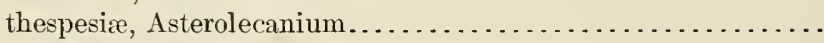

thespesiæ, Pulvinaria . . . . . . . . . . . . . . . . . . . .

tinerfensis
Page.

7

38,64

83

69

44

44

12

66

84

11

55

14

90

88

7

14

88

68

38

11

6

43,87

43,87

41

68

33

90

94

15

14,16

$55,71,94$

16

12

12 


\begin{tabular}{|c|c|c|}
\hline tonilensis s. sp., Icerya......... & $\begin{array}{c}\text { Technical } \\
\text { Series No. } \\
12\end{array}$ & $\begin{array}{r}\text { Page. } \\
2\end{array}$ \\
\hline & 16 & 58 \\
\hline townsendi, Monophlebulus................. & 12 & 2 \\
\hline towasendi, Hemichionaspis.......................... & 12 & 12 \\
\hline 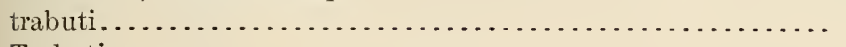 & 16 & 53 \\
\hline 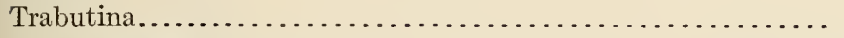 & 12 & 4 \\
\hline 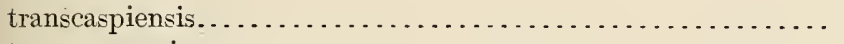 & 16 & 53 \\
\hline 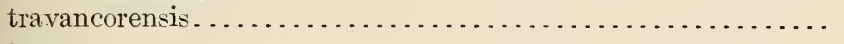 & 16 & 95 \\
\hline 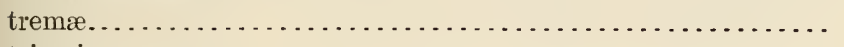 & 16 & 89 \\
\hline 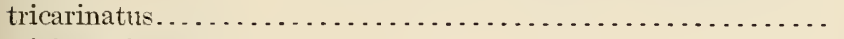 & 12 & 4 \\
\hline 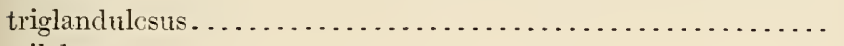 & 16 & 55 \\
\hline 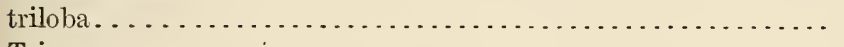 & 16 & 35 \\
\hline 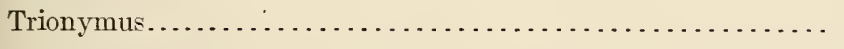 & 12 & 4 \\
\hline & 16 & 58,86 \\
\hline troglodytes..... & 16 & 47 \\
\hline 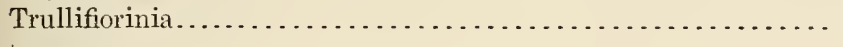 & 16 & 50 \\
\hline 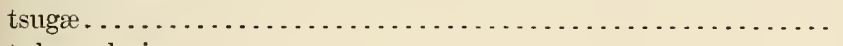 & 16 & 94 \\
\hline 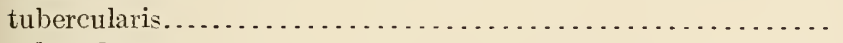 & 16 & 49 \\
\hline 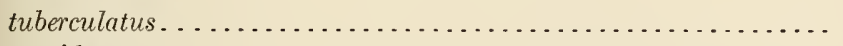 & 16 & 45,67 \\
\hline 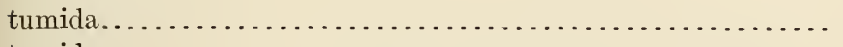 & 16 & 51 \\
\hline 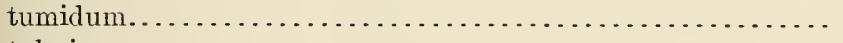 & 16 & 63 \\
\hline tyleri. . . . . . . . . . . . . . . . . . . . . . . . . . . . . & 12 & 7 \\
\hline 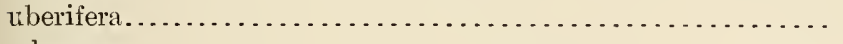 & 16 & 95 \\
\hline 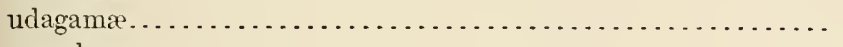 & 16 & 63 \\
\hline 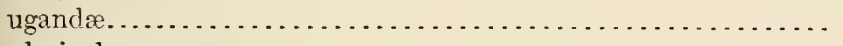 & 16 & 88 \\
\hline 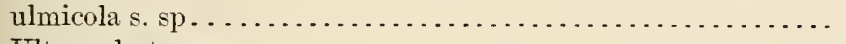 & 16 & 57 \\
\hline 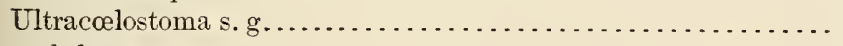 & 12 & 2 \\
\hline 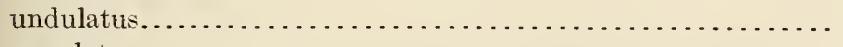 & 16 & 70 \\
\hline 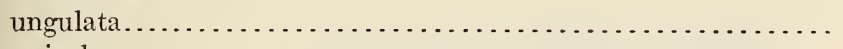 & 12 & 17 \\
\hline 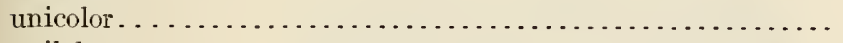 & 16 & 58 \\
\hline 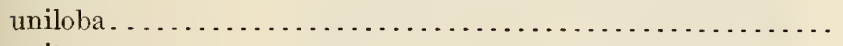 & 16 & 72 \\
\hline 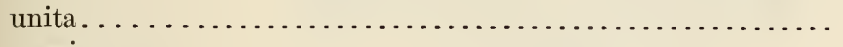 & 16 & 91 \\
\hline 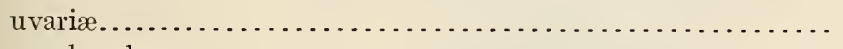 & 16 & 45 \\
\hline 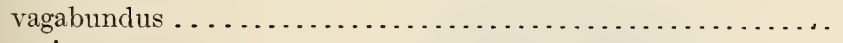 & 12 & 5 \\
\hline 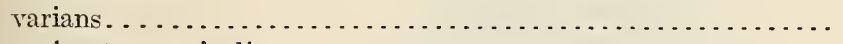 & 16 & 94 \\
\hline 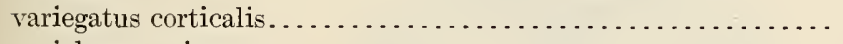 & 16 & 37 \\
\hline 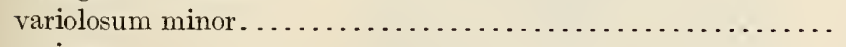 & 16 & 63 \\
\hline 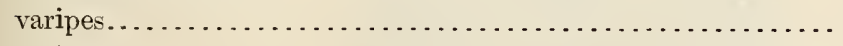 & 16 & 84 \\
\hline 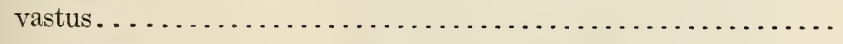 & 16 & 37 \\
\hline 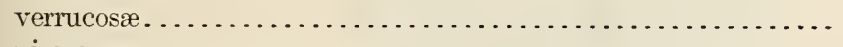 & 12 & 7 \\
\hline 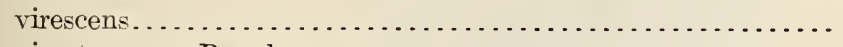 & 16 & 66 \\
\hline virgatus var., Pseudococcus........................ & 12 & 5 \\
\hline virgatus madagascariensis, Psendococcus.................. & 16 & 41 \\
\hline 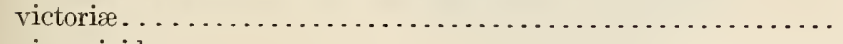 & 12 & 17 \\
\hline 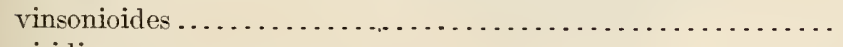 & 16 & 88 \\
\hline 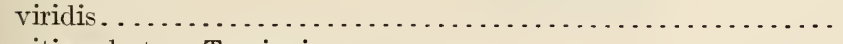 & 16 & 92 \\
\hline vitis arbutus, Targionia. . . . . . . . . . . . . . . . . . . & 16 & 71 \\
\hline 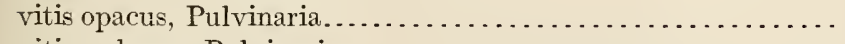 & 12 & 7 \\
\hline vitis sorbusæ, Pulvinaria . . . . . . . . . . . . . . . . . . . . & 12 & 7 \\
\hline 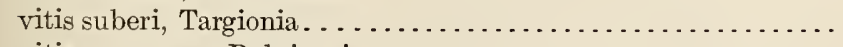 & 16 & 55 \\
\hline 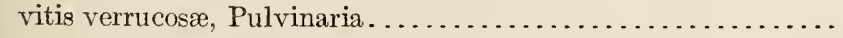 & 12 & 7 \\
\hline . . . . . . . . . & 16 & 39 \\
\hline$\ldots . . .6$ & 16 & 41 \\
\hline
\end{tabular}




\begin{tabular}{|c|c|c|}
\hline & $\begin{array}{l}\text { Technical } \\
\text { Series No. }\end{array}$ & Page. \\
\hline vuilleti, Aspidiotus.............. & 16 & 53 \\
\hline 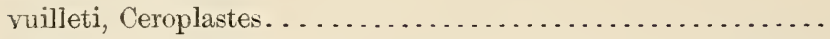 & 16 & 45 \\
\hline 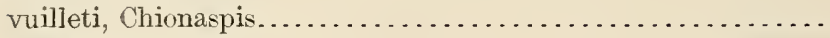 & 16 & 48 \\
\hline Walkeriana. . . . . . . . . . . . . . . . . . . . . . . . . & 16 & 34,61 \\
\hline 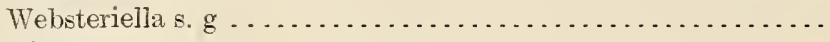 & 12 & 18 \\
\hline 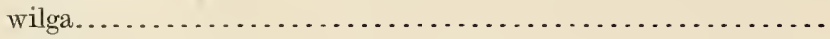 & 12 & 17 \\
\hline Xylococcus................... & 12 & 2 \\
\hline & 16 & 35 \\
\hline ул:lupæe & 16 & 53 \\
\hline zimmermanni . . . . . . . . . . . . . . . . . . & 16 & 83 \\
\hline zonatum & 12 & 9 \\
\hline
\end{tabular}

ADDTTIONAL COPIES of this publication A may be procured from the SUPERINTENDENT OF DOCUMENTS, Guvernment Printing Office, Washington, D. C., at 5 cents per copy

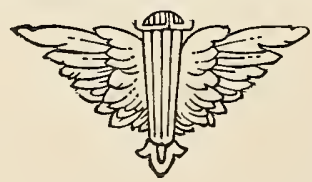


Technical Series, No. 17, Part I.

U. S. DEPARTMENT OF AGRICULTURE, BURHAU OF FN'TOMOLOGT.

L. O. HOWARD, Entomologist and Chief of Bureau.

\title{
CONTRIBUTIONS TOWARD A HONOGRAPII OF THE SCOLYTID BEETLES.
}

\section{THE GENUS DENDROCTONUS.}

wx

\author{
A. D. HOPKINS, Pн. D., \\ In Charge of Forest Insect Incestigations.
}

Issued June 30, 1909.

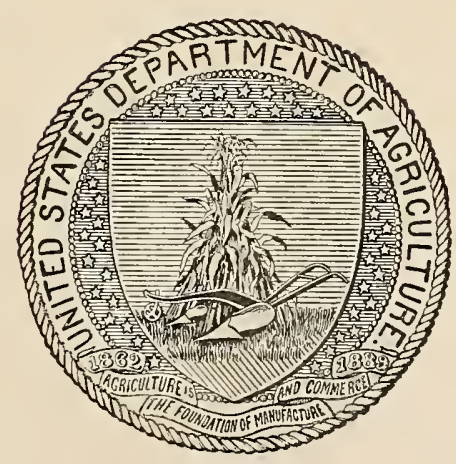

WASHINGTON:

GOVERNMENT I'RINTING OFFICE.

1909. 



\section{LETTER OF TRANSIITTAL.}

\section{U. S. Department of Agriculture, Bureau OF ENTOMOLOGY, Washington, D. C., March 16, 1909.}

Sir: I have the honor to transmit herewith manuscript of the first part of a bulletin of the technical series to be entitled "Contributions toward a Monograph of the Scolytid Beetles." This family of beetles includes some of the most important enemies of North American forests, as well as of crude forest products, and therefore must demand special attention in future systematic and economic investigations by this Bureau and by forest entomologists connected with other public institutions and private enterprises. It is necessary, as a foundation for such work, that the heretofore-described species should be accurately identified, that those new to science should be described, and that this information, together with other systematic data based on original research by this Bureau, should be made available in the form of contributions to a monograph. This awork has been undertaken by Doctor Hopkins, of this Bureau, and the greater part of the collecting and working up of the material has been completed. Delay in publication will be avoided, and it is believed that the published results will be more useful in future systematic and economic investigation if the results relating to groups of species which have similar characters and characteristics and similar relations to given economic problems are published as parts of a bulletin rather than in one undivided publication. These technical parts are to be supplemented in a like manner by parts of a bulletin of the regular series, giving information of immediate practical importance to the forester and owners and managers of private forests.

The first part of this bulletin is entitled "The Genus Dendroctonus.". It embodies the results of extensive systematic investigations of the genus, carried on by Doctor Hopkins during the past seventeen years, and is of especial interest and importance from the fact that it deals with a small group of beetles which are the most. destructive enemies of the principal coniferous forest trees of North America.

The discussions and illustrations relating to anatomical and technical details are necessary as a basis for the correct description, 
interpretation, and recognition of generic and specific characters, on which depends the future success of economic work on the scolytid beetles, and as aids in the preparation of technical and economic contributions to the monograph.

I recommend the publication of this paper as Part I of Technical Series, No. 17, of the Bureau of Entomology.

Respectfully,

Hon. James Wilsox,
L. O. Howard,

Chief of Bureau.

Secretary of Agriculture. 


\section{PREFACE TO BULLETIN.}

During the writer's investigations of extensive insect depredations in the forests of West Virginia, from 1890 to 1902, he was forcibly impressed with the importance of the forest-insect problem in any future efforts toward the successful management of the forests of this country, and was thus led to give special attention to the subject. It was soon realized that among the principal groups of insect enemies of forest trees the scolytid bark and wood boring beetles must occupy first rank, both in economic importance and in systematic interest. Subsequent investigations in West Virginia, in connection with the work of the West Virginia Agricultural Experiment Station, and in all of the principal forest regions of the country, in connection with the work of the Bureau of Entomology, have served to confirm these first impressions.

In these investigations special efforts have been made to acquire information on habits and seasonal history of the various species, and other facts relating to them, and to collect an abundance of material for systematic study - all to form a basis for conclusions in regard to the principal enemies of American forests and practical methods for their control.

The large amount of material has been pretty thoroughly worked over and identified, and synoptic tables and descriptions for the greater part have been completed for some time. Delay in publishing the results of the systematic part of the investigations has seemed necessary, in order that sufficient time might be given for the determination of taxonomic details as a basis for reliable conclusions in a comprehensive treatment of the group as a whole, but with increasing duties in the general work on forest insect investigations, and the more and more limited time available for systematic work, it is realized that these taxonomic studies can not be completed for many years.

To avoid further delay in the publication of data of immediate interest and importance, the writer has decided to postpone the discussion of the taxonomic and other subjects of a philosophical nature, required for a completed monograph, and for the present to issue separate contributions, each part to be restricted to one genus, or, at 
most, to a few closely allied genera. These parts will include synoptic tables, the necessary revisions of old descriptions of species and genera, and descriptions of genera and species which appear to be new to science.

It is proposed to follow these technical contributions with parts of a bulletin in the regular series, to include the determined bionomic and economic facts.

A somewhat comprehensive treatment of the anatomical details, fully illustrated, is given in Part I of this technical bulletin in order that it may serve as a basis for reference and comparison in the subsequent treatment of the other genera and groups of the family.

\section{LABELS AND RECORDS OF TYPE AND OTHER MATERIAL.}

A single specimen (a female, if possible) is designated as the type of a described species by a printed red label ("Type No.

U.S.N.M."), with the type catalogue number of the U. S. National Museum written in the blank. When additional specimens are availáble, the type, with one other specimen representing the opposite sex, labeled " " type" (or "q type") on red label, without type number, together with revision types ${ }^{a}$ and other specimens showing range in variation, constitute the type series which is deposited in the type collection of the U. S. National Museum. Other paratypes and typical examples of revised descriptions, comprising one or more specimens of each species, described, are marked with small red labels, and together with the duplicate collection of pinned, alcoholic, and biologic material, are kept in the reference collection of the Branch of Forest Insect Investigations, Bureau of Entomology, U. S. Department of Agriculture.

All pinned, alcoholic, and biologic material collected or recenved from correspondents are referred to in the field or laboratory records and bears number labels, each number referring to a consecutively numbered record of the observations made at the time the specimens were collected or" received.

Material collected by the writer during his connection with the West Virginia Agricultural Experiment Station between 1890 and 1902 is designated by "Hopk. W. Va.," number labels. Material collected by the writer during his temporary employment on special explorations and trips of investigation for the U. S. Department of Agriculture between 1899 and July, 1902, as well as that collected during the investigations of forest insects subsequent to April, 1902, or received from correspondents, is distinguished by a "Hopk. U. S." number label. In addition to the note number label each completely

a The term "revision type" is used to designate the specimens, male and female, on which a revised description is based. 
labeled mounted specimen bears labels which supply the following data: Collector or correspondent, locality, collecting or rearing date, host, and sex. The numbered notes are permanently bound in volumes of 1,000 numbers, each note relating to one or more species and to one or more specimens. The "Hopk. W. Ta." numbers begin with 1 and were limited in June, 1902, to 7,791, and in January, 1907, to 7,793. The "Hopk. U. S." numbers began with 1 in April, 1899, and will be limited to the period during which the writer is in charge of the Branch of Forest Insect Investigations in the Bureau of Entomology.

\section{MATERIAL STTUDIED.}

Unless otherwise mentioned, the material which forms the basis of information and study, so far as it relates to matter in this bulletin, is that bearing the "Hopk. U. S." or "Hopk. W. Ta." note numbers. The former is in the forest insect collection of the Bureau of Entomology, U. S. Department of Agriculture; the latter belongs to the collection of the West Tirginia Agricultural Experiment Station, but at present is in charge of the author, and forms a distinct part of the forest insect collection of the Bureau of Entomology.

\section{ABBREVIATIONS.}

The abbreviations adopted in this publication in referring to material in the different collections examined and that identified by the writer are as follows:

D. A.-Division and Bureau of Entomology, U. S. Department of Agriculture, Washington, D. C., other than Hopk. U.S.

Hopk. U. S.-Branch of Forest Insect Investigations, Bureau of Entomology, U. S. Department of Agriculture, Washington, D. C.

Hopk. W. Va.-IT. Va. Agricultural Experiment Station, Morgantown, W. Va.

U. S. N. M.-U. S. National Museum, Washington, D. C.

H. \& S.-H. G. Hubbard and E. A. Schwarz collection in the U. S. National Museum.

B. \& S.-Collected by H. S. Barber and E. A. Schwarz for the U. S. National Museum.

Soltau.-H. Soltau collection in the U. S. National Museum.

Lec.-Le Conte collection, Museum of Comparative Zoology, Cambridge, Mass.

Horn.-Horn collection, American Entomological Society, Philadelphia, Pa.

A. E. S.-American Entomological Society, Philadelphia, Pa.

A. M. N. H.-American Museum of Natural History, New York, N. Y.

N. Y. S. M.-New York State Museum, Albany, N. Y.

Harris.-Harris collection, Boston Society of Natural History, Boston, Mass.

Fitch.-Asa Fitch collection, as represented in the U. S. National Museum.

Wickham.-Wickham collection of Scolytidæ in the U. S. National Museum.

ACKNOWLEDGMENTS.

The writer desires to acknowledge the indispensable assistance and encouragement, during his earlier studies of the scolytid beetles 
(1890-94), rendered by Mr.E. A. Schwarz, of the U. S. National Museum, Oberforster W. Eichhoft, of Strasburg, Germany, Mr. W. H. F. Blandford, of London, England, and M. L. Villard, of Lyon, France. Messrs. Eichhoff and Schwarz especially were most kind and generous in furnishing identifications of species and in liberally loaning and donating specimens. Finally, the writer wishes to acknowledge the help of his associates and assistants during the prosecution of the work, and especially Mr. W. E. Rumsey, of the West Virginia Experiment Station, and the office and field force of the Branch of Forest Insect Investigations, in the Bureau of Entomology.

A. D. H. 


\section{CONTENTS}

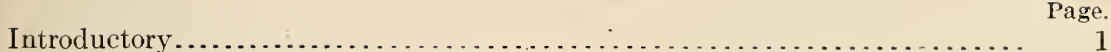

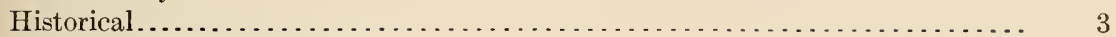

Original description of genus..................................... 4

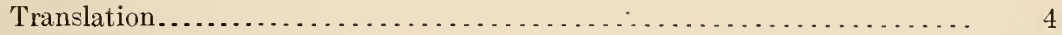

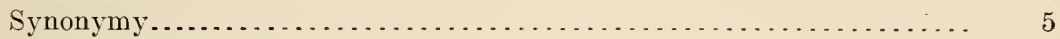

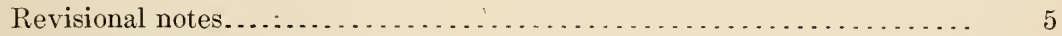

Revised description of genus.................................... 5

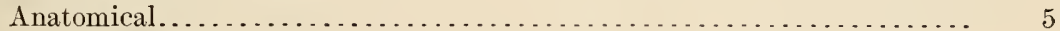

Nomenclature.................................... 7

Illustrations........................................... 9

External characters of the imago............................ 9

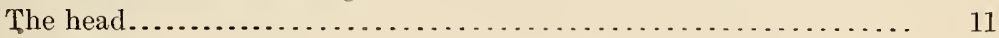

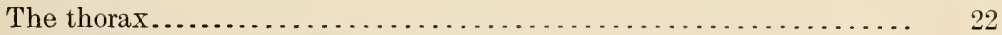

Divisions of the thoracic segment...................... 23

Elements of the adult thorax ........................... 26

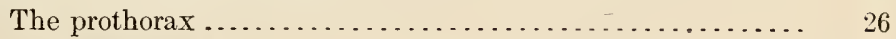

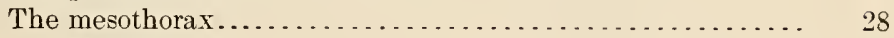

Mesotergum................................. 28

Mesoplura.................................... 29

Mesosterna................................ 30

The metathorax............................... $\quad 30$

Metatergum................................ 30

Metapleura............................... 34

Metasterna .................................. 35

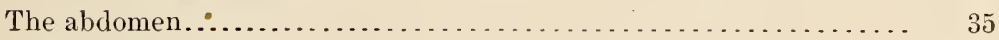

Abdominal tergites.................................. 36

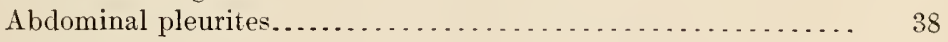

Abdominal sternites.................................. 38

Spiracles........................................ 39

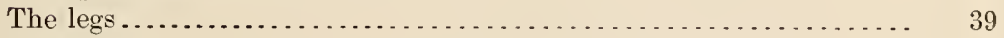

The wings.......................................... 40

Mesothoracic and metathoracic wings................. 42

Metathoracic or hind wings............................. 43

Mesothoracic wings or elytra........................ 49

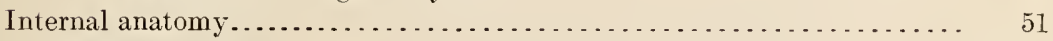

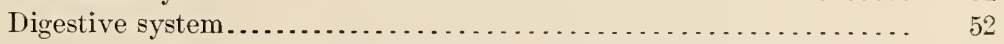

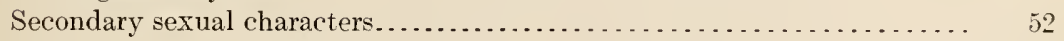

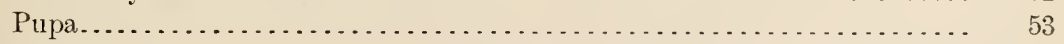

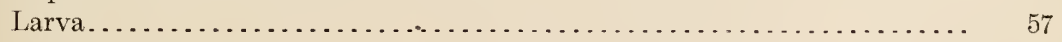

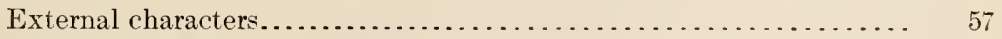

Digestive system...................................... 64

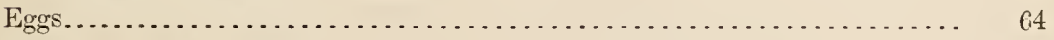

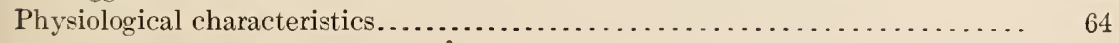


Specific distinctions....................................... 66

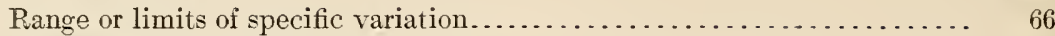

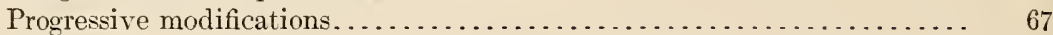

Distinction of major and minor divisions of the genus.............. 68

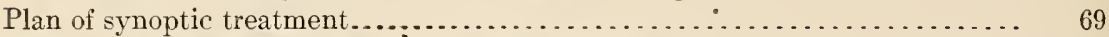

Synopses of morphological and physiological character $3 \ldots \ldots \ldots \ldots \ldots \ldots .69$

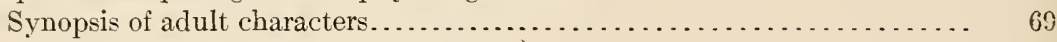

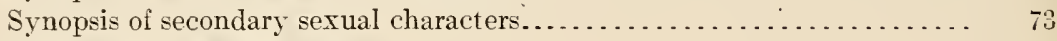

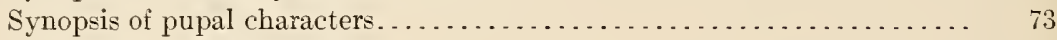

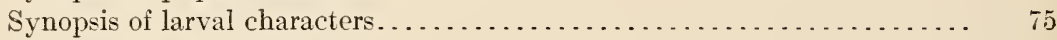

Synopsis of gallery characters............................... 76

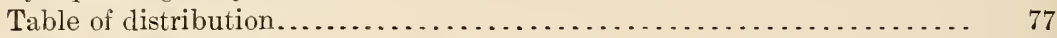

Table showing relation of species to host trees..................... is

Table of host trees........................................... 79

Revision and systematic notes, with descriptions of new species ......... 79

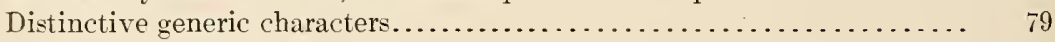

Bibliography and synonymy of genus........................ 80

Division I........................................... 81

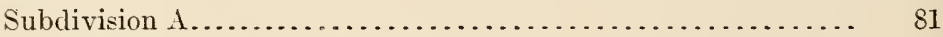

1. Dendroctonus brevicomis Le Conte............... 81

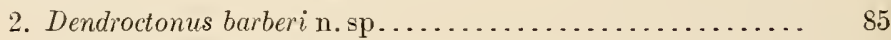

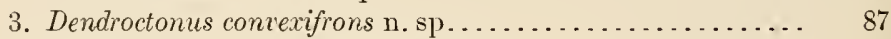

4. Dendroctonus frontalis Zimmerman ............... 90

5. Dendroctonus arizonicus n. sp................... 95

6. Dendroctonus mexicanus Hopkins................. 97

7. Dendroctonus parallelocollis Chapuis ............... 99

8. Dendroctonus approximatus Dietz................ 101

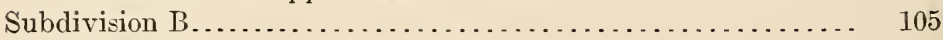

9. Dendroctonus monticolæ Hopkins ................ 105

10. Dendroctonus ponderose Hopkins ............... 109

11. Dendroctonus jeffreyi n. sp................... 114

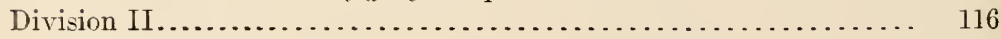

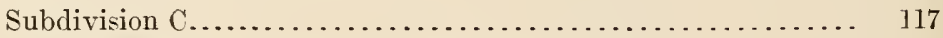

12. Dendroctonus simplex Le Conte................ 117

13. Dendroctonus pseudotsugæ Hopkins................. 121

14. Dendroctonus picea perda Hopkins................ 126

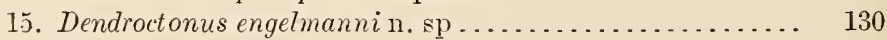

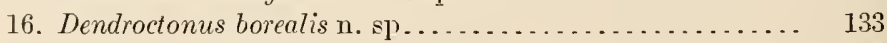

17. Derodroctonus obesus (Mannerheim) ................. 135

18. Dendroctonus rufipennis (Kirby)................. 138

19. Dendroctonus murrayanx n. sp................... 140

20. Dendroctonus punctatus Le Conte............... 142

21. Dendroctonus micans (Kugelann) ................ 143

Subdivision D ............................. $\quad 146$

22. Dendroctonus terebrans (Olivier) ................. 147

23. Dendrocionus valens Le Conte.................. 151

24. Dendroctonus adjunctus Blandford ............... 157

Bibliography.............................................. $\quad 159$ 


\section{ILLUSTRATIONS.}

\section{PLATES.}

Plate I. Classification of the genus Dendroctonus, showing technical and com-

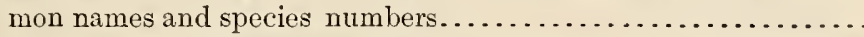

II. Map of world, showing geographical distribution of the genus Den-

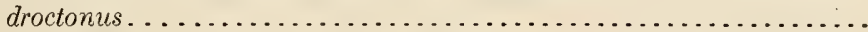

III. Dendroctonus adults. Fig. 1.-D. brevicomis. Fig. 2.-D. barberi. Fig. 3.-D. convexifrons. Fig. 4.-D. frontalis. Fig. 5.-D. arizonicus. Fig. 6.-D. mexicanus. Fig. 7.-D. parallelocollis.......

IV. Dendroctonus adults. Fig. 8.-D. approximatus. Fig. 9.-D. monticolæ. Fig. 10.-D. ponderosæ. Fig. 11.,D. jeffreyi...........

V. Dendroctonus adults. Fig. 12.-D. simplex. Fig. 13.-D. pseudotsugæ. Fig. 14. -D. piceaperda. Fig. 16.-D. borealis...........

VI. Dendroctonus adults. Fig. 17.-D. obesus. Fig. 18.-D. rufipennis.

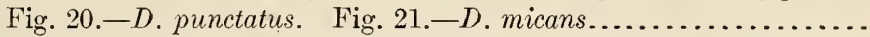

VII. Dendroctonus adults. Fig. 22.-D. terebrans. Fig. 23.-D. valens.... VIII. Dendroctonuslarvæ. Fig.1.-D.brevicomis. Fig. 19.-D. murrayanæ.

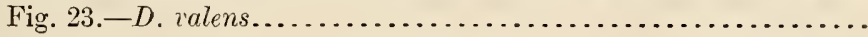

TEXT FIGURES.

FIG. 1. Dendroctonus valens: Adult, dorsal aspect................... 6

2. Dendroctonus valens: Adult, ventral aspect................. 8

3. Dendroctonus valens: Adult, lateral aspect................... 9

4. Dendroctonus valens: Head, dorsal and lateral aspects........... 12

5. Dendroctonus valens: Head, ventral aspect, and mouthparts........ 13

6. Dendroctonus valens: Head, oral aspect, epistoma, etc........... 14

7. Pterostichus californicus: Head, dorsal and ventral aspects.......... 15

8. Pissodes strobi: Head, ventral aspect, and mouthparts............. 16

9. Pissodes strobi: Head, dorsal aspect, and mandibles............. 17

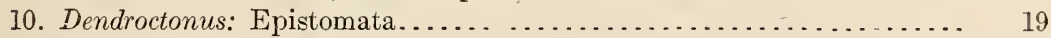

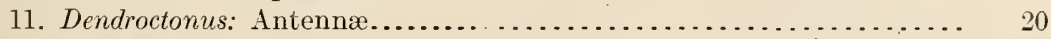

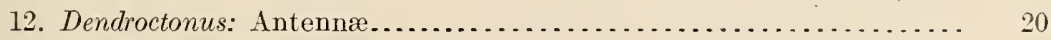

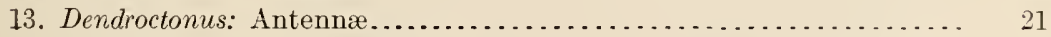

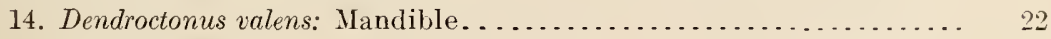

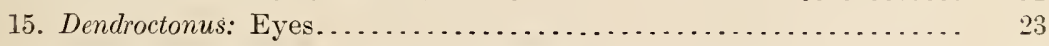

16. Dendroctonus valens: Areas of pronotum................... 23

17. Dendroctonus valens: Areas of prothorax, ventral aspect......... 24

18. Dendroctonus valens: Mesothorax, ventral aspect.............. 24

19. Dendroctonus valens: Mesotergum and mesopleurum............. 28

20. Dendroctonus valens: Metatergum and metapleurum............. 31

21. Dendroctonus valens: Metatergum, inner aspect............. 33

22. Dendroctonus valens: Abdominal tergites.................. 35

23. Dendioctonus valens: Male, abdominal tergites 7 and $8 \ldots \ldots \ldots \ldots \ldots 36$

24. Dendroctonus valens: Female, abdominal tergites 7 and $8 \ldots \ldots \ldots \ldots . . . . .37$ 
FIG. 25. Dendroctonus valens: Abdominal sternites, ventral and lateral as-

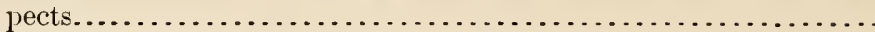

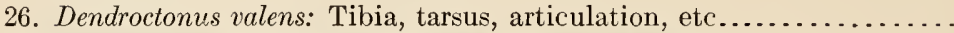

27. Dendroctonus: Left tibiæ, dorsal and ventral aspects.............

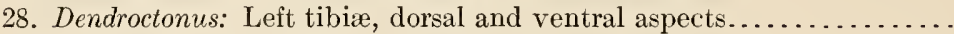

29. Dendroctonus: Left tibiæ, dorsal and ventral aspects................

30. Dendroctonus valens: Diagram of basal area of hind wing...........

31. Dendroctonus valens: Right elytron, ventral aspect................

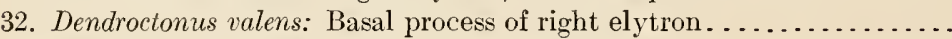

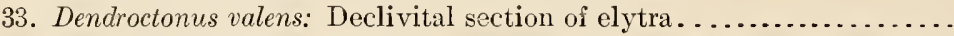

34. Dendroctonus valens: Diagram of elytron, showing striæ, interspaces,

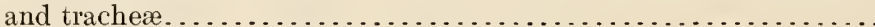

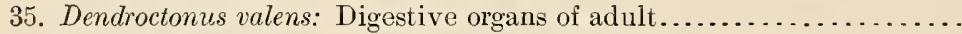

36. Dendroctonus valens: Fore intestine, showing details.............

37. Dendroctonus valens: Pupa, dorsal, lateral, and ventral aspects.......

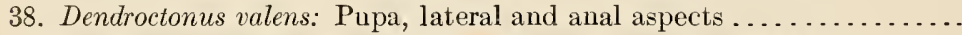

39. Dendroctonus valens: Larva, dorsal, lateral, and ventral aspects......

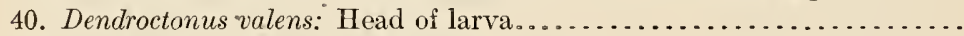

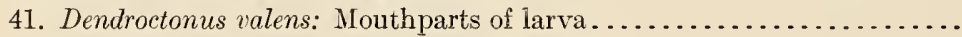

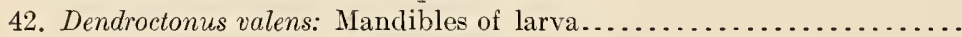

43. Dendroctonus valens: Digestive organs of larva................

44. Dendroctonus brevicomis: Egg galleries . . . . . . . . . . . . . . . .

45. Dendroctonus brevicomis: Bark showing pupal cells, exit burrows, and

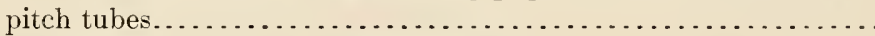

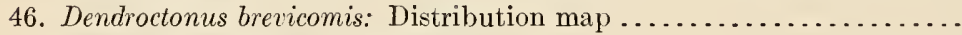

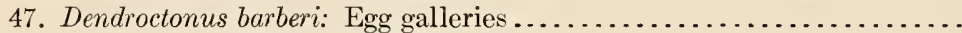

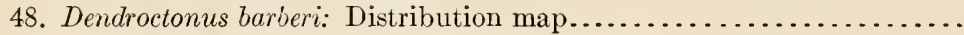

49. Dendroctonus convexifrons: Egg galleries and larval mines............

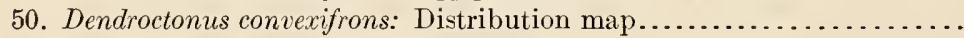

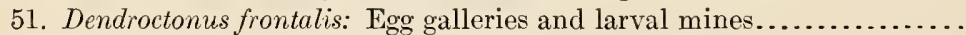

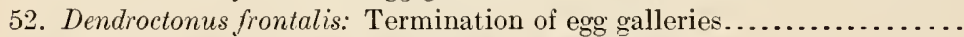

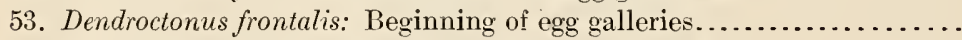

54. Dendroctonus frontalis: Bark showing pitch tubes, etc................

55. Dendroctonus frontalis: Old egg galleries in living tree.............

56. Dendroctonus frontalis: Egg gallery in living tree, the resulting wound

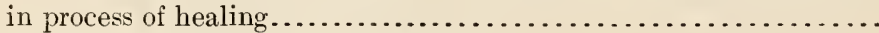

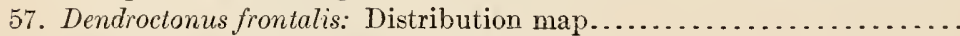

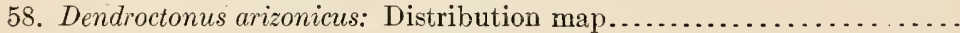

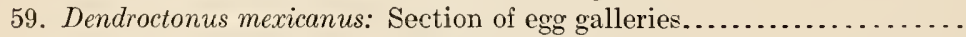

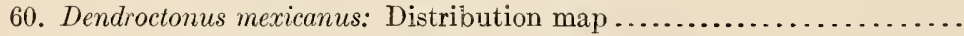

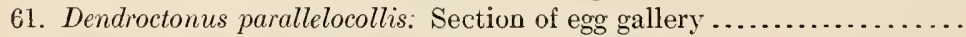

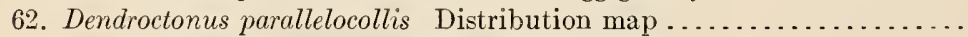

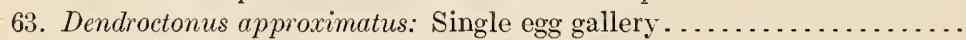

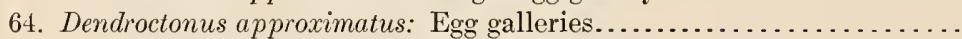

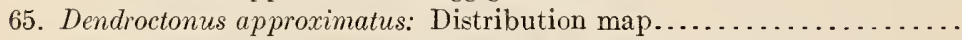

66. Dendroctonus monticolæ: Egg galleries and larval mines in bark.......

67. Dendroctonus monticolx: Egg galleries and larval mines grooved in surface of wood...

68. Dendroctonus monticolx: Distribution map.................. 109

69. Dendroctonus ponderosæ: Egg galleries and larval mines.......... 112

70. Dendroctonus ponderosæ: Tree with bark removed, showing egg gal-

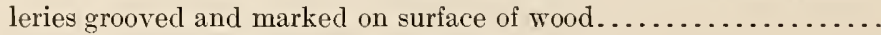

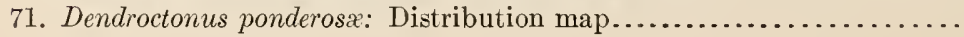


Page.

FIG. 72. Dendroctonus jeffreyi: Distribution map.................... 116

73. Dendroctonus simplex: Egg galleries and larval mines............ 119

74. Dendroctonus simplex: Distribution map................... 120

75. Dendroctonus pseudotsugx: Egg galleries and larval mines......... 122

76. Dendroctonus pseudotsugæ: Egg gallery and larval mines........... 123

77. Dendroctonus pseudotsugx: Section of $\log$ with bark removed, showing brood galleries marked and grooved on surface of wood ......... 124

78. Dendroctonus pseudotsugæ: Distribution map................. 125

79. Dendroctonus piceaperda: Egg gallery and larval mines ........... 128

80. Dendroctonus piceaperda: Distribution map................. 129

81. Dendroctonus engelmanni: Egg gallery and eggs in living bark...... 132

82. Dendroctonus engelmanni: Distribution map................ 133

83. Dendroctonus borealis: Distribution map ................... 134

84. Dendroctonus obesus: Distribution map..................... 137

85. Dendroctonus rufipennis: Distribution map.................... 140

86. Dendroctonus murrayanæ: Distribution map................... 141

87. Dendroctonus punctatus: Distribution map .................. 143

88. Dendroctonus micans: Egg galleries and larval chamber.......... 145

89. Dendroctonus micans: Distribution map..................... 146

90. Dendroctonus terebrans: Distribution map................... 150

91. Dendroctonus valens: Egg galleries and larval chamber.......... 152

92. Dendroctonus valens: Work in bark at base of stump............ 153

93. Dendroctonus valens: Basal wound in living tree resulting from primary injury by this species.............................. 154

94. Dendroctonus valens: Distribution map.................... 155

95. Dendroctonus adjunctus: Distribution map................. 158 


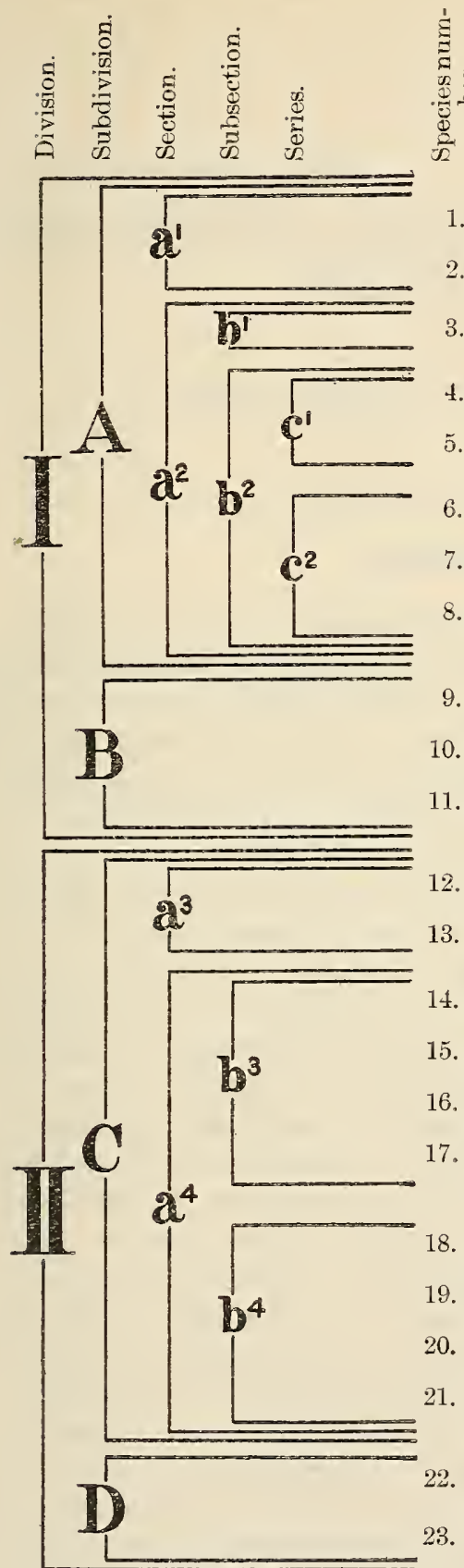

Position doubtful-

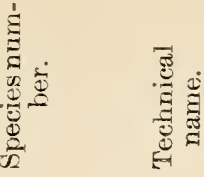

1. brexicomis Lec.

2. barberi Hopk.

3. convexifrons Hopk.

4. frontalis Zimm.

5. arizonicus Hopk.

6. mexicanus Hopk.

7. parallelocollis Chap.

8. approximatus Diet

9. monticolx Hopk.

10. ponderosæ Hopk.

11. jeffreyi Hopk.

11. Jeffrey Pine Beetle 71,114

12. simplex Lec.

13. pseudotsugæ Hopk. 13. Douglas Fir Beetle 71, 121

14. piceaperda Hopk.

15. engelmanni Hopk.

16. boreatis Hopk.

17. obesus Miann.

18. rufipennis Kirby.

19. murrayanz Hopk.

20. punctatus Lec.

21. micans Kug.

22. terebrans Oliv.

23. valens Lec.

1. Western Pine 70,81 Beetle.

2. Southwestern Pine 70,85 Beetle.

3. Roundheaded Pine 70,87 Beetle.

4. Southern Pine 70,90 Beetle.

5. Arizona Pine 70,95 Beetle.

6. Smaller Mexican 70,97 Pine Beetle. Pine Beetle.

olorado Pine 70,101 Beetle.

9. Mountain P in e 71,105 Beetle.

10. Black Hills Beetle 71, 109

12. Eastern Larch 71,117 Beetle.

14. Easter $n$ Spruce 71,126 Beetle.

5. Engelmann Spruce 71, 130 Beetle.

16. Alaska Spruce 72,133 Beetle.

17. Sitka Spruce Beetle 72, 135

18. Redwinged Pine 72,138 Beetle.

19. Lodgepole Pi n e 72, 140 Beetle.

20. Allegheny Spruce 72,142 Beetle.

21. European Spruce 72,143 Beetle.

22. Black Turpentine $72,1 \pm 7$ Beetle.

23. $\mathrm{R}$ e d Turpentine 72, 151 Beetle.

24. adjunctus Blandf. 24. Guatemala Beetle 157

\section{Classification of the Genus Dendroctonus, Slowing Technical and Common Names and Species Numbers.}

This diagram will enable the reader to refer at once to the technical and common names of any species number mentioned in the text, and will show at a glance the position and relations of the divisions, subdivisions, sections, subsections, series, and species into which the genus is divided. 



\title{
CONTRIBUTIONS TOITARD A IONOGRAPH OF THE SCOLYTID BEETLES.
}

\section{THE GENUS DENDROCTONUS.}

\author{
By A. D. Hopkins, \\ In Charge of Forest Insect Investigations.
}

INTRODUCTORY.

The active work on forest insects conducted by the West Virginia Agricultural Experiment Station in 1890-91, and by the Division and Bureau of Entomology of the U. S. Department of Agriculture since 1899 , has resulted in the accumulation of a mass of systematic and biological data on the principal described and undescribed insect enemies of forest trees and forest products of the United States. Whenever an attempt has been made, however, to work up the material relating to a given species, or group of species, it has been apparent that the publication of anything without first describing the new species and revising the data in both the systematic and economic literature would contribute to confusion rather than to advancement. Indeed, it becomes more and more evident that in order to give reliable information on applied entomology we must have at our command the knowledge gained by careful technical, or systematic, studies of the insects with which we have to deal. Therefore, when we find, as we do in many cases; that the published results of systematic work on a given genus or species are meager or otherwise unsatisfactory, it becomes necessary to revise and verify the descriptions and biological records, and to adjust the classification to meet the requirements of the newly discovered facts relating to the described and undescribed species.

The genus Dendroctonus presents a striking example of the need of systematic study as a basis for economic investigation. It is both the most important group of insect enemies of the coniferous forest trees of North America and one of the most difficult for systematic study. Le Conte (1876) expressed the difficulty met with in a study of the species when he said in his later revision:

If I have failed to indicate more strongly the differences between these species, it is because they are not distinguishable by any prominent or definite characters; and the student who may have difficulty in identifying the species as here defined would have almost equal difficulty if the specimens in my collection were before him. 
Until within recent years little progress had been made toward the discovery and clear definition of the specific and sexual characters. In consequence the identification of the species was both difficult and uncertain and has led to much confusion in both systematic and economic literature. With our prasent knowledge of the genus, based on an exhaustive study of the systematic and biologic details, most, if not all, of the difficulties have been removed, so that the identification of the species is comparatively easy.

It is the purpose of this paper to revise and bring up to date the available information on the described species, to describe those that appear to be new to science, and to record the results of original investigations relating to the more technical details that can not well be included in the paper which is to follow as a part of a bulletin in the regular series and which will give full information on the bionomic features.

The material which has served as a basis for the study of this genus consists mainly of the notes and specimens taken by the writer in the field during his connection with the West Virginia Agricultural Experiment Station, between 1890 and July, 1902, including special investigations for the Division of Entomology, U. S. Department of Agriculture, in 1899, 1900, and 1901, and those taken during the investigations by this Bureau between July, 1902, and July, 1908. In addition to the large amount of material thus accumulated the writer has studied the type and other specimens in the larger collections of this country.

The writer desires to acknowledge, in this connection, the assistance rendered by the following gentlemen in providing facilities for the study of specimens in the collections of which they have charge: Mr. Samuel Henshaw, in charge of the Le Conte collection in the Museum of Comparative Zoology, Cambridge, Mass., and of the Harris collection, Boston Society of Natural History; Dr. Henry Skinner, in charge of the Horn collection of the American Entomological Society and the general collection of the American Entomological Society, Philadelphia, Pa.; Mr. E. A. Schwarz, honorary custodian of Coleoptera in the Division of Insects, U. S. National Museum; Dr. W. G. Dietz, who loaned type and other specimens from his collection, and Mr. C. O. Waterhouse, of the British Museum, who compared specimens with the type of Dendroctonus rufipennis Kirby.

It also gives the writer pleasure to acknowledge the efficient assistance of Messrs. J. L. Webb, H. E. Burke, and W. F. Fiske in the field and office work, of Mr. E. J. Kraus in the more recent office work, and of Messrs. J. F. Strauss and R. E. Snodgrass in the preparation of the illustrations for this part of the bulletin. 


\section{HISTORICAL.}

The genus Dendroctonus was described by Dr. W. F. Erichson (1836) to include (Bostrichus) micans Kug., (Scolytus) terebrans Oliv., (Dermestes) piniperda L., (Iylesinus) minor Hartig, and (Hylesinus) minimus Fab.

Eichhoff (1864) revisect the genus and referred $D$. piniperda (L.) and D. minor (Hartig) to Blastophagus Eichh. and later (1879) to Myelophilus Eichh., and D. minimus (Fab.) to Carphoborus Eichh., leaving $D$. micans (Kug.) as the type.

Lacordaire (1868) referred to the synonymy and revised the description, including Dendroctonus junipiri Doeb. $[=$ Phloosinus junipiri (Doeb.)], D. valens Lec., and D. simitis Lec.

Zimmerman (1S68) divided the genus into three groups, placing D. bifurcus (=Carphoborus bifurcus Eichh.) in the first, none in the second, and D. terebrans (Oliv.) and D. frontalis Zimm. in the third group.

Le Conte (1868) revised the classification for the North American species to include D. terebrans (Oliv.), Hylurgus obesus Mann., Hylurgus rufipennis Kirby, D. frontalis Zimm., and two new species, D. punctatus Lec., and $D$. simplex Lec. He here referred $D$. valens Lec. to $D$. terebrans (Oliv.), and D. similis Lec. to D. obesus (Mann.). He recognized two divisions, Division $\mathrm{B}$ represented by $D$. frontalis, and Division $\mathrm{A}$ by the other five species.

Chapuis (1869) included D. micans (Kug.), D. valens Lec., D. terebrans (Oliv.), D. obesus (Mann.), and added one new species, D. parallelocollis Chap., but did not recognize D. frontalis Zimm.

Le Conte (1876) included D. terebrans Lac. (=Oliv.), D. simitis Lec., D. rufipennis (Kirby), D. punctatus Lec., D. simplex Lec., D. frontalis Zimm., and one new species, D. brevicomis Lec. He here restored $D$. similis and omitted $D$. obesus.

Dietz (1890) in his "Notes on the Species of Dendroctonus of Boreal America," revised the classification, principally on the character of the epistoma, which he considered of primary importance in separating the species. He included $D$. terebrans, with varieties $a, b, c, d, D$. rufipennis, D. simitis Lec., D. simplex Lec., D. frontalis, arlded one new species, D. approximatus Dietz, and referred D. puncticollis Lec. to $D$. rufipennis (Kirby) and $D$. brevicomis Lec. to $D$. frontalis Zimm.

Blandford (1897) mentioned D.terebrans (Oliv.), D. parallelocollis Chap., and an undescribed species from Texas-probably D.terebrans (Oliv.) - and added one new species, D. adjunctus Blandf.

The writer (Hopkins, 1899a) referred to D.terebrans, D. rufipennis (Kirby), D. simplex Lec., and D. frontalis Zimm., with clescriptions of $79980-09-2$ 
different stages, habits, etc., of $D$. frontalis, and larvæ and habits of $D$. terebrans $(=D$. valens). In 1901 he described D. piceaperda in all stages in connection with an account of habits, seasonal history, etc., and referred to the type of D. rufipennis (Kirby). In 1902 he described $D$. ponderosæ in all stages, in connection with an account of habits, seasonal history, etc. In 1902, under"Some Notes on the Genus Dendroctonus," he referred to a statistical method of determining natural positions of the species, and gave a list of described species and manuscript names of undescribed species, as follows: D. pinicida MSS., D. arizonicus MSS., D. monticola MSS., D. ponderosæ Hopk. MSS., D. keeni MSS., D. fletcheri MSS., D. piceaperda Hopk., D. dietzi MSS., D. californicus MSS., D. shoshone MSS., D. wickhami MSS., and $D$. borealis MSS. He restored D. brevicomis Lec. and D. punctatus Lec. from Dietz's synonymy; and recognized D. obesus (Mann). In 1905 he described D. pseudotsugæ and D. monticola in connection with accounts of habits, seasonal history, etc.

\section{ORIGINAL DESCRIPTION OF GENUS.}

Dr. W. F. Erichson (1836) described the genus Dendroctonus as follows:

\section{Dendroctonus.}

[p. 52] Antennæ funiculo 5-articulato, capitulo 4-annulato, suborbiculari, compresso. Tibiæ extus denticulatæ.

Palpi maxillares articulo primo brevissimo, secundo maximo, sequentibus duobus sensim minoribus. Labium fortiter compressum. Palpi labiales articulo primo longiore, subclavato, secundo tenuiore, cylindrico, minuto, tertio obtuse subulato. Antennæ breves, scapo clavato, funiculi articulo primo breviter clavato, secundo obconico, reliquis brevibus transversis; capituli segmentum primum reliquis conjunctis æquale, politum. [p. 53] Corpus oblongum, cylindricum. Rostrum brevissimum. Prosternum antice obsolete impressum. Coxæ anticæ approximatæ. Tibiæ compressæ, extus denticulatæ. Tarsi articulo tertio dilato, bilobo. Elytra margine antico elevato.

\section{[Translation.]}

Antennæ with 5-jointed funicle; the club suborbiculate, compressed, with four segments (annulæ). Tibiæ externally denticulate.

Maxillary palpi with the first joint very short, the second the longest, the two following gradually smaller. Labium strongly compressed. The labial palpi with the first joint rather long, subclavate, the second joint more slender, cylindrical, small, the third obtusely subulate. Antennæ short, scape clavate, first joint of funicle shortly clavate, second joint obconical, the remaining joints short, transverse; first segment of club equal to the others conjointly, polished.

Body oblong, cylindrical. Beak very short. Prosternum anteriorly obsoletely impressed. Anterior coxæ approximate. 'Tibiæ compressed, externally denticulate. Tarsi with the third joint dilated and bilobed. Elytra with the anterior margin elevated. 
SYNONYMY.

The following species were included, all but two of which were subsequently referred by Eichhoff (1864) to other genera:

Bostrichus micans Kugelann = Dendroctonus micans (Kugelann).

(Type of genus.)

Scolytus terebrans Olivier $=$ Dendroctonus terebrans (Olivier).

Dermestes piniperda Linnæus $=$ Myelophilus piniperda (Linnæus).

Hylurgus minor Hartig = Myelophitus minor (Hartig).

Hylesinus minimus Fabricius=Carphoborus minimus (Fabricius.)

\section{REVISIONAL NOTES.}

The generic characters mentioned by Erichson in the original description are recognized in the type and other species except that the maxillary palpi are not 4-jointed. The first or basal joint has a basal ring or outward curved basal margin for the attachment of the membrane connecting the joint with the palpiger. This might have been mistaken for the "very short first joint" referred to, but it is evident that this or any other structure does not represent such a basal joint. In the type species the first joint of the club is equal to the others, but ranges from shorter to longer in the other species.

Le Conte's added characters in his revision of 1868 and 1876 are generally correct, except that the antennal club is not always concave on one (external) side or anterior face, the sutures are more often curved than straight, and in some species only two sutures are visible on one side of the club. The prosternum is sometimes flat, the fifth joint of the tarsus is never longer than the others united, and the ventral segments are only approximately equal in length, the last one being usually as long as the two preceding combined.

Dietz (1890) called attention to the unreliability of the sutures and joints of the antennal club in dried specimens, and laid special stress on the value of the epistoma in distinguishing the species. It appears, however, that while the form of the epistoma is a good generic and subdivisional character, it is of little or no value in distinguishing the species.

The additional generic characters recognized by the writer will be found described under external and internal anatomy, and the characters distinguishing the major and minor divisions will be found in the synoptic tables.

\section{REVISED DESCRIPTION OF GENUS.}

\section{ANATOMICAL.}

The following discussion of anatomical details includes the imago, larva, and pupa, and is based primarily on the results of original dissections and anatomical investigations by the author during the 
past eighteen years, and of those conducted by assistants under his immediate supervision during the past three years.

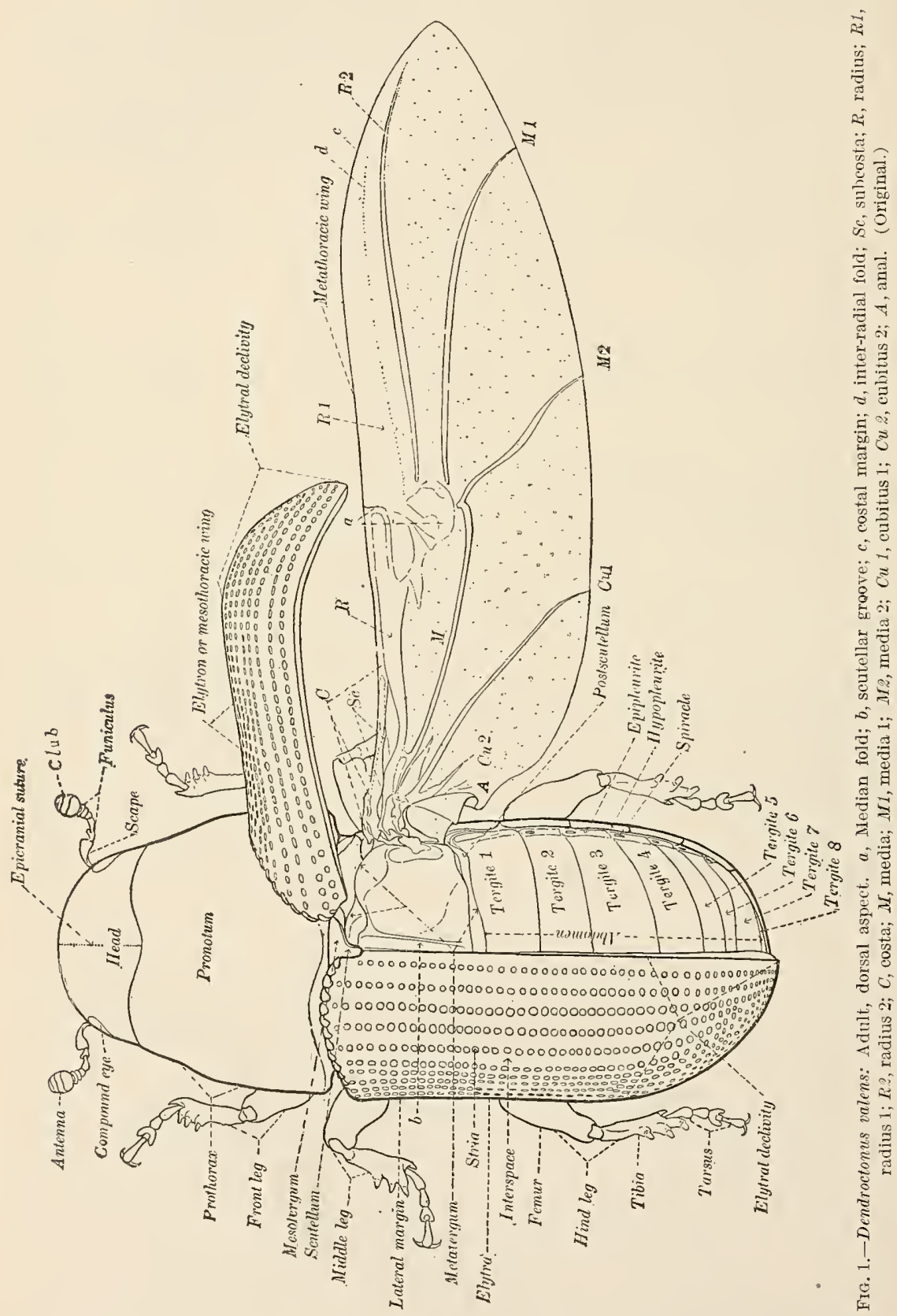

Dendroctonus valens Lec. has served as the principal subject for dissection, comparison, and illustration, both on account of the 
abundance of material at hand and because of the comparatively large size of the individuals of this species. Sufficient comparative studies have been made, however, of the other species of the genus and of representatives of other genera of the family and suborders to form a reliable basis for the interpretations and conclusions relating to the more important taxonomic characters and the significance of their modifications in the distinction of species, genera, etc.

Through the assistance of Mr. R. E. Snodgrass an extensive investigation has also been made of the thoracic segments of representatives of all of the principal orders of insects. The results have served as additional data and evidence on which to base conclusions in this paper, and will be utilized by Mr. Snodgrass as a basis for a more detailed discussion in a paper entitled "The Thorax of Insects and the Articulations of the Wings," to be published later. This will include a quite complete bibliography and references to the principal systems of nomenclature proposed or adopted by the leading authors, thus rendering it unnecessary to include extensive bibliographic references in the present paper.

In all of this anatomical work the object of the author has been to acquire direct information on the facts as they exist in the subjects examined; such information to furnish a basis for the determination, naming, description, and illustration of the anatomical elements as represented in the scolytid beetles, and at the same time to serve as a guide to the determination of further facts relating to insect anatomy in general.

The literature on insect anatomy has been utilized as a guide in securing additional information on the facts and principles involved, and with the idea of adopting such interpretations and nomenclature as appeared to conform more nearly to the facts and contribute to uniformity. No attempt is made to discuss the -merits of opposing opinions or theories, or to prove or disprove them.

In this presentation of the results of independent investigation and discussion of the facts as interpreted by the author, it is hoped that something has been accomplished toward the advancement of information on the general subject of insect anatomy, and that its special reference to the anatomy of the scolytid beetles will make the future systematic study of this troublesome group less difficult and more accurate, and thus lead to the determination of bionomic and economic data of immediate practical importance.

\section{NOMENCLATURE.}

There is yet much confusion in the literature and considerable difference of opinion among the best authorities in regard to anatomical nomenclature as applied to the structure of insects in general and especially to representatives of different orders. There is 


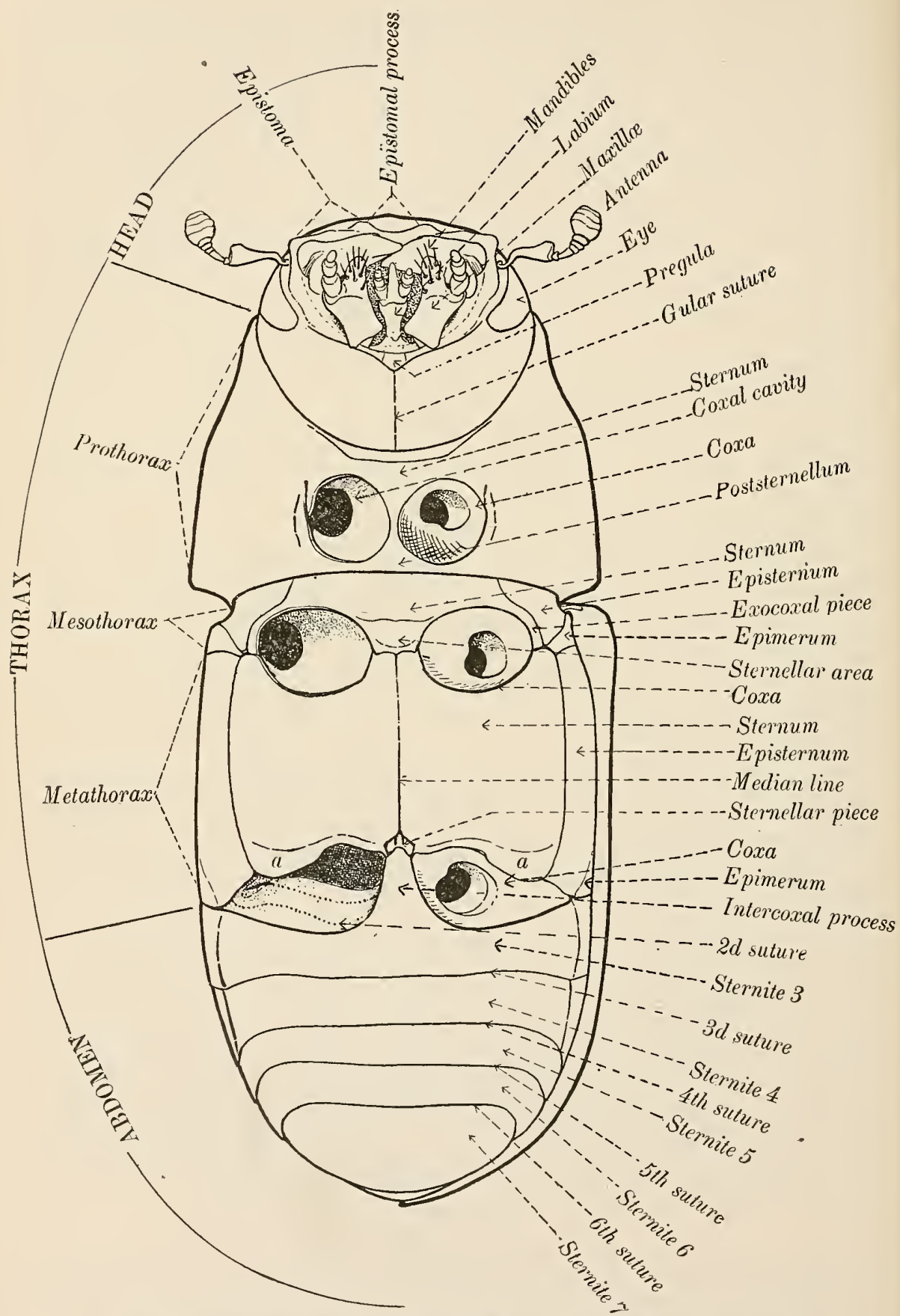

FIG. 2.-Dendroctonus valens: Adult, ventral aspect. c, Sternellar area. (Original.) 
evidently much room for improvement in the line of uniformity in names and interpretations. In the present paper the writer has endeavored to adhere to the more generally accepted names proposed

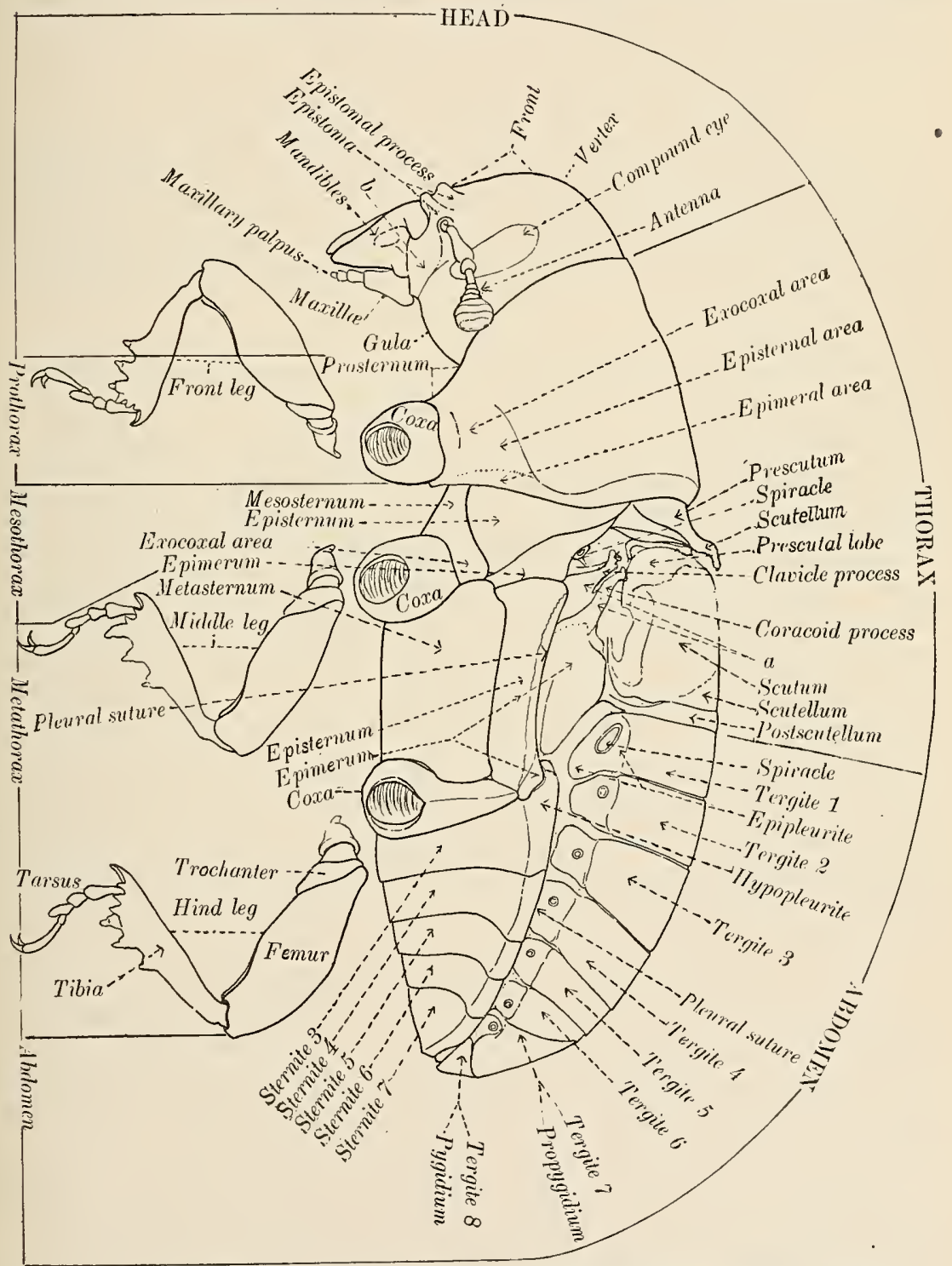

FIG. 3.-Dendroctonus valens: Adult, lateral aspect. $a$, Pleural clavicula; $b$, pregena. (Original.)

by Audouin and other writers for the principal parts, and to suggest only such revisions and new names as the immediate requirements of clear definition in comparative anatomy and taxonomy appear to demand. 


\section{ILLUSTRATIONS.}

The figures are intended to be sufficiently complete to leave little to be added in the way of description, except to emphasize and elucidate some of the more important features, or to call attention to the variation within the genus or species.

\section{EXTERNAL CHARACTERS OF THE IMAGO.}

The structural details and general external anatomy and sculpture are shown in figures 1,2 , and 3 . The principal characters peculiar to the genus are found in the large, prominent head, the epistomal process (figs. 2, 3, 4, 6, 10) (referred to by Dietz as the median segment of the epistoma), the form of the antenna (figs. 11, 12, 13), the approximate or subcontiguous anterior coxæ (fig. 2), and the strongly recurved hypopleural sutures 4,5 , and 6 of the abdominal sternites (fig. 25).

Length and relative proportions. - The length of the imago ranges from $2.5 \mathrm{~mm}$. in $D$. frontalis to $9 \mathrm{~mm}$. in $D$. valens. There is considerable range in length within the limits of some of the species, while in others the length is more constant. The relative proportions of the width of the head, width and length of the prothorax, width and length of the elytra, or a composite of the ratios, serve as a taxonomic index for the classification of the species, and, together with other characters, serve to distinguish the major and minor divisions and, to a certain extent, the species. The progressive modification appears to be from a head nearly as broad as the pronotum and the latter as broad as the elytra, with the sides nearly parallel, to a head much narrower than the pronotum, the latter slightly narrower than the elytra, with the sides narrowed and constricted toward the head; also, from a slender, subelongate, to a stout body.

Color.-The color ranges from pale yellowish-red to brown and deep black, but is fairly constant in the matured individuals of a species. The immature individuals are always lighter, and some of those of the black species are reddish. In some species the head, prothorax, and ventral surface of the body are darker than the elytra, while in others little or no difference is noticeable.

Vestiture.-The body is more or less clothed with short to long hairs, the presence or absence of which on different areas is of far more taxonomic significance than was at first recognized. Except in old rubbed specimens, the vestiture serves as one of the important characters distinguishing the major, as well as some of the minor, dirisions. See synopsis, Divisions I and II, sections a1 and a2 (Pl. I).

Sculpture.-Within the genus and also within each species there is considerable variation in the sculpture of the front, pronotum, and elytra. Nevertheless, such characters as the presence or absence 
of frcntal grooves and tubercles serve to distinguish, some of the minor divisions of the genus, while the presence or absence of a posterior median impression in those species without a frontal groove is of considerable importance in distinguishing some of the minor divisions. The relative size, density, and arrangement of the punctures of the pronotum, while variable within the species, is of considerable taxonomic value. The character of the rugosities of the interspaces and the punctures of the striæ are also variable within the species and are of secondary value in distinguishing minor divisions. The sculpture of the elytral declivity is of special specific and sexual importance, and in some cases the characters are of value in distinguishing minor divisions.

\section{THE HEAD.}

The general characters and details of the external skeleton and appendages of the head are shown in figures 4,5 , and 6 . It will be noted that the elements which in some other Coleoptera and other insects are more or less clearly defined are quite completely fused and obscured in this genus as in other rhynchophorous beetles. The labrum and clypeus are obsolete. The epistoma, or "post-clypeus," or "pre-front," as recognized by different authors, is not separated from the front by a line or suture, but is quite clearly defined, and the epistomal process is far more prominent than in other allied genera. The front is completely fused with the epicranium, which in turn is fused with the genæ, the latter joined beneath with a single gular suture. Anterior to the gular suture there are three quite clearly defined sclerites, which may be designated as pregula, pregena, and hypostoma (fig. 5, E). By comparing the head of Dendroctonus with that of a carabid beetle, Pterostichus (fig. 7), and a typical curculionid beetle, Pissodes strobi (figs. 8, 9), the striking difference in structure and relative position of the corresponding elements and their extreme modification are at once apparent.

Labrum.-The labrum is not present as a distinct element, but may be represented by a part of the anterior margin of the epipharynx beneath the anterior median section of the epistoma (fig. $6, A$ ).

Clypeus.-The clypeus is not represented unless it is by the produced anterior margin of the epistoma, and by the long epistomal bristles.

Epistoma (figs. 2, 3, 4, 5, 6, 7, 10, 40, B, D, E.)-The epistoma is apparently represented in both the larvæ and adults of all true mandibulate insects, but is more distinctly defined in some than in others. In some insects it is separated from the clypeus by a suture, line, or articulating membrane, while in others there is no evidence of separation or the clypeus is not represented. Its separation from the front is often defined by a line, impression, elevation, or otherwise, although sometimes it is so completely fused that the line of junction 
is entirely obscured, as in Pterostichus. It serves the important function of a rigid bridge over the oral foramen and support for the clypeus, labrum, and epipharynx, and at its lateral angles provides the necessary rigid support for the dorsal articulation of the man-

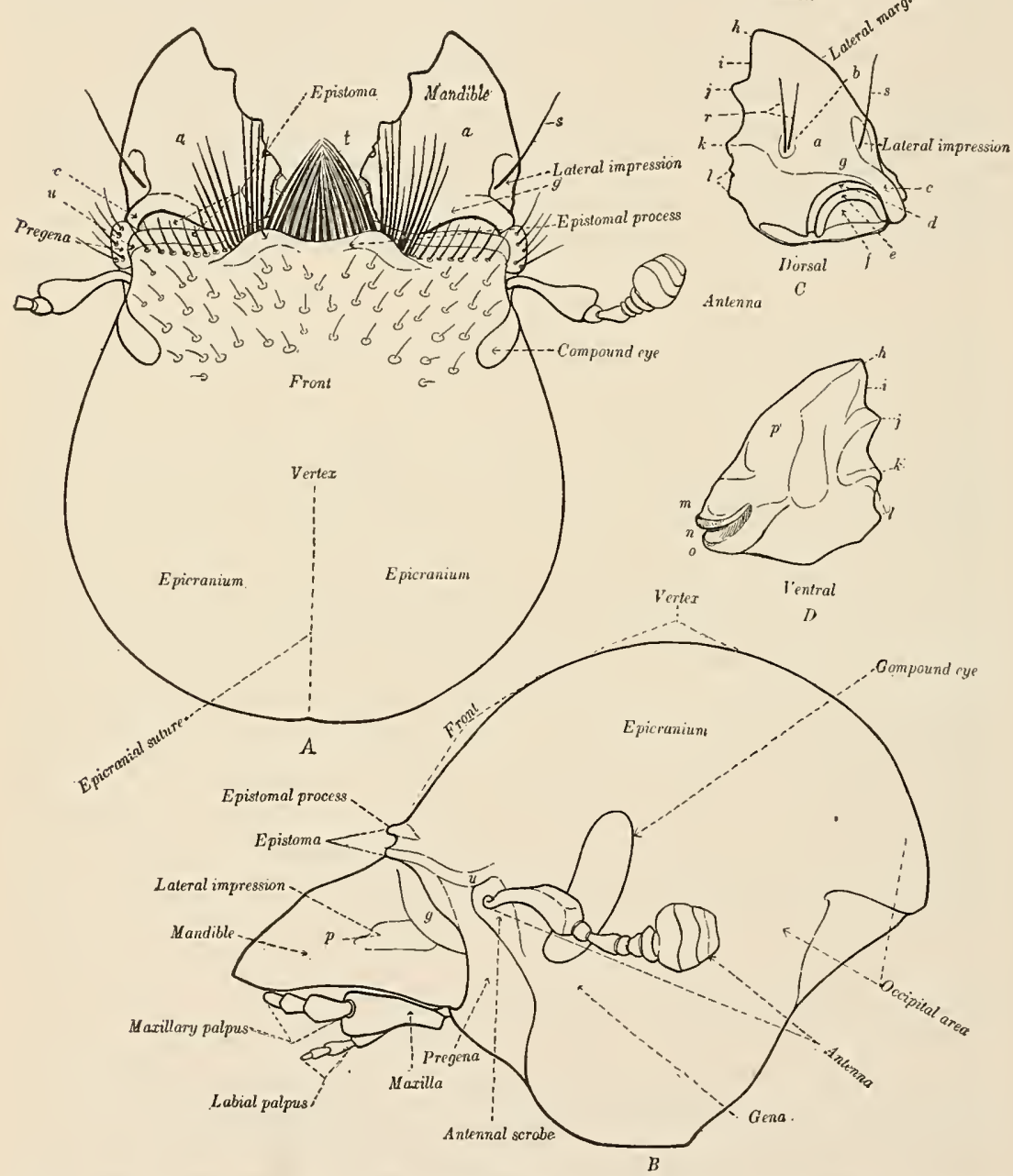

FIG. 4.-Dendroctonus valens: Head, dorsal and lateral aspects. $A$, Dorsal aspect of head; $B$, lateral aspect of head; $C$, dorsal aspect of right mandible; $D$, ventral aspect of right mandible; $a$, dorsal area; $b$, dorsal impression; $c$, anterior condyle; $d$, median fossa; $e$, median condyle; $f$, posterior fossa; $g$, basal ridge; $h$, apical tooth; $i$, acute margin; $j$, subapical tooth; $k$, median tooth; $l$, molar; $m$, anterior condyle; $n$, median fossa; $o$, posterior condyle; $p$, lateral area; $r$, dorsal bristles of mandible; $s$, lateral bristles of mandible; $t$, epistomal bristles; $u$, lateral angle of epistoma. (Original.)

dibles. In fact the latter function serves to distinguish it from other parts. The median area is variously and sometimes greatly modified in insects of the same order or family, and it appears that in Coleoptera generally this element is of much greater taxonomic value than has been usually recognized heretofore. 
Epistomal process.-In Dendroctonus the epistomal process serves to clearly distinguish the genus from other genera of the suborder to which it belongs. This process is usually composed of a median and

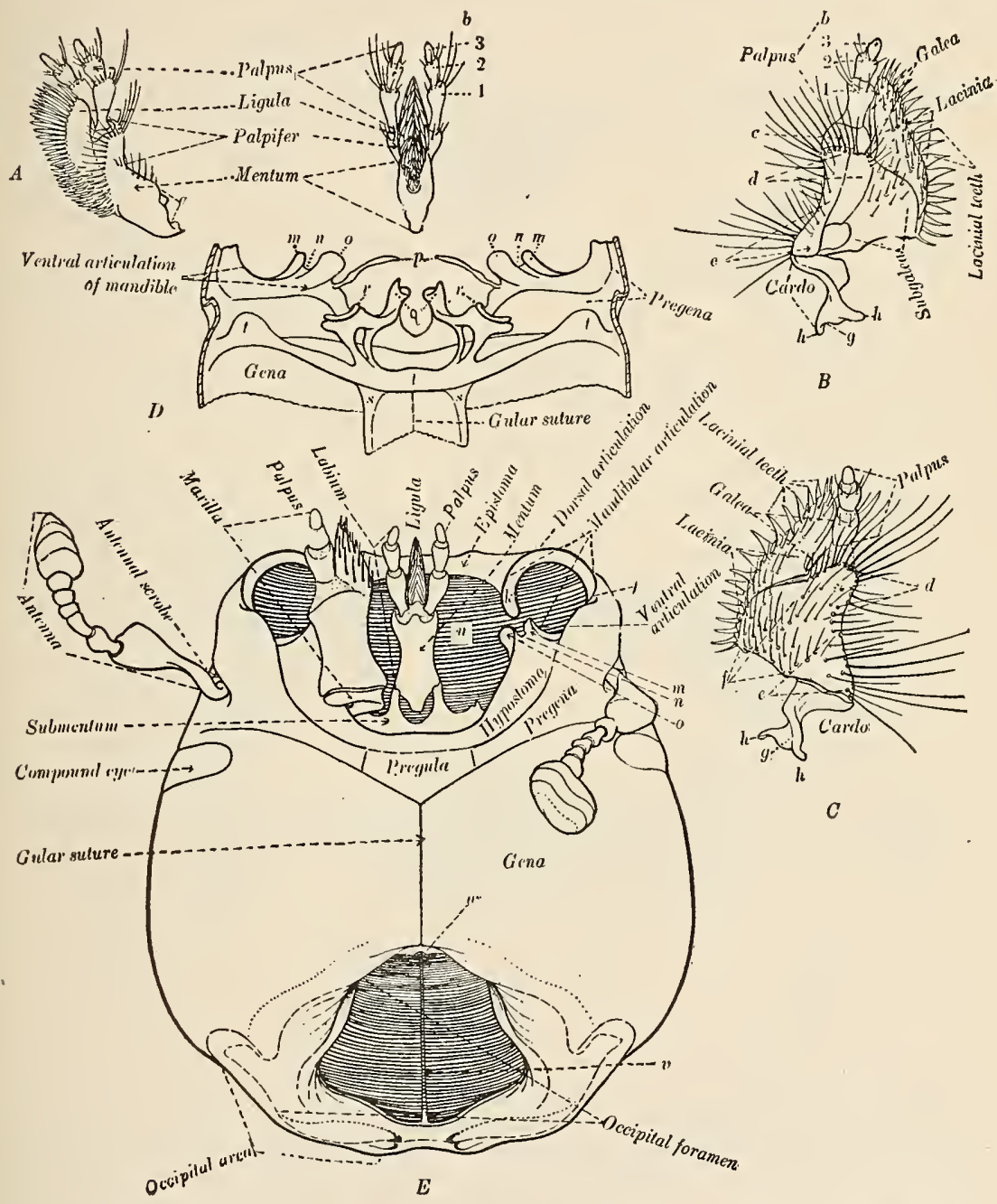

FIG. 5.-Dendroctonus valens: Head, ventral aspect, and mouthparts. $A$, Labium; $B$, maxilla, internolateral aspect; $C$, same, externo-lateral aspeet; $D$, hypostomal region, dorsal aspect; $E$, head, ventral aspect; $a$, basal fossa of mentum; $b$, joints; $c$, basal membrane; $d$, palpiferal area; $e$, stipal area; $f$, subgaleal area; $g$, fossa; $h$, muscle processes; $k$, median condyle; $l$, lateral fossa; $m$, anterior condyle; $n$, median fossa; $o$, posterior condyle; $p$, hypopharyngeal bracon; $q$, submental process; $r$, maxillary condyle; $s$, gular apodeme; $u$, oral foramen; $v$, occipital apodeme; $v$, postgular piece. (Original.)

two lateral sections and is fringed anteriorly with thickly set, long bristles which completely cover the anterior median epistomal area.

Hypostoma (fig. 5).-This, as here interpreted, is a ventral piece or area which corresponds in general function to the epistoma in forming a rigid ventral rim of the oral foramen for the support of the 
articulatory accessories of the labium and maxillæ, and at the lateral angles supports the ventral articulations for the mandibles. It seems to the writer that this part or area, whenever sufficiently distinct to be recognized, should be designated as the hypostoma, not

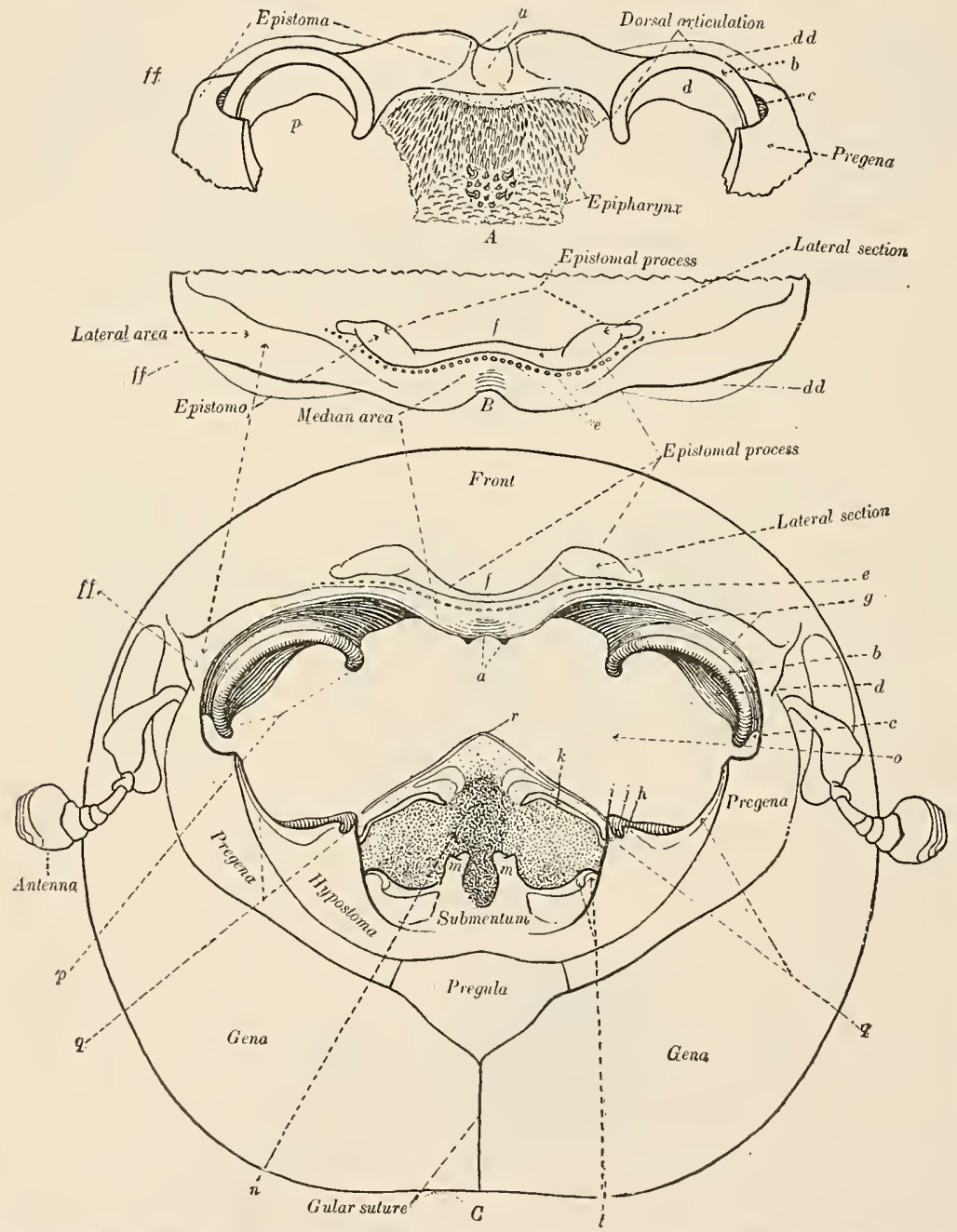

FIG. 6.-Dendroctonus valens: Head, oral aspect, epistoma, etc. A, Ventral aspect of epistomal region; $B$, dorsal aspect of epistomal region; $C$, oral aspect of head; $a$, median impression and longitudinal elevations; $b$, median condyle; $c$, lateral fossa; $d$, posterior fossa; $d d$, projection over median condyle; $e$, base of epistomal bristles; $f$, median section of epistomal process; $f f$, lateral angles of epistoma; $g$, anterior fossa; $h$, anterior condy le of ventral articulation; $i$, posterior condyle of ventral articulation; $j$, median fossa of ventral articulation; $k$, hypopharyngeal bracon; $l$, maxillary condyle; $m$, submental processes; $n$, ventral view of hypopharynx; 0 , oral foramen; $p$, dorsal articulation of mandible; $q$, ventral articulation of mandible; $r$, apex of hypopharynx. (Original.)

on account of any theory of origin from a primitive segment, but because its location and function are similar to those of the epistoma.

Front (figs. 3, 4).-The front is not defined by sutures or lines, but is fused anteriorly with the epistoma and laterally and posteriorly with 
the epicranium. It is represented by a frontal area, however, which not only in this genus but in other scolytids presents characters of special value in distinguishing major and minor divisions, species, sexes, etc. The significance of frontal characters in this genus is defined in the synopses of adult and secondary sexual characters and shown in the figures.

Antennæ (figs. 1-6, 11-13).- The characters of the antennæ are clearly shown in the figures. The scape, funiculus, and club are

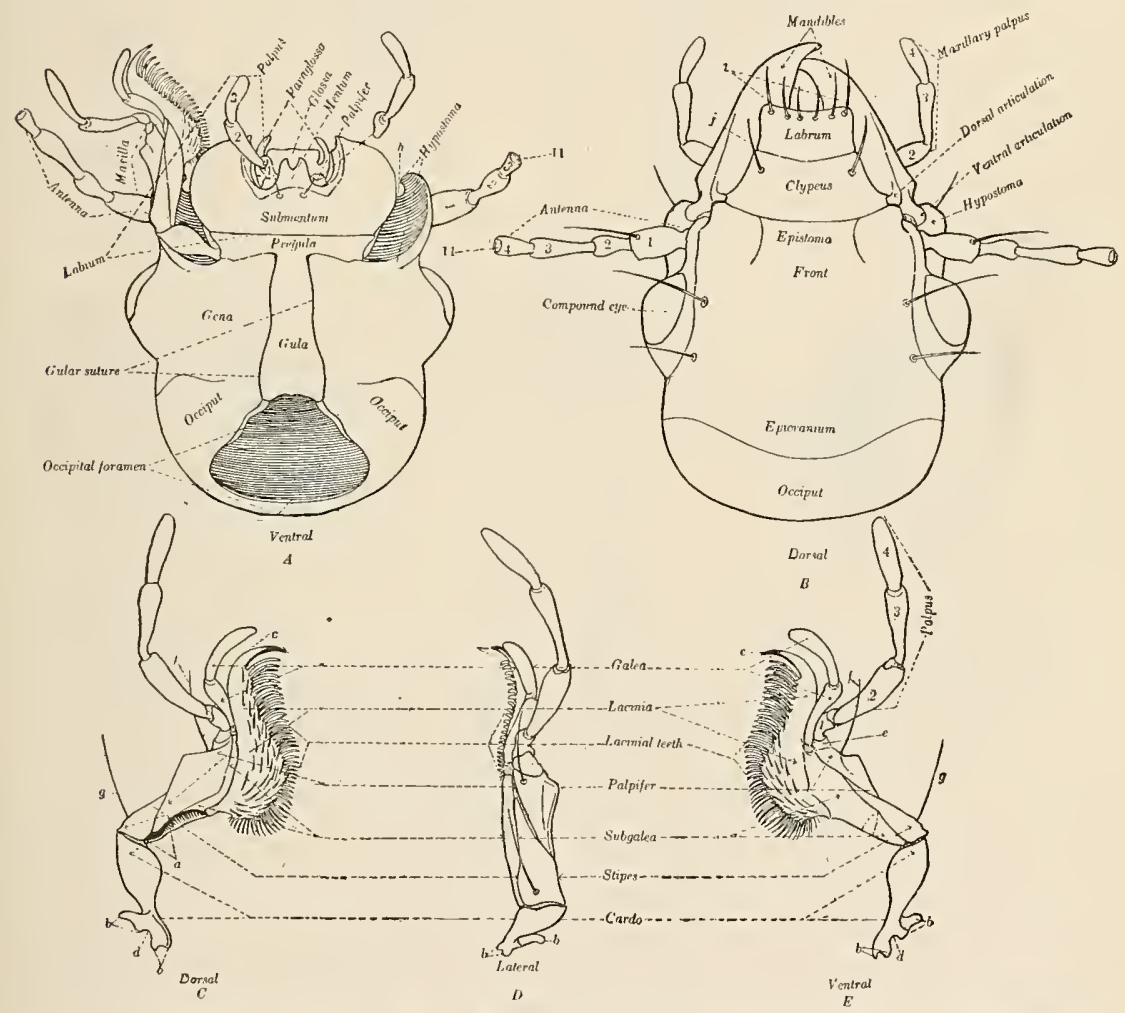

FIG. 7.-Pterosíichus caỉifornicus: Head, dorsal and ventral aspects, and maxillæ. $A$, Ventral aspect; $B$, dorsal aspect; $C$, dorsal aspect of left maxilla; $D$, lateral aspeet of left maxilla; $E$, ventral aspect of left maxilla; $a$, stipal foramen; $b$, muscle processes; $c$, lacinial digitus; $d$, cardo fossa; $e$, basal membrane; $f$, palpiferal bristle; $g$, stipal bristle; $h$, median fossa of ventral articulation of mandible; $i$, labral bristles; $j$, clypeal bristles. (Original.)

nearly equal in length. The scape toward the apex is clavate-cylindrical to angular. The funiculus is 5-jointed and always slightly longer than the club. The first joint (or pedicel of some authors) is of the usual form and as long or longer, rarely shorter, than the second. The second joint is as long as the third, fourth, and fifth together, or slightly shorter in some species, and the second to fifth increase in width toward the club, which is broad, thickened toward the base and compressed toward the apex, and has three or four distinct segments, with two or three slightly to strongly curved 
sutures. The relative concavity or convexity of the anterior face, as well as the relative lengths of the segments on the opposite faces,

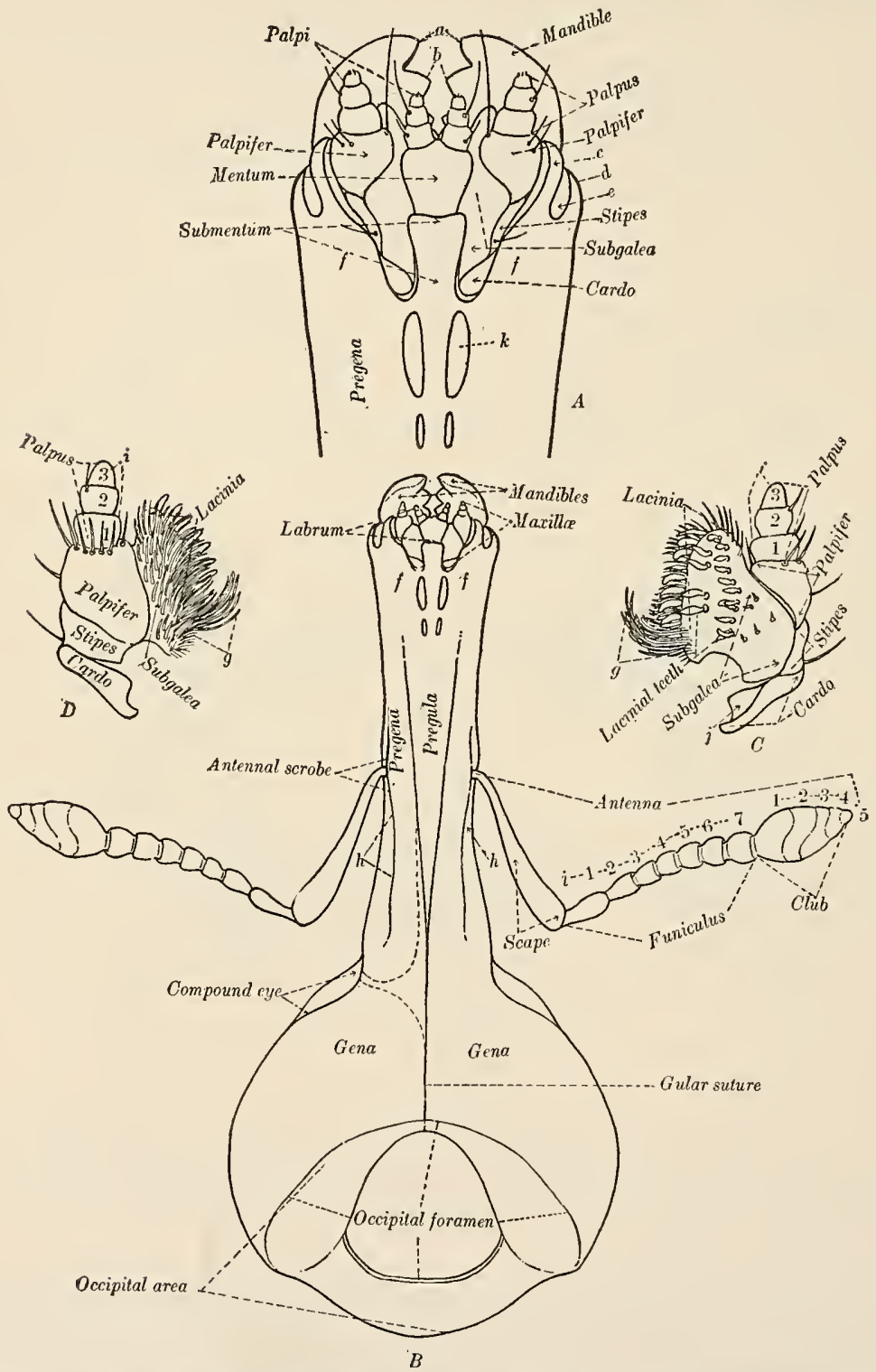

FIG. 8.-Pissodesstrobi: Head, ventral aspect, and mouthparts. $A$, Ventral aspect of apical region of beak; $B$, ventral aspect of head; $C$, interno-lateral aspect of maxilla; $D$, externo-lateral aspect of maxilla; $a$, apical tooth; $b$, subapical tooth; $c$, lateral arm of hypostoma; $d$, pleurostoma; $e$, mandibular scrobe; $f$, hypostomal area; $g$, lacinial bristles; $h$, antennal groove; $i$, joints; $j$, cardo fossa; $k$, hy postomal puncture. (Original.)

contour of the suture, etc., are shown in figures 11 to 13 , but often appear different in dried specimens. The articulatory attachment 
of the scape is in a rather deep scrobe (figs. 4,5 ), situated in front of the eye near the base of the mandible and lateral angle of the epistoma.

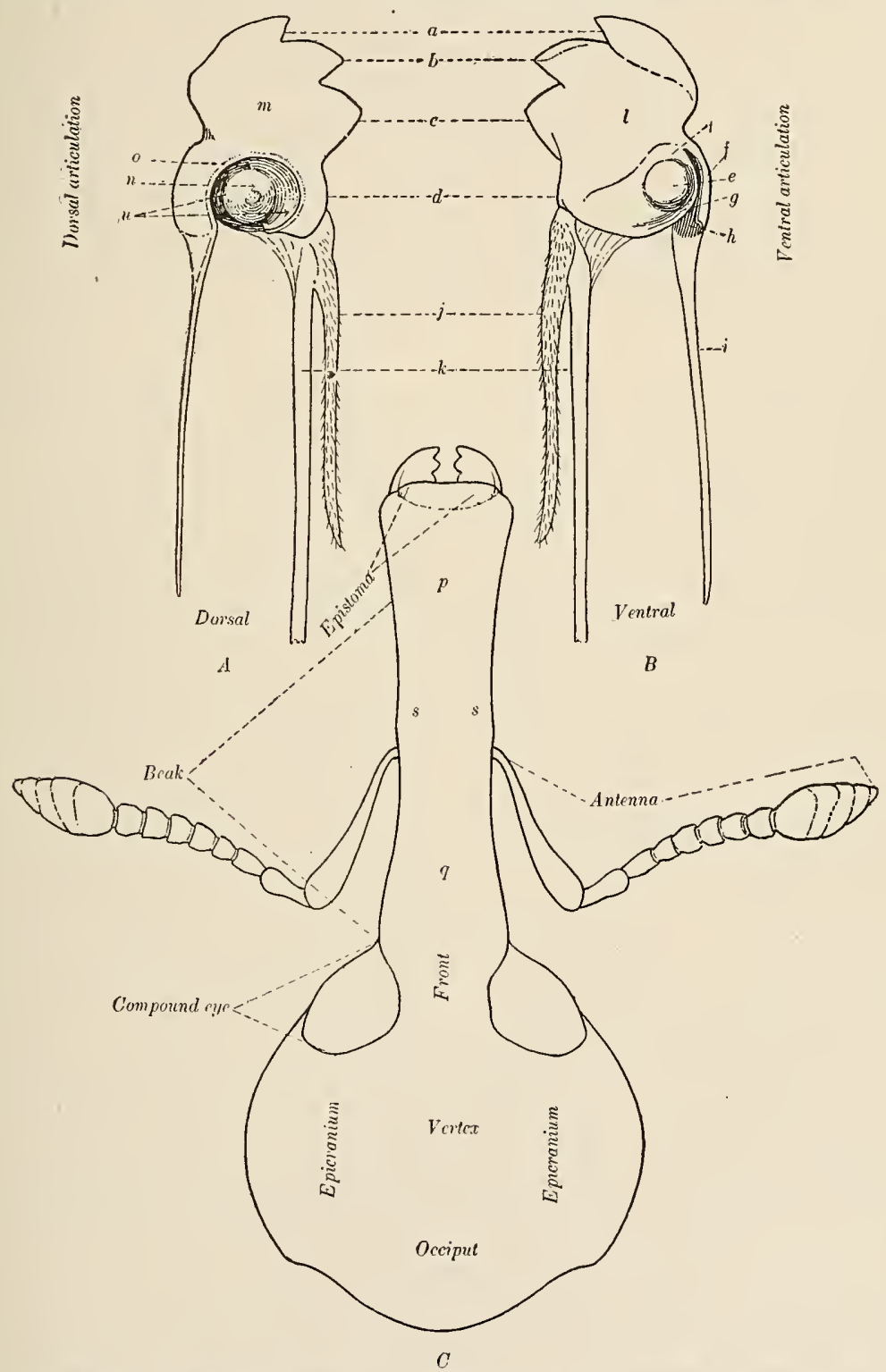

FIG. 9.-Pissodcs strobi: Head, dorsal aspect, and mandibles. $A$, Dorsal aspect of left mandible; $B$, ventral aspect of left mandible; $C$, dorsal aspect of head; $a$, apical tooth; $b$, subapical tooth; $c$, median tooth; $d$, molar; $e$, median condyle; $f$, lateral muscle process; $g$, lateral condy le; $h$, lateral fossa; $i$, extensor tendon; $j$, pharyngeal bracon; $k$, retractor tendon; $l$, ventral area; $m$, dorsal area; $n$, median condyle; 0 , anterior fossa; $p$, anterior section of beak; $q$, posterior section of beak; $s$, dorsal area; $t$, anterior condyle; $u$, lateral fossa. (Original.)

Epicranium.-The epicranium is not defined from the front or gena by sutures or lines, but the area is quite clearly indicated by the 
smoother surface and by the presence of the compound eye, which is situated on the side of the head near the base of the antennæ. The anterior end of the epicranial suture defines the anterior dorsal limit of the epicranium, designated as the vertex, while the gena is represented by the rentral area between the eyes and the gular suture. The epicranial suture is more distinct in some species than in others.

Eyes.-The eyes vary from slightly oblong oval to oblong ovate and are obliquely placed in the anterior angle of the epicranial area, just posterior to the base of the antennæ. The variation in form within the genus and within the same species is shown in figures 1 to 6 and 15 . There are about four hundred facets, which are small and densely placed.

Occiput (figs. 4, 5).-The occiput is not clearly defined, as it is in Pterostichus, but the posterior area of the cranium to the occipital foramen may be designated as the occipital region or area.

Occipital foramen (fig. 5).--The posterior opening in the head, or occipital foramen, is small as compared with the oral foramen. The invaginated wall forms a part and posterior support to the tentorium, and the dorsal apodeme is continuous with the epicranial suture.

Gula.-The gula is not represented by a space defined by two longitudinal sutures, as in most Coleoptera other than the Rhynchophora. The gular apodemes are present (fig. 5, D), but the gular space is invaginated, so that there is but a single gular suture.

Pregula.- In Dendroctonus there is a small sclerite immediately anterior to the gular suture (figs. 5, 6) which is distinctly separated from the gula and genæ by an invaginated apodeme, laterally from the pregena by an evident external line, and anteriorly from the hypostoma by a ridge which defines the anterior margin. In the rostrate beetles this is extended with the pregena and forms a more or less distinct gular space of the rostrum to a similar anterior space which supports the so-called gular peduncle, or submentum. Therefore it appears that the term pregula should serve to distinguish this important element, which is also more or less distinctly represented in Coleoptera other than the Rhynchophora. (Compare figs. 6, 7, S.)

Gena.-The gena is not defined by lines, but it is represented by the ventral area between the gular suture and the epicranial area, as described under epicranium and gular suture.

Pregena (figs. 5, 6).-The pregena is a distinct pleural area situated between the base of the antennæ and the pregula, bounded posteriorly by the genal area and anterior angle of the epicranium, and anteriorly by the hypostoma.

Submentum (figs. 5, 6).-The submentum is represented by a bifid process or median extension of the hypostoma, and is supported by two stout braces rising from the large transverse rostral apodeme beneath the posterior angle of the pregula. 
Labium proper (figs. 2, 5, A).--In Dendroctonus and other rhynchophorous beetles, the mentum, palpifer, glossæ, and paraglossa, while more or less clearly indicated, are not represented as separate elements of the labium. Mentum: The mentum articulates with the bifid submentum and completely surrounds the basal portion of the labrum, being subcylindrical, with the anterior ventral area strongly retuse. Palpifer: The palpifer is represented by the area between the ventral impression of the mentum and the row of palpiferal bristles which define the anterior limit of the mentum. Palpi: The labial palpi are distinct, 3-jointed, and as long as the mentum, or longer, with the first joint longer than the other two, or rarely equal. Ligula: The ligula is situated between the palpi, is thickly set with long lacinial teeth, and occupies the greater part of the dorsal area. It is evident that this ligular area represents the glossæ and paraglossa of other insects, and that it is homologous with the galea and lacinia of the first maxilla.

Maxillx (figs. 2, 5, B, C).-The maxillæ (fig. $5, B$ ) have the characteristic form of those of all other rhynchophorous beetles and are strikingly different from those of other Coleoptera. The form and relative proportions are shown in the figures. Cardo: The cardo is the stout basal section which articulates with a condyle on the maxillary process of the hypostomal apodeme. Stipes: The
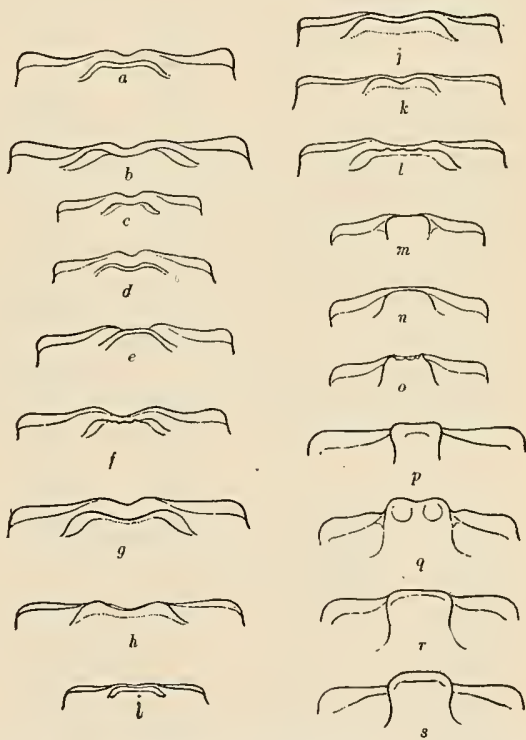

FIG. 10.-Dendroctonus: Epistomata. $a$ te $l, D . v a l-$ ens; $m$ to $o, D$. simplex; $p$ to $s, D$. pseudotsugæ. (Original.)

stipes articulates with the cardo and, while it does not appear as a separate piece, it is represented by the posterior ventro-lateral and externo-lateral part of the median section of the maxilla. Palpifer, galea, subgalea, and lacinia: The palpifer is fused with the stipes and is represented by the anterior part of the median section (fig. 5). The palpifer and stipes are also fused with the subgalea on the exto-lateral area, but on the interno-lateral area the line separating the palpifer from the subgalea is distinct, as is also the suture between the latter and the lacinia and galea, which are fused, the latter being represented by a narrow chitinous margin next to the palpus and palpifer. The lacinia is armed on the inner edge with stout lacinial teeth. The length of the base of the subgalea from the apex 
to the posterior angle is usually greater than the length of the palpifer and stipes, but is sometimes equal and rarely shorter. The ventral
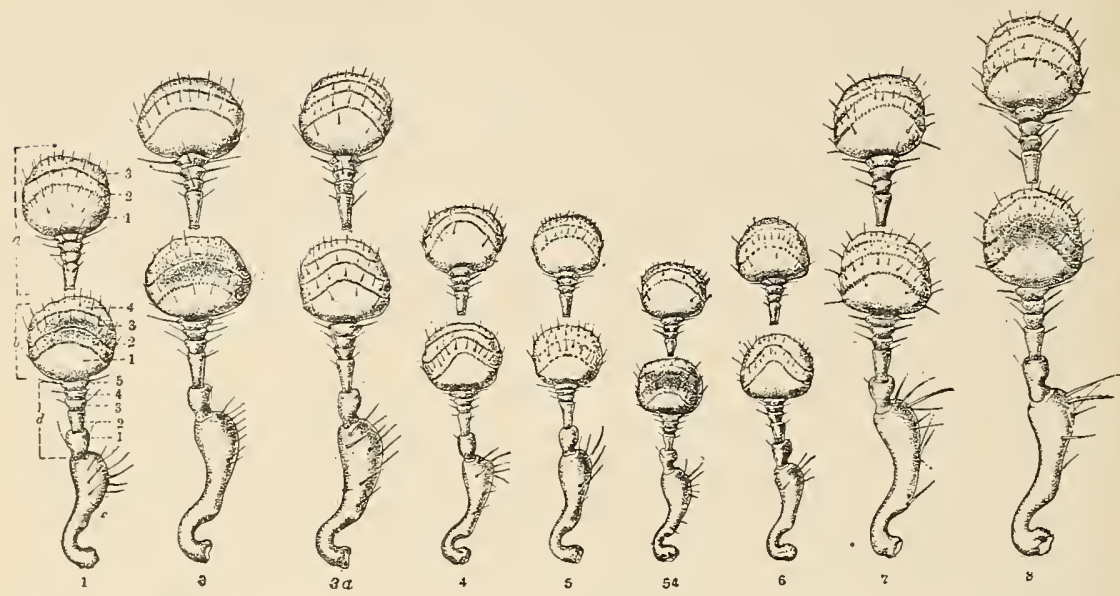

FIG. 11.-Dendroctonus: Antennæ. 1, brevicomis; 3, convexifrons $9 ; 3 a$, convexifrons $8 ; 4$, frontalis $8 ; 5$, arizonicus 8 ; 5 a , arizonicus $\$ ; 6$, mexicanus; $\gamma$, parallelocollis; 3 , approximatus + . (Original.)

$1-a$, posterior face of club when antenna is extended at right angles to head, joints $1,2,3 ; b$, anterior face, joints $1,2,3,4 ; d$, funiculus, joints $1,2,3,4,5 ; c$, scape.

chitinous area of the palpifer and stipes together is always a third or more longer than the combined chitinous parts of the joints of

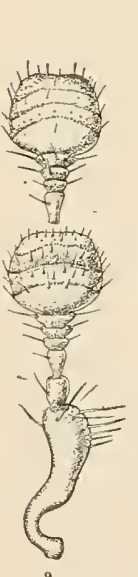

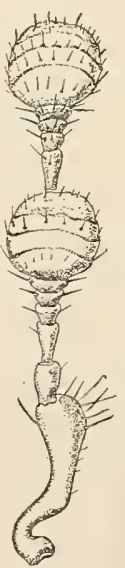

10

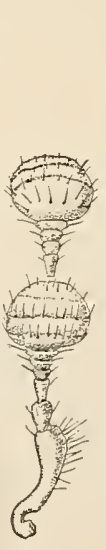

12

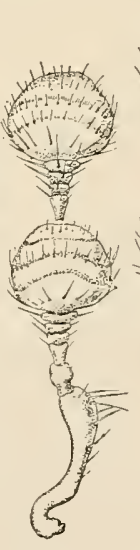

13

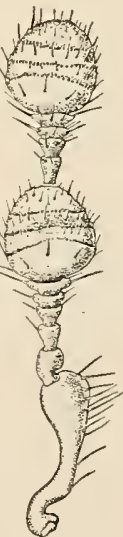

If

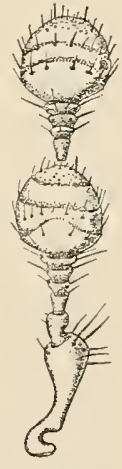

15

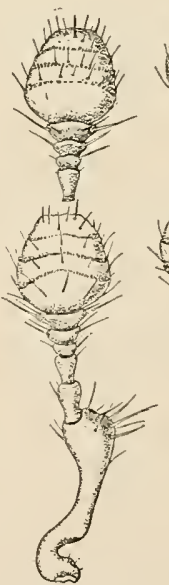

17

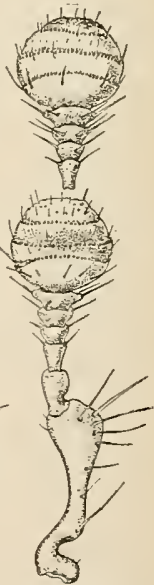

$17 \mathrm{~B}$

FIG. 12.-Dendroctonus: Antennæ. 9, monticolæ; 10, ponderosæ: 12, simplex; 13, pseudotsugæ ; 14, picea-

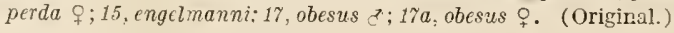

the palpi. Palpi: The palpi are 3-jointed, the joints connected with each other and with the palpifer by flexible membrane which allows for a certain amount of telescoping, but not adapted for free 
lateral movements as in Pterostichus (fig. 7). The relative lengths of the joints vary considerably in the species of the genus, and more or less in the individuals of a species. The first joint is usually longer than the other two together, but is sometimes equal or shorter; the second joint is usually longer than the third, but is sometimes shorter.

Mandibles (figs. 4, 14).-The mandibles are prominent, stout, triangular, and especially adapted for burrowing in the bark. The inner edges are acute, with a subapical and a median tooth toward the middle and a molar on the basal angle. The lateral area toward the base has a large impression and there is usually a less evident one on the dorsal area, each bearing one or two bristles. The dorsal
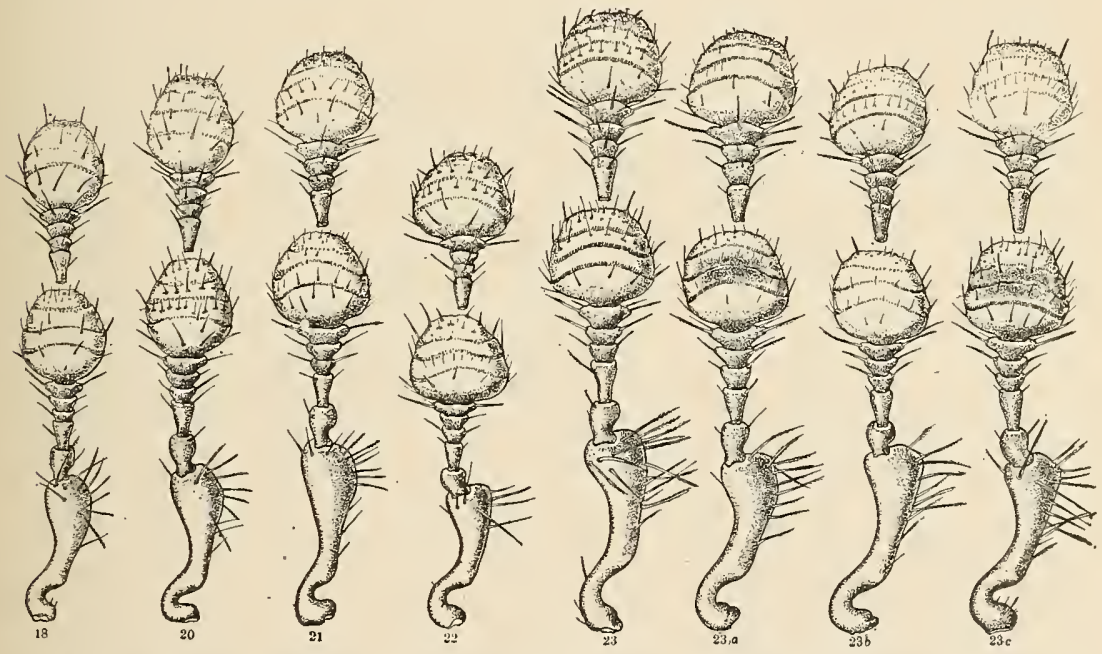

FiG.13.-Dendroctonus: Antennæ. 18, rufipennis; 20, punctatus; 21, micans; 22, terebrars; 23, valens ${ }^{*}$;

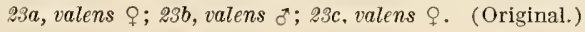

articulation with the epistoma is especially adapted to meet its several requirements. The peculiar trochlear mechanism of the articulating condyles and fossa are illustrated in figure 14; that of the dorsal condyle appears to be common to other rhynchophorous beetles, but apparently not represented in other Coleoptera, including those with similar bark and wood boring habits. The ventral articulation also appears to be different from that in other Coleoptera, but to a less degree. A detailed comparative study of the mandibles may reveal specific characters, but as a rule such characters are unsatisfactory from the fact that in comparisons the mandible must be viewed from exactly the same position to avoid error in conclusions. 
THE THORAX.

The thorax, as usual, consists of three distinct segments. The prothorax freely articulates with the mesothorax, but the pleurites and sternites of the mesothorax and metathorax are rigidly connected. The combined length of the ventral areas of the three thoracic segments is slightly greater than that of the ventral area of the abdominal segments, while the combined length of the dorsal

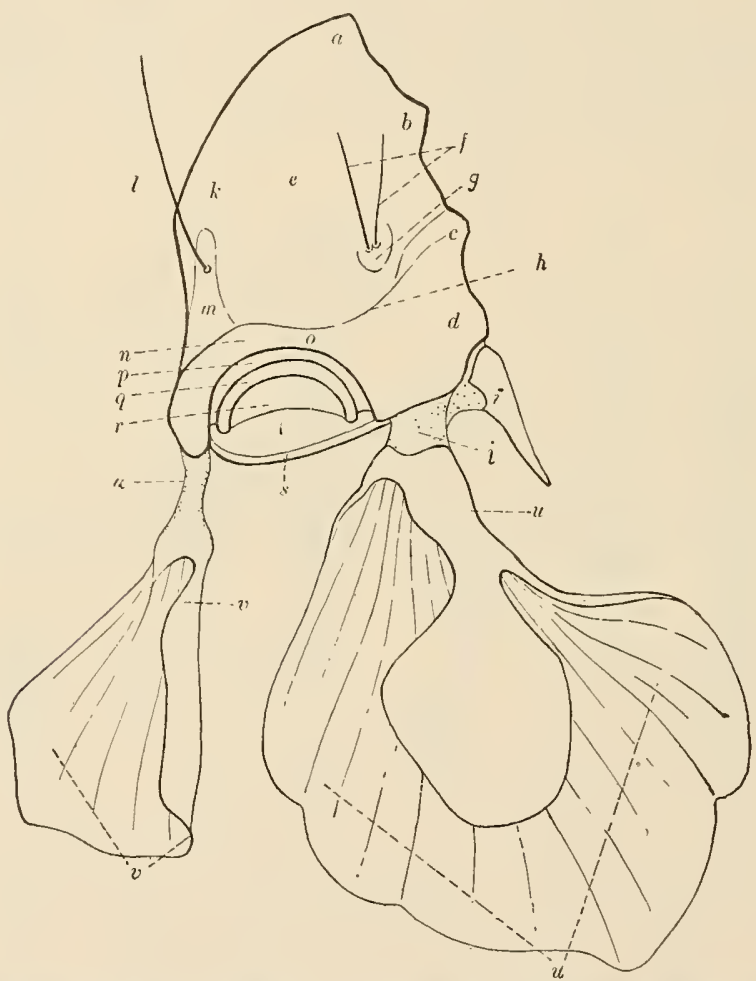

FIG. 14.-Dendroctonus valens: Mandible. $a$, Apical tooth; $b$, subapical tooth; $c$, median tooth; $d$, molar tooth; $e$, dorsal area; $f$, dorsal bristles or setæ; $g$, dorsal impression; $h$, transverse ridge; $i$, pharyngeal process; $j$, retractor tendon; $k$, lateral area; $l$, lateral bristle; $m$, lateral impression; $n$, anterior condyle; $o$, basal ridge; $p$, median fossa; $q$, median condyle; $r$, posterior fossa; $s$, condyle of ventral articulation; $t$, basal foramen; $u$, retractor disk; $v$, extensor disk; $w$, extensor tendon. (Original.)

areas of the thoracic segments is about equal to that of the area of the abdominal segments, or slightly longer. The pronotum is as long as both the mesotergum and the metatergum together. The prosterna and mesosterna are about equal in length, and both together about equal to the metasterna, while the combined length of the thoracic pleura is slightly greater than that of the abdominal pleura. The anterior dorsal margin of the pronotum and the posterior margin of the metatergum are greatly extended anteriorly 
beyond the ventral margin of the same segments, while the posterior dorsal margin of the pronotum and the anterior dorsal margin of the mesonotum are not produced beyond the corresponding sternal margin.

Divisions of the Thoracic Segment.

The divisions and other characters peculiar to the thoracic segments of a scolytid beetle are shown in figures 16 , $17,18,19$, and 20 .

It will be noted that while the usual divisions or sclerites are quite clearly defined in the metathorax, corresponding divisions are less distinct in the mesothorax, and are obsolete or completely fused in the prothorax. The taxonomic significance of this wide range in the modification of similar parts or areas in the three thoracic segments of the same insect is realized when we compare these parts with coiresponding segments in representative species of other families, suborders, and orders of insects. It will be seen that each segment has characters peculiar to the order or minor group to which the species

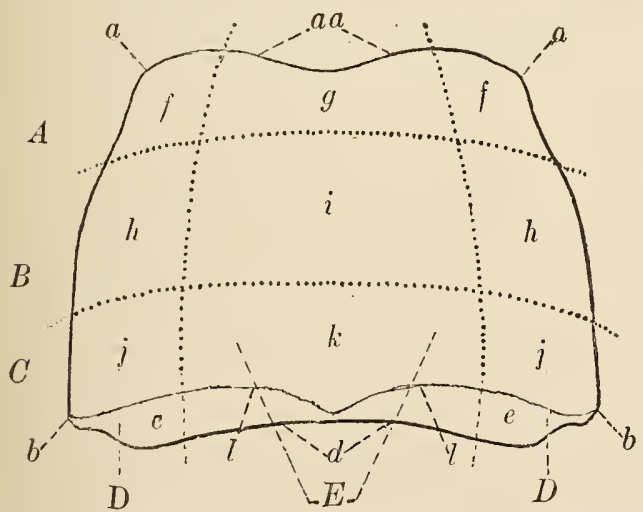

Fig. 16.-Dcndroctonus valens: Areas of pronotum. $A$, anterior area; $B$, median area; $C$, posterior area; $D$, lateral area; $E$, dorsal area; $a$, anterior angle; $a a$, anterior margin; $b$, posterior angle; $d$, basal margin; $e$, posterior declivity; $f$, anterior section of lateral area; $g$, anterior section of dorsal area; $h$, median section of lateral area; $i$, median section of dorsal area; $j$, posterior section of lateral area; $k$, posterior section of dorsal area; $l$, posterior margin or vertex.

(Original.)

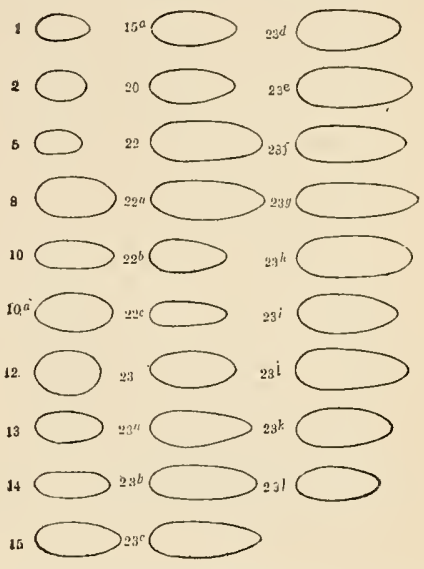

FIG. 15.-Dcndroctonus: Eyes. 1, brevicomis; 2, barberi; 5, arizonicus; 8 , approximatus; 10, 10a, pondcrosæ; 12, simplex; 13, pseudotsugæ; 14, piceaperda; 15, 15a, engelmanni; 20, punctatus; 22, $22 a, b, c$, terebrans; $23,23 a, b, c, d, e, f$, $g, h, i, j, k, l$, valens. (Original.) belongs, and that in like manner the combined characters of any two or all three in the same insect present many. features peculiar to the groups, the suborder, family, genus, or species represented.

It is also significant of the influence of a dominant principle or plan of structure and order of modification that one or more thoracic segments of practically any insect examined will show certain divisions more or less clearly defined, which are common to all other insects, and that

when we compare the segments of different stages of insects of all orders, we find that a composite segment would represent a system of four longitudinal and four transverse divisions. The longitudinal 
divisions are one dorsal, two lateral, and one ventral; the transverse divisions are one anterior, two median, and one posterior.

Audouin (1824) recognized the four longitudinal divisions and named them sternum, pleuræ, and tergum. He also recognized two divisions of the pleura and named them episternum and epimerum, and four transverse divisions of the tergum, which he named pres-

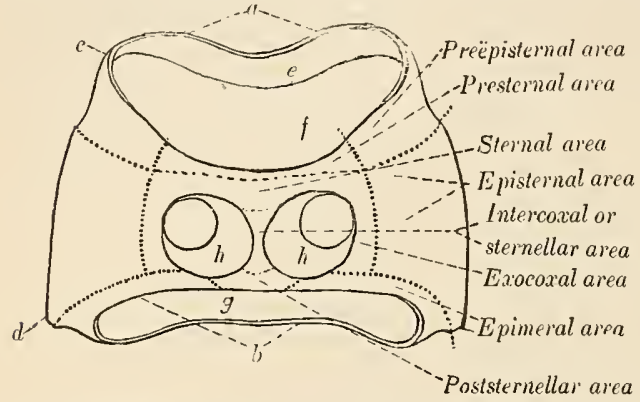

Fig. 17.-Dendroctonus valens: Areas of prothorax, ventral aspect. $a$, Anterior margin; $b$, posterior margin; $c$, anterior angle; $d$, posterior angle; $e$, anterior entothoracic fold for attachment of intersegmental membrane; $f$, anterior foramen; $g$, posterior foramen; $h$, coxal cavity. (Original.) cutum, scutum, scutellum, and postscutellum. These names have been adopted with but slight modification by most of the leading writers on insect anatomy, including McLeay, 1830; Newport, 1839; Kolbe, 1889; Amans, 18s5; Comstock, 1902; and Toss, 1905. The same divisions have been recognized by many other authors, who have designated them by different names.

The first, second, third, and fourth transverse divisions of the ventral or sternal area were recognized by McLeay in 1830, and named, in order, presternum, sternum, sternellum, and poststernellum.

All of the divisions and subdivisions mentioned as having been recognized by Audouin and McLeay are here recognized by the writer, and, in addition, the first and fourth transverse divisions of the pleura; thus four longitudinal and four transverse divisions of each segment in the adult insect have been recognized. The writer has also recognized the same or a similar system of division in the thoracic and abdominal segments of larvæ and pupæ. While the taxonomic significance of the character and modification of these

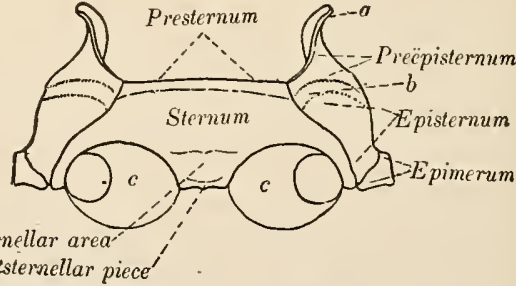

Poststernellar piece

FIG. 18.-Dendroctonus valens: Mesothorax, ventral aspect. $a$, Preepisternal process; $b$, transverse impression; $c$, coxal cavity. (Original.)

primary and secondary divisions as represented in one or more thoracic segments of the same insect, or in one or more segments in insects of different orders and minor groups, has been recognized, there has been wide difference of opinion as to the origin or homology of these divisions and in their interpretation or definition. This has naturally resulted in much confusion in the adoption and application of the nomenclature proposed by different authors, and, more than anything else 
connected with the anatomical problem, it was this state of confusion which led the writer to make a study of the subject in order to determine the facts and principles involved and to establish a basis for his future systematic and economic work on the scolytid and other beetles.

There appear to be two opposing ideas regarding the origin and evolution of the primary and secondary elements of the insect segment. One involves the principle of reduction of several primitive segments into one, on the theory that the transverse divisions represent modifications of several primitive segments. The other involves the principle of complex modification from a simple undivided primitive segment into many primary and secondary divisions, on the theory that this has been brought about more or less independently through the influence of the requirements of function to meet the demands of peculiar life activity in different forms or species, and that this plan of modification has been controlled and limited by the fundamental plan of structure in the hexapodal type of organism, and by the principle of relative proportions and correlation of parts. so as to conform to the general modification of the entire body in the evolution of the species.

The writer does not deem it advisable, in this connection, to discuss the relative merits of these theories or any of the other theories advanced by different authors. He is inclined to believe that while it is important to utilize any good evidence relating to the probable origin and homology of parts, it is more important for present needs to deal with the facts as they are found in existing forms and stages and to so name and define the major and minor divisions or elements of the segment that they may be readily recognized and utilized in any comparative study of their modification and in the description and identification of species, genera, and larger groups. Therefore the writer's interpretation of the recognizable elements in the thoracic segments of Dendroctonus does not involve any theory of origin or evolution, but is based on the recognition of a dominant tendency in the insect segment to represent a system of four longitudinal and four transverse divisions, any one or all of which may or may not be clearly represented in one or more segments of the same insect.

With this conception of a prevailing principle as a guide to the location of the possible primary and secondary divisions of the anatomical elements as they are indicated in any given segment, and to the recognition of the possible range of modification and distinction as manifested in the different segments of the same insect or in the corresponding segment of different insects, many of the difficulties and confusing factors relating to the proper definition of parts and application of names are eliminated. 
In the following discussion of the thoracic segments reference is made to the named parts as represented or not represented, as the case may be, rather than to say that they are present or not present, because in some cases where they are not defined on the external surface they may be indicated by apodemes or lines on the inner surface of the body wall, while in other cases their position or relative areas are indicated only by some character of surface sculpture or vestiture.

In the adult Dendroctonus there is a wide range of difference in the representation of parts in the prothorax, mesothorax, and metathorax. In the pupa there is a similar but not so marked difference between the three thoracic segments, the divisions being less evident in the mesothorax and metathorax than in the adult, but in the abdominal tergites the divisions are quite plainly indicated. In the larvæ there is not only less difference in the three thoracic segments, but these are only slightly different from the first to seventh abdominal segments. In the thoracic segments the prescutal and scutellar divisions are clearly represented, with evidence of the scutal division on the sides. The sternal and sternellar divisions are also clearly represented, with evidences of the presternal and poststernellar divisions in the prosternum, and the latter clearly defined in the mesosternum and metasternum. The pleurites are also represented by pleural lobes. In the abdominal tergites 1 to 6 the prescutal, scutal, and scutellar divisions are clearly represented and the sternal, sternellar, and poststernellar divisions are in like manner represented in abdominal sternites 1 to $\delta$, inclusive. Whether or not these divisions or lobes are homologous with divisions occupying relatively the same positions in the pupa and adult may be a subject for difference of opinion, but the names here applied to what appear to be corresponding parts should serve as a reliable guide to their recognition and accurate definition and description in comparative studies and identification of species.

Elements of the Adult Thorax.

The primary and secondary elements as represented in the thoracic segments of an adult Dendroctonus beetle are shown in the figures and are interpreted, named, and described as follows: ${ }^{a}$

THE PROTHORAX.

In this genus, as in rhynchophorous beetles generally, the tergal, pleural, and sternal areas are fused into a continuous band. The

a Notum and tergum.- While the names notum and tergum are synonymous, the former has been applied more specifically to the dorsal division of the prothorax, especially in beetles, and is here utilized in that sense. The name tergum is here used to designate the dorsal areas of the mesothorax, metathorax, and abdomen, on account of the use of the term tergite to designate a subdivision. 
primary and secondary divisions are not indicated by lines or sutures, but the corresponding areas are suggested by peculiar characters of sculpture and vestiture, which are of more or less taxonomic importance, and thus may be arbitrarily indicated, as in figures 16 and 17 , to serve as guides to the location of characters in comparative study and description.

Pronotum.-The pronotum is the dorsal or tergal area of the prothorax, as defined by the anterior, posterior, and lateral margins. There is considerable specific variation in its structure, sculpture, and relative proportions. It ranges from about one-fourth to about onethird broader than long, with about the same range of difference in the width of the posterior and anterior areas. In some species the lateral margins are nearly parallel, while in others they are distinctly convergent and constricted anteriorly. The anterior margin is broadly sinuate, while the vertex or dorsal margin of the posterior declivity is bisinuate. The anterior area is broadly transversely impressed, except in the females of some species, where the median section of the area is transversely elevated. The posterior declivity, which perhaps represents the postscutellum, is more distinctly exposed and defined in this genus than it is in allied genera and is therefore an important character of generic distinction. The pleural and stemal areas are indicated in figure 17.

Episternal area.-The episternal area is limited dorsally by the lateral margins of the notum, ventrally by the smooth exocoxal area, posteriorly by the epimeral area, and anteriorly by a preepisternal impression or in some species by a ridge. The sculpture of this area is quite variable and in some species furnishes characters of considerable value.

Epimeral area.-The epimeral area is represented by a flattened, smooth space situated between the roughened episternal area and the posterior margin of the prothorax and between the coxæ and the basal angle of the notal area.

Sternal area.-The entire sternal area between the anterior and basal margins is largely occupied by the coxal cavities, which are separated by the very narrow intercoxal or sternellar piece. The elevated anterior margin evidently represents the presternum, while the sternum is quite clearly defined by a nearly vertical flat to concave space between the presternum and the coxæ, the lateral limit being indicated by the smooth, shiny exocoxal area between the coxæ and the episternal area. The sternum proper is quite variable, ranging from concave, smooth, and shiny, without trace of a median longitudinal line to nearly flat, roughened, or with a median subcarinate line; but apparently none of these minor characters is sufficiently constant, even within the same species, to be of much taxonomic value. 
Poststernellar area-The poststernellar area is well defined and serves to completely inclose the coxal carity. It has been referred to as the epimeron, but since the epimeral is so clearly defined as a lateral area, it appears to more correctly represent the poststernellum, which in the mesosternum and metasternum is not evident, or is modified to accommodate the large coxal cavities.

THE MESOTHORAT.

The mesothorax (figs. 18, 19) is short and partially hidden from view by the prothorax, which covers the anterior third of the sterna, pleurites, and tergites, while the base of the elytra covers

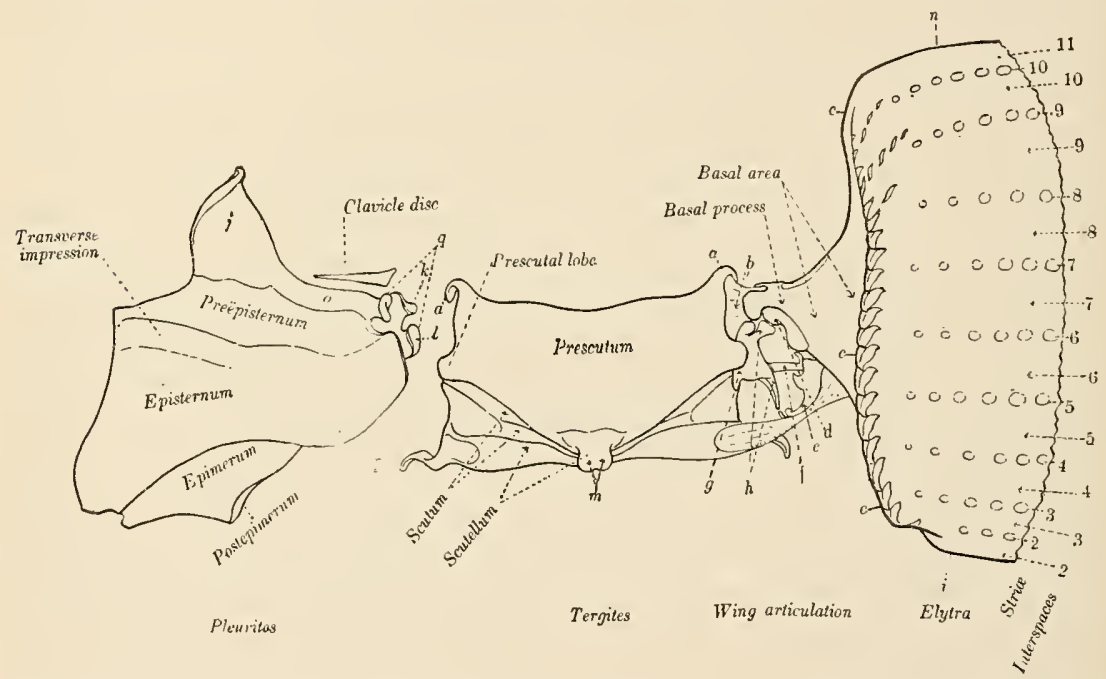

FIG. 19.-Dendroctonus valens: Hesotergum and mesopleurum. a, Lateral arm of prephragma and preseutum; $b$, wing root or connecting membrane; $c$, basal margin of elytra; $d$, radial plate; $e$, flexor plate; $f$, median plate; $g$, scapular plate; $h$, subscapular plate; $i$, sutural or anal margin; $j$, preepisternal process; $k$, clavicle condyle; $l$, coracoidal condyle; $m$, scutellum; $n$, lateral margin of elytra; $o$, arm of preepisternal process; striæ 2-10; interspaces 2-11; $p$, lateral arm of postphragma; $q$, pleural claviculus. (Original.)

the posterior third and dorsal area of the tergum, leaving but a small triangular area exposed between the thorax and inner angles of the elytra. Upon removing the prothorax and elytra this segment is found to represent most of the primary and secondary divisions of the normal segment.

MESOTERGUM.

The mesotergum (fig. 19) is rectangular in form, with the prescutum occupying two-thirds of the area, while the scutum, scutellum, and postscutellum are less clearly defined or rudimentary.

Prescutum.-It is evident that the large subtriangular dorsal section represents the prescutum, as indicated by the evident prescutal lobe and prescutal process, attachment of wing accessories, etc. 
Prephragma.-The prephragma is strongly flexed beneath the median area, but the anterior arms, in conjunction with the anterior angles of the prescutum, are prominent and strongly produced.

Scutum.-The oblique, impressed, triangular section situated beneath the posterior margin of the prescutum evidently represents the scutum.

Scutellum.-The hornlike process situated at the apical angle of the prescutum apparently belongs to the scutellum and corresponds, perhaps, to the structure which forms the scutellar groove of the metathorax. This, with the posterior lateral section, represents the median and lateral sections of the scutellum.

Postscutellum.-The postscutellum apparently is not represented by an external piece, but by an evaginated fold beneath the scutellum and by the lateral arms of the postphragma (fig. 19).

Postphragma.-The postphragma is represented by the posterior invagination or fold beneath the scutellum and by the lateral arms, as evidenced by the attachment of the scutal muscle to the arm and the connection of the arm with the invaginated phragma.

MESOPLEURA.

The episternum, preepisternum, epimerum, and postepim€rum are all represented and together occupy an area greater than that of the sternal and slightly greater than that of the tergal.

Preepisternum. - The preepisternum occupies the area in front of a transverse impression and is quite prominent. The anterior margin bears the preepisternal process (fig. $19, j$ ), which is common to most of the Rhynchophora, and is more or less represented in certain other Coleoptera, such as Carabidæ, Cicindelidæ, Scarabæidæ, etc., but it is surprising to find that it is not represented in Ips (Tomicus) and allied genera of the Scolytidæ. It is peculiar to the mesothorax and is progressively modified in character and function through various groups of Coleoptera from an obscure accessory of the clavicle disk to a prominent process. In Dendroctonus it is fused with the anterior margin of the preepisternum and has an arm extending to the dorsal angle to form an accessory to the wing process. It bears a set of powerful muscles, which are attached to the inner wall of the postscutellar and scutellar areas of the pronotum, thus forming a powerful muscle connection between the two segments. The mesothoracic spiracle is situated in the angle between this process and the sternal area and is covered by the epicranial area of the prothorax.

Clavicle disk.-The slender plate situated in front of the arm of the preepisternal process appears to correspond with the clavicle disk of the metapleurum. It is connected by a ligament to the head of the elytra, and its muscle is attached to the rudimentary antecoxal piece. Both the preepisternal process and the clavicle plate, 
as here defined, are probably modifications of the episternal paraptera of Audouin.

Episternum.-The episternum is the clearly defined, large, exposed triangular pleurite situated between the posterior margin of the preepisternum and the epimerum, with the dorsal angle dilated, produced, and flexed ventrally at the apex and with the apex of the epimerum and preepisternal process forming the pleural claviculus with its clavicle and coracoidal condyle for the articulation of the elytra. The posterior angle of the episternum is acute, and the suture between it and the sternum is obliquely sinuate. The episternal impression is clearly clefined by the elevated posterior margin of the preepisternum, and is usually covered by the posterior margin of the prothorax.

Epimerum.-The epimerum is exposed at its posterior ventral half and has its posterior margin fused with the metasternum and metepisternum and the produced anterior dorsal angle with its coracoidal condyle is covered by the episternum.

Postepimerum. - The postepimerum is represented by a small declivous area beneath the posterior dorsal angle, where it covers the metathoracic spiracle.

\section{MESOSTERNA.}

Presternum (fig. 18).-The presternum is quite clearly represented by the narrow, slightly elevated, anterior margin joined directly with the anterior ventral angle of the preepisternum.

Sternum.-The sternum is short, flat, and subdeclivous, with the posterior angle (exocoxal piece) extending around the coxal cavity to its junction with the anterior angle of the metasternum.

Sternellar area.- The sternellar area appears to be represented by the elevated and rather broad intercoxal piece, while the poststernellum is apparently represented by a poststernellar piece.

THE METATHORAX.

METATERGUM.

From a systematic and taxonomic point of view, the metatergum is by far the most important and interesting part of the thorax of beetles. We find in it not only evidence of the four transverse divisions, but examples of the possible extremes in modification to meet the requirements of wing articulation and wing motion.

Transverse sutures.-By a comparison of the metatergum of representatives of different orders of insects and of the larvæ, pupæ, and adults of some insects, as in Dendroctonus, we find that the prevailing. principle of division involves three transverse external lines, sutures, or impressions, and three corresponding entothoracic ridges, apodemes, or invaginated ectoderm, which define more or less clearly the four divisions, viz, prescutum, scutum, scutellum, and postscu- 
tellum. We also find that these transverse sutures are subject to great variation in position, contour, character of surface, manifesta-

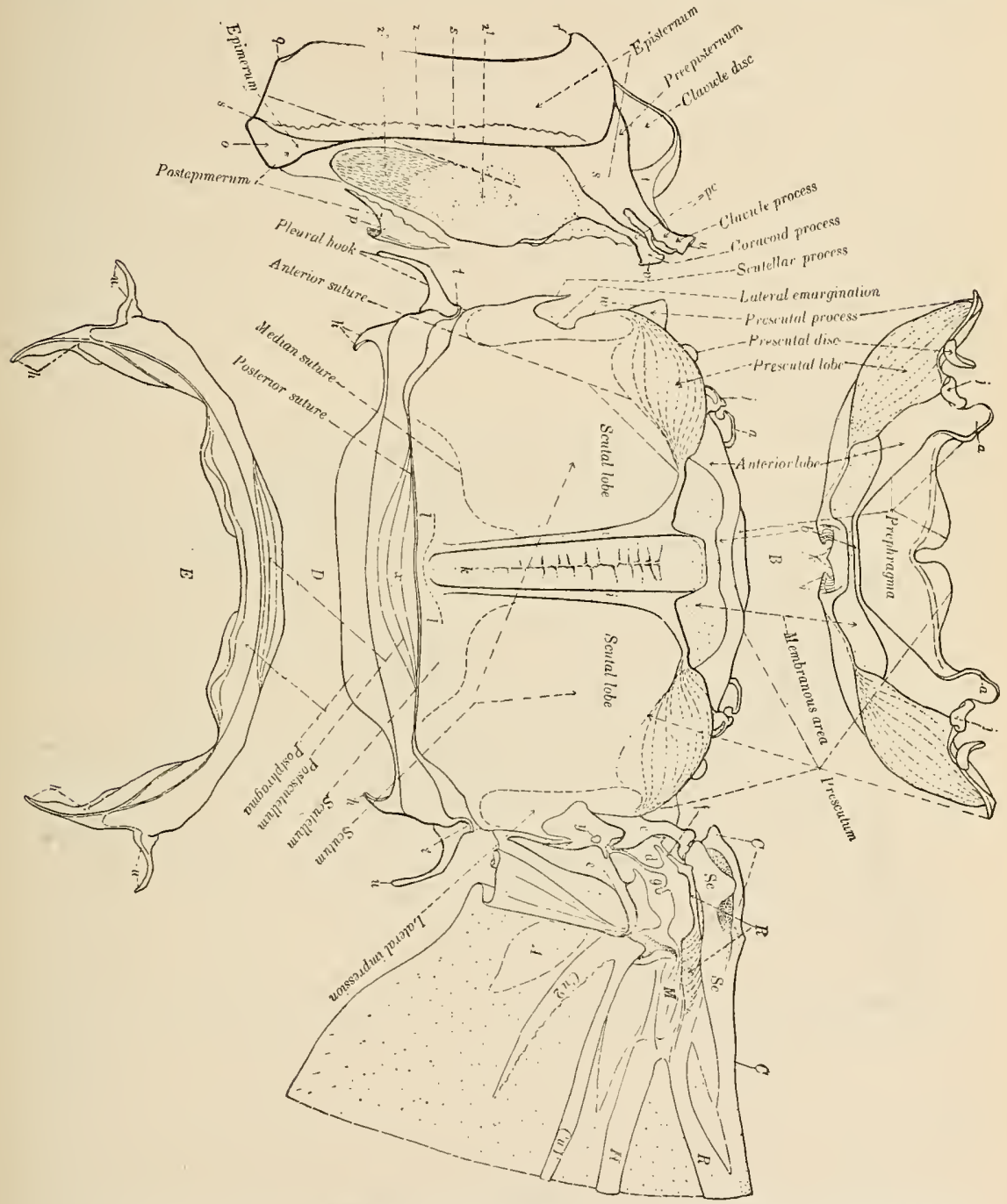

FIG. 20.-Dendroctonus valens: Metatergum and metanleurum. $B$, Anterior aspect of prephragma and prescutum; $D$, metatergum and metapleurum; $E$, posterior aspect of postphragma and postseutellum; $a$, lateral arm of prephragma; $b$, dorsal band; $c$, scapular plate; $d$, subscapular plate; $e$, flexor plate; $f$, radial plate; $g$, medial plate; $h$, lateral arm of postphragma; $i-i$, metatergal costæ; $j$, anterior disk; $k$, scutellar groove; $l$, posterior ridge; $o$, exposed triangular plate of postepimeron; $p$, pleural hinge; $p c$, pleural clavicula; $q$, posterior ventral angle of episternum; $r$, anterior ventral angle of episternum; $s$, pleural suture; $t$, postscutellar process; $u$, clavicle condyle; $v$, coracoidal condyle; $w$, attachment and articulation of scapular plate; $x$, dorsal area of postscutellum; $y$, pleural disk; $z$, elevated acute margin; $z 1$, membranous area; $z 2$, villous area. Wing reins: $C$, costa; $S c$, subcosta; $R$, radius; $M$, media; $C u 1$, cubitus 1 ; $C u 2$, cubitus $2 ; A$, anai. (Original.)

tions, etc., to correspond with the enormous range of modification to which one or all four of the transverse divisions are subject. These external evidences of separation of parts are here referred to as sutures, 
although in some cases they may be but faintly or obscurely indicated. The lateral and median sections of the anterior suture separating the prescutum from the scutum have a tendency to curve posteriorly, and especially the median section, which has a very strong tendency in this direction, and is often manifested to such an extent as to separate the scutum into two lateral sections, as shown in figure 20. The median suture has a reverse tendency, the lateral sections extending anteriorly, the submedian section posteriorly, and the median strongly anteriorly. Thus we often find, as shown in figures 20 and 21, that the two sutures overlap and form external longitudinal ridges and internal oblique apodemes, with an external median longitudinal impressed area. It appears that the dorsal groove may belong to either the scutellum or prescutum or represent a combination of the two, but for the sake of uniformity in its definition the name scutellar groove is here adopted. The posterior suture is usually distinct in the metatergum, especially in that of Coleoptera, and is much less subject to striking modifications in contour, etc., than the two preceding. Thus, it clearly defines the postscutellum, as in figure 20.

Transverse divisions.--The writer's interpretations of the modifications and position of the four transverse divisions as represented in Dendroctonus are demonstrated in figure 20.

Prescutum (fig. 20).- The area designated as the prescutum is that involving the attachments of the principal sternotergal muscles and the anterior lateral process for the attachment and articulation of the scapular plate. The anterior limit is defined by the prephragma, its posterior limits by the anterior suture and apodeme and the posterior limit of the prescutal lobes, and laterally by the anterior angle or limit of the lateral emargination. The most important features are the prominent prescutal lobes and anterior lobes for the attachment of the depressor muscles, the prescutal disk for the small muscle connecting it with the pleural clavicula, and the triangular prescutal process for the attachment and articulation of the scapular plate. (See, also, figure 21 for the entotergal characters and anterior apodeme.)

Prephragma (fig. 20,B).-The prephragma is the median section of the anterior vertical area of the prescutum. Its dorsal and lateral limits are defined by the line of attachment of the intersegmental membrane. The lateral arms in conjunction with the anterior process of the anterior lobe of the presternum are greatly extended ventrally.

Scutum.--The scutum is represented by the large scutal lobes situated each side of the scutellar groove. These lobes are for the anterior attachment of the large scutal muscles with the posterior attachment to the lateral arms of the postphragma. The lateral margin of the scutum is defined by the lateral emargination and elevated scutellar ridge which terminates in the scutellar process, and poste- 
riorly by the oblique sinuated line of the median suture and the lateral section of the posterior ridge.

Scutellum.-The scutellum is represented externally by the area posterior to the oblique line of the median suture and by the sublateral and lateral ridge which terminates in the scutellar process, as is indicated by the character of the entotergum and by comparison with the less modified scutellar division in other insects. The median longitudinal groove appears to represent the median produced section of the scutellum rather than a part of the scutum or prescutum, as indicated by the character of the entotergum and the widelyseparated apodemes of the median suture which extend to and join

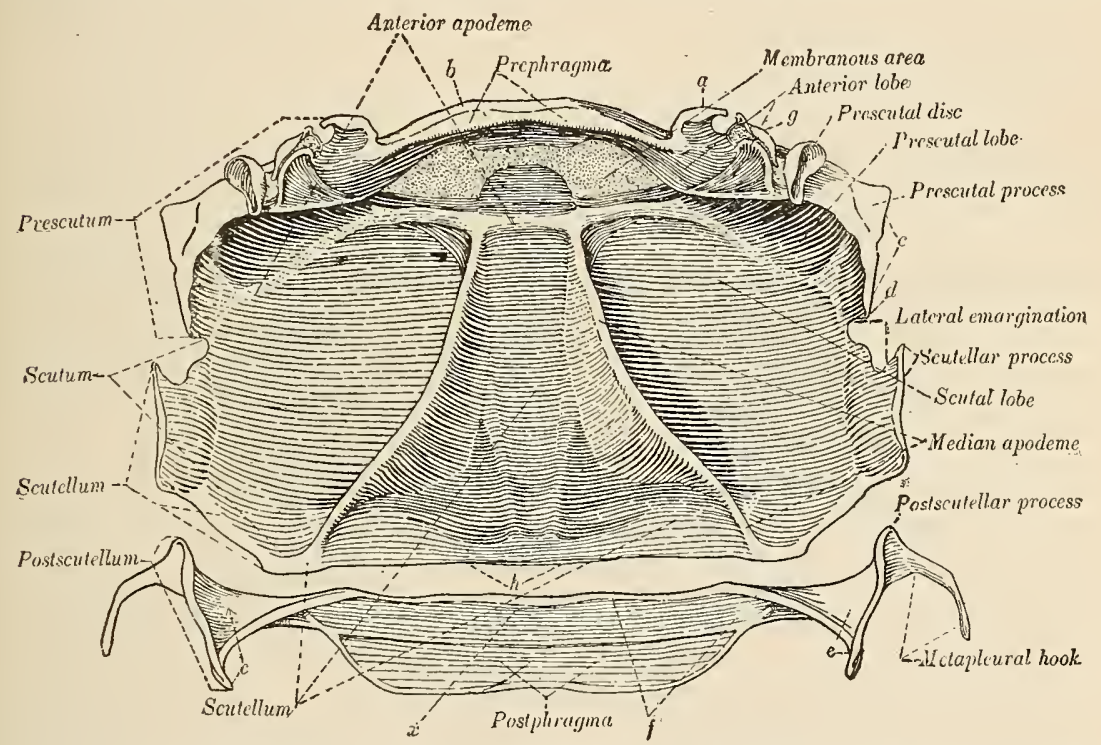

FIG. 21.-Dendroctonus valens: Metatergum, inner aspect. $a$, Lateral arm of prephragma; $b$, dorsal band; $c$, scapular articulation; $d$, posterior angle of prescutum; $e$, posterior arm of postphragma; $f$, posterior apodeme; $g$, anterior disk; $h$, posterior margin of scutellum; $x$, ventral wall of postscutellum. (Original.)

with the anterior apodeme (fig. 21), thus defining a large median triangular area which is evidently scutellar.

Postscutellum.-The postscutellum is the exposed dorsal and lateral area between the clearly defined posterior suture and the line of attachment of the first abdominal tergite. It is firmly connected with the scutellum toward each side at a point near the base of the oblique apodeme of the middle suture, otherwise the connection is membranous. The anterior angles support the metapleural hooks (fig. 20, E, u), which fit into a fold in the dorsal margin of the postepimerum (fig. 20, p).

Postphragma.- The postphragma is an invagination of the posterior section of the postscutellum and, with the produced posterior disks and arms, serves as important posterior attachments for the longitudinal, tergal, and oblique scutal muscles. 
METAPLEURA.

The metapleurum is well developed and distinctly represented by the two longitudinal sclerites, episternum and epimerum (figs. 3, 20 ), with their anterior dorsal angles greatly produced to form the pleural clavicula with its clavicle and coracoidal processes.

Pleural suture and apodeme.-The pleural suture marks the line of division between the episternum and epimerum, and extends from the dorsal angle of the coxæ to the apex of the pleural clavicula and between the clavicle and coracoidal process. That this is the true pleural suture is indicated by the corresponding prominent pleural apodeme. It is also quite evident that the episternum corresponds to the hypopleurites and the epimerum to the epipleurites of the abdominal segments (figs. 3, 22).

Episternum.-The episternum is exposed when the elytra are closed (fig. 2). The suture between it and the sternum is distinct and nearly straight, with the anterior end curved toward the coxa. The posterior ventral angle is oblique and joins the posterior dorsal angle of the sternum; from here the posterior margin is oblique to its acute junction with the epimerum and the dorsal angle of the coxal cavity. From here the dorsal margin is acutely elevated to fit into the anterior lateral groove of the elytron, and is nearly paralle! with the ventral margin to the preepisternum.

Preepisternum.-The preepisternum appears to be represented by the narrow declivous anterior section of the episternum connected with the anterior basal area of the pleural clavicula and is apparently involved in the formation of the clavicle process. The clavicle disk evidently represents one or both of the paraptera of certain other insects and belongs to the prepleura. It is situated immediately anterior to the preepisternum. It is large, prominent, and partially exposed, and is connected by a chitinous tendon to the side of the clavicle process. This disk supports the set of large clavicular or sterno-pleural muscles, the opposite ends of which are attached to the sternum and sternellum.

Epimerum.-The epimerum is situated between the pleural suture and the tergum. With the exception of the extreme posterior ventral angle of the postepimerum it is covered by the elytra. The anterior dorsal angle is strongly produced to form the coracoid process. The ventral area is chitinous and is joined to the episternum by the pleural suture, while the dorsal area is submembranous tc membranous to its junction with the base of the wing membrane.

Postepimerum.-The posterior ventral angle and posterior lateral section represent the postepimerum, as is indicated by its articulatory junction with the poststernellum (fig. 20, $p$ ). The posterior 
ventral angle or ventral section of the postepimerum, which might be mistaken for a postepisternum, is indicated by the pleural apodeme and pleural suture which here join the dorsal angle of the coxa. It is not impossible, however, that this plate may represent a combined postepisternum and postepimerum.

METASTERNA.

The metasterna (figs. 2, 3) form a broad rectangular plate separated into two lateral sections by a median longitudinal line. The presternum and poststernellum are not represented by external parts.

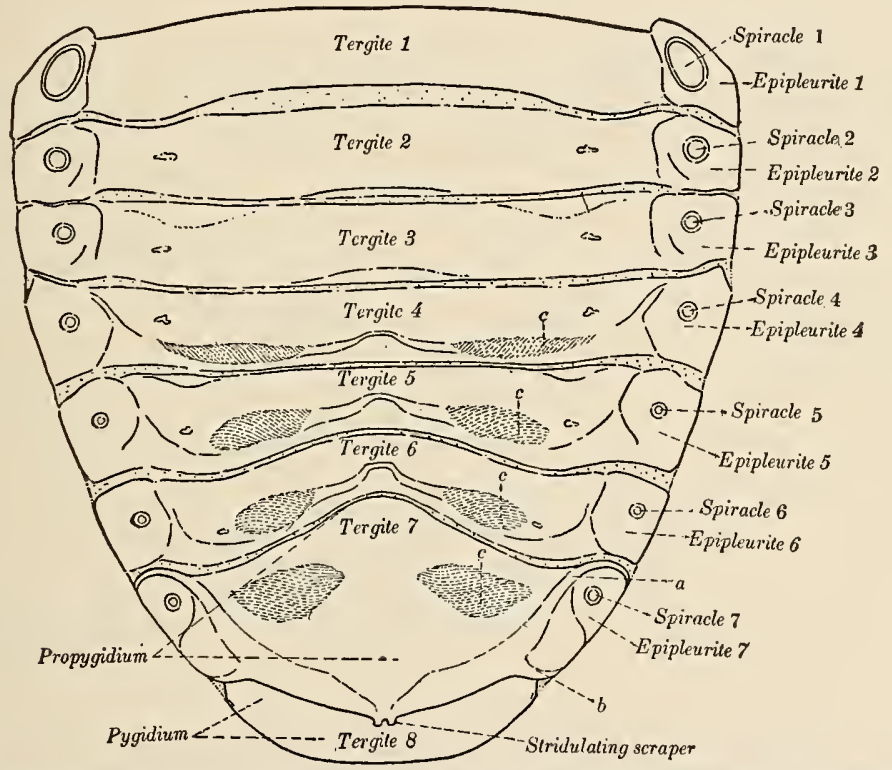

FIG. 22.-Dendroctonus valens: Abdominal tergites. $a$, Anterior arm of epipleurite 7 ; $b$, posterior arm of epipleurite 7 ; $c$, membranous lobes. (Original.)

Sternum.-The sternum is evidently represented by the large continuous area between the mesocoxæ and the small median plate and the slightly acclivous area anterior to the metacoxa.

Sternellum.-The sternellum is evidently represented by the posterior median plate and the posterior acclivous areas (fig. 2,a). The relation of the latter to the sterneilar area is indicated by the attachment of the posterior pair of clavicular muscles.

\section{THE ABDOMEN.}

The abdominal terga, pleura, and sterna, and their relative proportions, are shown in figures $1-3$ and $22-25$. 
Abdominal Tergites.

The eight abdominal tergites are normally covered by the elytra. The apparent difference in the relative proportions, as indicated by figures 3 and 22, is due to the flexible intersegmental membrane and the fact that figure 20 is from a balsam mount. The integument of 1 to 6 , inclusive, is more or less membranous, while that of 7 and 8 , with the exception of the finely sulcate membranous lobes of 7 , is chitinous. In the female, 8 is covered by 7 , and forms the so-called
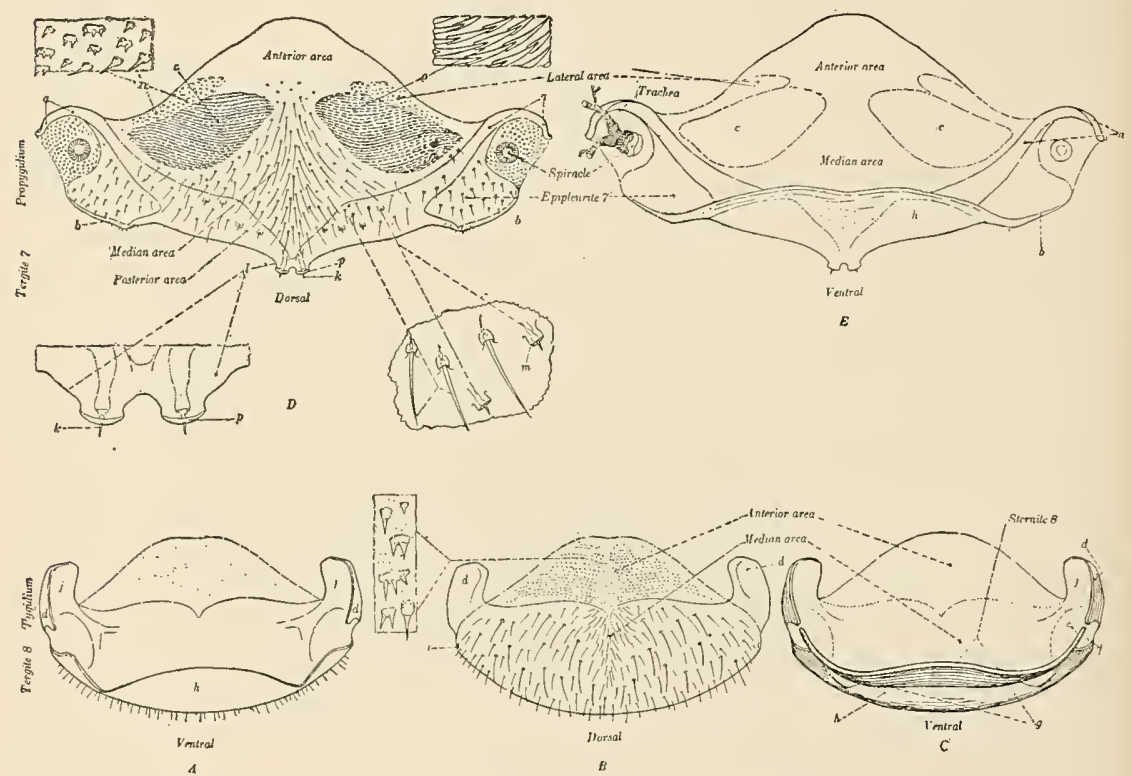

Frg. 23.-Dendroctonus valens: Male, abdominal tergites 7 and 8. $A$, Tergite 8 (pygidium), ventral; $B$, same, dorsal; $C$, same, ventral, showing position of sternite $8 ; D$, tergite 7 (propygidium), dorsal; $E$, same, ventral; $a$, anterior arm of epipleurite $7 ; b$, posterior arm of epipleurite $7 ; c$, membranous lobe; $d$, epipleural process; $e$, hypopleural arm of sternite 8 ; $f$, pleural opening; $g$, anal space; $h$, ventral fold; $i$, rudimentary spiracle 8 ; $j$, epipleural disk; $k$, apical spine; $l$, stridulating process; $m$, sensory bristles; $n$, enlarged section of lateral area; 0 , enlarged section of membranous lobe; $p$, stridulating scraper. (Original.)

"pygidium," while in the male 8 is distinct and together with 7 forms the so-called "divided pygidium."

Pygal tergites of the male.-The pygal tergites of the male are shown in figure $23, A, B, C, D, E$. Tergite 7 is the propygidium and as a bearer of generic and sexual characters is the most important of the entire series. In the male the posterior margins between the epipleurites converge toward the apex, which is produced into a bifid process and supports the stridulating scrapers. The posterior area of the tergite is thickened and strengthened to meet the requirements of stridulation. There is a broad ventral fold (fig. $23 E, h$ ) of the integument which may serve a similar function to that of a sounding board. 
The median area is triangular in form and covered with bristles and hairs rising from variously formed bases. On its face and sometimes on the posterior area there are a few irregularly arranged truncate tubercles $(D, m)$, each bearing a short, stiff bristle. These may possibly function as sense organs.

The membranous lobes are subovate, finely sulcate, and thickly clothed with reclining microscopic spines (o). The exact function of these lobes is not known to the writer. Tergites 4, 5, and 6 have similar lobes. The other dorsal and ventral characters are made sufficiently clear in $D$ and $E$.

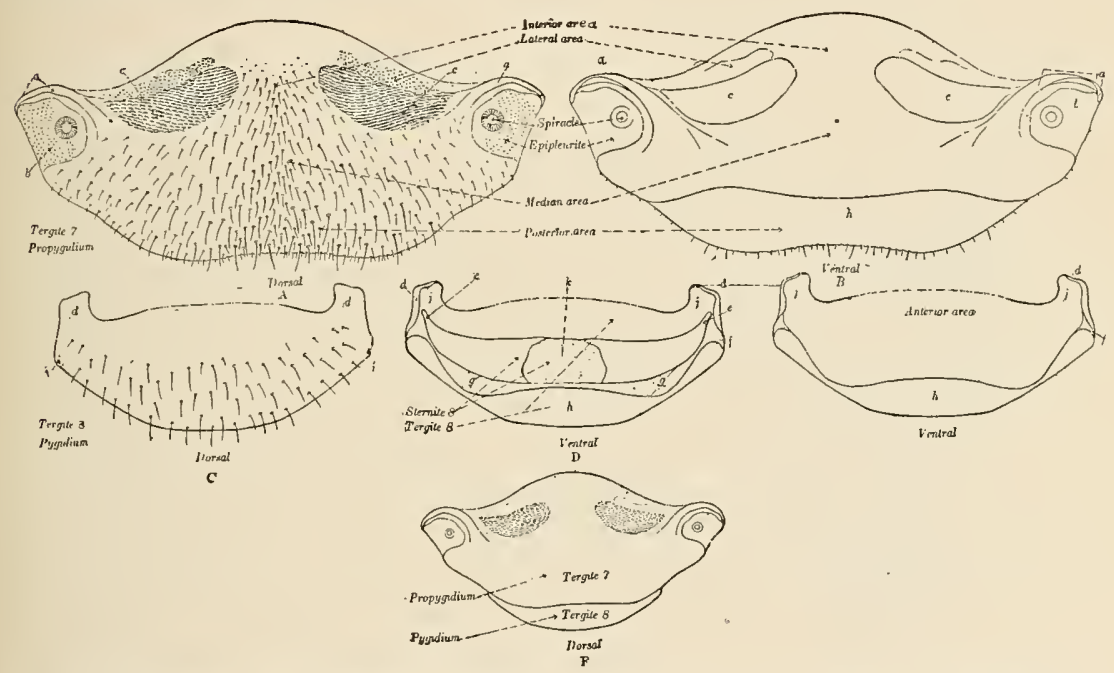

FIG. 24.-Dendroctonus valens: Female, abdominal tergites 7 and 8. a, Anterior arm of epipleurite 7; $b$, membranous area surrounding spiracle; $c$, membranous lobe; $d$, epipleural process; $e$, hypopleural process of sternite $8 ; f$, pleural opening; $g$, anal space; $h$, ventral fold; $i$, rudimentary spiracle; $j$, epipleural disk; $k$, median membranous connection of the lateral sections of sternite 8 . (Original.)

Tergite $8(A, B)$ is the pygidium. This, in the male, is always larger and more exposed beyond the margin of tergite 7 than in the female. The relative proportions, as compared with 7 , and the dorsal and ventral characters are clearly shown in $A$ and $B$. The lateral arms serve as attachments for pleural muscles and articulating membrane and ligaments. In $C$ the abdominal sternite is added to show its relative position and proportions.

Pygal tergites of the female.-The pygal tergites of the female are shown in figure $24, A, B, C, D, E, F$.

'Tergite 7 (propygidium) is much more simple in structural details in the female than in the male, and tergite 8 (pygidium) is also more simple and shorter, being almost or entirely covered by 7 when in normal position.

The characters of sternite 8 are shown in $D$, the most important of which is the median membranous area. 


\section{Abdominal Pleurites.}

At the lateral ends of the abdominal tergites and sternites there are well-defined areas (figs. 3, 22, 25), which may be designated as pleurites. Those situated immediately above the pleural suture and bearing the spiracles may be referred to as epipleurites, while those of the sternites which are immediately below the pleural suture may be designated as hypopleurites; both series are well defined in Dendroctonus.

In a lateral view (fig. 3) seven epipleurites and five hypopleurites are clearly defined, with the eighth epipleurite and the second hypopleurite indicated, and when the abdomen is removed both the first and second of the latter series are quite distinct.

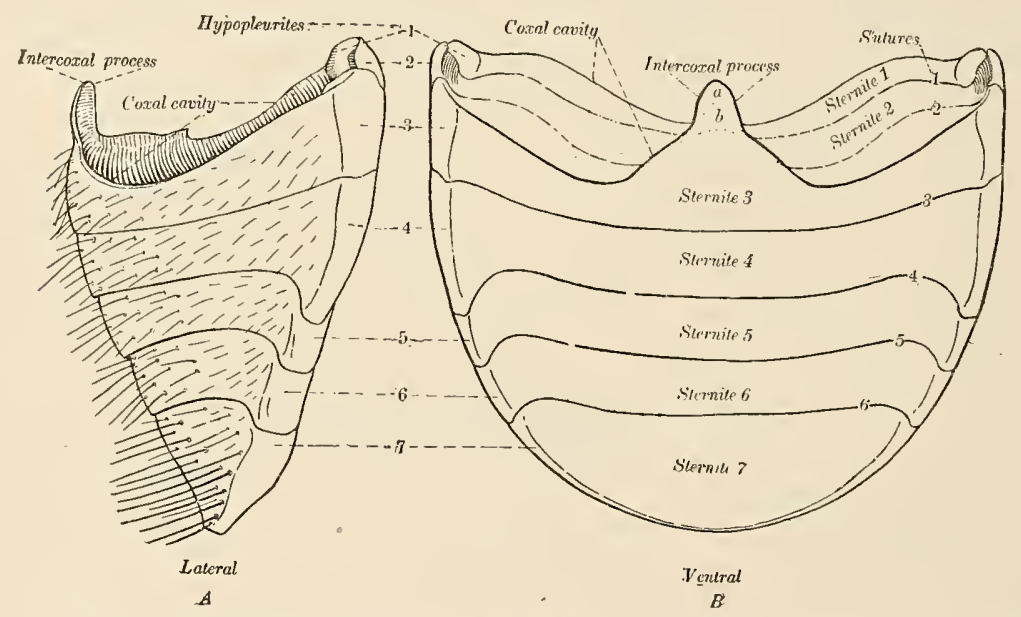

F1G. 25.-Dendroctonus valens: Abdominal sternites, ventral and lateral aspects. $A$, Lateral; $B$, ventral;

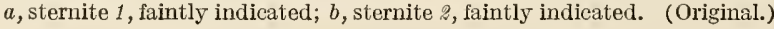

\section{Abdominal Sternites.}

The characters of the abdominal sternites are shown in figures 2, 3 , and 25. There are eight, corresponding to the eight tergites, but only five are exposed, viz, 3 to 7 , which are densely chitinized and clearly defined by four sutures.

Sternites 1 and 2 and the anterior portion of 3 are covered and obscured by the large metacoxa and form the posterior wall of the coxal cavity. They are fused, but the sutures are indicated by faint lines. Sternite 3 (first ventral segment of some writers) has the median area produced anteriorly, and with faintly indicated median portions of sternites 2 and 1 it forms the intercoxal process, the apex of which forms a junction with the metasternellar piece. The anterior exposed margin forms the posterior margin of the coxal cavity, but the junction with the preceding segment is but faintly 
indicated in the wall of the coxal cavity. Sternites 4, 5, and 6 are nearly of equal length, while sternite 7 is nearly as long as 5 and 6 together, with the posterior margin broadly curved and forming the apex of the exposed series. Sternite 8 (figs. 23, $C$, and 24, $D$ ) is entirely covered by 7 , and is represented in the male by a narrow chitinous rim below the anal opening, while in the female the median section of this stemite is membranous.

Suture 3 , between sternites 3 and 4 , is the first visible suture, and is rigid and straight throughout, while sutures 4,5 , and 6 are slightly flexible and are strongly recurved toward and between the hypopleurites, thus presenting an important generic character.

SPIRACles.

There are 9 well-developed spiracles, 2 thoracic and 7 abdominal, with the rudiments of a tenth. The large mesothoracic spiracle is located in the intersegmental membrane between the prothorax and mesothorax, and lies between the preepisternal process and the anterior ventral angle of the preepisternum. It overlaps the anterior margin of the latter for half its length, but is completely covered and obscured by the epimeral area of the prothorax. The metathoracic spiracle is situated in the intersegmental membrane between the metathorax and mesothorax, and concealed beneath the dorsal margin of the mesepimerum. The abdominal spiracles 1-7 are conspicuous; 1 is very large and situated in the epipleurite just posterior to the pleural hook of the metapostscutellum; $2-7$ are situated in their respective epipleurites, as shown in figures $3,22,23$, and 24 , while 8 is evident, but:rudimentary.

\section{THE LEGS.}

The structures and characters of the parts of the legs are so well illustrated in the figures (figs. 3, 26-29) that they do not require detailed description. The procoxæ and mesocoxæ are large, globose, and prominent, the former subcontiguous and the latter widely separated by the elevated intercoxal or sternellar piece, while the metacoxæ are oblong, oval, and separated by the process of the third abdominal sternite. There is no striking difference in the anterior, middle, and posterior trochanters, femora, tibiæ, and tarsi. The trochanters are small; the femora are moderately stout, and each is as long as its tibia, which is dilated toward the apex and armed on its outer lateral margin with stout teeth. The anterior dorsal area has a distinct tarsal groove for the retractile tarsus, as shown in figures 26 to 29 . The tarsi are each more than half as long as their tibiæ, and have five joints; joint 1 is always longer than 2 , but never as long as 2 and 3 together; 3 is distinctly bilobed, the 
lobes shightly longer than joint 4 ; joint 5 from tip of lobes of 3 is never as long as the others (1 to 3 ) together, but sometimes shorter than 1 and rarely equal to 2 and 3 . In the males this joint is often longer than in the female.

The trochlear articulation of the tibia with the tarsus is shown in

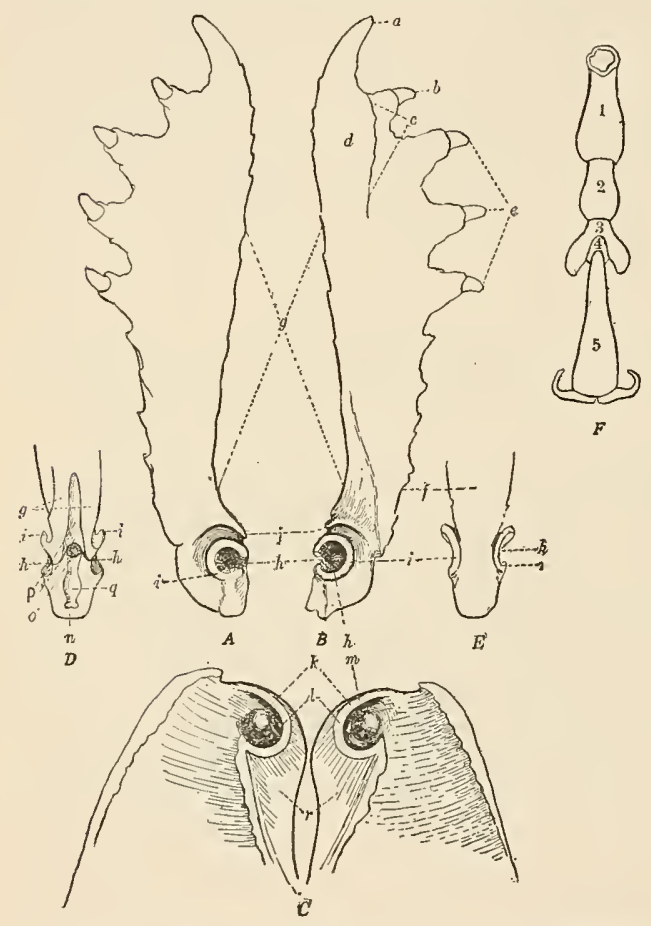

FIG. 26.-Dendroctonus valens: Tibia and tarsus, articulation, etc. $A$, Left tibia, rentral view; $B$, left tibia, dorsal view; $C$, left femora, ental view; $D$, left tibia, dextral view of base; $E$, left tibia, sinistral view of base; $F$, tarsus; $a$, apical tooth; $b$, subapical tooth; $c$, tarsal groove; $d$, subapical ridge; $e$, marginal teeth; $f$, sinistral margin; $g$, dextral margin; $h$, median fossa; $i$, lateral condyle of tibia; $j$, anterior fossa; $k$, lateral condyle of femur; $l$, lateral fossa of femur; $m$, median condyle of femur; $n$, attachment of extensor muscle; $o$, basal foramen; $p$, attachment of flexor muscle; $q$, basal groove; $r$, tibial groove. (Original.) figure 26 , in which the other more important characters are shown and named.

\section{THE WINGS.}

Notwithstanding the vast amount of published data on the wings of insects, there is yet much difference of opinion among the leading authors in regard to some of the details, and much confusion exists, due to different interpretations of the homologies of the elements of the wing and its articulatory accessories. A detailed investigation has been made of the basal areas of the wings of representatives of different orders of insects, to determine facts relating to the fundamental plan of development and modification, and the system of organization of the elements as represented in Dendroctonus.

Nomenclature.-While

the more generally accepted nomenclature has been adopted, it has seemed necessary to revise and more definitely define the application of some of the old names and to introduce some new ones to designate the elements heretofore obscurely defined.

Attachments and articulations.--There are certain elements in the structure, mechanism, attachments, and articulation common to the wings of all insects, but within defined limits and according to a definite system modifications, additions, and reductions occur. Therefore the presence or absence of a given element should be detected in any form of wing. 
Primary elements of the Dendroctonus wing.-The primary wing elements and their relations to each other as represented in Dendroctonus may be summarized as follows: The structure consists of a dorsal and ventral membrane or chitinous integument. The primary trachex are costal, subcostal, radial, cubital, and anal. The primary veins are costa, subcosta, radius, media, cubitus, and anal. The wing plates are scapular, subscapular, flexor, subflexor, radial, and medial. The wings are attached by membrane to the tergum and
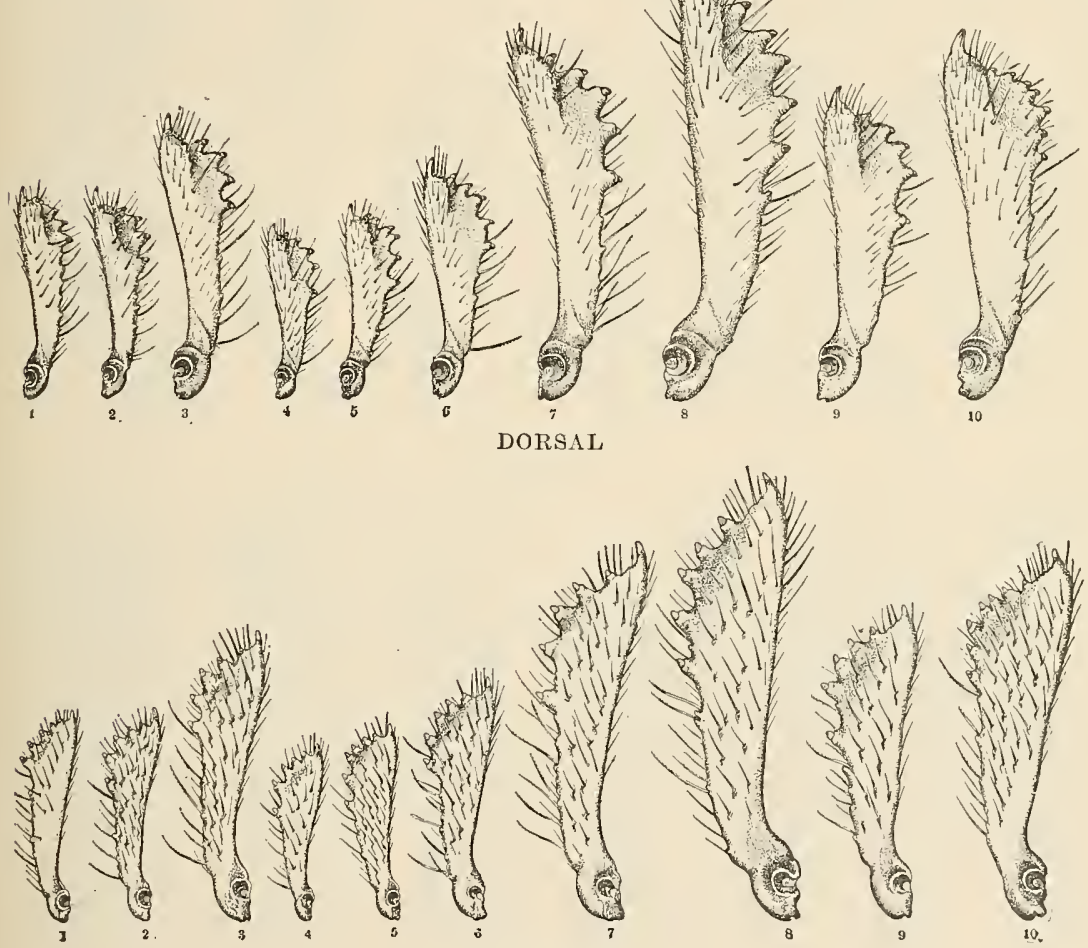

VENTRAL

FIG. 27.-Dcndroctonus: Left tibiæ, dorsal and ventral aspects. 1, brevicomis; 2, barbcri; 3 , convexifrons, 4, frontalis; 5 , arizonicus; 6 , mcxicanus; 7 , parallelocollis; 8 , approximatus; 9 , monticolx; 10, pondcrosæ. (Original.)

pleurum, and by ligaments and tendons to tergal and pleural processes and muscle disks. The pleural processes are the clavicle and coracoid processes, which together form the pleural clavicula. The tergal processes are the prescutal, scutellar, and postscutellar.

Elements of wing motion.-The elements of wing motion are the clavicular disk and clavicular muscle, pleural disk and pleural muscle, flexor and flexor muscles, prescutal disk and muscles, anterior prescutal lobe and anterior sternotergal muscles, posterior prescutal lobe and posterior sternotergal muscles, scutal lobe and scutal muscles, 
scutellar lobe, postscutellar processes, prephragma, and postphragma; also the pleural clavicula, clavicle, coracoidal, tergal, prescutal, scutellar, and postscutellar processes, and commecting ligaments.

\section{Mesothoracic and Metathoracic Wings.}

While there is a wide difference in the appearance and structural details of the elytra and the hind wings of beetles, they are evidently homologous and differ only in their modification in structure and function.

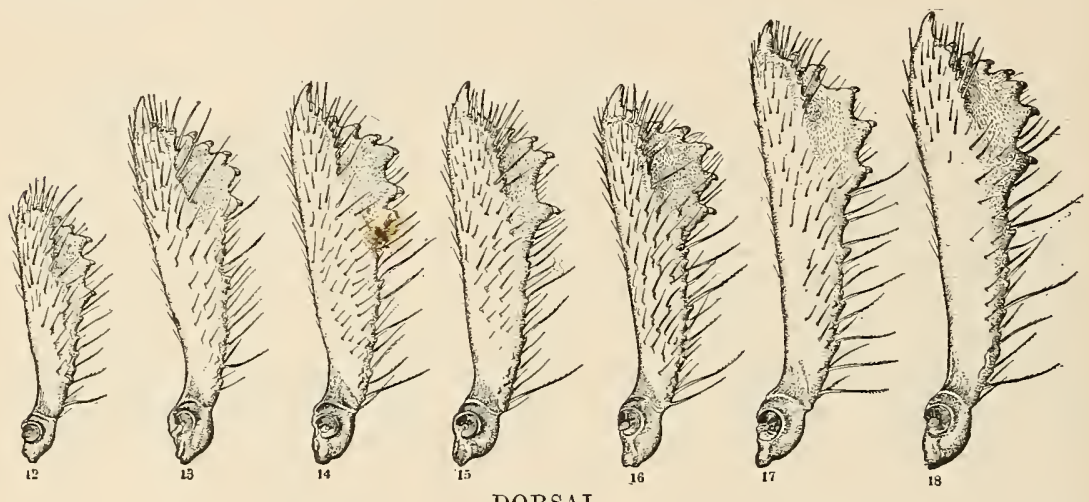

DORSAL

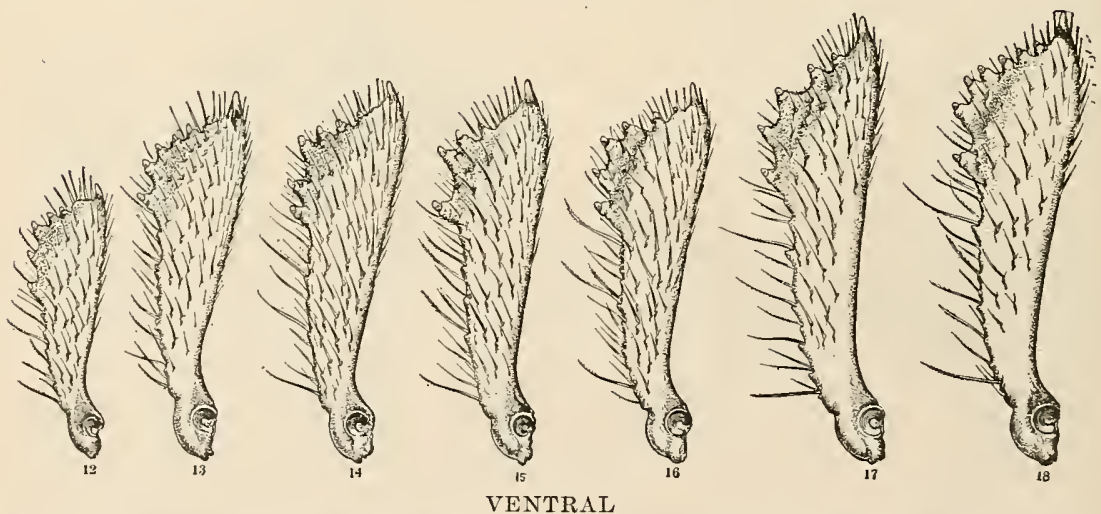

FIG. 28.-Dendroctonus: Left tibiæ, dorsal and ventral aspects. 12, simplex; 13, pseudotsugæ; 14, piceaperda; 15, engelmanni; 16, borealis; 17, obesus; 18, rufipennis. (Original.)

Structure.-The wing consists of two layers of integument, the dorsal evidently rising from the tergites and the ventral from the epipleurum (epimerum). Between these layers there is a system of tracheation and circulation. The integument of the mesothoracic wing or elytron is chitinous throughout, while that of the metathoracic or hind wing, with the exception of the veins and basal pieces, is membranous.

Tracheation.-The same system of primary tracheæ prevails in both the elytra and the hind wings. In the former it corresponds in 
general position to that of the primary veins in the latter, thus conforming to the prevailing system in fully developed wings of all insects. The primary tracheæ are costal, subcostal, radial, medial, cubital, and anal. In the elytron these occupy the marginal and alternating interspaces between the longitudinal strix or rows of
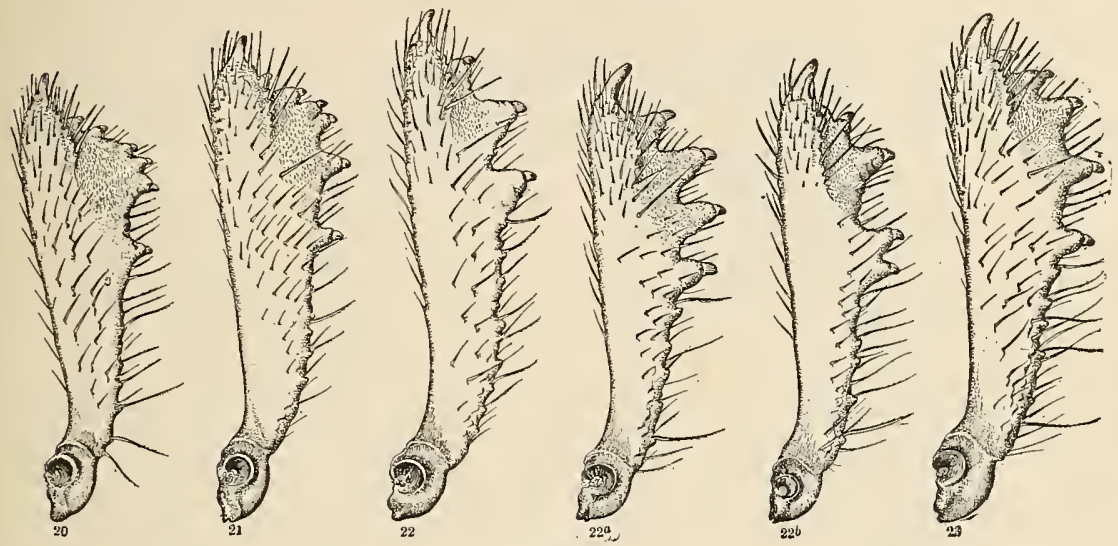

DORSAL
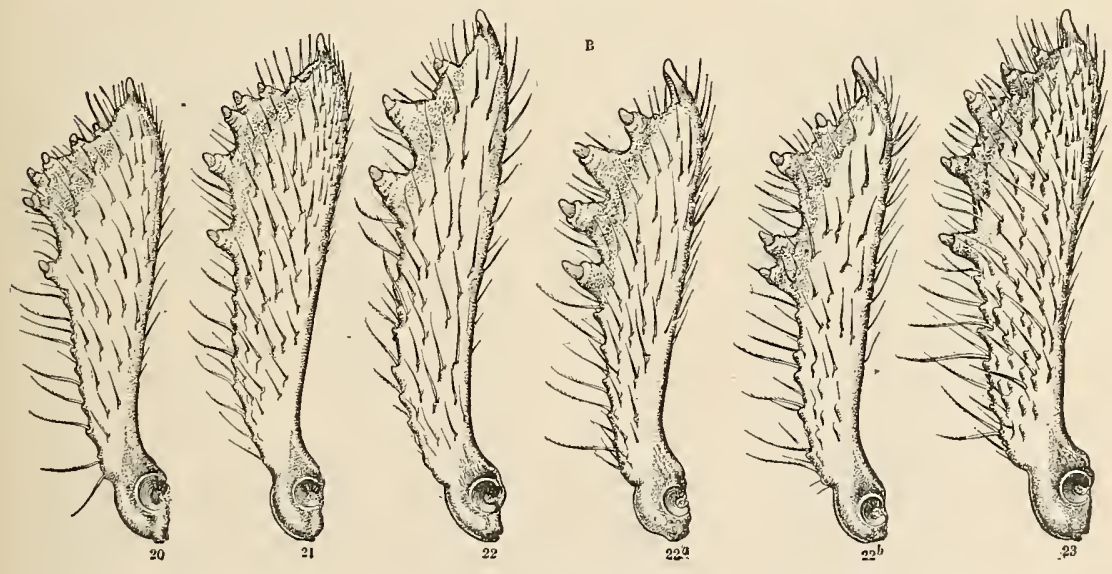

FIG. 29.-Dendroctonus: Left tibiæ, dorsal and ventral aspects. 20, punctatus; 21, micans; 22a, 22b, terebrans; 23, valens. (Original.)

punctures, while in the hind wing they follow approximately the primary veins.

\section{Metathoracic or Hind Wings.}

The hind or metathoracic wings (figs. 1, 20, and 30) are a third longer than the elytra or mesothoracic wings, under which they are folded when at rest. In consequence the veins toward the middle of the wings are flexible and adapted to the requirements of folding and unfolding. 
Basal area (fig. 30).- - The basal area is that in which the basal plates and head of the veins occur. In this area there are four axillary plates, which are more or less common to insect wings in general. These appear to belong to the wing rather than to the body structures, and are here designated as scapular, subscapular, flexor, radial, and medial plates. They are discussed in greater detail under wing articulation.

Veins.-The six primary veins represented in the hind wing are costa, subcosta, radius 1 and 2, media 1 and 2, cubitus 1 and 2, and anal, which last is rudimentary.

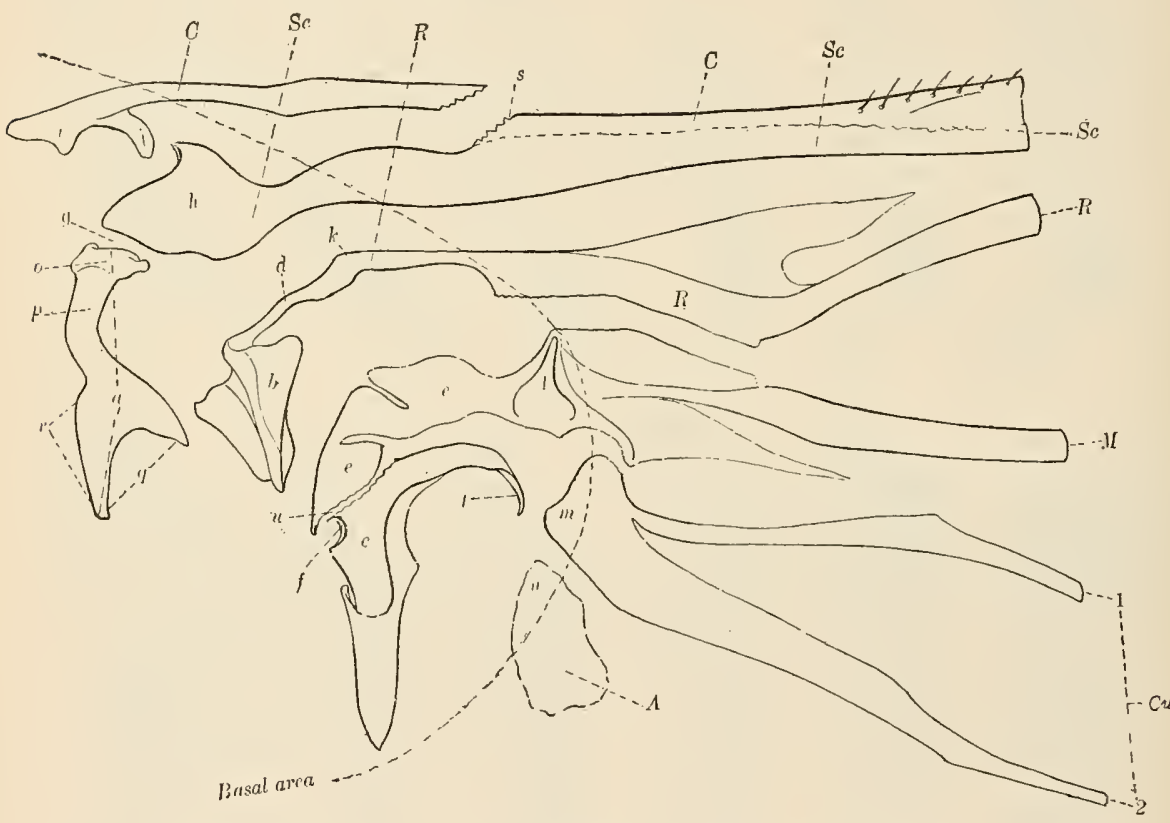

FIG. 30.-Dendroctonus valens: Diagram of basal area of hind wing. $a$, Scapular plate; $b$, subscapular plate; $c$, flexor plate; $d$, radial plate; $e$, medial plate; $f$, tendon attachment; $g$, arliculation; $h$, subcostal head; $i$, costal head; $j$, costal tongue; $k$, radial head: $l$, medial head; $m$, cubital head; $n$, anal head; $o$, scapular condyle; $p$, scapular arm; $q$, scapuIar base; $r$, articulatory margin; $s$, connection of costa with subcosta; $t$, flexor arm; $u$, connection of medial plate with flexor; $C$, costa; $S c$, subcosta; $R$, radius; $M$, media; $C u, 1,2$, cubitus 1 and $2 ; A$, anaI. (Original.)

Costa.-In Dendroctonus and most beetles the vein which corresponds to the costal trachea is confined to the basal area, and forms the anterior basal angle. The head is produced beyond the head of the subcosta, with which it is fused to form the articulating fossa. The produced head of this vein appears to function as an important accessory of the clavicle muscles in extending and depressing the wing, since it is connected with the clavicle condyle and clavicle disk by tendons. The vein proper extends outward but a short distance to its submembranous connection with the subcosta, and from that point the costal margin is occupied by it and the subcosta to its 
junction with the radius, which appears to form the broad chitinous costal area to near the apex, with branch 2 as a distinct rein.

Subcosta.-The subcosta is the principal vein of the wing. It gives rigidity to the base, and with the head of the costa forms the articu-

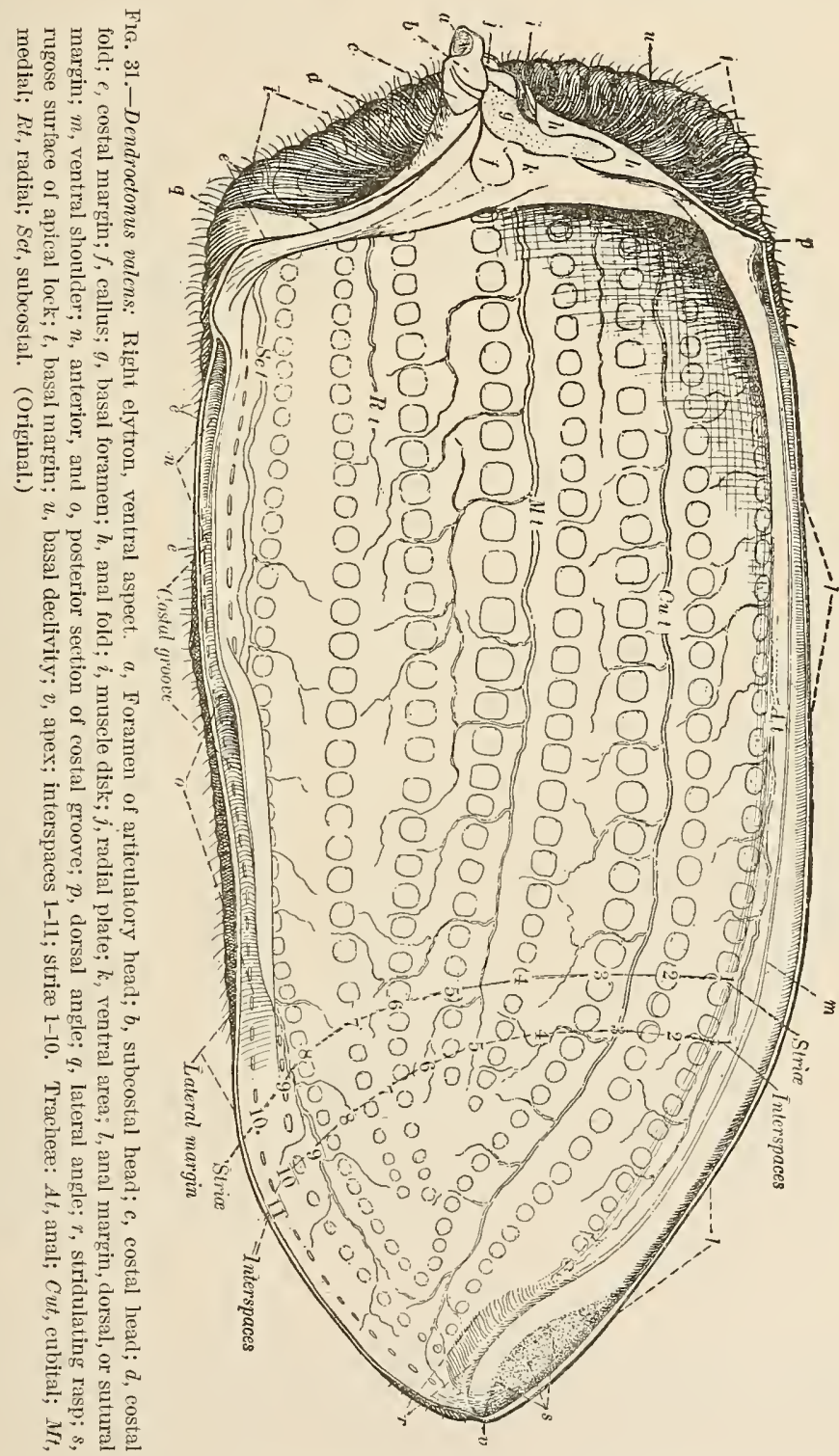

lating head. It is broadest where it is joined by the costa, and is strongly narrowed to its junction with the radius.

Radius.- The radius is an important vein in giving additional rigidity to the median, distal, and costal areas and in forming the folding 
hinge. It arises through the radial plate from the subscapula, and joins and fuses with the head and posterior edge of the subcosta to

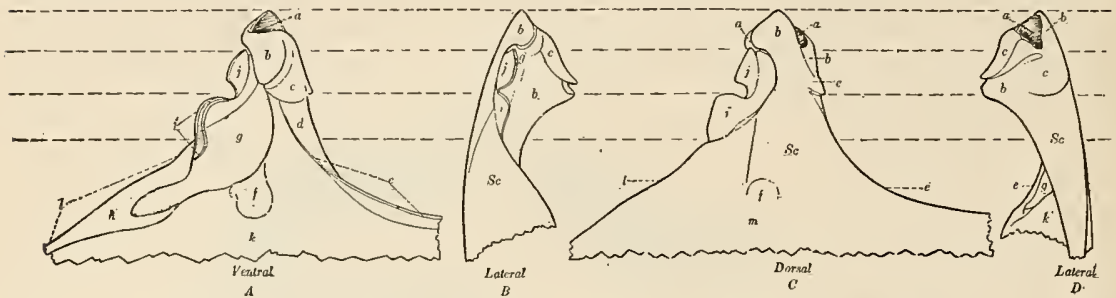

FIG. 32.-Dendroctonus valens: Basal process of right elytron. $A$, Ventral; $B$, latero-sinistral; $C$, dorsal; $D$, latero-dextral; $a$, foramen of articulatory head; $b$, subcostal head; $c$, costal head; $d$, costal fold; $e$, costal margin; $f$, callus; $g$, basal foramen; $h$, anal fold; $i$, muscle disk; $j$, radial plate; $k$, posterior ventral area; $l$, anal margin; $m$, posterior dorsal area; $S c$, subcostal area. (Original.)

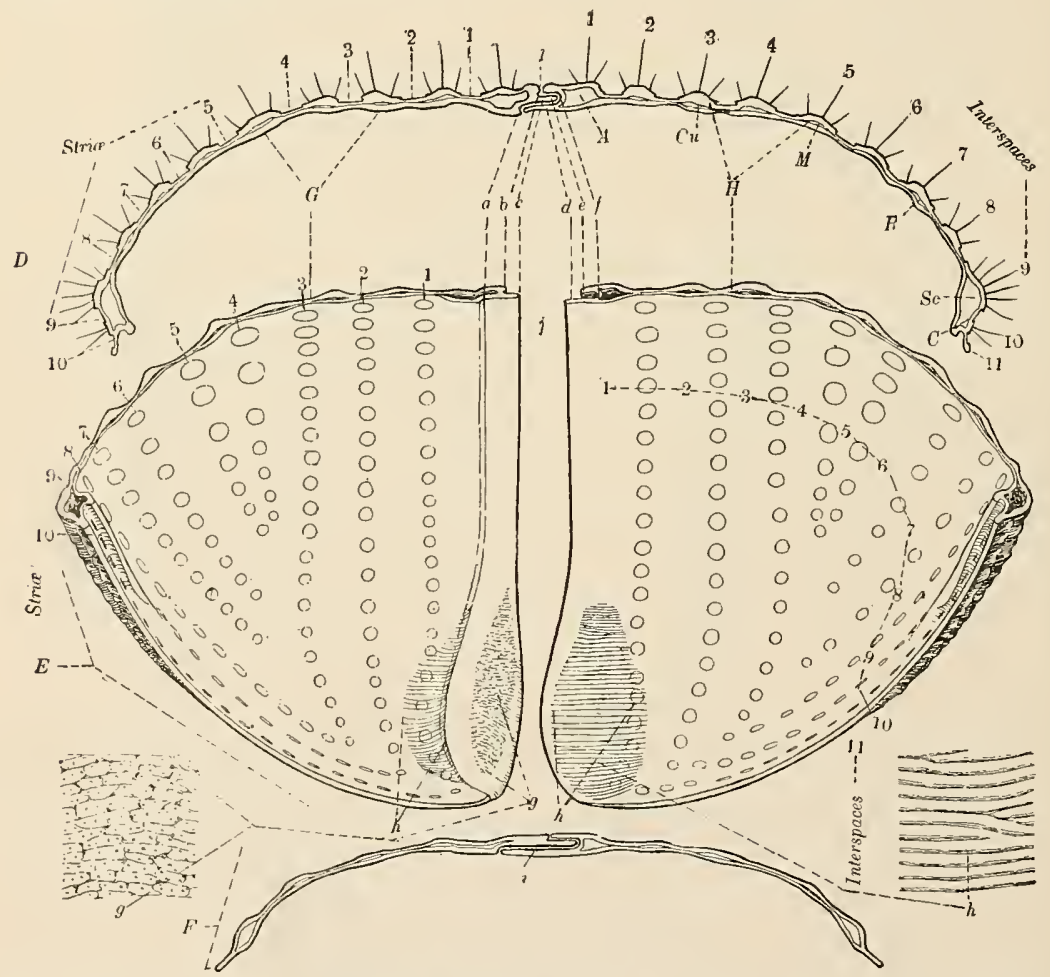

FiG. 33.-Dendroctonus valens: Declixital section of elytra. $a$, Ventral shouleler; $b$, ciotsal shoulder; $c$, sutural tongue; $d$, ventral lip; $e$, dorsal lip; $f$, sutural groove; $g$, rugose surface of apical wing-lock; $h$, stridulating rasp; $i$, apical wing-lock; $j$, suture; $A$, anal canal; $C u$. cubital canal; $M$, medial canal; $R$ radial canal; $S c$, subcost 1 canal; $C$, costal canal; $D$, transverse section; $E$, ventral aspect; $F$, transverse section through stridulating rasp; $G$, right elytron; $H$, left elytron. (Original.)

the point where it becomes broadened and obliquely rugose. Here it separates from the subcosta and joins the media by a short crossvein, and thence proceeds, as shown in the figure. 
Media.-The media is distinctly connected with a basal, irregular, flexible medial plate, which is joined to the flexor, radial, and subscapular plates by membrane and flexible chitin. Near the distal limit of the basal area there is an evident fold or cross vein connecting the base of the media with the base of the cubitus, from which it proceeds outward to the hinge, and from this point two branches extend to the anal margin.

Cubitus.-The cubitus rises from the outer border of the basal area and apex of the flexor and has two branches. Branch 1 extends to the margin. Branch 2 is short and more or less rudimentary.

Anal.-The anal vein is evidently represented by the broad, short spur arising from the base of the cubitus, and does not extend to the margin.

Wing attachment.-The wing is attached to the body by chitinous dorsal and ventral integument, the latter arising from the dorsal margin of the epimerum, and the former from the lateral margins of the prescutum, scutum, and scutellum, as indicated in the pupa. The heads or roots of the veins are attached by a system of connecting chitinous tendons and ligaments to the pleural and tergal processes and disks.

Wing articulation.-The principal articulation of the wing is between the wing head formed by the costa and subcosta and the condyles of the clavicle and coracoid processes together with the scapular plate.

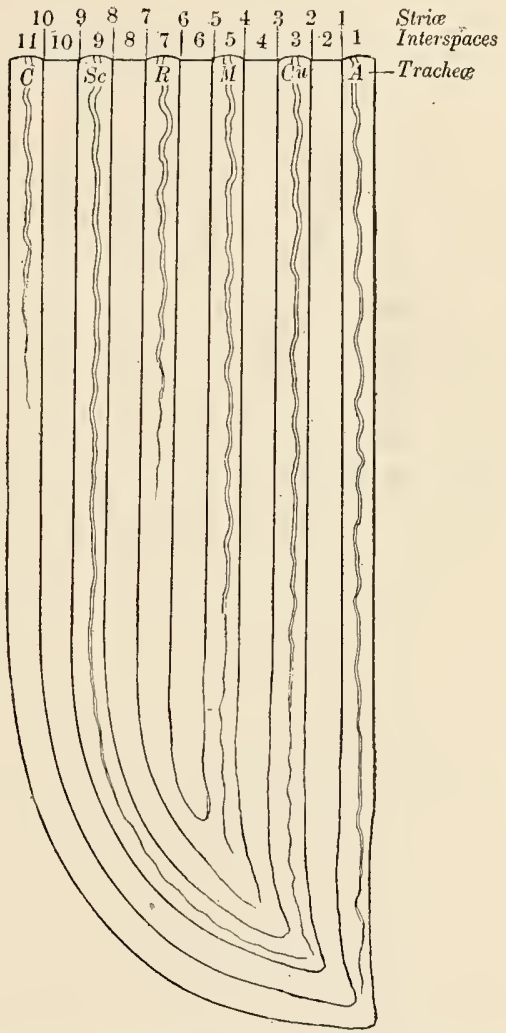

FIG. 34.-Dendroctonus valens: Diagram of elytron, showing striæ, interspaces, and tracheæ. Striæ 1-10; interspaces 1-11. Trachex: $C$, costal; Sc, subcostal; $R$, radial; $M$, medial; $C u$, cubital; $A$, anal. (Original.) nected with the prescutal process by articulating membrane and ligaments.

Pleural clavicula ("clavicula thoracique," Chabrier, 1820).-The position and function of the articular processes of the episternum and epimerum (fig. 20,pc), as represented more or less distinctly in all insects, are in Dendroctonus so strikingly analogous with that of the clavicle and coracoid in winged vertebrates as to suggest to the writer the same names. The giving of these names conforms with the practice of adopting for insect anatomy such of the nomenclature of ver- 
tebrate anatomy as is applicable to parts in insects having the same or similar functions. Subsequently the writer's attention was called to the fact that the same idea was suggested to Chabrier.

In Dendroctonus the clavicle and coracoid processes are prominent and clearly defined, the condyle of the former being definitely connected with that of the head of the subcostal vein, which articulates between the condyles of the clavicle process and scapular plate. Chabrier's name clavicula has been adopted for the combined clavicle and coracoid processes.

Tergal processes (fig. 20).-The processes of the tergal area, which have more or less important functions as articulatory accessories, may be designated as prescutal, scutellar, and postscutellar.

Prescutal process. - The prescutal process is represented by a triangular extension of the posterior angle of the prescutum, and is of primary importance as an accessory to the scapular plate.

Scutellar process. - The scutellar process is represented by the thickened lateral margin of the lateral impression and by the produced, acute, anterior angle. It is attached along its lateral margin to a pleural tendon connecting the pleural disk to the flexor and subscapula. This process is also accessory to the flexor.

Postscutellar process. - The postscutellar process is an extension or arm of the anterior angle of the postscutellum, and has its apex attached to the pleural disk and to the pleural hook.

Lateral emargination.-What is termed the lateral emargination is the emargination in the side of the scutum between the posterior angle of the prescutum and the scutellar process. It is present in most of the insects and appears to facilitate the functions of the flexor muscle.

Lateral impression.-The lateral impression is an impression to accommodate the flexor plate when the wing is at rest.

Basal elements.- The basal elements of the wing which function as articulatory accessories are here referred to as head of costal vein, scapular, subscapular, radial, medial, and flexor plates (fig. 30).

Head of costal vein (i).-The head of the costal vein is produced beyond its fused connection with the head of the subcosta. It is connected to the head of the clavicle by a ligament, and evidently functions in extending the wing forward as well as in contributing to other motions.

Scapular plate (a).-In form and function the fundamental basal plate, which we here call scapular plate, is very suggestive of the scapula of vertebrates, but its peculiar functions require quite different tergal connections. It is joined by ligaments to the prescutal process and lateral margin of the prescutal lobe in such a manner as to facilitate part of its functions-that of unfolding, elevating, and depressing the wing. Its condyle articulates directly with the 
dorsal or inner edge of the head of the subcosta and with the clavicle condyle.

Subscapular plate (b).-The subscapular plate is more complicated in its structure than the scapular plate, to which it is a direct accessory, the two being closely joined by articulating ligament. It functions as an intermediate patella-like connection of the system of tendons which connect the pleural disk at the head of the pleural muscle with the flexor, head of scapular plate, head of coracoidal process, head of subcosta, etc. Therefore it must be of fundamental importance in wing motion.

Radial plate $(d)$.- The radial plate is represented by a thin chitinous piece connecting the radius with the subscapula.

Medial plate (e).-The medial plate is of flexible chitin connecting the media with the flexor and subscapula.

Both the radial plate and flexor plate evidently function as articulating accessories.

Flexor plate $(c)$.- The flexor plate comes next to the scapular plate in its fundamental importance in wing connection and articulation, and is especially fitted in structure and muscular connection for its primary function of flexing and longitudinally folding the wing, as well as in the reverse action of contributing to its outward extension and rigidity during flight.

\section{Mesothoracic Wings or Elytra.}

The form and general structure of the elytra are shown in figures 1 and 31. They are oblong, rigid shields, with a subacute apex and a truncate declivous base and a produced articulating hearl. The structure, like that of the metathoracic wing, consists of two layers of integument inclosing the tracheal and circulatory system, but instead of the dorsal and ventral layers being partially composed of flexible membrane, they are chitinous throughout. The ventral layer is thin and smooth, while the dorsal one is thick and deeply sculptured.

Tracheation.-The six primary tracheæ (figs. 31, 34) occupy the marginal and the alternating longitudinal spaces between the rows of punctures. Each has numerous fine lateral branches passing between the punctures into the intervening interspaces, producing a network of fine trachex, with the punctures representing the mesh. Thus we have a probable explanation of the primary cause of the system of punctures in the elytra and the longitudinal and tranverse thickened spaces between them. The thickened and elevated areas are due to a concentration of chitin over the tracheal and circulatory canals, while the punctures and grooves are the points of adhesion or junction of the two layers to form the walls between the canals. 
Sculpture.-The dorsal chitinous layer presents many and varierl characters of sculpture, the principal elements of which are the striæ, including the longitudinal impression and rows of punctures. The interspaces are longitudinal spaces between the striæ. The rugosities of the interspaces and striæ and the elevated rugose basal margin are all characteristic elements of sculpture. There are ten striæ and eleven interspaces. For convenience in referring to the variable characters, these are numbered, beginning with those next to the dorsal suture, when the elytra are closed, or with the posterior or anal margin when the elytra are open. Thus we have interspaces 1 to 11 , and striæ 1 to 10 (figs. 31,33 ).

Interspaces.-In an ideal system (fig. 34) interspaces 1 to 5 are continuous toward the apex with 11 to 7 , leaving 6 independent between 5 and 7 . The primary tracheæ occupy interspaces $1,3,5,7$, 9 , and 11. There is, however, more or less variation and modification in the elytra of beetles from this ideal arrangement and especially upon the distal ends and their junctions with each other on the declivital area. In Dendroctonus interspace 1 is usually more elevated and continuous to apex, where it joins the very narrow marginal $11 ; 2$ is less elevated to flat, narrowed toward apex, and joins the very narrow and obscure submarginal 10 , which becomes broader and distinct toward the base; 3 joins the distinet $9 ; 4$ joins 6 around the apex of 5 , and also joins 8 around the apex of 7 .

Striæ.--In the ideal arrangement (figs. 1, 31, 34), striæ 1 to 5 are continuous with striæ 10 to 6 , but the usual arrangement on the declivity in this genus is 1 to 3 continuous with 10 to 8 , while 4 is continuous with 5 , and 6 with 7 . The strial punctures range from small to coarse and from very distinet to obseure, and are sometimes variable in size and appearance in the same species. The prevailing condition, however, of relative obseurity or distinetness in different species is of considerable specific importance. The strial impressions also vary within the genus from scarcely to distinctly or deeply impressed, and the prevailing condition within the species is of considerable value. The elytral declivity, as is usual in the scolytid beetles, bears some of the more important specific and secondary sexual characters.

The other character-bearing areas of the elytra are the lateral, median, and the dorsal toward the vertex and base.

Vestiture.-The elytra are more or less distinetly elothed with short or long hairs. The length, size, arrangenent, and areas occupied furnish important taxonomic characters in distinguishing the major and some of the minor divisions, as shown in the synoptic table. A progressive modification in vestiture is from very short hairs over the entire surface to longer hairs and sparsely arranged 
bristles toward the vertex of the declivity and on the declivity itself, or to fine and coarse long hairs over the entire surface.

Lateral fold or costal groove (fig. $31, n, o$ ).- In the costal edge of the elytron, from near the base to the median section, there is a lateral or costal groove for the reception, when the elytra is closed, of the corresponding produced and acute dorsal edge of the epistemum. There is also a deeper and broader groove in the median section of the costal area, for the reception of the produced dorsal edges of hypopleurites 3 and 4 . According to LeConte and other writers, this lateral groove is an important subordinal character.

Sutural tongue and groove (fig. 33, $a-f$ ).- - In the sutural edge of the left elytron there is a deep lateral groove and produced ventral edge for the reception of the corresponding produced lateral edge or tongue of the right elytron, thus forming a tongue and groove suture. Toward the apex both the ventral edge of the left and the tongue of the right are dilated to facilitate the locking of the elytra when they are closed.

Stridulating accessories.-In the male there is a transversely and microscopically sulcated area on the ventral surface toward the suture and apex of each elytron (fig. 33). When the elytra are closed this forms a continuous filelike surface situated directly above the stridulating scraper of the seventh abdominal tergite or propygidium. A peculiar, independent, upward and backward motion of the propygidium brings the scraper in contact with the file, and thus produces a peculiar chirping sound which is quite audible to the human ear.

The exact location of the organs of hearing in these beetles has not been determined.

Basal and pleural elements. - The basal process, or articulatory arm (fig. 32) of the elytron appears to represent the fused heads of the costa, subcosta, and radial veins. The usual scapular, subscapular, flexor, and medial plates are quite definitely represented, and occupy the same relative positions as in the metathoracic wing. The pleural clavicula are represented in the mesothorax by the clavicle and coracoidal processes, which are fused beneath the anterior dorsal angle of the episternum to form the condyles (fig. 19). The clavicle disk is not represented, unless it is by a narrow free piece attached to the costal angle of the elytral process, and represents the parapterum or extensor plate, to which the extensor muscle is attached.

INTERNAL ANATOMY.

While some study has been made of the internal anatomy of these beetles it has not been sufficient to warrant a detailed discussion in this connection.

$79980-09-5$ 
DIGESTIVE SYSTEM.

The general character of the digestive system is shown in figure 35 , and no further explanation is necessary in this connection than that given in the legend under figures 35 and 36 . In figure 36 some of the details of the internal anatomy of the fore intestine are shown,

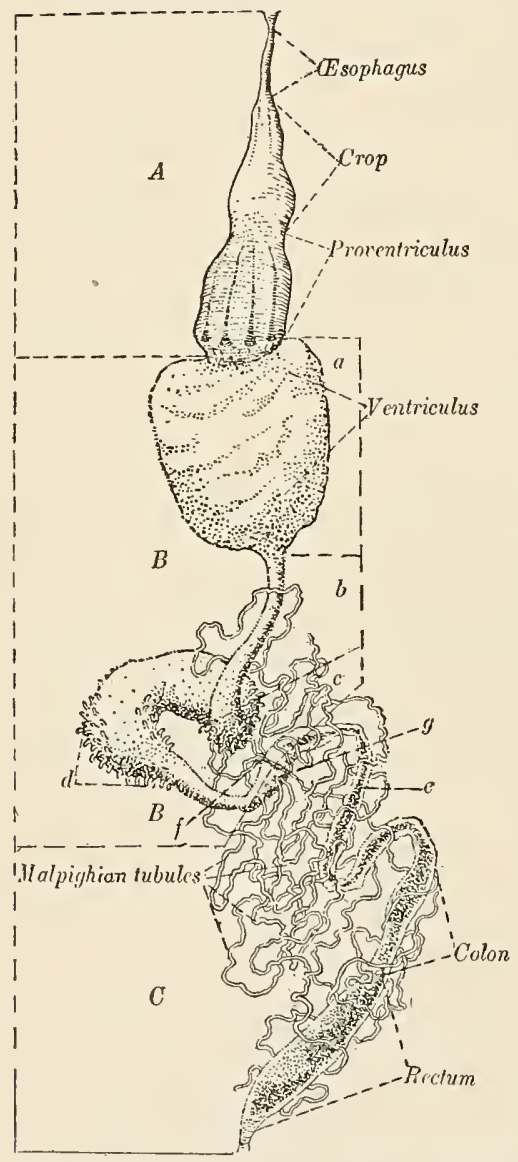

FIG. 35.-Dendroctonus valens: Digestive organs of adult. $A$, Fore intestine; $B$, mid intestine; $C$, hind intestine; $a$, anterior section of mid intestine; $b$, median section of mid intestine; $c$, posterior section of mid intestine; $d$, cœeal glands; $e$, ileum or small intestine; $f$, base of 4 malpighian tubes; $g$, base of 2 malpighian tubes. (Original.) and especially the structures and elements of the proventriculus and hypopharynx.

\section{SECONDARY SEXUAL CHARAC- TERS.}

While there are certain clearly defined secondary sexual characters in these beetles, they have not been recognized by other writers, and they were not found by the present writer until after much detailed study of the genus. When they were determined it was surprising how such prominent characters could have been overlooked. Thus we have another example of how thoroughly familiar one must be with a given group in order to recognize and properly interpret the significance of characters in structure, sculpture, vestiture, etc. In the first subdivision of the genus the females are distinguished by a transverse ridge across the anterior area of the pronotum, while the males are distinguished by the absence of this ridge and by more prominent frontal tubercles which are separated by a deeper frontal groove.

In the second subdivision the females are distinguished by the smoother and more shining elytral declivity. In the third subdivision the females have the elytral declivity distinctly more rugose, while that of the males is smooth and shining. Thus we have a reversal of the secondary sexual characters within the same genus, which is an unusual occurrence. 
In the fourth subdivision the sexes are more difficult to recognize, but the males are distinguished by stouter, more opaque mandibles, broader front, and by a narrower and more elongate antennal club. Whenever there is doubt as to the sex of an individual it can be settled by examining the pygal segments for the characters shown in figures 23 and 24 .

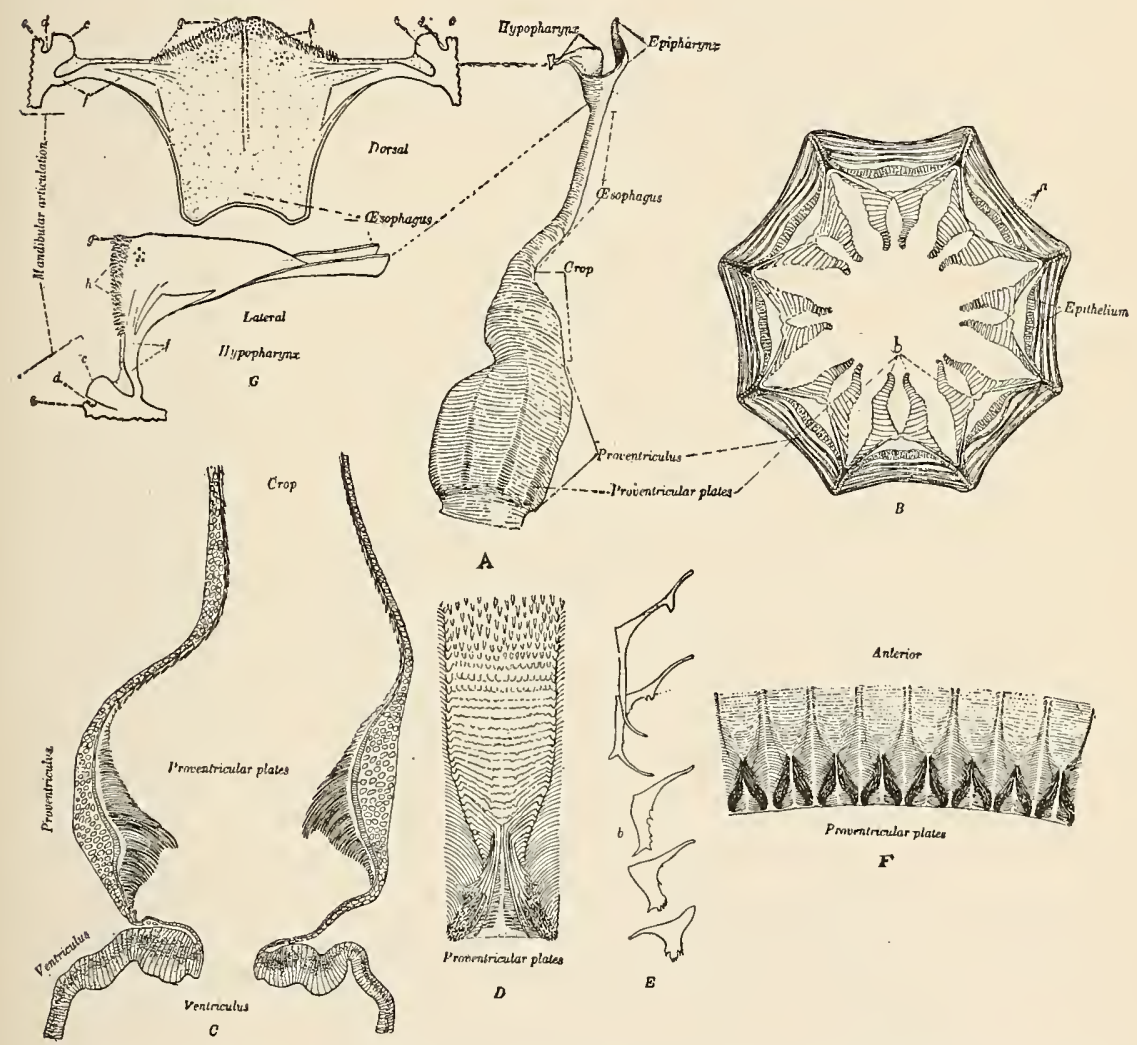

FIG. 36.-Dendroctonus valens: Fore intestine, showing details. $A$, Fore intestine; $B$, transverse section of proventriculus; $C$, longitudinal section of same; $D$, single plate; $E$, teeth; $F$, plates; $G$, hypopharynx; $a$, muscles; $b$, proventricular teeth; $c$, posterior condyle of mandibular articulation; $d$, median fossa of same; $e$, anterior condyle of same; $f$, hypopharyngeal bracon; $g$, anterior margin; $h$, hypopharyngeal papilli. (Original.)

\section{PUPA.}

The general structure, proportions, and anatomical details of the Dendroctonus pupa are shown in figures 37 and 38 .

Among the distinctive generic characters are the large prominent head and broad pronotum, while among the divisional and specific characters are the sculpture, armatures, etc., of the head, pronotum, elytra, and abdominal segments, as shown in the figures and defined in the synoptic tables and descriptions. 
Head.-The elements of the adult head recognizable in the young pupa are the antennæ, mandibles, maxillæe, labium, and what appears to be a well-developed labrum, which extends to the middle of the mandibles. Evidently, however, this does not represent the labrum or even the clypeus, but is a pad to accommodate the development of
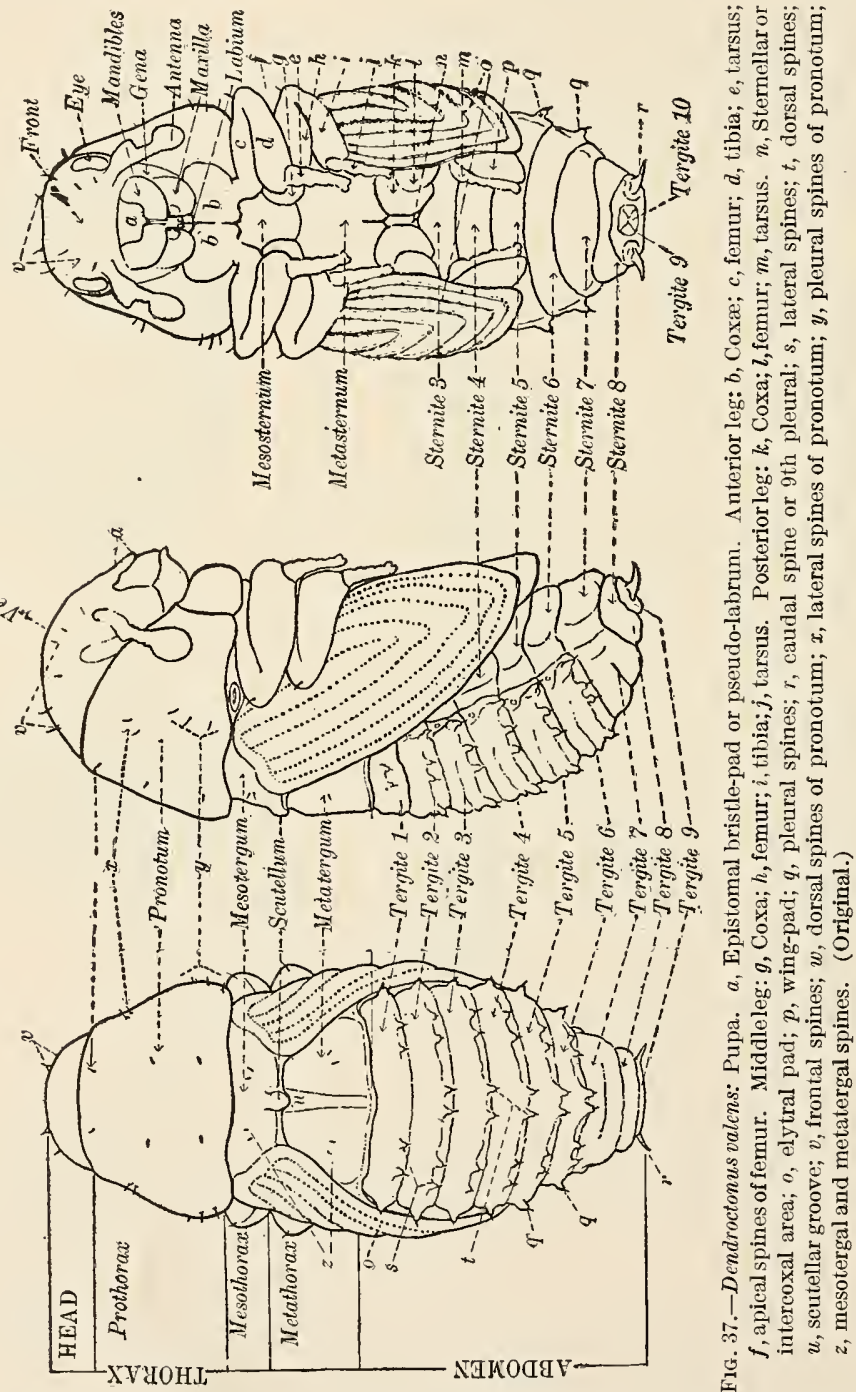

the long epistomal bristles. The frontal spines in examples representing different divisions and species are variable in size and position and are of considerable taxonomic importance. The antennæ do not extend to the base of the pronotum or scarcely beyond the mouth parts, and the club does not extend beyond the lateral margins of the pronotum. 
Prothorax-The form of the pronotum corresponds to that of the adult and its relative proportions are of some value in distinguishing the species. The number and position of the frontal spines are fairly constant in a species, although they vary in prominence with

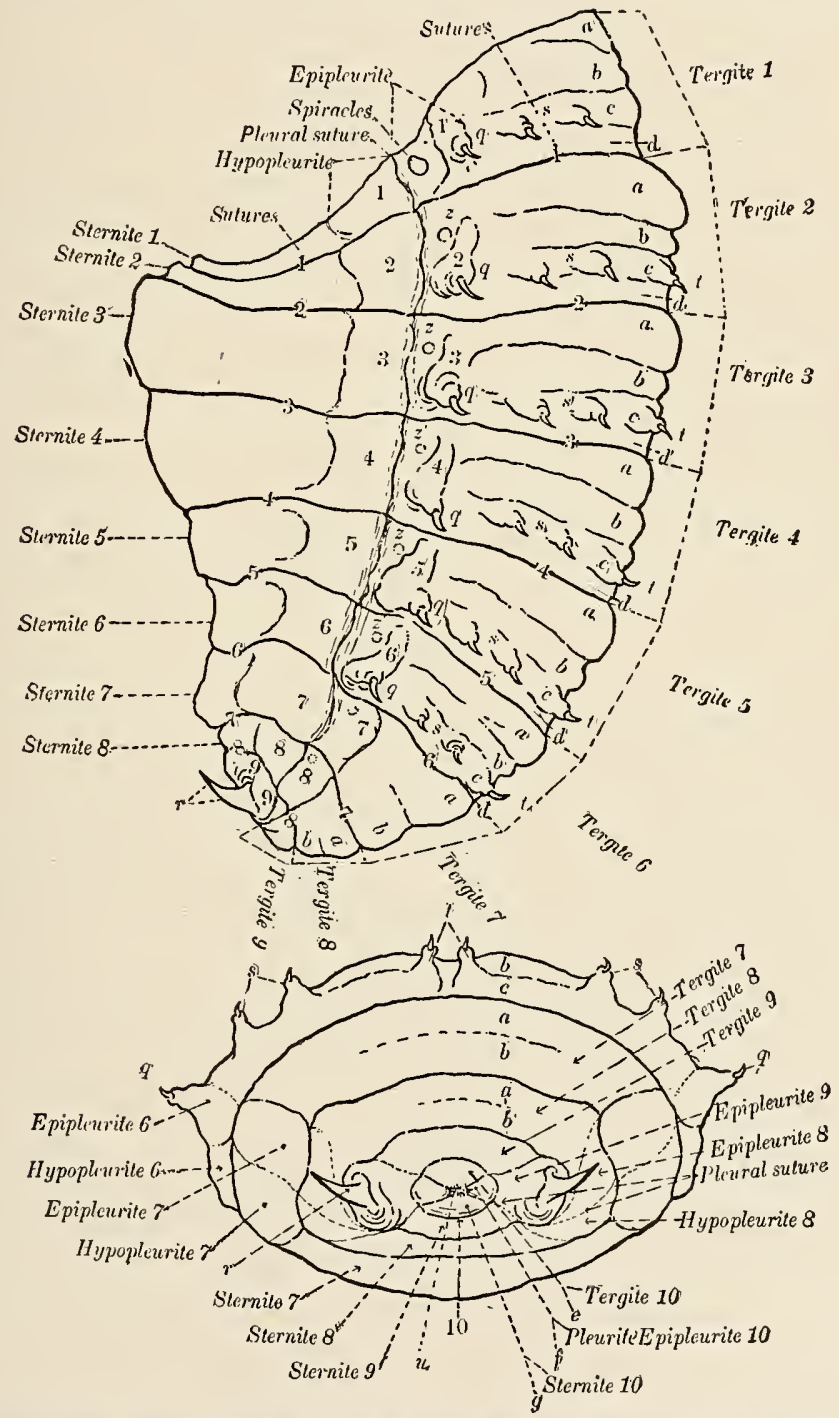

Fig. 38.-Dendroctonus valens: Abdomen of pupa, lateral and anal aspects. $a$, Prescutal lobe; $b$, scutal lobe; $c$, scutellar lobe; $d$, postscutellar area; $e$, supraanal lobe; $f$, paranal lobe; $g$, infraanal lobe; $q$, pleural spines; $r$, caudal spine or epipleural spine of the 9 th segment; $s$, lateral spines; $t$, dorsal spines; $u$, anal opening; 10, tenth segment. (Original.)

the age of the individual, as do other spines of the body, being much less prominent in the older or preimaginal stage.

Mesothorax.-The mesotergum is subrectangular and without special characters, except, perhaps, in the number and arrangement 
of the spines. The median process of the scutellum is prominent and the posterior or scutellar ridge is distinct. The base of the elytra is oblique and elevated, and its integument continuous with that of the tergum and scutellar ridge. The sternum is situated between the mesocoxæ and the trochantins of the prothoracic leg.

Metathorax.-The metatergum is prominent and has the usual dorsal or scutellar groove. The transverse posterior or scutellar ridge is distinct and joined at its ends with the basal angle of the wing pads. Each of the scutal lobes bears a pair of spines. It differs from the metatergum of the adult mainly in the absence of the prescutum and postscutellum, as defined by external elements.

Abdominal tergites (fig. 38). - There are nine tergites visible dorsally and a very small tenth visible ventrally. Tergites 3 to 6 are armed more or less distinctly with dorsal, lateral, and pleural spines. The dorsal spines are located each side of a narrow dorsal groove; the pleural spines on the epipleura posterior to the spiracles, and the lateral spines are situated between the dorsal and pleural. The size of the pleural spines and the size and number of the dorsal and lateral ones are quite variable and of considerable importance in defining the minor divisions. Tergites 7 and 8 are usually unarmed, but, as in the adults, show sexual differences in their relative prominence; 9 has the median lobe short, but the pleurites are greatly enlarged and each is armed with a prominent caudal spine.

The four transverse divisions of the segments are quite clearly indicated in tergites 1 to 6 . Tergites 7 and $\delta$ show two divisions, the first representing prescutal and the second the scutal and scutellar combined, while tergites 9 and 10 are undivided. It is interesting to note that the dorsal and pleural armatures are borne by what is evidently the scutellar division, and that the spiracles are in the prescutal division, thus indicating that the prescutal represents the first primary division and the combined scutal, scutellar, and postscutellar represent the second primary division.

Abdominal sternites.- There are eight exposed abdominal sternites. These are sternites 3 to 10,1 and 2 being concealed beneath the metacoxæ, as shown in figure 38 .

Abdominal pleurites.-Epipleurites and hypopleurites 1 to 8 are clearly defined in the removed abdomen (fig. 38), but in 9 and 10 only the epipleurites are represented, as indicated by the pleural suture. The pleural suture is distinct to the ninth segment, where it joins the lines marking the dorsal and ventral limits of the pleural division.

Spiracles. - There are nine spiracles in each side of the body, one large mesothoracic spiracle situated between the posterior lateral margin of the prothorax and the anterior ventral angle of the elytral pad, and eight abdominal ones, each in its respective epipleurite. 
The metathoracic spiracle is not represented. Spiracles 3 to 8 are exposed when the elytral pad is in normal position, but spiracles 7 and $S$ are very small and obscure. Thus the pupa has the same number of spiracles as the larva, while in the adult there is an additional one, although that of the eighth abdominal tergite is apparently rudimentary. The larva has one thoracic spiracle, apparently in the prothoracic segment. The pupa has one in the mesothoracic, and the adult has one in the mesothorax and one in the metathorax.

Legs. - The front and middle legs are exposed, while the hind legs are partially concealed beneath the elytra and wing pads. The front coxæ are large and contiguous, the anterior fourth covered by the maxillæ and labium, and the posterior margin extends over the anterior margin of the mesosternum. The middle coxæ are partially hidden by the apex of the front tibia and its tarsus. The hind coxæ are for the most part exposed, and distinctly separated by an intercoxal area. The positions of the different parts of the legs in their relation to the exposed structures are shown in figure 37, and are of considerable taxonomic importance. The apical and subapical spines of the femora are also of considerable importance as distinctive characters.

\section{LARVA.}

The structure and general characters of the larva are shown in figure 39. It is of the subcylindrical, wrinkled, legless type common to all of the true Rhynchophora, and also has the form of mouth parts characteristic of the larvæ of this suborder. There are three thoracic and ten abdominal segments, the tenth being represented by the anal lobes. The four longitudinal divisions, viz, one sternal, two pleural, and one tergal, are clearly represented in all of the segments. The tergal division occupies nearly one-half of the circumference, the two pleural divisions together about one-fourth, and the sternal division slightly more than one-fourth. The head is much narrower than the first thoracic segment and but slightly longer. The three thoracic segments together, or the thorax, is about one-third as long as the abdomen. With the exceptions of the scattering hairs on the head and on the scutellar lobes of the thoracic and abdominal segments, the body is without distinguishing vestiture.

EXTERNAL CHARACTERS.

Head (figs. 40, 41).- The head is by far the most important part of the body as a bearer of taxonomic characters in the larva. The general structure is shown in figure 40 , and the anatomical details in figures 41 and 42. All of the primary elements of the adult head are represented, but they are much more simple in their structural details. The more striking differences in the larval head are found in the 
presence of clearly defined front, clypeus, and labrum, in the articulation of the mandibles, and in their rudimentary hypostoma.

Labrum (figs. 40, 41).-The labrum is prominent, the dorsal area twice as broad as long, about one-third narrower than the clypeus, but nearly as long, with the apical margin broadly rounded, truncate

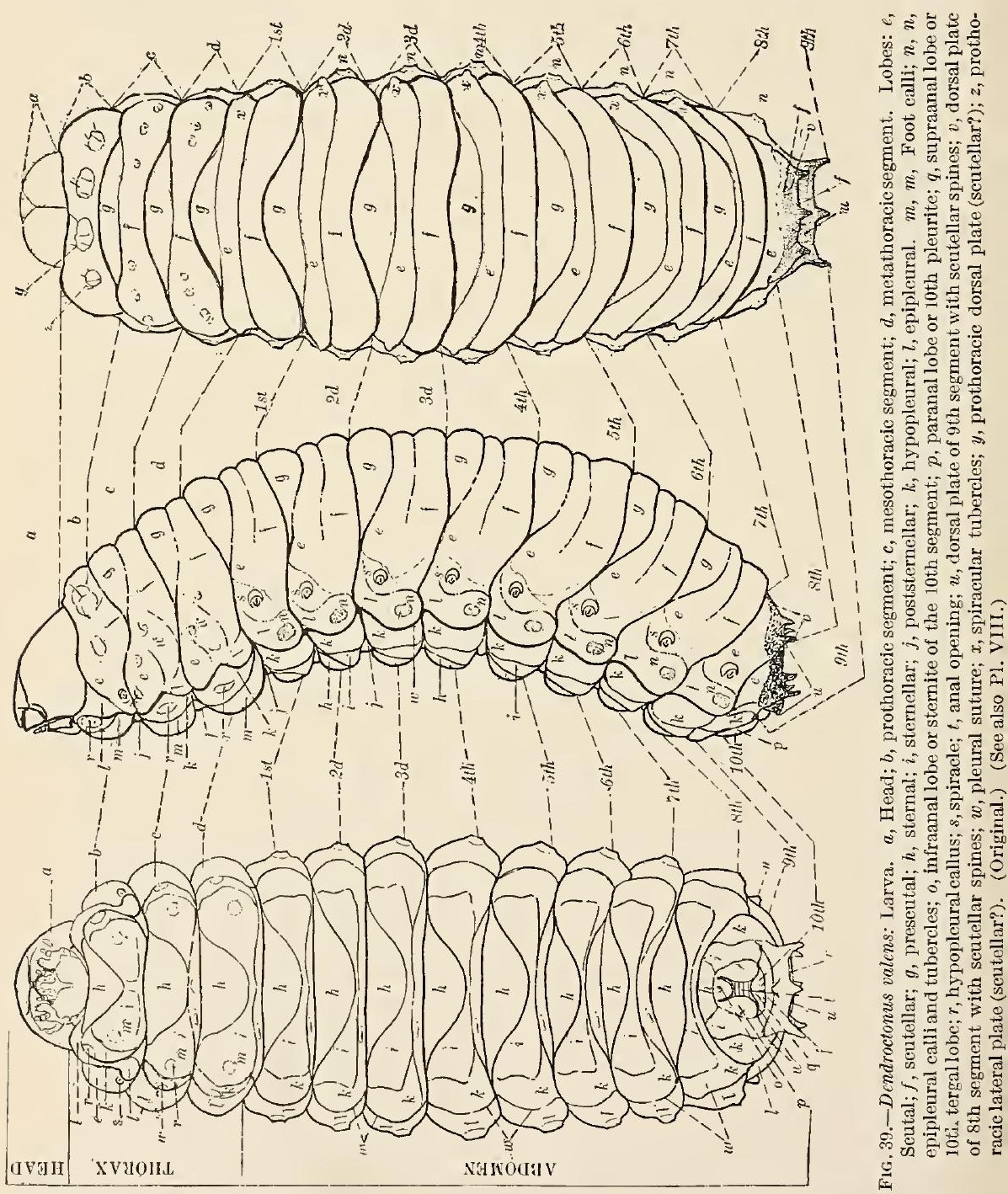

or faintly emarginate, and with several apical papillx. The median dorsal area bears several long hairs and two slightly elevated dark spots where the epipharyngeal bracons are attached. The latter somewhat resemble the mandibular hooks of dipterous larvæ, and may or may not represent paired elements of the head of a primitive arthropod. 
Whatever their origin may have been, the present function is to support the epipharynx and also serve as chitinous attachments for the depressor muscles of the labrum. They are covered by the epipharynx and extend down and back to the resophagus and to a point beneath the base of the clypeal area.
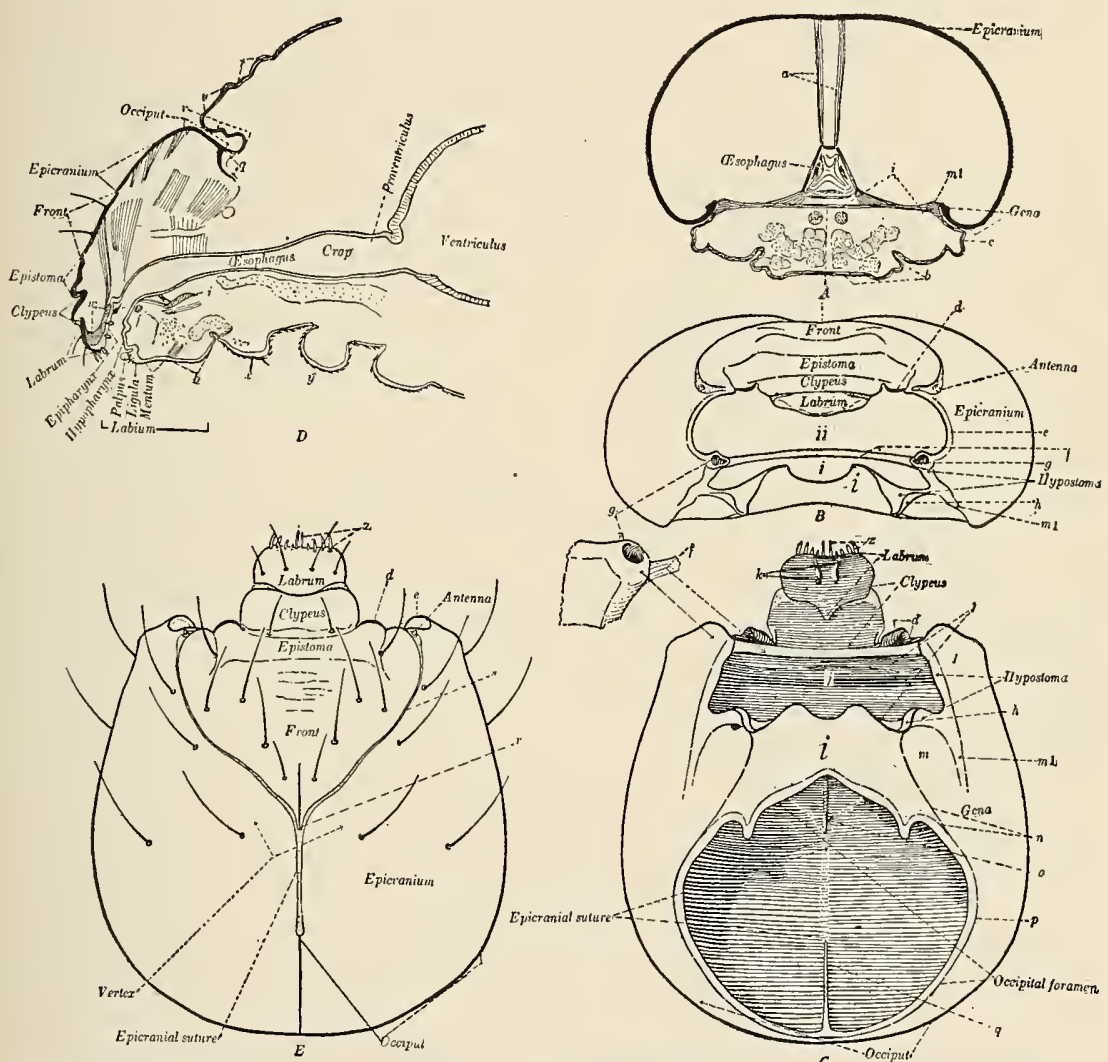
Epistoma.-The epistoma is quite clearly defined as a thickened transverse area between the clypeus and the frontal area. It does not extend laterally to the frontal sutures, but the ends, where they join the pleural ridge or pleurostoma, bear the condyles for the dorsal articulation of the mandibles. As in the adults, this area is quite vari-
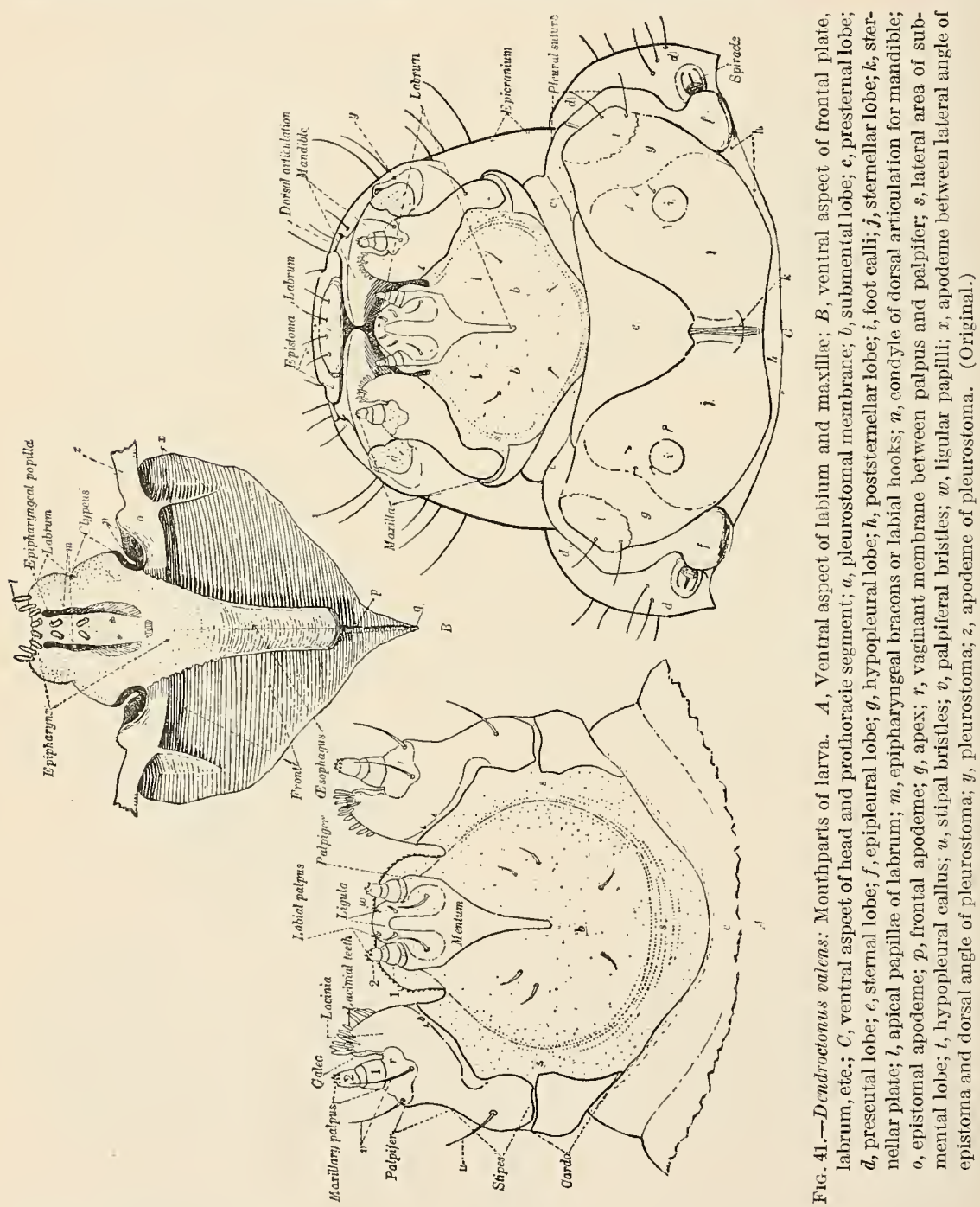

able within the genus. It is elevated to flat, with the anterior margin ranging from curved to nearly straight and the lateral angles elevated or slightly produced so as to form the rigid support for the dorsal condyles.

Hypostoma.-The hypostoma is not represented by an exposed piece, but by the apodeme which forms the thickened lateral and sub- 
lateral margins of the maxillary foramen. The anterior end supports the fossa $(g)$ of the ventral articulation for the mandible, and the ventral end supports the condyle for the articulation of the maxillary cardo. It is connected across the gular space by the entogular plate.

Pleurostoma (fig. $40, e$ ).-The pleurostoma is represented by the thickened lateral margin of the oral foramen. The dorsal end contributes to the rigid support of the dorsal articulation for the mandible and the ventral end to that of the ventral articulation.

Front.-The front is situated posterior to the epistoma and between two oblique sutures which converge from the anterior angles to the epicranial suture. The median area is quite variable within the genus. It may be flat and smooth to elevated. In the latter case it may be small, smooth, and convex, or prominent, transverse, and rugose.

Epicranium.-The epicranium is represented by the dorsal areas of the two large lobes each side of the distinct epicranial suture and frontal area. These lobes are continuous throughout the occipital and genal areas and accommodate the very large retractor muscles of the mandible. The genal areas are connected by the broad entogular plate.

Occipital foramen.-The occipital foramen is situated in the posterior ventral section of the head and occupies about one-half of the ventral area. It is bounded posteriorly and laterally by a broad entoccipital rim and anteriorly by a subchitinous rim. The occipital apodeme arises from the posterior margin, and extends anteriorly immediately beneath the epicranial suture.

Entogular plate (fig. $40, i$ ).-The entogular plate is the subchitinous plate which forms the entocranial connection between the genal areas and anteriorly between the lateral sections of the hypostoma. It is covered by the submental lobe, part of the muscles of which are attached to the posterior angles and posterior margin.

Maxillæ (fig. 41).-The maxillæ are quite simple in structural details. The cardo is present and distinct. Its basal articulation and attachment are by ligaments and a fossa to a condyle supported by the hypostomal apodeme. Its anterior attachment to the stipes is by articulating membrane. The median section is not divided into stipes, subgalea, and palpifer, but is one continuous piece with the anterior inner angle produced into a lacinial lobe which is armed with a number of papillæ situated on a membranous integument. The palpus is 2-jointed and telescopic as usual. The relative proportions, sculpture, and vestiture are shown in the figure.

Labium.-The labium of the larva is very different in structure from that of the adult. The submentum is represented by a lobe which is very broad and differs but slightly from the sternal lobe of the prothoracic segment with which its posterior integument is directly connected. The lateral integument is continuous with that 
of the maxilla and the anterior angles are extended forward to the base of the palpi. The mentum is represented by the median triangular chitinous plate, the posterior section of which is produced and narrowed, and the anterior median section is produced anteriorly between the palpi and supports the ligula. The short, conical, 2 -jointed palpi are situated on the anterior angles of the mentum and are scarcely longer than the simple lobelike ligula which bears a few simple papillæ.

Hypopharynx and epipharynx.-The position and character of these important elements of the oral opening are shown in figures $40, D$, and $41, B$.

Mandibles (fig. 42).--The mandibles are stout, with the laterodorsal surface rugose, except toward the apex, which is produced into an apical tooth; the inner edge toward the apex is provided with a subapical tooth and two small irregular medial teeth. The condyle of the ventral angle is globular and fits into the concave fossa (fig. 40, $g$ ) of the hypostoma, while in the dorsal articulation the fossa is borne by the mandible and the condyle by the epistoma (fig. $40, d$ ). The small extensor muscle is attached to the outer basal margin midway between the condyles, while the large and powerful retractor muscle is attached to the margin of the more produced inner angle, thus giving a direct lateral motion to the mandibles.

Tergites (fig. 39).- The dorsal area of the tergum of the prothoracic segment is undivided, but evidently represents the scutum $(e)$ and scutellum $(f)$. The dorsal area of the mesothoracic and metathoracic segments has two divisions. The anterior division evidently represents the prescutal lobe $(g)$. There is evidence of a scutal lobe $(e)$ on the lateral area of both segments, as indicated in the abdominal tergites, where the scutal lobe appears between the anterior and the posterior lobe. Thus the latter evidently represents the scutellar division, or scutellar lobe $(f)$.

Sternites.-The sternum of each of the segments has three sections, anterior, median, and posterior, or sternal $(h)$, sternellar $(i)$, and poststernellar $(j)$. In the thoracic segments the sternal is the larger and projects posteriorly over the middle of the sternellar lobe, which is represented by a coxal lobe each side of the sternal section. In some of the species these lobes have a median chitinous spot or foot callus at the point where a foot occurs in the legged larvæ of other Coleoptera. The abdominal sternites have the same number of sections, but the sternellar section is not covered by the sternal.

Pleurites.-The pleurum of each segment is divided longitudinally by an irregular pleural groove or suture $(w)$. The lobe immediately below the groove at the end of the sternites may be referred to as the hypopleural $(k)$ and that immediately above it as the epipleural $(l)$. The hypopleura of the thoracic segments represent the episternum, 
and the epimerum is obscurely represented by the epipleura, both of which are but little, if at all, different from those of the abdomen. The epipleural lobe of the prothoracic segment has a spiracle, while those of the mesothoracic and metathoracic segments are without a spiracle, but has lateral lobes or areas for the embryonic wing.

Spiracles.-It will be noted in figure 39 and Plate VIII that the prothoracic segment has a spiracle situated on the epipleurite near

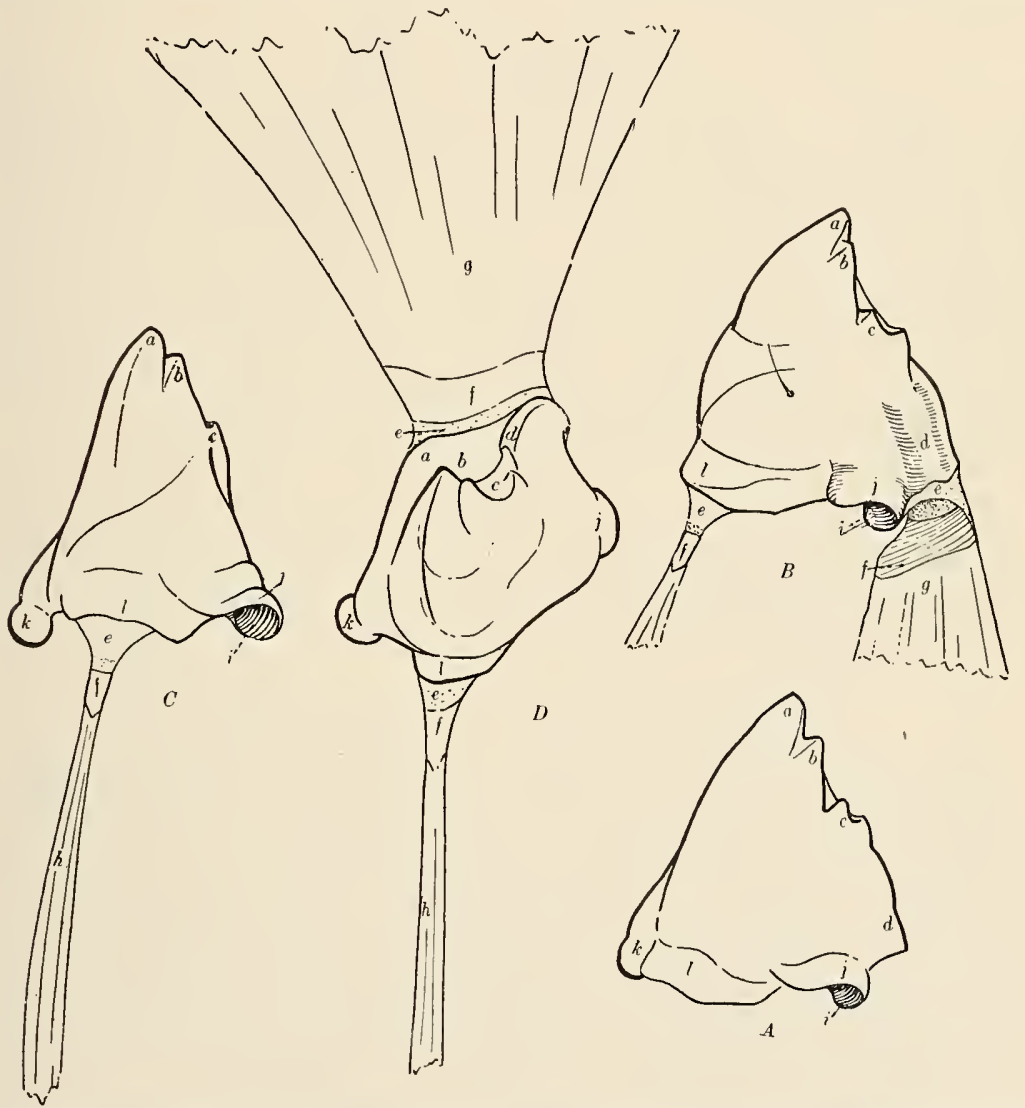

FIG.42.-Dendroctonus valens: Mandibles of larva. $A$, Latero-dorsal aspect; $B$, dorsal aspect; $C$, lateral aspect; $D$, apical aspect; $a$, apical tooth; $b$, subapical tooth; $c$, median tooth; $d$, molar tooth; $\epsilon$, extensor tendon; $f$, retractor muscle disk; $g$, retractor muscle; $h$, extensor muscle; $i$, dorsal fossa; $j$, dorsal condyle; $k$, ventral condyle; $l$, basal ridge. (Original.)

the epipleurite of the mesothoracic segment. The writer is not certain as to whether or not this really belongs to the prothoracic segment or, as in the abdomen, to the anterior or prescutal division of the mesothoracic segment. The metathoracic segment is plainly without spiracles, but the abdominal segments 1 to 8 , inclusive, have spiracles which are more or less distinct, being rather obscure in the first division and in section a3 (see PI. I) and without lateral tubercles, while in section a 4 and subdivision $\mathrm{D}$ both the spiracles and 
spiracular tubercles (Plate VIII) are distinct. The ninth segment is without spiracles.

Chitinous plates.-In some species (division I) there are no distinct chitinous plates or tubercles, while in others, section a4 and subdivision D, they are present and, excepting Dendroctonus micans, become more distinct toward and including subdivision $\mathrm{D}$, in which the dorsal plates of the eighth and ninth abdominal segments are distinctly armed.

\section{DIGESTIVE SYSTEM.}

The peculiar characters of the digestive system of the larva are illustrated in figure 43, showing, at right, a median longitudinal section through the body from the oral to the anal opening. In every respect the anatomical details of the digestive system are much more simple in the larva than in the adult. The same primary divisions of fore, middle, and hind intestine are represented and there is the same number of malpighian tubes, but the fore intestine is very simple as compared with that of the adult, the crop and proventriculus being scarcely different in general details from the œsophagus.

\section{EGGS.}

The eggs of Deudroctonus have not been studied in detail, but they are short, oval to oblong-oval, pearly white and shining, and apparently without distinctive generic or specific characters.

\section{PHYSIOLOGICAL CHARACTERISTICS.}

In addition to the morphological characters which serve to distinguish the genus, there are certain physiological characteristics peculiar to the specios of the genus which serve as additional evidence of distinction. Indeed, it becomes more and more evident that a correct interpretation of natural groups of individuals, termed species, and natural groups of species, termed genera, must be based not alone on a common plan of structure or similarity in one or more anatomical elements, but that, in order to come nearer the truth, the morphologic evidence of specific distinction must be supplemented by physiologic and bionomic evidence. Some of the physiological features common to the species of this genus, and more or less peculiar to them, are found in the character of their brood galleries, in their habit of attacking living trees, in their concentration of effort to overcome the resistance exerted by the tree attacked, and especially by their ability to manipulate and to dispose of the quantities of resin which flow into their burrows in the living bast and cambium; lastly, in their intimate bionomic relations to definite genera and species of conifers. ${ }^{a}$

a See, also, physiological characteristics of the species, as given in the forthcoming Bulletin No. 83, Part I, which deals with the bionomic and economic features, and other characteristics peculiar to the major and minor divisions as defined in the synoptic tables of galleries, host trees, and distribution in the present paper (pp. 76-79). 


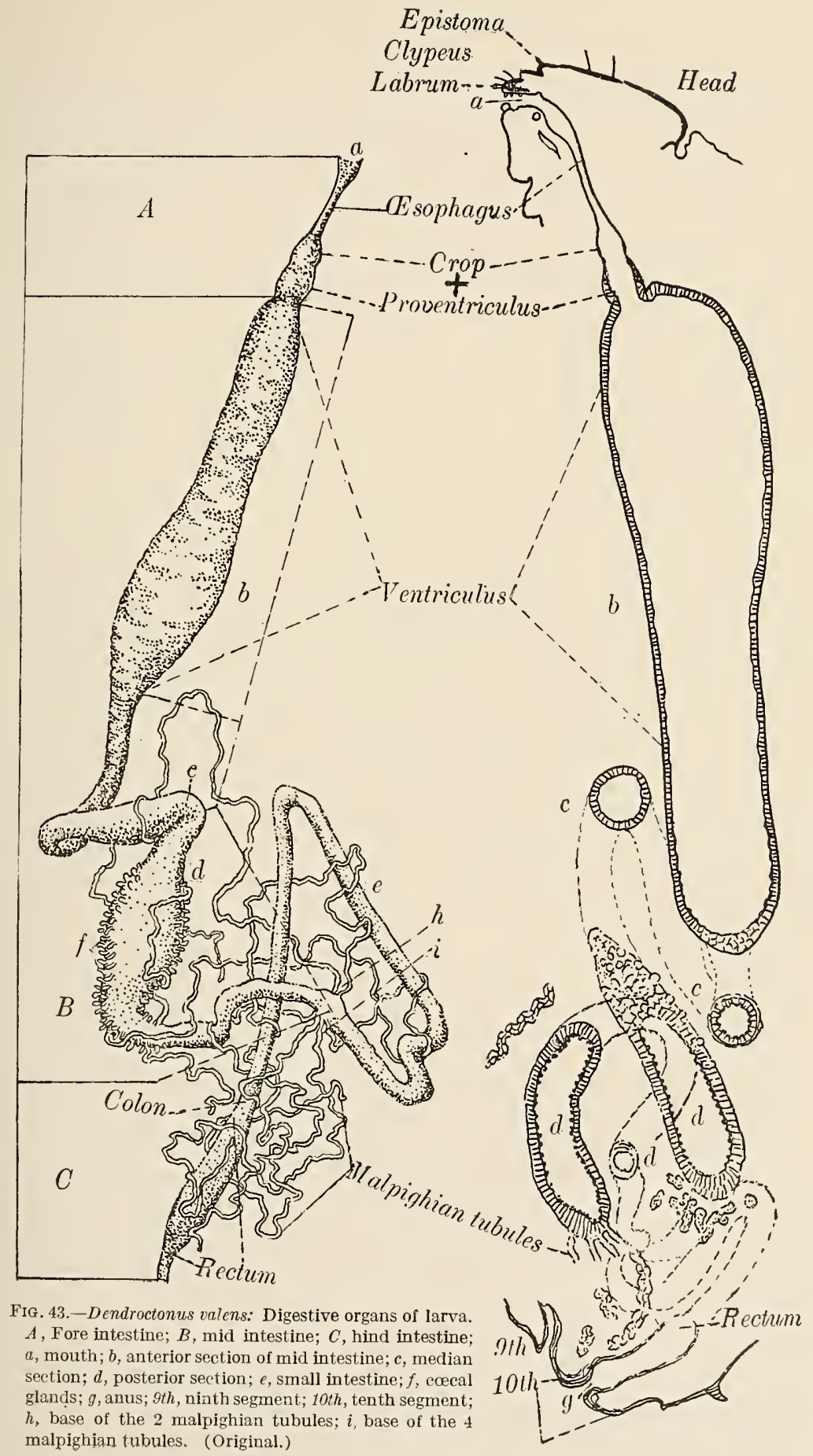




\section{SPECIFIC DISTINCTIONS.}

In the literature on Scolytidæe, and, for that matter, on almost any group of insects of special systematic and economic importance, there is much confusion, due to different interpretations of specific distinction. Some authors have combined many described species into one, while others have recognized many distinct forms among those heretofore included in one species, and have proposed as many different names for them. It is evident that whenever "lumping" or "splitting" is necessary for the clear definition and recognition of a species it should be done, but it is equally evident that neither should be attempted without an adequate knowledge of at least the genus represented, in order that the true characters of specific distinction may be recognized from those which serve to distinguish the genus or the major and minor divisions of higher rank than the species.

\section{RANGE OR LIMITS OF SPECIFIC VARIATION.}

The determination of the range or limits of variation in characters utilized for the distinction of a species is one of the most troublesome questions with which the systematist has to deal. With one or a few specimens the line separating one recognized species from another may be distinct and definite, but as the number of specimens from different localities increases the line of distinction from allied forms often becomes less and less distinct until it is almost or quite obscure. Here is where expert judgment, based on experience and a technical knowledge of the special group involved, is required in order to decide whether or not two heretofore recognized and closely allied species should be kept separate or be combined. The recognition of prevailing variants or constants, or of forms having abnormal or normal morphologic and physiologic characters, is of special importance in this connection, as is also the recognition of the disturbing factor of parallel modification in characters and habits among species of the same genus, as well as among those of different genera.

If the variants connecting two allied groups comprise only a small percentage of the individuals, they may be considered as departures from the constants of the species more nearly represented, and thus the groups so slightly connected will serve the purposes and requirements of species and neither of them should, in the writer's opinion, be designated as a named subspecies, race, or variety; but if, on the other hand, the connecting variants comprise a large percentage of individuals, and no other characters sufficiently distinct and constant can be found by which individuals may be readily referred to one or the other of the heretofore recognized species, it would indicate that the two are not specifically distinct. 


\section{PROGRESSIVE MODIFICATIONS.}

The writer has been forcibly impressed with the prevailing principle of progressive modification in relative proportions in form and structural details in scolytid and other beetles. Whenever these modifications in relative proportions are available for the statistical method of analysis it is often possible to express in numbers the difference between species and to indicate clearly the lines of modification and rates of departure among the species of a genus or larger group.

There are some good examples of this principle of progressive modification in the genus Dendroctonus, which is manifested not alone in the adults, but in the pupæ, larvæ, and character of work, and it is most interesting and significant to note that the modifications are in the same general direction in all cases. When the species are arranged in the order indicated by these modifications and other characters, the species of the first division to the last of those of the second division are found to be modified from small to larger size, the extremes being represented by $D$. frontalis, with the minimum length of $2.5 \mathrm{~mm}$., to $D$. valens, with the maximum length of 9 $\mathrm{mm}$. Naturally we find the same rate of difference in size of the immature stages and galleries. This same tendency toward increased size is manifested within each subdivision, section, or minor group of allied forms and appears to be a prevailing principle throughout the Scolytidæ, and thus serves, in connection with other lines of modification, as one of the first guides to a natural arrangement or classification of the species. In Dendroctonus the progressive modification of characters other than size is shown or indicated as follows:

Progressive Modification of Characters in the Genus Dendroctonus.

ADULTS.

Primary characters.

Body slender to stouter.

Head large to smaller.

Prothorax long to shorter.

Pronotum with sides nearly parallel to distinctly narrowed or constricted anteriorly.

Pronotum as broad as elytra to narrower.

(A mean composite ratio of the above gives a number which expresses the relative proportions and serves as a species index.)

Front grooved and tuberculate to convex and smooth.

Elytra without long hairs to long hairs over entire surface.

Tibia from slender to broader with a tendency to dilate toward the apex.

Funiculus of antenna with second joint long to shorter.

\section{Secondary sexual characters.}

Front of head with sexual differences to similar or alike in both sexes.

Pronotum with sexual differences to alike in both sexes.

Elytral declivity without sexual differences to distinct differences.

Declivity rugosities small to coarse, smooth in female to coarse in male or reversed.

Mandibles alike or similar in both sexes, to much stouter in the male.

79980-09-6 
PUPAE.

Front of head grooved to convex.

Body spines small to coarse.

\section{LARVA.}

Body simple, without chitinous plates or hairs, to distinct chitinous plates and more prominent hairs.

Eighth and ninth abdominal segments without chitinous plates to with plates, these last unarmed to armed.

Spiracles simple to complex, smooth to tuberculate.

Epipleurites without tubercle, to prominent tubercle.

GALLERIES.

Long and winding to short and straight.

Eggs isolated to grouped and massed.

Larval mines hidden to exposed and short to long:

HOSTS。

From one genus to many genera, and from one species to many species.

D. brevicomis is found in pine only, while D. valens infests Pinus, Picea, and Larix; D. simplex infests Larix only, and D. pseudotsugre infests Pseudotsuga and Larix.

\section{DISTINCTION OF MAJOR AND MINOR DIVISIONS OF THE GENUS.}

In a comparative study of the species of the genus to determine their relative positions, as indicated by degrees of resemblance or difference, they are found to fall according to progressive modification of characters into major and minor divisions, which may be designated as divisions, subdivisions, sections, subsections, series, and subseries, to the smallest practicable minor division of the genus, viz, the species.

In this classification of the genus the rank of a primary division may be that of the subgenus of some authors and the lower series of closely allied species may be recognized by some systematists as occupying the rank of subspecies, races, or varieties; but the writer has been guided by the belief that the principle of a less restricted range of generic and more restricted range of specific distinction will contribute toward a more correct knowledge of the forms of life than if the reverse principle is followed.

The classification of the species of a genus into major and minor divisions is necessarily arbitrary, and is subject to changes as may be suggested by increased knowledge and the addition of species. To a more limited extent, the designation of a species is arbitrary and with additional material and information is subject to revision; but since the species, next to the individual, is the constant or unit of classification and investigation, it should represent the lowest practical division of a genus that is recognizable from a description of a typical form or by comparison with the type on which the description was based. 


\section{PLAN OF SYNOPTIC TREATMENT.}

The plan here applied for the classification and synoptic treatment of the species of the genus is one which appears to be most available and practicable for the clear definition of the progressive modification of taxonomic characters and for indicating the relative systematic positions and limits of the major and minor divisions and the species. It is not radically different from some of the more generally adopted dichotomous systems, and it conforms to the primary objects of a synopsis in that it provides $(a)$ for a direct comparison of opposing characters, (b) for a direct line of references leading down to the specific characters, or vice versa.

With this method of indicating the supposed natural relation of the species, the described characters of the major and minor divisions and sections, together with those of specific distinction, serve as a description of the species. Thus, division I, subdivision $A$, section a2, subsection b2, series $\mathrm{c} 2$, defines the characters common to species 6,7 , and 8 , which are separated by their respective specific characters. Some additional advantages of this method are the consecutive arrangement of letters and figures which throughout a given table are not duplicated. The Roman numerals indicate at once the primary divisions, the capital letters the subdivisions, and the combined small letter and Arabic numeral the sections, subsections, series, etc., to any desired limit. The reference from right margin to center, instead of to left margin, is also an advantage in defining the limits of a major and minor division. It also provides for full paragraphs, thus econonizing space and cost of printing.

\section{SYNOPSES OF MORPHOLOGICAL AND PHYSIOLOGICAL CHARACTERS.}

\section{SYNOPSIS OF ADULT CHARACTERS.}

Pronotum somewhat elongate and as broad as elytra; not distinctly narrowed anteriorly except in subdivision $\mathrm{B}$; anterior dorsal half of elytra without long hairs.

Division I, pages 69, 81 .

Pronotum stout; usually narrower than elytra, and distinctly narrowed and constricted anteriorly; anterior dorsal half of elytra normally with long hairs, except in tere-

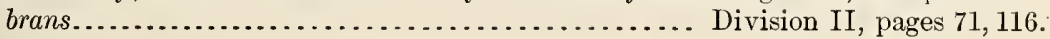

\section{DIVISION I.}

Body somewhat slender, pronotum but slightly narrowed anteriorly; elytral declivity with second stria straight, second interspace not distinctly broader or narrowed toward apex; head with frontal groove and tubercles except in convexifrons.

Subdivision A, pages 69,81 .

Body stout; pronotum distinctly narrowed and constricted anteriorly; elytral declivity with second stria curved, second interspace broad and distinctly narrowed toward apex; head without frontal tubercles or groove.

Subdivision B, pages 71, 105.

Subdivision A.

Elytral declivity without long hairs.

Section al, page 70

Elytral declivity with long hairs.

Section a:, page 70 . 


\section{Section a1.}

Length 3 to $5 \mathrm{~mm}$., brownish to nearly black; elytral rugosities fine, densely placed, the striæ obscure and but slightly or not at all impressed. California, Oregon, Washington, and Idaho, in Pinus................. 1. brevicomis Lec., page 81. Length 2.5 to $4.7 \mathrm{~mm}$., brownish to black; elytral striæ moderately to distinctly impressed; interspacial rugosities moderately coarse and obtuse to coarse and acute. Arizona, New Mexico, southern Colorado, southern Utah, and southern California. 2. barberi n. sp., page 85 .

\section{Section a2.}

Head without frontal tubercles or groove, but with posterior impression.

Subsection b1, page 70 .

Head with more or less prominent frontal tubercles each side of a distinct median

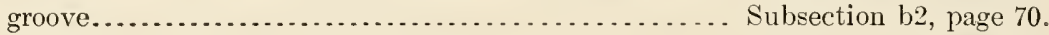

\section{Subsection $b 1$.}

Length 4 to $6 \mathrm{~mm}$; ; reddish-brown to black, shining; body slender; elytral rugosities moderately coarse but not densely placed, except toward base, the striæ faintly impressed, with rather coarse indistinct punctures; pronotum with long, erect hairs on the entire lateral area; declivity shining. Arizona, New Mexico, southern Colorado, and southern Utah, in Pinus..... 3. convexifrons n. sp., page 87.

Subsection b2.

Elytral striæ distinctly punctured........................ Series c1, page 70 . Elytral striæ not distinctly punctured................... Series c2, page 70 .

\section{Series 1 .}

Length 2.5 to $4 \mathrm{~mm}$.; brownish to black; elytral rugosities obtuse, moderately coarse, not very densely placed, and but moderately coarser toward the base and vertex than elsewhere; pronotum usually with a few long hairs on the anterior section of the lateral area. Pennsylvania to Florida, westward to Ohio and Texas, in Pinus and Picea......................... 4. frontalis Zimm., page 90 .

Length 4 to $5 \mathrm{~mm}$; brownish to black; elytral rugosities subacute, moderately coarse and distinctly coarser toward the base and vertex; pronotum with Iong erect hairs on the anterior half of the lateral areas; elytra with long hairs confined to declivity and posterior areas. Central Arizona, in Pinus... 5. arizonicus n. sp., page 95 .

Series $\mathrm{c}$.

Striæ distinctly impressed.

Length 3 to $4.5 \mathrm{~mm}$; brownish to black; elytral rugosities distinctly coarser toward the base and vertex, and with an evident row of acute rugosities on the first interspace; pronotum clothed with stout reclining hairs and the entire lateral area with long, erect hairs; elytral striæ moderately distinct. Southern Mexico, in Pinus....................... 6. mexicanus Hopk., page 97.

Striæ not distinctly impressed.

Length 5 to $6 \mathrm{~mm}$; black; elytral rugosities obtuse, rather densely placed, moderately coarse toward dorsal suture, fine and less evident toward side; striæ obscure, especially on the side; pronotum distinctly pubescent, with very long erect hairs on the entire lateral area; punctures moderately coarse. Southern Mexico, in Pinus.................... 7. parallelocollis Chap., page 99.

Length 4 to $7.4 \mathrm{~mm}$; black; elytral rugosities rather coarse and sparse; the strix toward the side rather distinct; pronotum moderately pubescent, with long hairs on the anterior two-thirds of the lateral area; punctures usually fine. Arizona, New Mexico, southern Colorado, and Utah, in Pinus.

8. approximatus Dietz, page 101. 


\section{Subdivision $B$.}

Pronotum with deep punctures.

Length 3.7 to $6.4 \mathrm{~mm}$.; brownish to black; elytra with striæ moderately impressed. punctures usually small or moderately coarse and distinct. North and west of northwestern Colorado, southward to Yosemite National Park, Caliionnia, in Pinus .............................. 9. monticolæ Hopk., page 105.

Length 4.5 to $7 \mathrm{~mm}$; black; elytral striæ distinctly impressed, punctures distinct and coarse. Black Hills, South Dakota, southward through Colorado and southern Utah, into New Mexico and Arizona, in Pinus and Picea.

10. ponderosæ Hopk., page 109.

Pronotum with small shallow punctures.

Length 6 to $8 \mathrm{~mm}$.; black; punctures of elytral striæ distinct throughout; pronotum distinctly shining. Yosemite National Park, California, in Pinus jeffreyi and P. ponderosa......................... 11. jeffreyi n. sp., page 114 .

\section{DIVISION II.}

Front usually with posterior impression; pronotum with large and small punctures intermixed . . ..................... Subdivision C, pages 71,117 .

Front without posterior impression; pronotum with regular punctures.

Subdivision D, pages 72, 146.

\section{Subdivision C.}

Elytral declivity with striæ deeply impressed; epistomal process narrow, flat, with lateral sections nearly parallel; pronotum with punctures moderately regular, and with long hairs on dorsal and lateral areas......... Section a3, page 71 .

Elytral declivity with striæ not deeply impressed; epistomal process broad, concave, and the lateral sections oblique; punctures of pronotum distinctly irregular.

\section{Section a. .}

Section a4, page 71 .

Pronotum with coarse punctures.

Length 3.5 to $5 \mathrm{~mm}$; reddish to brown; pronotum with short dorsal and lateral hairs; apex of epistomal process not extending beyond the anterior frontal margin. New Brunswick to Michigan and West Virginia, in Larix.

Pronotum with fine, shallow punctures.

12. simplex Lec., page 117.

Length 4 to $7 \mathrm{~mm}$; reddish to dark brown; pronotum shining, with long dorsal and lateral hairs; apex of epistomal process usually extending beyond the anterior margin of epistoma. British Columbia southward to Texas, westward to California, in Pseudotsuga and Larix..... 13. pseudotsugæ Hopk., page 121.

Section $a$ 4.

Posterior half of proepisternal area not distinctly punctured. Subsection b3, page 71 . Posterior half of proepisternal area distinctly punctured.... Subsection b4, page 72 .

\section{Subsection b3.}

Length 4.7 to $6 \mathrm{~mm}$; body stout; reddish to black; elytral striæ quite distinctly impressed toward sides, with punctures coarse and distinct; interspaces convex; rugosities acute, rather closely placed, irregular. New Brunswick, through Canada, New England, and Michigan, in Picea ... 14. piceaperda Hopk., page 126.

Length 5 to $7 \mathrm{~mm}$; reddish to black, shining; punctures of prothorax and elytra coarser; striæ of lateral area not distinctly impressed, the interspaces scarcely convex or rugose. Idaho and Black Hills, South Dakota, to New Mexico and westward to California, in Picea.......... 15. engelmanni n. sp., page 130 . 
Length $6 \mathrm{~mm}$; elytra reddish; pronotum darker; elytral striæ moderately impressed, punctures of striæ of dorsal area small, obscure, and those of the lateral area moderately coarse; interspaces flat, with rugosities moderately coarse, obtuse, and rather densely placed; pronotum with punctures more regular in size than usual. Alaska........................... 16. borealis n. sp., page 133 .

Length 6 to $7 \mathrm{~mm}$.; black; elytral striæ but faintly impressed; punctures rather coarse; interspaces flat; rugosities moderately coarse, not dense, acute toward vertex; pronotum with fine punctures, moderately dense, coarser toward sides. Pacific coast, Oregon to Sitka, in Picea sitchensis ........ 17. obesus (Mann.), page 135.

\section{Subsection 64 .}

Striæ of declivity with fine punctures..................... Series c3, page 72 . Striæ of declivity with coarse punctures................... Series c4, page 72 .

\section{Series c3.}

Length 5 to $7.3 \mathrm{~mm}$.; elytra red; pronotum brown to black; body rather stout; elytral striæ scarcely impressed, except on dorsal area; strial punctures moderately coarse; rugosities of interspaces moderately coarse, acute, not dense; pronotal punctures coarse, deep, moderately dense; elytral declivity with interspaces moderately punctured. Lake Superior, in Pinus strobus.

18. rufipennis (Kirby), page 138 .

Length 5.4 to $6.5 \mathrm{~mm}$.; elytra dark reddish; pronotum dark; body somewhat slender, as compared with species 18; elytral striæ moderately impressed; punctures coarse, shallow; pronotal punctures coarse, not distinctly irregular and moderately dense; elytral declivity with interspaces finely densely produced. Yellowstone National Park and Keystone, Wyoming; Alberta, and British Columbia, in Pinus ......................... 19. murrayanæ n. sp., page 140.

\section{Series c4.}

Length $6.5 \mathrm{~mm}$; brownish; elytral striæ impressed; punctures coarse, interspaces narrow and moderately coarse, acute, rugosities coarser toward the suture. New York to West Virginia, in Picea............ 20. punctatas Lec., page 142.

Length 7 to $8 \mathrm{~mm}$; brownish; elytral striæ not impressed on dorsal or lateral areas, punctures moderately coarse, shallow; interspaces broad, flat, shining; rugosities small, obtuse, sparse. Europe, etc., in Picea, Larix,? and Abies?

21. micans (Kug.), page 143 .

\section{Subdivision D.}

Pronotum somewhat elongate, slightly narrower than elytra, moderately constricted toward head, median and posterior dorsal areas without long hairs, but hairs present on anterior and lateral areas; head broad, epistomal process usually broad, concave, with sides strongly oblique; elytral rugosities variable, usually coarse. Body black.

Length 5 to $8 \mathrm{~mm}$; black; epistomal process moderately broad, with apical angles usually tuberculate; pronotal punctures very coarse, regular, moderately dense, scarcely decreasing in size toward base; elytra without long hairs toward base. Long Island, New York, south to Florida, west to West Virginia and Texas, in Pinus ....................... 22. terebrans (Oliv.), page 147. Body reddish.

Length 5.7 to $9 \mathrm{~mm}$; reddish, never black; epistomal process broad, with apical angles obtuse, never tuberculate; pronotum with punctures smaller and denser toward base; elytra with long hairs toward base. Eastern United States and Canada, north of mountains of North Carolina, westward to Pacific coast, south from British Columbia into Mexico, in Pinus and Picea.

23. valens Lec., page 151. 


\section{SYNOPSIS OF SECONDARY SEXUAL CHARACTERS.}

\section{DIVISION I.}

Females: Anterior pronotal area with transverse ridge ........... Subdivision A.

Females: Anterior pronotal area without transverse ridge.......... Subdivision B.

\section{Subdivision A.}

Females: With transverse ridge across the anterior area; elytral declivity slightly smoother, more shining, and less rugose............. Species 1 to 8 , inclusive. Males: Without transverse ridge across the anterior area, but with broad impression.

Species 1 to 8, inclusive.

\section{Subdivision B.}

Females: Elytral declivity with interspaces more shining, rugosities less prominent. Species 9 to 11, inclusive. Males: Elytral declivity with interspaces more opaque, rugosities more prominent. Species 9 to 11, inclusive.

\section{DIVISION II.}

Elytral declivity with distinct sexual characters in both sexes...... Subdivision C. Elytral declivity without distinct sexual characters in either sex.... Subdivision D.

\section{Subdivision C.}

Females: Interspaces of elytral declivity rugose. Nales: Interspaces of elytral declivity smooth.

Striæ of elytral declivity impressed; interspaces convex in both sexes.

Section a3, Species 12 and 13.

Striæ of elytral declivity not impressed; interspaces flat............. Section a4.

\section{Section a4.}

Females: Striæ of elytral declivity slightly impressed; interspaces subconvex.

Species 14 to 21 , inclusive.

Males: Striæ of elytral declivity not impressed; interspaces flat.

Specier 14 to 17 , inclusive.

Males: Striæ of elytral declivity slightly impressed; interspaces subconvex, but smoother than in female........................ Species 18 to 21 , inclusive.

\section{Subdivision D.}

Females: Head with front moderately broad; mandibles shining, moderately stout; antennal club broader........................... Species 22 and 23 .

Males: Head with front broad; mandibles opaque, stout; antennal club narrow, more elongate and less compressed...................... Species 22 and 23.

\section{SYNOPSIS OF PUPAL CHARACTERS.}

Vertex of head distinctly to faintly grooved, and with two small or prominent frontal spines on or toward the vertex each side of groove............... Division I.

Vertex of head faintly impressed, flat or convex, and with two small, widely separated frontal granules toward vertex........................ Division II.

\section{DIVISION I.}

Frontal spines small; elytral pads smooth; abdominal tergites 2 to 6 with or without small pleural spines................................ Subdivision $A$.

Frontal spines large, prominent; elytral pads rugose; abdominal tergites 2 to 6 with prominent pleural spines ......................... Subdivision B. 


\section{Subdivision A.}

Anterior and middle femora smooth; abdominal tergites 3 to 6 with small pleural spines;

1 and 2 without distinct dorsal and lateral spines. Section al, Species 1, 2, and 3. Anterior and middle femora with small apical spines ................ Section a2.

\section{Section a?.}

Abdominal tergites 2 to 6 without distinct pleural spines; 7 and 8 with small granules........................................... Species 4.

Abdominal tergites 2 to 6 with small pleural spines of equal size; 7 and 8 with smali

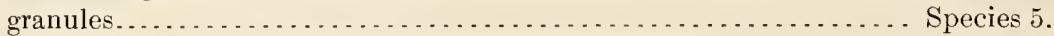

Abdominal tergites 1 to 6 with small pleural spines, increasing in size; 7 and 8 smooth.

\section{Subdivision $B$.}

Species 8.

Apex of anterior and middle femora with two spines................ Species 9.

Apex of anterior and middle femora with one spine; abdominal spines and elytral rugosities coarser than in species $9 . \ldots . \ldots . \ldots . \ldots . . . . . . .$. Species 10.

Apex of anterior and middle femora with two spines; abdominal spines apparently less

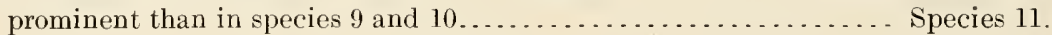

\section{DIVISION II.}

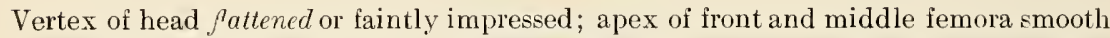
or with minute granule; abdominal tergites with pleural and dorsal spines moderately prominent.................................... Subdivision $\mathrm{C}$.

Vertex of head convex; front and middle femora each with a minute pilated, subapical granule; abdominal tergites with less distinct pleural and dorsal spines.

Subdivision D.

\section{Subdivision C.}

Tergal spines of abdomen with pale or white tips; segment 7 smooth...... Section a3. Tergal spines of abdomen with pale, dark, or black tips; segment 7 with a few setigerous

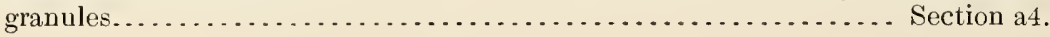

\section{Section as.}

Anterior and middle femora with minute apical spines; abdominal tergites 2 to 6 with stout, prominent pleural spines; 3 to 6 with prominent dorsal spines. Species 12 . Anterior and middle femora without apical spines; abdominal tergites 2 to 6 . with moderately stout pleural spines, and 3 to 6 with small dorsal ones...... . Species 13.

\section{Section $a$ -}

Vertex of head moderately impressed; anterior and middle femora without apical spines; abdominal tergites 2 to 6 with very small pleural spines; 4 to 6 with small dorsal spines, all with pale tips............................. Species 14.

Vertex of head distinctly impressed; abdominal tergites 2 to 6 with distinct pleural spines, and 3 to 6 with distinct dorsal ones................... Species 15 .

Abdominal tergites 2 to 6 with very small pleural, lateral, and dorsal spines, all with

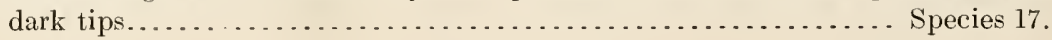

\section{Subdivision D.}

Abdominal tergites 1 to 6 with moderately small pleural spines, 2 to 6 with small dorsal and lateral ones, all with pale tips........................ Species 22 . Same as preceding, except spines have darker to black tips............ Species 23. 


\section{SYNOPSIS OF LARVAL CHARACTERS.}

Abdominal tergites 8 and 9 without dorsal plates................... Division I. Abdominal tergites 8 and 9 with dorsal plates, except in section a3..... Division II.

\section{DIVISION I.}

Front with or without median convexity. Subdivision A.

Front with transverse elevation slightly more prominent toward the sutures.

Subdivision B.

\section{Subdivision $\mathrm{A}$.}

Front without median convexity ........................... Section al.

Front with median convexity . . . . . . . . . . . . . . . . . . . . Section a2.

Section a1. .

Clypeus with apex subacutely emarginate...................... Species 1.

Clypeus with apex broadly emarginate...................... Species 2.

Section az.

Prothoracic lobes without foot calli......................... Subsection b1.

Prothoracic lobes with distinct foot calli.................... Subsection b2.

Subsection b1.

Front smooth, with shining convexity; clypeus with apex broadly emarginate.

Species 3.

\section{Subsection b2.}

Front smooth, with median smooth convexity; clypeus with apex deeply emarginate........................................ Species 4.

Front with anterior third transversely rugose and with transverse median convexity, produced toward apex; clypeus with apex broadly emarginate...... . Species 5.

Front with broad convexity; clypeus with apex truncated............ Species 8.

\section{Subdivision 13 .}

Front of head with posterior apex subacute; frontal elevation moderately stout in the middle; clypeus with faint median tubercle toward the base....... . Species 9 .

Front of head with posterior apex subobtuse; frontal elevation stout slightly posterior to the middle; clypeus with a faint median groove and elevation toward base.

Species 10 .

Front of head with posterior apex subacute; frontal elevation narrow, situated in the middle, not more distinctly elevated toward suture; clypeus with faint median groove, without elevation........................... Species 11.

\section{DIVISION II.}

Abdominal tergites 8 and 9 without dorsal plate, or with unarmed plates.

Abdominal tergites 8 and 9 with armed plates.................. Subdivision D.

Subdivision C.

Abdominal tergites 8 and 9 without dorsal plates.................... Section a3.

Abdominal tergites 8 and 9 with dorsal plates, excepting micans, in which 8 is un-

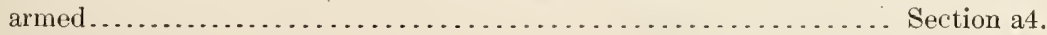


Section as.

Front with indistinct transverse elevation; clypeus with distinct median impression.

Species 12.

Front with distinct transverse elevation; clypeus with median impressed line.

Section a4.

Species 13.

Abdominal tergites 8 and 9 with rugose but unarmed plates; front with faint transverse elevation anterior to middle; clypeus with median groove... . . Species 14.

Frontal elevation near the middle.......................... Species 15.

Frontal elevation distinctly anterior to middle.................... Species 16.

Front with lateral impressions toward the anterior angles, and frontal elevation anterior to middle.................................... . Species 19.

Abdominal tergite 9 with dorsal plate; frontal elevation anterior to middle; clypeus with median groove............................... Species 21 .

\section{Subdivision D.}

Abdominal tergites 8 and 9 each with dorsal plate and armed with three permanent teeth; front of head without elevation; clypeus with faint median groove.

Species 22 and 23.

\section{SYNOPSIS OF GALLERY CHARACTERS.}

Egg galleries winding to straight; eggs isolated or in approximate groups, but never in masses; larval mines exposed or concealed in inner bark............ Division I.

Egg galleries longitudinal, straight to slightly winding; eggs in groups or masses; larval mines and pupal cells exposed in inner bark................ Division II.

\section{DIVISION I.}

Pupal cells in outer bark; eggs isolated, never in groups; egg galleries winding: larval mines short, narrow to broad, exposed or concealed........... Subdivision A.

Pupal cells in inncr bark; eggs in approximate groups; egg galleries slightly winding to straight; larval mines short, broad, always exposed......... Subdivision B.

Subdivision A.

Larval mines concealed in inner bark....................... Section al.

Larval mines exposed or concealed.......................... Section a2.

Section a1.

Egg galleries subtransverse, winding........................ Species 1.

Egg galleries distinctly transverse............................ Species 2.

Section a?.

Larval mines exposed.

Egg galleries longitudinal, winding...................... Species 3.

Egg galleries sublongitudinal, winding...................... Species 4 .

Larval mines concealed.

Egg galleries evidently transverse, or subtransverse, winding, with concealed larval mines................................... Species 5.

Egg galleries subtransverse, winding...................... Species 6 .

Egg galleries longitudinal, winding, with transverse branches. . Species 7 and 8 .

\section{Subdivision B.}

Egg galleries winding to straight.......................... Species 9 . Egg galleries usually straight......................... Species 10 and 11. 


\section{DIVISION II.}

Larval mines suparate, especially beyond the middle. Subdivision C.

Larval mines contiguous, forming broad larval chamber Subdivision D.

\section{Subdivision C.}

Egg galleries slightly winding to straight; eggs in groups, but larval mines separate

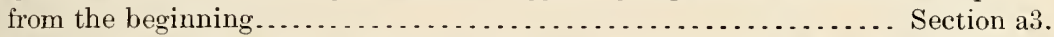

Egg galleries broad, nearly straight; eggs in small to large groups, the larva! mines usually contiguous toward the egg gallery................... Section a4.

Section a3.

Larval mines normally short and broad..................... Species 12 . Larval mines normally long.............................. Species 13.

\section{Section a4.}

Subsection b3.

Larval mines separated beyond the middle. Species 14, 15, and 16 .

Subsection b4.

Larval mines usually not separated beyond the middle, but forming a common chamber. Subdivision D. Species 19 to 21 .

Egg galleries broad to very broad, short to very long, straight to winding; larval mines forming a large common chamber..................... Species 22 and 23 .

\section{TABLE OF DISTRIBUTION. $a$}

America, north of Guatemala, and in northern Europe.

The genus.

\section{DIVISION I.}

\section{Subdivision A.}

North American continent, in South Atlantic and Gulf States and Southwestern States, southward to Guatemala and northward in Sierra Nevada and Cascade Mountains to British Columbia................... Sections al and a2.

\section{Section a1.}

West of western Montana and southwestern Idaho, and southward to Santa Barbara County, California............................ Species 1, page 81 . South of southern Colorado and Utah, into Texas and Mexico, and westward into southern California, and possibly in the Coast Range and northward along the forested foothills into northern California................. Species 2, page 85 .

\section{Section a2.}

Southern Colorado and Utah, southward into Mexico........... Species 3, page 87. Atlantic and Gulf States, southwestward into Texas........... Species 4, page 90. Central to southern Arizona ....................... Species 5, page 95 . Southern Mexico ........................ Species 6 and 7 , pages 97,99 . Central Colorado and southern Utah, southward to southern Arizona, and New Mexico. Species 8, page 101.

$a$ For exact and probable distribution see maps under description of each species. 
Subdivision B.

West of western Montana and southwestern Idaho, south through the Sierra Nevada Mountains of California....................... Species 9, page 105 .

Western South Dakota and southern Wyoming, southward through Utah, Colorado, to southern Arizona and New Mexico............... Species 10, page 109.

Northern California, southward in Sierra Nevada, into San Bernardino County, California..................................... Species 11, page 114 .

\section{DIVISION II.}

Subdivision C.

Maine to western Michigan, southward into northwestern West Virginia.

Species 12, page 117 .

Northern Idaho and Montana, south to southern Arizona and New Mexico, and northern Washington, south into Santa Barbara County, California. Species 13, page 121.

Section $a$.

Maine to northeastern Minnesota, south ward to central Pennsylvania.

Species 14, page 126.

Northern Idaho, east to western South Dakota, southward to southern Arizona and New Mexico............................... Species 15, page 130 . Alaska..................................... Species 16, page 133. Alaska?, along the coast to northwestern California.......... Species 17, page 135.

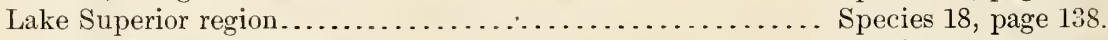
Western Montana southeast to central Colorado............. Species 19, page 140. Higher mountains of New York,Pennsylvania, and West Virginia. Species 20, page 142. Central Europe to Denmark, Russia, and eastward into Siberia. Species 21, page 143.

\section{Subdivision D.}

Atlantic States south of Massachusetts, to Tampa, Florida, westward to western West Virginia and Texas......................... Species 22, page 147 . Mountains and foothills of North Carolina, northward into Maine and northwestern

Washington, southward into Guatemala ............. Species 23, page 151 .

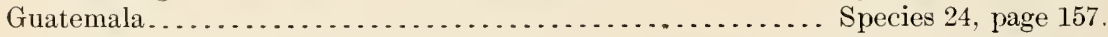

\section{TABLE SHOWING RELATION OF SPECIES TO HOST TREES.}

\section{DIVISION I.}

Section a1.

Species 1. Pinus lambertiana, ponderosa.

Species 2. Pinus ponderosa var. scopulorum, edulis; Pseudotsuga taxifolia.

Section a2.

Species 3. Pinus scopulorum.

Species 4. Pinus strobus, trda, rigida, tirginiana, pungens, echinata, glabra, palustris; Picea rubens and excelsc.

Species 5. Pinus scopulorum.

Species 6. Pinus teocotl?, lejophilta, and ayacahuite?

Species 7. Same as 6.

Species 8. Pinus arizonica, scopulorum, and chihuahuana.

\section{Subdivision B.}

Species 9. Pinus monticola, lambertiana, ponderosa, murrayana; Picea engelmanni. Species 10. Pinus flexilis and strobiformis.

Species 11. Pinus lambertiana and ponderosa. 


\section{DIVISION II.}

Section $a .3$.

Species 12. Larix laricina.

Species 13. Larix occidentalis; Pseudotsuga taxifolia and macrocarpa.

Species 14. Picea mariana, rubens, canadensis.

Species 15. Picea canadensis and engelmanni.

Species 16. Picea canadensis.

Species 17. Picea sitchensis.

Subsection b4.

Species 18. Pinus strobus.

Species 19. Pinus murrayana; Picea engelmanni.

Species 20. Picea rubens.

Species 21. Pinus, Picea, Abies?, Larix.

\section{Subdivision D.}

Species 22. Pinus strobus, txda, rigida, serotina, echinata, palustris.

Species 23. Pinus strobus, monticola, lambertiana, strobiformis, ponderosa, scopulorum, jeffreyi, chihuahuana, murrayana, radiata, rigida, virginiana; Larix luricina; Picea rubens, canadensis, excelsa.

\section{TABLE OF HOST TREES.}

Pinus strobus

Dendroctonus species number.

monticola....... 9, 23 .

lambertiana...... 1, 9, 11, 23.

flexilis......... 10.

strobiformis . . . . . 10, 23.

edulis.......... 2, 23.

arizonica....... 8, 23.

ponderosa......... 1, 9, 11, 23.

scopulorum....... 2, 3, 5, 8, 10, 23.

jeffreyi......... 11, 23 .

chihuahuana...... 3, 8, 23.

murrayana...... 9, 10, 19, 23.

radiata........... 23.

tæda ......... 4, 22 .

rigida.......... . 4, 22,23 .

serotina........ 22 .

virginiana....... 4, 23.

pungens.......... 4 .

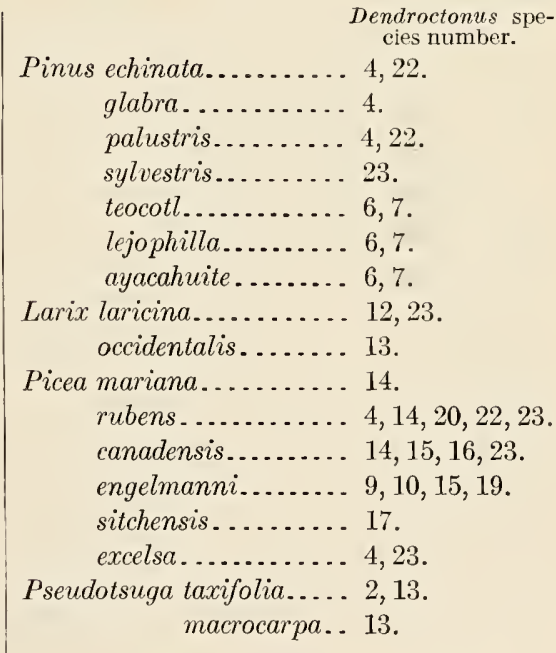

\section{REVISION AND SYSTEMATIC NOTES, WITH DESCRIPTIONS OF NEW SPECIES.}

\section{DISTINCTIVE GENERIC CHARACTERS.}

Adult (figs. 1, 2, 3).-Antennal funiculus 5-jointed; club broad, thickened at base, compressed toward apex, and usually with 4 distinct segments, the sutures curved or nearly straight; tarsi with joint 3 bilobed; tibia with inner angle produced and armed with a single tooth; outer angle oblique and armed with 3 or more stout teeth; distinct dorsal impression toward apex for the retractile tarsus. 
Anterior cóxæ approximate or subcontiguous. Abdominal sternites with ends of sutures 4,5 , and 6 strongly recurved. Body cylindrical, subelongate to stout, ranging in color from reddish and brown to deep black. Head prominent and large, with distinct epistomal process at anterior margin of front. Eyes transversely placed and oblong-oval to oblong-ovate. Antennal insertion in front of ventral end of eye. Pronotum with sides nearly parallel to narrowed and constricted toward head, one-fourth to one-third broader than long. Elytra with base elevated and rugose, remaining surface rugose, with punctured strix and the declivity convex to subconvex.

Pupa (figs. 37, 38).--The pupa is of the general size of the adult, and is distinguished by its broad prominent head, and the form of the prothorax. The sculpture and armature vary with the age of the specimen. In the preimaginal stage the granules and spines become more obscure.

Larva (text fig. 39; Pl. VIII).--The body of a matured larva of a given species is somewhat longer than the adult or pupa, and is cylindrical, deeply wrinkled, legless, and with a few long hairs on each segment, becoming longer on the posterior ones. The head is moderately large, shining, yellowish, and with a few hairs on the scutellar lobes. Front distinct; antennæ present, but obscure; eye spots not present. The thoracic segments are larger and more prominent in some species than in others. Abdominal segments 1 to 9 are of about equal width and length; 10 is represented by the anal lobe.

Egg.-Short, oval to oblong-oval, pearly white and shining, and apparently without sculpture and specific characters, except in relative size, corresponding with the size of adult representatives of the species.

Galleries.--The primary or egg galleries are excavated in the inner bark and sometimes mark or groove the wood and vary in their course in the bark of the tree from transverse and winding to longitudinal and straight, and normally are of the single unbranched type.

Distribution (P1. II).--Eastern continent: Central and northern Europe, from Denmark into Siberia. Western continent: Guatemala, northward through the United States into Alaska and Labrador.

Host trees.-Pinus, Picea, Pseudotsuga, Larix, and Abies, the latter rarely, if at all.

\section{BIBLIOGRAPHY AND SYNONYMY OF GENUS.}

Erichson, 1836, pp. 52-53, original description, to include D. micans (Kug.) (type), D. terebrans (Oliv.) (cotype), Myelophilus piniperda (L.), Myelophilus minor (Hartig), and Carphoborus minimus (Fab.). Eichhoff, 1864, pp. 26-27, Pl. I, figs. 5, 6, 7, tibia, maxilla, labium, revised description to include the single European species, D. micans (Kug.). Lacordaire, 1866, pp. 360-361, revision to include D. micans (Kug.) and D. terebrans (Oliv.). Zimmerman, 1868, pp. 148-149, revision to include Carphoborus bifurcus Eich., $D$. terebrans (Oliv.), and D. frontalis Zimm. Le Conte, 1868, pp. 172-173, revision to include D. terebrans Lac., D. obesus (Manu.), D. rufipennis (Kirby), D. punctatus Lec.. 


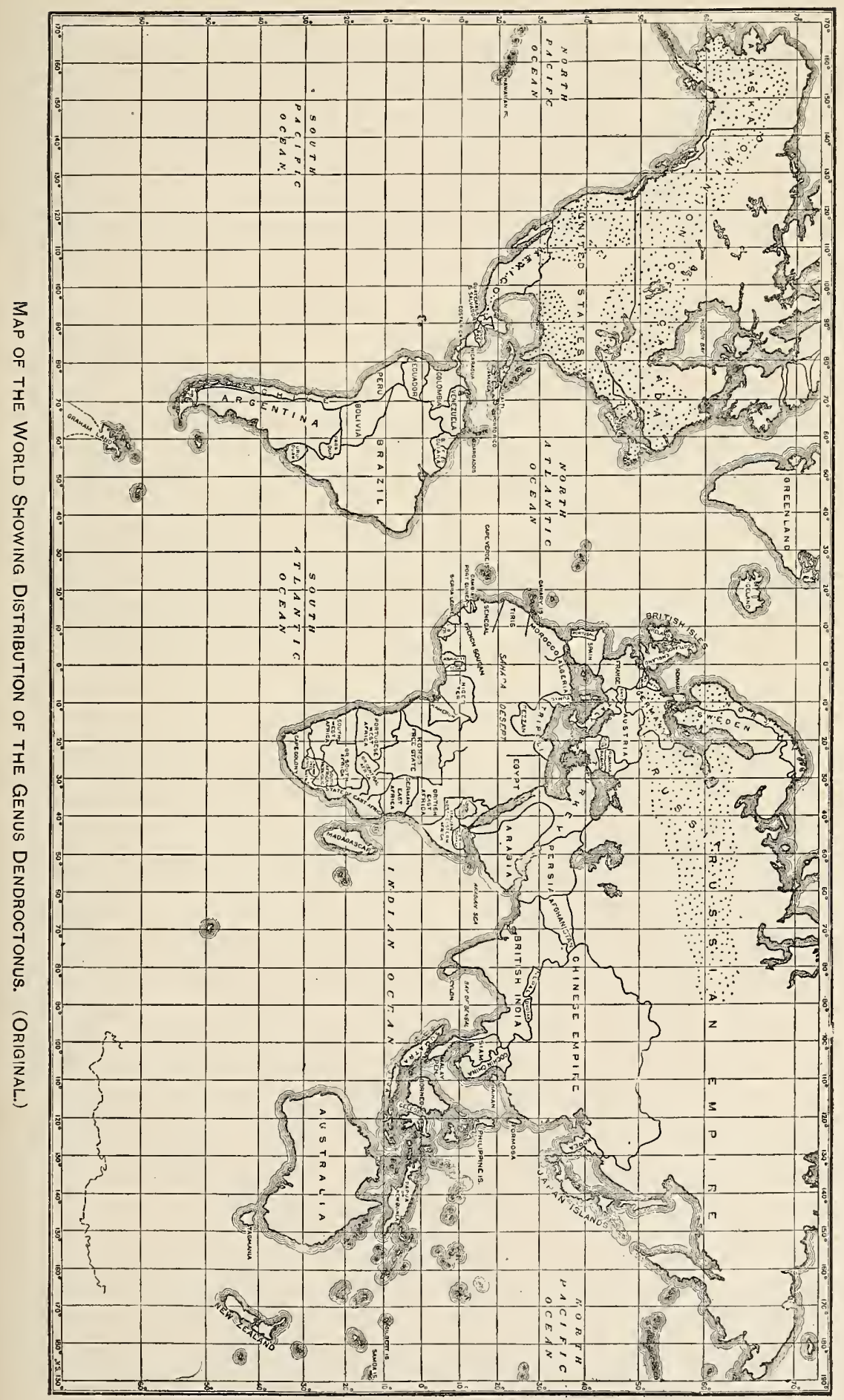



D. simplex Lec., D. frontalis Zimm., eliminating Carphoborus bifurcus Eichh. Eichhoff, 1881, pp. 125, brief revision, including D. micans (Kug.). Le Conte and Horn, 1883, p. 523, in synoptic table. Dietz, 1890 , pp. 27-28, revision and synopsis to include D. terebrans (Oliv.), D. rufipennis (Kirby), D. similis Lec., D. simplex Lec., $D$. approximatus n. sp., and $D$. frontalis; revised description of species, with synonymy, figs.1-6, epistomata and antennie. Hopkins, 1894b, p. 280, author's extra, p.7, sexual characters of D. terebrans (Oliv.), D. frontalis Zimm. Blandford, 1897, p. 143, synoptic table. Lovendal, 1898, pp. 86-87, Pl. II, fig. 7, antenna, fig. 8, tarsus. Hopkins, 1902a, pp. 3-4, secondary sexual characters, statistics, etc. Hopkins, 1906b, pp. 143-147, larval mouthparts.

\section{DIVISION I.}

The distinctive characters common to the species of the first division are as follows:

Adult.--Prothorax somewhat elongate and as broad as elytra; anterior dorsal half of elytra without long erect hairs.

Pupa.-Vertex of head distinctly to faintly grooved, and with two prominent to small frontal spines or granules on or toward the vertex each side of groove.

Larva.-Abdominal tergites 8 and 9 without dorsal plates.

Galleries.-Egg galleries winding to straight; the eggs isolated or in approximate groups, but never in masses; larval mines exposed or concealed in inner bark.

\section{Subdivision $\Lambda$.}

(Species numbers 1 to 8 , inclusive.)

The distinctive characters common to the species of the first subdivision are as follows:

Adult.-Body somewhat slender; prothorax with sides but slightly narrowed and not constricted toward the head; elytra with second stria of declivity straight; second interspace not distinctly broader in middle:

Sexes.-Female: Pronotum with transverse ridge across anterior area. Male: Pronotum without transverse ridge, but usually with anterior area broadly impressed.

Pupa.-Elytra smooth; vertex of head faintly grooved and with two small, widely separated frontal tubercles.

Larva.-Front with or without median convexity.

Galleries.--Egg galleries winding; larval mines exposed or concealed. Pupal cells in outer bark; eggs isolated, never in groups.

1. Dendroctonus brevicomis Le Conte.

(PI. III, fig. 1.)

Adult.--Typical female: Length, $4.6 \mathrm{~mm}$.; light brown. Elytral declivity without long hairs. Head with front convex, slight elevations each side of a faint median groove. Elytral rugosities fine, densely placed; striæ obscure and but faintly or not at all impressed. 
Pronotum with a few reclining long hairs on the anterior half, remaining areas with very few and stout pubescence. Secondary sexual characters: Pronotum with transverse ridge extending across the anterior area to near the sternum. Elytral declivity moderately smooth and shining; interspaces finely and densely punctured; striæ fine, with punctures scarcely visible.

Typical female labeled "type of revision," name label, "Hopk. 4/18/02," second name label, "Hopk. Jan 16/08, Pinus ponderosa, Hopkins, collector, 3/24/99, Grant's Pass, Or., ९, Hopk. U. S. 34.”

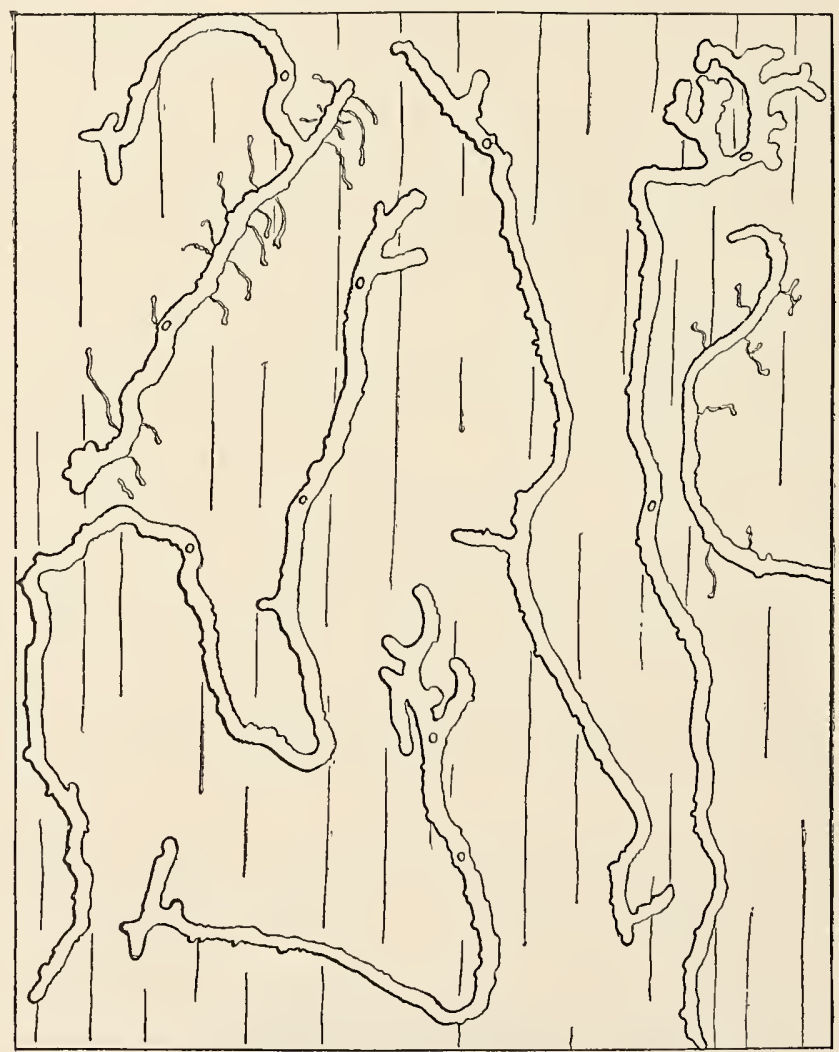

FIG. 44.-Dendroetonus brevicomis: Egg galleries. (Original.)

Typo male in Le Conte collection, labeled "Cal.," examined by writer.

Typical male: Length $4.6 \mathrm{~mm}$. Agrees with female, except in the more prominent frontal tubercles each side of a distinct groove and a transverse impression instead of an elevation across the anterior area of the pronotum, and the elytral declivity slightly less shining.

Typical male labeled "type of drawing," name label, "Hopk. 1/16/08, Pinus ponderosa, Hopkins, collector, 3/24/99, Grant's Pass, Or., శో, Hopk. U. S. 34." 
Variations.-Length, 3 to $5 \mathrm{~mm}$.; color light brownish to nearly black; punctures of pronotum ranging from moderately coarse to very fine, elytral striæ not at all impressed in some examples, in others the impression and punctures more distinct, but never as distinct as in the majority of $D$. barberi. The elytral rugosities also vary from very fine to moderately coarse. The front varies greatly, from convex without tubercles to deeply grooved and with prominent tubercles. The epistomal process varies from the normal concave form with angles elevated and lateral margins strongly oblique to flat with rounded apex and lateral margin suboblique.

Distinctive characters.The adults of this species are at once distinguished from its nearest ally, $D$. barberi, by the finer rugosities of the elytral interspaces and the much less distinctly impressed striæ.

Revisional notes.-The labeled type in the Le Conte collection agrees with the description, except that the prothorax is not nearly twice as broad as long. It is certainly distinct from $D$. frontalis. The specimens in the Horn collection under $D$. frontalis that evidently represent part of the material on which Doctor Dietz

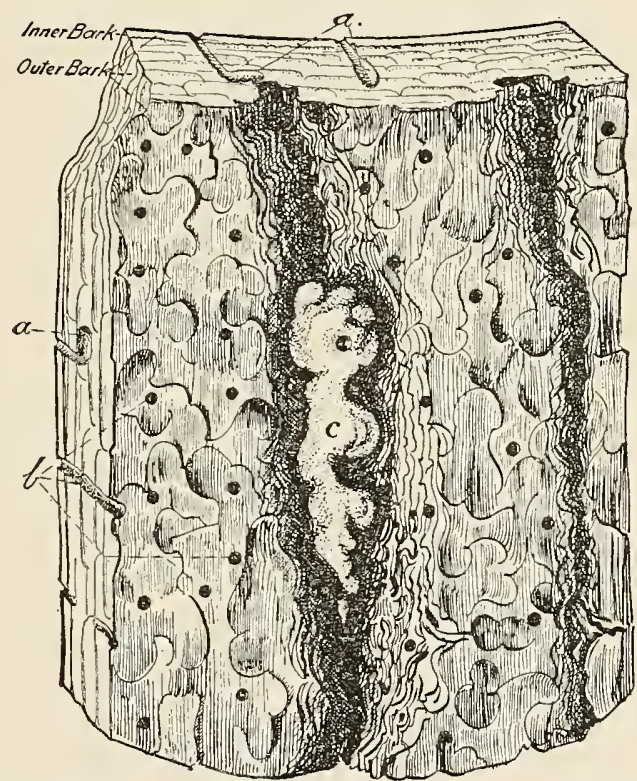

FIG. 45.-Dendroctonus brevicomis: Bark showing, $a$, pupal cells; $b$, exit burrows; $c$, pitch tubes. (From Webb.) based his revision, include one specimen of $D$. frontalis labeled with red disk, one specimen of D. brevicomis labeled "Cal.," one specimen of $D$. barberi labeled "Williams, Ariz. 7. 2S," one specimen of D. arizonicus(?) "Williams, Ariz. 7. 2S," and one specimen without locality label. One specimen was also received from Dietz, under $D$. frontalis, labeled "Arizona," which proved to be D. barberi. In 1898 D. brevicomis Lec. was not represented in the U. S. National Museum. Therefore it appears that up to 1899 there were only two specimens of the species in the large collections of the country.

Pupa.-In addition to the divisional and subdivisional characters, the pupæ range in length about the same as adults; the apices of the front and middle femora are smooth; abdominal tergites $3,4,5$, and 
6 with small pleural spines, 1 and 2 without distinct dorsal and lateral spines. Pupal type labeled "Hopk. U. S. 34."

Larva (PI. VIII, fig. 1). - In addition to the divisional and subdivisional characters the larvæ range slightly longer than the pupæ. Epistoma distinctly elevated. Front without median convexity; clypeus with apex subacutely emarginate; thoracic segments with prominent sternal lobes; the sternellar lobes with distinct foot calli; apex of abdomen subtruncate. Larval type labeled "Hopk. U.S. 25a."

Galleries (figs. 44, 45).-Egg galleries subtransversely winding; eggs isolated; larvæ concealed in inner bark; pupal cells in outer bark.

Distribution (fig. 46).-(Hopk. U. S.) California: McCloud, Badger, Chester, Wawona, Sterling, Summerdale, Yosemite, Ballard. Montana:

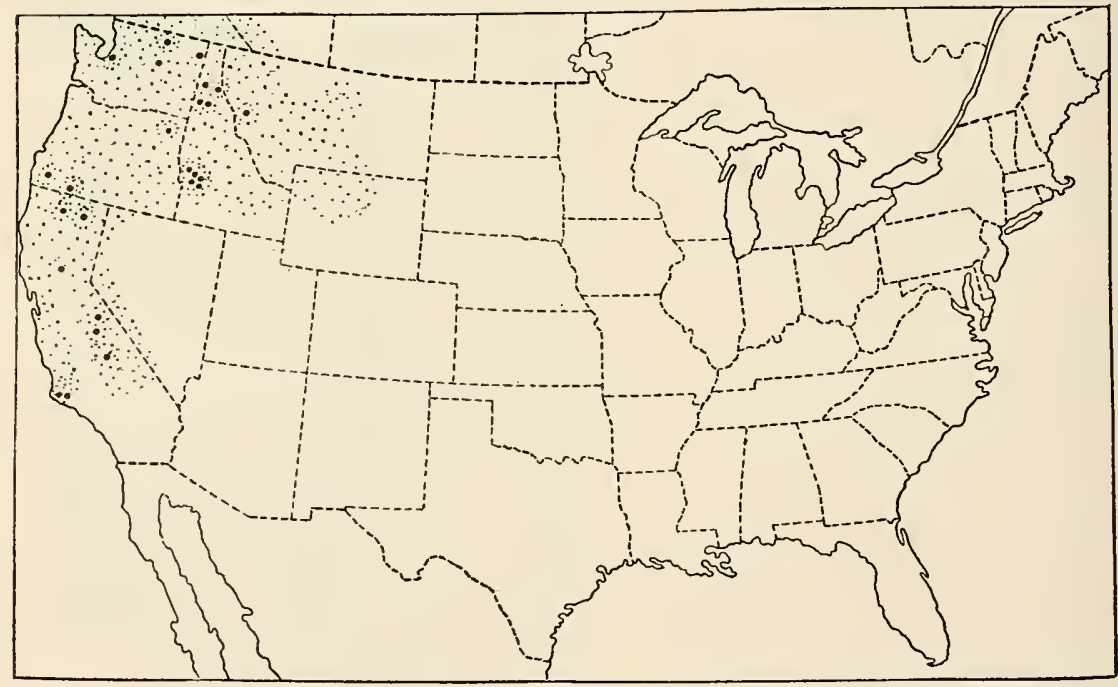

FIG. 46.-Dendroctonus brevicomis: Distribution map. (Original.)

Missoula. Oregon: Grants Pass, Joseph. Washington: Buckeye (near Spokane), Chelan. Idaho: Moscow, Smiths Ferry, Centerville, Stites, Kooskia (Harris Ridge), Pioneer (Grimes Pass), Garden Valley, Placerville, Cedar Mountains, Troy.

Host trees.-Pinus ponderosa and P. lambertiana.

Identified specimens.-Le Conte, 1; IIorn, 1; Hopk. U. S., several hundred, including all stages and work.

\section{Bibliography AND SyNONYMY.}

Dendroctonus brevicomis Le Conte, 1876, p. 386, original description, synopsis, localities. Packard, 1887, p. 177, Le Conte quoted. Packard, 1890, p. 722, Le Conte quoted. Hopkins, 1899a, p. 395, reference. Hopkins, 1899b, pp. 13, 20,26, first records of habits, hosts, etc. Hopkins, 1901b, p. 66, habits, galleries, etc. Hopkins, 1902a, p. 3, name restored. Hopkins, 1902c, p. 21, note. Hop- 
kins, 1903b, p. 281, mentioned. Hopkins, 1904, p. 18, habits, distribution, etc.

Webb, 1906, bulletin, Pls. II, III, figs. 7-12, stages and work illustrated, full account of habits, life history, etc. Hopkins, 1908, pp. 162-163, depredations. Dendroctonus frontalis (not of Zimm.) Dietz, 1890, p. 32 (in part), California. Dendroctonus brevicornis Dietz, 1890, p. 32 (in part), California.

\section{Dendroctonus barberi n. sp.}

(PI. III, fig. 2.)

Adult.-Type of species, female: Length, $4.5 \mathrm{~mm}$.; very dark brown. Elytra and elytral declivity without long hairs. Head with front convex, with slight elevation each side of a faint median groove. Elytral rugosities moderately coarse and dense; striæ distinctly impressed. Pronotum with a few long hairs on the anterior half of the lateral area, the remaining area with very fine and short pubescence. The secondary sexual characters are the same as in the preceding species.

Type labeled "Type No. 7444, U.S.N.M.," name label, "Hopk. $1 / 15 / 08$, $q$, individual $f$, Barber \& Schwarz, Coll[ectors], Williams, Ar., 7.6.' (= June 7).

Male type: Length, $4 \mathrm{~mm}$. Front with prominent tubercles each side of a distinct groove. Pronotum without transverse ridge across the anterior area, but with a broad transverse impression. The elytral declivity shining, with strial punctures distinct and interspaces slightly more rugose than in the female.

Male type labeled " o type," otherwise same as female, except type number.

Variations.-Length 2.5 to $4.7 \mathrm{~mm}$., color from brownish to black. The frontal and prothoracic variations are similar to those of $D$. brevicomis. The elytra vary from rugosities moderately coarse and obtuse to distinctly coarse and acute, and striæ from moderately to very distinctly impressed, and the punctures from obscure to distinct.

Distinctive characters.-The adults of $D$. barberi are at once distinguished from the next species by the absence of long hairs on the elytral declivity, and from $D$. brevicomis, to which it is closely allied, by the prevailing coarser rugosities of the elytral interspaces and the distinctly impressed strix. Some systematists might concede these characters of no more than subspecific or varietal value, but it must be remembered that in this genus there is a close general resemblance of allied species and that the characters which in other genera would be of special value in specific distinction are so variable and inconstant in this as to be of no value. Therefore any constant or prevailing character of distinction, even if it does seem insignificant, is of vastly higher value than would otherwise be allowable, especially when it is supported by differences in physiological characteristics. 
Revisional note.-This species is not represented in the Le Conte collection. One specimen labeled "Williams, Ariz., 7.28, 151," and one without label found in the Horn collection, both under D. frontalis, and one specimen labeled "Ariz.," received from Doctor Dietz under $D$. frontalis, all belong to $D$. barberi. These were evidently before Doctor Dietz when he prepared his revision of $D$. frontalis, $i b i d$.

Pupa.-In addition to the generic, divisional, and subdivisional characters, the apex of the front and middle femora is smooth; abdominal tergites 3 to 6 with very small dorsal, lateral, and pleural spines; 1 and 2 without dorsal or lateral spines; 3 to 6 with minute dorsal and lateral spines; 7 and 8 smooth, and 9 with small pleural spines. Pupal type, labeled "Topk. U. S. 5030" (in alcohol), differs from pupa of $D$. brevicomis in the absence of lateral spines on abdominal tergites 3 and 4 ; but these, with other pupal characters, are so variable that

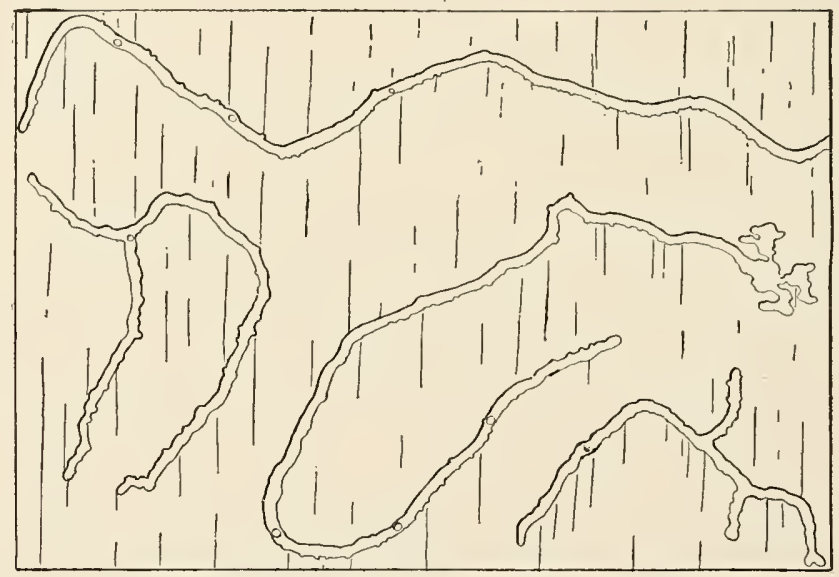

FIG. 47.-Dendroctonus barberi: Egg galleries. (Original.)

not much reliance can be placed on any of them to separate closely allierl species.

Larva.-In addition to the generic, divisional, and subdivisional characters, the clypeus has the apex broadly emarginate instead of subacutely emarginate, as in D. brevicomis. It also differs in the more rounded apex of the labrum and in the more distinctly rugose mandibles. Larval type labeled "Hopk. U. S. No. 5129" (mounted and alcoholic).

Galleries (fig. 47).--In addition to the divisional and subdivisional characters, the egg galleries are usually distinctly transversely winding, thus differing from $D$. brevicomis; otherwise there is little difference.

Distribution (fig. 48).-(Hopk. U.S.) Arizona: Williams, Flagstaff, San Francisco Mountains, Grand Canyon, Walnut Canyon, Dead Man's 
Flat, Show Low, Santa Catalina Mountains. New Mexico: Vermejo, Santa Fe, Meeks, Capitan (Mountains), Cloudcroft. Texas: Davis Mcuntains. Colorado: Fort Garland and Monte Vista. Utah: Escalante and Panguitch. Additional localities from other collections. (H. \& S.) Chiricahua Mountains, Ariz.

Host trees.-Pinus ponderosa var. scopulorum (very common), $P$. edulis (rare), and Pseudotsuga taxifolia (rare, probably abnormal).

Identified specimens.-Horn collection, 2; Dietz, 1; U. S. N. M., H. \& S., 2, B. \& S., 62 ; Hopk. U. S., more than 400, including all stages and work.

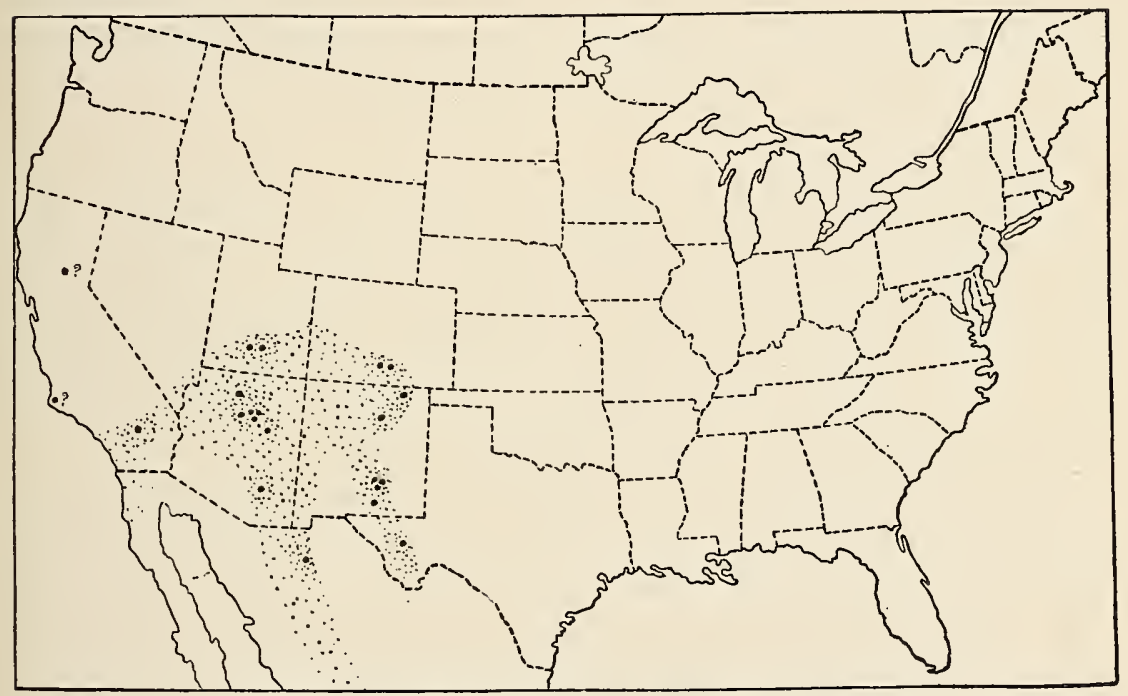

FIG. 48.-Dendroctonus barberi: Distribution map. (Original.)

Bibliography and Synonymy.

Dendroctonus frontalis (not of Zimm.) Dietz, 1890, p. 32 (in part), Arizona.

Dendroctonus arizonicus Hopkins, 1902a, p. 3 (in part), manuscript name only.

Dendroctonus n. sp. Hopkins, 1904, pp. 42, 44, habits, host, distribution, etc.

Dendroctonus brevicomis var. barberi Hopkins, 1906b, p. 147, Pl. IV, fig. 9, anatomy of larval head, manuscript name.

\section{Dendroctonus convexifrons n. sp.}

(Pl. III, fig. 3.)

Adult.-Type of species, female: Length, $6 \mathrm{~mm}$.; reddish-brown, shining. Elytral declivity with long hairs. Head with front convex; without median frontal groove or tubercles, but with posterior impression. Elytral rugosities moderately coarse, but not densely placed, except toward the base; striæ faintly impressed and with rather coarse, indistinct punctures. Pronotum with long, erect hairs on the entire 
lateral area, the remaining area with short, erect, and sparse pubescence. Secondary sexual characters: Pronotum with transverse ridge across the anterior area, extending to the sternum. Elytral declivity shining; striæ very slightly impressed; punctures obscure; interspacial granules sparse and small, but distinct.

Type labeled "'Type No. 7445 U.S.N.M.," name label, "Hopk. 1/16/08, Pinus ponderosa, Hopkins, Colr., 9/8/02, Williams, Ariz., ㅇ, Hopk. U. S. 1109."

Male type: Length, $5.6 \mathrm{~mm}$. Front convex and with faint anterior and posterior impressions, but without frontal groove or tubercles. Pronotum without transverse elevation. Elytral declivity less shining; striæ more impressed, with more distinct punctures and the interspacial granules distinctly coarser than in the female.

Male type labeled " $\delta$ type;" otherwise same as female, except type number.

Variations.-The length varies from 4 to $6 \mathrm{~mm}$., with the average at about $5.5 \mathrm{~mm}$.; the color ranges from reddish to black, with reddish-brown prevailing; front ranges from completely convex without median impression to more or less distinctly impressed, but never with frontal tubercles. The punctures of the pronotum vary as usual, and the dorsal area ranges from the absence of a longitudinal median space or line to a distinct elevated line.

Distinctive characters. - The adults of $D$. convexifrons are at once distinguished from $D$. approximatus by the more slender form and shining appearance, and the prevailing convex front in both sexes, which latter character also distinguishes small examples of the species from large examples of $D$. arizonicus. The long hairs on the elytral declivity render it absolutely distinct from $D$. barberi, to which it appears to be more closely allied on account of pupal characters.

Revisional notes.-This species is not represented in the Le Conte collection, but among the three specimens in the Horn collection, under D. approximatus Dietz, there was one labeled "N. M.," which certainly must be referred to it.

Pupa.-In addition to the divisional and subdivisional characters, the front and middle femora are smooth or with minute apical granule; abdominal tergites 1 and 2 without dorsal spines but with one or two lateral granules; 2 to 6 with very small lateral spines, and 3 to 6 with very small dorsal and lateral spines, becoming more prominent toward the sixth; 7 and 8 smooth and 9 with wiclely separated caudal spines. Pupal type labeled "Hopk: U. S. No. 5090."

Larva.-In addition to the divisional characters, the front has a median smooth, shining convexity; mandibles distinctly rugose on lateral area toward base; labrum with apex broadly rounded and 
clypeus with apex broadly emarginate. Sternellar lobes of thoracic segment without foot calli. Larval type labeled "Hopk. U. S. No. 5078."

Galleries (fig. 49).-Egg galleries longitudinally winding; eggs isolated; larval mines exposed in inner bark; pupal cells in outer bark.

The galleries of this species are at once distinguished from those of $D$. barberi and $D$. approximatus by the exposed larval mines.

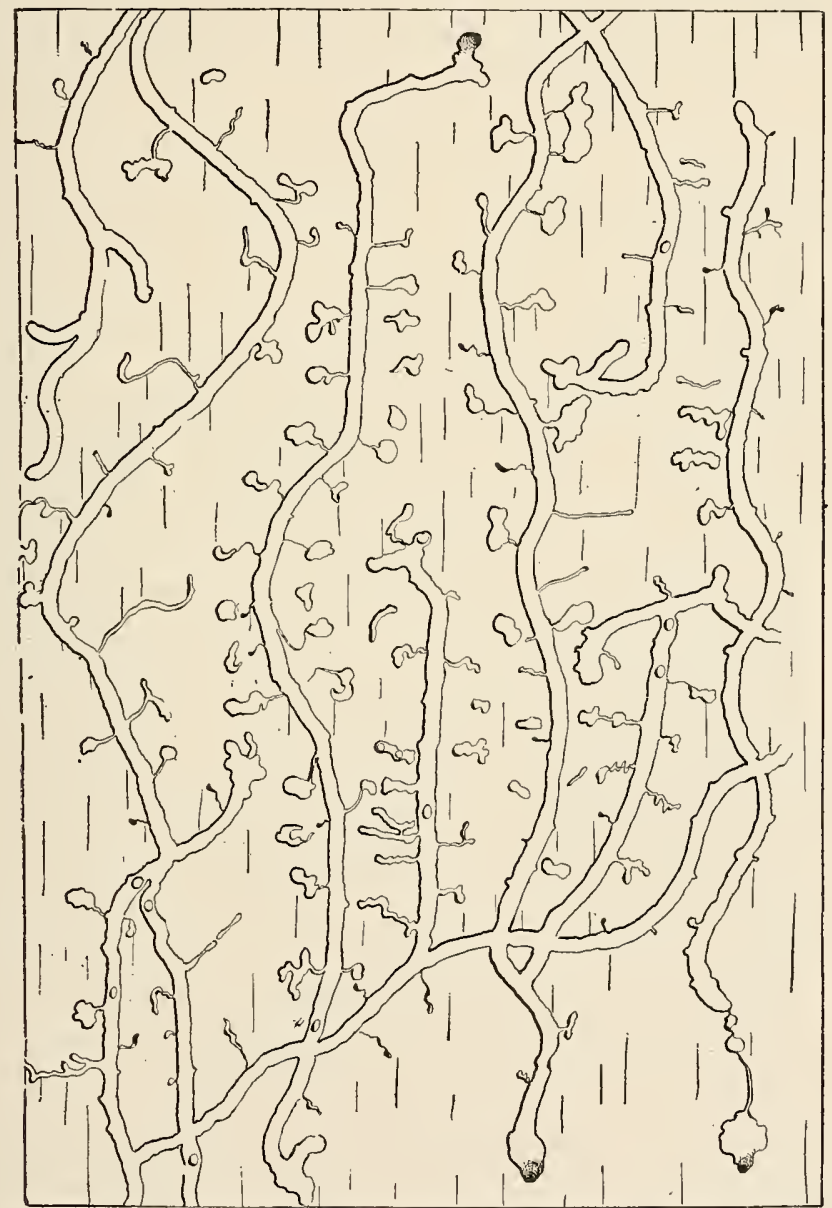

Fig. 49.-Dendroctonus convcrifrons: Ėgg galleries and larval mines. (Original.)

These three species usually infest the same tree, ancl often all of their galleries are represented in a piece of bark.

Distribution (fig. 50).-(Hopk. U. S.) Arizona: Williams, Flagstaff, Show Low, Paradise, Santa Catalina Mountains, and Chiricahua Mountains. Colorado: Las Animas County, La Veta, Fort Garland, and Monte Vista. New Mexico: Cloudcroft, Meeks, Capitan, Fort 
Wingate Military Reservation, Vermejo, Lincoln National Forest, and Sierra Blanca Mountains. Utah: Escalante, La Salle National Forest, and Panguitch Lake. Additional locality from other collections: (B. \& S.) Las Vegas, N. Mex.

Host trees.-Pinus ponderosa var. scopulorum (very common) and $P$. chithuahuana (rare).

Identified specimens.-Hopk. U. S., more than 100 specimens, including all stages and work; Horn, 1 specimen under D. approximatus, labeled "N. M." ; U.S.N.M., B. \& S., 7 specimens, Las Vegas, N. Mex., 17-8, No. 164, and Williams, Ariz., 5-6, 5-7, and 5-10.

BIBLIOGRAPHY.

Dendroctonus approximatus Dietz, 1890, p. 31 (in pari), New Mexico. Schwarz, 1902 , p. 32 (in part)

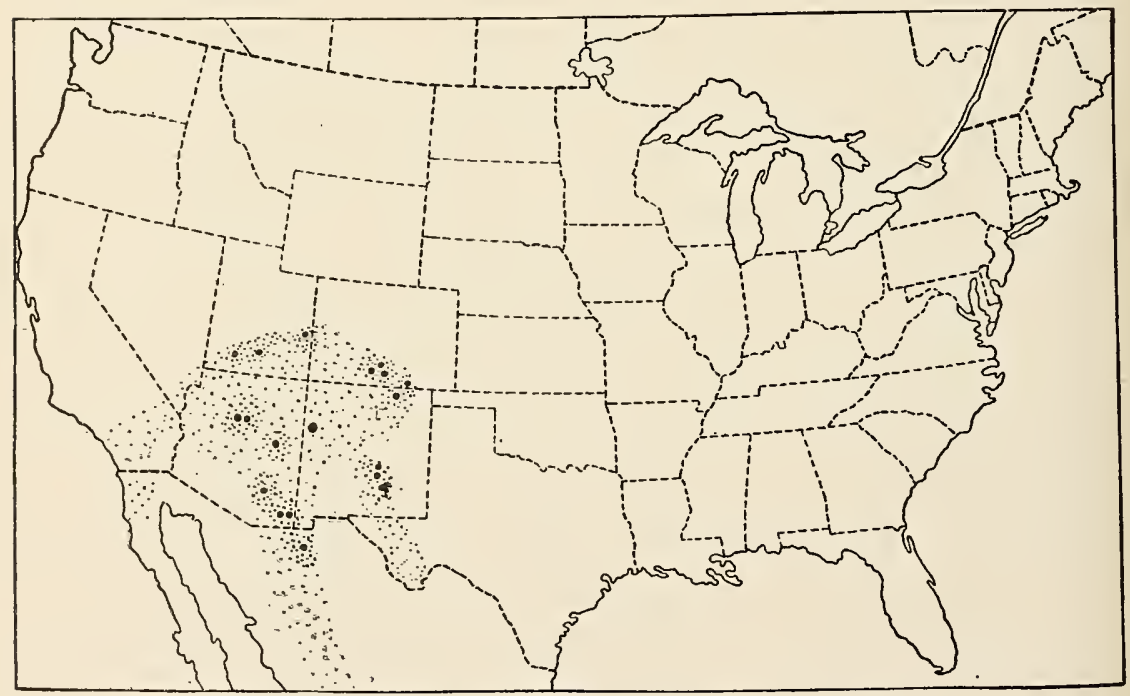

F1G. 50.-Dendroctonus convexifrons: Distribution map. (Original.)

4. Dendroctonus frontalis Zimmerman.

(Pl. 1II, fig. 4.)

Adult.-Typical female: Length, $3.6 \mathrm{~mm}$; reddish-brown. Elytral declivity with long hairs. Front with a moderately prominent tubercle each side of a distinct median groove. Elytral striæ distinctly punctured; interspacial rugosities moderately coarse, obtuse, not very densely placed, and not very distinctly coarser toward the base and vertex. Pronotum with a few long hairs on the anterior section of the lateral area. Secondary sexual characters: Pronotum with transverse ridge across the anterior area, the elytral declivity shining and with finely granulate interspaces, the striæ distinctly impressed, but the punctures obscure. 
Typical female labeled "type of revision, type of drawing," name label, "Hopk. 4-1S-02, ९, H. S. 58, S. C."

Type in Le Conte collection labeled "Type 1, D. frontalis (Fab.) Zimm.," red disk (= Carolinas).

Male type: Length, $3.5 \mathrm{~mm}$. Front with prominent frontal tubercle each side of a broad, deep frontal groove. Pronotum without transverse elevation or impression across the anterior area. Elytral declivity with strix more impressed and the interspacial granules coarser and more sparse than in the female.

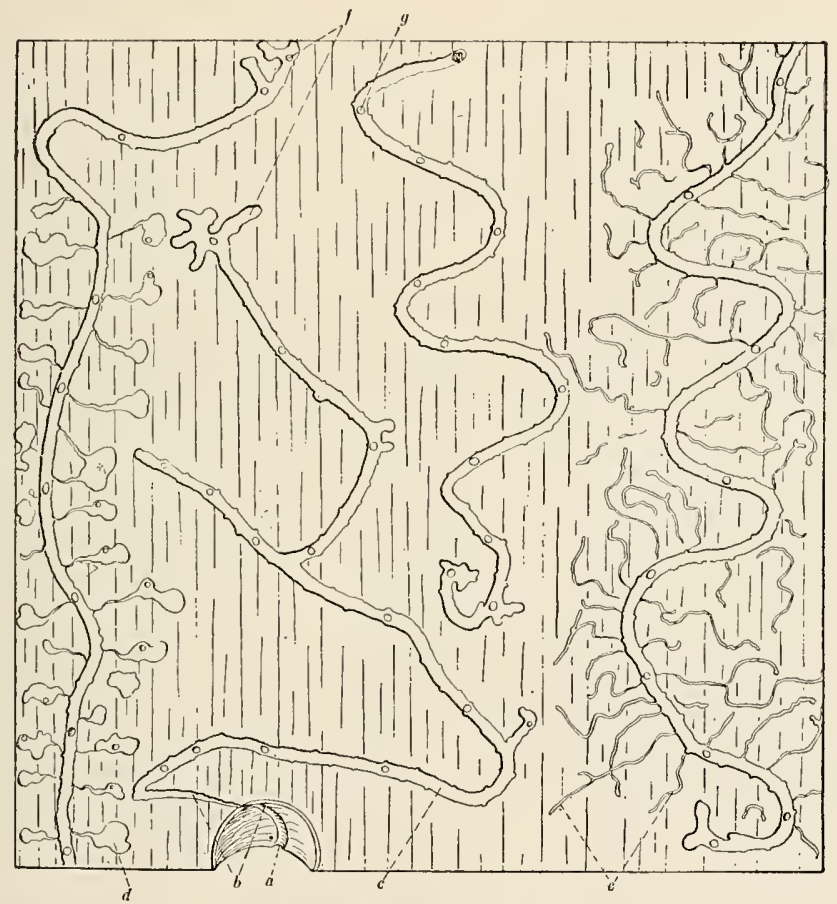

F1G. 51.-Dendroctonus frontalis: Egg galleries and larval mines. $a$, Entrance; $b$, entrance burrow; $c$, egg gallery; $d$, normal larval mine; $e$, abnormal larval mine; $f$, terminal; $g$, ventilating burrows. (Original.)

Typical male labeled with name, "Hopk. 1-16-08, ô, U.S.N.M. 37, sp., N. C."

Variations. - The length varies from 2.5 to $4 \mathrm{~mm}$., with the average at about $3.2 \mathrm{~mm}$. The color ranges from light brown to nearly black; the epistoma, front, prothoracic punctures, and elytral rugosities vary as usual. The anterior area of the pronotum, which is glabrous in the typical females and males, usually has a few long hairs.

Distinctive characters. - This species is distinguished from D. arizonicus, its nearest ally, by its smaller size, broader pronotum, with finer punctures, and finer and less acute rugosities of the elytra.

Revisional notes.- The type series in the Le Conte collection is represented by three specimens-one labeled "Type 1, D. frontalis (Fab.) 
Zimm.," red disk (=Carolinas), which should stand as the type, and the other two labeled "Type 2" and "Type 3," same locality. There are also two specimens, one labeled "Specimen 4, Lake Superior," and the other labeled "Specimen 5, Va." Both of these agree with the West Virginia form. In addition, there are three specimens labeled with an orange disk (=Georgia), one with light green disk (= Middle States), all of which were doubtless before Le Conte when he drew up his revised description.

The series in the Iorn collection, which was evidently before Doctor Dietz when he drew up his revised description, includes but one

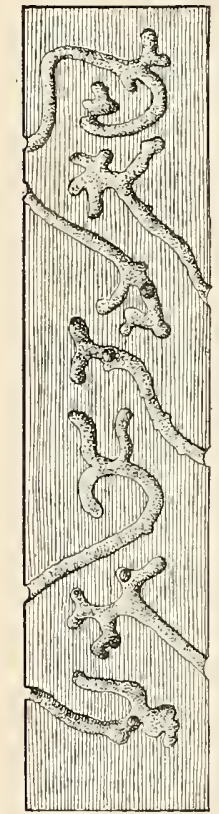

FIG. 52.-Dendrocto. nus frontalis: Termination of egg gal. leries. (Original.)
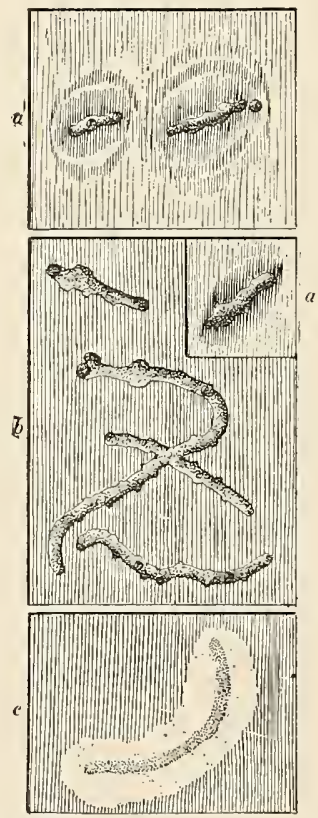

Fig. 53.-Dendroctonus frontalis: Beginning of egg gallerles; $a$, in living bark; $b$, in dying bark; $c$, marked on surface of wood (white area represents normal appearance of wood preserved by resin). (Original.)

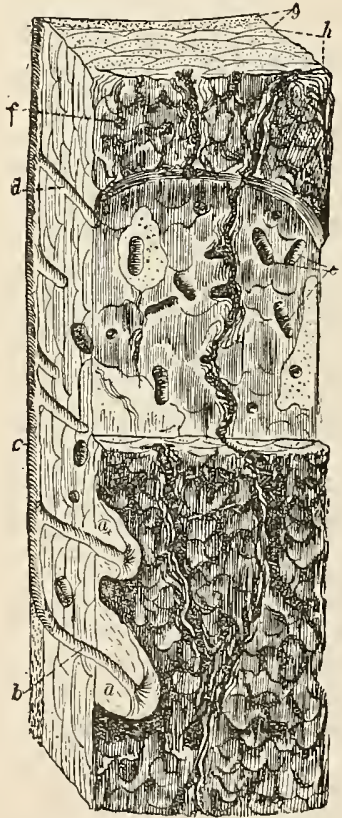

FIG. 54.-Dendroctonus fronialis: Bark showing, $a$, pitch tubes; $b$, entrance burrow; $c$, egg gallery; $d$, ventilating burrow; $e$, pupal cells; $f$, exit burrows; $g$, inner bark; $h$, outer bark. (Original.)

specimen labeled with red disk (=Carolinas). The specimens mentioned, together with two or three specimens in the United States National Museum, were probably all that were in the larger collections of the country up to 1890 .

The form which in 1891 and 1892 extended northward from the normal range of the species into Virginia and West Virginia is represented in the revision series by specimens labeled "Hopk. W. Va. ? individual 1" and "Hopk. W. Va. of individual 1." The West Virginia female differs from the typical South Carolina female in a more 
rugose front, prothorax slightly narrow in front, with a few short and long hairs on sides and the punctures of anterior dorsal surface coarser toward base and fine toward anterior margin; elytral rugosities more acute; strial punctures coarser and more distinct; elytral declivity with longer and more numerous hairs. The West Virginia male differs from the typical North Carolina male type in the more shining front, with punctures more distinct, while the pronotum and elytra show the corresponding differences mentioned under the female individual 1. At one time it seemed to the writer that this

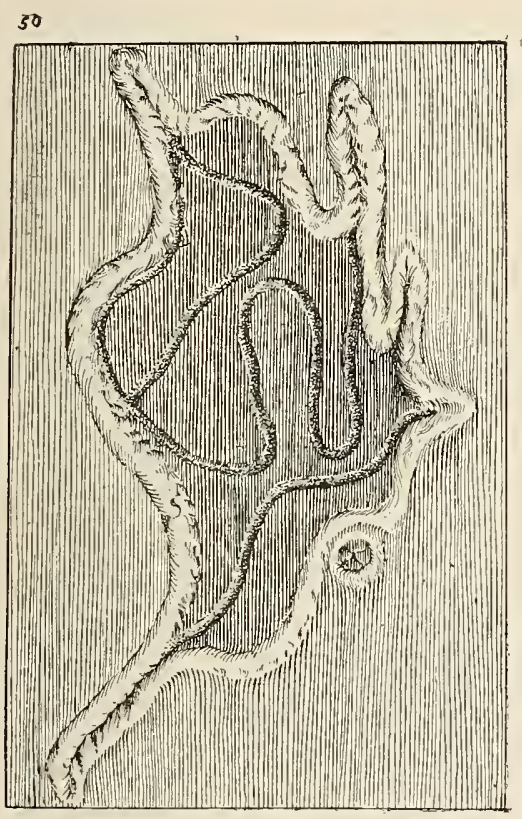

FIG. 55.-Dendroctonusfrontalis: Old egg galleries in living tree, with surrounding callus of new wood. (Original.)

northern form was worthy of specific distinction, and the manuscript name of $D$. pinicida was proposed for it, but it was later found that some southern examples showed the same, and even

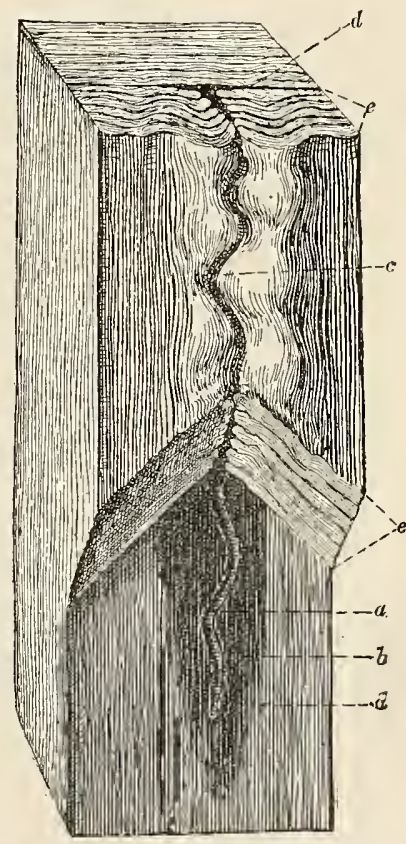

FiG.56.-Dendroctonus frontalis: Egg gallery in living tree marked on surface of wood six years before block was cut from tree. $a$, Mark of gallery on original surface; $b$, resinous wood; $c$, surface sear six years later; $d$, original surface or 7 -year-old annual layer of wood; $e$, six subsequent annual layers of wood formed over original wound. (Original.) greater, variations from the type. Therefore, since the species had disappeared from its northern range, it was decided that it would not be advisable to recognize it as specifically distinct.

Pupa.-In addition to the divisional and subdivisional characters the apices of the front and middle femora are armed with small apical spines or granules. Abdominal tergites 1 to 6 without pleural spines; 1,2 , and 3 without distinct dorsal and lateral spines; 4 to 6 with a pair of dorsal spines and one or two lateral ones; 7 and $S$ with 
a few dorsal granules, and 9 with medium-sized caudal spines. Pupal type labeled "Hopk. U. S. No. 2968."

Larva.- - In addition to the divisional characters, the front has a distinct, median, smooth, shining convexity produced toward vertex; clypeus short, broad, with apex deeply emarginate; prothoracic segments very large and sternellar lobes with distinct foot calli. Apex of abdomen truncate. Larval type labeled "Hopk. W. Va. No. 5976."

The frontal convexity is more rugose in some specimens than in others.

Galleries (figs. 51-56).-Egg galleries sublongitudinal, winding; the eggs isolated; larval mines exposed; pupal cells in outer bark:

Distribution (fig. 57).--(Hopk. W. Va.) Test Tirginia: Hampshire, Monongalia, Hardy, Pendleton, Randolph, Pocahontas, Tucker, Kanawha, Raleigh, Greenbrier, and Wood counties. Virginia: Port

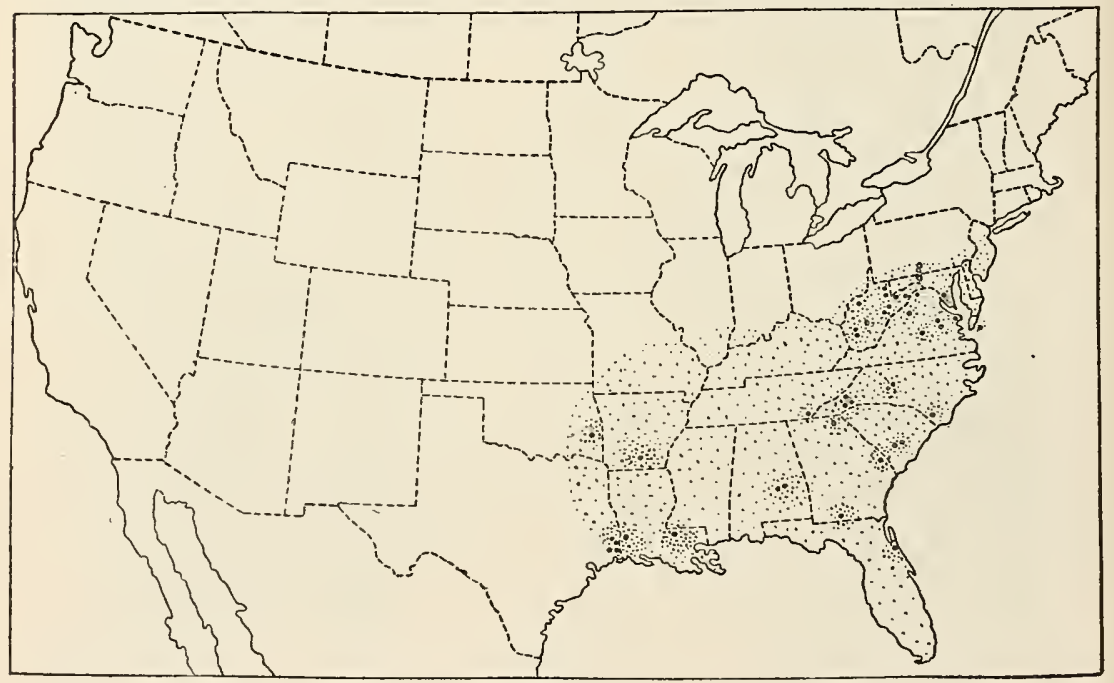

FIg. 57.-Dendroctonus frontalis: Distribution map. (Original.)

Republic. Work óbserved in southern Pennsylvania, Maryland, and Virginia (author). (IIopk. U. S.) Alabama: Calhoun, Montgomery. Arlansas: Hampton. Georgia: Clyo, Thomasville, Demorest. Louisiana: Singer, Wilson. Maryland: Near Cumberland. North Carolina: Tryon, Pisgah Ridge, Fletchers, Boardman, Pink Beds, Biltnore. South Carolina: Chicora (Pregnalls). Tennessee: Ducktowi. Texas: Call, Deweyville, Kirbyville, Beaumont. Virginia: Green Bay, Glen Allen, Auburn Mills, Virginia Beach. District of Columbia: Washington. Additional localities represented in other collections: (Le Conte) Lake Superior, Michigan. (There may have been some mistake in regard to the labeling of this specimen, since it is not likely the species will егеr be found that far north.) (H.\& S.) Haw Creek, Florida; Cobbs Island, Virginia; (A. M. N. H.) Black Mountains and Mount Graybeard, North Carolina; (Barber) "western Indian territory" [Oklahoma]. 
Host trees.-Pinus strobus, $P$. tæda, P. rigida, P. virginiana, $P$. pungens, $P$. echinata, $P$. glabra, $P$. palustris, Picea rubens, and $P$. excelsa. Identified specimens.-Le Conte collection, 9; Horn, 1; U.S.N.M., H. \& S., 5; D. A., 7; Barber, 2; Hopk. W. Va., 68; Hopk. U. S., more than 150 , including all stages and work.

\section{BiBLIOGRAPHY AND SYNONYMY.}

Dendroctonus frontalis Zimmerman, 1868, p. 149, original description, type, locality, Carolina. Le Conte, 1868, p. 173, synopsis and reference to p. 149 . Le Conte, 1876 , p. 386, revision, synopsis, synonymy excluded, bibliography, localities. Packard, 1887, p. 177, Le Conte quoted. Packard, 1890, p. 722, Le Conte quoted. Dietz, 1890, p. 32, in part, fig. 6, antenna and epistoma. Hopkins, 1892a, pp. 64-65, depredations in W. Va. Hopkins, 1892b, p. 353, importation of enemy. Schaufuss, 1892, p. 316, introduction of enemy. Hopkins, 1893a, pp. 187-189, habits, etc. Hopkins, 1893b, p. 143, No. 77 and index, habits, host, distribution, enemies. Hopkins, 1893c, p. 213, No. 301, same as 1893b. Hopkins, 1893d, pp. 123-129, habits and enemy. Lintner, 1894, p. 292, reference to Hopkins. Hopkins, 1894a, pp. 71-76, same as Hopkins 1893d. Hopkins, 1894c, p. 348, insects, birds, and forests. Lintner, 1895, same as 1894. Hopkins, 1896, pp. 246-250, disappearance in W. Va., occurrence in N. C. Hopkins, 1897a, pp. 29-41, importation and distribution of enemy. Hopkins, 1897b, pp. 35-36, enemy, etc. Hopkins, 1897c, pp. 79, 94, 95, Pl. I, dead trees, fig. IV, Clerus formicarius L., discussion of habits, etc., pp. 147, 151, reprint from 1896. Chittenden, 1897, pp. 67, 75, fig. 43, adult, destructive habits. Schwarz, 1898, p. 81, habits and disappearance. Hopkins, 1898b, pp. 104-105, habits, etc. Hopkins, 1899a, pp. 394-414, etc. (see index), full account, all stages and work illustrated and described, natural enemies, hosts, distribution, bibliography, etc. Hopkins, 1899b, pp. 11, 13, 14, reference to habits. Hopkins, $1899 \mathrm{c}$, p. 343, disappearance in W. Va. due to freezing. Chittenden, 1899, pp. 55, 56, fig. 5, habits, etc. Ulke, 1902, pp. 36, 56, host, habits, etc., in D. C. Hopkins, 1903a, p. 59, occurrence and habits in southeru States. Hopkins, 1903b, pp. 270, 275, figs. 26, 27, 28-32, stages and work, with account of habits, life history, etc. Hopkins, 1904, pp. 41, 42, 44, P1. I, fig. 2, Pl. VII, figs. $a, b$, stages and work, account of distribution, habits, etc. Felt, 1905 , p. 6, reference. Hopkins, 1906c, p. 81, mentioned in comparison. Webb, 1906, pp. 20, 22, mentioned. Hopkins, 1908, p. 163, depredations.

Bostrichus frontalis (not of Fab.) Zimmerman, 1868, p. 149, synonymical reference. Le Conte, 1868, p. 173.

Dendroctonus pinicida Hopkins, 1902a, p. 3, manuscript name only.

Dendroctonus frontalis Zimm. var. destructor Hopkins, 1902b, p. 21, note. Hopkins, 1902 c, p. 20, habits, etc.

Dendroctonus brevicornis Dietz, 1890, p. 32 (in part).

\section{Dendroctonus arizonicus n. sp.}

(P1. III, fig. 5.)

Adult.-Type of species, female: Length, $3.7 \mathrm{~mm}$., dark brown. Elytral declivity with long hairs confined to declivity and posterior lateral areas. Head with front convex, shining, and with distinct frontal tubercle each side of a broad median groove. Elytral strixe distinctly punctured; the interspaces with subacute, moderately coarse rugosities, distinctly coarser toward the base and vertex. Pronotum with long erect hairs on the anterior half of the lateral area. Secondary sexual characters same as in $D$. frontalis. 
Type labeled "Type No. 7446, U.S.N.M.," name label, "Hopk. 1/15/05, \&, Barber \& Schwarz Coll[ectors], Williams, Ar., 7.6" (= June 7).

Male type: Length, $3.3 \mathrm{~mm}$. Front with prominent tubercles each. side of a deep median groove. Pronotum with transverse impression and faint transverse elevation across anterior area. Elytral declivity less shining; striæ more distinctly impressed and punctured and the interspaces more convex and distinctly rugose than in the female.

Male type labeled, name label, "Hopk. Jan. 15/08, Pinus ponderosa, Webb, Collr., 8-22-04, Flagstaff, Ariz., ô, Hopk. U. S. No. 5118.

Variations.-Length 3.5 to $3.9 \mathrm{~mm}$., average about $3.6 \mathrm{~mm}$.; color from light brown to black. The short hairs of the lateral area of the elytra range from obscure to distinct, and the long hairs of the elytral declivity range from short and sparse to very long and numerous. The variation in the size of the punctures of the pronotum is less marked than in other species.

Distinctive characters.-The coarse punctures of the pronotum, and especially the very coarse shallow rugose ones, together with the coarser rugosities of the elytra, serve to distinguish specimens of this species from $D$. barberi, and the absence of short reclining hairs on the pronotum with the more distinctly impressed elytral striæ and less evident short and long hairs on the elytra serve to distinguish it from D. mexicanus, which is its nearest ally. It is also distinguished from $D$. frontalis by its larger size, coarser punctures of the pronotum, and coarser rugosities of the elytra, as it is from small examples of $D$. convexifrons by the grooved front, and from small examples of $D$. approximatus by the impressed elytral strix and the shorter, more yellow, and less numerous hairs of the declivity.

Revisional notes.--This species is not represented in the Le Conte collection and not in the Horn collection unless it is one specimen found under $D$. frontalis labeled "Williams, Ariz., 7.28, 152," which the writer has not seen since $D$. arizonicus has been recognized as a distinct species. If this specimen is $D$. arizonicus, it was evidently before Doctor Dietz when he prepared his revised description of $D$. frontalis.

Pupa.-In addition to the generic and divisional characters, the apices of the front and middle femora have each a small spine. Abdominal tergites 2 to 6 with small pleural spines and 4 to 6 with small dorsal, lateral, and pleural spines, increasing in size toward $6 ; 7$ and 8 with a pair of dorsal granules, coarser on 7 . Pupal type labeled "Hopk. U. S. No. 3129."

Larva.--In addition to the divisional characters, the front has a median transverse and rugose convexity produced toward apex; clypeus with apex broadly emarginate; labrum broad, with apex broadly rounded. Thoracic segments with foot calli on sternellar lobes. Larval type labeled "Hopk. U. S. No. 5156." 
Galleries.-While the galleries of this species have not been definitely recognized from those of $D$. barberi, with which they are nearly always present, it is evident that they are quite similar in general character to those of $D$. barberi, especially in the concealed larval mines.

Distribution (fig. 58).-(Hopk. U. S.) Arizona: Williams, Flagstaff, Santa Catalina Mountains (rare).

Host tree.-Pinus ponderosa var. scopulorum.

Identified specimens.-Horn collection, 1 (?), B. \& S., 2; Mopk. U. S., more than 50 specimens, including adults, larvæ, and pupæ.

\section{Bibliography.}

Dendroctonus arizonicus Hopkins, 1902a, p. 3 (in part), manuscript name.

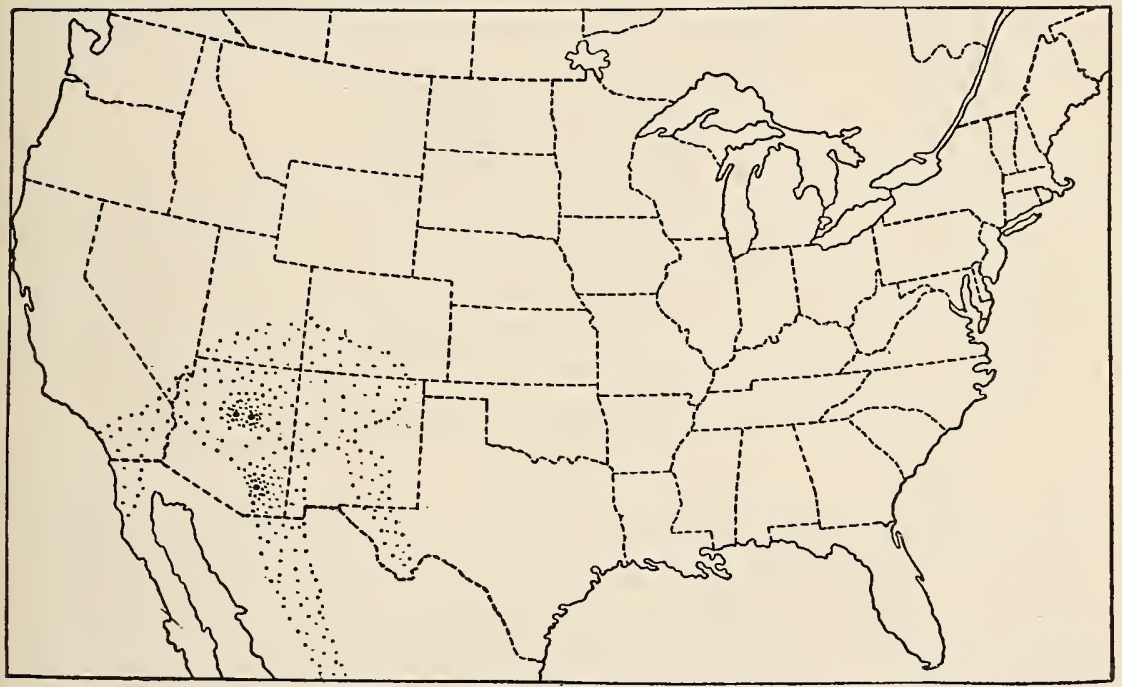

FIG. 58.-Dcndroctonus arizonicus: Distribution map. (Original.)

6. Dendroctonus mexicanus Hopkins.

(PI. 11I, fig. 6.)

Adult.-Type of species, female: Length, $4 \mathrm{~mm}$.; dark brown. Elytra with long hairs on posterior half and declivity. Head with front convex, shining, with small frontal tubercles each side of the short, shallow groove; elytral striæ distinctly impressed, but not distinctly punctured; elytral rugosities distinctly coarser toward the base and vertex, and with an evident row of acute rugosities on the first interspace. Pronotum clothed with short reclining hairs on entire lateral area. Secondary sexual characters: Pronotum with transverse ridge across the anterior area; elytral declivity shining, striæ distinct, obscurely punctured; interspaces roughened with sparsely exposed granules, becoming coarser toward the vertex in lateral area. 
Type labeled “'Type No. 7518, U.S.N.M., individual 1," name label, "'n. sp., Hopk., 4/18/02," name label, "1/15/08, A. L. Herrera, collector, + , Sacramento, Amecameca, Mexico."

Male type: Length, $4 \mathrm{~mm}$.; front with moderately prominent frontal tubercles each side of the distinct groove. Pronotum with rather distinct transverse elevation across the entire area similar to that of the female; elytral declivity more uniformly convex; striæ more impressed and deeply punctured and interspaces more convex and distinctly rugose.

Male type labeled "Type No. 7518, U.S.N.M., individual 5," remaining labels same as on female except sex label.

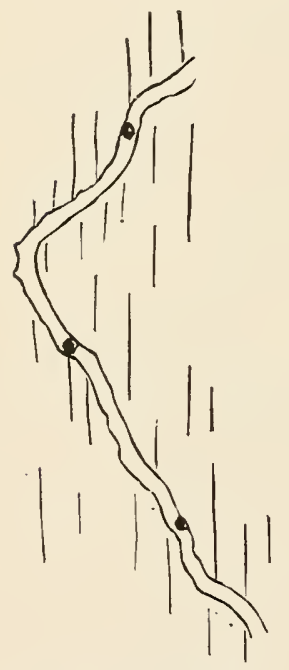

Fig. 59.-Dendroctonus mexicanus: Section of egg galleries. (Original.)

Variations.-Length from 3 to $4.5 \mathrm{~mm}$; average about $3.8 \mathrm{~mm}$.; color from brown to black. The prescutal ridge is more prominent in some females than in others and is present in some males and absent in others.

Distinctive characters.-This species is more closely allied to $D$. arizonicus than to any of the other species of the division to which it belongs and is distinguished from it by the presence of short, reclining hairs on the pronotum, less distinctly impressed elytral striæ, and more evident short pubescence of the elytra.

Revisional notes. - It is evident that this species was not represented in the material studied by Blandford. The size comes near that of his $D$. adjunctus, but the characters as given by him to distinguish this species from $D$. paralletocollis at once distinguish it from $D$. mexicanus.

The pupa and larva have not been seen.

Gallery (fig. 59).-A small section of the gallery, evidently of this species, was received with the specimens of adtult from Prof. A. L. Herrera. This indicates a winding egg gallery, with the eggs isolated, the larval mines concealed in the inner bark, and the pupal cells in the outer bark.

Distribution (fig. 60) and host trees.-The specimens received at different times from Prof. A. L. Herrera and Dr. S. J. Bonansea were evidently from Pinus teocotl, P. lejophilla, and P. ayacahuite in Amecameca, Michoacan, and Tacubaya, Mexico.

Identified specimens.-Thirty-six specimens of adults and one specimen of work were identified for Professor Herrera and Doctor Bonansea, a set of which were returned to them and the remainder retained for the forest insect collection of the Bureau of Entomology. 
BibliogRAPHy.

Dendroctonus mexicanus Пopkins, 1906c, p. 80, original description, both sexes, host, etc.

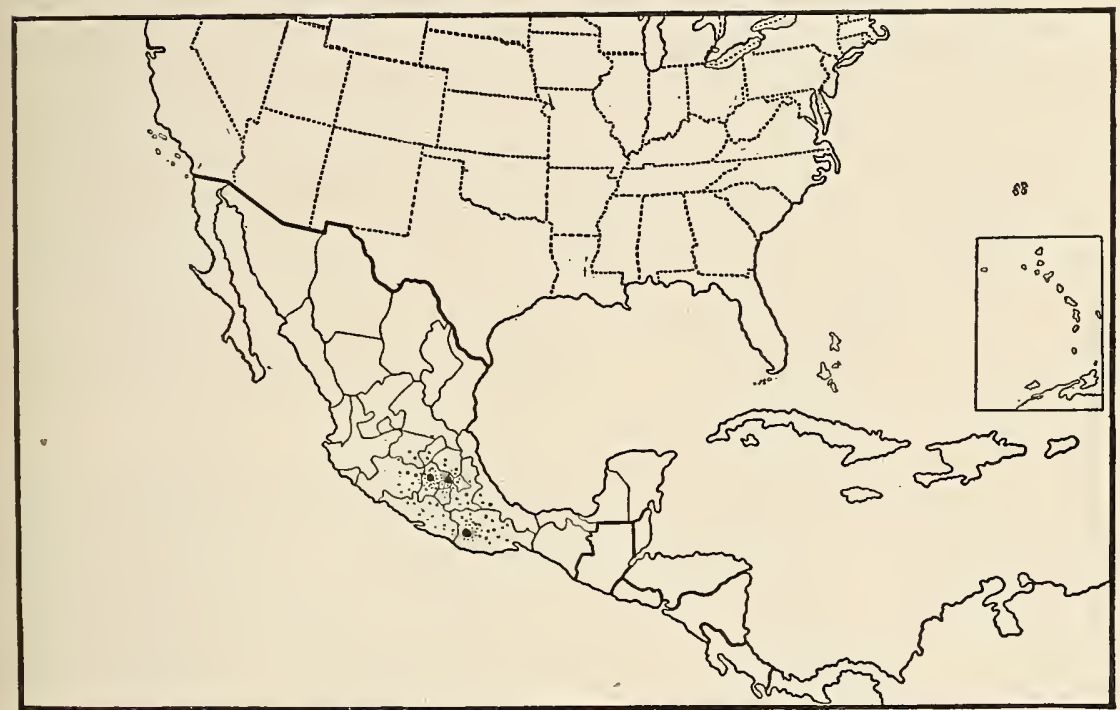

Fıg. 60.-Dendroctonus mexicanus: Distribution map. (Original.)

7. Dendroctonus parallelocollis Chapuis.

(PI. III, fig. 7.)

Adult.-Typical female: Length, $6.1 \mathrm{~mm}$., deep black; elytral declivity with long hairs; head with front convex, shining, without distinct frontal tubercles each side of the shallow median groove; elytral striæ not impressed or distinctly punctured except at vertex; elytral rugosities obtuse, rather densely placed, moderately coarse toward suture, fine and less evident toward and on the lateral area; striæ obscure, especialiy on the lateral area. Pronotum with numerous short, reclining hairs and with very long, erect hairs on the entire lateral area, punctures distinct. Secondary sexual characters: Pronotum with transverse ridge across the anterior area; elytral declivity subconvex, shining; striæ distinct, slightly impressed, punctures rather distinct; interspaces with a few granules and sparse punctures, the lateral areas more rugose and coarsely punctured.

Typical female labeled, name label, "Hopk., January 16/08, Michoacan, Mexico, A. L. Herrera, collector, ๆ, Hopk. U. S. 2S96b."

Typical male: Length, $6 \mathrm{~mm}$. Head with front convex and with prominent frontal tubercles each side of a deep groove. Pronotum with transverse impression across anterior area; elytral declivity 
subconvex; striæ distinct, slightly impressed, and the interspaces more distinctly rugose than in female.

Typical male labeled, name label, "Hopk. 1/16/08, type of drawing, Pinus, Michoacan, Mexico, A. L. Herrera, collector, ô, Hopk. U. S. 2896a."

Variations.-Length from 5 to $6.1 \mathrm{~mm}$., average about $5.5 \mathrm{~mm}$.; color, dark brown to black, with the usual variation in epistoma, pronotal punctures, pubescence, and median line.

Distinctive characters.-This species is distinguished from $D$. approximatus by the noticeably less shining and more pubescent pro-

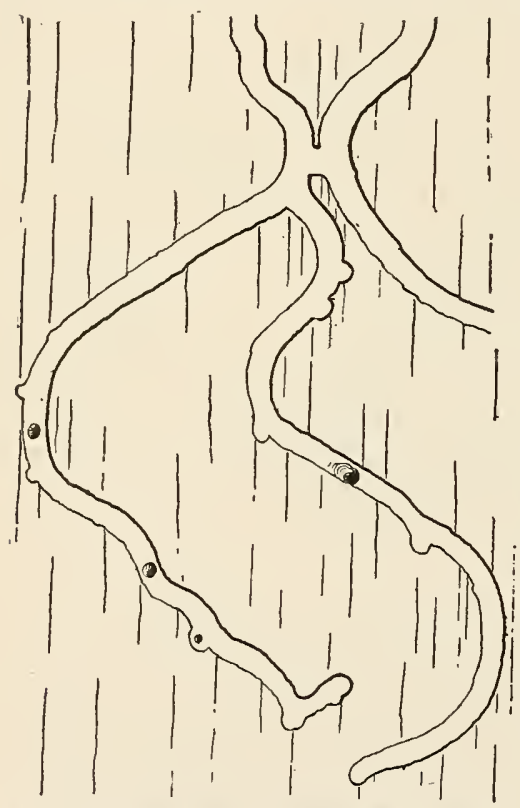

F1G. 61.-Dendroctonus parallelocollis: Section of egg gallery. (Original.) notum, the deeper punctures, the noticeably and constantly less impressed elytral' strix, and the less distinet punctures.

Revisional notes.-Agrees with original description, except that the specimens before the writer are smaller, the type being given as $6 \frac{2}{3}$ $\mathrm{mm}$. The median line is flat in all but one specimen, in which it is impressed toward the anterior and posterior margin. In Blandford's revision the length of the type is given as $6.3 \mathrm{~mm}$. Blandford states that it differs from D. approximatus Dietz by its smaller size, more elongate shape, more shining and strongly punctured prothorax, and indistinct elytral striæ. The last difference holds, but the other's do not.

In the writer's reference to this species (1905a, p. S1) it was considered to be the same as D. approximatus Dietz, but I am now convinced that the two are specifically distinct.

The pupæ and larve have not been observed.

Galleries (fig. 61).-A short section of the egg gallery, from which an adult was taken, indicates that it is quite similar, in its winding character and the absence of exposed larval mines, to that of $D$. approximatus.

Distribution (fig. 62).-Recorded from Mexico by Chapuis (1869) and Blandford (1897). Specimens were received with D. mexicanus from Prof. A. L. Herrera, labeled Mexico and Michoacan, Mexico, with his statement that it destroys the forests of Ionacatapec, Morelos, and many regions of Mexico. 
Host trees.-According to evidence from correspondence with Professor Herrera, it would appear that this species, like $D$. mexicanus, attacks Pinus teocotl (?), P. lejophilla, and P. ayacahuite, although there is no definite statement to that effect. It is quite evident, however, that this species is associated with $D$. mexicanus in the same manner as $D$. approximatus in its association with $D$. arizonicus and $D$. barberi.

Identified specimens.-Ten specimens of adults and one specimen of work identified for Prof. A. L. Herrera.

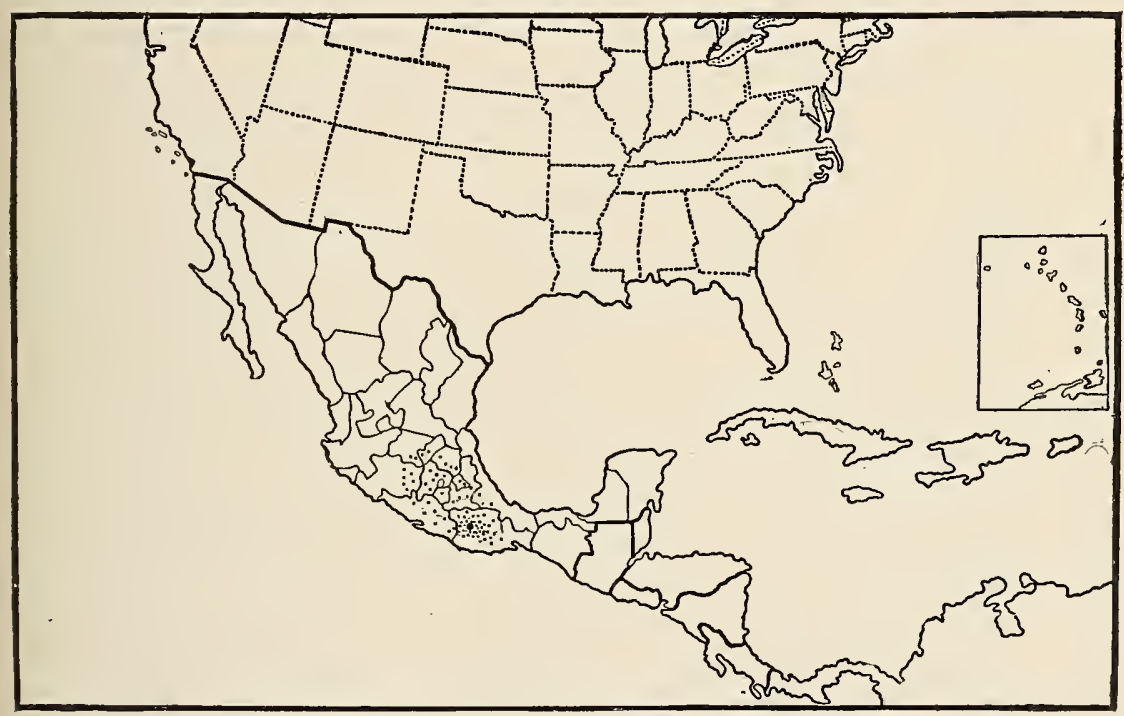

Fig. 62.-Dendroctonus parallelocollis: Distribution map. (Original.)

BibLiOgRAPHY.

Dendroctonus parallelocollis Chapuis, 1869, p. 36, original description. Chapuis, 1873 , p. 244, reprint. Blandford, 1897, p. 147, synopsis, revision, distribution, bibliography. Hopkins, $1906 \mathrm{c}$, p. 81 , systematic notes.

\section{Dendroctonus approximatus Dietz.}

(Pl. IV, fig. 8.)

Adult.-Typical female: Length, $6.5 \mathrm{~mm}$., reddish brown; elytral declivity with long hairs; head with front convex, shining, and with obscure frontal tubercles each side of short, median groove; elytral striæ not impressed or distinctly punctured; elytral rugosities rather coarse, sparse; strix on lateral area rather distinct; pronotum with long hairs on anterior two-thirds of lateral area, but not on posterior section. Secondary sexual characters: Pronotum with transverse ridge across the anterior area; elytral declivity subconvex, shining; 
striæ very distinct, impressed, and distinctly punctured; interspaces sparsely tuberculate, and with a few fine punctures; lateral area shining, with a few subacute tubercles, and rather coarse, distinct punctures.

Typical female labeled, name label, "Hopk. 1/16/08, + , individual $c$, Barber \& Schwarz, Coll[ectors], Flagstaff, Ar. 2.7" (=July 2).

Type of species, + , in Horn collection, A.E.S., Philadelphia, labeled "Type D. approximatus n. sp., Col[orado]."

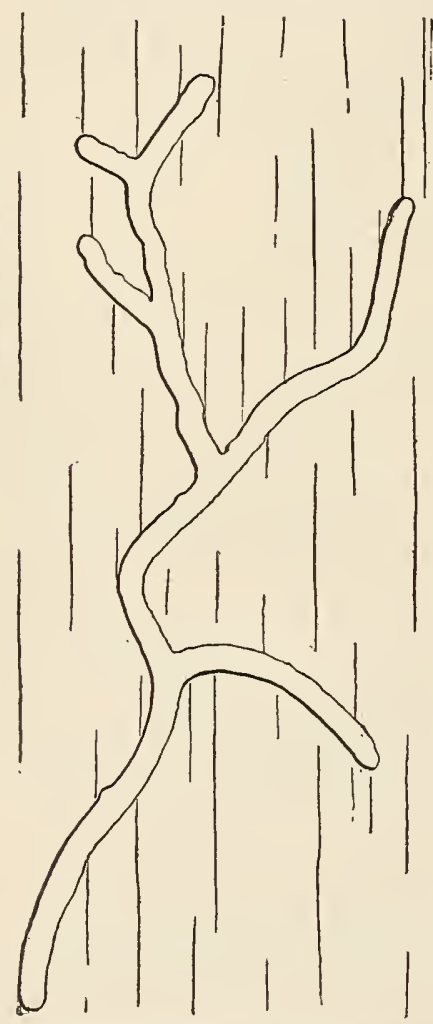

FIG. 63.-Dendroctonus approximatus: Single egg gallery. (Original.)

Male type: Length, $5.7 \mathrm{~mm}$. Head with front convex, shining, a prominent frontal tubercle each side of a deep groove. Pronotum with broad impression across the anterior area; elytral declivity same as female, except that the interspaces are more densely rugose.

Male type labeled, name label, "Hopk. $1 / 16 / 08$, $\delta$ type of revision, type of drawing, Williams, Ar., 7.6" (=June 7) "

Variations.-The length varies from 4 to $7.4 \mathrm{~mm}$., the average about $6 \mathrm{~mm}$. The color ranges from reddish-brown to black. The epistomal, frontal, pronotal, and elytral sculpture and vestiture vary as usual. The greatest variation is in the strial and interspacial punctures of the declivity.

Distinctive characters.--The characters which distinguish this species from $D$. parallelocollis, its nearest ally, are the noticeably more shining and less pubescent pronotum, with the punctures finer and more shallow, the elytral strix constantly more impressed, and the punctures distinct.

Revisional notes.-The original description (Dietz, 1890, p. 31), was based on "four specimens, two males and two females, from New Mexico and Colorado in Doctor Horn's collection." The specimen labeled type in the Horn collection is a female from Colorado, and agrees with the description, but one specimen labeled "N. M." is a female of $D$. convexifrons Hopk., and one other specimen with the type, but without locality label, is quite a different thing from either of the other two. The specimen has not been examined since the more distinctive characters of $D$. monticotæ Hopk. and $D$. ponderosæ Hopk. have been recognized, but it evidently belongs to one of these species. The fourth specimen mentioned by Dietz was not in the 
collection when examined by the writer on January 12, 1900. The reference in the original description to the front of the head "coarsely granulated, channeled" applies to the type, and at once distinguishes it from the other two specimens which are without a median frontal channel or groove. The "strong transverse impression about onefourth from the anterior margin" of the prothorax is associated with the more distinct transverse elevation which the author failed to mention. In the writer's remarks (Hopkins, 1905, p. 81) under D. parallelocollis it is stated that $D$. parallelocollis Chap. and D. approximatus Dietz are evidently the same, but further comparative studies have convinced him that they are specifically distinct. Pupa.-In addition to the generic, divisional, and subdivisional characters, the apex of the front and middle femora have each a minute subapical spine; abdominal tergites 1 to 6 with small pleural spines, 1 without distinct

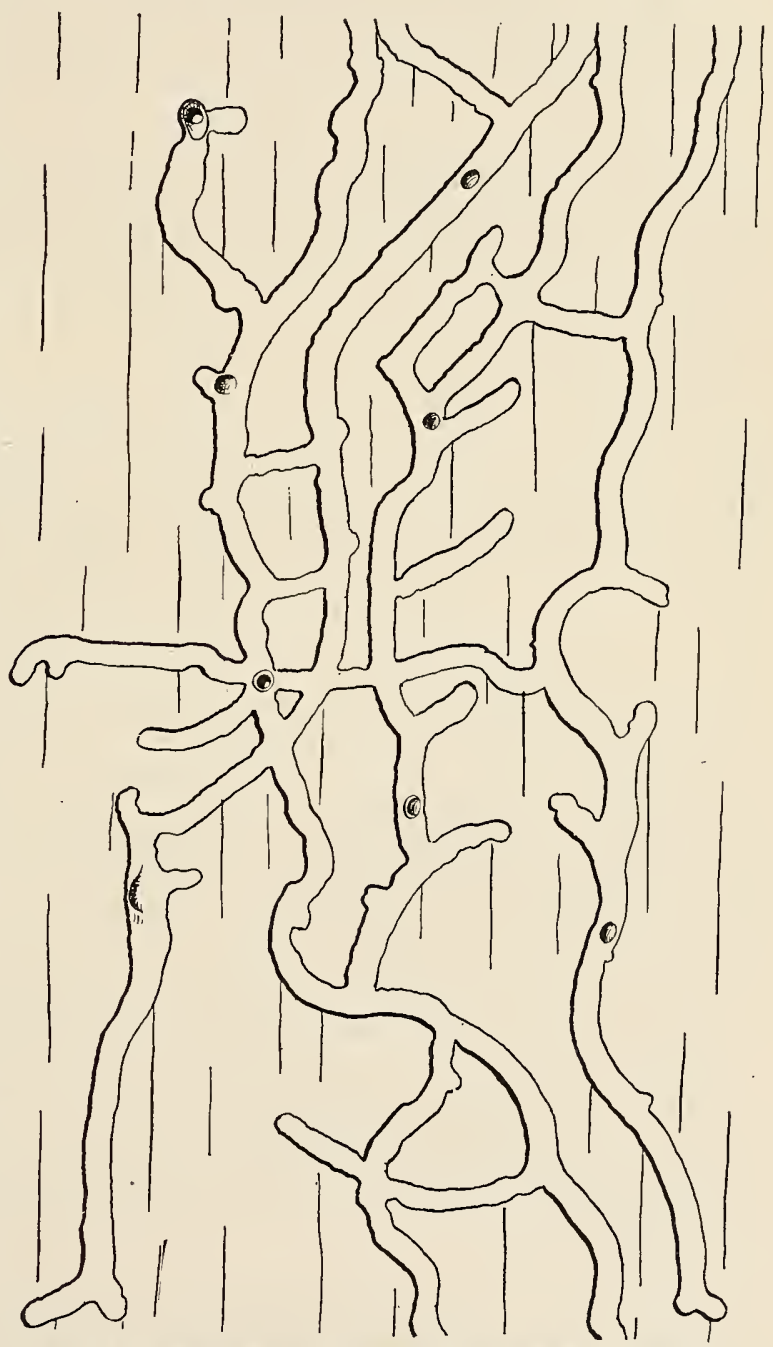

Fig. 64.-Dendroctonus approximatus: Egg galleries. (Original.) dorsal and lateral spines; 2 to 6 with distinct dorsal and lateral spines, increasing in length and prominence to and including tergite $6 ; 7$ and 8 smooth; 9 with long pleural spine. Pupal type labeled "Hopk. U. S. No. 5777."

Larva.-In addition to generic and divisional characters, the front has a broad, but not prominent, median elevation; clypeus short, broad, with apex truncate; prothoracic segments with prominent 
sternellar lobes, each with a distinct foot callus. Larval type labeled "Hopk. U. S. No. 5024."

Galleries (figs. 63, 64).--Egg galleries sublongitudinal, branched, slightly winding; eggs isolated; larval mines concealed; pupal cells in outer bark.

Distribution (fig. 65).-(Hopk. U. S.) Colorado: Brookville, Glen Haven, Las Animas County, La Veta, Monte Vista, and Palmer Lake. Utah: Escalante, Kamas, Panguitch. New Mexico: Capitan Mountains, Cloudcroft, Lincoln National Forest, Santa Fe. Arizona: Black Mesa Forest Reserve, Chiricahua Mountains, Flagstaff, Paradise, Rincon Mountains, Santa Catalina Mountains, Show Low, Tucson. Additional locality from correspondence: Glenhaven, Colo.

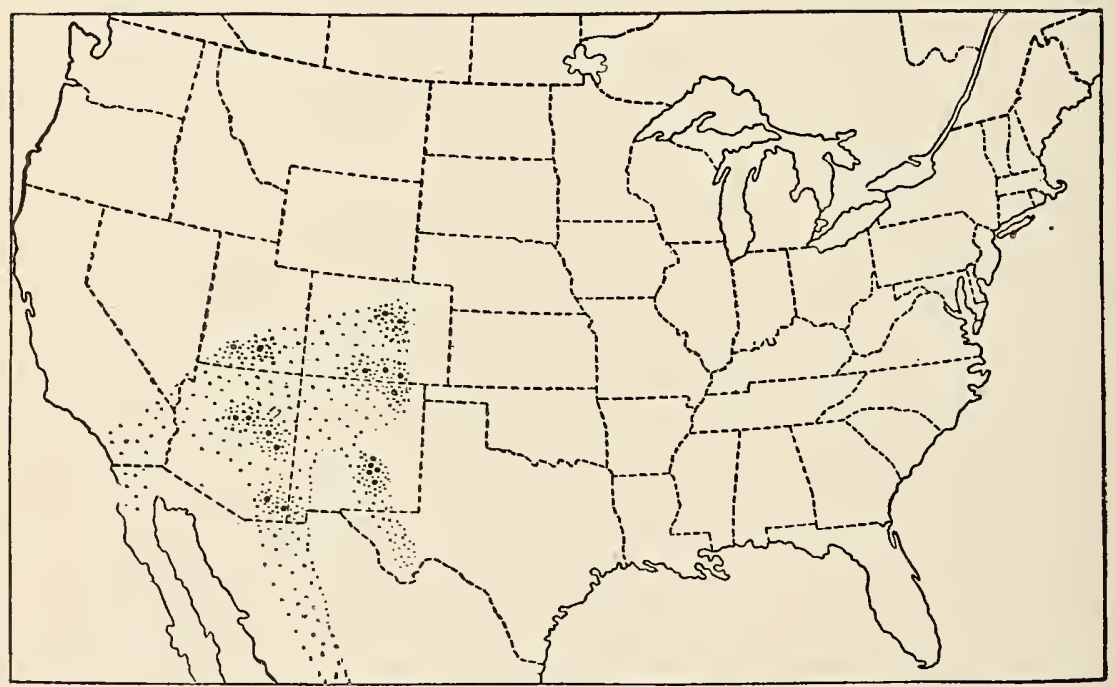

Fig. 65.-Dendroctonus approximatus: Distribution map. (Original.)

Host trees.-Pinus ponderosa scopulorum (common), P. arizonica (rare), and $P$. chithuahuana (rare).

Identified specimens.-Horn, A. F. S., 1 specimen, the type; U.S.N.M., 31; Hopk. U. S., more than 200 specimens, including all stages and work.

\section{Bibliography AND Synonymy.}

Dendroctonus approximatus Dietz, 1890, p. 31, fig. 5, antenna and epistoma; original description (applies to type only). Blandford, 1897, p. 147, reference to characters. Hopkins, 1S99a, p. 392, fig. LVIII, reference. Schwarz, 1902, p. 32 (in part), destructive to pine at Flagstaff, Ariz. (see also convexifrons). Wickham, 1902 , p. 310 (in part), list, Dietz quoted. Hopkins, 1903a, p. 60, reference to habits, etc. Hopkins, 1903b, p. 281, mention. Hopkins, 1904, p. 44, habits, distribution, hosts, etc. Hopkins, 1905, p. 11, some distinctive characters. Hopkins, 1906c, p. 81, referred to D. parallelocollis.

Dendroctonus (parallelocollis) var. approximatus (Dietz) Fall, 1907, p. 218, list, localities. 
Subdrision B.

(Species numbered 9 to 11 , inclusive.)

The distinctive characters common to the species of the second subdivision are as follows:

Adult.-Body somewhat stout, prothorax with sides distinctly narrowed and constricted toward the head; elytral declivity with second stria distinctly curved, second interspace broader toward middle, narrowed toward apex.

Sexes.-Female: Elytral declivity with interspaces smoother and more shining, mandibles less stout. Male: The reverse.

Pupa.-Elytral pads roughened with granules, vertex of head deeply grooved and with two prominent forward curved frontal spines toward the vertex; abdominal tergites 2 to 6 with long and prominent pleural spines.

Larva.-Front with prominent transverse and rugose elevation, more prominent toward the sutures.

Galleries.-Pupal cells in inner bark, eggs in approximate groups, egg galleries slightly winding to straight, larval mines always exposed in inner bark.

\section{Dendroctonus monticolæ Hopkins.}

(Pl. 1V, fig. 9.)

Adult.-Type of species, female: Length $5.6 \mathrm{~mm}$., light brown; elytral declivity with a few long hairs; head with front convex, without median elevation or groove, but with faint posterior impression; elytral rugosities coarse, rather dense, coarser on dorsal area; stria not distinctly impressed, except toward suture, punctures small. Pronotum with the anterior area transversely impressed, but with moderately long hairs on the lateral area, slightly longer on the anterior section. Secondary sexual characters: Elytral declivity convex, subopaque; striæ distinct, and impressed, with fine obscure punctures; interspaces with rather coarse granules, in approximate rows; lateral area with obscure punctures and subacute rugosities.

Type labeled "No 7447 U.S.N.M.," name label, "IIopk. 1/16/08, Pinus monticola, Hopkins, collector, 5/27/99, Kootenai, Idaho, \&, Hopk. U. S. 205."

Male type: Length $4.9 \mathrm{~mm}$. Head with front less distinctly punctured and more rugose than female; elytral declivity with striæ more distinctly punctured, interspaces more opaque, and rugosities slightly coarser, the mandibles stouter than in female.

Male type labeled same as female except sex label.

Variations.-The length varies from 3.7 to $6.4 \mathrm{~mm}$., averaging about $5.5 \mathrm{~mm}$. The color ranges from light brown to black; the sculpture and vestiture of the epistoma, front, pronotum, and elytra vary as usual, but the character of the strial punctures is fairly constant. 
The greatest variation is in size and in the presence or absence of dorsal line of the pronotum.

Distinctive characters. - The characters which distinguish this species from the next following, to which it is more closely allied, are the average smaller size and prevailing moderately impressed elytral striæ with distinct but moderately coarse punctures. While the strial punctures vary in size in different individuals, they are never so coarse as in the average $D$. ponderosæ. It is also distinguished from $D$. jeffreyi by the much smaller average length of body and the prevailingly coarser punctures of the pronotum.

Revisional notes.-A brief description (Hopkins, 1905, p. 11) was published under the name $D$. monticola, but the name should read $D$. monticolx, which, as the manuscript name indicates, was originally intended. The species is represented by three specimens from California in the Le Conte collection, with the type series, under $D$. simitis, bearing specimen numbers 4,12 , and 13 , and therefore may have been included in the revision by Le Conte (1876, p. 385), although the locality (California) is not given in that correction. There is also one specimen in the Horn collection, labeled "Cal.," under $D$. simitis. It is probable that the one under similis was before Dietz when he prepared his revision (1590, pp. 30-31) under the name similis. These specimens are evidently the only ones which may have been involved in Le Conte's or Dietz's revisions on the literature previous to Hopkins, 1899 b, pp. 14 and 26 .

Pupa.-In addition to the generic, divisional, and subdivisional characters, the apex of the front and middle femora is armed with two small apical spines; abdominal tergites 2 to 6 with long and prominent pleural spines, 1 is without distinct dorsal and lateral spines, but 2 to 6 have distinct dorsal and lateral ones, 2, 3, and 6 with a pair, and 4 and 5 with three lateral spines each side of the dorsal ones; 7 has two dorsal spines, while 8 is smooth and the pleural spines of 9 are long and prominent. Pupal type labeled "Hopk. U. S. No. 196."

There is the usual variation in the arrangement and number of minor spines, and one specimen from Yosemite National Park is quite different in the widely separated frontal spines, with the dorsal ones of the abdominal tergites coarser and tergite 7 with a pleural spine. It is possible that this may be a pupa of an unrecognized species. The characters of the pupa of $D$. monticolx, which serve to distinguish it from that of $D$. ponderosæ, are the less coarse spines of the abdominal segments, the less densely granulated elytral pads, and the presence of two apical spines on the front and middle femora.

Larva.-In addition to the generic and divisional characters, the front has the posterior angle subacute and a moderately stout, rugose elevation situated in the middle, becoming slightly thickened and elevated toward the suture. Clypeus shining, with faint median 
groove and usual elevation; apex broadly emarginate, labrum with apex broadly rounded, and the sternellar lobes of the thoracic segments with distinct foot calli. Larval type labeled "Hopk. U. S. No. 196."

There is some variation in the frontal elevation, but generally it is situated slightly anterior to the middle or in the middle, while the posterior angle of the front is distinctly subacute. These serve as

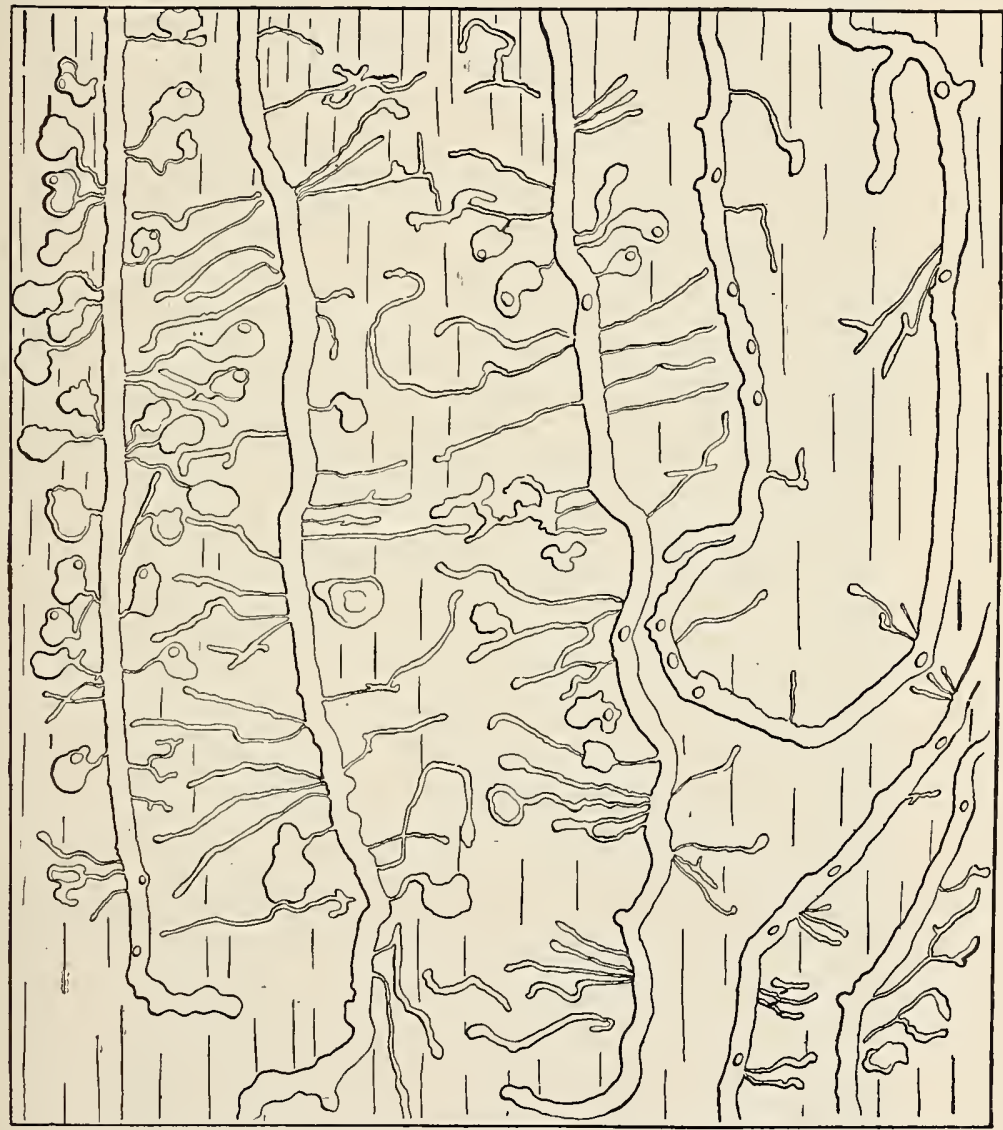

FiG. 66.-Dendroctonus monticolæ: Egg galleries and larval mines in bark. (Original.)

the most distinctive characters to separate the larva of this species from that of $D$. ponderosæ.

Galleries (figs. 66, 67).-The egg galleries are longitudinal, distinctly to slightly winding or straight, usually grooved on the surface of the wood and deeply grooved in the bark, the larval mines and pupal cells exposed in the inner bark; the eggs are placed in approximate groups, and the larval mines are short and broad. The egg galleries differ from those of $D$. ponderosæ in smaller size, more winding form, and are often of a much greater length. 
Distribution (fig. 68).-(Hopk. U. S.) California: Alder Creek, Chester, Fulda, Lake Tenaya, Mariposa Grove, Millwood, Siskiyou County, Soda Springs, Summerdale, Tioga Road, Wawona. Idaho: Boise County, Cedar Mountain, Centerville, Coeur d'Alene National

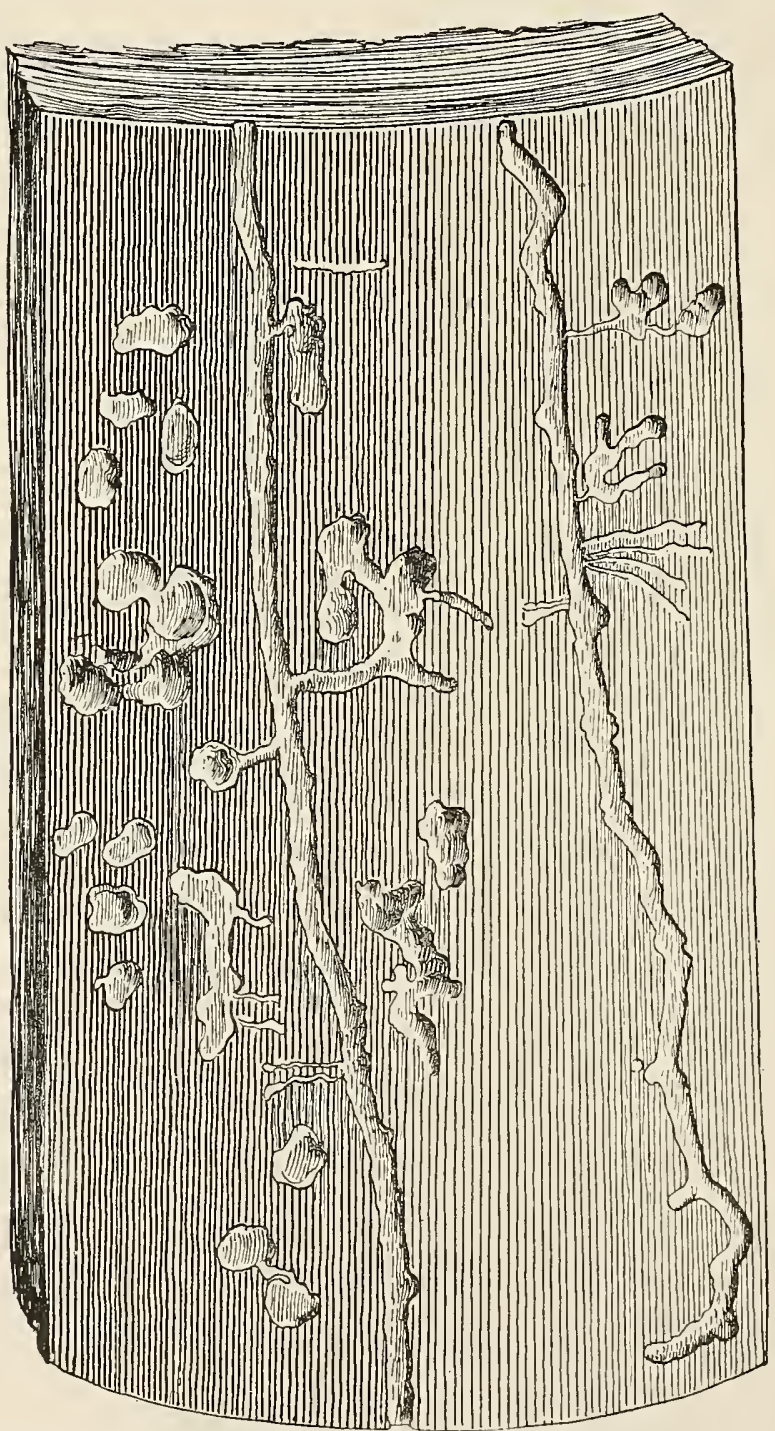

FIG. 67.-Dendroctonus monticolæ: Egg galleries and larval mines grooved In surface of wood. (Original.)

Forest, Collins, Helena, Kootenai, Moscow Mountains, Sand Point, Smith's Ferry, Weiser. Montana: Big Fork, Columbia Falls, Tron Mountain, Lolo, Lewis and Clark National Forest, Missoula, Saltese. Oregon: Ashland, Grants Pass, Joseph, Pokegama, Wallowa. Washington: Longmires Springs, Mount Rainier National Forest, Pialschie, 
Washington National Forest. Wyoming: North Fork Shoshone River, Wapiti. Additional localities from other collections: (A. M. N. H.) Millwood, Cal.; (U.S.N.M.) Columbia Falls, Mont.

Host trees.-Pinus lambertiana, $P$. monticola, $P$. murrayana and $P$. ponderosa (common); Picea engelmanni (rare).

Identified specimens.-Le Conte, M. C. Z., 3; Horn, A. E. S., 1; A. M. N. H., Webb collection, 1; Henry Edwards collection, 1; U.S.N.M., 2; D. A., 11; Webb collection, 14; Hopk. U. S., over 500, including different stages and work.

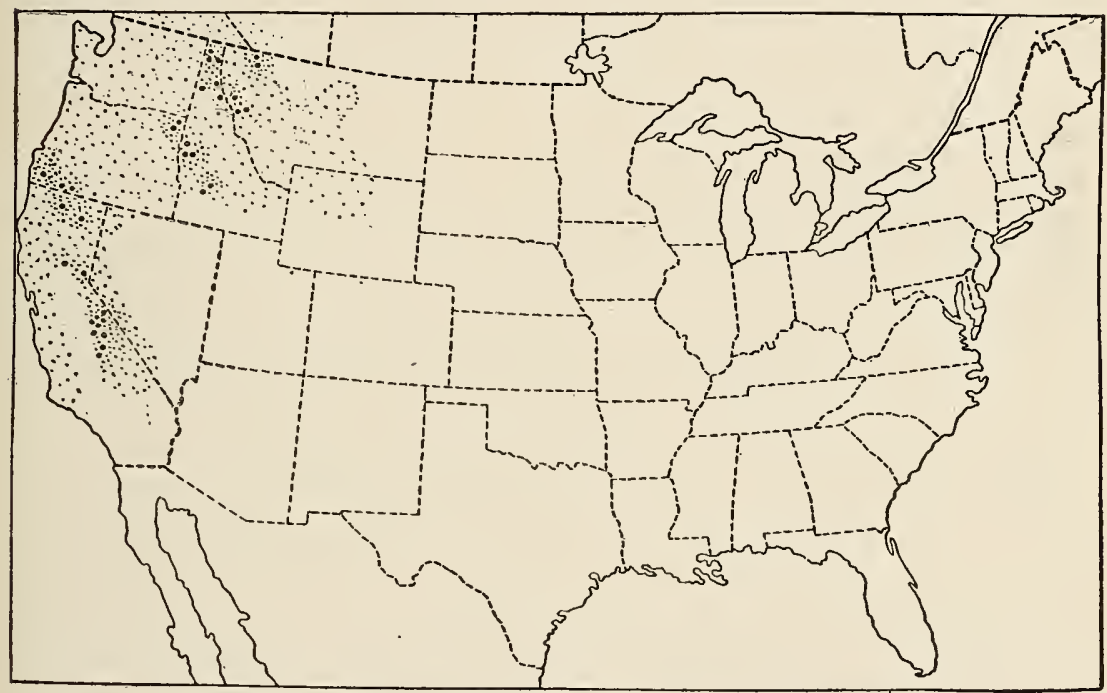

F1G. 68.-Dendroctonus monticole: Distribution map. (Original.)

Bibliography and Synonymy.

Dendroctonus similis (not of Le Conte, 1860) Le Conte, 1876, p. 385 (in part), locality. Dendroctonus n. sp. Hopkins, 1899b, pp. 14, 26, first record of habits and hosts.

Dendroctonus monticola Hopkins, 1901b, p. 67, referred to as new species but not described, habits, galleries. Hopkins, 1902c, p. 21, notes. Hopkins, 1905, p. 11, first description, distribution, characters, very brief. Webb, 1906, p. 22, mentioned.

Dendroctonus monticolx Hopkins, 1902a, p. 3, manuscript name.

Dendroctonus n. sp. (mountain pine Dendroctonus). Hopkins, 1904, pp. 19, 42, 45, habits, hosts, distribution, etc.

Mountain pine beetle. Hopkins, 1908, p. 162.

10. Dendroctonus ponderosæ Hopkins.

(Pl. IV, fig. 10.)

Adult.-Type of species, female: Length, $6 \mathrm{~mm}$. , black; elytral declivity with a few long hairs. Head with front convex, without median elevation or groove, but with faint posterior impression; elytral rugosities moderately coarse and moderately dense, becoming 
much finer on the lateral area and coarser toward and on the vertex. Pronotum with moderately long, erect hairs on the lateral area, considerably longer toward the anterior section; punctures of elytral striæ distinct and coarse. Secondary sexual characters same as in preceding species.

Type labeled "Type No. 7448 U.S.N.M.," name label, "Hopk. 1/16/08, Pinus ponderosa, Spearfish, S. D., 7/1/00, A. D. Hopkins, collector, \&, Hopk. U. S. 434."

Male type: Length $5.5 \mathrm{~mm}$. Characters same as in female, except pronotum with very dense, subrugose punctures toward the anterior margin, the elytral rugosities finer and leśs dense; elytral declivity with coarser interspacial granules, and the strial punctures slightly more distinct.

Male type labeled same as female, except sex label.

Variations.-The length varies from 4.5 to $7 \mathrm{~mm}$., with the average about $6 \mathrm{~mm}$. The color ranges from brown (in young specimens) to black in matured. The sculpture and vestiture of the epistoma, front, pronotum, and elytra vary as usual, and there is a quite noticeable variation from a somewhat slender form to a shorter and stouter one. The greatest variation is in length and in the size and density of the punctures of the pronotum and of the striæ of the elytra.

Distinctive characters. - The characters which distinguish this species from the one following are its average smaller size, less shining pronotum, with coarser and deeper punctures, and from the preceding by its average larger size and somewhat stouter form, with the elytral strix more distinctly impressed and the punctures distinctly coarser. There is a considerable range of variation in these characters, but the specimens with less distinctly impressed striæ and finer punctures which might be mistaken for D. monticola are exceptional, and should cause no confusion as long as the range of distribution of the two species is so distinct.

Revisional notes.--In March, 1902, the writer (Hopkins, 1902a, p. 3) published the manuscript name, $D$. ponderosæ, without description of any kind, and in April of the same year (Hopkins, 1902b, p. 10) he gave a brief description under $D$. ponderosa, but, as indicated by the manuscript name, it was intended that the name should relate to the host tree, Pinus ponderosa, therefore the name $D$. ponderos $x$, under which it is here fully described, should stand. The species is represented in the Le Conte collection by one immature example, which, in 1900 , was in the D. rufipennis series, labeled "Specimen 8, Col." In March, 1907, this specimen was again examined by the writer, and identified as $D$. ponderosæ. It is evident that it was in Le Conte's collection when he prepared his latest revision (1876), but there is 
evidence that the characters and locality were not involved in the revised description under D. rufipennis. It is probably represented in the Horn collection (A. E. S.) by one specimen, without locality label, found by the writer in 1900 as the third specimen in the type series, under D. approximatus. Two other specimens, labeled "Colo.," were found in the Horn collection and one specimen in the general Academy of Natural Sciences collection under D. rufipennis. The two in the Horn collection were evidently before Dietz when he prepared his revision under D. rufipennis and included in the Colorado locality if not in the revised description. The writer (1902, p. 10) refers in a footnote to wrong identifications under $D$. rufipennis and D. terebrans. This probably includes all of the published references in which this species has been in any manner involved in revisions or systematic notes.

Pupa.-In addition to the generic, divisional, and subdivisional characters, the front and middle femora are armed each with one small apical spine. Abdominal tergites 2 to 6 , with long and prominent pleural spines; 1 is without distinct dorsal and lateral spines, but 2 to 6 have distinct dorsal and lateral ones, and all of them have a pair of dorsal, and 2, 3, and 6 have a pair, and 4 and 5 have three lateral spines each side of the dorsal ones; 7 has two dorsal spines, while $S$ is smooth, and the pleural spines of 9 are long and prominent. Pupal type labeled "Hopk. U. S. No. 623."

In a number of individuals, the usual variation in the arrangement and number of minor spines is found, and between the younger and older examples there is a wide range of variation.

The characters which. seem to distinguish the pupa of this species from that of $D$. monticolx are the coarser spines of the abdominal tergites, the more densely granulate elytral pads, and the presence of but one apical spine on the front and middle femora.

Larva.-In addition to the generic and divisional characters, the front has the posterior angle subobtuse, and a stout prominent rugose transverse elevation situated slightly behind the middle and elevated and broad toward the sutures; clypeus with the base shining and bearing a faint median elevation, and the apex broadly emarginate; labrum less than half as long as broad, with the apex truncate; sternellar lobes of the thoracic segments with indistinct foot calli. Larval type labeled "Hopk. U. S. No. 755."

There is some variation in the frontal elevation, but generally it is situated behind the middle, and the posterior angle of the front is more obtuse than in the preceding, which latter serves as the most distinctive character separating the larva of this species from that of D. monticolx. 
Gailleries (figs. 69, 70).-The egg galleries are longitudinal, and usually nearly straight. They are usually grooved on the surface of the wood and deeply grooved in the inner bark, with the larval mines and pupal cells exposed. The eggs are placed in approximate groups,

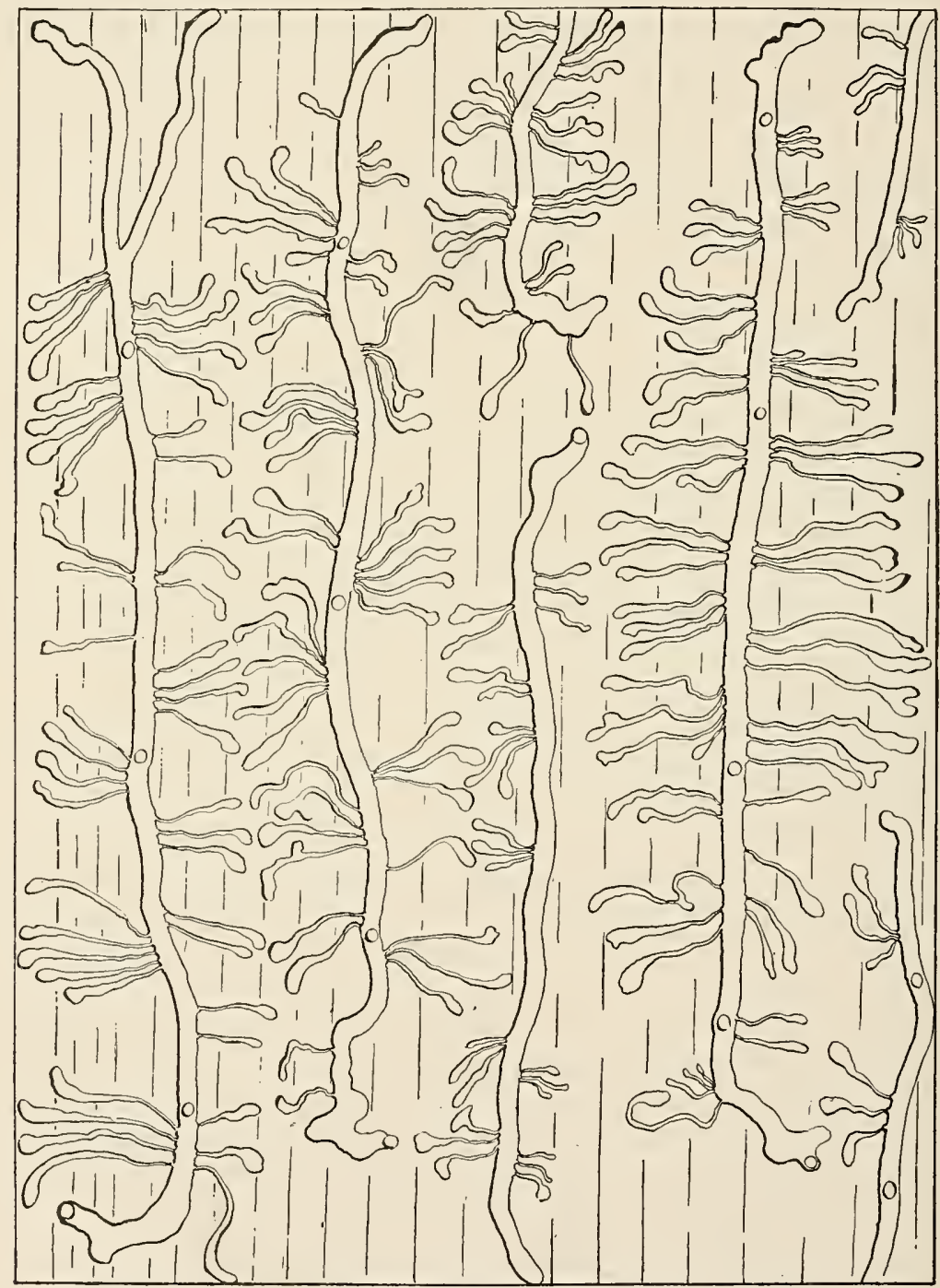

FIG. 69.-Dendroctonus pondcrosx: Egg galleries and larval mines. (Original.)

and the larval mines are short. The egg galleries differ from those of $D$. monticolæ in the larger diameter and straighter, shorter form.

Distribution (fig. 71).-(Hopk. U. S.) Arizona: Chiricahua National Forest, Flagstaff, Fredonia, San Francisco Mountains. Colorado: Bailey, Brookvale, Cascade, Cat Mountain, Cochetopa, Colo- 
rado Springs, Fort Garland, Glenwood Springs, Gunnison National Forest, Green Mountain Falls, Hahns Peak, Husted, Indian Creek, Larkspur, La Veta, Manitou, Medicine Bow National Forest, Meeker, Monte Vista, Ouray National Forest, Palmer Lake, Pikes Peak, Pine, Poncha Springs, San Isabel National Forest, San Juan National Forest, Sequache, Uncompahgre National Forest, White River National Forest. New Mexico: Gila National Forest, Vermejo. South Dakota: Custer, Elmore, Hill City, Lead, Nemo, Piedmont, Sylvan Lake. Utah: Escalante, Kiamas, Kanab, La Salle National Forest, Panguitch, Provo. Wyoming: Downington, Encampment, Keystone. Additional locality from other collectors: (Brown) Las Animas County, Colo. Localities reported by correspondents: Eagle, Florissant, Iclaho Springs, Kiennedy Station, La Veta, Montrose, Pagosa Springs, Porter, San Juan, Ute Pass, and West Cliff, Colo.

Host trees.-Pinus ponderosa scopulorum, P. flexilis, P. murrayana, $P$. strobiformis, and Picea engelmanni.

Economic relation to forests.-This species is exceedingly destructive to the pine forests of

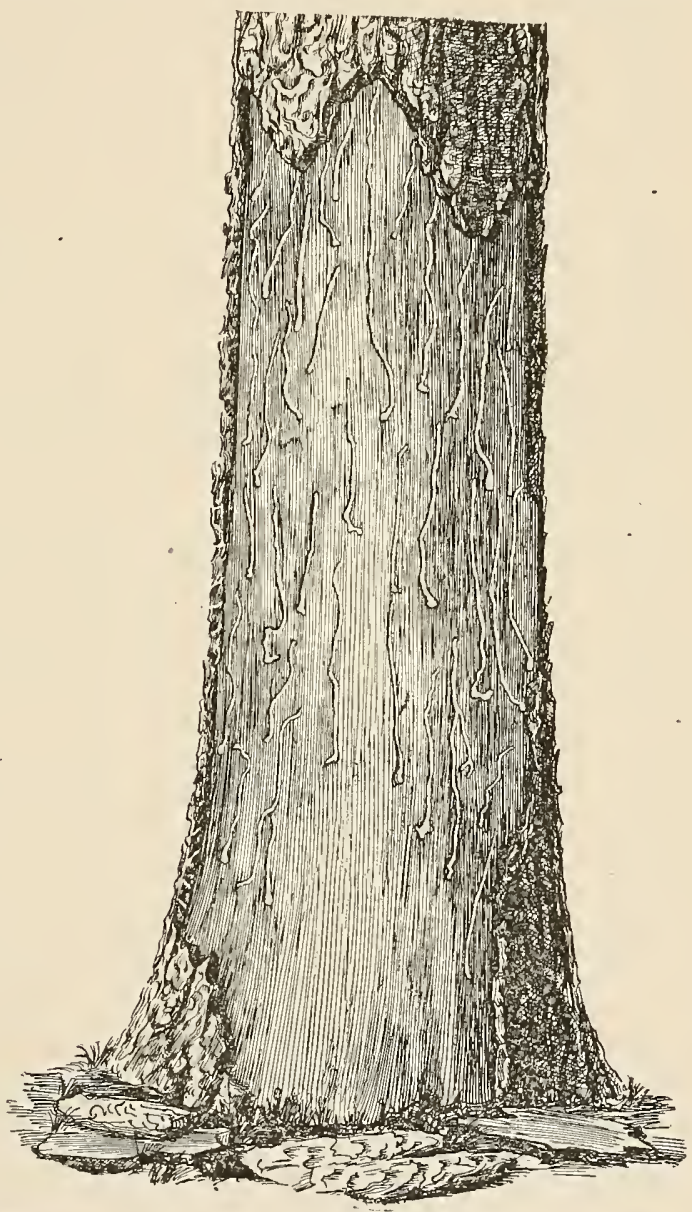

FIG. 70.-Dendroctonus ponderosx: Tree with bark removed, showing egg galleries grooved and marked on surface of wood. (Original.)

the central and southern Rocky Mountain region, having caused a loss of forest resources worth many millions of dollars. The rock pine, or bull pine (Pinus ponderosa var. scopulorum), is its favorite host tree, but it attacks and kills the other pines and infests the spruce, though apparently not destructive to the latter.

Identified specimens.-Le Conte (M. C.Z.), 1 specimen; Horn (A. E. S.), 2 specimens; A. N. S., 2 specimens; U.S.N.M., 1 specimen; $79980-09-9$ 
D. A., 14 specimens; Gillette, 2 specimens; Hopk. U. S., more than 10,000 specimens, including all stages and work.

\section{Bibliography and Synonymy.}

Dendroctonus similis (not of Le Conte, 1860) Le Conte, 1876, p. 385 (in part) (in collertion 1890).

Dendroctonus approximatus Dietz, 1890, p. 31 (in part?) (specimen with type series).

Dendroctonus ponderosæ Hopkins, 1902a, p. 3, manuscript name only. Hopkins, 1903b, pp. 275, 282, p. xxix, figs. 28, 32, stages and work figured, and full account of habits, life history, methods of control, etc. Hopkins, 1904, pp. 41, 43, 44, Pl. I, fig. 1, Pls. III, VIII, IX, XII, fig. 2, stages and work illustrated, habits, host, distribution, etc. Hopkins, 1905, pp. 1-24, full account of history, habits, life history, work, methods of control, etc., Pls. I, II, figs. 1-6, stages and work. Hopkins, 1906a, p. 4, old work. Hopkins, 1906b, p. 147, Pls. IV, V, figs. 1-5, anatomy of larval head. Fall, 1907, p. 218, list, locality. Hopkins, 1908 , p. 162, depredations.

Dendroctonus ponderosa Hopkins, 1902b, p. 10, brief original description, adult, etc., galleries and work illustrated, fig. 1, Pls. I, III, IV, VII, full account of habits, methods of control, etc. Hopkins, 1902c, p. 21, habits. Hopkins, 1903a, p. 59, habits, etc.

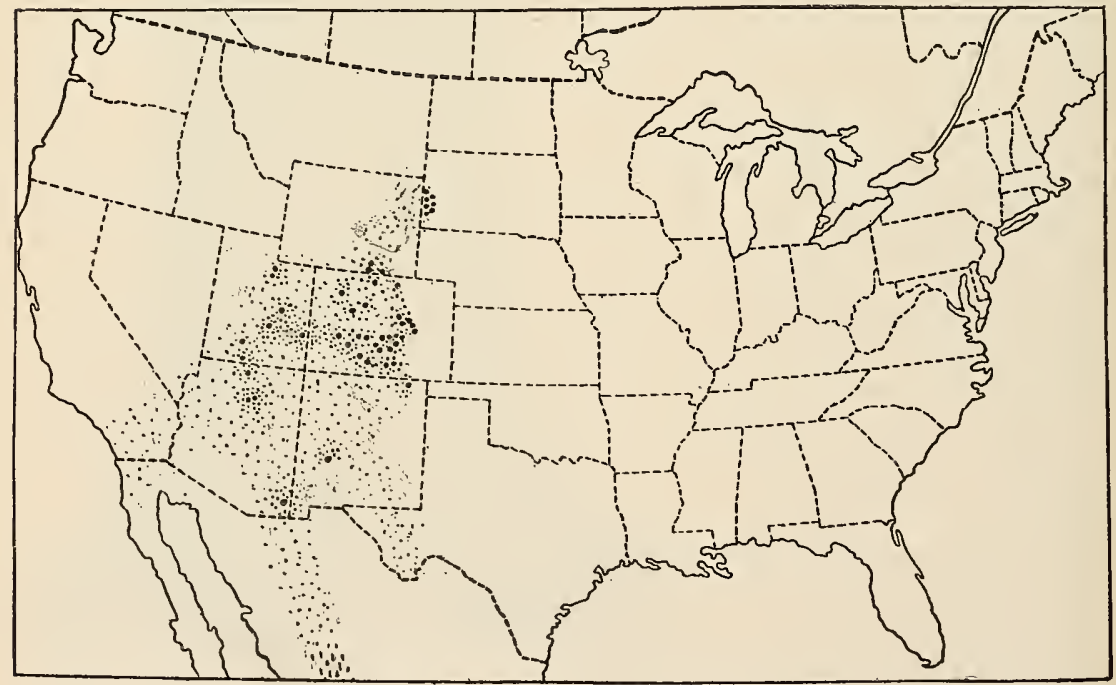

Fig. 71.-Dendroctonus ponderosæ: Distribution map. (Original.)

11. Dendroctonus jeffreyi n. sp.

(Pl. IV, fig. 11.)

Adult.-Type of species, female: Length $7.5 \mathrm{~mm}$., black; elytral declivity with a few long hairs. Head with front convex, with slight anterior and posterior impressions, without frontal elevations; elytral rugosities moderately coarse and dense, becoming much finer on lateral area and coarser toward the vertex. Pronotum shining, sides 
distinctly constricted toward the head, with moderately long, erect hairs on the lateral area, longer and denser on the anterior surface; punctures of elytral striæ distinct and coarse, the striæ more distinctly impressed on the dorsal area. Secondary sexual characters same as in preceding species.

Type labeled "Type No. 7449 U.S.N.M.," name label, "Hopk. 1/22/08, Pinus jeffreyi, Little Yosemite, Cal., H. E. Burke, collector,, , Hopk. U. S. 4394a."

Male type: Length $7 \mathrm{~mm}$., same characters as female, except elytral declivity is more opaque and with distinctly coarser interspacial rugosities.

Male type labeled same as female, except sex label.

Variations.-The length varies from 6 to $8 \mathrm{~mm}$., with the average about $7 \mathrm{~mm}$., and the color from brown in young specimens to deep black when matured. The sculpture and vestiture of the epistoma, front, pronotum, and elytra vary as usual. There is apparently less variation in size and in other characters than is found among the individuals of the other species.

Distinctive characters.-This species is at once distinguished from either of the two preceding by its average larger size and shining pronotum, with its fine and shallow punctures.

Note.-This species is not represented in any of the collections examined by the writer, and nothing has heretofore been published about it.

Pupa.--In addition to the generic and divisional characters, the apices of the front and middle femora are armed with two distinct spines; abdominal tergites 2 to 6 with long and prominent pleural spines; 1 is apparently without dorsal spines, 2 and 6 are evidently with dorsal and lateral spines, but in the single poor specimen the relative size and number can not be made out; they appear, however, to be less prominent than in either of the preceding species; 7 has two small dorsal, three distinct lateral spines, and a small pleural one; 8 is smooth, and 9 is with prominent pleural spines, as usual. Pupal type labeled "Hopk. U. S. No. 4412a."

The above description is based on a single specimen, which is damaged, therefore is subject to revision when more specimens are examined. It seems to be quite different from the unique pupa mentioned under D. monticola.

Larva.-In addition to the generic, divisional, and subdivisional characters, the front has the posterior angle subacute, and a narrow transverse elevation situated in the middle and not broadened or more elevated toward the sutures; clypeus shining, with median groove toward the base and with the apex broadly emarginate; labrum with apex broadly truncate; sternellar lobes of the thoracic segments 
with obscure foot scars. Larval type labeled "Hopk. U. S. No. 6204b."

There is very little variation in the four specimens before the writer, and the narrow smoother frontal elevation, not elevated and broadened toward the suture, is the most distinctive character separating the larva of this species from those of the two preceding species.

Galleries.-The egg galleries are longitudinal, nearly straight, grooved on surface of the wood, and deeply grooved in the inner bark, with the larval mines and pupal cells exposed. The eggs are placed singly and in approximate groups. The egg galleries and larval mines of this species differ from those of the two preceding in

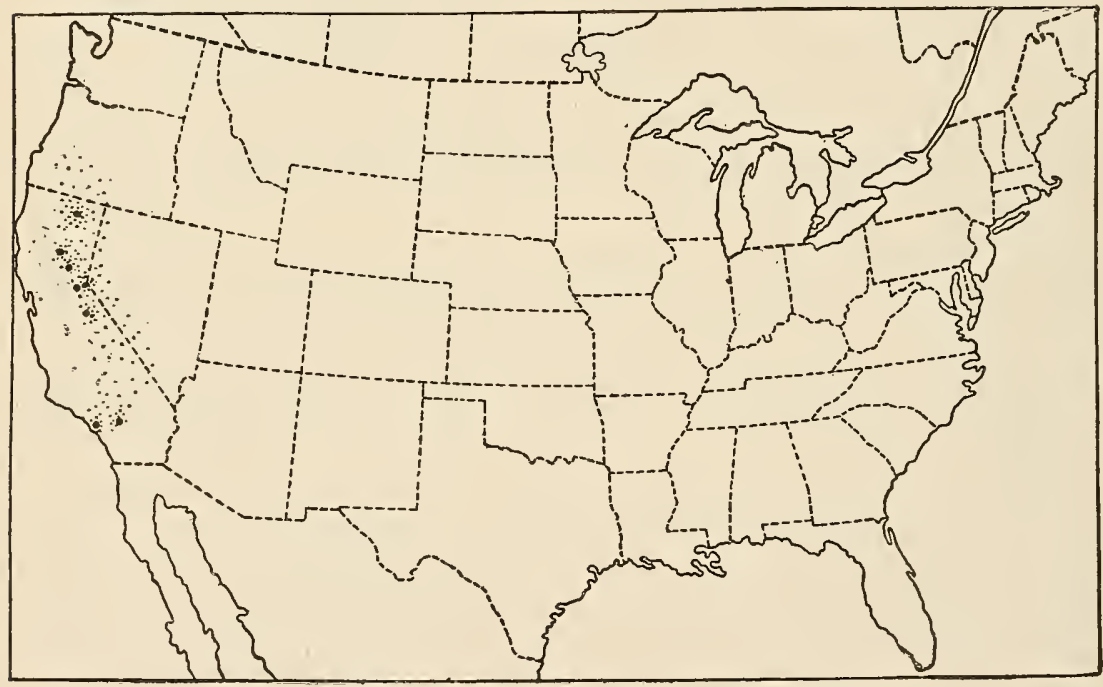

FIG. 72.-Dendroctonus jeffreyi: Distribution map. (Original.)

being much coarser; otherwise they appear to be more like those of monticolx.

Distribution (fig. 72).-(Hopk. U. S.) California: Chester, Little Yosemite, Nevada City, Pinogrande, Sterling, Tallac, Yosemite (Yosemite National Park), and Seven Oaks (San Bernardino National Forest).

Host trees.-Pinus jeffreyi. P. ponderosa, and P. lambertiana.

Identified specimens.--Hopk. U. S., over 160 specimens, including adults, pupæ, and larvæ.

\section{DIVISION II.}

The distinctive characters common to the species of the second division are:

Adults.-Prothorax stout, usually narrower than elytra, distinctly narrowed or constricted toward head; elytra with anterior dorsal 
half bearing long hairs, except in $D$. terebrans and badly rubbed specimens.

Pupa.-Vertex of head faintly impressed, flat or convex, and with two small widely separated frontal granules toward vertex.

Larva.-Abdominal tergites 8 and 9 with dorsal plates except in. simplex and pseudotsugr, and 8 without plate in micans.

Galleries.-Egg galleries longitudinal, straight to slightly winding; eggs in groups or masses; larval mines and pupal cells exposed in inner bark.

\section{Suborvision C.}

(Species Nos. 12 to 21, inclusive.)

The distinctive characters common to the species of this third subdivision are:

Adults.-Front usually with posterior impression, pronotum with large and small punctures intermixed. Pronotum with long hairs on dorsal and lateral areas.

Sexes.-Female: Interspaces of elytral declivity more roughened and the striæ more distinctly impressed. Malc: The reverse.

Pupa.-Vertex of head flattened or faintly impressed: apices of front and middle femora smooth; abdominal tergites with moderately prominent pleural and dorsal spines.

Larva - Abdominal tergites 8 and 9 without dorsal plate in simplex and pseudotsugx and with unarmed clorsal plate in the remaining species.

Galleries.-Egg galleries slightly winding to straight; eggs in groups, but larval mines separated from the beginning, or beyond the middle, except in D. micans.

\section{Dendroctonus simplex Le Conte.}

(PI. V, fig. 12.)

Adult.-Typical female: Length, $3.9 \mathrm{~mm}$., dark reddish-brown. Head with front distinctly convex, with faint posterior impression. Pronotum with distinctly coarse and fine punctures intermixed; elytral declivity with stria deeply impressed; epistomal process narrow, flat, the sides nearly para!lel, apex not extending beyond the anterior frontal margin; elytral rugosities moderately coarse, becoming finer on the lateral areas, sparse, coarser, and more acute on the dorsal area and vertex; striæ toward suture impressed, not impressed on lateral area; strial punctures coarse and distinct. Pronotum with moderately long reclining hairs on lateral area. Secondary sexual characters: Elytral declivity with interspaces more rugose and the striæ more distinctly impressed.

Typical female labeled, name label, "Hopk. 1/22/08, H. S. 41, , Grand Ledge, Mich., 21.4" (= April 21).

Typical male: Length, $3.8 \mathrm{~mm}$; elytra more shining, less rugose; declivity shining, interspaces convex and smooth, with fine, distinct 
punctures and with striæ distinctly impressed and finely punctured; otherwise as in female.

Typical male labeled, name label, "Hopk. 1/22/08, H. S. 40, శ, Grand Ledge, Mich., 20.5" (= May 20).

Variations. - The length varies from 3.5 to $5 \mathrm{~mm}$., with the arerage about $4.7 \mathrm{~mm}$. The color varies from reddish to reddish-brown, with the head and thoracic segments ranging from light to dark brown, and nearly black. The epistomal characters are more constant in this and the next species, otherwise the usual variation in the sculpture and vestiture of the head, pronotum, and elytra prevails. The greatest variation, other than size, is found in the punctures of the pronotum and in the strial punctures and interspacial rugosities of the elytra.

Distinctive characters.-The characters which distinguish this species from the following, to which it is more closely allied, are the much smaller average size of the individual and the coarser and deeper punctures of the pronotum.

Revisional notes.-The original description was based on two male specimens labeled "Canada," which have been examined by the writer and found to agree with the common species which lives in the eastern larch. The comparison in the description with $D$. obesus must refer to $D$. pseudotsugæ Hopk., representatives of which were then confused with the true D. obesus (Mann.). The smooth intervals on the declivity referred to is a male character. The reference to a much deeper sutural stria relates to what is now recognized as stria 1. The revision relates to the type specimens. With our present knowledge of the specific characters, those given in Le Conte's tables are only partially applicable. It is evident that no other species were confused with this one in Le Conte's description and revision, but it was involved in the revision under D. obesus (186S) and D. similis (1873). In 1900 it was in Le Conte's collection under D. rufipennis, labeled "Lake Superior" and "Tex.," and under D. similis, labeled "Lake Superior" and "Can." In Dietz's revision, the specimens from Colorado and California were evidently $D$. pseudotsugr, but did not involve any confusion in the description, except in the length, $6.2 \mathrm{~mm}$., which was evidently based on a specimen of $D$. pseudotsugæ.

The species was found to be represented in the Horn collection by one specimen, under simplex, labeled "Can.," and two specimens under $D$. similis, labeled "Can."

Pupa.-In addition to the generic, divisional, and subdivisional characters, the apex of the front and middle femora has a minute subapical granule. Abdominal tergite 1 with very small and 2 to. 6 with stout, prominent pleural spines, 1 without dorsal or lateral, 2 without dorsal, 3 to 6 with prominent dorsal spines, becoming larger toward 6,2 to 6 with two lateral spines each side, becoming more 
prominent toward the latter, 7 with two minute dorsal hairs, 8 smooth, 9 with prominent widely separated spines. Pupal type, labeled "Hopk. U. S. No. 6444b."

The usual variation in arrangement and number of minor spines prevails, but the pupa of this species is easily distinguishable from that of the following by its smaller size and the more prominent dorsal, lateral, and pleural spines.

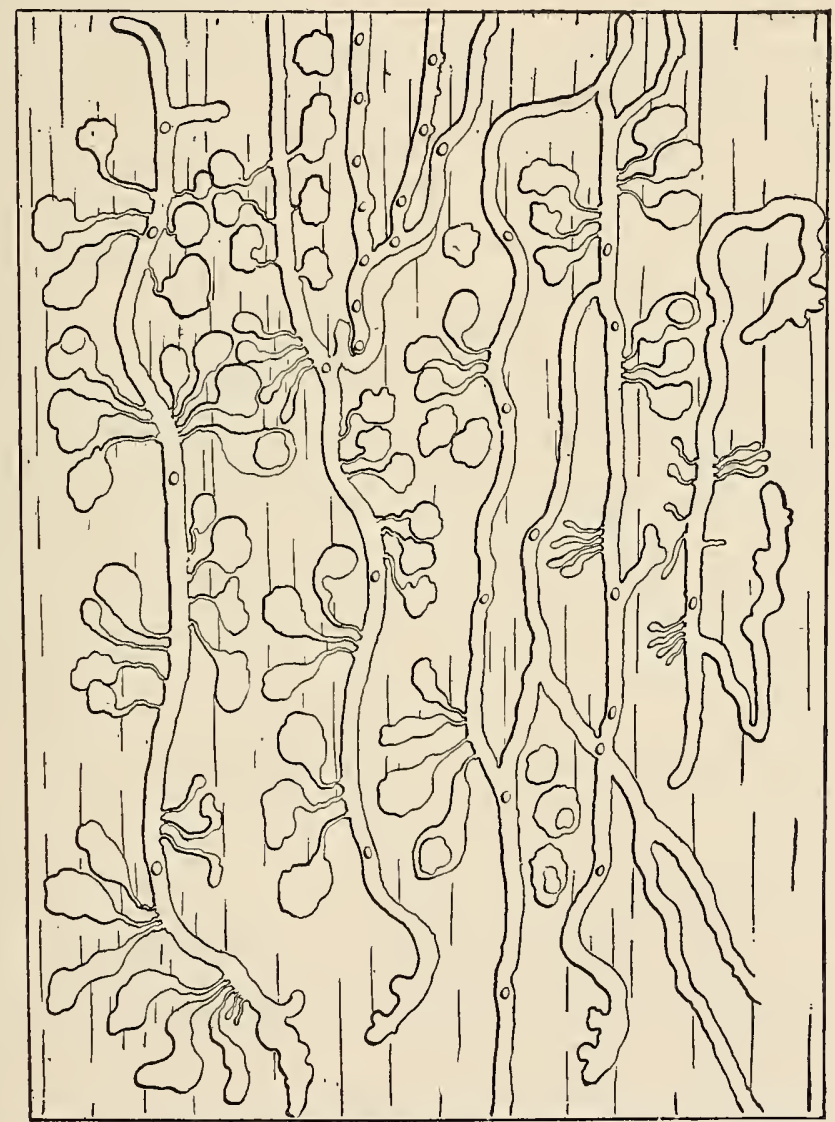

Fig. 73.-Dendroctonus simplex: Egg galleries and larval mines. (Original.)

Larva.-In addition to the generic and divisional characters, the front is convex, opaque, with the posterior angle obtuse, and the middle with an indistinct transverse elevation, and transversely rugose. The clypeus is prominent, shining, with a distinct median impressed line and the apex broadly emarginate; the labium is short, with the apex broadly rounded. The sternellar lobes of the thoracic segments are prominent and with distinct foot calli. Larval type labeled "Hopk. U. S. No. 6444b."

Galleries (fig. 73).-Egg galleries longitudinal, slightly winding, and sometimes branched and grooved on the surface of the wood, as 
well as deeply grooved in the inner bark; larval mines and pupal cells exposed in the inner bark. Eggs are placed in groups of three to five or more, and the larval mines, which are short, are separated from the start. The galleries differ from those of the next species by their smaller size, more elongate and winding form of the egg galleries, and the much shorter larval galleries arranged in much smaller groups.

Distribution (fig. 74).-(Hopk. U. S.) Maine: Cupsuptic. Michigan: Grand Island, Munising, Mackinac Island, Seney. (Hopk. W: Va.) West Virginia: Cranesville. Additional localities from other collections: (U.S.N.M.) Ungava Bay, Canada; Agricultural College, Mich. (H. \& S.) Marquette, Grand Ledge, and Port Huron, Mich.

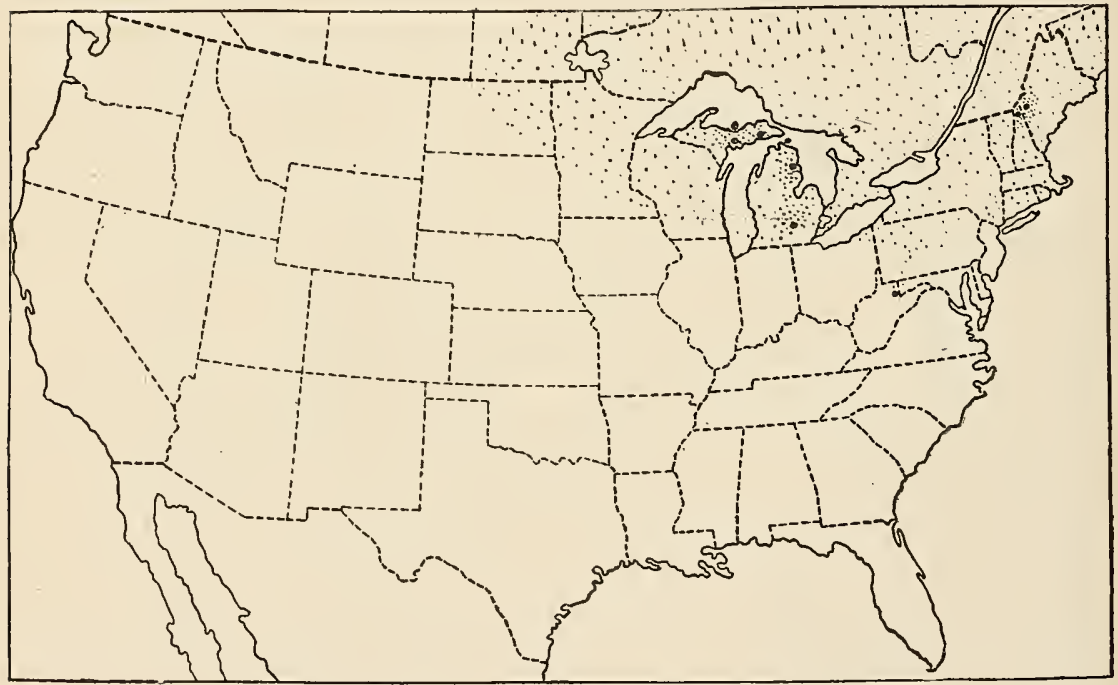

FIG. 74.-Dendroctonus simplex: Distribution map. (Original.)

(D. A.) West Stewartstown, N. H. One specimen in the Le Conte collection under D.obesus, labeled "Texas" (must be an erroneous locality, resulting from some mistake).

Host tree.-Larix laricina.

Identified specimens.-Le Conte, 10 specimens (2 under D. simplex, 3 under $D$. rufipennis, and 5 under $D$. simitis); Horn, 3 specimens (2 under simplex, 2 under simitis); U.S.N.M., 6 ; H. \& S., 10; D.A., 5 specimens; Hopk., W. Va., 157, and Hopk. U. S., over 150 specimens.

\section{Bibliography and Synonymy.}

Dendroctonus simplex. .Le Conte, 1868, p. 173, original description, synopsis, localities. Le Conte, 1876, p. 385, revision, synopsis, bibliography, localities. Packard, 1887, p. 177 (Le Conte quoted). Schwarz, 1888, p. 175, synonymy, habits in larch. Packard, 1887, p. 177, Le Conte quoted. Packard, 1890, p. 722 
(ibid). Dietz, 1890, p. 31 (in part), Michigan and Lake Superior, fig. 4, antenna and epistoma. Harrington, 1891, p. 27, habits and host. Hopkins, 1898a, p. 69, distinct from rufipennis (piceaperda). Hopkins, 1898b, in larch in W. Va. Hopkins, 1899a, p. 392, etc., fig. lviii, adult, revisional notes, etc., host, distribution. Hopkins, 1899c, p. 343, good species, habit, host, etc. Felt, 1906, p. 752 (in part), bibliography.

Dendroctonus similis (not of Le Conte, 1860) Le Conte, 1876, p. 385 (in part), revision, synonymy, bibliography, localities. Dietz, 1890, p. 31, Canada.

Dendroctonus rufipennis (not of Kirby) Le Conte, 1876, p. 385 (in part) (in collection 1900-1907, under rufipennis).

Dendroctonus sp. Harrington, 1884, p. 218. Packard, 1890, p. 903.

\section{Dendroctonus pseudotsugæ Hopkins.}

(Pl. V, fig. 13.)

Adult.-Type of species: Length $5.75 \mathrm{~mm}$.; reddish brown, with the prothorax darker. Head with front convex, with faint median and posterior impression; elytral declivity with striæ deeply inpressed; epistomal process narrow, slight, with sides nearly parallel, the apex scarcely projecting beyond the anterior margin. Pronotum with punctures fine, and moderately regular in size; elytral rugosities moderately coarse, finer on lateral area, coarse and more acute on dorsal area and vertex; striæ of dorsal area distinctly impressed, not impressed on lateral area; punctures coarse and distinct. Pronotum with moderately long hairs on the lateral area. Secondary sexual characters: Elytral declivity convex, with interspaces rugose and the striæ distinctly impressed and punctured.

Type labeled "Type No. 7450 U.S.N.M.," name label, "Hopk. 1/22/08, Pseudotsuga taxifolia, Hopkins, collector, Grants Pass, Or., १, Hopk. U. S. 39."

Male type: Length $5.75 \mathrm{~mm}$; elytral declivity with interspaces strongly convex and smooth, shining, sparsely punctured; striæ deeply impressed, punctures obscure, otherwise as in female.

Male type labeled " o type," name label, "Hopk. 1/22/08," otherwise same as female.

Variations. - The length varies from 4 to $7 \mathrm{~mm}$., with the average about $6 \mathrm{~mm}$. The color ranges from light reddish to nearly black. The usual variation in sculpture, vestiture, etc, prevails. The greatest variation is in the size and color, and in the size of the punctures of the pronotum. The epistomal process varies considerably, so that in some specimens it extends beyond the epistomal margin, while in others it does not.

Distinctive characters.--This species and the one preceding are at once distinguished from all of the other species of the genus by the characters of the epistoma and from each other by the sculpture of the pronotum and the difference in average size of representative individuals. $D$. pseudotsugæ is distinguished especially by the shining and finely punctured pronotum. 
Revisional notes.-This species has been an element of much confusion in descriptions, revisions, and identifications, under the names $D$. similis, $D$. obesus, $D$. rufipennis, etc. It is represented in the type series in Le Conte's collection under $D$. simitis, but the specimen which bears the name label, and therefore the type of D. similis, is a true D. obesus (Mann.). Le Conte (1868, p. 173) referred $D$. similis to obesus on account of the intervals of the elytra being "rough for their whole extent," which is the case in the type of $D$. simitis, and in all females of $D$. obesus. Later he evidently com-

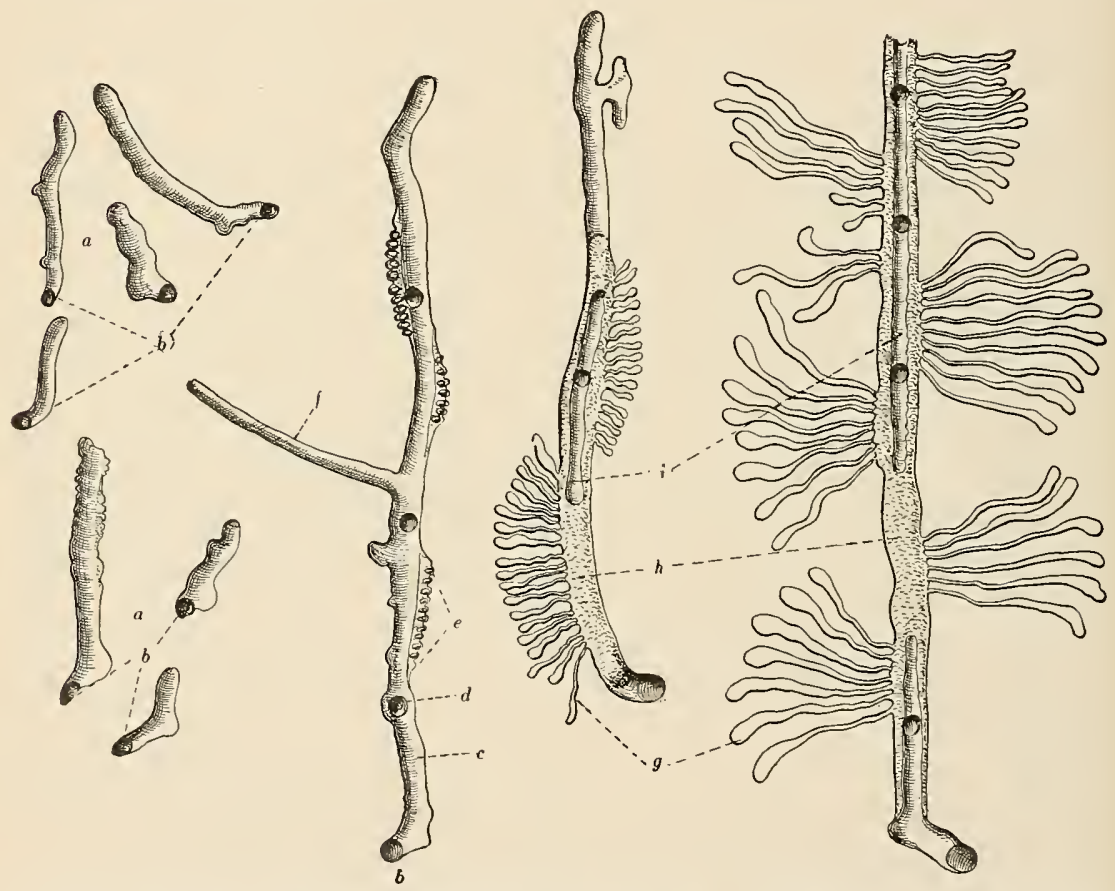

Fig. 75.-Dendroctonus pscudotsugx: Egg galleries and larval mines. a, Beginning or basal sections of egg galleries in bark; $b$, entrance; $c$, egg gallery; $d$, ventilating hole; $e$, egg nest; $f$, abnormal branch; $g$, larval mines; $h$, egg gallery packed with borings; $i$, subsequent passage or inner gallery through borings. (Original.)

pared the type of $D$. simitis with a single male specimen of $D$. obesus in his collection, which, according to Mr. Henshaw, is from the Mannerheim collection, and finding that this differed from his $D$. similis in the smooth elytral declivity he restored D. similis (Le Conte, 1876, p. 3S5) and called attention to the roughened interspaces of the declivity as a distinctive character; all of which makes it quite clear that he considered the specimen bearing the name label as the type of his $D$. similis and that therefore this name must fall as a synonym of $D$. obesus Mann. Thus the other specimens of the type series are left to represent a distinct species as here described. In 1900 it was 
represented in the Le Conte collection by two specimens labeled "Or." and three specimens labeled "Van." under $D$. similis, and one specimen labeled "Garland Pass, Col.," under D. rufipennis. In 1900 it was represented in the Horn collection by one specimen labeled "Col." and one specimen labeled "Cal.," and in the A. E. S. collection by three specimens from Oregon under D. similis and two specimens labeled "Col." under D. rufipennis. Dietz's revision under $D$. similis (1890, pp. 30-31) includes the characters of D. pseudotsugæ, as represented by the Oregon, Colorado, and California speci-

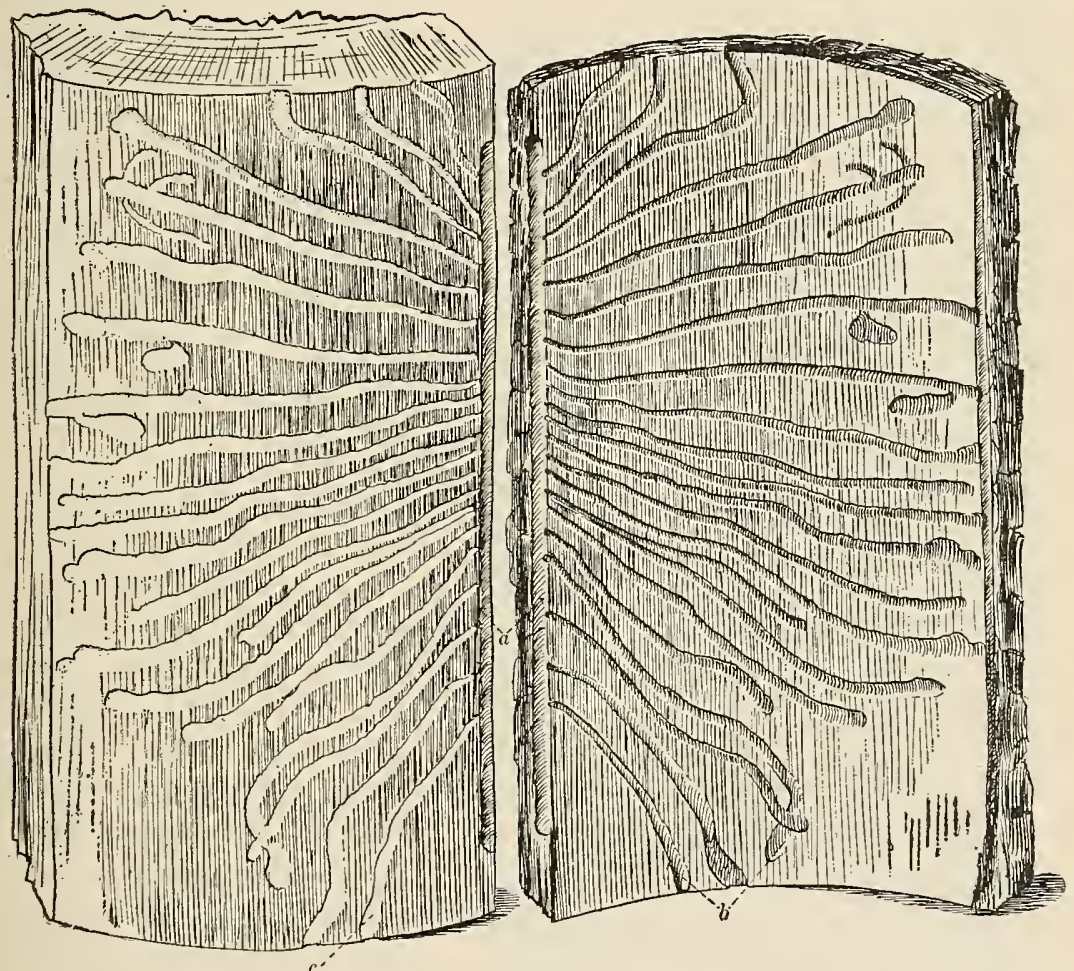

FIG. 76.-Dendroctonus pseudotsugæ: Egg gallery and larval mines. a, Egg gallery in bark and grooved in surface of wood; $b$, larval mines in bark; $c$, larval mines marked and slightly grooved on surface of wood. (Original.)

mens, while the specimens from Canada represented $D$. simplex, and one from California referred to in the note is $D$. monticolas.

Pupa.-In addition to the generic, divisional, and subdivisional characters, the apices of the front and middle femora are smooth; abdominal tergite 1 is without a pleural spine, 2 with small, and 3 to 6 with rather stout ones; 1 and 2 are without dorsal and lateral spines, while 3 to 6 have a pair of dorsal and a pair of lateral ones each side; 7 and 8 are smooth, and 9 has the usual prominent pleural spines. Pupal type labeled "Hopk. U. S. No. 2298." 
The usual variation in number and arrangement of minor spines prevails in other specimens, but they are easily distinguished from those of $D$. simplex by their larger size and less prominent dorsal, lateral, and pleural spines.

Larva.-In addition to the generic and divisional characters, the front is opaque, except toward the apex, where it is more shining, and the apex is subacute; the middle has a transversely rugose

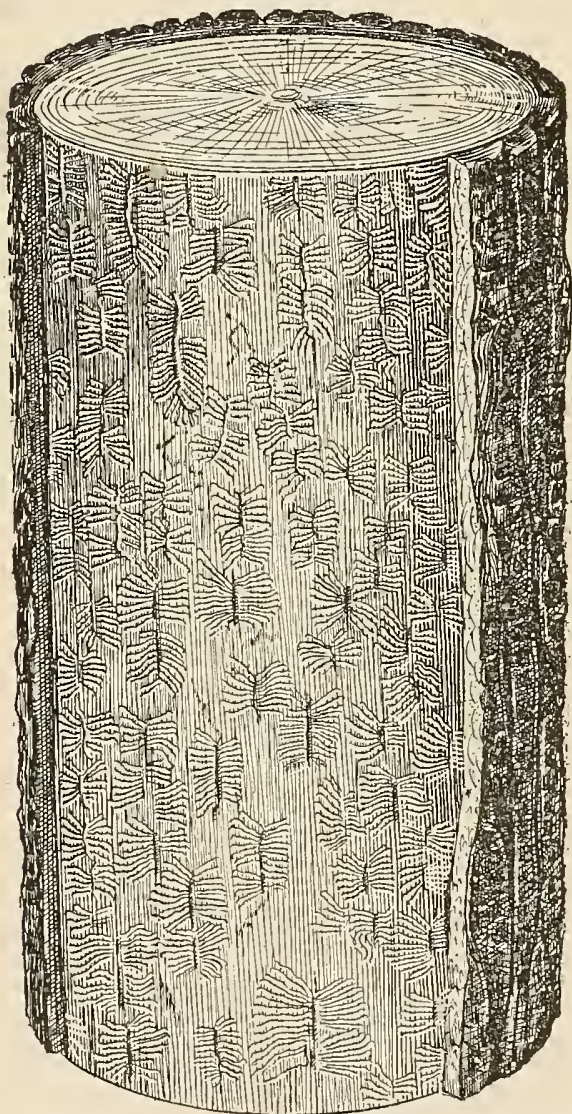

FIG. 77.-Dendroctonus pseudotsugx: Section of $\log$ with bark removed, showing brood galleries marked and grooved on surface of wood. (Original.) elevation, slightly more elevated and broader toward the suture. The clypeus is prominent, shining, and with an impressed line from the middle to the anterior margin, which is broadly emarginate; labium short, with the apex broadly rounded; the sternellar lobes are moderately prominent, with indistinct foot calli. Larval type labeled "Hopk. U. S. No. 2289."

Galleries (figs. 75-77).The egg gallery is longitudinail, short, but slightly winding, sometimes branched, slightly grooving the surface of the wood, and deeply grooved in the inner bark. The larval mines and pupal cells are exposed in the inner bark, and the eggs are rather closely placed in groups of three to ten or more, but the larval mines are separated from the start and are usually extended for some distance from the egg gallery. The galleries of this species differ from those of the one preceding by their larger size and shorter form of the egg gallery and the much larger larval mines, which are arranged in larger groups.

Distribution (fig. 78).-(Hopk. U. S.) Arizona: Chiricahua National Forest, Flagstaff, San Francisco Mountains, Santa Catalina National Forest. California: Fieldbrook, Guerneyville, McCloud, San Mateo County (Big Basin). Colorado: Colorado Springs, Fort Garland, Gunnison National Forest, Indian Creek, Leavenworth Valley, Moffat, 
Ouray, Palmer Lake, San Isabel National Forest, San Juan National Forest, Saguache. Idaho: Beaver Canyon, Centerville, Bailey, Henrys Lake National Forest, Kooskia, Kootenai, Pioneerville, Priest River, Sand Point, Smiths Ferry, Stites. Montana: Belton, Bozeman, Middle Creek (Gallatin County), Ovando. New Mexico: Capitan, Cloudcroft, Sacramento National Forest, Santa Fe, Vermejo. Oregon: Corvallis, Detroit, Grants Pass, Newport, Slate Creek, St. Helena. Utah: Panguitch. Washington: Ashford, Buckeye, Des Moines, Dole, Gray's Harbor City, Hoquiam, Junction, Kent, Keyport, Meredith, New London, North Bend, Orting, Pialschie, Port Angeles, Port Williams, Pullman, Puyallup, Rock

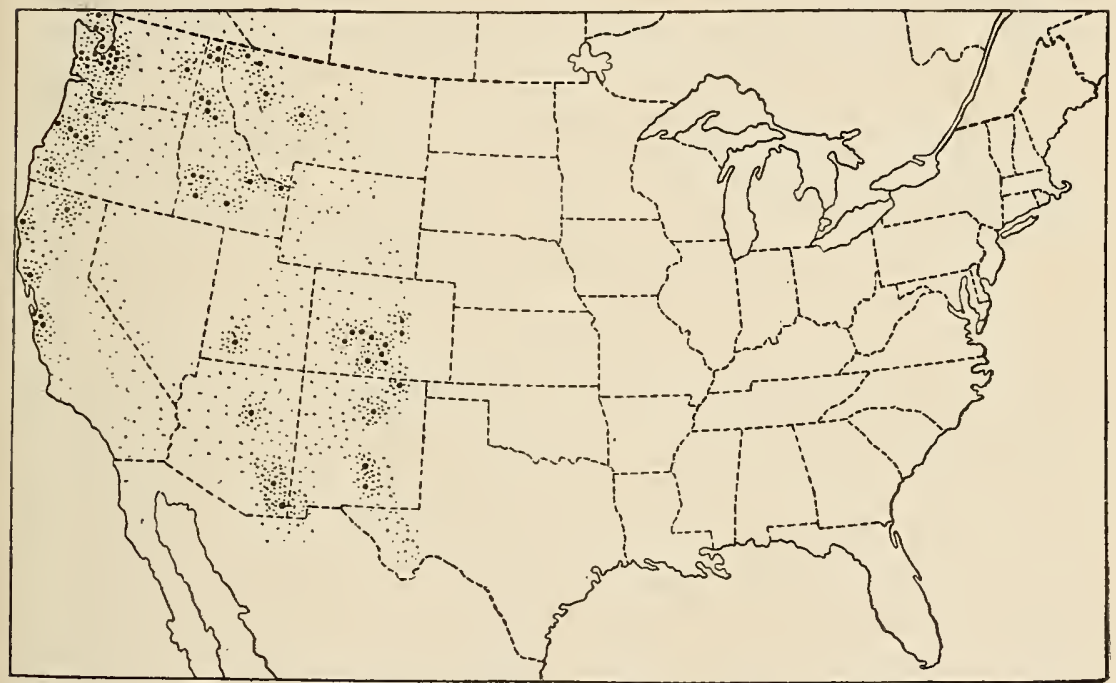

FIG. 78.-Dendroctonus pseudotsugx: Distribution map. (Original.)

Creek, Satsop. Additional localities from other collections: (Le Conte) Vancouver, B. C. (U.S.N.M.) Easton, Wash. (H. \& S.) Hood River, Oreg; Beaver Canyon, Idaho. (D. A.) Mount Angel, Oreg. (Soltau) Seattle, Wash. (Wickham) Leavenworth Valley and Kalispell, Mont.

Host trees.-Pseudotsuga taxifotia, P. macrocarpa, and Larix occidentalis.

Identified specimens.-Le Conte, 6 specimens (1 under mufpennis, 5 under D. similis); Horn, 2; A. E. S., 5; Dietz, 2; U.S.N.M., 7; H. \&. S., 2; Soltau, 3 ; Webb, 21; Wickham, 2; Laurent, 1; D. A., 5; Hamilton, 1; Hopk. U. S., over 700 specimens, including all stages and work. 
Bibliography and Synonymy.

Dendroctonus similis (not of Le Conte, 1860) Le Conte, 1876, p. 385 (in part), revision, synonymy, bibliography, localities. Le Conte, 1878, p. 469, listed, Leavenworth Valley, Colo. Packard, 1887, p. 177, Le Conte quoted. Packard, 1890, p. 722, Le Conte quoted. Dietz, 1890, pp. 30-31, from Oregon, California, Colorado, fig. 3 , antenna, epistoma. Hopkins, 1899a, p. 392, fig. lviii, adult. Hopkins, 1899b, pp. 10, 11-15, 21, 22, 26, first records, habits, hosts, etc. Wickham, 1902, p. 310, list and localities. Hopkins, 1903a, p. 61, synonymy. Fall, 1907, p. 218, in list, locality.

Dendroctonus rufipennis (not of Kirby) Le Conte, 1876, p. 385 (in part) (in collection 1900-1907, under rufipennis). Le Conte, 1878, p. 469 (in part). Packard, 1887, pp. 177, 243 (in part?). Hopkins, 1899b, p. 15, localities, note. Hopkins, 1904, p. 19, reference.

Dendroctonus simplex (not of Le Conte) Dietz, 1890, p. 31 (in part), Colorado, California. Wickham, 1902, p. 310 (on Dietz's authority).

Dendroctonus pseudotsugæ Hopkins, 1901b, p. 67, brief description of adult, galleries, habits, distribution, etc. Hopkins, 1903a, p. 60, habits, comparison with D. similis, which $=D$. obesus. Hopkins, 1905, pp. 10, 11, brief description, habits, etc. Hopkins, 1906a, p. 4, old work.

Dendroctonus n. sp. (Douglas spruce beetle.) Hopkins, 1904, pp. 19, 45.

14. Dendroctonus piceaperda Hopkins.

(Pl. V, fig. 14.)

Adult.-Type of species, female: Length, $5.75 \mathrm{~mm}$.; elytra red, thorax, head, and abdomen black; head with front convex and with faint median and posterior impression and anterior elevated line. Elytral declivity with strix not deeply impressed; epistomal process broad, concave, with the lateral section oblique; punctures of pronotum distinctly irregular; posterior half of proepisternal area not punctured; elytral striæ distinctly impressed in dorsal and lateral areas, with punctures rather coarse and distinct; interspaces slightly convex; rugosities acute, rather closely placed, irregular. Secondary sexual characters: Declivity convex; striæ very faintly impressed, with fine indistinct punctures; interspaces nearly flat, shining, with approximate row of fine granules.

Type labeled "Type No. 7451 U.S.N.M.," name label, "Hopk. 4/23/02, compared with Kirby type rufipennis, does not agree, Picea canadensis, Hopkins, collector, Camp Caribou, Me., \& type, Hopk. U. S. 326."

Male type: Length, $5.6 \mathrm{~mm}$; elytra dark reddish-brown; thorax and head darker; elytral declivity convex; striæ not impressed; punctures obscure; interspaces flat, shining, and finely punctured, with very small granules toward vertex.

Type labeled, " $\$$ type, type of drawing," name label, "Hopk. 1/22/08, Picea canadensis, Hopkins, collector, Camp Caribou, Me., § type, Hopk. U. S. 326."

Variations.- The length varies from 4.7 to $6 \mathrm{~mm}$., with the average about $5.5 \mathrm{~mm}$. The color ranges from uniform light red to black, to the head, thorax, and abdominal sternites dark to black, with the ely- 
tra lighter or red. The sculpture and vestiture of the epistoma, front, pronotum, and elytra vary as usual. The greatest variation is in size and color.

Distinctive characters.- The characters which distinguish this species from the next are its smaller average size, slightly less elongate form, less shining elytra, with the striæ more distinctly impressed on the sides and the interspaces slightly more convex and more acutely rugose. The difference is not so perceptible in comparing single individuals as when many individuals of both species are compared. It differs from $D$. borealis by the noticeably more elongate and narrower pronotum, and from species 17 to 21 it is distinguished by the distinctly impressed lateral striæ of the elytra, except $D$. punctatus Lec., which is at once recognized by the coarse punctures of the declivital striæ. It is at once distinguished from D. rufipennis (Kirby) by its smaller size and coarsely punctured and impressed lateral striæ.

Revisional notes.-Probably no species of the genus has been involved in so much confusion as this. It has been extensively discussed under D.rufipennis, and confused in collections with several other species under this name. There are three specimens in the Le Conte collection labeled "Anticosti," which were evidently the ones referred to in his revision $(1876$, p. 385). There are also two specimens without locality labels, which may have been the ones from Colorado, while the one from Alaska is here referred to D. borealis. The smoother and more shining declivity referred to by Le Conte as a distinguishing character relates to the males only. It is represented in the Horn collection by two specimens labeled "Canada," under D. rufipennis, which were therefore evidently included in Dietz's revision. It is also very probable that the specimens from New Brunswick belonged to this species.

It is very evident that the barkbeetle referred to under D. rufipennis by Peck, Packard, Hough, and other authors as depredating on the spruce of New Brunswick, Canada, New England, New York, and Pennsylvania was $D$. piceaperda.

Pupa.-In addition to the generic, divisional, and subdivisional characters, the apices of the front and middle femora are smooth; abdominal tergites 2 to 6 with very small pleural spines; 1 without distinct dorsal or lateral spines; 2 to 3 without dorsal, but with two small lateral spines each side; 4 to 6 with a pair of very small dorsal and three or four small lateral spines each side; 7 and 8 smooth; 9 with usual pleural spines. Pupal type labeled "Hopk. U. S. 377."

The usual variation in minor details prevails. It is distinguished from the pupa of $D$. engelmanni by the less impressed vertex of the head and the generally smaller spines and the absence of dorsal spines on the third abdominal tergite.

Larva.-In addition to the generic, divisional, and subdivisional characters, the front has a slight tranșverse, rugose elevation situ- 
ated slightly in front of the middle, the anterior surface, including the elevation, opaque. The area behind the elevation is impressed and shining; clypeus short, broad, with median groove and its apex subacutely emarginate (in dried specimens) ; labrum prominent, its anterior margin subtruncate; mandibles opaque, with slight dorsal impression or elevation; sternellar lobes of thoracic segments moderately

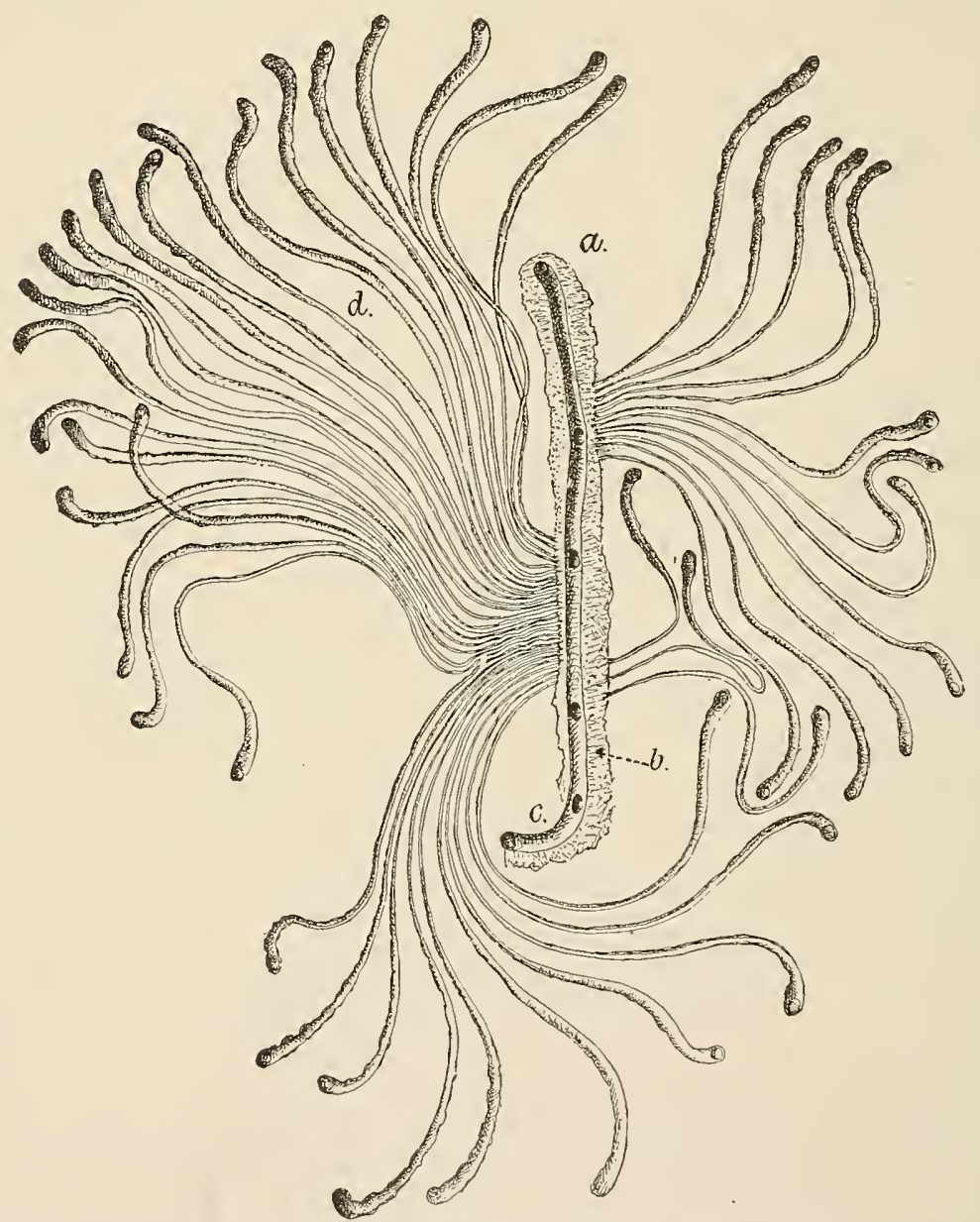

FIG. 79.-Dendroctonus piceaperda: Egg gallery and larval mines. $a$, Egg gallery; $b$, boring dust packed in gallery; $c$, entrance and subsequent or inner gallery; $d$, larval mines. (Author's illustration.)

prominent and with distinct foot calli. Larval type labeled "Hopk. U. S. No. 318."

The most distinctive characters are the opaque mandibles with moderate impression and elevation, and the distinctly elevated anterior margin of the epicranium.

Galleries (fig. 79).- The egg galleries are short, broad, longitudinal, grooving the surface of the wood and deeply grooved in the inner 
bark, the larval mines exposed and the pupal cells partially to entirely exposed. The eggs are closely placed in large groups, and the larval mines are at first contiguous or nearly so, near the egg gallery, but soon become separated and when completed are often as long as the egg gallery or longer. The egg galleries differ from those of all of the species of subdivisions $A$ and $B$ in being very much broader than the diameter of the beetle's body. This broad groove is packed with borings, through which a central gallery is excavated by the parent beetle after the eggs have been deposited.

Distribution (fig. 80).-(Hopk. U. S.) Maine: Beaver Pond, Camp Caribou, Cupsuptic, Meadows. Michigan: Grand Island, Munising. New Hampshire: Waterville. Additional localities from specimens

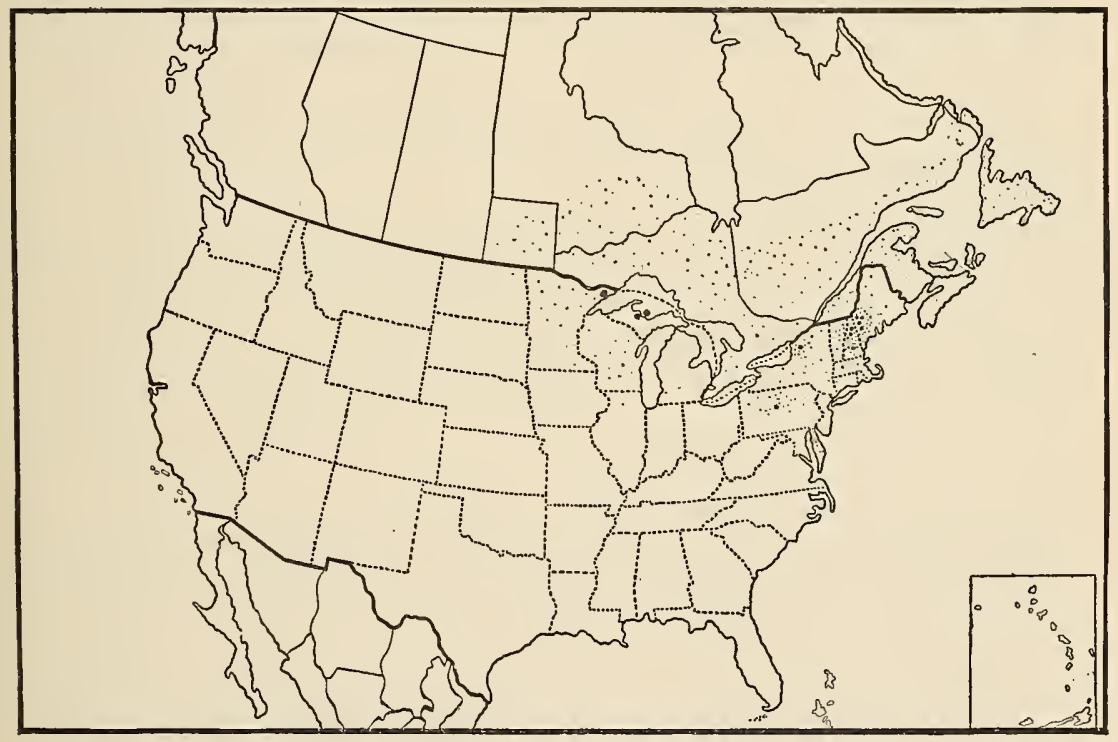

FIG. 80.-Dendroctonus piceaperda: Distribution map. (Original.)

identified in other collections: (Le Conte) Anticosti, Canada. (Horn) Canada. (U.S.N.M., H. \& S.) Isle Royale, Mich. (D. A.) Colebrook and West Stewartstown, N. IT. (Wenzel) Ricketts, Pa.

It is evident that this species follows the distribution of the spruce from the higher mountains of central Pennsylvania northward and eastward into New York, New Hampshire, Maine, New Brunswick, and Canada, and westward to the Lake Superior region.

Host trces.-Picea rubens, P. canadensis, and P. mariana.

Identified specimens.-Le Conte, 3 specimens from Anticosti, 2 without label, under D. rufipennis, 1 labeled "N. Y." under D. punctatus (Mar. 11, '07), 2 specimens without locality labels doubtfully referred to this species; Horn, 2 specimens labeled "Can.," under D. rufipennis; U.S.N.M., H. \& S., 1 specimen labeled "Isle Royale;" Weed and 
Fiske, 12 specimens; Hopk. U. S., over 300 specimens, including all stages and work.

\section{Bibliography and Synonymy.}

Hylurgus rufipennis (not of Kirby) Peck, 1876, pp. 283, 301, destruction of spruce in New York (evidently the work of $D$. piceaperda Hopk.). Peck, 1879, pp. 32-38, ravages in spruce in northern wilderness (same as 1876?). Packard, 1890, pp. 814815 (quotes Peck, ibid.). Hough, 1882, pp. 259-263, insect ravages in spruce forests of Maine.

Dendroctonus rufipennis (not of Kirby) Le Conte, 1876, p. 385, revision, synopsis, localities. Lintner, 1885, p. 54, destruction of spruce in New York. Fletcher, 1887, pp. 39-40, habits. Dietz, 1890, p. 30 (in part), Canada and New Brunswick. Packard, 1887, pp. 177-243 (in part). Packard, 1890, p. 722 (in part), quotes Le Conte. Harvey, 1898, p. 176, depredations on spruce in Maine; p. 98, host, distribution, etc. Hopkins, 1898a, p. 69, distinct from simplex. Weed and Fiske, 1898 , pp. $67-69$, report on investigations. Chittenden, 1898 , p. 96 , doubt as to Kirby's species. Smith, 1899, p. 364, Lakewood, N.J. Hopkins, 1899a, pp. 349393 (in part), reference. Hopkins, 1899c, p. 343 (in part?), reference. Chittenden, 1899, p. 56 (in part?), reference. Johnson, 1901, p. 92, habits in Pa. Hopkins, 1905, p. 6, reference to wrong determination. Felt, 1906, p. 753 (in small part), bibliography.

Polygraphus rufipennis (not of Kirby) Packard, 1890, p. 721, [fig. 251=Polygraphus rufipennis (Kirby)], Le Conte quoted (includes several species).

Xyloterus bivittatus (not of Kirby) Packard, 1890, p. 823, fig. 276 (in part), adult?; Pl. XXIV, fig. 1, larva?, 1 a, pupa?, destruction of spruce.

Barkbeetles. Packard, 1890, pp. 811-824 (in part), destruction of spruce, New Brunswick to New York.

Dendroctonus (Polygraphus) rufipennis (not of Kirby) Cary, 1900, pp. 52-54, depredations on spruce, methods of control.

Dendroctonus piceaperda Hopkins, 1901a, p. 16, Pl. II, larvæ, pupæ, adult, etc., original description, different stages and galleries, with full account of habits, host, natural enemies, methods of control, etc. (see also index and Pls. I-V, XIV, XV). Hopkins, 1902b, p. 21, mention. Hopkins, 1902a, p. 3. Hopkins, 1902c, p. 22, habits, etc. Hopkins, 1903b, pp. 266, 270, 281, Pl. XXVII, figs. 23-25, stages and work figured, revised account of habits, life history, methods of control, etc. Hopkins, 1904, p. 26, Pl. I, fig. 3, Pls. V, XII, fig. 1, Pls. XIII, XIV, XV, stages and work (reprints), habits, hosts, distribution, etc. Hopkins, 1905, pp. 10, 11, distinctive characters, brief. Felt, 1905, pp. 6, 7, habits and work. Felt, 1906, pp. 379-385, fig. 85 b, history, habits, etc. Hopkins, 1908, pp. 160-161, depredations.

\section{Dendroctonus engelmanni $\mathrm{n} . \mathrm{sp}$.}

Adult.-Type of species, female: Length $6.2 \mathrm{~mm}$., black. Head with front convex, faint median and posterior impression and faint anterior line. Elytral declivity with striæ not deeply impressed; punctures of pronotum distinctly irregular; posterior half of proepisternal area not punctured; punctures of prothorax and elytra rather coarse; striæ moderately impressed; interspaces moderately convex, and scarcely rugose, except on dorsal area. Secondary sexual characters: Declivity convex; striæ rather distinctly but not deeply impressed; punctures distinct; interspaces with rows of granules. 
Type labeled "Type No. 7452 U.S.N.M.," name label, "Hopk. 1/22/08, Picea engelmanni, Capitan, N. M., W. F. Fiske, collector, १, Hopk. U. S. 3958."

Male type: Length $5.5 \mathrm{~mm}$. Front without anterior line. Elytra with striæ less distinctly impressed and interspaces less convex than in female; declivity convex, with striæ and strial punctures obscure; interspaces flat, shining, finely but distinctly punctured and without granules except on vertex.

Type labeled, " o type," name label, "Hopk. 1/22/08, Picea engelmanni, Capitan, N. M., W. F. Fiske, collector, ô, Hopk. U. S. 3958."

Variations.-The length varies from 5 to $7 \mathrm{~mm}$., with the average at about $6.5 \mathrm{~mm}$. The color ranges from uniform light to dark red and black, to black head, thorax, and abdomen, and red elytra. The sculpture and vestiture of the epistoma vary as usual, with the greatest variation in size, color, and punctures.

Distinctive characters. - The characters which serve to distinguish this species from the one preceding are the larger average size, slightly more elongate form, more shining elytra, with the lateral strix somewhat less impressed, the punctures usually coarser, and the interspaces less acutely rugose. It is more closely allied to D. obesus, from which it is distinguished by the commonly darker prothorax, and more distinctly impressed lateral striæ of the elytra, with coarser punctures.

Revisional notes.- This species, like the preceding, has been involved in the confusion in revisions and collections under D. rufipennis. The species under this name was represented in the Le Conte collection by two specimens labeled "Alta, Ut." and "Colo.," by two in Horn's collection labeled "H. B.," and "Alta, Ut.," and by one specimen from Doctor Dietz, labeled "Ut." These were doubtless involved in Le Conte's and Dietz's revisions.

Pupa.-In addition to the generic, divisional, and subdivisional characters, the apices of the front and middle femora are smooth; abdominal tergites 2 to 6 with small pleural spines; 1 and 2 without dorsal but with lateral spines, and 3 to 6 with dorsal and lateral spines; 7 and 8 smooth; 9 with pleural spines, as usual. Pupal type labeled "Webb No. 2."

The usual variation in minor details prevails, but the pupa of this species is distinguished from that of the preceding one by the more distinctly impressed vertex of the head, the generally coarser spines, and the presence of dorsal spines on the third abdominal tergite.

Larva.-In addition to the generic, divisional, and subdivisional characters, the front has a transverse rugose elevation situated near the middle; the anterior surface, including the elevation, is opaque; the area behind the elevation is impressed and shining, clypeus 
broad, with median dorsal groove and the apex subacutely emarginate; labrum prominent, its anterior margin truncate; mandibles opaque toward base, more shining toward apex, with a distinct dorsal impression and oblique ridge near the middle; sternellar lobes of the thoracic segments moderately prominent and with distinct foot calli.

Larval type labeled "Webb

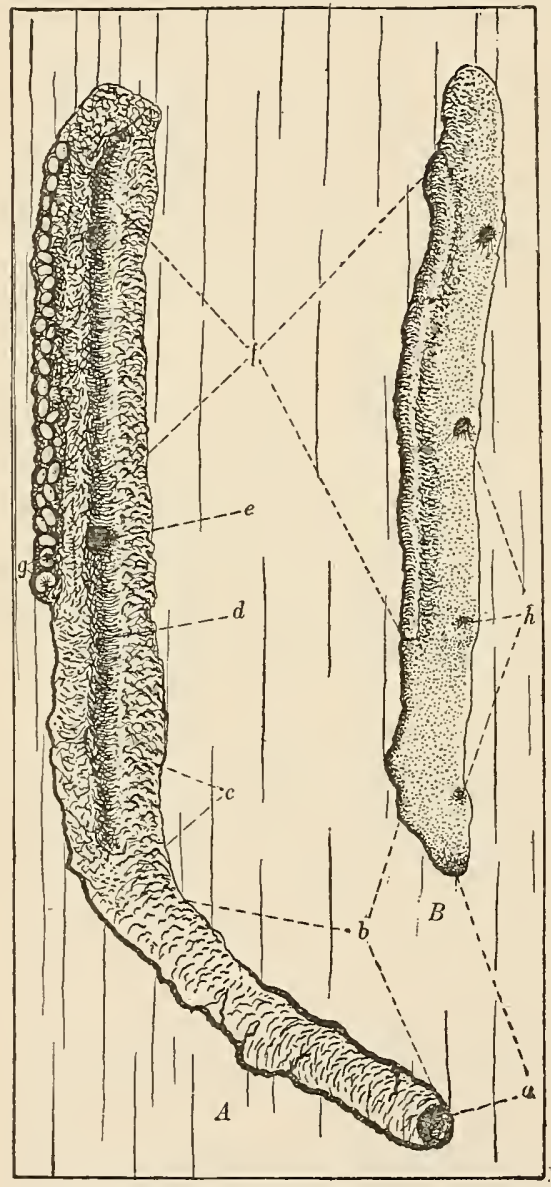

FIG. 81.-Dendroctonus engelmanni: Egg gallery in living bark. $A$, Normal; $B$, boring dust removed; $a$, entrance; $b$, basal section; $c$, boring dust packed in gallery; $d$, subsequent or inner gallery; $\epsilon$, rentilating burrow; $f$,egg nest, with and without eggs; $g$, freshly hatched larvæ; $h$, pits in roof of gallery. (Original.)
No. 2."

The most distinctive characters separating the larva of this species from that of the preceding one are the more shining mandibles, with much deeper dorsal impression and more prominent oblique ridge and the much less distinctly elevated anterior margin of the epicranium.

Galleries (fig. 81).-The galleries of this species are very much the same as those of the preceding one, except that the larval mines are more distinctly contiguous for a greater distance from the egg galleries.

Distribution (fig. 82).(Hopk. U. S.) Arizona: Chiricahua Mountains. Colorado: Clyde, Boulder, Craig, Fort Collins, Glenwood Springs, Gunnison, Hahn's Peak, Holy Cross National Forest, Meeker, Ouray National Forest, San Isabel National Forest, Steamboat Springs, White River National Forest. New Mexico: Capitan Mountains, Sierra Blanca Mountains, Sacramento National Forest. South Dakota: Spearfish Canyon, Black Hills.

Utah: Ephraim. Tyoming: En-

campment. Additional localities from specimens in other collections: (Horn) "H. B." (Northwest Territory, probably in Mackenzie River region) and Alta, Utah. (Wickham) Argentine, Leadville, and Silver Plume, Colo. (Cockerell) Las Vegas, N. Mex. (H. \& S.) Calgary, Alberta; Glacier, British Columbia. (Webb) Collins, Idaho. 
Host trees.-Picea engelmanni and P. canadensis.

Identified specimens.--Le Conte collection, 2 specimens; Horn, 2; Dietz, 1 (Utah); U.S.N.M. (H. \& S.), 4; Wickham, 4; Cockerell, 7 ; Webb, 25; Hopk. U. S., more than 200 specimens, including all stages and work.

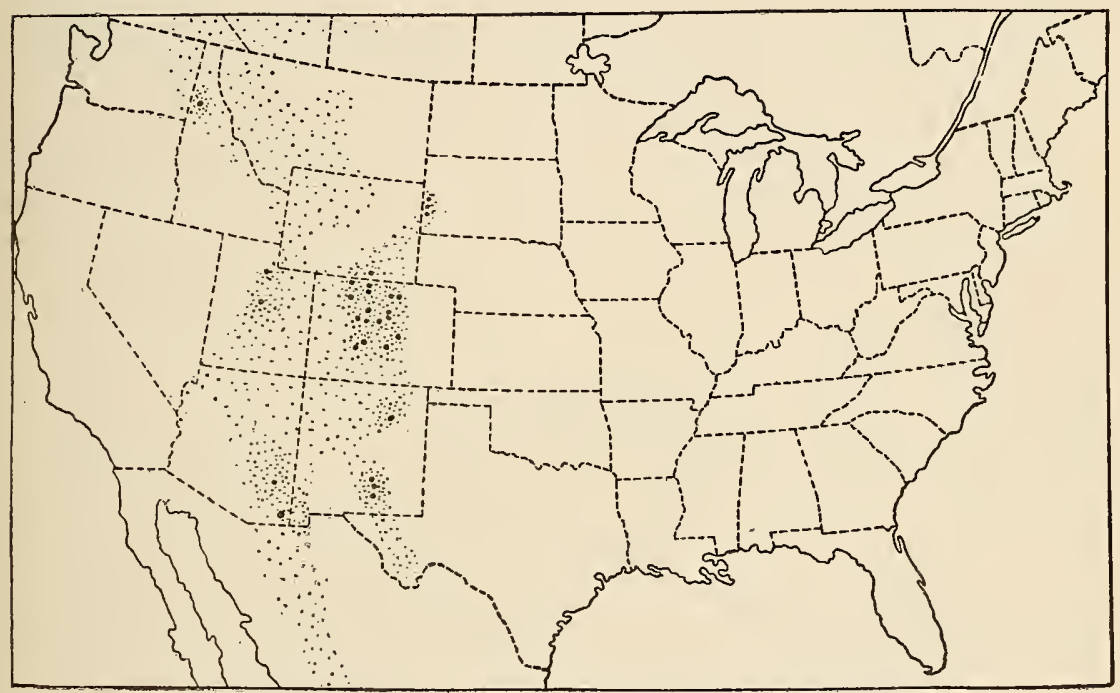

FIG. 82.-Dendroctonus engelmanni: Distribution map. (Original.)

Bibliography and Synonymy.

Dendroctonus rufipennis (not of Kirby) Le Conte, 1876, p. 385, revision (?). Le Conte, 1878, p. 469 (in part) (in collection 1900-1907, under D. rufipennis). Packard, 1887, pp. 177-243 (in part). Packard, 1890, p. 721 (in part), p. 722 (in part), quotes Le Conte. Dietz, 1890, p. 30, Colorado, Utah. Wickham, 1902, p. 309 , list, localities.

Dendroctonus dietzi Hopkins, 1902a, manuscript name only for variation (Utah).

Dendroctonus californicus Hopkins, 1902a, p. 3, manusrript name only, locality.

Dendroctonus wickhami Hopkins, 1902a, p. 3, manuscript name only.

Dendroctonus piceaperda (not of Hopkins) Wickham, 1902, p. 310, in list, locality, host, reference to synonymy. Hopkins, 1906a, pp. 4, 5, old work on Pike's Peak. Dendroctonus piceaperda var. engelmanni (Hopk.) Fall, 1907, p. 218, manuscript name, list, localities.

Dendroctonus piceaperda (not of Hopkins) var. Fall, 1907, p. 218, list, Cloudcroft, N. Mex.

The Engelmann spruce beetle. Hopkins, 1908, pp. 161-162, depredations.

16. Dendroctonus borealis $\mathrm{n}$. $\mathrm{sp}$.

(Pl. V, fig. 16.)

Adult.-Type of species, female: Length $6 \mathrm{~mm}$., nearly black. Head with front convex, with faint anterior and posterior impressions and faint anterior line; elytral declivity with striæ not deeply im- 
pressed; punctures of pronotum distinctly irregular; posterior half of proepisternal area not punctured; punctures of pronotum and elytra moderately coarse; elytral striæ scarcely impressed except in dorsal area; interspaces scarcely coarser and but faintly rugose, except toward base and vertex. Secondary sexual characters: Elytral declivity convex; striæ faintly impressed, with punctures moderately distinct; interspaces slightly convex, with distinct row of granules.

Type labeled "Type No. 7453 U.S.N.M.," name label, "Hopk. 1/22/08, U.S.N.M. 22, Alaska, , U.S.N.M. Acc. 25431."

Male type: Length $6 \mathrm{~mm}$., elytra red; thorax, head, and abdomen much darker; other characters the same as in female, except elytral declivity, which is shining, the striæ and strial punctures obscure;

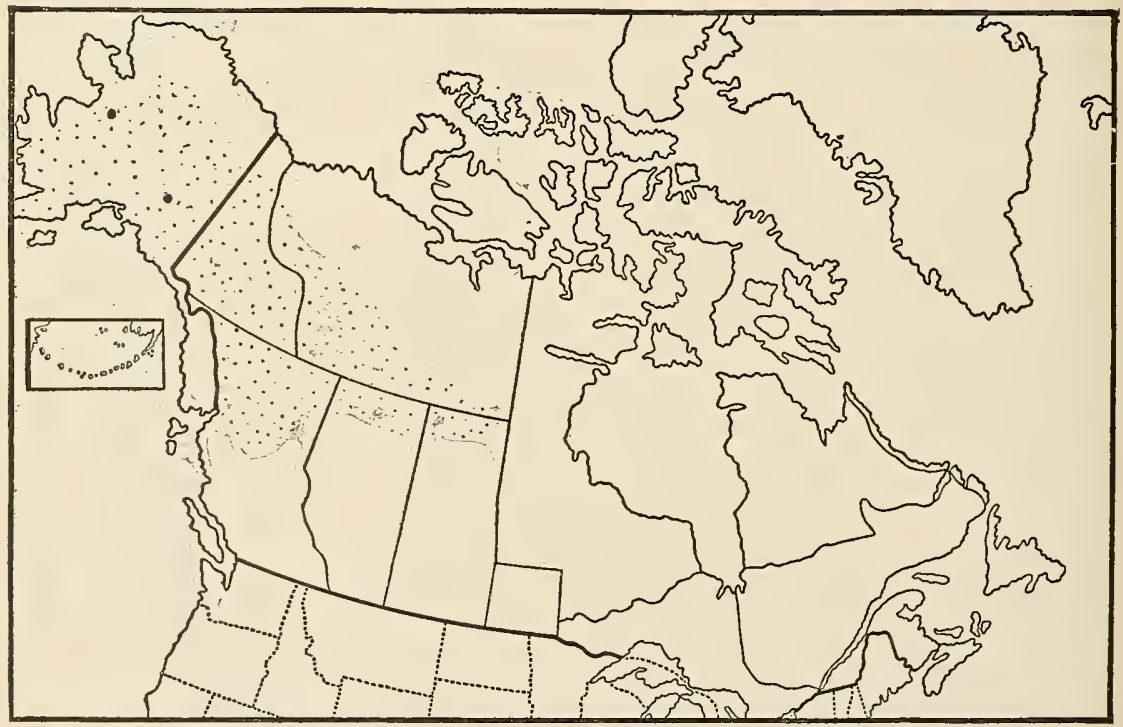

FIG. 83.-Dendroctonus borcalis: Distribution map. (Original.)

interspaces flat, shining, and 1 and 2 without granules except toward vertex.

Male type labeled "type of drawing," " ‘ type," name label, "Hopk. 1/22/08, Picea canadensis, Eagle, Alaska, W. H. Osgood, collector, ऊ, Hopk. U. S. 1170a."

Variations. - There is scarcely any variation in the four specimens in the collections, but the color varies from nearly black in the type to the head, thorax, and abdomen dark, and the elytra red in the other specimens.

Distinguishing characters.-The short, stouter form, short and broad pronotum, with the punctures more uniform in size, the punctures of the dorsal strix of the elytra finer and less distinct, serves to distinguish this species from all of the allied forms. It appears to be more closely allied to $D$. obesus, but is distinguished from it by its shorter pronotum and elytra, and the other characters mentioned. 
Revisional notes. - It is quite evident that the specimens described by Mannerheim (1853, p. 238) under D. rufipennis are D. borealis. The single specimen in Le Conte's collection under D. rufipennis, labeled "Hylurgus rufipennis Kirby," and locality Kenai, is evidently from Mannerheim's collection, and probably one of the specimens before him when he prepared his description under that name. Superficially, this specimen resembles $D$. piceaperda, which led Le Conte to identify his Anticosti and Canada specimens as D. rufipennis, and is evidently the one which represented the Alaska locality in his revisions (1S68 and 1876).

The immature stages and galleries of this species have not been observed.

Host tree.-Picea canadensis.

Distribution (fig. 83).--Alaska: Eagle, (?) Kenai Peninsula.

Identified specimens.-Le Conte, 1 specimen; U.S.N.M., 2; Hopk. U. S., 2, collected by W. H. Osgood, of the Biological Survey, U. S. Department of Agriculture, at Eagle, Alaska, August, 1903, from white spruce.

\section{Bibliography and Synonymy.}

Hylurgus rufipennis (not of Kirby). Mannerheim, 1853, p. - (in part). Dendroctonus rufipennis (not of Kirby). Le Conte, 1868-1876 (in part). Dendroctonus borealis Hopkins, 1902a, p. 3, manuscript name only.

\section{Dendroctonus obesus (Mannerheim).}

(Pl. VI, fig. 17.)

Adult.-Typical female: Length $6.5 \mathrm{~mm}$., nearly black. Head with front convex, with faint anterior and posterior impression and moderately distinct anterior line. Elytral declivity with striæ not deeply impressed; punctures of pronotum distinctly irregular; posterior half of proepisternal area not punctured; punctures of pronotum and elytra moderately coarse; elytral striæ scarcely impressed; interspaces flat, finely, sparsely rugose on dorsal area and toward base of vertex. Secondary sexual characters: Declivity convex, subopaque; striæ faintly impressed, with punctures moderately distinct; interspaces faintly convex, with distinct row of granules.

Typical female labeled, name label, "Hopk. 1/22/08, Picea sitchensis, Queen Charlotte Il., Keen [collector], \&."

Typical male: Length $6.7 \mathrm{~mm}$., black. Front convex, with faint anterior impression and distinct anterior line. Agrees with female, excepting that the punctures of elytral striæ and interspacial rugosities are coarser; declivity subopaque; strial impressions and punctures obscure; interspaces flat, faintly punctured, and with a few granules toward vertex; pronotum with distinctly elerated line.

Typical male labeled, name label, "1/22/08, Picea sitchensis, Queen Charlotte Il., J. H. Keen, Collr., ô ." 
Variations. - The length varies from 6 to $7 \mathrm{~mm}$., with the average about $6.5 \mathrm{~mm}$. The color ranges from uniform light red to brown in young specimens, to uniform black in matured ones, it being exceedingly rare to find examples with the pronotum darker than the elytra, which is so characteristic in the three preceding species. The sculpture and vestiture of the epistoma, front, pronotum, and elytra vary as usual. The greatest variation is in the punctures of the pronotum and in the presence and absence of the dorsal line; the presence or absence of a frontal carina is also an important variation, and in some examples the body is noticeably more elongate than in others.

Distinctive characters.-The characters which serve to distinguish this species from the three preceding are the uniform black color of the matured adults and the prevailingly less impressed elytral striæ, especially those of the lateral area, and also the prevailing slightly. more elongate form. Its host tree and distribution also serve as distinguishing characters, except, perhaps, in the case of borealis, which may be found in the Sitka spruce.

Revisional notes. - There can be little or no doubt that the material under observation represents Mannerheim's species, whose varieties $a, b$, and $c$ were evidently immature specimens. D. simitis Lec. is to be referred to this, which fact was recognized by Le Conte in his 1868 paper, but the beetle was subsequently confused with the species discussed in the present paper under D. pseudotsugæ. D. obesus is represented in the Le Conte collection by two specimens, one specimen from Mannerheim's collection, labelled D. obesus ("Specimen 5" under D. rufipennis in 1900), and one specimen, the type of $D$. simitis. It is possible that "specimen 2" under D. rufipennis is also $D$. obesus, but was not recognized by the writer when examined in 1900. Dietz, 1890, did not recognize or mention D. obesus, and it was not found by the writer in the Horn collection or that of the Academy of Natural Sciences.

Pupa.-In addition to the generic, divisional, and subdivisional characters, the apices of the front and middle tibiæ are smooth or rarely with a single granule, abdominal tergites 2 to 6 with very small pleural spines, 1 without dorsal but with small lateral spines, and 2 to 6 with dorsal and lateral ones, 7 and 8 smooth, 9 with prominent pleural spine as usual. Pupal type labeled "Hopk. U. S. No. 4049a."

The usual variation in minor details prevails, but the pupa of this species is distinguished from that of the three preceding by the more evident lateral spines of the first abdominal tergite and the prevailing darker tips to the abdominal spines.

Larva.-In addition to the generic, divisional, subdivisional, and sectional characters, the front has a faint transverse elevation dis- 
tinctly in front of the middle and the pronotal area is flat to apex. The clypeus is short and broad, with an anterior dorsal groove and the apex broadly emarginate, labium prominent, slightly longer than the clypeus, with the apex broadly rounded. Larval types, labeled "Hopk. U. S. Nos. 4081, 4046a, and 4049a."

The most distinctive characters appear to be the anteriorly placed transverse elevation of the front; the characters of the mandibles and anterior margin of the epicranium more nearly approach those found in D. engelmanni.

Galleries.-The galleries of this species are of the same, or of similar character to those of $D$. piceaperda, as given in divisional,

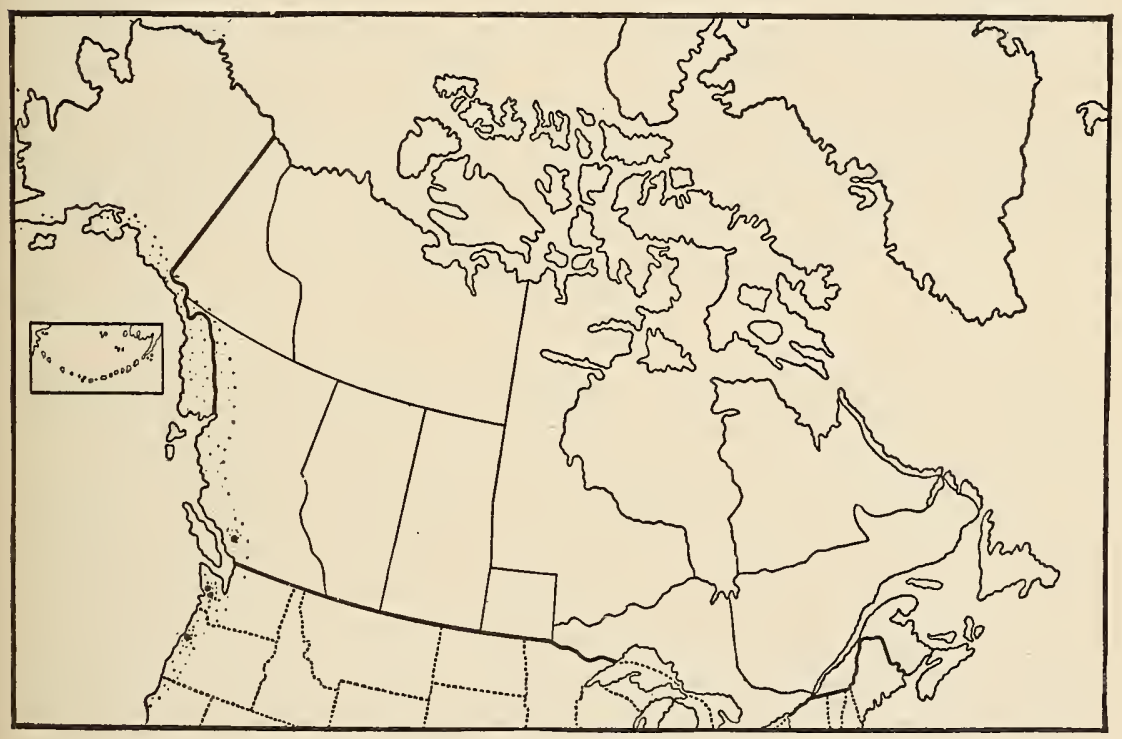

FIG. 84.-Dendroctonus obesus: Distribution map. (Original.)

subdivisional, or sectional characters, but differ in the more extended common larval chamber which precedes the independent larval mines which are usually so confused by crossing each other that they are difficult to follow.

Distribution (fig. 84).-(Hopk. U. S.) Oregon: Newport. Washington: Hoquiam, Aberdeen. Additional localities from other collections: (U.S.N.M.) (H. \& S.) Vancouver, British Columbia; (Rev. Keen) Queen Charlotte Islands, British Columbia.

Host tree.-Picea sitchensis.

Identified specimens.-Le Conte collection, 2 specimens: U.S.N.M., 1 from Doctor Fletcher; II. \& S., 3; Hopk. U. S., more than 120 specimens, including all stages. 


\section{Bibliography and Synonomy.}

Hylurgus obesus a Mannerheim, 1843, p. 296, original description. Mannerheim, 1852 , p. 356 , spec. 474 , list, variety $b$ and variety $c$, brief descriptions. Mannerheim, 1853, p. 238, separate p. 146, list, var. $d$ described. Le Conte, 1868, p. 173, mentioned, synonymy.

Dendroctonus similis Le Conte, 1860, p. 59, description (from one specimen which $=$ D. obesus). Le Conte, 1868 , p. 173, mentioned as synonymous with D. obesus Mann. Hopkins, 1902a, p. 3, recognized as synonymous with D. obesus (Mann.).

Dendroctonus obesus (Mann.) Le Conte, 1868, p. 173 (in part). Chapuis, 1869, p. 35; 1873 , p. 243, revised description. Hamilton, 1894, p. 35 (in part). Hopkins, 1899 b, pp. 15, 21, habits, host, etc. Schwarz, 1900a, p. 537, author's reprint p. 185 (in part), list. Hopkins, 1902a, p. 3, species recognized as distinct from $D$. rufipennis Kirby. Hopkins, 1902c, p. 22, habit and host. Hopkins, 1903a, p. 60 , reference.

Dendroctonus rufipennis (not of Kirby). Le Conte, 1868, p. $173 \quad(?=D$. obesus). Le Conte, 1876 , p. 385, revision, synonymy, bibliography, localities (in collection 1900-1907, under rufipennis). Packard, 1887, pp. 176, 243 (in part?).

Dendroctonus rufipennis (obesus Mann.) Harrington, 1890, p. 189, author's extra, p. 19. Dendroctonus keeni Hopkins, 1902a, p. 3, manuscript name only on variation. Dendroctonus fletcheri Hopkins, 1902a, p. 3, manuscript name only on variation.

\section{Dendroctonus rufipennis (Kirby).}

(Pl. VI, fig. 18.)

Adult.-Typical female: Length $6.2 \mathrm{~mm}$. Elytra red; thorax, head, and abdomen reddish brown. Head convex, with faint anterior and posterior impression and short anterior line; elytral declivity with striæ not deeply impressed; punctures of pronotum distinct, irregular; posterior half of proepisternal area punctured; striæ of elytral declivity with fine punctures; elytral striæ scarcely impressed, except toward suture; strial punctures moderately coarse; interspaces with rugosities moderately coarse, sparse, and acute; pronotal punctures coarse, deep, moderately dense. Secondary sexual characters: Elytral declivity convex; striæ faintly impressed; punctures obscure; interspaces faintly convex, with row of fine granules.

Typical female labeled "type of drawing," name label, "Hopk., 4/25/02. Agrees with Kirby's type, compared by C. O. Waterhouse, H. S. 28, $q$, White Fish Point, L[ake] S[uperior]."

Typical male: Length $6.7 \mathrm{~mm}$. Elytra dark red, thorax and head reddish brown. Agrees with female, excepting that the elytral declivity is more shining, the strial punctures are less distinct, and the interspaces have less distinct rows of granules.

Typical male labeled, nome label, "Hopk. 1/22/08, Pinus strobus, Grand Island, Mich., W. F. Fiske, collector, o, Hopk. U. S. 3761."

Variations. - The length varies from 5 to $7.3 \mathrm{~mm}$., with the average at about $6.5 \mathrm{~mm}$., the head, thorax, and ventral segments from

a This was Eschscholtz's manuscript name, published in Dejean Cat., 3me. Edit., p. 331, but Mannerheim published the first description. 
darker reddish brown to nearly black, while the elytra are light to dark red. The greatest variation noted in the few specimens under observation is in size, with less variation in sculpture and vestiture than in the preceding species, Nos. 14, 15, and 17.

Distinctive characters.-The characters which serve to at once distinguish this species from the preceding allied ones are the coarse punctures of the posterior section of the proepisternal area, the more distinctly red elytra, the bright-red hairs, and the much less distinctly impressed elytral striæ of the lateral area.

Revisional notes.-There is quite extensive literature under the name Hylurgus rufipennis Kirby and Dendroctonus rufipennis Kirby. Apparently no part of it except the original description refers to Kirby's species, and even the type series in the British Museum represents at least one other species. It appears that up to the fall of 1906 the only representative of the species in the collections of this country was a female specimen in the Hubbard \& Schwarz collection, U. S. National Museum, labeled "White Fish Point, L. S." This, with other specimens of the Dendroctonus of the U. S. National Museum and Hubbard \& Schwarz collections, was submitted to the writer in December, 1898, for study, and was then labeled "II. S. 28." In 1900 this specimen, together with another labeled "H. B." (Northwest Territory) from the National Museum collection, and some specimens collected by the writer from the spruce in Maine, were sent to the British Museum for comparison with Kirby's type of D. rufipennis. They were compared by $\mathrm{Mr}$. Charles $\mathrm{O}$. Waterhouse who, in a letter dated November 1, 1900, wrote as follows:

I have examined your species, but am only concerned with your two largest specimens. We have three of the specimens which Kirby had before him, all marked exactly alike. The one to which he attached his ticket is a dark-brown variety (unless it is stained with grease), but in all other respects agrees with your H. S. 28, with fairly equally distributed punctuation on the thorax. Kirby's two other specimens have red elytra and agree with your H. B. 7401, 824, and have a closely punctured impression or flattening at the base of the thorax.

The specimen in the type series which bore the name label when the comparison was made should be recognized as the type. Thus it is quite certain that our H. S. 28 from White Fish Point, Lake Superior, is a true representative of the species, while the two other specimens with which our H. B. 7401, 824, etc., agree evidently represent $D$. engelmanni and are probably the specimens referred to by Kirby as coming from Lat. $65^{\circ}$. The writer is informed by Mr. Schwarz that our H. B. (No. 7401) specimen came from about the same latitude. The other specimens from Maine, which were so different from the type as to be at once recognized as distinct, were representatives of D. piceaperda Hopk.

The pupæ, larvæ, and galleries have not been observed. 
Distribution (fig. S5).-Michigan: White Fish Point and Grand Island.

Host tree--Pinus strobus.

Identified specimens.-U.S.N.M.,H. \& S., 1 specimen; Hopk. U. S., 14 specimens of adults, collected by W. F. Fiske at Grand Island, Mich.

\section{Bibliography.}

Hylurgus rufipennis Kirby, 1837, p. 195, No. 261, original description. Packard, 1887, p. 176, note. Hopkins, 1899c, p. 343 (in part?). Schwarz, 1900a, p. 537, author's copy, p. 185 (in part?). Hopkins, 1901a, p. 16, reference to distribution, characters, first time recognized since description.

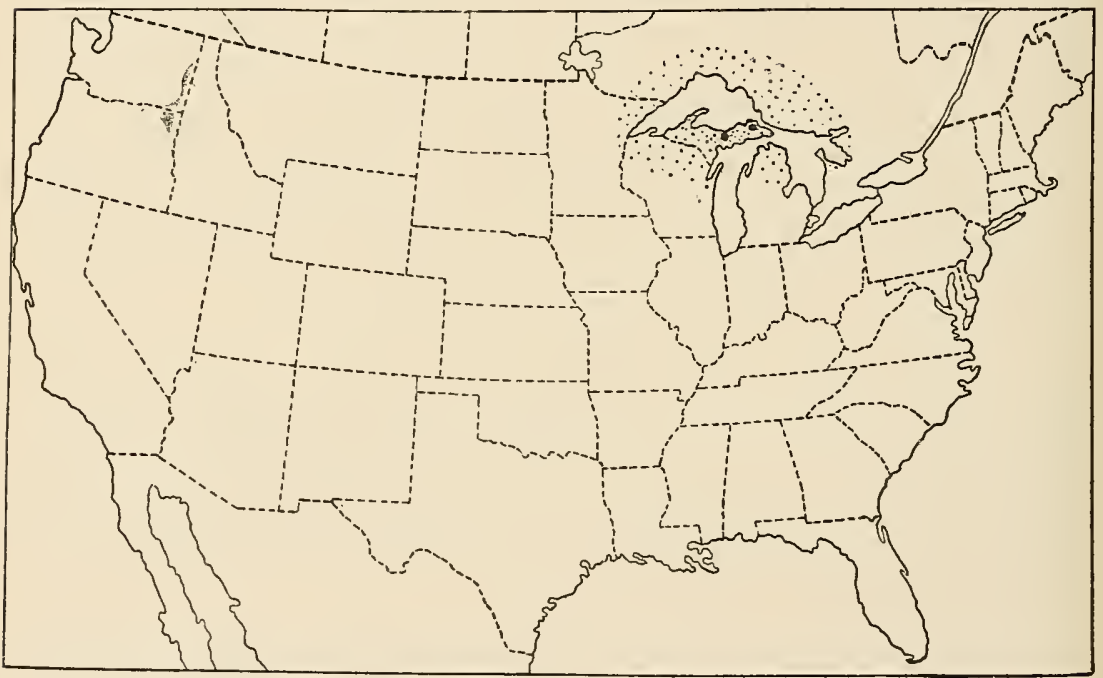

FIG. 85.-Dendroctonus rufipennis: Distribution map. (Original.)

19. Dendroctonus murrayanæ n. sp.

Adult.-Type of species, female: Length, $6.9 \mathrm{~mm}$; elytra red; thorax, head, and abdomen nearly black. Head convex, with obscure impression; elytral declivity with striæ not deeply impressed; punctures of pronotum distinct, coarse, irregular; posterior half of proepisternal area punctured; strix of elytral declivity with fine punctures; elytral striæ scarcely impressed; punctures moderately coarse; interspaces with rugosities moderately coarse, acute, and rather coarsely placed; pronotal punctures coarse, deep, moderately dense. Secondary sexual characters: Elytral declivity convex; striæ distinctly impressed; punctures obscure; interspaces convex, with irregular punctures and rows of granules.

Type labeled "No. 7454 U.S.N.M.," name label, "Hopk. 1/22/0S, Pinus murrayana, Keystone, Wyo., J. L. Rebmann, collector, + , Hopk. U. S. 2690." 
Male type: Length, $6.5 \mathrm{~mm}$. Agrees with female, except that the elytral declivity is more shining and the interspaces are more distinctly punctured and less rugose.

Type labeled " $\delta$ type," otherwise same as female.

Variations.--The length varies from 5.4 to $6.5 \mathrm{~mm}$., with the average about $6 \mathrm{~mm}$.; the head, thorax, and ventral segments are dark reddish brown to black, while the elytra are light to dark red. The greatest variation noted in the few specimens under observation is in the size, with less variation in sculpture and vestiture than in species Nos. 14,15 , and 17 .

Distinctive characters.-The characters which serve to distinguish this species from $D$. rufipennis, to which it is more closely allied, are its slightly smaller size and more distinctly impressed elytral striæ

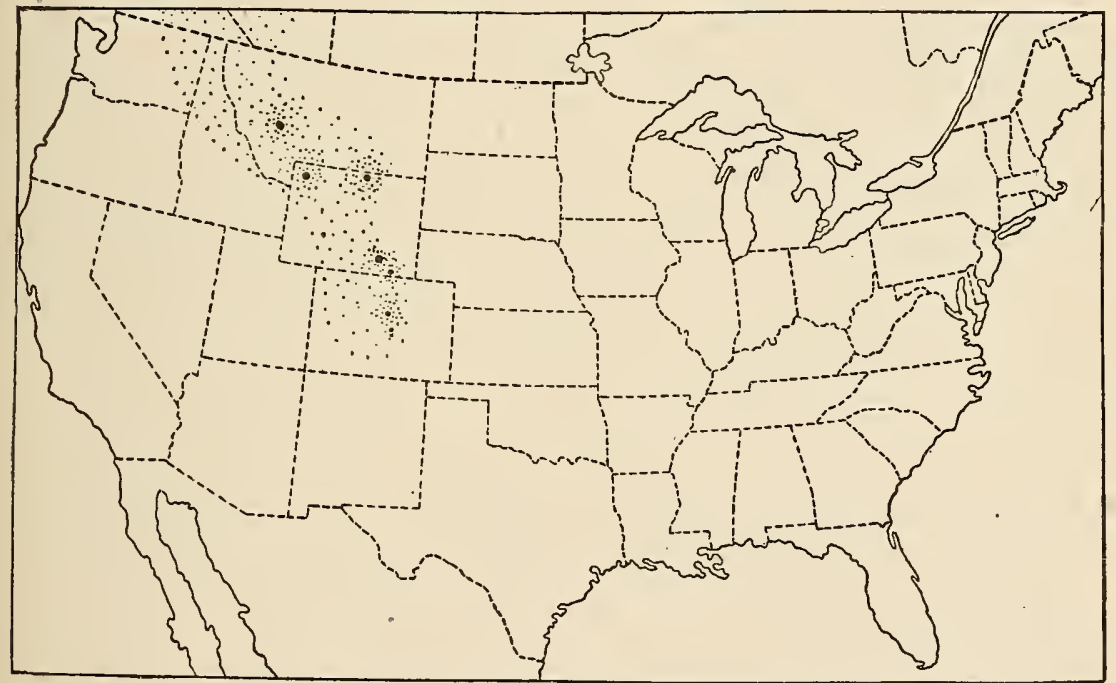

FIG. 86.-Dendroctonus murrayanæ: Distribution map. (Original.)

on the dorsal and lateral areas and the finely, densely punctured interspaces of the declivity in the male.

It appears that this species has not been referred to in literature.

The pupa has not been observed.

Larva (Pl. VIII, fig. 19).- In addition to the generic, divisional, and subdivisional characters, the front has an impression toward the anterior angles and a faint transverse elevation in front of the middle. The clypeus is longer than the labrum and marked with a median groove, and with the apex broadly emarginate; labrum with apex faintly emarginate, and the mandibles with distinct dorsal impression. Larval type labeled "Hopk. U. S. No. 2690c."

Galleries.-Only fragmentary specimens of the galleries have been observed, but they appear to come between piceaperda and valens, the larvæ, for the most part, excavating a common chamber. 
Distribution (fig. 86).-(Hopk. U. S.) Wyoming: Homestake, Saratoga, Keystone, Cheyenne National Forest, and Big Horn National Forest. Colorado: Jefferson. Additional localities from other collections: (U.S.N.M.) (H. \& S.), National Park, Wyoming.

Host trees.-Pinus murrayana and Picea engelmanni.

Identified specimens.-H. \& S., 5; Hopk. U. S., over 100 specimens, including adults, larvæ, and work.

\section{Bibliography.}

Dendroctonus shoshone Hopkins, 1902a, p. 3, manuscript name only.

\section{Dendroctonus punctatus Le Conte.}

(Pl. VI, fig. 20.)

Adult.-Typical female: Length $6.5 \mathrm{~mm}$., dark reddish brown. Head convex, with moderately distinct anterior impression. Elytral declivity with striæ distinctly impressed. Punctures of pronotum distinct, coarse, irregular; posterior half of proepisternal area punctured; striæ of elytral declivity with coarse punctures; elytral striæ distinctly impressed; punctures coarse and distinct; interspaces rather narrow, convex, moderately rugose on dorsal area, but nearly smooth on lateral area. Secondary sexual characters: Declivity convex, shining; striæ distinctly but not deeply impressed; punctures coarse and distinct; interspaces narrow, convex, with row of granules.

Typical female labeled "type of drawing," name label, "Hopk. 4/25/02; Picea rubens, Randolph County, W. Va., A. D. Hopkins, collector, , Hopk. W. Va. 6312."

Variations.-There appears to be very little variation in the few specimens observed.

Distinctive characters.-This species is at once distinguished from all of the preceding by the coarse punctures of the elytral strix, especially on the declivity. Its nearest ally is $D$. micans, of Europe, from which it differs in its smaller size, more elongate form, and more distinctly inpressed elytral striæ.

Revisional notes.- While the original description does not include the more distinctive characters, it was based on a type which was readily recognized as a distinct species. Dietz referred the specimen in the Horn collection, labeled $D$. punctatus Lec., to $D$. rufipennis (Kirby), but it is certainly distinct from what is now recognized as D. rufipennis.

Host tree.-Picea rubens.

Pupæ, larvæ, and galleries of this species have not been observed.

Distribution (fig. 87).-(Hopk., W. Va.) 1 specimen collected by the writer May 21, 1892, in the high mountains of Randolph County, 
West Virginia, under bark on spruce stump. (Le Conte, M. C. Z.) 3 specimens labeled "New York"; (Horn, A. E. S.) 1 specimen labeled "Pa."

\section{Bibliography AND Synonymy.}

Dendroctonus punctatus Le Conte, 1868, p. 173, original description, synonymy, locality. Le Conte, 1876, p. 385, revision, synonymy, bibliography, localities. Packard, 1857, p. 177, Le Conte quoted. Packard, 1890, p. 722, Le Conte quoted. Hopkins, 1899a, p. 447, habit, etc., West Virginia. Hopkins, 1902a, p. 3, recognized as a good species and restored.

Dendroctonus rufipennis (not of Kirby) Dietz, 1890, p. 30, Pennsylvania.

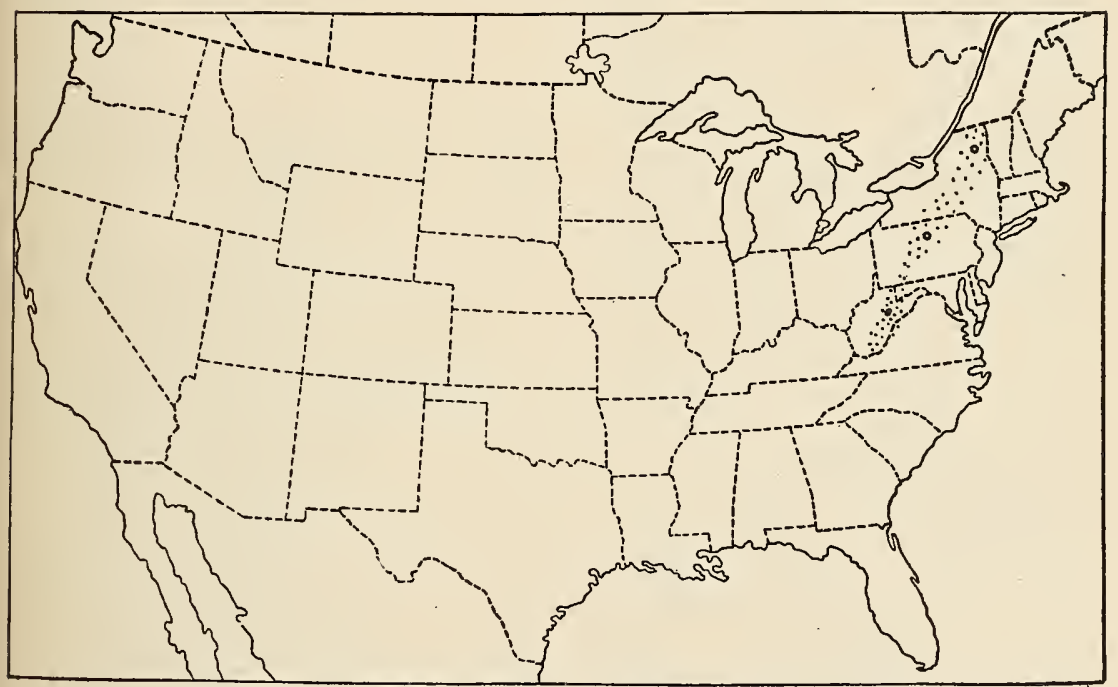

FIG. 87.-Dendroctonus punctatus: Distribution map. (Original.)

21. Dendroctonus micans (Kugelann).

(Pl. VI, fig. 21.)

Adult.-Typical female: Length $7.25 \mathrm{~mm}$., dark reddish brown. Head convex, with faint anterior impression, without anterior line; elytral declivity with striæ not deeply impressed; punctures of pronotum distinct, coarse, irregular; posterior half of proepisternal area punctured; strix of elytral declivity with coarse punctures; elytral striæ not impressed, punctures moderately coarse, interspaces broad and flat, sparsely and finely rugose. Secondary sexual characters: Elytral declivity convex, subopaque; striæ faintly impressed; punctures coarse and distinct; interspaces moderately convex, with sparse, irregular granules.

Typical female labeled "type of drawing," name label, "Hopk. 4/25/02, ㅇ. . Determination No. 20, Eichhoff, Sachsen, Horrung." 
Typical male: Length $6 \mathrm{~mm}$., black. Agrees with female in every respect, except that it may have stouter mandible, the club of antenna smaller, more elongate; the declivity of elytra with strial punctures finer, and the interspaces without granules.

Typical male labeled " ô, from Dr. Severin."

Variations.-Length 7 to $8 \mathrm{~mm}$., average about $7.5 \mathrm{~mm}$.; uniform reddish brown to nearly black, with usual variation in sculpture and vestiture.

Distinctive characters.-This species is more closely allied to $D$. punctatus than to any of the other species of the genus, from which it is distinguished by its larger size and stouter form, with the striæ scarcely at all impressed, and the punctures smaller.

The male of this species appears to be far more rare than in the other species, from the fact that among 83 specimens examined only 2 males were found. While the declivity is somewhat more shining and smoother in the male, this character is by no means as striking as in the other species of the section to which it belongs.

The pupa has not been studied by the writer, but is evidently similar in general character to that of $D$. piceaperda.

Larva.-Abdominal tergite 8 without, 9 with, small dorsal plate, which is not rugose. Front with distinct elevation. In addition to the generic, divisional, and subdivisional characters, the frontal elevation is subopaque, transversely wrinkled, situated in front of the middle and joined to the epistoma; lateral angles are curved back to their junction with the frontal sutures, which are broadly curved toward the apex. The area behind the elevation is broad, flat, and more shining. Clypeus broad, with faint median groove and the apex broadly emarginate. Labrum small, rather stout, with broad dorsal impression, the apex subtruncate; mandibles shining, with a distinct dorsal impression and oblique ridge near the middle; sternellar lobes of the thoracic segments moderately prominent and with distinct foot calli.

Type.-One of a large series of larvæ received from Dr. G. Severin, conservateur, Royal Museum of Natural History, Belgium.

The larva of this species is at once distinguished from that of all of the other species of the genus, so far as observed, by the faint dorsal plate of the ninth abdominal segment, by the absence of a plate on the eighth, by the frontal elevation connected with the epistoma, and by the greater number and more distinct hairs on the scutellar lobes of the thorax and abdomen.

Galleries (fig. 88).- The galleries are evidently quite similar to those of $D$. terebrans and $D$. valens, especially in the fact that the larva live together in a common chamber exposed in the inner bark. According to Dr. G. Severin, the egg gallery is vertical, frequently 
curved and somewhat irregular, sometimes doubly inflected and from 12 to $20 \mathrm{~cm}$. long. The female here deposits from 20 to 25 eggs in several places. The larvæ eat very close together, growing equally in size and age and making a common cavity underneath the bark. In order to go through the pupal stage, they return to the large space which they left behind them and which is now filled with excrement and resin. Departing from their common cavity, they eat out isolated galleries, and at the end of these they pupate.

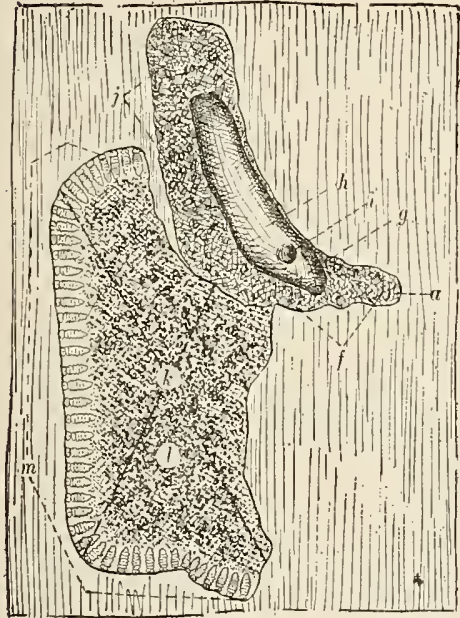

B

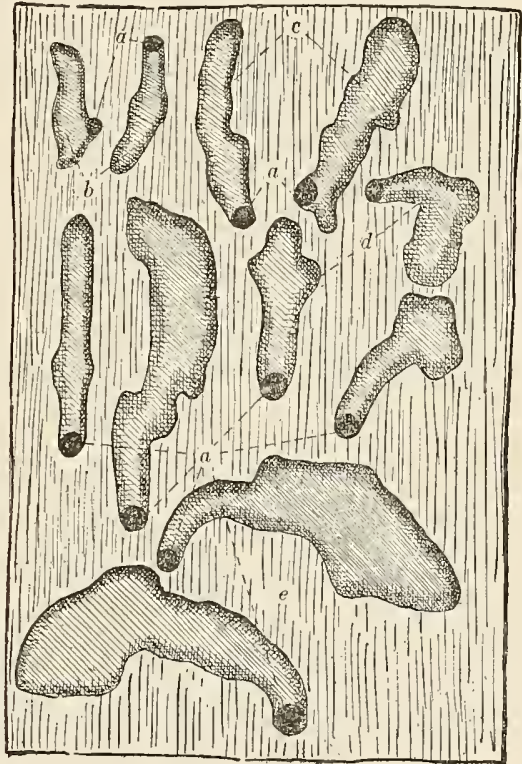

A

FIG. 88.-Dendroctonus micans: Egg galleries and larval chamber. $A$, Basal sections of egg galleries; $B$, advanced stage of work; $a$, entrance burrow; $b$, excavated July 8-16; $c$, excavated July 8-29; $d$, eight days old; $e$, three weeks old; $f$, basal section; $g$, boring-dust; $h$, subsequent or inner gallery ("mother gallery"); $j$, egg nest with eggs scattercd about in boring-dust; $k$, social chamber excavated by larvæ; $l$, boring-dust and resin; $m$, larvæ at work. (Adapted from Pauly Forstlich-natur wissenschaftliche Zeitschrift, 1 Jahrgang, figs. 3 and 4.)

Distribution (fig. 89).-According to the literature, this species ranges from central to northern Europe and from Denmark and Russia eastward into Siberia.

Host trees. - It is said to infest Pinus, Picea, Abies, and Larix.

Identified specimens. - The writer has examined 1 specimen received from W. Eichhoff, 8 from B. W. Schlick, Denmark; 2 with specimens of work from Reitter's collection, collected in Bohemia, and about 70 specimens of adults, as well as larvæ and specimens of work from Dr. G. Severin, of the Musée Royale d'Histoire Naturelle, Brussels, Belgium. 
Bibliography and Synonymy.

?Bostrichus ligniperda Herbst, 1793, p. 107 (in part).

Bostrichus micans Kugelann, 1794, p. 523, original description.

?Hylesinus ligniperda Gyllenhal, 1813, pp. 335, 336 (in part).

Derdroctonus micans (Kug.) Erichson, 1836, p. 53, type of genus. Bach, 1849, p. 144.

Stein, 1854, pp. 277-279, habits, destructiveness. Kollar, 1858, pp. 23-28, habits, control. Eichhoff, 1864, p. 27, pl. 1, fig. 5, tarsi, fig. 6, maxilla, fig. 7, labium, in revision of genus. Lacordaire, 1866, p. 360, in revision of genus. Chapuis, 1869, p. $35 ; 1873$, p. 243 , revised description. Lindemann, 1875 , pp. 213,221 , pl. 1, figs. 1-10, male reproductive organs described and illustrated. Eichhoff, 1881, pp. 125-128, fig. 23, adult, fig. 24, galleries, revision, bibliography, account of habits, distribution, etc. Altum, 1881, pp. 262-266, description, biology. Judeich and Nitsche, 1889, pp. 458-462, life history, habits, importance, remedy. Pauly, 1892, pp. 315-327, 4 figs. of galleries, habits. Verhoeff, 1896, pp. 124-133, anatomy. Ménégaux \& Cochon, 1897, pt. 2, p. 120, habits, etc. Severin, 1902, p. 145, habits in Belgium. Treber, 1902, p. 108, fig. 5, enemy. Brichet et Severin, 1903, pp. 244-258, habits, etc. Baudisch, 1903, pp. 151-152, habits, etc. Quairiére, 1904, pp. 626-628. Nüsslin, 1905, pp. 175-178, habits, description, importance. Quiévy, 1905, pp. 334, 335. Severin, 1908, pp. 1-20, deseription, habits, depredations, control.

Hylesinus micans (Kug.) Ratzeburg, 1839, p. 217, Taf. VII, fig. 3, adult.

Hylesinus (Dendroctonus) micans (Kug.) Ratzeburg, 1839, p. 217, Taf. VII, fig. 3, adult; Taf. VIII, figs. 1, 2, 3, galleries, young larvæ, pupæ.

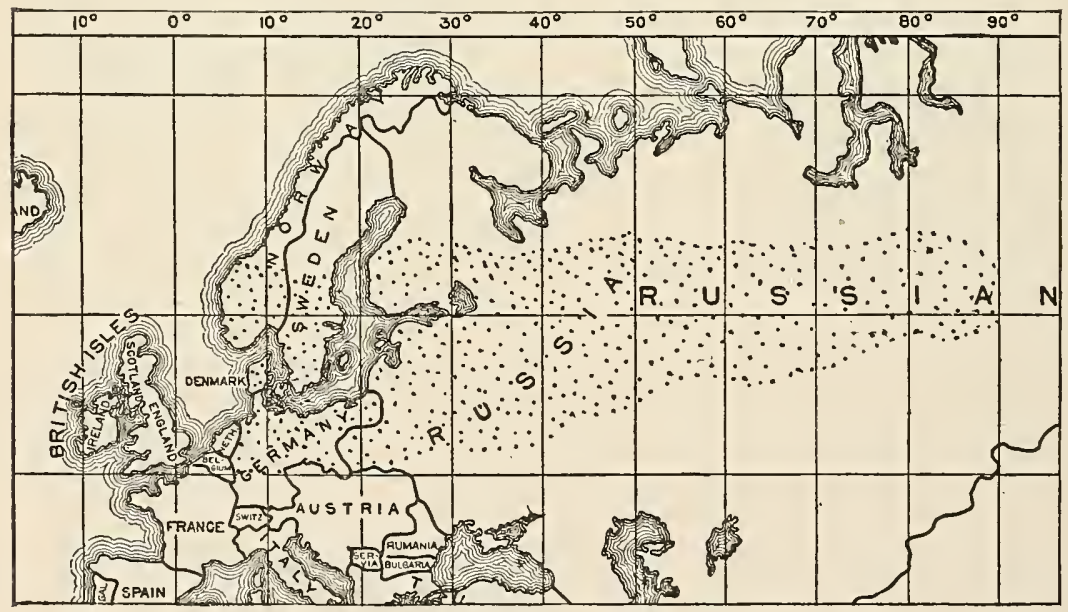

FIG. 89.-Dendroctonus micans: Distribution map. (Original.)

Subdivision D.

The distinguishing characters common to the species of the fourth subdivision are:

Adult.-Front without median or posterior impression. Pronotum somewhat elongate, slightly narrower than elytra, moderately constricted toward head, with regular punctures or without coarse and fine punctures intermixed, long hairs absent on median and posterior dorsal areas, present on anterior and lateral areas; head 
broad, convex; epistomal process and elytral rugosities variable within the same species.

Sexes.-Females with front of head moderately broad; mandibles shining, moderately stout; antennal club broad and stout; elytral declivity slightly more rugose; striæ impressed with distinct punctures.

Males with front of head distinctly broader; mandibles opaque, stout; antennal club narrow, more elongate, and the elytral declivity slightly less rugose; striæ less distinctly impressed, and the punctures more obscure.

Pupa.-Vertex of head convex; front and middle femur each with a minute subapical spine; abdominal tergites with moderately distinct spines.

Larva.-Abdominal tergites 8 and 9 with distinct dorsal plates, each armed with three prominent teeth.

Galleries.--Egg galleries slightly winding to nearly straight; larval mines not separated, except very rarely near the outer extremity, but forming broad common larval chambers.

\section{Dendroctonus terebrans (Olivier).}

(PI. VII, fig. 22.)

Adult.-Typical female: Length $5.6 \mathrm{~mm}$., black. Front convex, without impressions; epistomal process moderately broad, lateral angles tuberculate. Pronotal punctures very coarse, regular, moderately dense, scarcely decreasing in size toward base; elytra without long hairs toward base.

Typical female labeled, name label, "Hopk. 1/22/08, Pinus echinata, Hopkins, collector, Tryon, N.C., \&, Hopk. U. S. 530aa."

Typical male: Length $5.6 \mathrm{~mm}$. Differs from female in stouter mandibles and slightly coarser rugosities of elytral declivity.

Typical male labeled same as female.

Variations.--The length varies from 5 to $8 \mathrm{~mm}$., with the average about $7 \mathrm{~mm}$. The color ranges from piceous to deep black, the latter prevailing. Immature specimens are reddish, but fully matured. ones are always darker than the darkest $D$. valens. The greatest variation is in size, and while the usual variation prevails in some of the other characters, it is much less so than in D. valens. In New Jersey, Pennsylvania, Virginia, and West Virginia, where there is an overlapping of the range of $D$. valens and $D$. terebrans, specimens are sometimes found which appear to be hybrids, but it appears that the more dominant characters of $D$. terebrans prevail in such hybrids, so that the darker color and coarse punctures of the pronotum serve to distinguish them as being more closely allied to the latter species.

Distinctive characters. - The characters which serve to distinguish this species from $D$. valens, to which it is more closely allied, are its 
prevailing black or dark color, the more uniform and coarser punctures of the pronotum, the narrower epistomal process, with the angles more tuberculate, and the less evident long hairs on the anterior dorsal area of the elytra.

Revisional notes. - While the type of this species has not been seen by the writer, it is clearly evident from Olivier's description and figures (Olivier, 1795) that the large black form common to the southern United States represents the species described. The only distinctive specific character mentioned, however, is the reference to the Black Scolytus and to the body being black, brown, or brownishblack. The confounding of Dendroctonus valens and D.terebrans under the latter name has resulted in much confusion in the literature. With our present knowledge, however, it is not difficult to clear up some of the confusion and to revise and correct the literature so that it may be known in many cases whether or not one or both species was included in a given reference. Erichson, 1836, Lacordaire, 1866, and Chapuis, 1869 , evidently did not compare D. valens and D. terebrans. While a specimen of this species has been in the Harris collection since 1839, Harris apparently made no reference to its characters. Zimmerman, 1868, page 149, did not mention $D$. valens, but evidently had the two species confused in his revised description. Le Conte, 1868, page 173 , referred $D$. valens to $D$. terebrans, and in 1876 , pages 384-385, confuses the characters and distribution of the two species. Dietz, 1890 , page 29, included this species under his variety $a$, and (p. 30) evidently includes two specimens from Florida under his revision of D. mufipennis. In subsequent literature up to 1906 there is more or less confusion of this species with $D$. valens. The writer, $1906 \mathrm{c}$, page 81 , restored $D$. valens Lec. and called attention to the characters distinguishing $D$.terebrans (Oliv.). In 1900 the writer found one specimen in the Harris collection, under Hylurgus terebrans, under his No. 99, referred to in his note as "Dark specimen abundant under bark of pitch pine, October 27, 1839," but it appears that no reference was made to this dark specimen in any of his publications. The locality is not given, but it is presumably Cambridge. It appears that this species was not represented in the Horn collection under D.terebrans when Doctor Dietz prepared his revision, and that the only example involved in the revision under D. terebrans was the one in the Ulke collection from Pennsylvania, designated as "variety $a$." Two examples were found in the Horn collection under D. rufipennis, labeled "Fla.," and it was evidently on these that Doctor Dietz based his Florida locality in his revision of D. rufipennis. In 1907 this species was represented in the Le Conte collection by 9 specimens and 8 additional specimens in the general collection of the Museum of Comparative Zoology. 
Pupa.-In addition to the generic, divisional, and subdivisional characters, the front and middle femora are armed each with a minute apical spine; abdominal tergites 1 to 6 have moderately small pleural spines, 1 is without dorsal spine, but with distinct lateral ones; 2 to 6 have small dorsal and lateral spines, the former increasing in size to 6 . All have pale tips; 7 and 8 unarmed; 9 with usual stout pleural spine. Pupal type labeled "Hopk. W. Va. 7701."

The usual variation prevails in the number and arrangement of minor spines and between the young and older examples.

The character which in general serves to distinguish the pupa of this species from the preceding is found in the paler tips of the body spines.

Laria.-In addition to the generic, divisional, and subdivisional characters, front of head with posterior angle and median area not elevated but transversely rugose except near apex, where it is smooth; epistoma flat, opaque, smooth, with straight anterior margin; clypeus broad, prominent, convex, with faint median longitudinal line, sides rounded, apex broally emarginate; labrum short, with sides nearly parallel and apex tuberculate. Prothoracic tergum with two broad, shining dorsal plates separated by a rather broad median space, and a smaller lateral plate each side; sternellar lobes each with a faint foot callus; mesoterga and metaterga with shining plates on the lateral lobes. Abdominal scutellar lobes with a rather prominent tubercle on each epipleurum. Larval type labeled "Hopk. U. S. 1201."

The larva of this species is scarcely to be distinguished from that of D. valens.

Galleries.-The egg galleries are generally longitudinal, more or less winding, and vary greatly in length, sometimes being very long. They are irregular in width, sometimes with branches, and are slightly grooved in the surface of the wood. The eggs are placed in masses at intervals along the sides and in the inner bark; the larvæ excavate broad chambers which vary in size from a square inch to many square feet. The galleries of this species do not differ materially from the following, and have a wide range of variation in size and general character.

Distribution (fig. 90).-(Hopk. U. S.) Alabama: Calhoun. Delaware. District of Columbia: Takoma. Georgia: Cornelia, Thomasville. New Jersey: Lakewood, New Brunswick. New York: Islip (Long Island). South Carolina: Chicora, Lumber, New Landing, Pregnall. Texas: Austin, Call, Deweyville, Kirbyville, Tarkington. Virginia: Glen. West Virginia: Kanawha Station. (Hopk. W. Va.) West Virginia: Crow, Marion County, Morgantown, Romney. Additional localities from other collections: (Le Conte) Georgia, North Carolina, New Hampshire, Pennsylvania. (M. C. Z.) Texas, South 
Carolina, Maryland. (A. E. S.) New Jersey, Delaware. (A. N. S.) Marion County, Fla. (U.S.N.M.) Lakewood, N. J. (D. A.) Islip, Long Island, N. Y. (Laurent) Pennsylvania.

Host trees.-Pinus palustris, $P$. rigida, $P$. tæda, $P$. serotina, $P$. strobus, $P$. echinata, Picea rubens.

Identified specimens.-Le Conte, 9 specimens; M. C. Z., 8; Horn, 7; U.S.N.M., 2; H. \& S., 4; D. A., 7; Hopk. U. S., about 400 specimens, including adults, larvæ, and work.

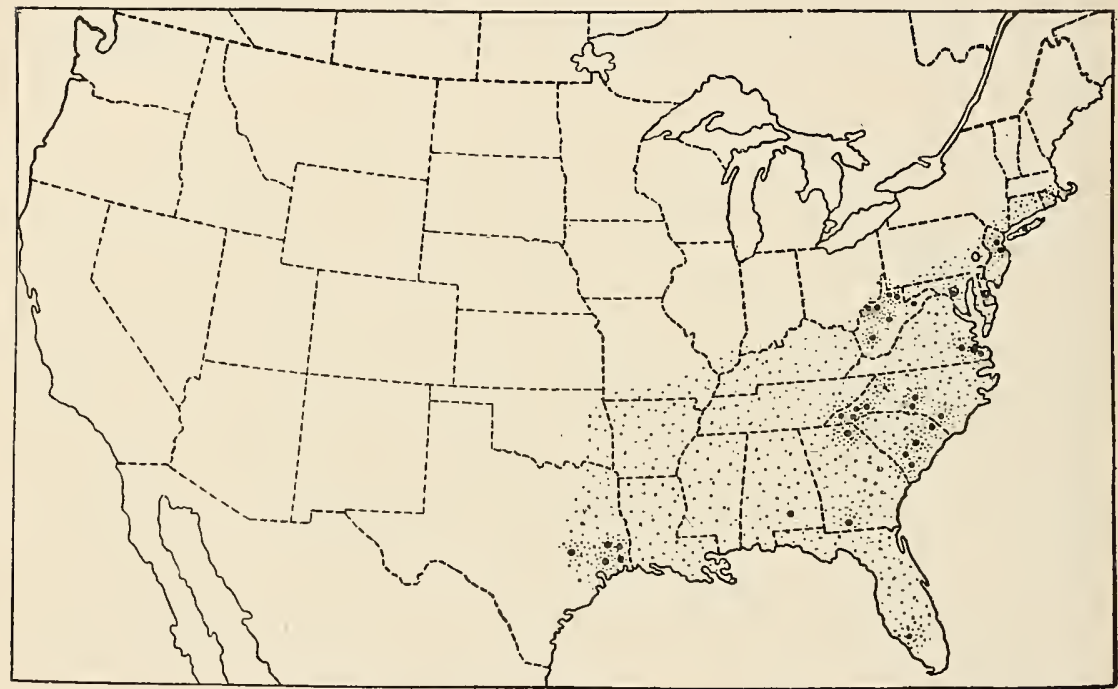

FIG. 90.-Dendroctonus terebrans: Distribution map. (Original.)

\section{Bibliography and Synonymy.}

Scolytus terebrans Olivier, 1795 , p. 6, Pl. I, fig. 6, adult; original description, locality southern U. S. (Southern Georgia, Schwarz).

Dendroctonus terebrans (Oliv.) Erichson, 1836, p. 53 (cotype of genus). Lacordaire, 1866 , p. 360. Zimmerman, 1868, p. 149 (in part), South Atlantic States. Le Conte, 1868, p. 173 (in part). Chapuis, 1869, pp. 35-36. Chapuis, 1873, pp. 243-244, revision, Texas. Schwarz, 1878, p. 469, list, Florida. Packard, 1887, p. 177 (in part), Le Conte quoted. Packard, 1890, p. 721 (in part). Dietz, 1890 , p. 29 (in part). Hopkins, 1893b, p. 143, No. 76 (in part), Hampshire and Monongalia counties, W. Va. Hopkins, 1893c, p. 213, No. 300 (in part), list, host, etc. Smith, 1899, p. 364 (in part), distribution, habits. Chittenden, 1899 , p. 56 (in part). Smith, 1901, p. 92, destructive to pine, Lahaway [Bordentown], N. J. Ulke, 1902, pp. 36-56, list, habits, etc. Hopkins, 1902b, p. 10, footnote, mention. Hopkins, 1906c, p. S1, distinguishing characters. Felt, 1906, pp. 342-345, Long Island.

Dendroctonus terebrans (Lacordaire) Le Conte, 1876, p. 385 (= Oliv. in part), bibliography, distribution, systematic note, on specimens from Georgia.

Dendroctonus rufipennis (not of Kirby) Dietz, 1890, p. 30, Florida.

?Dendroctonus sp. Blandford, 1897, p. 147, reference to black form from Texas. 
23. Dendroctonus valens Le Conte.

(Pl. VII, fig. 23.)

Adult.-Typical female: Length, $8.7 \mathrm{~mm}$. Head with front broad, convex, and with broad anterior impression. Epistomal process broad, with lateral sections oblique. Pronotum with punctures moderately coarse, much smaller and denser toward base. Elytra with a few long hairs toward base; declivity convex; striæ impressed, with small distinct punctures; interspaces moderately convex, distinctly rugose.

Typical specimen labeled, name label, "Hopk. 1/22/08, Pinus ponderosa, Hopkins, collector, McCloud, Cal., \&, Hopk. U. S. 18a."

Typical male: Length $7.6 \mathrm{~mm}$. Differs from female in stouter mandibles, narrower antennal club, more opaque declivity, less distinctly impressed striæ, and more obscure punctures.

Typical male labeled same as female.

Variations.- The length ranges from 5.7 to $9 \mathrm{~mm}$., with the average about $8 \mathrm{~mm}$. The color of the elytra, pronotum, and vertex of head ranges from light to dark red, but is never black, while the ventral part of the body varies from light red to black. The greatest variation is in size, but there is a wide and remarkable range in the epistoma and front and in the sculpture of the pronotum and elytra, as in almost every other character. Thus a large number of individuals may be easily selected, each of which might be considered as representing a good species, but when a large series of specimens is examined from any given faunal region or locality no sufficiently distinctive and constant characters have been found by which they can be readily recognized as distinct from those of any other faunal region, so that those examples from Maine can not be distinguished from examples collected in the mountains of Mexico.

Distinctive characters.-The characters which serve to distinguish this species from $D$. terebrans, to which it is closely allied, are its prevailing red color, the less uniform and more densely placed pronotal punctures, the much broader epistomal process, with the lateral sections less angular and more oblique, and the more evident and numerous hairs on the anterior dorsal area of the elytra.

Revisional notes.--See same heading under D. terebrans.

The typical specimen on which Le Conte's original description (Le Conte, 1860) was based is from California and represents the common red form which has heretofore been confused with $D$. terebrans. The distinguishing character, "finer and denser punctures of the thorax," mentioned by Le Conte is undoubtedly a good specific character when taken with color and other characters. The species is represented in the Le Conte collection by the type and 9 speci- 
mens, and in the collection of the Museum of Comparative Zoology by over 50 specimens.

Pupa.-In addition to the generic, divisional, and subdivisional characters, the front and middle femora are armed each with a minute apical spine; abdominal tergites 1 to 6 with moderately small pleural spines; 1 is without dorsal spines, but with distinct lateral ones; 2 to 6 have small dorsal and lateral spines, the former increasing in size to 6 , and all have dark tips; 7 and 8 are unarmed; 9 has the usual stout pleural spine. Pupal type labeled "Hopk. U. S. 2824.'

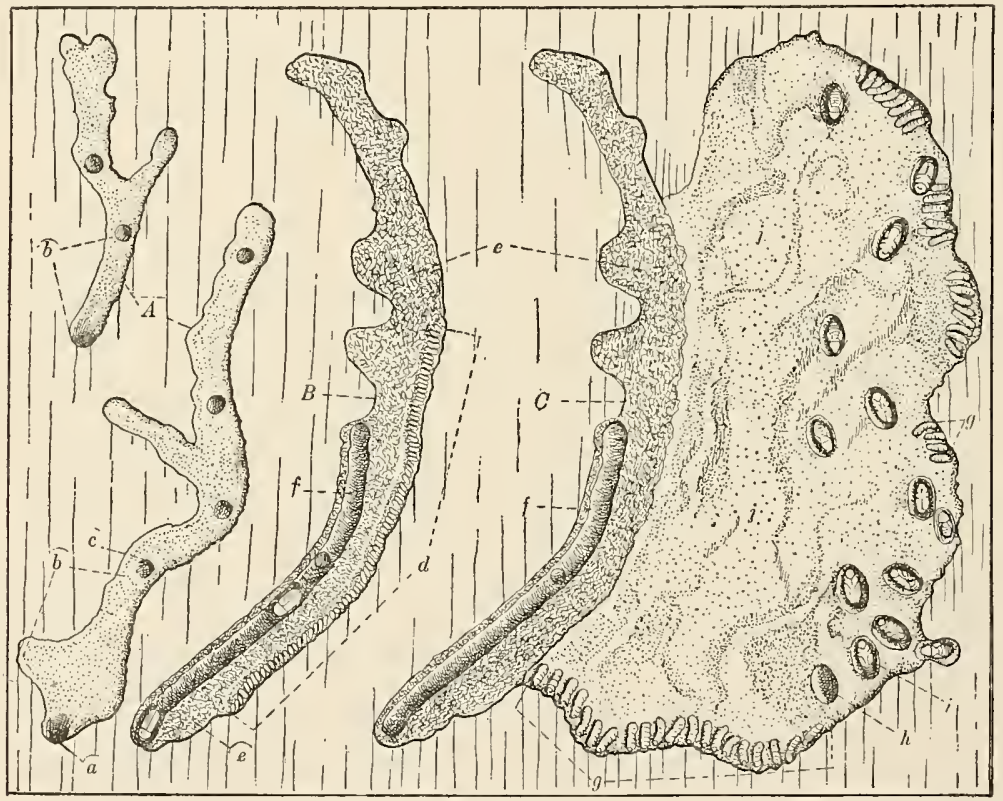

FIG. 91.-Dendroctonus valens: Egg galleries and larval chamber. $A$, Incomplete egg galleries with boring dust removed; $B$, normal gallery; $C$, advanced stage of work; $a$, entrance burrow; $b$, basal section; $c$, ventilating burrow; $d$, egg nest with eggs; $e$, boring dust; $f$, subsequent or inner galleries; $g$, larvæ at work; $h$, pupal cell in boring dust mixed with resin. (Original.)

The usual variation prevails in the number and arrangement of minor spines and between the young and older examples.

The character which in general serves to clistinguish the pupa of this species from the preceding is found in the darker tips to the bocly spines.

Larva (text fig. 39 and Pl. VIII, fig. 23).- In addition to the generic, divisional, and subdivisional characters, front of head with posterior angle, median area not elevated but transversely rugose, except near apex, where it is smooth; epistoma flat, opaque, smooth, with straight anterior margin; clypeus broad, prominent, convex, with faint median longitudinal line, sides rounded, apex broadly emarginate; 
labrum short, sides nearly parallel, and apex tuberculate. Prothoracic tergum with two broad, shining dorsal plates separated by a rather broad median space, and a smaller lateral plate each side; sternellar lobes each with a faint foot callus; the mesoterga and metaterga with shining plates on the lateral lobes. Abdomen with a rather prominent tubercle on each epipleurum. Larval type labeled "Hopk. U. S. 2824."

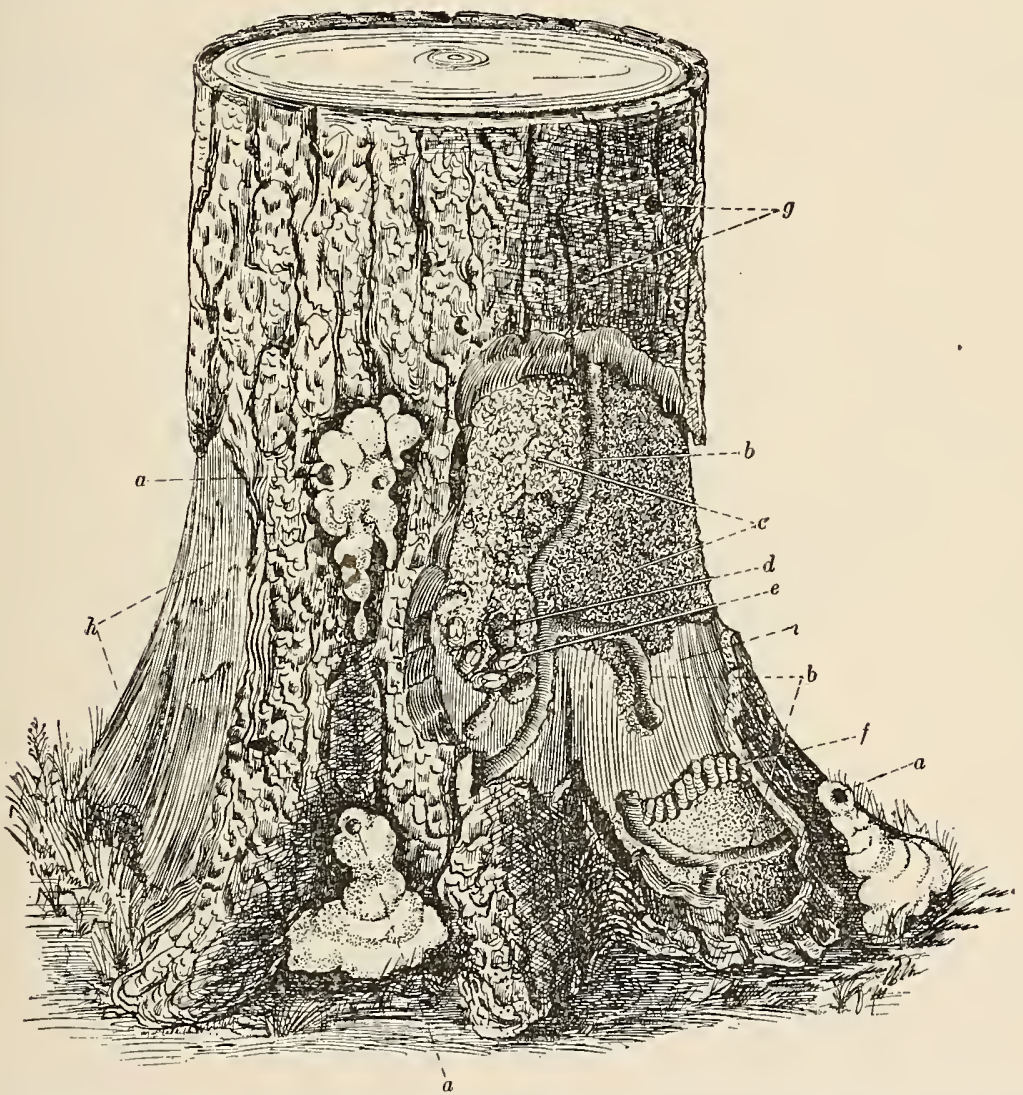

FIG. 92.-Dendroctonus valens: Work in bark at base of stump. $\quad a$, Entrance and pitch tube; $b$, egg gallery; $c$, boring dust and resin; $d$, pupal cell; $e$, pupa; $f$, larvæ at work feeding on inner living bark; $g$, exit burrows; $h$, resulting old scar or basal wound, often referred to as basal fire wound; $i$, inner bark with outer corky bark removed. (Original.)

The larva of this species is scarcely to be distinguished from the preceding.

Galleries (figs. 91-93).- The egg galleries are generally longitudinal, more or less winding, and vary greatly in length, sometimes being very long; they are irregular in width and sometimes with branches, and are slightly grooved into the surface of the wood. The eggs are placed in masses at intervals along the sides in the inner bark, and the larvæ excavate broad chambers, which vary in size from a 
square inch to many square feet. The galleries of this species do not differ materially from the preceding, and have a wide range of variation in size and general character.

Distribution (fig. 94).-(Hopk. U. S.) Arizona: Chiricahua Mountains, Flagstaff, Fredonia, Grand Canyon, Paradise, Ramsey Canyon, Rincon Mountains, Santa Catalina National Forest, Williams. California: AlderCreek, Berkeley, Chester, Del Monte, La Moine, Little Yosemite, Madera County, Merced, McCloud, Nevada City, Pacific Grove, Palo Alto, Pinogrande, San Bernardino, Sterling, Summerdale, Wawona, Yosemite. Canada. Colorado: Fort Garland, Manitou Park, Palmer Lake, San Isabel National Forest. Guatemala: Cabon.

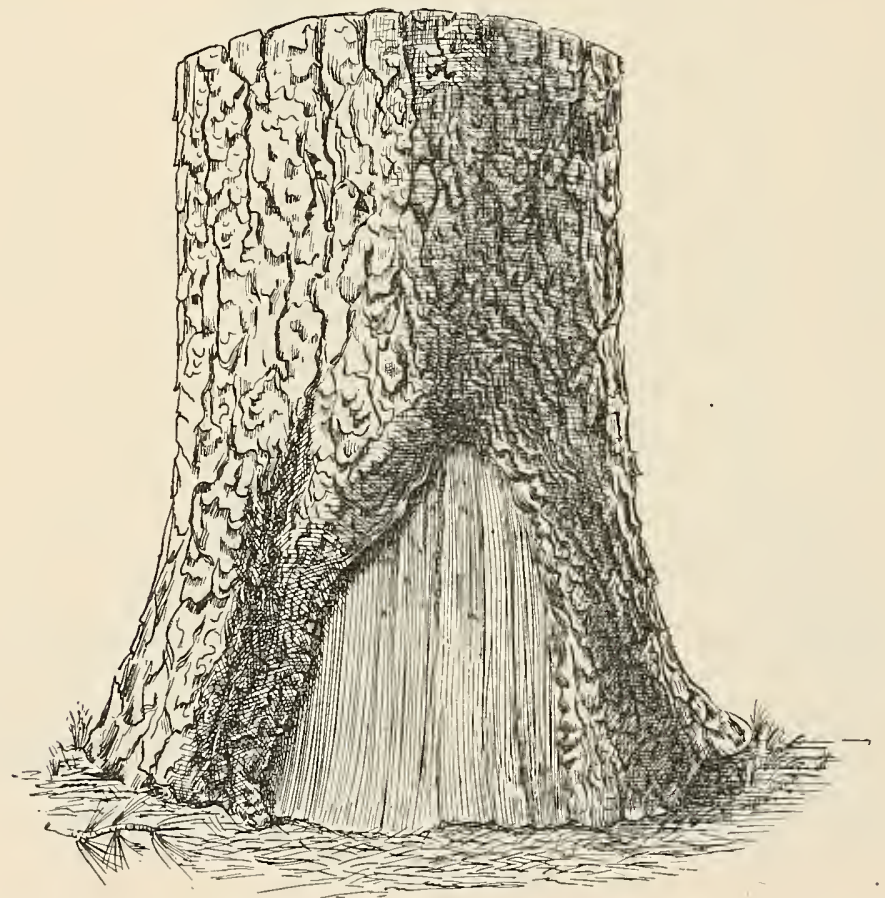

FIG. 93.-Dendroctonus valens: Basal wound in living tree resulting from primary injury by this species. Often mistaken for fire wound. (Original.)

Idaho: Cedar Mountain, Centerville, Grimes Pass, Harris Ridge (Kooskai), Pioneerville, Priest River, Smiths Ferry. Kansas. Maine: Brunswick, Casco Bay, Limerick, Peak Island, Portland. Massachusetts: Lynn, Wyoming. Mexico: Chalco, Chihuahua, Mexico City, Michoacan, Ponada, Satazin. Michigan: Grand Island. Montana: Missoula. Nevada. New Ilampshire: Durham, Webster. New Mexico: Capitan, Capitan Mountains, Clouderoft, Lincoln National Forest, Vermejo, White Mountains. New York: Ithaca. Norli Carolina: Biltmore, Pink Beds. Oregon: Albany, Ifood River, Joseph, Slate Creek. Pennsylvania: Milford, Philadelphia. South 
Dakota: Black Hills, Elmore, Lead, Spearfish. Otah: Escalante, Kamas, Kanab, Panguitch Lake. Vermont: Fairlee. Virginia. Washington: Buckeye, Easton, Pullman, Skykomish. West Virginia: Crow, Hampshire County, Hardy County, Kanawha Station,

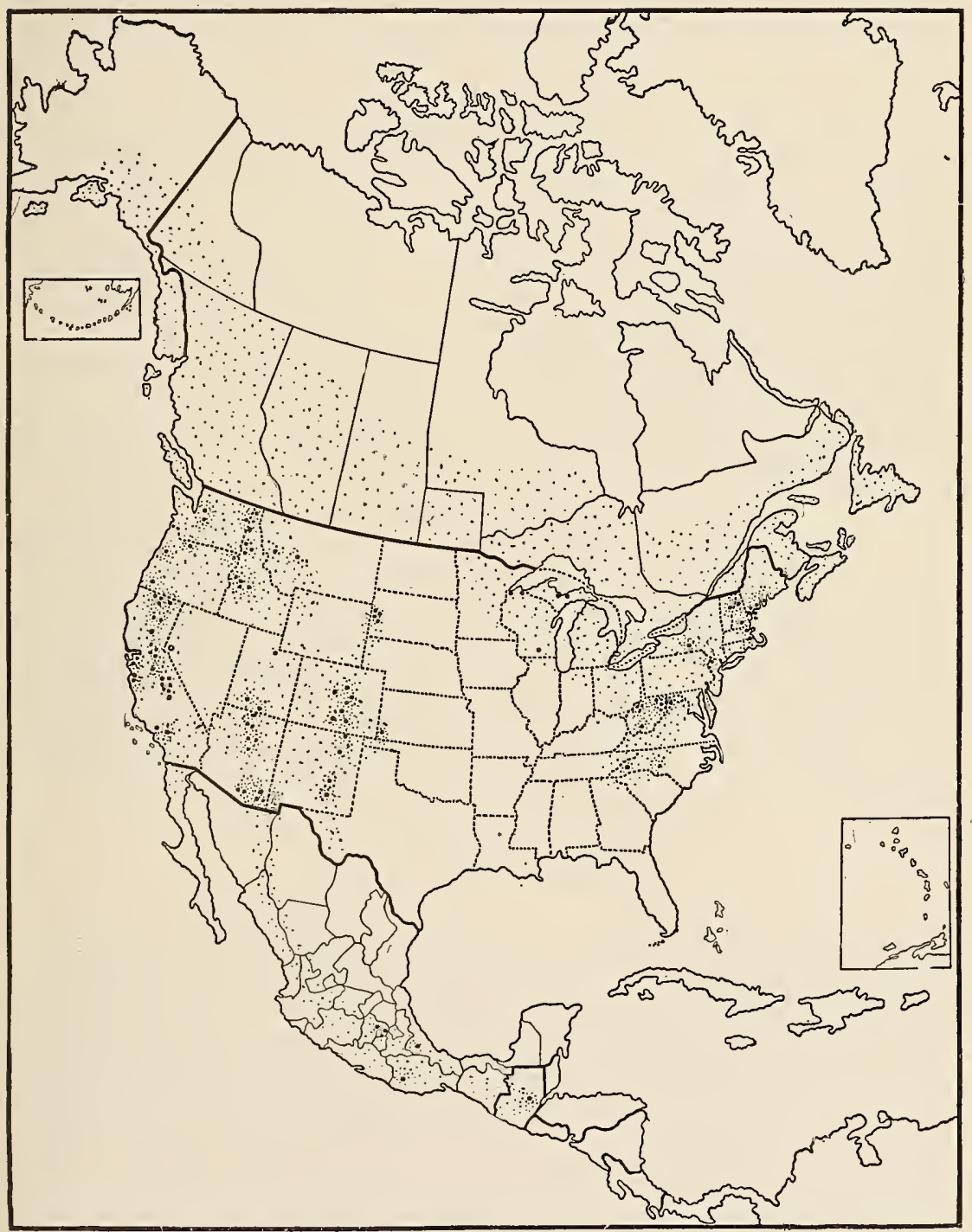

FIG. 94.-Dendroctonus valens: Distribution map. (Original.)

Nonongalia County, Morgantown, Pendleton, Raleigh County, Romney, Roosevelt, Tucker. Wisconsin: Ashland, Madison. (Hopk. W. Va.) West Virginia: Bretz, Cranesville, Deckers Creek, Dellslow, Mayfield Hill, Moorefield, Morgantown, Pendleton, Randolph, 
Romney. Additional localities from other collections: (M. C. Z.) New Mexico; California; Pennsylvania; Idaho; Maine; Massachusetts; Cambridge, Mass. (Le Conte) Middle States; Connecticut; Garland, Colo.; California. (Horn) North Carolina, Oregon, Wisconsin, Maine, California, New Mexico, and Pennsylvania. (A. E. S.) Kansas, Idaho, Nevada, Colorado, Canada, Virginia, Illinois, New Jersey. (W. \& F.) Durham, N. H. (U.S.N.M., H. \& S.) Marquette, Mich.; Cambridge, Mass.; Helena, Mont.; Garland, Colo.; Coeur d'Alene, Idaho; Hood River, Oregon; Chiricahua Mountains, Arizona; Sisson, Cal.; Coldridge, N. Mex. (U.S.N.M., B. \& S.) Las Vegas, N. Mex.; Bright Angel, Prescott, Flagstaff, and Williams, Ariz. (Gillette) Colorado; Bailey, Colo. (U.S.N.M.) Easton, Wash.; Placer, Colo.; Shasta County, Cal.; Powder River, Colorado; Lake Superior; Skokomish River, Washington; New Mexico; Siskiyou County, Cal.; Ozumba Mountain, Mexico. (Weed \& Fiske) Durham, N. H. (Webb) Pullman, Wash. (Dietz) Pennsylvania, California, Arizona, Washington [State]. (D. A.) Dunsmuir, Cal.; Custer County, Cal. (Chittenden) Duluth, Minn.; Ithaca, N. Y.; Grangeville, Idaho; California. (Baldwin) Ventura County, Cal. (Soltau) Colorado.

Host trees.-Pinus ponderosa, $P$. strobus, $P$. radiata, $P$. rigida, $P$. lambertiana, $P$. murrayana, $P$. strobiformis, $P$. chihuahuana, $P$. edulis, $P$. jeffreyi, P. sylvestris, $P$. virginiana, $P$. arizonica, $P$. sp.; Picea canadensis, P. excelsa, P. rubens; Abies concolor; Larix laricina.

Identified specimens.-Le Conte, 10 specimens; M. C. Z., 55; Horn, 14; A. E. S., 8; U.S.N.M., 12; H. \& S., 20; Dietz, 5; D. A., 3 specimens. This species is also represented in the forest insect collection of this Bureau by about 5,000 specimens, including all stages and work.

\section{Bibliography AND Synonymy.}

Scolytus terebrans (not of Oliv.) Harris, 1826, pp. 169, 170, character and habits. Harris, 1862 , p. 86 , footnote, name only. Zimmerman, 1868, p. 149, as synonym for D. terebrans (in part).

Hylurgus terebrans (not of Oliv.) Harris, 1841, p. 72, brief description of larva? and habits. Harris, 1842 , pp. 72, 73, repeated. Harris, 1852, p. 76, repeated. Fitch, 1858, pp. 728-729, description of adult and larva, habits? Harris, 1862, p. 86, repeated, fig. 42 , adult. Harris, 1863 , pp. 84-86, fig. 42 , adult, account repeated. Thomas, 1876, p. 146, brief description of adult and habits of larva. Smith, 1877, p. 52 , work in pine.

Dendroctonus valens Le Conte, 1860, p. 59, original description. Le Conte, 1868, p. 173, mentioned as synonym of $D$. terebrans Lacordaire. Chapuis, 1869, p. 35; Chapuis, 1873, p. 243. Le Conte, 1878, p. 472, list, Atlanta, Idaho. Hopkins, 1903a, p.61, reference to habits, etc. Hopkins, 1904, p. 19, P1. VII, figs. $a, b, g$ (reprint). Powell, 1904, anatomy. Powell, 1905, ibid. Hopkins, 1905, pp. 6, 11, 17, distinctive characters. Hopkins, 1906b, p. 147, Pl. IV, figs. 6, 8, anatomy of larval head. Hopkins, 1906c, p. 81, mentioned as a good species, host, localities, etc. Fall, 1907, p. 218, list, localities. 
Dendroctonus terebrans (not of Oliv.) Zimmerman, 1868, p. 149 (in part), revision. Le Conte, 1868, p. 173 (in part), synopsis, bibliography. Le Baron, 1871 (in part), economic reference. Le Conte, 1876, p. 385 (in part), revision, synopsis, bibliography, locality. Packard, 1887, pp. 175, 243 (in part). Packard, 1890, p. 721, fig. 250 (in part), adult, quotes Harris and Le Conte. Dietz, 1890, p. 29 (in part), Eastern States, California, Washington, fig. 1, antenna and epistoma; var. $b$, Washington, California, Colorado, Arizona, and Idaho; var. $c$, New Mexico, Arizona, Nevada, California; var. $d$, Pennsylvania. Hopkins, 1892a, pp. 64-65 (in part), habits, etc. Hopkins, 1893b, p. 143, No. 76 (in part), and index, habits, distribution, host, enemies, etc., in West Virginia, all except part of two references from Hampshire and Monongalia counties. Hamilton, 1895, pp. 346, 378, list, etc. Wickham, 1896a, p. 169, listed, Lake Superior. Wickham, 1906b, p. 170, list, Coolidge, N.Mex.; Walnut and Williams, Ariz. Hopkins, 1897a, p. 41, habits, etc. Blandford, 1897, pp. 146-147, synopsis, redescribed, distribution in Mexico, bibliography. Wickham, 1898, p. 312, list, Arizona. Hopkins, 1899a, pp. 392-393, 415-421, and index (in greater part), different stages, galleries, etc., described and illustrated (except egg and pupa), with full account of habits, and distribution in West Virginia, etc. Hopkins, 1899b, pp. 14, 15, habits, hosts, etc. Hopkins, 1899c, p. 343 (in part), stridulation, etc. Chittenden, 1899, p. 56 (in part). Wickham, 1902, p. 309, list, locality. Felt, 1903, pp. 480-481, figs. 1-3 (in part), adult, larva, pupa, New York State except Long Island (in part?), habits, hosts, enemies, etc. Felt, 1906, pp. 342-345 and index, fig. 64, adult; 65, pupa; 66, larva (in part), habits, host, etc.

Dendroctonus terebrans (not of Lacordaire) Le Conte, 1868, p. 173.

Dendroctonus obesus (not of Mann.) Packard, 1877, p. 803, description and probable habits in Colorado, compared with $D$. terebrans (not of Oliv.).

?Dendroctonus rufipennis (not of Kirby) Packard, 1887, p. 176, in pitch pine.

?Dendroctonus simitis (not of Lec.).Slosson, 1902, p. 319, list, locality.

Dendroctonus valens Lec. var. occidentalis Hopkins, 1902b, p. 12, manuscript name for variety.

Dendroctonus (terebrans) var. valens (Lec.) Wickham, 1902, p. 309, Garland, Colo.

24. Dendroctonus adjunctus Blandford.

ORIGINAL DESCRIPTION.

"Long. 4.6-5.3 millim.

"Oblong, less elongate than $D$. parallelocollis, slightly depressed, piceous-black, with apex of elytra lighter. Median segment of epistoma shorter than the lateral segments, its sides very oblique and elevated, its apical border concave; front covered with close granules and punctures, with an interrupted median impressed line deepest at its junction with a slight transverse subocular impression; vertex finely punctured; antennæ piceous, the scape with rounded club, second joint of funiculus scarcely longer than first, club transverse oval, its sutures curved toward apex. Prothorax more transverse than in D. parallelocollis, constricted in front, the apical emargination and basal bisinuation distinet; surface impressed behind apex and somewhat flattened, shining, the punctures sparse and not strong, the median line obsolete. Elytra feebly striato-punctate, shining, except 
at the closely granulate base, with somewhat scattered granules, obsolete on the declivity, interstices with rows of distinct long dark hairs from middle to apex, the first with a single series of stronger granules. Legs piceous.

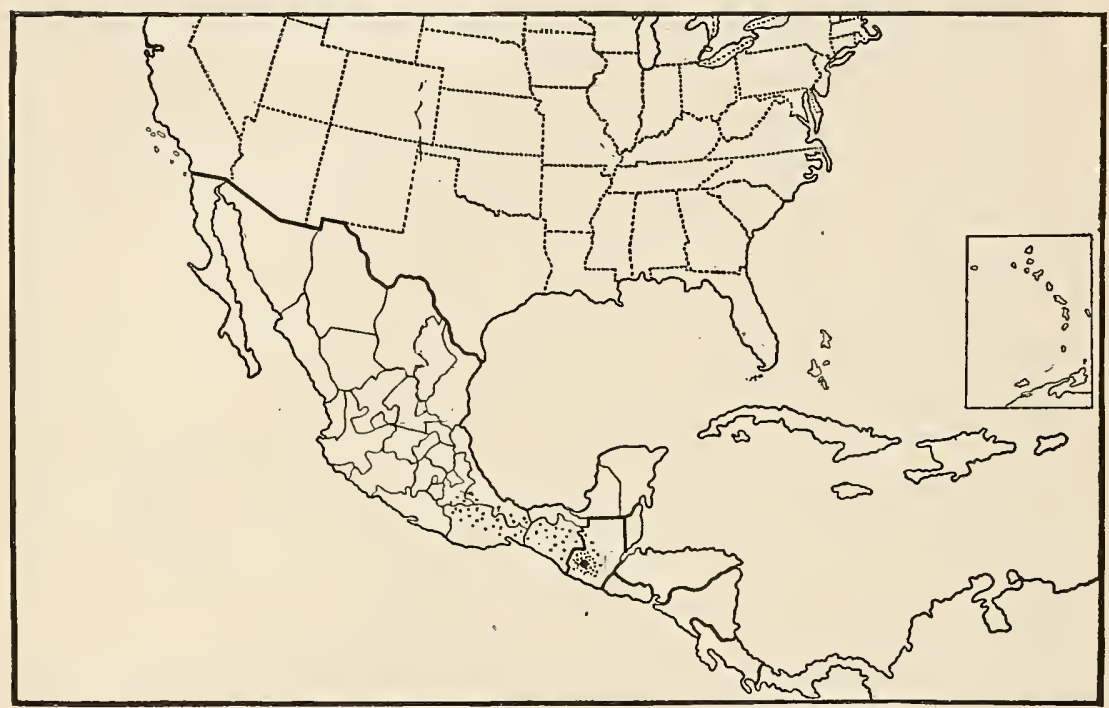

FIG. 95.-Dendroctonus adjunctus: Distribution map. (Original.)

"Hab. [See fig. 95.] Guatemala, Totonicapam (Champion).

"A distinct species, resembling a Myelophilus rather than a Dendroctonus. But two specimens were taken."

BiBLIOGRAPHY.

Dendroctonus adjunctus Blandford, 1897, p. 147. 


\section{BIBLIOGRAPHY.}

1793. Herbst, J. F. W.-Natursystem aller bekannten in- und ausländischen Insekten-Käfer, fünfter Theil, p. 107, Taf. 48, fig. 5 .

1794. Kugelann.-Schneid., Mag., 5, p. 523-12.

1795. Olivier, A. G.-Entomologie, ou histoire naturelle des insectes, Vol. IV, Genus 78 , p. 6 , No. 6, Pl. I, fig. $6, a, b$.

1813. Gyllenhal, L.-Insecta Suecica, Tom. I, Pars III, pp. 335-336.

1820. Chabrter, J.--Essai sur le vol des insectes.<Mém. du Mus. d'Hist. Nat., VI, pp. 410-472, pls. 18-21.

1824. Audouin, Victor.--Recherches anatomiques sur le thorax des animaux articulés, et celui des insectes hexapodes en particulier.<Ann. Sci. Nat., I, pp. 97-135, 416-432.

1826. Harris, T. W.-Trees.< New England Farmer, V, December 22, pp. 169-171.

1830. MacLeay, II. S.-Explanation of the comparative anatomy of the thorax of winged insects, with a review of the present state of the nomenclature of its parts.<Zool. Journal, V, pp. 145-179, Pls. V, VI.

1836. Erichson, IV. F.-Systematische Auseinandersetzung der Familie der Borkenkäfer (Bostrichidæ).<Archiv für Naturgeschichte v. A. F. Wiegmann, zweiter Jahrgang, erster Band, pp. 45-65.

1837. Kirsy, Wм.-Fauna Boreali Americana; or the zoology of the northern parts of British America. Part IV, Insecta, p. 195.

1839. Ratzeburg, J. T. C.-Die Forst-Insekten, Vol. I, p. 217.

1839. Newport, George.--Insecta. Cyclopædia of anatomy and physiology (R. B. Todd), II, pp. 853-994, figs. 329-439.

1841. HARRIs, T. W.-A report on the insects of Massachusetts injurious to vegetation, p. 72 .

1842. Harris, T. T.-A treatise on some of the insects of New England which are injurious to vegetation, pp. 72-73.

1843. Mannerheim, G. G.-Beitrag zur Kaefer-Fauna der Aleutischen Inseln, Insel Sitka und Neu-Californiens.<Bull. Soc. Imp. Nat. Mosc., Tom. XVI, II, pp. 175-314. Moscou.

I849. ВАсH, M.-Käfer, II, p. 144.

1852. Stein, Friedrich.-Beiträge zur Insektenkunde.<Tharand Jahrbuch, T. 8, p. 235.

1852. Mannerheim, G. G.-Zweiter Nachtrag zur Kaefer-Fauna der nordamerikanischen Laender des Russischen Reiches.<Bull. Soc. Imp. Nat. Mosc., Tom. XXV, II, pp. 283-387. Moscou.

1852. Harris, T. W.-A treatise on some of the insects of New England which are injurious to vegetation, p. 76 .

1853. Mannerheim, G. G.-Dritter Nachtrag zur Kaefer-Fauna der nordamerikanischen Laender des Russischen Reiches. <Bull. Soc. Imp. Nat. Mosc., Tom. XXVI, II, pp. 95-273. Moscou.

1854. Stein, F.-Jahrbuch der Akademie für Forst- und Landwirthe zu Tharand, III, pp. 277-279.

1858. Kollar, Vincenz.-Beiträge zur Naturgeschichte des grossen Fichten Bastkäfers, Hylesinus (Dendroctonus) micans Kug., aus den Beobachtungen des Herrn Conr. Leinweber, k. k. Hofgärtner, zusammengestellt von Vincenz Kollar, pp. 23-28. 
1858. Fitch, Asa.-Fourth report on the noxious, beneficial and other insects of the State of New York.<Trans. N. Y. St. Agr. Soc., XVIII, pp. 728-729.

1860. Le Conte, J. L.-Peports of explorations and surveys * * * from the Mississippi River to the Pacific Ocean, p. 59 .

1862. Harris, T. W.-A treatise on some of the insects injurious to vegetation, p. 86.

1862. DöBNER.-Einige Bemerkungen über schädliche Forstinsekten.<Allgemeine Forst- und Jagd-Zeitung, neue Folge, 38 Jahrgang, pp. 275-277.

1863. Harris, T. W.-A treatise on some of the insects injurious to vegetation, Flint edition, pp. 84-86.

1864. Еichноғ, W. J.-Über die Mundtheile und die Fïhlerbildung der europäischen Xylophagi sens. strict.<Berliner entomologische Zeitschrift, pp. $17-46$.

1866. Lacordaire, T.-Genera des Coléoptères, VII, p. 360.

1868. Еiснноғ, W. J.-Berliner entomologische Zeitschrift, Heft I und II (pp. i-viii, 1-176, 313-368. Published May, 1868). Heft III und IV (pp. ix-xiv, 177-312, 369-432. Published March, 1869). Note especially p. xi, footnote. Reference to scolytids, pp. 145-152, 273-282.

1868. Le Conte, J. L.-Synopsis of the Scolytidæ of America north of Mexico. Appendix.<Trans. Amer. Ent. Soc., XV, pp. 150-17S.

1868. Zimmerman, C.-Synopsis of the Scolytidæ of America north of Mexico. <Trans. Amer. Ent. Soc., XV, pp. 141-150, September.

1869. Chapuis, F.-Synopsis des Scolytides.<Mém. Soc. Sci. Liège, author's extra issued 1869, pp. 1-61. (See also Chapruis, 1873.)

1871. LE BARON, W.- Means against larvæ in timber; answers to correspondents. $<$ Prairie Farmer, vol. 42.

1873. Chapuis, F.-Synopsis des Scolytides.<Mém. Soc. Sci. Liège, III, pp. 213-269.

1875. Lindemann, C.-Vergleichend-anatomische Untersuchung über das männliche Begattungsglied der Borkenkäfer.<Bull. Snc. Imp. Nat. Moscou (Bull. Mose.), XLIX, pp. 196-252, Pls. I-V.

1876. Le Conte, J. L.-The Rhynchophora of America north of Mexico. $<$ Proc. Amer. Phil. Soc., pp. 384-386, December, 1876.

1876. PeCk, C. H.-The black spruce.<Trans. Albany Inst., VIII, pp. 283-301.

1876. Thомаs, Cyrus. - Sixth report of the State Entomologist on the noxious and beneficial insects of the State of Illinois, p. 146.

1877. Sмiтн, E. A.- Shade trees, indigenous shrubs and vines, by J. T. Stewart, M. D., and insects that infest them, by Miss Emma A. Smith. Peoria, Ill., 1877, p. 52.

1877. Packard, A. S.-Report on the Rocky Mountain locust and other insects now injuring or likely to injure field and garden crops in the Western States and Territories.<9th Ann. Rep. U. S. Geol. and Geog. Surv. Terr., pp. 589-810.

1878. Schwarz, E. A.-The Coleoptera of Florida.<Proc. Amer. Phil. Soc., XVII, p. 469.

1878. Le Conte, J. L.-The Coleoptera of the Alpine Rocky Mountain Regions, Part I.<Bul. U. S. Geol. and Geog. Surv., IV, pp. 469, 472, November 30.

1879. Етснноғ, W.-Ratio, descriptio emendatio eorum Tomicinorum. Extrait des Mémoires de la Société Royale des Sciences de Liège, $2^{e}$ série, VIII.

1879. Peck, C. H.-Report of the Botanist.<28th Ann. Rep. N. Y. State Mus. Nat. Hist., pp. 32-38.

1881. Altum, B.-Forstzoologie. III. Insekten, I. Abtheil., pp. 262-266.

1881. Еıснноғғ, W. J.-Die europäischen Borkenkäfer. Berlin, pp. 37, 125-128.

1882. Hough, F. B.-Report on Forestry, submitted to Congress by the Commissioner of Agriculture, Part VIII, Insect Ravages, pp. 259-274. 1. The injuries done to spruce and other coniferous timber by insects. 
1883. Le Conte and Horn.-Classification of the Coleoptera of North America, p. 523.

1884. Harrington, W. Hague.-Canadian Entomologist, XIV, p. 218.

1885. Lintwer, J. A.-Second report on the injurious and other insects of the State of New York, p. 54.

1885. Amans.-Comparaisons des organes du vol dans la série animale.<Ann. Sci: Nat., Ser. 6, Zool., XIX, pp. 9-222, Pls. I-VIII.

1887. Fletcher, J.-The spruce barkbeetle (D. mufipennis). Appendix to the report of the Minister of Agriculture. Report of the Entomologist and Botanist, pp. 39,40 .

1887. Packard, A. S.-Insects injurious to forest and shade trees. $<$ Bul. 7, U. S. Ent. Comm., pp. 175, 176, 177, 243.

1888. Schwarz, E. A.-Proc. Ent. Soc. Wash., I, p. 175, November 1.

1889. Judeich, J. T., und Nitsche, H.-Lehrbuch der mitteleuropäischen Forstinsektenkunde, pp. $458-462$.

1889. Kolbe, H. J.-Einführung in die Kenntnis der Insekten.

1890. Packard, Alpheus S.-Insects injurious to forest and shade trees. Revision and enlarged edition of Bul. 7.<5th Rep. U. S. Ent. Comm., U.S. Dept. Agr., pp. 721,722 , etc.

1890. Harrington, IV. Hague.-On the lists of Coleoptera published by the Geological Survey of Canada, 1842-1888.<Can. Ent., XXII, No. 9, p. 189 (author's extra, p. 19).

1890. Dietz, W. G.-Notes on the species of Dendroctonus of Boreal America. < Trans. Amer. Ent. Soc., IVII, pp. 27-32.

1891. Harrington, W. Hague.-General notes.<Can. Ent., XXIII, No. 2, p. 27. Ibid., Science, XX, pp. 256-257, November 4, 1892.

1892. Paulr, A.- Über die Brutpflege und jahrliche Geschlechterzahl des Riesenbastkäfers, Hylesinus micans Ratz.<Forstlich-naturwissenschäftliche Zeitschrift, I. Jahrgang, pp. 315-327.

1892a. Hopkins, A. D.-Notes on a destructive forest tree scolytid. <Science, XX, pp. 64-65, July 29.

1892b. Hopkins, A. D.-Proc. Ent. Soc. Mash., II, p. 353, October 6.

1892. Schaufuss, C. F.-Barkbeetle destroyer. <Can. Ent., XXIV, No. 12, p. 316.

1893. Cockerell, T. D. A.-The entomology of the Mid-Alpine Zone of Custer County, Colorado.<Trans. Amer. Ent. Soc., XX, p. 336.

1893a. Hopkins, A. D.-Damage to forests by the destructive pine barkbeetle. <Insect Life, V, No. 3, pp. 187-189, January.

1893b. Hopkins, A. D.-Catalogue of West Virginia Scolytidæ and their enemies. <Bul. 31, W. Va. Agr. Exp. Sta., No. 76 [=p. 143], April.

1893c. Hopkins, A. D.-Catalogue of the West Virginia forest and shade tree insects. $<$ Bul. 32, W. Va. Agr. Exp. Sta., May.

1893d. Hopkins, A. D.-Destructive scolytids and their imported enemy. < Insect Life, VI, No. 2, pp. 123-129, December.

1894. Lintwe R, J. A.-Gardening, II, p. 292, May 15.

1894. Haunton, John.-Catalogue of the Coleoptera of Alaska, with the synonymy and distribution.<Trans. Amer. Ent. Soc., XXI, p. 35.

1894a. Hopkins, A. D.-Destructive scolytids and their imported enemy. $<24$ th Ann. Rep. Ent. Soc. Ontario, pp. 71-76.

1894b. Hopkins, A. D.-Sexual characters in Scolytidæ.<Can. Ent., XXVI, pp. 274 280.

1894c. Hopkins, A. D.- The relations of insects and birds to present forest conditions. $<$ Garden and Forest, VII, p. 348.

1895. Haymton, John.-Catalogue of the Coleoptera of southwestern Pennsylvania, with notes and descriptions.<Trans. Amer. Ent. Soc., XXII, pp. 346, 378, October.

$79980-09-12$ 
1896a. Wiскнам, H. F.-A list of the Coleoptera from the southern shore of Lake Superior.<Proc. Davenport Acad. Nat. Sci., II, p. 169.

1896b. Wickнам, H. F.-A list of some Coleoptera from the northern portion of New Mexico and Arizona.<Bul. Lab. Nat. Hist. State Univ. Iowa, Vol. III, No. 4, p. 170.

1896. Hopkins, A. D.- Some notes on insect enemies of trees.<Can. Ent., XXVIII, No. 10, pp. 246, 250, October.

1896. Verhoeff, Carl.- Über das Abdomen der Scolytiden.<Arch. f. Naturg., Jahrgang 62, I Bd., pp. 109-144, Pis. TiI, VIII.

1897. MÉnégaux, A., et Cochon, J.-Sur la biologie de I'Hylésine brillante.<C. R. Acad. Sc. Paris, Tome 124, No. 4, pp. 206-209. (Abstr. Journ. R. Micr. Soc. London, pt. 2, p. 120.)

1897a. Hoprins, A. D.-Report of Entomologist.<6th Ann. Rep. W. Va. Agr. Exp. Sta. for fiscal year ending June 30,1893 , pp. 29-42.

1897b. Hopkins, A. D.- Report of Entomologist.<7th Ann. Rep. W. Va. Agr. Exp. Sta, for fiscal year ending June 30, 1894.

1897c. Hopkins, A. D.-Report of the Entomological Department. $<9$ th Ann. Rep. W. Va. Agr. Exp. Sta. for fiscal year ending June 30, 1896, pp. 79, 94-95, 147, 151, Pl. I.

1897. Blandford, Walter F. H.-Fam. Scolytidæ.<Biol. Centr.-Amer., Coleopt., IV, pt. 6, August, 1897, pp. 146, 147.

1897. Сhittenden, F. H.-Insect injury to chestnut and pine trees in Virginia and neighboring States. Some Miscellaneous Results of the Work of the Division of Entomology.<Bul. 7, n. s., Div. Ent., U. S. Dept. Agr., pp. 67-75, fig. 43.

1898. Harvey, F. L.- Notes on insects of the year.<13th Ann. Rep. Maine Agr. Exp. Sta., Orono, Maine, 1897. Part II of the Annual Report of the University of Maine, p. 176. Note on depredations on spruce in Maine.

1898. Howard, L. O., and Chittenden, F. H.--Notes from correspondence. Some Miscellaneous Results of the Wrork of the Division of Entomology. $<$ Bul. 10, n. s., Div. Ent., U. S. Dept. Agr., p. 98.

1898a. Hopkins, A. D.-Proceedings of the Tenth Annual Meeting of the Association of Economic Entomologists.<Bul. 17, n. s., Div. Ent., U.S. Dept. Agr., p. 69.

1898b. Hopkins, A. D.-Insects detrimental and destructive to timber and timber products. < Proceedings of the Nineteenth Annual Meeting of the Society for the Promotion of Agricultural Science, held at Boston, Mass., 1898, pp. $104,105$.

1898. Schwarz, E. A.-Proc. Ent. Soc. Wash., IV, No. 2, pp. 81, 82, March 21.

1898. Weed, Clarence M., and Fiske, W. F.-Notes on spruce bark-beetles. Proceedings of the Tenth Annual Meeting of the Association of Economic Entomologists.<Bul. 17, n. s., Div. Ent., U. S. Dept. Agr., pp. 67-69.

1898. Chittendes, F. H.-Recent injury by bark-beetles. A correction. Some Miscellaneous Results of the Trork of the Division of Entomology, III.<Bul. 18, n. s., Div. Ent., U. S. Dept. Agr., p. 96.

1898. Wicknasi, H. F.-The beetles of southern Arizona.<Bul. Lab. Nat. Hist. State Univ. Iowa, Tol. IT, No. 3, p. 312.

1898. Johnson, Chas. W.-Report on insects injurious to spruce and other trees, Chap. T. $<3 d$ Ann. Rep. Pa. Dept. Agr., Part II, 1897, issued in 1898 after September, pp. 69-110.

1898. Lovendal, E. A.-De Danske barkbiller (Scolytidæe et Platypodidæ Danicæ), pp. $86-91$.

1899a. Hopkins, A. D.-Report on in restigations to determine the cause of unhealthy conditions of the spruce and pine from 18s0-1893. <Bul. 56, W. Va. Agr. Exp. Sta., April. 
1899b. Hopkins, A. D.-Preliminary report on the insect enemies of forests in the northwest. <Bul. 21, n. s., Div. Ent., U. S. Dept. Agr., pp. 10, 11, 13, 14, $15,20,21,22,26$.

1899c. Hopkins, A. D.-Notes on Dendroctonus.<Proc. Ent. Soc. Wash., IV, No. 3, p. 343 , May 24.

1599. Sмrт, J. B.-Insects of New Jersey. <Supplement to the 27th Annual Report of the State Board of Agriculture, p. 364.

1899. Chittenden, F. H.-Insect enemies of the white pine. The white pine (Pinus strobus Linnæus).<Bul. 22, Div. For., U. S. Dept. Agr., pp. 55, 56, figs. 5.

1900a. Schwarz, E. A.--Papers from the Harriman Alaska Expedition, XVIII. Entomological results (12); Coleoptera. < Proc. Wash. Acad. Sci., II, p. 537, December 20.

1900b. Schwarz, E. A.-Coleoptera of the expedition. < Ibid., Author's extra, p. 185.

1900. Carr, Austin.-Insect damage to spruce timber in Maine and New Hampshire.<The Forester, VI, No. 3, pp. 52-54.

1901. Surth, J. B.-Doings of societies.<Ent. News, XII, No. 3, p. 92, March.

1901. Johnson.-Doings of societies. Ent. News, XII, No. 3, p. 92, March.

1901a. Hopkins, A. D.-Insect enemies of the spruce in the northeast. <Bul. 28, n. s., Div. Ent., U. S. Dept. Agr., pp. 1-48, Pls. I-V, XIV, XV (issued October 1, 1901).

1901b. Hopkins, A. D.- Some insect enemies of living trees. $<$ Proceedings of the Twenty-Second Annual Meeting of the Society for the Promotion of Agricultural Science held at Denver, Colo., pp. 66-69.

1902. Slosson, A. T.-Additional list of insects taken in the Alpine Region of Mount Washington.<Ent. News, pp. 319-321, December, 1902.

1902. Сомstock, J. H., and KellogG, V. L.-Elements of insect anatomy. Fourth edition.

1902. Severin, G.-Le Dendroctonus micans (Kugelann) en Belgique.<Bull. Soc. Centr, forestière Belg., Vol. IX, pp. 72-S1.

1902. Severin, G.-L'invasion de l'Hylésine géante.<Bull. Soc. Centr. forestière Belg., Vol. II, pp. 145-152.

1902. Ulike, Henry.-A list of the beetles of the District of Columbia.<Proc. U. S. Nat. Mus., XXV, pp. 1-57.

1902a. Hopkins, A. D.-Some notes on the genus Dendroctonus. Proc. Ent. Soc. Wash., V, No. 1, pp. 3-4, May 17, 1902 (author's extra published March 28, 1902).

1902b. Hopkins, A. D.-Insect enemies of the pine in the Black Hills Forest Reserve. <Bul. 32, n. s., Div. Ent., U. S. Dept. Agr., pp. 1-24, Pls. I-VII, figs. 1-5 (issued April 29, 1902).

1902c. Hopkins, A. D.-On the study of forest entomology in America. Proceedings of the Fourteenth Annual Meeting of the Association of Economic Entomologists. <Bul. 37, n. s., Div. Ent., U. S. Dept. Agr., pp. 5-32.

1902. Schwarz, E. A.-Proc. Ent. Soc. Wash., V, No. 1, p. 32, May 17.

1902. Weber, L.-Zur Biologie von Rhizophagus grandis Gyllh.<Allg. Zeitsch. f. Ent., VII, p. 108.

1902. Wiскнам, H. F.-A catalogue of the Coleoptera of Colorado.<Bul. Lab. Nat. Hist. State Univ. Iowa, Vol. V, No. 3, pp. 217-310.

1903a. Hopkins, A. D.-Forest insect explorations in the summer of 1902.<Can. Ent., XXXV, No. 3, pp. 59-61, March.

1903b. Hopkins, A. D.-Some of the principal insect enemies of coniferous forests in the United States.<Yearbook U. S. Dept. Agr., for 1902, pp. 265-2S2.

1903. FELT, E. P.-Insects affecting forest trees. $<7$ th Rep. Forest, Fish and Game Comm. State N. Y., pp. 480-481, 2 plates, figs. 1-3. 
1903. Brichet, O., et Severin, G.-Le Dendroctonus micans, dégâts moyens préventifs et destructifs.<Bull. Soc. Centr. Forestière Belg., X, pp. 244-258.

1903. Baudisch, Fr.-Über Dendroctonus micans Kug.<Centralbl. ges. Forstwesen, Jahrg. 29, pp. 151-152.

1904. Hopkins, A. D.-Catalogue of exhibit of insect enemies of forests and forest products at the Louisiana Purchase Exposition, St. Louis, Mo., 1904.<Bul. 48, Div. Ent., U. S. Dept. Agr.

1904-5. Quairière, C.-Le Dendroctonus micans.<Bull. Soc. Centr. Forestière Belg., XI, pp. 626-628; XII, pp. 183-186.

1904. Powell, P. B.-The development of wings of certain beetles, and some studies of the origin of the wings of insects.<Journ. N. Y. Ent. Soc., XII, pp. 237-243, Pls. XI-XVII.

1905. Ibid. (continued), XIII, pp. 5-22.

1905. Hopkins, A. D.- The Black Hills beetle, with further notes on its distribution, life history, and methods of control. $<$ Bul. 56, Bur. Ent., U. S. Dept. Agr., pp. 1-24, Pls. I, II, figs. 1-6.

1905. Quiévy, Prosper.-Dendroctonus micans, invasion.<Bul. Soc. Centr. Forestière Belg., T. 12, pp. 334-335.

1905. Felt, E. P.-Insects affecting park and woodland trees. $<$ N. Y. State Mus., Mem. 8, Vol. 1, pp. 6-7.

1905. Nüsslin, O.-Leitfaden der Forstinsektenkunde, pp. 175-178.

1905. Voss, Friedrich.-Ü̈ber den Thorax von Gryllus domesticus, mit besonderer Berücksichtigung des Flügelgelenks und dessen Bewegung. $<$ Zeitschr. f. wiss. Zool., LXXVIII, pp. 268-521, 654-759, Pls. XV, XVI, XXIV.

1906a. Hopkins, A. D.-Barkbeetle depredations of some fifty years ago in the Pikes Peak region of Colorado. < Proc. Ent. Soc. Wash., IIII, Nos. 1-2, pp. 4-5, July $13,1906$.

1906b. Hopkins, A. D.-Notes on scolytid larvæ and their mouthparts.<Proc. Ent. Soc. Wash., VII, Nos. 2-3, pp. 143-149, Pls. IV, V, January 10.

1906c. Hopkins, A. D.-Notes on some Mexican Scolytidæ, with descriptions of some new species.<Proc. Ent. Soc. Wash., VII, Nos. 2-3, pp. 71-81, January 10.

1906. Wевв, J. L.-Some insects injurious to forests. The western pine-destroying barkbeetle.<Bul. 58, Pt. II, Bur. Ent., U. S. Dept. Agr., pp. 17-30, Pls. II, III, figs. 7-12, August 18.

1906. FELT, E. P.-Insects affecting park and woodland trees. $<$ N. Y. State Mus., Mem. 8, Tol. 2.

1907. FAld, H. C., and Cockerell, T. D. A.-The Coleoptera of New Mexico. $<$ Trans. Amer. Ent. Soc., XXXIII, pp. 145, 218.

1908. Severin, G.-Le genre Dendroctonus.<Bull. Soc. Centr. Forestière Belg. Author's extra, pp. 1-20. Received May, 1908.

1908. Hopkins, A. D.-Notable depredations by forest insects.<Yearbook U. S. Dept. Agr., for 1907, pp. 149-164. 


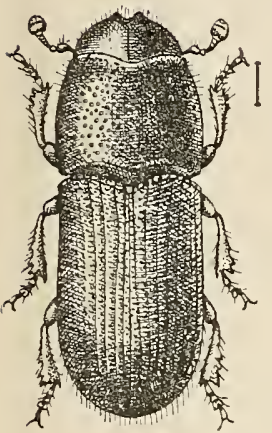

4
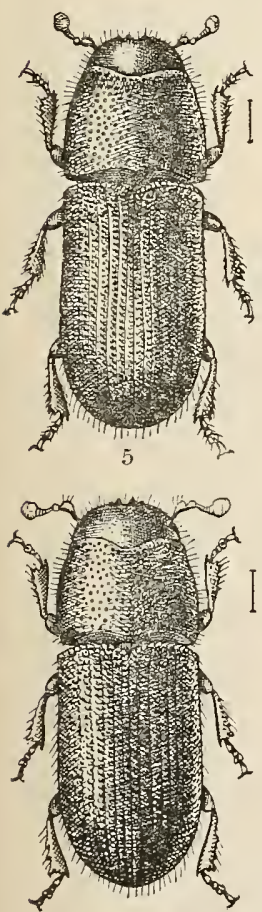

6
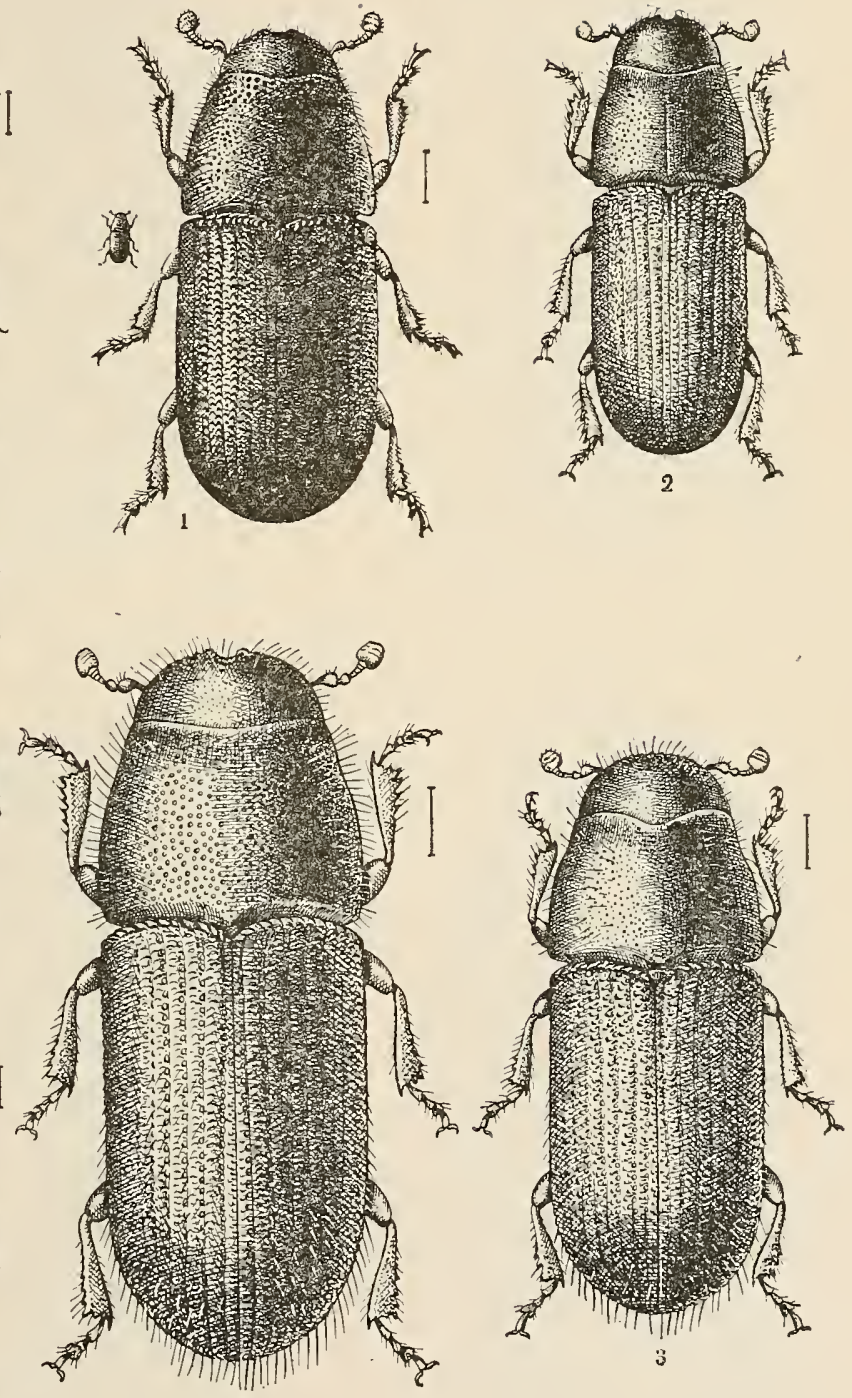

7

DENDROCTONUS ADULTS.

Fig.1.-D. brevicomis. Fig. 2.-D. barberi. Fig. 3.-D. convexifrons. Fig.4.-D. frontalis, Fig, 5. D. arizonicus. Fig. 6.-D. mexicanus. Fig. 7.-D, parallelocollis, (Original.) 


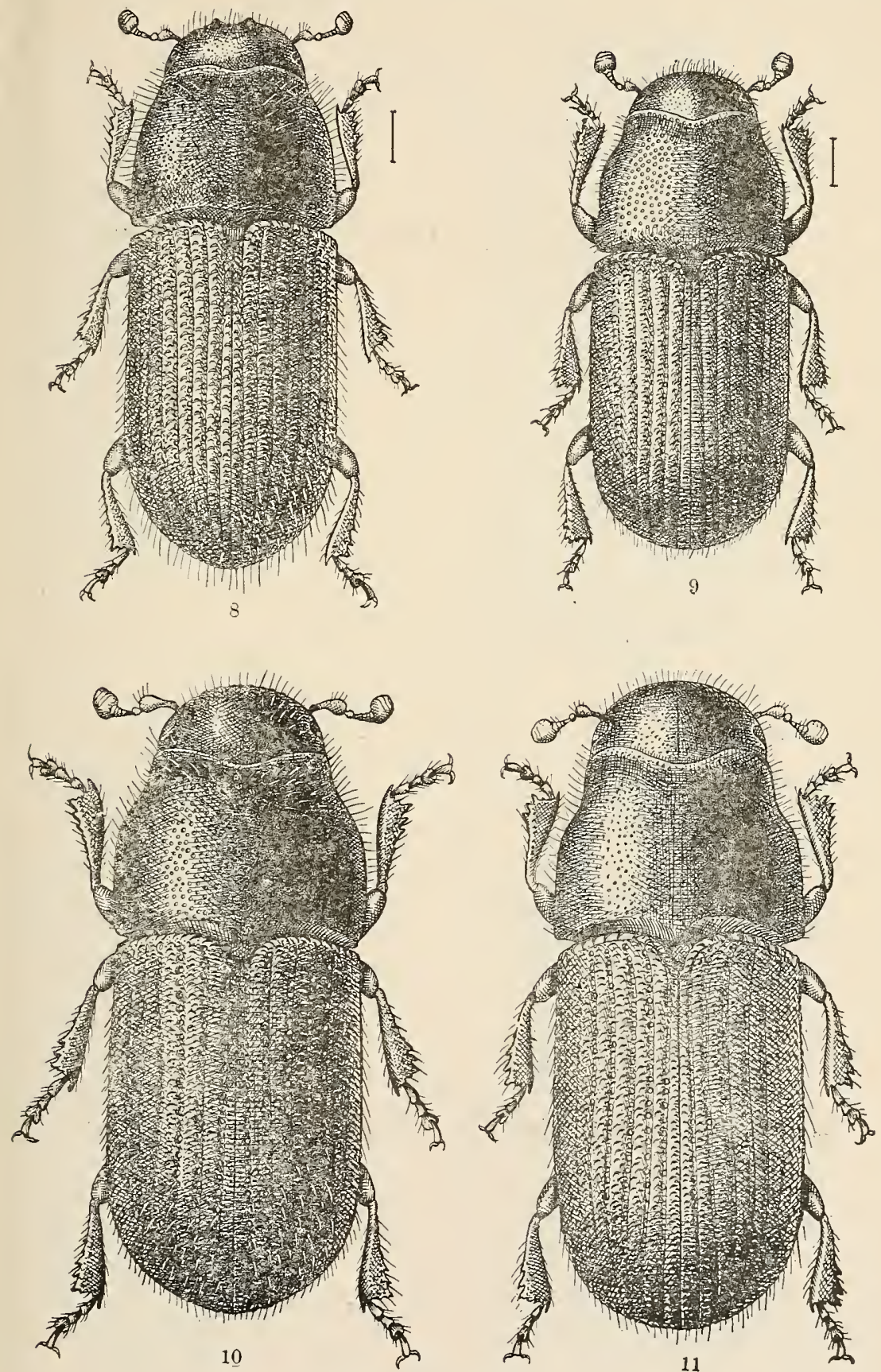

DENDROCTONUS ADULTS. Fig. 8. $-D$. approximatus. Fig. 9. -D. monticolæ. Fig. 10.-D. ponderosæ. Fig. 11.-D.jeffreyi.
(Original.) 


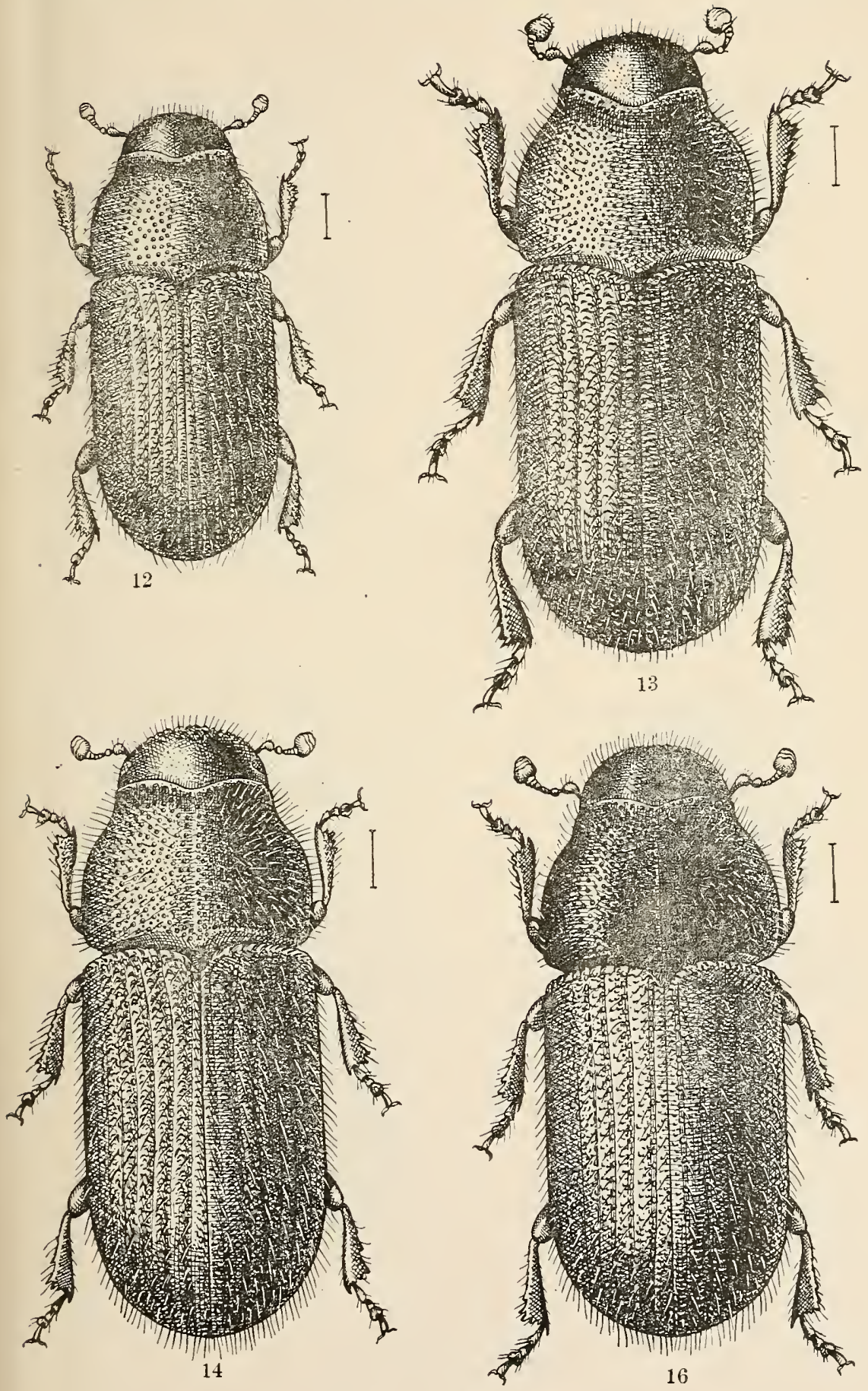

DENDROCTONUS ADULTS.

Fig. 12.-D. simplex, Fig. 13.-D. pseudotsugx, Fig. 14.-D. piceaperda. Fig. 16.-D. borealis. 


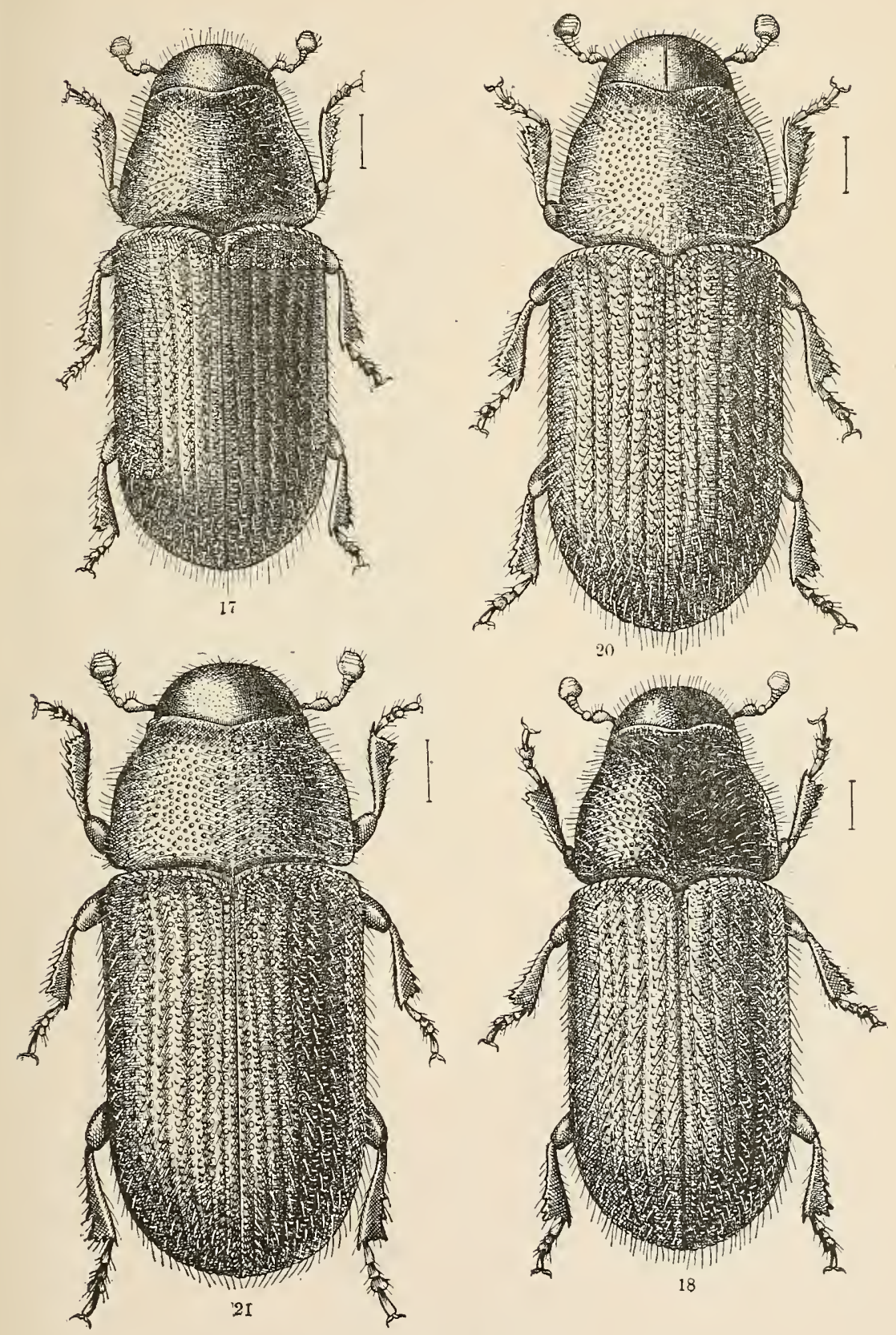

DENDROCTONUS ADULTS.

Fig. 17.-D. obesus. Fig. 18.-D. rufipennis. Fig. 20,-D. punctatus. Fig. 21.-D. micans. (Original.) 


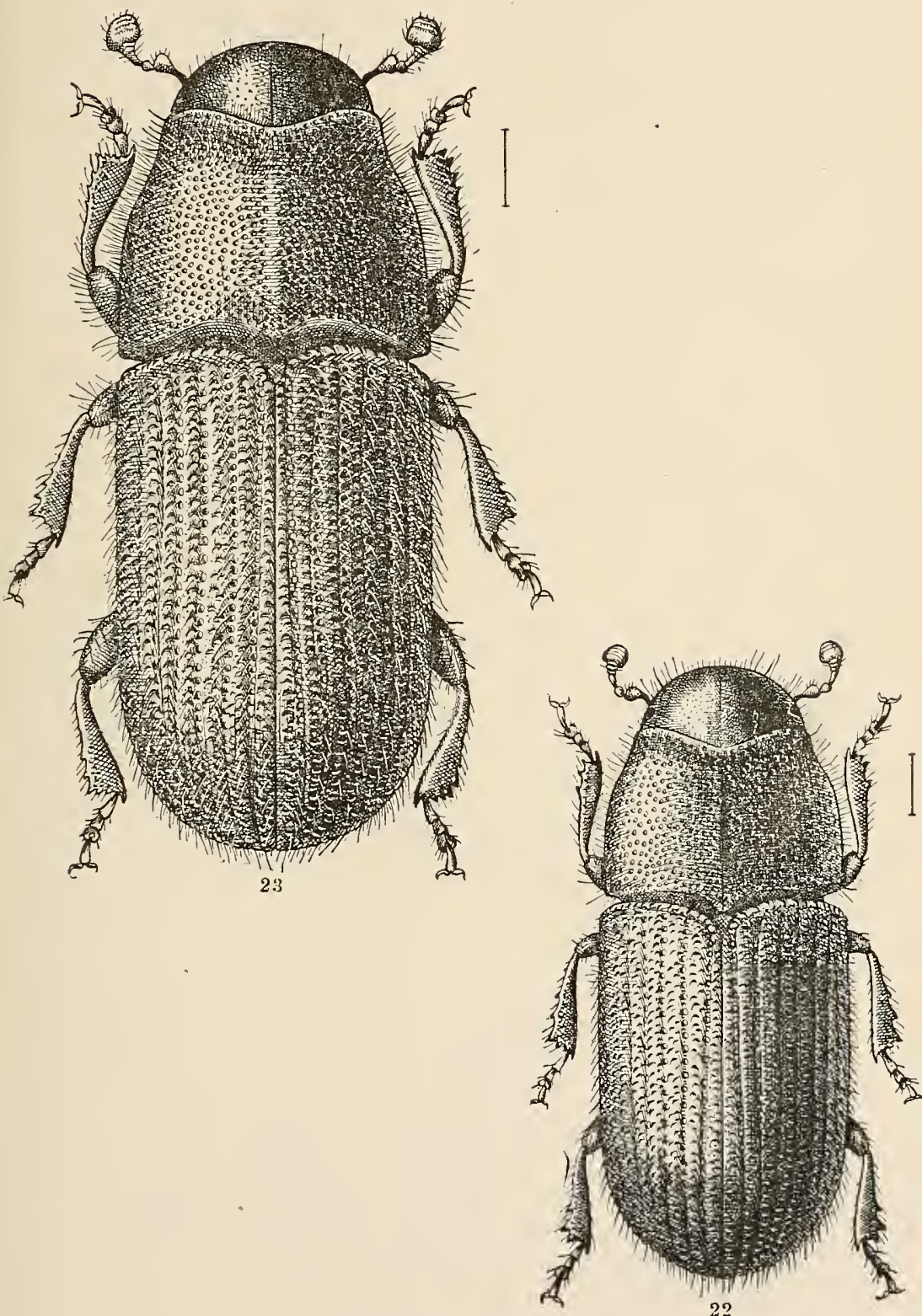

DENDROCTONUS ADULTS.

Fig. 22.-D. terebrans. Fig. 23,-D. valens. (Original.) 


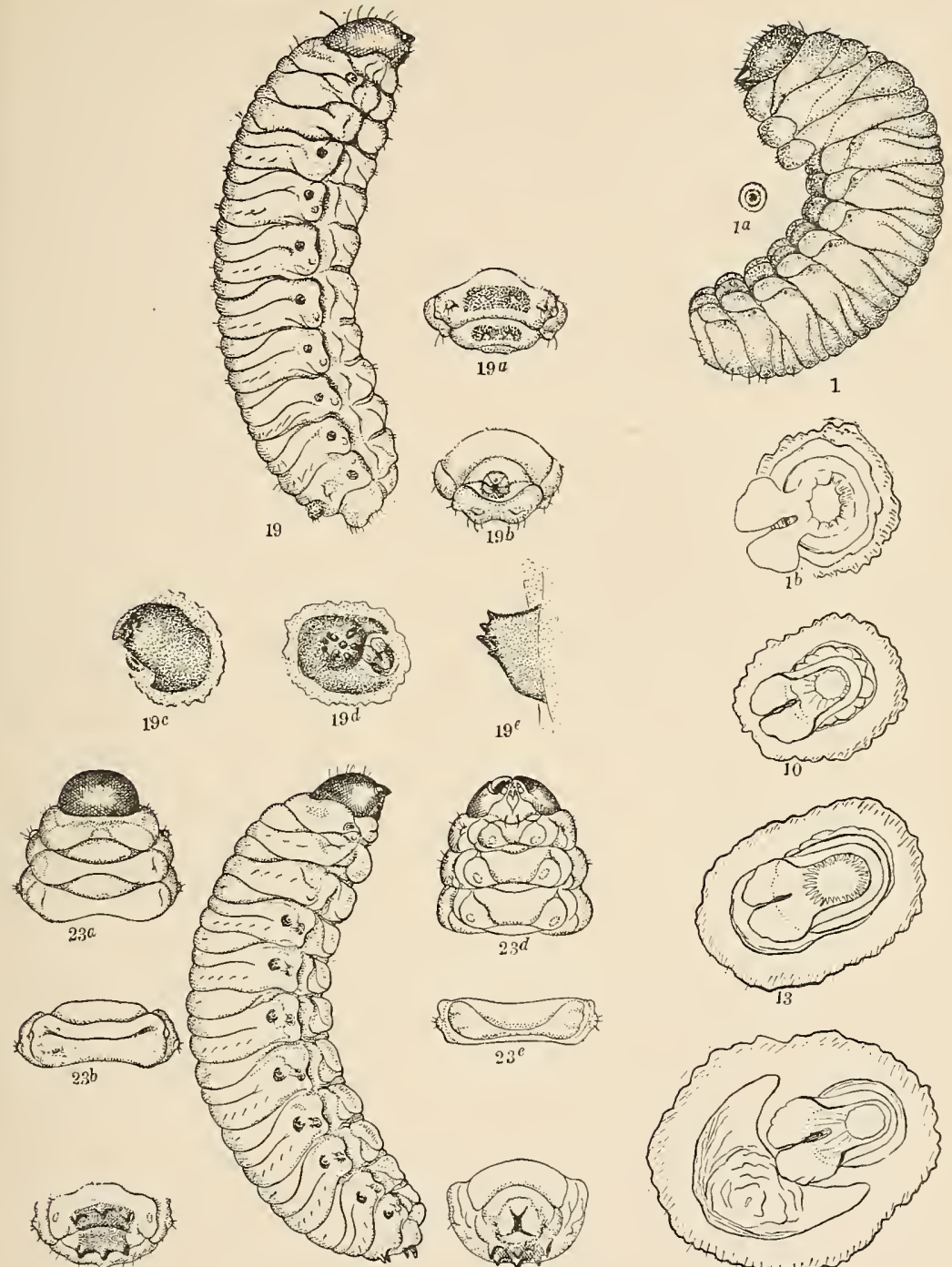

23
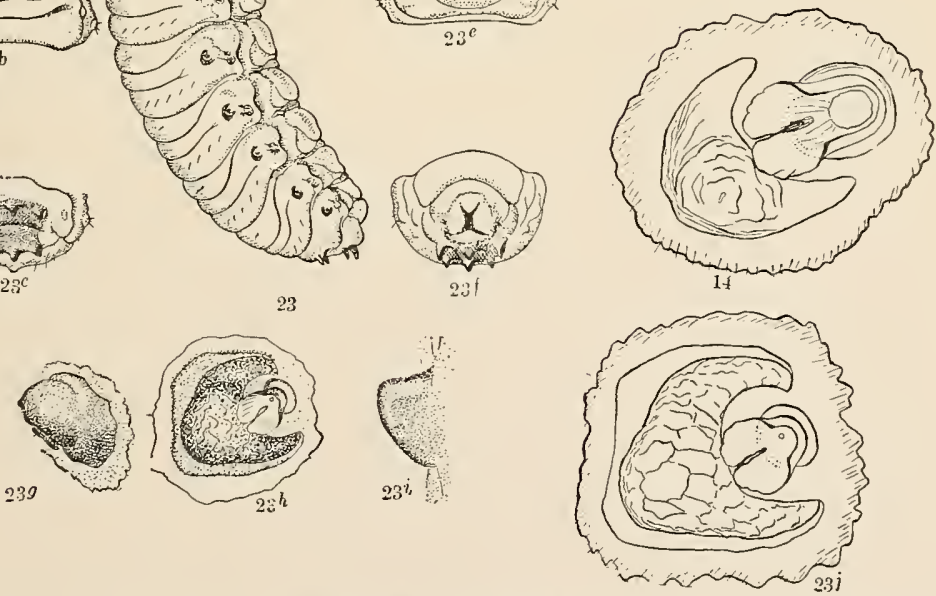

DENDROCTONUS LARVE.

Fig. 1.-D.breviconis; $1 \alpha$, spiracle, enlarged; $1 b$, spiracle, greatly enlarged, showing simple bifid processes. Fig. 10.-D. ponderose, spiracle, greatly enlarged. Fig. $13 .-D$. pscudotsuga, spiracle, greatly enlarged. Fig. 14.-D. piceaperda, spiraele, greatly enlarged. Fig. 19.-D. murrayanz; $19 a$, dorsal aspect of abdominal segments 8 and 9 , showing plates; $19 b$, anal aspect: $19 c, 19 d$, and 19e, different aspects of spiracular tuberele, much enlarged Fig. 23.-D. valens: 23a, dorsal asuect of thoracic segments; 23b, dorsal aspect of abdominal segments; $23 c$, dorsal aspeet of abdominal segments 8 and 9 , showing armed plates; $23 i$, ventral aspect of thoraeic segments; '23e, ventral aspeet of abdominal segment; $23 f$, anal axpect of abdominal segments 8, 9, and 10:23 $q, 23 h$, 23i, different aspeets of spiraeular tubereles, moderate] $y$ enlarged; $23 j$, spiracle and spiracular tuberele, greatly enlarged. (Original.) 



Technical Series, No. 17, Part 11.

U. S. DEPARTMENT OF AGRICULTURE, BUREAU OF HINOMOLOGX.

L. O. HOWARD, Entomologist and Chief of Bureau.

\title{
CONTRIBUTIONS TOWARD A MONOGRAPH OF THE SCOLYTID BEETLES.
}

\section{PRELIVINARY CLASSIFICATION OF THE SUPERFAIILY SCOLYTOIDEA.}

\author{
BY \\ A. D. HOPKINS, Рh. D., \\ In Charge of Forest Insect Investigations.
}

IsSUED JANUARY 9, 1915.

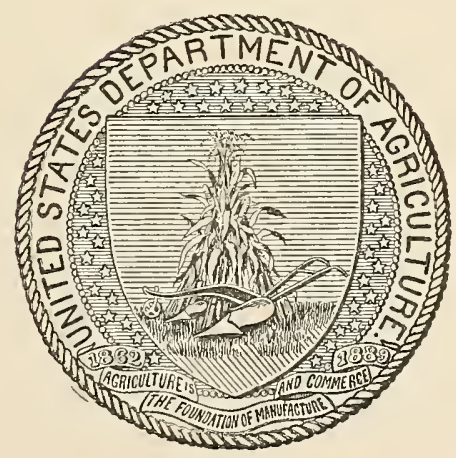

WASHINGTON:

GOVERNMENT PRINTING OFFICE. 


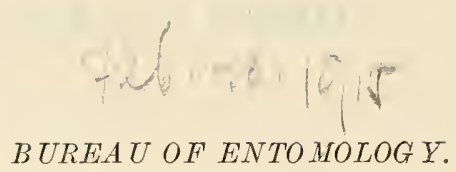

L. O. Howard, Entomologist and Chief of Bureau.

C. L. MAruatt, Entomologist and Acting Chief in Absence of Chief.

R. S. Clifton, Chief Clerk and Executive Assistant.

F. H. Chittenden, in charge of truck crop and stored product insect investigations.

A. D. HopkINs, in charge of forest insect investigations.

W. D. Hunter, in charge of southern field crop insect investigations.

F. M. WEBSTER, in charge of cereal and forage insect investigations.

A. L. Quanntance, in charge of deciduous fruit insect investigations.

E. F. Philuips, in charge of bee culture.

A. F. Burgess, in charge of gipsy moth and brown-tail moth investigations.

Rolla P. Currie, in charge of editorial work.

Mabel Colcord, in charge of library.

\section{Forest Insect Investigations.}

A. D. Hopkins, in charge.

H. E. Burke, August Busck, W. D. Edhonston, Josef Brunner, T. E. Snyder, F. C. Craighead, J. M. Muler, S. A. Rohwer, A. G. Boving, C. T. Greene, IV. S. Fisher, JACOB Kotinskr, B. T. HARvey, entomological assistants.

Carl Heinrich, A. B. Champlain, Wm. Midnleton, Mary E. Fauncea, Mary C. JoHNSON, scientific assistants.

Morris Chrisman, Geo. Hofer, J. D. Riggs, P. D. Sergent, J. J. Suldivan, Albert Wagner, IT. E. Glendinning, J. C. Evenden, F. B. Herbert, P. F. Keen, J. H. Pollock, entomological rangers.

Esther H. Hart, artist.

Margaret Fagan, Elizablth Ritchie, Maude Taylor, Edna O. Haslup, Pearl L. Boone, preparators. 


\section{CONTENTS.}

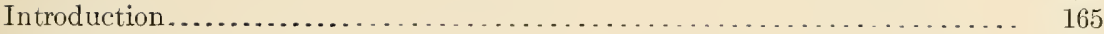

Position of the Scolytoidea.................................. 167

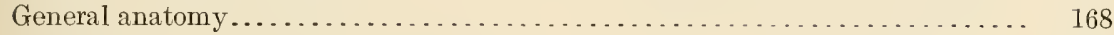

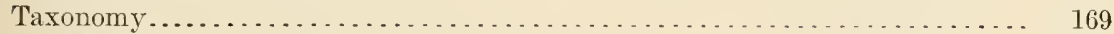

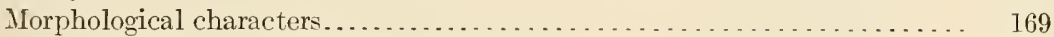

Superfamily characters................................. 169

Family characters................................. 170

Subfamily characters............................... 170

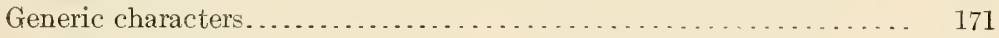

The antennæ.................................... 171

The eyes...................................... 174

The mouthparts...................................... 174

Characters in general................................... 175

The body ........................................ 175

Form......................................... 175

Color.......................................... 176

Vestiture......................................... 176

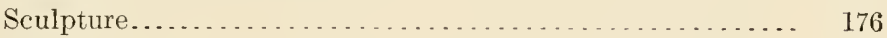

Armatures................................ 176

Head................................... 177

Prothorax..................................... 177

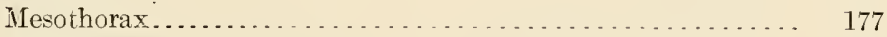

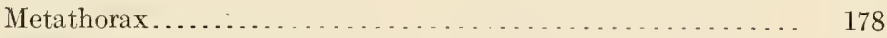

Legs.......................................... 179

Elytra..................................... 179

Posterior wings................................. 179

Abdominal tergites.............................. 180

Abdominal spiracles............................ 181

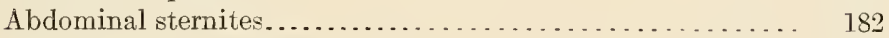

Stridulating accessories......................... . . 182

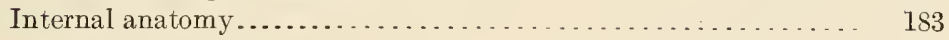

Digestive system............................ . . 183

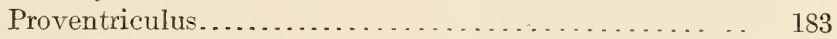

Reproductive organs........................... 184

The reproductive organs of the male............... 184

Posterior elements........................ 185

Anterior and median elements................ 190

Variations and combinations of the elements...... 190

Terminology of the reproductive organs........... 192

Classifications based on the reproductive organs....... 194

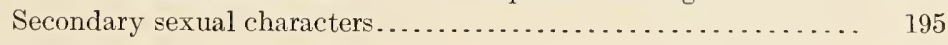

The pupæ....................................... 196

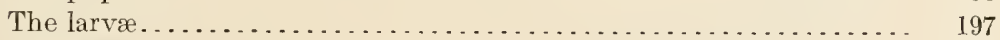

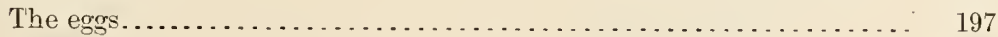

The embryo.......................................... 197 
Taxonomy-Continued. Page.

Physiological characteristics................................ 198

General habits........................................ 198

Classification according to habits........................ 198

Food habits of the adults.............................. 199

Food habits of the larvæ......................... 199

Pupal habits...................................... 199

Flight habits...................................... 200

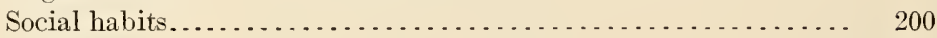

Galleries............................................ 201

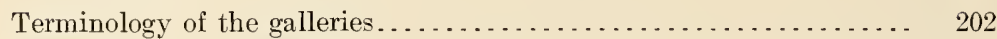

Classification of the galleries......................... 204

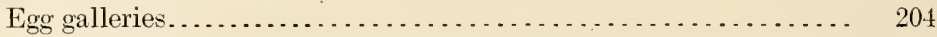

Larval mines................................... 201

Types and subtypes of egg galleries.................. 205

Relation of types of galleries to the subfamilies and families.. 206

Taxonomic relation between the beetles and their host plants...... 207

Part of plant selected by the beetles................ 207

Condition of the plant........................... 208

Relation of the species of beetles to the systematic position of their host................................... 208

Range of host plants.......................... 208

Associations of species of beetles and species of plants........ 209

Sumniary of taxonomic evidence furnished by host relations .... 209

Geographical distribution in its bearing on taxonomy ............. 210

Review of taxonomic characters and characteristics.............. 211

Norphological characters........................... 212

Physiological characteristics............................ 213

Correlation of morphological and physiological elements.......... 213

Parallel modifications.................................... 214

Reversals........................................... 214

Progressive modifications............................... 215

Examples of progressive modification . . . . . . . . . . . . . . 215

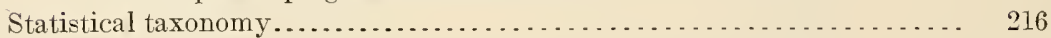

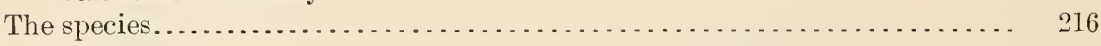

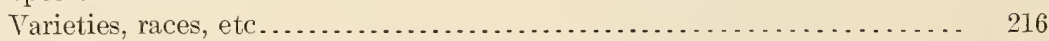

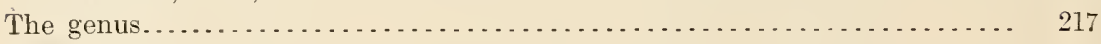

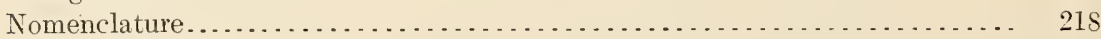

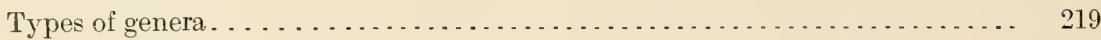

Genus Scolytus Geoffroy . . . . . . . . . . . . . . . . . . . . . . . . 219

Genus Ips De Geer . . . . . . . . . . . . . . . . . . . . . . . . . . 220

Genus Tomicus Latreille. . . . . . . . . . . . . . . . . . . . . . . . 220

Genus Hylastes Erichson. . . . . . . . . . . . . . . . . . . . . . . . 221

Genus Cryphalus Erichson .............................. 221

Genus Hypothenemus Westwood... . . . . . . . . . . . . . . . . . . . . 221

Genus Polygraphus Erichson. . . . . . . . . . . . . . . . . . . . . . . 222

Genus Lepisomus Kirby................................. 222

Description of a new genus and species ....................... 222

Preliminary classification of the Superfanily Scolytoidea.............. 224

Key to the families . . . . . . . . . . . . . . . . . . . . . . . . . . . 224

Division I. . . . . . . . . . . . . . . . . . . . . . . . . . . . . 224

Subdivision A. . . . . . . . . . . . . . . . . . . . . . . . . 224

Family Ipidæ.................................. 224 
Preliminary classification of the Superfamily Scolytoidea-Continued.

Key to the families-Continued.

Division I-Continued. Page.

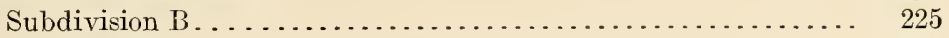

Family Scolytidx............................ 225

Family Scolytoplatypodidæ................... 225

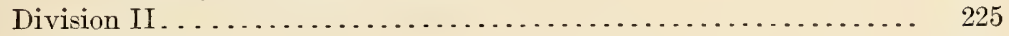

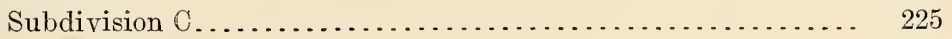

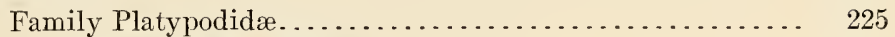

Family Ipidæ. Key to the subfamilies ...................... 225

Division I. . . . . . . . . . . . . . . . . . . . . . . . . . . . . . 225

Subdivision A. . . . . . . . . . . . . . . . . . . . . . . 225

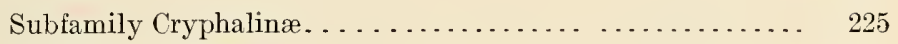

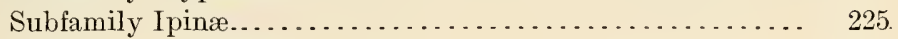

Subfamily Corthylinæ......................... 225

Subfamily Micracinæ........................... 225

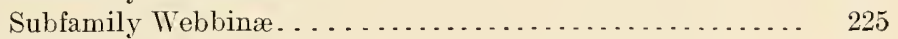

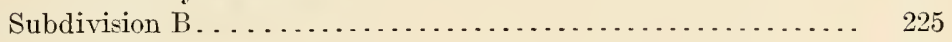

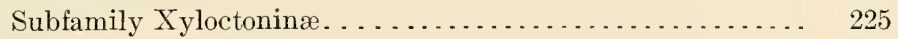

Division II . . . . . . . . . . . . . . . . . . . . . . . . . . 225

Subdivision C . . . . . . . . . . . . . . . . . . . . . . . . 225

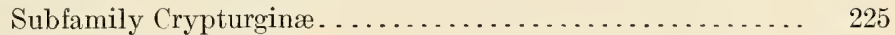

Subfamily Phlœotribinæ........................ 225

Subdivision D . . . . . . . . . . . . . . . . . . . . . . . . 225

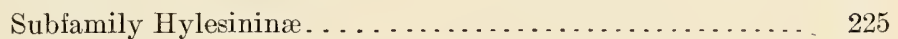

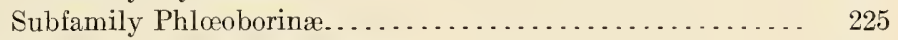

Family Scolytidæ. Key to the subfamilies .................. 225

Division I. . . . . . . . . . . . . . . . . . . . . . . . . . . 225

Subfamily Coptonotinæ........................ 225

Division II....................................... 225

Subdivision A. . . . . . . . . . . . . . . . . . . . . . . . 225

Subfamily Hexacolinæ........................ 225

Subfamily Bothrosterninæ. . . . . . . . . . . . . . . . . . 225

Subfamily Hyorrhynchinæ. . . . . . . . . . . . . . . . 225

Subdivision B.................................. 225

Subfamily Camptocerinæ........................ 225

Subfamily Scolytinæ......................... 225

Family Scolytoplatypodidx............................ 225

Family Platypodidæ. Key to the subfamilies . . . . . . . . . . . . . . 225

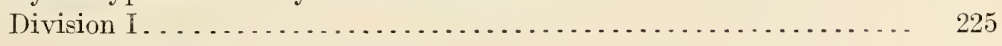

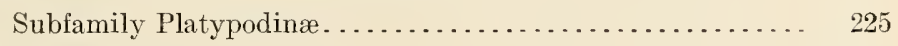

Division II. . . . . . . . . . . . . . . . . . . . . . . . . . 225

Subfamily Genyocerinæ....................... 225

Subfamily Chapuisinæ...................... 225

Position of the principal described genera in the preliminary classification..... 226

Genera described in 1911-12, not included in foregoing list, but here pro-

visionally assigned to the subfamilies . . . . . . . . . . . . . . . . . 227

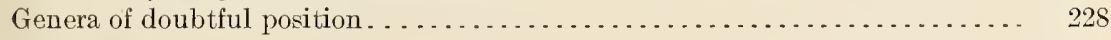

Bibliography .............................................. 229 


\section{ILLUSTRATIONS.}

PLATES.

Plate IX. Figs. 1-18.-Typical tarsi and tibiæ of the subfamilies of Scoly-

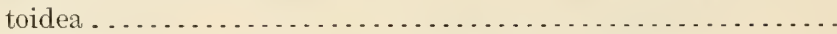

X. Figs. 1-5a.-Antennæ of typical species of the subfamilies of Scolytoidea . . . . . . . . . . . . . . . . . . . . . . . . . . . . .

XI. Figs. 7-10a.-Antennæ of typical species of the subfamilies of

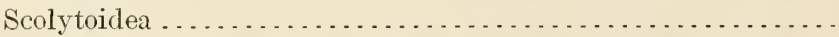

XII. Figs. 12-18b.-Antenuæ of typical species of the subfamilies of Scolytoidea. . . . . . . . . . . . . . . . . . . . . . . . . .

XIII. Figs. 1-9b.--Tibiæ and tarsi of typical species of the subfamilies of

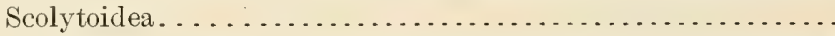

XIV. Figs. 10-10b.-Tibiæ and tarsi of typical species of the subfamilies of Scolytridea . . . . . . . . . . . . . . . . . . . . . . . . . .

XV. Figs. 12-15b.-Tibiæ and tarsi of typical species of the subfamilies of Scolytoidea. . . . . . . . . . . . . . . . . . . . . . . . . .

XVI. Figs. 16-18b.-Tibiæ and tarsi of typical species of the subfamilies

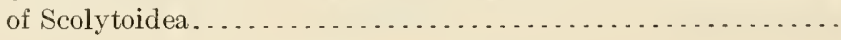

Page.

170

170

170

170

178

178

178

178

TEXT FIGURES.

Fig. 96. The antenna in scolytoid beetles: Diagram and terminology ....... 172

97. Abnormalities in the antennal funicle of Xyleborus tachygraphus .... . 173

98. Ips emarginatus: Proventricular plate.................... 183

99. Scolytus scolytus: Proventricular plate...................... 183

100. Crossotarsus lecontei: Proventricular plate................... 183

101. Dendrocionus valens: Membranous and nonchitinous elements of male reproductive organs.............................. 184

102. Xyleborus saxeseni: Chitinous elements of male reproductive organs.. 184

103. Ips emarginatus: Chitinous elements of male reproductive organs.... 185

104. Pityophthorus s..: Chitinous elements of male reproductive organs. $\quad 186$

105. Pityophthorus bellus: End plates and seminal rod of male reproductive organs. . . . . . . . . . . . . . . . . . . . . . . . . . . . . .

106. Micracis suturalis: Posterior elements of male reproductive organs...

107. Dendroctonus valens: Posterior elements of male reproductive organs.

108. Scolytus rugulosus: Posterior elements of male reproductive organs. -

109. Scolytus quadrispinosus: Posterior elements of male reproductive organs. . . . . . . . . . . . . . . . . . . . . . . . . . . . . 189

110. Crossotarsus lecontei: Posterior elements of male reproductive organs.. 191

111. Dendroctonus valens: Female reproductive organs............. 194

112. Classification of galleries of Scolytoidea................. 205 


\title{
CONTRIBUTIONS TOWARD A MONOGRAPH OF THE SCOLYTID BEETLES.
}

\section{PRELIMINARY CLASSIFICATION OF THE SUPERFAMILY SCOLYTOIDEA. ${ }^{a}$}

\author{
By A. D. Hopkins, Ph. D., \\ In Charge of Forest Insect Investigations.
}

\section{INTRODUCTION.}

The object of this contribution is to discuss the taxonomy and present a preliminary classification of the families and subfamilies of the scolytoid beetles of the world. The discussion and classification are based on a study of representatives of about 122 described and undescribed genera and about 1,000 species of North America and other countries, in the collections of the U. S. National Museum and certain other museums and institutions of this country.

The types of North American species described by Zimmermann, LeConte, Fitch, Harris, Schwarz, Ulke, and, with a few exceptions, those of other North American authors, have been studied by the writer. Nearly all of the North American species described by Eichhoff are represented in the U. S. National Museum collections by specimens sent by him to the writer and to Dr. C. V. Riley. Many of these specimens are from the type series not only of North American but of many foreign species described by Eichhoff. Central and South America, the West Indies, the Eastern Continent, Australia, and Oceania are represented to a greater or less extent by described and undescribed species, of which 31 genera and 96 species are from Europe, principally from the collections of Eichhoff of Germany, Blandford of England, and Villard of France:

The material in the forest insect collections of the Bureau of Entomology and the West Virginia Agricultural Experiment Station, collected by the writer and his associates, includes nearly all of the described North American species and in addition a large

a See Hopkins, A. D. List of generic names and their type-species in the coleopterous superfamily Scolytoidea. Proc. U. S. Nat. Mus., vol. 48, No. 2066, pp. 115-136, December 16, 1914. 
number of undescribed species and a great amount of new biological material. With this amount of material at hand and a special study of this group of insects extending over a period of twenty years, the writer feels justified in proposing a revised classification and in defining the characters which it appears to him are of special taxonomic importance.

In presenting the preliminary classification of the Scolytoidea the author does so with no idea of criticising the systems proposed by other authors. The whole presentation is simply to stand as the writer's interpretation of the characters and characteristics represented by the material before him, and to serve, so far as it may, as a step in the evolution of artificial systems of classification toward the ideal or natural. Each comprehensive system of classification proposed since that of Linnæus has contributed something toward the evolution of better systems. Some of them have been progressive, others in part retrogressive, and a few have been revolutionary in their character. But, as in most conflicts of opinion, general progress results. Therefore those investigators of the present and the future who, without prejudice as to any opinion or theory, can sift out the true from the erroneous in that which has been published, and add new truths from their own observations, will make the most rapid progress toward the attainment of the ideal.

The anatomical investigations conducted by the writer and outlined in Part I of this bulletin have revealed heretofore unrecorded facts relating to structural characters, which, in connection with a greatly increased knowledge of the physiological characteristics of the stages of development and of the habits, host relations, and distribution of described and undescribed forms, seem to warrant a somewhat different classification from those proposed by other writers.

It seems that a study of the facts as revealed by modifications in morphological characters and physiological characteristics of existing forms, without any attempt to explain their origin or phylogeny, will lead to a more correct interpretation of natural affinities than any amount of speculation on hypothetical ancestral forms from which present species may have evolved. Indeed, it would seem that we have, in the progressive modification of the more fundamental and dominant characters and characteristics, a better taxonomic basis on which to correlate the characters and construct a so-called natural system than can be found in those characters which are subject to special modification through similar use and influences of environment. ${ }^{a}$

$a$ In this connection see Part I of this bulletin, p. 25, second paragraph, and pp. $67-68$. 


\section{POSITION OF THE SCOLYTOIDEA.}

The contrasting characters which indicate the position of the superfamily Scolytoidea in the order Coleoptera are as follows:

Order COLEOPTERA.

Maxilla undivided, the palpi rigid and with not more than three joints; larvæ legless. . . . . . . . . . . . . . . . . . . . . . . . . . . Suborder Rhynchophora.

Maxilla divided, more or less flexible, and with a flexible palpus, usually 4-jointed; larvæ rarely without $\operatorname{legs........................~other~Coleoptera.~}$

\section{Suborder RHYNCHOPHORA.}

Head without prominent rostrum or beak and the submentum never produced into a gular peduncle............................ Superfamily Scolytoidea. Head usually with prominent rostrum or beak and the submentum always more or less produced into a gular peduncle.................... All other Rhynchophora.

It is evident to the writer that, in consideration of the extremes in morphological characters to be found in the order Coleoptera, the superfamily Scolytoidea occupies a position opposite to that of the Carabidæ, and that in the Rhynchophora it occupies an opposite position to that of the Apionidæ.

It seems desirable to place the Scolytoidea first in the classification of the Coleoptera, not because of any theory as to their origin or phylogeny but because their e'ements of structure seem to form a better and more correct basis from which to proceed in the interpretation of the progressive modification of the characters which serve to distinguish the major and minor divisions and groups. Such a method should not conflict with other methods because it should make little difference whether we begin with the Scolytoidea or the Carabidi. If the interpretation of the progressive modifications and natural relations is correct, the relative positions of the various groups will be the same, or similar. It is simply a matter of choosing between the two directly opposite methods to attain the same result and of adopting the one which seems to be more in accord with the natural course of change or evolution from one extreme to the opposite.

If we begin with the scolytoid beetles we find throughout the suborder Rhynchophora two dominant or constant characters, namely, the rigid maxillæ and the legless larvæ. We find also certain changeable characters repeatedly paralleled in the various major and minor groups, and that the general progressive modification of these characters, as, for example, the tendency toward a prolongation of the head, represents a separate and greatly diverging line of morphological expression or evolution from that prevailing in the other divisions of the Coleoptera.

In the other divisions of the Coleoptera the divided maxilla, with flexible palpi, and the legged larvæ are the prevailing and more domi- 
nant characters. Here, again, there are a number of changeable and frequently parallel characters, the progressive modification of which shows many diverging lines toward the extreme, as, for example, the greatest development of jointed and differentiated appendages ${ }^{a}$ in the larvæ, the large size, the odd shapes, and the extraordinary elements of structure and habit.

It is evident that the scolytoid beetles could not have been derived from the highly differentiated carabids or scarabæids and that these groups could not have been derived from any existing group of the Rhynchophora. It is also evident that the species in the two primary divisions of the Coleoptera which may be the nearest representatives of their primitive ancestors are themselves so highly differentiated from one another and from ancestral forms of Coleoptera that they can not be recognized, or, if they could, they would be of little or no use as a basis for speculation on the origin and evolution of the order; then, too, we have no material in fossils on which to base a reliable hypothesis, because only the highly specialized forms have been preserved. Therefore we must rely on facts as they exist and endearor to discover and interpret the elements of distinction and relationship which have survived in the course of their evolution, under the influence of natural selection, dominant differentiation, and progressive and parallel evolution. The writer's interpretation of these facts, so far as they apply to morphological characters and the distinction of groups and species, will be expressed in the tables of families, subfamilies, genera, and species, in the succeeding contributions toward a monograph, as will also the progressive modification of characters indicative of the lines of divergence from one extreme toward the opposite.

\section{GENERAI ANATOMY.}

The discussion, illustrations, and terminology of the anatomical elements of Dendroctonus given in Part $\mathrm{I}$ of this bulletin will serve as a basis for comparing the anatomy of representatices of other genera. The writer has made a detailed study of the entire anatomy of only a few representatives of other genera, but the more important elements of the external and internal anatomy of representatives of all of the genera in the local collections have been studied, involving the preparation of over 1,200 microscope slides. This, together with the work of other investigators, notably Lindemann, Nüsslin, Fuchs, and Eichhoff, gives us a basis for a somewhat comprehensive view of the subject. There remains, howerer, an immense amount of anatomical work to be done before a knowledge of the subject is anything like complete.

a The writer holds that it is by no means proven that larvæ with jointed appendages are more primitive than those without such appendages. 


\section{TAXONOMY.}

\section{MORPHOLOGICAL CHARACTERS.}

The principal morphological characters adopted by the writer to distinguish the families, subfamilies, and genera, and the major and minor divisions of each are to be found in the external anatomy of the imago. However, some consideration has been given to the location of correlated characters in the internal anatomy and in the physiological characteristics of the different stages of development from the egg to the imago.

It has seemed to the writer that in order to have a classification which would indicate natural positions and lines of modification, and at the same time be simple and practicable, we should endeavor to locate and utilize, as far as possible, external characters which are readily available for examination by a hand lens or the microscope without serious mutilation of the specimens by those who make use of the systematic tables and descriptions. The small size of most of the scolytoid beetles renders it difficult and tedious to examine the minute and obscure elements of the external and internal anatomy, such as the mouthparts and the digestive and sexual organs. It is very important, in fact essential, that the taxonomist should study in detail, and comprehensively, the various elements of external and internal anatomy in order to have a broad basis for his conclusions, but the general student and investigator should not be required to go to such extremes in order properly to interpret the conclusions. Therefore it has been the object of the writer to conform to the simple method of expression rather than to that involving a complexity of detail.

The principal character-bearing parts of the external anatomy which appear to serve as the best taxonomic guides toward a natural system of classification are mentioned in the following pages merely as a basis for the preliminary classification, which is subject to revision in the more detailed treatment of the several subfamilies.

\section{SUPERFAMILY CHARACTERS.}

The superfamily is at once separated into two primary divisions by the relative length of the first tarsal joint, and the subdivisions, sections, and families are distinguished by characters of the tibia (Pl. IX). It is interesting to note that while the most dominant character is found in the first joint of the tarsus, the modification of this joint within the families, subfamilies, and genera is of minor importance. The same, to a lesser degree, may be said of the tibia, in which the character of the apical angles is constant within each subdivision of the superfamily but the modification of these angles 
throughout the minor groups to the species, except in a few cases, is of little or no importance.

The complete opposition in the characters of the apical angles of the tibia, as shown in the subdivisions, is of special interest. There is no apparent explanation on any theory of use or natural selection, but it does appear to signify widely diverging lines of descent in which this reversed element in the two subdivisions has remained as the dominant and distinctive character.

\section{FAMILY CHARACTERS.}

In the classification of the families Ipidæ and Scolytidæ into subfamilies the principal characters used to distinguish the divisions are found in the head (2) ${ }^{a}$, pronotum (4), and tarsi (2).

The subdivisional characters are found in the antennæ (2), tibia (2), and abdominal sternites (2).

The sectional characters are found in the antennæ (2), eyes (2), pronotum (2), tibia (4), and form of body (2).

The subfamily characters are found in the pronotum (4), antennæ (2), serenth abdominal sternite (2), elytra (2), and third tarsai joint (2).

It will be seen that in the classification of the two families into subfamilies the principal characters are found in the head (8), pronotum (10), and tibia ( 7 ).

\section{SUBFAMILY CHARACTERS.}

In the classification (in manuscript) of the 16 subfamilies of Ipidæ and Scolytidæ into genera the principal character-bearing parts for the divisions, subdivisions, and sections are as follows:

Divisions: Head (1), antennal club (3), funicle (3), eyes (4), epistoma (2), maxilla (1) - total for head (14); pronotum (5), tarsi (3), and elytra (2).

Subdivisions: Antennal club (5), eyes (4), funicle (2), epistoma (1), maxilla (1)-total for head (13); third tarsal joint (2), anterior coxæ (3), seventh abdominal sternite (2), and pygidium (2).

Sections: Antennal club (4), funicle (2), eyes (1) - total (7).

It will be seen that in the classification of the subfamilies the characters are found in the head (35), tarsi (7), pronotum (5), elytra (4), coxæ (3), seventh abdominal sternite (3), pygidium (2), and tibia (1).

Subsections and series to genera: The dichotomous characters of the subsections and series and the distinctive characters of the genera are as follows: Antennal club (13S), funicle (110), scape (7) - total for

a The number following the name of a structure indicates the relative importance or the number of times it figures in the dichotomy. 


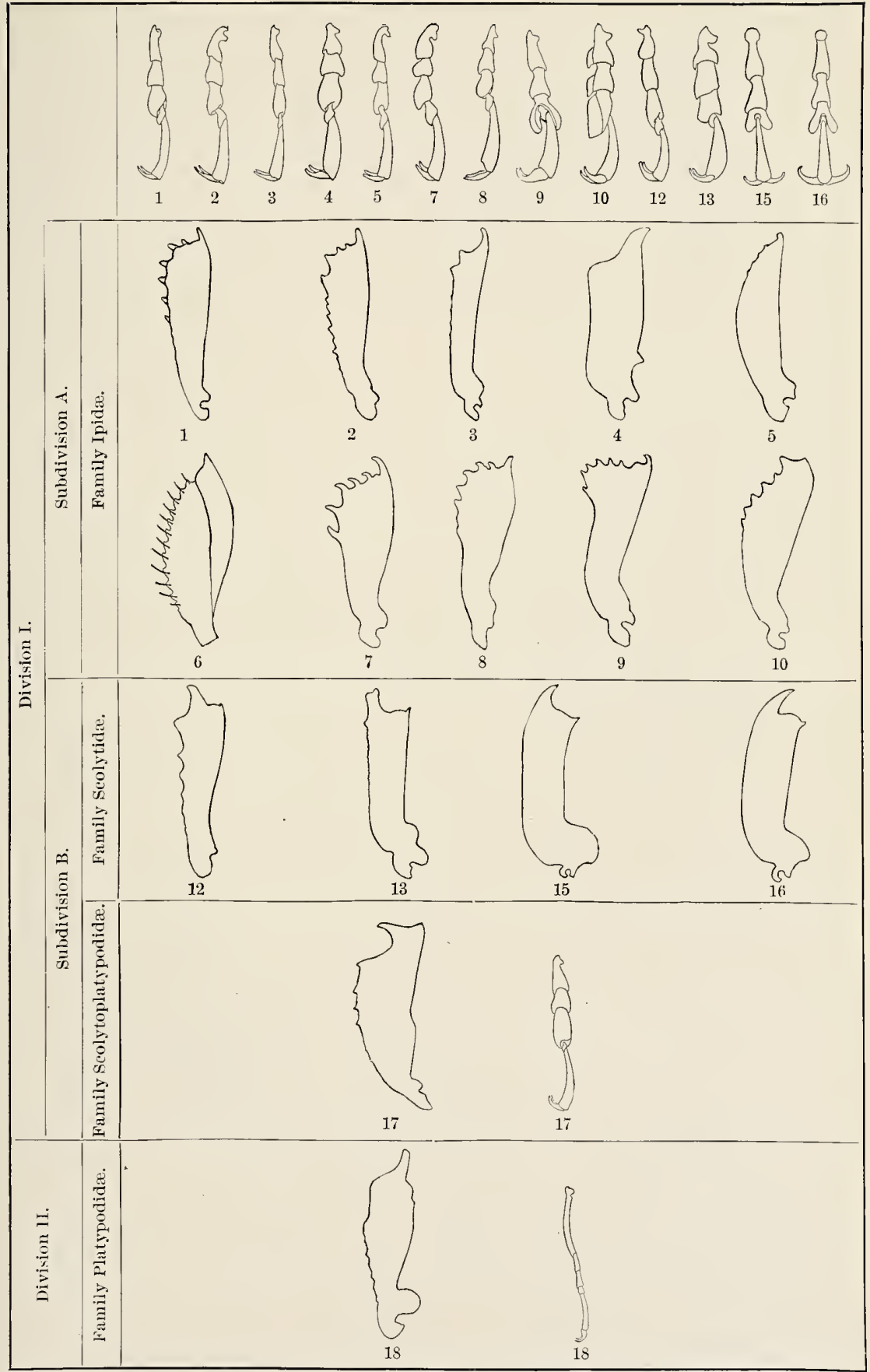

TYPICAL TARSI AND TIBIF OF THE SUBFAMILIES OF SCOLYTOIDEA.

Fig. 1.-Cryphalinæ (Cryphalus asperatus). Fig. 2.-Ipinæ (Ips typographus). Fig. 3.-Corthylinæ (Corthylus columbianus). Fig. 4.-Micracinæ (Micracis suturalis). Fig. 5.-Webbinæ (Tebbia dipterocarpi). Fig. 6.-Xyloctoninæ (Xyloctonus scolytoides) (adapted from Eichhoff). Fig. 7.Crypturginæ (Crypturgus pusillus). Fig. 8.-Phlœotribinæ (Phlœotribus oleæ). Fig.9.-Hvlesininæ (Hylesinus crenatus). Fig. 10.- Phlœeoborinæ (Phloeborus rurlis). Fig. 12.- Hexacolinæ (Hexacolus sp.). Fig. 13.-Bothrosterninæ (Bothrosternus sculpturatus). Fig. 15.-Camptocerinæ (Camptocerus zeneipennis). Fig. 16.-Scolytin:e (Scolytus scolytus). Fig. 17.-Scolytoplatypodinæ (L'colytoplatypus sp.). Fig. 18.-Platypodinæ (Platypus cylindrus). (Original.) 

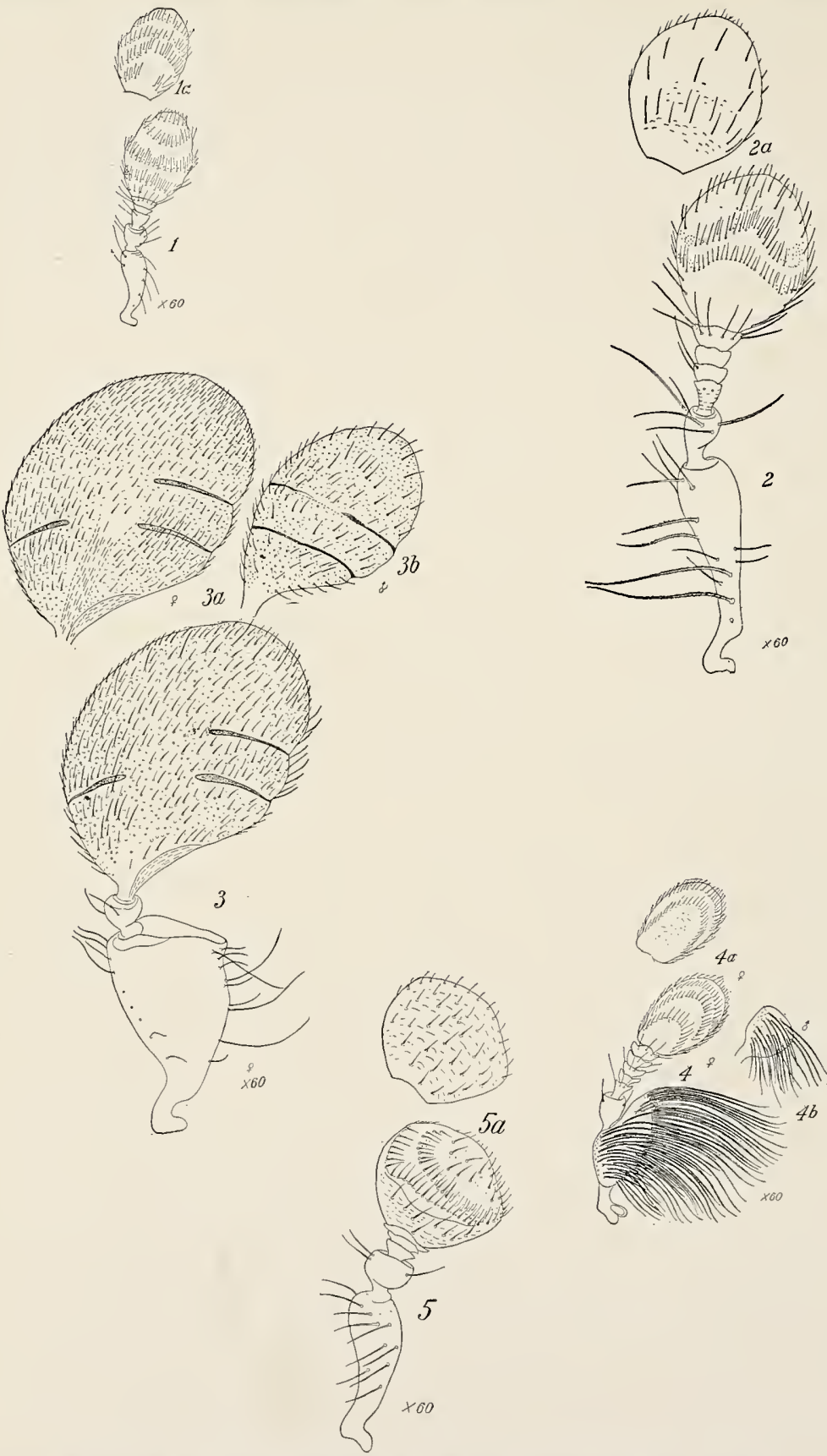

ANTENNF OF TYPICAL SPECIES OF THE SUBFAMILIES OF SCOLYTOIDEA.

Fig. 1.-Cryphalus asperaius (Cryphalinæ), anterior aspect of left antenna. Fig. 1a.-Posterior aspect of left antenna of same. Fig. 2.-Ips typographus (Ipinæ), anterior aspect of leit antenna. Fig. 2a.Posterior aspect of left antenna of same. Fig. 3.- Corthylus columbianus (Corthylinæ), female, anterior aspect of left antenna. Fig. 3a.-Female of same, posterior aspect of left antenna. Fig. 3b.-Male of same, club. Fig. 4.- Micracis suturalis (Micracinæ), female, anterior aspect of left antenna. Fig, 4a.-Female of same, posterior aspect of left antenna. Fig. 4b.-Male of same, scape. Fig. 5.- Webbia dipterocarpi (V ebbinæ), anterior aspect of left antenna. Fig. 5a.-Posterior aspect of left antenna of same. (Original.) 
Tech. Series 17, Part II, Bureau of Entomology, U. S. Dept, of Agriculture.

PLATE. XI.
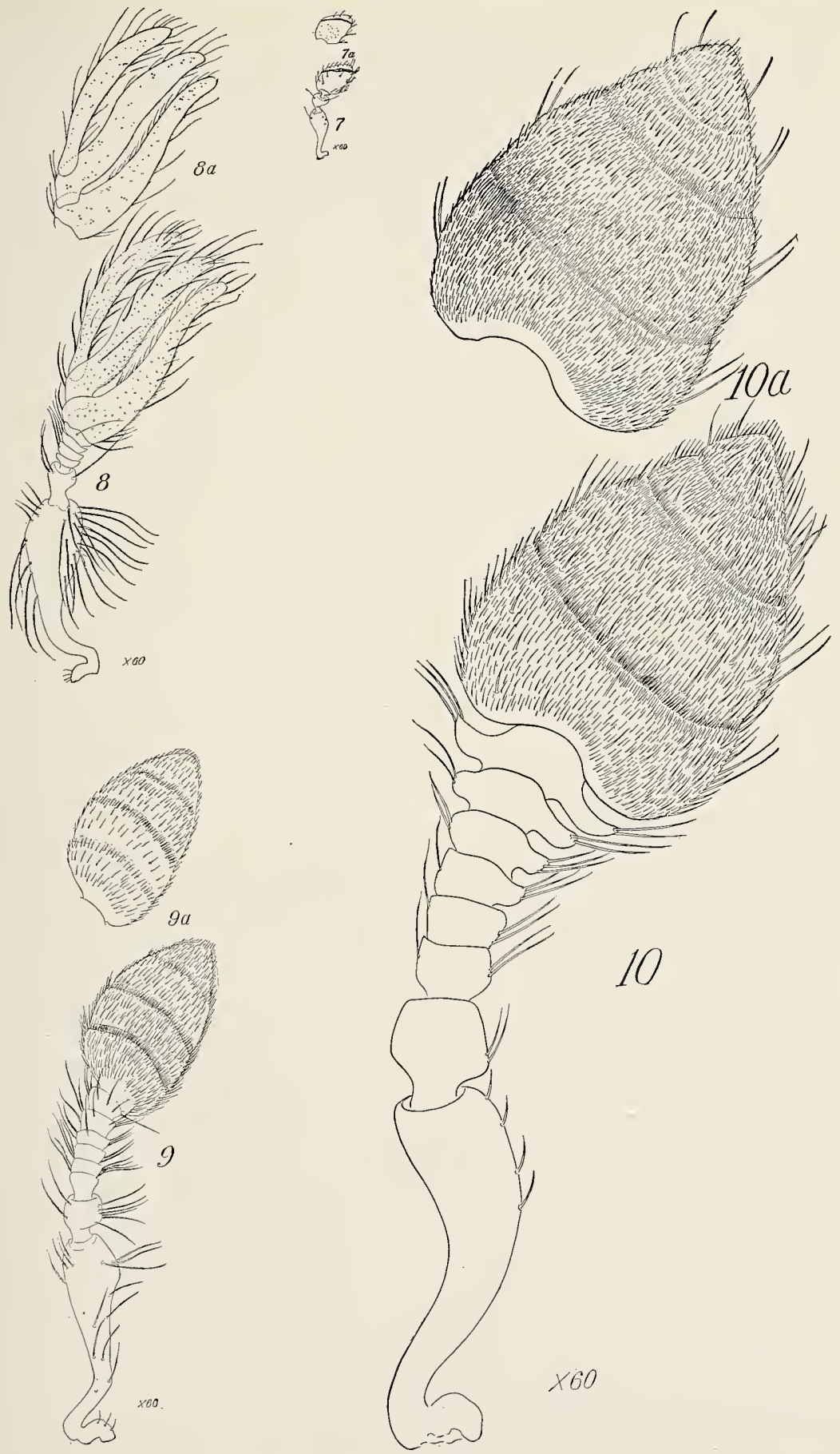

ANTENNAE OF TYPICAL SPECIES OF THE SUBFAMILIES OF SCOLYTOIDEA.

Fig. 7.-Crypturgus pusillus (Crypturginæ), anterior aspect of left antenna. Fig. 7a.-Posterior aspect of left antenna of same. Fig. 8.-Phlootribus ole æ (Phlœetribinæ), anterior aspect of left antenna. Fig. sa.Posterior aspect of left antenna of same. Fig. 9.-Hylesinus crenatus (Hylesininis), anterior aspect of left antenna. Fig. 9a.-Posterior aspect of left antenna of same. Fig. 10.-Phlœoborus redis (Phlœoboring), anterior aspect of left antenna. Fig. 10a. -Posterior aspect of left antenna of same. (Original.) 

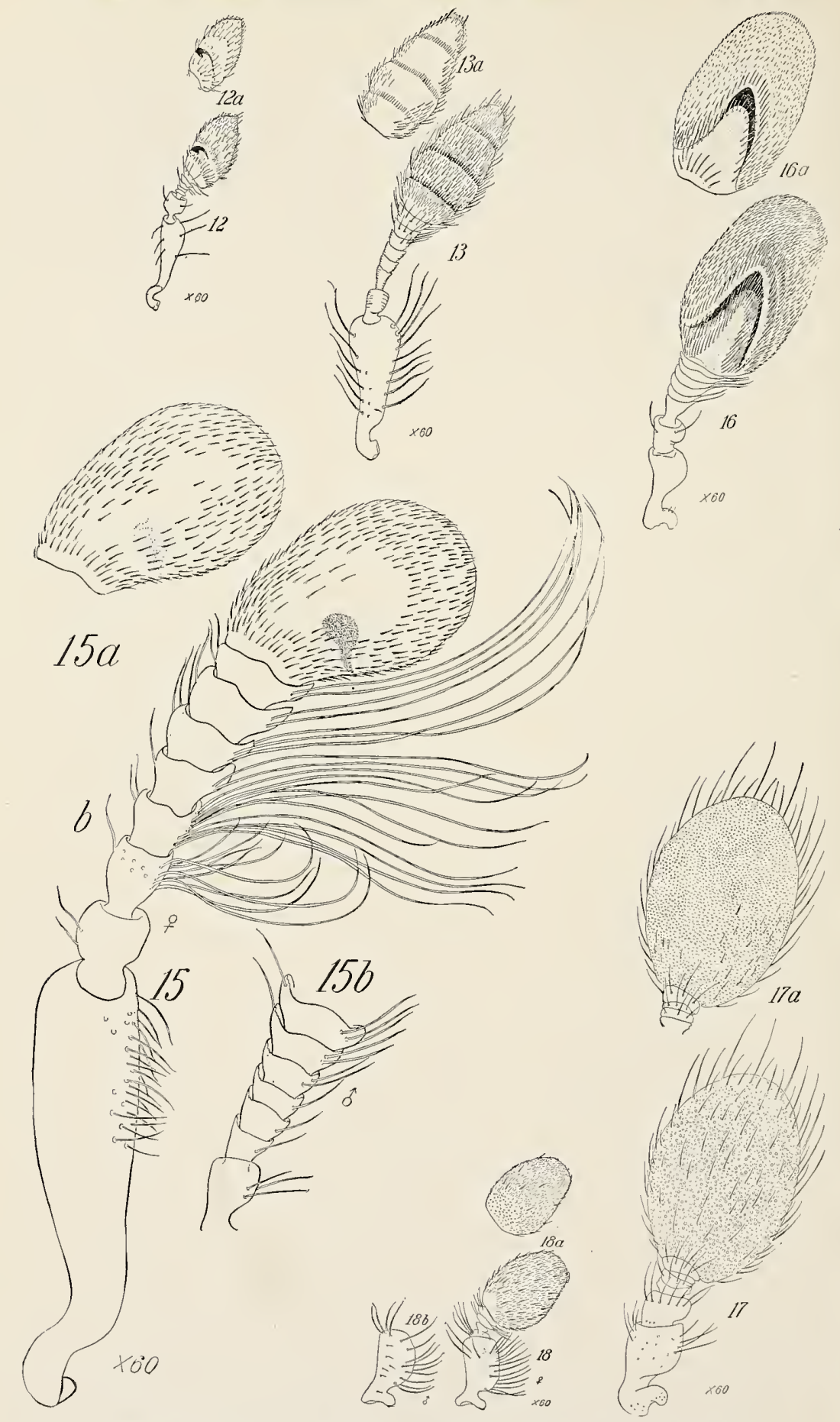

AntenNF of Typical Genera of the subfamilies of Scolytoidea.

Fig. 12.-Hexacolus sp. (Hexacolinæ), anterior aspect of left antenna. Fig. 12u-Posterior aspect of left antenna of same. Fig. 13.-Bothrosternus sculpturatus (Bothrosterninæ), anterior aspect of left antenna. Fig. 13a.- Posterior aspect of left antenna of same. Fig. 15.-Camptocerus æneipcnnis (Camptocerinæ), anterior aspect of left antenna of female. Fig. 15a.-Club of female of same. Fig. 15b. - Scape of male of same. Fig. 16.-Scolytus scolytus (Scolytinæ), anterior aspect of left antenna. Fig. 16ia.-Posterior aspect of left antenna of same. Fig. 17.-Scolytoplatypus sp. (Scolytoplatypodinæ), anterior aspect of left antenna. Fig. 17a.-Posterior aspect of left antenna of same. Fig. 18.-Platypus cylindrus (Platypodinæ), anterior aspect of left antenna of female. Fig. 1sa,-Posterior aspect of left antenna of same. Fig. 1sb.-Male scape of same, (Original.) 
antennæ (145); eyes (143), epistoma (6), front of head (2)-total for head including antennæ (297); pronotum (29), elytra (12), tarsi (8), tibia (6), form of body (5), pygidium (2), abdominal sternites (2), and coxæ (5). Thus it is shown that the most important generic characters are found in the antennæ and eyes.

A summary of the principal character-bearing parts, as recognized by the writer in his preliminary classification, may be tabulated as follows:

TABLE I.-Summary of principal character-bearing parts in the superfamily Scolytoidea.

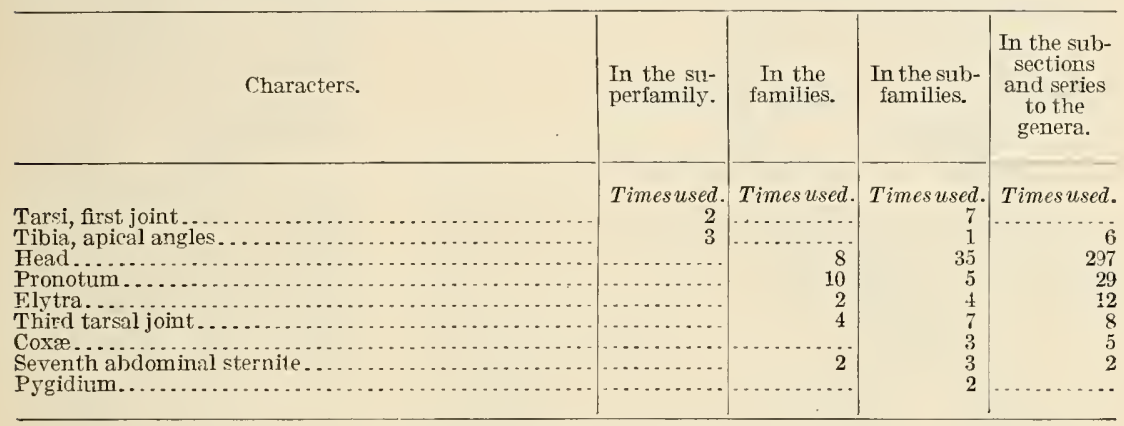

GENERIC CHARACTERS.

The Antennæ.

(Fig. 96; Pls. X-XII.)

ANTENNAL FUNICLE.

The antennal funicle is perhaps the most important taxonomic element of the scolytoid beetles. It is one of the first things to be looked for as a guide to the combination of characters which distinguish the genus and, at the same time, indicate its position in the classification. While the same number of joints may be paralleled many times in the genera of the same subfamily and in different subfamilies, the writer holds that, with very few exceptions, there must be the same number of joints in the funicle of all of the species of a genus. The exceptions are found in Hypothenemus and Stephanoderes, in which the males are smaller than the females and the antennal funicle has a less number of joints. The males in Xyleborus and allied genera are also smaller than the females, but usually have the same number of joints. Occasionally there is a smaller number or other abnormal developments. (See fig. 97.)

The writer's conclusions are based on the study of balsam mounts of representatives of all of the genera which have been available to him, and of a large percentage of the commoner species. It has been found that a normal variation in the number of joints in the 
same sex of the species of a well-defined genus is exceedingly rare. Therefore, an odd number of joints in examples of the dominating sex either indicates an abnormal development or a different genus. If abnormalities occur, they may be easily detected by the combination of other generic characters. The number of joints in the antennal funicle of the scolytoid beetles is limited to seven, and there is

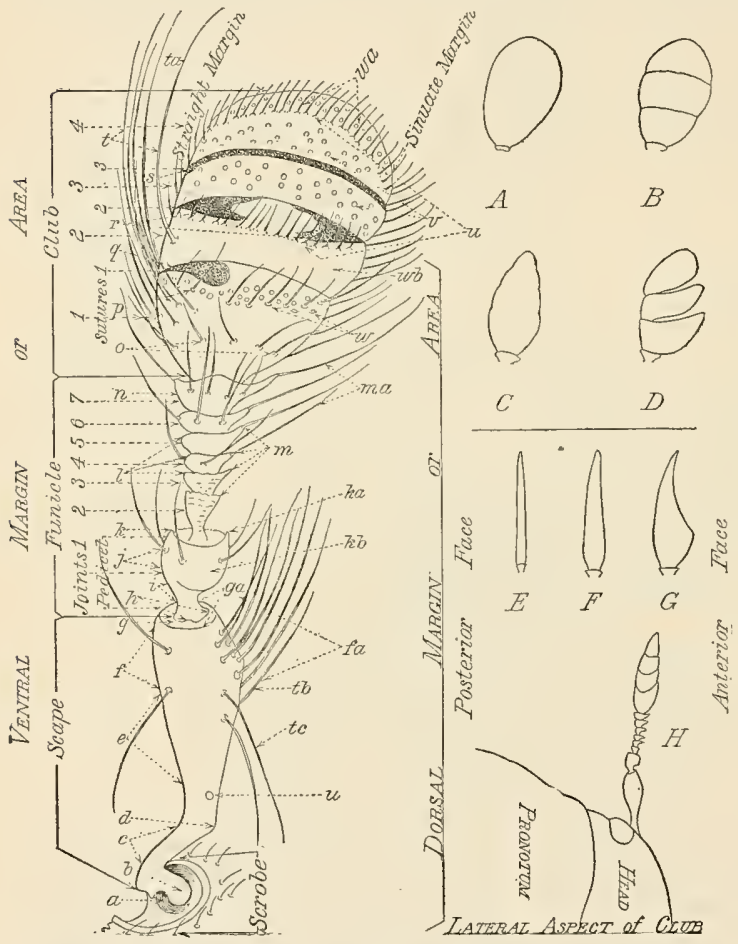

FIG. 96.-The antenna in scolytoid beetles: Diagram and terminology. Scrobc: $a$, Fossa. Scape: $b$, Condsle; c, basal section or neck; $d$, elbow $c$, median section; $f$, apical section; $f a$, dorsal fringe; $g$, apical fossa; $g a$, apical margin. Funicle: $h$, Base or condyle; $i$, basal section; $j$, median section; $k$, apical section; $k a$, apical angle; $k b$, dorsal lobe; $l$, ventral angles of joints; $m$, dorsal angles; $m a$, funicular fringe or dorsal bristles; $n$, apical joint. $C l u b: o$, Basal annulation; $p$, apical or sutural annulation of joint 1 ; $q$, rentral septum or single septum; $r$, dorsal and ventral septa or double septa; $s$, chitinous suture; $t$ ventral fringe; $t a$, ventral bristle; $t b$, procumbent bristle; $t c$, recumbent bristle; $u$, setaceous annulation or sutural annulation; $v$, sensitive pores; $w$, sensitive and setal granules; $w a$, sensitire area; $w b$, chitinous area. Club: $A$, solid; $B$, anmulated: $C$, conical; $D$, separated joints or sublamellate; $E$, compressed: $F$, thickened at base; $G$, obliquely truncate; $H$, antenna extending at right angles to the head. (Original.) probably no normal exception to this in the superfamily, and probably not in the entire Rhynchophora, or, if so, it will be exceedingly rare.

According to the number of joints in the funicle, the 221 genera, including many new ones, are distributed as follows:

TABLE II.-Funicular joints in the superfamily Scolytoidea.

1 joint in 3 genera representing 1 subfamily.

2 joints in 6 genera representing 2 subfamilies.

3 joints in 13 genera representing 4 subfamilies.

4 joints in 44 genera representing 7 subfamilies.

5 joints in 73 genera representing 9 subfamilies.

6 joints in 31 genera representing 9 subfamilies.

7 joints in 51 genera representing 9 subfamilies.

Total, 221 genera representing 16 subfamilies.

Among eight genera of doubtful position the number of joints in the funicle is not given in the description of one genus. Three genera have 5 , one has 6 , and three have 7 joints.

Within the subfamilies the progressive modification in generic characters and characteristics appears to be associated with the

a This table includes eleven recently described genera which have been provisionally referred to subfamilies. 
increase in the number of joints in the funicle. The exception to this rule appears to be shown in the Corthylinæ where the one-jointed and two-jointed funicles are characteristic of genera which, in certain lines, have progressed further than genera in other subfamilies with five, six, and seven joints. But it is by no means certain that these Corthylinæ are not highly specialized survivors of one of the most ancient groups in which a one-jointed funicle became the fixed and dominant character.

It is interesting to note in Table II that the five-jointed funicle is common to the greater number of genera. All but two of the classified genera with a five-jointed funicle fall in the subfamilies of the Ipidæ and the large majority of them in the first division; while the genera with a serenjointed funicle fall in the last part of Division II of the Ipidæ and in the family Scolytidæ.

ANTENNAL CLUB.

The antennal club comes next to the funicle as a bearer of important generic characters. The range in modifieations of form is from a narrow, somewhat com-

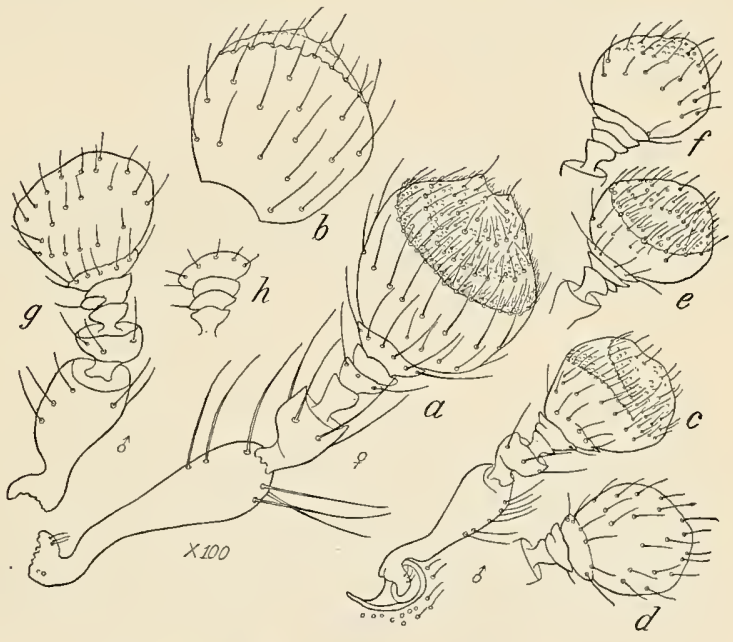

FIG. 97.-Abnormalities in the antennal funicle of Xyleborus tachygraphus: $a$, Anterior aspect of right antenna of female; $b$, posterior aspect of club of $a ; c$, anterior aspect of left antenna of male; $d$, posterior aspect of club and funicle of $c$; $e$, anterior aspect of right club and funicle of same specimen as $c ; f$, nosterior aspect of $e ; g$, posterior aspect of right antenna of another specimen; $h$, anterior aspect of g. (Original.)

pressed and distinctly annulated club like that of Hypothenemus and Pityophthorus to the broad, thinly compressed, thickened at base, obliquely truncated, solid conical, or separated joint form.

In 179 genera 123 have a more or less compressed and annulated club, in 44 the club is thickened at base, and in 12 it is conical. In 170 genera 144 are annulated, 36 not annulated, and in 9 the joints are separated. In 136 genera 52 have sutural septa, 74 are without sutural septa, and 10 have chitinized sutures.

It appears that the chitinized septum of the club, while variable and paralleled in different genera, is a good generic character. The septa vary in number from one to four and usually occur toward the ventral margin, but may also occur toward the dorsal margin of one or two sutures. The range of modification appears to be $59026^{\circ}-15-2$ 
from a club with one or more septa to an annulated club with chitinized sutures and without septa, to a solid club without annulations or septa, or to a conical club with chitinized joints.

The septum is evidently the remnant of the chitinized elements of a movable joint, indicating that the progressive modification of the antemn toward the opposite extreme has been by the process of reduction or fusion of two or more joints, while the modification of the funicle has evidently been along the line of accession by division as is indicated in the funicle of the retrograde sexual forms (fig. 97) and in the nymphs of certain Hemiptera and Isoptera.

Thus we have in a single organ evidence of progressive modification by reversed processes which is not unreasonable and does not necessarily conflict with the facts and principles of other evolutionary processes.

\section{ANTENNAL SCAPE.}

The antennal scape is variously modified from simple and slender to short, stout, dilated, and fringed, but is of less importance as the bearer of generic characters than either the funicle or the club.

\section{The Eyes.}

The eyes are variously modified and range from simple, elliptical, round or oval, to emarginate or completely divided and from widely separated on the dorsal or ventral area to approximate on one or on both areas. In 114 genera the eyes in 65 are simple, in 98 emarginate, and in 10 divided. Among those with simple eyes, 4 have them approximate on the dorsal or ventral areas.

\section{The Mouthparts.}

The characters of the mouthparts have been quite extensively used by systematists in the definition of genera, but while the writer recognizes that some excellent characters are to be found in the mouthparts, he is convinced that they are by no means essential for the definition or classification of the genera. The principal objection to their use, as every systematist has doubtless recognized, is that they are not available for interpretation without mutilating the specimen, which in the case of rare or unique specimens and those from other collections is out of the question. Another serious objection is in the fact that no two balsam mounts of a maxilla of the same species present the same contours and angles, and, therefore, these may appear to be quite different except, perhaps, in the number and relative lengths of the joints of the palpus. 
EPISTOMA.

The epistoma in all of the species examined shows more or less important generic and specific characters. There is a wide range of modification, from a simple, transverse, chitinous piece with few or no epistomal bristles to the epistomal process of Dendroctonus and the exceedingly long epistomal horn of Cactopinus, or the flatitened labral-like form in Pycnarthrum.

\section{HYPOSTOMA.}

The hypostoma is also quite variable and can be used to good advantage in the more detailed definition of a genus or larger group.

LABRUM.

The absence of a true labrum in the adult scolytoid beetle appears to be universal. It has been stated by Eichhoff that it was present in Pycnarthrum, but an examination of a balsam mount has convinced the writer that this is only a produced median area of the epistoma.

\section{CHARACTERS IN GENERAL.}

\section{The Body.}

The size, form, color, vestiture, sculpture, and armature of the body represent characters of more or less importance in indicating lines of progressive modification and as aids in generic and specific definition. The size ranges from 0.4 or $0.5 \mathrm{~mm}$. in the males of some Hypothenemus to $13 \mathrm{~mm}$. in Phlooborus. While there is more or less variation in the size of the individuals of a species, the length is important not only as a guide to the recognition of a species but as an index to its proper position in the minor section of the genus to which it belongs. The writer has found that, as a rule, the smaller species of a division, subdivision, or section of a genus will, according to other correlated characters, occupy a position opposite to that of the larger species. In the system adopted by the writer the genera with the average smaller species come first in the subfamily and in each primary and minor division, and in the genus the smaller forms, as a rule, precede the larger. There are, of course, exceptions to this rule, especially in genera with few and widely separated species.

FORM.

The form of the body ranges from elongate and slender to short and stout, and it would appear that the range in progressive modification is from the slender to the stouter forms. 
COLOR.

The color, except in a few genera, is of little taxonomic importance. It ranges from pale yellow through yellowish red, reddish brown, brown, and black. In a few genera the chitinous integument of the elytra or other parts of the body is bicolored; in others the variegated color is confined to the vestiture. Metallic and iridescent colors are rare.

\section{VESTITURE.}

The vestiture is of considerable taxonomic importance. It consists of scales, stout hairs, barbed hairs, plain hairs, fine pubescence, gummy exudations, or adherents. The range in progressive modification of the vestiture appears to be from scales to stout hairs, from barbed hairs to simple hairs, and from a sparsely pubescent to an entirely glabrous body.

\section{SCULPTURE.}

In the sculpture of the body there is endless variety. It may be rugose or smooth, the rugosity fine or coarse, the punctures sparse or dense, arranged in rows or confused, regular or irregular in size, irregularly distributed on given areas, etc. Some of the elements of sculpture, such as the rugose or smooth pronotum, are of value in separating the major and minor groups of the families, but the characters of the rugosities and punctures are of special value in defining the smaller groups and species. Concavities and convexities of the front of the head and of the apical declivity of the elytra are often important generic, specific, and secondary sexual characters.

\section{ARMATURES.}

The armatures of the pronotum, head, and elytra are important in the definition of genera, species, and sexes. The armature of the head reaches its extreme development in the epistomal horn of Cactopinus. The armature of the declivity is strongly developed in Xyleborus, Xylocleptes, and Eccoptopterus of the Cryphalinæ; in Pityogenes and lps of the Ipinæ; in Hylocurus in the Micracinæ; in Monarthrum and Amphicranus of the Corthylina, and in most of the genera of the Platypodinæ. As a rule the modification from a simple unarmed body to one with moderately or strongly armed parts is correlated with other elements of progressive modification. The serrate armature of the anterior margin of the pronotum is of considerable taxonomic importance. The apical serrations are common in the Cryphaline and Ipine, but rare or absent in the other subfamilies. The extremes in apical armature are found in Hypothenemus miles Lec., and in some other species, as, for example, the 
males of certain species of Xyleborus, and in Amphicranus fastigatus Blndfd. The modification of the apex appears to progress from an apically serrate to a simple one or to one with an apical process.

IIEAD.

The head is the most important part of the body in representing the greatest number of taxonomic characters. Its modification is from a short and narrow or broad and globular form concealed from above by the pronotum, toward a narrow elongate form exposed beyond the apical margin of the pronotum. The tendency toward the prolonged subrostrate form indicates a line of progressive modification which is characteristic of the major and minor groups of all of the Rhynchophora, the extremes of which are found in the small, short, globular head of the Ipidæ and the exceedingly prolonged beak of Apion, Balaninus, and other genera. In the Scolytoidea, Cosmoderes to Stephanoderes of the Cryphalinæ have the shortest, simplest head, while the extreme is reached in certain genera of the Hylesininæ, Hexacolinæ, and Chapuisinæ, with the extreme, or nearest approach to Curculionidæ, in Hylurgops and Hylastes. With a few exceptions the concealed head is characteristic of the first division of the Ipidæ and the Scolytidæ, while the exposed head is characteristic of the second division of the Ipidæ and the Platypodidæ. The antennæ, eyes, and mouthparts have been discussed in preceding pages. The front of the head is of special importance in defining the species and. sexes, and ranges from convex and glabrous to deeply concave and densely pubescent.

\section{PROTHORAX.}

The prothorax (Part I, figs. 16 and 17, pp. 23-24) represents a wide range of progressive modification from long and narrow to short and broad; the pronotum with sides and base not margined to margined and simple or to emarginate, while the anterior dorsal area ranges from closely and finely rugose to coarsely asperate, and from alutaceous or opaque to smooth and shining. The pleura range from convex to flat and concave, the anterior coxæ from contiguous to widely separated, and the sternal, sternellar, and poststernellar areas vary with the form of the prothorax and the size and position of the coxæ. The vestiture and sculpture of the anterior median and posterior dorsal and lateral areas often represent generic and specific characters of special importance.

MESOTHORAX.

The mesothorax (Part I, figs. 18, 19) is exceedingly variable, conforming to the variable form of the body. It doubtless contains many group, generic, and specific characters which may settle difficult 
questions of distinction and definition and should be considered in all detailed studies of single genera and allied groups of genera. The scutellum has been extensively used by systematists, and a detailed comparative study of this element in a wide range of genera and species should be made to determine its real significance in taxonomy. The pleurum (Part I, fig. 19) is also exceedingly variable in the form and sculpture of the epimeron, episternum, and preepisternum, while the remarkable structure designated as the preepisternal process (Part I, p. 29) is of special taxonomic importance since its presence or absence is peculiar not only to groups and divisions of the Scolytoidea but to many other groups of Coleoptera, and evidently represents an extreme in progressive modification which, in connection with other progressively modified elements, will doubtless serve as an index to the systematic position of genera and species. The elements of the sterna (Part I, fig. 18) are also variable, but, like the prosterna, their modification conforms to the variable form of the body, and they are of less importance than the more independent structures like the scutellum and preepisternal process.

\section{METATHORAX.}

The metathorax (Part I, figs. 20, 21) is quite variable in general characters and especially so in some of the elements of the tergum, probably due to the variable form of the body and the requirements of flight. There is considerable variation of this element within the species of a genus and often there are wide differences in allied genera. Perhaps the element subject to the greatest variation is the postscutellum, which ranges from obscure or rudimentary to almost the length of the combined anterior elements. The scutellar groove, the transverse sutures, and the entothoracic ridges or apodemes are also quite variable. The writer has examined the metatergum of quite a large number of species and it would appear that there may le in it some important characters peculiar to minor groups of genera, but the taxonomic value of the variations is largely limited to the species. It would therefore be difficult to trace correlated lines of progressire modification. Nevertheless, a special comparative study of the metathorax should be made of a very large number of examples representing all of the genera to determine whether or not there are special taxnnomic elements or recognizable lines of modification. The episternum (Part I, fig. 20) is quite variable in length, width, sculpture, and restiture and is of considerable taxonomic importance. The metasterna are also variable in conformity with the variable form of the body. The sternum always occupies the greater part or nearly all of the area. The greatest range of rariation between the elements of the metathorax is to be found in the short and broad forms of the stouter species of the Ipidæ and Scolytidæ and the exceedingly long and narrow forms peculiar to the Platypodidæ. 

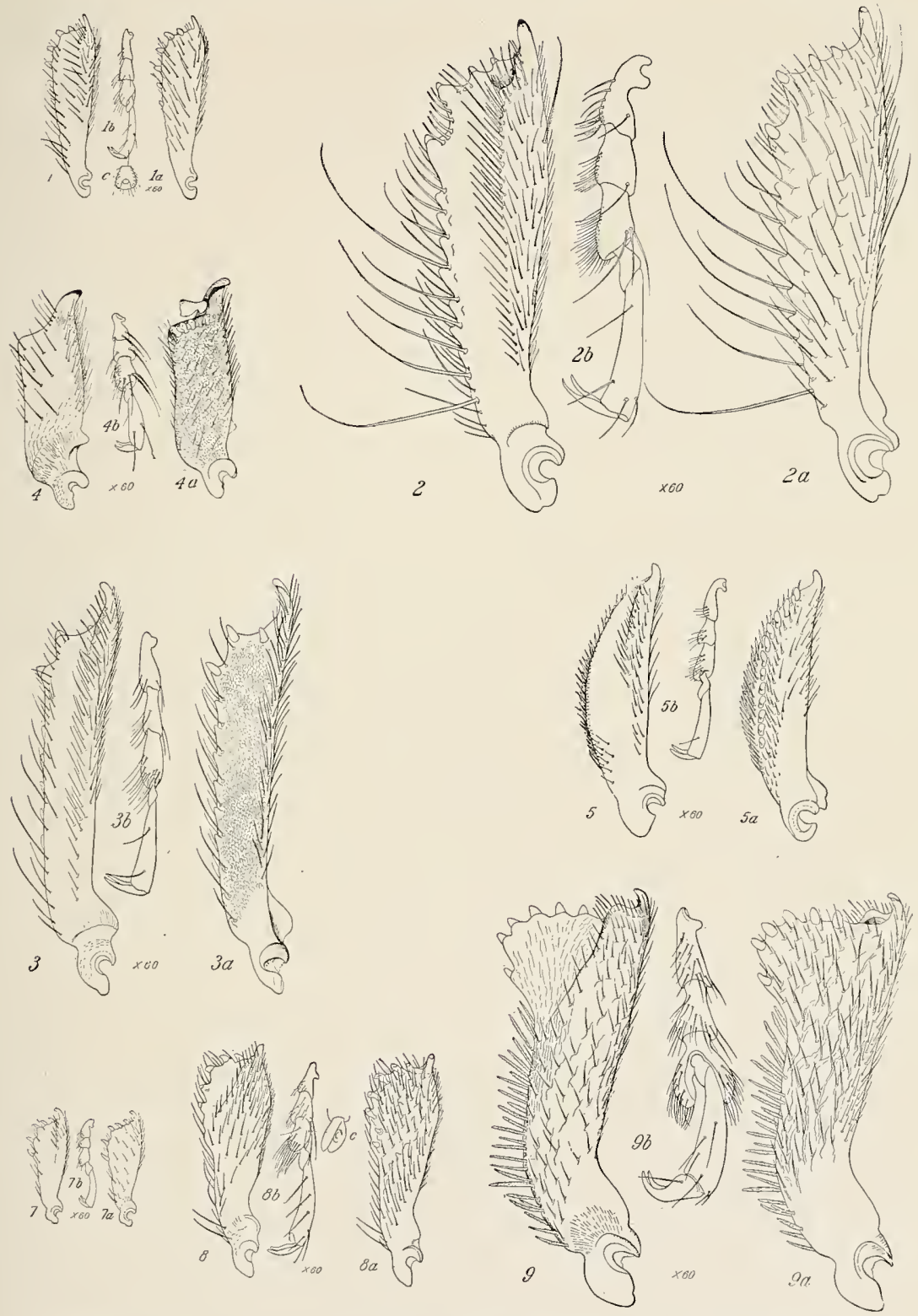

TIBIE AND TARSI OF TyPICAL SPECIES OF THE SUbFamilies of SCOLYTOIdea.

Fig. 1.-Cryphalus asperatus (Cryphalinæ), left tibia, dorsal aspect. Fig. 1a.-Left tibia of same, rentral aspect. Fig. 1b.-Tarsus of same, lateral aspect; $c$, third tarsal joint, dorsal aspect. Fig. 2.Ips typographus (Ipinæ), left tibia, dorsal aspect. Fig. 2a.-Left tibia of same, ventral aspect. Fig. 2b.- Left tarsus of same, lateral aspect. Fig. 3.-Corthylus columbianus (Corthylinæ), left tibia of same, dorsal aspect. Fig. 3x.-Left tibia of same, ventral aspect. Fig. 3b.-Left tarsus of same, lateral aspect. Fig. 4.-Micracis suturalis (Micracinæ), left tibia, dorsal aspect. Fig. 4x.Left tibia of same, ventral aspect. Fig. $4 b$. - Left tarsus of same, lateral aspect. Fig. 5.- Hebbia dipterocarpi (Webbinæ), left tibia, dorsal aspect. Fig. 5a.-Left tibia of same, rentral aspect. Fig. 5b.-Left tarsus of same, lateral aspect. Fig. 7.-Crypturgus pusillus (Crypturginæ), left tibia, dorsal aspect. Fig. $7 a$-Left tibia of same, ventral aspect. Fig. $7 b$-Left tarsus of same, lateral aspect. Fig. 8.-Phlœotribus oleæ (Phlœotribinæ), left tibia, dorsal aspect. Fig. Sa.-Left tibia of sams, ventral aspect. Fig. $8 b$.- Left tarsus of same, lateral aspect; $c$, third tarsal joint of same, subdorsal aspect. Fig. 9.- Hylesinus venatus (Hvlesininæ), left tibia, dorsal aspect. Fig. 9a.-Left tibia of same, ventral aspect. Fig. $9 b$.-Tarsus of same, sublateral aspect. (Original.) 



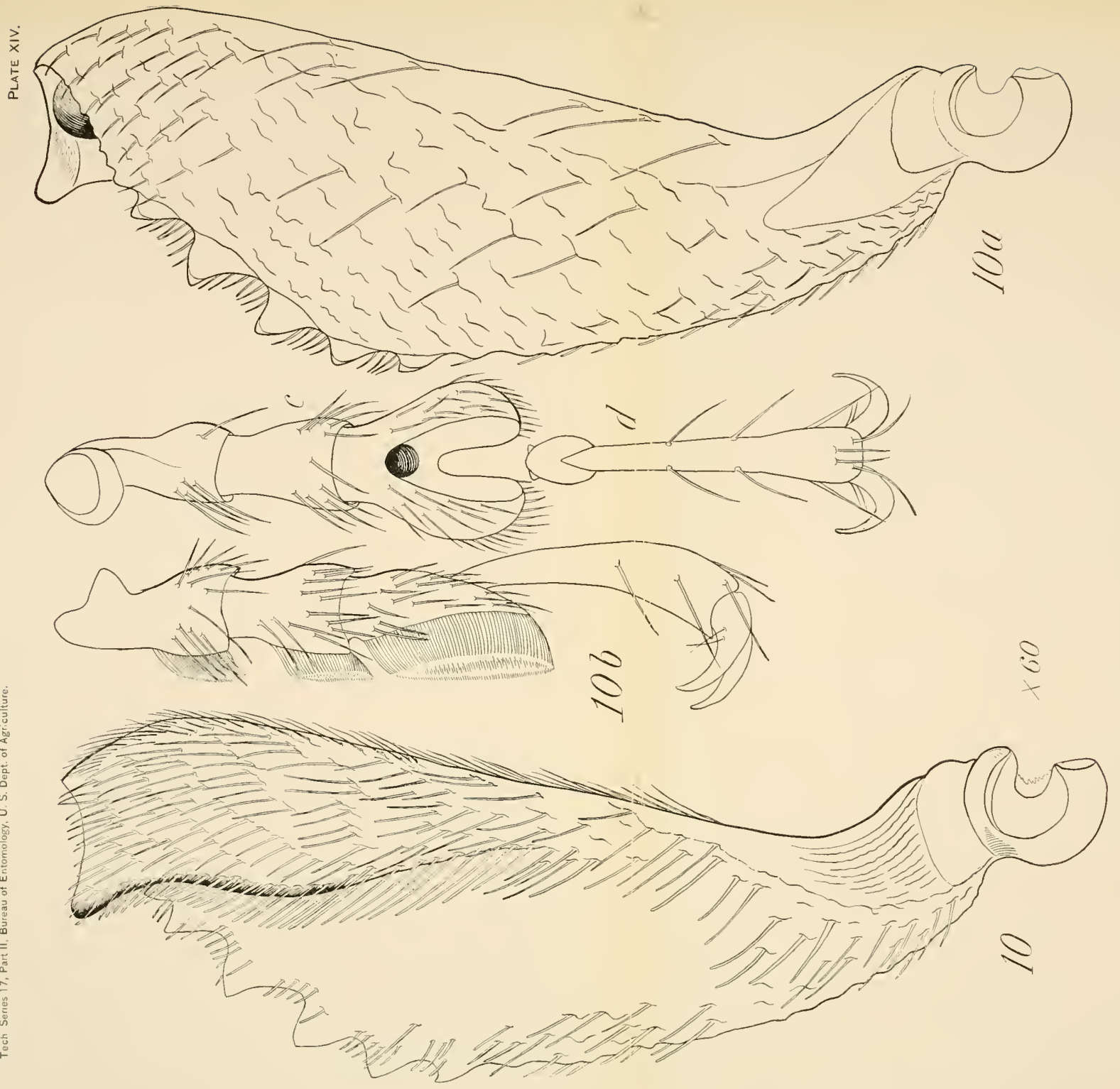




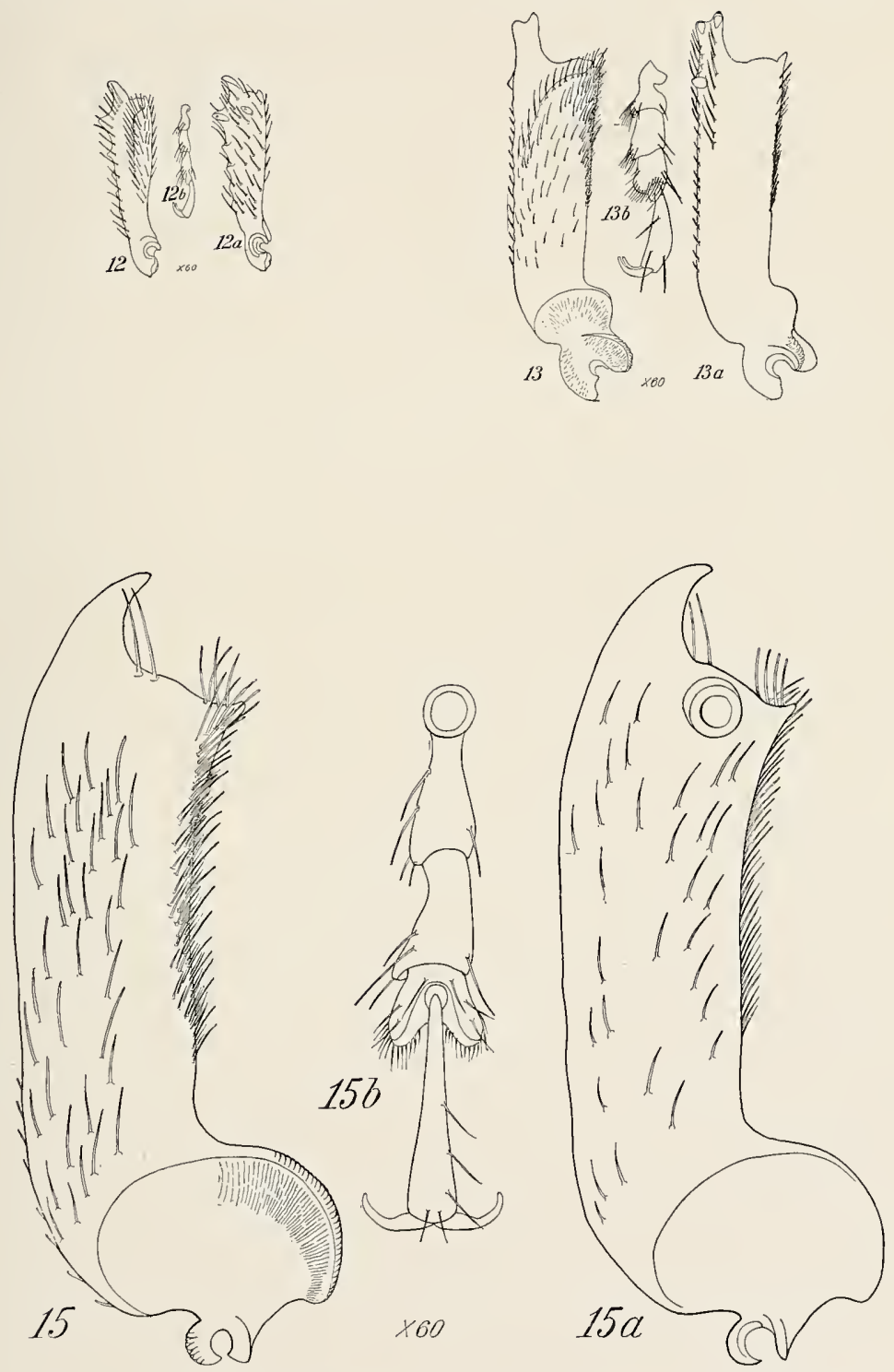

TIBIE AND TARSI OF TYPICAL SPECIES OF THE SUbFamilies OF SCOLYTOIDEA.

Fig. 12.-Hexacolus sp., left tibia, dorsal aspect. Fig. 12a.-Left tibia of same, ventral aspect. Fig. 12b.-Left tibia of same, lateral aspect. Fig. 13.-Bothrosternus sculpturatus (Bothrosterninæ), left tibia, dorsal aspect. Fig. 13a. - Left tibia of same, rentral aspect. Fig. 13b.-Left tarsus of same, lateral aspect. Fig. 15.-Camptoccrus æneipennis (Camptocerinæ), left tibia, dorsal aspect. Fig. 15a.-Left tibia of same, ventral aspect. Fig. 15b.-Left tarsus of same, dorsal aspect. (Original.) 

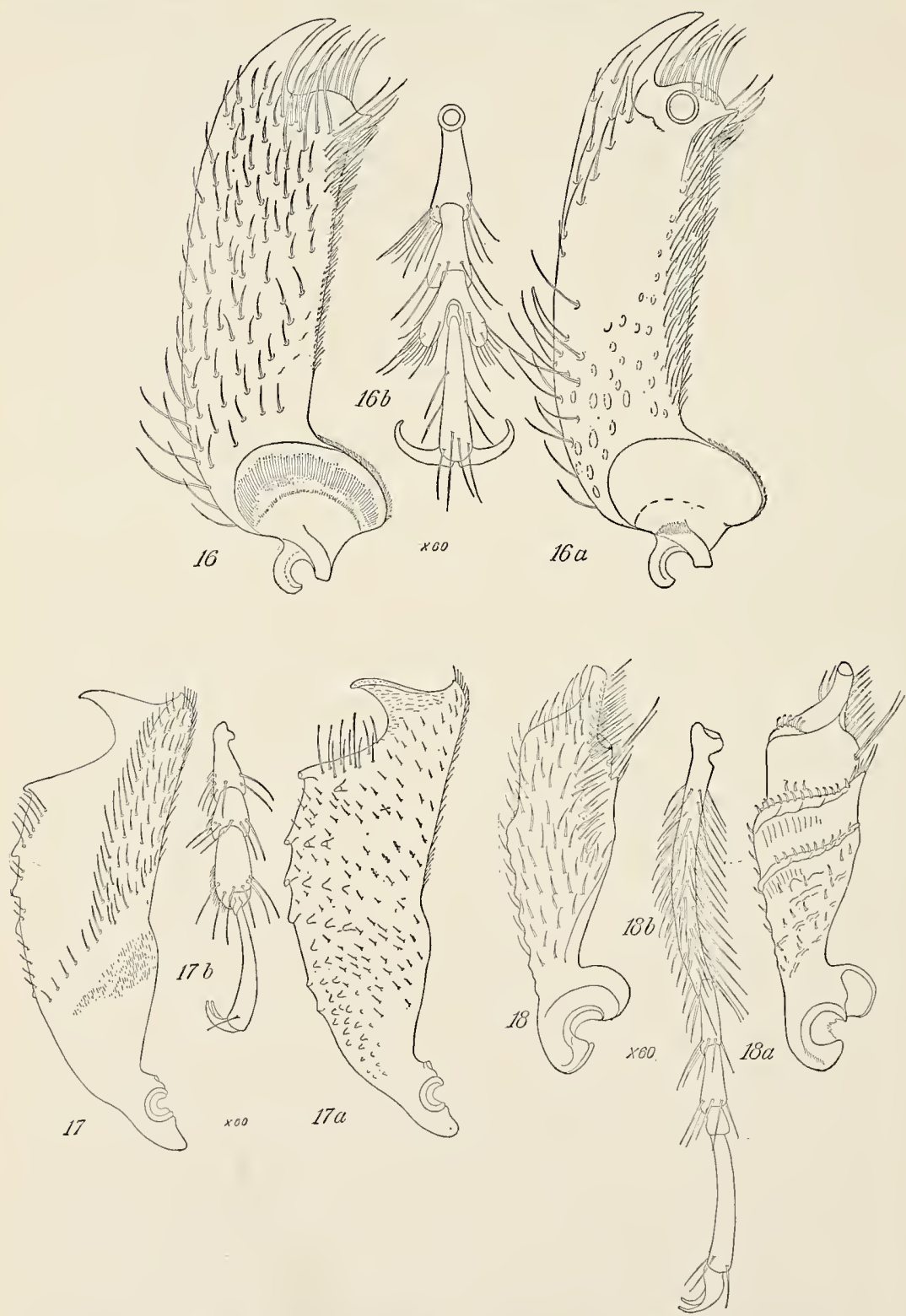

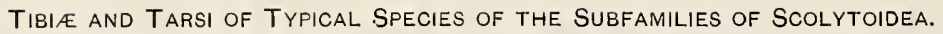

Fig. 16.-Scolytus scolytus (Scolytinæ), left tibia, dorsal aspect. Fig. 16a.-Left tibia of same, ventral aspect. Fig. 16b. - Left tarsus of same, dorsal aspect. Fig. 17.-Scolytoplatypus sp. (Scolytoplatypodinæ), left tibia, dorsal aspect. Fig. 17a.-Left tibia of same, ventral aspect. Fig. 17b.-Left tarsus of same, dorsal aspect. Fig. 18.- Platypus cylindrus (Platypodinæ), left tibia, dorsal aspect. Fig. 18a.-Left tibia of same, ventral aspect. Fig. 18b. - Left tarsus of same, lateralaspect. (Or iginal.) 
LEGS.

There is a wide range of variation in the form, color, sculpture, and relative proportions of the coxa, trochanter, tibia, and tarsus of the anterior, median, and posterior legs. (Part I, figs. 1, 3, 26-29.) ${ }^{a}$ The anterior tibia and tarsus are of special taxonomic importance in distinguishing the primary and secondary divisions of the superfamily and, to a less extent, in distinguishing the primary or minor groups of the families, subfamilies, and genera. (Pls. X, XIII-XVI.) The variation in the tibia is from a simple, compressed, slightly dilated form with the outer margin serrate, as in Hypothenemus, to a short, broad form with parallel, smooth margins, as in Micracis and Scolytus, or broader at the base, as in Webbia and Hypoborus, and to extreme and odd forms as in Platypus. The character of the vestiture usually conforms to that of the body, such as scales, barbed hairs, and simple hairs, varying in distribution and density on the ventral and dorsal areas and the margins. The sculpture ranges from smooth to imbricate and from irregular rugosities to prominent ridges, the latter reaching a maximum development in Platypodidæ. The tarsi vary in form from slender to stout and the joints in relative lengths, widths, and vestiture. The third joint varies from simple to emarginate and deeply bilobed, with the ventral surface ranging from nearly glabrous to pubescent and to densely padded, which latter extreme is found in Phlooborus.

\section{ELYTRA.}

The elytra, or anterior wings, are exceedingly variable in form, vestiture, and sculpture, ranging from the simple types with scales, fine punctures, and obscure striæ which are not impressed, as in Hypothenemus, to the forms with hairs and with distinctly impressed striæ and elevated interspaces, the latter with rugosities and rows of punctures or smooth and without punctures; the base from plain to strongly elevated and serrate; the sides from parallel to converging posteriorly or strongly rounded; the dorsal area from flat and straight to convex and strongly rounded from base to apex; the declivity from plain, steep, and convex to retuse or armed and strongly oblique from base to apex, and the side margins from serrate to straight or emarginate. With all of these almost endless variations and their different combinations of elements there is available a profusion of characters for the definition of groups of genera and species.

\section{POSTERIOR WINGS.}

The true functional wings, as pointed out by Nüsslin (1911), are quite variable in form, proportions, and character of the venation and represent two specified types, one with and the other without

a Figures 26-29, Part I, represent the reverse faces of the right instead of the left tibia, a mistake which was unfortunately overlooked in the manuscript and proofs. 
a basal lobe. The witer has given considerable attention to the study of the wings of the Scolytoidea and other insects, but he has failed to find any constant and readily recognizable characters in the Scolytoidea which appear to be of sufficient taxonomic value to justify giving them special attention. If there is any particular line of progressive modification in the wings it is to be found in the subfamilies and minor groups, in which the range appears to be from a simple type, like that of Hypothenemus, Cryphalus, and Crypturgus, with a narrow, simple base, long fringe, and simple venation, toward a broader base, lobed or not, and with an increasing number and complexity of veins. The writer realizes that the complex type of venation is generally supposed to be more primitive than the simple type with few or no veins, but he is by no means convinced that this is the correct interpretation as applied to the wings of all insects. The wings in different orders of insects may be, in spite of the prevailing opinion, the result of independent origin from simple types of primitive winglike processes, and their evolution may have been influenced by two primary factors: (1) A dominant tendency to perpetuate and promote lines of modification peculiar to and in conformity with the dominant morphologica! characters peculiar to the order, and (2) adjustment of this modification to the peculiar mechanical needs of the varying related forms, with frequent examples of parallel modifications in unrelated species.

In Nüsslin's table (1911, pp. 302-304) the wings without basal lobes are found in widely separated genera, representing, according to the present writer's classification, two families (Ipidæ and Scolytidæ) and five subfamilies, while the wings with basal lobes are found in five subfamilies of the Ipidæ. It is evident that whenever the wings are studied in their relation to other of the more important taxonomic characters and characteristics of the species, the variations noted by Nüsslin will be of considerable value in the definition of minor groups of genera and species, but the difficulty of spreading the wings and securing good balsam mounts will preclude their general use.

\section{ABDOMINAL TERGITES.}

The general character of the abdominal tergites is shown in Part I, figures 22, 23, and 24. While there is considerable variation in the first to sixth tergites, inclusive, in the same individual and between individuals of different species, the seventh and eighth are the ones of special importance in the identification of the genus or sex. According to Nüsslin (1911), who examined 16 genera, the eighth tergite is not covered in either sex in 11 genera, and is exposed in the male and covered in the female in 5 genera. The writer has found 
the eighth to be uncovered in both sexes in three genera, uncovered in the male and covered in the female in 13 genera, and covered in both sexes in 3 genera.

According to the writer's classification, the 31 genera in which species were examined by Nüsslin and the writer represent the following subfamilies:

TABLE III.-Abdominal tergites in the subfamilies of Scolytoidea in which species were examined by Nüsstin and the writer.

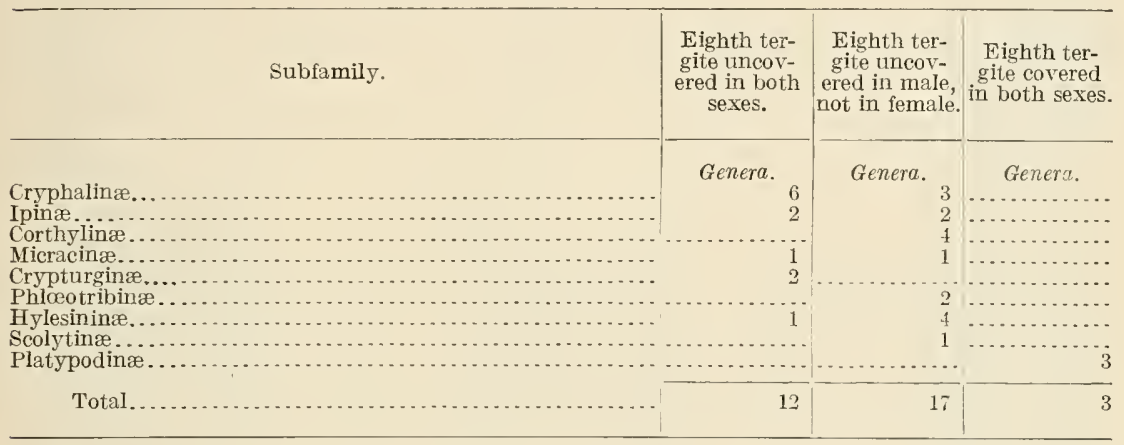

From the foregoing it will be secn that the characters of the seventh and eighth tergites are paralleled in widely separated genera and subfamilies. The writer has found that the eighth tergite may or may not be exposed or covered in the same genus or in individuals of the same species, especially in Platypus, where the eighth tergite is of the same or similar form in both sexes and may be covered or not, depending upon the expansion or contraction of the abdomen. It is evident that a much more extensive study of these elements is necessary before any conclusions are warranted as to their taxonomic value or lines of progressive modification. In a number of genera the seventh or eighth tergite, or both, is exposed beyond the apex of the elytra and is either oblique, declivous, or vertical. The ninth and tenth tergites are absent as such or are modified into elements of the genital organs.

\section{ABDOMINAL SPIRACLES.}

According to Nüsslin (1911) and Fuchs (1912) the number of functional abdominal spiracles (stigmata) ranges from five to seven. The larvæ and pupæ, so far as studied by the writer, have eight.

The spiracles are variable in structure and doubtless, upon further investigation, will furnish excellent taxonomic characters. The writer, however, is doubtful as to the phylogenetic significance of the variability in number. The genera given by Nüsslin (1911, pp. 2-5) and Fuchs (1912, pp. 13-14) which are represented by species having 
from five to eight spiracles fall into the following subfamilies as recognized by the writer:

TABLE IV.-Abdominal spiracles in the subfamilies of Scolytoidea in which species were examined by Nüsslin and Fuchs.

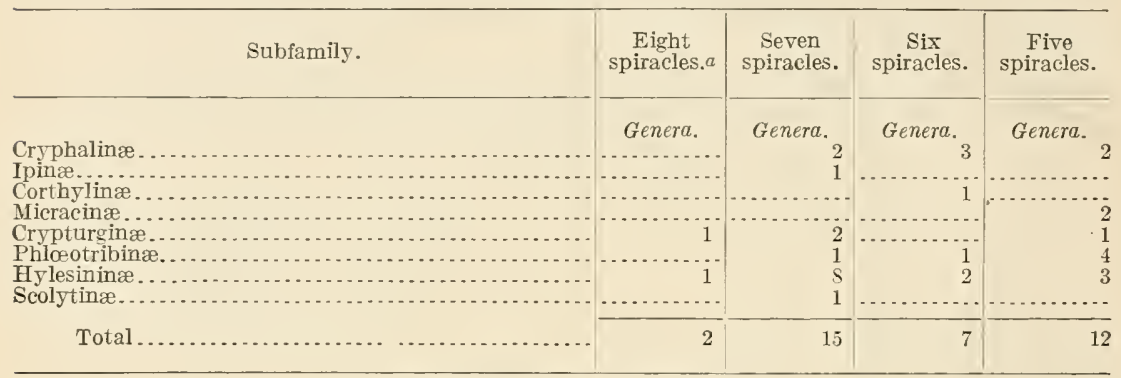

a The eighth spiracle is rudimentary.

In the genus Hylesinus (Fuchs, ibid., p. 13) there are from five to seven spiracles with the sixth and seventh rudimentary, while in Dendroctonus and Hylurgops the eighth is rudimentary. Doubtless if the number of abdominal spiracles were determined for all of the species, some good evidence would be furnished as to lines of modification.

\section{ABDOMINAL STERNITES.}

The abdominal sternites 1 and 2 are fused and concealed in the coxal carity, 3 to 7 are exposed, and the eighth is covered by the seventh, while the ninth and tenth evidently are represented by the genital organs. (See Pt. I, pp. 25 and 38, and Technical Series 20, Pt. I, Pls. VII, VIII, and IX, as also the discussion of the reproductive organs in the present paper.) The exposed sternites are quite variable in the different genera and species, and certain characters are of value in designating minor groups of genera, but few, if any, are common or peculiar to a subfamily.

The modifications range from the simple type found in the Cryphalinæ to the steep, excavated, armed, and odd forms of the Scolytidæ and Platypodide. There is a wide variation, which is apparently of specific importance, in the eighth ventral segment. The palpi of the ninth ventral segment (Nüsslin, Fuchs, and others) found in the females of Scolytus and Hylesinus, may after all represent the tenth tergite or sternite, one or both of which may be represented by the oripositor as in certain Curculionoidea (Pissodes), Cerambycoidea (Cyllene), and many other insects. But this is a matter iequiring more comprehensive investigation.

\section{STRIDULATING ACCESSORIES.}

The stridulating accessories hare not been inrestigated by the writer in many genera but they appear to be confined largely to the seventh abdominal tergite and the inner subapical area of the elytra 
(Part I, figs. 23, 31, and 33) and to the anterior margin of the pronotum and the posterior dorsal area of the head.

\section{Internal Anatomy.}

Considerable study has been made by Lindemann, Nüsslin, Fuchs; and others, of certain elements of the internal anatomy, especially the proventriculus of the digestive system and the male and female reproductive organs. It is evident, however, from a review of the

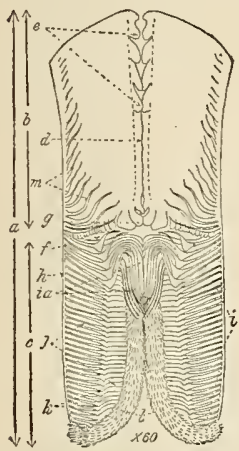

FIG. 98.-Proventricular plate of Ips aspect: $a$, Entire plate; $b$, divided anrior or masticatory plate; $d$, median Iongitudinal suture $\ell$, sutural teeth; $f$, median transverse suture; $g$, transverse or apical teeth of anterior plate; $h$, lateral margin or marginal suture; $i$, lateral or masticatory teeth; $i a$, closing bristles or teeth; $j$, femora of the masticatory teeth; $k$, femoral teeth or ridge; 7 , masticatory brush; $m$, marginal bristles or fringe. (Original.) emarginatus, inner terior plate; $c$, poste-

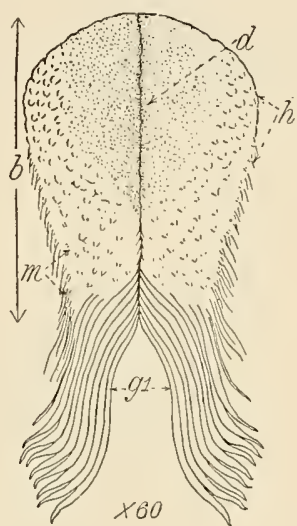

Fig. 99.-Proventricular plate of Scolytus scolytus: $b$, Divided anterior plate; $d$, median suture; $h$, lateral margin; $g 1$, apical laminate teeth of posterior plate. (Original.)

results, that as a sufficient basis for general or specific conclusions a far more comprehensive study is necessary.

\section{DIGESTIVE SYSTEM.}

The general type of the digestive system is shown in Part I, figures 35 and 36 , for the adult and figure 43 for the larva. Lindemann (1876, pp. 148-169), Nüsslin (1912, pp. 85-87, figs. 135-143), and Sedlaczek (1902, pp. 241-263, figs. 1-20) show that there is a wide variation in some of the elements and especially in the proventriculus and the median and posterior section of the midintestine, but to what extent these variations are of value in taxonomy has not been determined.

\section{Proventriculus.}

The proventriculus (figs. 98-100; Part I, figs. 35-38) is of special interest, and the work of Lindemann, Fuchs, Nüsslin, and others has contributed much valuable information on the structural elements. 
There is a wide range of variation in the proventricular plates and their armatures, such as the various divided and undivided forms with and without the "brush" of fine masticatory teeth. These variable forms appear to be of considerable taxonomic importance when correlated with other internal and external characters.

The classification proposed by Lindemann and Nüsslin, as based on the structural characters of the proventricular plates, with a few plainly evident exceptions, correlates in a striking manner with the external characters adopted by the writer for the major and minor groups of genera. When the principle of parallel modification is considered, the genera which seem to be out of place in the classifi-

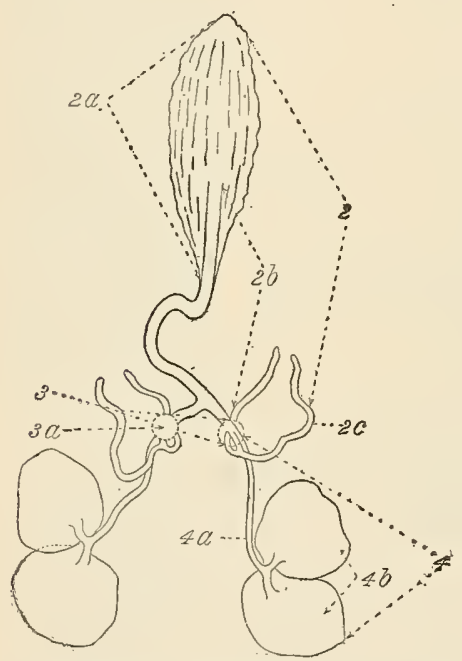

FIG. 101.-Dendroctonus valens: Membranous and nonchitinous elements of the inale reproductive organs. See terminology under Divisions 2, 3, 4, pp. 192-193. (Original.)

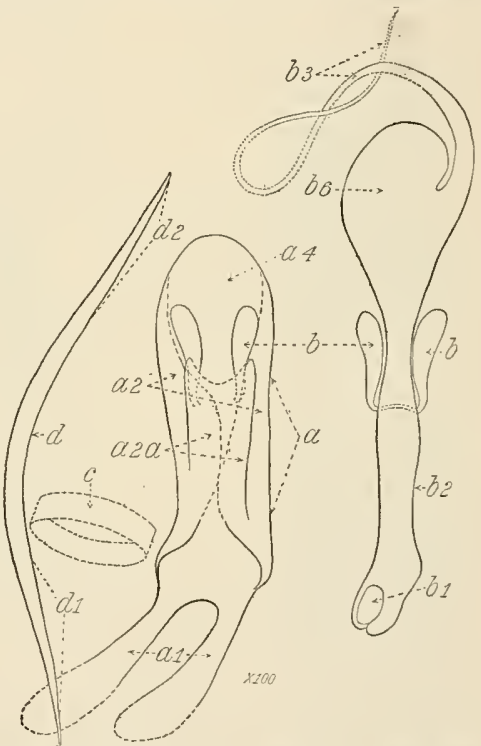

Fig. 102,-Xyleborus saxeseni- Chitinous elements of male reproductive organs. See terminology, Division 1, pp. 192-193. (Original.)

cations based on proventricular characters alone will, when correlated with a combination of characters, fall into their natural positions.

\section{REPRODUCTIVE ORGANS.}

The Reproductive Organs of the Male.

The reproductive organs of the male (figs. 101-110) have been studied and figured by several investigators as follows:

TABLE V.-Summary of previous studies of the male reproductive organs by various authors.

\begin{tabular}{|c|c|c|c|c|}
\hline Author. & 7 & $\begin{array}{l}\text { Year of } \\
\text { publi- } \\
\text { cation. }\end{array}$ & $\begin{array}{l}\text { Number } \\
\text { of species } \\
\text { figured. }\end{array}$ & $\begin{array}{l}\text { Number } \\
\text { of genera } \\
\text { repre- } \\
\text { sented. }\end{array}$ \\
\hline 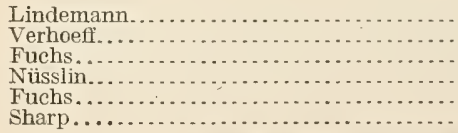 & n. & $\begin{array}{l}1575 \\
1896 \\
1911 \\
1912 \\
1912 \\
1912\end{array}$ & $\begin{array}{r}32 \\
3 \\
20 \\
24 \\
30 \\
2\end{array}$ & $\begin{array}{r}15 \\
3 \\
4 \\
22 \\
27 \\
2\end{array}$ \\
\hline
\end{tabular}


In addition to the foregoing, the writer, during the years from 1892 to 1912 , has studied the male reproductive organs of 68 species, representing 43 genera. The total species studied by all authors, without duplication, is 147 , representing 57 genera.

The reproductive organs of the male represent four primary divisions or elements: (1) The posterior chitinized division (fig. 102); (2) the posterior membranous division (fig. 101), (3) the median division, and (4) the anterior division. (See terminology, pp. 192-194.)

POSTERIOR ELEMENTS.

The posterior chitinized elements (division 1) consist of four primary sections, $(a)$ the body, $(b)$ the end plates, (c) the tegmen, and $(d)$ the spicule. In addition to these more constant elements there are (b1) the seminal valve and (b2) the seminal rod, both of which appear to be more intimately associated with element $b$ than with element $a$; also, there are $(e)$ the connecting membrane and $(f)$ the muscles. From a somewhat comprehensire study of the chitinized elements in the scolytoid beetles in comparison with those in

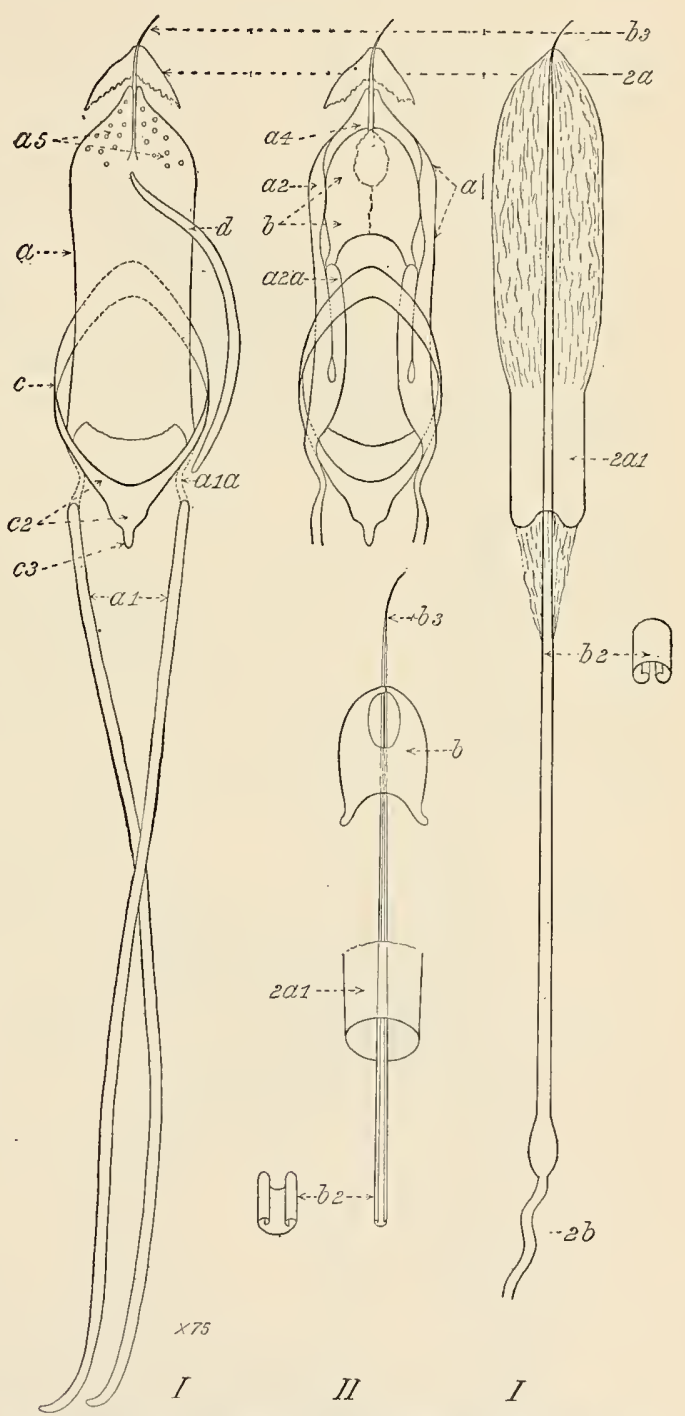

Fig. 103.-Ips emarginatus: Chitinous elements of male reproductive organs. $I$, ventral aspect; $I I$, dorsal aspect. See terminology, Division 1, pp. 192-193. (Original.)

other insects it seems plain that, so far as these beetles are concerned, the chitinized parts of the male reproductive organs represent elements of the ninth and tenth abdominal segments, either as direct modifications of primitive sclerites or as independent developments 
from the same fundamental source as that from which the various segmental lobes, sclerites, and appendages have developed. It would appear best to refer to the chitinous element of the copulatory

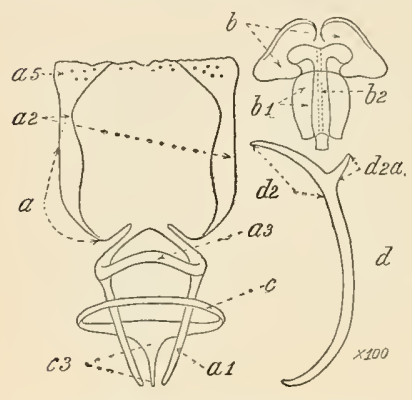

FIG. 104.-Pityophthorus sp.: Chitinous elements of male reproductive organs. See terminology, Division 1, pp. 192-193. (Original.)

apparatus as representing certain segmental elements rather than to assume that they have beenderived through modification from sclerites or appendages which had existed as such in a primitive ancestor.

It is quite evident that element $a$ represents the tenth sternite, $b$ the tenth tergite, $c$ the nin th tergite, and $d$ the ninth sternite, while $b 1$ and 62 appear to represent elements of either the tenth tergite or of both the tenth tergite and tenth sternite. It might also be well to consider in future investigations the possibility of their representing the tenth pleurites or even

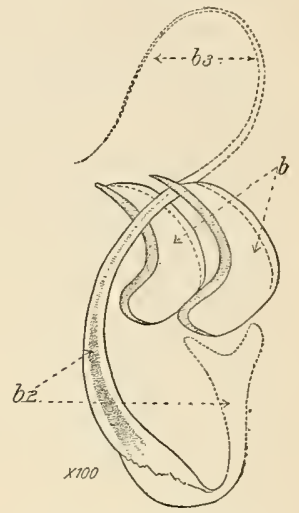

FIG. 105.-Pityophthorus bellus: E $\mathrm{nd}$ plates and seminal rod of male reproductive organs, lateral aspect. Note contrast between this and fig. 104. See terminology, Division 1, pp. 192193. (Original.)

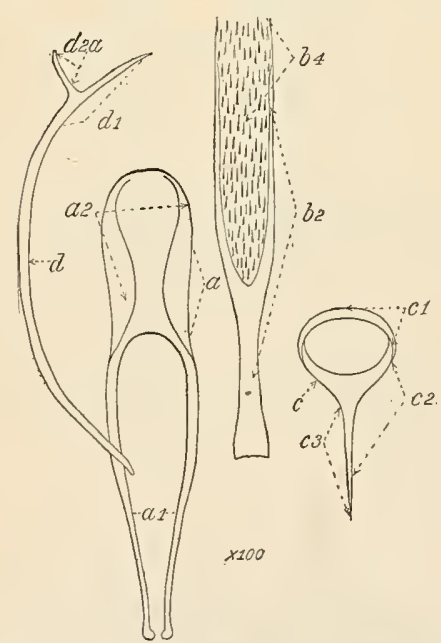

FIG. 106.-Micracis suturalis: Posterior elements of male reproductive organs, dorsal aspect. See terminology, Djvision 1, pp. 192-193. (Original.) an additional eleventh segment. The wide range in the variation of these elements, the absence of some of them in certain species, and the joining or fusion of two or more in other species render it exceedingly difficult properly to interpret the primary and secondary elements, especially in the more complex and in the apparently simple forms.

The body, or element $a$, is present in all species. It is more or less distinet from the other elements and is nearly always suggestive of a modified sternite; the femora (a1) appear to represent the produced posterior angles, or apodemes, of a typical abdominal sclerite, and the lateral folds ( $a 2)$ appear in some cases to represent the hypopleurites, especially in Ips, where they resemble end plates and were so identified by Lindemann. The function of element $a$ is that of a sheath or tube for the ejaculatory sack (2a) and for the seminal ralve 


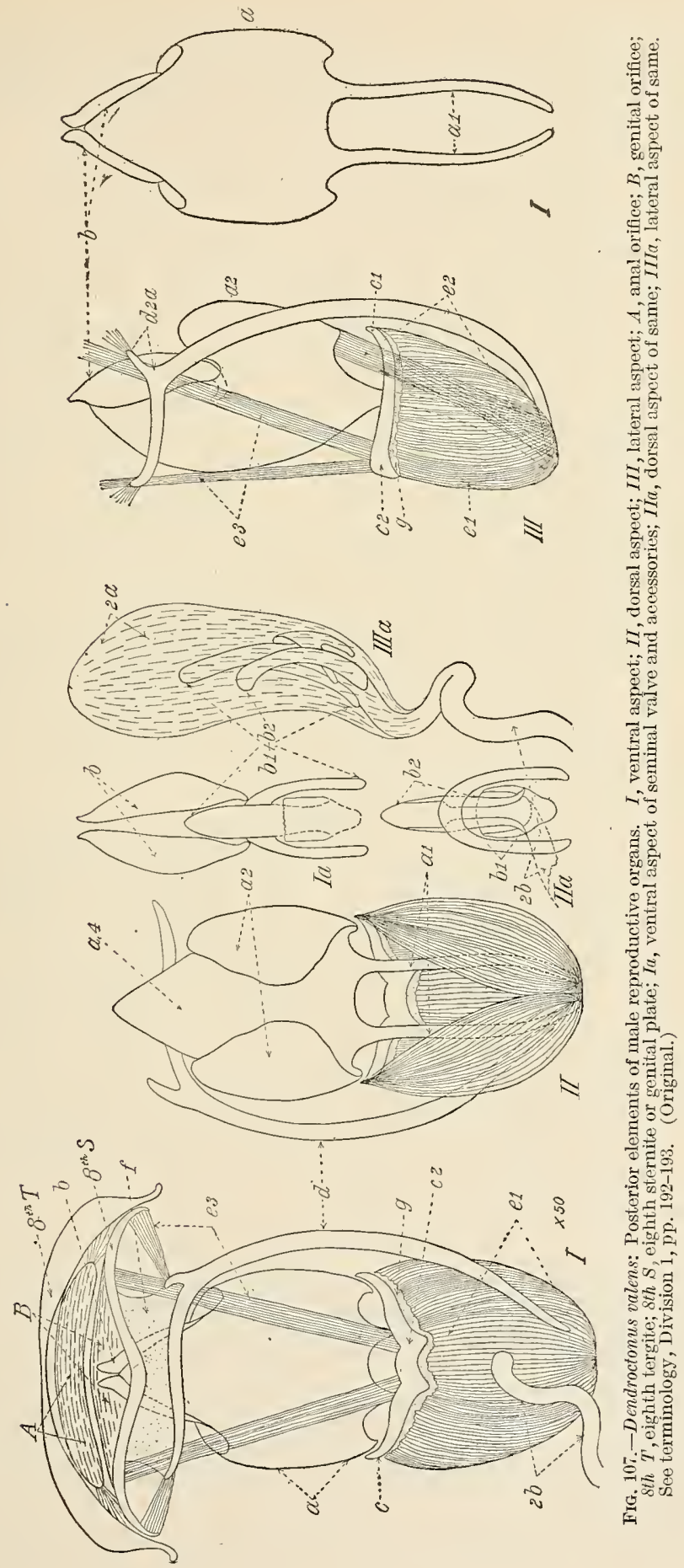


(b1) or the seminal rod (b2), or both, as the case may be. The end plates (b) are commonly present. They aro sometimes fused with $a 2$ but are more often separated or more directly connected with $b 1$ or b2. ${ }^{a}$ The end plates proper appear to function as accessories to $a$ in forming the sheath or outer tube; $b 1$ may function as a valve to close the seminal duct while muscular or blood pressure is brought to bear on the ejaculatory sack to force the seminal fluid into the copulatory pouch, or they may function, as indicated by Lindemann, as a furrow or troughlike support for the posterior end of the seminal duct. The end plates are subject to great modification, from simple chitinous pieces, as in Pissodes, to the more complex structure with many parts, as in Dendroctonus (fig. 107), and especially Hylesinus, or into a long slender troughlike rod, as in Ips (fig. 103), a stouter rod with apical dilation and a long flagellum, as in Xyleborus, or a brushlike form, as in Micracis (fig. 106), and Xylocleptes. The function of the slender rod or apical filament is not known, but it may serve to conduct the seminal fluid directly into the spermathecal duct.

When we consider the enormous range of possibilities in the modification of tergal and pleural sclerites, as manifested in the tergum and pleura of the metathoracic segment, we can readily understand that the most complicated and complex copulatory apparatus yet found in insects is comparatively simple and that the possibilities of further modification have not been exhausted.

The tegmen, or ring $(c)$, is generally present but may be obscure or absent. There is a wide range of variation, from a simple and ventral plate (Scolytus rugulosus, fig. 108) or fork (S. quadrispinosus, fig. 109, and Crossotarsus, fig. 110) to a continuous simple ring or band (fig. 102), and from a plain or forked dorsal piece to a forked or plain ventral piece. In nearly all cases it functions as an apodeme for the attachment of the primary and accessory muscles for the posterior extension and movements of elements $a$ and $b$. The sections of the various forms of the tegmen may be referred to as $(c 1)$ the posterior section, (c2) the median section, and (c3) the apodemal process. Section $c 1$ may be either dorsal or ventral; in whichever case section c2 will occupy the opposite position.

The spicule or rod (element $l$ ) is usually present in a more or less distinct form which may vary from a curved forked rod to a simple rod, and in its various modifications and functions may oceupy a dorsal, sublateral, lateral, or subventral position. . The sections of the various forms may be referred to as the anterior section (d1) and the posterior section (d2). It functions as an apodeme for the attach-

$a$ Verhoeff (1896) and Nüsslin (1912) considered the end plates as belonging to the body. 
ment of the primary and accessory muscles for the retractile movements of the tube ( $a$ and $b$ ).

The muscles (e) are more or less complicated and variable in size, number, and attachments. In some cases, as in Dendroctonus, the
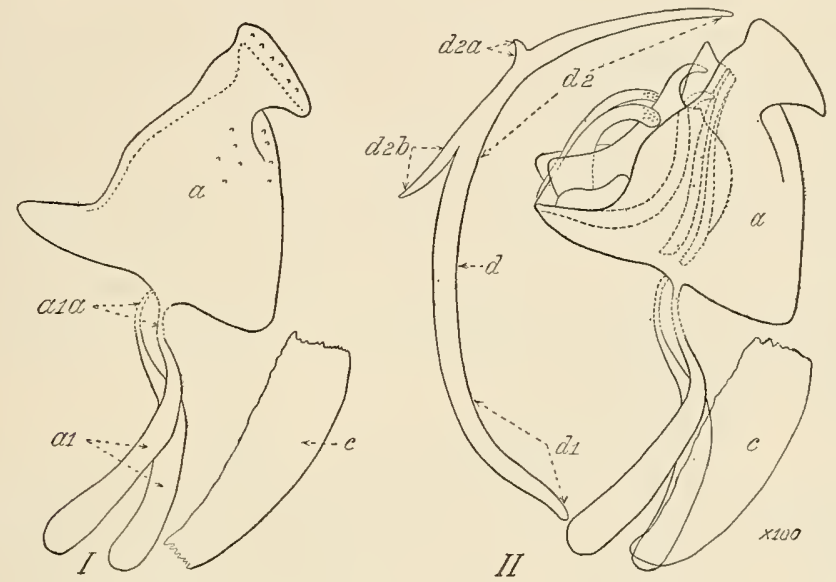

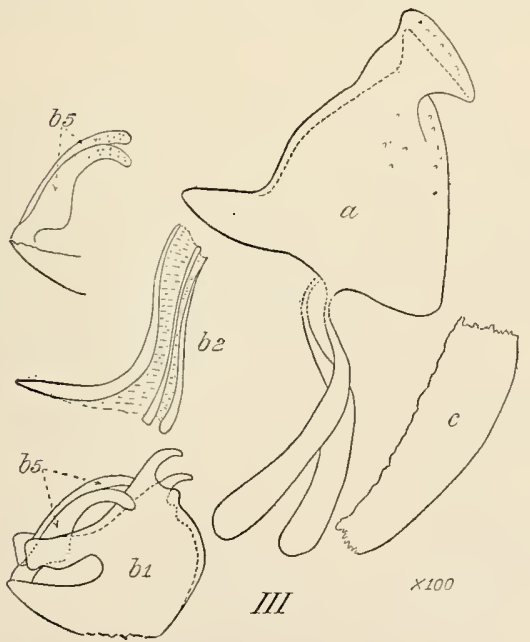

FIG. 108.-Scolytus rugulosus: Posterior elements of male reproductive organs. $I$, lateral aspect of body; $I I$, lateral aspect of body and accessories in situ; III, body accessories separated. See terminology, Division 1, pp. 192-193. (Original.)

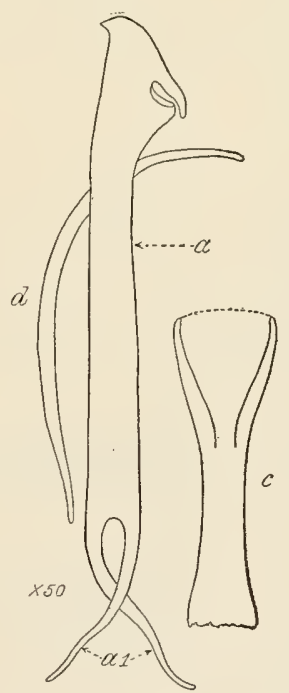

FIG. 109,-Scolytus quadrispinosus: Posterior elements of male reproductive organs, lateral aspect. Seeterminology, Division 1, pp. 192-193. (Original.)

extensor and retractile muscles are prominent, the former (e1) attached posteriorly to the anterior edge of element $c$, while the supplementary muscles (e3) are attached anteriorly to the posterior edge of $c$ and posteriorly to the inner surface of the eighth sternite, as in Dendroctonus, or to the anterior section of element $c$ and the eighth 
tergite, as in Crossotarsus. In Dendroctonus the retractile muscles $(e 2)$ are attached to the anterior end of the spicule $(d)$ and to the basal angles of the body (a), while in Crossotarsus they are attached to $e 2$ and to the sides of a ventral groove in $a$.

The connecting membrane $(f)$ is very difficult to locate and follow to its primary connections, but if it could be accurately traced it would doubtless furnish good evidence as to the proper assignment of the chitinous elements to their respective tergal and sternal origins, unless, as is the case with muscles, the attachments are changed or even reversed to harmonize and economize the requirements of function. The connecting membrane between the posterior section of element $d$ and the eighth abdominal sternite in Dendroctonus seems to furnish quite conclusive evidence that the spicule represents the ninth sternite.

ANTERIOR AND MEDIAN ELEMENTS.

The anterior (4) and median elements (3) of the male reproductive organs have received special attention by Nüsslin, who bases a classification on the length of the ductus ejaculatorius (2b) and the character of the testes $(4 b)$, seminal vesicles (3), vas deferens $(4 a)$ and mucous glands (2c).

VARIATIONS AND COMBINATIONS OF THE ELEMENTS.

Various combinations of the elements of the copulatory apparatus are found in the species of allied genera. Quite a wide range of variation is also found in the character of the elements in the species of the same genus. Even species which in all other respects appear to be closely allied have very different characters, either in the form of one or more elements or in different combinations of the elements.

In Division I of the family Ipidæ the absence of the seminal valve and the presence of the sominal rod appear to predominate. The valve, as a definite part, is absent in 21 genera and 52 species and present in 10 genera and 16 species. The rod is present in 25 genera and 55 species and absent in 8 genera and 14 species. Both the rod and valve appear to be absent in 6 genera and 10 species, representing: 4 subfamilies, and both are present in 10 genera and 15 species, representing the same four subfamilies, and especially in Corthylinæ. The striking feature of the Subfamily Ipinæ is the apparent ${ }^{a}$ separation. of the femora from the body, especially in I $s$ and the closely allied genera. In Pityophthorus (figs. 104, 105) they are found to be fused with the body in some species and separated in others; within still other species there is a supplementary band (a3) connecting them at or near the base.

a The writer has found that the femora are connected to the body by ligaments. 
In Division II of the Ipidæ the presence of the seminal valve and absence of the seminal rod predominate. The valve is present in 20 genera and 44 species and the rod is absent in 20 genera and 43 spe-

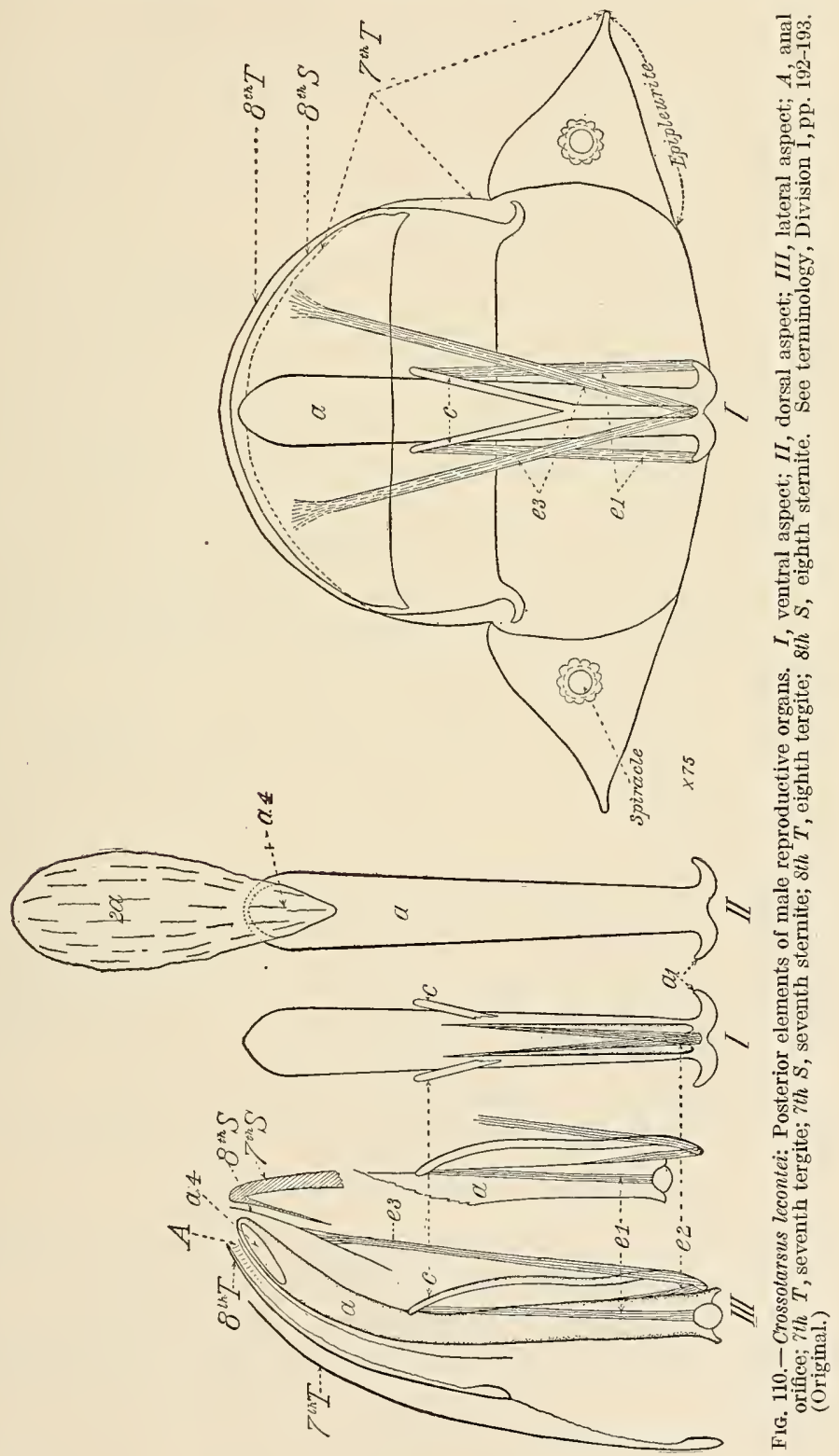

cies. The valve is absent in 2 genera and 4 species and the rod is present in 6 genera and 12 species. The combination of rod and valve is found in 4 genera and 10 species. 
In the family Scolytidæ there appears to be a wide range of variation. In Erineophilus schwarai Hopk., of the subfamily Hexacolinæ, the rod is absent, the valve present, and the femora are long and slender. In some species of the genus Scolytus the body is greatly modified, somewhat resembling a seminal rod. The valve is absent and the femora are rudimentary in S. muticus Say and S. quadrispinosus Say (fig. 109). In S. rugulosus Ratz., however, (fig. 108) the femora are long, the valve is represented, and there are some additional parts; in fact, all of the elements are radically different from those of the other two species.

In one genus and one species of Scolytoplatypodidæe the rod is absent and the femcra are large and very broad, differing in this respect from anything yet observed in the entire superfamily.

In two genera and five species of the subfamily Platypodinæ the body is long and slender, but without the spicule, end plates, seminal valve, or rod, and the femora are represented by short hooks at the basal angles of the body. The tegmen is present in the form of a fork.

A study of the available data relating to the primary and secondary elements of the male organs of reproduction shows that within the families, subfamilies, and genera there is a very wide range of variation and that the same or similar elements individually, or in various combinations, are often paralleled in species of widely separated genera and subfamilies, so that their principal taxonomic value appears to be restricted to the separation of species and minor divisions of the genus.

It appears that if there is any line of progressive modification within the major and minor groups, it is from a simple form without seminal valve, seminal rod, or end plates, as in some of the Cryphalinæ and in the Platypodinæ, to the most complex forms with or without the valve and with or without the rod, the rod reaching its highest development in Xyleborus, Dryocoetes, Lymantor, Ips, and allied genera; while the valve without the rod reaches its highest development in Hylesinus and allied genera in the Hylesininæ.

\section{Terminology of the Reproductive Organs.}

In the following list it is intended that the numbers and letters should serve to designate the elements of the reproductive organs rather than names, because the names proposed by different authors, including the writer, do not agree in all cases in designation or interpretation.

Male Reproductive Organs.

(Figs. 101-110.)

Division 1. Posterior chitinous division.

Division 2. Posterior membranous division.

Division 3. Median division.

Division 4. Anterior division. 


\section{Division 1.}

a. Body.

a1. Body apodemes (femora).

$a 1^{a}$. A podemal ligament.

a2. Lateral folds.

$a 2 a$. Lateral plates (accessory pieces, Nüsslin).

a3. Supplementary body apodemes or transverse band.

a4. A pical orifice or ejaculatory canal.

a5. Sensory area or pores.

$b$. End plates.

b1. Seminal valve and accessories.

b2. Seminal rod.

b3. A pical flagellum of 62 .

b.4. Apical brush of 62 .

b5. Sensory claspers (fig. 108, $b 5$ ).

b6. Apical lobe.

c. Tegmen.

c1. Posterior or dorsal section.

c2. Anterior or ventral section.

d. Spicule.

c3. A podemal process.

d1. Anterior section.

d2. Posterior section.

$d 2^{a}$. Lateral apodeme or minor prong.

$d 2 b$. Lateral barb.

e. Muscles.

e1. Extensors.

e2. Pietractors.

e3. Supplementary.

$f$. Connecting membrane.

g. Ligament.

Division 2.

2a. Ejaculatory sac or præputial sac.

2a1. Chitinous base, or tube.

2b. Seminal duct.

2c. Mucous glands.

Division 3.

3a. Seminal vesicle.

Division 4 .

4a. Vas deferens.

4b. Testes.

\section{Female Reproducive Organs.}

(Fig. 111.)

Division 1. Posterior division.

Division 2. Anterior division.

1a. Vagina.

Division 1.

1b. Bursa copulatrix.

$1 b^{a}$. Accessory sac.

1c. Unpaired oviduct.

$1 c^{a}$. Apex and apical orifice of oviduct. 
1d. Spermatheca.

1e. Spermathecal gland.

1f. Seminal duct.

1g. Cement glands.

1h. Chitinous plates.

Division 2.

2a. Paired oviducts.

2b. Ovaries.

Classifications Based on the Reproductive Organs.

In the classifications of Nüsslin (1911), Fuchs (1911), and others, as based on the male reproductive organs, we find, as we do in the classi-

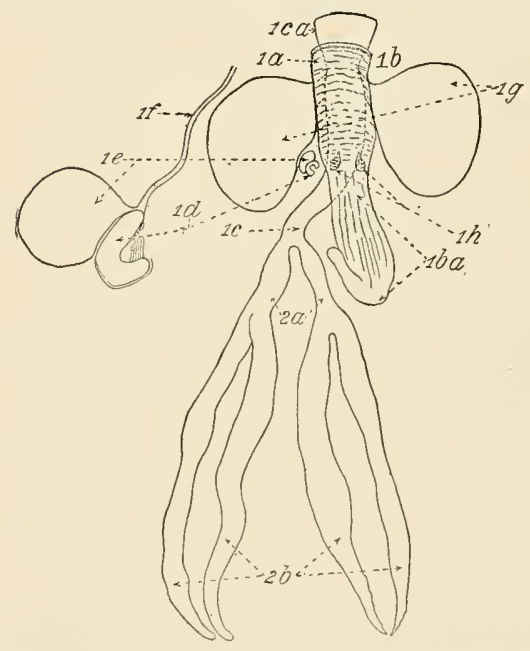

FIG. 111.-Dendroctonus valens: Female reproductive organs. See terminology, Division 1, pp. 193-194. (Original.) fications based on the elements of any single organ, that genera and groups which are plainly not closely allied are brought together and those which by the majority of external and internal characters are closely allied have been placed in widely separated divisions or subdivisions. When, however, the facts of parallel modification are taken into consideration and the principal elements are correlated with those of other organs, the results are quite different and the true taxonomic value of the elements is recognized. It is evident that a study must be made of the male organs of reproduction in a much larger number of species of all available genera before the true taxonomic value of any of their elements can be determined and correlated.

Nüsslin (1912), who has given the subject of the female reproductive organs (Fig. 111) of Scolytidæ late consideration, calls attention to the taxonomic importance of the female genital organs in separating the Adephaga and Polyphaga of the order Coleoptera and in distinguishing the suborder Rhynchophora, which he claims is peculiar in having only two pairs of ovaria.

The absence of a true ovipositor is apparently common to all scolytoid beetles, although in some species there are rudimentary parts which in other Rhynchophora and Coleoptera belong to the ovipositor, especially the genital palpi, which have been found only in Scolytus and Hylesinus. The presence of paired or single cement glands appears to be an important and more or less peculiar element in the Scolytoidea, although it is said to be absent in Scolytus and Ernoporus, as 
in other Rhynchophora. The bursa copulatrix, according to Nüsslin, is present in Scolytus, Hylesinus, Polygraphus, Crypturgus, and Hypoborus, much less evident in Carphoborus, Pityophthorus, Dryocotes, Taphrorychus, and Lymantor, and obscure or absent in Cryphalus, Xyloterus, Xylocleptes, Thamnurgus, Ips, and Pityogenes.

Conclusions as to whether or not the presence or absence of a given element is primitive in the Scolytoidea, as based on morphological interpretations, are becoming much less reliable than formerly because of the frequency of parallel origin or disappearance of adaptive elements.

Nüsslin's (1911, pp. 333-338) classification as based on the female organs of reproduction relates primarily to the presence or absence of the cement gland and to its varying forms; secondarily, to the presence and character, or the absence, of the bursa copulatrix, and the character of the spermatheca and its seminal duct.

When the characters of the female reproductive organs as given by Nüsslin are correlated with the external characters on which the writer's preliminary classification is based, Scolytus falls into the subfamily Scolytinæ; Hypoborus and Thamnurgus into the Micracinæ; Crypturgus and Carphoborus into the Crypturginæ; Polygraphus into the Phlœotribinæ; Pityophthorus, Pityogenes, and Ips into the Ipinæ; and Xyloterus into the Corthylinæ; while Ernoporus, Cryphalus, Taphrorychus, Lymantor, Dryoccetes, Xyleborus, and Xylocleptes fall into the Cryphalinæ.

With a more comprehensive study of the female organs in numbers of species representing all the genera it will evidently be found that there are some excellent taxonomic characters in the primary elements and in their lines of progressive modification, which in combination with other internal and external characters will be of special value in defining groups of allied genera and in indicating relative positions of the groups in the classification.

\section{Secondary Sexual Characters.}

There is a wide range in the types and position of the secondary or external sexual characters, such as difference in the size of the body, as in Hypothenemus, Stephanoderes, Coccotrypes, Xyleborus, and allied genera, and the radical and contrasting differences in the structure, vestiture, and sculpture of various external parts and areas. The front of the head may be convex and glabrous in one sex and in the opposite sex it may be flat to deeply concave, smooth, and shining, punctured, and with dense and long pubescence or the margins fringed with long hairs. The armature of the declivity and the character of the sutural impressions or broad excavation often vary to a remarkable extent in the two sexes. The scape of the antenna may be stouter to dilated and fringed with long hairs or not fringed. The funicle, club, mouthparts, tibia, tarsus, abdominal tergites, and stemites, in 
fact almost every important element of the body, may be the bearer of characters for distinguishing one or the other sex.

It would appear. that as a rule there is a certain degree of constancy in the location and general appearance of a male or female character within the limits of a genus, but there are some remarkable differences, and even reversals, even in the major and minor divisions of a genus. In Dendroctonus, for example (Part I of this bulletin, p. 73), the females of subdivision $A$ are distinguished by the presence of a transverse ridge on the anterior area of the pronotum, while in subdivisions $B, C$, and $D$ this character is not present. In subdivision $B$ the elytral declivity is more rugose in the female, in subdivision $C$ this is reversed, and in subdivision $D$ there is no difference in this respect. In some genera the pubescent or concave front is a female character, while in other genera it is a male character. Other reversals may not only occur in different, widely separated genera but in the same genus. Therefore it is not safe to conclude that because certain characters designate the female in one species this will hold true for the other species of the same genus or for allied genera. This can only be definitely settled by dissection, which can be done without seriously mutilating the specimen if the abdomen is carefully removed from the body and the sternites are remounted on a card point after the examination is made. The presence of the chitinized spermatheca in the female and the presence of the chitinized elements of the posterior section of the male organs are sufficient to settle the point, even in old dried specimens.

The lines of progressive variation or modification in secondary sexual characters appear to range from absent and obscure to common and prominent.

\section{THE PUPE.}

Comparatively very little study has been made of the pupæ of even our common species of Scolytoidea, and until a comprehensive study has been made it is scarcely necessary to mention the characters in connection with general taxonomy. The description and figures of the pupa of Dendroctonus valens (Part I, pp. 53-57, figures 37-38; synopsis, pp. 73-74, and descriptions, pp. 81-152) will serve as an example of the general type, while the figures and terminology will serve as a guide to future study.

The writer has examined the pupæ of quite a large number of North American species and finds that there is quite a wide range of variation, but no attempt has been made to analyze the taxonomic characters except in the genus Dendroctonus, in which the form of the head and the character of the frontal, tergal, lateral, pleural, caudal, and femoral spines serve as important characters for identification and classification and, when correlated with the adult characters, give the same or similar taxonomic result. 
THE LARVÆ.

The structural and morphological elements of the larvæ of Dendroctonus are shown in Part I, figures 39-43, and Plate VIII, figures $1-23 j$, and these, with the terminology and descriptions, will serve as a guide to a greatly needed further study of the larval stage before we can have a basis for conclusions as to their importance in taxonomy. The writer has examined the larvæ of quite a large number of species, but no detailed study has been made except in Dendroctonus and of the labrum of a number of species in other genera (Hopkins, 1905, Plate I). This has been sufficient, however, to indicate the wide range of variation in some of the elements and the great importance of a more comprehensive knowledge of the subject. In Dendroctonus the important characters are found in the eighth and ninth abdominal tergites, and the front of the head. An example of progressive modification is found in the sculpture and armature of the eighth and ninth abdominal tergites from those without dorsal plates in Division I and Division II, section $a^{3}$, to the unarmed plates of section $a^{4}$ and to the armed plates of subdivision $D$, which correlates so nicely with progressively modified characters in the adults and in the galleries. The larvæ of the species of Platypus and Crossotarsus examined by the writer show radical differences in form and in some of the anatomical elements, as, for example, the labrum (Hopkins, 1905).

\section{THE EGGS.}

While the eggs of many species have been observed by the writer, they have not been studied in detail. They appear to conform in general to an oblong, oval, or nearly globular shape, and are pearly white and smooth, with few elements of vestiture or sculpture to serve as taxonomic characters. However, this is a subject worthy of detailed study. The size of the egg in comparison with the size of the abdomen varies enormously in different species. In a species of Carphoborus a fully developed single egg was found to be so large as to occupy almost the entire abdominal cavity.

\section{THE EMBRYO.}

The embryology of the scolytoid beetles is another subject which has not received much attention. While the writer feels that there is need of detailed study of the embryo to determine any additional facts which may be of value, he is inclined to the belief that more attention should be given to a comparative study and correlation of characters of the postembryonic stages (young to matured larvæ) of a wide range of species in the order Coleoptera, in order that we may know something more of the fundamental facts and be better able to interpret their real significance. 


\section{PHYSIOLOGICAL CHARACTERISTICS.}

As pointed out in Part I (p. 64), the physiological characteristics are of special taxonomic importance when correlated with morphological characters. The food, social, and sexual habits, character of the brood galleries, choice of host plants, and distribution of genera and species are all more or less rich in facts of taxonomic importance.

\section{GENERAL HABITS.}

The scolytoid beetles are distinguished from nearly all other Rhynchophora by their habit of excavating characteristic egg galleries in the living or dead plant tissue. The few notable exceptions are found in the genus Stenoscelis, of the Calandridæ, the adults of which excavate a primary egg burrow, but as a rule this habit within the suborder is peculiar to the Scolytoidea. The egg galleries of Scolytoidea are excavated in the bark or wood of trees and shrubs, the roots, stems, and leaves of herbaceous plants, the fruits or seeds of palms and other plants, young pine cones, the wood of barrels or casks containing water or spirituous liquors, etc. Some of the species excavate their galleries in decaying bark or wood or even in the fruiting bodies of fungi, while others confine their work to the bark or wood of weakened, dying, or recently dead plants, and still others prefer to enter the living and sound tissues.

The food of the adults and larvæ consists of the sugars, starches, and other nutritive elements of their host plants, or of fungi which grow in their brood galleries.

\section{CLASSIFICATION ACCORDING TO HABITS.}

Any classification of the families or subfamilies based on food habits alone would not indicate a natural arrangement, as is plainly indicated by the parallel habits of groups of species in widely separated families, subfamilies, and genera. It is true that there are several well marked classes according to habits, such as bark beetles, twig beetles, seed beetles, cone beetles, and ambrosia beetles. It is evident, however, that food habits, like many other characteristics and structural characters, have evolved along parallel lines in allied as well as in widely separated groups. There are many examples illustrating this principle. The genera Xyleborus, Corthylus, Scolytoplatypus, and Platypus are, according to fundamental morphological elements as well as groups of correlated characters, so widely separated that they each represent a different family or subfamily; yet the habit of excavating their galleries in wood and feeding on ambrosial fungi is common to them all. Between some of these genera there is also a more or less constant resemblance in certain morphological characters, especially in the hairs and slender teeth of the 
lacinia of the maxilla, but this is evidently due to parallel adaptation to similar uses and not to common origin or phylogenetic descent from a common ambrosia-feeding ancestor.

\section{Food Habits of the Adults.}

As a rule the adults obtain their food from the substance in which they excavate their egg galleries or from the fungi growing on the walls of the galleries, but there are numerous examples of special food habit such as that found in Scolytus, Pteleobius, Phloosinus, and Tomicus (see p. 220), which excavate food burrows in the living twigs of their host trees.

\section{Food Habits of the Larva.}

There is a wide range of variation in the food habits of larvæ of different species, especially in the character of their food burrows or larval mines. Each species of a group of closely allied species may have similar habits, but, as shown in the genus Dendroctonus, there may also be a wide range of variation and some striking examples of progressive modification in this habit within a genus in which there is a restricted range in structural characters in the adults. In the genus Dendroctonus there is a tendency throughout for the larval mines to occur in groups of increasing numbers from the simple, isolated mine of Dendroctonus brevicomis to closely placed groups in Dendroctonus simplex and $D$. piceaperda and to the large social chamber of micans, valens, and terebrans. (See figs. 73, 75, 79, 88, and 91, of Part I.) Thus the stage in the modification of the larval mine of a given species may indicate, in connection with stages in the modification of structural characters, the natural position of the species.

In the ambrosia beetles the larvæ of some species and groups of genera, as Xyleborus, Stephanoderes, and Crossotarsus, live in the primary galleries in direct association with the eggs, larvæ, pupæ, young adults, and parent adults, while in the subfamily Corthylinæ, the genus Scolytoplatypus, and at least some of the species of Platypus, the larvæ occupy separate chambers in the sides of the gallery, these chambers not extending beyond a size sufficient for the accommodation of the body.

\section{Pupal Habits.}

Considerable variation exists in the habits of the pupæ and in the cells occupied by them in transformation from larvæ to adults. In perhaps the majority of species the transformation takes place at the end of the food burrow with or without a definite cell. In some ambrosia beetles the pupation takes place in the social galleries occuped by different stages of the brood, in others it is in the lateral larval cell, and in Stephanoderes the transformation takes place in closely joined 
cells at or toward the inner end of the social gallery, the walls and partitions of these cells consisting of an ambrosia-like substance mixed with fine borings.

\section{Flight Habits.}

Further observations should be made on the flight habits of these beetles, but from what we know of a few species it would appear that in the same species flight may be either individual or collective. In one example noted by the writer (Hopkins, 1899a, pp. 346348), a large number of species, together with some of their associates, scavengers, and predaceous enemies, were found in one great swarm. The periods of flight vary with the number of generations in a season. Thus species with a single generation have but one definite period of flight, while those with more than one generation have two or more periods, or, when the generations overlap, there may be a continuous period of flight throughout the season.

\section{Social Habits.}

In the social habits we find some features of special interest both in their relation to taxonomy and to parallel lines of modification. In the relation of the sexes there is a wide range of variation from simple or unorganized and intensive polygamy to specialized or organized polygamy, and a gradual reduction in the proportion of the number of females, from 1 male and many females to 1 male and 2 females, and finally to specialized monogamy.

In Hypothenemus, Stephanoderes, Xyleborus, and allied genera the males are much smaller than the females and very rare. In certain species of $X$ yleborus as many as 60 females to 1 male have been found in one brood gallery, and the proportion appears to be even greater in Hypothenemus. In these groups there is no system in the relation of the sexes or in eggs of the brood galleries of the females, and all live together in the same galleries. In the other groups of genera of the subfamily Cryphalinæ where there is no difference in the size of the sexes there is more evidence of separate egg galleries for the different females of the social group, and the galleries begin to take on more definite and characteristic forms or patterns. In the Ipidæ the tendency toward a specialized polygamous relation of the sexes reaches its highest development in Pityogenes, while in Ips there is a tendency toward fewer females, the numbers of which in some cases are limited to 2 or 3 to the gallery. In Corthylinæ the sexes are more equally divided, while in Crypturginæ, Phlœotribinæ, and Hylesininæ there is a tendency toward 2 females and 1 male or to 1 of each. The last seems to prevail to a greater extent in the subfamily Scolytinæ, or at least in the genus Scolytus, than in other subfamilies. 


\section{Galleries.}

There is a wide variation in the types or forms of the egg and brood galleries within the families, subfamilies, and the major and minor groups, and in some cases within the genus. Each species or group of allied species of a genus or group of allied genera is usually characterized by some peculiar form or feature which in many cases is sufficent in itself to indicate the species, genus, or group to which it belongs; therefore the galleries are of special taxonomic importance in indicating the natural position and grouping of the species and genera.

It has been supposed that a peculiar type of gallery was due to the character of the plant tissue in which it was excavated or that it had some relation to the species of plant. It is found, however, that the type of the gallery is the same, or similar, for the same species, regardless of the character of the substance or the species of plant in which it is excarated. In fact, the same species of spruce or pine, and the bark on the trunk or branches, or the wood of the same part of the tree, may have as many radically different types of galleries as there are different species of beetles to make them.

It has also been supposed that the type of a gallery was due to the peculiar structure of the beetles, such as the retuse or concave and armed elytral declivity in Ips, ascending or excavated abdominal sternites of Scolytus, ete., but it is found that certain species with the same or similar structures make very different types of galleries, while certain other species with very different structures make similar galleries.

The fact that there is quite a definite relation between the type of the gallery and the systematic position of the species, genus, and group would indicate that the evolution of the gallery has been from the simple to the complex and that it has progressed with the evolution of the beetles that make and inhabit it in a somewhat similar manner to that of the dominant tendency in the evolution of human dwelling places from the simple cave to the modern palace. In other words, the simple and complex galleries represent evolution within the maximum and minimum limits of an instinctive or dominant tendency common to all of the individuals of the superfamily Scolytoidea and are expressed by each species of a genus in the varying degrees of simplicity or perfection according to the varying stages in the evolution of the species.

The fact that the same or a similar type of gallery is made by species of widely separated genera and subfamilies indicates that we should not look for an explanation of the origin and evolution of types of galleries in the phylogeny of the species, but that a thorough consideration should be given to the explanation to be found in paral- 
lel evolution due to a common tendency which may lead to the same or similar results during the same or similar stage in the evolution of the species.

While the varying types of the egg and brood galleries furnish some very important taxonomic evidence, any attempt to elassify the species of a family or subfamily according to such characters alone would give the same heterogeneous results as are found in the different classifications based on the elements of a single external or internal part or organ of the body. On the other hand, if the galleries of the species of the major and minor divisions of a subfamily are studied separately, it will be found that the character of the gallery and the species of the host tree will serve as most important guides to the natural position of a species or group of allied species.

\section{TERMINOLOGY OF THE GALLERIES.}

Following is a reviser list with definitions of the terms used to designate the different elements of the scolytoid gallery.

Egg gallery.-The egg gallery is the burrow excavated by the parent beetles preliminary to depositing the eggs in niches along the sides or loosely in the gallery itself.

Social gallery.-The social gallery is one in which all stages of the broods from the eggs to the matured individuals and the parents live, as in Xyleborus, certain species of Platypus, Crossotarsus, etc.

Social chamber or brood chamber.-The social chamber, as in Xyleborus saxeseni, is a dilated portion of the tubelike gallery to accomodate all stages of the brood.

Death chamber (catacomb or garbage chamber). - The death chamber (Hubbard, 1897; also Hopkins, 1898) is a section in the social chamber in which the dead individuals of the colony or the guests and enemies as well as other refuse matter are deposited and separated from the main chamber by a wall of the ambrosia fungus mixed with boring dust.

Entrance burrow.-The entrance burrow is made by one or the other sex as a preliminary to the excavation of the egg gallery, and may connect in a direct manner or laterally with the base of the gallery in the case of single galleries, or with the middle.in the case of double galleries.

Nuptial (lateral or central) chamber.-The nuptial chamber is excavated by one or the other sex (probably in most cases by the male) at the base of the entrance burrow and the mouth of a single or many egg galleries. In Pityophthorus, Ips, etc., this chamber is short and broad, oblong, or rectangular. In some species of Scolytus, Phloophthorus, Hylesinus, etc., the lateral entrance appears to serve the same purpose as the nuptial chamber, while in Phloosinus the chamber is at the base of the egg galleries and entrance burrow and 
extends to one or both sides. These chambers are usually occupied by the male of the polygamous colony or of the monogamous pair.

Ventilating burrow.-The ventilating burrow is the vertical burrow which is located at more or less regular intervals in the roof of the egg gallery and extends to or near the surface. It may serve the purpose of ventilating the gallery, or, perhaps more frequently, as a place for the storage of boring dust or an opening through which this dust may be ejected. Short burrows in the roof or sides may be used as places in which the beetles turn around, or may serve the purpose of nuptial chambers.

Branching gallery.-The branching gallery may branch from the central or nuptial chamber, or from the side of one of the main egg galleries. In the latter case it is referred to as a lateral branch.

Connecting galleries. - The connecting galleries are those of one or more colonies which are connected either through the central chamber or by lateral and primary galleries, as in many species of Pityogenes, Pityophthorus, Carphoborus, etc.

Terminal burrows.-The terminal burrows are excavated usually by the female beetle at the farther end of a primary or a lateral gallery, after the egg gallery is completed and while the brood is developing, as in Dendroctonus frontalis (Part I, figs. 51 and 52).

Brood burrows. - The brood burrows are those excavated by the adults of a brood before the individuals emerge. They radiate from the respective pupal cells of the individuals, as in Dendroctonus, certain species of Ips, etc. In the case of species with a single generation annually, the developed brood may overwinter in the brood burrows.

Hibernating burrows.-The hibernating or overwintering burrows are those excavated in places other than that in which the broods developed, such as those of Ips, in the twigs and branches, or in the thick corky bark at the base of the trees, and those of Phloeophthorus, in the outer bark on the trunks of the living host trees.

Food burrows. - The food burrow is excavated by the adult in the same part of the tree in which it excavates its egg galleries, or in a different part, as in Scolytus rugulosus and S. quadrispinosus, which burrow in the living twigs at the base of a leaf stem or bud, and in Phloosinus, which burrows at the base of living twigs.

Trial burrows. - The trial burrows are those made by the parent beetles in the bark of living trees preliminary to the general attack and the excavation of successful egg galleries.

Abandoned or failure gallery.-The abandoned or failure gallery is one which, through the resistance exerted by the vital part of the plant attacked, the beetles are compelled to abandon or be drowned in the resin or sap. 
Exit burrow.-The exit burrow is that through which one or many individuals of a developed brood emerge. In the case of ambrosia beetles the entrance may also be utilized as an exit, but in the barkbeetles the exit is usually direct or indirect from the pupal chamber.

Larval mine.-The larval mine is the food burrow excavated by the larvæ from the point where it hatches from the egg. The individual mine may be widely separated from or closely approximate to those of other individuals of the same brood, and they may be arranged in groups or those of the entire brood may be connected to form one common larval chamber.

Larval cell.-The larval cell is excavated by the larvæ in the side of the gallery simply to accomodate the increasing size of the body, as in the case of many species of Corthylinæ where tho food consists of ambrosial fungi provided by the parent.

Pupal cell.-The pupal cell is formed by the prepupal larva or by the pupa itself and is usually located at the end of the larval mine or food burrow of the larva. This is especially true in the case of the barkbeetles or the wood-mining larvæ, which latter, as in Micracis, Thysanoes, Scolytus muticus, etc., extend their burrows for a long distance from the bark mines into the wood. On the other hand, certain species of Dendroctonus form the pupal cell in the outer corky bark ( $D$. frontalis) or in the social larval chamber (D.valens), instead of at the end of the larval mine as in $D$. ponderosæ.

All of the named parts of the gallery have characters more or less peculiar to the species or group of allied species. Therefore the galleries as a whole, or in their various elements individually, or in various combinations, are worthy of special attention in the search for taxonomic characteristics.

CLASSIFICATION OF THE GALLERIES.

\section{Egg Galleries.}

In an attempt to classify the scolytoid egg galleries it is important to remember that the newly excavated galleries in which the first sets of eggs are deposited are more reliable in suggesting the type or group they represent than are the older ones, because in some species they may be so radically changed and confused by secondary branches and the intermingling of two or more galleries that the characteristic type may be obscured.

\section{Larval Mines.}

The larval mines furnish, to a limited extent, evidence of progressive modification, as is found in Dendroctonus. The larval mines in most of the Cryphalinæ are without distinctive characters, while in Ipinæ, Hylesinimæ, and Scolytinæ their symmetrical arrangement 
represents a high stage of progress, and consequently they are more characteristic of the species.

The form of the egg gallery of any species consists of one or more of three primary elements in relation to the substance and its fiber in which the gallery is made, as follows: (1) The longitudinal gallery, (2) the transverse gallery, and (3) the broad, irregular chamber.

\section{Trpes and Subtypes of Egg Galleries.}

The various modifications and combinations of the three primary elements seem to represent 8 general types or groups, which are designated by numbers, and 32 more specific subtypes or forms, which are designated by letters, as follows (see fig. 112):

Group 1.-The simple or generalized type. (a) Simple, longitudinal; (b) simple, transverse; $(c)$ simple cavities; $(d)$ various combinations of $a$ and $b$, with lateral branches.

Group 2.-The simple, irregular type branching from an irregular central or basal chamber. (a) Long, longitudinal, branching; (b) short, sublongitudinal, branching; (c) short, transverse, branching; $(d)$ various combinations of $b$ and $c$.

Group 3.-Ambrosia galleries. Division I, without lateral larval chambers. (a) Simple, longitudinal, single or branching; (b) long, transverse, branching; (c) short,

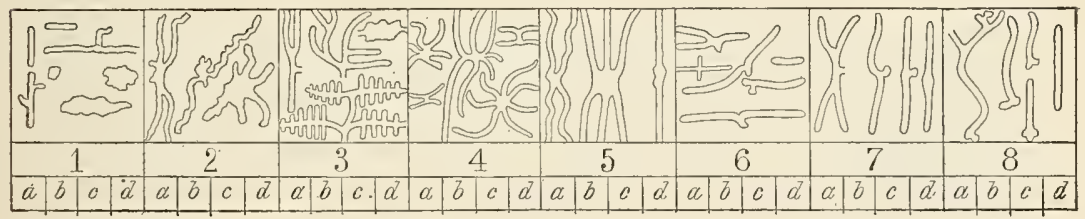

FIG. 112,-Classification of galleries of Scolytoidea, (Original.)

transverse, branched, dilated. Division II, with lateral larval chambers. (d) Double, transverse, branching;

Group 4.-The specialized, intermediate, short type, branching from a regular central nuptial chamber. (a) Simple to complex, transverse; (b) simple to complex, sublongitudinal; $(c)$ intermediate combinations of $a$ and $b ;(d)$ complex, symmetrical combinations of $a$ and $b$.

Group 5.-The specialized, intermediate, long, longitudinal type, branching from a regular central chamber. (a) Simple, irregular types with few branches; (b) specialized, many-branched types; $(c)$ specialized, with few branches, usually three; $(d)$ specialized, double, longitudinal.

Group 6.-The specialized, short, transverse type. (a) Simple, irregular, single or: double, transverse or subtransverse, and sometimes branching; (b) intermediate, regnlar, double, transverse or subtransverse; (c) specialized, regular, double or single, transverse, with or without lateral entrance chamber.

Group 7.-The specialized, short, double, longitudinal type. (a) Irregular, branched ( I icracis) type; $(b)$ irregular, without branches, but with lateral entrance chambers; $(c)$ intermediate, more specialized, with or without lateral entrance chambers; $(d)$ highly specialized, without lateral entrance chambers.

Group 8.-The specialized long or short, single, longitudinal type. (a) Long, irregular, wincing, sometimes with lateral branches, with or withont lateral entrance chambers at base; $(b)$ short, irregular, without branches, but with lateral entrance $59026^{\circ}-15-4$ 
chambers at base; (c) regular, short or long, with lateral entrance chambers at base; $(d)$ the most highly specialized short or long type, without lateral entrance chambers at base.

The foregoing classification and terminology is based on the observed galleries of a large number of species representing 57 genera and includes the galleries of European species figured by other writers.

\section{RELATION OF TYPES OF GALLERIES TO THE SUBFAMILIES AND FAMILIES.}

The relation of the eight groups of galleries to the subfamilies is shown in the following table. In some cases one genus may be represented by several groups. In Pityophthorus 26 species are represented in groups 1, 4, and 5, and in Ips 39 species are represented in groups 2,4 , and 5 .

TABLE VI.--Relation of groups of galleries to the subfamilies in the Scolytoidea.

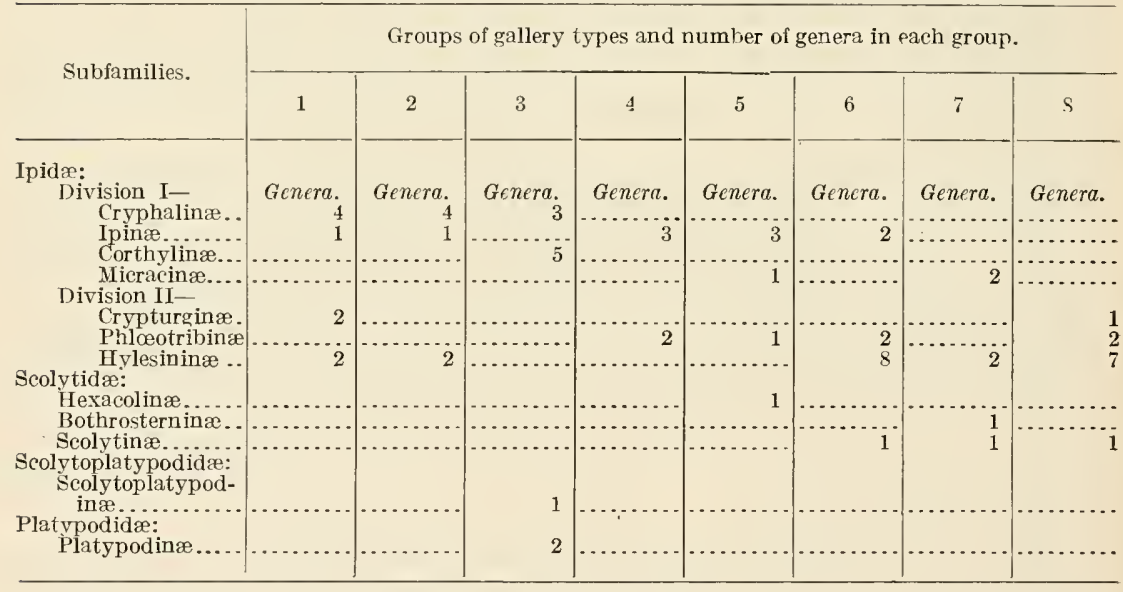

This table shows that all of the simple types (1 and 2) are in the Ipidæ and that most of them fall in the first part of Division I, while the more specialized types fall in the last part of Divisions I and II, with the far greater number in the latter; also, that in Scolytidæ specialized types only have been found. It is probable, however, that simple types will be found in the Scolytidæ when we know more about the habits of the species of the other genera of this family. It is also interesting to note from Table VI the number of subfamilies and genera in which the same group types are paralleled. 
TABLE VII.-Relation of groups of galleries to the families of Scolytoidea.

\begin{tabular}{|c|c|c|c|c|c|}
\hline \multirow{2}{*}{ Groups. } & \multicolumn{2}{|c|}{ Ipidæ. } & \multirow{2}{*}{$\begin{array}{l}\text { Scoly- } \\
\text { tidæ. }\end{array}$} & \multirow{2}{*}{$\begin{array}{c}\text { Scolyto- } \\
\text { platy- } \\
\text { podidæ. }\end{array}$} & \multirow{2}{*}{$\begin{array}{l}\text { Platy- } \\
\text { podidæ. }\end{array}$} \\
\hline & $\begin{array}{c}\text { Division } \\
\mathrm{I} .\end{array}$ & $\begin{array}{l}\text { Division } \\
\text { II. }\end{array}$ & & & \\
\hline $\begin{array}{l}1 \\
2 \ldots \ldots \\
3 \ldots \ldots \\
4 \ldots \ldots \\
5 \ldots \ldots \\
6 \ldots \ldots \\
7 \ldots \ldots \\
8 \ldots \ldots \\
\ldots\end{array}$ & $\begin{array}{r}\text { Genera. } \\
5 \\
4 \\
9 \\
3 \\
4 \\
2 \\
3 \\
0\end{array}$ & $\begin{array}{r}\text { Genera. } \\
5 \\
3 \\
0 \\
2 \\
1 \\
8 \\
2 \\
9\end{array}$ & $\begin{array}{r}\text { Genera. } \\
0 \\
0 \\
0 \\
0 \\
1 \\
1 \\
2 \\
1\end{array}$ & $\begin{array}{r}\text { Genera. } \\
0 \\
0 \\
0 \\
1 \\
0 \\
0 \\
0 \\
0 \\
0\end{array}$ & $\begin{array}{r}\text { Genera. } \\
0 \\
0 \\
2 \\
0 \\
0 \\
0 \\
0 \\
0\end{array}$ \\
\hline
\end{tabular}

In Hypothenemus the types of galleries do not extend beyond group 1 and represent specific types $a, b, c$, and $d$; Cryphalus is also confined to the same group and types, while Pityophthorus represents group 1, $a$ and $d$; group $4, a, b, c$, and $d$; and group 5, $a$ and $d$. Ips represents group 2, $a, b, c$, and $d$, and group $5, a, b, c$, and $d$.

The relation of types of galleries to species shows some striking examples of progressive modification within a genus and of parallel characters in different genera. It is not desirable to present a table to illustrate these relations in this connection, but it is intended to do so in subsequent parts dealing with the subfamilies.

While considerable attention has been given to the subject, a far more comprehensive study of the egg and brood galleries than has yet been made is required as a basis for correlating their taxonomic characters with the morphological characters of the species.

TAXONOMIC RELATION BETWEEN THE BEETLES AND THEIR HOST PLANTS.

Among the scolytoid beetles there is often a close taxonomic relation between the species, genera, and groups of the beetles and the species, genera, or groups of plants they infest, so that we may often know the insect by the host, or the host by the insect.

In other words, the host, together with the character of the gallery of a beetle, will often not only serve to identify the species to which it belongs but will indicate its systematic position. In a like manner the presence of certain species of beetles will serve to identify the species of plant and indicate its systematic position.

\section{Part of Plant Selected by the Beetles.}

The part of the plant in which the egg galleries are excavated is also of interest. In some species it is limited to the root or stem of an herbaceous plant; in others to the bark on the roots, main trunk, larger branches, and smaller branches, or to the twigs or fruit of a 
shrub or tree. Indeed it is found that the species of an entire genus of beetles may confine their breeding places to a restricted part of the plants of a single genus or closely allied group. Therefore even the part of the plant infested by a species may be of considerable taxonomic importance in indicating the natural position of a species or genus of heretofore doubtful position.

Condition of the Plant.

The condition of the plant or plant tissue at the time it is occupied by the beetles is of considerable systematic and economic importance. It ranges from young to old plants, living, declining, dying, and dead, and to different stages of decay of the plant or some part of its tissue. The fact that there is a relation between the species of beetles and one or more of the conditions mentioned shows that there is something of taxonomic value in this phase of the subject.

Relation of the Species of Beetles to the Srstematic PosiTION OF Their Host.

The primary and minor divisions and groups of plant species represented in which one or more species of beetles live range from the fruiting bodies of certain fungi of the Eumycetes to the higher flowering shrubs and trees of the Angiospermæ, the greater number of species and genera being confined to the Pinaceæ of the Gymnospermæ and the shrubs and trees of the Dicotyledoneæ of the Angiospermæ.

\section{Range of Host Plants.}

The range of host plants in the families of the Scotytoidea may be designated as follows:

TABLE VIII.--Range of host plants in the families of Scolytoidea.

\begin{tabular}{|c|c|c|c|c|}
\hline \multirow{2}{*}{ Family in the Scolytoidea. } & \multicolumn{4}{|c|}{ Group of host plants. } \\
\hline & Fungi. & $\begin{array}{l}\text { Gymno- } \\
\text { spermæ. }\end{array}$ & $\begin{array}{l}\text { Monocoty- } \\
\text { ledoneæ. }\end{array}$ & $\begin{array}{l}\text { Dicoty- } \\
\text { ledoneæ. }\end{array}$ \\
\hline $\begin{array}{l}\text { Ipidæ................ } \\
\text { Scolytidæ..... } \\
\text { Scolytoplatypodidæ... } \\
\text { Platypodidæ......... }\end{array}$ & \begin{tabular}{l} 
Rare...... \\
None...... \\
. do....... \\
\hdashline. do......
\end{tabular} & $\begin{array}{l}\text { Common... } \\
\text { Rare....... } \\
\text { None....... } \\
\text { Common... }\end{array}$ & $\begin{array}{c}\text { Rare...... } \\
\text { None...... } \\
\ldots \text {. do........ } \\
\ldots . \text { do...... }\end{array}$ & $\begin{array}{l}\text { Common. } \\
\text { Do. } \\
\text { Rare. } \\
\text { Common. }\end{array}$ \\
\hline
\end{tabular}

The range of host plants in the genera of true barkbeetles is usually more restricted and characteristic than in the genera of ambrosia beetles or in those species which live in dead or decaying bark or wood.

Examples of restricted range of host plants.-In the Cryphalinæ we find that Cryphalus is partial to Abies and Picea; Trypophloeus to 
Alnus, Salix, and Populus. In Ipinæ the true Pityogenes and Ips are largely confined to Pinus and Picea. In Corthylinæ the genus Gnathotrichus is confined to the Pinus group, while Monarthrum is partial to the dicotyledonous trees. In Crypturginæ the species of Crypturgus, Dolurgus, and Dendroctonus are confined to Pinus and allied genera. In Hylesininæ Tomicus (Myelophilus), Hylurgus, and Hylastes are confined to Pinus, while the true Hylesinus and Pteleobius are particularly associated with Fraxinus.

Examples of wide range of host plants.-In Cryphalinæ Hypothenemus has a range of host plants from fungi up through many genera of the Monocotyledoneæ and Dicotyledoneæ but is rarely found as an inhabitant of the Gymnospermæ. Tyleborus has the widest range of allthrough the Coniferæ and Angiospermæ. Dryocoetes is divided between the conifers and allies of Quercus. In Corthylinæ the genus Yyloterus is divided between the Gymnospermæ and a wide range of the trees of the Angiospermæ. Corthylus is confined to a wide range of trees in the Angiospermæ, as is also Monarthrum, except in the case of a few records from the Pinus and Juniperus groups. In Scolytinæ the genus Scolytus as at present recognized is divided between the genera of the Pinales (except Pinus) and the Amentales and Rosales. In Platypodinæ there is a wide range of food plants in the trees of the Gymnospermæ and Angiospermæ.

\section{Associations of Species of Beetles and Species of Plants.}

In some of the genera which are restricted in the range of host plants as well as in those with the widest range there are many species which are restricted to a single species or group of closely allied species of plants. In Phlœotribinæ there are species peculiar to Morus, Celtis, etc., and in Phlcosinus, with but very few exceptions, each species is peculiar to, or prefers, a different species of cypress, cedar, or juniper, or group of allied species. In Scolytus we find Hicoria, Ulmus, Fagus, Betula, Celtis, Quercus, Abies, Picea, Pseudotsuga taxifolia, etc., with species of beetles peculiar to each plant genus.

\section{Summary of Taxonomic Evidence Furnished by Host Reia- TIONS.}

In a study of the relations between the insects and their hosts some rather striking facts have been determined which have furnished evidence to clear much of the confusion in classification based on morphological characters alone and in which parallel or analogous characters have been mistaken for those of affinity. By the old method of morphological distinction closely allied species and genera have been widely separated in the classification and distantly related ones placed together. A number of such cases have been detected where the host plant and the character of the galleries have been studied. 
In other words, the physiological characteristics gave the best clue to the natural affinities of the various groups and led to the discovery of heretofore overlooked morphological characters which furnished conclusive evidence of their true position.

The close relationship between some of the existing representatives of ancient groups of plants and representatives of evidently ancient types of the beetles indicates that the beetles and plants may have been closely associated in their evolution from their respective primitive forms.

\section{GEOGRAPHICAI DISTRIBUTION IN ITS BEARING ON TAXONOMY.}

\section{Superfamily SCOLYTOIDEA.}

It is evident from our present knowledge that the superfamily Scolytoidea is represented to a greater or less extent in every section of the world where woody plants grow.

\section{Family IPIDE.}

The family Ipidæ is also represented by species in all of the great faunal regions. The subfamily Cryphalinæ, with its widely distributed Hypothenemus, Stephanoderes, and Xyleborus, has a wider range of distribution perhaps than is found in any of the other subfamilies. The Ipinæ are more restricted to the Holarctic regions and to the distribution of Pinus and its allies, Abies, Picea, Larix, ete. The Corthylinæ are more restricted to temperate, subtropical, and tropical America except in the genus Xyloterus, which extends through the Palæarctic and Nearctic regions. The Micracinæ, with the exception of Liparthrum and Hypoborus, are largely restricted to north temperate America. In Crypturginæ the genus Aphanarthrum is restricted to Madeira and the Canary and Cape Verde Islands, while Crypturgus has a wide range through the Palæaretic and Nearctic regions, and Dendroctonus, with one exception, is confined to North and Central America. The Phlœotribinæ and Hylesininæ are widely distributed throughout the regions of tree growth.

\section{Family SCOLYTIDE.}

The famiiy Scolytidæ, as represented by the genus Scolytus, extends over a wide range of the Palæarctic and Nearctic regions, but the greater number of genera and species are evidently to be found in the subtropical and tropical regions of Central and South America.

\section{Family SCOLYTOPLATYPODIDE.}

The family Scolytoplatypodidæ, so far as known, is restricted to small sections of the eastern Palæarctic and of the Ethiopian regions. 


\section{Family PLATYPODIDA.}

The family Platypodidæ has a wide range through the temperate, subtropical, and tropical regions of both continents.

There are many features in the distribution of genera and species which are of special interest, but there is need of information on many species from the different countries which at present are poorly or not at all represented in collections.

\section{PAIRED SPECIES.}

The subject of so-called paired or parallel species is of special interest in connection with a study of the distribution. There are some striking examples of paired species in the genus Dendroctonus which, if they occupied the same local faunal area, would be difficult of separation on account of their close resemblance in structural characters. These paired species are brevicomis and barberi, frontalis and arizonicus, mexicanus and parallelocollis, monticolx and ponderosæ, piceaperda and engelmanni, punctatus and micans, and terebrans and valens. In each case the pairs are more or less widely separated from each other in their geographical distribution, as, for example, micans of northern Europe and punctatus of the Appalachians of North America, frontalis of the Southern States and arizonicus of Arizona, barberi of Arizona and New Mexico and brevicomis of the Pacific Slope States, Idaho, Montana, and part of Wyoming, ponderosæ of the central and southern Rocky Mountains and monticolæ in the Northern Rocky Mountains and Pacific Slope.

There are any number of similar cases of so-called paired species in other genera, and the supposition that some of them are one and the same species has led to considerable confusion concerning the true range of a species. Between North America and Europe we have several examples, such as Anisandrus pyri of America and Anisandrus dispar of Europe, Dryocotes autographus of Europe and Dryocotes septentrionis of the western coast and Alaska of America, Xyloterus lineatus of Europe and Xyloterus bivittatus of America, Hylurgops glabratus of Europe and Hylurgops pinifex of America. There are many others common to two or more countries which superficially seem to be the same.

\section{REVIEW OF TAXONOMIC CHARACTERS AND CHARACTERISTICS.}

In a review of the foregoing discussion of the morphological characters to be found in the different stages of the scolytoid beetles and of the physiological characteristics in their habits, it is shown that there is a wide range of taxonomic elements by which to distinguish species and genera and to indicate or fix their position in the classification. Indeed the vast number of these characters and characteristics 
and the wide range in their variation, together with the disturbing factors, or reversals, and parallel modifications, are enough to overwhelm, confuse, and discourage anyone who attempts to study and utilize them in a comprehensive classification. It is plain, however, that it is only through such a comprehensive treatment that we can hope to approach the ideal natural classification.

\section{MORPHOLOGICAL CHARACTERS.}

In a review of the morphological characters it is found that the tarsus and tibia are of special value in the classification of the superfamily; the head, pronotum, elytra, and third joint of the tarsus for the family; the head, tarsi, pronotum, elytra, anterior coxæ, abdominal stemite, and pygidium for the subfamily; the antennæ, eyes, pronotum, elytra, tarsi, tibiæ, body, abdominal sternites, anterior coxæ, and mouthparts for the genus, and for the species there is such a wide range of characters of varying, and sometimes reverse, value in different genera that they can not be specified except for limited groups. However, the size, form, color, vestiture, and sculpture of the body, the front of the head, elytral declivity, etc., are in general among the most important bearers of specific characters.

In the digestive system the masticatory plates of the proventriculus appear to be of special taxonomic value when applied to subfamilies, genera, and species.

In the reproductive organs of the male there is a very wide range of variation in the primary and secondary elements of the posterior or chitinized section, but with a few exceptions their taxonomic value appears to be restricted to major and minor divisions of the genus and especially to the separation of the species. In the anterior section of the organs the length of the ductus ejaculatorius and the form of the testes, seminal vesicles, vas'deferens, and mucus glands appear to represent the principal taxonomic elements, and they are of varying value as applied to major and minor groups.

The female reproductive organs, like the proventriculus, appear to possess a number of taxonomic characters of family, subfamily, and generic value, such as the presence or absence of the cement glands and their varying characters and the presence and character of the spermathera with its seminal duct.

In the secondary sexual characters we find a few which are peculiar to a genus or to groups of allied genera, but in general their principal value appears to be in distinguishing the species.

In the pupx it is found that the head and the tergal, laterai, pleural, candal, and femoral spines appear to be the most important taxonomic elements.

In the larvæ there is a wide range of variation in the form of the body and in some of the primary elements of the head and posterior 
abdominal segments, spiracles, etc., which are of value in separating the families, but the majority of these characters are of greatest value in connection with the genera and species.

The egg and embryo doubtless bear some important characters, but they have not been sufficiently studied by the writer to justify their discussion in this connection.

\section{PHYSIOLOGICAL CHARACTERISTICS.}

A review of the evidence relating to the physiological characteristies shows that the feeding, breeding, flight, and social habits, the galleries, larval mines, host plants, the species of plant, the part of the plant occupied, conditions of the plant, restricted or wide range of host relations, and features in geographical distribution have something to contribute in facts and evidence of more or less taxonomic importance.

CORRELATION OF MORPHOLOGICAL AND PHYSIOLOGICAL ELEMENTS.

In order to arrive at satisfactory conclusions in regard to the proper correlation of the mass of taxonomic data mentioned in the foregoing review one must have a far more comprehensive and first-hand knowledge of the subject as applied to the species of the world than is possessed by any investigator at the present time. Therefore it is the object of the writer to call attention to the need of further investigation of this broader principle of zoological taxonomy rather than to attempt to draw conclusions. It is evident, however, that at some future time the essential facts will be correlated into a system which will not only indicate true natural relations but perhaps give a better clue to the action of natural laws and a better interpretation of the fundamental principles involved in the evolution of life in general.

In order to arrive at sound conclusions the whole subject must be investigated withont prejudice for or against any theory as to phylogenetic origin of the organism, or as to the primitive or recent character of an organ or element. The problem must be attacked with the view of locating the more important or essential facts relating to the distinguishing characters and characteristics as applied to the species and their various aggregations into genera, subfamilies, and familios and the major and minor divisions of each. In other words, a given group of organisms should be studied in all of its morphological and physiological aspects with the view of locating, by the process of elimination, the elements of primary importance until one or more characters in each of the principal morphological and physiological groups of taxonomic elements are found to correlate in the formation of a harmonious taxonomic compound.

It has been shown in the foregoing pages that a classification based on any limited set of external or internal elements of the adult body, 
such as those found in the proventriculus or in the male or female organs, will suggest a phylogenetic system, but when it is found that each system differs from the other to such an extent that the same genus or species will occupy a radically different position in the different systems it is perfectly plain that the true taxonomic value of the elements has not been correctly interpreted or applied. On the other hand, it is equally plain that if characters can be found in all or a majority of the groups of external and internal elements which point in the same direction, we may safely assume that we have more nearly approached the true principle involved and the ideal classification.

Examples of an attempt by the writer to correlate and harmonize the various morphological and physiological elements will be found in the synoptic tables of Dendroctonus, Part I of this bulletin, and of Pissodes in Technical Series 20, Part I.

\section{PARALLEL MODIFICATIONS.}

Parallel modification in morphological and physiological elements is without doubt an important factor to be considered in taxonomy. It is evident from a comparative study of the various systems of classification that the failure of taxonomists fully to realize its importance has in many cases led to wrong conclusions. It has been shown in the foregoing discussion that there are a great many examples of parallel characters and characteristics in widely separated species and genera and that if they are not recognized and properly interpreted as such by the taxonomist, radically wrong positions will be assigned to many species and genera.

\section{REVERSALS.}

The reversal of characters and characteristics in different species of the same genus or in different genera and larger groups is another important fact to be kept in mind, especially as related to secondary sexual characters. 'Therefore it is never safe to conclude that because a given character or a group of characters is of special value in distinguishing one group, genus, species, or sex, it will hold in all cases. There have been numerous examples of wrong determination of the sexes from a failure to recognize this principle, as has been pointed out by the writer (Hopkins, 1894, pp. 274-280) and Blandford (1895, pp. 83-86). As has been shown on preceding pages, reversals are also found in specific, generic, and group characters, even to the subdivision of the superfamily, where we find a most striking example in the reversal of the apical spine or process of the anterior tibia from the inner to the outer angle. 


\section{PROGRESSIVE MODIFICATIONS.}

The discontinuous yet more or less progressive change or variation in the modification of morphological and physiological elements along definite lines within the minor to major groups is very evident in every group. The more this subject is studied the more we are convinced that there are certain important facts involved in this principle that have not been satisfactorily explained by any theory of the processes of evolution. The recognition and application in taxonomy of those unexplained features does not, however, necessarily require the acceptance or rejection of any theory of orthogenesis or phylogenesis. It is only necessary to correlate them with other more easily explained elements of distinction or to utilize them as guides to the position a species or group should occupy in a given series.

\section{Examples of Progressive Modification.}

The examples of progressive modification in morphological characters and physiological characteristics which have been noted by the writer in the scolytoid beetles may be summarized as follows:

Morphological characters.

Body small to large.

Body slender to stout.

Body with scales to hairs, to glabrous.

Head concealed to exposed.

Head short and broad to narrow and subrostrate.

Head with front convex, glabrous, to concave and pubescent or fringed.

Head with eyes oblong, elliptical and not emarginate, to short, oval, and deeply emarginate or divided.

Antennal joints of funicle increasing in number to the limit of seven.

Antennal joints of club decreasing in number through fusion or disappearance of sutures.

Prothorax long and narrow to short and broad.

Prothorax with sides not margined to margined, or not emarginate to emarginate.

Prothoracic pleurum convex to flat and concave.

Tarsi with third joint simple to emarginate and bilobed.

Tarsi with first joint short to long.

Elytral declivity convex and smooth to rugose and armed; retuse to concave, with the margin unarmed to strongly armed.

Sexes of unequal size and the males rare to equal size and the males common.

Secondary sexual characters obscure to prominent.

\section{Galleries.}

Simple cavities in decaying bark and wood, to complex designs and regular forms of egg galleries and larval mines.

Excavated in bark to excavated in wood, seeds, etc.

\section{Social habits.}

Unorganized polygamy to organized polygamy, to highly organized monogamy.

Independent larvæ, procuring their own food, to dependent larvæ, with the food provided by the maternal parent. 


\section{STATISTICAL TAXONOMY.}

The subject of statistical taxonomy has received considerable attention by the writer and an attempt has been made (Hopkins, 1911, pp. 28-30, Pl. II) to show its successful application in the genus Pissodes. The detail and accuracy required for this method and the difficulty of determining a specific and taxonomic formula are so great, however, as to be rather trying on the patience of the investigator. Therefore it is the opinion of the writer that it should not be resorted to except in cases in which other methods fail to give satisfactory results and then only when the elements to be included are of such a nature as to be readily arailable for the mathematical determination of relative proportions. There is in this, as in many subjects relating to taxonomy, a need of a more comprehensive investigation in order that the most reliable basis for conclusions may be reached.

\section{THE SPECIES.}

Reference has been made (Part I, p. 66) to the writer's views on specific distinction and the range and limits of specific variation. In addition it may be said that no species can be established beyond dispute without a knowledge of both the morphological and physiological elements of distinction. 'This does not, however, preclude the recognition and naming of imperfectly defined and poorly represented species and of retaining them as long as they can be readily distinguished from other allied forms. Such names and definitions serve as a basis for study until it is more definitely shown whether or not the forms are worthy of permanent specific distinction. There is necessarily a wide range in the relative prominence of the distinguishing characters as between a species which is the only representative of a genus and subfamily and one of a group of closely allied species. It is found, however, that for the purpose of systematic and economic investigation the isolated species may be of no more value for study and may contribute no more to the advancement of knowledge than the one which is with difficulty separated from its congeners.

Since we now insist upon a single specimen as the author's designation of the type of a described species it is deemed by the writer to be perfectly proper to base the description of a new species on a single specimen, provided the author of the description is sufficiently familiar with the previously described allied species and genera to enable him to recognize the characters and characteristics which are of real specific importance.

\section{VARIETIES, RACES, ETC.}

There is in all species a greater or lesser range of rariation from the type, and often some groups of individuals may be so different as to indicate a distinct variety or race. If such variant forms are 
found intermingled with the broods of the typical forms and the characters are not sufficiently constant to distinguish them as separate species they should simply be considered as coming within the range of specific variation, but in the writer's opinion these varieties should not be distinguished by a trinomial.

In some genera and species the sexes may so differ in whole groups of characters as to indicate, in some cases, different genera. But there is always some character or set of characters common to both sexes which would point to the same species even if they were not found associated in the same brood.

There is evidence that in some of the species of Xyleborus and allied genera in the Cryphalinæ there may be occasional individuals which represent a degenerate form or a caste in the social relations of a brood or colony, with uniform but radically different characters from those of either sex, and that on account of the radical differences which separate them from the species with which they have been found they have heretofore been recognized as good species. Xyleborus planicollis Zimm. may be such an odd member of the Xyleborus inermis colony and Xyleborus viduus Eichh. an odd type of the Xyleborus fuscatus colony, but further observations will be needed to settle the question. If this should be true in these cases it may hold with isolated cases in other social species, like those of Hypothenemus, Stephanoderes, Dryocates, etc.

\section{THE GENUS.}

There is more latitude, perhaps, for the selection of distinguishing characters of the genera than there is for the species, but the same principle applies. There must be some single character or group of characters common to a group of allied species which will serve to distinguish the group readily from all other allied groups. The range of departure or variation from the type of the genus is restricted in some genera, but in other genera with many species there may be a very wide range, so that the species will fall in distinct divisions and subdivisions, which are designated by some authors as subgenera.

Unfortunately there is a wide range in the opinions of different authors as to the limits of a genus. Some go to the extreme in restricting it to closely allied species while others go to the opposite extreme (Hagedorn, 1910) and include a large number of genera or so-called subgenera. It is plain to the writer that of the two extremes the latter is the more objectionable because it will certainly contribute more than the former toward retarding than advancing knowledge. The writer believes that there is a middle ground on which systematists should endeavor to get together in order that there may be more uniformity in the conception and definition of the genus. 


\section{NOMENCLATURE.}

Nomenclature, as applied to taxonomy, is a subject on which there are wide differences of opinion, and it is evident that until there is more uniformity there will be continued contributions to the confusion of knowledge along with those which contribute to its advancement.

It seems to the writer that the subject of designating by name varieties, forms, races, subspecies, and subgenera should demand the special attention of systematists with the view of coming to an understanding as to the limiting of such names to the more definite concepts, as those of the species or genus. It would seem that if we should limit the names to the species, genera, subfamilies, families, and superfamilies within an order and designate the major and minor divisions of each as divisions (I, II), subdivisions (A, B, C, D), sections (a1, a2, etc.), subsections (b1, b2, etc.), series (c1, c2, etc.), and subseries (e1, e2, etc.), it would be in the line of progress toward a consistent, practical, and uniform method of expressing the varying ranks as interpreted by different authors. It would avoid, at the same time, the use of names for divisions and subdivisions which have different meanings in the systems proposed by different authors and prevent the accumulation of obsolete names with every change or important advance in the classification.

In the systematic treatment of the scolytoid beetles the writer fails to see the need of recognizing subspecies or subgenera. The species and the genus are the two most important biological concepts on which to base both systematic and economic investigations. They serve, also, as the most important units on which to base a classification. Therefore the writer holds that the individual represents a species and that a species represents a genus; hence the introduction of the trinomial for a subspecies and the naming of a subgenus are unnecessary. Moreover, he believes that a general practice of giving names to such divisions of these taxonomic units will ultimately lead to endless confusion and retard rather than advance the spirit of research and the acquisition of knowledge. At best the designation of the species and the genus to which a given individual should be referred is an arbitrary interpretation of a concept. Therefore, when an author designates an individual or a group of individuals as representing a subspecies, or a group of species as representing a subgenus, it involves the assumption that the concept is a fact and that he has sufficient knowledge of this fact to enable him to analyze it into component categories the relations of which are so definitely determined as to justify the subordination of one part to another.

There is such a wide range for the interpretation of specific and generic distinctions and such a vast difference in the relative rank of such distinctions, between isolated survivors of highly specialized and 
ancient groups and common, closely allied, and variable forms, that the difference between two species in one genus may be equivalent to or greater than that between two allied genera. In a like manner the difference between two genera may be almost equivalent in rank to that between two allied subfamilies. Therefore the fact that a given group of individuals or a group of species appears to represent a position of lower rank than that of an allied species or genus is not sufficient reason that it should be designated as a subspecies or subgenus. In other words, it is the writer's opinion that if a group of individuals is sufficiently distinct from allied groups to justify its designation by a name, it should be recognized as a species; and if, on the other hand, the group is connected with allied forms by such a number of intermediate forms as to render its specific distinction doubtful, it should be included with other variable types under a species name, and that the same principle should hold in regard to the genus.

All of the purposes served by the subspecific designation can be served just as well, if not better, by classifying the individuals of a species into major and minor divisions, sections, etc., and letting these represent the same conception as that represented by the named subspecies, and on the same principle the divisions and subdivisions of a genus will serve the same purpose as if designated by names.

\section{TYPES OF GENERA.}

Difference of opinion among systematists who have worked on the scolytoid beetles, guided as they have been by different rules and conceptions as to what constitutes a valid genus, has led to much uncertainty and confusion as to some of the older names for the genera of our common species. Therefore it seems necessary that the author should present the evidence which appears to him to be conclusive in regard to the generic names and the synonymy of Scolytus, Ips, Tomicus, Cryphalus, Hypothenemus, etc.

\section{Genus SCOLYTUS Geoffroy.}

It has seemed to the writer that there is not sufficient reason or authority for the suppression of the name Scolytus as proposed and clearly defined by Geoffroy (1762, p. 309). The single "species" of the "genus" recognized by him was at the same time (p. 310) indicated by a number, the genus name (Scolytus), and a reference to a figure (Vol. I, pl. 5, fig. 5), and the characters were more clearly defined in a description.

Müller (1764, p. xiv) recognized the genus Scolytus Geoff. and referred to the original description and figures.

Schaeffer (1766, Tab. CXII, figs. 1, 2, 3, 4) redescribed the genus Scolytus and described and figured the species indicated by Geoffroy, but did not name it. 
Limnæus (1767) failed to mention the genus or to refer to Geoffroy, Müller, or Schaeffer.

Fabricius (1775, p. 59) recognized the species described by Geoffroy and redescribed it under the name Bostrichus scolytus, with the citation "Geoff. Ins. 1-310, [No.] 1, Tab. 5, fig. 5, Mal." Thus Fabricius recognized the species indicated by Geoffroy on page 310 , but did not refer it to the genus described on page 309 under the name $S$ colytus because he (Fabricius) evidently considered it synonymous with Bostrichus. Consequently, the name proposed by Geoffroy for the genus should stand with Bostrichus scolytus (Fab.) as the type.

Sulzer (1776, Th. 1, p. 21; Th. II, Tab. II, f. 13k), under the name Dermestes scolytus, described and figured the species indicated by Schaeffer, 1766.

Müller $(1776$, p. 57) published a description under the name Scolytus punctatus but referred it doubtfully to Geoffroy's figures.

Goeze (1777, p. 143), under the name "Dermestes scolytus Geoffroi," cited Bostrichus scolytus Fab. (1775), Scolytus Geoff. (1762), and Scolytus punctatus Müll. (1776). Goeze evidently did not mention "Geoffroi" as a specific name but merely to indicate that Geoffroy was the author of or authority for the name Scolytus.

Linnæus (178s, 1793, p. 1602) recognized Bostrichus scolytus Fab. and cited Fabricius, 1787, Geoffroy, 1762, Sulzer, 1776, and Schaeffer, 1766.

Herbst (1793, p. 124) described the genus Eccoptogaster with Bostrichus scolytus Fab. as the type.

Olivier (1795, No. 78, p. 5, Pl. I, fig. 4 a, b, c) adopted the name Scolytus for the genus and cited Geoffroy, 1762, and Fabricius, 1775, but substituted for the species the name destructor in the place of Scolytus Fab., evidently concluding, as other contemporary writers did, that the generic and specific names could not be the same. In fact this opinion evidently influenced the action of Fabricius, Müller, Herbst, and others.

Curtis (1824, p. 43) designated the type of the genus Scolytus as Bostrichus scolytus Fab.

\section{Genus IPS De Geer.}

There appears to be no room for doubt that the genus Ips of De Geer (1775, p. 190), with Dermestes typographus Linn., 1758, as the type, has priority over Ips of Fabricius (1776, p. 23).

Genus TOMICUS Latreille.

Latreille (1802, p. 203) described the genus Tomicus with Hylesinus piniperda Fab. (1S01, p. 392) as the type, but H. piniperda of Fabricius is, as cited by him (1801, p. 392), the same as Bostrichus piniperda (L.) Fab. (1775, p. 60; 1792, p. 367) and Dermestes pini- 
perda Limn. (175s, p. 355 and 1767 , p. 563). Therefore it appears that the name Tomicus should stand, with Hylesinus piniperda (L.) Fab. as the type. The slight difference in the description by Fabricius of the insect he identified as Linnæus's species does not warrant the conclusion that it was different, because the species has the characters mentioned.

The species piniperda $L$.

piniperda L., Dermestes Linnæus, 1758, p. 355; 1761, p. 143; 1767, p. 363.

piniperda L., Bostrichus Fabricius, 1775, p. 60; 1792, p. 367.

piniperda L., Hylesinus Fabricius, 1801, p. 392.

piniperda L., Tomicus Latreille, 1802, p. 203. (Type of genus.)

piniperda L., Blastophagus Eichhoff, 1864, p. 25. (Type of genus.)

piniperda L., Myelophilus Eichhoff, 1878, p. 400. (Type of genus.)

\section{Genus HYLASTES Erichson.}

Erichson (1836, p. 48) described the genus Hylastes to include Bostrichus ater Paykull, Bostrichus angustatus Herbst, etc., stating that Bostrichus ater Fab. was not a scolytid. Therefore, since Bostrichus ater Paykull is a good species, it stands as the type of the genus Hylastes Erichson, as designated, by Thomson, 1859, p. 146.

\section{Genus CRYPHAIUS Erichson.}

Erichson (1836, p. 61) described the genus Cryphatus to include Apate tilix Panz., Apate fagi Fab., and Bostrichus asperatus Gyll. Thomson (1859, p. 146) designated (Bostrichus) Cryphalus asperatus Gyll. as the type and (p. 147) referred Cryphalus tilix Panz. to his monobasic subgenus Ernoporus and (1865, p. 360) Cryphalus fagi Fab. to Ernoporus.

Hypothenemus Westw., 1834, p. 34; Ernoporus Thom., 1859, p. 147; Trypophtous Fairm., 1868, p. 105; Stephanoderes Eichh., 1871, p. 132, and Cryphaloides Form., 1908, p. 91, are all sufficiently distinct from Cryphalus Erich. and from one another to stand as separate and distinct genera; therefore they should not, in the opinion of the writer, be considered as subgenera of Cryphalus.

\section{Genus HYPOTHENEMUS Westwood.}

Westwood (1834, pp. 34, 36, Pl. VII, fig. 1a to h) described the genus Hypothenemus with eruditus Westw. as the only species and mentioned and illustrated a three-jointed funicle of the antenna as one of the distinguishing characters.

Duvall (1868, p. 105, pl. 33, fig. 161) examined specimens from the type series and redescribed and figured the species, and referred to the funicle as having bat three joints.

Eichhoff $(1879$, p. 165) referred the genus Hypothenemus Westw., and species eruditus Westw. to synonymy under Stephanoderes $59026^{\circ}-15-5$ 
ariccæ (Hornung, 1842, p. 117 [not 115]) because he found that certain species previously referred to Hypothenemus had five joints in the funicle of the antenna instead of three, as designated by Westwood.

Fauvel (1884, p. 315) examined specimens of H. eruditus Westw. from the type series and compared them with examples of Bostrichus boieldieui Perroud, 1864, p. 188, and B. ariccæ. Hornung, 1842, p. 117, identified by Eichhoff, and concluded that all three were identical, and that Homoocryphalus Lind., 1876, p. 168, as represented by Stephanoderes ehlersi Eichh., was identical with Hypothenemus Westw.

Newberry (1910, p. 83) determined that the funicle had four joints.

Through the kindness of Prof. Poulton, the writer had the opportunity of examining a specimen of $H$. eruditus Westw. from the type series, and the funicle was found to be four-jointed. It is not improbable, however, that the antenna examined by Westwood was from a male, which, in this genus, is smaller than the female and has but three joints in the funicle. Therefore there can be no doubt as to the validity of the genus Hypothenemus Westw. as distinguished from the genus Stephanoderes Eichh., which has a five-jointed funicle.

\section{Genus POIYGRAPHUS Erichson.}

Erichson (1836, p. 57-58) described the genus Polygraphus, citing Dermestes polygraphus I. (1758, p. 355) as synonymous with $P$. pubescens Fab. (1792, p. 368); but since P. polygraphus L. has priority, the genus stands with Dermestes polygraphus L. as the type.

\section{Genus LEPISOMUS Kirby.}

Kirby (1837, p. 193) described Lepisomus as a subgenus of Apate Fab., including three species, one of which, Apate (Lepisomus) nigriceps, has been referred to synonymy (Lec., 1868, p. 169) while A pate (Lepisomus) brevicornis is not recognizable, probably a synonym. Therefore Apate (Lepisomus) rufipennis Kirby is the type of the genus Lepisomus, which, on account of the six-jointed funicle, is a good genus. For the same reason Polygraphus grandiclava Thom. (1886, p. 62) must also be referred to this genus.

\section{DESCRIPTION OF A NEW GENUS AND SPECIES.}

\section{WEBBIA n. gen. ${ }^{a}$}

Antennal funicle four-jointed, the fourth broad; club narrowed from middle to base, broater than long, with one sinuate chitinous suture on the obliquely truncate anterior face, the posterior face

a This genus and species is described here in order that the subfamily may be included in the classification. 
without sutures; eyes oblong, elliptical, deeply emarginate; anterior tibia strongly narrowed to apex, with submarginate row of closely placed teeth on the ventral side; elytral declivity with many closely placed marginal teeth; lateral margin of pronotum acute, anterior margin without serrations. Type of genus, Webbia dipterocarpi new species.

This genus is named for Mr. J. L. Webb on account of the large number of scolytoid beetles collected by him during his brief employment in the Philippine service.

\section{Webbia dipterocarpi n. sp.}

Length, female type, $3.1 \mathrm{~mm}$. Subelongate; pronotum and all but the declivity of the elytra light ferruginous, the declivity black. Pronotum with anterior area swollen, opaque, nearly smooth; apex steep, subtruncate, and finely rugose; median and posterior areas smooth, subopaque, and very finely punctured. Front moderately narrow, subconvex, opaque, with fine median line. Elytra to near declivity smooth, shining, with fine, closely placed, and confused punctures with no trace of strix, narrow, and near vertex slightly swollen, densely opaque, nearly black; declivity steep, flat, opaque; interspace 1 elerated, smooth; interspaces 2 and 3 each with straight rows of granules; margin from vertex to apex armerl each side with 10 closely placed serrations or teeth, becoming slightly larger toward apex. These teeth evidently represent the 10 interspaces of the normal elytra. Near Pagbilao, Philippine Islands, in wood of dead $\log$ of Dipterocarpus grandiflorus Blco., August 7, 1903. J. L. Webb, collector. Under his number 94c.

Type.-Cat. No. 7406, U. S. National Museum.

Length, male type, $2.6 \mathrm{~mm}$. Subelongate; pronotum slightly broader than elytra which are narrowed toward declivity, light ferruginous throughout. Head narrow, shining, with deep epistomal impression and a slight posterior impression. Pronotum opaque, finely rugose throughout, with distinct median impressed, shining line to anterior declivity which is steep and strongly retuse to anterior margin, sides slightly narrowed from anterior angles to base, lateral margins subobtuse; elytra with sides slightly narrowed toward declivity, shining, punctured as in female but with striæ evident and faintly impressed; declivity steep, flat, opaque, rugose, but without elevated interspaces, margin with but seven marginal teeth, coarser toward vertex and arranged in groups of 3-2-2. In a lateral aspect the dorsal line forms a broad curve from the mandibles to the apex of the abdomen. From same colony as the female.

The smaller size and general appearance of the male suggests affinities with the Xyleborus group but it is radically different in all of the more important characters. 
The fact that specimens were collected in the wood indicates that the food habits are similar to those of Crossotarsus lecontei, found in the same log.

The pupa is peculiar in the absence of caudal spines, the presence of tergal and pleural hairs instead of tubercles, and the length of the wing-pads, which extend to the apex of the abdomen.

The larva, as shown by a dried specimen, appears to have the posterior part of the body stouter, then narrowed toward the apex of the abdomen.

\title{
PRELIMINARY CLASSIFICATION OF THE SUPERFAMILY SCOLYTOIDEA.
}

\author{
Key to the Families.
}

(See Pl. IX.)

I. Anterior tarsi with joint 1 shörter than 2, 3, and 4 together.

A. Anterior tibia without prominent process on the outer apical angle.

B. Anterior tibia with prominent process on the outer apical angle.

Family Ipidæ.

al. Anterior tibia without prominent rugosities on ventral area.

a2. Anterior tibia with prominent rugosities on ventral area.

Family Scolytidæ.

Family Scolytoplatypodidæ.

II. Anterior tarsi with joint 1 longer than 2, 3, and 4 together.

C. Anterior tibia with prominent apical process and with rugosities on the ventral area........................... Family Platypodidæ.

\section{Family IPIDE.}

Key to the Subfamilies.

(See Pls. X, XI, XIII, XIV.)

I. Pronotum with anterior dorsal area commonly rugose; head concealed from above; anterior tarsi with joint 3 simple.

A. Abdominal sternites 5-7 not strongly ascending.

a1. Anterior tibia broader toward apex or serrate on outer margin.

b1. Abdominal sternite 7 with posterior margin always rounded.

1. Subfamily Cryphalinæ.

b2. Abdominal sternite 7 with posterior margin rarely rounded.

c1. Pronotum and elytra clothed with scales or hairs, very rarely glabrous ........................ Subfamily Ipinæ.

c2. Pronotum and elytra without scales, commonly glabrous or sparsely pubescent................. Subfamily Corthylinæ.

a2. Anterior tibia not distinctly broader toward apex or not serrate on outer margin.

b3. Anterior tibia not strongly narrowed toward apex, apical tooth stout; antennal club compressed; elytra with scales.

4. Subfamily Micracinæ.

b4. Anterior tibia strongly narrowed torrard apex, apical tooth small; antennal club thickened at base, with anterior face obliquely truncate; elytra with hairs................ 5. Subfamily Webbinæ.

B. Abdominal sternites 5-7 strongly ascending; tibia broadly compressed, outer margin serrate . . . . . . . . . . . . . . . . . . . . . 
II. Pronotum with anterior dorsal area commonly smooth; head exposed or rarely concealed from above; tarsi with joint 3 simple or bilobed.

C. Antennal club subglobose, compressed to laminate, never conical.

a3. Body slender to moderately stout; pronotum longer than broad or not broader than long..................... Subfamily Crypturginæ. a4. Body stout; pronotum always broader than long.

8. Subfamily Phlcotribinæ.

D. Antennal club usually conical, rarely compressed ...9. Subfamily Hylesininæ.

10. Subfamily Phlœoborinæ.

\section{Family SCOLYTIDE.}

Key to the SubFamilies.

(See Pls. XII, XV, XVI.)

I. Pronotum constricted toward the middle; anterior tarsi with joint 3 simple.

11. Subfamily Coptonotinæ.

II. Pronotum not constricted toward the middle; anterior tarsi with joint 3 simple or bilobed.

A. Anterior tibia with small tooth on inner apical angle extending beyond the tarsal insertion; tibia with at least one tooth on the outer margin, in addition to the apical one.

al. Eyes not divided; tibia with outer margin armed.

b1. Pronotum with transverse rugosities on anterior area.

12. Subfamily Hexacolinæ.

b2. Pronotum without transverse rugosities on anterior area.

13. Subfamily Bothrosterninæ.

a2. Eyes divided; tibia with outer margin unarmed. ${ }^{a}$

14. Subfamily Hyorrhynchinæ.

B. Anterior tibia with small tooth on inner apical angle not extending beyond the tarsal insertion.

a3. Abdominal sternum convex throughout; antennal scape not very short.

15. Subfamily Camptocerinæ.

a4. Abdominal sternum not convex throughout; antennal scape very short.

16. Subfamily Scolytinæ.

\section{Family SCOLYTOPLATYPODID必.}

(See Pls. XII, XVI.)

Anterior tibia with prominent lateral process at outer angle; third tarsal joint simple ........................... 17. Subfamily Scolytoplatypodinæ.

\section{Family PLATYPODIDE.}

\section{Key to the Subfamilies.}

(See Pls. XII, XVI.)

I. Third tarsal joint simple................. 18. Subfamily Platypodinæ.

II. Third tarsal joint bilobed .................. 19. Subfamily Genyocerinæ.

20. Subfamily Chapuisinæ.

a Uncertain from description whether or not inner angle of anterior tibia is produced beyond the tarsal insertion. 


\section{POSITION OF THE PRINCIPAL DESCRIBED GENERA IN THE PRELIMINARY CLASSIFICATION.}

Family Ipidæ.

Subfamily Cryphalinæ.

Cosmoderes Eichh.

Cryphalomorphus Schauff.

IIypothenemus Westw.

Stephanoderes Eichh.

Ernoporus Thoms.

Trypophloeus Fairm.

Cryphalops Reitt.

Cryphaloides Form.

Cryptarthrum Blndfd.

Cryphalus Erich.

Eidophelus Eichh.

Kyrtogenius Stroh.

Lepicerus Eichh.

Lymantor L $\phi \mathrm{v}$.

Dendroterus BIndfd.

Xylocleptes Ferr.

Taphrorychus Eichh.

Thamnurgus Eichh.

Coccotrypes Eichh.

Ozopemon Haged.

Dryocœtes Eichh.

Xyleborus Eichh.

Anisandrus Ferr.

Eccopiopterus Motsch.

Cnestus Sampson.

Subfamily Ipinæ.

Pityophthorus Eichh.

Olonthogaster Motsch.

Acanihotomicus Blndfd.

Pityogenes Bedel.

Ips De Geer.

Subfamily Corthylinæ.

Metacorthylus BIndfd.

Monarihrum Kirsch.

Cosmocorynus Ferr.

Phthorius Eichh.

Anchonocerus Eichh.

Glochinocerus Blndfd.

Tricolus Blndfd.

Amphicranus Erich.

Steganocranus Eichh.

Corthylus Erich.

Brachyspartus Ferr.

Gnathotrichus Eichh.

Premnobius Eichh.

$X y l o t e r u s$ Erich.

Subfamily Micracinæ.

Pocilips Schauf.

Thysanoes Lec.
Family Ipidæ-Continued.

Subfamily Micracinæ-Continued.

Hieracis Lec.

Hylocurus Eichh.

Styracopterus Blndfd.

Liparthrum Woll.

Dacryostactus Schauff.

Hypoborus Erich.

Glochiphorus Stroh.

Cactopinus Schwarz.

Subfamily Webbinæ.

Jebbia n. gen.

Subfamily Xyloctoninæ.

Scolytogenes Eichh.

Scolytomimus Blndfd:

Scolytodes Ferr.

$X y$ loctonus Eichh.

Gtonoxylon Haged.

Subfamily Crypturginæ.

A phanarthrum Woll.

Triotemnus Woll.

Crypturgus Eichh.

Cisurgus Reitt.

Dolurgus Eichh.

Dendroctonus Erich.

Subfamily Phlœotribinæ.

Phlocophthorus Woll.

Eulytocerus Blndfd.

Phlocotribus Latr.

Dryotomus Chap.

Renocis Casey.

Chrtophlous Lec.

Chramesus Lec.

Choriastus Schauff.

Carphoborus Eichh.

Cladoctonus Stroh.

Lissoclastus Schauf.

Tiarophorus Schrein.

Phrixosoma Blndid.

Lepisomus Kirby.

Polygraphus Erich.

Spongotarsus Hageo.

Subfamily Hylesininæ.

Xylechinus Chap.

Kissophagus Chap.

Hylurgus Latr.

Pachycotes Sharp.

Tomicus Latr. (Myelophilus

Eichh.)

Hylastinus Bedel.

Scierus Lec. 
Family Ipidæ-Continued.

Subfamily Hylesininæ-Continued.

Hylesinus Fab.

Pteliobius Bedel.

Dendrosinus Chap.

Acanthophorus Stroh.

Hylurgops Lec.

Hylastes Erich.

Subfamily Phlœoborinæ.

Phlootrupes Erich.

Phlooborus Erich.

Dactylipalpus Chap.

Family Scolytidæ.

Subfamily Coptonotinæ.

Craniodicticus Bindfd.

Microborus BIndfd.

Coptonotus Chap.

Strbfamily Hexacolinæ.

Erineophilus Hopk.

Hexacolus Erich.

Epomadius Blndfd.

Problechilus Eichh.

Aricerus Blndfd.

Pycnarthrum Eichh.

Prionoceles Blndfd.

Rhopalopselion Haged.

Strombophorus Haged.

Sphærotrypes Blndfd.

Diamerus Erich.

Bothryperus Haged.

Subfamily Bothrosterninæ.

Pagiocerus Eichh.

Cnesinus Lec.

Meringopalpus Haged.
Family Scolytidæ-Continued.

Subfamily Bothrosterninæ-Contd.

Eupagiocerus Blndfd.

Bothrosternus Eichh.

Subfamily Camptocerinæ. Ceratolepis Chap.

Cnemonys Eichh.

Camptocerus Dej.

Loganius Chap.

Subfamily Scolytinæ.

Scolytopsis Blndfd.

Scolytus Geoff.

Family Scolytoplatypodidæ.

Subfamily Scolytoplatypodinæ.

Scolytoplatypus Schauff.

Spongocerus BIndfd.

Tæniocerus Blndfd.

Family Platypodidæ.

Subfamily Platypodinæ.

Spathidiceres Chap.

Periommatus Chap.

Tesserocerus Saund.

Symmerus Chap.

Cenocephalus Chap.

Mitosoma Chap.

Diapus Chap.

Cylindropalpus Stroh.

Platypus Herbst.

Crossotarsus Chap.

Subfamily Genyocerinæ.

Genyocerus Motsch.

Subfamily Chapuisinæ.

Chapuisia Dugès.

\section{GENERA DESCRIBED IN 1911-12, NOT INCLUDED IN FORE- GOING LIST, BUT HERE PROVISIONALLY ASSIGNED TO THE SUBFAMILIES.}

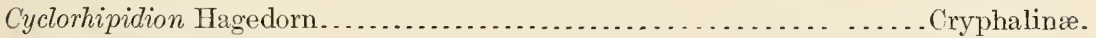

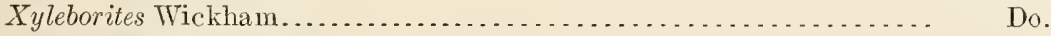

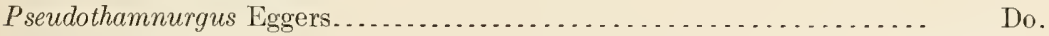

Neotomicus Fuchs...................................... Ipinæ.

Xestips Hagedorn....................................... Do.

Pityokteines Fuchs.......................................... Do.

Trigonogenius Hagedorn................................ Do.

Allarthrum Hagedorn......... . . . . . . . . . . . . . . . . . . . . . Micracinæ.

Acacicis Lea........... . . . . . . . . . . . . . . . . . . . . . . . . Hylesininæ.

Hapalogenius Hagedorn...................................... Do.

Hylesinosoma Lea........................................... Do.

Chxtophorus Fuchs..................................... Do.

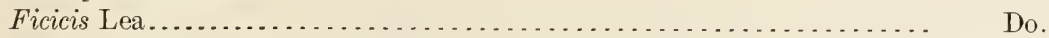

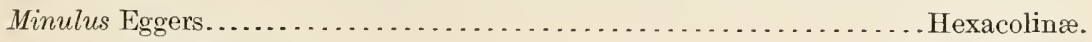

Mesoplatypus Strohmeyer................................. Platypodinæ.

Notoplatypus Lea..................................... Do. 


\section{GENERA OF DOUBTFUL POSITION.}

Mesoscolytus Blndfd. Phthorophloeus Rey. Hyloscyllus Schauff. Dendrotrupes Broun.
Styphlosoma Blndfd.

Acrantus Broun.

Inosomus Broun.

Araptus Eichh. 


\section{BIBLIOGRAPHY.}

1758. Linnaeus, C.-Systema naturæ per regna tria naturæ. Ed. 10, Vol. I, p. 355.

1761. Linnaeus, C.-Fauna suecica, pp. 140-143.

1762. Geoffroy, E. L.-Histoire abrégée des insectes, Tom. I, pp. 309-310, Pl. V, fig. V.

1764. Müller, O. F.-Fauna insectorum fridrichsdalina, sive Methodica descriptio insectorum agri fridrichsdalensis, cum characteribus genericis et specificis, nominibus trivialibus locis natalibus iconibus allegatis, novisque pluribus speciebus additis, p. XIV, No. 26.

1766. SchatefFir, J. C.-Elementa entomologica, P1, CXII.

1767. Linnaeu's, C.-Systema naturæ. Ed. 12, Vol. I, Pt. 2, pp. 562-564.

1775. Fabricius, J. C.-Systema entomologiæ, pp. 59-60.

1775. De GEer, C.-Mémoires pour servir à l'histoire des insectes, Vol. 5, pp. 190-198, Pl. 6.

1776. Sulzer, J. H.-Abgekürzte Geschichte der Insecten nach dem Linaeischen System, pp. 20-21, PI. II.

1776. FA вRicius, J.C.-Genera insectorum eorumque characteres naturales, secundum numerum, figuram, situm et proportionem omnium partium oris adjecta mantissa speciorum nuper detectarum, pp. 211.

1776. MÜlLeR, O. F.-Zoologiæ Danicæ prodromus, seu Animalium Daniæ et Norwegiæ indigenarum characteres, nomina, et synonyma imprimis popularium, pp. $56-57$.

1777. Goeze, J. A. E.-Entomologische Beyträge zu des Ritters Linné zwölften Ausgabe des Natursystems, Vol. I, pp. 130-151.

1785. Fourcroy, A. F. DE-Entomologia Parisiensis, sive Catalogus insectorum quæ in agro parisiensi reperiuntur; secundum methodum Geoffræanum in sectiones, genera \& species distributus: cui addita sunt nomina trivialia \& fere trecentæ novæ species, p. 139.

1787. FABRicius, J. C.-Mantissa insectorum sistens eorum species nuper detectas, adjectis characteribus genericis, differentiis specificis emendationibus, observationibus, Vol. I, pp. 36-38.

1788-93. Linnaeus, C.-Systema naturæ. Ed. 13, pp. 1592-1599 and 1601-1603.

1792. FABRICIUS, J. C.-Entomologia systematica emendata et aucta, secundum classes, ordines, genera, species, adjectis synonimis, locis, observationibus, descriptionibus, Tom. I, Pt. I, p. 180; Tom. I, Pt. 2, pp. 363-368.

1793. НеRbst, J. F. W.-Natursystem aller bekannten in- und ausländischen Insekten. Der Käfer, Th. V, pp. 81, 103, 122, 127-128.

1795. Olivier, A. G.-Entomologie, ou Histoire naturelle des insectes, Coléoptères, Tom. 4, No. 78, pp. 1-14, Pls. I-II.

1800. Paykull, G.-Fauna suecica. Insecta, Vol. 3, pp. 145-156.

1801. Fa B Ricius, J. C.-Systema Eleutheratǫrum secundum ordines, genera, species, adjectis synonymis, locis, observationibus, descriptionibus, Tom. II, pp. 384-395.

1802. MARSHAM, T.-Entomologia Britannica, sistens insecta Britanniæ indigena secundum methodum Linnæanam disposita, Tom. I, Coleoptera, pp. 51-60.

1802. Latreille, P. A.- Mistoire naturelle, générale et particuliere des crustacés et des insectes, Vol. 3, p. 204. 
1802. Illiger, J. K. W.-Zusätze, Berichtigungen und Bemerkungen zu Fabricii Systema Eleutheratorum, Tomus. I. Magazin für Insektenkunde, Bd. 1, pp. 306-425, with special reference to p. 367 .

1807. Illiger, J. K. IV.- Vorschlag zur Aufnahme im Fabricischen Systeme fehlender Käfergattungen. Magazin für Insektenkunde, Bd. 6, pp. 318-349, with special reference to p. 367 .

1807. Latreille, P. A.-Genera crustaceorum et insectorum secundum ordinem naturalem in familias disposita, iconibus exemplisque plurimus explicata, Vol. 2, pp. 273-280.

1813. Gyllenhal, L.-Insecta suecica descripta, Tom. I, Pars. III, pp. 335-372.

1824. Curtis, JohN-British entomology, Vol. I, No. 43.

1834. Westwood, J. O.-Description of a minute coleopterous insect, forming the type of a new subgenus allied to Tomicus, with some observations upon the affinities of the Xylophaga. Trans. Ent. Soc. London, Vol. I, Pt. I, pp. 34-36, Pl. VII, figs. la-lh.

1836. Erichson, W. F.-Systematische Auseinandersetzung der Familie der Borkenkäfer (Bostrichidæ). Archiv für Naturgeschichte v. A. F. Wiegmann, Jahrg. II, Bd. I, pp. $45-65$.

1837. KuRBy, W.-Fauna Boreali-Americana; or the zoology of the northern parts of British America. Part 4. The insects, pp. 191-195.

1839. Ratzeburg, J. T. C.-Die Forst-insecten, Th. I, pp. 168-232, Pls. 7-15.

1842. HorNung, A.- - Ueber einige in den Betelnüssen vorkommende Käfer. Stettin Ent. Ztg., Jahrg. 3, pp. 115-117.

1859. Thomson, C. G.-Skandinaviens Coleoptera syuoptiskt bearbetade, Tom. I, pp. 146-147.

1864. Perroud, B.P., \& Montrousier, A.-Essai sur la faune entomologique de Kanala (Nouvelie-Calédonie) et description de quelques espèces nouvelles on peu connues. Ann. Soc. Linn. Lyon, Tom. II, pp. 46-257, Pl. I. See p. 188.

1864. Еіснноғт, W.--Ueber die Mundtheile und die Fühlerbildung der europaischen Xylophagi sens strict. Berlin Ent. Ztschr., Jahrg. S, pp. 17-48.

1865. Thомson, C. G.-Skandinaviens Coleoptera synoptiskt bearbetade, Tom. 7, pp. $345-378$.

1866. Lacordaire, J. T.-Histoire naturelle des insectes. Genera des coléoptères, Tom. 7, pp. 358-376.

1868. Jacquelin Du Val, P. N. C., \& Fairmaire, L.-Manuel entomologique. Genera des coléoptères d'Europe, Vol. 4, pp. 97-105, Pls. 31-34.

1868. Zimuermann, C.-Synopsis of the Scolytidæ of America north of Mexico. Trans. Amer. Ent. Soc., Vol. II, pp. 141-149.

1868. Le Conte, J. L.-Appendix and notes to Zimmermann, C. Synopsis of Scolytidæ of America north of Mexico. Trans. Amer. Ent. Soc., Vol. II, pp. 150-178.

1869. Chapuis, F.-Synopsis des scolytides. Mem. Soc. Sci. Liège, Sér. 2, Vol. 3, pp. 213-269 (author's extra issued 1869).

1871. Еiснноғғ, W.-Neue exotische Tomiciden-arten. Berlin Ent. Ztschr., Jahrg. 15 , pp. 131-137.

1872. Gemminger, M.. \& Harold, B. de.-Catalogus Coleopterorum, Vol. 9, pp. $2669-2702$.

1875. Lindeuany, C.-Tergleichend anatomische Lntersuchung über das mænnliche Begattungsglied der Borkenkäfer. Bul. Soc. Imp. Nat. Moscou, Tom. 49, No. 1, pp. 196-252, Pls. I-V.

1876. Le Conte, J. L.-The Rhynchophora of America north of Mexico. Scolytidæ. Proc. Amer. Phil. Soc., Vol. 15, pp. 341-391. 
1876. Lindemann, C.-Monographie der Borkenkäfer Russlands. Die cryphaloiden Tomiciden. Bul. Soc. Imp. Nat. Moscou, Tom. 51, No. 4, pp. $320-380$, figs. 6-55.

1878. Егснноғғ, W.-Ueber die Borkenkäfer-Gattungen Hylurgus Latr. und Blastophagus Eich. Stettin Ent. Ztg., Jahrg. 39, pp. 399-400.

1879. Еiснноғ, W.-Ratio, descriptio, emendatio eorum Tomicinorum, p. 165.

1880. Rupertsberger, M.-Biologie der Käfer Europas, Scolytidæ, pp. 224-232.

1881. Eтснноғғ, W. J.-Die europaischen Borkenkäfer, pp. 315, figs. 104.

1884. Fauver, A.-Sur l'identité des genres Hypothenemus, Stephanoderes et Homøecryphalus. Revue d'entomologie, Tom. 3, p. 315.

1886. Thomson, C. G.-[Note on Polygraphus grandiclava Thoms.] Bul. Soc. Ent. France, p. LXII.

1888. Beder, L.-Faune des coléoptères du Bassin de la Seine, Tom. VI, pp. 385-421.

1894. Hopkrns, A. D.-Sexual characters in Scolytidæ. Canad. Ent., Vol. 26, pp. 274-280, October.

1894. Reitter, E.-Bestimmungs-tabelle der Borkenkäfer (Scolytidæ) aus Europa und den angrenzenden Ländern, Hft. 31, pp. 40-97.

1894. Rupertsberger, M.-Die biologische Literatur über die Käfer Europas von 1880 an, mit Nachtragen aus früherer Zeit und einem Larven-Cataloge, pp. 236-243.

1895-1905. Blandford, W. F. H.-Scolytidæ. Biologia Centrali-Americana. Insecta. Coleoptera, Vol. 4, Pt. 6, pp. 81-298, Pls. IV-IX.

1895. Judeich, J.F., \& Nitsche, H.-Lehrbuch der mitteleuropäischen Forstinsektenkunde, Vol. I, pp. 435-556, figs. 142-178.

1896. VerhoefF, C.--Ueber das Abdomen der Scolytiden, ein Beitrag zur vergleichenden Morphologie des Hinterleibes der Coleopteren. Archiv für Naturgeschichte, Jahrg. 62, Bd. I, pp. 109-144, figs. A-D.

1897. Hubbard, H. G.-The ambrosia beetles of the United States. Bul. 7, n. s., Div. Ent., U. S. Dept. Agr., pp. 9-30, figs. 1-34.

1898. Hopkins, A. D.- On the history and habits of the "wood engraver" ambrosia beetle-Xyleborus xylographus (Say), Xyleborus saxeseni (Ratz.)-with brief descriptions of different stages. Canad. Ent., Vol. 30, pp. 21-29, Pls. $2-3$, January.

1899. Hopkins, A. D.-Report on investigations to determine the cause of unhealthy. conditions of the spruce and pine from 1880-1883. Bul. 56, W. Va. Agr. Exp. Sta., pp. 197-461, figs. XCIX, April.

1901: Barbey, Auguste.-Les scolytides de l'Europe centrale. pp. 121, Pls. 18.

1902. Sedpaczer, W.-Ueber den Darmcanal der Scolytiden. Centralblatt für das gesamte Forstwesen, Jahrg. 28, Hft. 6, pp. 241-263, fold. P1., Juni.

1903. Ganglbauer, L.--Systematisch-koleopterologische Studien. Münchener koleopterologische Zeitschrift, Vol. I, pp. 271-319.

1905. Hopkins, A. D.-Notes on scolytid larvæ and their mouth parts. Proc. Ent. Soc. Wash., Vol. 7, No. 2-3, pp. 143-149, Pls. 4-5, October.

1906. Heyden, L. von, Reitter, E., \& Weise, J.-Catalogus Coleopterorum Europæ, Caucasi et Armeniæ rossicæ. Ed. 2, column 707-714.

1907. TRÉDL, R.-Nahrungspflanzen und Verbreitungsgebiete der Borkenkäfer Europas. Entomologische Blätter, Bd. 3, pp. 2-4, 15-22, 37-42, 53-56, 6972,87 .

1908. Formanek, Roman.-Eine neue Borkenkäfer-gattung. Entomologische Blätter, Jahrg. 4, p. 91, May 15.

1909. Hopkins, A. D.-Contributions toward a monograph of the scolytid beetles. I. The genus Dendroctonus. Tech. Ser. No. 17, Pt. I, Bur. Ent., U. S. Dept. Agr., pp. 1-164, figs. 1-95, Pls. I-VIII, June 30. 
1909. Swarne, J. M.-Catalogue of the described Scolytidæe of America north of Mexico. 24th Report of New York State Entomologist. Appendix B. New York State Education Dept. Bul. 455, New York State Museum, Museum Bul. 134, September.

1910. Hagedorn, M.-Tpide. Schenkling, S., ed. Coleopterorum Catalogus, Pars. 4, p. 134.

1910a. HAGEDORN, M.-Coleoptera. Fam. Ipidæ. Wytsman, P. Genera Insectorum, fasc. 111, pp. 178, Pls. 14.

1910. Newberry, E. A.- On Hypothenemus eruditus, Westwood. Ent. Mo. Mag., Vol. 46 (Ser. 2, Vol. 21), pp. 83-84, April.

1910. Lea, A. M.-On Australian and Tasmanian Coleoptera, with descriptions of new species. Part I. Proc. Roy. Soc. Victoria, Vol. 22 (new ser.), Part II, pp. 133-150.

1911. Hopkins, A. D.-Contributions toward a monograph of the bark weevils of the genus Pisodes. Tech. Ser. No. 20, Pt. I, Bur. Ent., U. S. Dept. Agr., pp. 1-68, figs. 1-9, Pls. I-XXII, January 7.

1911: Nüssisn, O.--Phylogenie und System der Borkenkäfer. Ztschr. Wiss. Insektenbiol., Bd. 7, No. 1-12.

1911. Fuchs, G. Morphologische Studien über Borkenkäfer I. Die Gattungen Ips De Geer und Pityogenes Bedel. pp. 1-45, figs. 1-39.

1912. Nüssuın, O.-Phylogenie und System der Borkenkäfer. Ztschr. Wiss. Insektenbiol., Bd. 8, No. 1-7.

1912. Fuchs, G.-Morphologische Studien Uber Borkenkäfer. II. Die europäischen Hylesinen, pp. 1-13, figs. 1-85, 3 fold. pls.

1912. Sharp, D., \& MUIR, F.- The comparative anatomy of the male genital tube in Coleoptera. Proc. Ent. Soc. London, Pt. III, pp. 477-642, Pls. XLIILXXVIII, December.

Note.-The next contribution toward this monograph, entitled "Preliminary Classification of the subfamily Cryphalinæ, with descriptions of new genera and species," will be published as Report No. 99, Office of the Secretary, U. S. Department of Agriculture. 
ADDITIONAL COPIES

OF THIS PUBLICATION MAY BE PROCURED FROM THE SUPERINTENDENT OF DOCUMENTS GOVERNMENT PRINTING OFFICE WASHINGTON, D. C.

AT

20 CENTS PER COPY 



Technical Series, No. 18.

U. S. DEPARTMENT OF AGRICULTURE, BUREAU OF mNTOMOLOGY.

L. O. HOWARD, Entomologist and Chief of Bureau.

\section{THE ANATOMY OF THE HONEY BEE.}

B Y

R. E. SNODGRASS, Agent and Expert.

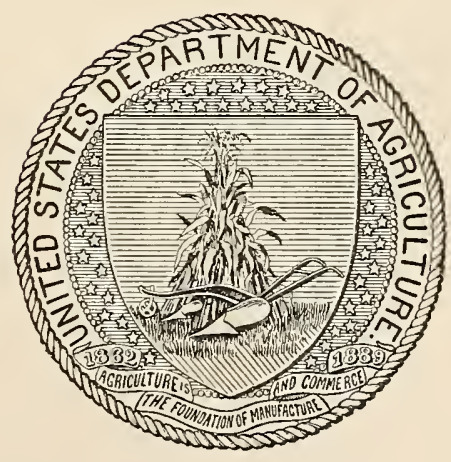

WASHINGTON:

GOVERNMENT PRINTING OFFICE. 1910 . 


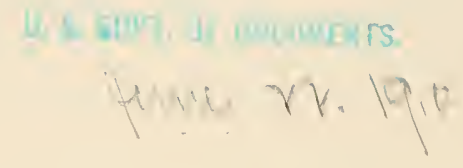

BUREAU OF ENTOHOLOGY.

L. O. Howard, Entomologist and Chief of Bureau.

C. L. Marlatt, Assistant Entomologist and Acting Chief in Absence of Chief.

R. S. Clifton, Executive Assistant.

W. F. Tastet, Chief Clcrk.

F. H. Chittenden, in charge of truck crop and stored product insect investigations.

A. D. Hopkins, in charge of forest inscet imvestigations.

W. D. Hunter, in charge of southern field crop insect investigations.

F. M. WeBster, in charge of cereal and forage inscet investigations.

A. L. Quaintance, in charge of deciduous fruit insect investigations.

E. F. Phillips, in cluarge of bee culture.

D. MI. Rogers, in charge of preventing spread of moths, field work.

Rolla P. CURrie, in charge of editorial work.

mabel Colcord, librarian.

\section{Investigations in Bee Culture.}

E. F. Phillips, in charge.

G. F. White, J. A. Nelson, B. N. Gates, R. E. Snodgrass, A. H. McCray, agents and experts.

Ellen Dashiell, preparator.

JESSIE E. MARKs, clerk.

T. B. Srmons, collaborator for Marylaud.

H. A. Surface, collaborator for Pennsylvania.

J. C. C. PRice, collaborator for Tirginia. 


\section{LETTER OF TRANSMITTAL.}

U. S. Departinent of Agriculture,

Bureau of Entomologr, Wrashington, D. C., October 19, 1909.

SIR: I have the honor to transmit herewith a manuscript entitled "The Anatomy of the Honey Bee," by Mr. R. E. Snodgrass, agent and expert, of this Bureat. It embodies the results of detailed studies made by Mr. Snodgrass and should prove of value as bringing to the bee keeper reliable information concerning an insect of such great economic importance, and also as furnishing a sound basis in devising new and improved practical manipulations. I recommend its publication as Technical Series, No. 18, of the Bureau of Entomology.

Respectfully,

L. O. Howard, Entomologist and Chief of Bureau.

Hon. James Wilson,

Secretary of Agriculture. 



\section{CONTENTS.}

Page.

I. Introduction. . . . . . . . . . . . . . . . . . . . . . 9

II. General external structure of insects..................... 10

III. The head of the bee and its appendages. . . . . . . . . . . . . . 26

1. The structure of the head . . . . . . . . . . . . . . . . . . . . . 26

2. The antennæ and their sense organs................ 32

3. The mandibles and their glands..................... 39

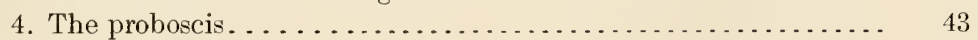

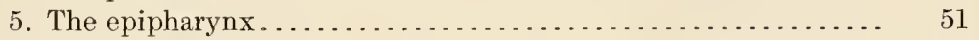

IV. The thorax and its appendages. . . . . . . . . . . . . . . . . 53

1. The structure of the thorax ....................... 53

2. The wings and their articulation. . . . . . . 59

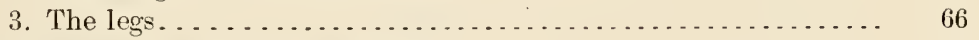

V. The abdomen, wax glands, and sting. . . . . . . . . . . . . . . 69

VI. The alimentary canal and its glands...................... 84

1. The general physiology of digestion, assimilation, and excretion. 84

2. The salivary glands.......................... 87

3. The alimentary canal . . . . . . . . . . . . . . . . . . . . . . 90

VII. The circulatory system. . . . . . . . . . . . . . . . . . . . . . 107

VIII. The respiratory system. . . . . . . . . . . . . . . . . . . . . . . . . . 112

IX. The fat body and the œnocytes. . . . . . . . . . . . . . . . . . . . . . . . 119

X. The nervous system and the eyes . . . . . . . . . . . . . . . . . . . . . 122

XI. The reproductive system. . . . . . . . . . . . . . . . . . . . . . . . . . . . . 130

1. The male organs. . . . . . . . . . . . . . . . . . . . . . . . . 132

2. The female organs............................... 134

Explanation of the symbols and letters used on the illustrations.... . . 139

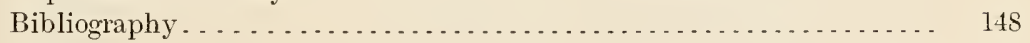

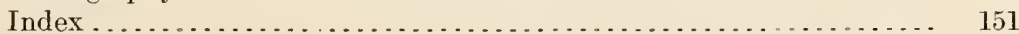




\section{ILLUSTRATIONS.}

Page.

2. Diagram of generalized insect embryo....................... 12

3. Example of generalized insect mouth parts................... 17

4. Diagram of generalized thoracic segment.................... 19

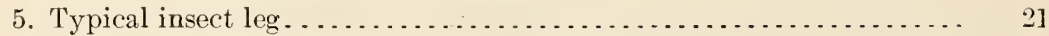

6. Diagram of generalized insect wing and its articulation.......... 22

7. Diagram of terminal abdominal segments of a female insect and early stage in development of gonapophyses..................... 25

8. Example of a swordlike ovipositor ........................... 25

9. Head of worker bee . . . . . . . . . . . . . . . . . . . . . . . . . . . 27

10. Heads of worker, queen, and drone...................... 29

11. Median longitudinal sections of heads of worker and drone... . . . . . 30

12. Antennal hairs and sense organs........................ 36

13. Mandibles of worker and drone ......................... 40

14. Internal mandibular gland of worker....................... 42

15. Mouth parts of worker................................ 43

16. Median section through distal half of mentum and base of ligula of

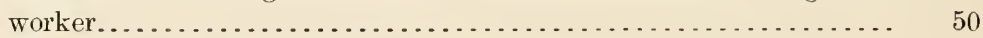

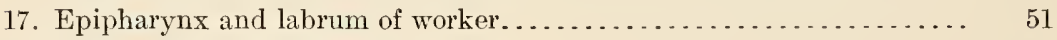

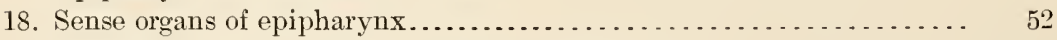

19. Median longitudinal section of head of worker................... 52

20. Dorsal view of ventral walls of body of worker................. 53

21. Thorax of worker....................................... 54

22. Lateral view of mesotergum of worker...................... 56

23. Thoracic terga of worker................................. 57

24. Upper part of left mesopleurum of worker . . . . . . . . . . . . . . 58

25. Wings of Hymenoptera........................................ 60

26. Basal elements of wings of Hymenoptera .................. 61

27. Median section through thorax of drone................... 64

28. Internal view of right pleurum of mesothorax of drone......... 65

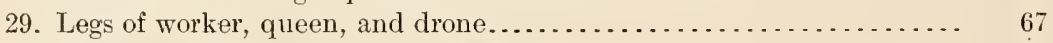

30. Claws and empodium of foot of worker.................. 68

31. Tarsal claws of worker, queen, and drone................ 69

32. Lateral view of abdomen of worker...................... 70

33. Ventral view of abdomen of worker. . . . . . . . . . . . . . . . . 70

34. Dorsal view of abdominal sterna of drone................... 70

35. Sixtl abdominal sternum of worker, queen, and drone......... 72

36. Semidiagrammatic view of left side of sting of worker........... 75

37. Ventral view of sting of worker......................... 76

38. Section of small piece of wall of poison sac................. $\quad 79$

39. Sections of alkaline gland of sting. . . . . . . . . . . . . . . . . . $\quad 79$

40. Details of sting of worker. . . . . . . . . . . . . . . . . . . 81

41. Tip of abdomen of worker with left side removed............. 82 


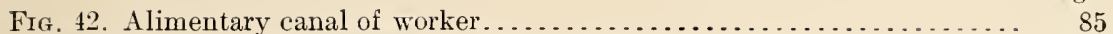

43. Details of pharyngeal and salivary glands ................. 88

44. Honey stomach of worker, queen, and drone .................. 94

45. Longitudinal section of honey stomach and proventriculus of queen . $\quad 97$

46. Histological details of alimentary canal of worker . . . . . . . . . . 103

47. Dorsal diaphragm of drone, from one segment . . . . . . . . . . . . 108

48. Small part of dorsal diaphragm of drone .................. $\quad 110$

49. Pericardial chamber of one segment in worker . . . . . . . . . . . 111

50. Tracheal system of worker ......................... 113

51. Tracheal system of worker .......................... 117

52. Nervous system of worker ........................... 123

53. Brain and subœsophageal ganglion of worker ............... 125

54. Horizontal section of compound eye and optic lobe of worker . . . . . 127

55. Histological details of compound eye of worker ................ 128

56. Reproductive organs of drone ......................... 133

57. Reproductive organ and sting of queen ................. 135 


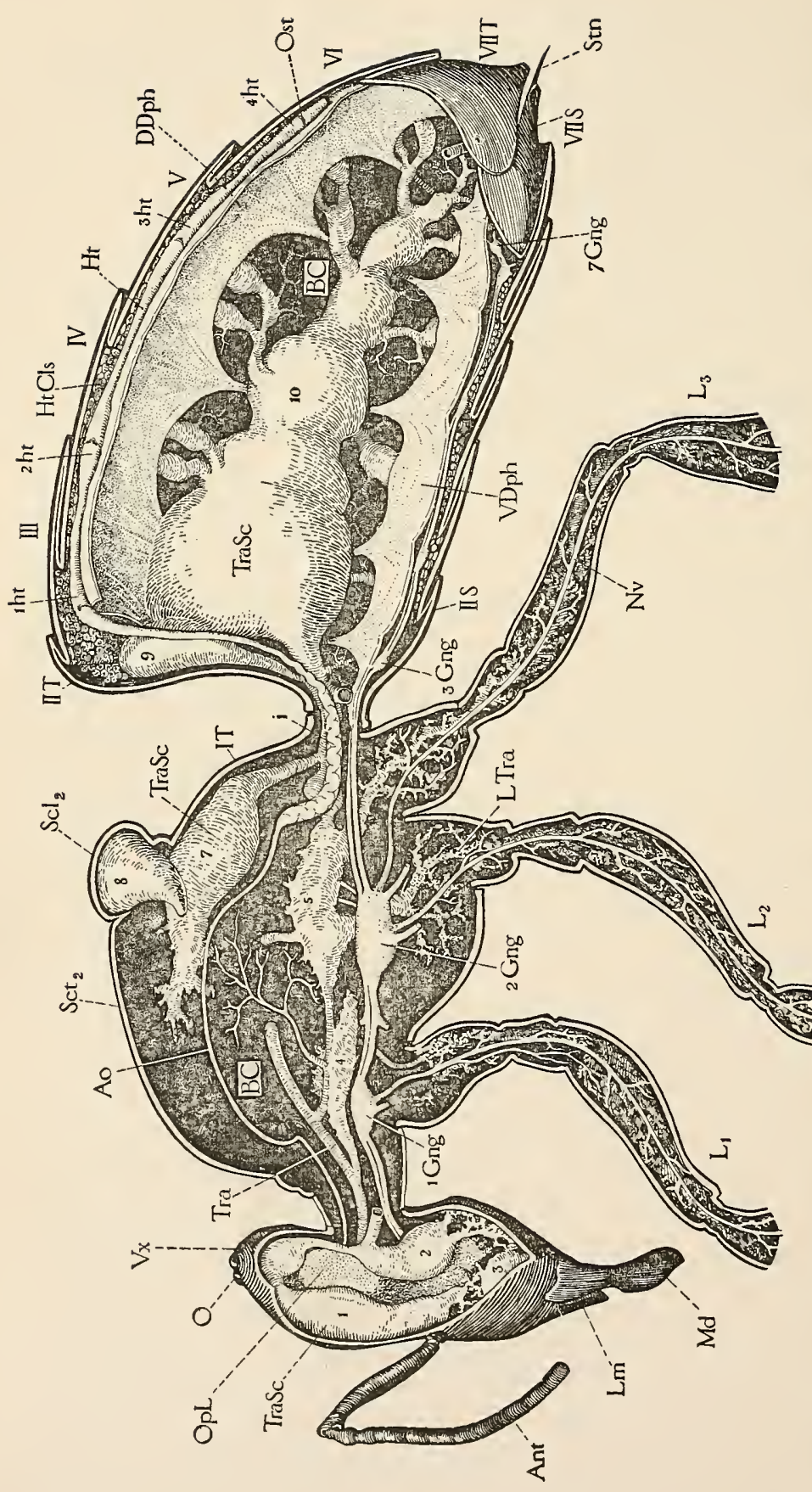

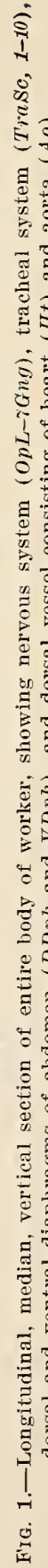




\section{THE ANATOMY OF THE HONEY BEE.}

\section{INTRODUCTION.}

The anatomy of the honey bee has been for years a subject of much interest to those engaged in bee keeping both for pleasure and for profit. This interest is due not only to a laudable curiosity to know more of the bee, but to the necessity of such information in order to understand fully what takes place in the colony. All practical manipulations of bees must depend on an understanding of the behavior and physiology of bees inder normal and abnormal circumstances, and those bee keepers who have adranced bee keeping most by devising better manipulations are those, in general, who know most of bee activity. In turn, a knowledge of bee activity must rest largely on a knowledge of the structure of the adult bee.

Studies on the anatomy of the bee have not been lacking, for many good workers have taken up this subject for investigation. The popular demand for such information, howerer, has induced untrained men to write on the subject, and most accounts of bee anatomy contain numerous errors. This is probably to a greater extent true of the anatomy of the bee than of that of any other insect. Frequently the illustrations used by men not trained in anatomical work are more artistic than those usually found in papers on insect anatomy, and they consequently bear the superficial marks of careful work, but too often it is found that the details are inaccurate. It has therefore seemed the right time for a new presentation of this subject based on careful work.

The drawings given in the present paper are original, with the exception of figures 12.54, and 55, and have been prepared with a thorough realization of the need of more accurate illustrations of the organs of the bee, especially of the internal organs. Mistakes will possibly be found, but the reader may be assured that all the parts drawn were seen. Most of the dissections, moreover, were verified by Dr. E. F. Phillips and Dr. J. A. Nelson, of this Burean, before the drawings were made from them. An explanation of the abbreviations and lettering is given on pages $139-147$.

It is hoped that the work will furnish the interested bee keeper with better information on the anatomy of the bee than has heretofore been offered to him, that it may provide a foundation for more detailed work in anatomy and histology, and, finally, that it will be 
of service to future students of the embryology and physiology of the bee. With this last object in view the writer has tried to sum up under each heading the little that is at present known of insect physiology in order to bring out more clearly what needs to be done in this subject.

\section{GENERAL EXTERNAL STRUCTURE OF INSECTS.}

When we think of an animal, whether a bee, fish, or dog, we unconscionsly assume that it possesses organs which perform the same vital functions that we are acquainted with in ourselves. We know, for example, that an insect eats and that it dies when starved; we realize therefore that it eats to maintain life, and we assume that this involves the possession of organs of digestion. We know that most insects see, smell, and perform coordinated actions, and we recognize, therefore, that they must have a nervous system. Their movements indicate to us that they possess muscles. These assumptions, moreover, are entirely correct, for it seems that nature has only one way of producing and maintaining living beings. No matter how dissimilar two animals may be in shape or even in fundamental constitution, their life processes, nevertheless, are essentially identical. Corresponding organs may not be the same in appearance or action but they accomplish the same ends. The jaws may work up and down or they may work sidewise, but in either case they tear, crush, or chew the food before it is swallowed. The stomach may be of very different shape in two animals, but in each it changes the raw food into a soluble and an assimilable condition. The blood may be red or colorless, contained in tubes or not, but it always serves to distribute the prepared food which diffuses into it from the alimentary canal. The situation of the central nervous system and the arrangement of its parts may be absolntely unlike in two organisms, but it regulates the functions of the organs and coordinates the actions of the muscles just the same.

Hence, in studying the honey bee we shall find, as we naturally expect to find, that it possesses mouth organs for taking up raw food, an alimentary canal to digest it, salivary glands to furnish a digestive liquid, a contractile heart to keep the blood in circulation, a respiratory system to furnish fresh oxygen and carry off waste gases, excretory organs for eliminating waste substances from the blood, a nervous system to regulate and control all the other parts, and, finally, organs to produce the reproductive elements from which new individuals are formed to take the places of those that die.

The study' of anatomy or the structure of the organs themselves is inseparably connected with a study of physiology or the life functions of the animal. While physiology is a most interesting and important subject, and, indeed, in one sense might be said to be 
the object of all anatomical research, yet the mere study of the structure of the organs alone, their wonderful mechanical adaptations, and their modifications in different animals forms a most fascinating field in itself, and besides this it gives us an insight into the blood relationships and degrees of kinship existing between the multitudes of animal forms found in nature. In the study of comparative anatomy we are constantly surprised to find that structures in different animals which at first sight appear to be entirely different are really the same organs which have been simply changed in a superficial way to serve some new purpose. For example, the front wing of a bee and the hard shell-like wing cover of a beetle are fundamentally the same thing, both being front wings-that of the beetle being hardened to serve as a protection to the hind wing. Again, the ovipositor of a katydid and the sting of a bee are identical in their fundamental structure, differing in details simply because they are used for different purposes. Hence, in the study of anatomy we must always be alert to discover what any special part corresponds with in related species. In order to do this, however, it is often necessary to know the development of an organ in the embryo or in the young after birth or after hatching, for many complex parts in the adult have very simple beginnings in an immature stage.

Thus it becomes evident that the structural study of eren one organisn soon involves us in the subjects of anatomy, physiology, and embryology, and, if we add to this a study of its senses, its behavior, and its place in nature, the field enlarges without limit. The student of the honey bee realizes that a lifetime might be spent in exploiting this one small insect.

The differences between animals are much greater on the outside than on the inside. In the descriptions of the organs of the honey bee anyone will know what is meant by the "alimentary canal," the "nervous system," or the "respiratory system," but the external parts are so different from those of animals with which we are more familiarly acquainted that no general reader could be expected to know what is meant by the names applied. Moreover, the bee and its allies are so modified externally in many ways that, at first sight. their parts look very different eren from those of other insects. Hence, we shall give a preliminary account of the external structure of insects in general, for it is hoped that the reader will then more easily understand the special structure of the honey bee, and that the application of the terms used will appear more reasonable to him.

Since all animals originate in an egg, the change into the adult involves two different processes: One is growth, which implies merely an increase in size, the addition of material to material; the other is development, which means change in shape and the produc- 
tion of a form with complex organs from the simple protoplasmic mass of the egg. The part of clevelopment that takes place in the eggshell is known as embryonic development; that which takes place subsequent to hatching is known as postembryonic development. In insects there are often two stages in the postembryonic development, an active one called the larval stage and an inactive one called the pupal stage. During the first of these the young insect is termed a larea; during the second, a pupa. When there is no resting stage the immature creature is often called a nymph. The final and fully developed form is an adult, or imago.

Since this paper is to deal only with the anatomy of the adult, the attractive fields of embryonic and postembryonic development must

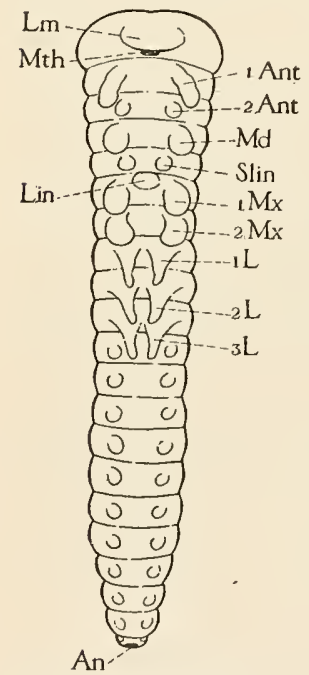

FIg. 2.-Diagram of a generalized insect embryo, showing the segmentation of the head, thoracic, and abdominal regions, and the segmental appendages.

be passed over, except for a few statements on fundamental embryonic structure, a knowledge of which is necessary to a proper understanding of the adult anatomy.

When the embryo, in its course of derelopment, first takes on a form suggestive of the definitive insect, it consists of a series of segments called metameres, or somites, and shows no differentiation into head, thoracic, and abdominal regions. Typically, each segment but the first is provided with a pair of latero-ventral appendages, having the form of small rounded protuberances. These appendages are of different sizes and take on different shapes in different parts of the body, for some of them are destined to form the antennæ, some the mouth parts, others the legs and perhaps the cerci, while the rest of them remain very small and finally disappear. What we know of the embryology of insects is based on the observations of a number of men who have worked mostly on the derelopment of different species. Their observations are not all alike, but this is probably due in large part to the fact that the embryos of different insects are not all alike. Embryos have a very proroking habit of skipping over or omitting little and yet important things in their development, but fortunately they do not all omit the same things. Therefore, by putting together all the reliable information we possess, we can make up an ideal embryo which would be typical of all insects. Such a generalized embryo is represented diagrammatically by figure 2 .

The first six or seren metameres rery early begin to unite with one another and continue to fuse until their borders are lost. These consolidated embryonic segments form the head of the adult insect. 
Observers differ concerning the fate of the seventh segment, but it is most probable that a part of it fuses with the sixth segment, thus taking part in the formation of the head, and that a part of it forms the neck or some of the neck plates of the adult.

The appendages of these first seven segments form the antennæ and mouth parts, except one or two pairs that disappear early in embryonic life. It is not certain that the first segment ever possesses appendages, but from it arise the large compound eyes and apparently also the upper lip, or labrum $(\mathrm{Lm})$. The appendages of the second segment form the feelers, or antennæ (1Ant) of the adult, those of the third ( $2 A n t)$ disappear in insects, but they correspond with the second antennæ of shrimps and lobsters. The appendages of the fourth segment form the mandibles $(M d)$. Those of the fifth segment (Slin), when present, fuse with a median tonguelike lobe $(\operatorname{Lin})$ of the following segment, and the three constitute the hypopharynx, or lingua of the adult. The next pair $(1 / 1 x)$ form the maxillæ, while the last $(2 M x)$, or those of the seventh segment, coalesce with each other and constitute the adult labium, or lower lip.

The bodies of the head metameres fuse so completely that it is impossible to say positively what parts of the adult head are formed from each. The last, as already stated, possibly takes part in the formation of both the head and the neck. Some embryologists attribute the plates which usually occur in this region to the last embryonic head segment, while others believe they come from the next segment following. Sometimes these plates are so well developed that they appear to constitute a separate segment in the adult, and this has been called the microthorax. If this name, however, is given to the embryonic segment from which these plates are said to be derived, it must be remembered that it is not "thoracic" at all and belongs partly to the head. The name cervicum has been applied to the neck region with greater appropriateness since it does not imply any doubtful affiliation with adjoining regions. What we really need, however, is not so much a name as more information concerning the development of the rear part of the head and the neck plates in different insects.

The next three segments remain distinct throughout life in nearly all insects, but, since they bear the legs and the wings, they become highly specialized and together constitute the thorax. The indiridual segments are designated the prothorax, the mesothorax, and the metathorax. The legs are formed from the embryonic appendages (fig. $2,1 L, 2 L, 3 L$ ) of these segments, but the wings are secondary outgrowths from the mesothorax and metathorax and are, hence, not appendages in the strict embryological sense.

The remaining segments, nearly always 10 in number, constitute the abdomen. The appendages of these segments, except possibly 
those of the tenth, disappear early in embryonic life in all insects, except some of the very lowest species, in which they are said to form certain small appendages of the abdominal segments in the adults.

An adult insect is often described as being "divided" into a head, a thorax, and an abdomen, but this is not true in most cases. While all insects consist of these parts, the divisions of the body are usually not coincident with them. The prothorax in the adult is separated from the head by the neck and is very commonly separated from the mesothorax by a flexible membranous area. On the other hand, the mesothorax and metathorax are almost always much more solidly attached to each other, while, in most insects, the metathorax is solidly and widely joined to the first abdominal segment, though in the flies these latter two segments are usually separated by a constriction. In such insects as ants, wasps, and bees-a slender, necklike peduncle occurs between the first and second segments of the abdomen, the first being fused into the metathorax so that it appears to be a part of the thorax. This is the most distinctive character of the order Hymenoptera, to which these insects belong.

The body wall of insects is hard on account of the thick layer of chitin which exists on the outer side of the true skin. Chitin is a substance similar to horn, being brittle, though tough and elastic. It gives form and rigidity to the body and affords a solid attachment for the muscles within, since insects have no internal framework of bones such as vertebrate animals have. The skin between the segments is soft and unchitinized and thus forms a flexible intersegmental membrane which is often very ample and, in the abdomen, allows each segment to telescope into the one in front of it.

The chitin of each segment is not continuous, but is divided into plates called sclerites. The most important of these are a tergum above and a sternum below, but, in the case of the thorax, these two plates are separated on each side by another called the pleum, which lies between the base of the wing and the base of the leg. Plemral plates are sometimes present also on the abdominal segments. These principal segmental plates are usually separated by membranous lines or spaces, which permit of more or less motion between them. Such lines are called sutures in entomology, though strictly this term should be applied only to the lines of fusion between adjoining parts.

The terga, pleura, and sterna of each segment are furthermore subdivided into smaller sclerites, which may be termed tergites, pleurites, and sternites, respectively. The sutures between them are sometimes membranous also, but most frequently have the form of impressed lines or narrow grooves. In such cases they are generally nothing more than the external marks of ridges developed on the inside of the body wall to strengthen the parts or to give attachment to muscles. Since these sutures are conspicuous marks on the outside 
of an insect, they are usually regarded as morphologically important things in themselves, representing a tendency of the tergum, pleurum, or sternum to separate into smaller plates for some reason. The truth about them would appear to be just the opposite in most casesthey are the unaroidable external marks of an internal thickening and strengthening of the plates. In a few cases they may be the confluent edges of separate centers of chitinization. Hence, most of the sutural lines in insects appear to signify a bracing or solidifying of the body wall rather than a division of it.

Since the body wall of insects is continuous over all the surface it contains no articulations of the sort that occur between the bones in the skeleton of a rertebrate. Although insects and their allies belong to the class of animals known as the Articulata, yet an articulate articulation is simply a flexibility-two chitinous parts of the exoskeleton are movable upon each other simply by the intervention of a nonchitinized, flexible, membranous part. While there are often special ball-and-socket joints developed, these are always produced on the outside of the membranous hinge and simply control or limit the movement of the articulation.

The head of an adult insect is a thin-walled capsule containing the brain, the ventral head ganglion of the nerrous system, the pharynx and anterior part of the osophagus, the tracheal tubes, and the muscles that move the antenne and the mouth parts. Its shape varies a great deal in different insects, being oval, globular, elongate. or triangular. In some it is flattened dorso-rentrally so that the face is directed upward and the mouth forward, but in most, including the bee, it is flattened antero-posteriorly so that the face looks forward and the mouth is directed ventrally. In a few it is turned so that the face is ventral. The walls of the head are usually divided by sutures into a number of sclerites, which in general are located and named as follows: The movable transverse flap forming the upper lip is the labrum. Above it is a sclerite called the clypens, which is a part of the solid wall of the head and carries the anterior articulations of the mandibles. The clypeus is sometimes divided transversely into an anteclypeus ("clypeus anterior." "epistoma") and into a post-clypeus ("clypeus posterior"). Above the clypens is the front, a plate usually occupring the upper half of the face between the compound eyes and carrying the antennæ. The top of the head is called the vertex, but does not constitute a separate sclerite. The sides of the head below the compound eyes are often separated by sutures from the anterior and posterior surfaces and are known as the gence. The back of the head is formed by the occiput, which surrounds the large opening or foramen magnum that leads from the cavity of the head into that of the neck. The parts posterior to the genæ, carrying the posterior mandibular articulations, 
are sometimes separated from both the occiput and the genæ and are known as the postgence. In a few insects, especially beetles, one or two median plates occur in the ventral wall of the head posterior to the base of the labimm. These are the gutar sclerites. Finally, small plates are sometimes found about the bases of the antennx and between the bases of the mandibles and the genæ. The latter have been termed the trochantins of the mandibles. The term epicranium is often used to include all the immovable parts of the head, but is frequently applied only to the dorsal parts. Most of these sclerites preserve a pretty definite arrangement in the different orders, and they are probably homologous throughout the entire insect series, though they are in some cases very much distorted by special modifications and are often in part or wholly obliterated by the disappearance of the sutures. Embryologists are coming to the conclusion that the sclerites of the head have no relation to the primitive segments. The latter very early consoliclate into a head with a continuous wall, while the sutures defining the sclerites are formed later. Some of the older entomologists were led, from a study of the sclerites, to suppose that the head consisted of a number of segments, but it has been shown that these anatomical segments do not correspond with the embryonic ones.

The appendages growing from the front of the face are the antennæ (fig. 9A, Ant) or "feelers" and consist of a series of joints or segments.

At the lower edge of the face is the front lip or labrum (fig. 9A, Lm), behind which are the median epipharynx, the paired mandibles $(M d)$ and maxilla, the median hypopharyn. and the labium or under lip. All these organs together constitute what are known as the mouth parts or trophi. They vary greatly in shape and appearance in clifferent insects according to the nature of the food, but their typical form is usually taken to be that shown by the lower insects which feed on solid food and have biting mouth parts. Figure 3. representing the jaws and lips of the common black cricket, is given as an example of generalized insect mouth parts.

The labrum (fig. $9 \mathrm{~A}, \mathrm{Lm}$ ) is usually a simple transverse flap in front of the mouth, being developed, as already shown, from a similarly situated lobe on the first segment of the embryo (fig. 2, Lm).

The epipharynx (fig. 19, Ephy) is a sort of dorsal tongue, and is situated on the membrane leading into the mouth from behind the labrum.

The mandibles (figs. $3 \mathrm{~A} ; 9 \mathrm{~A}, M d$ ) are typically formed for biting, being heary organs situated immediately behind the labrum and working sidewise on a hinge articulation with the head. Their cutting edges are usually notched and toothed, though smooth in the worker bee. 
The maxillæ (fig. $3 \mathrm{~B}$ and $\mathrm{B}$ ) are complicated appendages in their typical form. Each consists of a principal piece called the stipes $(S t)$, which is hinged to the head by means of a smaller basal piece, the cardo $(C d)$. Terminally the stipes bears an outer lobe, the galea $(G a)$, and an inner lobe, the lacinia $(L c)$. On the outer side, at the base of the galea, it carries a jointed appendage called the maxillary palpus $(P l p)$.

The hypopharynx (fig. $3 \mathrm{C}$ and $\mathrm{D}, H p h y$ ) is a median, ventral, tonguelike organ, called also the lingua, situated either on the upper surface of the labium or on the membrane between this organ and the mouth. It is developed principally from a median lobe of the head of the embryo behind the mouth (fig. 2, Lin), but some entomologists claim that it is compounded of this lobe and two smaller lateral ones developed from the appendages of the fifth embryonic head segment (fig. 2, Slin), the superlinguce.

The labium (fig. $3 \mathrm{C}$ and $\mathrm{D}$ ) constitutes the under lip of the adult, but it is formed from the two appendages of

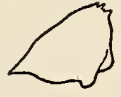

A

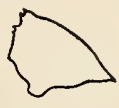

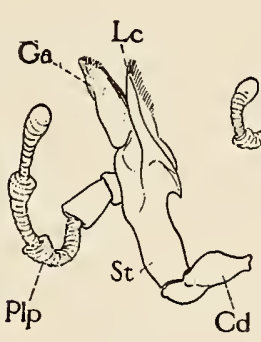

B
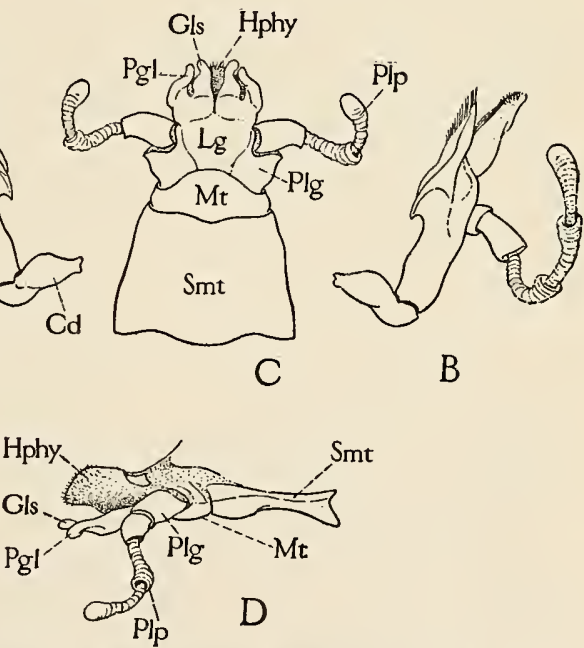

FIG. 3.-Example of generalized insect mouth parts, from common black cricket (Gryllus pennsylvanicus): A, mandibles; B, B, maxillæ, ventral view; C, labium or second maxillæ, ventral view; D, labium, lateral view.

the seventh segment in the embryo, which fuse with each other. For this reason it is often called the second maxille. It consists of a basal submentum (Smt) bearing the mentum ( $M t)$, which in turn carries three parts, a median ligula $(L g)$ and two lateral palpigers $(P l g)$. The latter support the labial palpi $(P l p)$, while the ligula bears four terminal lobes, of which the median ones are called the glossce $(G l s)$ and the lateral ones the paraglosse $(P g l)$. If we should cut the labium into two parts along its midline we should see that even in the adult stage each half is very similar to one maxilla. The only discrepancy to be noticed in the example given (fig. 3) is that there $22181-$ No. $18-10-2$ 
is no maxillary palpiger, but many insects possess a corresponding part in the maxilla, frequently distinguished as the palpifer.

The neck or cervicum is usually a short membranous cylinder which allows the head great freedom of motion upon the thorax. In nearly all insects its lateral walls contain several small plates, the cervical sclerites, while, in many of the lower species, dorsal, ventral, and lateral sclerites are present and highly developed. As already stated, the origin of these plates is doubtful. Some entomologists would derive them from the prothorax, others think they come from the last head segment, while still others think that they represent a separate segment. Only pure anatomists, however, entertain this last view and call this supposed segment the "microthorax," for embryologists have not yet reported a metamere between the labial segment and the prothoracic segment. Most embryologists who have studied the subject admit that some of the cervical sclerites may be formed from the last embryonic head somite which carries the labium and probably forms a part of the back of the head. Therefore, if it is desirable to retain the word microthorax as a name for a true segment, it can be applied only to this labial metamere. ${ }^{a}$

The thorax, as has already been stated, is a distinct anatomical region of the body rather than a "division" of the body, since it carries both the legs and the wings and contains the large muscles for each. Since the prothorax does not possess wings, it is not so highly developed otherwise as the two wing-bearing segments, and is, indeed, generally reduced in some ways, some of its parts being frequently rudimentary. Therefore we shall base the following description of a typical segment on the structure of the wing-bearing segments.

A typical thoracic segment, then, presents four surfaces, as does also the entire body. These are a dorsum above, a venter below, and a latus $^{b}$ on each side. From these names we have the terms "dorsal,"

${ }^{a}$ In a former paper on the thorax of insects (Proc. U. S. Nat. Mus., XXXVI, 1909, pp. 511-595) the writer probably drew a too definite conclusion on the subject of the "microthorax." The origin of the neck sclerites has probably nevei" yet been actually observed. Comstock and Kochi (Amer. Nat., XXXVI, 1902, pp. 13-45), in summarizing the segmentation of the head, accredited the gular and cervical sclerites to the labial segment, but did not recognize the latter as taking part in the formation of the true head capsule. Riley, however, in his study of the development of the head of a cockroach (Amer. Nat., XxxviII, 1904, pp. $777-810$ ), states that in Blatia the labial segment does form a part of the back of the head and that the posterior arms of the tentorium are derired from it. Börner (Zool. Anz., XXVI, 1903, pp. 290-315) and Crampton (Proc. Acad. Nat. Sci. Phila., 1909, pp. 3-5t) believe that the cervical sclerites are derived principally from the prothoracic segment. The notion that they constitute a separate segment, the "microthorax," equivalent to the maxilliped segment of the centipedes, has been elaborated principally hy Verhoeff in his numerous writings on the Chilopoda and Dermaptera.

$b$ The writer introduces this word here because he knows of no other term applied to the side of the segment in this sense. 
"ventral," and "lateral." The chitinous parts of the dorsum constitute the tergum; of the venter, the sternum; and of the latus, the pleurum.

The tergum of the wing-bearing segments usually consists of two plates-a front one or true notum (fig. 4, $N$ ) carrying the wings, and a posterior one, which the writer has termed the postnotum or pseudonotum $(P N)$, having no connection with the wings. The first is often more or less distinctly marked into three transverse parts called the prescutum (Psc), scutum (Sct), and scutellum $(S c l)$. In such cases the exposed part of the postnotum is called the postscutellum $(P s c l)$. From either the anterior or the posterior margin of the tergum, or from both, a thin transverse plate projects downward into the interior of the thorax for the attachment of muscles. These plates are the phragmas ( $A p h$ and $P p h)$. The notum supports the wing on each side by two small lobes, the anterior and posterior notal wing processes (ANP and PNP). Behind the latter is the attachment of the axillary cord $(A x C)$ or basal ligament of the wing. A large $V$-shaped ridge on the under surface of the notum having its apex forward is the "entodorsum." (A better name would be entotergum.)

The pleurum consists principally of two plates, the episternum (fig. 4, Eps) and the epimerum (E pm) lying before

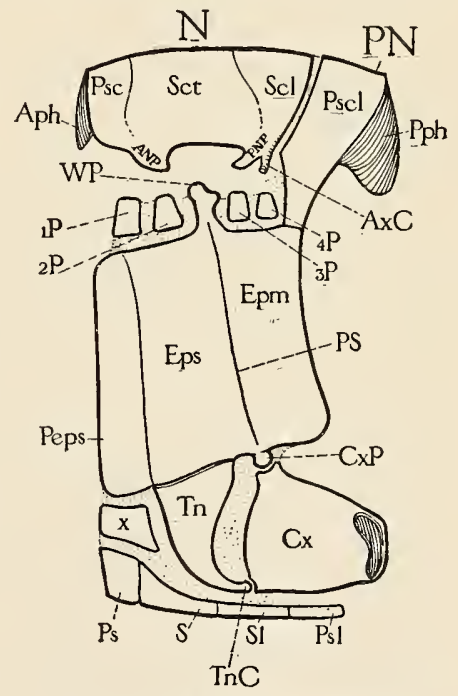

FIG. 4.-Diagram of generalized thoracic segment, left side. and behind a vertical groove, the pleural suture (PS), which extends from the pleural coxal process $(C x P)$ below to the pleural wing process (WP) above. The pleural suture marks the position of a heavy internal ridge, the pleural ridge or entopleurum. The epimerum is connected with the postnotum $(P N)$ behind the base of the wing. These parts occur in almost all insects. In some of the lower ones another plate is present in front of the episternum which may be called the preepisternum (Peps). ${ }^{a}$ Lying along the upper edge of

a Objection may be made to the use of the term "preepisternum" on the ground that it combines a Latin prefix with a word compounded of Greek elements. The same may be urged against " prephragma," " postphragma," "preparaptera," and "postparaptera," words introduced by the present writer in a former paper on the thorax (Proc. U. S. Nat. Mus., XXXVI, 1909, pp. 511-595). However, we are barred from making up equivalent terms with the Greek prefixes pro and meta because these are used to designate the first and the third 
the pleurum and associated with the under surface of the wing base are several small plates known as the paraptera $(P) .^{a}$ Two lie above the episternum in front of the pleural wing process and are the episternal paraptera or preparaptera (1P and $2 P)$, while one or occasionally two are similarly situated behind the wing processes and are the epimeral paraptera or postparaptera $(3 P$ and $4 P)$. The preparaptera afford insertion for the muscle concerned in the extension and pronation of the wing.

The coxa $(C x)$, or basal segment of the leg, is hinged to the segment by a dorsal articulation with the pleural coxal process $(C x P)$, and by a ventral articulation $(\operatorname{TnC})$ with a plate called the trochan$\operatorname{tin}(T n)$ lying in front of it and connected above with the lower end of the episternum (Eps). Hence, while the leg is of course continuous all around its base, by means of membrane, with the bodywall, its movement is limited to a hinge motion by these two special articulations of the chitin.

The sternum or ventral plate of the segment is not so complicated as are the tergum and pleurum. It is often divided transversely into three parts, however, and some authors say typically into four. These parts have been named the presternum $(P s)$, sternum proper $(S)$,

segments of the thorax or their respective parts. Entomologists have already established the system of referring a part to the front or back of any indiridual segment by the Latiu prefixes pre (or pree) and post as used in "prescutum," "prestermum," "postscutelium," and "poststernellum." Furthermore, pre and post are so indiscriminately used in English combined with Latin, Greek, and eren Anglo-Saxon words that they may be regarded as general property. Hence, in order not to sacrifice an anatomical system. which certainly needs to be fostered in every way, the writer has preferred to sacrifice strict grammatical rules by applying pre and post, regardless of the origin of the noun in the case, to designate anterior and posterior parts of the same segment. We already use such hybrid terms as " presternum," "mesotergum," and "metatergum."

The name "preepistermum" has been applied bo Hopkins (Bul. 17, Pt. I, technical-series, Bur. Ent., C. S. Dept. Agr.. 1909) to a part of the mesepisternum of Dendroctonus - a plate apparently not homologous with the preepisternal element of the thorax in primitive insects.

"The name "parapterum" is taken from Andonin's term paraptère (Ann. des Sci. Nat., I, 1824, pp. 97-135, 416-432), and its application. as used by the present writer, is based on Audonin's definition given in his Chapter III, "Considerationes generales sur le Thorax," where he says (p. 122) : "Finally there exists a piece but little dereloped and seldom observed, comnected with both the episternum and the wing. It is always supported by the episternum and is sometimes prolonged rentrally along its anterior margin, or again, becoming free, passes in front of the wing and may even come to lie above the base of the latter. At first we designated this sclerite by the name of Hypoptere but on account of its change of position relative to the wing base we now prefer the name of PARAPTìn." The first part of his description lea res no doubt that Audonin referred to the little plenral plate beneath the front of the wing which is usually very inconspicuous except in carefully dissected 
sternellum $(S l)$, and poststemellum $(P s l)$. In some of the lower insects a plate $(x)$ occurs at each side of the presternum or of the sternum which seems to fall in line with the preepisternum of the pleurum. This has been variously called a part of the presternum, the coxosternum, an accessory sternal plate, and the sternal laterale.

The inner surface of the sternum carries a large two-pronged process called the furca or entosternum.

This plan of structure for the mesothorax and the metathorax prevails thronghont all insects. The honey bee probably presents the greatest departure from it, but even

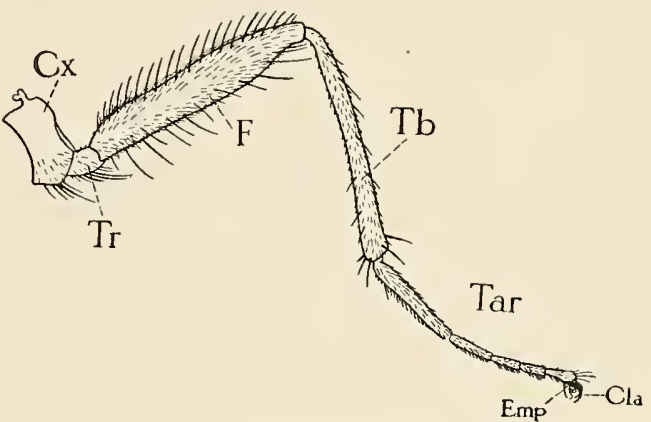

Fif. 5.-Typical insect leg.

here the modification consists principally of a suppression of the sutures of the plenrum resulting from a condensation of the parts.

The leg (fig. 5) of an adult insect consists of a number of joints or segments. It is attached to the body, as just described, by a thick

specimens. In such preparations, however, one finds that there are in most cases two sclerites hele instead of one, and, furthermore, that one or occasionally two other's are similarly situated beneath the rear part of the wing base behind the pleural wing process. The present writer has, therefore, made the term " paraptera" cover this whole row of little plates, distinguishing those before and those behind the pleural wing process by the designations given above.

In the latter part of Audouin's definition it would seem that he may have confused the rudimentaly tegula as it exists in some insects with the parapterum, but eren this is not probable since he says it is always connected with the episternum, which is nerer true of the tegula. In his description of the thorax of beetles, Dytiscus, Curabus, Buprestis, and Curculio, it is evident that he regards the anterior npper lart of the episternum as the parapterum fused with the latter plate. In fact, in each case he definitely states that such is the case and, in describing Dytiscus circumflexus, he says (p. 420): "The episternum, the parapterum, and the epinerum all fuse dorsally and constitute a support for the wings and tergum." While Audonin is undoubtedly mistaken in this homology, especially in the mesothorax, he at least shows that his "paraptère" is a part of the pleurum. Hence modern miters such as Packard and Folsom who make the term "paraptera" synonymous with "tegulie" are certainly wrong. The tegula is a dorsal scale or its rudiment at the humeral angle of the wing, while the parapterum is a co-existent sclerite below this part of the wing base. The present writer agrees with Comstock and Kellogg, who, in their Elements of Insect Anatomy (first edition), define the little sclerite in front of the base of the wing in the locust, articulated to the dolsal extremity of the episternum, as the " parapteron," though in this insect there are here really two of these parapteral plates instead of one. 
basal joint called the coxa $(C x)$. Beyond this is a smaller joint called the trochanter $(T r)$, this is followed by a long and strong segment, the femur $(F)$, which extends outward from the body, while bending downward from its distal end is the long and slender tibic (TZ), followed finally by the foot, or tarsus ( $\left(a r^{2}\right)$. The tarsus itself consists typically of five small segments of which the last bears a pair of claws $(C l a)$. The under surfaces of the tarsal joints are often provided with small cushions or pads called pulvilli. Those between the claws are generally specially prominent and are called the empodia (Emp). The leg varies greatly in shape in different insects but nsually preserves all of these parts. The segments of the tarsus, however, are frequently reduced in number.

The adult wing is a thin expanse of membrane supported by hollow branching rods called veins. It originates as a hollow outgrowth of the body-rall, but soon becomes flattened out dorso-ventrally and the

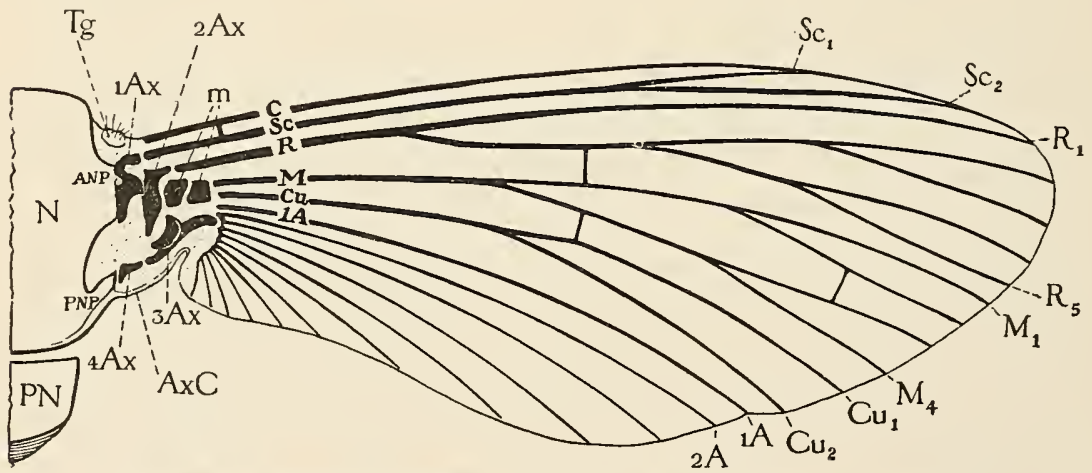

FIG. 6.--Diagram of generalized insect wing and its articulation to first plate $(X)$ of the tergum.

contained tracheæ or air tubes mark out the courses of the reins. These reins form rarions patterns in different insects, but they can all be derived by modification from one fundamental plan. This plan is showi: diagrammatically by figure 6 . The first vein, which ustally forms the anterior margin of the adult wing. is the costa $(C)$. The next vein is the subcosta $(S c)$, which in typical cases divides into two branches $\left(S c_{1}\right.$ and $\left.S c_{2}\right)$. The third and usually the principal vein is the radius $(R)$. It divides dichotomously into five branches $\left(R_{1}\right.$ to $\left.R_{5}\right)$, the anterior branch of the first fork remaining single. The next vein is the media $(M)$, which forms four branches $\left(M_{1}\right.$ to $\left.M_{4}\right)$. The fifth is the cubitus $(C u)$, which again is two-branched. The remaining veins are called the anals and are designated individually as the first anal (1A), second anal (2.A), etc.

Several cross-eeins of common recurrence should be noted. The first is situated near the base of the wing between the costal and subcostal veins and is known as the humeral cross-vein. A second 
occurs between the radius and the media near the center of the wing and is called the radio-medial cross-vein. Another one, the mediocubital, is similarly located between the media and the cubitus, while a fourth, called the median, occurs between the second and third branches of the media. The areas of the wing surface inclosed by the veins, the cross-veins, and the margins of the wing are known as the cells.

A great many different names are applied by different entomologists to the veins of the wings, both of the same and of different insects. The nomenclature here given is the one first consistently applied by Comstock and Needham and now used by a large number of entomologists working in different orders of insects.

The wing is articulated at its base (except in mayflies and dragonflies) to the anterior and posterior wing processes of the notum (fig. 6, ANP and PYP) and to the wing process of the pleurum (fig. 4, $W P$ ) by several small articular sclerites called axillaries. Two of these, the first $(1 A x)$ and the fourth $(4 A x)$, form a hinge with the anterior and the posterior notal wing processes, respectively, while the second $(2 A x)$ articulates below with the wing process of the pleurum, constituting thus a sort of pivotal element. The third axillary $(3 A x)$ intermediates between the bases of the anal veins and the fourth axillary-except when the latter is absent (as it is in nearly all insects except Orthoptera and Hymenoptera), in which case it articulates directly with the posterior notal process. The thin membrane of the wing base may be called the axillary membrane $(A x M)$. On its anterior edge is a hairy pad, the tegula $(\mathrm{Tg})$, which is sometimes a large scale overlapping the hmmeral angle of the wing. The posterior margin of the axillary membrane is thickened and may be called the axillary cord $(A x C)$ or basal ligament of the wing.

The base of the costa is not directly associated with any of the axillaries, but is specially connected by tough membrane below with the episternal paraptera. The subcosta abuts against the end of the curved neck of the first axillary. The radius is either attached to or touches upon the anterior end of the second. The media and cubitus are usually associated with each other at their bases and also more or less closely with one or two median plates $(m)$ in the wing base. These plates, however, are not of constant shape and occurrence as are the articulating axillaries. The anals are generally attached to the outer end of the third axillary, which acts as a lever in the folding of the wing.

A few insects have a generalized wing almost identical with the diagram (fig. 6), but most of them depart from it in varying degrees. Few go so far, however, as the honey bee, whose venation is very different, but yet the fundamental basal structure is the same even 
here, as will be shown in the special description of the wing of the bee.

The abdomen consists almost always of 10 segments. There are never any more than this number well developed in adult insects, and if there are fewer the reduction is due to a modification of the terminal segments to accommodate the external organs of reproduction. The posterior opening of the alimentary canal is at the end of the tenth segment, which carries also two small appendages at the sides of the anus. These are called the cerci (fig. $8, C e r$ ). In some insects they are short, styletlike processes, in others they are long and many jointed, while in many they are absent. The cerci are supposed to be developed from the embryonic appendages of the tenth segment, although, on the other segments, these appendages disappear before the embryo hatches, except in some members of the lowest wingless order of insects, which have a pair of cercuslike appendages on each segment of the abdomen.

Each abdominal segment presents a tergum above and a sternum below; the former usually also reaches far down on the sides and overlaps the edges of the sternum. In some insects one or more small pleural plates intervene between the tergum and the sternum, but the abdominal pleura are never dereloped in any way suggestive of a thoracic pleurum. Very frequently there is present an upper pleural plate, or epipleurite, adjoining the edge of the tergum and a lower, or hypopleurite, adjoining the edge of the sternum. The line separating these two sclerites, however, is horizontal and can not correspond with the rertical suture of a thoracic pleurum between the episternum and the epimerum extending from the base of the leg to the base of the wing.

The most complicated structures on the abdomen are the external organs of reproduction. In the male these serve as clasping organs and take on a great variety of forms in different species. The organs in the female form an ovipositor and are of much more definite and constant structure.

The ovipositor (fig. 8), in its most perfect development, consists of three pairs of long, closely appressed bladelike processes ealled gonapophyses $(1 G, 2 G, 3 G)$. These six pieces fit neatly together and form an organ by means of which the female makes a hole in the ground or in the bark of a tree, or punctures some other insect, and then places her eggs in the cavity thus produced. An interesting fact in this connection is that the sting of a wasp or bee is simply a modified ovipositor. This can be proved by a comparison of the organs themselves or by a study of their development. Each is formed from six little peglike processes that grow ont from the sterna of the eighth and ninth abdominal segments of the larra or young soon after hatch- 
ing (fig. $7,1 G, 2 G$, and $3 G$ ). At first there is only one pair of these processes on each of the two segments, but those on the ninth soon split each into two, thus producing two pairs on this segment. The opening of the oriduct $(O v O)$ is on the eighth segment between the bases of the first gonapophyses.

The ovipositor of the longhorned grasshopper, shown by figure 8 , may be taken as a typical example of this organ. The median pair of gonapophyses on the ninth segment (2G) remain slender and fuse at their bases into a small bulblike swelling open below $(S h B)$. The pair from the eighth segment $(1 G)$ form two long bladelike pieces, which fit by sliding articulations upon the lower edges of the corresponding second gonapophyses $(\mathscr{R} G)$. The first can therefore be worked back and forth while they are braced and held in position by the second pair. The third gonapophyses $(3 G)$, or the outer pair of

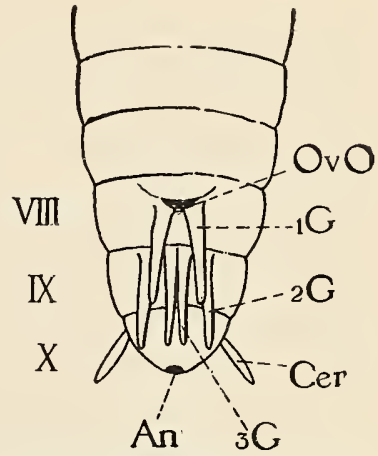

FIG. 7.-Diagram of terminal abdominal segments of a female insect and early stage in development of gonapophyses $(1 G, 2 G$, and $3 G)$, from which is formed the ovipositor of most insects and the sting of wasps and bees.

the ninth segment (the left one in figure 8 is shown as if cut off near its base), form two long flat blades which are closely appressed against the outer surfaces of the others. In the detailed study of the bee it will be shown how closely the structure of the sting corresponds in every way with that of this ovipositor.

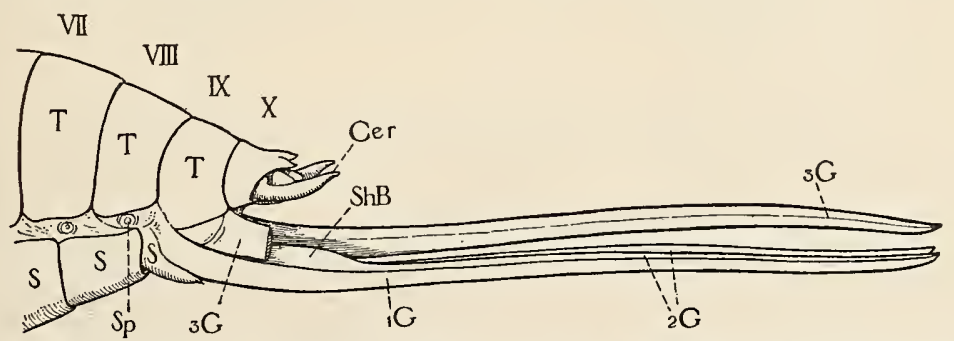

Fig. 8.-Example of a swordlike ovipositor, from a longhorned grasshopper (Conocephalus sp.), illustrating the fundamental similarity of structure with the sting of the bee, fig. 36 .

Some entomologists have supposed that the original two pairs of gonapophyses represent the embryonic appendages of the eighth and ninth segments, and they would thus establish a homology between the ovipositor or sting and the legs and mouth parts. It has been shown, however, that the true appendages of the abdominal segments disappear in embryonic life while the gonapophyses appear much later, during early nymphal or larval life. Furthermore, each pair 
of gonapophyses arises in a median depression on the ventral side of the segment while the true appendages are latero-ventral. Hence, the evidence is very much against this theory and the gonapophyses appear to be special secondary processes of the body wall.

All insects do not have ovipositors of the sort described above. Flies, beetles, moths, and butterflies do not. Such insects simply drop their eggs from the orifice of the oviduct or deposit them in masses upon the external surfaces of various objects. In some of the flies, however, the terminal segments are long and tubular and entirely telescoped into one another. They are hence capable of being protruded in the form of a long tapering tube having the opening of the oviduct near the tip. This enables the insect to deposit its eggs in deep crevices, but the structure is not a true ovipositor--it is simply the abdomen itself stretched out.

Insects breathe through a series of small holes situated along each side of the body. These breathing apertures are called spiracles and they lead into a system of internal air tubes called trachea. There are nearly always 10 spiracles present on each side of the body. Two are located on the thorax, the first between the prothorax and the mesothorax, the second between the mesothorax and the metathorax, while the other eight are situated on the first eight abdominal segments. Some embryologists beliere that the spiracles of the prothorax move forward in early embryonic life and unite with each other in front of the hypopharynx to form the salivary opening, their trache⿰ constituting the salivary ducts.

After this review of the general external structure of insects we may proceed to a more detailed account of the parts and organs of the honey bee.

\section{THE HEAD OF THE BEE AND ITS APPENDAGES.}

The head of an insect, as already explained, is a composite organ formed of six or seven primitive segments, each of which, except the first, typically bears a pair of appendages (fig. 2). The antennæ are developed from the embryonic appendages of the second segment, the mandibles from the fourth, the maxillæ from the sixth, and the second maxilli, or labium, from the seventh. The appendages of the third segment disappear in early embryonic life while those of the fifth segment, when the latter is present, fuse with a median tonguelike lobe of the next segment to form the hypopharynx of the adult.

\section{THE STRUCTURE OF THE HEAD.}

The general appearance and ontline of the head of a worker bee are shown from before and behind by figure 9, A and B. In facial riew the head is triangular, with the apex below. The side angles 
are rounded and capped by the large compound eyes $(E)$. In the opposite direction the head is rery much flattened, the greatest diameter being crosswise through the middle of the eyes. The face is convex, while the posterior surface is somewhat hollowed out and fits snugly upon the anterior end of the thorax.

The large lateral eyes (fig. $9 \mathrm{~A}, E$ ) are called the compound eyes, because each is composed of a large number of separate eye elements forming the little hexagonal facets visible on the surface. All of these facets together constitute the cornea, or the transparent outer surface of the eye, which in the bee is densely clothed with long hairs. The dark color of the eye is located in the deeper parts, but these will be described in the section dealing with the nervons system. On the
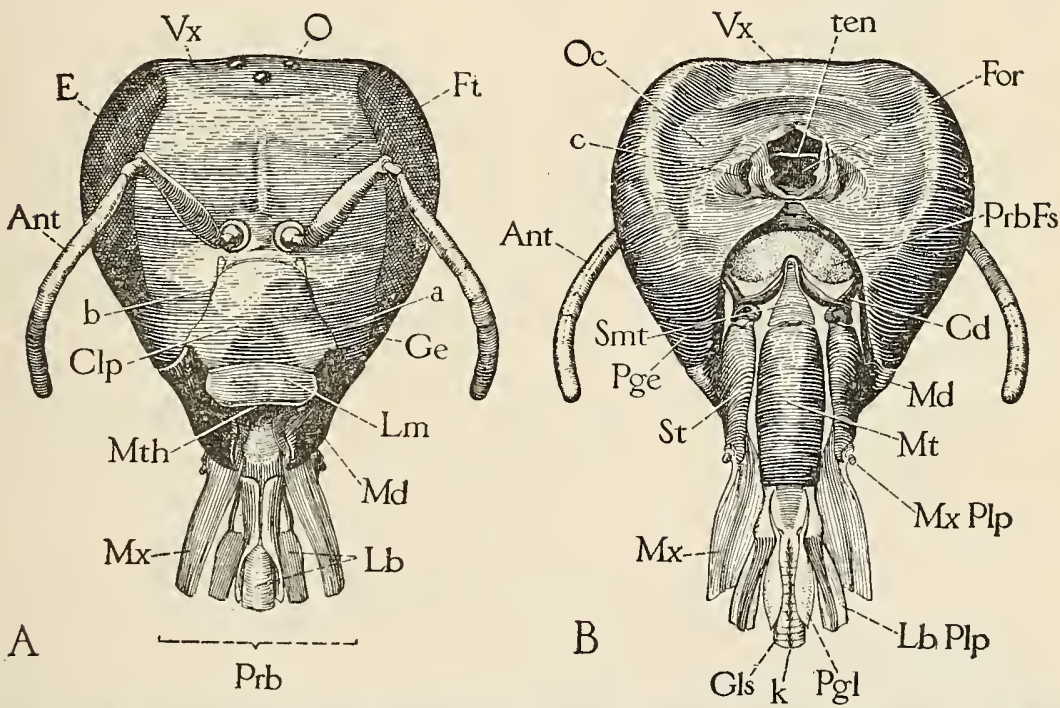

FIG. 9.-A, front view of head of worker bee with mouth parts $(P r b)$ cut off a short distance from their bases: B, corresponding view of posterior surface of head.

top of the head between the compound eyes are the three simple eyes, or ocelli $(O)$, arranged in a triangle with the median ocellus in front.

Between the lower halves of the large eyes and near the center of the face arise the antennæ $(A n t)$, each of which is inserted into a small, circular, membranous socket of the head wall, and consists of a long, basal, 1-segmented stalk carrying a terminal 11-jointed arm movably articulated to the stalk and generally hanging downward from it. (In the drone the terminal arm consists of 12 joints.)

The mouth parts are attached at the lower part of the head, and consist of the mandibles $(M d)$ laterally and the maxillee $(M x)$ and labium $(L C)$ mesially. The latter two include the set of elongate bladelike organs surrounding the protrusible "tongue," which together constitute what is commonly known as the proboscis $(P r b)$. 
When not in use the parts of the proboscis are bent back beneath the head. By referring to figure $9 \mathrm{~B}$, giving a posterior view of the head, it will be seen that the basal parts of both the maxillæ $(S t)$ and the labium $(M t)$ are suspended in a large hollow on the back of the cranium. This may be called the cavity or fossa of the proboscis $(P r b F s)$. Between the mandibles on the front of the head (fig. $9 \mathrm{~A})$ is a transverse movable flap, the labrum $(\mathrm{Lm})$, attached to the lower edge of the front wall of the head and constituting the ipper lip. The mouth (Mth) lies behind the labrum and the mandibles close beneath it.

Below the antennal sockets is a transverse, slightly arched suture (a) which turns downward on each side and extends to the inner angles of the bases of the mandibles. The area bounded by this suture is the clypeus $\left(C l_{p}\right)$ and the suture itself may be called the clypeal suture.

On the posterior surface of the head (fig. 9B) is seen the pentagonal foramen magnum (For) by means of which the cavity of the head communicates with that of the thorax and through which pass the nerves, œsophagus, blood vessel, and tracheal tubes. A small rod (ten) inside the head arches transversely over the foramen magnum, cutting it into a dorsal and a ventral half. At each side of the foramen is a large pit $(c)$ which marks the base of an internal chitinous beam of the head known as the mesocephalic pillar. The opposite end of this pillar unites with the front wall of the head on the clypeal suture below the antenna, where it produces another smaller pit $(b)$.

Below the foramen magnum and separated from it by a wide transverse bridge of the cranial wall is seen the large fossa of the proboscis (fig. 9B, PrbFs) having the shape of an inverted U. The side walls of this cavity are chitinous and from their upper edges are suspended the maxillæ, while the base of the labium is contained in the membranous floor of the fossa. The base of the labium projects from the head beneath or behind the mouth opening and its dorsal surface forms the floor of a preoral cavity surrounded by the bases of the mouth parts and labrum.

It will be seen from the above description that the head wall of the bee contains no suture except that bounding the clypeus and the one which separates the labrum from the latter. Many of the higher insects have the head wall completely continuous, showing no division at all into sclerites, but, in such forms as a grasshopper or cockroach, and, in fact, most of the lower insects, the head as well as the other parts of the body is made up of a number of plates. Hence this may be regarded as the primitive condition, and it is presumed that the head of the bee has been produced from one whose wall was divided by sutures into a number of distinct parts. Therefore the different 
regions of the bee's head may be named according to the sclerites with which they correspond in other insects. Thus, the part of the face above the clypeus and between the compound eyes may be called the front (fig. $9 \mathrm{~A} . \mathrm{Ft}$ ), the parts below the compound eyes the gence $(\mathrm{Ge})$, and the top of the head the vertex $(V x)$. The area on the back of the head around the foramen magnum may likewise be termed the occipital region (fig. $9 \mathrm{~B}, O_{c}$ ) and the parts behind the genæ and the lower halves of the compound eyes the postgence (Pge).

The worker, queen, and drone differ conspicuously in the shape and size of the head, as will be seen by comparing $\mathrm{A}, \mathrm{B}$, and $\mathrm{C}$ of figure 10 . In these drawings the front has been removed in order to show various internal parts, which will be described later. While the head of the worker (A) is triangular in facial view, that of the queen $(\mathrm{B})$ is more rounded and wider in proportion to its length. The head of the drone $(\mathrm{C})$ is much larger than that of the female and is nearly circular in outline. In shape the head of the queen is intermediate between that of the worker and that of the drone, but in size it is somewhat smaller than the head of the worker. The eyes $(E)$ of the worker and queen are about equal, but those of the drone are enormously enlarged and are broadly contiguous on the vertex and the upper part of the front. On this account the ocelli $(O)$ of the drone are crowded down on the front nearer the bases of the antennæ and the front itself is very much narrowed above. The antennæ of the drone consist of 13 segments, while those of the females
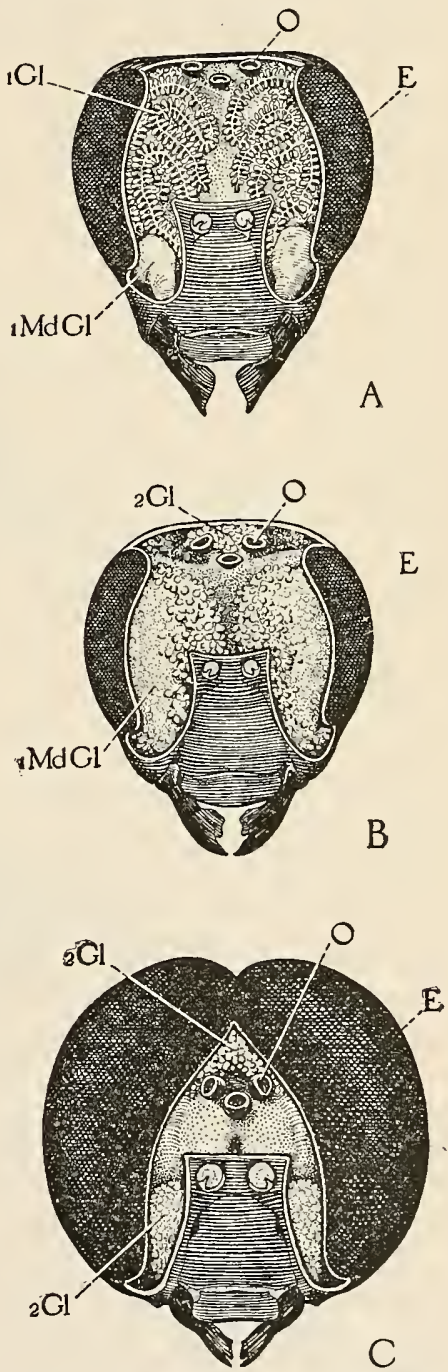

FIG. 10.-A, anterior view of head of worker, with front, antenne, and proboscis removed; B, corresponding view of head of queen; C, same of drone.

have but 12 segments. The mandibles are largest proportionately in the queen and are very small in the drone. Those of the worker have a smooth terminal edge, while this edge is notched in the queen and the drone. The parts of the proboscis are much longer in the worker 
and capable of much more action than in the queen and drone, which are almost entirely dependent upon the workers for their foor.

The internal structure of the cranium may be studied best in a longiturdinal section of the head (fig. 11). In order to prepare a section for this purpose imbed the head in paraffin and then carefully slice off one side with a sharp knife or razor just outside of the bases of the mandible and antenna. Holding the remainder in the block of paraffin or fastening the whole in a dish of water or alcohol, carefully dissect away the soft parts from the head cavity so as to expose

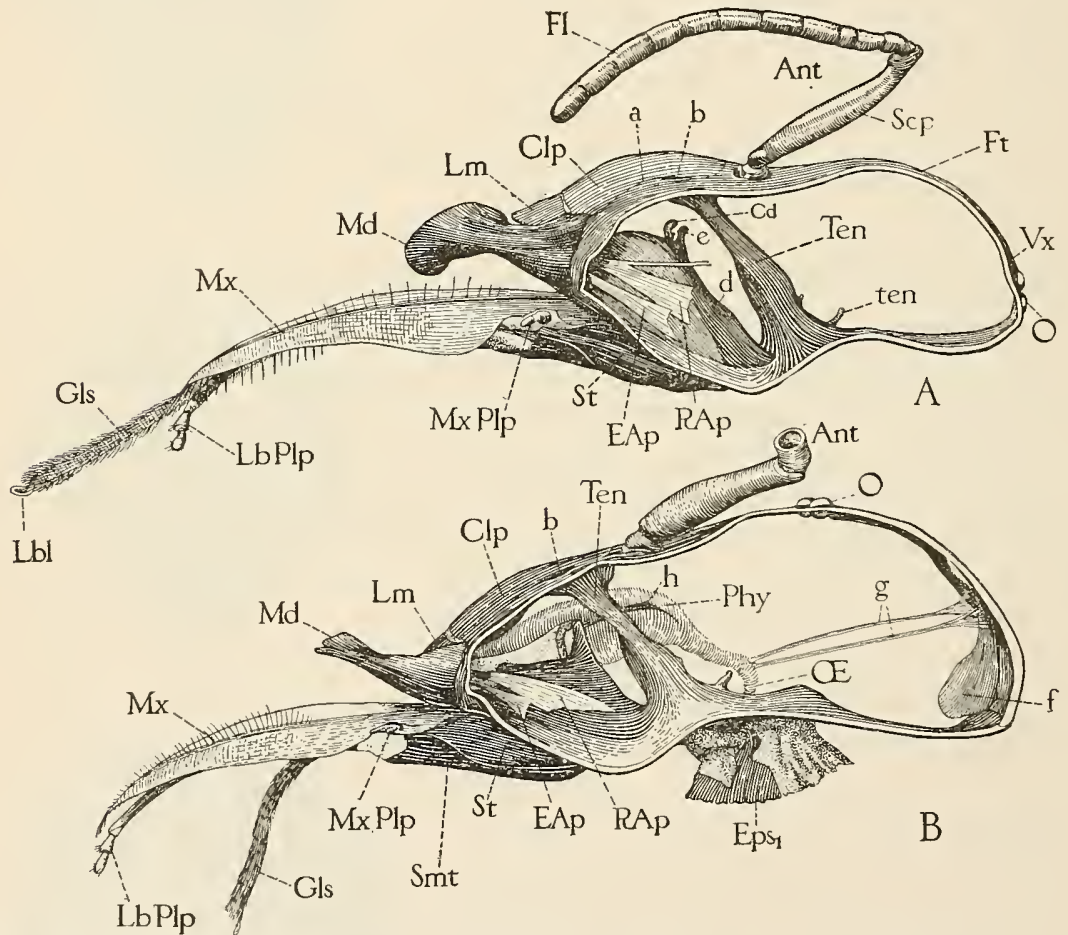

FIG, 11.-1, longitudinal section through head of morker between the median plane and outer edges of mandibles $(M d)$ and antennæ $(A \| t)$ of left side, all internal soft parts removed; B. corresponding section through head of drone, except that the pharyns $(P h y)$ and osophagus $(\sigma E)$ are not removed.

the internal chitinous parts shown in figure $11 \mathrm{~A}$ and $\mathrm{B}$. These figures, howerer, represent a slice of the head taken from between the median plane and the onter edges of the antemial and mandibular bases of the left side. Thus only the parts on one side of the midline are shown. Figure $\mathrm{A}$ is from a worker and Figure $\mathrm{B}$ from a drone. In the latter the pharynx and aesophagus are retained and the neck is not removed. Figure 20 shows the head cut open front above and the mouth parts removed. I specimen so cut and builed a short time in canstic soda or potash to remore the soft parts will be found a valuable adjunct to this study. 
The principal parts of the internal skeleton of the head, or entocranium, consist of two large, oblique, strongly chitinous bars forming a brace between the anterior and the posterior walls of the head (fig. $11 \mathrm{~A}$ and B, Ten, showing the parts on the left side only, and fig. 19, Ten). These bars have been named by Macloskie (1881) the mesocephatic pillars. As already pointed ont the base of each is marked externally by a conspicuous pit (fig. $9 \mathrm{~B}, c$ ) laterad of the foramen magnum, and its facial end by a smaller pit (fig. 9 $\mathrm{A}, b$ ) in the clypeal suture near the upper end of each side of the latter. The bases of these pillars are connected by the slender bar (fig. $11 \mathrm{~A}$, ten), already noticed, arching over the foramen magnum (fig. $9 \mathrm{~B}$, ten). This bar and the two pillars represent what is called in other insects the tentorium. In the embryo the tentorium is formed from tubular ingrowths of the head wall which unite internally and assume different shapes in different insects. Since the air tubes of the body also first appear as tubular ingrowths of the body wall, some entomologists have supposed that the hollow tentorial ingrowths of the head represent the spiracular tubes of the head which are, otherwise, lacking. However, there is not sufficient evidence to support such a view as this, and there is no reason why the tentorium should not have been originally designed simply to give greater rigidity to the walls of the head where the latter support the appendages.

The usual form of the tentorium in the lower insects is that of an $\mathrm{X}$, with a large central body, situated like a brace across the lower part of the head, having two of the arms directed anteriorly and laterally and two directed posteriorly and laterally, and while the former are said to be ingrowths from the mandibular segment, there is some difference of opinion concerning the segment to which the latter belong. Riley states that they are formed in the labial segment of the cockroach and Carriere and Burger describe the same thing for the mason bee. Other anthors have ascribed them to the maxillary segment, but they may, in later stages. lie in this segment and thus appear to belong to it, while they originated in the one following, having moved forward on account of the condensation of the back part of the head. The tentorium of the honey bee, consisting as it does of the two great mesocephalic pillars (fig. 11 $\mathrm{A}$ and B, Ten) and the small arched bar (ten) is so highly modified that it is hard to see just how its parts are to be homologized with the parts of an $\mathrm{X}$-shaped tentorium. Probably the two pillars represent the separated halves of the $\mathbf{X}$, while the slender arch is an additional structure. In any case we have not enongh evidence to warrant us in regarding the tentorial invaginations as modified trachex, or their external pits as rudimentary spiracles. Similar processes extend inward from the walls of the thorax to strengthen it or to give attachment of muscles. Such processes in general form the 
entoskeleton and are individually called apodemes. Those of the head constitute the entocranium, those of the thorax the entothorax.

The side walls of the fossa of the proboscis form two high, thin, vertical plates, as seen from the interior of the head (fig. 11), in front of the mesocephalic pillars. The posterior edge $(d)$ of each of these plates is so much thicker than the rest of it in the worker that it appears at first sight to be a separate rod. Its upper end projects above the body of the plate as a free arm $(e)$ to which is articulated the basal piece of the maxilla $(C d)$. It thus constitutes the maxillary suspensorium. (Macloskie includes under this term both the arm of the cranial wall and the cardo of the maxilla.)

The head of the drone (fig. $11 \mathrm{~B}$ ) presents, besides the parts described, a thin plate $(f)$ depending from the vertex of the cranium along the line between the compound eyes.

Besides these apodemes of the cranial wall itself there are others which project into the head cavity from the bases of the appendages to afford points of insertion for their muscles. These are specially developed in connection with the mandibles and will be described in the discussion of these organs. Still other internal chitinizations are developed in the walls of the pharynx, but these likewise will be described later.

\section{THE ANTENNA AND THEIR SENSE ORGANS.}

The antennæ of the bee are the two slender, jointed appendages movably attached to the center of the face, where each is inserted into a circular membranous area or socket just above the upper part of the clypeal suture. Their general shape and position are shown by figures $9 \mathrm{~A}, 11 \mathrm{~A}$, and 19, Ant. Each is seen to consist of two parts, forming a prominent elbow with each other, and usually so held that the first or proximal part extends outward and upward from its frontal attachment and carries the other in a pendent position from its distal end. The first part thus forms a basal stalk, called the scape (figs. $9 \mathrm{~A} ; 19, S c p$ ), consisting of a single joint inserted into the antennal socket of the front by a prominent basal condyle bent toward the face. This articular knob is attached to the rim of the socket by a circle of membrane, but it is also pivoted on a slender peglike process projecting upward from the lower edge of the socket. Hence, while the flexible membrane allows each antenna to revolve freely in any direction, the latter is at the same time held firmly in position by the pivot. The antennæ are moved by special sets of muscles inserted upon their bases within the head. The second or distal division of the antenna is cylindrical and longer than the first, forming a flexible flagellum (fig. $9 \mathrm{~A} ; 19, F 7$ ) hanging downward from the distal end of the scape. It is composed of 11 
small joints in the worker and queen and of 12 in the drone. The male antenna thus consists of 13 joints in all, while that of the female has but 12. The first joint of the flagellum is freely articulated to the seape, but the other's do not have much play upon one another, though they give flexibility to the flagellum as a whole.

Each antenna is a hollow tube containing the large antennal nerve, minute extensions of the tracheal system, and the small muscles which move the segments upon one another.

Popularly the antennæ of insects are known as the "feelers," because they are constantly moved about in all directions with a nervous kind of motion as if the creature were feeling its way along by means of them. In fact "feelers" is a better name for these appendages than the scientific term, for there can be no doubt that the sense of touch is very highly developed in them and that by means of them insects acquire a great deal of information concerning their surroundings and their companions. Moreover, a large mass of evidence derived from experiments shows unquestionably that the organs of smell also are located upon the antennæ in a great many if not all insects, while some investigators believe that in some species they carry in addition the organs of hearing.

The study of the senses of insects is a most elusive subject, and becomes more so the more we ponder on the results of experiments. In the first place, it is manifestly impossible for us to acquire any real knowledge of an insect's sensations, for what is to us an odor, a taste, a color, or a sound ina be something quite different to such a differently organized creature. We can, however, by experiments determine that some things which give us the sensation of an odor are perceived also by insects when placed near them. Also it can be shown that some of them distinguish substances of different taste in their food, and likewise that they perceive movement and distinguish the colors and in a vague way the outlines of objects. Furthermore, it is known that some of their perceptions are more delicate than ours, and that some insects at least see color where we see none. They may eren possess senses of which we have no conception.

Hence, while it ean be positively stated that insects perceive differences of touch, taste, smell, sound, and light, and act accordingly, we can not say what the sensations they acquire are like. In fact we do not know that they have conscions sensations at all. What looks like an action due to intelligent perception may be purely a reflex one, unaccompanied by any sensation. This of course involves the question as to whether such creatures or insects are possessed of conscionsness or not-a question which can not be answered one way or the other.

Understanding, then, that our knowledge of insect senses amounts only to this, that what gives us the sensation of light, sound, taste, 
touch, or smell makes also some sort of an impression on the insect and varies in degree and kind much as it does in us, we may go on to a study of the senses located on the antennæ.

Here, again, howerer, we are confronted by a difficulty, for while, at first thought, it seems very easy to hold some strong-smelling substance near the antennæ of a beetle, ant, or bee and observe the evident displeasure with which the creature turns away, yet we may be entirely wrong if we conclude that the insect "smells" the substance that repels it. Strong-smelling, volatile liquids may simply produce pain in some of the delicate nerve endings of the antennæ. Some other kind of a being, experimenting on our senses, might close up our nose and mouth and prove that we smell by means of our eyes on observing the blinking we should perform when strong formalin or ammonia was held close to the face. Furthermore, irritant gases and rolatile liquids affect the mucous membranes of our noses and throats in a way quite independent from the odor that we perceive, and there is no reason why the same may not be true of insects. As pointed out by Forel, experiments on the sense of smell should be made with odorous substances that the insect meets with in a state of nature, which would be principally the materials it feeds on. Insects are indifferent to almost every mildly odorous substance not used as food, which, however, does not prove that they do not smell them.

Again, in many cases, it would be difficult to decide whether the results of an experiment should be accredited to smell or sight. For example, every bee keeper knows that hungry bees are attracted to honey a long distance from their hives, and it would seem almost selfevident that they are guided by a sense of smell. Yet one might contend that they find the honey by sight, as, indeed, is claimed by a number of entomologists who have made experiments on the olfactory powers of bees. This question has been decided in some other insects by painting the eyes with some opaque substance or by removing the antennæ, but the evidence is not conclusive on either side in the case of bees.

Experiments made by a large number of competent investigators, including Lubbock, Schiemenz, and Forel, have proved conclusively that the organs of the sense of smell in insects are located principally on the antennx. The most interesting of these experiments are perhaps those which Forel (1903) made on carrion-feeding beetles. He found the dead and putrid bodies of a hedgehog and a rat infested by a swarm of these beetles belonging to several genera. He collected more than 40 specimens from the carcasses and remored their antennæ. Then he placed them all at one place in the grass and moved the dead bodies to a distance of 28 paces from the beetles where he concealed them in a tangle of weeds. Examination the next day 
revealed the fact that not one of the mutilated beetles had found the carcasses. Repeated experiments gave the same results-no beetle without its antenne was ever found on the dead animals, although at each examination new individuals of the several species were present. It might be supposed that the mutilation itself distracted the beetles to such an extent that they did not care to eat. In order to test this point Forel next cut off all the feet on one side of the body from a dozen intact beetles and changed the location of the dead bodies again. The next day five of this lot were found on the carcasses.

The same results have been obtained from experiments on other insects. Ants distinguish between their comrades and enemies by means of their antennal sense organs. Males of the silkworm moth and many other moths and butterflies perceive the presence of the females and are guided to them by an evident sense of smell located on the antenne, for they fail completely to find them when these appendages are removed, although one immediately recognizes a female when placed in contact with her.

Similar experiments have been made on the bee, testing the ability of the workers to find honey hidden from their sight. The results, according to Forel, seem, curiously enough, to indicate that bees can perceive odors but a very short distance from their heads. Forel found that hungry bees in a cage would pass and repass hundreds of times within a few millimeter's of some honey concealed from their sight by a lattice without discovering it. They ate it greedily, however, when the lattice was removed, though it had been perfectly accessible to them all the time. Forel believes that " bees guide themselves almost exclusively by vision," and Lubbock holds the same opinion. At the same time it would probably be a very difficult matter to convince many practical bee keeper's that bees do not "smell" from long distances. It is a well-known fact that at times when nectar is scarce bees are attracted in large numbers to the honses of an apiary where honey is stored, though, when the natural flow is sufficient, they pay no attention to it. Tests of the olfactory sense should undoubtedly be made under natural conditions. Bees inclosed in a box with some honey concealed from their sight might not be able to locate it in such close quarters though they might be smelling it all the time. In odor in a room may so fill the air that it does not seem to come from any particular direction and we ourselves would have to exert our intelligence to discover its source.

While, then, it does not seem probable that bees have such limited olfactory powers as some investigator's claim their experiments indicate, it may be accepted as proved that the organs of smell are located principally on the antenna. It has aheady been stated that the sense of touch also is very highly developed on these organs, although in at less sensitive degree it is distributed over most of the other parts of 
the body. It is again specially developed on the palpuslike appendages of the sting. (See figs. 36 and 37 , StnPlp.) Sections of a bee's

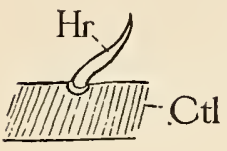

A
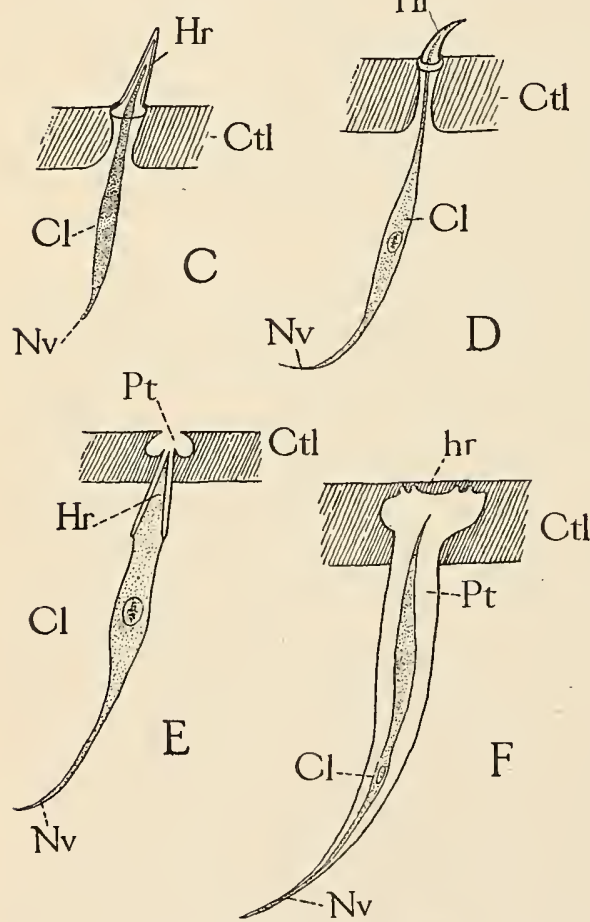

FIG. 12.-Antennal hairs and sense organs (aiter Schiemenz). A, example of anteunal hail's $(H r)$ imbedded in cuticle $(\mathrm{Ctl})$ but having no nelve comnection; $\mathbf{B}$, hollow hair containing prolongation of special cell ( $\mathrm{Cl}$ ) ; C, D, straight and curved tactile hairs connected with basal cells ( $\mathrm{Cl}$ ) and nerve fiber's $(N v)$; E, conical hair $(H \cdot)$ sunkell in a pit $(P t)$ of the cuticle, probably an olfactory organ; 1 , closed sac shut in by thin disc $\left(h r^{*}\right.$ on surface of antenna and containing a delicately poised cell (Cl) with nerve connection $\left(T^{\circ}\right)$.

bee is that of Schiemenz (1883). whose druwings are here reproduced (fig. 12) and whose text is the basis of the following descriptions. The organs consist, as before stated, of modified hairs and their basal antenna show that there are on its surface a great number of minute structures of several different kinds, though all apparently are to be regarded as modified hairs, which are undoubtedly the sense organs. Now the difficulty arises of deciding which of these to assign to the sense of touch and which to the sense of smell. Different authors have made such different interpretations of the sense organs of insects that the student attempting to get information on the subject from books must soon be discouraged by their conflicting statements. But it must be realized that only intelligent guessing is possible where several senses are located on the same part. In the case of the bee some authors have ascribed even a third sense, tenna, but there is little evidence that bees possess the power of hearing. The senses of taste and touch are possessed by the month parts, and some entomologists think that they contain organs of smell also. Thus, the organs of sight are apparently the only ones that can not be confused with some other sense.

The best account of the antennal sense organs of the that of hearing, to the an-

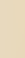


insertions which are connected with the ends of nerve fibers. Some of them stand exposed on the surface of the cuticle while others are sunken into, or entirely concealed within, pits of the integument. In addition to these, there are two other kinds of special hairs on the antennæ which have no nerve connections, while, finally, the ordinary hairs, such as are found on all parts of the body, occur also on them, especially on the scape.

The special hairs not provided with nerve endings are of two sorts. One is a solid curved or hooked hair (fig. $12 \mathrm{~A}, H r$ ) which is simply articulated into a socket of the cuticle $(C t l)$, while the other (B) is hollow and is situated over a channel through the cuticle. and contains a prolongation of a specially enlarged epithelial cell $(\mathrm{Cl})$ lying beneath it. These hairs can not be regarded as sensory, since they have no communication with the central nervous system, and it is not clear just what purpose they do serve.

The simplest sensory organ is a short, hollow, conical hair (C, $I r$ ) arising directly from the surface of the cuticle, over a wide oprning through the latter, and containing the end of a sensory cell $(C l)$ connected with a nerve fiber $(N v)$, which goes into the main trunk of the axial antennal nerve. A modified form of this organ consists of a curved hair $\left(\mathrm{D}, H r^{r}\right)$ set into a small depression orer the cuticular channel. Such hairs are probably tactile in function; that is to say, by means of them the bee can perceive that its antenne are in contact with some surface. The general integument is too thick and dense to allow of any sort of delicate touch sensation being communicated through it, but if one of these movable hairs brushes against an object the nerve within it must be at once stimulated. Tactile or tonch hairs are distributed especially over the outer surface of the antennx and at its apex, but occur also scattered over the other parts of the body and on the mouth parts.

Microseopic sections of the antenne reveal still other organs which are not so apparent on the surface as the hairs just described. One of these is shown at $\mathrm{E}$ of figure 12. It consists of a small pit $(P t)$ in the integument, widened basally, and having a small papilla on its floor, in whose summit is the opening of a still deeper cavity which also expands toward its deeper end. This inner cavity is almost filled up by a conical plug $(H r)$ which arises from its floor and ends just below the aperture into the outer pit. The plug contains a thick nerve ending which arises from a ganglion cell connected with the antennal nerve by a nerve fiber. Ten or more of these sense organs occur on the terminal and the first three segments of the flagellum. It is evident that each is simply a sensory hair which has been doubly sunken into a cavity of the integument. 
As before stated, it has been conclusively proved by several investigators that bees perceive odors, and it is said that if the antenna are covered with shellac, bees can distinguish between distasteful substances only by means of the proboscis. Schiemenz and most other writers on the subject therefore conclude that the sunken cones are the organs of smell, since, being below the surface, they could not be organs of tonch. Some other anthors, howerer, among whom are Cheshire, regard these inclosed cones as hearing organs. They suppose that the sonnd waves of the air enter the pit, as into an ear carity, and these set up a vibration in the cone which stimulates the attached nerve ending. Howerer, the appearance of one of these cones would suggest that it is too stable a structure to be affected by sound waves, so the olfactory theory seems much more probable.

Finally, Schiemenz describes the most specialized of all the antennal sense organs as a closed cavity $(P t)$ in the cuticle $(C t l)$ extending into the hollow of the antenna as a long, curved, tapering sac. This is shown at $\mathrm{F}$ of figure 12. A nerve $(N v)$ enters the lower extremity of the pouch, expands slightly into a nucleated ganglion cell $(C l)$, and then extends toward the top as a delicate spindle drawn out into a fine tapering point. The surface covering of the pit is a thin layer of chitin presenting several concentric light and dark rings surrounding a central disc $(h r)$. Sections show that this appearance of rings is due to circular thickenings of the membrane. and Schiemenz points out that the central disc is probably a modified hair, while the whole structure is to be regarded simply as a modification of a tactile organ such as that shown at D with the nerve-ending and its ganglion inclosed in a sac. These organs are most abundant on the antenne of the drones, where they are situated, especially on the under surface, so close together that but little space is left between them for the tactile hairs, while in the workers and queens they are farther apart and are interspaced with many tactile hairs. Hence, whaterer sense they accommodate must be much more highly dereloped in the males than in the females. Schiemenz described these organs, as well as the sunken cones, as organs of smell. He ascribed only the senses of tonch and smell to the antennæ, and both Cheshire and Cowan concur in his riew of the closed pits. Arnhart (1906), however, argues that an organ of smell must be open to the air in order to permit the ingress of odor particles. Such an organ is constituted by the sunken cones, but the closed pits have nothing to recommend them for an olfactory function. Arnhart then further points ont that the buried sacs, inclosing a delicately poised nerve-ending and covered by an external tympanum, have all the mechanical elements of an organ of hearing. He finally argues that bees must hear, since they produce special sounds such as the piping of the queens, and that, since no possible 
organs of hearing have been discovered on any other part of the body, some of the antennal sense organs must be auditory in function. His conclusion from these premises is, of course. ineritable that the closed sacs on the antenna are the hearing organs of the bee. What invalidates the argument, however, is the fact that no one has yet produced any actual evidence that bees perceire sound.

The following, then. may be stated as a general summary of the evidence concerning the antennal senses and their sense organs in the bee: (1) The antenna are highly sensitive to tonch and are the seat of the sense of smell. (2) They are corered by several kinds of mimute structures which are modified hairs containing special nerre-endings. (3) By inference, it would seem certain that these are the sense organs, but we can only form an opinion, based upon their structure, as to which are tactile and which olfactory. (t) Oné set of organs does not appear to belong to either of these categories and their structure suggests an auditory function, but, in the absence of evidence that bees hear, the purpose of these organs must be regarded as problematical.

\section{THE MANDIBLES AND THEIR GLANDS.}

The mandibles (fig. 9 A, $I / d$ ) are the dark, strongly chitinous appendages of the head, commonly called the jaws, situated at each side of the mouth, anterior to the base of the proboscis. In all insects with biting mouth, parts the jaws work sidewise, each being attached to the head by an anterior and a posterior articulation. They can thus swing in and out on a longitudinal axis in such insects, as the bee, that carry the head with the mouth directed downward, or in the same way on a vertical axis in those that carry the head with the month forward.

Both mandibular articulations are of the ball-and-socket type, although in the bee the socket is a very shallow one, the anterior consisting of a condyle on the outer angle of the clypens fitting against a facet on the mandible, and the position of a facet on the lower edge of the postgena receiving a condyle from the mandible. The motion of the mandible is thus reduced to a hinge-joint movement, and, on this account, insects can only bite and crush their food; they can not truly chew it, since their jaws are incapable of a grinding motion. Each mandible is, of course, as pointed out in the introduction, really suspended from the head by a continuous membrane between its base and the cranium. being simply a modified saclike outgrowth of the head wall. The two articulations are productions of the chitin on the outside of this membrane.

Figure $9 \mathrm{~A}$ shows the location and shape of the mandibles $(1 / d)$ of the worker as seen in a facial view of the head. Figure $11 \mathrm{~A}$ 
shows the appearance of the left mandible in side view, while the right one is shown detached from the head in figure $13 \mathrm{~A}$. The mandibles differ conspicnously in size and shape in the three forms of the bee as already described and as shown in figure $10 \mathrm{~A}, \mathrm{~B}$, and $\mathrm{C}$. That of the worker is hollowed out somewhat on the distal half of its inner face (fig. $13 \mathrm{~A}, \boldsymbol{M d}$ ) forming a spoon-shaped organ, the edge of which is smooth and rounded. The mandibles of both the queen (fig. $10 \mathrm{~B}$ ) and the drone (C), howerer, are pointed at the apex and have a conspicuous subapical notch. Those of the drone

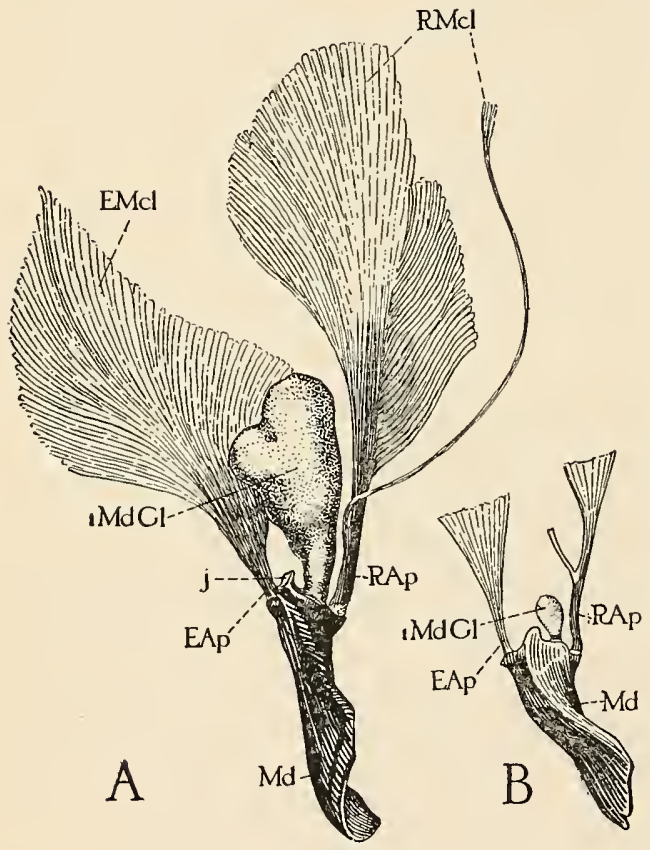

FIG. 13.-A, right mandible of worker, anterior view, with extensor and flexor muscles ( $\mathrm{EHCl}$ and $R \Psi C l$ ) and mandibular glands (1MdGl) attached; $B$, corresponding view of mandible of drone, with muscles cut off a short distance from their bases. are smaller than those of either form of the female, but appear to be especially small on account of the great size of the drone's head. The mandible of the worker is undoubtedly to be regarded as the specialized form, since the notched mandible of the drone and queen is of the ordinary Hymenopteran type. Both the drone and the queen are, under normal circumstances, fed almost entirely by the workers, and they probably never have any use for their jaws as feeding organs. The queen needs her large, sharppointed mandibles for biting her way out of the thick wax cell in which she is reared, but the drone, on the other hand,

being reared in an ordinary cell resembling that of a worker, except in size, is easily able to cut through the thin cell cap with his comparatively weak jaws. The workers, however, have numerous ises for their mandibles, such as biting through the cell caps, eating pollen, and modeling wax. The last is the especial function of the worker mandible, and probably it is to accommodate this purpose that it has acquired its specialized spoonlike shape.

Each mandible is moved by two sets of muscles within the head. The outer one constitutes the extensor muscle (fig. $13 \mathrm{~A}, \mathrm{EM} / \mathrm{Cl}$ ) and the inner the flexor muscle $(R M C l)$. The latter is the stronger of 
the two, since all the work of the mandible falls upon it. the extensor being used simply to open the jaw. While these muscles have their origins on the walls of the head, they are not inserted directly upon the mandibles, but on large apodemes (fig. $13 \mathrm{~A}, E .1 p$ and $R A p$ ) attached to the edges of the mandible.

A gland opens at the inner margin of each mandible between the anterior articulation and the base of the apodeme of the flexor muscle (fig. $13 \mathrm{~A}$ and $\mathrm{B}, 1 \mathrm{I}(d G \mathrm{G})$ ). In the worker it consists of a large sac corered with secreting cells lying within the front part of the head between the clypeus and the compound eye (fig. $10 \mathrm{~A}$, $11 / d G 7)$. These mandibular glands may be most easily studied by removing the front as shown in fignre $10 \mathrm{~A}, \mathrm{~B}$, and $\mathrm{C}$. In order to do this. pull the head from the thorax and allow the prothoracic legs, which will usually come off with the head, to remain attached to it. Next melt a small hole in the bottom of a paraffin dish with a heated needle and fasten the head face upward into this, the attached legs helping to anchor the head in the paraffin. Cover the specimen with weak alcohol and by means of sharp needles remove the part of the front on either side between the clypens and the lower half of the compound eye in the worker and drone and the entire front of the queen. In figure 10 the whole front is removed in all three forms in order to expose other internal parts of the head.

The mandibular gland $(1 / K d G l)$ is of greatest size in the queen (fig. $10 \mathrm{~B}$ ), though it is large in the worker (fig. $10 \mathrm{~A}$ and fig. $13 \mathrm{~A}$ ), but it is reduced in the drone (fig. $13 \mathrm{~B}$ ) to a very small oval sac, which is hidden by another gland ( $2 G l$ ) in front (fig. $10 \mathrm{C}$ ). It was first described by Wolff (1875) as an olfactory mucous gland (Riechschleimdrüsse) and was supposed by him to secrete a liquid which was poured upon the roof of the month in order to keep this surface, on which Wolff thought the olfactory organs were located, in a moist condition capable of absorbing odor particles. There is absolutely no evidence, however, of the presence of organs of smell in the month, and furthermore, as pointed out by Schiemenz (1883), the gland varies in the three forms of the honey bee according to the size of the mandible, which is proportionately largest in the queen and smallest in the drone. Of the three, we should expect the drone or the worker to have the sense of smell most highly developed, and hence, even if we did not know that the sense of smell is located in the antennæ, it would seem more reasonable to suppose that the glands of the mandibles are connected in some way with the functions of these organs themselves.

The mandibles, as already stated, are used for eating pollen and as tools for manipulating and modeling wax. Therefore, according to Arnhart (1906), since the queen does not eat raw pollen, the product 
of the mandibular glands must be intended for softening the wax when it is worked in the jaws. The secretion of the glands is said to be rery volatile and strong smelling and to have an acid reaction. It is probably entirely possible that it may have a solvent effect upon the wax, or even. when mixed with it, change somewhat the chemical composition of this substance: in fact. some investigators claim that the wax of the comb differs chemically from that freshly taken from the wax plates. Even this explanation, howerer, does not seem entirely satisfactory, for the only occasions on which the queen has anything to do with wax is when she gnaws her way ont of her cell after hatching or bites her way into the cells of young queens in order to sting them. Howerer, these occasional uses by the queen of her mandibles appear to be important enough to maintain the large size of these organs in the queen, and it may be reasonable to assume that the demand upon their glands is likewise a large one when it does

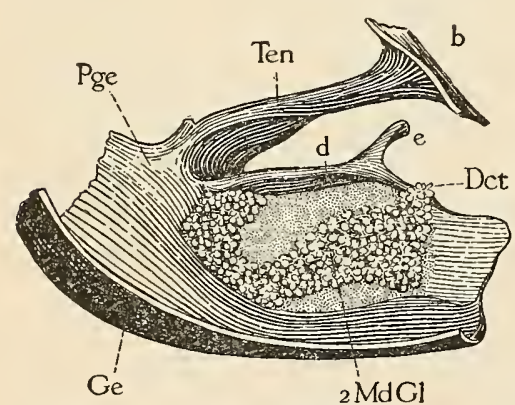

FIG. 14.-Internal mandibular gland (2MdGI) of worker, lying against inner wall of postgena (Pge) and opening (Dct) at inner edge of base of mandible. occur. Yet the mandibles of the queen are toothed and sharp pointed, which should provide her with sufficient cutting power both to emerge from her own cell and to enter the cells of other queens, and so, on the whole, the opinion of Schiemenz that the secretion of the mandibular glands is merely salivary in function would seem to be the simplest explanation and the most logical one. Howerer, an actual test should certainly be made to determine whether the worker's manipulation of the wax with her mandibles produces any change in it. and to discover whether the queen simply bites her way mechanically through the wall of the cell or at the same time softens the wax by a secretion from her month. The male in any case has little use for his mandibles, and the glands are so small that they must certainly be functionless.

A second mandibular gland (fig. $14,2 M d G l$ ) is present in the worker. It consists of a delicate, flattened. racemose mass lying against the internal face of the wall of the fossa of the proboscis. whose duct opens into the mouth cavity at the posterior inner edge of the mandible. This gland was first described by Bordas (1895) as the internal mandibutar gland. According to him, it corresponds with a similar gland in the Bombide (bumblebees) and in the Vespide (yellow jackets) and to the maxillary glands of other $\mathrm{Hy}$ menoptera. Nothing is known of its secretion. 


\section{THE PROBOSCIS.}

The conspicuous group of month appendages in the honey bee, forming what is commonly known as the proboscis (fig. $9 \mathrm{~A}, \operatorname{Pr} \mathrm{b}$ ),

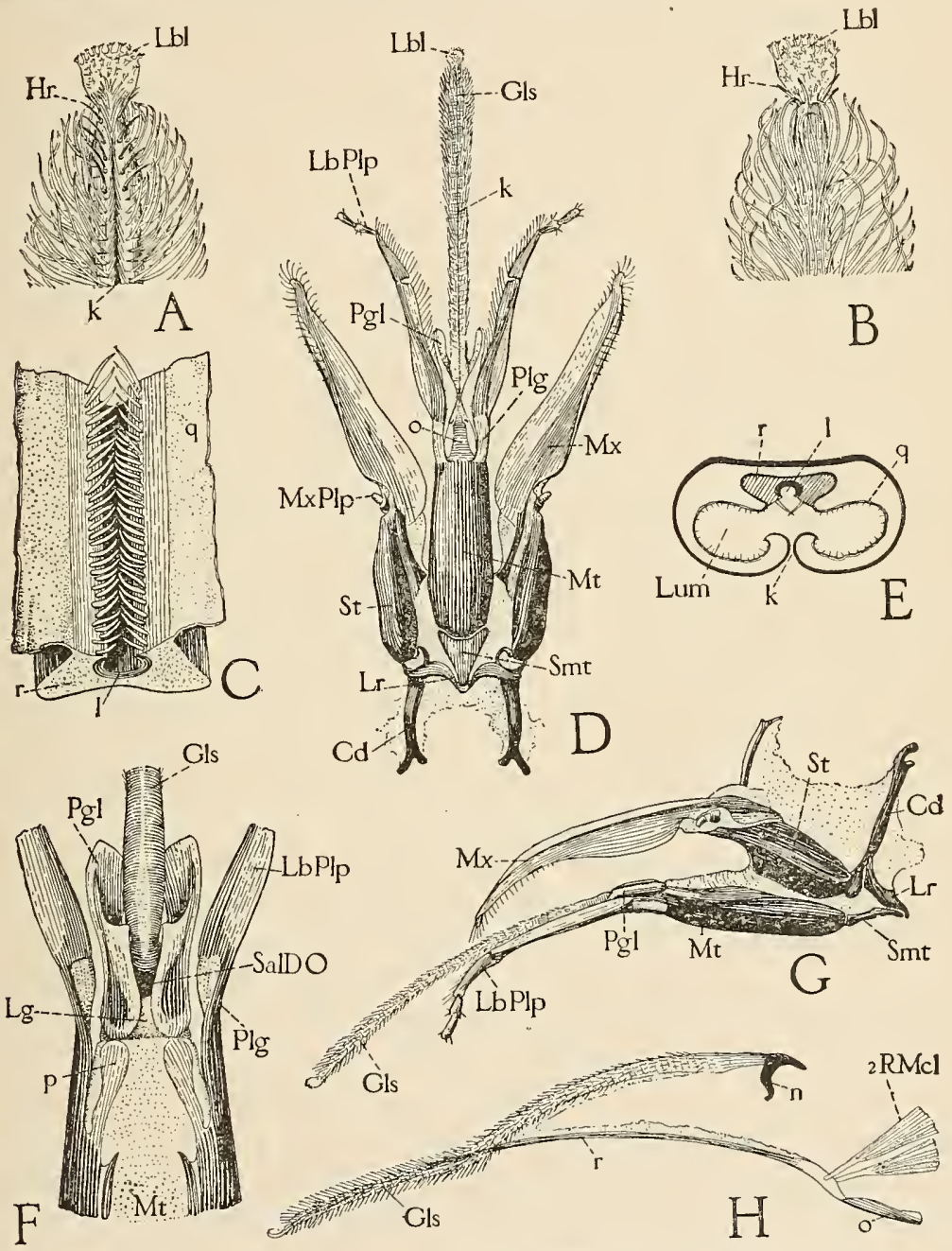

Fig. 15.-Mouth parts of the worker: A, tip of glossa, slowing labellum ( $L b 7$ ), guard hairs $(H r)$, and ventral groove $(k)$; $\mathrm{B}$, same, from above ; C, small piece of glossal rod $(r)$ with adjoining parts of walls $(q)$ of glossal canal attached, showing rentral channel ( $l$ ) guarded by rows of hairs. D, parts forming the proboscis, labium in middle and maxillæ at sides, flattened out, ventral view; W, cross section of glossa showing its invaginated channel $(\mathrm{Lum})$ and position of rod $(v)$ along its dorsal wall, and likewise position of channel ( $l$ ) of rod along median line within the glossal channel; $F$, end of mentum ( $H t$ ) and bases of ligula $(L g)$ and labial palpi (LLPlp), showing opening of salivary duct (SalDO), dorsal view; G, lateral view of proboscis showing parts on left side; H, lateral view of glossa $(G l s)$ with its rod $(r)$ torn away at base showing attachment of letractor muscles $(2 R M C l)$.

by means of which the bee takes up liquid food, consists of what correspond with the maxilla and the labium of insects that feed on solid 
food alone. By separating the parts of the proboscis a little (fig. $9 \mathrm{~B})$ it will be seen that, while there are fire terminal pieces present, three of them arise from one median basal sclerite $(. M t)$, the two wider lateral appendages $(K x)$ being carried each by a separate lateral basal piece $(S t)$. The median group constitutes the labium and the separate lateral parts the maxillac.

If the reader will now tumn again to figure $3 \mathrm{C}$ (p. 17), which may represent any generalized insect labium, and compare with it the drawing of the bee labium, forming the median series of parts in fig. $15 \mathrm{D}$, he will at once be able to identify the parts of the latter. The principal elongate median basal plate is the mentum ( $I t)$, the small triangular plate at its base is the submentum ( $S m t)$, and the two jointed lateral appendages of the mentum are the labial palpi $(L b P l p)$, each carried by a basal palpiger $(P l g)$. It is only the parts of the bee's labium that lie between the palpi which are actually different from those in the generalized diagram where they consist of the four lobes of the ligula ( $G l s$ and $P g l$ ). But even here it will be seen that the two small lobes $(P g l)$ in the bee's labium, partly concealed within the bases of the palpi, correspond with the paraglossa. Hence we have only the long median appendage to account for and it is unquestionably the representative of the glossce $(G l s)$ which are here fused together and drawn ont into this flexible tonguelike organ. In fact, a comparison with the mouth parts of other Hymenoptera in which the elements are much less modified leaves no doubt of this being the true interpretation of the bee's labium. It is simply an example of how nature constantly prefers to modify an already existing part to serve some new purpose rather than to create a new organ.

If, then, we bear in mind that the slender median appendage of the bee's labium represents the glossæ of other insects, we may for convenience call it the "tongue," as it is popularly termed, or, since it is a single organ, there is probably no grammatical objection to calling it the glossa. The word "tongue," however, to use it properly, should be applied to the true lingua or hypopharynx (fig. $3 \mathrm{C}$ and D, I phy) which arises from the upper surface of the labium. Many of the older entomologists, adopting the notion from Kirby and Spence, who defined the term in 1826, regarded the glossa of the bee as the homologne of the lingua in other orders. Even Packard in his Text-book of Entomology calls the glossa the "hypopharynx." Cheshire named it the "lignla," and his mistake has been perpetuated by several other writers on bee anatomy, including Cook and Cowan. The term ligula properly includes both the glossa and the paraglossa, or shonld signify the basal piece from which these four lobes arise (fig. $3 \mathrm{C}, L g$ ), so that it can not be applied to the glossa alone. 
The derivation of anatomical names counts for nothing in their application-this must be determined by scientific usage and priority. Thus, glossa is the Greek word for "tongue," but it was first applied in entomology to the median lobes of the labium; lingua is its equivalent in Latin and was first given to the true tongue or hypopharynx in insects; ligula is a diminutive derivative from "lingua" and has come to be applied collectively to the terminal parts of the labium beyond the mentum but not including the palpi. Hence, all these words mean the same thing by their origins, but their anatomical applications should be carefully distinguished. In this paper therefore the slender median appendage $(G l s)$ of the labium will be called the glossa, or, for convenience, the tongue, but with the strict understanding that the organ in question is not the true tongue. This latter should be called the "hypopharynx," but, as will be shown later, it is absent in the bee.

The glossa of the bee (figs. $9 \mathrm{~B} ; 11 \mathrm{~A}$ and $\mathrm{B}$, and $15 \mathrm{D}, \mathrm{F}$, and $\mathrm{G}$, $G l s)$ is corered with long hairs which increase in length toward the end. The tip is formed of a small spoon-shaped lobe, the labellum or bouton $(L b l)$, which is covered by short delicate processes branched at their ends (fig. $15 \mathrm{~A}$ and B, Lbl). The long hairs of the glossa are arranged in circles and the transverse rows of hair bases give the tongue a multiarticulate appearance. Surrounding the dorsal side of the base of the labella and forming two short subterminal rows on the ventral side of the glossa are a number of stiff, outwardly curved, spinelike hairs $(I I r)$. These hairs have been described as taste organs, but their appearance would suggest that they are simply protective spines guarding the delicate tip of the tongue. Between the two ventral rows of these spines is the termination of a groove $(\Lambda, k)$ which extends along the midline of the under surface of the glossa $(\mathrm{D}, k)$ to its base (fig. $9 \mathrm{~B}, k)$. The cleft of this groove is covered by two fringes of converging hairs whose tips are inclined also toward the tip of the tongue.

Let us now return to a study of figure $15 \mathrm{D}$. The series of lateral pieces as already explained are the maxillox. A comparison with figure $3 \mathrm{~B}$ representing a generalized maxilla will show that these organs in the bee have suffered a greater modification than has the labium, but the parts can yet be quite easily made out. The main basal plate $(S t)$ is the combined stipes, subgulea, and palpifer, the basal stalk is the cardo $(C d)$, and the little peglike process $(I / x P l p)$ at the outer end of the stipes is the greatly reduced maxillary palpus. Hence, we have left only the terminal bladelike lobe $(I x)$ to account for, and it is evident that it must be either the galea or the lacinia (see fig. $3 \mathrm{~B}, G a$ and $L c$ ) or these two lobes combined. Here again a comparative knowledge of the mouth parts of Hymenoptera comes 
to our aid and shows clearly that the part in question is the outer lobe or galea, for the inner one becomes smaller and smaller in the higher members of the order and finally disappears.

The base of the submentum is connected in the bee with the upper ends of the cardines by a flexible, widely $\mathrm{V}$-shaped band. the tom $(L r)$. The posterior angle of the submentum rests in the apex of the lorum, while the tips of the loral arms are movably articulated with the distal ends of the cardines. The name "lora "was given to this structure by Kirby and Spence, but "lorum " is more correct, since this is the Latin form of the rord (meaning a thong or lash). Some recent entomologists have spoken of the structure as consisting of two rods, thus making the word do duty as a plural, but the thing itself is all one piece. Cheshire and some others have incorrectly applied the name to the submentum.

The lorum is peculiar to the Hymenoptera, and the reason for it is clear when we examine the attachments of the parts of the proboscis to the head. As already stated. the maxillae and labium are suspended in a large cavity on the back of the head which may be called the fossa of the proboscis (fig. $9 \mathrm{~B}$, PrbFs). The maxille are articulated by their cardines $(C d)$ to the maxillary suspensoria (fig. 11 A, e) at the upper edges of the side walls of the fossa. The labium, on the other hand, is not attached to the solid walls of the craninm but is suspended in the membranous floor of the fossa. This is to afford it freedom of morement during feeding, but, in order to give it more substantial support and to make the regulation of its motions possible, the submentum is slung to the ends of the cardines by the lortum.

The terminal lobes of the labium and maxilla when not in use are ordinarily folded down beneath the head against the mentum and stipites (fig: 19). When, however, the bee wishes to imbibe a thick liquid such as honey or sirup in large quantity, these parts are straightened out and held close together so as to form a tube between them leading into the mouth, the terminal joints of the labial palpi alone diverging from the rest (fig. $11 \mathrm{~A}$ ).

The action of the mouth parts while feeding may be observed quite easily if some bees are given a small amount of honey and then watched through a lens while they are eating. A most convenient method is to put a few workers in a small screen-covered cage. such as are used for queen nurseries. spread a small drop of honey on the wire, and then place the cage under a simple microscope. It will be seen that the maxillie are held almost stationary but that the base of the labium slides back and forth between the maxillary bases with a very regular to-and-fro movement as if the honey were being either pumped or sucked up into the month. It is probable that there is a sucking force exerted by the pharynx (fig. $11 \mathrm{~B}, P h y$ ) but not 
by the honey stomach (fig. $44, \Pi S$ ), which latter, as Cheshire remarks, could no more suck honey through the rosophagus than a balloon could suck gas from a pipe. The liquid undoubtedly runs up the temporary tube between the blades of the mouth parts first by capillary attraction, but it must be greatly assisted along its way to the mouth by the retraction of the labium. The load bronght up when this is pulled back is then sucked into the mouth by the pharynx while the labium immediately goes out again after more. It acts thus as a sort of mechanical feeder and this function is probably derived from the lapping motion of the under lip in wasps and hornets.

The mentum (fig. 15 D and $\mathrm{G}, 1 / t$ ) is hinged freely upon the submentum (Smt), the latter, as already described, is set into the socketlike angle of the lorum, while, finally, the arms of the lorum are articulated to the distal ends of the cardines of the maxillæ. Now, when the labium is retracted by means of muscles attached to the mentum, the submentum turns in the loral socket and assumes a position at right angles to the mentum while the lorum itself turns somewhat on its articulations with the cardines. This great freedom of motion is permitted by the loose membrane of the fossa in which both the maxillae and the labium are suspended.

The observer, howerer, can not fail to note that beside this motion of the entire labium the tongue itself. or glossa (Gls), performs a conspicuous independent movement of its own. It is by far the most active member of the mouth parts during feeding. being actively thrust out and retracted while its tip is constantly moved about in a way suggestive of its being delicately perceptive of taste or touch or perhaps to both of these senses. So great is the retractile power of the tongue that its tip, which normally extends far beyond the end segments of the labial palpi, can be drawn back entirely within the latter. This contractile activity appears at first sight to be due to elasticity, but a closer examination will show that the entire ligula, i. e., the paraglossæ $(P g l)$ as well as the glossa $(G l s)$. moves back and forth and that the action is due to a retraction of the base of the ligula (fig. $15 \mathrm{~F}, L g$ ) into the anterior end of the mentum ( $1 / f t$ ). The ligula is supported on a membranons cone at the end of the mentum whose walls are strengthened by three thin chitinous plates, two above $(\mathrm{F}, p)$ and one below $(\mathrm{D}, o)$. By the contraction of muscles situated within the mentum (fig. $16,1 R 1 / \mathrm{cl}$ ) and inserted upon the base of the ligula the latter is pulled into the end of this cone whose walls, including the chitinous plates, simply turn inward.

But the tongue does possess also a contractile power of its own by means of which it actually shortens its length. A flexible rod arising from the median ventral supporting plate (fig. $15 \mathrm{D}, o$ ) of the ligula extends throughout its length. The base of this rod is curved down- 
ward and has two muscles attached to it. This is shown by figure $15 \mathrm{H}$, where the rod $(r)$ is torn from the glossa $(G l s)$ basally so as to show the muscles $(2 R M C \mathrm{cl}$ ) inserted upon it and its connection with the plate $(o)$. By the contraction of the muscles the rod bends at its base and is drawn back into the mentum. The glossa thus shortens and becomes bushy just as does a squirrel's tail when one attempts to pull the bone out of its base.

The protrusion of the parts is due to the pressure of blood driven into the ligula from the mentum, while probably the glossa extends also by the straightening of its rod as the muscles relax. Wolff described a protractor muscle at the base of the ligula. The rod of the tongue is certainly not in itself contractile, as supposed by Cheshire, who looked for eridence of muscular striation in it. It has mostly a transparent and cartilaginous appearance, but is presumably chitinous.

The mouth parts, their action in feeding, and the muscular mechanism by which they are moved have been elaborately described and illustrated by Wolff (1875) in his monograph on the organs of smell in bees. Most unfortunately. however, Wolff's paper was written to show that the seat of the sense of smell is in the mouth, a most erroneous notion, and the title of his paper based on this notion has caused little attention to be paid to this work on the mouth parts of the bee, which is one of the best anatomical treatises ever produced on the mouth parts of any insect.

It still remains for us to describe the details of the glossa and its particular function in feeding. The tongue is not a solid appendage nor yet is it truly tubular. A compromise is effected by the longitudinal groore (fig. $15 \mathrm{~A}$ and $\mathrm{D}, k$ ) on its ventral surface which expands within the tongue into a large carity occupying half of its interior (E, Lum). The glossal rod $\left(r^{2}\right)$, which has already been mentioned, lies in the dorsal wall of this chamnel and is, hence, really not an internal but an external structure. The rod is itself grooved along its entire ventral length (E, $l$ ) and this groove again is converted into a tube by two rows of short hairs which converge from its margins. The lips of the ventral groove of the glossa are so deeply infolded that its cavity is almost divided along the midline. Hence, the glossa might be described as containing three channelsa small median dorsal one $(l)$ and two large latero-rentral ones (Lum).

The glossal rod (fig. $15 \mathrm{C}, r$ ) is very flexible but not contractile, as already stated, and is mostly clear and cartilaginous in appearance, its ventral groove $(l)$ alone being lined by a deposit of dark chitin (fig. 15 $\mathrm{C}$ and $\mathrm{E}$ ). Its shape in section is sufficiently shown by the figures. The walls of the large channels of the proboscis consist of a delicate membrane $(\mathrm{C}$ and $\mathrm{E}, q)$ covered with very small hairs. 
The entire ventral cavity $(\mathrm{Lum})$ with the rod $(r)$ can be evaginated through the rentral cleft $(k)$ by blood pressure from within. As Cheshire points out, this permits of the channels being cleaned in case of clogging by pollen or any foreign matter.

It is supposed that these glossal tubes are of especial service to the bee by enabling it to take up the smallest drops of nectar--quantities that wonld be lost in the clumsy tube formed between the parts of the labium and the maxillæ. The suction must be in large part capillary attraction, but here again the shortening of the glossa by the retraction of its rod must squeeze the contained nectar out of the upper ends of the channels where it is received upon the ventral flaps of the paraglossa (fig. $15 \mathrm{~F}, \mathrm{Pgl}$ ), from which it runs around the base of the tongue $(G l s)$ within the paraglossæe to the dorsal side of the mentum $(M t)$ and so on to the mouth.

The maxillæ and labinm of both the queen and the drone (fig. 11 B) are smaller and weaker than those of the worker, and neither of these two forms is capable of feeding itself to any extent. If a hungry queen be given some honey she attempts to eat it and does imbibe a small quantity, but at the same time she gets it rery much smeared over her head and thorax.

The month is hard to define in insects; practically it is the space surrounded by the bases of the mouth parts, but strictly speaking it is the anterior opening of the alimentary canal situated behind the bases of the mouth parts (fig. 19, Mth). Yet the enlargement of the alimentary canal (Phy) immediately following this opening is never spoken of as the mouth cavity but is called the pharynx. On the other hand the so-called epipharynx (Ephy) and hypopharynx (absent in the bee) are located in front of this opening and are consequently not in the pharynx at all, the former being attached to the under surface of the labrum and clypeus, while the latter is situated on the upper surface of the base of the labium. These and numerous other inconsistencies in the nomenclature of insect morphology have to be endured because the parts were originally named for descriptive purposes by entomologists who were not familiar with scientific anatomy. In this paper the term mouth will be applied to the true oral opening (fig. 19, $M(t h$ ). The space in front of it between the bases of the mouth parts may be called the preoral cavity.

The duct of the salivary glands of insects in general opens upon the base of the labium in front of the hypopharynx. In the honey bee the salivary opening is on the dorsal side of the base of the ligula between the paraglossæe (fig. $15 \mathrm{~F}, S a l D O$ ). This alone would show that the glossa is not the hypopharynx of the bee, as many anthors have supposed, for otherwise the opening of the salivary duct should be ventrad to the base of the glossa. In fact, this makes it clear that 
the bee does not possess a hypopharynx. There is, however, a conspicuous chitinous plate located on the anterior part of the floor of the pharynx (fig. 19, $s$ ) having two terminal points hanging downward over the lower lip of the oral aperture, but, although this plate is truly hypopharyngeal in position, it is not the homologue of the organ called the hypopharynx in other insects. It is variously developed in all Hymenoptera, being simply a chitinization of the floor of the pharynx, and should be called the pharyngeal plate (Schlundbein of Wolff). It will be more fully described in connection with the alimentary canal. If a hypopharynx were present it should be situated on the upper side of the labium (see fig. $3 \mathrm{D}, H p h y$ ) but there is here present only a plain arched membranous surface in the honey bee and other typical Hymenoptera.

The external location of the salivary opening enables the saliva to be mixed with the food before the latter enters the mouth. This is necessary in insects since the jaws are also on the outside of the

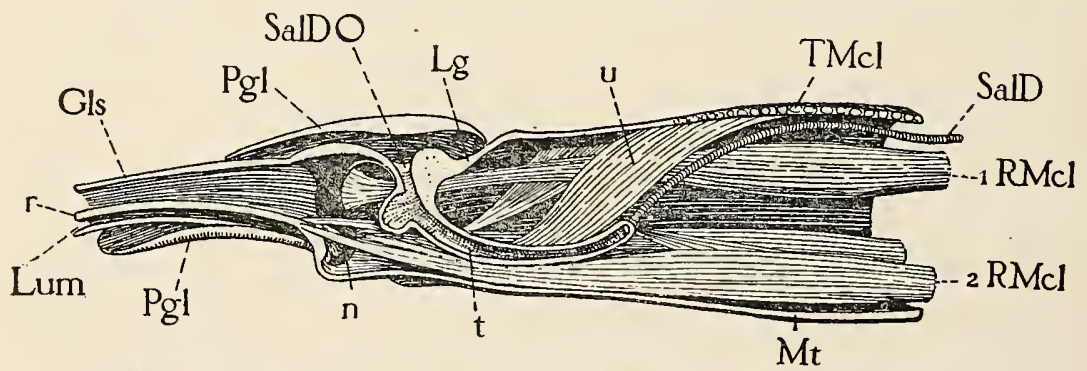

FIG. 16.-Median section through distal half of mentum (Mt) and base of ligula $(L g)$ of worker, showing opening of salivary duct $(S a l D O)$, and muscles connected with ligula and the "salivary syringe" $(t)$.

mouth, and whatever chewing or crushing the food receives from them is consequently done in the preoral cavity.

In some insects the saliva is used for other purposes than digestion. For example, the saliva of some predaceous insects with piercing mouth parts belonging to the order Hemiptera is poisonous, and when one of these insects "bites," the saliva is injected into the wound by a special pump. The bite of the mosquito is made painful likewise by an irritant secretion from a part of the salivary glands. Bees appear to have the power of letting their saliva run down the tongue when necessary to dissolve a hard substance like sugar and render it capable of being taken up in solution, for they, do not eat sugar with their mandibles. Moreover, there is even a sort of pump or so-called "salivary syringe" at the termination of the salivary duct in the ligula, by means of which the secretion can be forcibly ejected from the opening.

The salivary opening on the base of the ligula (fig. $15 \mathrm{~F}$, SalDO) leads into a deep transverse pit with collapsible cartilage-like walls having its deepest part turned horizontally toward the base of the 
labium (fig. 16, $t$ ). The salivary duct $(S a l D)$ bends downward in the anterior part of the mentum $(J / t)$ and opens into the posterior end of the pit $(t)$. When the retractor muscles $(1 R 3 / \mathrm{cl})$ of the ligula pull the latter back into the mentum the lips of the salivary pit must necessarily be closed. The simultaneous contraction of the elevator muscle $(u)$ attached to the roof of the horizontal part of the pit must expand the latter and suck the saliva from the salivary duct. When, finally, these muscles relax and the ligula is driven out by blood pressure in the mentum, probably produced in part by the contraction of its dorsal transverse muscles ( $T M C c l$ ), the saliva in the temporarily formed bulb must be squirted out upon the base of the tongue. Wolff (1855) calls each dorsal longitudinal muscle of the mentum (1RAICl) - the two inserted upon the basal hooks $(n)$ of the glossa (fig. $15 \mathrm{II}$ and fig. 16) -the retractor linguce longus. The large ventral retractor muscle of each side ( $2 R M C \mathrm{Cl}$ ) he calls the retractor lingua biceps since its anterior end divides into two parts, one of which is inserted by a tendonous prolongation upon the base of the glossal rod (fig. $15 \mathrm{H}$ and fig. 16, $r$ ) and the other upon the base of the ligula. The use of the word "lingua" in these names is objectionable because, as already explained (page 45), the lingua is properly the true tongue or hypopharynx. "Ligulæ" should be substituted for "linguæ." The dilator muscle (fig. 16, $u$ ) of the salivary pit $(t)$ is termed the protractor linguce by Wolff becanse, as he supposes, when the ligula is pulled back into the mentum the position of this muscle is reversed, so that a contraction of its fibers would help to evert the ligula.

The glands that furnish the saliva lie within the head and the thorax and will be described later in connection with the alimentary canal and the process of digestion.

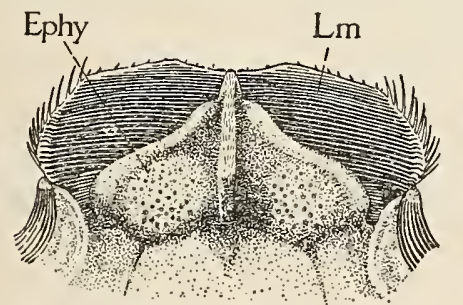

A

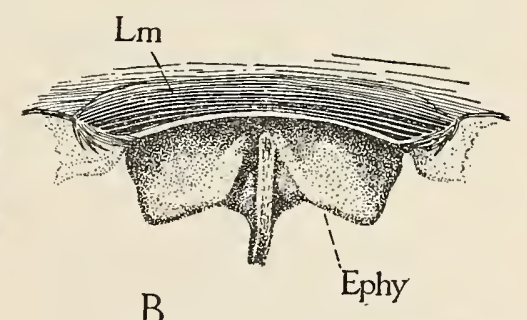

B

Fig. 17.-Epipharynx $(E p h y)$ and labrum $(L m)$ of worker: A, ventral view; B, anterior view.

\section{THE EPIPHARYNX.}

The epipharynx of insects in general may be described as a dorsal tongue, it being a median lobe developed on the roof of the preoral cavity from the under surface of the clypeus or labrum and situated opposite the hypopharynx. 
The epipharynx of the bee is a large three-lobed appendage depending from the roof of the preoral cavity just in front of the mouth (fig. 19, Ephy). Seen from below it is triangular (fig. 17 A) with

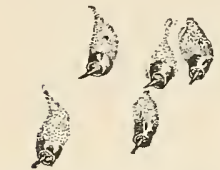

F'IG. 18.-Sense organs, probably of taste, f rom e p i pharyns. the apex forward. Its median lobe has the form of a high, vertical, keel-like plate, while the lateral lobes are rounded but have prominent elevated edges converging toward the front of the keel. The appearance in anterior view is shown by figure $17 \mathrm{~B}$. Situated on the posterior parts of the lateral lobes are a number of sense organs, each consisting of a small cone with a pit in the summit bearing a small hair (fig. 18). These are regarded as organs of taste.

Wolff (1875) made a most thorough study of the epipharynx, which he called the "palate sail" (Gaumensegel) on accomnt of the high median crest. His drawing is the standard illustration of the organ found in nearly all books on the anatomy of the honey bee

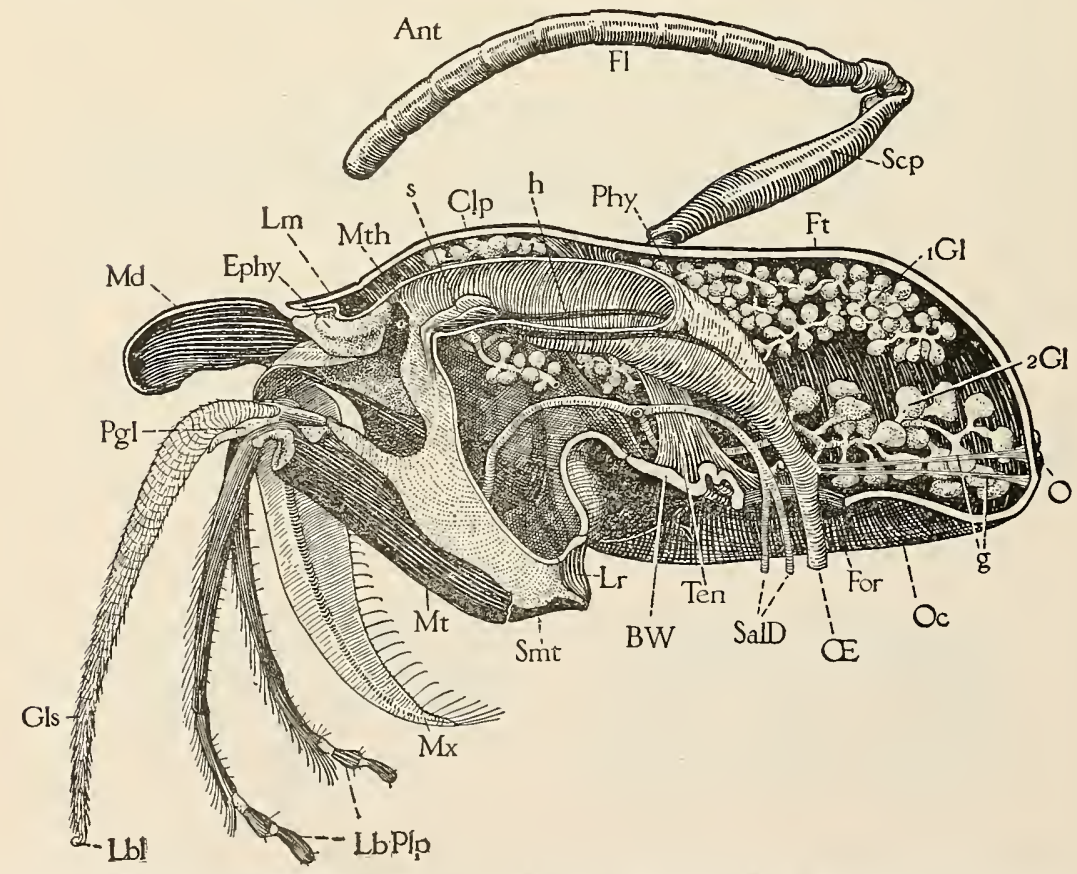

Fig. 19.--IIedian longitudinal section of head of worker, but with entire labium attached, showing internal organs except muscles and brain.

and in most works on general insect anatomy and the sense organs. Wolff, however, regarded the sensory cones as having an olfactory function, and this led him to erroneous conclusions regarding the functions of several other organs. For example, he thought that the mandibular glands poured a liquid upon the surface of the 
epipharynx which kept it moist and capable of absorbing odor particles, while he explained the inhalation of the latter into the preoral cavity as brought about through the contraction of the air sacs situated about the mouth. Wolff's anatomical researches are without doubt some of the best ever made on the bee, and it is due to his mistaken idea of the location of the sense of smell, which, as already explained, is on the antennæ, that re have received from him a most excellent account and detailed drawings not only of the epipharynx but of the mandibular glands, the mouth parts, the salivary "pump," and the respiratory organs.

\section{THE THORAX AND} ITS APPENDAGES.

\section{THE STRUCTURE OF} THE THORAX.

The apparent thorax of the bee (fig. 20, $T_{1}-I T$, and fig. 21) and of most other Hymenoptera is not exactly the equivalent of the thorax in other insects. The middle division of the body, so conspicuons in this

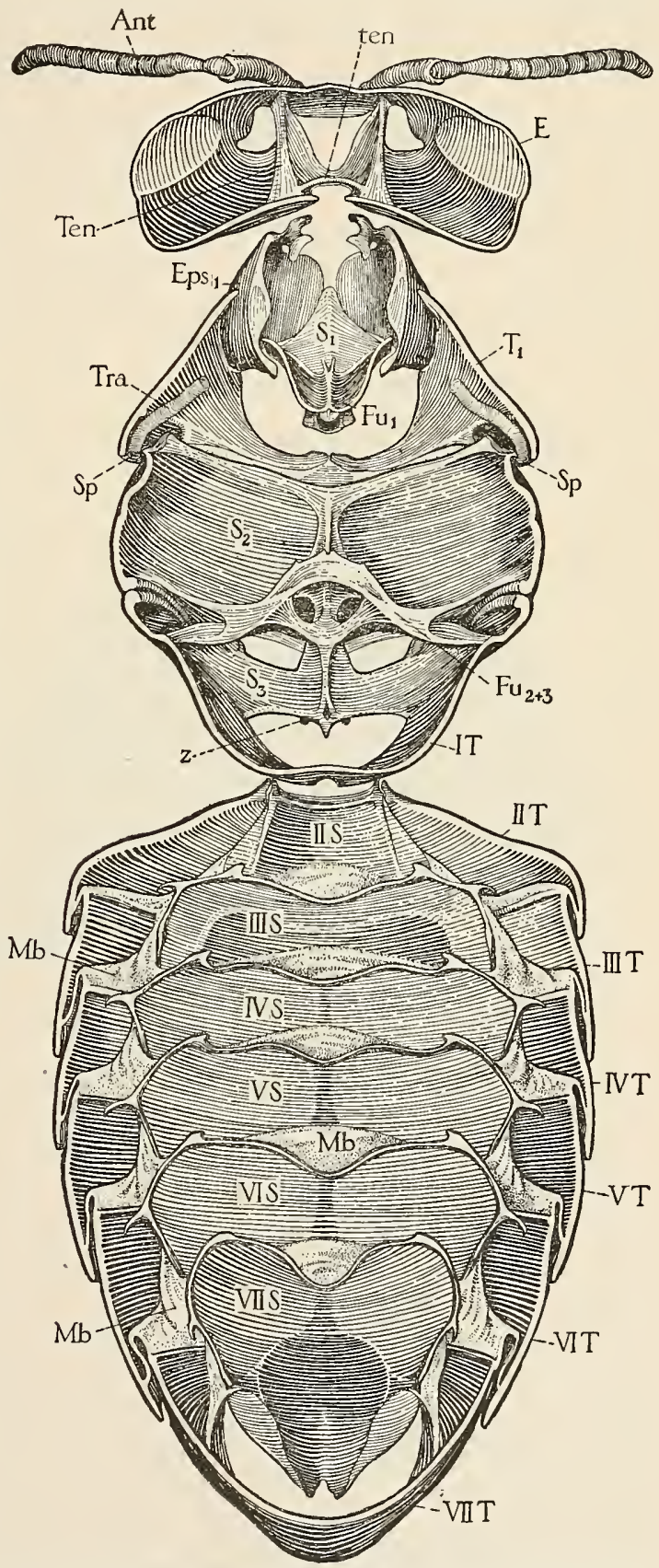

FIG. 20.-Dorsal view of ventral walls and internal skeleton of body of worker. order, consists not only of the three leg-bearing segments, which alone 
constitute the thorax of all other insects, but also of the first abdominal segment. The conspicuous necklike constriction posterior to the base of the hind legs (fig. 21, $P d$ ) is, therefore, between the first and the second abdominal segments (fig. 1, IT and IIT).

The thorax of the honey bee at first sight looks entirely different in structure from that of all other insects except related Hymenoptera, in the higher families of which group it is more highly modified than in any other order of the whole series of insects. When, however, we examine the thorax of one of the lowest members of the Hymenoptera, such as a sawfly, we are surprised to find that, in each segment, the structure agrees very closely with our ideal diagram of a general-

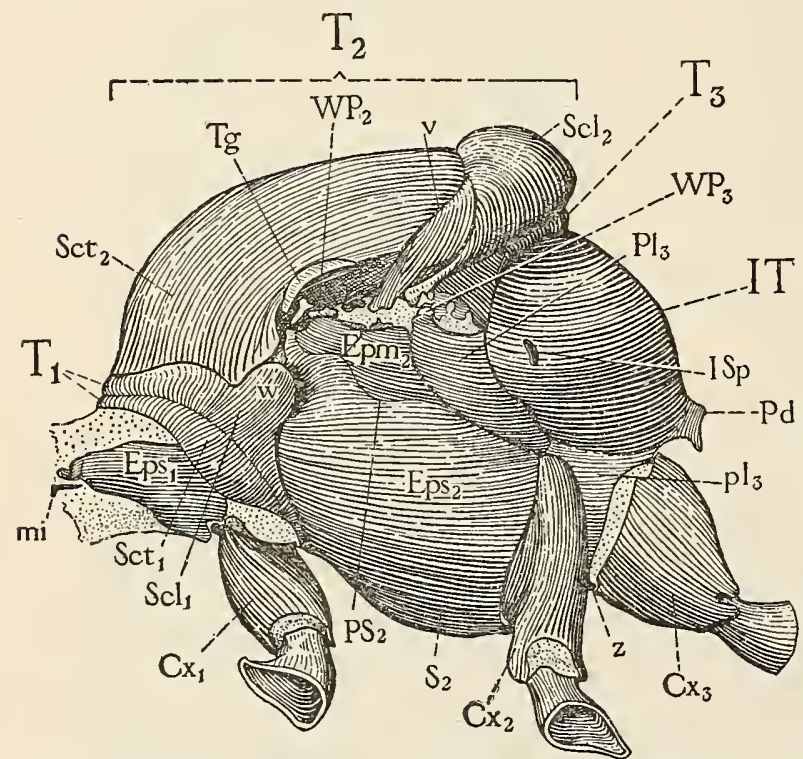

FIG. 21.-Thorax of worker, left side, with intersegmental lines somewhat exaggerated, showing prothorax $\left(T_{1}, E p s_{1}, C x_{1}\right)$. mesothorax $\left(T_{2}, E p s_{2}, E p m_{2}, \mathbb{S}_{2}, C x_{2}\right)$, metathorax $\left(T_{3}, P l_{3}\right.$, ${ }_{n} l_{3}, C x_{3}$ ) and propodeum or first abdominal segment $(I T)$. ized thoracic segment (fig. 4). The three segments are perfectly distinct, and the first abdominal segment, while it may be clearly separated from the rest of the abdomen, is not fused into the thorax so as to appear to be a part of it. If, now, we examine representatives of several families intermediato between the samflies and

the bees, the line of specialization that has produced the bee thorax becomes perfectly evident. The principal features in these modifications are the following:

(1) The lateral and rentral parts of the prothorax (figs. 20 and 21 , $E p s_{1}$ and $S_{1}$ ) are suspended loosely in a large membranous area which is continuous anteriorly as the neck. They thus form a sort of suspensorium for the front legs, which appears detached from the rest of the thorax. (2) The protergum $\left(T_{1}\right)$ is solidly attached to the anterior edge of the mesothorax and its lateral parts extend downward till they meet on the venter behind the prosternum (figs. 20 and 21). (3) The postnotum (postscutellum) of the mesothorax (figs. 22, $P N ; 23 \mathrm{~A}, \mathrm{PN}_{2}$ ) is entirely invaginated into the cavity of the thorax and is reduced to the form of two lateral arms of the large 
internal pos'phragma $(P p h)$ which has no median tergal comnection at all. (4) The metatergum (figs. 21 and $23 \mathrm{~A}, T_{3}$ ) consists of a single narrow plate. (5) The metapleurum (fig. 21, $P l_{3}$ and $p l_{3}$ ) shows no trace of a division into episternum and epimerum, but is divided into an upper $\left(P l_{3}\right)$ and a lower $\left(p l_{3}\right)$ pleural plate. The first abdominal tergum (fig. 21, IT) is solidly attached to the metathorax and forms an intimate part of the thoracic mass.

We shall now proceed with a more detailed account of the thorax. and the reader should occasionally turn back to figure 4 (p. 19) in order to keep clearly in mind the parts that make up a generalized thoracic segment.

The parts of the prothorax are so separated from each other that they appear to belong to different segments. The protergum (fig. 21, $T_{1}$ ) forms a collar completely encircling the front of the mesothorax. On each side a large lobe $(w)$ projects posteriorly as far as the base of the front wing and constitutes a protective shield over the first thoracic spiracle. The tergum presents a median transverse groove, dividing it into an anterior and a posterior part, which parts may be called the scutum (fig. $23 \mathrm{~A}, T_{1}, S c t$ ) and scutellum $(S c l)$. The propleurum (figs. 20,21,Eps ${ }_{1}$ ) consists of a large plate presenting both a lateral surface (fig. 21) and a ventral surface (fig. 20). On account of the position of the coxal articulation (fig. 21) this plate would seem to be the anterior pleural plate alone (see fig. 4), which is the episternum. In some Hymenoptera the epimerum is represented by a very small plate on the rear edge of the episternum. The anterior ends of the two episterna form knobs which loosely articulate with the occipital region of the head (figs. $11 \mathrm{~B}, 20$, and 21). Lying just ventrad of each is a slender cervical sclerite (fig. 21, $m i)$. The prosternum $\left(S_{1}\right)$ is shown by figure 20 . It carries a large entosternum $\left(F u_{1}\right)$, forming a bridge over the nervous system behind the prothoracic ganglion (fig. 52).

The mesotergum, as seen in its natural position (fig. 21, $T_{2}$ ), consists of a large anterior scutum $\left(S c t_{2}\right)$ and of a smaller but very prominent posterior scutellum $\left(S c l_{2}\right)$, separated by a very distinct suture $(v)$. The scutellum has two latero-anterior' areas partially separated from the median area by sutures. When the mesotergum is detached from the rest of the thorax (fig. 22) it is discovered that there is attached laterally to the scutellum a large posterior internal part, which does not show on the surface at all. This is the representative of the postscutellum $(P s c l)$ and its phragma $(P p h)$ constituting the postnotum $(P V)$ of our diagrammatic segment (fig. 4). The proof of this, again, is to be derived from a study of the lower Hymenopteran families. In some of the horntails (Siricidæ) the postnotum or postscutellum is a prominent plate on the surface of the dorsum behind the schtellum. In Sirex (Siricida) this plate is sunken below 
the general surface and mostly concealed between the mesothorax and the metathorax. In higher families such as the Pompilidx the postnotum of the mesotergum is entirely concealed by invagination, but it still carries a very large phragma. When, now, we come to the highest members of the order we find that the median part of the postnotum in the mesothorax is gone entirely and that it is represented only by the lateral arms (figs. $22 . P_{1} Y ; 23 \mathrm{~A}, P N_{2}$ ) carrying the large, purely internal postphragma $(P p h)$.

The mesopleurum is large and consists principally of the episternum (fig. 21, Eps. $s_{2}$, which, however, is continuously fused with the mesosternum (figs. 20 and $21, S_{2}$ ). The pleural suture (fig. 21, $P S_{2}$ ) is short and sinuous and does not reach more than half way from the wing process to the base of the iniddle leg. The epimerum is reduced to a small double plate lying above the episternum and posterior to the wing process (figs. 21, E pm. and $24 \mathrm{~A}$, Epm and Epm). The

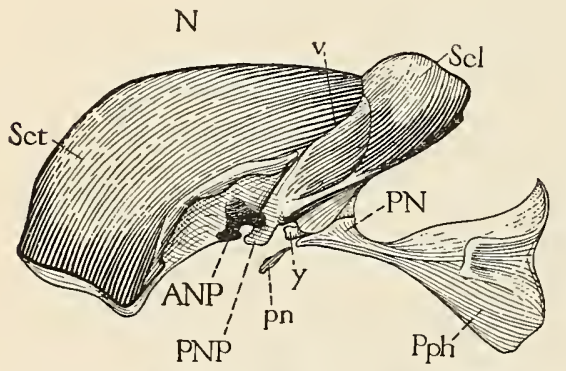

Fig. 22.-Lateral view of mesotergum of worker, removed from the rest of thorax to show large internal postscutellum (postnotum, $P Y)$ and its phragma $(P p h)$ not visible normally in the bee from exterior. pleural ridge (fig. $2+\mathrm{B}, P R$ ) is weak, but the wing process ( $\mathrm{IT}^{\prime} P$ ) is well braced by a number of accessory internal ridges. One preparapterum $(\mathscr{Q P})$ and one postparapterum $(3 P)$ are present. Lying behind the postparapterum is another larger sclerite (fig. $24 \mathrm{~A}$ and $\mathrm{B}, \mathrm{pn})$, whose anterior end is articulated to the edge of the epimerum and whose posterior tapering end is loosely associated with the terminal arms of the postnotum (fig. 22. $P . Y$ and $p m$ ). This sclerite might be regarded as the fourth parapterum, but it is much more probably the representative of a small terminal bar of the postnotum present in other Hymenoptera, such as Pepsis, which connects this tergal plate with the epimerum, though in this genus it is not detached from the main postnotal sclerite.

Both the mesosternum (fig. $20, S_{2}$ ) and the metasternum $\left(S_{3}\right)$ contribute to the formation of a large entosternum $\left(F u_{2+3}\right)$, which forms a protecting bridge over the combined mesothoracic and metathoracic ganglia (fig. 52) and affords attachment for the ventral longitudinal muscles of the thorax (fig. $\cdot 27,7 \mathrm{mcl}$ ).

The metathorax consists of a very narrow series of plates (fig. 21, $T_{3}, P_{3}$, and $p l_{3}$ ) compressed between the mesothorax and the first abdominal tergum $(I T)$. Its back plate is a single, narrow, transverse sclerite (figs. 21 and $29 \mathrm{~A}, T_{3}$ ) widening on the sides, where it carries the wings by the two wing processes (fig. $23 \mathrm{~A}, \Lambda N P$ and PNP). The 
ordinary tergal divisions seem to be entirely obliterated. The metapleurum consists of a dorsal plate (fig. $21, P l_{3}$ ) supporting the hind wing and of a ventral plate $\left(p l_{3}\right)$ carrying the hind leg. These two functions certainly identify these two plates as constituting together the metapleurum, but there is absolutely no trace of a division into an episternum and an epimerum. Once more, therefore, we have to go back to the generalized Hymenoptera to find out what has happened.
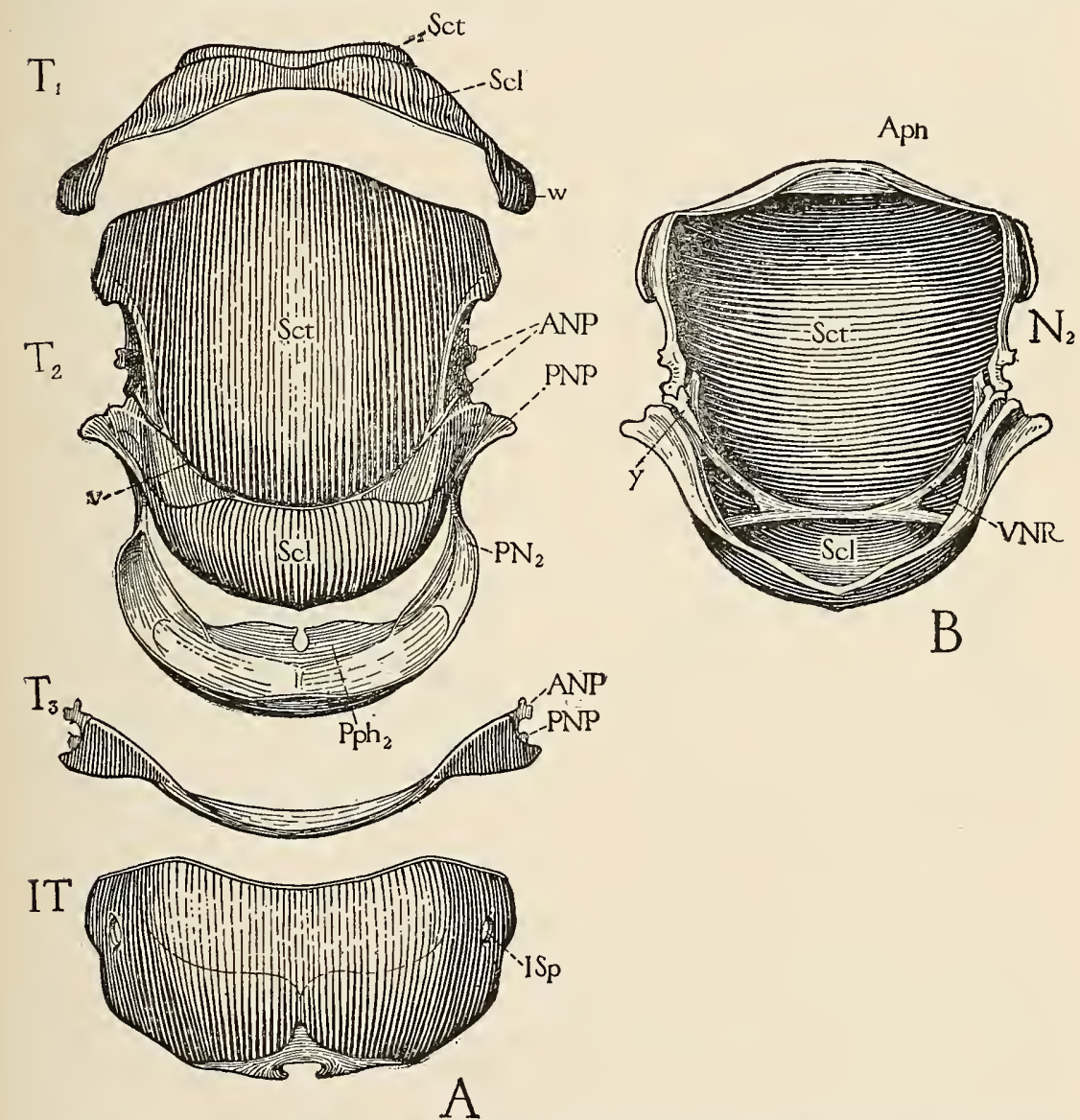

FIG: 23.-A, thoracic terga of worker separated from one another, showing protergum $\left(T_{1}\right)$, mesotergum $\left(T_{2}\right)$ and its internal postscutellim (postnotum $P N_{2}$ ) and phragma $\left(P p h_{2}\right)$, metatergnm $\left(T_{3}\right)$ and propodeum or first abdominal tergum $(I T)$; $\mathrm{B}$, ventral view of principal or notal plate of mesotergum.

The answer is simple. Sirex has a typical metapleurum consisting of an episternum and epimerum separated by a complete pleural suture. In the higher forms this suture simply disappears, and consequently the pleurum shows no traces of its original component plates. The division into a wing-bearing and a leg-bearing plate is, therefore, a purely secondary one.

None of the Hymenoptera has separate trochantinal sclerites (see fig. $4, T n)$, but, since the coxæ are articulated ventrally to knobs 
(figs. 20 and $21, z$ ) apparently belonging to the sterna, it might be supposed that the trochantins have fused with the latter plates.

The posterior part of the thoracic mass (fig. 21) consists of the first abdominal tergum (IT), which fits into the deeply concave posterior edges of the metathorax and forms the peduncle $(P d)$ that carries the rest of the abdomen (fig. 32). It consists of a single large, strongly convex sclerite (figs. 21 and $23 \mathrm{~A}, I T$ ) bearing the first abdominal spiracles laterally $(I S p)$ and having its surface divided into several areas by incomplete sutures.

Many entomologists find it difficult to believe that this plate, which so apparently belongs to the thorax, is really derived from the abdomen. But the proof is forthcoming from a number of sources. In the first place, the thorax is complete without it and the abdomen is incomplete withont it, the latter having otherwise only nine segments. Again, if the plate is reckoned as a part of the thorax we

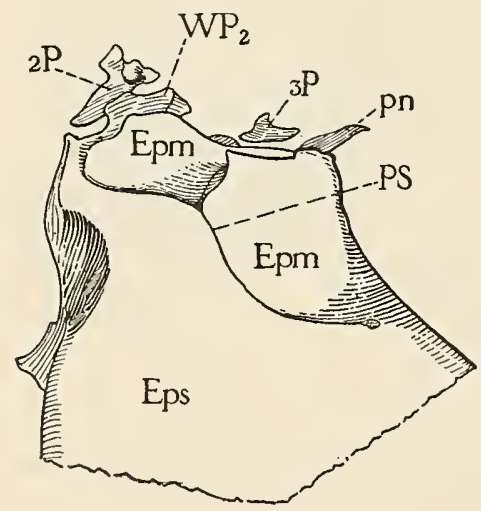

A

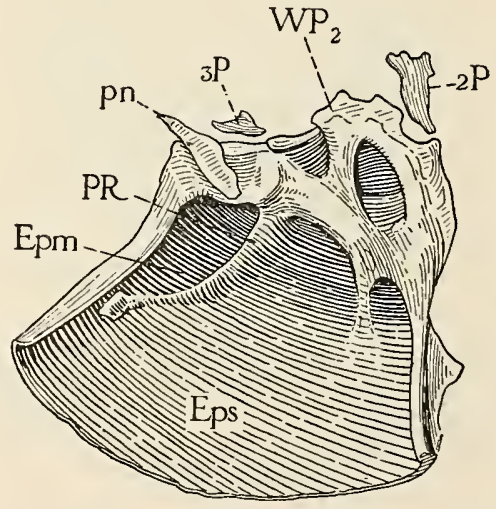

B

Fig. 24.-A, upper part of left mesopleurum of worker, external; B, inner view of same.

should have the anomaly of a thorax with three pairs of spiraclesthere being the normal two on each side situated, as they always are, between the true thoracic segments. Furthermore, comparative anatony shows us that in some of the sawflies (Tenthredinida) the first abdominal tergum, while separated by a wide membranous space from the second, is not at all incorporated into the thorax. In a horntail such as Sirex (Siricidx) the entire first abdominal segment is fused to the posterior edge of the metathorax and is only loosely joined to the next abdominal segment by membrane. This insect affords, therefore, a most complete demonstration of the transference of this segment from the rest of the abdomen to the thorax. Finally, we have absolute proof of its abdominal origin based on a knowledge of derelopment, for it has been shown by Packard from a study of the bumblebee that the first abdominal segment of the larva is transferred during the pupal metamorphosis to the thorax and forms the 
part under discission. We hence see that not only the first abdominal tergum but the entire segment has undergone transposition, though the ventral part has disappeared in all the higher families. This transferred part has been named both the median segment and the propodeum by writers who recognize it as belonging to the abdomen and not to the thorax.

The names current among systematists for the back plates of Hymenoptera afford an excellent example of the errors that entomologists may be led into through an ignorance of the comparative anatomy of insects. They recognize the protergum as such and then, knowing that there are yet two segments to be accounted for, they call the mesoscutum the "mesonotum," the mesoscutellum the "scutellum," the metatergum the "postscutellum" (being unaware that the true postscutellum is deeply concealed within the thorax), while the first abdominal tergum is called the metathorax. Such a nomenclature assigns both pairs of wings to the mesothorax. Too many systematists working in only one order of insects do not care whether their names are applied with anatomical consistency or not.

\section{THE WINGS AND TIIEIR ARTICLLATION.}

In the study of insects the wings always form a most interesting subject because by them insects are endowed with that most coveted function-the power of flight. It has already been stated that the wings are not primary embryonic appendages, but are secondary outgrowths of the body wall from the second and third thoracic segments. Therefore it is most probable that the early progenitors of insects were wingless, yet for millions of years back in geological time they have possessed these organs in a pretty well developed condition.

Nearly all of the insect orders have some characteristic modification of the wing-veins and their branches. None of them, however, departs nearly so far from the normal type as do the Hymenoptera, even the lowest members of this group possessing a highly specialized venation. Before beginning a study of the Hymenopteran series which leads up to the bee the student should first turn back to figure 6 (p. 22) and again familiarize himself with the generalized condition of the veins and the articular elements of the wing. By comparing, now, with this diagram the basal parts of the wing of a samfly (Itycorsia discolor, fig. $26 \mathrm{~A}$ ) it will be easy to identify the parts of the latter. Vein $C$ has two little nodules $(C, C)$ cut off from its basal end which lie free in the axillary membrane. Vein $S c$ articulates by an enlarged and contorted base $(S c)$ with the first axillary $(1 A x)$, while vein $R$ is continuous with the second $(2 A x)$. The next two veins that come to the base and unite with each other are apparently not the media and cubitus but the first and third anals ( $1 \mathrm{~A}$ and 
$3.4)$. since they are associated with the third axillary $(3.4 x)$. In this species the subcosta $\left(S_{c}\right)$ is entirely normal, but in the related horntail (Sirer flaricomis, fig. $26 \mathrm{~B}$ ) the enlarged basal part of the subcosta is almost separated from the shaft of the rein, while the latter (fig. 25.1 , $\left.S_{c}\right)$ is short and reak. A study of the renation of this wing leads us to believe that the rein which arises from the radius a short distance from its base is the cubitus $(C u)$. Therefore the basal part
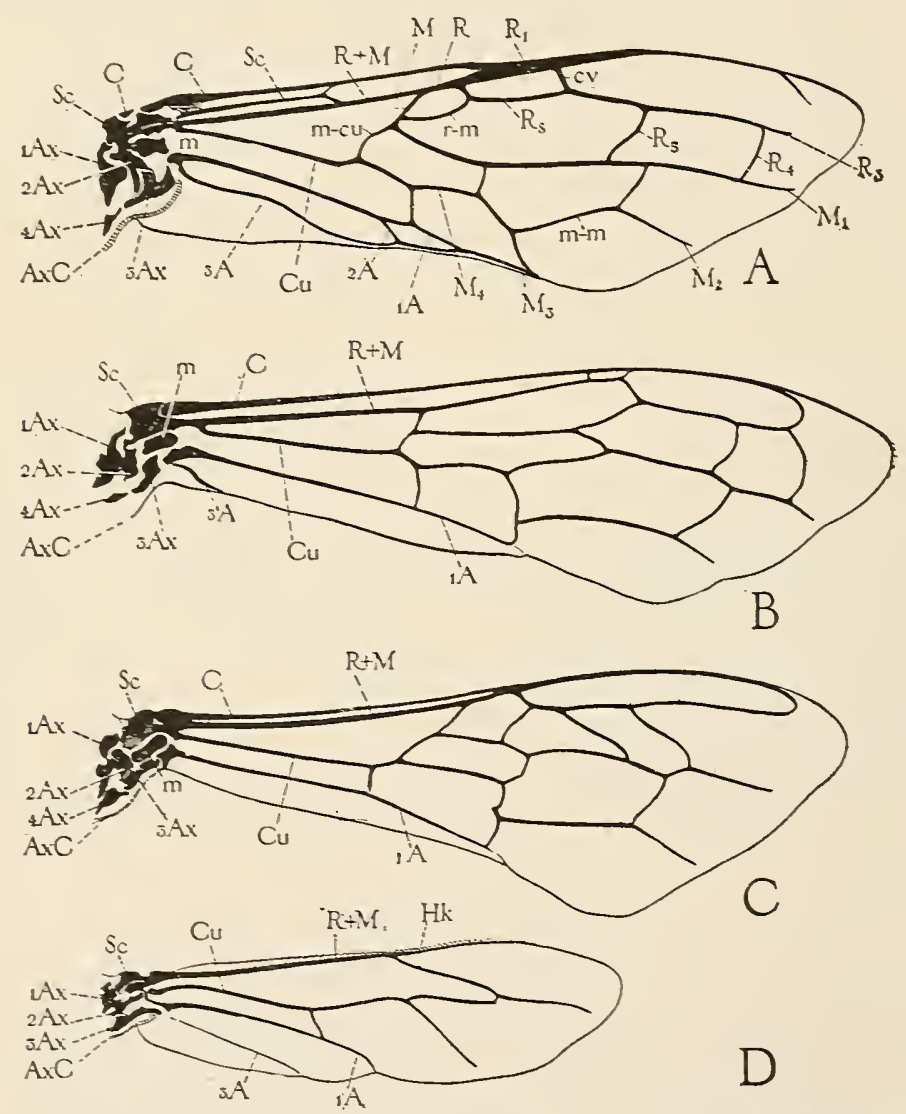

FIG. 25.- Tings of Hrmenoptera and their basal articular sclerites $(1-x-4 \cdot x): A$, Sirex flaricomis, front wing; B. Pepsis sp., front wing: C, honey bee, front wing: D, honey bee, hind wing.

of the media is either gone or is fused with the radius. Since we discorer its branches in the distal field of the wing, arising from the trunk of the radius, we conclude that the latter is the case. By this sort of reasoning we may arrive at the Comstock and Needham interpretation of the wing illustrated at -1 , fig. 25. From this it is evident that the branches of both the radius and the media hare been bent back toward the posterior margin of the wing. 

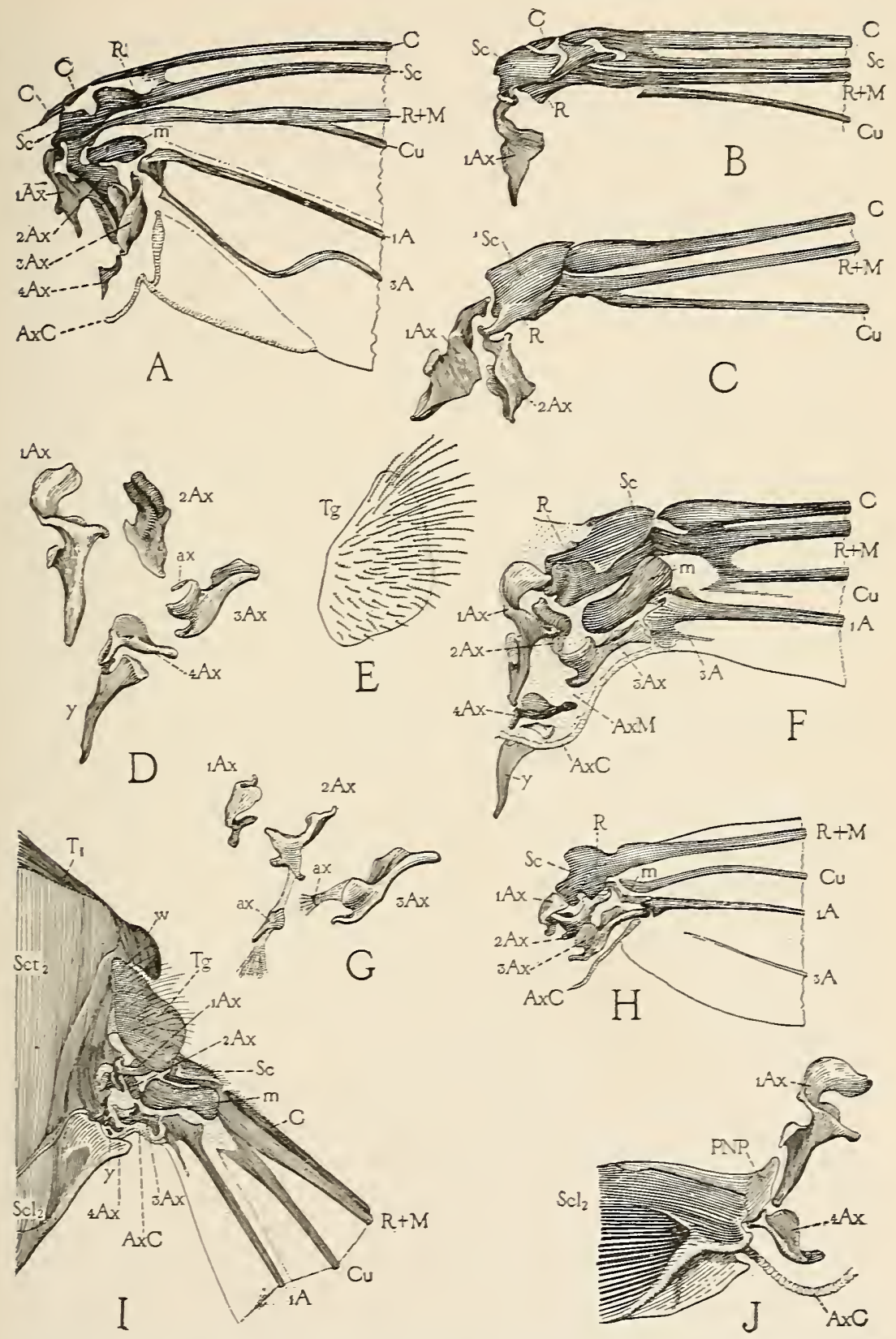

FIG. 26.-Basal elements of wings of Hrmenoptera: A, base of front wing of a samflr (Itycorsia fiscolor) showing comparatirely zeneralized arrangement of reins and axillaries: $B$, bases of anterior reins of front wing of a horntail (sirex flaricarnis,, showing detachment of base of subcostal rein $1.5 \mathrm{c})$ from its shaft; C. corresponding riew of anterior reins in front wing of a tarantula-killer (Pepsis sp.), shoming complete absence of shaft of subcosta. but presence of basal part iscl fosed with base of radius $(R)$; L axillaries of anterior wing of hones bee worker : E. tegula of worker: $F$. base of anterior wing of worker shoming absence of shaft of subcosta but presence of scale $(S C)$ derired ftom its base: $G$. axillaries of hind wing of worker. the fourth absent in bee: $H$, base of hind wing of morker, showing absence of costal and subeostal reins and fusion of bases of subcosta (sc) and radins $(R)$ into large humeral mass: I. attach-

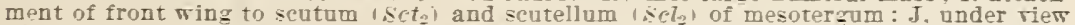
of end of mesoscutellum lsck shoming attachment of both first $(1+x)$ and foarth axillaries (4A $x)$ to posterior $\pi$ in process $(P Y P)$, an unusual connection for first axillars. 
Taking this wing of Sirex as a foundation let us proceed a little higher and examine the wing of a Pompilid, such as Pepsis (figs. $26 \mathrm{C}$ and $25 \mathrm{~B}$ ). We observed that in Sirex (fig. $26 \mathrm{~B}$ ) the basal part of vein $S c$ is almost separated from the distal shaft. In Pepsis (fig. $26 \mathrm{C}$ ) it is entirely a separate piece, to which is fused also the base of vein $R$. Moreover, the shaft of $S c$ has disappeared entirely (fig. 25, B). Thus there is at the humeral angle of the wing a large chitinons mass (fig. $26 \mathrm{C}, S c$ and $R$ ) representing the fused bases of both the subcosta and the radius, which is associated with both the first axillary $(1+x)$ and the second axillary $(2 A x)$.

If now we proceed to a study of the front wing of the bee we find that its basal characters (fig. $26 \mathrm{~F}$ ) are more similar to those of Sirex (B), while its renation (fig. $25 \mathrm{C}$ ) resembles more closely that of Pepsis (B). The subcostal seale at its base (fig. $26 \mathrm{~F}, S c$ ) is not fused with the base of the radius, but the distal part of the subcosta is gone (fig. $25 \mathrm{C}$ ). as in Pepsis. In the hind wing of the bee (fig. $26 \mathrm{H}$ ) the bases of the subcosta and radius are fused into one large humeral mass articulating with the first two axillaries $(1 A x$ and $2: x)$. The third axillary $(3 A x)$ is well developed but the fourth is absent. The venation (fig. 2.5 D) is reduced to a rery simple condition, but to one just the opposite from primitive.

The details of the axillaries in the two wings are shown by figure $26 \mathrm{D}$ and $\mathrm{G}$. The fourth $(4 \mathrm{~A} x)$ is well developed in the front wing (D) and has a large accessory sclerite $(y)$ connected with it, upon which is inserted a long slender muscle (fig. $28, c c$ ). A rery small accessory sclerite $(a x)$ occurs close to the muscle plate of the third axillary $(3+1 x)$. These are called "accessory" sclerites because they are of irregular occurrence in the wing bases of insects generally and are developed in connection with the muscle attachments. Similar ones occur in the hind wing $(\mathrm{G}, a x)$ in connection with the second $(2 A x)$ and third axillaries $(3 A x)$.

The front wing is attached to the posterior half of the side of the mesonotum. The anterior notal wing process is bilobed (figs. 22, $23 \AA, T_{2}, A N P$ ) and is carried by the scutum, while the posterior process (PNP) is carried by the scutellum and is mostly hidden beneath the anterior wing process. The two wing processes, in fact, are so close together that the first axillary articulates not only with the first but also with the second (fig. $26 \mathrm{~J}$ ). The axillary cord (fig. $26 \mathrm{~F}, A x C$ ) arises from a lobe of the scutellum orerlapperl by the lateral margin ( $\mathrm{I}$ and $\mathrm{J}, A x C$ ). In the hind wing, where the fourth axillary is absent, the third articulates directly with the posterior notal wing process of the metatergum (fig. $23 \mathrm{~A}, T_{3}, P_{\Lambda} Y^{\top}$ ).

The base of the front wing is overlapped by a large scale (fig. 26, $\mathrm{E}$ and $\mathrm{I}, T g$ ) called the tegula. It is carried by the axillary mem- 
brane, to which it is attached between the humeral angle of the wing base and the edge of the notum. The tegula are present in most insects, generally on the base of each wing, but they usually luave the form of small inconspicuous hairy pads, as shown in the diagram (fig. 6, $T g$ ). In the flies, moths, butterflies, and Hymenoptera, however, the tegula of the front wings develop into large conspicuous scales overlapping the humeral angles of the bases of these wings.

The motion of the wing in flight consists of both an up-and-down movement and a forward-and-backward movement, which two combined cause the tip of the wing to describe a figure-eight course if the insect is held stationary. Corresponding with these four movements are four sets of muscles. In the dragonflies nearly all of the wing muscles are inserted directly upon the base of the wing itself, but in other insects, excepting possibly the mayflies, the principal muscles are inserted upon the thoracic walls and move the wing secondarily. In the lower insects, such as the grasshoppers, crickets, stoneflies, net-winged flies, etc., the two wing-bearing segments are about equal in their development and each is provided with a full equipment of muscles. In these insects the wings work together by coordination of their muscles, although each pair constitutes a separate mechanism. In such insects, howerer, as the true flies and the wasps and bees the metathorax, as we have seen in the case of the bee, is greatly reduced, and what is left of it is solidly attached to the mesothorax. In the flies the hind wings are reduced to a pair of knobbed stalks having no function as organs of flight, while in the bees the hind wings, which are very small, are attached to the front wings by a series of hooklets on their anterior margins (fig. $25 \mathrm{D}, H k$ ) which grasp a posterior marginal thickening of the front wings. Moreover, when we examine the interior of the bee's thorax we find that the muscles of the metathorax are greatly reduced or partly obliterated and that the great mesothoracic muscles serve for the movement of both wings, thus assuring a perfect synchrony in their action. Hence, it is clear that the union and consolidation of the thoracic segments in the higher insects is for the purpose of unifying the action of the wings.

The muscles of flight in the bee may be very easily studied by cutting the thorax of a drone into lateral halves. The cavity of the thorax is occupied almost entirely by three great masses of muscles. One of these is longitudinal, median, and dorsal (fig. 27, $L M C \mathrm{Cl}_{2}$ ), extending from the mesoscutum $\left(S c t_{2}\right)$ and the small prephragma $(A p h)$ to the large mesothoracic postphragma $\left(P p h_{2}\right)$. A small set of muscles $\left(\mathrm{LMCl}_{3}\right)$ then connects the posterior surface of this phragma with the lower edge of the propodeum $(I T)$. On each side of the 
anterior end of this great longitudinal muscle is a thick mass of dorso-ventral fibers $(\mathrm{VMcl})$ extending from the lateral areas of the mesoscutum $\left(S c t_{2}\right)$ to the lateral parts of the mesosternum $\left(S_{2}\right)$. A contraction of the vertical muscles must depress the tergal parts, at the same time expanding the entire thorax in a longitudinal direction and stretching the longitudinal muscles. A contraction, then, of the latter muscles $(L M C l)$ restores the shape of the thorax and elevates the tergal parts. Remembering, now, that the wings are

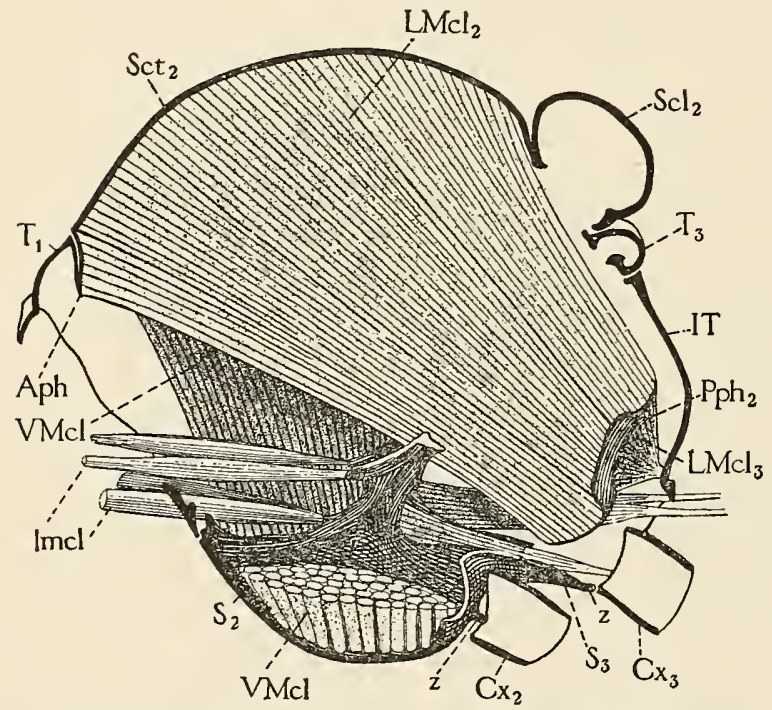

Fig. 27.-Median section through thorax of drone, showing longitudinal muscles $\left(\mathrm{LMCl}_{2}\right)$ of mesothorax going from mesotergal scutum $\left(S c t_{2}\right)$ and small anterior phragma $(A p h)$ to posterior phragma $\left(P p h_{2}\right)$ of internal postscutellum (postnotum) of same segment, also showing vertical mesothoracic muscles ( $\mathrm{V} / \mathrm{Cl}$ ) , and ventral longitudinal muscles $(7 \mathrm{mcl})$, and longitudinal muscles of metathorax $\left(\mathrm{LMcl}_{3}\right)$ going from postphragma of mesothorax $\left(P p h_{2}\right)$ to posterior edge of propodeum or first abdominal tergum $(I T)$. By alteruate contraction of dorsal longltudinal muscles and vertical muscles, roof of thorax is elevated and depressed, causing wings to beat downward and upward respectively, being supported on fulcra formed by pleural wing processes (fig. 2S, $\mathrm{IT}_{2}$ ) of side walls of thorax. supported from below upon the pleural wing processes and that each is hinged to the back by the notal wing processes, it is clear that a depression of the dorsum of the thorax must elevate the wings and that an elevation of the dorsum depresses them-the pleural wing processes acting as the fulcra. Hence, the chief up-and-down movements of the wings are produced by these great thoracic muscles acting upon the shape of the thorax as a whole and not directly upon the wings themselves. The vertical muscles are the elevators and the longitudinal the depressors.

But besides being moved up and down the wings can also, as before stated, be extended and flexed, i. e., turned forward and backward in a horizontal plane upon the pleural wing process. The muscles which accomplish these movements lie against the inner face of the pleurum (fig. 28), and each wing is provided with a separate set. The extensor muscle $(P . I / c l)$ is the most anterior and is inserted by a long neck upon the preparapterum $(2 P)$. The latter is closely 
connected with the anterior part of the base of the wing so that a contraction of the muscle turns the wing forward and at the same time depresses its anterior margin. For this reason the parapterum and the extensor muscle have been called the monator apparatus, and the muscle is known also as the pronator muscle. In some insects which fold the wings back against the body this muscle is a great deal larger than in the bee. The flexor muscle $(R M L C l$ ) consists of three parts situated upon the anterior half of the pleurum and inserted upon the third axillary $(3.4 x)$ by long tendonlike necks. These muscles are antagonistic to the extensor and by their contraction pull the wing back toward the body.

The mechanism which produces the wing motion thus seems to be a very simple one and may be summarized as follows: Each wing rests and turns upon the wing process of the pleurum (figs. 24 and 28, WP) by means of the pivotal sclerite or second axillary in its base (figs. $26 \mathrm{~F}$ and $28,2 A x)$. It is linged to the back by the first and fourth axillaries (fig. $26 \mathrm{~F}, 1 A x$ and $4 A x)$ which articulate with the anterior and posterior notal wing processes (fig. 23 $\mathrm{A}, T_{2}, A N P$ and $\left.P N P\right)$, respectively. The large vertical muscles (fig. 27, $\mathrm{VMCl}$ ) of the thorax depress the tergum, which pulls down with it the base of the wing and hence elevates the distal part-

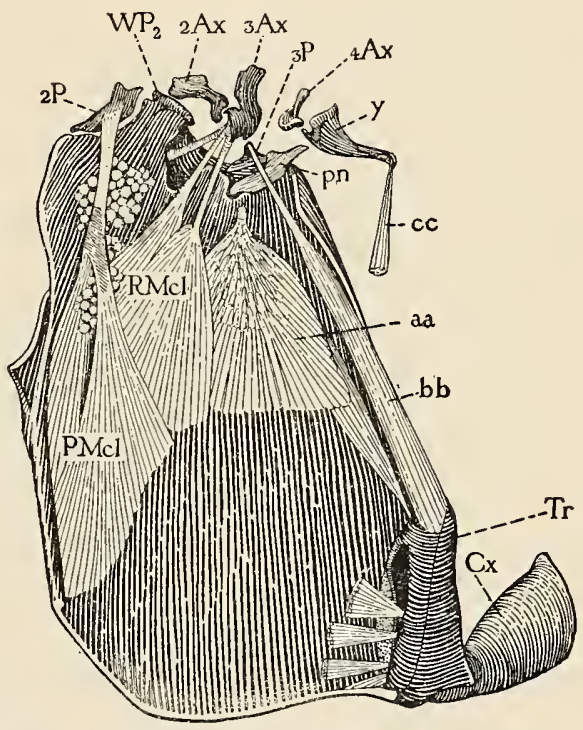

FIG. 28.-Internal view of right pleurum of mesothorax of drone, showing muscles inserted upon parapteral plates $\left(2 P\right.$ and $\left.3 P^{\prime}\right)$ and upon third axillary $(3.4 x)$. The wing rests upon wing process of pleurum $\left(W P_{2}\right)$ by second axillary $(2.4 x)$; it is turned forward and downward by the pronator muscle $(P M C l)$, inserted upon anterior parapterum (2P) which is attached to costal head of wing, and is turned back toward body by flexor muscle $(R M I C l)$ inserted upon third axillary $(3.4 x)$.

the fulcrum being the pleural wing process. The dorsal longitudinal muscle $(L M C l)$ restores the shape of the thorax, elevates the tergum, and consequently depresses the wing. Extension and flexion of the wing are produced by special muscles (fig. 28, $P . M c l$ and $R M L c l$ ) acting upon its base before and behind the pleiral wing process, respectively.

Besides these muscles there are several others (fig. 28) associated with the wing whose functions are less evident. MIost conspicuous of these is a muscle occupying the posterior half of the mesopleurum (aa) and inserted upon the outer end of the scutellum. This may 22181-No. $18-10-5$ 
be simply accessory to the large vertical sterno-scutal muscle (fig. 27 , $V M(c)$. Another is a long slender muscle (bb) attached to the upper end of the mesocoxa and inserted upon the postparapterum $(3 P)$. This is sometimes termed the coxo-axillamy muscle. A third $(c c)$ is inserted upon the tip of the accessory sclerite $(y)$ of the fourth axillary and is attached to the lateral arm of the large entosternum of the mesothorax and metathorax.

\section{THE LEGS.}

The legs of the honey bee are highly modified for several special purposes besides that of walking, but they are so well known and have been so often described that it will not be necessary to devote much space to them here.

The front legs (fig. $29 \mathrm{~A}$ ) have a structure formed by the adjoining ends of the tibia and the first tarsal joint, which is called, on account of its use, the antenna cleaner. It consists (fig. $29 \mathrm{C}$ ) of a semicircular notch $(d d)$ in the base of the first tarsal joint (1Tar) provided with a comblike row of bristles. A specially modified, flat, movable spur $(e e)$, shown in ventral view at $B$, is so situated on the end of the tibia that it closes over the notch when the tarsus is bent toward the tibia. By grasping an antenna between the notch and the spur and drawing it through the inclosure the bee is able to remore from this sensitive appendage any pollen or particles of dirt that may be adhering to it.

The middle legs (fig. $29 \mathrm{D}$ ) present no special modifications of any importance. It will be observed, however, that they, as well as the other legs ( $A$ and $F)$, have the first joint of the tarsus (1Tar) very greatly enlarged.

The hind legs of all three forms, the worker (F), the queen (E), and the drone (H), have both the tibia and the large basal segment of the tarsus very much flattened. In the queen and drone there seems to be no special use made of these parts, but in the worker each of these two segments is modified into a very important organ. The outer surface of the tibia ( $F, T Z$ ) is fringed on each edge by a row of long curved hairs. These constitute a sort of basket $(C Z)$ in which the pollen collected from flowers is carried to the hive. The structures are known as the pollem bustects, or corbicula. The inner surface of the large, flat, basal segment of the tarsus $(1 T a r)$ is provicled with sereral rows of short stiff spines $(G)$ forming a brush by means of which the bee gathers the pollen from its body, since it often becomes corered with this dust from the flowers it visits for the purpose of getting nectar. When a sufficient amount is accumulated on the brushes it is scraped off from each orer the edge of the tibia of the opposite hind leg and is thus stored in the pollen baskets. Hence the worker often flies back to the hive with a great mass of 

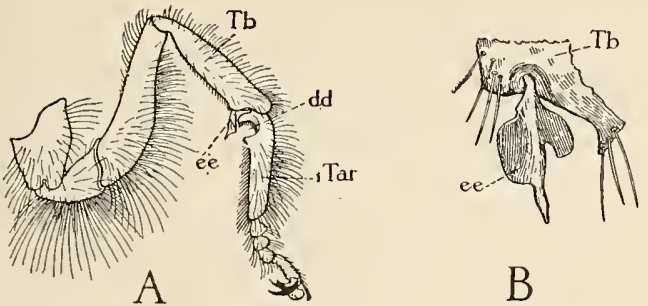

B
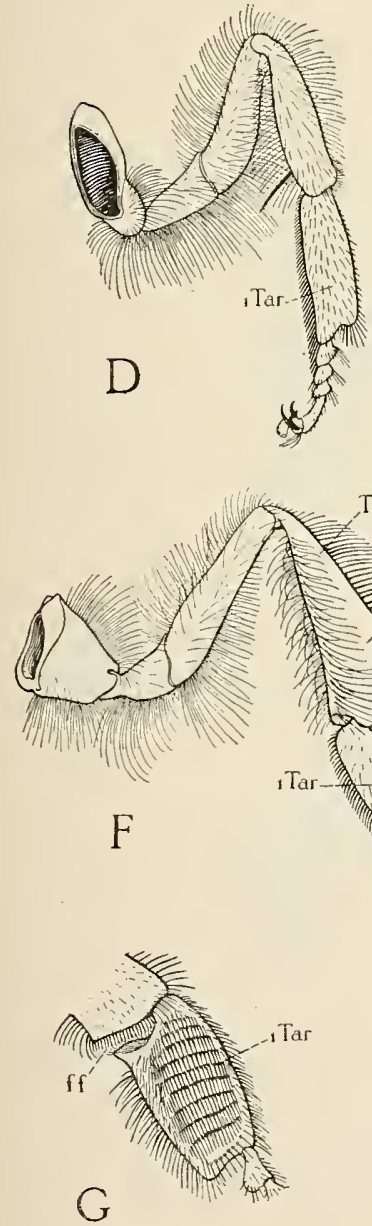

$\mathrm{Tb}$

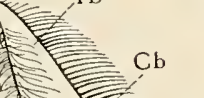

Cx
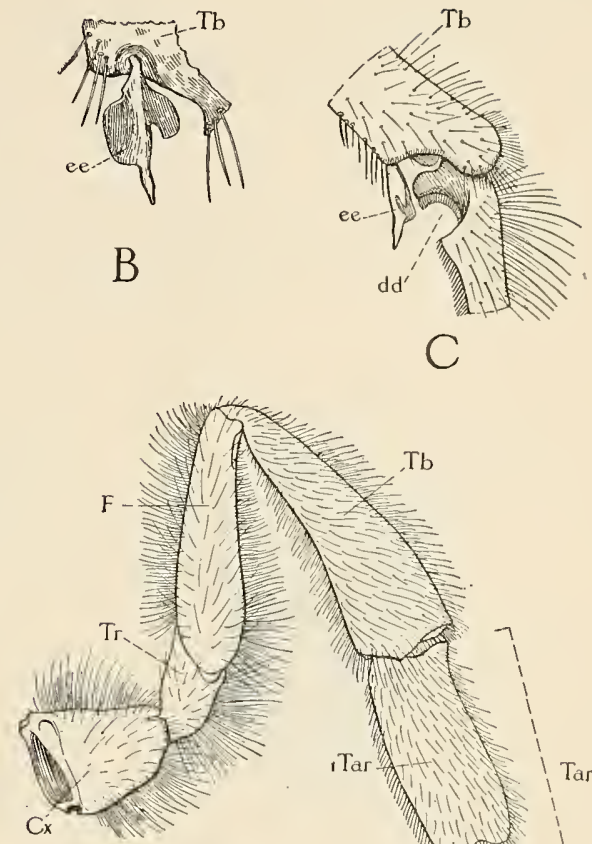

C
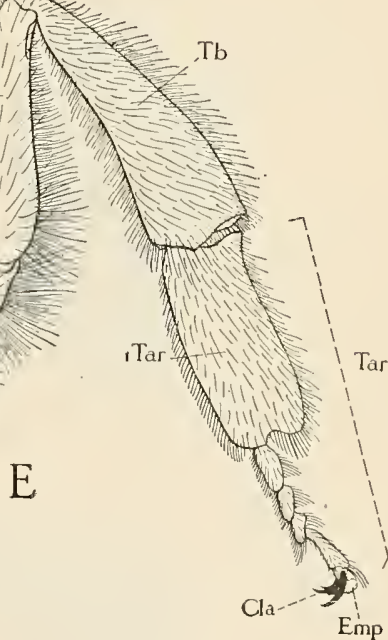

F'IG. 29.-A, left front leg of worker, anterior view, showing position of notch $(d l l)$ of antenna cleaner on base of first tarsal joint (1Tar) and of closing spine ( $c c$ ) on end of libia $(T b)$; $\mathrm{B}$, spine of antenna cleaner $(e c)$ in flat view; $\mathrm{C}$, details of antenn: cleaner; D, left middle leg of worker, anterior view; E, left hind leg of queen, anterior or outer view; F, left hind leg of worker, anterior or onter view, showing the pollen basket $(C U)$ on outer surface of tibia $(T U)$; G, inner view of first tarsal joint of hind leg of worker showing rows of pollen-gathering hairs and the so-called "wax shear's" (ff) ; H, left hind leg of drone, anterior or outer view. 
pollen adhering to each of its hind legs. The pollen baskets are also made use of for carrying propolis.

Between the ends of the hind tibia $(T b)$ and the first tarsal joint $(1 T a r)$ is a sort of pincerlike cleft ( $F$ and $G, f i$ ) guarded by a row of short spines on the tibial edge. This is popularly known as the "wax shears" and it is supposed to be used for picking the plates of wax out of the wax pockets of the abdominal segments. The writer, however, has watched bees take the wax from their abdomen and in these observations they always poked the wax plates loose
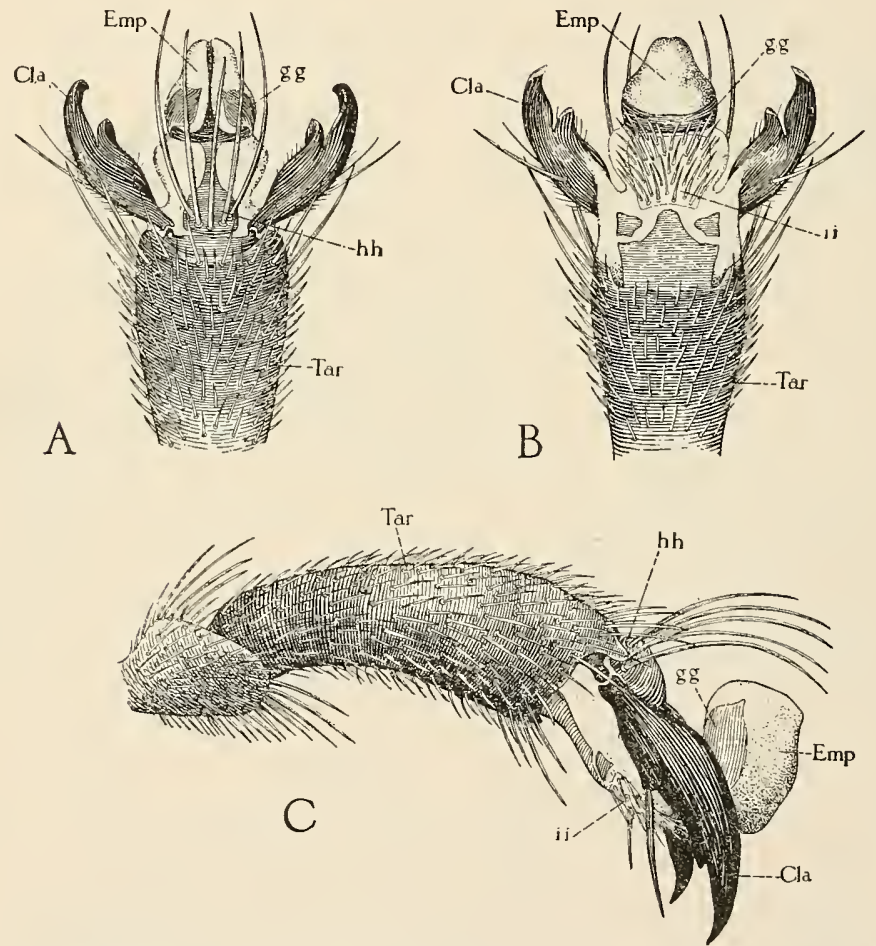

Fig. 30.-A, dorsal view of end of last tarsal joint of first foot ( $T a r)$, the claws $(C l a)$, and empodium ( $E m p)$ of worker; 1), rentral view of same; C, lateral view of same, showing empodium in ordinary position when not in use.

with the ordinary hairs or spines of the tibie or tarsi and then by means of the feet passed them forward beneath the body to the mandibles.

The last tarsal joint of each leg bear's a pair of claws (E, Cla) and a single median empodium (Emp). Each one of the claws is bilobed, consisting of a long tapering onter point and a smaller inner one (figs. 30 and 31). The claws of the worker (fig. $31 \mathrm{~A}$ ) and the queen (B) are only slightly different in details of outline, although the claws of the queen are much greater in size than those of the 
worker, but the drone's claws (C) are large and very strikingly different in shape from those of either the worker or the queen.

The empodium (fig. $30 \mathrm{~A}, \mathrm{~B}$, and C, Emp) consists of a terminal iobe bent upward between the claws (C) and deeply cleft on its dorsal surface $(A)$, and of a thick basal stalk whose walls contain a number of chitinous plates. One of these plates is dorsal ( $A$ and $\mathrm{C}, h h$ ) and bears five very long, thick, curved hairs projecting posteriorly over the terminal lobe, while a ventral plate $(B$ and $C, i i)$ is provided with numerous short thick spines. A third plate $(\mathrm{A}, \mathrm{B}$, and $\mathrm{C}, g g$ ) almost encircles the front of the terminal lobe, its upper ends reaching to the lips of the cleft.

When the bee walks on any ordinary surface it uses only its claws for maintaining a foothold, but when it finds itself on a smooth, slippery surface like glass the claws are of no avail and the empodia are provided for such emergencies as this. The terminal lobe is pressed down against the smooth surface and its lateral halves are flattened out and adhere by a sticky liquid excreted upon them by
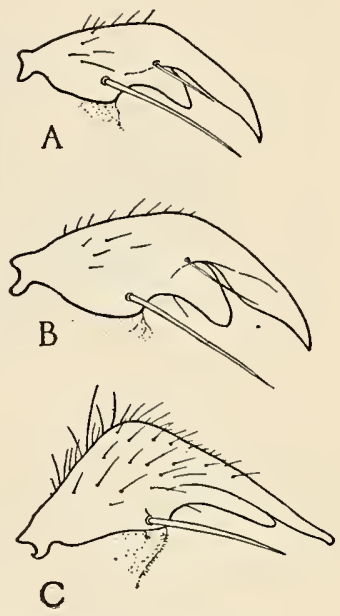

FIG. 31.-A, onter view of hind claw of worker; $\mathrm{s}$. same of queen; $C$, same of drone.

glands said to be situated in front of them. On the relaxation of the muscle that flattens the empodial lobes the latter spring back into their original position by the elasticity of the chitinous band $(g g)$ in their walls.

\section{THE ABDOIMEN, WAX GLANDS, AND STING.}

The abdomen of the worker and queen appears to consist of six segments (figs. 1, 32, 33, II-TII), but it must be remembered that, as has already been explained, the thoracic division of the body in the Hymenoptera includes one segment, the propodeum or median segment, which really belongs to the abdomen and is its true first segment according to the arrangement in all other insects. Hence, counting the propodeum (figs. 21 and $32, I T$ ) as the first, we find seven exposed abdominal segments in the worker and queen and nine in the drone. Each one except the first consists of a tergum $(T)$ and a sternum $(S)$, the former reaching far down on the side of the segment, where it carries the spiracle $(S p)$ and overlaps the edge of the sternum. The two plates of the last or seventh segment in the worker and queen are separated by a cleft on each side, and if they are spread apart it is seen that the tip of the abdomen 
incloses a cavity which lodges the sting and its accessory parts. The end of the abdomen of the male (fig. $56 \mathrm{D}$ ) is quite different from that of the female, while in it parts at least of nine segments are

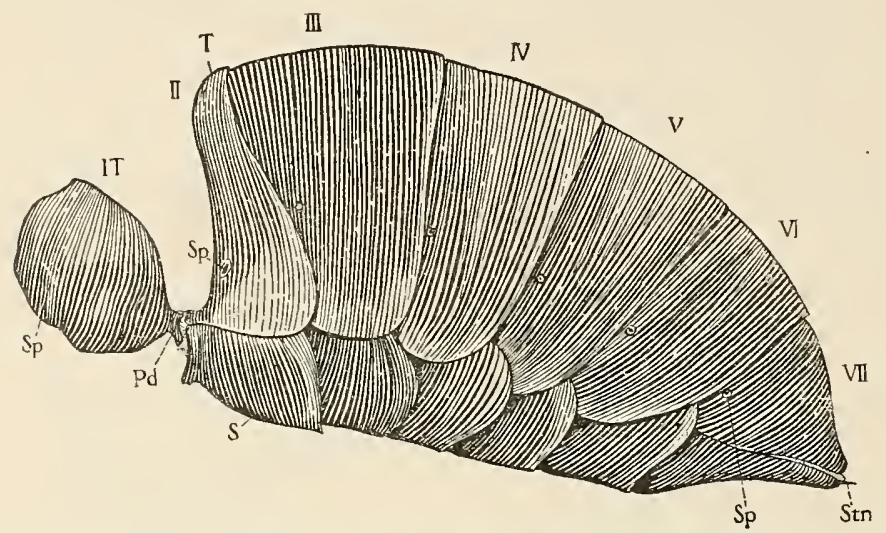

Fig. 32.-Lateral view of abdomen of worker, showing the propodeum (IT) as a part of the abdomen, of which it is the true first segment.

visible, the last is very much modified and is exposed only on the sides and below.

An internal view of the rentral plates and the lateral parts of the

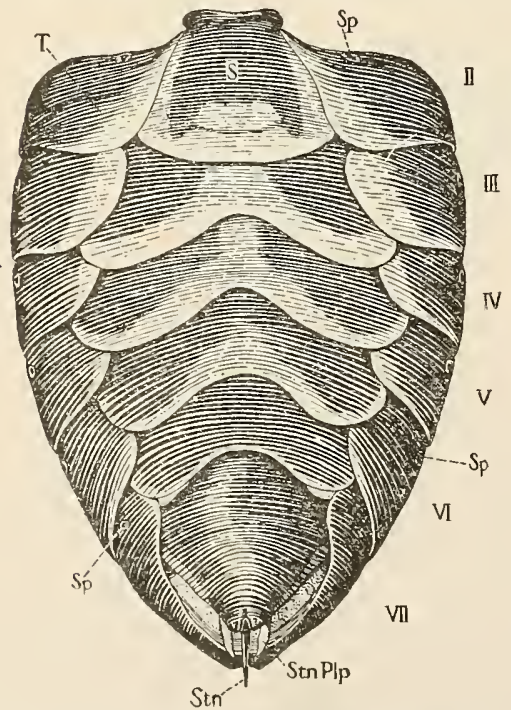

Fig. 3i.-Tentral view of abdomen of worker, slowing tip of sting (Stn) and palpuslike appendages (StnPlp) projecting from sting chamber within seventh sesment $(T I I)$.

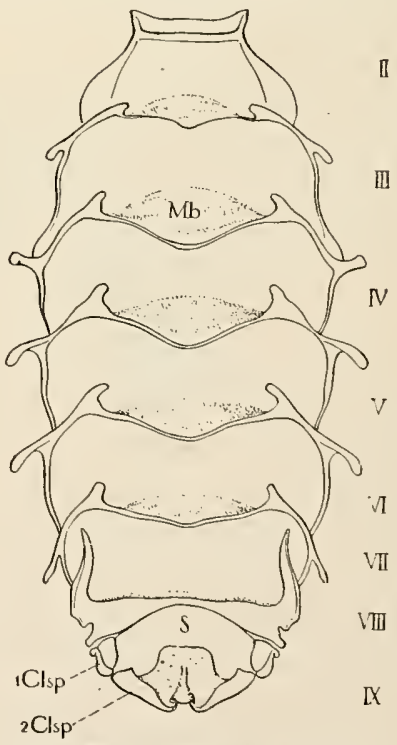

Fig. 34.-Dorsal view of abdominal sterna of drone, showing clasping appendages (1C7sp and $2 \mathrm{C} 7 \mathrm{sp}$ ) of ninth segment.

terga in the worker is shown by figure 20, while a corresponding view of the male sterna is shown by figure 34 . It will be seen that each sternum is very widely underlapped (viewed from above) by the 
one next in front of it and that the intersegmental membrane $(M / b)$ is reflected from the middle of the dorsal surface of each to the anterior edge of the following sternum. By removing an individual plate (fig. $35 \mathrm{~A}$ ) this is more easily shown. It is also clearly seen that the transverse line of attachment of the membrane (MV) divides the sternum into a posterior part $(R d)$, which is merely a prolonged reduplication underlapping the following sternum, and into an anterior part underlapped by the preceding stemum. The posterior half is, hence, purely external while the anterior half forms the true rentral wall of the segment, its dorsal face being internal and its ventral face external. The anterior part is also very smooth and shiny and somewhat bilobed and for this reason it is sometimes called the "mirrors." Its elge is bounded by a thickened ridge giving off a short apodeme $(\alpha p)$ on each side. The mirrors of the last four sterna are also, and more appropriately, called the wax plates because the wax is formed by a layer of cells lying over them. It accumulates on the ventral side in the pocket between the wax plates and the posterior underlapping prolongation of the preceding sternum. Wax is formed only on the last four visible segments, i. e., on segments IV-VII, inclusive.

In studying any part of the body wall of an insect it must always be borne in mind that the chitin is originally simply an external cuticular layer of a true celhular skin or epidermis (erroneously called "hypodermis" in insects), but that in the adult stage the latter almost everywhere disappears as a distinct epithelinm. Thus the chitin comes to be itself practically the entire body wall, the cell layer being reduced to a very inconspicuous membrane. However, in certain places the epithelium may be developed for special purposes. This is the case with that over the wax plates which forms a thick layer of cells that secrete the wax and constitute the so-called wax glands. The wax is first secreted in a liquid condition and is extruded through minute pores in the wax plates of the sterna, hardening on their under surfaces into the little plates of solid wax with which every bee keeper is acquainted.

The secretion of the wax has been studied by Dreyling (1903), who made histological sections throngh the glands at different times in the life of the bee. He found that in young, freshly emerged workers the epidermis of the wax plates consists of a simple layer of ordinary epithelial cells. As the activities of the bee increase, however, these cells elongate while clear spaces appear between them and, when the highest development is reached, the epithelium consists of a thick layer of very long cells with liquid wax stored in the spaces between them. In old age most of the cells become small again and in those bees that live over the winter the epithelium degenerates to a simple sheet of nucleated plasma showing no cell boundaries. It is thus evident that the secretion of wax is best performed during the prime 
of life, which in bees is at about 17 days of age or before, and that old bees can only gather honey and pollen. Bees do not normally secrete wax while performing the other more ordinary duties of their iife. When comb is needed a large number of young bees or bees that have not passed their prime hang together in vertical sheets or festoons within the hive and are fed an abundance of honey. After about twenty-four hours they begin to construct comb. During this time the wax is excreted through the wax plates and accumulates in

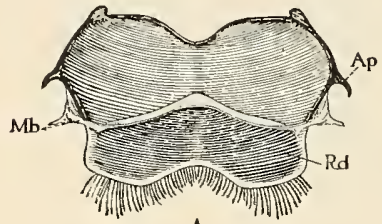

A

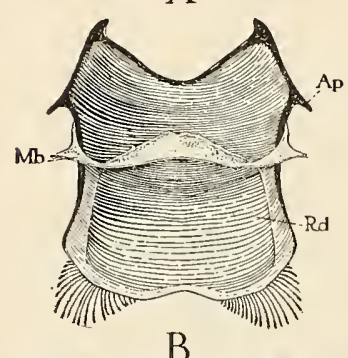

B

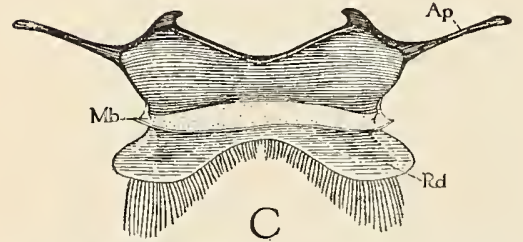

Fig. 35.-Dorsal surface of sixth abdominal sternum : A, worker : $\mathbf{B}$, queen ; C. drome: showing division of plate by line of attachment of intersognental membrane $(M b)$ into anterior part with polished internal surface, in worknr boaring wax glands, and into large posterior extrrnal part $(R d)$ nnderlapping antrior late of succeeding sternum.

production and egg laying. In the female these segments are entirely concealed within the seventh, but, in the male, parts of both the eighth and ninth segments are visible externally.

The seventh segment of the drone (counting the propodeum as the first) is the last normal segment, i. e., the last one having a complete tergum and sternum resembling those of the anterior part of the abdomen (fig. 56 D, TIIT and TIIS). Behind the seventh tergum and partly concealed within it is the eighth tergum (TIIIT) carrying the last abdominal spiracles $(S p)$. The eighth sternum is 
almost entirely concealed within the seventh. It is very narrow below, but is expanded at the upper parts of its sides (VIIIS), where it is partly risible below the eighith tergum and behind the serenth sternum. The dorsal part of the ninth segment is membranous except for a small apodeme-bearing plate on each side hidden within the eighth tergum. The ninth sternum, on the other hand, is a welldeveloped semicircular band $(I Y S)$ forming the ventral and rentrolateral parts of the ninth segment. It bears on each side two conspicuous lobes-one a small, darkly chitinized, dorsal plate (1Clsp) carrying a large bunch of long hairs, the other a large, thin, ventral plate $(2 C 7 s p)$. Between these four appendicular lobes is ordinarily a deep cavity, which is the invaginated penis (fig. $56 \mathrm{E}$ ), but in figure D this organ is shown partly evaginated $(P e n)$. While the penis is really an external organ, the details of its structure will be described later in connection with the internal organs of reproduction. The tenth segment is entirely lacking in segmental form. The anal opening is situated in a transverse membrane beneath the eighth tergum (VIIIT), and below it is a thin chitinous plate, which may belong to the tenth segment.

In many insects the modification of the terminal segments of the males in connection with the function of copulation is much greater than in the bee. The ninth segment often forms a conspicuous enlargement called the hypopygium, which is usually provided with variously developed clasping organs in the form of appendicular plates and hooks.

The development of the external genital parts of the drone has been described by both Michaelis (1900) and Zander (1900). A small depression first appears on the under surface of the ninth segment of the larva shortly after hatching. Soon two little processes grow backward from the anterior wall of this pouch and divide each into tro. The part of the larval sternum in front of the pouch becomes the ninth sternum of the ardult, while the two processes on each side form the upper and lower appendicular lobes (the valva externa and the ratua interna of Zander). The penis at first consists of two little processes which arise between the valvæ internæ, but is eventually formed mostly from a deep invagination that grows forward between them. These four processes arising on the ventral side of the ninth segment of the male larra are certainly very suggestive of the similar ones that are formed in the same way on the same segment of the female and which derelop into the second and third gonapophyses of the sting. If they are the same morphologically we must homologize the two clasping lobes of the ninth sternum in the male with the two gonapophyses of this segment in the female. Zander (1900) argues against such a conchusion on the ground that the genital ponch is situated near the anterior edge of the segment in the female and 
posteriorly in the male, while the parts in the two sexes derelop later in an absolutely different manner. These arguments. however, do not seem very forcible-in the earliest stages the processes certainly look alike in the two sexes.

The sting of the bee is situated in the sting carity at the end of the abdomen, from which it can be quickly protruded when occasion demands. This sting chamber contains also the reduced and modified sclerites of the eighth. ninth, and tenth abdominal segments. In fact, the sting chamber is formed by an infolding of these three segments into the serenth. It is consequently not a part of the true interior of the body or body carity which contains the riscera, but is simply a sunken and inclosed part of the exterior, in the same sense that the oven of a stove is not a part of the real inside of the stove. Consequently the parts of the sting, thongh normally hidden from view, are really external structures.

A very gentle pull on the tip of the sting is suflicient to remove it from its chamber, but a sting thus extracted brings along with it the ninth and tenth segments, most of the eighth segment, the poison glands, and the terminal part of the alimentary canal. This is due to the fact that the inclosed segments are attached to the surrounding parts by very delicate membranes. For the same reason they so easily tear from the living bee as the latter hurriedly leares its rictim after stinging. The worker thus inflicts a temporary wound and pain at the cost of its own life. Tndoubtedly, however, nature regards the damage to the enemy as of more importance to the bee community as a whole than the loss of one or a dozen of its members. The entire stinging apparatus with a bag of poison attached is thus left sticking in the wound while the muscles, which keep on working automatically, continue to drive the sting in deeper and deeper and at the same time pump in more poison. Such a provision certainly produces much more effective results than would a bee giving a thrust here and another there with its sting and then rapidly flying away to escape from danger.

The sting itself, when extracted from its chamber, is seen to consist of a straight tapering shaft with its tip directed posteriorly and its base swollen into a bulblike enlargement. In superficial appearance the shaft appears to be solid. although we shall presently show that it is not, but the bulb is clearly hollow and is open below by a distinct median cleft. Several plates of definite shape and arrangement always remain attached to the sting and overlap its base. The entire apparatus, including the base of the large poison sac, is shown somewhat diagrammatically in side view by figure 36 . The bulb of the sting $(S h B)$ is connected with the lateral plates by two arms which curve ontward and upward from its base. (Only the left side is shown in the figure.) Between these arms the two poison glands 
( $P s n S c$ and $B G l$ ) open into the anterior end of the bulb. From the posterior ends of the plates two whitish fingerlike processes (StnPlp) project backward. When the sting is retracted these lie at the sides of the shaft (figs. 33 and 37 ), but in figure 36 the sting is shown in a partly protracted position. These appendages, often called the sting palpi, undoubtedly contain sense organs of some, sort by means of which the bee can tell when her abdomen is in contact with the object upon'which she desires to use her sting.

A close examination of the sting shows that it is a much more complicated structure than it at first sight appears to be. The shaft, for example, is not a simple, solid, tapering, spearlike rod, but is a hollow organ made of three pieces which surround a central canal. One of these pieces is dorsal (fig. 36, ShS) and is the true prolongation of the bulb $(S h B)$, while the other two $(L c t)$ are ventral and slide lengthwise on tracklike ridges of the dorsal piece. Moreover, each basal arm of the sting is double, consisting of a dorsal or posterior piece $(S h A)$, which is likewise a prolongation of the bulb, and a ventral or anterior piece $(L c t)$, which is continuous with the ventral rod of the shaft on the same side. Hence the sting may be analyzed into three elements, which

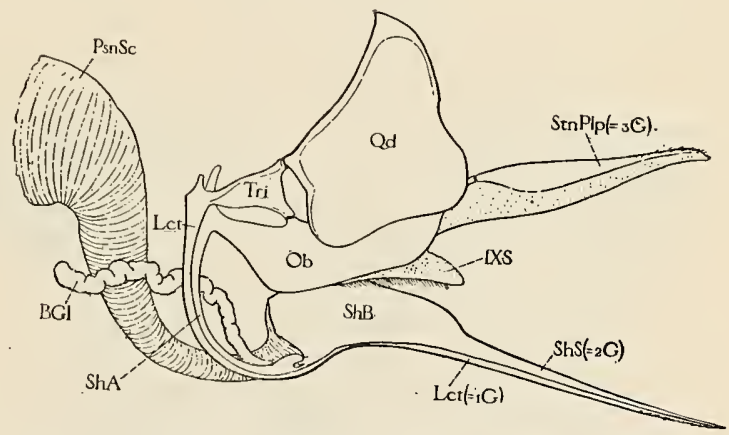

FIG. 36.-Semidiagrammatic riew of left side of sting of worker, accessory plates $(T r i, O b, Q d)$, sting palpus (StnPlp), alkaline poison gland $(B G l)$, and base of large poison sac $\left(I^{\prime} s n S c\right)$ of acid gland.

are characterized as follows: The dorsal piece, known as the sheath, consists of a prominent basal swelling or bulb (ShB) containing a large cavity, of a terminal tapering shaft $(S h S)$, and of two curved basal arms (ShA). The ventral part consists of two long slender rods, called the lancets or darts (Lct), which slide freely upon two tracks on the rentral edges of the sheath and diverge upon continuations of these tracks along the basal arms of the latter $(S h A)$. The bulb is hollow, containing a large cavity formed by invagination from below, where it is open to the exterior by a lengthwise cleft. This cavity continues also through the entire length of the shaft of the sting as a channel inclosed between the dorsal sheath and the latero-ventral lancets. This channel, as will be explained later, is the poison canal of the sting.

Each arm of the sheath (ShA) is supported at its end farthest from the bulb by an oblong plate (fig. 36, Ob), which normally over- 
laps the side of the bulb, and which carries distally the palpi of the sting $(S t n P l p)$. Each lancet is attached at its base to a triangular plate (Tri) which lies latero-dorsad to the base of the oblong plate and articulates with a knob on the dorsal edge of the latter by its rentral posterior angle. By its dorsal posterior angle the triangular plate is articulated to a much larger quadrate plate $(Q d)$ which overlaps the distal half of the oblong plate. A thick membranous lobe $(I T S)$, concave below, where it is thickly set with long hairs, overlaps the bulb of the sting and is attached on each side to the edges of the oblong plates. All of these parts are shown flattened out

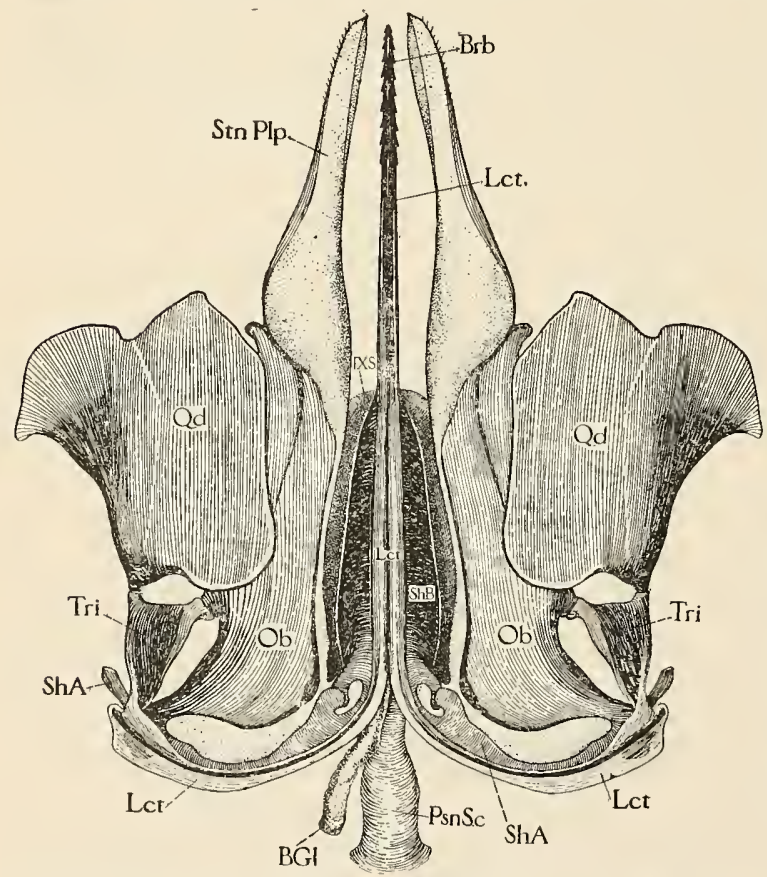

Fig. $3 \bar{i}$.-Ventral riew of sting of worker and accessory parts, flattencd out. in rentral view by figure 37 .

The presence of the two basal arms of the sheath might suggest that this part is to be regarded as made up of fused lateral halves. In this case we should have six appendicular elements, viz, the two lancets, the two halves of the sheath, and the two palpuslike organs. If now we turn back to figure 8 , showing the component parts of the oripositor of a longhorned grasshopper, we can not fail to be struck at once by the great similarity between this organ and the sting of the bee (fig. 36). The first gonapophyses $(1 G)$ of the ovipositor are identical with the lancets (Lct) of the sting, and their sliding connection, by means of longitudinal tracks, with the second gonapophyses $(2 G)$ suggests at once that the latter represent the sheath of the sting $(S h S)$. The identity is still more strongly suggested when we observe the small bulb $(S h B)$ formed by the fused bases of these gonapophyses. The third gonapophyses $(3 G)$, which inclose between them the other parts of the oripositor, represent the palpi of the sting $(S t n P 7 p)$. If. finally, we study the development of the parts of the sting we are convinced that this similarity between the sting and an ovipositor means something more than an accidental resemblance 
between two different organs-in fact we can not doubt that the sting is simply an ovipositor which, being no longer needed for egg-laying purposes, has been modified into a poison-injecting apparatus. Zander $(1899,1900)$ and others have shown that the sting of the bee arises from six little abdominal processes of the larva, two of which arise on the eighth segment and four on the ninth. Those of the first pair develop into the lancets, those of the middle pair on the ninth segment fuse to form the sheath, while those of the outer pair become the palpi. The ovipositor, it will be remembered, develops in the lower insects from two pairs of processes arising on the eighth and ninth abdominal sterna, the second pair of which very soon splits into four processes. The simultaneous appearance of six on the bee larva is simply an example of the hurrying process or acceleration that the embryos and young of most higher forms exhibit in their development.

It is only the higher members of the Hymenoptera, such as the wasps and the bees and their close relatives, that possess a true sting. The females of the lower member's have ovipositors which closely resemble those of such insects as the katydids, crickets, and cicadas, but which, at the same time, are unquestionably the same as the sting of the stinging Hymenoptera. It is said that the queen bee makes use of her sting in placing her eggs in the cells, but both the wasps and the bees deposit their eggs in cells or cavities that are large enough to admit the entire abdomen, and so they have but little use for an eggplacing instrument. But the females of the katydids and related forms like Conocephalus (fig. 8) use their ovipositors for making a slit in the bark of a twig and for pushing their eggs into this cavity. The cicada and the sawfly do the same thing, while the parasitic Hymenoptera often have extremely long and slender piercing ovipositors for inserting their eggs into the living bodies of other insects.

An examination of the sting in place within the sting chamber, as shown by figure 41, will suggest what the accessory plates represent in other less modified insects. It has already been explained that the last external segment of the female abdomen (fig. 32, VII) is the seventh. Within the dorsal part of the sting chamber is a slight suggestion of the eighth tergum (fig. $41, V I I I T$ ), which laterally is chitinized as a conspicuous plate bearing the last or eighth abdominal spiracle $(S p)$. The triangular plate (Tri), as Zander has shown by a study of its development, is a remnant of the eighth sternum, and the fact that it carries the lancet $(L c t)$ shows that even in the adult this appendage belongs to the eighth segment. The quadrate plate $(Q d)$, since it is overlapped by the spiracle plates of the eighth tergum, might appear to belong to the eighth sternum, but Zander has shown that, by its development, it is a part of the ninth tergum. In many other adult Hymenoptera, moreover, the quadrate plates are undoubtedly tergal, 
for they are sometimes connected by a bridge behind the eighth tergum. The oblong plate $(O b)$ and its stalk represent the ninth sternum, and since it carries both the arm of the sheath (ShA) and the palpus $(S t n P l)$ it still maintains its original relationships to the gonapophyses. The membranous lobe arising from between the oblong plates and overlapping the bulb of the sting (figs. 36 and 37, IXS) must belong to the median part of the ninth sternum.

The tenth segment (fig. 41, $X$ ) consists of a short, thick tube having the anus $(A n)$ at its tip. It takes no part in the formation of the sting, but is entirely inclosed in the dorsal part of the sting chamber beneath the seventh tergum.

In the accessory plates of the bee's sting we have a most excellent illustration of how the parts of a segment may become modified to meet the requirements of a special function, and also an example of how nature is ever reluctant to create any new organ, preferring rather to make over some already existing structure into something that will serve a new pupose.

There are four glands connected with the sting, two of which are known to secrete the poison, which is forced through the canal between the sheath and the lancets and ejected into the wound made by the latter. It is this poison that causes the pain and inflammation in the wound from a bee's sting, which would never result from a mere puncture. The other two glands have been described as "lubricating glands," being supposed to secrete a liquid which keeps the parts of the sting mechanism free from friction. They lie within the body cavity, one on each side against the upper edge of the quadrate plate, where they are easily seen in an extracted sting, each being a small oblong or ovate whitish cellular mass. Transverse microtome sections through this region show that each of these glands opens into a pouch of the membrane between the quadrate plate and the spiracle-bearing plate of the eighth tergum. Each gland cell communicates with this pouch by a delicate individual duct. The secretion of the glands is thus poured upon the outer surfaces of the quadrate plates and might easily run down upon the bases of the lancets and the arms of the sheath, but, for all that, the notion that it is lubricative in function is probably entirely conjectural.

The large, conspicuous poison sac (figs. 36. 37, 41, and $5 \overline{7}, P s u S c$ ) that opens by a narrow neck into the anterior end of the bulb of the sting is well known to everyone at all acquainted with bees. The poison which it contains comes from the delicate branched thread attached to its anterior end (fig. 57), a minute tube which. if traced forward a short distance from the sac, will be seen to divide into two branches, which are long and much coiled and convoluted, each terminating finally in a small oval enlargement $(A G l)$. These terminal swellings are generally regarded as the true glands and the tubes 
$(1 G 7 D)$ as their ducts, but the epithelium of the tubes appears to be of a secretory nature also, and, if it is not, it is hard to see any reason for their great length. It also does not look probable that the two little end bodies could form all the poison that fills the comparatively enormons sac.

The walls of the poison sac (fig. 38) are lined by a thick coat of laminated chitin (Int) thrown into numerons high folds. In the neck part of the sac the folds are arranged very regularly in a transverse direction and form interrupted chitinous rings, holding the neek rigidly open. The epithelium (Epth) contains nuclei $\left(. V_{u}\right)$, but the cell boundaries are rery slightly marked. There is a distinct basement membrane $(B . M)$, forming a tunica propria externally, but there are no muscle fibers of any sort present except

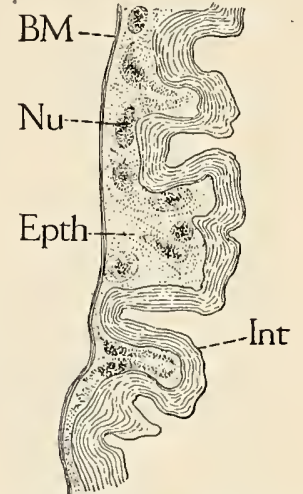

Fig. 38, - Section of small piece of wall of poison sac of sting. a few which are inserted npon the sac from some of the surrounding organs and which apparently act as suspensoria.
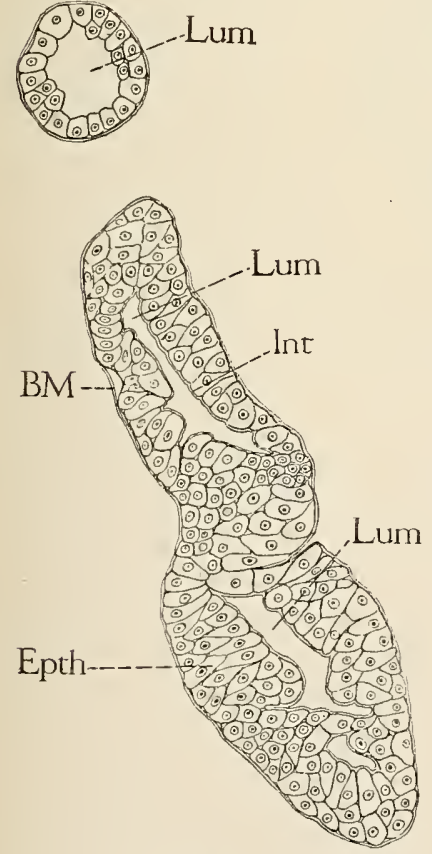

FIG. 39.--Sections of alkaline glaud of sting.

The poison found in the sac has an acid reaction and is supposed to consist principally of formic acid. Hence its gland is known as the acid gland $(A G l)$ of the sting.

The other sting gland is a short, very inconspicuous, and slightly convolnted whitish tube (figs. 36, 37, 41, and 57, $B G l$ ) opening directly into the base of the bulb ventrad to the opening of the poison sac. Its walls consist of a thick epithelium of distinct cells (fig. 39, Epth) lined with a thin chitinous intima (Int) and surrounded by a distinet basement membrane $(B . M)$, but, as in the other gland, there are no muscles present. The secretion of this gland is said to be alkaline and the gland is therefore known as the allatine gland $(B G 7)$ of the sting.

Experiments made by Carlet (1890) show that it is only the mixture of the products from the two poison glands that is fully effective in stinging properties. Carlet's experiments were made upon houseflies and blowflies. He shows (1) that flies stung by a bee die almost instantly, (2) flies artificially inoculated with the secre- 
tion of either gland alone do not die for a long time even in spite of the necessary mutilation, while (3) successive inoculations of the same fly first from one gland and then from the other produce death in a much shorter time than when inoculated from one gland alonepresumably as soon as the two liquids mix within the body.

The two secretions, one acid and the other alkaline, are poured together into the base of the sting bulb and mix within the cavity of the latter. The resulting poison is then driven through the channel in the shaft to near the tip of the latter, where it makes its exit into the wound. Since the large poison sac is not muscular, the poison is not forced through the sting by it, as is often supposed. A glance at figure 57 (see p. 135) will show that the accessory plates of the sting support several very compact sets of muscles on their inner faces. These muscles so act during the process of stinging that the triangular plates (figs. 36 and 37, Tri) turn upon their hinge-joint articulations with the oblong plates $(O b)$. By this motion of the triangular plates the attached lancets $(L c t)$ are moved back and forth along the tracks on the lower edges of the sheath and its arms (Sh+L). Each of these tracks consists of a ridge with a constricted base which dovetails into a correspondingly shaped groove on the dorsal surface of the lancet. This structure, as seen in cross sections through the shaft and bulb of the sting, is shown by fig. $40 \mathrm{~A}, \mathrm{~B}$, and $\mathrm{C}$. The lancets are thus held firmly in place, while at the same time they may slide back and forth with perfect freedom. The figures show also that all three parts of the sting are hollow, each containing a prolongation $(b c)$ of the body cavity. Between them, however, is inclosed another carity through which the poison flows. This is the poison canal $(\mathrm{PsnC})$. In the bulb (fig. $40 \mathrm{C}$ ) the body cavity is reduced to a narrow cleft $(b c)$ by the great size of the invaginated poison canal $(P s h C)$.

It will now be most convenient to describe the apparatus by means of which the poison is ejected from the sting. As before pointed out, the large poison sac can have no functions in this connection becanse its walls are entirely devoid of muscle fibers. On the other hand, there is an actual pumping apparatus situated within the bulb. This consists of two pouchlike lobes, having their concarities directed posteriorly, attached to the upper edges of the lancets (fig. $40 \mathrm{D}$ and $\left.G, V l c^{\prime}\right)$ on the anterior ends of the parts of the latter which slide within the lower edges of the bulb chamber. The lobes lie side by side within the bulb (fig. $40 \mathrm{C}, V l c^{\circ}$ ). when the lancets are in the same position, and each has an accessory lamina against its own inner wall. When the lancets are pushed backward the walls of the lobes flare apart against the poison contained in the bulb and drive this liquid lefore them into the channel of the shaft. while at the same time they suck more poison into the front of the bulb from the glands. When, 
or the other hand, the lancets are retracted the pouches collapse so that they may be drawn back throngh the poison-filled buib withont resistance, but they are ready for action again as soon as the movement of the lancets is reversed. The whole apparatus thus constitutes an actual force pump in which the lobes on the lancets alternately act as a piston and as valves. The lancets need not work together; in fact, they more often perhaps work alternately, the lobes being of such a size as to be effective either when acting together $\mathrm{or}^{\circ}$ separately.

The reader acquainted with other works on

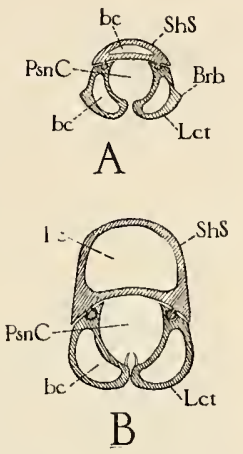

the anatomy of the bee, such as those of Cheshire (1886), Cook (1904), Cow a (1904), and Arnhart (1906), will see often repeated the statement that the poison leaves the sting both by a ventral opening between the lancets near their tips and by several lateral pores near the ends of the lancets opening from the poison canal upon lancet.
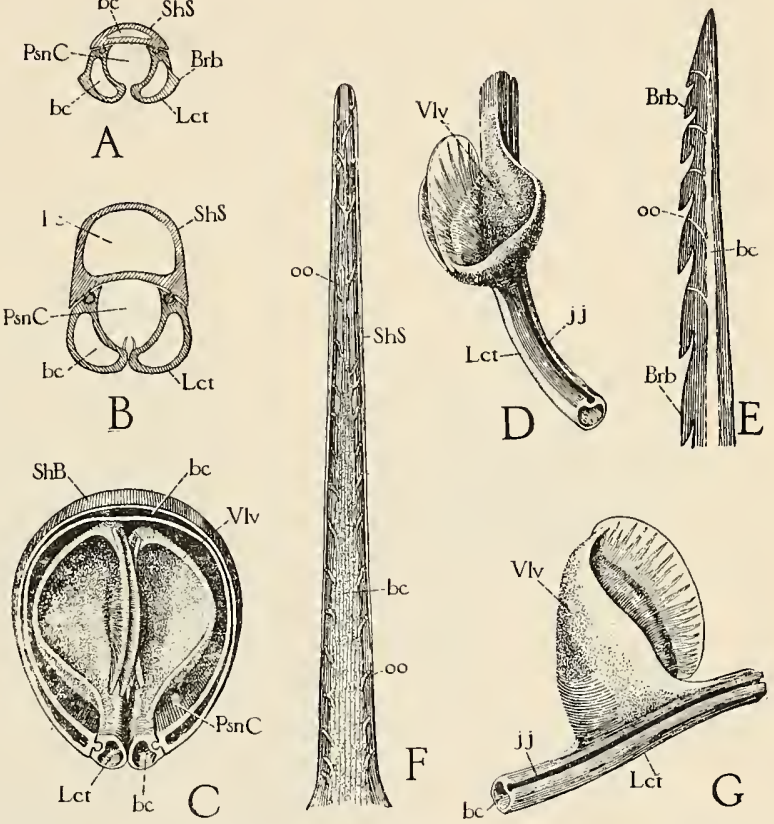

Fig. 40.-Details of sting of worker: $\downarrow$, section through tip of sting showing lancets (Let) and shaft of sheath (Shs') surrounding central poison canal (PsuC), and each containing a prolongition of the body-eavity ( $b c$ ) ; $\mathbf{B}$, section of same near base of bulb; C, scetion of sting through basal bulb, showing poison canal as large invaginated cavity $(P s n C$ ) in bulb of sheath ( $S h B$ ) containing the two valves ( Vlv) of lancets (Lct); D, part of left lancet carrying valve (Vlv), dorsal view; E, tip of lancet showing pores opening on bases of barbs (oo) coming from body-cavity $(b c)$ of lancetnot from poison canal; F, dorsal view of shaft of sheath showing lateral series of pores $(o o)$ from prolongation of body-cavity $(b c)$; $G$, lateral view of left valve and part of

the bases of the barbs. The writer, however, has never been able to observe the exit of the poison from any such lateral pores, while, on the other hand, it is very easy to watch it exude from between the lancets on the ventral side of the sting near the tip. If an excited bee is held beneath a microscope and the tip of the sting observed, the poison will be seen to accumulate in little drops near the tip on the ventral side. If, also, the bulb of an extracted sting 
be squeezed gently between a pair of forceps the poison will be seen to emerge in the same way. In fact, it can be actually squirted ont by a sudden compression when the bulb is well filled with poison, but there is never any evidence of its escape through the sides.

An examination of the end of each lancet does reveal a number of oblique pores (fig. $40 \mathrm{E}, 00$ ) which have been figured by other writers, and they certainly open on the bases of the barbs as described, but their inner ends apparently communicate with the body cavity (bc) of the lancet instead of passing clear through the lancet and opening into the poison canal. Furthermore, a paired series of exactly similar pores extends the entire length of the shaft of the sheath (fig. $40 \mathrm{~F}, o o$ ), opening on its dorsal surface from the body cavity $(b c)$. No one could possibly claim that the poison emerges

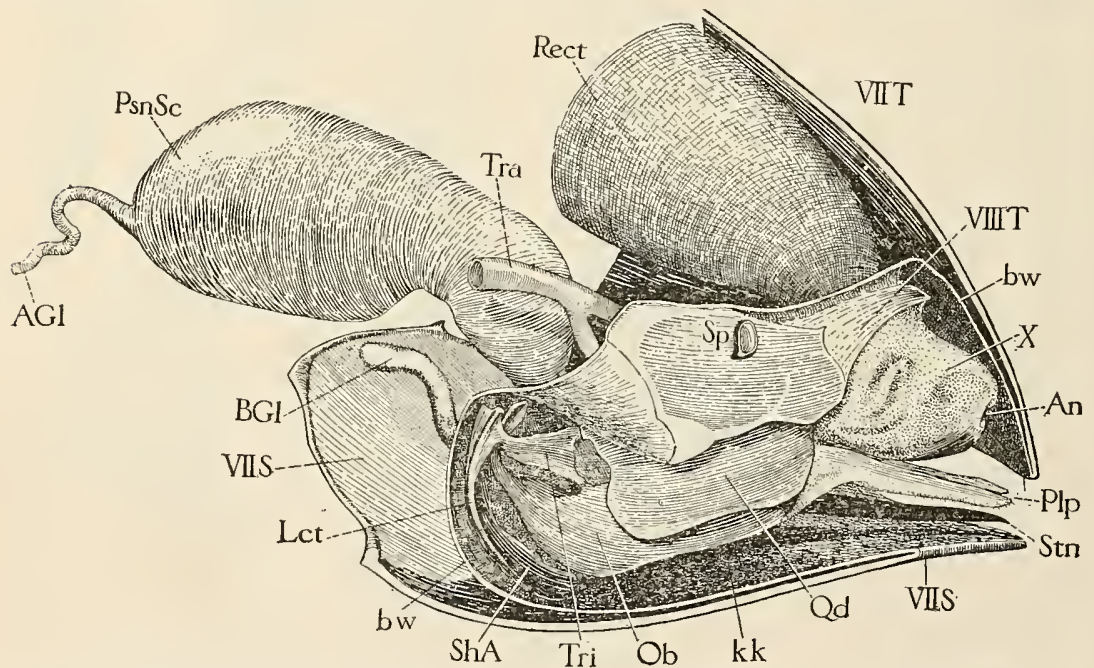

FIG. 41.-Tip of abdomen of worker with left side removed, showing right halves of seventh tergum $(\nabla I I T)$ and sternum ( $\left.T^{\top} I I S\right)$, containing the sting chamber (kk) cut open along the line $b w$, exposing the eighth tergum (IIITT), the rudimentary tenth segment $(X)$ carrying the anus $(A n)$, and the sting and accessory parts shown by fig. 36 .

also through these pores, which, rery curiously, do not appear to have been described bufore, although they are eren more conspicnons as well as more numerous than those of the lancets. The writer has not been successful in preparing histological sections of the sting which show these pores, but they probably constitute the ducts of some kind of subcuticular glands.

A cross-section through the sting a short distance in front of its tip shows that the lancets are here separated by a narrow cleft (fig. $40 \mathrm{~A}$ ), while elsewhere ( $\mathrm{B}$ and $\mathrm{C}$ ) they are contiguous. This cleft between the ends of the lancets forms the exit for the poison from the channel.

'The sting of the queen is much longer than that of the worker and is more solidly attached within the sting chamber. Its shaft is 
strongly decurved beyond the bulb. The lancets have fewer and smaller barbs than those of the worker, but the two poison glands are well developed (fig. 57, $A G l$ and $B G l$ ), while the poison sac $(P s n S c)$ is especially large.

A number of minute unicellular glands open upon the intersegmental membrane between the seventh and eighth terga of the abdomen. These are sometimes called the glands of Nassanoff, after their discoverer. Nassanoff suggested that they are sweat glands, while Zoubareff thought that they form small drops of liquid saic to be excreted by bees during flight derived from the excess of water in the newly collected nectar. Their function, however, has been much more carefully investigated by Sladen (1902), who found that they are scent organs producing a strong odor even when the part. of the back to which they are attached is removed from the rest of the abdomen. He furthermore identified this smell as the same that bees give off when a lot of then are shaken from a frame on the ground close to the front of the hive. Under such circumstances also, as in natural swarming or during the first flights in the spring or after a period of bad weather, bees are well known to produce a peculiar sound called the "joyful hum." Sladen observed that this was produced, in the case of bees shaken before the hive, by those individuals who first found the hive entrance, then by those next to them, until very soon all the others were informed of the location of the entrance and proceeded to make their way in. Also, when a swarm loses sight of its queen, those'that find her first set up this "joyful hum" and immediately the rest of the swarm is attracted to the spot. In the springtime the young bees seem to be guided in their flights by this same hum of the old ones. Sladen, however, observing the ddor emitted at the same time, thinks that this and not the sound is the real means of information, the sound being simply incidental to the special movement of the wings produced for the purpose of blowing the odor away from the body. He argues that we have no evidence of an acute sense of hearing in bees, while it is well known that they possess a delicate sense of smell located on the antennie. This argument certainly seems reasonable, and we may at least accept Sladen's theory as the best explanation of the function of the glands of Nassanoff. 


\section{THE ALIMENTARY CANAL AND ITS GLANDS.}

1. THE GENERAL PHYSIOLOGY OF DIGESTION, ASSIMILATION, AND

\section{EXCRETION.}

It is no exaggeration to say that eating is the most important thing that any animal does and that its alimentary canal is the most important organ it possesses. The entire system suffers when there is a deficiency in the food supply or an impairment in the digestive apparatus. Every other function is either subservient to or dependent upon that which furnishes nourishment to the cells. The senses of sight, smell, and taste are all more or less concerned in the acquisition of food. The muscular system enables the animal to hunt for it, to dig for it, to climb for it, or to chase living prey either on the ground, in the water, or in the air, and to kill, tear, and chew it when obtained. The blood is the servant of the stomach, for its entire function in insects is to carry the products of digestion to the body cells. The heart furnishes the motor power of the blood. 'The respiratory function is accessory to that of digestion, inasmuch as it furnishes the oxygen which unites with the waste materials ejected from the cells and renders them capable of being remored from the blood. This removal is accomplished partly by the respiratory system itself and partly by special excretory organs. Thus we see that the sense organs and the muscular system are the agents that cooperate in obtaining the raw food, the digestive tract is the kitchen of the body in which the food is prepared for use, the blood is the waiter that distributes it, while the respiratory and excretory systems are the refuse gatherers that remove waste products. The nervous system holds the controlling power over all these organs. It regulates them in the performance of their duties and coordinates their actions so that they all work together. It makes a unified organism ont of what would otherwise be simply a complex mass of variously specialized cells.

The reproductive function alone contributes nothing to the individual. In fact, the production of spermatozoa by the male and of eggs by the female and the nourishing of the embryo and the young create a demand upon all the other organs for material which is separated from the individual that produces it. But this is what the organism exists for; this is its reason for being. At least this is what it amounts to in the case of the individual, though from a wider philosophical standpoint the real truth is probably just the reverse, viz, any species exists because its individuals reproduce themselves.

The writer has already made frequent use of the word "cell," assuming that the reader is familiar with the meaning of this word as used in anatomy and physiology. The entire body of an animal or plant is made up of cells or their products. The word, however, is misleading, for a cell is not a small sac or empty space, as was at 


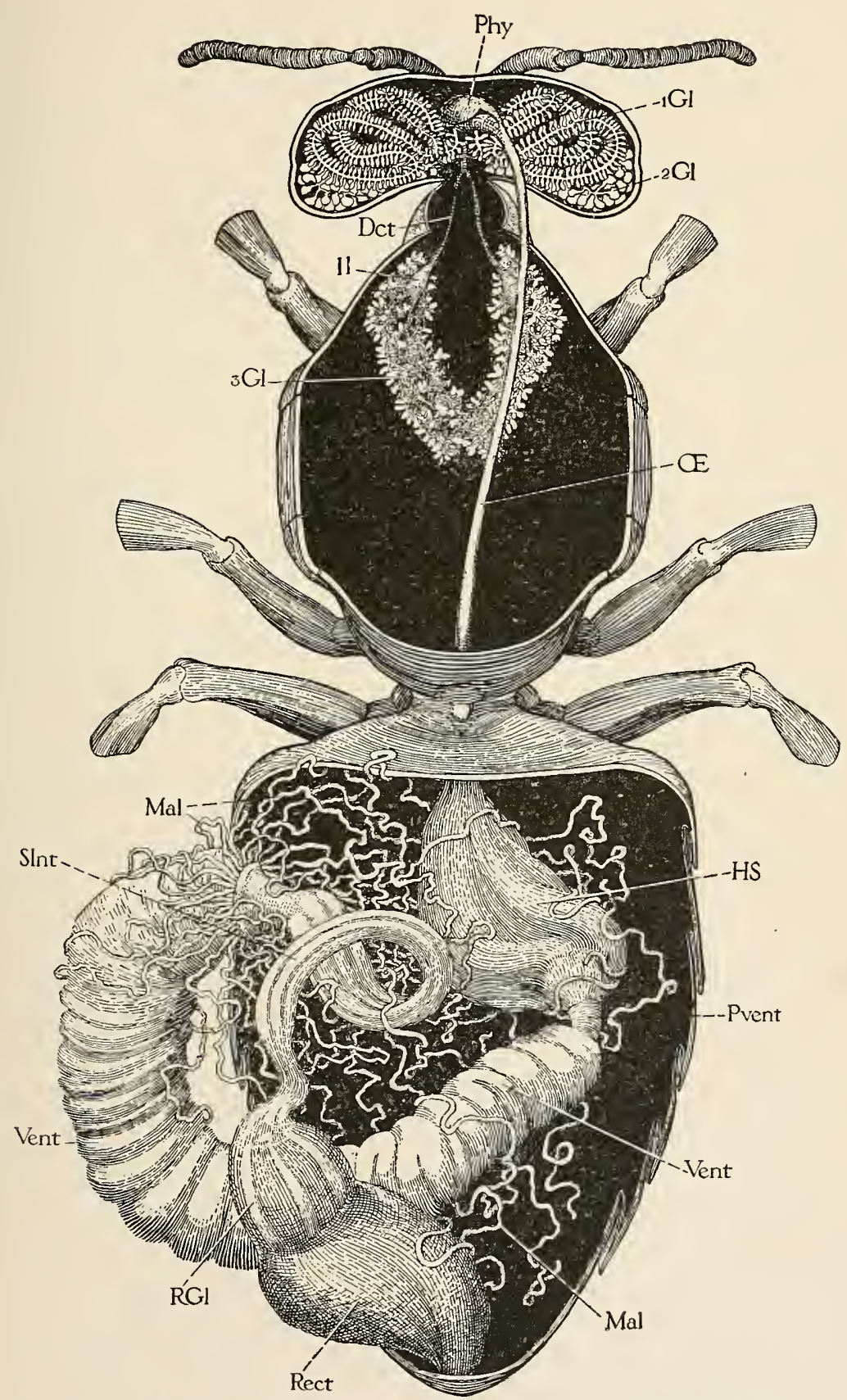

FIG. 42.-Alimentary canal of worker (Phy-Rect), together with pharyngeal glands (1Gl), and salivary glands of head $(2 G 7)$ and of thorax (3G7), as seen by cutting body open from above and pulling the ventriculus (Vent) out to left. 
first supposed from the study of plants, but is a little protoplasmic body or corpuscle, visible only under the microscope, surrounded by a membranous cell wall and containing a small internal body called the nucleus. The different cells of the body are specialized in groups to do some one particular thing-the salivary cells secrete saliva, the muscle cells contract, the excretory cells pick ont waste substances from the blood, and so on. But this specialization does not signify that each cell does not perform its own vital processes in addition to its specialty. The fact that it remains alive and works means that the complex chemical components of its body substance or protoplasm are constantly being reduced to simpler compounds which are expelled, while new protoplasm is built up from the supply of food material brought by the blood. This double process of destruction and reconstruction is known as metabolism, while its two phases, the breaking-down process and the building-up process, are known as liatabolism and anabolism, respectively.

Now, while all the cells of the body must have nourishment, none of them, except those of the alimentary canal, is capable of utilizing the raw food materials that an animal obtains in a state of nature. These materials must therefore be changed into some other form in. order that they may be assimilated by the cells. This change is called digestion.

The single cell composing the body of a Protozoan, living free in nature, digests its own food and then assimilates the products of its own digestion. But, of the cells constituting the body of any multicellular animal, only those of the alimentary canal are capable of digesting raw foodstuffs, and, moreorer, as digestion is the specialty of these cells, they have also to digest the food for all the other cells of the body.

The two most important changes that must be brought about in the natural food by digestion are those which make it soluble in the blood and which render it capable of passing through animal tissues. In the first place, the food must diffuse through the walls of the alimentary canal as a liquid which mixes with the blood, for there are no pores or openings of any sort from the alimentary canal into the body carity; and in the second place, it must pass through the walls of the cells themselves. The digestive changes result chiefly in a breaking down of the complex molecules of the raw food materials into more simple chemical substances. These are taken up by the cells and reconstructed into complex protoplasmic molecules which can not escape through the cell membrane until they are again broken down into simpler forms.

The waste products of the cells consist principally of carbon, hydrogen, and nitrogen. These are conrerted by the oxygen supplied by the respiratory system into carbon dioxid, water, and compounds of 
urea. The first, being a gas, mixes with the air in the tracheal tubes and so reaches the exterior during exhalation. Much of the water is also given off through the tracheal system in the form of vapor which exhales from the spiracles, but, since insects are covered by their hard chitinous shell, it is probable that they do not "sweat." The compounds of urea, and probably also some water, are separated from the blood by the excretory glands, called Malpighian tubules in insects, which empty their products back into the alimentary canal, whence they are discharged with the faces from the intestine.

Digestion is brought about by substances called enzymes which are contained in the various liquicts mixed with the food in the alimentary canal. These liquids are secreted by the salivary glands and by the cellular walls of the stomach.

\section{THE SALMARY GLANDS.}

The opening of the salivary duct on the base of the proboscis has already been described (see pp. 49-51). The true salivary glands, or those corresponding with the salivary glands of other insects, are arranged in two pairs, one situated within the head (figs. 19 and 42, $2 G l$ ) and the other within the thorax (fig. 42, 3Gl). The four ducts unite into one median tube, which enters the base of the labium (fig. 19, SalD) and opens upon the upper surface of the ligula (fig. $15 \mathrm{~F}$, and fig. 16, SalDO). The large and conspicuons glands lying within the anterior and rpper parts of the head and opening into the pharynx will be described later in connection with this organ. They are special pharrngeal glands in no way homologous with the salivary glands of other insects, and are by many supposed to secrete the brood food instead of a digestive liquid like saliva.

The salivary glands of the head (System No. 2 of Cheshire, postrevelral glands of Bordas) lie against the posterior walls of the cranium. In the worker each consist of a loosely arranged mass of pear-shaped follicles or acini whose individual ducts unite inregularly with one another and erentually form a common duct on each. side (figs. 19, 42, and $43 \mathrm{~F}, 2 G l$ ). Their two ducts unite with the median duct from the thoracic glands just before the bases of the mesocephalic pillars (fig. 19). In the drone these glands have a quite different appearance from those of the female, each consisting of a compact mass of very small follicles connected by minute ducts and flattened against the posterior walls of the head (fig. $43 \mathrm{~B}$ and $\mathrm{C}$, $2(r l)$. A lirge lobe of this gland in the drone extends forward on each side against the face, between the compound eye and the clypeus (fig. $10 \mathrm{C}, 2(\mathrm{rl})$ ), thus occupying the position of the large mandibular gland in the worker $(\mathrm{A}, 1 \mathrm{M}(\mathrm{d} G \mathrm{~T})$ and in the queen $(\mathrm{B}, 1 . M d G l)$. There is also a prominent triangular mass of glandular cells in the drone situated just above the ocelli (fig. $10 \mathrm{C}, 2 G l$ ) which has been 
described by Bordas (1895) as a separate gland opening by two ducts into the osophagus just behind the pharynx. The writer, however, has been utterly unable to discover any such ducts, though two suspensorial ligaments of the anterior end of the osophagus are attached to the wall of the head at the posterior ends of these glands (fig. $11 \mathrm{~B}, g$ ) and might easily be mistaken for ducts. These "postocellar glands" of Bordas, moreover, appear to be simply detached lobes of the postcerebral glands. They are prominent also in the queen (fig. $10 \mathrm{~B}, 2 G l$ ) and are represented by a few follicles in the worker.
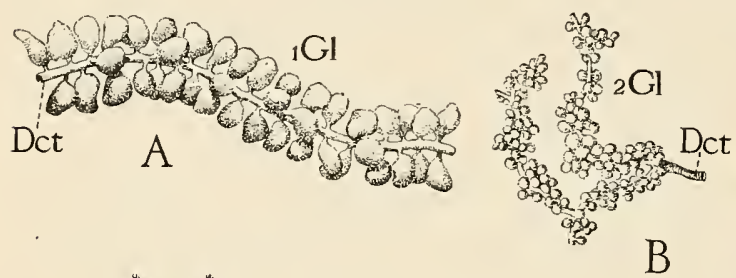
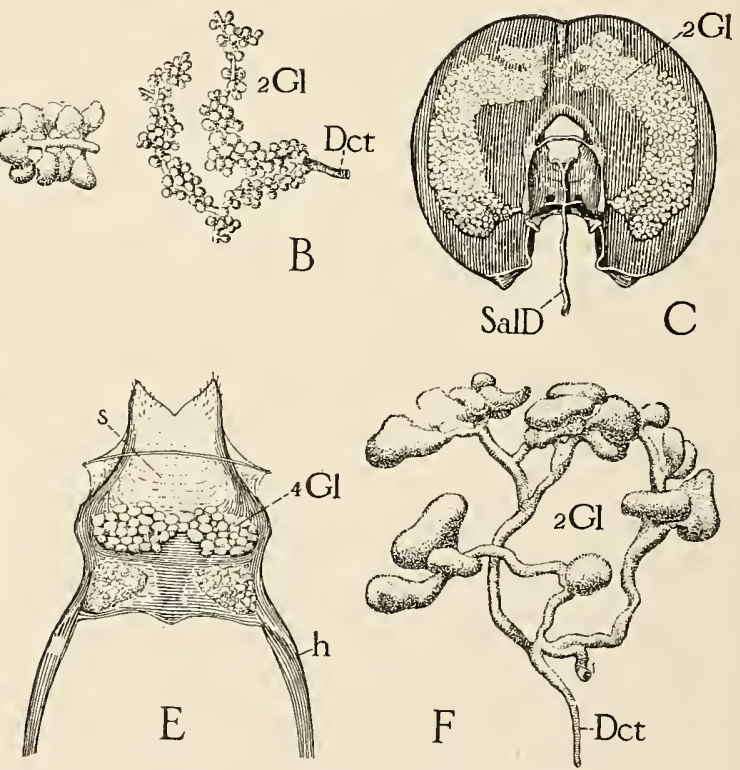

Fig. 43.-1, small piece of large lateral pharrngeal glands in head of worker; $B$, piece of postcerebral salivary glands in head of drone; C. posteerebral glands (2Gl) in normal position against posterior wall of head in drone: $D$, pharyngeal plate $(s)$ of worker, ventral view, showing bases of lateral pharyngeal glands ( $1 G l$ ) and their receptacula $(\mathrm{mm})$, and median ventral pharyngeal gland $(\mathrm{g} G l)$; E, corresponding view of pharyngeal plate of drone, showing entire absence of lateral pharyngeal glands, and greater development of small median glands $(, G l)$; F, part of postcerebral gland of worker.

Bordas describes the follicles of the postcerebral glands in the worker as hollow sacs, each having a large lumen lined with a chitinous intima. Their secretion, he says, is a thin viscid liquid, pale yellow in color and having a slightly alkaline reaction. According to Schiemenz (1883) each gland is developed as an outgrowth from the common duct of the thoracic glands.

The salivary glands of the thorax in the bee (System No. 3 of Cheshire, thoracir sulivary glands of Bordas) are the ones that correspond with the ordinary salivary glands of other insects. They are described by Schiemenz (1883) as being formed inside of the 
outer covering (tunica propria) of the first part of the larval silk glands. But it is of common occurrence in insects that the salivary glands are temporarily specialized as silk-producing organs in the larva. In the adult worker these glands lie in the ventral part of the anterior half of the thorax (fig. 42, $3 G l$ ). The two are widely separated anteriorly, but their posterior ends are contiguous. Each consists of a mass of small, many-branched, glandular tubes opening into several collecting ducts which empty into a sac near the anterior end of the gland $(l l)$. From each of these reservoirs, then, a duct (Dct) runs forward and fuses with the one from the opposite side just within the foramen magnum of the head. The common duct thus formed turns downward within the head, receiving the two ducts of the postcerebral salivary glands and then enters the base of the mentum (figs. 19 and $43 \mathrm{C}, S a l D$ ), to open as already described on the upper side of the ligula at the root of the glossa and between the bases of the two paraglossa (fig. $15 \mathrm{~F}$ and 16, SalDO). The secretion of the thoracic glands is said also to be weakly alkaline. Therefore the entire salivary fluid poured out upon the labium is alkaline, and it must be designed to act especially upon the food taken through the proboscis. This action, furthermore, on account of the location of the salivary opening, may take place before the food enters the month.

The food of the bee consists normally of pollen, nectar, and honey. The first is eaten entirely with the mandibles, while the other two are taken through the proboscis. The pollen is to the diet of the bee what meat is to ours; that is to say, it contains the proteid or nitrogencontaining ingredient of the food which is necessary to the support of any animal, and also substances comparable with fat, called in general hydrocarbons. The nectar and honey consist principally of grape sugar, fruit sugar, and cane sugar, which belong to the class of chemical substances known as carbohydrates. Now, all of these foodstuffs, except the grape and fruit sugars, have to be changed chemically by the digestive process before they can be absorbed into the blood. The pollen, which contains the proteids and hydrocarbons of the food, is taken directly into the month by means of the mandibles and apparently is not digested until it reaches the small intestine, and therefore it would seem that it is the cane sugar which must be affected by the saliva. The change, or inversion, as it is called, of cane sugar, which has a very large molecule $\left(\mathrm{C}_{12} \mathrm{H}_{22} \mathrm{O}_{11}\right)$, consists of its reduction to grape and fruit sugars which have smaller molecules $\left(\mathrm{C}_{6} \mathrm{H}_{12} \mathrm{O}_{6}\right)$. Starch $\left(\mathrm{C}_{6} \mathrm{H}_{10} \mathrm{O}_{5}\right)$ must also be reduced to simpler and more soluble compounds before it is capable of absorption. Its inversion is effected in us partly by the saliva, but starch appears to form a very inconsiderable element in the bee's diet. 


\section{3. 'THE ALIMENTARY CANAL.}

The alimentary canal is a tube which extends through the entire length of the body and, on account of being more or less coiled, it is generally considerably longer than the length of the body in insects. It has no openings of any sort into the body carity. The internal organs are packed closely about it, and the interstices are filled with the blood, there being no special arteries or veins in insects. The amount of space oceupied by the alimentary canal raries according to the amount of food it contains, and for this reason it seldom looks exactly alike in any two individuals examined.

The part of the canal immediately following the mouth forms an enlargement (fig. 42, Phy) called the phamynx. Succeeding this is a slender tube which leares the head by the foramen magnum above the small transverse tentorial bar and traverses the entire length of the thorax. This is the resopharnes $(E)$. In the anterior part of the abdomen the osophagus expands into a large thin-walled sac which is ordinarily called the crop or ingluries, but which, in the bee, is known as the honey stomach (IIS). Bchind this is a short. narrow, necklike division, with rigid walls constituting the proventriculus (Pvent). Then comes a large U-shaped part, with thick, spongy-looking walls containing numerous annular constrictions. This is the ventriculus ( $\mathrm{T}$ ent), or stomach, of the bee, frequently referred to as the "chyle stomach." Following the rentriculus is a short, narrow, coiled small intestine (SInt) having a circle of about one hundred long, greatly coiled, blind, threadlike tubes opening into its anterior end. These latter are called the Malpighiom tublutes (Mal). Functionally they do not belong to the digestive tract, since they are excretory organs, corresponding with the nephridia of other invertebrates and with the kidneys of vertebrates. Following the small intestine is the large intestine, or rectum (Rert). which is often distended by its contents into a great sac occupying a large part of the abdominal cavity. Six whitish bands on its anterior, end are called the rertal glands ( $R G 7)$. The rectum opens to the exterior through the anus, which is situated, as already described, at the end of the mdimentary tenth or last segment of the abdomen (fig. $41, A n$ ).

After this brief general surrey of the parts of the alimentary canal, we shall proceed with the description of cach in detail, and at the same time give what is known of the rôle each plays in the process of digestion. What is known, howerer, about digestion in the bee, or in any insect, for that matter, really amounts to nothing. but the views of varions writers on the subject must be discussed briefly, in order to show how little has actually been demonstrated.

The pharynx (figs. $11 \mathrm{~B}, 19$, and $42, P h y$ ) lies in the anterior part of the head close behind the clypeus, extending from the mouth 
dorsally to above the antennæ, where it turns posteriorly and contracts into the much narrower osophagus $(E)$. Attached to its walls are numerous suspensorial muscles, whose contraction must expand the pharyngeal cavity, while the latter may be contracted by the sheet of muscles surrounding its walls. In this way the pharynx is undonbtedly able to perform a sncking action, by means of which the liquid foods are taken into the mouth. Its lateral walls are strengthened by two long, chitinous rods (figs. $11 \mathrm{~B}$ and $19, h$ ), which arise from a median anterior plate in its floor (fig. 19, $s$ ). The anterior end of this plate is prolonged into two free, tapering lobes which hang down over the lower rim of the month. The plate, in the worker, and the bases of the rods are shown in ventral view, removed from the pharyngeal wall, in figure $43 \mathrm{D}$. Near where the rods join the plate are two long, chitinous pockets $(\mathrm{mm})$, opening above, which receive the ducts of the two large glands (1G7) lying within the anterior part of the head. Between these two pockets is a transverse row of cel!s ( 4 G7), which have been described by Bordas (1895) as the "sublingual glands," but this name is not appropriate in insects, for, while the gland in question may be suggestive of the sublingual salivary gland of vertebrates, it does not lie beneath the tongue or lingua of the bee. Although the pharyngeal plate lies upon the floor of the true mouth, it is not, as already explained ( $p$. 44 ), the equivalent of what is properly called the tongne, lingua, or hypopharynx in other insects-this organ being absent in most Hymenoptera. The only suggestion the writer can make, howerer, is to call this group of cells the ventral or median ventral pharyngeal gland in distinction to the large lateral glands. A comparative view of the pharyngeal plate and its accessory parts in the drone is given in figure $43 \mathrm{E}$. The plate itself $(s)$ is shorter than in the worker, and its anterior lobes are smaller. The lateral glands and their receptacula are entirely absent, but the median glands $(4 \mathrm{Gl})$ are much larger than those of the worker. Bordas says that each acinus of the latter glands in both the worker and the drone is provided with a fine, sinnons canaliculus, and that these tiny ducts open separately in two bundles on the lateral parts of the pharyngeal plate. The lateral glands are present in the queen, but are very small and rudimentary.

Especial interest attaches to the large lateral pharyngeal glands of the worker (System No. 1 of Cheshire, the supracerebral glands of Bordas), because they are regarded by many as the source of the brood food and the so-called "royal jelly," which is fed to the larra and to the adult queens and drones by the workers. Each consists of a long coiled string of small orate follicles attached to one median duct (fig. $43 \mathrm{~A}$ ) and the two are intricately packed into the anterior and upper parts of the head (figs. $10 \mathrm{~A}, 19$, and $42,1 G l$ ). Each 
ncinus consists of a solid mass of several small cells, which are penetrated by a large number of fine, chitinous ducts, arising in the neck of the acinus from the common duct of the gland. These follicular ducts can be very clearly shown by treating a part of the gland with weak caustic potash, which dissolves the protoplasm of the cells and brings out the bunch of ductules very clearly.

The fact that these glands are entirely absent in the drone and at best rudimentary in the queen shows that they must in some way be connected with the special functions of the worker. Schiemenz (188?) and Cheshire (1S86) have shown that their development in the different species of bees is in proportion to the social specialization. They vary from a group of cells opening by separate ducts upon the pharyngeal plate to the highly dereloped condition they present in the honey bee. The writer questions, however, whether these anthors did not mistake the median pharyngeal glands of these lower genera of bees for rudimentary representatives of the lateral glands. Bordas states that the former occur in all Hymenoptera, but Schiemenz and Cheshire did not seem to recognize them. The bumblebees (Bombus) hare them almost as well dereloped as the honey bee (A pis), especially the large females. In the genus Psythimes they are similar to those of Bombus but are smaller, while in such genera as Andrena and Anthophora they are rudimentary or consist of a few scattered cells. Both Schiemenz and Cheshire have thus argued strongly that these glands of the pharynx are the organs that produce the brood food. On the other hand, Schönfeld (1856) has made an equally strong plea in favor of the ventriculus as the producer of this important material. He believes that the brood food, especially royal jelly, is regurgitated chyle. Both Schönfeld and Cook (1904) fed bees in a hive some honey containing powdered charcoal and later found this in the brood food in the comb cells, thus apparently confirming its ventricular origin. However, the charcoal that got into the cells might have come from the mouth, the osophagus, or the honey stomach. It, of course, conld not have gone throngh the stomach walls and entered the pharyngeal glands, as proved by Dr. J. A. Nelson, of this Bureau, from microtome sections of bees fed on lampblack. The arguments, then, in favor of the stomach and the pharyngeal glands seem equally strong, and perhaps the truth is, as occurs in so many such cases, that both sides are right-that the brood food is a mixture of chyle from the stomach and of secretion from the pharyngeal glands.

Arnhart (1906) seems to adopt the position that the brood food is chyle which has been acidified by the addition of an acid from the glands. He states that the acid reaction of the royal jelly is due to the presence of three-fourths of 1 per cent of tartaric acid. The contents of the ventriculus, on the other hand, and for that matter 
of all the parts of the alimentary canal, are alkaline. Hence, it seems very logical to suppose that if the brood food comes from the stomach, its acid constituent is furnished by the glands in the head. But the difference between the brood food fomnd in the cells and the contents of the ventriculus is so great that it would seem as if a very substantial addition of something more than a mere preservative acid must be made to the latter.

The brood food given to the queen larve, known as royal jelly, is a gummy paste of a milky-white color when fresh, but when taken out of the cell it soon acquires a darker tone with a yellowish tint. Under the microscope it appear's to be a homogeneous, very minutely granular mass. It is very acrid and pungent to the taste, and must be strongly acid. Samples examined by the writer taken from cells containing queen larve two and four days old contained a number of fresh undigested pollen grains but no bits of hairs such as oceur in the stomach.

The possible rentricular origin of a part of the brood food and its regurgitation will be further discussed when we treat of the stomach (page 98). The writer does not advocate any personal view regarding the origin of this larval food-the fact is, there is not enough known about it to enable one to formulate any opinion worth while. We know only that the whitish paste comes out of the mouths of the workers, but we know nothing of where it is made or of how it is made. Hence we can but a wait the evidence of further investigation.

The brood food is fed to the larve by the workers and is produced in greatest abundance by the younger individuals. The larva of the queens are said to receive nothing but pure royal jelly throughont their entire developmental period, while the larva of the drones and the workers are given the pure product only during the first three days of their life. From the beginning of the fourth day on, honey is said to be mixed with the diet of the drones and workers and, in the case of the former, undigested pollen also. Moreover, the adult queens and the drones receive a certain amount of prepared food throughout their lives; if they do not get it they become weak. While they can feed themselves with honey they apparently can not eat pollen, and consequently are not able to obtain the proteid element of diet unless fed this in a predigested condition by the worker's. During egg-laying activity the queen especially demands this food, and by furnishing or withholding it the workers probably have the power of stimulating or inhibiting her production of eggs. Arnhart (1906) says that the workers feed it to weak or starved members of their own class, the material being accumulated upon the upper surface of the mentum of one bee whence it is sucked up through the proboscis by the other. All of these statements, however, concerning the feeding of the brood and the differences in the diet need to be verified. They 
are based chiefly on the work of Planta. published in 1888. Cheshire (1886) states that the stomachs of queens contain a substance which is "microscopically indistinguishable from the so-called royal jelly," scarcely a pollen grain being discoverable in it. If this is so, it would seem to prove that the queen is fed this substance by the worker, for the stomach of the latter is invariably filled with a dark-brown slime containing a vary-
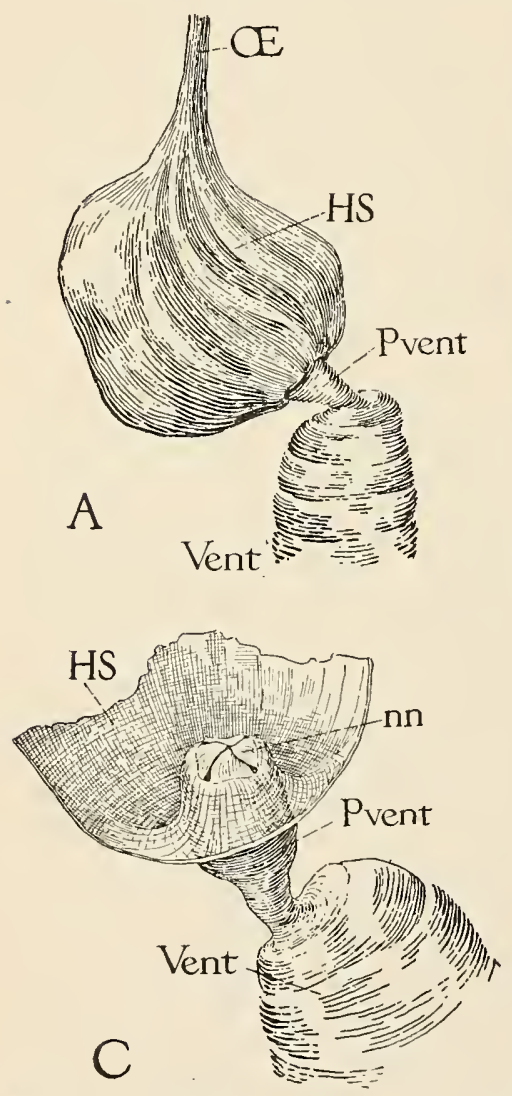

$\mathrm{B}$
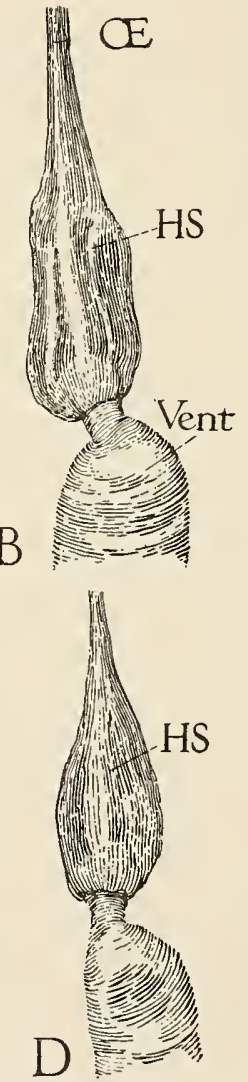

Fig. 44.- - I, honey stomach (HS) of worker with posterior end of œesophagus ( $\left.E^{\prime}\right)$, proventrieulus (Pient), and anteriol end of ventriculus ( $\mathrm{C}$ (nt) ; $\mathrm{L}$, same of queen; C, honey stomach (IIS) of worker mostly cut away exposing the stomach-mouth $(n n)$ of proventriculus (Prent) leading into ventriculus (Vent); D, honey stomach of drone. ing amount of pollen and in no way resembling royal jelly. Cheshire further says that before impregnation the stomachs of the queens always contain pollen, the royal jelly being found in then two or three days after impregnation, when all traces of pollen have disappeared.

The narow œsophagus (fig. 42, $(E)$ is a simple tube with a thick chitinous lining and muscular walls. The epithelium (fig. $45)$ is very rudimentary, its cell boundaries being lost and its nuclei $(T u)$ appearing ats if imbedded in the lower layers of the thick transparent intima $(\operatorname{Int})$. The muscles are disposed in an outer layer of transverse fibers $(T M C l)$ and an inner layer of longitudinal ones $(L M C c l)$.

The honey stomach (fig. $42, I I S$ ) is simply an enlargement of the posterior end of the osophagus lying within the anterior part of the abdominal cavity. It is best developed in the worker (fig. $44 \mathrm{~A}$ ), but is present also in the queen (B) and in the drone (D). The organ should perhaps have been named the nectar stomach, for its 
principal function in the bee is to hold the nectar as it is collected from the flowers and to allow the worker to accumulate a considerable quantity of this liquid before going back to the hive. Hence, since the honey stomach is a sac with very distensible walls, its apparent size varies greatly. When empty it is a small flabby ponch, but when full it is an enormous balloon-shaped bag with thin tense walls. The histological structure of the honey stomach (fig. $45, I I S$ ) is exactly the same as that of the esophagus. The numerous high folds into which its epithelimn (Epth) is thrown permit the enormons expansion of which the sac is capable. When a worker with its honey stomach filled with'nectar reaches the hive, the nectar is either stored directly in a cell or is given up first to some other worker, who places it in a cell.

It would appear that all the food swallowed by a bee must go first into the honey stomach, and since the bee's diet consists of pollen and honey as well as nectar, one would suppose that in regurgitating the latter the bee would also disgorge the pollen it might have recently eaten. Honey which is made from the regurgitated neetur does indeed contain some pollen, but most of the pollen eaten by the bee is undoubtedly retained in the stomach as food. The apparatus by means of which the pollen is supposed to be separated from the nectar belongs to the following division of the alimentary canal, but it is not known that the worker takes nectar, and pollen for food, into its honey stomach at the same time.

The proventriculus (figs: 42 and 44 , Pvent) forms the necklike stalk between the honey stomach $(H S)$ and the true stomach or ventriculus (Vent), but a very important part of it also projects up into the honey stomach. (fig. $44 \mathrm{C}$ ). If the honey stomach be slit open, a short. thick, cylindrical object will be seen invaginated into its posterior end and having an X-shaped opening at its summit (fig. $44 \mathrm{C}$, $n n$ ). This opening is the mouth of the proventriculus, and its four triangular lips, which are thick and strong, mark four longitudinal ridges of the proventricular tube. This structure is commonly known as the "stomach-mouth" and is supposed to be an apparatus designed especially to enable the worker to pick out pollen grains from the honey stomach and swallow them on down into the true stomach or ventriculus, while the nectar is left to be stored in the hive. Cheshire says: "While the little gatherer is flying from flower to flower her stomach-mouth is busy separating pollen from nectar." This notion is so prevalent among bee writers in general that it passes for a known truth. Yet it has really never been shown that the worker eats pollen while she is gathering nectar. Probably no more pollen is ever mixed with the nectar in the honey stomach than is found in the honey itself. Furthermore, under normal conditions pollen never accumulates in the honey stomach, even when the bee 
is not collecting nectar-or, at least, the writer has not observed it-while, finally, both the proventriculus and its mouth are just as well developed in the queens and drones as in the workers, though neither of the former are known to eat pollen, and they certainly do not gather nectar.

If the honey stomach be cut open in a freshly killed bee, the proventricular mouth may be seen still in action. The four lips spasmodically open wide apart with a quivering motion and then tightly roll together and sink into the end of the proventricular lumen. This, of course, suggests their picking pollen out of the nectar, but it is probably simply the ordinary process by means of which the proventriculus passes any of the food in the honey stomach on to the ventriculus. Nearly all insects have some such proventricular apparatus, which simply takes the stored food from the crop as it is needed by the stomach. In some insects it forms apparently a straining apparatus, which prevents coarse, indigestible fragments from entering the stomach, while in some the proventriculus may be a triturating organ comparable with a bird's gizzard. Bees, however, do not crush the pollen either in their mandibles or in the proventriculus, for it occurs in perfect condition in the ventriculus.

Hence, before the current notion that the "stomach-mouth" is for the special purpose of taking pollen ont of the nectar in the honey stomach can be accepted it must be first demonstrated that the workers eat pollen while the honey stomach contains nectar to be stored in the cells, i. e., any more than is disgorged along with the nectar; and, secondly, a reason must be shown why the queens and drones should have a "stomach-mouth" as well developed as that of the worker. In the meantime it appears most logical to regard the proventricular mouth as simply the ordinary apparatus, possessed by insects in general, by means of which all of the food is passed from the crop to the stomach.

A longitudinal section through the honey stomach, the prorentriculus, and the anterior end of the rentriculus is shown in figure 45 , which is made from a queen. The proventriculus does not differ from that of a worker, but the honey stomach is smaller and not so much turned to one side (ef. fig. $44 \mathrm{~A}$ and $\mathrm{B}$ ). The two muscle layer's of the oesophagus continue down over the walls of the honey stomach ( TMLCl and $L M C l$ ). The onter layer of transverse fibers, however. ceases at the posterior end of this organ, while the longitudinal fibers continue posteriorly over the proventriculus and the rentriculus as an external layer $(L M C l)$. A new layer of internal transverse fibers begins on the proventricnlar walls and extends backward on the ventriculus $(T . M C l)$ beneath the longitudinals. Hence the muscles on the osophagus and crop are in reverse order from those of the proventriculus and ventriculus. The proventriculus is deeply in- 
vaginated into the posterior end of the honey stomach. Each lobe of its mouth forms a thick triangular ridge on the walls of its lumen, in which lies a special mass of longitudinal muscle fibers $(L M C l)$. The epithelium of the lumen is lined by a thick, smooth, chitinous intima (Int), while the lobes of the mouth $(n n)$ are provided with bristles pointing inward and backward into the mouth opening.

The posterior opening of the proventriculus into the ventriculus is guarded by a long tubular fold of its epithelium (fig. 45, PventVlv), the proventricular valve. This would appear to constitute an effective check against the escape of any food back into the proventriculus. It looks like one of those traps which induces an animal to enter by a tapering funnel but whose exit is so small that the captive can not find it from the other side. Yet Schönfeld has elaborately described experiments by means of which he induced the ventriculus to discharge its contents through the proventriculus into the honey stomach and even into the end of the œsophagus. He says that he did this by gently tapping on the honey stomach and the ventriculus at the same time. The experiment

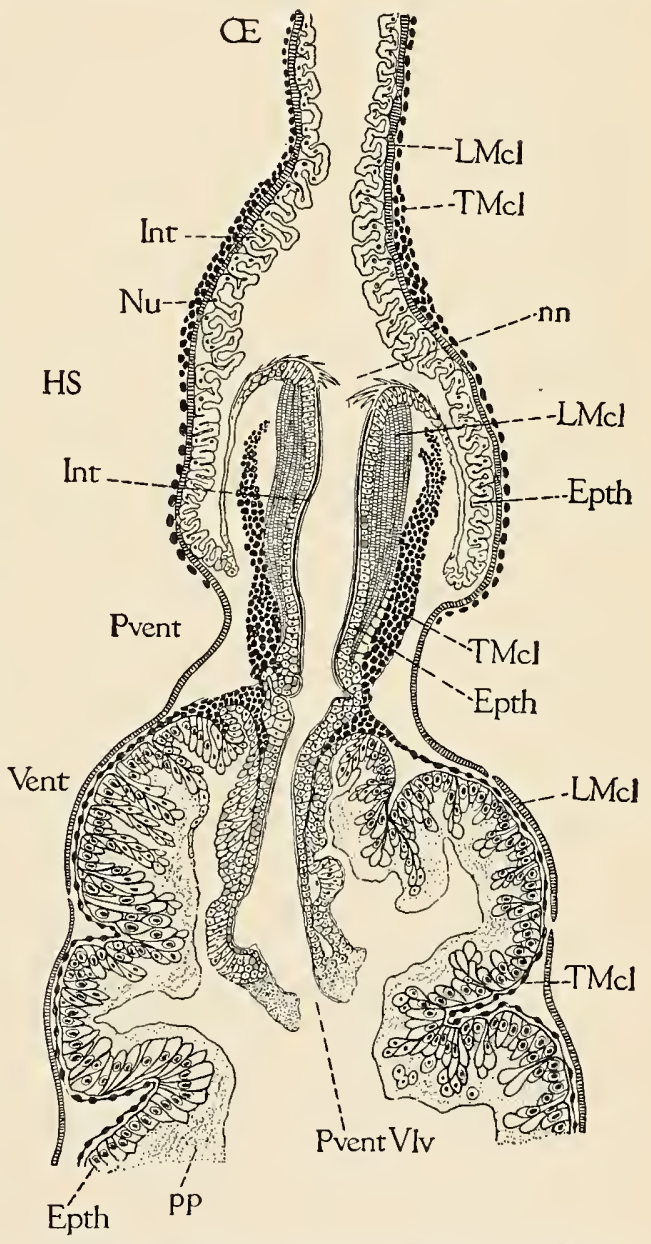

FIG. 45.-Longitudinal median section of base of œsophagus $(C E)$, honey stomach ( $H S)$, proventricuIus (Pvent) and ventriculus (Vent) of a queen. was repeated many times with unvarying results and Schönfeld describes so minutely what happened that we can not disbelieve his statements. From these experiments he argues that the larval foodstuff is prepared in the stomach and regurgitated through the proventriculus directly into the ossophagus by a contraction of the honey stomach which brings the stomach-mouth against the base of the osoph- 
agus. We shall have to postpone a further discussion of this subject to page 99, after the ventriculus and its contents have been described. The ventriculus (fig. $42, V$ ent) is the largest part of the alimentary canal in the bee and is bent into a $U$-shaped loop of which the posterior arm is dorsal. It is cylindrical and does not vary so much in shape and diameter according to its contents as do the other parts of the canal, although the numerous transverse constrictions which give it a segmented appearance are not at all constant. When examined under alcohol the ventriculus has an opaque whitish appearance, but in the natural condition-that is, as seen when examined in a freshly killed or asphyxiated bee-it is of a dark-brown color with lighter rings corresponding to the constrictions. The latter represent internal folds where the walls are really thicker than elsewhere, the color being dne to the contents which naturally show more plainly through the thin parts.

The contents of the ventriculus invariably consist of a dark brown mucilaginous slime and generally also of a varying amount of pollen. The latter is most abmulant in the posterior arm of the ventricnlar loop and is often densely packed in its rear extremity, while the anterior arm may be almost entirely free from it. The pollen in the ventriculus is always fresh-looking, the native color showing distinctly through the enveloping slime while most of the grains yet retain all of their contents. The writer has examined many samples of pollen from the stomachs of workers and, in all, the great mass of it showed no evidence of digestion, the color being fresh and the contents perfect-only a few had the latter shrmken and seldom was an empty shell observed. On the other hand, the pollen contained in the small intestine has invariably lost its bright color, the contents of the majority of the grains are more or less shrunken, while a number of empty shells are to be found. That in the rectum, finally, consists in large part of empty shells or of grains having the contents greatly shrunken and apparently mostly dissolved ont, although a few perfect and bright-colored grains are always present, looking as if entirely unaffected by the digestive liquids. From these observations the writer would conclude that the digestion of pollen takes place principally in the intestine. In all parts of the alimentary tract there occur numerous bits of feathered bee-hairs. but these seem to be especially numerous in the rentriculns.

We are now in a position to discuss the possibility of the production of the brood food in the stomach. Schönfeld (1886), as has already been stated, argues that this substance is regurgitated "chyle" from the rentriculus. Arnhart (1906) adopts this view and elaborates considerably upon the chemical process by means of which the transformation of "chyle" into this larval food is effected through the addition of tartaric acid from the pharyngeal glands of the head. 
The ventricular contents do become slightly milky when treated with a solution of tartaric acid, but they are not changed into anything at all resembling royal jelly. Moreover, a transformation of the brown slimy contents of the ventriculus into the white gummy paste on which the larvæ are fed does not seem possible without the addition of much other material. In fact the added material must make up the conspicuous part of the larval foodstuff and, from a purely argumentative standpoint, it would not seem necessary to assume that it contains any "chyle" at all. Again, if it were not for Schönfeld's experiments one could not easily believe that the food could be disgorged through the proventricular valve. The conspicuous action of the proventricular mouth is a swallowing motion, and the writer has not been able to induce the ventriculus to disgorge its contents through it in the way that Schönfeld describes, although perhaps sufficient care was not observed in exposing the organs. Cheshire states that the proventricular tube (fig. 45, PventVlv) in the ventriculus "rather makes regurgitation improbable than impossible," while he argues that the down-pointing bristles of the stomach-mouth would further interfere with this process. Cowan adopts the view of Dufour and Schönfeld that the brood food is of ventricular origin, and says in this connection: "Although saliva from the glands (especially System I) is probably added to the food, this can not, from its great variability, be entirely a secretion, as stated by Schiemenz. The work of Doctor Planta, we think, conclusively proves that the food is not a secretion, and that the nurses have the power of altering its constituents as may be required for the different bees." If the rariation of the food is under the control of the workers producing it, it does indeed look impossible that it should be produced entirely by glands. Cowan illustrates by a diagram how regurgitation through the proventriculus may be possible in spite of the proventricular tube projecting into the ventriculus. Since this tube is simply a cylindrical fold its walls, as shown in figure 45, PventVle, consist of two layers, and Cowan says that "when the bee wishes to drive the chyle food from the chyle-stomach (Vent) into the cells it forces the stomach-mouth $(\mathrm{nn})$ up to the osophagus $(E)$ and the prolongation (PventVlv) unfolds, extending the chyle-stomach to the resophagus, making a direct communication through which the food is forced by compression of the chyle-stomach by its muscles." The honey-stomach of the worker is much larger than that of the queen, shown by figure 45, in which there is not enough space for the unfolding of the proventricular tube. This mechanism suggested by Cowan looks simple and conclusive in a diagram, but when one attempts to unfold the proventricular tube by grasping the stomach-mouth in a pair of fine forceps and pulling the top of the proventriculus upward it is found that, while the tube can be entirely straightened out, doing 
so involves the tearing of all the fine muscle fibers and tracheal branches uniting the honey-stomach to the upper end of the ventriculus (fig. 45). If, then, the organ itself can not be made to work according to this scheme, it might be supposed that the inner wall of the proventriculus and the tube are evaginated through the stomachmouth $(n n)$, but the walls of the former certainly appear to be entirely too rigid to permit of any such performance as this. Finally, it is not clear how any eversion of the tube could be produced by the proventricular muscles as they exist.

The various facts and arguments bearing on the origin of the brood food may be summarized as follows:

1. The brood food itself is a milky-white, finely granular, and gummy paste having a strong acid reaction said to be due to the presence of tartaric acid.

2. The pharyngeal glands of the head are developed in proportion to the social specialization of the various species of bees; they are always largest in those individuals that feed the brood, and they reach their highest development in the workers of the honey bee. From this it would seem that they are accessory to some special function of the worker.

3. The contents of the stomach in the workers consist of a dark brown, slimy, or mucilaginous substance in no way resembling the brood food, even when acidulated with tartaric acid. Pollen is present in varying quantity, mostly in the posterior end of the stomach, and shows little or no evidence of digestion. Since the brood food is highly nutritious, it must contain an abundance of nitrogenous food material which is derived only from pollen in the bee's diet. Therefore it is not clear how the stomach contents can alone form brood food.

4. The constituents of the food given to the different larva, at different stages in their growth, and to the adult queens and drones show a constant variation apparently regulated by the workers producing it. A variation of this sort can not be explained if it is assumed that the brood food is produced by the glands alone.

5. Powdered charcoal fed to a hive of bees appears after a short time in the brood food in the cells, and this has been urged as proof that the latter is regurgitated "chyle." But it is certainly entirely possible that the charcoal found in the food might have come only from the honey stomach or even from the cesophagus or mouth.

6 . We have Schönfeld's word for the statement that a regurgitation of the stomach contents may be artificially induced by irritation of the honey stomach and ventriculus in a freshly dissected bee, but all explanations offered to show how this is mechanically possible in spite of the proventricular valve are unsatisfactory when the actual anatomical structure is taken into consideration. 
The only conclusion, then, that we are really warranted in drawing concerning the origin of the royal jelly or of any of the larval food paste is that we do not know anything about it. Cheshire is probably responsible for the widespread opinion that it is formed by the pharyngeal glands, though Schiemenz (1883) published a large paper containing this theory three years before Cheshire's book was printed. The "chỵle" theory, which also has many advocates, originated with Dufour but was principally elaborated by Schönfeld. Arnhart would derive the brood food from both the stomach and the glands. But we are still absolutely in the dark, since we lack definite and conclusive information. A satisfactory study of the subject wonld involve the chemical investigation of very minute quantities of substances, and it may be a long time before any interested person is found capable of undertaking a work of this sort. The writer of the present paper is professedly preparing an account only of the structure of the organs, but is doing this with the hope that it may furnish a basis for some future investigator who shall have time to devote himself to a study of the chemistry and physiology of the digestive organs and their glands.

In vertebrate animals the digestive secretion of the stomach is acid and its enzymes bring abont especially the digestion of proteids. The resulting acid mixture is called chyme. In the intestine the contents are flooded with varions alkaline liquids whose enzymes then take up the digestion of the other food elements. The final prepared product, which is absorbed by the lacteals, is called chyle. These names have been applied to the contents of the alimentary canal in insects-especially by Arnhart (1906), who speaks of the material undergoing digestion as "chyme" and the completed products as "chyle." But absolutely nothing is known of the digestive process in insects beyond the fact established by Plateau (1874) that the contents of all parts of the alimentary tract are alkaline during digestive activity and either neutral or weakly alkaline at other times. Hence, if we make use of these words in insect physiology, it must be with the understanding that no chemical significance is implied. The ventriculus is very commonly called the "chyle stomach " but there is probably no reason for calling it a "chyle stomach" any more than a "chyme stomach," and likewise there is no reason for supposing that the intestine does not contain chyle-in fact, it almost certainly does. The word "chyle" may be used with entire propriety in insect physiology to signify the completed products of digestion, but to designate a part of the alimentary tract as the "chyle stomach" is applying the term withont an adequate basis of facts.

The contents of the ventriculus are surrounded by several concentric layers of thin filmy membrane which form an interior tube extending the entire length of the stomach and reaching down into the 
anterior end of the intestine. This tube can be very easily seen by carefully cutting open the outer walls of the ventriculns, but it is best demonstrated by transverse microtome sections of a specimen prepared for histological purposes. Such a section is shown by figure $46 \mathrm{~A}$. A small amount of solid food matter $(q q)$ is seen in the center of the specimen, surrounding which are numerous irregular concentric rings of membrane $(P m b)$, some adhering to euch other in places, other's entirely free, most of then structureless, but others partly cellular. These are known as the peritrophic membranes $(P m b)$. They keep the solid contents of the stomach away from the epithelial walls, from which, as will be presently explained, they are given off from time to time.

The walls of the ventriculus (fig. $46 \mathrm{~A}$ ) are thick and consist of numerous cells (Epth) apparently very irregularly arranged. On their inner surfaces is a thin intima $(I n t)$ and on their outer surfaces a still finer basement membrane $(B . M)$. Outside of the last are two layers of muscles, the external layer consisting of longitudinal fibers $(L M C l)$ and the inner of transverse ones $(T . M C l)$. Numerous annular depressions of the walls form internal folds (fig. 45), but any part of the ventricular wall can be stretched out into a flat sheet, which is then seen to be full of little pits, giving the whole a screenlike appearance. Sections show that the pits result from circular invaginations of the basement membrane (fig. $46 \mathrm{~B}, B M$ ), and that at the bottom of these pockets the cells are very small and convergent, while those on their lips are very large. Figure $46 \mathrm{~B}$ is a very perfect example of this structure of the epithelium, which is usually more or less obscured, as in figure $46 \mathrm{~A}$, by a great proliferation of small cells from the lips of the cups-and then a large section seldom gives a symmetrical view of all the parts. The cups are all filled to overflowing by a gelatinous mass $(p p)$ which fuses over their edges into a continuous coating beneath the intima over the entire inner surface of the epithelium. This mass appears to be formed mostly by the cells at the bottoms of the cups, for the outermost of these (fig. $46 \mathrm{~B}$, $r r$ ) often insensibly fade into it.

Figure $46 \mathrm{E}$ shows an opposite condition of the epithelial cells. Here the lip cells of the cups appear to be very actively dividing, and proliferating a great number of small cells ( $E n z)$ which float off into the gelatinous covering. These discharged cellules are all nucleated, but their protoplasm does not stain in preparations and consequently they appear clear and transparent as compared with the cells they apparently come from. The writer has not been able to find any of these cells actually in the process of division, but a comparison of figures B and E (which are camera lucida drawings and not diagrams) would certainly suggest that the condition of the cells in $\mathrm{E}$ has resulted from a very active division of the cells of the walls and 
lips of the cups, which are quiescent in B. Comparing this with what is known to take place in other insects during digestion, there is every reason for believing that the proliferated cellules are filled with the digestive secretion, and that $\mathrm{E}$ represents a stage immedi-
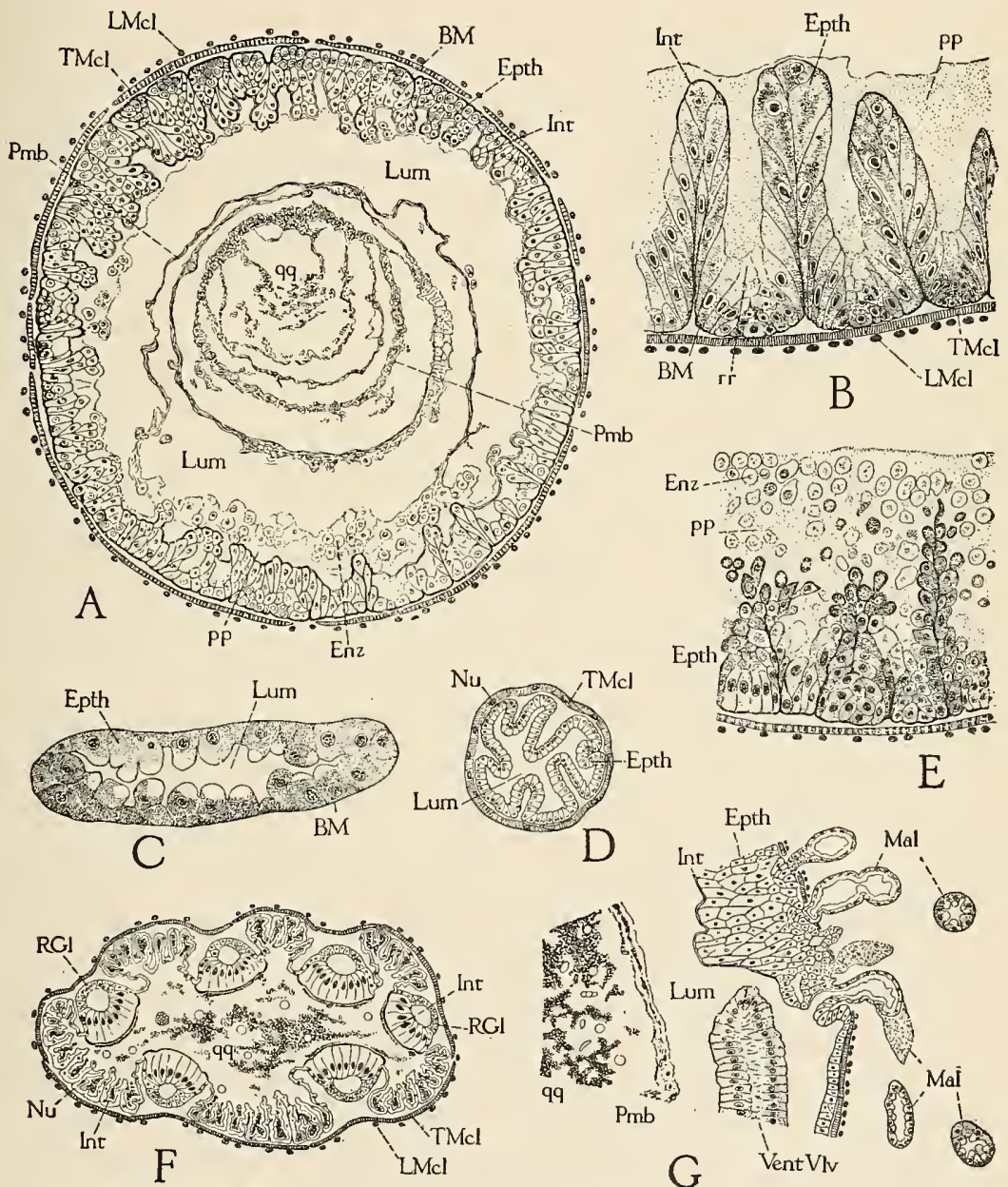

FIG. 46.-Histological details of alimentary canal of worker : $\lambda$, cross section of ventriculus showing peritrophic membranes $(P m b)$; B, section of wall of ventriculus showing epithelial cups with cells in resting condition and covered by gelatinous mass $(p p)$; C, section of Malpighian tubule; D, cross section of small iutestine; E, section of ventricular epithelium after formation of numerous small digestive or enzyme cells $(E n z)$ given off into gelatinous matrix $(p p)$; F, section of anterior end of rectum through rectal glands $(R G l)$; G, part of slightly oblique section through posterior end of ventriculus and anterior end of small intestine, showing openings of Malpighian tubules ( $\mathrm{Mal}$ ) into the latter.

ately subsequent to one of greatest secretive activity, in which there is a large number of little cells (Enz) highly charged with the enzyme-containing digestive juices imbedded in a gelatinous matrix covering the inner surface of the epithelium. This matrix next 
separates itself from the ends of the remaining epithelial cells, which at the same time secrete a new intima over their inner surfaces. The lower part of figure $46 \mathrm{~A}$ shows this indisputably. The whole thing, then, finally contracts about the food and, as the digestive cellules give up their contents, shrivels and shrinks and becomes a peritrophic membrane. In figure $\mathrm{A}$ the outermost peritrophic layer is still in both conditions-its dorsal part is shrunken to a thin membranous form, while its lower part is gelatinous and filled with secretion cellules, though it is separated from the epithelium by a new intima and is detached at intervals from the latter. Beneath the new intima, furthermore, is seen at places the formation of a new gelatinous mass. Some of the inner peritrophic layers shown in A also retain remnants of cells.

Figure $46 \mathrm{~A}$ is drawn from a specimen which is typical of all in several series of sections through the ventriculus. The peritrophic layer partly adhering to the epithelium is no artifact, because the same condition may often be directly observed in dissections of fresh specimens. In the opposite end of the series from which the specimen was selected this layer is entirely free from the epithelium.

The peritrophic membrane has been described in some insects as being a prolongation from the intima of the proventriculus, the ventriculus itself being supposed never to secrete an intima. It is perfectly conceivable that the anterior end of the membranes might be generated by the outer cellular layer of the proventricular funnel and remain attached to it after the rest of it had become free from the ventricular wall, and thus give the appearance of belonging to the proventriculus. The writer, however, has several sets of longitudinal sections through these parts in the bee, but none of them nor any dissections made show such a condition.

Absorption is commonly supposed to take place largely in the ventriculus. If so, the food must pass through the several peritrophic membranes and then through the thick epithelium. It is entirely possible that it may do so, but the pollen contained in the ventriculus, as already stated, shows little or no evidence yet of digestion and does not begin to do so until it reaches the small intestine. On the other hand, the dark mucilaginous slime of the ventriculus does not appear in any quantity in the much drier contents of the small intestine. Therefore it may be supposed that this slime contains the sugar elements of the food and that the latter are principally digested in, and absorbed from, the ventriculus. The absorption of the proteids and hydrocarbons must take place in the intestine and rectum since these food elements in the bee's diet are derived only from the pollen. However, these conclusions are purely tentative, being based on the writer's observation of the contents of the different parts of the alimentary tract, which, while fairly extensive and continued through 
most of a year, are confessedly not nearly adequate to serve as a basis for conclusive statements on the digestive process. They are sufficient, however, to show the utter lack of a basis in facts for many other opinions on this subject.

Cheshire (1886) describes two kinds of cells in the ventricular epithelium, "one secreting a digestive fluid (gastric juice) from the surrounding blood into the stomach, so that the pollen grains may be made fit for assimilation by a transformation not unlike that liquefying gluten in our own case; the other absorbing the nutrition as prepared and giving it up to the blood." Though Cheshire refers to his figures to show these two kinds of cells, he does not point out which are which-in fact, he does not even designate two different kinds in his drawings nor even represent two kinds.

The small intestine (fig. 42, SInt) forms a loop upon itself and constitutes a narrow tube connecting the stomach (Vent) with the large intestine or rectum (Rect). Its anterior end is somewhat enlarged and carries the circle of malpighian tubules $(\mathrm{M} / \mathrm{al}$ ). Its epithelium (fig. $46 \mathrm{D}, E p t h$ ) is very simple and is thrown into six longitudinal folds that project into its lumen. On the outside is a thick sheath of transverse muscle fibers $(T M I c l)$ with distinct nuclei $(V u)$. The latter are designated by Cheshire (1886) as "longitudinal muscles" (see his figure $14 \mathrm{D}$ ), but this is a rery erident mistake-the small intestine has no longitudinal muscles at all. It is evident that the folds of the epithelium permit the ordinarily narrow tube to expand very considerably when necessary to allow the passage of a large amount of food. The contents of the small intestine are usually drier than those of the ventriculus, consisting principally of masses of partly digested pollen, that is to say, the contents of the grains are partly dissolved out-presumably signifying that they are undergoing digestion. There is usually only a small amount of the brown slime present such as fills the rentriculus.

The Malpighian tubules (fig. 42, $\mathrm{Mal}$ ) are wrapped and coiled about one another and about the riscera of the abdominal cavity. There are about 100 of them in the honey bee and they all open separately into the anterior end of the intestine. Each is a very long threadlike tube consisting of a single layer of epithelial cells provided with a very delicate basement membrane and intima (fig. $46 \mathrm{C}$ ). The ends of many of the cells are clear and bulge into the lumen. Figure $46 \mathrm{G}$ shows a section through the junction of the ventriculus and the intestine where the tubules open by narrow necks penetrating the epithelium. The wall of the ventriculus forms a short double-layered fold (VentVlv) projecting backward into the anterior end of the intestine, behind which are the orifices of the Malpighian tubules. The section from which figure G was drawn is cut somewhat obliquely and takes in this fold only on one side. 
The Malpighian tubules are regarded as excretory in function and are supposed to remove from the blood the nitrogenous waste products resulting from metabolism. Minute crystals of mates are often to be found in them and they probably perform the work of the kidneys in vertebrate animals.

The large intestine (fig. 42, Rect), called the rectum in insects, is an enormous sac which may lie limp and flabby in the rear part of the body or it may be so immensely distended by the amount of its solid and liquid contents as to occupy a large part of the abdominal cavity. The recognizable elements of the material within it consist mostly of the empty shells of pollen grains or of grains haring their contents greatly shrunken and distorted-presumably as a result of the absorption of the protoplasm, although a considerable number are usually present which are only slightly digested, while there are always to be observed a few perfect and fresh-looking grains showing no evidence at all of digestion. The rest of the indefinite mass of solid rectal material consists of some unrecognizable, finely triturated substance, probably derịved in part from fragments of the peritrophic membranes. There are always present a few bits of feathered bee hairs.

The epithelium of the rectum is, like that of the csophagus, rudimentary, being distinguishable only by the nuclei (fig. $46 \mathrm{~F}, N u$ ) remaining in the outer layer of the thick transparent intima (Int). Outside of this is an external layer of longitudinal muscle fibers $(L . M C l)$ and an inner layer of transverse fibers $(T . M C l)$. The intima (Int) is thrown into numerous folds whose edges converge, forming pocketlike grooves between them in which are lodged small masses of the rectal contents. This is very suggestive that absorption takes place in this part of the alimentary tract, although it is not commonly supposed to do so, but if the pollen is not fully digested until it reaches the rectum, how can it be absorbed by the anterior part of the alimentary canal?

The so-called rectal glands (fig. 42, $R G l$ ) consist of six hollow epithelial tubes (fig. $46 \mathrm{~F}, R G 7$ ) and are the only parts of the rectal epithelium in which the cells are well developed. The cells on the outside of each "gland" are small, but the inner ones are very large and are covered by a thick layer of dark chitin $(\operatorname{In} t)$. The lumen is intercellular and does not communicate with that of the rectum. When the rectum is distended the "glands" bulge out on the surface as six short opaque ridges (fig. $42, R G l$ ), but when it is empty they sink into the walls as in figure $46 \mathrm{~F}$. Nothing is known of the function of these organs, and their glandular nature is entirely conjectural. If they are glands, it is not clear why the intima should be so especially dense on their inner faces. 


\section{THE CIRCULATORY SYSTEM.}

The liquid medium that distributes the digested food from the alimentary canal to the cells of the body tissues is called the blood, and the contractile organ that keeps the blood in motion is the heart. In vertebrate animals the blood is contained entirely within tubes called arteries and veins, but in insects and most other invertebrate animals the blood simply fills the empty spaces between the viscera of the body-cavity, which spaces may, however, constitute definite channels or sinuses, and may even be shut in by special membranes. Besides carrying and distributing the digested food that is absorbed into it in solntion, the blood of animals generally has also to distribute oxygen to the tissue cells and carry off their waste products. Oxygen is obtained from the air and, like any other gas, is soluble in liquids. Hence it is present in the blood not in the form of small bubbles of gas but in solution, just as it is in all water exposed to the air. The respiratory system (see page 116) is simply a special contrivance for bringing air into close proximity to the blood so that its gases may diffuse into the latter, but many soft-bodied animals like earthworms absorb air directly throngh the skin. Vertebrate animals have a substance in their blood called hemoglobin which is contained in the red corpuscles and has a great capacity for absorbing oxygen. It, therefore, enables the blood to carry much more of this gas than could be dissolved simply in its plasma. Invertebrate animals do not need so much oxygen as vertebrates, and, therefore, most of them can get along with that which dissolves in the colorless blood plasma without the special aid of hemoglobin. Most insects, however, being excessively active creatures, must have a rapid metabolism in their cell tissues, and consequently they need much oxygen to consume the product of this metabolism, but they belong to the class of animals without red blood and, hence, nature has provided them with another means of obtaining a special supply of air, namely, a set of air-tubes branching minutely over nearly all the internal organs, the tissues, and even most of the cells in the body. (See "The Respiratory System," page 112, for discussion of oxidation and removal of waste products.)

The blood of insects is usually a colorless liquid containing opaque granular cells or corpuscles floating in it. There are no special blood vessels, but there are very definite channels between the muscles and viscera through which the blood flows, while conspicuous membranes stretched across the dorsal and ventral walls of the abdomen (fig. 1, $D D p h$ and $V D p h$ ) inclose special dorsal and ventral sinuses which play an important part in the circulation. These membranes, called diaphragms, are rhythmically contractile, and contribute much to 
maintaining the circulation of the blood. The heart (fig. 1, Ht) is located in the dorsal sinus, which latter is therefore often called the pericardial chamber. The pulsations of the diaphragms are produced by fine muscle fibers lying in their walls. These are usually arranged in a number of fan-shaped bunches on each side radiating from the edges of the diaphragm (fig. $4 \bar{\tau}, D p h M c l$ ) toward the middle, where most of them are continuous with the fibers from the opposite side. It used to be supposed that those of the dorsal diaphragm produced the expansion of the heart, and they were for this reason called the "wing muscles of the heart," but the latter organ is now known to be a muscular tube and to contract and expand by its own

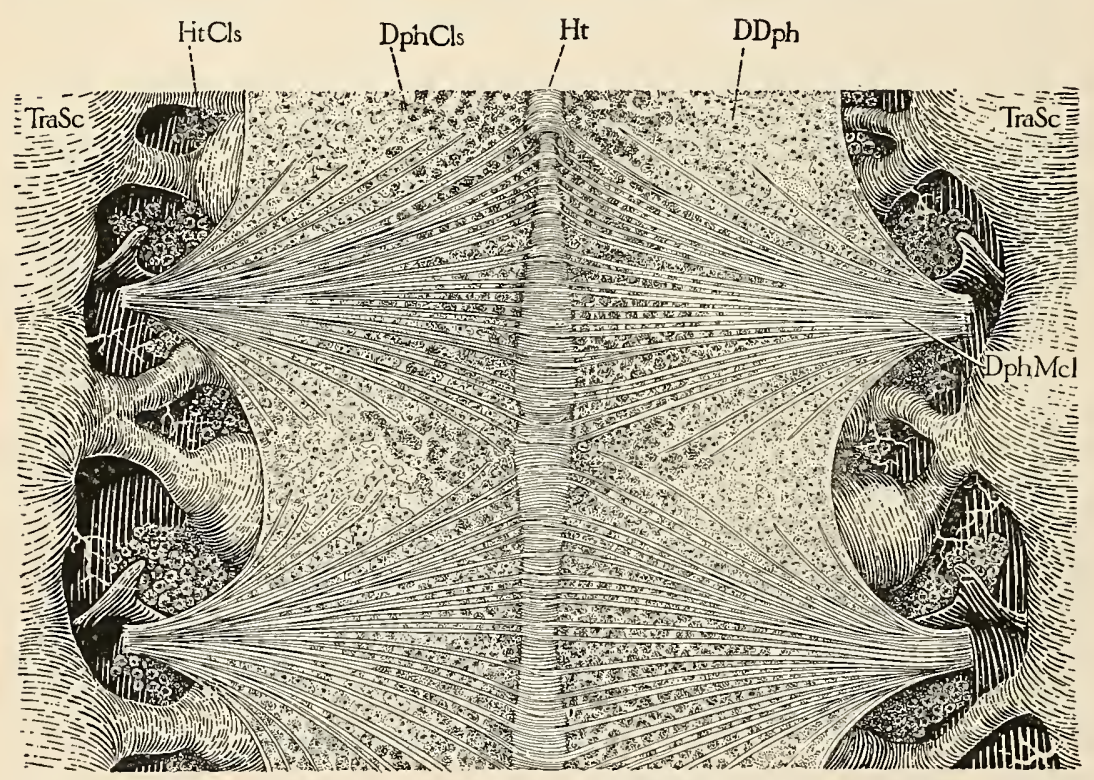

FIG. 47.-Dorsal diaphragm of drone, from one segment and adjoining parts of two neighboring segments, showing median heart $(I t)$ as seen through transparent diaphragm $(D D p h)$, fan-shaped bunches of diaphragm muscles ( $D p h / / c h$ ). and lateral tracheal sac (TraSc) giving off sac-bearing trunks into pericardial chamber above diaphragm.

power. In some insects the muscles of the dorsal diaphragm form a meshwork of fine fibers surrounding numerons large and small holes in the membrane, which probably permit the entrance of blood into the sinus above, but in most species the diaphragm is imperforate and the blood enters the pericardial chamber above its scalloped edges (figs. 1 and 47).

The heart of insects in general is a long narrow tube (fig. 1, Ht) situated in the dorsal sinus or pericartial chamber of the abdomen along the midline of the body. It is swollen toward the middle of each segment into a heart chamber ( $h t$ ) which presents a vertical slitlike opening or ostium (Ost) on each side. Theoretically, in 
generalized insects, there should be a chamber to each segment, but the heart is variously shortened from both ends so that the chambers are always fewer than the segments. The posterior end of the heart is closed, but its anterior end is produced into a long narrow tube called the aorta (fig. 1, Ao) which extends through the thorax and opens by a few simple branches into the cavity of the head.

The heart of the bee (fig. 1, $H t$ ) consists of only four chambers (1ht-4ht) lying in the third, fourth, fifth, and sixth segments of the abdomen. In the front of this part of the body it bends downward and forms a large convoluted loop $(i)$ of about 18 folds where it passes through the abdominal constriction. All of this convoluted part really belongs to the abdomen, since it lies in the propodeal part of the apparent thorax, which is the true first abdominal segment. The aorta $(A O)$ extends forward from here as a very fine tube making a large arch between the muscles of the thorax and then enters the back of the head. According to Pissarew (1898) the convolutions of the anterior end of the heart are peculiar to the honey bee, being absent in its nearest relatives such as Bombus and 1Legachile. The heart walls, as before stated, are muscular and produce a rhythmical contraction of the tube whose pulsations follow each other from behind forward. Thus the contained blood is driven out of the anterior end of the aorta into the head, where it bathes the brain and the other organs of this region, and then flows backward, percolating through the spaces between the organs of the thorax.

From the thorax it enters the cavity of the ventral sinus-not the general abdominal eavity, at least in the bee-and is pumped backward by the pulsations of the ventral diaphragm and dorsally over the imer walls of the thorax and through definite channels about all the viscera, finally collecting in the dorsal sinus where it again enters the heart through the lateral ostia. The lips of the ostia are provided with small membranous lobes which project inward and constitute valves that prevent the expulsion of the blood. A similar valve is placed at the anterior end of each chamber of the heart to prevent a possible backward flow.

In the bee, both the dorsal and the ventral diaphragms are well developed, the former (fig. 1, $D D p h$ ) extending from the third abdominal segment to the seventh, inclusive, while the latter (VDph) extends from the abdominal constriction to the eighth segment. The ventral diaphragm is much more muscular than the dorsal and its pulsations, which are very strong, follow each other from before backward. They may easily be observed by removing the top of the abdomen from an aspliyxiated bee. The ventral sinus is very ample, inclosing the nerve cord of the abdomen, and receives into its anterior end the blood channels of the thorax, so that the latter 
communicate with the general cavity of the abdomen only through the ventral sinus.

The dorsal diaphragm (fig. $1, D D p h$ ) ends by a free transverse edge near the front of the third abdominal segment. A part of it is shown by figure 47 extending across one segment and the adjoining parts of two others. The fan-shaped bunches of muscle fibers $(D p h M C l)$ are seen radiating from the anterior edges of the terga toward the midline, where they are mostly continuous with those from the opposite side, only a few of the anterior and posterior ones ending free in the membrane of the diaphragm. The latter is imperforate, but its edges are deeply scalloped between the points where the muscles are attached, allowing free entrance to the blood from the intervisceral channels of the abdomen. The dorsal surface of the diaphragm is covered by a network of cells (figs. 47 and 48, DphCls) arranged in flat branching and fusing bands. These cells

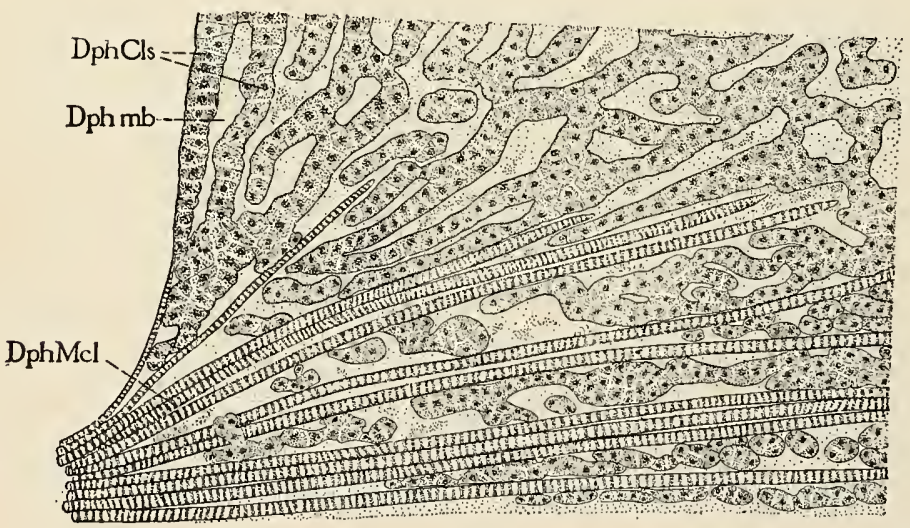

Fig. 48. - Small part of dorsal diaphragm of drone, showing bands of flat diaphragm cells

$(D p h C l s)$, the diaphragm membrane itself $(D p h m b)$, and the muscle fibers $(D p h M c l)$.

may be called the diaphragm cells to distinguish them from the pericardial cells to be described later.

The abdominal circulation is very easy to observe in a living bee. The best way to demonstrate it is to pin an asphyxiated bee to a block of cork or paraffin and remove the top of the abdomen by making an incision with a small pair of scissors clear around it. Gently pull the alimentary canal to one side so as to expose the ventral diaphragm, which will be observed pulsating strongly backward. Next cut a small hole in the top of the thorax and insert into it a drop of some stain in a water solution (the writer used carmalum). Almost immediately this will appear in the ventral sinus of the abdomen, in which it is pumped backward by the diaphragm, and from which it goes upward through invisible channels between the air sacs and the alimentary canal and especially up 
wide channels against the lateral walls of each segment. It does not r'un out free into the abdominal cavity, however, unless through a rent, nor does it enter the latter from the thorax except by way of the ventral sinus. The dorsal circulation of course can not be observed in this specimen because the back is removed. Therefore, take another bee and fasten it in the same manner, but make simply a shallow median slit along the back, thus exposing the dorsal sinus and the heart from above. Now insert a drop of stain into the thorax as before. After about two minutes this will appear in perceptible amount in the dorsal sinus, very much diluted, to be sure, with the blood, but there will be enough to give white blotting paper a distinct red tint. In a short time the heart becomes filled with the stained blood and appears as a red tube along the median line.

The dorsal sinus contains not only the heart but also two pairs of pericardial air sacs in each segment. These are seen entering the

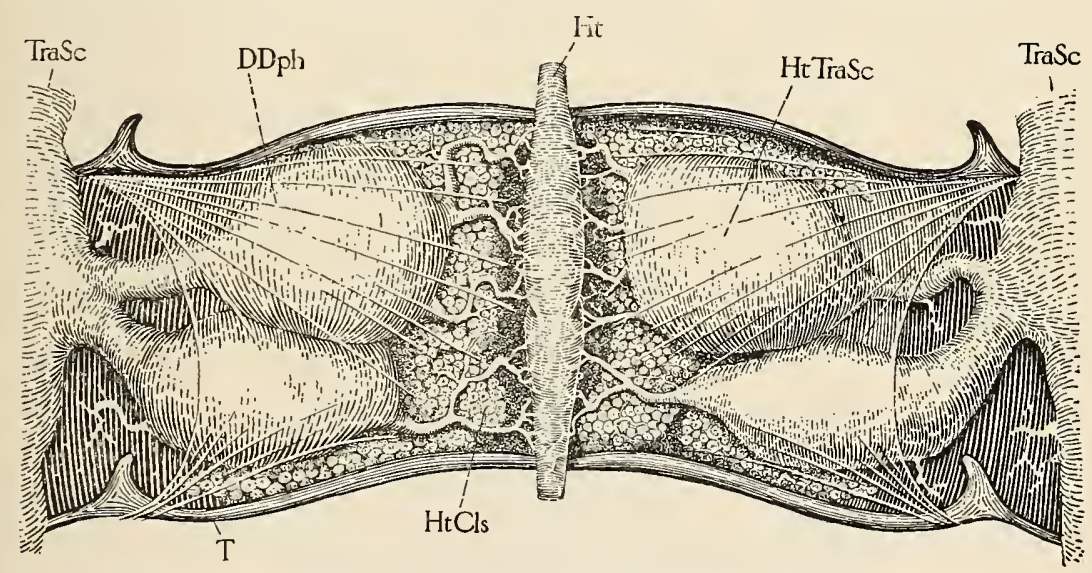

FIG. 49,-Pericardial chamber of one segment in worker, seen from below looking through transparent dorsal diaphragm $(D D p h)$, showing median heart $(H t)$, Iateral pericardial air sacs (HtTrase) given off from large lateral sacs (TraSc), and the padding of pericardial celIs $(H t C l s)$ against inner surface of tergum $(T)$.

sinus from the large lateral air sacs of the abdomen (TraSc) in figure 1 and also in figure 47 . In the latter the heart $(I I t)$ is seen along the median line as it shows through the diaphragm. Figure 49 gives a view of the pericardial sinus as seen from below, in one segment, by focusing through the transparent diaphragm $(D D p h)$. In the middle lies a chamber of the heart $(H t)$ with the slitlike ostium on each side. Laterally are the four pericardial air sacs (IItTraSe) giving off branches that ramify profusely upon the heart. Above the heart and the air sacs is a thick bed of large granular cells (IItCls) which make a soft padding between the hard tergal wall and the delicate organs of the sinus. These are called the pericardial cells. They may have some physiological function, as has often been supposed, but if so no one has decided what it is. 


\section{THE RESPIRATORY SYSTEM.}

The lives of all animals depend upon a constant distribution of free oxygen gas throughont their bodies. This oxygen, continually inhaled and exhaled, is not used in the formation of tissues, it does not become a part of the living protoplasm of the animal-it is the physiological scavenger that eats up certain waste products of metabolism which are deadly to the system mless constantly removed or changed into less harmful compounds. The action of oxygen upon these waste substances within the body is comparable with ordinary combustion in that it results in the formation of carbon dioxid gas and water and in the generation of heat. Since the air, which is composed of both oxygen and nitrogen, is the somrce of the oxygen supply, the ordinary breathing processes involve an inhalation also of nitrogen gas, and the tissues become permeated with it as well as with oxygen. The nitrogen of the air, however, is not known to serve any physiological purpose in the body, its presence being simply unavoidably incidental to the inhalation of oxygen. While oxygen and nitrogen are two most important food elements, the tissues of animals can not make use of either in the gaseous condition, but must be supplied with substances containing these elements in combination with others in the form of solid and liquid food stuffs taken into the alimentary canal. Hence, air is not a food, and the respiratory system is to be regarded as chiefly excretory in function.

The means by which different animals receive oxygen into their systems are various. All aquatic breathers of course use that which is naturally dissolved in water. Many of the lower animals absorb air directly through their skins and into their tissues, while the carbon dioxid escapes the same way. Others that live in the water and whose bodies are covered by an impervious skin or shell have thin-walled, hollow, branching appendages, called gills, through which the blood circulates freely and throngh whose walls the necessary exchange of gases takes place. Land animals very commonly have some sort of an invagination from the exterior which allows the air to enter thin-walled tubes or carities and be absorbed into the blood. Land vertebrates have a tube opening from the back of the month whose inner end branches profusely and forms a pair of organs called the lungs, through which the blood circulates freely in delicate tubes that allow the transfer of gases. Insects, finally, have a system of internal air tubes, called trachere, opening to the exterior by a number of small orifices, called spiracles, situated along the sides of the thorax and abdomen, which give off branches that ramify minutely to all parts of the organism, thus virtually making a lung of the entire body. The trachex are thin tubes made of flat epithelial 


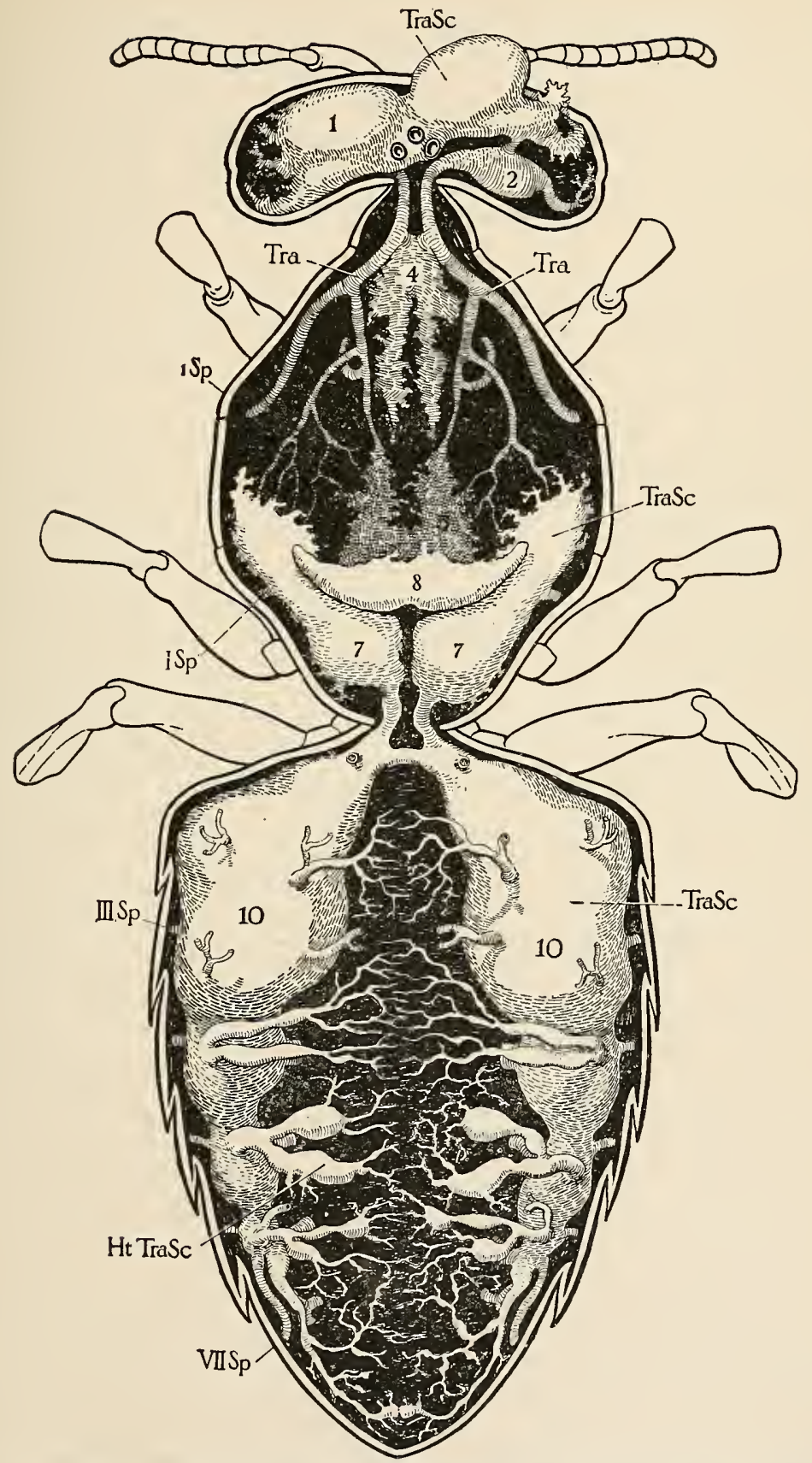

FIG. 50.- Tracheal system of worker as seen from above, one anterior pair of abdominal sacs (fig. 1,9) removed and transverse ventral commissures of abdomen not shown. 
cells lined with a delicate layer of chitin. The latter, howerer, is strengthened by circular thickenings which give the appearance of an internal spiral thread, but a closer examination shows that each thickening makes only a few tmins and that several lie in parallel bands. This structure is for the purpose of maintaining an open passageway for the air through the very thin-walled tubes. The trachex branch into fine capillaries and these terminate in excessively delicate end-tubes. In some cases it is easy to see that a great number of capillary branches surround the cells of a tissue, if they do not actually enter the cell walls, but in other's it can not be shown that the trachea really penetrate below the surface of a mass of cells.

Gases in solution, like solids, pass freely back and forth through moist animal nembranes, going in the direction of the least pressure of each particular gas. By this simple method the gases go back and forth through the walls of the gills, lungs, or air tubes and permeate the tissues themselves. Vertebrate animals, as already explained, have a red substance in the blood called hemoglobin which has a very great oxygen-absorbing power and which greatly increases the oxygen-carrying power of the blood, but still a certain amomnt of oxygen is carried in solution by the liquid or plasma of the blood. Now, the blood of insects has none of this hemoglobin and all the oxygen it can carry is that which dissolves in its plasma, but, on account of the extensive ramification of the air tubes, it is not necessary for the blood to distribute the oxygen to the organs. It is usually stated that the blood in insects does not carry oxygen at all, except for its own nse, but it would seem phrsically impossible that the gases should not diffuse out of the fine terminal air-tubes into the blood when they do so in all other cases. If the blood of a crab or crayfish is capable of carrying enough oxygen in solution to supply the wants of the body, there is no reason why that of an insect. which has much better facilities for obtaining air, should not do-the same. Furthermore, we can not suppose that the products of katabolism have to accumulate about the end trachea in order to be oxidized. They are produced wherever metabolism is going on, which is everywhere in the living cell substance, and, hence, the latter must be permeated with oxygen in solution, which must also be in the blood along with the carbon dioxid formed. The carbon dioxid diffuses back into the end trachex from the blood. Therefore, while the great extent of the tracheal system in insects relieves the blood of the work of distributing the oxygen, the blood must nevertheless serve as an intermediary medium for both the oxygen and the carbon dioxid between the fine terminal tracheal branches and the cells.

It has sometimes been suggested that certain large cells called anocytes, found especially in connection with the tracheal system, 
function as intermediaries between the trachex and the cells, but Koschevnikov (1900) has shown that these cells appear to be temporary storehouses for waste products from the tissues-presumably uric acid compounds which have been already oxidized. Even the fat-body has been regarded as a sort of lung in which oxidation takes place, but there is no evidence to support this theory, although, for that matter, there is little evidence in favor of any theory in insect physiology.

The process of metabolism, or the vital activity of the cells themselres, results in a breaking down of the complex and highly unstable protoplasmic molecules into chemical substances of much simpler construction, and it is these by-products of metabolism that are attacked by the oxygen in the blood furnished by the respiratory system. Protoplasm consists principally of the elements carbon, oxygen, hydrogen, and nitrogen, and the oxidation process results, as before stated, in the formation of carbon dioxid $\left(\mathrm{CO}_{2}\right)$ and water $\left(\mathrm{H}_{2} \mathrm{O}\right)$, while the residuary products are mostly organic compounds of nitrogen related to uric acid $\left(\mathrm{C}_{5} \mathrm{H}_{4} \mathrm{~N}_{4} \mathrm{O}_{3}\right)$ and urea $\left(\mathrm{CON}_{2} \mathrm{H}_{2}\right)$. The carbon dioxid is a soluble gas which diffuses into the end tubes of the tracher and is exhaled. A part of the water at least is given off with the "breath" in the form of water vapor, for drops of it can be collected by inclosing bees or any insects in a tube for a short time. The nitrogen compounds and probably a part of the water are dissolved in the blood and removed by the Malpighian tubules, which are the kidneys of insects.

Besides this oxidation of waste products, which allows the process of metabolism to go on unhindered, the inhaled oxygen serves also another purpose, namely, that of maintaining the body heat. Although insects are usually classed as "cold-blooded" animals, they nevertheless maintain a temperature which is always higher than that of the surrounding air and is often a number of degrees above it. It is well known that the temperature of a beehive during the brood-rearing season is alnost as high as that of the human body, and that even during winter it remains at nearly $80^{\circ} \mathrm{F}$; ; but this is, of course, due to the accumulation and condensation of the warmth from the bodies of a great many bees, and is much higher than the temperature of any bee outside of the hive. In our own bodies certain substances are consumed by oxidation in the blood simply to produce the necessary heat energy for maintaining metabolism, and hence it seems reasonable to suppose that the same thing takes place in insects, although of course to a much less degree.

There are generally ten pairs of spiracles or breathing apertures in insects, two being sitnated on the sides of the thorax between the segments, but probably belonging to the mesothorax and the 
metathorax (although the first is often regarded as prothoracic), while the other eight are situated on the sides of the first eight abdominal segments-in the bee on the lateral parts of the terga (figs. 32 and $33, S p$ ). The breathing apertures are usually provided with a closing apparatus of some sort consisting of the swollen lips of slitlike spiracles, of a small lid, or of a flexible and collapsible chitinous ring, each with special occlusor muscles attached. In the bee a chitinous band surrounds the tracheal tube opening at each spiracle, a short distance from the aperture, and has two opposite loops projecting on the same side, connected by a muscle whose contraction approximates the two halves of the band so as to close the lumen of the trachea. ${ }^{a}$ It is supposed that after an inhalation the spiracles are closed momentarily, so that the first force of the expiratory contraction of the abdomen is exerted against the air shut in the tracher, with the result of driving it into the extreme tips of the latter-the spiracles then opening, the rest of the contraction is expended in exhalation.

The internal tracheal system consists, among insects generally, of a large tracheal trunk lying along each side of the body, connected by short tubes with the spiracles and by transverse commissures with each other, while they give off segmental branches into the body cavity which ramify minutely upon the organs and tissues. In the thorax specially large tubes are given off on each side to the legs and to the bases of the wings, while in the head others go to the eyes, antennæ, and montl parts. The whole body is thus virtually a lung with ten pairs of openings along the sides.

The tracheal system of the bee (figs. 1, 50, and 51) is best dereloped in the abdomen, where the longitudinal trunks are enlarged into two enormous lateral air sacs ( TraSc), which are of greatest diameter in the anterior end of the abdomen. They are segmentally connected by large transverse ventral commissures (fig. 51, TraCom), most of which are themselves distended into small air sacs. Dorsally the lateral sacs give off in each segment a large tube which divides into two sacculated branches (figs. 49 and 50, HtTraSc) that enter the pericardial chamber and supply the heart and pericardial cells with trachere. In the thorax a large sac lies on each side of the propodeum (figs. 1 and $50, \%)$, which bears a short tube opening to the first abdominal spiracle (figs. 21 and $50, I S p)$. Above these sacs is a narrow transver'se median one (figs. 1 and $50, \delta$ ) occupying the large cavity of the turgid mesoscutellum (fig. $21, S c l_{2}$ ). In the ventral part of the thorax there is a large median posterior sac (figs. 1, 50, and 51,5)

\footnotetext{
${ }^{a}$ For a detailed description of the spiracles in the bee and their occlusor apparatus see Djathchenko (1906).
} 


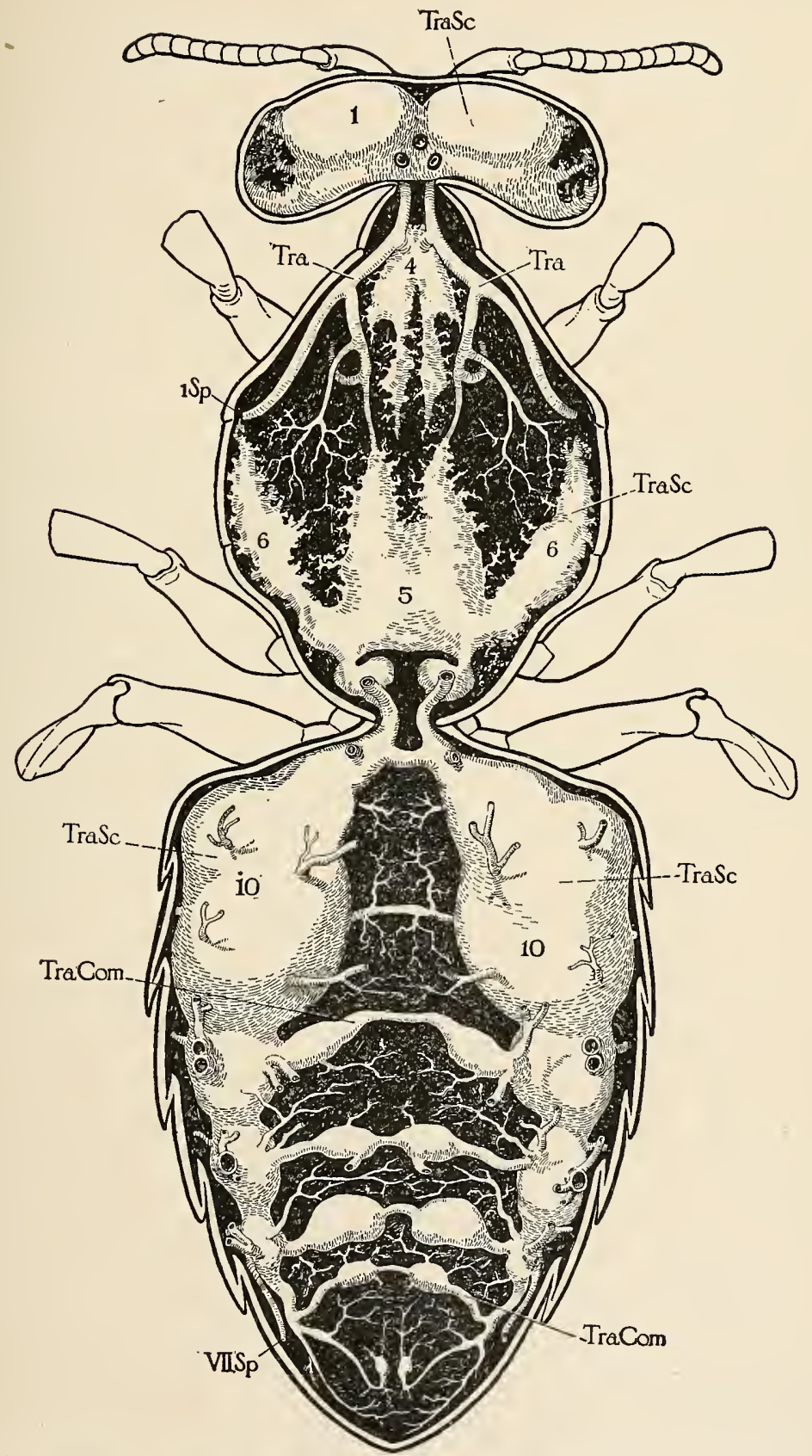

Fig. 51.-Tracheal system of worker showing lateral and ventral parts as seen from above, with dorsal saes and trunks removed in both thorax and abdomen. 
which gives off trunks to the middle and hind legs and a large sac on each side (fig. 51,6 and 6 ) to the rentro-lateral walls of the thorax. Two large strong tubes (figs. 1, 50, and 51, Tra) - the only trachea in the bee's body well dereloped as tubes-extend backward from the head throngh the neck and prothorax to the first thoracic spiracles (figs. 50 and $51,1 S p$ ). Each of these gives off a branch which divides into the trachea for the first leg and into another that connects with the posterior ventral thoracic sac (5). An anterior median thoracic sac (4) is connected with the two large anterior tubes near where these enter the neck. In the head are a number of large sacs which are situated above the brain (see figs. 1, 50, and 51,1), about the bases of the eyes and optic lobes (see figs. 1 and 50,2 ), and above the bases of the mandibles (see fig. 1, 3).

Nearly all of the tracher in the bee's body are excessively delicate and their walls mostly lack the spiral thickening that ordinarily holds a tracheal tube open. They are consequently very distensible and, when inflated, they show as opaque glistening white vessels, which, however, when empty, are extremely difficult or actually impossible to see. The smaller branches are so numerous and flabby in the thorax and the legs (fig. 1, LTra) that they appear to form everywhere meshworks or sheets of tiny glistening air-cavities imbedded between the muscle fibers. Only the large trunks in the anterior part of the thorax have the normal tracheal appearance.

The body of the bee is thus most abundantly aerated, probably more so than that of any other insect. The numerous large and small sacs form great storehonses of air-tanks containing reserve supplies of oxygen. They are not present for the purpose of lightening the weight of the body, because inflation with air does not decrease the weight of any object surrounded by air.

The respiratory morements are limited to the abdomen in the bee on accomnt of the solidity of the thorax. They vary a great deal according to the activity of the individual. While sitting quietly at the entrance of the hive or walking slowly about, bees usually exhibit almost no respiratory motion, only a very slight vibratory trembling of the abdomen being noticeable. Others that are walking hurriedly about lengthen and shorten the abdomen very perceptibly, the motion being specially pronounced at the tip. A bee that has just alighted after flying exhibits still more pronounced abdominal movements, not only a contraction and expansion but an upand-down motion as well. When a bee is becoming asphyxiated in a killing bottle the extension and contraction of the abdomen is most pronounced, although much slower than in the ordinary breathing movements.

The muscles of the abdomen that produce respiration have been described by Carlet (188t), who distinguishes seven different sets of 
them as follows: There are two dorsal sets: (1) The internal dorsal, going from the anterior edge of one tergum to the anterior edge of the next following tergum, and (2) the external dorsal, going from the lateral edge of one tergum to the corresponding edge of the following tergum. Both of these are expiratory, since their contractions bring the two segments together. On the sides are three sets: (3) The external oblique, going from the anterior edge of each tergim to the side of the corresponding sternum; (4) the internal oblique, crossing under the last from the anterior edge of each tergum to the side of the preceding sternum. These two sets are likewise expiratory, because their contractions approximate the terga and sterna. The third set of lateral muscles is (5) the transverse, lying between the orerlapping surfaces of each tergim and its corresponding sternum and being, therefore, inspiratory, because the contraction separates the terga and sterna. Finally, there are two sets of ventral muscles: (6) The external ventrals and the internal ventrals, forming a letter $M$ between the anterior edge of each sternum and the one following, and $(\tau)$ the interventral, situated between the overlapping surfaces of consecutive sterna and causing their separation by contraction. These last are therefore also inspiratory.

It would thus seem that the abdomen is much better equipped with expiratory than with inspiratory muscles. Perhaps the expansion is partly due to elasticity, and perhaps, also, it is true that the abdomen contracts upon the full trachea and air sacs, before the spiracles open to allow exhalation, in order to drive the air into the farthest recesses and terminal tubes of the tracheal system, which necessitates an extra contractive force.

\section{THE FAT BODY AND THE CENOCYTES.}

The fat tissue of insects is not miscellaneously distributed through the tissues, imbedded beneath the skin and packed between the muscles, but is disposed in sheets and strands within the body cavity, especially in the abdomen, or forms a definite mass, the fat body. The fat cells are large and extensively racuoled with clear globules of fatty oils. In some insects the fat bodies have a brilliant yellow, golden, or orange color. Associated with the fat cells are other much larger and often gigantic cells, called senocytes, attaining the largest size of all the cells in the body except the eggs. They were first discovered in segmental clusters attached to the tracheæ near the spiracles, but they are now known also to be scattered through the depths of the body cavity, where they occur imbedded especially between the fat cells. The term " onocyte" signi- 
fies merely that those cells first observed by Wielowiejski, who gave them this name, were slightly wine-colored.

Both the fat cells and the onocytes of the honey bee have been specially studied by Koschernikor (1900), who gives the history of the fat body as follows: In the larva it consists of gigantic lobes, the cells of which are in general all alike and so closely packed in 30 or more layers that, in the younger stages, most of them assume angular forms. Many of them are binucleate, and the protoplasm is strongly racuolated except for a small area about the nuclei. In the full-grown larve the fat cells become globular and filled with a number of round granules, which, during the early part of the pupal stage, are set free by a dissolution of the cell walls and float free in the body cavity. In pupæ a little older, having even but a very thin chitinous covering, the adult fat body is fully formed, and yet neither the disappearance of the larval gramules and nuclei nor the formation of new adult fat cells is to be observed. It seems that the granules of the larval fat cells, set free at the beginning of histolysis, are reassembled about the nuclei to form the fat cells of the adult. In the very young imago the cells of the fat body are very distinct, and each possesses a considerable amount of protoplasm, with enormous vacuoles which press upon all sides of the nucleus. In old bees the vacuolation is much reduced and may even be entirely lacking, while the cells become filled with a solid granular plasma. Old workers examined in the fall show the fat cells united into syncytia or masses in which the cell boundaries are lost, although the nuclei remain distinct. A queen does not appear to form these syncytia in old age.

The function of the fat body is still unsettled, but we do not know of any reason why it should not be comparable physiologically with the fat of vertebrate animals and constitute a reserve supply of materials which can be used both as food and as a source of heat oxidation. It has already been stated (p. 115) that insects maintain several degrees of body temperature. Some entomologists have supposed that the fat body gives rise to the corpuscles of the blood, others have believed it to be an excretory organ because concretions of uric-acid salts are often found associated with its cells, while still others have regarded it as the seat of the combustion of waste products by the tracheal oxygen.

The œnocytes of the bee are described by Koschernikor (1900) as enormous cells imbedded in the fat bodies. He says that those of the larva persist into the pupal stage where they undergo dissolution and disappear, while new imaginal onocytes are formed from proliferations of the ectodermal epithelium. The new ones are at 
first small and increase about five times in diameter before reaching their adult proportions. The fat cells and the onocytes, although closely associated with each other, are easily distinguishable by their size and by their reaction in life to staining solutions. Koschevnikov fed some bees honey or sugar sirup containing sesquichlorate of iron and then, after a few hours, removed the fat body, washed it in ferrocyanide of potassium, and placed it in alcohol acidulated with hydrochloric acid. He found a precipitate of Berlin blue in the fat cells while the œnocytes remained perfectly colorless. Thus he showed conclusively that the two classes of cells are physiologically different in life, although, he says, if a piece of dissected fat body be placed in the staining solution the color diffuses alike throughout all the cells.

The œnocytes have a golden brown pigmentation but no differentiated contents in young workers and queens. In old workers, toward the end of the summer, yellow granules begin to appear in them. During winter and especially in early spring the œnocytes of the workers contain a great number of these granules, but they are present in greatest quantity in queens several years old, while in the latter the fat cells also contain similar granules. Although Koschernikov admits that the chemistry of these granules is entirely unknown, he thinks that they are undoubtedly excretory substances, that the waste products of metabolism are first taken up by the onocytes and then delivered to the blood, and that the accumulation of the granules in the cells during old age means the loss of power to discharge them, which brings on the decline in the life activity of the bee. If this is so, then the œnocytes are, as he states, excretory organs without ducts-cells which serve as depositories for waste products.

According to this theory of Koschevnikov, the œnocytes might be likened in function to the liver of vertebrate animals, which, according to the present views of physiologists, is the seat of the splitting up of the immediate nitrogenous products of katabolism, discharged into the blood from the tissues, into those final compounds of nitrogen excreted by the kidneys.

Wheeler ${ }^{a}$ also describes the fat cells and onocytes of insects as perfectly distinct in their origins, the fat cells arising from the mesoderm, which is the embryonic cell layer between that which forms the outer body wall and that which forms the embryonic alimentary canal, while the œnocytes are derived from internal proliferations of ectodermal cells.

${ }^{a}$ Concerning the Blood Tissue of Insects. Psyche, VI, 1892, pp. 216-220, 233-236, 258-258, Pl. VII. 


\section{THE NERVOUS SYSTEMI AND THE EYES.}

We have learned so far that the bee is a complex animal made up of a large number of tissues and organs all definitely interrelated, and we speak of these tissues and organs as performing their own special functions. Yet, in itself, a mass of cells, even though a living mass, is incapable of doing anything-it is inert unless stimulated into action. The legs would not move, the heart would not beat, the glands would not secrete, the respiratory movements would not be produced, and the animal would cease to live were it not for a vital force that incites them all into activity. This force is generated by certain cells of the nervons system and is sent out to the other organs along the nerve cords, but we know nothing more about it than simply that it exists in living animals and is dependent upon the maintenance of the nerve cells.

Now, in order that an animal may be "alive," it is not only necessary that the muscles should be made to contract, the glands to secrete, and all the other organs induced to perform their individual rôles, but it is equally important that they should all work together and accomplish definite results. The muscles must perform harmonious movements to produce walking, flying, breathing, or swallowing, the heart must beat in proper rhythm, the glands must secrete their juices at the right time and in needed amounts. Hence, the functions both of stimulation and coordination derolve upon the nervous system. The nerve-cells generate a force which, delivered through the nervefibers to the various organs, irritates the tissues into activity, but, at the same time, the cells send out this force in such a methodical manner that the activities produced in the different organs are definitely correlated and cooperate in maintaining the necessary condition for the life of the cells.

The nervous system, however, is more than simply the source of these physical and chemical processes that constitute the visible phenomena of life, for it is also the seat of all sense perceptions and, in the higher animals, of consciousness. We do not know, however, that insects possess conscionsness-that they are actually aware of their own existence, and we therefore do not know that they have conscious sense perceptions. Tre do know that they are affected by external objects-by light, heat, taste, odor, pressure, and perhaps somd acting upon specially sensitized cells of the ectoderm called sense organs, but we do not know that the reaction of the individual is anything more than the exhibition of a very highly developed reflex nervons system. It is most probable that bees do all that they do-make the comb, store up honey and pollen, feed the young, attend to the wants of the queen, and so on-without knowing why, and we have no evidence that they are even conscious of the fact that they do 


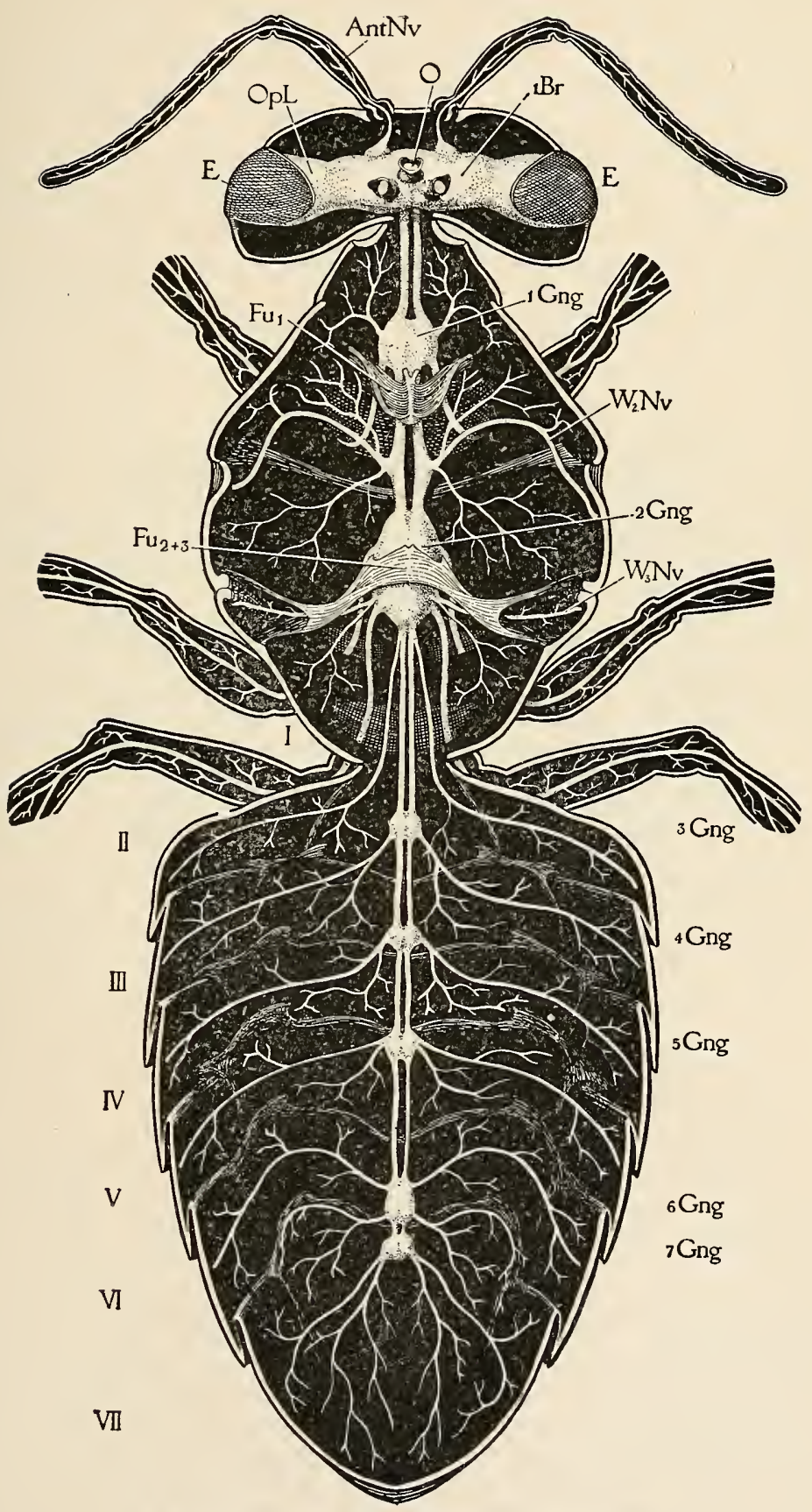

Fia. 52.-Nervous system of worker, dorsai view. 
these things. Some authors have tried to prove that insects reason, but the burden of proof is still with them. Te can admit that insects may be possessed of rery slight conscious intelligence, but we can not admit that any one has ever proved it. Of course, a great deal of very interesting insect literature owes its readableness to the fact that the author endows his subjects with human emotions and some intelligence, or makes it appear that they consciously do things from a blind sense of obligation. The bee of literature is often quite a different creature from the bee of science.

If, then, we are forced to admit that we have no proof of intelligence or of conscious sensations in insects, we have, on the other hand, all the more evidence of a very high degree of nervous coordination. The body of a bee can be very greatly mutilated and the creature will still remain "alive" as long as the nervous system is left intact. The segments can be cut apart and each will yet be able to move its appendages as long as its nerve center is not destroyed. This shows that there are numerous vigorous centers of nervous stimulation, but proper coordination results only when all the parts are together and intact.

The nervous system of insects (figs. 1 and 52) is comparatively simple, consisting of a series of small nerve masses called ganglia (Gng) lying along the mid-ventral line of the body, each two consecutive ganglia being connected by a pair of cords called the commissures. The ganglia contain the nerve cells, which are the source of the stimuli sent out to the other tissues, while they also receive the stimuli from the ectodermal sense organs. Thus there are incoming or afferent stimuli and outgoing or efferent stimuli. The commissures and the nerve-trunks that branch to all parts of the body consist of fibers which are fine prolongations of the nerve cells. These fibers are the electric wires that convey the stimuli to and from the nerve centers and are of two kinds, afferent and efferent, according to the direction of the stimulus each transports.

In a generalized embryo we should theoretically find a nerve ganglion developed from the ventral wall of each segment, making seven head ganglia, three thoracic, and at least ten abdominal ones. In the adult, however, many of these fuse with one another. In the head, for example, in place of seven ganglia there are only two, one situated above the osophagus, called the brain, and one situated below it and called the subosophageal ganglion. The connecting cords are konwn as the circumosophageal commissures. The brain is composed of three embryonic ganglia, and in the adults of many lower insects these are still evident as three well-marked cerebral divisions or swellings, called the protocerebrum, the deutocerebrum, and the tritocerebrum. The first carries the optic lobes and innervates the compound and simple eyes, the second bears 
two large antennal lobes, from which are given off the antennal nerves. The third innervates the lower part of the face and the labrum, while it gives off also a pair of nerves which unite in a small swelling, the frontal ganglion, that lies between the pharynx and the front of the head. A nerve runs posteriorly from this on the dorsal side of the pharynx or cesophagus to behind the brain, where it divides into several branches, some of which bear small ganglia while others extend backward on the osophagus to the stomach. These nerves, originating in the frontal ganglion, constitute the stomatogastric system, sometimes called also the "sympathetic system."

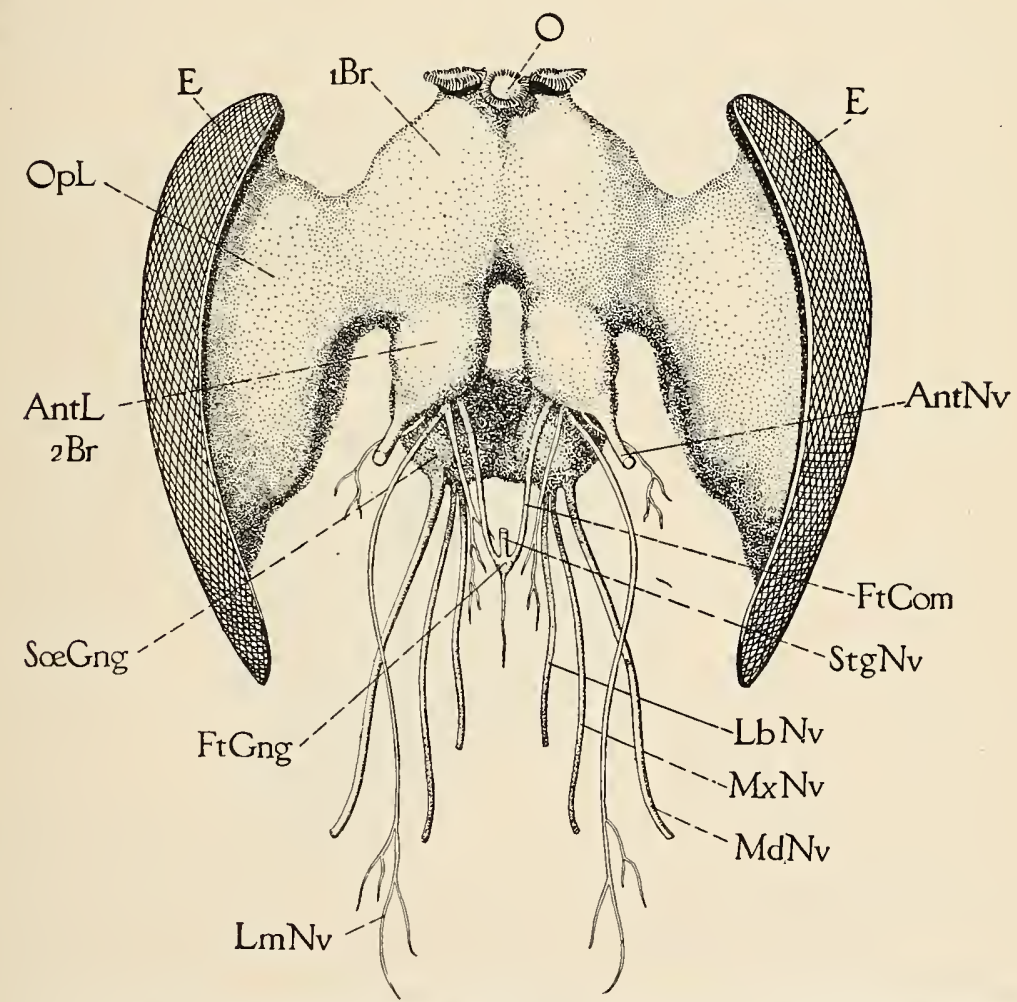

FIG. 53.-Brain and subcesophageal ganglion of worker and their principal nerves, anterior view.

The subosophageal ganglion consists of at most four ganglia which innervate the mandibles, the hypopharynx, the first maxilla, and the labium or second maxilla. In adult insects the body ganglia also very commonly fuse with one another in rarying combinations, for the number present is always less than the number of segments, varying from eleven to one.

The brain of the bee (fig. $53, \mathrm{Br}^{2}$ ) is distinctly composed of two parts, the protocerebrum $(1 \mathrm{Br})$, carrying the large optic lobes $(O \mathrm{pL})$, and the deutocerebrum $(2 B r)$, which consists principally of the con- 
spicuous antennal lobes $(A n t L)$ that give off the large antennal nerves $(A n t N v)$. The tritoeerebrum is not present as a distinct brain division, and its nerves, the labral $(\mathrm{LmNv})$ and the frontal (FtCom), appear to arise from the dentocerebrum at the base of the antennal lobes. The frontal ganglion (FtGng), formed at the union of the two frontal nerves, gives off a very small, anterior, median nerve and a much larger, posterior, stomatogastrie trunk ( $S \operatorname{tg} \mathrm{N}_{\imath}$, represented in the drawing as cut off a short distanee behind the frontal ganglion) which goes baekward on the dorsal side of the pharynx beneath the brain. Behind the latter, and just where the pharynx contracts to the tubular osophagus, the stomatogastric nerve bears a pair of small ganglia which are connected by short nerves with the brain, and then it breaks up into branches that go posteriorly along the oesophagus but have not been traced.

The circumœsophageal commissures are so short in the bee that the subœsophageal ganglion appears to be attached directly to the lower ends of the brain, while the cesophagus appears to penetrate the latter between the antennal lobes. The three principal pairs of nerves from the lower ganglion $(M d N v, M x N v$, and $L b V v)$ go to the mouth parts.

A most thorough study of the internal structure of the brain of the bee has been made by Kenyon (1896), to whose paper the reader is referred if interested in this subjeet. Kenyon's descriptions have never been verified, but his work has an appear'ance of thoroughness and carefulness. He applies the term "brain" to both of the nerve masses of the head, distinguishing the upper as the "dorsocerebrum" and the lower as the "ventrocerebrum," being led to do this from physiological eonsiderations, the separation of the two being merely incidental to the passage of the osophagus.

In the thorax of the bee (figs. 1 and 52) there are two large ganglia ( $1 G n g$ and $2 G n g$ ). The first is prothoracic, being situated above the prosternum, in front of the entosternum (fig. 52, $F u_{1}$ ), and it innervates the prothorax and the first pair of legs. The seeond, which is situated in front of the middle legs and is proteeted above by the arch of the common entosternum of the mesothorax and metathorax (fig. 52, $F u_{2_{+3}}$ ), is a combination of the mesothoracie and metathoracic ganglia and the first two abdominal ganglia. This composite structure is evident from the fact that it innervates both the middle and the hind legs, the bases of both pairs of wings, the mesothorax, the metathorax, the propodeum, and the first abdominal segment behind the constriction (the true second segment). The first and seeond ganglia of the abdomen (fig. 52, $3 G n g$ and $4 G n g$ ) lie in the first two segments (II and $I I I$ ) behind the eonstrietion, which are the true second and third segments. But since the nerve trunks of these ganglia go, in each case, to the segments behind them, we 
assume that they really belong to these latter segments, that is, to segments $I I I$ and $I V$. The next three ganglia (5Gng, GGng, and $\left.{ }^{\prime} G n g\right)$ lie in the segments they innervate $(V, V I$, and $V I I)$ and, hence, belong to the fifth, sixth, and seventh abdominal segments. The last, that is, the seventh ganglion, supplies all of the segments behind it with nerves and is therefore probably a compound of the ganglia originally belonging to the seventh, eighth, ninth, and tenth segments.

In connection with the nervous system it is most convenient to give a description of the simple and compound eyes. The other

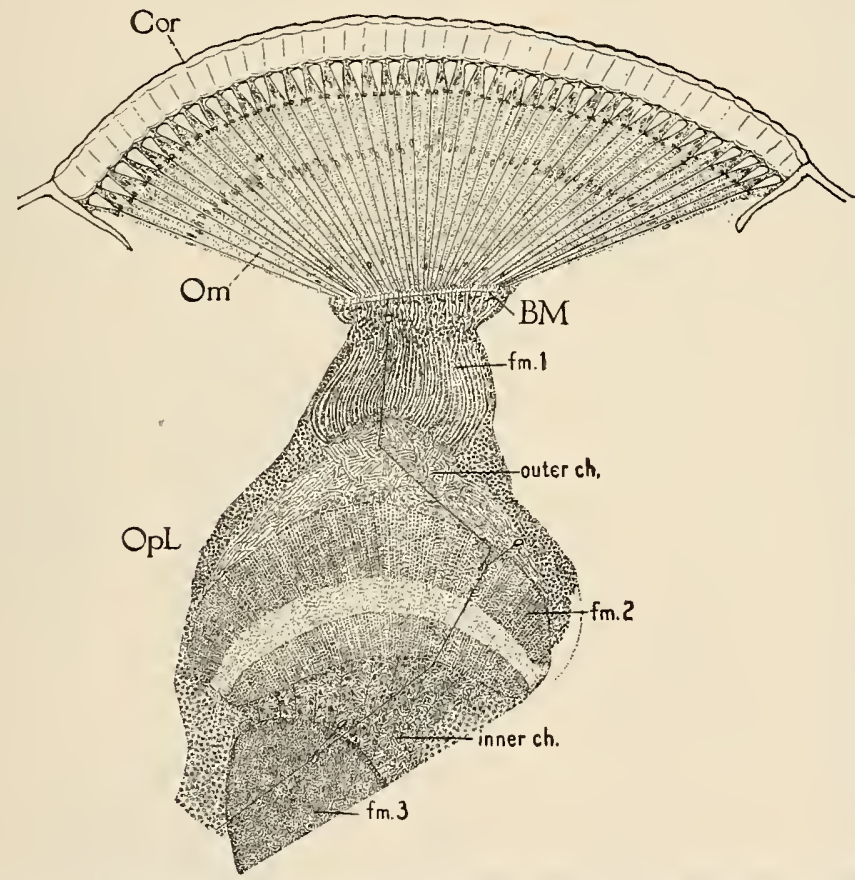

Fig. 54.-Horizontal section of compound eye and optic lobe of worker (after Phillips) : $B M$, basement membrane; Cor, cornea; $f m_{1}, f m_{2}, f m_{3}$, outer, middle, and inner fibrillar bodies of optic lobe; inner $\mathrm{ch}$, inner chiasma; Om, ommatidium; OpL, optic lobe ; outer $c h$, outer chiasma.

sense organs will be found already described along with the parts on which they are located (see pp. 36 and 52). All the sense organs, to be sure, are of ectodermal formation and are only secondarily connected with the nervous system, but the eyes are so intimately associated with the optic lobes of the brain that their description here seems most appropriate.

The compound eye of the bee (figs. $9 \mathrm{~A}, 10,52$, and $53, E$ ) has been specially studied by Phillips (1905) and figures 54 and 55 are reproduced from his drawings, while the following statements are based on his paper: The convex outer surface or cornea of the eye 
presents a honeycomb appearance inder the microscope, and each little hexagonal facet is the outer end of an eye tube called an omma-
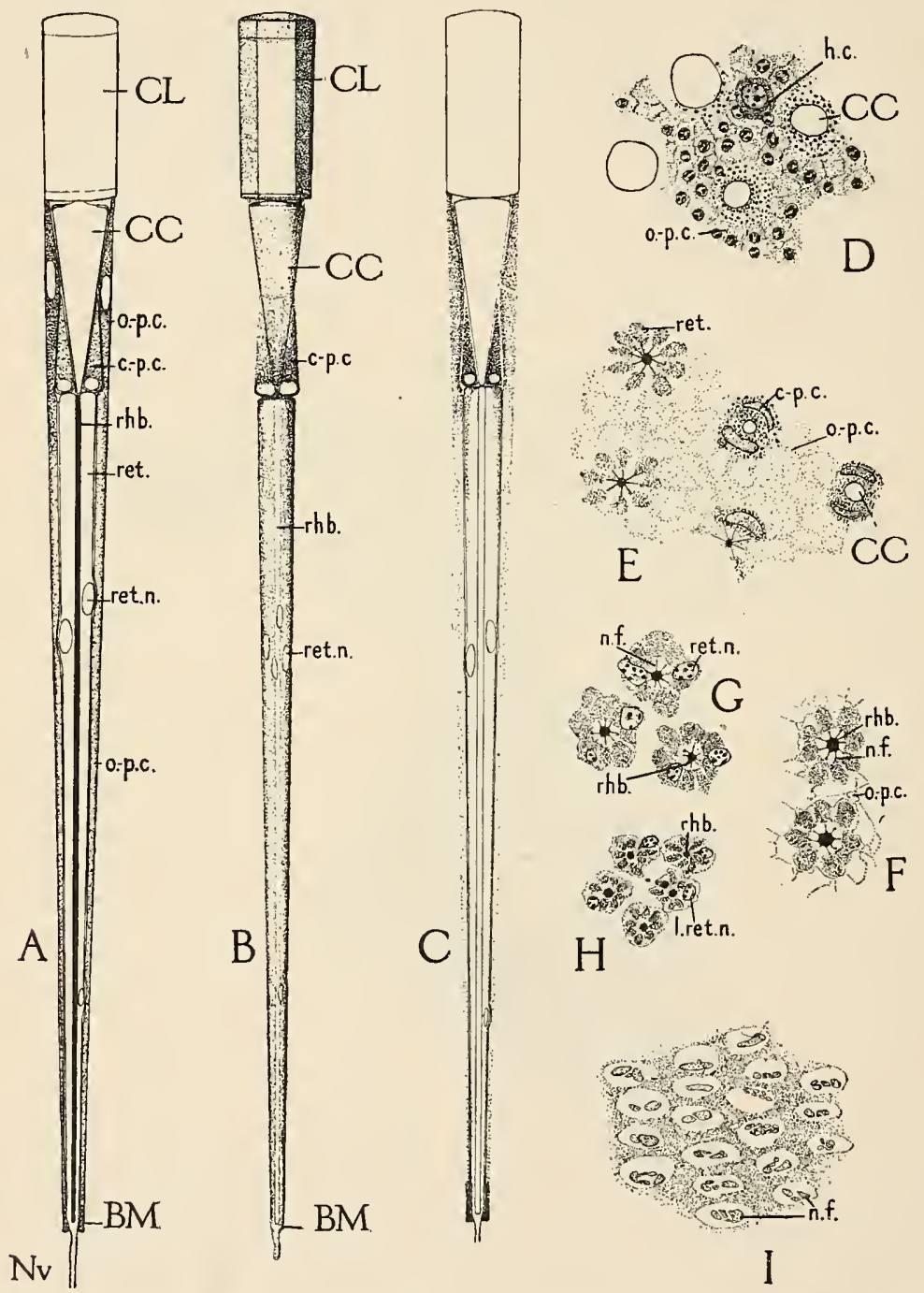

FIG. 55.--llistological detaits of compound eye of worker (after Phillips) : $\Lambda$, entire ommatidlum (somewhat diagrammatic), adult; $B$, entire ommatidium, as if dissected out, without outer pigment cells (diagrammatic), adult; C, section of entire ommatidium, showing distribution of pigment, adult; D, cross section just proximal to lens, slightly oblique; $\mathrm{L}$, cross section through extreme distal ends of retinula and proximal ends of cones, slightly oblique; $F$, cross section through retinulæ, showing relation of outer pigment cells in this region; $G$, cross section through retinulæ in region of nuclei; $\boldsymbol{H}$, cross section througl retinulæ in region of proximal nucleus: $\mathbf{I}$, cross section of eye, eutting basement membrane parallel (the distinctuess of nerve fibers of each ommatidium is shown): $B M$, basement membrane; $C C$, crystalline cone ; $C L$, crystalline lens; c.-p.c., corneal pigment cell; $7 . c$. , hair-cell ; 7.ret.n., lower retinular nucleus; $n . f$. nerve fiber ; $N$ r, nerve ; o.-p.c., outer pigment cell ; ret, retimula ; ret.n., retinular nucleus; $r h b$, rhabdome.

tidium, all of which converge toward the internal base of the eye, since each is vertical to the outer surface. Figure $5 t$ is a horizontal 
section through the eye and the optic lobe of the brain. The ommatidia $(O m)$ are seen converging upon the basement membrane $(B M)$ which is penetrated by the nerve fibers from the optic lobe $(O p L)$. The outer ends of the ommatidia are transparent, forming the facets which together constitute the cornea ( $C O r$ ) of the eye. The nerve fibers, by a complicated course through the optic lobe, reach the nerve cells of the brain, which are the true seat of sight perception, as of all other sensations, whether conscious or otherwise.

The ommatidia $(\mathrm{Om})$, or eye tubes, are separated from one another by cells containing a dark coloring matter and known as the pigment cells. Each tube (fig. $55 \mathrm{~A}$ ) consists of several parts, as follows: First, on the outside, is a clear six-sided, prismatic structure, with convex outer and inner surfaces, called the crystalline lens $(C L)$, and which forms one of the facets of the cornea. Beneath the lens is a crystalline cone $(C C)$ having its apex directed inward and followed by a crystalline rod or rhabdome ( $r h b)$ which extends to the basement membrane $(B M)$ through the middle of the ommatidium. (The rhabdome is represented black for the sake of distinctness in figure $55 \mathrm{~A}$; its natural appearance is more as shown in B and C.) Surrounding the rod is a circle of eight or nine long retinule cells (ret), each containing a conspicuous nucleus (ret. n) above its middle and continuing basally into an optic nerve fiber $\left(\mathrm{I}^{\prime} \mathrm{c}\right)$ penetrating the basement membrane. The arrangement of these cells about the rhabdome is shown in cross section at $\mathrm{F}$ and $\mathrm{G}$. The inverted apex of the crystalline cone $(\mathrm{A}, \mathrm{B}$, and $\mathrm{C}, C C)$ is surrounded by the corneal pigment cells $(c .-p . c$. $)$, while the entire ommatidium below the lens-the base of the cone, the corneal pigment cells, and the retinulæ-is surrounded by the long outer pigment cells (o.-p. c.), forming a packing between all the ommatidia, as shown in cross section at $\mathrm{E}$.

The entire compound eye is simply a modified part of the epidermis (so-called "hypodermis" of insect histologists) in which the cuticle is transformed into the lenses or cornea, the cones, and the rods, the epithelium into the pigment and retinula cells, and the basement membrane into the floor of the eye perforated by the optic nerve fibers. According to Phillips the ommatidia arise from the ectoderm of the bee larva as groups of epithelial cells which become arranged in the form of spindles surrounded by smaller cells. The cells of the spindles become the retinulæ, while the surrounding small cells become the pigment cells and the cone cells. The cone cells come to occupy a position external to the retinule by an invagination of the latter, and, through a transformation of most of their protoplasm into a crystalline substance, they form the crystalline cone of the eventual ommatidium. The approximated edges of the retinulæ cells are 221S1-No. 1S-10-9 
transformed into the crystalline rod. The cornea is secreted by the corneal pigment cells, which at first lie distal to the cone, and possibly also by the outer pigment cells. The nerve fibers are formed as differentiated parts of the retinula which penetrate throngh the basement membrane (fig. 54, B.II) and enter the retinular ganglion beneath it at the onter end of the optic lobe of the brain. Hence the retinula are simply sense end-organs of the skin comparable at an early stage of their development with other sensory epidermal cells, and we thus see how a simple layer of epithelium may be transformed into such an immensely complex organ as the compound eye.

There has always been a great deal of discussion as to how insects see by means of the compound eyes. The weight of opinion now favors the theory that they see a part of the object or field of vision with each ommatidium. But it is most certain that, at best, most insects see very indistinctly, and, in fact, it is often questioned whether they really see the shape of objects at all or not. A few of them, however, such as dragonflies, appear to have a very acute vision. In the case of the honey bee there is yet much difference of opinion as to whether the workers discover nectar by the bright color of the flowers (i. e., by the sense of sight) or by the sense of smell. The sense of sight in bees and in insects generally. howerer, may be found elaborately discussed in many books dealing with the senses of insects.

The simple eyes or ocelli (figs. $9 \mathrm{~A}, 10,52$, and 53,0 ) are constructed on quite a different plan from that of the compound eyes, each consisting of a lenslike thickening of the cuticle back of which the epithelial cells are specially elongated, and sensitized by nerve connections. The ocelli of the bee, however, have never been carefully studied.

\section{THE REPRODUCTIVE SYSTEM.}

The reproductive organs are those that produce the cells from which new individuals are formed. All animals grow from at least one cell called the egg and almost all from a combination of the egg. with another cell called a spermatosoon. The uniting of these two cells is called the fertilization of the egg. In a few animals the two different kinds of reproductive cells are formed in the same individual, but in most of them, including all insects, the sperm and the eggs are produced in different individnals-the males and the females. In the honey bee the males are called drones, while the females are called queens or workers, according to their functions in the hive. The queens have the egg-producing organs or oraries greatly developed, while these organs are rudimentary in the workers. The single active queen in each hive, therefore, normally produces all the eggs of the colony, while the work of rearing and providing for the brood 
falls to the lot of the workers. Most other female insects lay their eggs at some place where the young will be able to find food when they hatch out, and the mother never in any way feeds or protects her offspring; in most cases she dies before her brood emerges from the eggs. But the wasps and bees are different in that nearly all of them make a nest of some sort for the protection of the young larve when they hatch, in which also they store up food for them to eat. In many species of wild bees all the work of constructing the nest, laying the eggs, and collecting and storing food for the young devolves upon the single female, as it naturally should, since insects do not ordinarily have servants, and the males of most species are utterly irresponsible in such matters. In some of the higher wasps, such as the hornets and yellow jackets, however, the first females that hatch out as adults in the spring help their mother provide for a still larger family by increasing the size of the house and collecting more provisions. Nature designed them for this purpose, moreover, by making them all sterile, allowing them to retain the maternal instincts, but depriving them of organs capable of producing offspring of their own. Thus there is here a beginning of that division of labor which reaches its highest development in the honey bee, where one form of the female is specialized entirely to produce the young and the other to rear the brood, keep the home in order, gather the food, and ward off enemies. The differences between the queens and the worker's are supposed to result from the different diet on which larvæ designed to be queens are brought up, but a more thorough investigation of the food given to the different larva of the brood is yet needed before we can decide on the merits of this explanation. The work of numerous investigators seems to have demonstrated conclusirely that the drone of the honey bee is always produced from an egg cell alonethat is, from an unfertilized egg-while the queens and workers are produced from fertilized eggs. The production of eggs that develop normally without the addition of the male element is called parthenogenesis. In a number of insects, such as some species of scales, a few beetles, and some of the gall-forming Hymenoptera, there are no males known, although the females are extremely abundant. Such cases are often regarded by entomologists as examples of parthenogenesis, and, if they are such, the result of the development of unfertilized eggs is here the formation of females only. A few other insects, snch as some of the plant lice, produce eggs that develop without fertilization into females or into both males and females, but such cases nearly always occur in a cycle of alternating generations in which, at some stage, all the eggs are fertilized. As far as is known the production of males alone from parthenogenetic eggs is confined to the order Hymenoptera. 


\section{THE MALE ORGANS.}

The reproductive organs of the drone are shown by figure $56 \mathrm{~A}$. They consist of the testes (Tes), the vasa deferentia (VDef), the vesiculce seminales (Ves), the accessory or mucous glands (AcGl), the ductus ejaculatorius ( $E j D)$, and the penis (Pen).

The testes of the bee ( $\mathrm{Tes}$ ) are said to be best developed in the pupa, at which stage they form the spermatozoa. Each consists of a large number of small tubules opening into a collecting reservoir at the end of the vas deferens. The spermatozoa pass down through the coiled vas deferens ( VDef) and collect in the saclike enlargement of this duct, which constitutes the vesicula seminalis ( $V e s)$. In the mature adult drone these elongate sacs are densely packed with the active spermatozoa, while the testes that produced them become rudimentary. The vesiculie when freshly dissected appear to be alive, for they bend and twist themselves about like small worms. Each opens by a short duct into the base of the accessory mucous gland ( $A c G l$ ) of the same side. These organs have the form of two great sacs and are filled with a thick, white, homogeneous, finely granular liquid, which is supposed to mix with the spermatozoa as the latter are discharged. The two open at the bases into the single median ejaculatory duct $(E j D)$ which opens into the anterior end of the penis $(P e n)$. This last organ, shown in lateral view by figure $56 \mathrm{E}$, is an unusually large structure in the bee and is deeply inraginated into the cavity of the abdomen from the end of the ninth segment (D, Pen) as already described (see page 73 ). While the penis is simply an ectodermal tube, its walls present a number of very curious differentiations. The upper part is enlarged into a bulb (fig. $56 \mathrm{~A}$ and $\mathrm{E}, B$ and $\operatorname{Pen} B$ ) having two large irregular but symmetrical chitinons plates $(t t)$ in its dorsal wall, beneath which is a large gelatinous thickening (B, ss). Near the base of the bulb is a double pinnate lobe (A and $\mathrm{E}, u u$ ) projecting from the dorsal wall. Below this, on the rentral side, is a series of close-set, transverse plates $(\mathrm{E}, v v)$, followed again by large dorsal and rentral plates $(w w$ and $x x$ ). The terminal part makes a thin-walled chamber (A and $\mathrm{E}, y y$ ), from which project backward two very large membranous ponches (z:z) ending in blunt points. The whole tube of the penis is capable of being turned inside ont, and it is said that copulation is effected by its eversion into the oviduct of the queen, the basal pouches of the penis (zz) being forced into corresponding ponches of the oviduct, and the spermatozoa in the bulb placed near the opening of the spermatheca in the vagina. By their own actirity probably the spermatozoa now make their way up into this receptacle of the female, the spermatheca, where they remain until ejected upon eggs passing down the oviduct. The spermatozoa received from one drone normally last the queen 


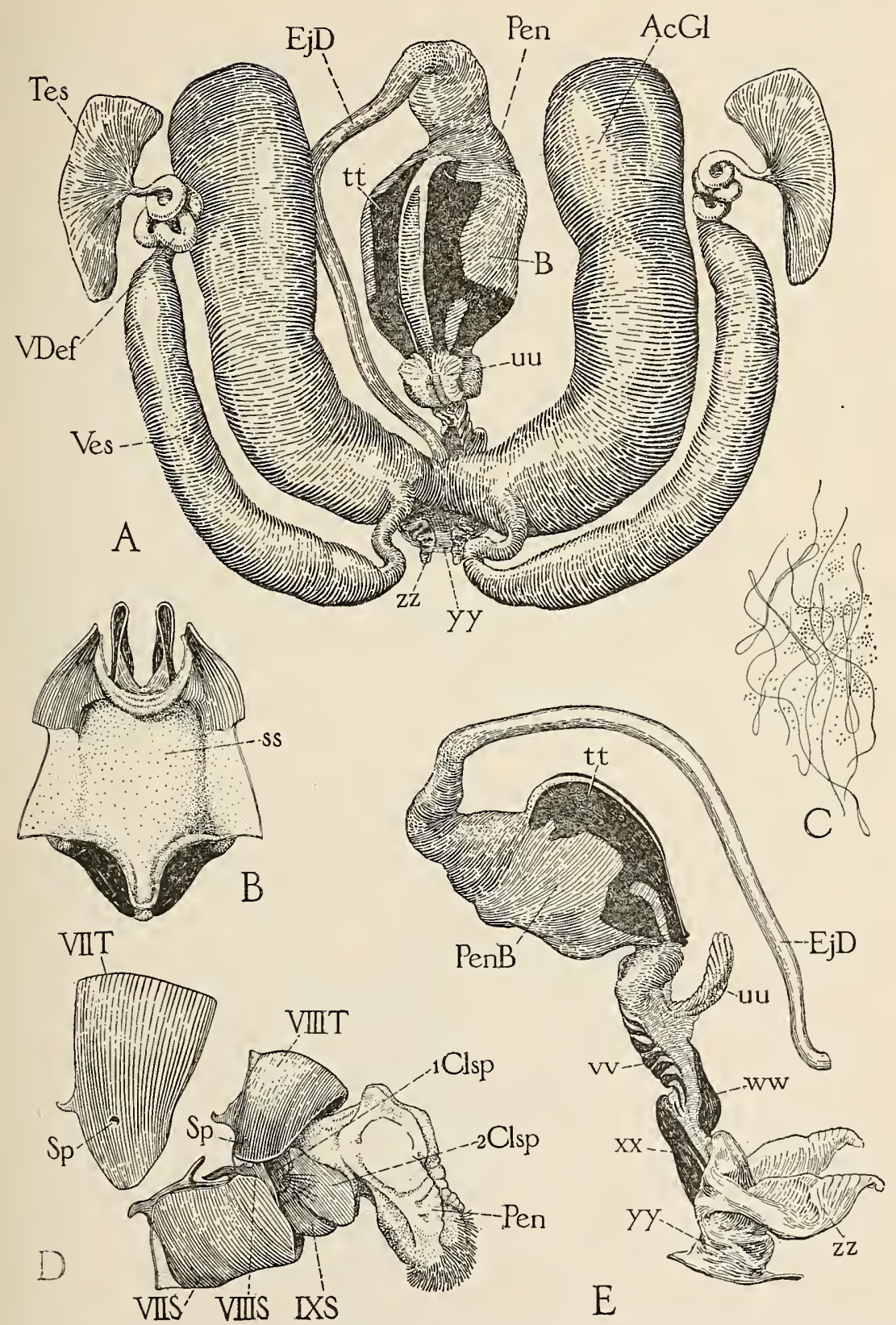

FIG, 56-A, reproductive organs of drone, dorsal view, natural position; $\mathrm{B}$, inner surface of dorsal wall of bulb of penis $(\mathrm{E}, \operatorname{PenB})$, showing gelatinous thickening $(s s)$; $\mathrm{C}$, group of spermatozoa and intermixed granules; D, terminal segments of male abdomen, showing the seventh tergum (VIIT) removed from its sternum (VIIS) and the penis $(P e n)$ partly protruded; E, lateral view of penis as invaginated within abdomen, and ejaculatory duct $(E j D)$. 
throughout her life, so that after mating she goes into the hive never again to emerge except with a swarm, and her entire life is devoted to egg laying. The drone, on the other hand, dies immediately after mating, while those that do not mate are driven out of the hive in the fall and left to starve.

The spermatozoa (fig. $56 \mathrm{C}$ ) are minute threadlike cells, capable of a vibratory motion. As found in the resiculæ, they are usually bent into closely compressed loops, although many are extended to their entire length. One end is blunt, but not noticeably enlarged, the other is tapering, while the half toward the tapering end seems to be the part chiefly endowed with the power of motion. The sperm threads are contained in a liquid within the vesicula, in which float also a great number of minute granules. The vibrations of the spermatozoa keep these granules in constant motion.

\section{THE FEMILE ORGANS.}

The organs of the female that produce the eggs are called the ovaries (fig. 57, Ov). In insects they consist of a varying number of egg tubules or ovarioles $(o v)$ forming two lateral groups, in each of which the tubules converge at both ends, the anterior ends being drawn out into fine threads whose tips are connected, while the posterior ends are widened and open into the anterior end of the oviduct $(O v D)$ on the same side of the body. An egg is simply a very large cell whose size is due to the great accumulation of yolk in its protoplasm, which serves as food for the future embryo. The eggs are formed in the terminal threads of the ovarioles and are at first apparently ordinary undifferentiated cells, but as they pass downward in the tubule they increase in size at the expense of some of the other ovarian cells. Hence the ovarioles usually have the form of a string of beads arranged in a graded series from very tiny ones at the upper end to others the size of the mature egg at the lower end. The two oviducts converge posteriorly and unite into the common median duct or vagina ( $\mathrm{Vag}$ ) which in most insects opens to the exterior upon the eighth sternum, as already described in the general account of the external anatomy of insects (see page 25 ), but in the bee and many other insects the eighth sternum is entirely lacking as a distinct sclerite, and the genital opening is therefore behind the seventh sternum and below the base of the sting. The posterior part of the vagina is very large, forming a bursa copulatrix $(B C p x)$. In addition to these parts there is nearly always present in insects a special receptacle for the spermatozoa called the spermatheca $(S p m)$. This, in most insects, opens directly into the vagina as it does in the bee, but in some it opens into the roof of the genital chamber above the eighth sternum, when this is present, by a separate orifice behind that of the 


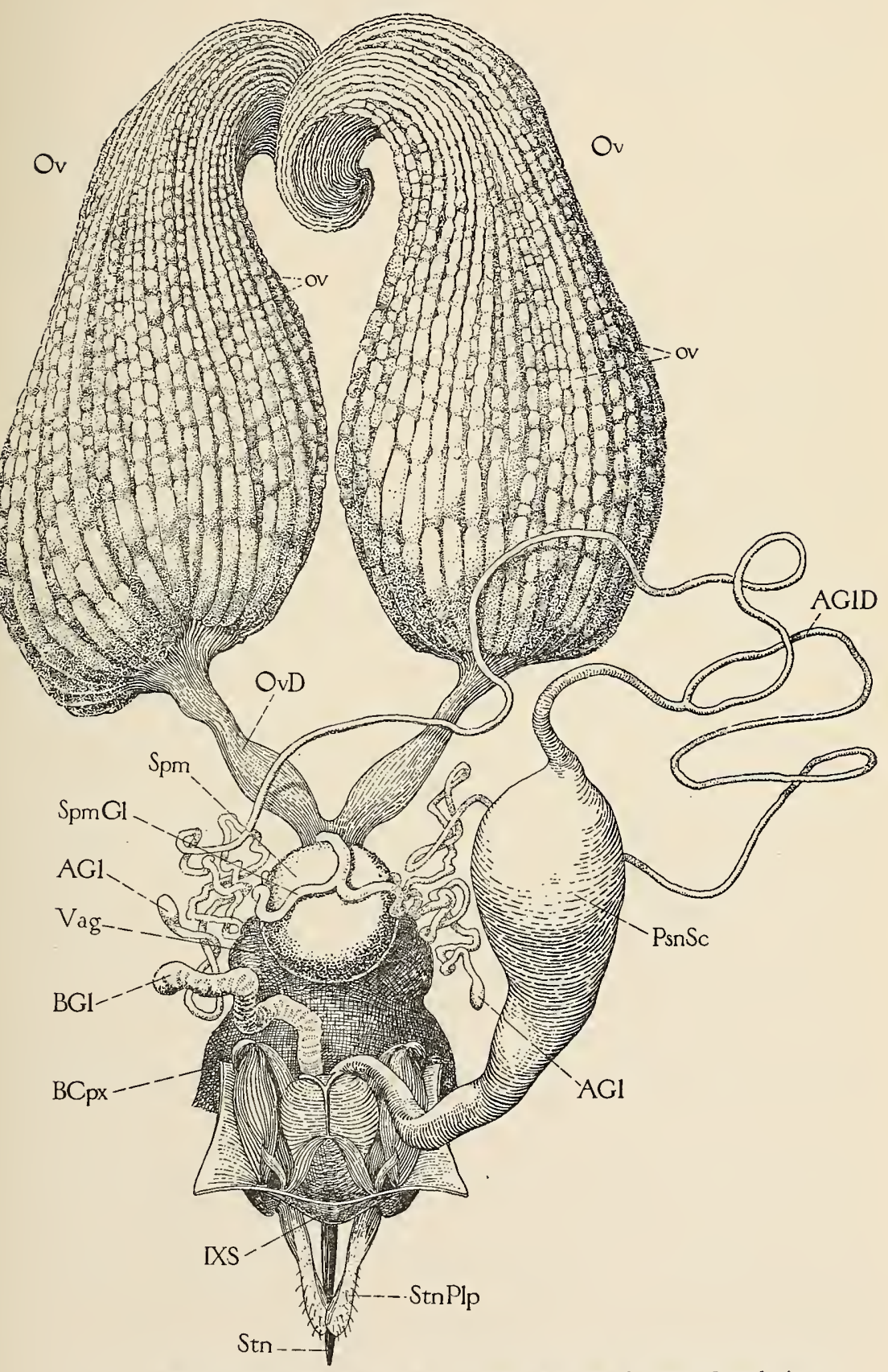

FIG. 57.-Reproductive organs, sting, and poison glands of queen, dorsal view. 
vagina. In the bee the two poison glands ( $A G l$ and $B G l$ ) do not open into the ragina but, as already described, into the base of the sting. They are, hence, probably special organs having no homologues in nonstinging insects.

The ovaries of the queen bee form two large gourd-shaped masses (fig. 57, Ov) whose posterior or basal ends are enlarged and whose anterior ends are narrowed, curved, and attached to each other. Since the queen lays eggs continuously during her entire life the ovaries always contain eggs in all stages of growth, and consequently do not vary so much in appearance as they do in those insects that ripen only one lot of eggs and deposit these all at one time.

The structure of the ovarioles and the formation of the eggs in the bee have been specially studied by Paulcke (1900) and the following is a résumé of his paper: The terminal threads of the ovarioles are covered by a thin tunica propria and are filled with a protoplasmic mass containing transversely elongate nuclei in a single close series, but no cell outlines. Fanther down, in the upper end of the ovariole proper, the nuclei become arranged in two rows, while here also the cell boundaries begin to appear; still farther along, where the cells are clearly defined, the latter become differentiated into epithelial cells and germ cells. Next, the germ cells themselves divide into egg cells and food or nurse cells. When first formed the egg cells occur in any part of the diameter of the tube, but they soon become arranged in a low down the middle of the ovariole and are separated by groups of nurse cells. The epithelial cells at this time arrange themselves on the periphery just within the tunica propria, but farther down they form a capsule or follicle about the egg and, less definitely, about the group of nurse cells at its upper end. The upper end of the egg becomes narrowed by a constriction of the epithelial capsule, which, however, does not shut it off from the nurse cells, a connection being retained with the latter in the form of a neck from the egg abutting against them. There are 48 of these nurse cells to each egg, which fact is accounted for by supposing that each original germ cell divides into 4 , one of which ceases further division and becomes the egg cell, while each of the other 3 divides into 16 by four consecutive divisions. The latter are the nurse cells and their function is to nourish the egg cells. They persist down to the time when the egg is fully formed, when they suddenly disappear by being absorbed bodily into its yolk. Toward the end of the growth of the egg the follicle cells become thinner and thinner, so that when the egg is ready to go into the oviduct it has but a thin membrane to break through.

The organs of most especial interest to the student of the bee are the spermatheca and the apparatus by means of which the queen is able to dole out the spermatozoa to the eggs as she deposits the latter. 
The spermatheca consists of a globular seminal sac (fig. $57, S \mathrm{pm}$ ), of a pair of tubular accessory glands $(S p m G l)$, and of a duet whose upper end is connected with the sac and receives also the duct of the glands, and whose lower end opens into the anterior part of the dorsal wall of the ragina just caudad of the united bases of the oviducts.

The spermatozoa are discharged by the male into the upper end of the vagina, and in some manner they make their way up into the sperm sac through the duct. Cheshire (1885) described the latter as forking toward its lower end into an anterior branch which opens into the vagina and into a posterior branch which turns backward and becomes lost in the lower end of the raginal wall. This second branch he believes is open in the young queen and is the one throngh which the spermatozoa enter the sac. Breslau (1906) has shown, however, that Cheshire was entirely wrong in his supposed observation of the forking of the duct. that the latter is a single tube, and that consequently the spermatozoa must both enter and leave the sac by the same conduit. It used to be supposed that the sperm sac had muscular walls and that it forced the spermatozoa out as from a compressed bulb, but Breslau has shown that this also is a mistaken notion, that the walls of the sac are entirely devoid of muscular fibers, and that the spermatozoa are sucked out by a muscular apparatus in the wall of the duct, which structure he names the sperm pump. Cheshire (1885) had previously described this apparatus in a very imperfect manner without recognizing any pumping function, for he supposed that by the relaxation of certain muscles the spermatozoa simply passed out of the sac and went down the tube. Breslau says, however, that the spermatozoa have not enough energy of their own to come out of the sac and, hence, do not need to be kept in by a special sphincter muscle, as described by Leydig.

The upper end of the spermatheeal duct makes an S-shaped bend just beyond the opening of the sac, and a number of muscles disposed upon this part constitute Breslau's sperm-pump. Breslau shows that a contraction of certain of these muscles flattens the bend of the $\mathbf{S}$ and causes an enlargement of the lumen of the upper end of the loop. This, therefore, sucks into itself a small bundle of spermatozoa from the sac. The contraction then of other muscles forces the rest of the sperm-threads back into the mouth of the sac and drives the small bundle thus cut off down through the duct and into the vagina. Moreover, Breslau claims that this explanation is not theory only, for, by preparing histological sections from queens killed at different moments of egg-laying, he procured specimens showing the various stages in the pumping process and in the passage of the sperm throngh the duct. Cheshire calculated that a normal queen lays 1,500,000 eggs in her lifetime and that the spermatheca 
holds about 4,000,000 spermatozoa, and therefore, allowing for drones, he concludes that there can not be more than four sperm-threads given to each female egg. But Breslau, figuring from the size of the spermbundle taken into the duct for each egg, states that each egg is actually given 75 to 100 spermatozoa. We feel that the latter calculation must be much more reliable than that of Cheshire because it is based on an actual observation of the size of the sperm mass delivered to the egg. Moreover, the myriads and myriads of tiny spermatozoa contained in the spermathecal sac make any attempt at a calculation of the number look absurd, and we can not believe that it is possible to even approximate the number present. Furthermore, as Breslau states, 100 spermatozoa make such an excessively small bundle that it requires a most effective and perfect apparatus to deliver even this number with anything like exactness-it is inconceivable that a mechanism could be perfect enough to give out only 4 or 5 or even 7 at a time.

On the floor of the vagina, opposite the opening of the spermathecal duct, is a free flap provided with muscles, which is so situated that when elevated its end fits into the opening of the duct above. Leuckart (1858) explained this flap as a contrivance for holding the passing egg tight against the upper vaginal wall so that its aperture through which the spermatozoa is received, called the micropyle, would come against the opening of the duct and thus insure fertilization. Breslau, on the other hand, does not think the flap in question has any such function and he regards it as a valve which by fitting into the orifice of the spermathecal duct closes the latter and so prevents the pump from sucking up the contents of the vagina at the same time that it sucks a bundle of spermatozoa out of the sac. Since, however, the flap is on the floor of the vagina and is pressed down by the passing egg it is not clear how it can at such a time act as a valve to close the orifice of the duct in the dorsal wall, since the pump is supposed to work by reflex action as the egg is entering the vagina, though, of course, it may so function before the egg has gone far enough to interrene between it and the duct opening; but it would certainly seem that a valve to close the latter, if needed at all, would be developed in the dorsal wall of the vagina in connection with the orifice itself. Furthermore, a collapsible tube like the spermathecal duct. even though lined with chitin, should automatically close at its lower end when a suction force is applied at the upper end.

Finally, Breslau attributes to the sperm pump not only the function of delivering a definite mass of spermatozoa to each egg, but also that of sucking the spermatozoa up from the vagina of a newly fertilized queen into the spermathecal sac. He does not seem now to see in the ralre any obstacle to such an action. The spermatozoa are usually supposed to make their way up the duct by their own vibratory motion. 
The anatomy of the spermatheca and the muscular apparatus of its duct for delivering the spermatozoa to the egg does not, as Breslau points out, throw any light on the determination of sex in bees. It is a common notion that all eggs of an unfertilized female develop into drones, but this is by no means proved; in fact, there is just as good reason for believing that, while no females develop, there are also no more than the normal number of drones produced-the eggs that might otherwise have developed into females, if laid by a fertile queen, all dying in the cells of the comb, from which they are removed by the workers. Modern investigation of the determination of sex shows that there is probably just as much reason in many cases for supposing that sex is established in the egg of the ovary before fertilization, as there is for believing it to result from fertilization or from subsequent environment of the egg or young embryo. Hence, it is not only very doubtful that the queen determines the sex of her offspring by controlling the fertilization of the eggs, but it is also very uncertain that fertilization itself has anything to do with it. Parthenogenesis in the bee may amount simply to this, that the male eggs, predetermined as such in the ovary, are capable of developing without fertilization, while the female eggs are incapable of such a development and die if they are not fertilized.

Each unlaid egg of insects in general has a small hole in the upper end of its shell, called the micropyle, which admits the spermatozoa to its interior. One or several spermatozoa may enter the egg throngh this aperture, but the nuclear part of only one unites with the egg nucleus, this constituting the fertilization of the egg. After this the micropyle closes and the egg is deposited in a cell of the comb by the queen. The nucleus and a part of the protoplasm of the egg then begin to split up into a number of small cells which-but this is taking us into the development of the next generation, which is beyond the limits of our subject, and so here we must stop.

\section{EXPLANATION OF THE SYMBOLS AND LETTERS USED ON THE ILLUSTRATIONS.}

The writer has made an attempt to work out a set of convenient symbols for all the principal extermal and internal parts in the anatomy of an insect. It has been found, however, that entire consistency is incompatible with practicability, especially in making compound abbreviations, and, therefore, the latter has been given first consideration in many cases. For example, the symbol Dct suggests the word "duct" when standing alone much better than simply the letter $D$, but such combinations as SalDct and OvDct are unnecessarily long and the shortened forms of $S a l D$ and $O v D$ are sufficiently suggestive. of "salivary duct" and "oviduct." The abbreviation $S c$ is used in such compound symbols as PsnSc for "poison sac" and TraSc 
for "tracheal sac," notwithstanding that $S c$ alone means "subcosta." The symbol $T$ is used for "tergum," and $T_{1}, T_{2}$, etc., and IT, IIT, ete., indicate individual thoracic and abdominal terga, but $\mathrm{T} \mathrm{Mcl}$ is used to signify "transverse muscle." And so, in several other cases, it has been found expedient to sacrifice strict uniformity to practical considerations.

A combination of lower-case letters duplicating one entirely or partly of capitals signifies that the part so designated is a part or subdivision of the other. For example, Ten refers to the principal part of the tentorium and ten to a minor part; $P l$ and $p l$ are subdivisions of the same pleurum; Lmcl and $7 m c l$ are both longitudinal muscles.

The most logical method of referring symbols to any particular segment of the body would be, perhaps, to prefix them with either a Roman or an Arabic numeral corresponding with the number of the segment. A common objection, however, to both would arise from the fact that entomologists are not at all agreed as to how many segments there are in any region of an insect's body. Furthermore, Roman numerals prefixed to all the symbols necessarily used on a drawing of the thorax, for example, would occupy entirely too much space. Finally, it is very desirable to have a method of referring to repeated struetures without implying any segmental connection, and prefixed Arabic numerals are certainly most eonvenient and suggestive for such a purpose. A system often adopted to indicate the segment to which a part belongs, especially in the thorax, is the use of one, two, or three accents in connection with the abbreviation. But accented symbols lack artistic unity, and some of the accent marks are too easily lost in the engraving and printing. For these several reasons the writer has adopted the following system:

Numerical order of any repeated structure is indicated by an Arabic numeral placed before the abbreviation, and has no segmental significance. Thus $1 P$, $2 P$, etc., mean simply "first parapterum," "second parapterum," etc; $1 G n g, 2 G n g$, etc., mean "first ganglion," "second ganglion," etc., without implying that the ganglion belongs to any particular segment.

Symbols are referred to the prothorax, the mesothorax, or the metathorax, respectively, by the figures 1, 2, and 3 placed below and after them, except on the wings, where such numbers designate the branches of the veins according to the Comstock-Needham system.

The abdominal segments, counting the propodeum as the first, are indicated by the Roman numerals $I$ to $X$, and, when any one of these is placed before an abbreviation, it refers the symbol to that individual segment.

The lower-case letters are used, singly and in pairs, to refer to miscellaneous parts having, in most cases, no individual or general anatomical names. 


\section{1. sYMBOLS.}

A,

AcGl,

L. $G l$.

AGlD,

An,

$4 N P$,

$A N R$,

Ant,

AntL,

AntNv,

Ao,

$A p$,

Aph,

$A x$,

$a x$,

$A x C$,

$A x M$,

$B$,

$B C$,

$b c$,

$B C p x$,

$B G l$,

$B M$,

$\mathrm{Br}$,

$1 B r$,

$2 B r$,

$3 B r$,

$B r b$,

$B \mathrm{~W}$,

$C$,

$\mathrm{Cb}$,

$C C$,

$C d$,

Cer,

$C L$,

cl, Cls,

cla,

Clp,

Clsp,

1Clsp,

2Clsp,

Com,

Cor,

ctl,

Cu,

anal rein; $1 A$, first anal, $2 A$, second anal, etc. accessory gland of male reproductive organs. acid gland of sting, opening into poison sac (PsnSc). duct of acid gland of sting.

anus.

anterior wing process of notum.

anterior marginal ridge of notum.

antenna.

antennal lobe of brain.

antennal nerve.

aorta.

apodeme, any internal chitinous process of body-wall.

anterior phragma of any tergum, prephragma.

the axillaries or articular sclerites of the wing base, designated individually as $1 A x, 2 A x, 3 A x$, and $4 A x$.

accessory axillary sclerites of irregular occurrence in connection with the principal axillaries $(A x)$.

axillary cord, or ligament-like thickening of posterior edge of basal membrane of wing, attached to posterior angle of scutellum.

axillary membrane, the thin membrane of wing base, containing the axillary sclerites and forming in some cases the lobes called alulæe.

bulb (bulb of penis or of sheath of sting).

body-carity.

any particular part of body cavity such as that prolonged into the mouth parts, legs or pieces of the sting.

bursa copulatrix.

alkaline gland of sting.

basement membrane.

brain.

protocerebrum.

deutocerebrum.

tritocerebrum.

barb.

body-wall.

costa, first vein of wing.

pollen basket or corbiculum on hind tibia of worker.

crystalline cone of compound eye.

cardo.

cercus.

crystalline lens of compound eye.

cell, cells.

claw.

clypeus.

clasping lobes of ninth segment of male, perhaps equivalent to the

four gonapophyses of winth segment of female.

upper or outer clasper.

lower or inner clasper.

commissure (of either nervous or tracheal system).

cornea.

cuticle, the chitinous layer of the epidermis.

cubitus, fifth vein of generalized wing. 
$C v, \quad$ closs-rein.

Cx, coxa.

$C x P$, plenral coxal process.

Det, duct.

$D D p h, \quad$ dorsal diaphragm.

Dph, diaphragm.

DphCls, diaphragn cells.

Dphmb, membrane of diaphragm.

DphHcl, muscle fibers of diaphragm.

E,

EAp,

compound eye.

EjD,

$E m$,

EMcl,

Emp,

Enz,

Ep,

Ephy,

Epm,

Eps,

Epth,

F,

$F l$,

For,

Ft,

FlCom, frontal commissure.

FtGng, frontal ganglion.

$F t N v$, frontal nerve.

$F u$,

$G$,

Ga,

Ge,

Gl,

$1 G 7$,

2G1,

$3 G 1$,

iGl,

Gls,

Ging,

$G u$,

furca or median

ejaculatory duct.

lateral emargination of notum.

extensor muscle.

empodium.

digestive resicles formed by rentricular epithelium.

epicranium.

epipharynx.

epinerum.

cpisternum.

epithelium.

femur.

1lagellum.

foramen magnum.

front.

gonapophysis.

galea.

gena.

gland.

large pharyngeal gland in anterior part of head of worker.

salivary gland in posterior part of head.

thoracic salivary gland.

small median gland below pharyngeal plate $(s)$.

glossa.

ganglion.

$H$, head.

Hk, hooks on front edge of hind wing.

IIphy, hypopharynx.

$H r$, hair.

$h r$, surface disk of "auditory" organ of antenna, probably moulified base of sensory hair.

HS, honey stomach.

$H t$, heart.

$h t$. individual chamber of heart.

HtC7s, pericaldial cells.

HtTraSc, lericardial tracheal sac.

Int,

intima, the chitinous lining of any internal organ.

$I T$,

tergum of first abdominal segment, the median scgment, or propodeum, incorporated into thorax. 
$L$,

$L b$,

$L b]$,

$L b N v$,

LbPlp,

Lc,

Let,

$L g$,

Lit.

Lin,

$L m$,

LIICl,

linel,

$\operatorname{Lm} x^{\top} t$,

Lr,

LTra,

Lum,

M,

$m$,

Jal,

$\mathrm{IIb}$,

$m b$.

$m-c u$,

$M D$,

IIa,

IJIGl,

2MdGl,

$M d N v$,

Mes,'

Met,

Mi,

$m i$,

$m-m$,

I ps,

IIt,

IIth,

$M x$,

IIxPlp,

$M x N v$,

$N$,

$N u$,

Nv,

$O$,

$O b$,

$O c$,

$E$,

ECom,

$\mathrm{Om}$,

$O p L$, leg.

labium.

labellum.

labial nerve.

labial palpus.

lacinia.

lancet of sting, equivalent to first gonapophysis $(I G)$.

ligula.

"lubricating" gland of sting (not shown in figures).

median lobe of lingua or hypopharynx.

labrum.

longitudinal muscles.

ventral IongitudinaI muscles of thorax.

labral nerre.

lorum.

trachea of leg.

lumen, the carity of any hollow organ, whether the glossa, sting, alimentary canal, or gland.

media, fourth rein of wing. $I_{1}-I_{4}$, first to fourth branches of media.

median plate or plates of wing base.

Malpighian tubules.

intersegmental membrane.

membrane.

medio-cubital cross-rein.

disclike muscle apodeme.

mandible.

outer saclike mandibular gland.

inner racemose mandibular gland.

mandibular nere.

metathorax, designated by figure 3 placed after and below any thoracic symbol.

metathorax, designated by figure 3 placed after and below any thoracic symbol.

the chitinous plates of the neck collectively, the "microthorax," individually designated $m i$.

cervical (microthoracic) sclerites.

median cross-rein.

mouth parts or trophi.

mentum.

mouth.

maxilla.

maxillary palpus.

maxillary nerve.

notum.

nucleus.

nerve.

ocellus.

oblong plate.

occiput.

nesophagus.

circumœesophageal commissures.

ommatidium.

optic lobe. 


Ost,
$O v$,
$o v$
$O v D$
$O v O$
$P$

$1 P, 2 P$, $3 P, 4 P$,

$P A$,

Pcl,

$P D$,

$P d$,

Pen,

PenB,

Peps,

Pge,

Pgl,

Pgu,

Ph,

Phy,

$P l$,

$p l$,

Plf,

Plg,

Plp,

Pmb,

PHel,

$P N$,

$p n$,

$P N P$,

PNR,

Pph,

PR,

Prt.

PrbFs,

PS,

Ps,

Psc.

Pscl,

Psl,

Psnc,

PsuSc, ostium or lateral aperture of heart.

ovary.

ovariole, individual ovarian tube.

oviduct.

opening of vagina or median oviduct.

paraptera, small pleural plates below base of wing, typically two episternal paraptera or preparaptera ( $1 P$ and $2 P$ ) before pleural wing process ( $I P P$ ), and two epimeral paraptera or postparaptera $(3 P$ and $f P$ ) behind wing process.

episterual paraptera, preparaptera.

epimeral paraptera, postparaptera.

arim of pleural ridge.

postclypeus.

muscle disc of episternal paraptera, giving insertion to pronator muscle (not present in the bee).

peduncle.

penis.

bulb of penis.

preepisternum.

postgena.

paraglossa.

pregula.

phragma.

pharnyx.

plenrum.

subdivision of plenrum.

palpifer, palpus-carrying lobe of maxilla.

palpiger, palpus-carrying lobe of labium.

palpus.

peritrophic membrane.

pronator muscle.

postnotum or psendonotum, the second or postalar tergal plate of the wing-bearing segments of most insects, the "postscutellum" of higher orders.

small rod connecting postscutellum (postnotum $P N$ ) with upper edge of epimernm, probably a detached piece of the former (see figs. 22 and 24 ).

posterior notal wing process.

posterior marginal ridge of notum.

posterior phragma or postphragna of any tergum, carried by the second notal plate or postnotum ( $\left.P X^{\top}\right)$, the ".postscutellnm" of highel forms.

internal plenral ridge, the entopleurum, marked externally by plemal suture $(P S)$.

proboscis.

fossa of proboscis.

plenral suture, externál line separating episternum and epimerum, marking site of internal plenral ridge. presternum.

prescutum.

postscutellum (postuotum).

poststernellum.

poison canal of sting.

poison sac of sting into which opens the acid gland $(A G l)$. 


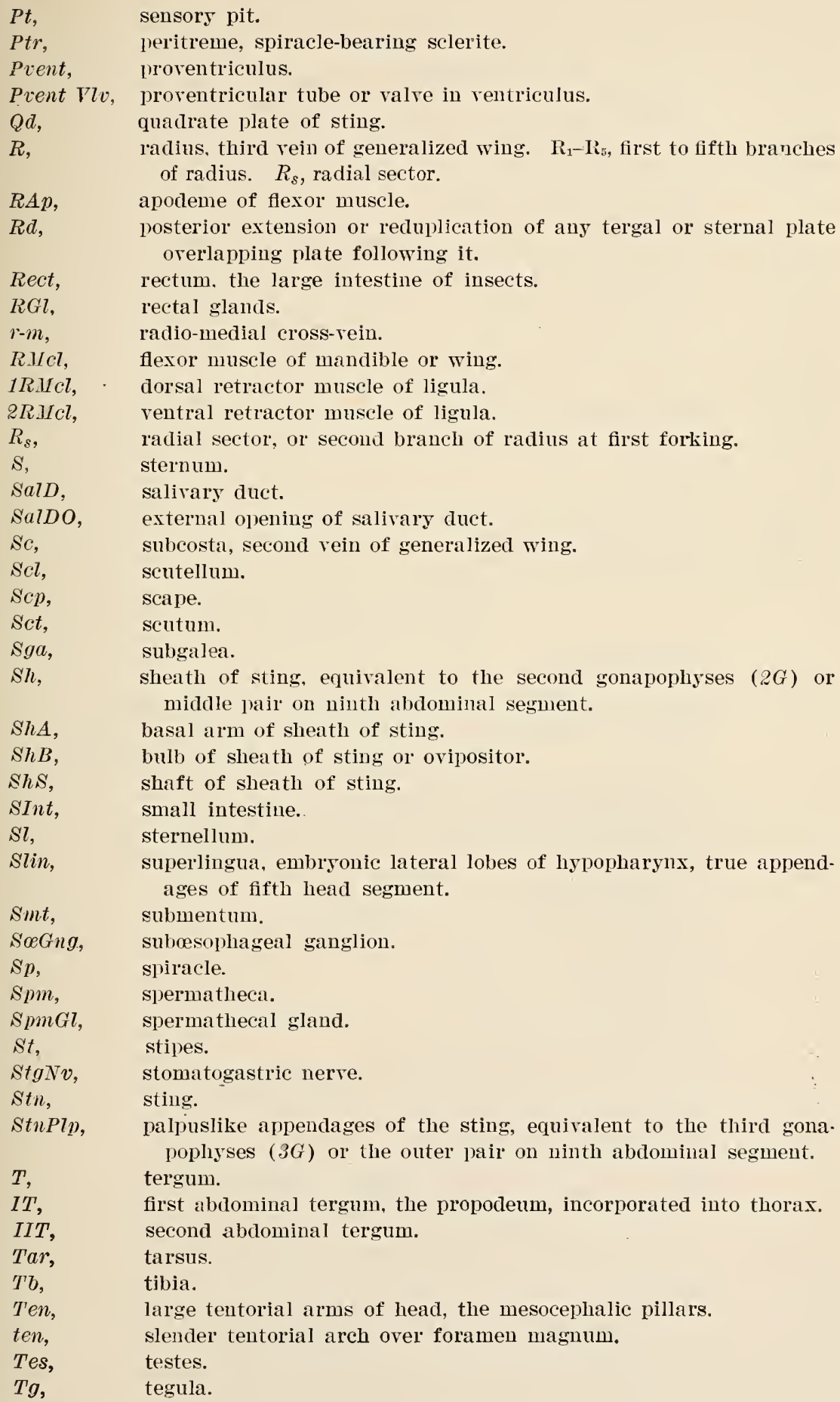




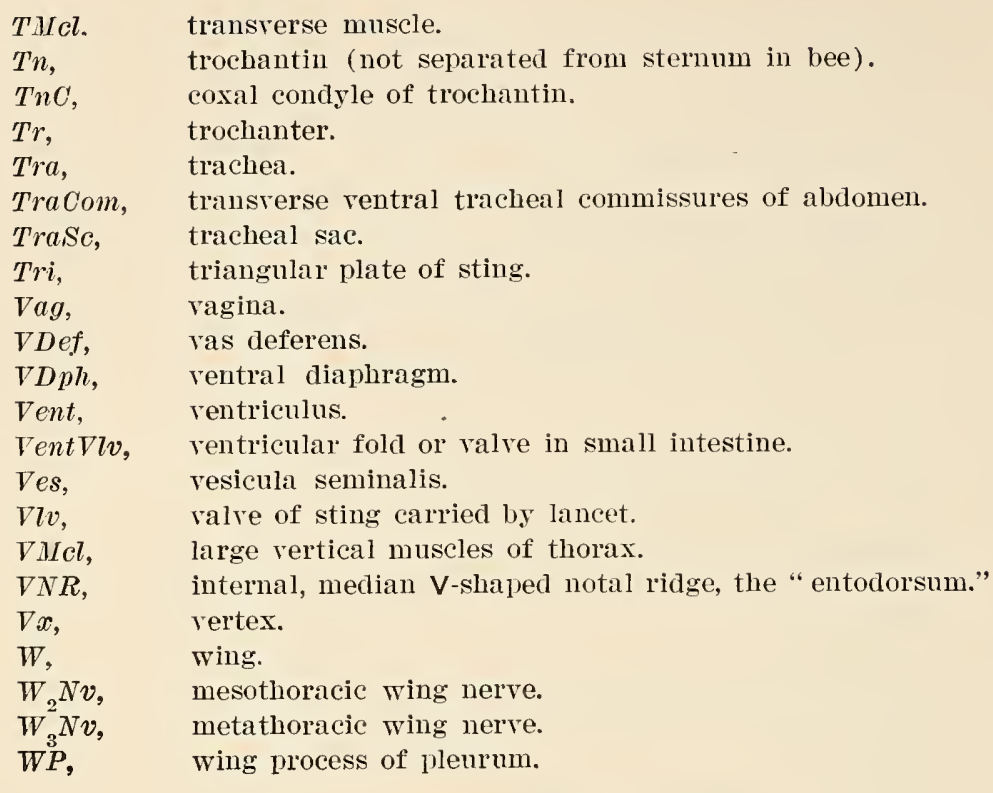

\section{ALPHABETICAL LETTERING.}

$a$,

$b$,

c,

$d$,

$e$,

$f$,

$g$,

$h$,

$i$,

j,

$k$,

$l$,

$m$,

$n$,

o,

$p$,

$q$

$r$,

$s$,

$t$,

$u$,

$v$,

$w$

clypeal suture.

anterior tentorial pit, in clypeal suture.

posterior tentorial pit, in occiput beside foramen magnum.

thickened posterior edge of lateral wall of fossa of proboscis.

process at upper end of $d$ articulating with cardo of maxilla and forming maxillary suspensorium.

internal median keel of vertex in cranium of drone.

suspensorial ligaments of anterior end of œsophagus.

pharyngeal rod.

convolutions of dorsal blood ressel.

anterior articular knob of mandible.

rentral groove of glossa.

ventral groove of maxilary rod.

median plates of wing base.

basal hooks of glossa.

median ventral plate of ligula.

dorsal plates of anterior end of mentum, supporting ligula.

inner wall of canal of glossa.

chitinous rod of glossa.

pharyugeal plate, on anterior part of floor of pharynx.

salivary pouch opening on dorsal side of base of ligula, receiving common duct of salivary glands ( $S a l D)$.

oblique muscles inserted upon dorsal side of salivary pouch of ligula.

transverse or V-shaped suture on surface of mesonotum or metanotum, formed by the internal V-shaped ridge or "entodorsum" $(T N R)$.

lateral lobe of pronotum projecting posteriorly over the first spiracle. 
$x$,

$y$

z,

$a a$,

$b b$

$c c$

dd,

ee,

ff,

$g g$,

$7 h$,

$i$,

$j$,

$k i$

ll,

$m m$,

$n n$,

oo,

$p p$,

$q q$,

$r r$,

$s \&$,

$t t$,

ur,

$v v$,

wow,

$x x$,

$y y$,

z' $z$, thoracic plate lying laterad of anterior part of sterum, often regarded as a part of presterumm.

accessory sclerite of fourth axillary. $(4 A x)$ of front wing, affording insertion for sleuder muscle (fig. 28, $c c$ ) attached below to common apodeme of mesosternum and metasternum.

coxal condyles of mesothoracic and metathoracic sterna, probably really the coxal condyles of trochantins (fig. 4, TnC) fused entirely with the sterna and episterna in each segment.

muscle arising from inner wall of mesothoracic pleurum and inserted upon outer end of corresponding scutellum, probably accessory in function to the great vertical muscles (fig. 27, $\mathrm{VM} \mathrm{cl}$ ) between the mesothoracic sternum and scutum.

coxo-axillary muscle, extending from upper end of coxa to third parapterum $(3 P)$.

muscle inserted upon accessory sclerite $(y)$ of fourth axillary $(4 A x)$ from common entosternum of mesothorax and metathorax.

notch of antenna cleaner on first tarsal joint (1Tar) of front leg. spine of antenna cleaner situated on distal end of tibia $(T b)$. so-called "wax shears" or " wax pincers."

transverse chitinous band of empodium ( $E m p)$, which compresses its two lobes when not in use and spread out by muscular effort. dorsal plate supporting emporium.

rentral plate supporting empodium.

dorsal groove of lancet interlocking with ventral ridge of sheath of sting.

sting chamber within end of serenth abdominal segment, lodging sting whose accessory plates are derived from eighth and winth segments.

reservoir of thoracic salivary gland.

receptacular chitinous pouches on ventral sicle of pharyngeal plate

(s) receiving ducts of large lateral pharyngeal glands of head $(1 G l)$.

"stomach-mouth" at summit of proventricular projection within honey stomach ( $H S)$.

pores on lancets (fig. $40 \mathrm{E}$ ) and shaft of sting sheath (F) opening to exterior from prolongation of body-cavity $(b c)$ contained in each.

gelatinous layer secreted upon inner surface of ventricular epithelium.

food contents of alimentary canal.

cells of rentricular epithelium apparently forming the internal gelatinous layer.

cartilaginous mass on inner surface of dorsal wall of bulb of penis (fig. $56 \mathrm{E}, \operatorname{PenB}$ ).

dorsal plates of bulb of penis.

fimbriated dor'sal lobes of penis at base of bulb.

ventral scalariform row of plates on tube of penis.

dorsal basal plates of penis.

ventral basal plates of penis.

basal pouch of penis.

copulatory sacs of penis. 


\section{BIBLIOGRAPHY.}

ABONYI, SÁNDOR.

1903. Morphologische und physiologische Beschreibung des Darmkanals der Honigbiene (Apis mellifica). Ablatt Közlem., II, pp. 137-168, pls. XI-XIV.

ARNhaRT, LudWig.

1906. Anatomie und Physiologie der Honigbiene, 99 pp., 4 pls., 53 figs. Wien. 1906. [Extract from "Allgemeines Lehrbuch der Bienenzucht" by Alois Alfonsus.]

BORDas, L.

1894. Anatomie du tube digestif des Hyménontères. Comptes Rendus de l'Acad. des Sci., Paris, CX'III, pp. 1423-1425.

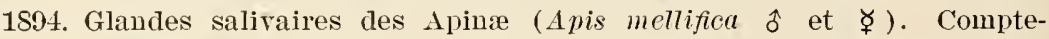
rendu de la Soc. Phil. de Paris, 1894, No. 4, pp. 12-14.

1894. Glandes salivaires des Apinæe (Apis mellifica $\Varangle$ et $\hat{o}$ ). Bul. de la Soc. Phil. de Paris, 8 ser., VII, 1894-1895, pp. 9-26, 9 figs.

1895. Appareil gênital mâle des Hyménoptères. Ann. Sci. Nat., XX, 7 ser., 1895, pD. 103-181.

Breithaupt, Paul Franz.

1856. Ueber die Anatomie und die Functionen der Bienenzunge. Arch. f. Naturg. LIII, pN. 47-112, pIs. IV-V. [Brief summary in Journ. Roy. Micr. Soc., VII, Pt. I, 1SS7, pp. 224-225.]

Breslat, Ernst.

1905. Die Samenblasengang der Bienenkönigin. Zool. Anz., XXIX, 19051906, pp. 299-323, 7 figs.

BrIANT, T. J.

1884. On the anatomy and functions of the tongue of the honey bee (worker). Journ. Limn. Soc. London, Zool., pp. 40S-417, PIs. XVIII, XIX.

Carlet, G.

1SS4. Sur les muscles de l'abdomen de l'abeille. Comptes Rendus de l'Acad. des sci. de Paris, XCVIII, pp. 758, 759.

1884. Sur le renin des Hyménoptères et ses organes sécrêteurs. Comptes Rendus de l'Acad. des Sci. de Paris, XCVIII, pp. 1550, 1551.

1890. Mémoir sur le venin et l'aiguillon de l'abeille. Ann. des Sci. Nat., Zool., 7 ser., IX, pl. 1-17, pl. 1.

1890. Sur les organes sécréteurs et la sécrétion de la cire chez l'abeille. Comptes Rendus de l'Acad. des Sci. de Paris, CX, pp. 361-363.

Cineshire, Frank R.

1855. The apparatus for differentiating the sexes in bees and wasps. An anatomical investigation into the structure of the receptaculum seminis and adjacent parts. Journ. Roy. Micr. Soc., ser. 2, V, pp. 1-15, Pls. I, II.

1856. Bees and bee keeping, 2 vols., London. (Vol. I deroted mostly to anatomy of the bee.)

Clerict, F.

1875. L'Ape sua anatomia-suoi memici. Milan. [30 colored plates drawn from anatomical preparations by G. Bartò.]

Cook, A. J.

1904. The bee keeper's guide, 18th ed., Chicago.

Copeland, Manton, and Mark, E. L.

1907. Some stages in the spermatogenesis of the honey bee. Proc. Amer. Acad. Art. and Sci., XLII, pp. 103-111, 1 pl. 
CoWAN, T. W.

1904. The honey bee, $2 \mathrm{~d}$ ed., London.

DJathCHenko, Sophie.

1906. Zur Frage der Athumsorgane der Biene. Ann. de l'Inst. agron. de Moscou, XII, pp. 1-14, 9 figs.

DREILING, L.

1903. Ueber die wachsbereitenden Organe der Honigbiene. Zool Anz., XXVI, pp. 710-715, 2 figs.

Forel, AUguste.

1907. The senses of insects. English ed., translated by Macl zod Yearsley, London.

Grand, Maudice.

18tS. Les abeilles. Paris.

GIRDworn, MICHEL.

1876. Anatomie et phrsiologie de l'abeille. Mem. de Ia Soc. Polonaise des Sci. Exac., VI, 39 pp., 12 pls., Paris. [Also published separately.]

HOMMELL, R.

1904,1905. Anatomie et physiologie de l'abeille domestique. Le Microg. Prép., XII, pp. 49-60, pls. XXVII, XXVIII; XIII, pp. 15-25, $60-67$.

1906. Apiculture (Encyclopédie Agricole). Anatomie de l'abeille, pp. 20 103 , Paris.

Hurer, Francors.

1S14. Nouvelles observations sur les abeilles, 2 vols. 2d ed.. Paris and Genera.

KENYON, F. C.

1896. The brain of the bee. Journ. Comp. Neurol., VI, pp. 133-210, pls. XIV-XXII.

1897. The optic lobes of the bee's brain in the light of recent neurological methods. Amer. Nat., XXXI, pp. 369-376, pl. IX.

Koschevnikov, G. A.

1900. Ueber den Fettkörper und die Wnocyten der Honigbiene (Apis mellifera L). Zool. Anz., XXIII, pp. 3зт-3.;.

KRAEPELIN, K.

1573. Untersuchungen iiber den Bau, Mechanismus und Entwickelung des Stachels der bienenartigen Tiere. Zeit. f. wiss. Zool., XXIII, pp. 2S9-330, pls. XV, XVI.

Ludwig, August.

1906. Unsere Bienen. Die Anatomie, pp. 34-112, Berlin.

Macloskie, George.

1SS1. The endocranium and maxillary suspensorium of the bee. Amer. Nat., XV, pp. 353-362, 6 figs.

Mark, E. L., and Copeland, Manton.

1907. Some stages in the spermatogenesis of the honey bee. Proc. Amer. Acad. Art. and Sci., XLII, pp. 103-111, 1 pl.

Metes, Friedrich.

1903. Ueber Richtungskürperbildung im Hoden von Hymenopteren. Anat. Anz., XXIV, pp. 29-32, \& figs.

1907. Die Spermatocytenteilungen bei der Honigbiene (Apis mollifica L.), nebst Bemerkungen über Chromatinreduction. Arch. f. Microsk. Anat. und Entwick., LXX, pp. 414-491, 5 figs. pls. XXII-XXVI. 
Michä̈LIS, Georg.

1900. Bau und Entwickelung des männlichen Begattungsapparates der IIonigbiene. Zeit. f. wiss. Zool., LXVII, pp. 439-460, pl. XXVI.

Paulcke, Wilhelit.

1900. Ueber die Differenzirung der Zellelemente im Orarium der Bienenkönigiu (A pis mellifica). Zool. Jahrb., Anat. und Ontog., XIV, 1900, 1901, pp. 177-202, pls. 12-13a.

Phillips, Everett Franklin.

1905. Structure and development of the compound eye of the honey bee. Proc. Acad. Nat. Sci. Phila., LVII, pr. 128-157, 7 figs., pls. VI-TII.

Pissarew, IV. J.

1898. Das Herz der Biene (Apis mellifica). Zool. Anz., XXI, pp. 2\$2. 2\$.3, 1 fig.

Planta, A, von.

$1 S 8 S$ and 1859. Ueber den Futtersaft der Biene. Zeit. f. Physio. Chemie, XII, 1888, pp. 327-354; XIII, 1S89, pp. 552-561.

Plateau, Felix.

1574. Recherches sur les phénomènes de la digestion chez les insectes. Mém. de l'Acad. Roy. des Sci., des Let. et des Beaux-arts de Belgique, XLI, pp. 3-124, pls. I-III.

Rоот, A. I., and Root, E. R.

1908. The A B C and X Y Z of Bee Cultme, Metina, Ohio.

SAMUelson, J., and Hicks, J. B.

1860. The honey bee. London.

Schiemenz, Paulus.

1853. Ueber des Herkommen des Futtersaftes und die Speicheldrïsen der Bienen, nebst einem Anhange iber das Riechorgan. Zeit. f. wiss. Zool., Xxxvill, pp. 71-135, pls. V-TiII.

Sichmid, A., and KLeine, G.

1S61. Turisse zur Anatomie und Physiologie der Bienen. Die Bienenzeitung, I, pp. 49S-525, pls. I-VII.

SChönfeld, Pastor.

18S6. Die physiologische Bedeutung des Magenmundes der Hönigbiene. Arch. f. Anat. und Physiol., Physiol. Abth., pl. 451-45s.

Sladen, F. W. L.

1901. A scent-producing organ in the abdomen of the bee. Gleanings in Bee Culture, XXIX, August, pp. 639, 640, 1 fig.

1902. A scent-producing organ in the abdomen of the worker of Apis mellifiea. Ent. Mag. Lond., XxxviI, pp. 208-211, 1 fig.

WOLFF, O. J. B.

1S75. Das Riechorgan der Biene. Nova Acta der Kss. Leop.-Carol. Deut. Akad, der Naturf., XXXVIII, pp. 1-251, pls. I-VIII.

ZANDER, ENOCH.

1599. Beitrïge zur Morphologie des Stachelapparates der Hymenopteren. Zeit. f. wiss. Zool., LXVI, pp. 2SS-333, pls. XVIII, XIX.

1900. Beiträge zur Morphologie đer männlichen Geschlichtsorgäne der Hymenopteren. Zeit. f. wiss. Zool., LXVII, pp. 461-489, 9 figs,, pl. XXVII, 


\section{INDEX.}

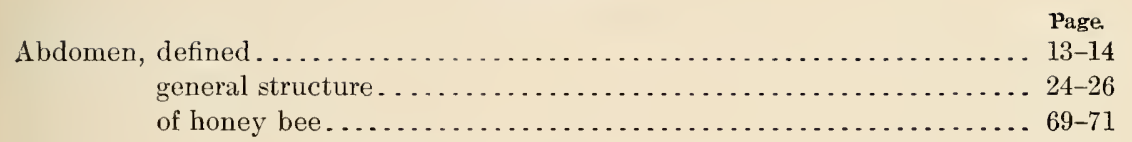

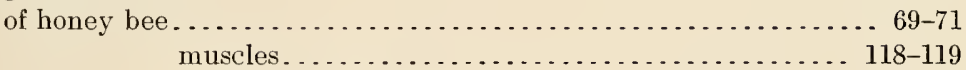

wax glands and sting....................... $69-83$

Absorption . . . . . . . . . . . . . . . . . . . . . . . . . . . . . . . . . 104 105

Accessory sternal plate in generalized thorax .................... 21

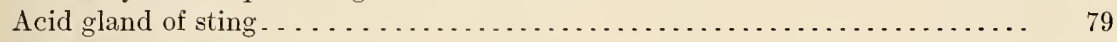

Alimentary canal . . . . . . . . . . . . . . . . . . . . . . . . . . . . . 90

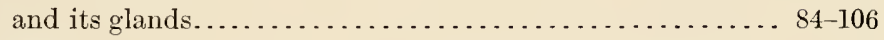

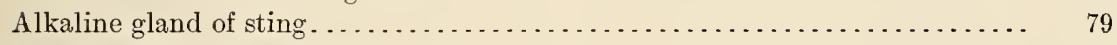

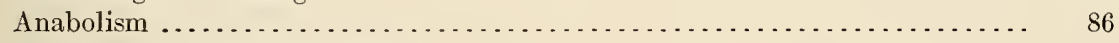

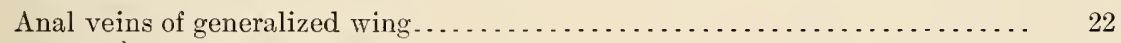

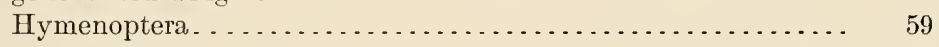

Andrena, pharyngeal glands . . . . . . . . . . . . . . . .

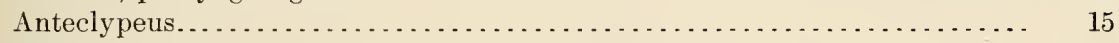

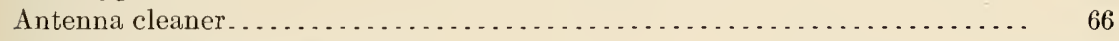

Antennæ and their sense organs. . . . . . . . . . . . . . . . . . . . $32-39$

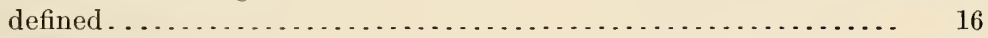

of honey bee. . . . . . . . . . . . . . . . . . . . . .

sense organs............................ $36-39$

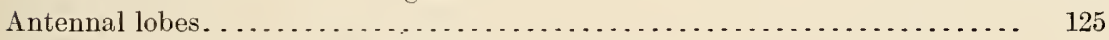

Anterior notal wing process, defined................................. 19

of mesothorax of honey bee.............. 62

metathorax of honey bee ............... 56

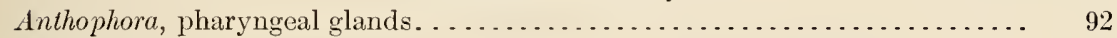

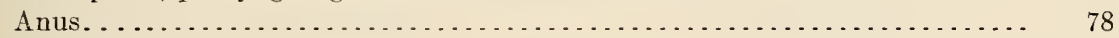

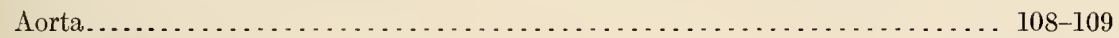

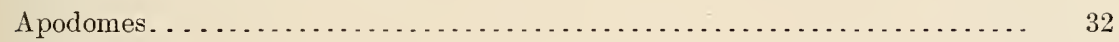

Appendages. . . . . . . . . . . . . . . . . . . . . . . . . . . . . . . . . . . . . . 12-13

Assimilation . . . . . . . . . . . . . . . . . . . . . . . . . . . . . . . . . . $84-87$

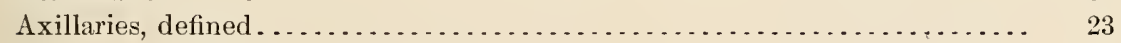

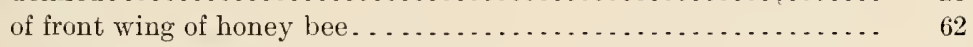

hind wing of honey bee.............................. 62

Hymenoptera................................. $59-62$

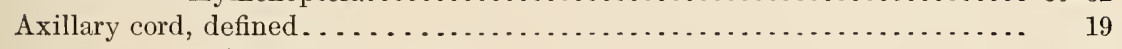

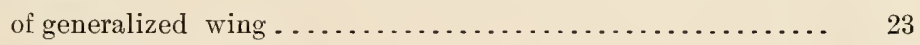

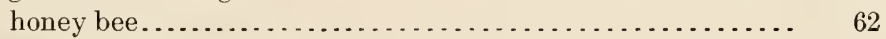

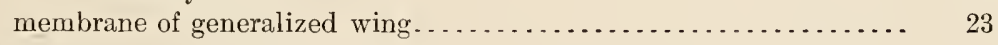

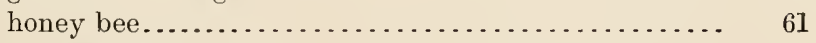

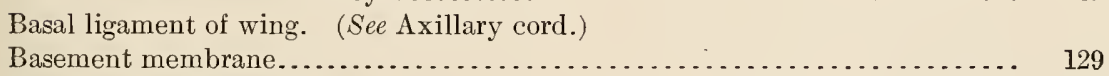

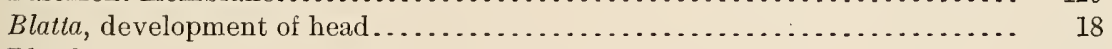

Blood....................................................... 107

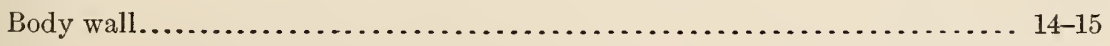


Bombus, pharyngeal glands................................... ${ }_{92}$

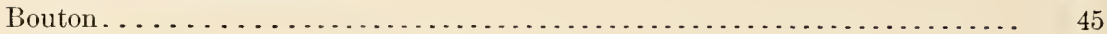

Brain, general description. . . . . . . . . . . . . . . . . . . . . . . . 124

of honey bee... . . . . . . . . . . . . . . . . . . . . . . . . . . . 125-126

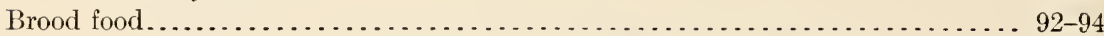

production of, and summary of facts known concerning it ....... .98-101

Bursa copulatrix........................................... 134

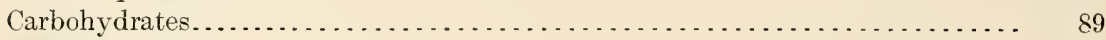

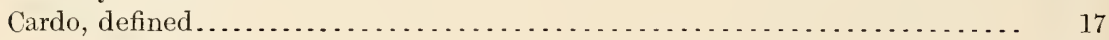

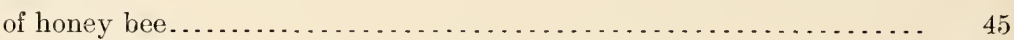

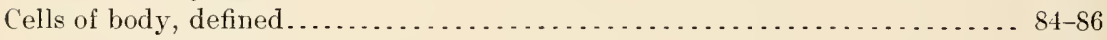

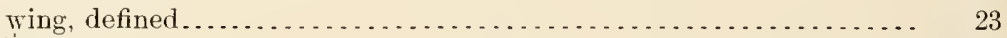

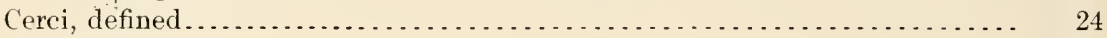

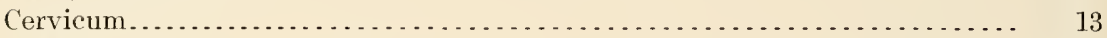

Chiasma, inner................................................ 127

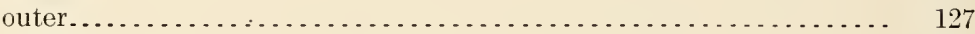

"Chyle"

"stomach"

"Chyme"

Circulation of the blood................................. 107-111

Circulatory system.................................... 107-111

Circumœsophageal commissures, defined.......................... 124

in honey bee...................... 126

Clasping organs, defined.......................................... 24

of drone....................................... 73

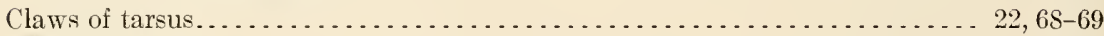

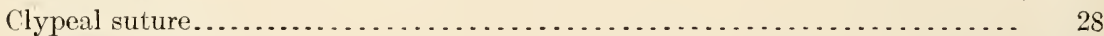

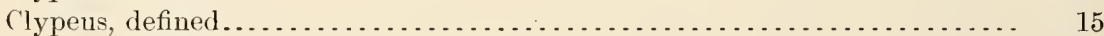

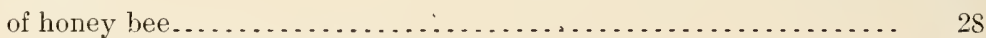

Cockroach, Blatta, development of head........................... 18

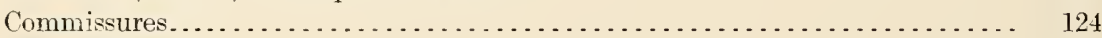

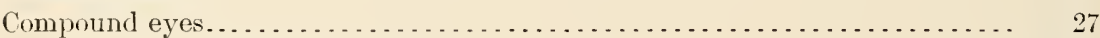

detailed structure ............................ 127-130

Conocephalus, ovipositor.......................................... 25

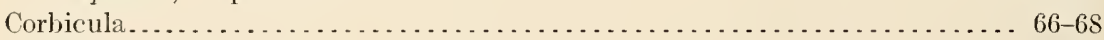

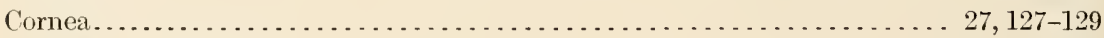

Corneal pigment cells......................................... 129

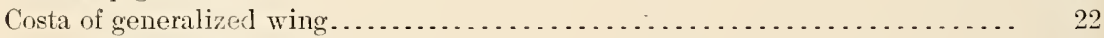

Hymenoptera........................................... 59

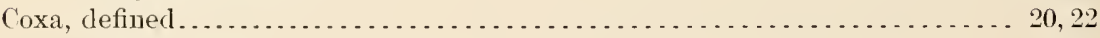

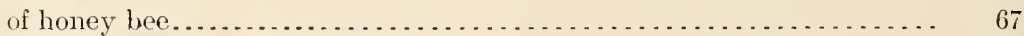

Coxo-axillary muscle of wing of honey bee .......................... 66

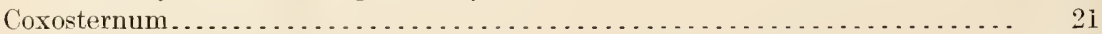

Cranium, internal structure.............................. $30-32$

Cricket, Gryllus pennsylvanicus, mouth parts..................... 16-18

Crop, defined............................................ $\quad 90$

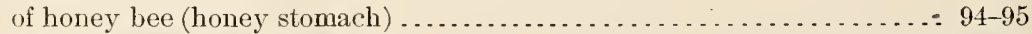

Cross veins of generalized wing .............................. 22-23

Crystalline cone............................................ 129

lens. . . . . . . . . . . . . . . .

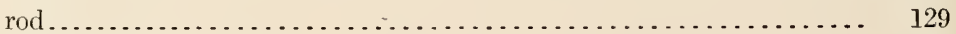

C'ubitus of generalized wing................................. 22

Hymenoptera........................................... 60 
Darts. (See Lancets.)

Page.

Dendroctonus, "preepisternum"............................... 20

Depressor muscles of wing of honey bee ........................... 64

Determination of sex in honey bees............................. 139

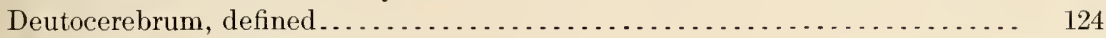

in honey bee................................ 125-126

Development, defined....................................... 11-12

Diaphragm cells............................................ 110

Diaphragms, defined................................... 107-108

dorsal.............................................. 109-110

ventral........................................... 109

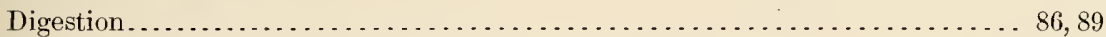

assimilation, and excretion, general physiology . . . . . . . . . . . 81-87

Dorsal diaphragm........................................ 109-110

sinus............................................ 107-108, 111

"Dorsocerebrum"............................................. 126

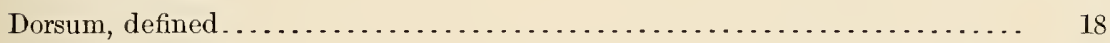

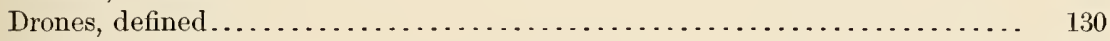

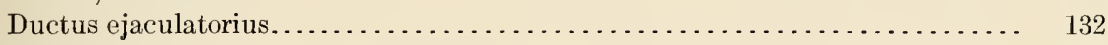

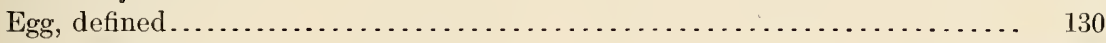

fertilization........................................ 137, 139

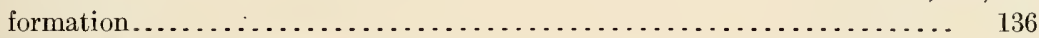

Elevator muscles of wing of honey bee......................... 64

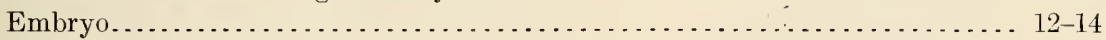

Embryonic development, defined.................................. 12

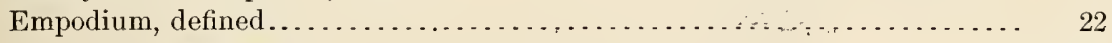

of honey bee..................................... 69,69

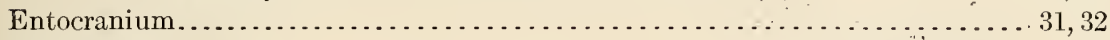

Entodorsum, defined .......................................... 19

Entopleurum, defined....................................... 19

of mesothorax of honey bee. (See Pleural ridge.)

Entosternum (furca), defined . . . . . . . . . . . . . . . . . . . . . . . . . 21

of prothorax of honey bee.................... 55

mesothorax and metathorax of honey bee ............ 56

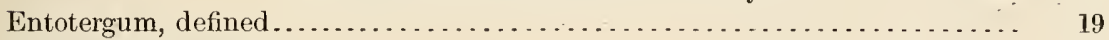

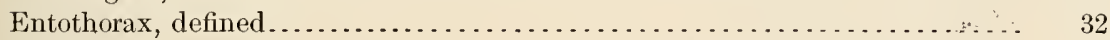

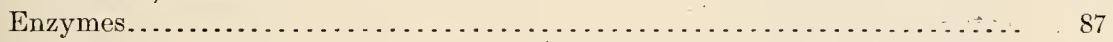

Epicranium, defined........................................... 16

Epimeral paraptera (postparaptera), defined...................... 20

Epimerum, defined

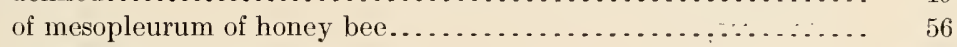

Epipharynx, defined............................................ 16

of honey bee................................... $51-53$

sense organs............................. $52-53$

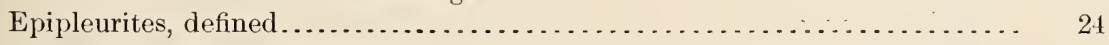

Episternal paraptera (preparaptera), defined....................... 20

$\begin{array}{cr}\text { of mesopleurum of honey bee............ } & 56 \\ \ldots \ldots \ldots \ldots \ldots \ldots & 19\end{array}$

of mesopleurum of honey bee...................... 56

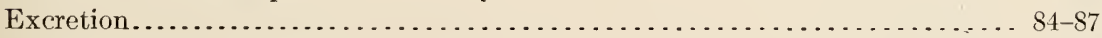

Extensor muscle of mandible of honey bee....................... 40

External genital organs of drone honey bee..................... $72-73$

development................... : $73-74$ 
External mandibular glands...........

External mandibular glands........................................ 41

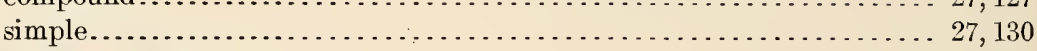

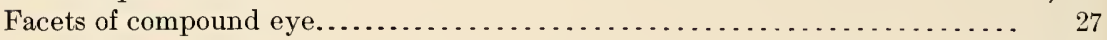

Fat body ............................................ 119, 120

and enocytes.................................... . . 119-121

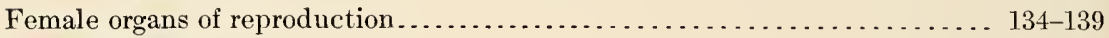

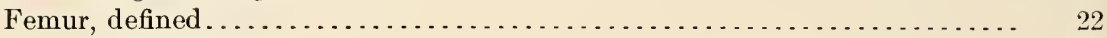

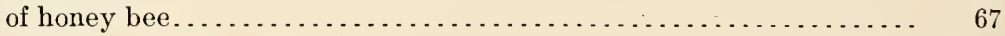

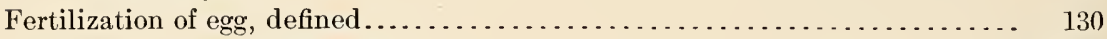

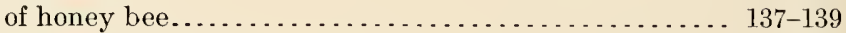

First abdominal segment $($ propodeum) . . . . . . . . . . . . . . . . . . . . . 58-59

Flagellum. ....................................... $32-33$

Flexor muscle of mandible of honey bee. . . . . . . . . . . . . . . . . . . 40

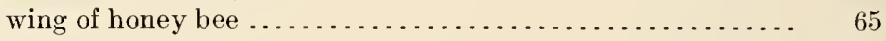

Food of adult honey bees...................................... 89

larvæ. (See Brood food and Royal jelly.)

Foramen magnum, defined................................. 15

of head of honey bee........................... 28

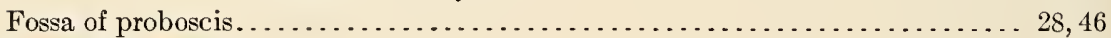

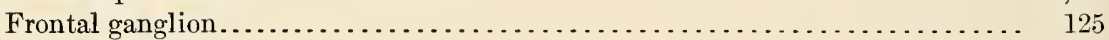

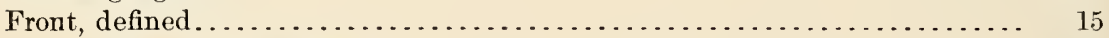

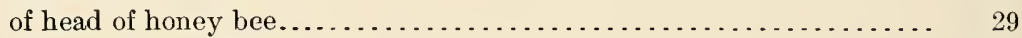

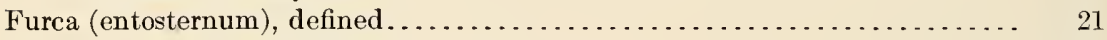

of prothorax of honey bee. .................. 55

mesothorax and metathorax of honey bee.......... 56

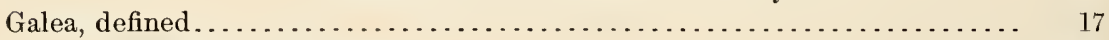

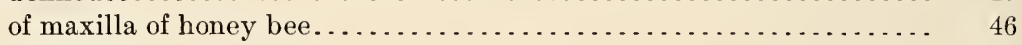

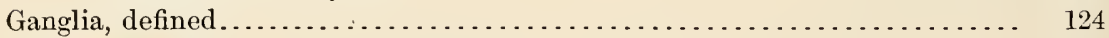

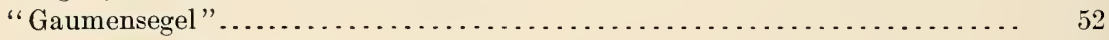

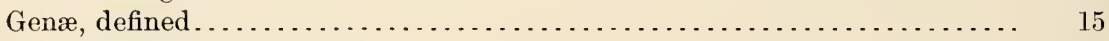

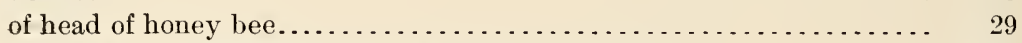

General physiology of digestion, assimilation, and excretion. . . . . . . . . . . 84-87

Gills, defined........................................... 112

Glands, external mandibular. . . . . . . . . . . . . . . . . . . . . . . . 41

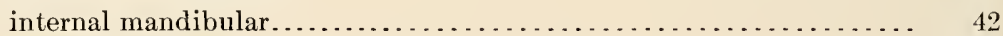

lateral pharyngeal. . . . . . . . . . . . . . . . . . . . . . . 91,92

median pharyngeal. ................................... 91

mucous glands of male organs.......................... 132

of Nassanoff......................................... 83

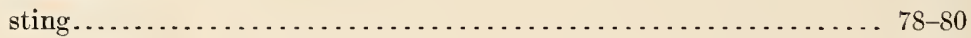

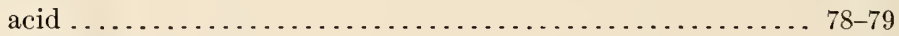

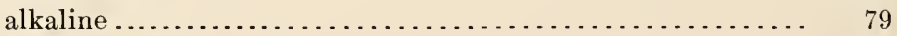

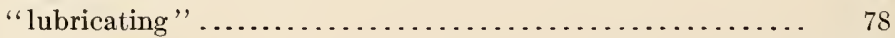

postcerebral ........................................ $87-88$

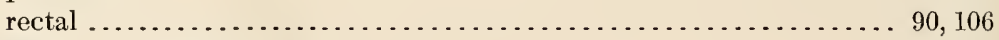

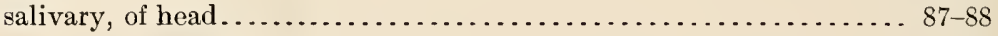

thorax ................................. $88-89$

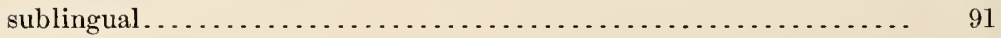

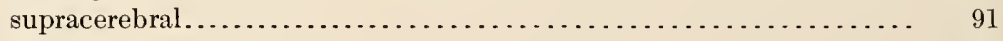

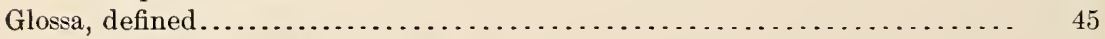

details, in worker of honey bee........................... 48

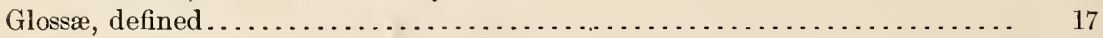

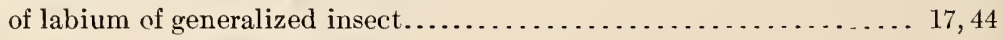


Page.

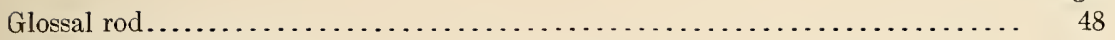

Gonapophyses, defined . . . . . . . . . . . . . . . . . . . . . . . . . . . . . 24

of ovipositor of longhorned grasshopper.............. 25

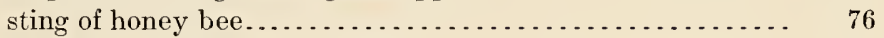

Grasshopper, longhorned (Conocephalus), ovipositor.................. 25

Growth, defined........................................ 11

Gryllus pennsylvanicus, mouth parts............................ 16-18

Gular sclerites, defined .................................... 16

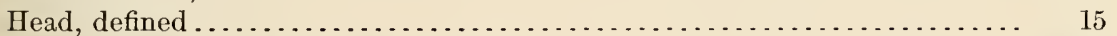

of honey bee and its appendages....................... 26-53

external structure......................... 26-30

internal structure ....................... . 30-32

worker, queen and drone, compared .............. 29-30

Heart, chambers..................................... 108

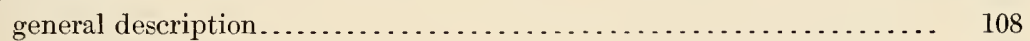

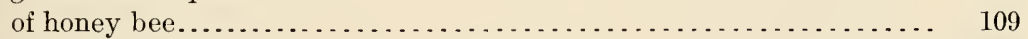

Honey stomach . . . . . . . . . . . . . . . . . . . . . . . . . . . 90,94-95

Horntail, Sirex flavicornis, first abdominal segment . . . . . . . . . . . . . 58

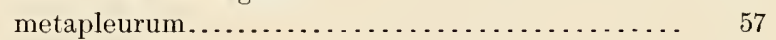

wing veins..........................60 60.62

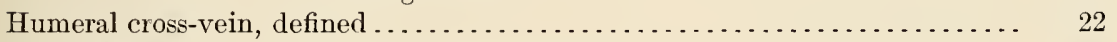

Hydrocarbons ....................................... 89

Hypopharynx, confusion with glossa of honey bee . . . . . . . . . . . . . . . . 44

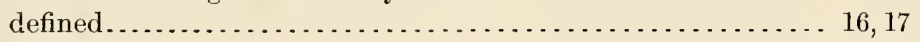

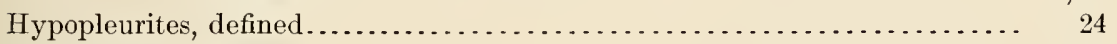

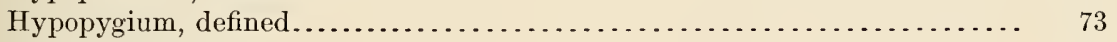

Imago, defined . . . . . . . . . . . . . . . . . . . . . . . . . . . . . . . . 12

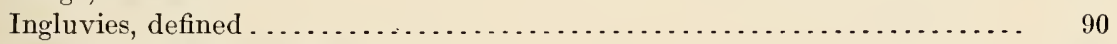

Insects, general external structure ... . . . . . . . . . . . . . . . . . . . . . . . $10-26$

Internal mandibular glands. . . . . . . . . . . . . . . . . . . . . . . . . . . . . . 42

Intersegmental membrane, defined............................ 14

in abdomen of honey bee................. $70-71$

Intestine...................................... 90. 105,106

Itycorsia discolor, wing veins................................. $59-61$

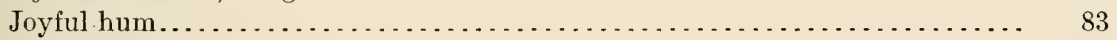

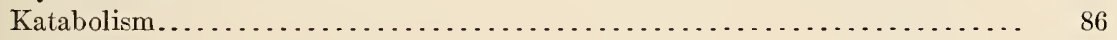

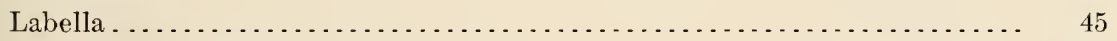

Labial palpi, defined.................................. 17

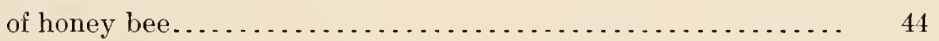

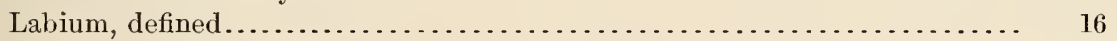

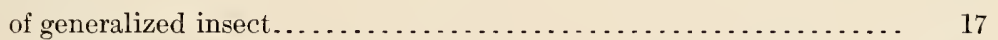

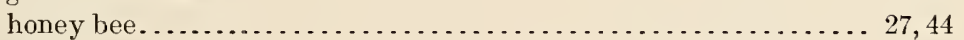

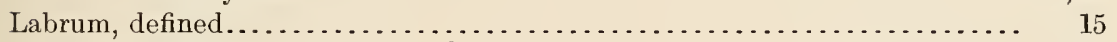

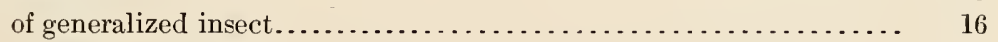

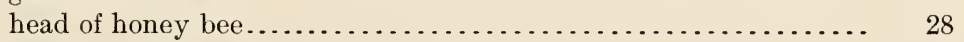

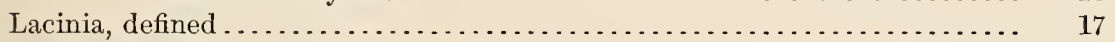

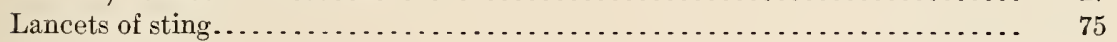

Large intestine . . . . . . . . . . . . . . . . . . . . . . . . . . . . . . 9 90, 106

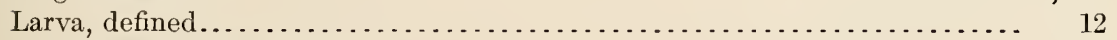

Larval stage, defined . . . . . . . . . . . . . . . . . . . . . . . . . . . 12

Lateral pharyngeal glands . . . . . . . . . . . . . . . . . . . . . . . . . . . . 91-92

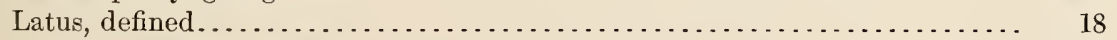

Legs of generalized insect. . . . . . . . . . . . . . . . . . . . . . . . . . . . . . 21-22

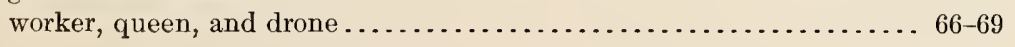




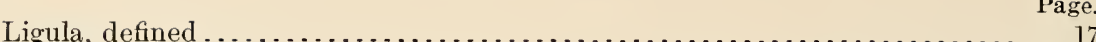

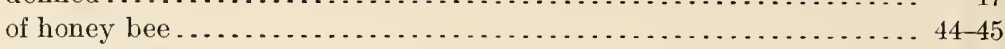

Lingua, confusion with other terms.......................... 44,45

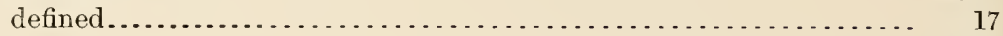

Lorum ..................................................... ${ }_{46}$

"Lubricating" glands of sting...................................... 78

Male organs of reproduction ................................. 132-134

Malpighian tubules, defined .................................. 90

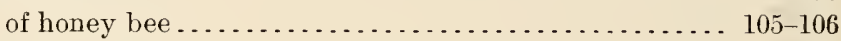

Mandibles, defined............................................. 16

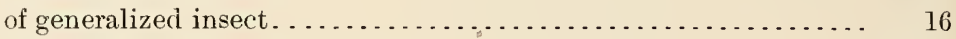

honey bee.............................. 27, 39-41

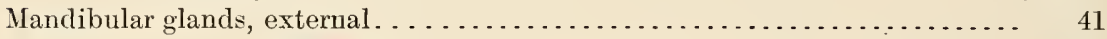

internal. . . . . . . . . . . . 42

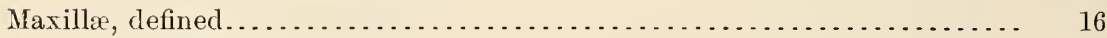

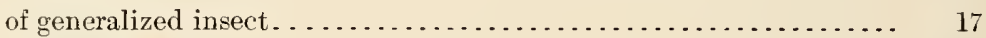

honey bee........................................ 44

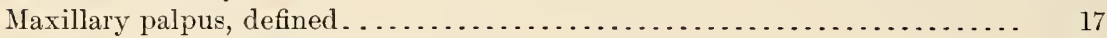

of honey bee............................... 45

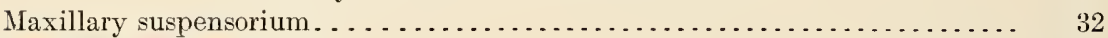

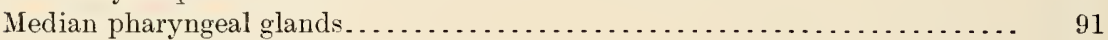

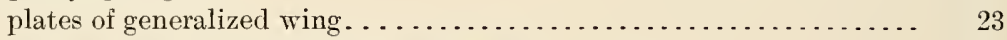

segment (propodeum) of Hymenoptera . . . . . . . . . . . . . . . 59

Media of generalized wing . . . . . . . . . . . . . . . . . . . . . . . . 22

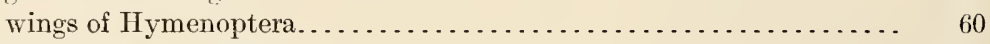

Medio-cubital cross-vein, defined . . . . . . . . . . . . . . . . . . . . . . 23

Mentum, defined . . . . . . . . . . . 17

of labium of honey bee. . . . . . . .

Mesocephalic pillars. . . . . . . . . . . . . 31

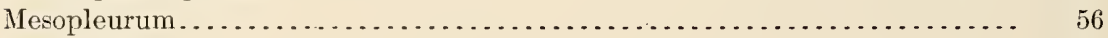

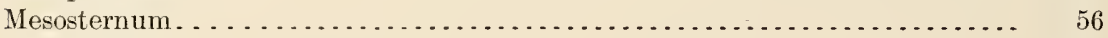

Mesotergum. . . . . . . . . . . . . .

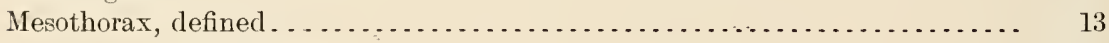

of honey bee. . . . . . . . . . . . . . . . . . . . . . $55-56$

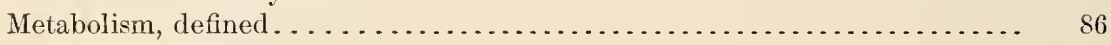

process............................................ 115

Metameres, defined. . . . . . . . . . . . . . . . . . 12

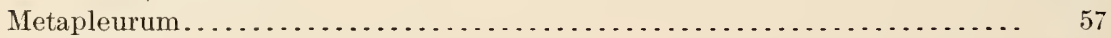

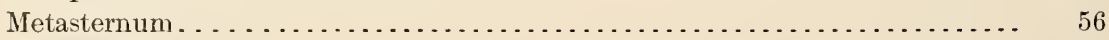

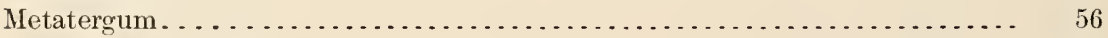

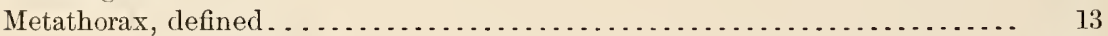

of honey bee. . . . . . . . . . . . . . . . . . . . . . . . . 56,58

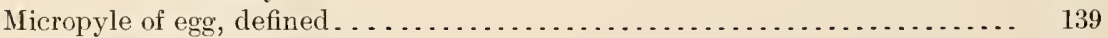

Microthorax, defined ........................................ 13

of generalized insect............................... 18

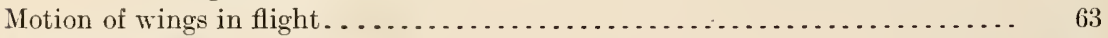

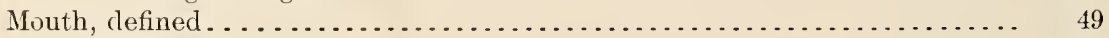

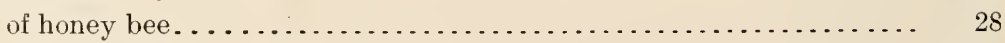

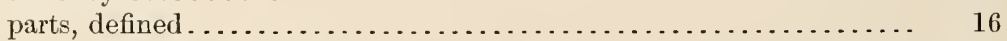

of generalized insect............................. 16-18

honey bee. . . . . . . . . . . . . . . . . . . 27-28, 39-53

action in feeding...................... $46-49$

Mucous glands of male organs................................ 132

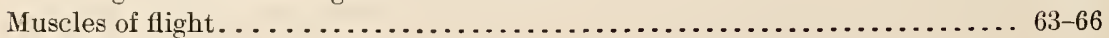




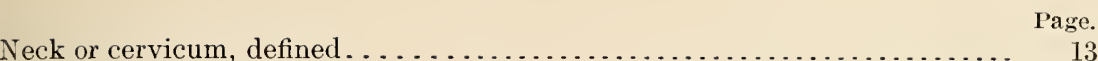

of generalized insect......................... 18

Nervous system and the eyes . . . . . . . . . . . . . . . . . . . . . . . . . 122-130

general description. . . . . . . . . . . . . . . . . . . 124-125

physiology ............................ 122-124

of abdomen of honey bee. . . . . . . . . . . . . . . . . 126-127

head of honey bee. . . . . . . . . . . . . . . . . . . 125-126

thorax of honey bee. . . . . . . . . . . . . . . . . . 126-127

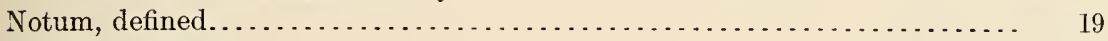

Nymph, defined . . . . . . . . . . . . . . . . . . . . . . . . . . . . . . . . . 12

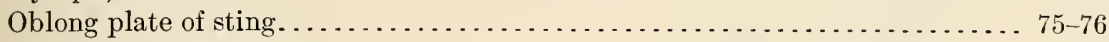

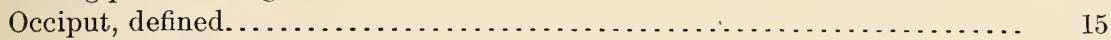

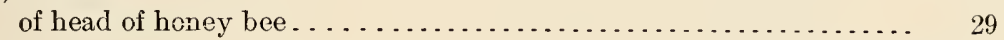

Ocelli.......................................... 27, 130

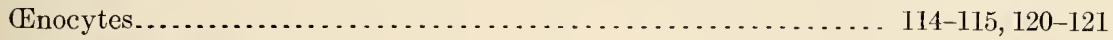

Esophagus, defined....................................... 90

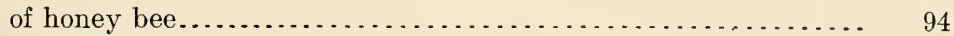

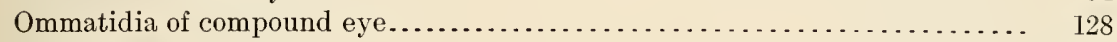

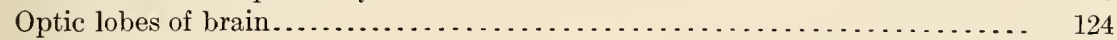

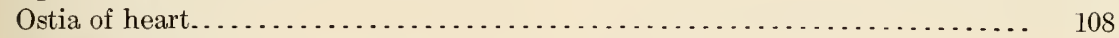

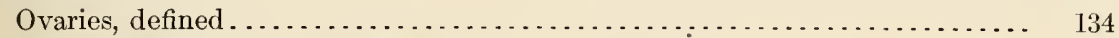

structure in queen bee. . . . . . . . . . . . . . . . . . 136

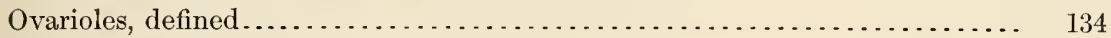

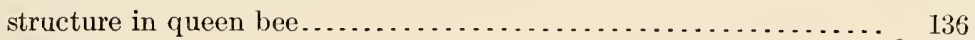

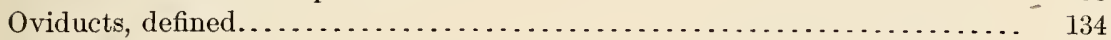

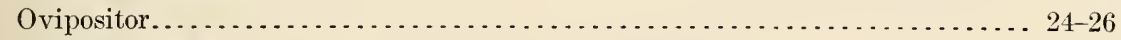

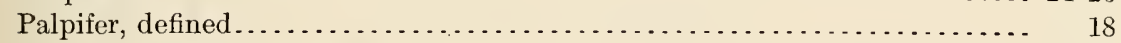

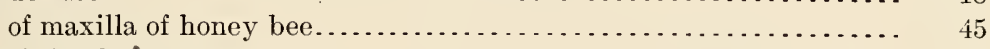

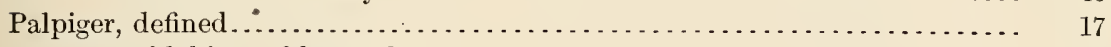

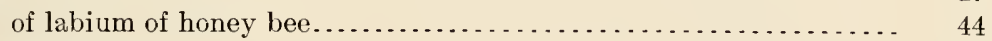

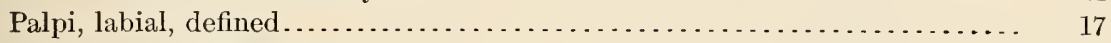

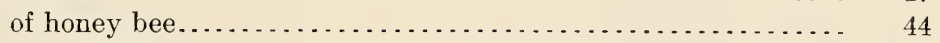

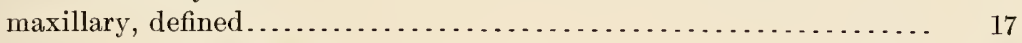

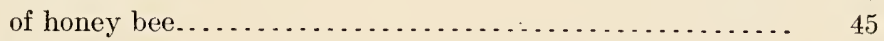

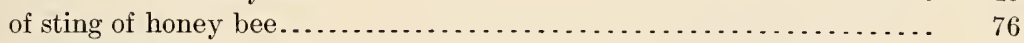

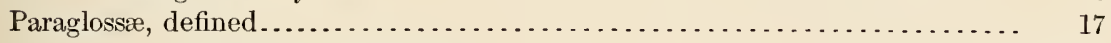

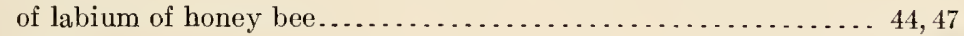

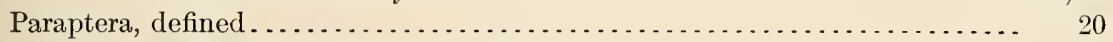

of mesopleurum of honey bee. . . . . . . . . . . . . . . 56

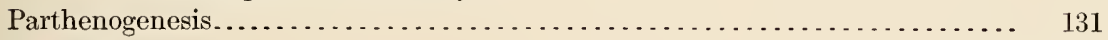

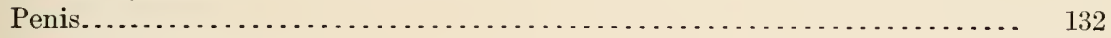

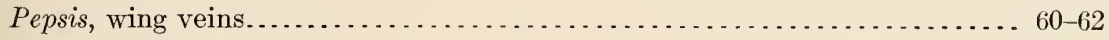

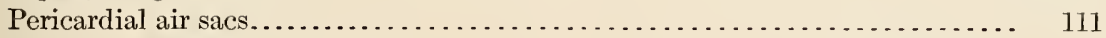

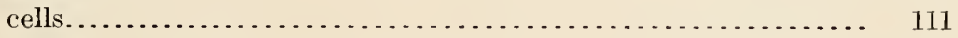

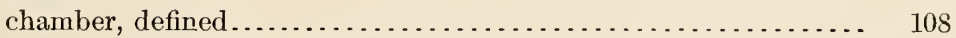

of honey bee (dorsal sinus) . . . . . . . . . . . . . . . . 107, 111

Peritrophic membranes.................................... 101-102, 104

Pharyngeal glands, lateral. . . . . . . . . . . . . . . . . . . . . . . . . . . 91-92

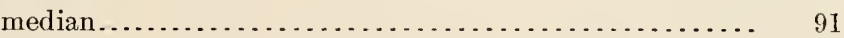

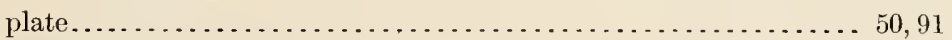

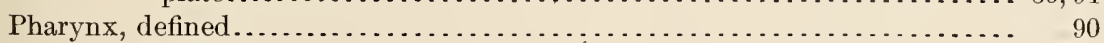

of honey bee. . . . . . . . . . . . . . . . . . . . . . . . $90-91$

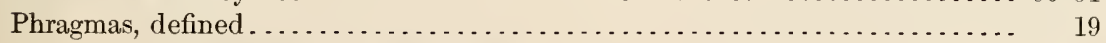

of mesotergum of honey bee........................ $55-56$ 
Pigment cells of compound eye . . . . . . . . . . . . . . . . . . . . . . . 129

Pleural coxal process, defined.................................... 19

ridge (entopleurum), defined.......................... 19

of mesopleurum of honey bee............. 56

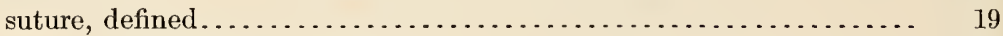

of mesopleurum of honey bee..................... 56

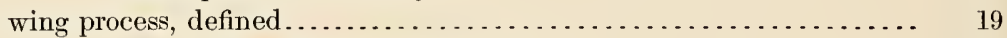

of mesopleurum of honey bee................ 56

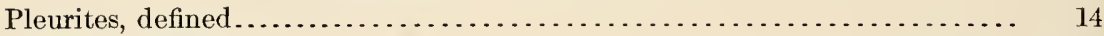

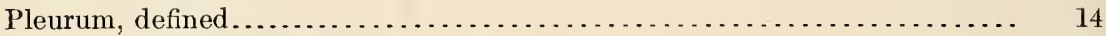

of generalized insect.......................... 19-20

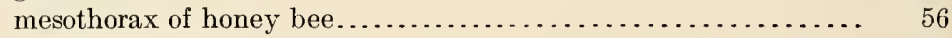

metathorax of honey bee............................. 57

prothorax of honey bee.............................. 55

Poison glands of sting of honey bee. . . . . . . . . . . . . . . . . . . . . . . . $78-79$

sac of sting of honey bee. . . . . . . . . . . . . . . . . . . . . . . . $78-79$

Pollen baskets of worker bee. . . . . . . . . . . . . . . . . . . . . . . . 66

Postcerebral glands... . . . . . . . . . . . . . . . . . . . . . . . . . . . . . $87-88$

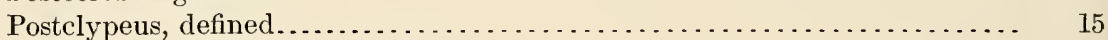

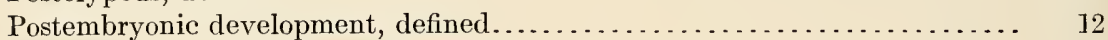

Posterior notal wing process, defined............................. 19

of mesothorax of honey bee............... 62

metathorax of honey bee............... 56

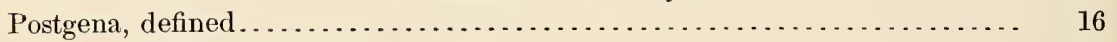

of head of honey bee............................... 29

Postnotum (pseudonotum), defined............................. 19

of mesotergum of honey bee. . . . . . . . . . . . . 55-56

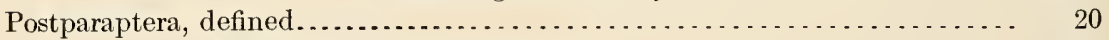

of mesopleurum of honey bee. . . . . . . . . . . . . . . . 56

Postscutellum, defined.................................... 19

of mesotergum of honey bee..................... 55

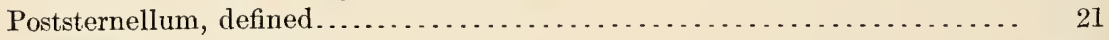

Preepisternum, defined..................................... 19-20

Preoral cavity . . . . . . . . . . . . . . . . . . . . . . . . . . . . . . . . . . . . . 49

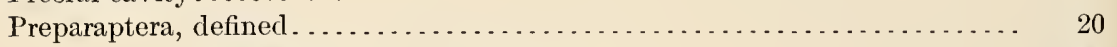

of mesopleurum of honey bee....................... 56

Prescutum, defined. ....................................... 19

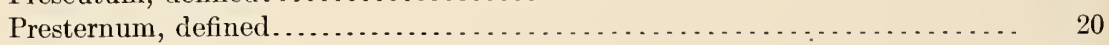

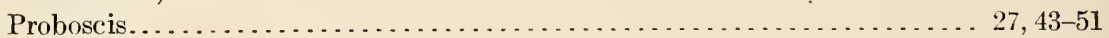

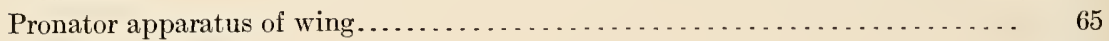

Propodeum . . . . . . . . . . . . . . . . . . . . . . . . . . . . . $58-59$

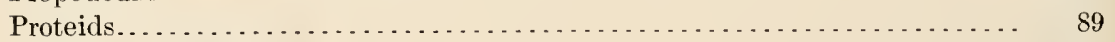

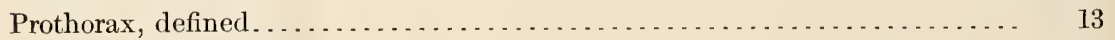

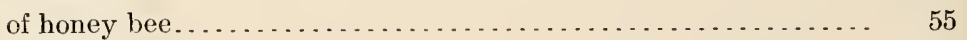

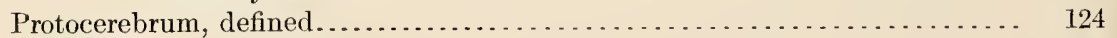

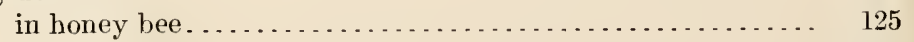

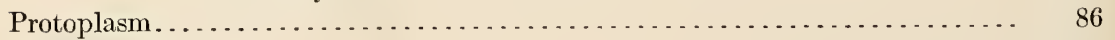

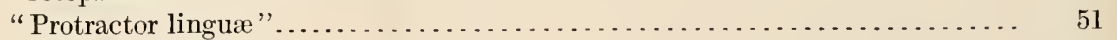

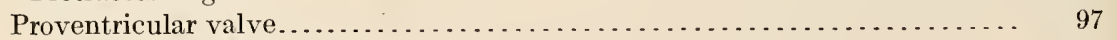

Proventriculus, defined...................................... 90

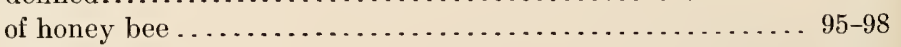

Pseudonotum, defined..................................... 19

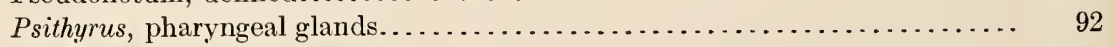




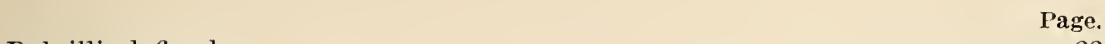

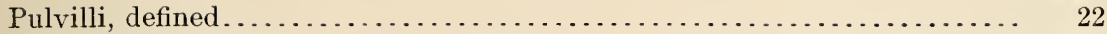

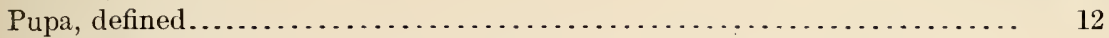

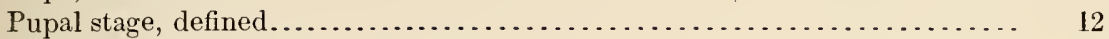

Quadrate plate of sting of honey bee........................ 76

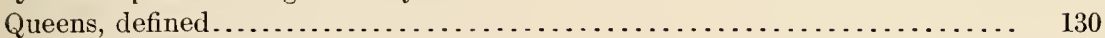

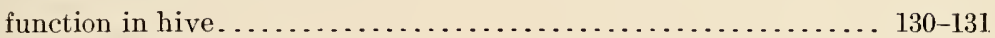

Radio-medial cross-vein, defined............................. 23

Radius of generalized wing . . . . . . . . . . . . . . . . . . . . . . . . 22

wings of Hymenoptera.......................... $59-62$

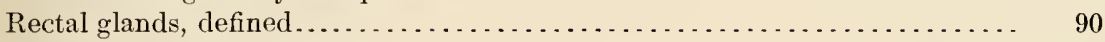

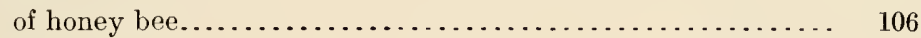

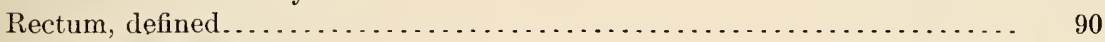

of honey bee. . . . . . . . . . . . . . . . . . . . . . . . . 106

Reproductive system...................................... . 130-139

of drone bee........................... 132-134

queen bee............................ 134-139

Respiration, movements .................................. 118

muscles................................ 118-119

physiology ................................. 112-114

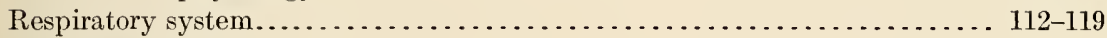

Retinulæ cells. . . . . . . . . . . . . . . . . . . . . . . . . . . . . . . . 129

"Retractor linguæ biceps"

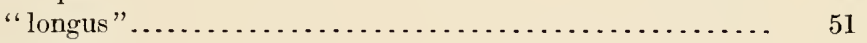

Rhabdomes of compound eye............................. 129

"Riechschleimdrüsse" .................................... 41

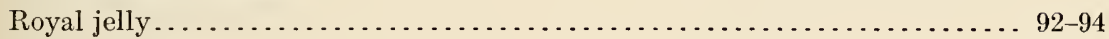

Salivary glands....................................... $87-89$

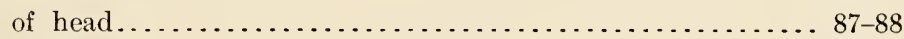

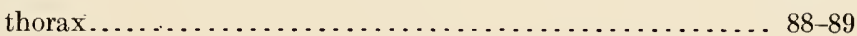

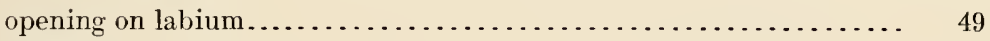

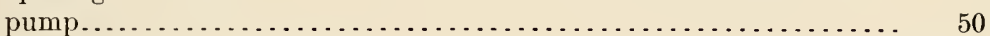

Sawfly, Itycorsia discolor, wing veins....................... $59-61$

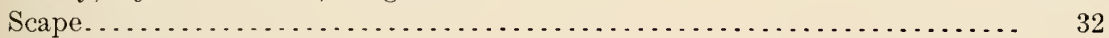

"Schlundbein"

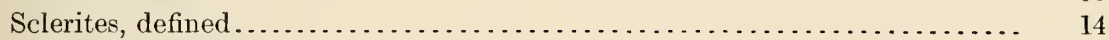

Scutellum, defined.................................... 19

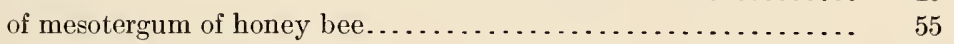

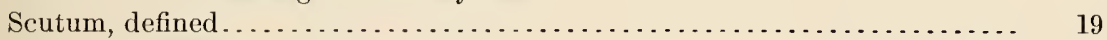

of mesotergum of honey bee.......................... 55

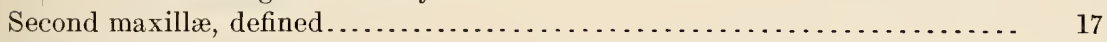

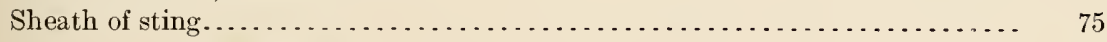

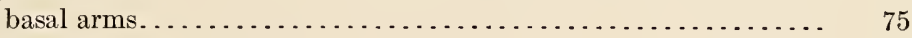

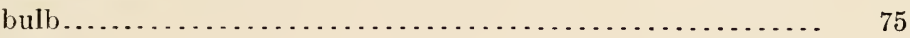

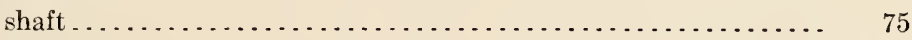

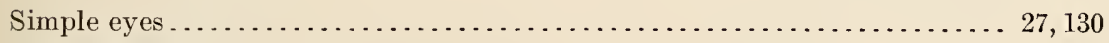

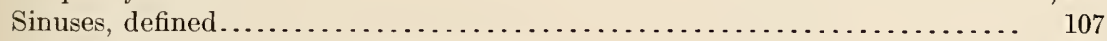

Sirex flavicornis, first abdominal segment....................... 58

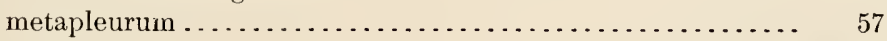

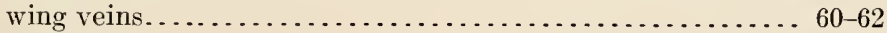

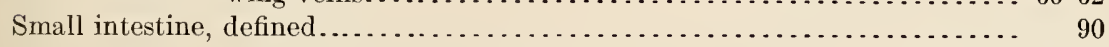

of honey bee................................... 105

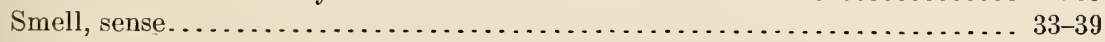


Somites, defined.

Page.

Spermatheca, defined

$134-135$

structure in queen.

136-137

Spermatozoa, defined......................................... ${ }_{130}$

of honey bee..................................... 134, 137-138

Sperm pump of spermatheca............................ 136-138

Spiracles, defined................................................. 112

of honey bee...................................... 115-116

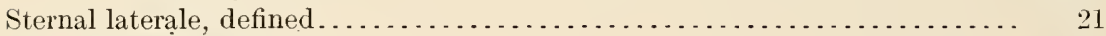

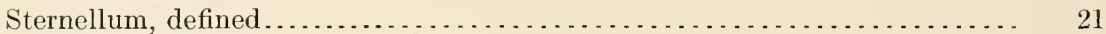

Sternites, defined ............................................. 14

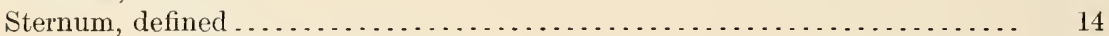

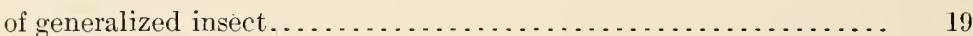

mesothorax of honey bee........................... 56

metathorax of honey bee........................... 56

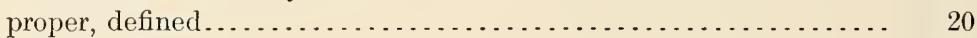

Stimuli, afferent, defined..................................... 124

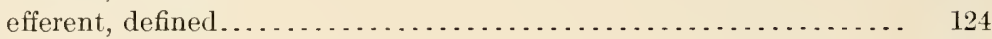

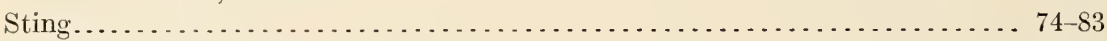

injection of poison................................. $80-82$

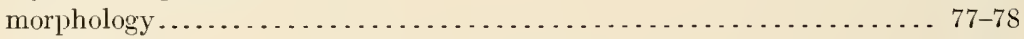

of queen bee...................................... $82-83$

Stipes, defined ............................................ 17

of maxilla of honey bee................................. 45

Stomach mouth (proventriculus) . . . . . . . . . . . . . . . . . . . . . 95-36

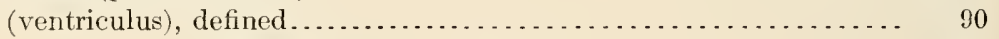

of honey bee................................ 98

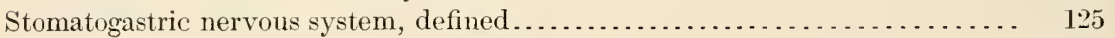

of honey bee...................... 126

Subcosta of generalized wing ................................ 22

wings of Hymenoptera.................................. 59

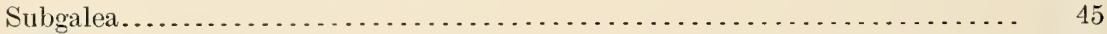

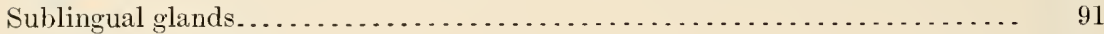

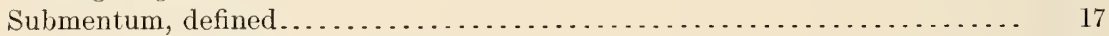

of labium of honey bee............................. 44

Subœsophageal ganglion, defined.............................. 124

of honey bee.......................... 126

Superlinguæ of embryo.......................................... 17

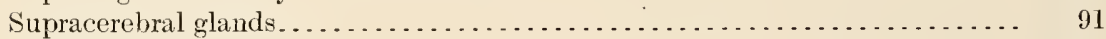

Sutures, defined.................................................. 14

Sympathetic nervous system, defined............................. 125

of honey bee.......................... 126

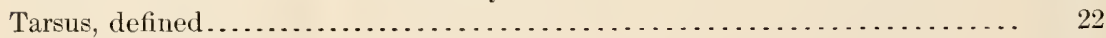

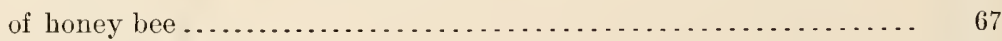

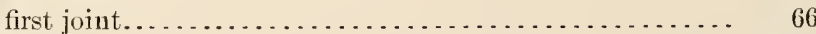

last joint................................ $68-69$

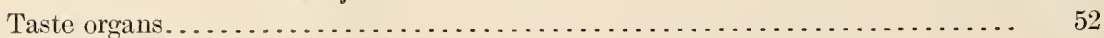

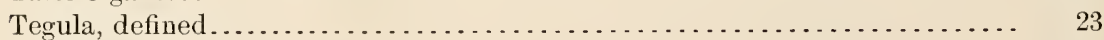

Temperature of honey bees..................................... 115

Tenth segment of abdomen...................................... 78

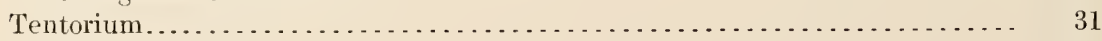

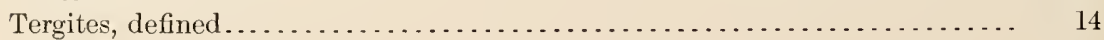


Page.

Tergum, defined.................................................. 14

in generalized thoracic segment........................... 19

of abdominal segments of honey bee . . . . . . . . . . . . $69-70,72-73$

first abdominal segment of honey bee.................. . $58-59$

mesothorax of honey bee........................... 55

metathorax of honey bee......... . . . . . . . . . . . . . . . 56-57

prothorax of honey bee............................ 55

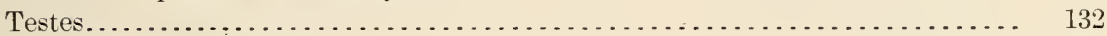

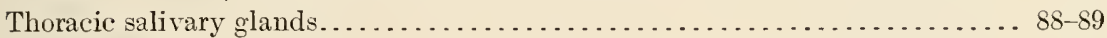

segment, typical.................................... 18-19

Thorax, defined.................................................. 13

generalized segment................................... 18 19

of honey bee and its appendages. . . . . . . . . . . . . . . . . . . 53-69

special characters, in honey bee........................... $54-55$

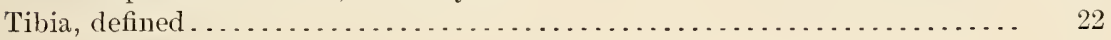

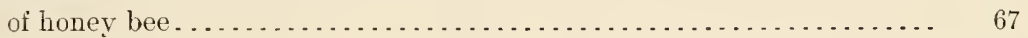

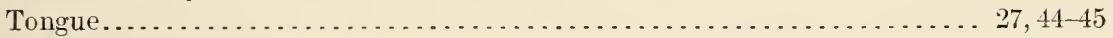

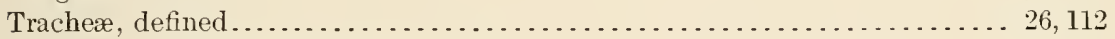

of honey bee.................................... 116-118

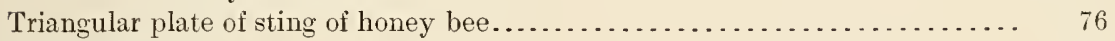

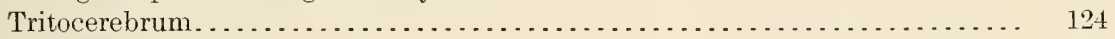

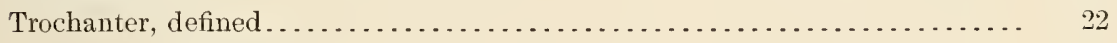

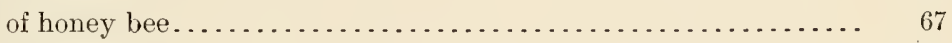

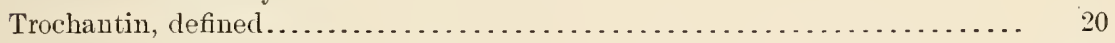

of honey bee.................................. $57-58$

mandibles, defined................................. 16

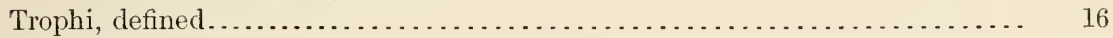

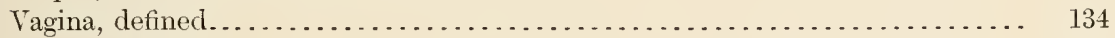

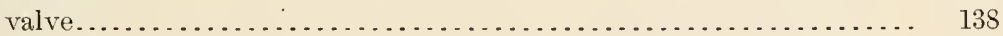

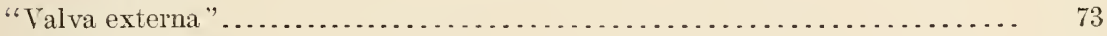

"interna "............................................. 73

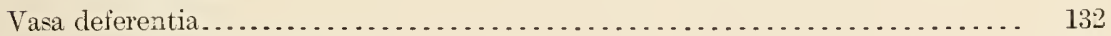

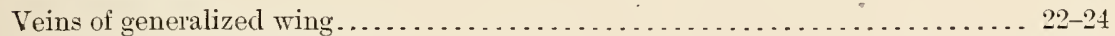

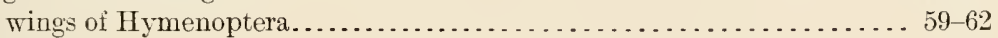

Venter, defined................................................... 18

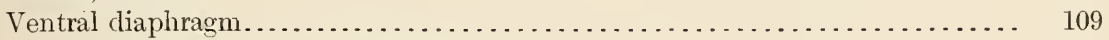

or median pharyngeal glands.............................. 91

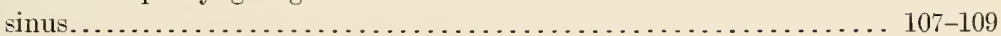

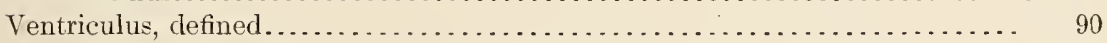

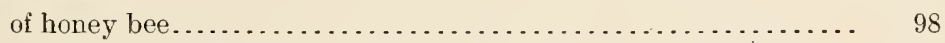

contents................................. 98

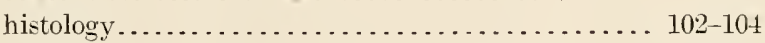

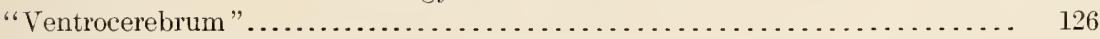

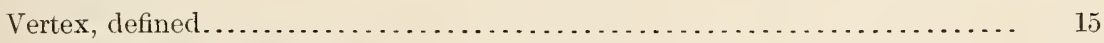

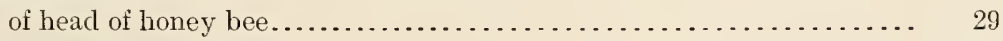

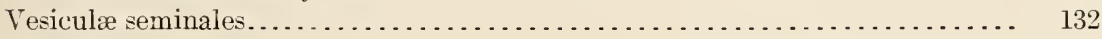

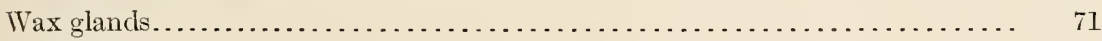

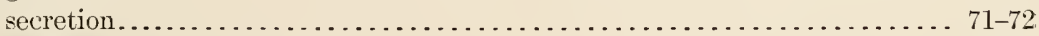

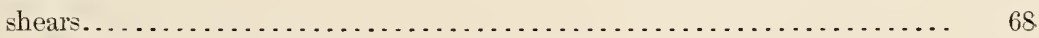

Wing processes of notum, defined................................. 19

of mesonotum of honey bee................. 62

metanotum of honey bee.................. $\quad 56$

$22181-$ No. $18-10-11$ 
Wing processes of pleura, defined............................... 19

of mesoplcurum of honey bee............... 56

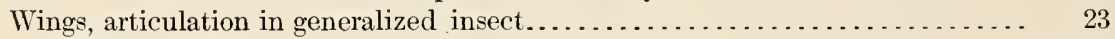

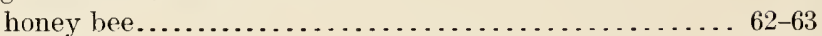

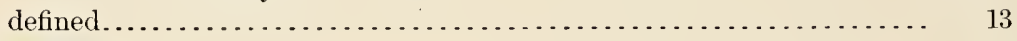

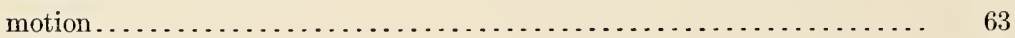

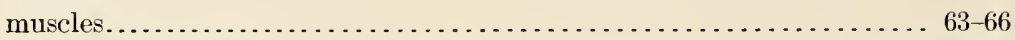

of generalized insect.................................. . $22-24$

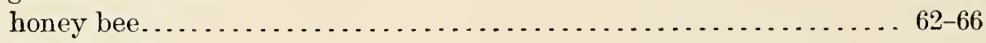

Hymenoptera.................................... 59-62

pronator apparatus. . . . . . . . . . . . . . . . 65

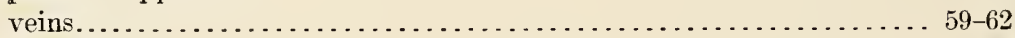

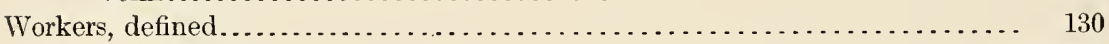

function in hive................................. 130-131 


TeChnical Series, No. 19, Part 1.

U. S. DEPARTMENT OF AGRICULTURE,

C BUREAU OF FiN'TOMOLOGY.

L. O. HOWARD, Entomologist and Chief of Bureau.

\section{TECHNICAL RESULTS FRON THE GIPSY HOTH PARASITE LABORATORT.}

\section{THE PARASITES REARED OR SUPPOSED TO HAVE BEEN REARED FROII THE EGGS OF THE GIPSY IIOTH.}

By L. O. IIOTVARD, PH. D.

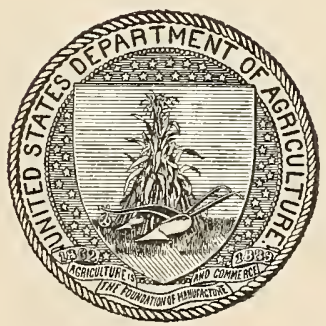

WASHINGTON:

GOVERNMENT PRINTING OFFICE. 


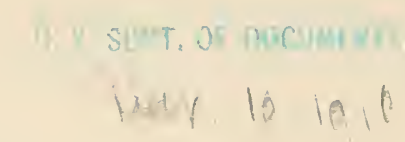

\section{BUREAU OF ENTO HOLOGY.}

L. O. Howard, Entomologist and Chief of Bureau.

C. L. Marlatt, Assistant Entomologist and Acting Chief in Absence of Chief.

R. S. Chifton, Executive Assistant.

Chas. J. Gilliss, Chief Clerk.

F. H. CHITTENDEN, in charge of truck crop and stored product insect investigations.

A. D. Hopkins, in charge of forest insect investigations.

TW. D. Hunter, in charge of southern field crop insect investigations.

F. M. WEBSTER, in charge of cereal and forage insect investigations.

A. L. Quanntance, in charge of deciduous fruit insect investigations.

E. F. Phillips, in charge of bee culture.

D. M. RogERs, in charge of preventing spread of moths, field work.

Rolla P. CURRIE, in charge of editorial work.

Mabel Colcord, librarian.

\section{Preventing Spread of Moths.}

PARASITE LABORATORT.

W. F. Fiske, in charge; A. F. Burgess, H. S. Smith, H. L. Tiereck, IT. R. Thompsos, C. IT. Collins, T. L. Patterson, R. Wooldridge, assistants.

FIELD WORK.

D. M. Rogers, in charge; H. B. Dalton, A. L. Connolly, H. W. Mntos, D. G. Murphy, I. L. Bailey, H. L. McINtyre, assistants 


\section{PREFACE TO BULLETIN.}

In the course of rather more than three years' work with the parasites and natural enemies of the gipsy moth and brown-tail moth, nearly all imported from Europe or Japan, it has been necessary to work with a number of species new to science and to make the most careful life-history observations upon all the species concerned in order to ascertain points of possible importance in the practical handling of the material. It is proposed in this Technical Series No. 19 to include a series of short papers giving some of the systematic and biological results of this work, the practical deductions for the most part being reserved for consideration in bulletins of the general series.

The present paper, therefore, forms the first of such a series. It describes several new egg-parasites and gives some consideration to others already describerl. It also includes a brief consideration of other forms supposed to have been reared from gipsy moth eggs.

Technical Series No. 12, Part VI, entitled "A Record of Results from Rearings and Dissections of Tachinidæ," by Charles H. T. Townsend, published September 18, 1908, really should have starterl this Technical Series No. 19, since it directly concerns itself with results of work at the gipsy moth parasite laboratory.

The laboratory in question, it should be stated, is now stationed at Melrose Highlands, Mass. (No. 17 East Highland avenue). It is conducted under the joint cooperation of the State of Massachusetts and the U. S. Department of Agriculture. The rental of the building, all construction work, nonexpert assistance, and the expendable supplies, together with the compensation of foreign agents, are charged to the State of Massachusetts. The Bureau of Entomology of the Department of Agriculture is charged with the salaries and expenses of all expert assistants and with all nonexpendable supplies and apparatus.

L. O. H. 



\section{CONTENTS.}

Page.

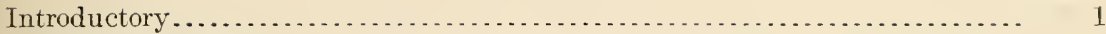

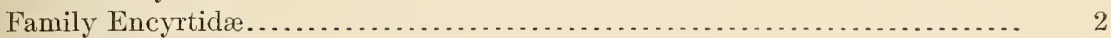

Subfamily Encyrtinæ............................................... 2

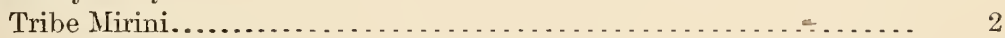

Genus Schedius .................................... 2

Genus Tyndarichus ...................................... 5

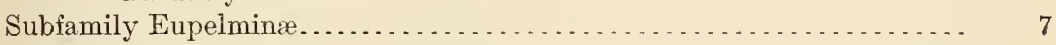

Tribe Eupelmini....................................... 7

Genus Anastatus..................................... 7

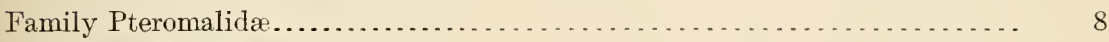

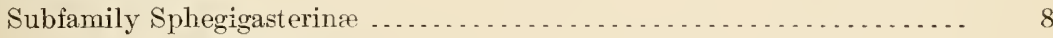

Tribe Pachyneurini.................................... 8

Genus Pachyneuron................................ 8

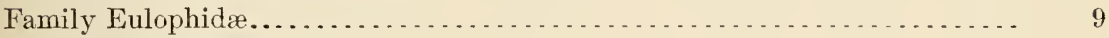

Subfamily Elachertinæ.................................. 9

Tribe Elachertini.......................................... 9

Genus Atoposomoidea . . . . . . . . . . . . . . . . . . . . . . . . 9

Subfamily Aphelininæ....................................... 11

Tribe Aphelinini ......................................... 11

Genus Perissopterus... . . . . . . . . . . . . . . . . . . . . . 11

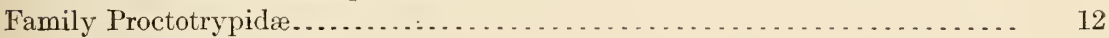

Subfamily Scelioninæ ... . . . . . . . . . . . . . . . . . . . . . . . . . 12

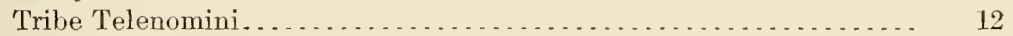

Genus Telenomus.................................... 12

\section{ILLUSTRATIONS.}

Fig 1. Schedius tuvanx. Female. Page.

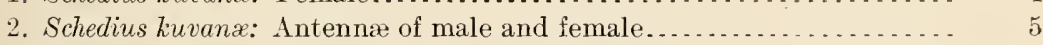

3. Schedius kuvanx: Fore and hind wings of female................. 5

4. Tyndarichus navæ: Antennæ of male and female ................. 6

5. Tyndarichus navæ: Fore and hind wings of female .............. 6

6. Anastatus bifasciatus: Female............................... T

7. Atoposomoidea ogimx: Female and details.................. 9 



\title{
TECHNICAL RESULTS FROII THE GIPSY MOTH PARASTTE LABORATORY.
}

\section{On Some Parasites Reared or Supposed to have been Reared from the Eggs of the Gipsy Moth.}

\author{
By L. O. Howard, Ph. D.
}

\section{INTRODUCTORY.}

No native American egg-parasites have ever been reared from the eggs of the gipsy moth (Porthetria dispar L.) since its introduction into this country in the late sixties. This seems strange, since native Lepidopterous eggs are very frequently attacked by eggparasites of several genera, notably by Trichogramma and Telenomus, as well as occasionally by Anastatus and Ooencyrtus. Nonparasitism of dispar by native species is probably due to the character of its egg-mass, which is so compact and so thoroughly protected by the scales of the parent as possibly to disguise its character from species unacquainted with it for many generations, while actual experiments with Trichogramma seem to show that it is unable to pierce the shell of the gipsy moth egg.

In the course of the extensive importations of parasites of this species from Europe and Japan, however, carried on cooperatively by the State of Massachusetts and the Bureau of Entomology of the U. S. Department of Agriculture, several primary and secondary parasites have been reared from these eggs at the Gipsy Moth Parasite Laboratory at Melrose Highlands, Mass., where they have been studied in greater or less numbers by Mr. W. F. Fiske, of the Bureau of Entomology, in charge of the laboratory, and by the corps of assistants working under his direction, and have in some cases been colonized in the open. In the following pages descriptions are given of the new forms, together with brief notes concerning their habits, the notes being the result of the observations of Mr. Fiske and assistants. Only two of the species, namely, Anastatus bifasciatus Fonsc. and Schedius kuvanæ How., appear to be of primary importance, but it is obvious that once acclimatized these two species will perform a very considerable part in the reduction in numbers of the gipsy moth in the United States.

The parasites so far reared have all come from Japan, southern Russia, and Hungary. The Anastatus has a wider range, occurring 
in many parts of Europe, but has other hosts. Shipments of dispar eggs received at the Parasite Laboratory from Switzerland and northern Germany have given out no parasites whatever. Silvestri states that he has never been able to secure parasites from the eggs of dispar in Italy, but there is a reasonable chance that he did not keep his material long enough to have secured the summer-issuing forms had they been present. There is no evidence as yet that gipsy moth egg-parasites occur in western Europe-that is, France or Spain.

Other insects are occasionally sent to this country accidentally with these egg-masses, one of them, a small Dermestid beetle, really feeding upon the eggs. This insect was found in considerable numbers in a large shipment of dispar eggs, sent by Prof. Trevor Kincaid from Japan, which were collected after the caterpillars had emerged. This species has been examined by Mr. E. A. Schwarz, who states that it is probably an undescribed species and genus of the group Attageni. The larvæ of Anthrenus verbasci L. are constantly found in the old cocoon masses of the white-marked tussock moth (Hemerocampa leucostigma S. \& A.) in this country and under the batches of eggs already hatched, where they are engaged in feeding upon the dry remains of pupæ and eggs. The writer ${ }^{a}$ has pointed out that these larvæ also eat the healthy eggs, and that Trogoderma tarsale Melsh., another Dermestid, has the same habit. This has since been seen to be the case with the white-marked tussock moth in Massachusetts, and one of these species has several times been reported as destroying the eggs of the gipsy moth in Massachusetts.

The cocoons of Glyptapanteles have also been sent in on bits of bark attached to the egg-masses; and other small miscellaneous insects, including several species of small moths which had sought the protection of the egg-masses for pupation, have come in, indicating not only the great possibility of error in rearing insects from large masses of material, but also the necessity for great care to avoid the introduction of new insect pests.

\section{Family ENCYRTID正 Walker. \\ Subfamily FiNCYRTIN AE Howard. \\ Tribe MIRINI Ashmead. \\ Genus SCHEDIUS, new genus.}

Female.-Mandibles broad at apex, very obscurely tridentate; outer tooth rather short, acute; middle tooth rounded, inner tooth flat and with a straight edge. Antennæ inserted just above border of the mouth; facial depression well marked; clypeus well rounded and elevated; vertex rather narrow, head well produced in front;

$a$ Technical Series No. 5, Bur. Ent., U. S. Dept. Agr., p. 46, 1897. 
ocelli at angles of slightly acute-angled triangle, lateral ocelli nearer eye-border than to each other; occipital margin somewhat rounded; eyes large, well rounded, rigid (keeping their shape after death), very faintly hairy. Antennal scape slender, subcylindrical; pedicel nearly three times as long as broad; funicle subcylindrical, joint 1 short, about one-half length of pedicel, remaining joints increasing slightly in length and width to club, except that joint 6 is slightly shorter than 5 ; club ovate, flattened, nearly as long as last three funicle joints together, basal joint longest. Body stout; mesonotal axillæ well separated at tips; mesoscutellum well rounded; abdomen shorter than thorax, short-ovate. Wings long and broad; marginal vein punctiform; stigmal rather long, slender, slightly enlarged at tip, extending into the wing-dise at an angle of about 35 degrees with the costa; postmarginal evident, but not so long as stigmal; wing-disc with an oblique hairless streak extending from stigmal vein toward the base of the wing; hind wings rather narrow, but densely and uniformly ciliate.

Male.-Differs from female principally in the shorter abdomen and in the antenna. Antenna with scape slightly widened below; pedicel obconical, very slightly longer than width at tip; first funicle joint slightly longer than pedicel; funicle joints 1 to 5 subequal in length and width, 6 somewhat shorter; all funicle joints somewhat convex on outer side, nearly straight on inner side; club ovate, rather broadly flattened, somewhat longer than funicle joints 5 and 6 together; all of flagellum beyond pedicel rather closely furnished with hairs averaging about two-thirds the length of the respective sclerites that bear them.

Type.-The following species:

SCHEDIUS KUVANÆ, new species.

(Figs. 1-3.)

Female.-Length, $0.99^{\mathrm{mm}}$; expanse, $2.39^{\mathrm{mm}}$; greatest width of fore wing, $0.43^{\mathrm{mm}}$. Vertex and cheeks very faintly shagreened; mesoseutum nearly smooth, shining, with minute, rather sparse punctures; mesoscutellum densely and rather coarsely shagreened, well rounded at tip; propleura very faintly shagreened, somewhat shining. General color black; mesoscutellum with a bronzy luster; trochanters, tips of femora, apical half or a little more of front and middle and hind tibiæe yellowish; all tarsi lighter; antenna dark brown; dark parts of the legs more brown than black. Wings hyaline.

Male.-Length, $0.9^{\mathrm{mm}}$; expanse, 2.28 $\mathrm{mm}$; greatest width of fore wing, $0.43^{\mathrm{mm}}$. Resembles female, except that the flagellum of the antenna is light brown, and except for the structural characters mentioned in the generic diagnosis.

Described from numerous male and female specimens reared September, 1908, at the Gipsy Moth Parasite Laboratory of the State of 17215-No. 19-10-2 
Massachusetts and the Bureau of Entomology, at Melrose Highlands, Mass., from the eggs of Porthetria dispar received from Tokyo, Japan, from Prof. S. I. Kuwana, Entomologist of the Imperial Agricultural Experiment Station at Nishigahara, Tokyo, after whom the species is named in partial recognition of his great services to the United States in sending parasites from Japan.

Type.-No. 12158, U. S. National Museum; Gipsy Moth Laboratory No. 1698.

This species appears to be an important parasite of the gipsy moth. It has been imported in very large numbers through the courtesy of Professor Kuwana. The great majority of the specimens have been dead upon arrival, but small numbers have emerged living at the Gipsy Moth Parasite Laboratory at Melrose Highlands. The species appears to be more common in the ricinity of Tokyo than

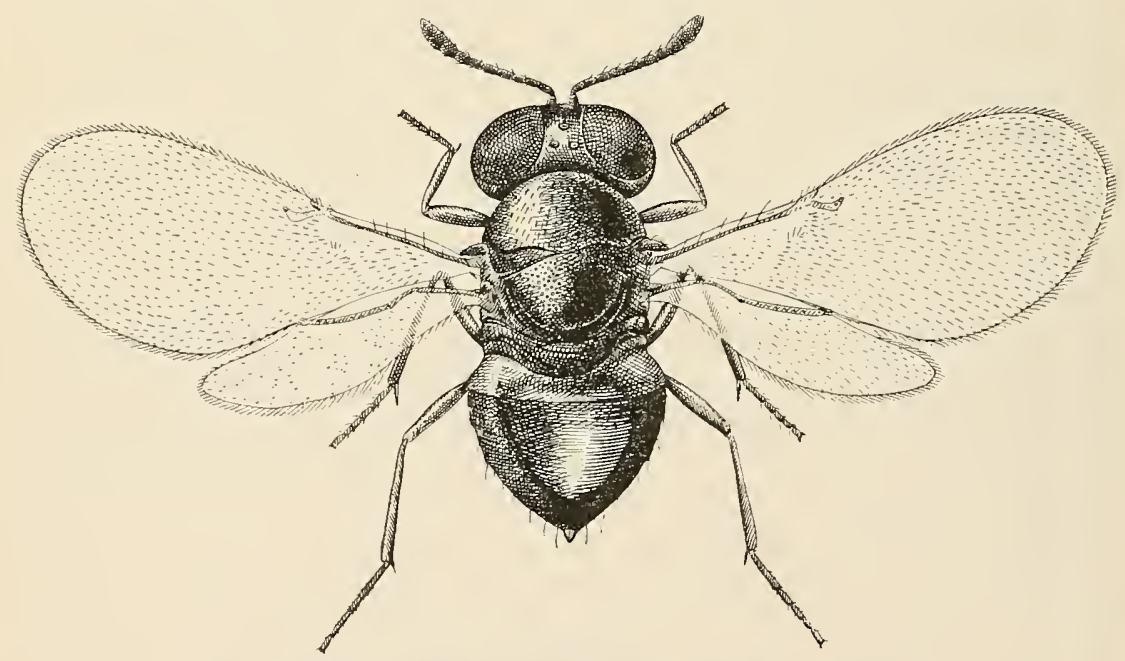

FIG. 1.-Schedius kuvanæ: Female. IIiglhly magnified. (Original.)

in other parts of Japan. This parasite in the field issues from dispar eggs in the autumn after they have been deposited. For some reason it has not been reared freely from Japanese eggs collected and forwarded during the winter. The possible inference that it does not hibernate in the eggs of this host in Japan is not in accord with its behavior in America. There is ample time for two and possibly three generations in the same autumn after the gipsy moth has laid its eggs. The species is easily controlled in the laboratory, as determined by Mr. Fiske, and more than twenty thousand have been reared and liberated from a total importation of about twenty living individuals. The early stages have been worked out at the laboratory by Messrs. Fiske and H. F. Smith, and are very remarkable. It attacks the eggs of its host when freshly deposited and with equal 
freedom those which contain the fully developed caterpillar all ready to hatch.

Genus TYNDARICHUS, new genus.

Female.-Mandibles like those of Schedius. Antennæ short; scape rather short, with a rather broad leaflike extension below; pedicel long, obconical, two and one-half times as long as width at tip and half as long as funicle; first funicle joint narrower than tip of pedicel and rather shorter than broad; funicle joints 2, 3, and 4 each about as long as 1 , but gradually widening; 5 and 6 somewhat longer and considerably wider, thus making the width increase from 1 to 6 ; club very broad, somewhat flattened, having three segments subequal in length, but with the dividing sutures slightly oblique, tip obliquely truncate from a point immediately before the last suture; flagellum with sparse hairs, and scape and pedicel with a few bristles. Body short, stout, re-

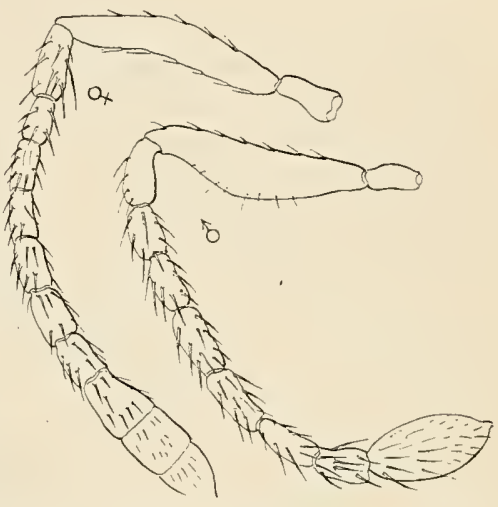

FIG. 2.-Schudius kivanæ: 3, Antenna of nale; $q$, antenna of female. Highly magnified. (Original.) sembling Schedius in general appearance. Antennæ inserted slightly above mouth border; facial depression and clypeus resembling Schedius; vertex narrower than with Schedius, but ocelli placed in
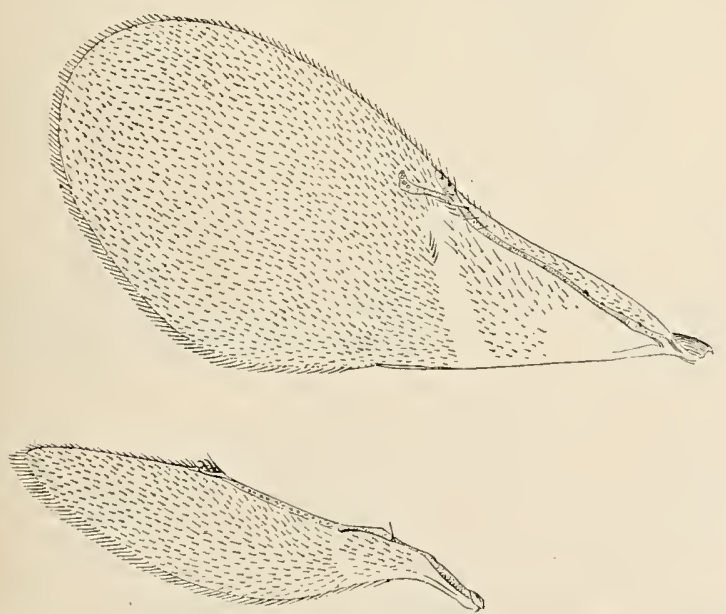

FIs. 3-Schedius kuvanæ: Fore and hind wings of female. Highly magnified. (Original.) the same manner; occipital margin acute; eyes naked, not rigid (falling in after death). Axillæ of mesonotum barely meeting at tip; abdomen flat tened above, triangular, nearly as long as thorax. Fore wings broar; disc closely ciliate though not so densely as with Schedius, oblique hairless line below stigma faintly indicated, but the entire disc below submarginal vein only sparsely ciliate; marginal vein punctiform, stigmal much as with Schedius; submarginal vein with a pronounced and curious break beyond middle as illustrated in figure 5; hind wings broader than with Schedius. 
Male.-Body short, stout; mesonotum highly arched; abdomen flat, broadly ovate. Intennæ long, submoniliform, ventral outline

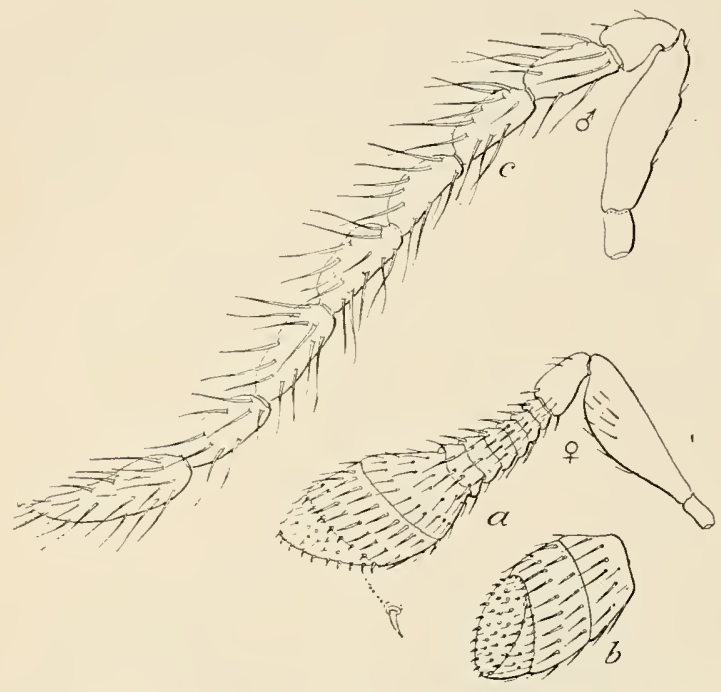

FIG. 4.-Tyndarichus naræ: $a$, Intenna of female; $b$, club of same; from below; $c$, antenna of mnale. Highly magnified. (Original.) of funicle joints nearly straight, dorsal outlines somewhat rounded ; scape short, subcylindrical, very slightly widened ventrally; pedicel shorter than first funicle joint; all funicle joints subequal in length and width, the sixth rather shorter; club slightly flattened, long-ovate, pointed at tip, one and one-half times longer than sixth funicle joint; the whole flagellum beyond pedicel rather abundantly furnished with long, slightly curving bristles, having no marked tendency to form definite whorls, each bristle about as long as its sclerite.

Type.-The following species:

TYNDARICHUS NAVA, new species.

(Figs. 1,5.)

Female.-Length, $1.08^{\mathrm{mm}}$; expanse, $2.19^{\mathrm{mm}}$; greatest width of fore wing, $0.39^{\mathrm{mm}}$. Entire body black, shining; head and mesonotum very faintly shagreened; vertex and cheeks with steel-blue reflections; mesoscutellum with coppery reflections; antennæ dark brown, with light brown pile; all leys dark brown, nearly black except at tips of tibire and all tarsi.
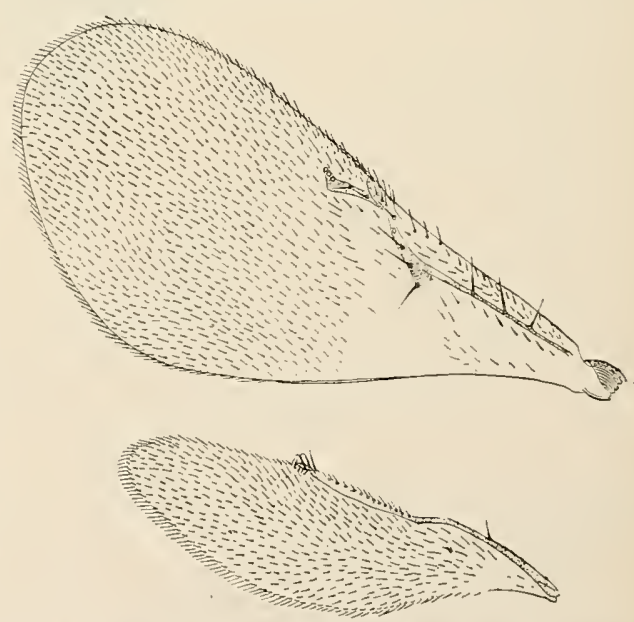

F16. 5. - Tyndarichus navæ: Fore and hind wings of female. Highly magnified. (Original.)

Male.-Length, $0.93^{\mathrm{mm}}$; expanse, $2.19^{\mathrm{mm}}$; greatest width of fore wing, $0.44^{\mathrm{mm}}$. Differs from female, aside from characters mentioned in generic description, very slightly. Antennæ brownish, with black 
hairs. General appearance of body more opaque than with the female and metallic reflections less distinct; leg coloration identical.

Described from seven female and four male specimens reared from the eggs of Porthetria dispar, June, July, and August, received from U. Nawa, Gifu, Japan, after whom the species is named.

Type.-No. 12159, U. S. National Museum; Gipsy Moth Laboratory Nos. 1625,1020 , and 1039.

This parasite has also been imported from Japan in eggs collected by Professor Kuwana, and seems to follow Schedius in distribution in Japan. It is very much less common, but varies in abundance in different lots of eggs. Unlike Schedius, it has been reared freely from the eggs collected and forwarded during the winter, emerging at rarious times in the spring and summer. So far as indicated by a considerable number of dissections made by Messrs. Fiske and

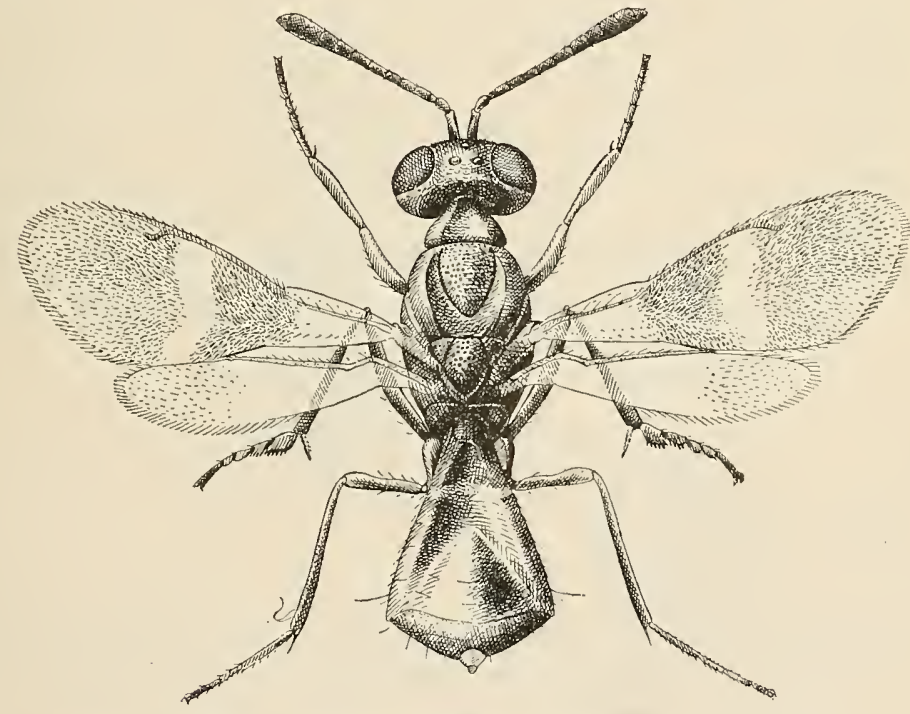

FIG. 6.-A nastatus bifasciatus: Female. Highly magnified. (Original.)

Smith, it is invariably secondary. Its host is usually Schedius, occasionally Pachyneuron, and possibly Anastatus.

Subfamily FUPFLMIN AE Howard.

Tribe FUPFLMINI Ashmead.

Genus ANASTATUS Motschulsky.

ANASTATUS BIFASCIATUS (Fonscolombe).

(Fig. 6.)

Cynips bifasciata Fonscolombe.

Eupelmus bifasciatus Förster, 1860.

Eupelmus bifasciatus Wachtl, 1882 (from eggs of Ocneria dispar).

This very widespread parasite is an important enemy of the gipsy moth. It has been reared at the Parasite Laboratory at Melrose 
Highlands by Mr. Fiske and assistants from egg-masses received from all parts of Japan, but more commonly from those collected in Fukuoka, these egg-masses having been sent in by several of the energetic Japanese correspondents of the Bureau, but principally by Mr. U. Nawa and Prof. S. I. Kuwana. It has also been reared from eggs sent from the Crimea by Prof. S. Mokshetsky, and in especial abundance from eggs sent from Hungary by Prof. J.. Jablonowski. The species appears to be much more common in European countries, but is apparently local in its European distribution. Dalla Torre records it from France and from lower Austria. Many thousands of specimens of this species have been reared at the Parasite Laboratory. It attacks the egg of dispar very shortly after the latter is deposited, and requires a full year for a generation-a fact which, while it would seem to reduce its possible value as an effective parasite of the gipsy moth, really enlances it as an introduced species, since it is independent of other insects for alternate hosts at seasons when eggs of the gipsy moth are not available. The accompanying figure was drawn from a museum specimen. In life the abdomen is not sunken dorsally.

\section{Family PTEROMALIDE Ashmead.}

Subfamily SPFEGIGASTHRIN AE Ashmead.

Tribe PACHYNEUIRINI Ashmead.

Genus PACHYNEURON Walker.

PACHYNEURON GIFUENSIS Ashmead.

Pachyneuron gifuensis Ashmead, Journ. X. I. Ent. Soc., xII, No. 3, p. 158, September, 1904.

This species, described by Ashmead as above, was part of a collection referred to the U. S. National Museum some years ago by Professor Mitsukuri, of Tokyo. It has recently been imported from Japan in eggs of dispar collected by Prof. S. I. Kuwana, and is apparently common in the vicinity of Tokyo. In habits it is like Tyndarichus navæ, as determined by Messrs. Fiske and Smith at the Parasite Laboratory, but it is a little less common and issues in the spring. It is a hyperparasite, and attacks Schedius kuvanæ and Tyndarichus navæ as well; in the first instance being secondary and in the other instance tertiary. In one instance at the laboratory it was reared from an egg which originally contained Anastatus bifasciatus. The type and two other specimens were reared by Mr. I. Nawa from an aphis at Gifu, Japan, undoubtedly parasitic on some primary parasite of the Aphidid. 
Family EULOPHIDE Ashmead.

Subfamily HIACHIHRTIN AI Ashmead.

\section{Tribe ELACHERTINI Ashmead.}

Genus ATOPOSOMOIDEA, new genus.

Female.-Apparently this genus comes near Atoposoma Masi, as the proposed name suggests, and is distinguished chiefly by the solid thorax, naked eyes, somewhat less elevated vertex, slightly different dentation of the mandibles, low insertion of the antennæ, different proportions of the antennal sclerites, and greater length of postmarginal vein-all of which are indicated in the accompanying illustration (fig. 7). Atoposoma is closely related to Zagrammosoma Ashmead, also parasitic on a Lepidopterous larva.

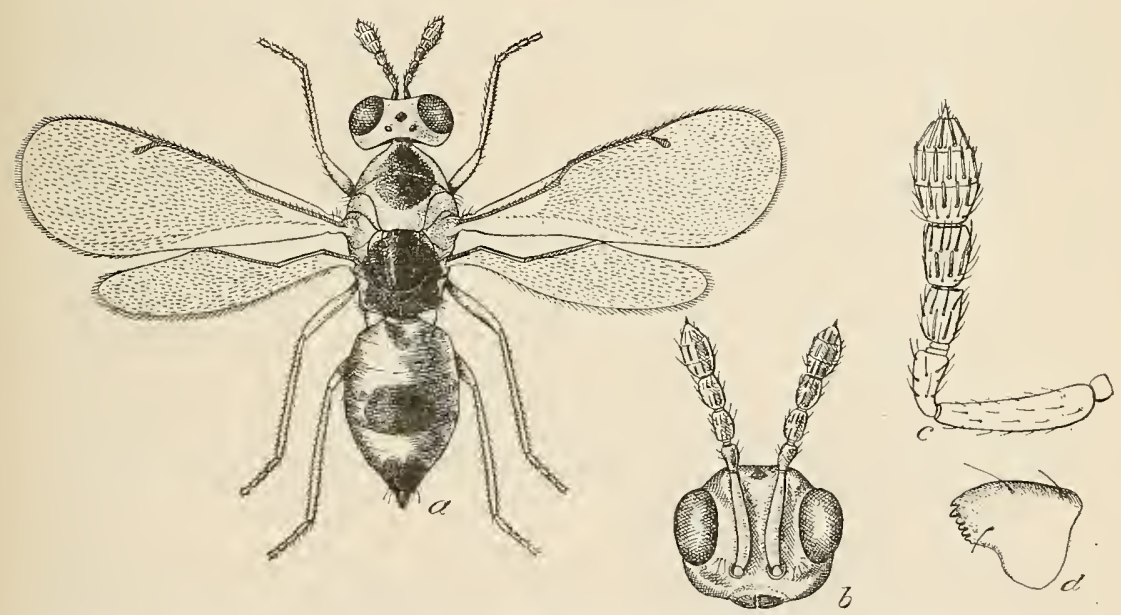

Fig. 7.-A toposomoidea ogimx: $a$, Female; $b$, head of same, anterior aspect; $c$, antenna of same; $d$, mandible of same. $a$, Very much enlarged; $b-d$, highly magnified. (Original.)

Male.-Differs from female in its shorter antennæ, which are furnished with rather dense pile which is shorter than with female. It also has a shorter abdomen.

Type.-The following species:

ATOPOSOMOIDEA OGIMA, new species.

(Fig. 7.)

Female.-Length, $1.65^{\mathrm{mm}}$; expanse, $2.66^{\mathrm{mm}}$; greatest width of fore wing, $0.5^{\mathrm{mm}}$. Pronotum and entire mesonotum finely shagreened. Mesopleura also finely shagreened. General color lemon-yellow. Head with a large, black occipital spot; a large, nearly circular, black spot on pronotum and mesonotum, divided in about its middle by the pronotal suture; central portion of mesoscutellum black, and 
the sides as well, below middle; metanotum black; abdomen with a black, rounded spot dorsally just below middle, abdomen also black at tip; antennæ brownish, with a whitish pile; all legs light yellow.

In the markings the species is extremely variable. A frequent variation from what we may call the typical markings as shown in the illustration, is the absence of the black spot on mesoscutellum, although sometimes it is represented by a minute central dot; the occipital black spot is frequently lacking; the pronotal and mesoscutal spots frequently become greatly reduced in size. On the other hand, in many specimens the black spots become greatly enlarged so as to make black almost the predominant color of the insect.

Male.-Length, $1.26^{\mathrm{mm}}$; expanse, $2.43^{\mathrm{mm}}$; greatest width of fore wing, $0.43^{\mathrm{mm}}$. Antennæ yellowish, with abundant, long, white pile. Color as with female, except that entire apical half of dorsum of abdomen is black, and entire pronotum is black. There is almost the same range of variation in size of black spots as with the female.

Described from 43 female and 8 male specimens reared from cocoons of Glyptapanteles japonicus Ashmead, received from Trevor Kincaid during the summer of 1908 from various localities in Japan, and from other cocoons of the same species received from S. I. Kuwana during the summer of 1909 from different localities in Japan. Named after Prof. G. Ogima, Assistant Entomologist, Kyushiu Experiment Station, Kumamoto, Japan, in recognition of his valuable services.

Type--No. 12681, U. S. National Museum; Gipsy Moth Laboratory Nos. 1623 and 1074.

There is a single female of this species, labeled "Kumamoto, Japan, reared 10th of May, 1907, by G. Ogima, egg-parasite of P. dispar." This specimen was not sent to the writer by Professor Ogima himself directly, but either through Professor Kuwana or Mr. Kincaid, and it is the receipt of this specimen which justifies the description of this new genus and species in a paper on the egg-parasites of the gipsy motil. Very large numbers of this parasite, however, have been reared at the Parasite Laboratory at Melrose Highlands, by Mr. Fiske, from the cocoons of the Glyptapanteles, and it is very possible that a mistake has arisen in Japan through the rearing of this species apparently from an egg-mass of dispar which had been laid over a mass of Glyptapanteles cocoons. Similar instances have occurred before, notably in the case of Ashmead's Ablerus clisiocampæ, which apparently came from an egg-mass of Clisiocampa but in reality from Chionaspis furfura on the bark of the twig under the egg-mass of the Lepidopterous insect. Similarly the writer's Isodromus iceryæ was apparently reared by Mr. D. W. Coquillett from egg-masses of Icerya purchasi but in reality came from a Chrysopa 
cocoon hidden among the egg-masses and so covered with wax as probably to be indistinguishable.

Several species of Elachertines of this general type, including at least one undescribed genus in addition to Atoposoma and Zagrammosoma, have been reared from Microlepidopterous larvæ. The first one that the writer ever saw was reared from Lithocolletis fitchella in Washington in 1879. Others were reared from leaf-miners from Florida, but none of these striking forms was described until Ashmead $^{a}$ described the genus Hippocephalus for a species, multitineatus, reared by Mr. C. L. Narlatt from Lithocolletis ornatella. On account of the preoccupation of the name Hippocephalus, Ashmead, in his monograph of the Chalcidoidea, changed the name to Zagrammosoma. Masi's type of Atoposoma (A. variegatum) fed in the larval state exteriorly on a larva of the Lepidopter, Ecophyllembius neglectus. The present genus, Atoposomoidea, appears to be the first Chalcidid of this markedly beautiful and peculiar facies to have been reared from a Braconid cocoon, and we must assume from the great numbers in which these rearings have been made that the habit is normal for this species.

\section{Subfamily APHFiLININ AE Floward. \\ Tribe APHELININI Ashmead.}

Genus PERISSOPTERUS Howard.

\section{PERISSOPTERUS JAVENSIS Howard.}

Perissopterus javensis Howard, New Genera and Species of Aphelininae, Tech. Ser. 12, Pt. IV, Bur. Ent., U. S. Dept. Agr., Washington, p. 88, July 12, 1907.

The type series of this beautiful little parasite was reared in February, 1900, by A. Koebele from a scale insect of the genus Tachardia on an ornamental plant at Singapore, Straits Settlements. All of the other species of the genus have been reared invariably from scale insects and nothing else. A record of the issuance of $P$. javensis from gipsy moth eggs is therefore open to doubt, and one's first impression is that it must have come from some scale insect over which a dispar egg-mass had been laid. Nevertheless, according to $\mathrm{Mr}$. Fiske, the single female submitted to the writer for determination came from a dispar egg received from Professor Kuwana from near Tokyo. The apparent great discrepancy between this statement and the previous records renders it desirable to give an explicit statement of the facts as observed by Mr. Fiske. From his original notes it is found that December 9, 1908, a lot of $250 \mathrm{egg}$-masses of dispar, collected in Tokyo November 5, 1908, by Professor Kuwana, was received. One of these egg-masses was thin, with the hairy covering badly weathered, and many of the eggs exposed. Critical examina- 
tion of this mass indicated that 181 of the eggs were apparently healthy. Parasites had emerged from 108, while the dead or doubtful eggs numbered 35. Mr. Fiske thinks that the parasites that had emerged were probably Schedius. On December 14 the $35 \mathrm{eggs}$ of the third category were assorted into those which appeared to contain parasites and those which were dead. They were emptied into a watch glass, and a single, small, living parasite (the Perissopterus under consideration) was found. Careful examination of the eggs showed two which had very small round holes in the side, from either of which the parasite might have come. These holes were smaller than those usually made by any of the other known parasites. These eggs were separated from the others, and on March 4 one of them was boiled in caustic potash $(\mathrm{KOH})$ and its contents examined. Fragments of the pupal exuvium of a small Chalcidid different from that of any other parasite studied was found and mounted. There was no other indication of any other parasite in the egg, and the one which emerged appeared to have fed upon the caterpillars primarily. No parasite remains were found in the other pierced egg. The parasite found on December 14 was placed in a small vial with a variety of eggs, including some of dispar that contained larvæ of Anastatus, others that contained healthy dispar caterpillars, and some of the tussock moth. The Perissopterus (which was a female) lived for some days, but showed no interest in any of the eggs.

\section{Family PROCTOTRYPIDE Ashmead.}

Subfamily SCFLIONINAE Howard.

\section{Tribe TELENOMINI Ashmead.}

Genus TELENOMUS Haliday.

TELENOMUS, new species.

In the autumn of 1897 there was received from Prof. S. Mokshetsky, of Simferopol, Russia, a single specimen of a new species of Tetenomus, which he reared during September, 1906, from the eggs of the gipsy moth. As probably Professor Mokshetsky will describe this species himself, it is given no name at this time. Curiously enough, it belongs to the same group of the genus to which Telenomus cultratus Mayr belongs much more closely than to any of the species reared from Lepidopterous eggs. T. cultratus lives both as larva and pupa in the eggs of the Pentatomida, from which it has been reared by Rogenhofer and Hofmann. This new species does not appear to be an important parasite of dispar eggs, since this is the only rearing known to us, and none has been recorded. 


Technical Series, No. 19, Part II.

U. S. DEPARTMENT OF AGRICULTURE, BURFAU OF HNTOMOLOGY.

L. O. HOWARD, Entomologist and Chief of Bureau.

\title{
TECHNICAL RESULTS FROM THE GIPSY MOTH PARASITE LABORATORY.
}

\section{DESCRIPTIONS OF CERTAIN CHALCIDOID PARASITES.}

\author{
By J. C. CRAWFORD,
}

Assistant Curator, Division of Insects, U. S. National Museum.

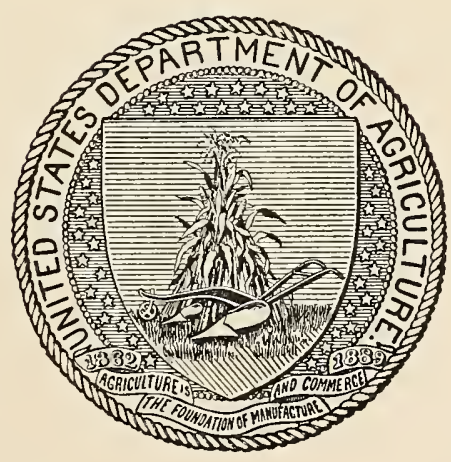

WASHINGTON :

GOVERNMENT PRINTING OFEICE. 


\section{U. S. SUPT. OF IINCYMI N S.}

\section{BUREAU OF ENTOMOLOGY}

L. O. Howard, Entomologist and Chief of Bureau.

C. L. Marlatt, Assistant Entomologist and Acting Chief in Absence of Chief.

R. S. Cuifton, Executive Assistant.

Chas. J. Gilliss, Chief Clerk.

F. H. Chittenden, in charge of truck crop and stored product insect investigations.

A. D. HopkINs, in charge of forest insect investigations.

W. D. HunTer, in charge of southern field crop insect investigations.

F. M. WeBster, in charge of cereal and forage insect investigations.

A. L. Quaintance, in charge of deciduous fruit insect investigations.

E. F. Phililps, in charge of bee culture.

D. M. Rogers, in charge of preventing spread of moths, field work.

Rolla P. CuRRIE, in charge of editorial work.

MABEl Colcord, librarian.

Preventing Spread of Moths.

PARASITE LABORATORY.

W. F. Fiske, in charge; A. F. Burgess, H. S. Smith, H. L. Viereck, I. R. Thompson, C. W. Collins, T. L. Patterson, R. Wooldridge, P. H. Timberlake, assistants.

FIELD WORK.

D. M. Rogers, in charge; H. B. Dalton, A. L. Connolly, H. W. Vinton, D. G. Murphy, I. L. Bailey, H. L. McIntyre, assistants. 


\section{CONTENTS.}

Page.

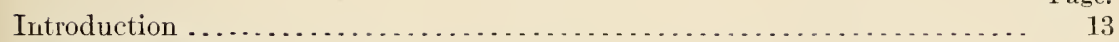

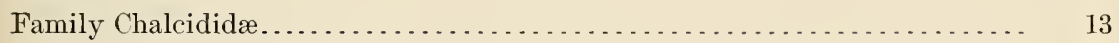

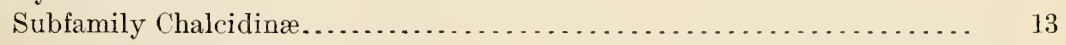

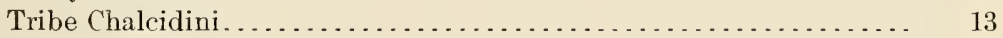

Genus Chalcis................................ 13

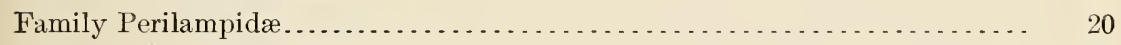

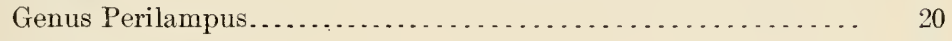

Family Pteromalidæ. . . . . . . . . . . . . . . . . . . . . . . . . . . . . . . 21

Subfamily Pteromalinæ....... . . . . . . . . . . . . . . . . . . . . 21

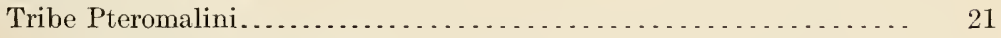

Genus Hypopteromalus... . . . . . . . . . . . . . . . . . . . . . . . 21

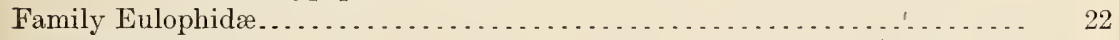

Subfamily Entedoninæ... . . . . . . . . . . . . . . . . . . . . . . 22

Tribe Entedonini................................. 22

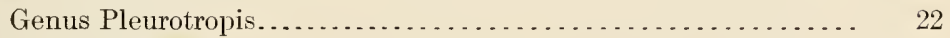

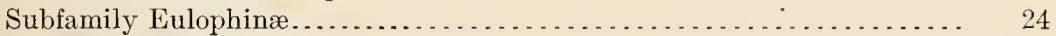

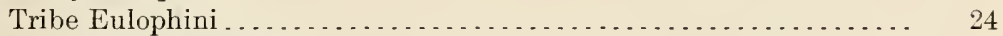

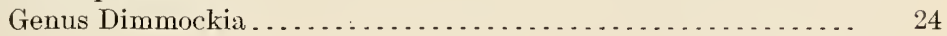




\section{ILLUSTRATIONS.}

FIg. 8. Chalcis ovata, female: Head, showing carina at front of malar space....

Page.

9. Chalcis orata female: Ventral view of hind coxa, showing tubercle...

10. Chalcis ovata, female: Hind femur and tibia, showing markings....... 15

11. Chalcis robusta, female: Hind femur and tibia, showing markings..... 15

12. Chalcis incerta, female: Hind femur and tibia, showing markings..... 16

13. Chalcis fiskei, female: Hínd femur and tibia, showing markings....... 16

14. Chalcis fiskei, female: Head, showing carina at front of malar space.... 16

15. Chalcis obscurata, female: Hind femur and tibia, showing markings.... 17

16. Chalcis obscurata, female: Head, showing carina at front of malar space. 17

17. Chalcis flavipes, female: Hind femur and tibia, showing markings ..... 18

18. Chalcis flavipes, female: Head, showing carina at front of malar space.. 18

19. Chalcis minuta, female: Hind femur and tibia, showing markings...... 18

20. Chalcis minuta, female: Hind femur, inner side, showing tubercle near base............................................... 18

21. Chalcis minuta, female: Head, showing carina at front of malar space.. 18

22. Chalcis paraplesia, female: Hind femur and tibia, showing markings... 19

23. Chalcis paraplesia, female: Head, showing carina at front of malar space. 19 


\title{
TECHNICAL RESULTS FROMI THE GIISY MOTH PARASITE LABORATORY.
}

\section{Descriptions of Certain Chalcidoid Parasites.}

\author{
By J. C. CrawFord, \\ Assistant Curator, Division of Insects, U. S. National Museum.
}

INTRODUCTION.

The new species described in this paper came from material imported from Japan and Europe for the purpose of rearing parasites of the gipsy moth and the brown-tail moth. The work of rearing these parasites is conducted at the Gipsy Moth Parasite Laboratory, now situated at Melrose Highlands, Mass.

In the study of these parasites a Zeiss binocular microscope has been used with magnifications of from 24 to 35 . In cases where the description states that the series includes more than one specimen of each sex the description is drawn from one specimen of each sex, and any variations in the other specimens, which are designated as paratypes, are cited.

In considering the genus Chatcis it has been deemed desirable to display in a synoptic table not only all of the species of this genus which have been introduced purposely as parasites of the gipsy moth or the brown-tail moth or accidentally included in shipments of parasite material, but also all of the species of the genus known to occur in the United States. In the same way it has been deemed desirable to publish a table separating the common American form from the two species of the genus Hypopteromalus accidentally included in shipments of parasite material, and also to separate in a synoptic table the different Japanese species of the genus Pleurotropis which have three funicle joints. As pointed out, $P$. atamiensis belongs probably to an undescribed genus.

\section{Family CHALCIDIDA Walker. \\ Subfamily CHALCIDIN AE Howard.}

\section{Tribe CHALCIDINI Ashmead.}

Genus CHALCIS Fabricius.

Since some of the species of Chalcis from Europe and Japan are being introduced into this country, it appears best to give a table of all of the species of the genus known to occur in the United States and to include in this table the exotic species which are involved. 
In the following table and descriptions of species the term "tubercle of hind coxæe "refers to a small projection on the ventral side of certain species (fig. 9). The tubercle of the hind femur is the small elevation on the inner side near base and on the lower margin of the femur (fig. 20).

In all of the figures showing the carina which separates the malar space from the face, the drawings are made facing the left.

\section{Table of Species of the Genus Chalcis.}

1. Hind femora on outer side black or black and yellow ................. 2

Hind femora on outer side red, or red and yellow, or red and black....... 12

2. Carina at front of malar space not branched, running direct to eye . . . . . . 3 Carina at front of malar space branched or directed backward before reaching

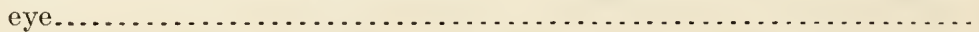

3. Hind femora closely punctured, tooth nearest base on lower margin of hind

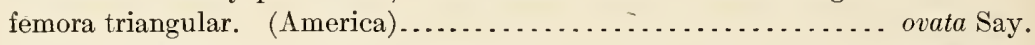

Hind femora almost impunctate, especially the inner side, tooth nearest base of hind femora massive.................................. 4

4. Hind femora on outer side yellow at base and apex. (America). . robusta Cresson. Hind femora yellow only at apex. (America).............. incerta Cresson.

5 . Scape in front with a yellow spot................................ 6

Scape in front entirely dark .................................. 7

6. Hind femora mostly yellow. (America)................. tegularis Cresson. Hind femora mostly black. (America)............... o coloradensis Cresson.

7. Inner side of hind femora distinetly, closely punctured.............. 8

Inner side of hind femora almost entirely impunctate................ 11

8. Posterior tibiæ behind mostly black........................... 9

Posterior tibiæ behind yellow except basally ..................... 10

9. Hind femora entirely black, hind tibiæ black with a small yellow spot at apex. (America).............................. tarsata Dalla Torre.

Hind femora with a yellow spot at apex; hind tibiæ with a yellow annulus near base. (Japan) ........................... fiskei, new species.

10. Hind tibiæ at base black; a small area beneath antenna smooth; pupal skin light colored. (Japan)........................... obscurata Walker.

Hind tibiæ at base yellow or reddish; no smooth area beneath each antenna; pupal skin dark brown. (Europe).................... flavipes Panzer.

11. Wings hyaline; tooth of metathorax less prominent, the outline more obtuse, the front edge directed backward. (Japan)......... paraplesia, new species.

Wings dusky; tooth on metathorax more prominent, the outline more acute, the front edge almost vertical. (Europe)............. minuta Linnæus.

12. Mesonotum red. (America)....................... belfragei Crawford.

Mesonotum black........................................... 13

13. Face with a distinct carina between antennal fossa and eyes, originating back of anterior ocellus; antennal fossa carinate. (America)........ pedalis Cresson.

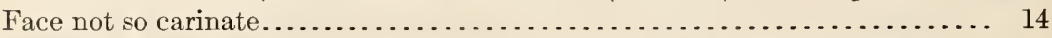

14. Antennal fossa very wide, separated from eyes by about length of first joint of

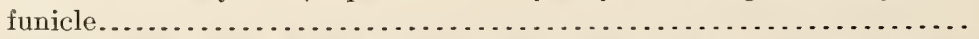

Antennal fossa narrow; separated from eyes by more than length of first joint

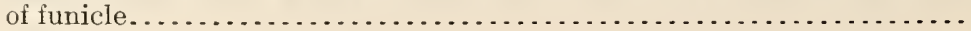


15. Small; abdomen basally red; tooth nearest base of hind femora not larger than rest; hind coxæ of female not toothed. (America)........ columbiana Howard.

Large; abdomen black; tooth basad on hind femora very large; hind coxæ of female toothed. (America)....................... slossonæ Crawford.

16. Scape in front with a yellow spot. (America)........... coloradensis Cresson. Scape in front black ...................................... 17

17. Small, about $4 \mathrm{~mm}$, wings milky hyaline, lateral teeth on metathorax not prominent. (Europe)................................. fonscolombei Dufour.

Larger, about $6^{\mathrm{mm}}$, wings dusky, lateral teeth on metathorax prominent, acute. (Japan)...................................... callipus Kirby.

\section{CHALCIS OVATA Say.}

(Figs. 8-10.)

Chalcis ovata Say, Keating's Narrat. Exped., II, app., p. 326, 1824.

This native species is separated from all the exotic species discussed in this article by the fact that the carina at the front of the

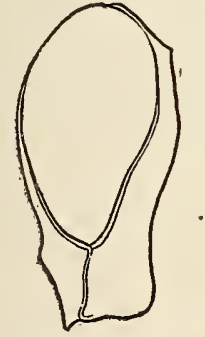

Fig. 8.-- Chalcis ovata, female Head, showing carina at front of malar space. (Original.)

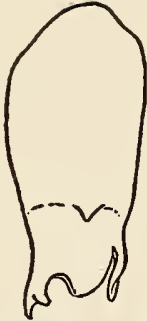

Fig. 9.-Chalcis ovata, female: Ventral view of hind coxa, showing tubercle. (Original.)

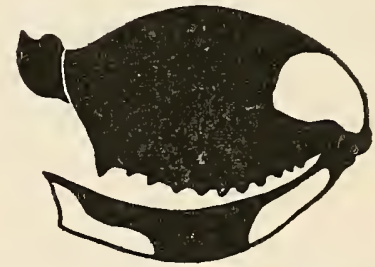

F1G. 10.-Chalcis ovata, female: Hind femur and tibia, showing markings. (Original.)

malar space runs direct to the eye; in the female the hind coxæ are armed with a small tubercle; the inner side of the hind femora is distinctly punctured, and without a tubercle on the lower margin near base; the hind tibiæ are either with or without a black annulus medially; the form with the annulus is illustrated.

\section{CHALCIS ROBUSTA Cresson.}

(Fig. 11.)

Chalcis robusta Cresson, Proc. Ent. Soc. Phila., 1v, p. 101, 1865.

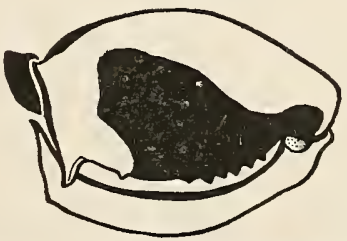

FIG. 11,-Chalcis robusta, female: Hind femur and tibia, showing markings. (Original.) 


\section{CHALCIS INCERTA Cresson.}

(Fig. 12.)

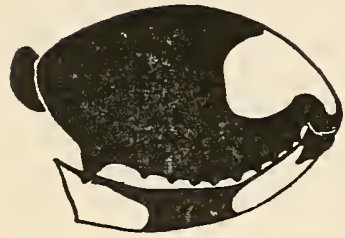

FIG. 12.-Chalcis incerta, female: Hind femur and tibia, showing markings. (Original.)
Chalcis incerta Cresson, Proc. Ent. Soc. Phila., Iv, p. 101, 1865 .

Both of the Cuban species, Chalcis robusta and $C$. incerta, are to be found in southern Florida. The massive basal tooth of the hind femora distinguishes them from the other species in the United States.

\section{CHALCIS COLORADENSIS Cresson.}

Chalcis coloradensis Cresson, Trans. Amer. Ent. Soc., Iv, p. 60, 1872.

In the male of this species the hind femora are black, except the apex, which is yellow; the female, however, has the femora red; the hind femora have on the lower edge near base an indistinct tubercle. I am unable to distinguish $C$. tachinæ Howard from this species.

CHALCIS FISKEI, new species.

(Figs. 13-14.)

Female.-Length, about $6.5^{\mathrm{mm}}$. Black, head and thorax strongly, umbilicately punctured, with long yellowish pubescence; face below insertion of antennæ rugoso-punctate; antennal fossa extending to anterior ocellus; carina at front of malar space running backward to join the carina at the rear, making a

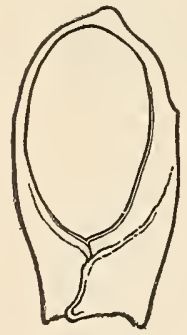

Fig. 14.-Chalcis fiskei, female: Head, showing carina at front of malar space. (Original.)

triangularly inclosed malar space; antennæ black, pedicel short, transverse; depressed apical margin of scutellum broad, slightly enarginate medially; me-

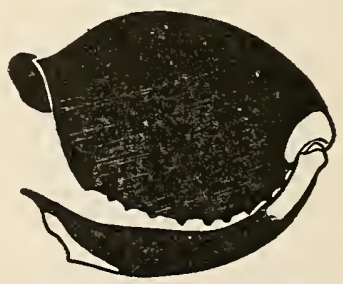

FIG. 13.-Chalcis fiskei, female: Hind femur and tibia, showing markings. (Original.)

tathorax, back of outer end of metathoracic spiracle, with a toothlike elevation; tegulæ yellow; wings dusky; postmarginal vein about twice as long as the short stigmal; legs black; front and middle legs with the femora apically, the tibiæ at bases and apices, the tarsi, and the anterior tibiæ in front, yellow; a small yellow spot at the apex of the hind femora, and a small yellow spot at the base and one at the apex of the hind tibiæ on the outer side; the hind tarsi entirely yellow; 
hind femora on the lower margin with a triangular tooth near base, the space between this tooth and the apex of the femur occupied by about a dozen teeth, those in the middle of the series the largest and almost as large as the basal tooth, the teeth in the series decreasing in size from the middle toward both ends; hind femora distinctly punctured on the inner side; first segment of abdomen smooth, having a spot on each side with setigerous punctures; second segment at sides and, on base with large setigerous punctures, the dorsal apical part of the segment with small punctures; the following segments basally smooth, the apical margins with fine punctures mixed with large setigerous punctures, sixth segment entirely covered with large punctures.

Male.-Length, about $6.5^{\mathrm{mm}}$. Similar to the female, but with more yellow on the legs, the front and middle tibiæ mostly yellow, the spots on the hind tibiæ larger and occasionally meeting, making a yellow stripe on the outer side; teeth along the lower margin of the femora smaller.

\section{Habitat.-Japan.}

Described from 12 specimens reared at the Gypsy Moth Parasite Laboratory from material received from Prof. Trevor Kincaid and Prof. S. I. Kuwana. This is a parasite of Tachinidæ.

Type.-Cat. No. 12789, U. S. National Museum.

\section{CHALCIS OBSCURATA Walker.}

(Figs. 15-16.)

Chalcis obscurata Walker, Trans. Ent. Soc. London, f. 1874, p. 399.

In this species the hind coxæ of the female have a small tubercle; the hind tibiæ are yellow except the extreme base, which is black; the face immediately below the anten-

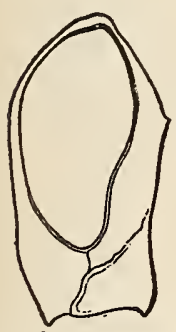

FIG. 16.-Chalcis obscurata, female: Head, showing carina at front of malar space. (Original.)

nal fossa is smooth and polished, especially a spot below the insertion of each antenna; the hind femora are distinctly punctured on the inner side and without a tubercle near

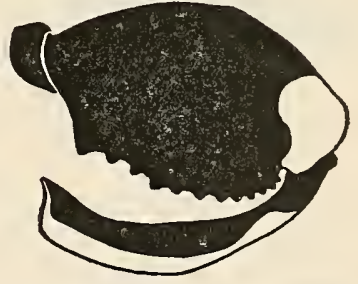

FIG. 15.-Chalcis obscurata, female: Hind femur and tibia, showing markings. (Original.) the base. This species and the following resemble superficially the form of $C$. ovata which has the hind tibiæ without the medial black annulus but the structure of the carina at the front of the malar space readily separates them. This Japanese species is a parasite of Porthetria dispar and has been reared by G. Ojima, Kumamoto, and S. I. Kuwana, Tokyo. 


\section{CHALCIS FLAVIPES Panzer.}

(Figs. 17-18.)

Chalcis flavipes Panzer, Fauna Insect. German, vII, p. 78, 1801.

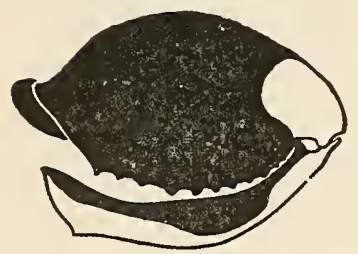

FIG. 17.-Chalcis flavipes, female: Hind femur and tibia, showing markings. (Original.)

This European species closely resembles the above, having the tubercle on the hind coxæ of the female, and the inner side of the lind femora punctured and without the tubercle near base, but is separated by the characters given in the table. It, also, is parasitic on Porthetria dispar.

\section{CHALCIS MINUTA Línnæus.}

(Figs. 19-21.)

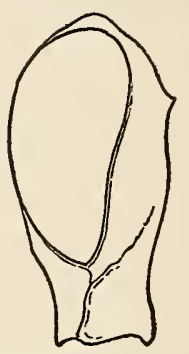

FIG. 18.-Chalcis flavipes, female: Head, showing carina at front of malar space. (Original.)

Vespa minuta Linnæus, Syst. Nat., Ed. 12, I, p. 952, 1767.

In this European species the hind femora have a tubercle near base on the inner side below. The inner side of the hind femora is not distinctly punctured. In the female the hind coxæ are without

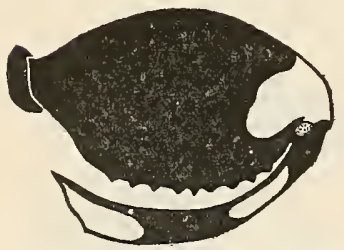

Fig. 19.-Chalcis minuta, female: Hind femur and tibia, showing markings. (Original.)

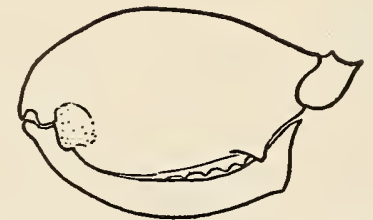

FIG. 20.-Chalcis minuta, female: Hind femur, inner side, showing tubercle near base. (Original.)

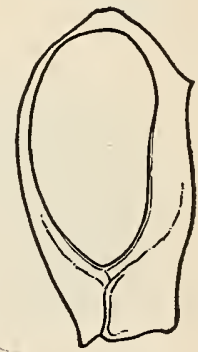

FIG. 21.-Chalcis minuta, female: Head, showing carina at front of malar space. (Original.)

a tubercle. This species and the following superficially resemble C. ovata, but are distinguished by the form of the carina at the front of the malar space, as well as by having the inner side of the hind femora impunctured and with a tubercle near base. It is a parasite of flies of the family Sarcophagidæ, which are scavengers on the dead pupæ of the gipsy moth. 
CHALCIS PARAPLESIA, new species.

(Figs. 22-23.)

Female.-Length, about $5.5^{\mathrm{mm}}$. Head and thorax coarsely, umbilicately punctured, face below insertion of antennæ rugosopunctate; the carina at front of the malar space runs almost to eye, then obliquely backward and upward to join carina at rear; malar space shiny, weakly sculptured; depressed apical margin of scutellum deeply emarginate; metathorax at sides with a small toothlıke projection; tegulæ yellow; wings hyaline; legs black, marked with yellow; all the tarsi, tips of all femora, bases and tips of front and middle tibiæ, a line on front of anterior tibiæ, and apical third of hind tibiæ and a spot near base, yellow; hind femora on inner side with small, sparse, indistinct punctures; hind femora on inner side below with a distinct

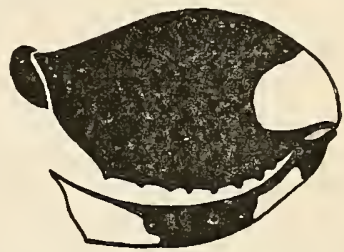

Fig. 22.-Chalcis paraplesia, female: Hind femur and tibia, showing markings. (Original.) tubercle near base; lower margin of hind femora with a sawlike tooth near base, followed by a series of about ten smaller teeth, these decreasing in size to apex of femora; abdomen smooth, second segment and following segments at sides with some large punctures and apically minutely punctured.

Male.-Length, $5^{\mathrm{mm}}$. Similar to the female, but the tooth of the

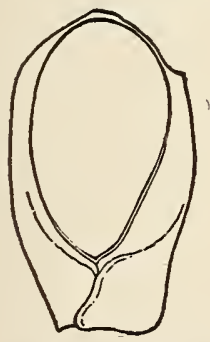

FIG. 23.-Chalcis paraplesia, female: Head, showing carina at front of malar space. (Original.) metathorax represented by a slightly raised carinate ridge.

\section{Habitat.-Japan.}

Described from 6 specimens reared at the Gipsy Moth Parasite Laboratory from material collected by Prof. Trevor Kincaid and Prof. S. I. Kuwana. This species is parasitic in the pupæ of Sarcophagidæ.

Type.-Cat. No. 12791, U. S. National Museum.

This species is closely related to $C$. minuta Linnæus, but is distinguished by the hyaline wings and the less prominent tooth on the metathorax, which has the front edge running backward instead of almost vertical, as in minuta. The male of minuta occasionally has almost hyaline wings and is then easily separated by the strong teeth of the metathorax, the teeth being about as prominent in the male as in the female. 


\section{CHALCIS FONSCOLOMBEI Dufour.}

Chalcis fonscolombei Dufour, Ann. Soc. Ent. France, x, p. 16, 1841.

This European parasite of Sarcophagidæ often has the basal half of the hind femora black; the hind tarsi are red at base and apex and black medially, the red part ornamented with a small yellow spot; the hind femora have a small tubercle on the inner side below near the base; the hind coxæ of the female are without a tubercle.

\section{CHALCIS CALLIPUS Kirby.}

Chalcis callipus Kirby, Journ. Linn. Soc. London, Zool., xvп, p. 75, 1883.

In this species the hind coxæ of the female are without a tubercle, the hind femora are very sparsely punctured on the inner side and have a tubercle near the base; the carina at the front of the malar space has, before reaching the eyes, a branch directed backward.

Of this species only one female has been seen, collected at Nishigahara, Tokyo, Japan, by Prof. S. I. Kuwana, with the record "bred from the pupa of a gipsy moth, July 12, 1908."

\section{Family PERILAMPIDA Foerster. \\ Genus PERILAMPUS Latreille.}

PERILAMPUS INIMICUS, new species.

Female.-Length, about $2^{\mathrm{mm}}$. Deep violaceous, with purple reflections, the head, metathorax, and abdomen more bluish; face not carinate; face and vertex impunctate, with scattered pubescence on the vertex; scape of antennæ blue or greenish, flagellum reddish brown, beneath more reddish; first joint of flagellum hardly longer than the pedicel; thorax umbilicately punctured, parapsidal areas along inner side, with a broad smooth area; punctures on disc of scutellum more separated, leaving a more or less distinct smooth line along center; wings hyaline; legs brown, hind legs in front purple; knees, anterior tibiæ in front, bases and tips of all tibiæ, and the tarsi entirely, light testaceous; apical margin of first abdominal segment straight.

Male.-Length, about $2^{\mathrm{mm}}$. Similar to the female; apical twothirds of scape swollen and flattened in front, with a slight constriction between the normal base and the swollen part; legs with more light color at the bases and apices of tibiæ.

Habitat.-Japan.

Described from 6 specimens reared from cocoons of Glyptapanteles japonicus Ashmead at the Gipsy Moth Parasite Laboratory, from material received from Prof. Trevor Kincaid and Prof. S. I. Kuwana.

Type.-Cat. No. 12793, U. S. National Museum. 


\section{Family PTEROMALIDE Walker.}

\section{Subfamily PTEROMALIN AE Ashmead.}

\section{Tribe PTEROMALINI Ashmead.}

\section{Genus HYPOPTEROMALUS Ashmead.}

- Since the type species of this genus has a well-developed neck to the metathorax and a short but plainly visible petiole, it does not well fit in the place in Doctor Ashmead's tables in which he has put it. The following table based on antennal characters and the color of the legs separates both sexes:

Table of Species of the Genus Hypopteromalus.

1. First joint of funicle elongate, longer than the pedicel................. 2

First joint of funicle not elongate, scarcely longer than the pedicel. (America.)

tabacum Fitch.

2. Femora and tibiæ light testaceous. (Japan.)........ apantelophagus, new species.

Hind femora green; other femora partly dark; in female the tibiæ mostly dark.

(Europe.)...........................................

HYPOPTEROMALUS APANTELOPHAGUS, new species.

Female.-Length, about $2.75^{\mathrm{mm}}$. Bluish green, the head distinctly wider than the thorax; head, pronotum, mesonotum, and metathorax between the lateral folds, with thimblelike punctures; antennæ light brown, the scape testaceous; transverse line near rear of scutellum distinct; neck of metathorax with sculpture similar to that on basal part; lateral folds well developed; median carina wanting or very slightly indicated; wings hyaline, veins testaceous, postmarginal vein as long as the marginal, the stigmal vein distinctly shorter; coxæ blue-green, the rest of the legs yellowish testaceous, the femora and tibiæ more or less suffused with brownish; abdomen smooth, shiny, narrow, the apical segments finely lineolated.

Male.-Length, about $2^{\mathrm{mm}}$. Similar to the female except in secondary sexual characters; head and thorax more greenish than in the female; abdomen basally with a large yellowish spot; legs less suffused with brownish than in the female.

\section{Habitat.-Japan.}

Described from 6 females and 6 males from the series reared at the Gipsy Moth Parasite Laboratory from Glyptapanteles japonicus, received from Prof. Trevor Kincaid and Prof. S. I. Kuwana.

Type.-Cat. No. 12973, U. S. National Museum.

HYPOPTEROMALUS PCECILOPUS, new species.

Female.-Length, about $3^{\mathrm{mm}}$. Green or bluish-green; head slightly wider than the thorax; head, pronotum, mesonotum, and metathorax 
between the lateral folds with thimblelike punctures; antennæ dark brown, the scape basally testaceous; transverse line on scutellum distinct, the punctures back of it larger than those immediately in front of it; neck of metathorax with sculpture similar to that of basal part; median carina distinct, lateral folds well developed; wings hyaline, veins testaceous; marginal and postmarginal veins subequal in length, the stigmal vein shorter; coxæ green, front and middle femora brown with a metallic tinge, basal half of middle and hind tibiæ brown; hind femora green; knees, front tibiæ, apical half of middle and hind tibiæ, and all tarsi yellowish; abdomen smooth, shiny, the apical segments finely lineolated.

Male.-Length, about $2^{\mathrm{mm}}$. Similar to the female, except in secondary sexual characters; the scape entirely testaceous; tibiæ entirely light, slightly suffused with brownish; front and middle trochanters light, abdomen with a light spot basally.

Habitat.--Europe.

Described from 2 specimens reared at the Gipsy Moth Parasite Laboratory from Glyptapanteles sp.

Type.-Cat. No. 12974, U. S. National Museum.

Family EULOPHIDÆ Foerster.

Subfamily FN'THDONINAI Ashmead.

Tribe ENTEDONINI Ashmead.

Genus PLEUROTROPIS Foerster.

The species described from Japan by Ashmead in the genus Derostenus have lateral carinæ on the metathorax and a distinct ring-joint to the antennæ, so that they are properly to be referred to the genus Pleurotropis.

The following table will separate the females of the species from Japan which have 3 joints in the funicle; P. atamiensis Ashmead has 4 joints in the funicle and is probably an undescribed genus.

\section{Table of Species of the Genus Pleurotropis.}

1. Median lobe of mesothorax at apex with two large foveæ.... bifoveolatus Ashmead. Median lobe of mesothorax at apex without foveæ................... 2

2. Legs, including femora, testaceous . . . . . . . . . . . . mitsukurii Ashmead. Legs with the femora dark..................................... 3

3. Head above with deep thimblelike punctures........................ 4 Head above weakly sculptured....................... nawaii Ashmead.

4. Hind tibiæ whitish ................................ orientalis, new species. Hind tibiæ dark colored.............................. howardi, new species. 
PLEUROTROPIS ORIENTALIS, new species.

Female.-Length, about $1.5^{\mathrm{mm}}$. Bronzy black, with green or purple reflections, the vertex and base of abdomen more greenish, the metathorax distinctly green; vertex with coarse thimblelike punctures, the frontal declivity above transverse groove smooth, below furrow with finer punctures, those below the insertion of the antennæ still finer; antennæ brown; mesonotum reticulate, parapsidal furrows not very apparent; scutellum reticulate all over, basally the lines more regular and longitudinal; metathorax smooth, median and lateral carinæ distinct; femora green, tibiæ testaceous, tarsi more whitish; first segment of abdomen medially at apex and following segments finely punctured.

Male.-Unknown.

Habitat.-Japan.

Described from 5 specimens reared from Glyptapanteles japonicus at the Gipsy Moth Parasite Laboratory, from material received from Prof. Trevor Kincaid and Prof. S. I. Kuwana.

Type.-Cat. No. 12975, U. S. National Museum.

PLEUROTROPIS HOWARDI, new species.

Female.-Length, about $2^{\mathrm{mm}}$. Green, with bluish reflections, the sides of the scutellum, the apical part of the parapsidal areas, and the pleuræ purplish-black; face below the transverse furrow bluish, with fine thimblelike punctures down to the insertion of antennæ, below this still more finely and weakly punctured; above the furrow with coarse thimblelike punctures; antennæ green; pubescence of eyes distinct; mesothorax coarsely reticulate, the parapsidal furrows not very distinct anteriorly, posteriorly formed by triangular depressed areas which resemble scars, each with a single setigerous puncture; median lobe of mesonotum strongly emarginate at apex; scutellum at sides longitudinally striate, the apical portion reticulate, leaving the median basal area smooth; metathorax smooth, medially with two carinæ close together, lateral carinæ distinct; first segment of abdomen basally smooth, green, beyond this the abdomen purplish-black and finely punctured; legs green, the tarsi white, apically brown.

Male.-Unknown.

Habitat.-Japan.

Described from 8 specimens reared from cocoons of Glyptapanteles japonicus, at the Gipsy Moth Parasite Laboratory, from material received from Prof. Trevor Kincaid and Prof. S. I. Kuwana.

Type-Cat. No. 12976, U. S. National Museum.

Named in honor of Dr. L. O. Howard, under whose direction the parasite work is conducted. 
Subfamily EULOPHIN AE Howard.

Tribe EULOPIINI Ashmead.

Genus DIMMOCKIA Ashmead.

DIMMOCKIA SECUNDUS, new species.

Female.-Length, about $2^{\mathrm{mm}}$. Bright green, the face and occiput covered with very fine, close striæ; antennæ brownish testaceous, the scape lighter colored; ring-joint distinct, pedicel shorter than first joint of funicle, about as long as joint 2 ; joints $2-4$ subequal, only slightly longer than wide; club showing only 2 joints; mesonotum and metathorax between the lateral folds with fine thimblelike punctures, those of the scutellum finer than on the middle lobe of the mesonotum, those of the axillæ still finer and becoming in part fine striæ; scutellum with a median longitudinal line of punctures which are finer than the rest; median and lateral carinæ of metathorax very distinct; mesepisternum with thimblelike punctures; mesepimeron below finely reticulate, the upper part smooth; metapleuræ and metathorax laterad of lateral carinæ rugose; legs light yellow, the hind coxæ at base above with a small green spot; abdomen green, the apical margins of abdominal segments brownish; first and second segments smooth, the others with very fine lineolations.

Male.-Unknown.

Habitat.-Japan.

Described from 5 female specimens reared at the Gipsy Moth Parasite Laboratory from Glyptapanteles japonicus, from material received from Prof. Trevor Kincaid and Prof. S. I. Kuwana.

Type.-Cat. No. 12977, U. S. National Museum.

In this genus the funicle is 4-jointed and the club shows only 2 joints, so that the antennæ show 9 joints instead of 10 as given by Doctor Ashmead in his Classification of Chalcidoidea. 
Technical Series, No. 19, Part III.

U. S. DEPARTMENT OF AGRICULTURE, BUREAU OF FNTOMOLOGY.

L. O. HOWARD, Entomologist and Chief of Bureau.

\title{
TECHNICAL RESULTS FROM THE GIPSY MOTH PARASITE LABORATORY.
}

\section{INVESTIGATIONS INT0 THE HABITS OF CERTAIN SARCOPHAGID AL.}

\author{
By T. L. PATTERSON, \\ Assistant in Biology, Sheffield Scientific Schnol, Yale University,

\section{WITH AN INTRODUCTION} \\ By W. F. FISKE, \\ In Charge of Gipsy Moth Parasite Laboratory, Bureau of Entomology.
}

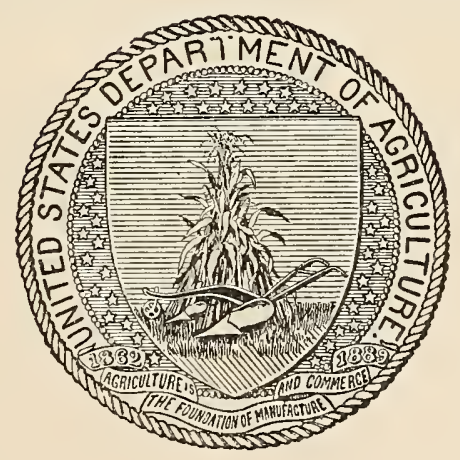

WASHINGTON:

GOVERNMENT PRINTING OFEICE.

1911. 


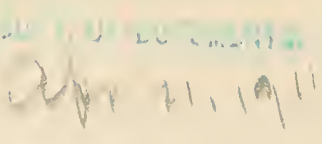

\section{BUREAU OF ENTOMOLOGY.}

L. O. How ARD, Entomologist and Chief of Bureau.

C. L. Mardatt, Entomologist and Acting Chief in Absence of Chief.

R. S. Clifton, Exccutive Assistant.

W. F. TAstet, Chief Cler $\ddot{k}$.

F. H. ChitTenden, in charge of truck crop and stored product insect investigations.

A. D. Hopkins, in charge of forest inscet investigations.

W. D. Hunter, in charge of southern field crop insect investigations.

F. M. WEBster, in charge of cereal and forage insect investigations.

A. L. Quaintance, in charge of deciduons fruit insect investigations.

E. F. Phillips, in eharge of bce culture.

D. M. Rogers, in charge of preventing spread of moths, field work.

Rolla P. CuRrie, in charge of editorial work.

MABel Colcond, librarian.

Preventing Spread of Moths.

PARASITE LABORATORY.

W. F. Fiske, in charge; A. F. Burgess, H. L. Viereck, C. W. Collins, R. WoolDRidge, Jno. D. Tothill, C. W. StockWel., H. E. Smith, assistants.

FIELD WORK.

D. M. Rogers, in charge; H. B. Dalton, H. W. Vinton, D. G. Murphy, I. L. BAILEY, H. L. MCINTYRe, assistants. 


\section{CONTENTS.}

Page.

Introduction..- 25

General conditions__-_-_-_-_-_-_- 27

Collections of gipsy-moth pupæ for maggots of Sarcophagidæ_________ 27

Experiments with adult Sarcophagidæ_______- 29

Experiments with first-stage maggots on living and dead material__..__-_ $\quad 30$

Relation of decomposition to oviposition

Conclusion _- 31 



\section{TECHNIGAL RESULTS FRONI THE GIPSY MOTH PARASITE LABORATORY.}

\section{Investigations into the Habits of Certain Sarcophagida.}

By T. L. Patterson,

Assistant in Biology, sheffeld Scientific School, Yale University.

\section{INTRODUCTION.}

That there are among the Sarcophagidæ a number of species which, to all intents and purposes, are primary parasites of grasshoppers is a fact concerning which there is no ground left for argument. Whether the young larvæ of these flies bear a relation to the living host which is in any way comparable to the extraordinary intimacy which characterizes the relations between the tachinid parasites and their hosts is beside the present question. They assuredly do gain access to the living body of their host, and after a time destroy it, and by so doing qualify themselves to be considered among the insect parasites.

There are numerous species of the Sarcophagidæ which have been reared in association with the gipsy moth (Porthetria dispar L.). Each year after the caterpillars have pupated and when the moths are beginning to emerge, interested persons have found pupæ with the shell apparently unbroken, the contents in a state of decomposition, and an active sarcophagid larva luxuriating in the surroundings thus provided. The condition of the pupa containing the sarcophagid is always different from that of a pupa containing a tachinid maggot, but the distinction is not instantly apparent nor easily described. To the ordinary observer the pupa containing the sarcophagid answers perfectly to the description of a pupa destroyed by a tachinid, and each year it has been necessary to explain anew the difference between parasite and scavenger. That sarcophagid maggots found under these conditions are always scavengers and never parasites has never seriously been questioned.

It must be admitted, however, that in thus rather summarily cunsigning the whole group of sarcophagids to the rôle of scavengers, in so far as their relations to the gipsy moth were concerned, there has been an undercurrent of uneasiness lest among them should eventu-

${ }^{1}$ Introduction by W. F. Fiske, in charge of Gipsy Moth Parasite Laboratory, Bureau of Fintomology, Melrose Highlands, Mass. 
ally be found some which created rather than took advantage of the conditions under which they were encountered. It required hardly any stretching of the imagination to conceive of sarcophagid maggots deposited upon living pupæ, effecting an entrance, and eventually bringing about the death and decomposition of the host. From time to time tentative attempts to acquire more definite information were made, but without positive results one way or the other. Large numbers of gipsy-moth pupæ, apparently living, were collected in the open and upon one or two occasions sarcophagid maggots were subsequently found, but there were always very satisfactory explanations for their presence other than that they were parasitic, and it was increasingly evident that if such experiments were to be decisive, they would have to be conducted with exceedingly great care. Several attempts were also made to keep the adult sarcophagids reared from gipsy-moth pupæ imported from Europe or Japan until they reached their full sexual development and were ready to deposit their brood, but there were a good many things to learn about the best way of conducting an experiment of this sort and none of them was successfully concluded.

In the summer of 1910 the question of Sarcophaga in its relations to the gipsy moth was rather suddenly reopened as the immediate result of a study in parasitism conducted by Mr. P. H. Timberlake, of this laboratory, upon the "pine tussock moth" which was causing some injury to pine in northern Wisconsin. The results of his studies, which will be published in another part of this bulletin, were such as strongly to indicate the parasitic character of certain sarcophagids and to suggest that they were, in effect, of rather considerable importance in the control of this moth.

This, when taken in connection with the fact that a vastly larger number of sarcophagids were continually being received in shipments of gipsy-moth pupæ from Europe and Japan than would be secured from an equal number of similar pupæ collected in America, was a circumstance which could no longer be overlooked. The evidence was such as materially to support a contention that among the European sarcophagids occurred species which were primarily enemies of the gipsy moth. If, as did not seem so very improbable, there existed in Europe such an important group of dipterous parasites of gipsy-moth pupæ, no time should be lost in attempting to secure their introduction into America.

Most unfortunately it is impossible in this case, as in a great many others, to conduct the necessary investigations to the best advantage. Independent European entomologists can not, of course, conduct elaborate investigations along lines wholly outside of their own affairs, and the establishment of a European branch of the Gipsy Moth Parasite Laboratory has never been considered as practicable. 
As usual we were forced to do what could be done with such opportunities as were offered. It was decided to institute at once a new series of studies upon the relations of the American sarcophagids to the gipsy moth, and to conduct them so carefully that if they did not produce positive results they would at least possess negative value.

Fortunately the services of Mr. Patterson were available at that time, and the affairs of the laboratory were in such condition as to permit him to give the work his undivided attention. For the first time it was possible to conduct the experiments, which he will describe himself, with the adequate attention to detail which is absolutely necessary if the results are to be considered as decisive. His results seem to justify the retention of the ideas previously held. in so far as they can be justified by a study of American conditions. It is sincerely to be hoped that in the very near future similar investigations may be conducted in Europe, since the only other additional studies which seem worth while in America will be of the sarcophagids in relation to other lepidopterous hosts, and the findings, whatever their character, would not be directly applicable to the problem of gipsy-moth parasite introduction.

\section{GENERAL CONDITIONS.}

Since the establishment of the Gipsy Moth Parasite Laboratory in 1905 considerable interest has been excited each year from the number of sarcophagids reared in connection with gipsy-moth pupæ, and even more from the larger percentage of sarcophagids received from gipsymoth pupæ imported annually from Europe and Japan. It would seem probable from the above that certain species of sarcophagids had always been parasitic, or else that they had within recent years developed the parasitic habit, which is the more likely; hence, instead of having to depend wholly upon dead material as a host they had joined the ranks of certain of the Tachinidæ in waging war against one of the most injurious insect pests that has ever invaded New England, the gipsy moth. During the last few years certain tentative experiments have been made at the laboratory, but all this work, while it proved rather interesting, was not convincing, and gave neither positive nor negative results. In the summer of 1910 conditions again became favorable for further investigations into the habits of native Sarcophagidre and the writer attempted to determine, by the series of experiments which follow, whether any of these flies are parasitic in habit, or whether they are scavengers on the gipsy motl.

\section{COLLECTIONS OF GIPSY-IIITH PUPझ FOR MIAGGOTS OF SARCOPHAGID $\nRightarrow$.}

Collections were made of gipsy-moth pupæ from localities in towns within a radius of 10 miles of the laboratory. The smallest collection contained 225 and the largest 790 pupæ, each of which was care- 
fully examined and placed into one of two separate lots, namely, the live and active, or the dead, abnormal, and inactive. A few small collections were also made of active prepupal larvæ which were kept separate from the other lots. All of these lots were placed in small pasteboard boxes about 8 by 5 by 4 inches, with tight covers, and were examined almost daily for either maggots or puparia of Sarcophagidæ, or parasites, and the moths as they issued from the pupæ were removed and killed. The small number of pupæ from which no moths issued was dissected for parasites at the close of the experiments. Three thousand two hundred and fifty-seven pupæ and prepupal larvæ were collected for the experiments, 300 of which were active prepupal larvæ, 591 were dead and inactive pupæ, and the remaining 2,366 were active pupæ. No sarcophagids were reared from the lots of active pupæ and active prepupal larvæ, but 2 puparia of the tachinid parasite Compsilura concinnata Meig. developed from one of the lots of the active pupæ and 14 were secured from the prepupal larvæ. This parasite of the gipsy moth and brown-tail moth was introduced from Europe and liberated in eastern Massachusetts. It has become so well established here, according to the best authorities and records, that it is now distributed over more than 200 square miles of the infested territory.

From the dead and inactive pupæ, as might have been expected, sarcophagids were obtained, as well as other species which work as scavengers or parasites. This material yielded 4 third-stage maggots and 1 second-stage (dead) maggot of the Sarcophagidæ; 4 puparia and 1 third-stage maggot (dead) of Compsitura concinnata; 1 Exorista blanda O. S.; 2 third-stage maggots and 1 second-stage tachinid maggot of an unknown species; 14 Monorlontomerus adults and 2 pupæe of the same; 8 pupæ of Gaurax anchora Loew (?); and 1 adult and 4 pupe of Theronia and 5 Dibrachys (dead) in 1 gipsy moth pupa. A special lot of 5 prepupal larva was collected, and on dissection 2 proved to be alive, 2 dead, and 1 had pupated while being brought in from the field. In one of the live prepupals a second-stage maggot of Compsitura concinnata was obtained, while the other was not parasitized. One of the dead prepupals produced 3 third-stage maggots of the Sarcophagidx, while the other, as well as the freshly formed pupa, contained no parasites.

The above experiments not only uphold, but seem rather to strengthen the old belief that the sarcophagids are simply scavengers. Another point of interest in this line of investigation is that there are sometimes found in a single pupa more than one parasite, which often belong not only to entirely distinct and separate genera, but even to entirely distinct and separate families. This point was rell illustrated in making one of the collections, when the posterior end of a 
dead gipsy-moth pupa was accidentally broken off in removing it from the tree, thus disclosing within its almost empty case 2 third-stage maggots, one Compsilura concinnata and the other a sarcophagid. This may be very satisfactorily explained by the fact that this pupa, when in the caterpillar stage, was first parasitized by Compsilur a concinnata, and after reaching the pupal stage the maggot within became large enough to kill the pupa. The decomposition which resulted furnished a favorable place for the oviposition of a female sarcophagid. In various other cases, when it appeared as an almost absolute certainty that maggots of the Sarcophagidæ came from living material, their presence could be accounted for in some such way as the above. The following experiments with the native sarcophagids will also go to strengthen and substantiate the above theory.

\section{EXPERIMENTS WITH ADULT SARCOPHAGIDAE.}

Collections were made of these flies for reproduction experiments from different localities in the infested area. Each collection was kept separate in cylindrical wire screen (one-twelfth-inch mesh) cages, 10 inches in height by about 4 inches in diameter. The top consisted of a circular piece of wood, to which was tacked the wire screen, while the lower edge of the screen fitted into a groove in the wooden base. This arrangement allowed the quick removal of the base and furnished easy access to the cage. A sprig of leaves, with the stem wrapped with cotton batting, was inserted in a tube of water attached to the inside of each cage, and this was sprayed with a solution of sugar and water twice daily, which furnished food for the flies. At first only active prepupal larvæ of the gipsy moth were placed in these cages. They pupated in a day or two and were allowed to remain there for several days, where the flies could have free access to them, before they were transferred to jelly glasses, which were covered with cheesecloth. These were kept under observation for sarcophagid maggots until the moths emerged or the pupæ died. in which cases they were always dissected. All these experiments gave negative results, showing almost conclusively that these flies did not oviposit on living pupæ. The writer then added some badly decomposed caterpillars to the living ones in the cages and observed in a short time that the female flies deposited tiny maggots on the dead material, but not on the living, although frequently they crawled over the live pupæ until these wriggled, which seemed to frighten the flies away. The living material from these experiments was also placed in jelly glasses, but all finally gave negative results. All dead material was now placed in the cages and first-stage maggots were obtained quite plentifully and appeared to be perfectly healthy. 


\section{EXPERIMENTS WITH FIRST-STAGE MAGGOTS ON IIVING AND} DEAD MIATERIAL.

Some of these maggots were placed on mature active pupæ, but in every instance they showed little, if any, desire to bore through the pupal cases. This would probably be an impossibility, as the exterior of the pupæ is tough and hard, but the maggots did not enter even the soft prepupal larvæ. In both cases the pupæ and prepupal larvæ were greatly disturbed and irritated when maggots were crawling on them, and they wriggled violently, dislodging the maggots. If they were placed on a soft, freshly formed pupa the maggots at once would make frantic attempts to bite into it, but without success; although, in one instance, when the membrane which holds the wing cover to the body of the pupa became ruptured, the maggot took advantage of this opportunity of concealment and crawled beneath, and although the maggot was still on the external surface of the pupa it caused such an irritation by its movements that a dark secretion oozed out, coming either from the pupa, maggot, or both, and in the course of a few hours the wing cover became sealed to the body of the pupa, so that only the anal stigmata of the maggot were left exposed. After the lapse of about 12 hours the pupa was found to be dead, and in 18 or 20 hours the maggot disappeared into the body of the pupa. A dissection was made the following day. The maggot was found dead midway in the body of the pupa. This would seem to indicate that the environment which the maggot found within the pupa was not favorable for its development.

To further illustrate the above idea the writer took active pupæ, making a puncture about midway in the body of each, and allowed a live maggot to crawl in, but in all cases the maggots died, showing that they can not live under such circumstances. However, a few came out of the pupæ and died on the outside. Similar experiments were made on dead material with entirely different results. In most cases the maggots went in without experiencing any difficulty and usually survived, which showed that they were in a natural environment.

\section{RELATION OF DECOINPOSITION TO OVIPOSITION.}

It was observed that the flies would not oviposit on freshly killed material in the cages, even though the females had been ovipositing previously on older decomposing caterpillars. This would seem to refute the parasitic theory and would tend to show that the material must reach a certain stage of decomposition before the females would oviposit. Selecting the only cage where females were ovipositing the writer removed all the old material and replaced it with a single freshly killed caterpillar. The flies at once ceased to oviposit, 
although they would crawl about over it. Two days later the writer observed one of the female flies in this cage spending the most of her time crawling about over this caterpillar. A little later she began to make a buzzing noise with her wings and was feeling here and there with her proboscis over the body of the decomposing caterpillar. Proceeding to the anterior portion of the caterpillar a few segments back of the head she succeeded in puncturing the decaying skin with her proboscis, and then moving along far enough so that the end of her ovipositor was directly over this puncture she slowly deposited a maggot which immediately. true to its instincts, worked its way through this puncture into the body of the caterpillar. Several maggots were deposited by this fly, and later a second female was observed to oviposit on the caterpillar in the same incision. This not only indicates that a certain stage of decomposition must be reached, but that the skin of the caterpillar must be either broken, or in such a condition that the female fly can puncture it with her proboscis before she will oviposit, thus allowing an opportunity for the maggots to crawl into the dead host. There were a few living pupæ in this cage, and although the females not infrequently crawled about over them, they did not attempt oviposition. This was the case with a freshly killed caterpillar which was placed beside a dead specimen upon which flies were ovipositing, but when decomposition reached the proper stage, the flies began to oviposit freely. It must be stated here that the true source of the flies in the cage with which this last experiment was tried was unknown, and that they were selected only for the reason that they happened to be the only flies available that were ovipositing. They were secured from a jar containing dead European Calosoma beetles which had been exposed for several weeks to the attack of various species of sarcophagids. It is possible that these flies might have been imported from Europe, but this is extremely doubtful.

\section{CONCLUSTON.}

These experiments indicate very conclusively that the sarcophagids in New England do not destroy living gipsy-moth larvæ or pupæ in the field. From a collection of 2,666 specimens not a single sarcophagid was reared.

In cages the flies would not oviposit on healthy or recently killed caterpillars or pupæ, but did so freely after they became slightly decomposed.

First-stage maggots, when placed artificially within living pupæ, failed to develop in every instance, showing that the conditions were not favorable for their growth. 
When living and decomposing larvæ or pupæ were placed side by side in a cage, the flies selected the latter on which to oviposit, and normal larvæ dereloped.

In conclusion it must be understood that the writer has not attempted to work with any one species of the Sarcophagidæ, nor to separate them into species, but, on the other liand, he has worked with them only as a family, taking for granted that if any of these flies are ever parasitic on the gipsy moth, they would naturally be found in the infested localities. Although all the experiments have given negative results, yet they are nevertheless of economic importance, because in Europe and Japan, where sarcophagids are more commonly associated with the gipsy moth than in this country, it is possible that there may be several species that have the parasitic habit. If so, foreign investigations should be hastened, for if introduced into America these parasitic sarcophagids would be an important addition to the natural enemies of the gipsy moth. 




Technical Series, No. 19, Part IV.

U. S. DEPARTMENT OF AGRICULTURE, BURFAU OF FNTOMOLOGY.

L. O. HOWARD, Entomologist and Chief of Bureau.

\section{TECHNICAL RESULTS FROM THE GIPSY MOTH PARASITE LABORATORY.}

\section{THE CHALCIDOID GENUS PERILAMPUS AND ITS RELATIONS TO THE PROBLEM OF PARASITE INTRODUCTION.}

By HARRY S. SMITH, Expert.

Íssued April 22, 1912.

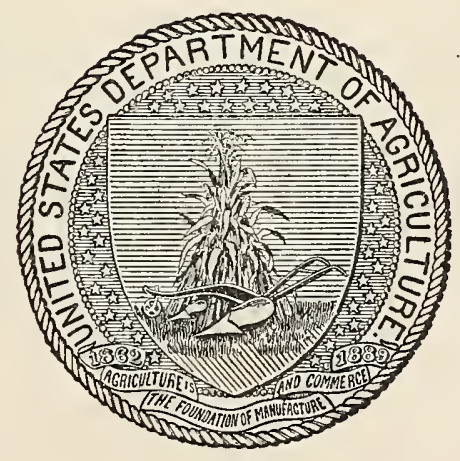

WASHINGTON:

GOVERNMENT PRINTING OFFICE. 


\section{Hans: $n^{\prime}$}

BUREAU OF ENTOMOLOG Y.

L. O. Howard, Entomologist and Chief of Bureau.

C. L. Marlatt, Entomologist and Acting Chief in Absence of Chief.

R. S. Clifton, Executive Assistant.

W. F. Tastet, Chief Clerk.

F. H. Chittenden, in charge of truck crop and stored product insect investigations.

A. D. HopkINs, in charge of forest insect investigations.

W. D. Hunter, in charge of Southern field crop insect investigations.

F. M. WeBsten, in charge of cereal and forage insect investigations.

A. L. QuaInTANCE, in charge of deciduous fruit insect investigations.

E. F. PHILlips, in charge of bee culture.

D. M. Rogers, in charge of preventing spread of moths, field work.

Rolla P. Currie, in charge of editorial work.

MaBel Colcond, in charge of library.

\section{Preventing Spread of Moths.}

- parasite laboratory.

W. F. Fiske, in charge; A. F. Burgess, Harry S. Sirth, ${ }^{1}$ P. H. Thmberlake, ${ }^{2}$ C. W. Colinis, H. E. Smith, F. H. Mosher, J. N. Summers, Chas. W. Minott, C. W. STOCKWELL, assistants. FIELD WORK.

D. M. Rogers, in charge; H. B. Dalton, H. W. Vinton, D. G. Murphy, I. L. Bailey, H. L. MCINTYRE, assistants. 


\section{CONTENTS}

Introductory ..... Page.

Biology of Perilampus hyalinus Say.............................. 34

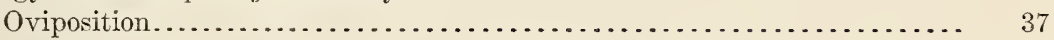

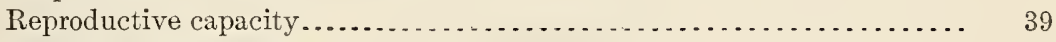

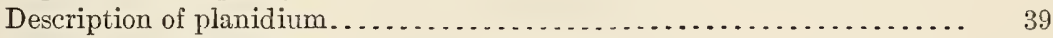

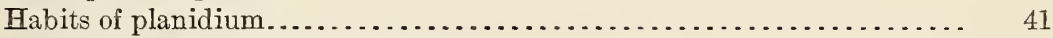

Life as a parasite of Varichrta......................... 42

As a parasite of Limnerium validum Cresson.................. 43

As a parasite of summer-issuing Hymenoptera $\ldots \ldots \ldots \ldots \ldots \ldots . . .44$

As a parasite of 0 ther hosts............................... 45

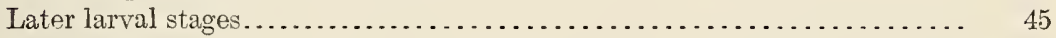

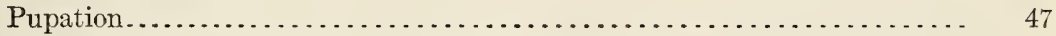

Food habits of the adult...................................... 48

Longevity and oögenesis.................................... 49

Length of life cycle and influence of temperature.................. 49

Effect of parasitism upon host............................... 51

Percentage of parasitism.................................. ${ }_{52}$

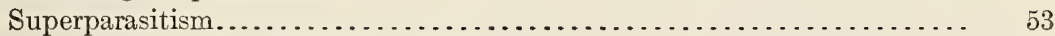

Perilampus versus Perilampus............................... 53

Perilampus versus Dibrachys................................ 55

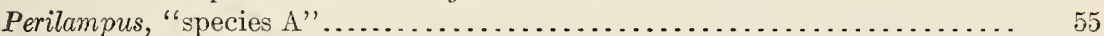

Development of Orasema....................................... ${ }_{57}$

Planidium of Orasema viridis Ashmead............................. 59

Relationship of Eucharidæand Perilampidæ...................... 59

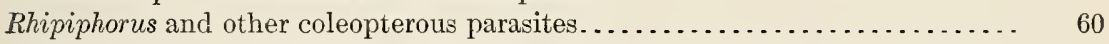

Host relations of the genus Perilampus............................ 61

Rearing records of Perilampus hyalinus at the laboratory............. 61

Other American rearing records of Perilampus.................. 62

European rearing records of Perilampus....................... 64

European species of Perilampus reared at the laboratory............. 65

Résumé of host relations of the genus....................... 66

The economic aspects. . 


\section{ILLUSTRATIONS.}

FIG. 24. Perilampus hyalinus: Planidium, ventral view

25. Perilampus hyalinus: Planidium, dorsal view

26. Pupa of Varichæta aldrichi, parasitized by Perilampus hyalinus; pupa of same unparasitized; planidium of Perilampus hyalinus, before and

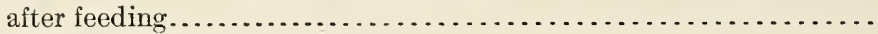

27. Perilampus hyalinus: Mature larva..................... 47

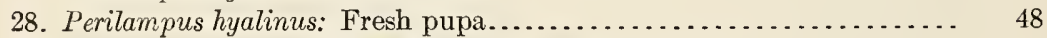

29. Perilampus hyalinus: Pupa just previous to eclosion............... 48

30. Perilampus, "species A": Planidium, ventral view.............. 56

31. Perilampus, "species A": Planidium, dorsal view .............. 56 


\title{
TECHNICAL RESULTS FROII THE GIPSY MOTH PARASTTE LABORATORY.
}

\section{The Chalcidoid Genus Perilampus and its Relations to the Prob- lem of Parasite Introduction. ${ }^{1}$}

\author{
By Harry S. SMith, Expert.
}

INTRODUCTORY.

Practical utilization of parasites in the control of noxious insects is becoming a more and more important means of warfare in economic entomology. For that reason accurate and detailed knowledge of the life history of the various parasitic groups is indispensable to an intelligent handling of the intricate problems which continually present themselves in work of this kind. It does not suffice merely to know that an insect is a primary parasite or a hyperparasite. Familiarity with the intimate details in its life and habits is of the utmost importance in order that it may be brought to its maximum of efficiency with the least possible delay; or, should it prove to be a hyperparasite, that an injurious insect may not thus be released unwittingly and irreparable damage be done. The great desirability of bringing this phase of economic entomology to a position of prominence has been the prime motive for a solution of some of the most perplexing problems which have confronted the student of insect parasitism ; for example, the work of Marchal and Silvestri on the development of the hymenopterous, and of Townsend and Nielsen on the dipterous parasites. These men are economic workers and their discoveries of the extraordinary phenomenon of polyembryony or germinogony in the parasitic Hymenoptera and of the unusual habits of oviposition and larviposition in the tachinid parasites were made in connection with a study of the practical utility of these insects in the control of injurious species. Such investigations are interesting not only from the purely scientific standpoint, but are more than justifiable from that of applied entomology.

The few forms studied by these entomologists are among the most common species, which goes to show how limited the present knowledge of the biology of insect parasites really is. A fascinating field of study is open to those in a position to undertake research of this

1 The writer is indebted to Mr. W. F. Fiske for valuable suggestions and eriticisms throughout the course of his work on Perilampus. 
kind, the requirements for investigating these most interesting phenomena, where the more common species are concerned, being, as stated by Dr. L. O. Howard, "simply good laboratory facilities and a skilled technique, together with trained powers of observation." These, as he points out, are to be found in many institutions and with many individuals in this country. The element of a chance discovery sometimes enters into consideration, however, even when a common insect is made the subject of study. Quite as often as not the discovery of the thread which will later lead to an unraveling of the complete life history is nothing more nor less than an accident, the clue being stumbled upon in a place and at a time altogether unlooked for. The investigations of the life history of Perilampus hyalinus Say received their initial impetus from just such an accidental discovery.

\section{BIOLOGY OF PERILAMPUS FYAIINUS SAY.}

When time and opportunity have permitted, the parasites of certain among the native leaf-feeding caterpillars have been studied at the Gipsy Moth Laboratory in order to determine the part which parasitism plays in their natural control, and in an endeavor to arrive at a better understanding of the varied phases of the problem. Among others, the fall webworm (Hyphantria textor Harris) was selected as a promising subject, and, coming as it does at a season just after the summer's work on gipsy moth parasite importation and colonization is over, it has been possible to devote a larger share of our attention to it than to other even more interesting species which complete their transformations earlier in the season. Upon several occasions the young caterpillars have been brought in from the field, placed in insect-proof rooms and cages, and fed. In due time primary parasites, usually tachinids, species of the ichneumonid genus Limnerium, and occasionally Apanteles, emerged from these caterpillars, and the cocoons and puparia were removed to tightly stoppered vials and placed aside for the emergence of the adults. Later examination revealed the fact that adults of the species which formed the puparia or cocoons could not always be expected to emerge, for usually a certain percentage produced adults of Perilampus instead. How the adult female Perilampus obtained access to these puparia and cocoons in order to oviposit in them was a mystery inasmuch as especial pains had been taken to make the rooms and cages containing the caterpillars parasite-proof. But for a fortunate discovery during the spring of 1909 the true significance of these perplexing observations would doubtless have remained a mystery for some time to come.

While engaged in experimentation for developing a better technique in the preparation of hymenopterous larvæ for microscopical study, in which work the larvæ of the common Limnerium validum Cresson, an important parasite of the fall webworm, were used as subjects, a 
strange little creature was discovered which was obviously the larva of an insect, but which differed very materially from any familiar form. It was impossible, from external characters, to assign it to any particular order with assurance, and consultation with several of the ablest entomologists of the country failed to throw any light upon the subject.

It was less than three-tenths of a millimeter in length, and therefore almost invisible to the unaided eye, oblong-ovate in shape and dark brown in color. Examination under the microscope showed it to be a highly organized being with well-defined mouth parts, strong, curved mandibles, conspicuous tracheal system, etc. The 13 segments were well differentiated, the first forming a distinct head, which was armed with several recurved hooks. The dorsal segments consisted of a series of heavy, chitinous, and overlapping plates, which nearly encircled the body. Most of these were furnished with one or two pairs of bristles. Ventrally the larva was furnished with several backwardprojecting spines, which were evidently ambulatorial in function. An attempt to rear the adult from this larva was unsuccessful.

Among the minor projects under way at the laboratory at this time was a study of the biology of Dimmockia incongrua Ashmead, a rather common and important native chalcidoid parasite of tachinids. As a host for the rearing experiments with Dimmockia one of the most common native dipterous parasites, Varichrta aldrichi Townsend, also an important enemy of the fall webworm, was utilized.

In the course of an examination of the pupæ of this tachinid for the eggrs and young larvæ of Dimmockia a second specimen of the remarkable creature referred to above, or to be more accurate one similar to it, was encountered. This second specimen, instead of being firmly attached to its host by its anterior end as was the former, was quite free and crawled about over the body of the tachinid pupa in a startlingly businesslike manner. This observation very naturally led to a further search through the abundant material at hand, and the presence of the strange parasite, for such it was now suspected of being, was found to be of not at all rare occurrence. An excellent opportunity was at once afforded for ascertaining the identity of the parasite and the subsequent rearings through the different stages were made with a great deal of eagerness. Immediately upon the completion of the first ecdysis it was seen that the larva resembled rather closely what was known to be the mature larva of Peribampus, and the further development of the specimens under observation confirmed that suspicion. The first-stage larva is of a very unusual type, which, with a single exception so far as known, has not been observed before. This exception is the larva of Orasema viridis Ashmead, clescribed and figured by Dr. William Morton Wheeler. ${ }^{1}$ 
A comparison of the peculiar first-stage Perilampus larva with the Orasema material in Dr. Wheeler's possession indicated that while the two were very different in anatomical detail, they were of the same general character and constitute a type which, Dr. Wheeler has suggested, may be designated by the term "planidium." ${ }^{1}$

The establishment of the identity of the planidium did not assist materially in clearing up the mysterious circumstance attending the rearing of the Perilampus from the Limnerium, Varichxta, and Apanteles parasitic on the fall webworm, and with the end in view of determining if possible the manner in which Perilampus gained access to its host, several thousand young caterpillars of Hyphantria were collected during the following fall, placed in rearing trays, and reared to maturity. At frequent intervals a large series of these caterpillars was killed and preserved in order that abundant material might be had for study during the winter.

Apanteles hyphantrix Riley was found to be a fairly common parasite of the younger caterpillars, and Varichæta aldrichi and Limnerium validum of the older ones, as during the preceding summer. Examination of the puparia and cocoons of the parasites disclosed the fact that the planidia of Perilampus were even more common than they were during the preceding year, and as large quantities of material in all stages had been preserved an excellent opportunity was afforded for working out the life history of this remarkable parasite.

As has been mentioned on a preceding page, Perilampus was frequently reared from puparia and cocoons formed in tight rooms or breeding cages into which it was thought impossible for an adult parasite to gain entrance. Consequently in seeking an explanation of the presence of the planidia of Perilampus in the puparia and cocoons of these primary parasites of Hyphantria, it seemed most plausible that the female oviposited in or on the caterpillar containing the parasite which was later to become the host of the young Perilampus. Acting upon this hypothesis, maggots of the tachinid which had emerged from the caterpillar were examined and found to contain the planidia internally. The planidium, by reason of its dark color, was easily visible through the semitransparent integument of the maggot, and even after the latter had ceased activity and had formed its puparium the Perilampus larva could be seen through the shell until it had changed color and had become quite. opaque. Dissection of the fully developed caterpillars revealed the fact that the tachinid maggots while still within the caterpillar contained these planidia, and going back still further, to the younger caterpillars, the planidia were found to be present here irrespective of whether the caterpillar was infested by a primary parasite or not.

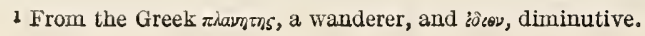


Examination of a considerable number of the Hyphantria caterpillars showed that the planidium could be found in almost any portion of the caterpillar's anatomy, although they generally "floated about" freely in the body cavity. Occasionally specimens attached to the larval organs, such as the alimentary canal or silk glands, were encountered. Further study of still younger caterpillars revealed the most interesting and significant feature of the whole life cycle, namely, the presence of the planidia upon the exterior of the caterpillars. These were apparently about to make their way through the integument to the interior in a search for suitable hosts upon which to complete their development. 'The less heavily chitinized portions of the caterpillar's skin, that is, the portion between the different segments, offered the most vulnerable point of attack and almost invariably this was the place selected by the parasite for making an entrance. Individuals which had not yet started an opening were found quite as frequently upon the middle of the segments as between them. Just how these planidia came to be located upon the skin of the caterpillars and how, when, and where the adult female Perilampus places her eggs, we have been unable to ascertain up to the present time, and any statement in regard to this portion of the life cycle must take the form of mere conjecture.

\section{OVIPOSITION.}

There have been made, so far as published records go, at any rate, no observations upon the oviposition of members of the genus Perilampus. It is known, however, that oviposition does not occur in the normal way, or in the manner we are accustomed to regard as the normal method of oviposition among the parasitic Hymenoptera, and for this reason speculations on what may actually occur are rather interesting.

In the first place it is obvious from the facts recorded in the preceding pages that Perilampus does not oviposit directly in or "upon its host. In the second place, it does not oviposit within the caterpillar of which its host is a primary parasite, which is equally obvious from observations already made. That it places its eggs upon the young caterpillar is improbable, the adult Perilampus being too slow and clumsy to be capable of accomplishing this act with any degree of certainty.

There are two plausible methods which Perilampus might adopt for the deposition of its eggs, and the writer is strongly inclined to the view that one of these methods is in part at least correct. As in the case of some of the parasitic beetles, it may deposit its eggs upon flower heads or upon leaves of plants not in the immediate vicinity of the caterpillar colony, the planidia hatching from these $19242^{\circ}-12-2$ 
eggs being conveyed to the caterpillars by means of some intermediate carrier. In the Coleoptera cited above the carrier is frequently a parasitic bee upon which, by means of their claws, the triungulins attach themselves and are conveyed to the nest of their host. With Perilampus, should this method prove to be the one which really takes place, the intermediate carrier might be any of the primary parasites which attack Hyphantria; that is, the hymenopterous parasites Limnerium or Apanteles, or the tachinid Varichæta. The planidium seems more or less fitted for this sort of a life and is apparently analogous to the triungulin of the coleopterous parasites. The chitinous plates with which it is armored are especially serviceable in preventing injury of various kinds, and the mandibles and hooks and spines would serve it very well as a means of clinging to its conveyer.

Varichxta as a conveyer of the planidia would expose the young Perilampus to one more vicissitude, as it does not oviposit upon the caterpillars, but deposits young maggots upon the leaves of the food plant of its host. These maggots, should they by good fortune happen to have been placed upon a leaf which is later crawled over by a caterpillar, fasten themselves upon their host when the opportunity offers. Perilampus then would twice be subjected to the same conditions as these maggots, and their success in finding a host would depend entirely upon whether or not caterpillars came within their reach.

The other method, which seems much more plausible, is that of oviposition upon the food plant in the vicinity of a colony of the caterpillars. This would do away with the necessity of an intermediate carrier, but would expose the delicate eggrs to great danger unless they hatched immediately after deposition.

Both theories have their faults and it may easily be that neither is correct. They are offered simply as suggestions to anyone who has the opportunity to make observations upon this parasite, in the hope that they will be of assistance in completing the knowledge of this strange life cycle. The former hypothesis has the advantage of a parallel in the parasitic Coleoptera, while something similar to the latter is known to occur in certain of the tachinid parasites (notably Varichæta, as mentioned above) which deposit young maggots upon the leaves, the maggots attaching themselves to the caterpillar as it crawls over the leaf upon which they are located.

While the eggs of Peritampus have not been observed after deposition, those contained in the ovarian tubes, in one case apparently mature, have been examined. They are of the usual elongate-oval shape, not stalked, and whitish in color. 


\section{REPRODUCTIVE CAPACITY.}

It is a well-known fact that insects which are subject to very high mortality in their younger stages must have a high potential rate of reproduction in order to offset this loss and still prevent the species from becoming extinct; and conversely, we may say that insects laying a great number of eggs must of necessity expcrience a very high death rate or else they would in time increase beyond all bounds. We have found by the dissection of adult female Perilampus that the eggs are very numerous, the abdomen containing as high as 250 fully developed eggs at one time. It is therefore apparent that in some stage or stages before maturity many of the young die. As Perilampus is eminently well fitted to withstand the vicissitudes encountered in its later existence, the logical place to find this high death rate is during the planidium stage, while the tiny larva is wandering about either within or outside the caterpillar in search of its host. That this wandering habit of the younger, pre-eruciform stages of parasitic larvæ is accompanied by great mortality is well exemplified in the case of the Strepsiptera. Newport, in his "History and General Anatomy of Meloë and Its Affinities," ${ }^{1}$ records the production of more than 7,000 triungulins by a single female of the genus Stylops. Perilampus is apparently not only subject to a considerable mortality by reason of its wandering habit, but large numbers meet their death through a failure to find a proper host within the caterpillar and through the operations of superparasitism after they do find their host.

Whatever be the real method by which the planidium becomes affixed to the caterpillar, the life history from this point on has been worked out by actual observation in the laboratory, with an abundance of material for study.

\section{DESCRIPTION OF PLANIDIUM OF PERILAMPUS HYALINUS.}

(Figs. 24, 25.)

Length about $0.3 \mathrm{~mm}$., depending on the amount of distension; diamcter at widest place about $0.06 \mathrm{~mm}$. Shape obovate; composed of 13 distinct segments or rings which are dark brown and heavily chitinized, and which "telescope" into each other more or less.

Head heavily margined, both laterally and posteriorly above, the rim strongly emarginate or indented posteriorly, where it is also strongly elevated in life and darker than other portions of the head. Mandibles well developed, hook-shaped, situated in a buccal cavity, and crossing at tips; bases broad, with a rather large area for muscular attachment. Immediately back of the mandibles are two flattened, heavily chitinized organs, which are probably homologous to the 
maxillæ, but the minute character of which makes it impossible to determine their nature without considerable uncertainty. Head heavily armored with two powerful hooks or horns on the anterior

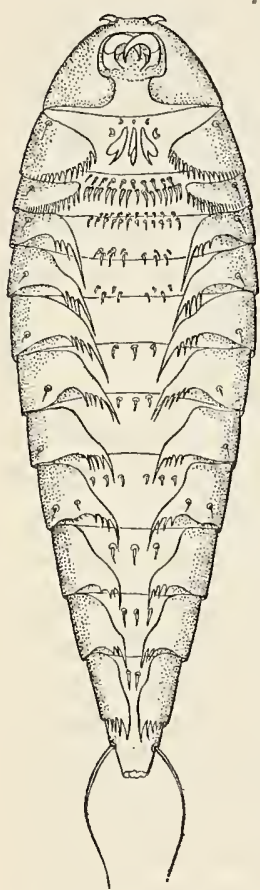

FIG. 24.-Pcrilampus hyalinus: Planidium, ventral view. Magnified about 350 diameters. (Original.) margin, projecting laterally, about the size of the mandibles; above are seen two rather strong hooks at about the middle, both eurved backward at tips; just back of hooks on dorsal portion of head are several semitransparent round spots, which probably bear small bristles, and may be sensory in function.

Body segments as follows: First segment (excluding head) provided dorsally with two very minute semitransparent round spots, with dark spot in center, which is probably a minute spine, but which is rendered practically invisible by the clearing action of the balsam; ventrally the same segment is provided with two othersimilar spots, but which bear very distinct curved spines, one in the center of each. The heavy chitinous ring does not join beneath the body, each side ending instead with the ventro-posterior margin, which is serrated or fringed with long teeth, about 30 in number, becoming gradually shorter as they approach the lateral margin of the planidium. Between these fringed margins, situated in the center of the ventral portion of the segment, are three peculiar appendages which apparently function as ambulatory organs; these are somewhat flattened pyriform, with the broad end heavily notehed somewhat at one side and attached at small end; at the bases of these are several small irregular appendages. The second segment is provided with the dorsal, backwardly eurved spines, much eloser together than on preceding segment and rather larger, and two ventral smaller spines; the teeth are slightly smaller. Between the serrate margins, as in

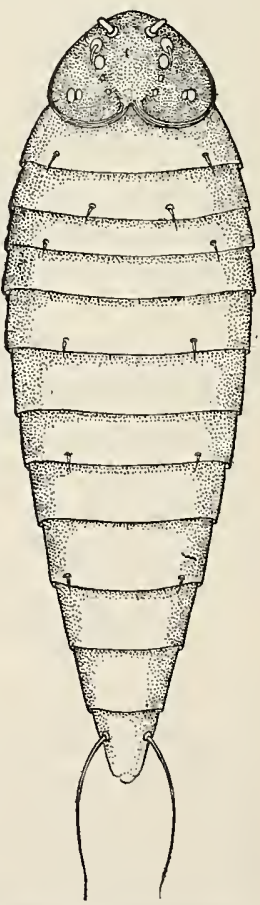

F1G. 25.-Pcrilampus hyalinu:: Planidium, dorsal view. Magnified about 350 diameters. (Original.)

preceding segment, are several hooks or motor appendages, but of quite a different type, these latter being simply plain hooks projeeting backward, there being two transverse rows, about 10 in first row and about 16 in second. Between first and second segments on the 
ventral side, situated in the elastic integument connecting the chitinized plates, are two stigmata, apparently the only spiracular openings in the whole tracheal system. Third segment similar to preceding, the two dorsal spines being considerably farther apart; the ends of the chitinous plate, however, are of quite a different type; instead of ending in a serrate margin the inner margin is smooth, but the posterior corner terminates in a long tapering projection considerably longer than the width of the chitinous sclerites; laterad of the long tapering projection referred to above are two or three much smaller ones, also situated on the apical margins of the segment; between the ends of the chitinous plates, as in preceding segments, are several hooklike motor appendages, smaller and fewer in number, however, than in the second segment; an additional series of hooks which is not provided in preceding segments is situated just laterad of these. The fourth segment seems to have no dorsal spines; there are two ventral ones, however, situated at the extreme outer margin of the ring; the chitinous plate terminates as in the third segment; motor appendages as in third segment but fewer in number. The fifth segment differs from the fourth apparently only in the possession of a pair of dorsal spines and in the smaller number of ventral motor appendages. The sixth segment does not have the dorsal spines but in other respects is similar to the fifth; the seventh segment possesses the dorsal spines; the eighth does not, nor does the tenth, eleventh, or twelfth; these latter, however, are similar in other respects, excepting that they become gradually less in size. The last segment is provided with an unjointed stylet on each side attached at about the middle of the segment, this stylet about twice the length of the segment itself.

HABITS OF PLANIDIUM.

Starting with the planidium upon the skin of the caterpillar, this makes its way through the thinner portion of the integument found at the junctures of the segments, this passage being effected by means of its well-developed mouth parts and speciallya rmored head. Just how the search for the host parasite is conducted is not known excepting as it may be deduced from dissections of preserved material. The planidium has been found in almost every part of the caterpillar and it appears that its search for a host is rather thorough and extensive. The time of its attack upon the host larva has not been very definitely determined, although from the data at hand it seems most likely that this follows at once upon the finding of another parasite within the caterpillar. This supposition is substantiated by the fact that the planidium is found within the very young tachinid larvæ which have just completed their first molt. In this stage the disparity in size between the larvæ of Perilampus and of Varichæta is very much less than it is later, and it seems remarkable that the 
tiny tachinid maggot can, without inconvenience apparently, continue in its development with the Perilampus larva boring about within its body, and sometimes with not only one but five or six.

What becomes of the planidium in case the caterpillar does not contain a primary parasite is a question which has not yet been answered, and to do so would require considerable care and patience. There are two courses open to the-Perilampus in case it has selected an unparasitized caterpillar. It may either wander about within the body of the latter until it dies from starvation and exhaustion, or it may make its way to the outside again and continue the search for a host in another caterpillar. That it might possibly develop upon the caterpillar itself is not to be considered. Even should it remain within the caterpillar until the latter pupated, ${ }^{1}$ it is not likely that it could make its way through the hard pupal shell of Hyphantria, and if this were possible the older Perilampus larva is very much too delicate a creature to be able to feed externally unprotected.

In case the former alternative is what actually takes place, there must be a great percentage of mortality due to the lack of a proper host, for relatively only a small proportion of the caterpillars hatching from the eggs ever reach an age sufficient to nourish a host for Perilampus. Of those that do reach that age a great many are never attacked by primary parasites and hence would not be available for Perilampus.

Just what is the effect upon the caterpillar itself which is infested by Perilampus but which contains no primary parasite is a matter for conjecture. It seems likely, however, that its presence would not prevent the caterpillar from reaching its full development and it is probably only slightly inconvenienced if affected at all. ${ }^{2}$

Having followed the Perilampus planidium to its host within the caterpillar it is now necessary to trace out the slightly different modes of development upon the various parasites of Hyphantria which are subject to its attack.

Life as a Parasite of Varichata.

Varichæta aldrich $i$ Townsend ${ }^{3}$ has been by far the most common of all of the parasites of the fall webworm in Massachusetts during the past two years. As stated on a preceding page, it beiongs to that group of tachinids which deposit living maggots upon the stems and foliage in the vicinity of the caterpillars of their chosen host, a habit first discovered by Mr. C. H. T. Townsend in the course of his work

1 Later dissection of Hyphantria pupæ, made in the spring of 1911, by Mr. H. E. Smith, discovered the planidium alive and still "waiting for something to turn up." In one insiance the planidium was embedded in the gonad of the Hyphantria.-W. F. FISKE.

2 The occurrence of the planidium in the gonad, as noted in preceding footnote, suggests that partial eastration might possibly result.

3 Determination furnished by Mr. W. R. Thompson. 
at this laboratory and briefly described by him in an earlier bulletin of this bureau. ${ }^{1}$ The maggots rarely leave their host until after it has become full fed and prepared for pupation in the fall. The tachinid maggots pupate soon after emerging from their hosts, the pupæ remain unchanged during the winter, and the subsequent transformations are accomplished quite early in the spring.

In case the planidium chooses a maggot of Varichrta as its host, it remains endoparasitic until the puparium is formed. During the process of histolysis the Perilampus either orients itself in such a manner that it will be external to the tachinid pupa when pupation is completed, or it emerges from the pupa immediately after pupation; in either case, of course, it remains within the puparium. When parasitic upon this host the planidium, so far at least as the writer has been able to learn, normally hibernates in this stage and probably without nourishment.

It is quite likely, however, that a late warm fall would start the development of the planidium on Varichæta at once. This would without doubt result in the death of the secondary parasite, as it would scarcely be able to pass the winter in the normal larval stage. In fact dead second-stage Peritampus larvæ have occasionally been found upon the pupæ during the winter, and this would seem to be evidence in corroboration of the above statement. It is probably an attempt to go through two generations per year, as this insect does, without much doubt, farther south, and the individual specimens found in the second stage during the winter in New England are probably those from the puparia which emerged as larvæ from the caterpillars earliest in the fall, although we have no absolute evidence that this is the case. The development, or rather the conduct, of the planidium up to and including its change from endoparasitism to ectoparasitism, as stated on a previous page, seems entirely dependent upon the development of its host, such are the intimate relations between the two. After the planidium has emerged from its host development takes place in the usual way.

As a Parasite of Limnerium validum Cresson.

Of the primary hymenopterous parasites attacked by Perilampus probably the most common one is Limnerium validum Cresson, an ophionine parasite emerging from the older caterpillars in the fall and hibernating as larva in a silken cocoon. The larva of this parasite, like that of Varichrta aldrichi, does not reach full maturity until its host has prepared for pupation, and the cocoons are to be found in the same situations as the pupæ of Hyphantria and are afforded the same protection. In this respect it differs radically from the other species of Limnerium parasitic upon the fall webworm. 
Perilampus hyalinus in this case always remains endoparasitic throughout the winter, at least so far as our observations go, and several hundred cocoons have been examined to date. At first it seemed rather puzzling that the same species should pass the winter ectoparasitically upon tachinids and endoparasitically upon Limnerium validum, but dissections of hundreds of the puparia and cocoons brought to light the fact that the habit of Perilampus in this regard was dependent entirely upon the life cycle of the host parasite, that is to say, the planidium lives internally in its host until histolysis takes place, when it changes its mode of life from an intemal parasite to an external parasite. Varichæta pupates in the fall, so the planidium makes its exit at this season of the year and hibernates externally. Limnerium validum hibernates as a larva and pupates in the spring, hence the planidium in this case remains internal until spring, when it emerges by means of its efficient mandibles and spined head, completing its development in precisely the same manner as those individuals which happen to have chosen Varichxta as their host. The internal disturbances which take place in the body of the host at the time of histolysis probably act as a stimulus to the activities of the planidium, and the condition of the integument is such as to make the exit of the secondary parasite especially easy at this time. The development of the host, so far as our observations have gone, invariably ceases at the time of the exit of the planidium. Whether or not it is actually killed at this time is not evident. In any case decomposition does not take place immediately, the host being left in a condition somewhat comparable to that of the prey of certain aculeate Hymenoptera.

As a Parasite of Summer-Issuing Hymenoptera.

The other primary parasites of IIyphantria from which we have reared Perilampus are two additional species of Limnerium, differing from $L$. validum in that they spin their cocoon within the skin of the caterpillar and emerge in the fall, and the braconids Apanteles hyphantrix Riley and a Meteorus (probably M. communis Cresson). In all four of these species the Perilampus completes its development at once. Whether or not these individual specimens manage to survive the winter is open to question. It is quite possible that many of them remain within the cocoon of their host throughout the winter. This is quite strongly indicated by the result of an experiment in which a collection of old webs containing cocoons of the several parasites was made on October 20, 1908, from which several adult Peritampus issued between 6 and 10 days later. The material was kept in a warm room; had it remained out of doors it is very unlikely that emergence would have occurred so soon, and probable that it would have been deferred until spring. 
We know that the adult of one of the European species of Perilampus hibernates in the puparium of certain tachinids parasitic on the gipsy moth and brown-tail moth. Most of these tachinids, like the summer-issuing hymenopterous parasites, pupate comparatively early in the fall, thus making the two cases similar. For this reason the writer feels justified in surmising that the same thing occurs in the case of Perilampus hyalinus parasitic on the summer-issuing Hymenoptera.

As a Parasite of Other Hosts.

There is another group of parasites of the fall webworm which hibernate either as partially grown or as full-fed larvæ within the pupæ of their host. These include certain large solitary ichneumonids, Anomaton ambiguum Norton, Ichneumon cinctitarsis Provancher, and Melanichneumon sp. At least one species of Tachinidæ has also been found hibernating in this manner in Massachusetts. We have not actually found Perilampus to be a parasite of any of the ichneumonids named above, but only a very small number of the larva of these parasites have been seen." There seems to be no good reason why the secondary should not attack these hibernating hymenopterous larve, and it is practically certain that the examination of a considerable number would show the planidium to be present.

We have absolute proof, however, that it does attack the hibernating tachinids, ${ }^{2}$ having found the planidium actually within the maggot of this species within the pupa of Hyphantria. Whether or not the adult Perilampus is able to make its way through the pupal shell of the fall webworm (presuming that the tachinid completes its larval development and pupates internally) we are unable to state definitely, as no record has been made of Perilampus having issued from these pupæ. There seems to be little doubt as to its ability to do this, as it has very powerful jaws. Specimens in the laboratory will eat away quite a large quantity of cork in attempting to escape from a vial in which they have been confined.

\section{LATER LARVAL STAGES.}

On the return of warm weather in the spring, the winter having been passed upon the various hosts in the manner indicated in the preceding pages, the planidium begins feeding by sucking the juices of its host. Growth takes place gradually and first becomes apparent through the planidium taking on a banded appearance due to the

1 It has since been found by Mr. H. E. Smith within the larve of Ichneumon (which attacks the pupa of the host) and that of Exochilum, which hibernate in what must be considered as an embryonic state within the Hyphantria pupæ.-W. F. Fiske.

2 Probably Compsilura concinnata, the recently imported parasite of the gipsy and brown-tall moths.

$19242^{\circ}-12-3$ 
separation of the chitinous rings or plates by a stretching of the intersegmental mcmbranes which are transparent. (See fig. 26, $d, d^{\prime}$.) The underside of the planidium also gradually fills out until the larva has attained a bulk several times greater than that of the hibernating planidium and presents the appearance of an ovate semitransparent sack with dark median crossbars dorsally.

After a short resting period, ecdysis takes place. The skin of the planidium breaks transversely just back of the second thoracic segment, the posterior segment slips backward, and the old head and first two thoracic segments are shed at the anterior end of the larva. Just how long the planidium feeds before ecdysis has not been aseer-
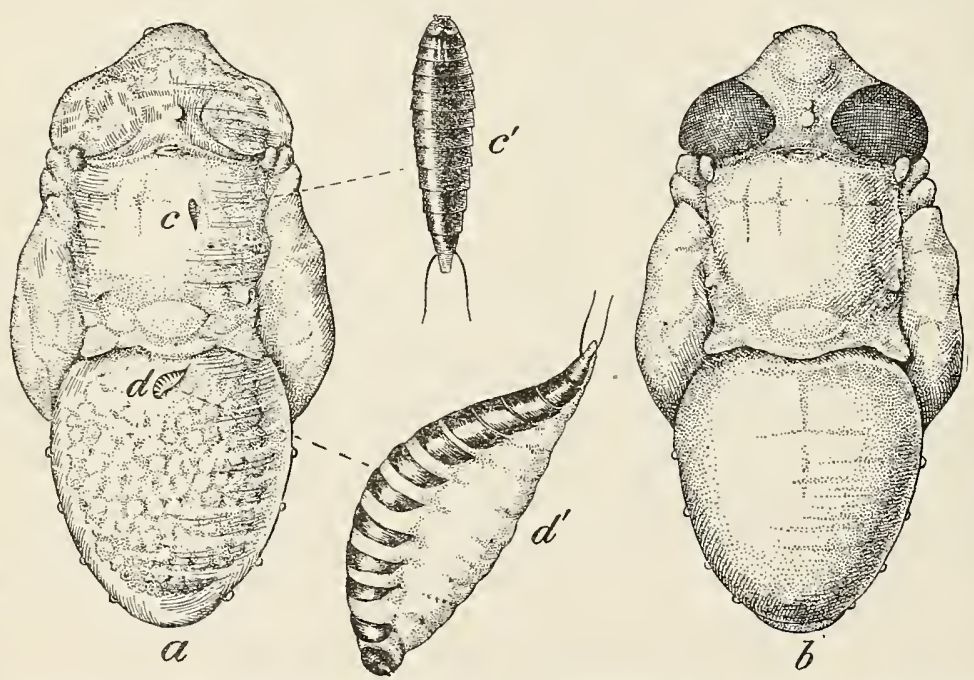

Fig. 26.-a, Pupa of Varichæta aldrichi parasitized by Perilampus hyalinus: $b$, unparasitized pupa of Varichæta aldrichi; c, planidium of Perilampus hyalinus before feeding; $c^{\prime}$, same, more enlarged; $d$, planidium of Perilampus hyalinus after feeding; $d^{\prime}$, same, more enlarged. (Original.)

tained. The perior probably varies greatly in accordance with the prevailing temperature. Usually, though not always, the larva crawls away a short distance before it resumes feerling.

After settling down the second time it is likely to remain stationary for the rest of the larval and the pupal life. The larva in the second stage is of a whitish color, with the tracheal system showing through the transparcnt skin. The borly is ovate in shape, with the head bent underneath the anterior portion. The growth during this stage is little compared to that accomplished in the third, and after feeding a short time the second ecdysis takes place.

Growth now becomes quite rapid and the larva assumes a very different appearance. (See fig. 27.) The mandibles have not increased in size to any great extent, but the mouth as a whole and the head 
change quite materially. The mouth parts are in this stage situated in a triangular basinlike depression which is bounded on two sides and parts of the third by a strong chitinous carina or rim. Besirles the mandibles there are two bulblike appendages just beneath, which are probably homologous to the maxillæ of the adult. Immediately above the oral opening are situated two large rounded elevations which may be called larval antennæ. The segments forming the head are now separated by a more or less distinct neck from the remaining segments and are bent beneath them with face downward, as in the second stage. The first two thoracic segments are each provided laterally with a raised tubercle at about the middle of the segment, viewed from the side, and just above this tubercle is another more or less distinct one, one also occurring on the third thoracic segment in a corresponding location. The next three segments each bear a pair of much larger tubercles or projections which give the larva a very unusual appearance. These tubercles, if they may be called such, correspond to those described and figured by Dr. Wheeler as occurring in Orasema, but are somewhat differently arranged. Just posterior to these there occurs an abrupt declivity, the segments becoming much smaller toward the posterior end of the larva. Beneath, the larva is smooth and free from constrictions, but the segmental sutures are visible to some extent. Dorsally through a transparent median line formed by a break in the corpus adiposum may be seen a large number of white urate masses,

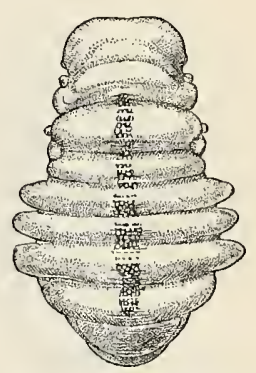

FIG. 27.-Perilampus hyalinus: Mature larva. Greatly enlarged. (Original.) which pulsate slowly back and forth as the larva feeds. The tracheal system is rather conspicuous and is of the normal holopneustic type.

\section{PUPATION.}

(Figs. 28, 29.)

As soon as the larva is full fed, pupation takes place. The meconium is discharged, leaving the larva scarcely more than half its former bulk, and creany white instead of translucent gray-white in color. Beneath the larval skin the imaginal appendages and the head gradually appear, and the tubercles so characteristic of the larva become less conspicuous. Finally the larval skin is discarded, and the pupa assumes its own distinctive shape.

The pupa is short and robust, corresponding very closely, of course, to the form of the adult. The abdomen bears five or six transverse carinæ or ridges, one for each segment, which are interrupted on the disk. These are very similar to those occurring on the ant parasite Orasema viridis, but differ in that they are not continuous dorsally 
At first the pupa is white or yellowish white, but the eyes soon become pigmented with reddish, then the thorax becomes black, later changing to a metallic green. In about two days the head and abdomen assume the same metallic hue as the thorax, with the sculpture of the adult insect showing through, and soon after this the pupal skin is shed and the adult insect issues.

\section{FOOD HABITS OF THE ADULT.}

No observations upon the food habits of the adult Perilampus have been made in connection with this work, excepting that in confinement they will consume, in common with many other chalcidoid parasites, comparatively large quantities of sweetened water upon banana peelings. During June, 1905, the author found specimens of this genus in abundance upon the leaves of Ambrosia, Helianthus,

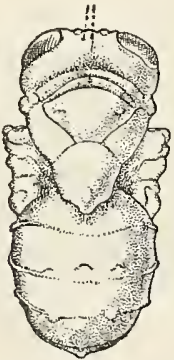

FIG. 28.-Perilampus hyalinus: Fresh pupa. Greatly enlarged. (Origlnal.)
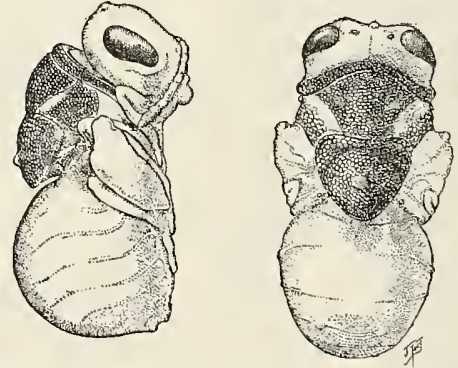

FIG. 29.-Perilampus hyalinus: Pupa just previous to ecloslon. Greatly enlarged. (Original.)

and other vegetation at West Point, Nebr., where they were apparently feeding upon the honeydew secreted by aphides.

Dr. S. Graenicher, of the Public Museum of Milwaukee, has in the course of his extensive studies upon the pollination of Wisconsin flowers ${ }^{1}$ recorded two species of Perilampus, hyalinus Say and cyaneus Brullé, as visitors of the following Compositæ: Eupatorium perfoliatum, Solidago juncea, S. canadensis, Achillea millefolium, Tanacetum vulgare, and Erigeron canadensis. In considering the insect visitors to the last named flower he has the following to say:

It is noteworthy that the chalcid-flies Perilampus cyaneus and P. hyalinus seem to have a certain preference for these flowers. They were regular attendants, day after day, at Cedar Lake, and were also present at Milwaukee.

Dr. Graenicher in a recent letter kindly informs me that he has also taken P. cyaneus at flowers of Angelica atropurpurea, Pastinaca sativa, and Sium cicatrfolium. 


\section{LONGEVITY AND OÖGENESIS.}

While the Perilampus adults as a usual thing are very shortlived in the laboratory, there is no doubt that they live for a considerable period when out of doors under natural conditions. This is indicated by the fact that the females, when newly emerged, never contain eggs within the ovarian tubes, as rlo those insects which oviposit at once upon emerging.

In one instance a female was kept alive from April 6 to May 12, a period of 36 days, at the end of which time she was apparently ready to oviposit. Upon dissection approximately 250 eggs, nearly all of which seemed to be ready for deposition, were found. It is probable that many more would have developed had the individual remained alive under natural conditions.

\section{LENGTH OF LIFE CYCLE AND INFLUENCE OF TEMPERATURE.}

The time required for Perilampus to develop from egg to adult is dependent upon several factors, one of the most important of which is the host. When parasitic upon Varichrta, the planidium begins to feed early in the spring. On Limnerium validum, however, the planidium must wait until its host begins pupation before it can become external, thus throwing it several days or even weeks behind the individuals infesting Varichxta.

There are no complete data at hand concerning the development upon Limnerium, owing to the failure of any individual to complete its transformations upon this host after removal from the cocoon. Its progress has been followed beyond the first ecdysis several times in the laboratory. In an apparently typical instance a larva of Limnerium containing two planidia was brought into the laboratory from out of doors on January 28 and placed in an incubator kept at a temperature of $78^{\circ} \mathrm{F}$. On the morning of February 4 histolysis had begun, and during the evening of February 5 both planidia had made their exit. Two days later the host larva was apparently dead and the planidia were feeding. February 11 one had molted its first-stage skin, but died a short time later.

With Varichxta as a host it is a much simpler matter to carry the Perilampus through to maturity. When a single individual is watched through its development more time is required than in undisturbed puparia, owing to the fact that it is impossible to keep the host pupa from deteriorating somewhat. A typical instance of the development upon Varichxta under laboratory conditions follows: On January 28 a pupa of Varichæta with a single planidium was brought in from out of doors and placed in the incubator. On the next day the planidium had started to feed and filled up rapidly. February 1 the distance between the dorsal plates of the planidium 
was rather greater than the width of the plates themselves. Three days later the first ecdysis was completed and the second-stage larva had moved some distance away from its original feeding place. The next day it had become very much distended and glistening. On February 7 it had apparently molted a second time and was very strongly tuberculate. On the 9 th it was again feeding freely. Five days later it had reached full growth and ceased feeding. The next day pupation had taken place, but the pupa was still pale in color and covered with little "perspirationlike" globules. On the 19th the thorax of the pupa had begun to turn dark and the sculpture of the adult to show, and three days later it had become entirely dark colored. On February 25 the adult Perilampus emerged. The time required for development from start of external feeding to maturity was 28 days. The incubator' was kept at a constant temperature of $78^{\circ} \mathrm{F}$.

In the unopened puparia brought in at the same time Perilampus required about 25 days from the time they were placed in the incubator until they emerged as adults, but the period of development is dependent somewhat upon how much time they have been left out of doors, and there is some variation among the individuals themselves. From puparia brought in and placed in the incubator November 22 to 28 Perilampus began emerging December 27, about a month later, and continued coming out intermittently until approximately February 13, covering a period of about 48 days. Puparia brought in December 13 to 19 produced Perilampus first on January 17 and continued producing until February 6, a period of about 20 days. Puparia brought in January 17 to 23 produced adult Perilampus first on February 14 and continued until March 3, a period of about 17 days. From the above data it is seen that the later in the winter the puparia are brought in and placed under conditions favorable for the development of Perilampus, the shorter is the period during which the adults emerge. It is also evident that when infested puparia are brought in early in the winter a longer period of time elapses until the first adult Perilampus emerges than when left for a more extended period out of doors. Whether bringing the planidium in later in the winter causes it to develop more rapidly or whether it simply does not require so much time before becoming ready to begin feeding under these conditions is not known, but the latter explanation seems more reasonable.

The relative time of emergence of the adult Perilampus and adults of the host insect of the same lot is of considerable interest and will be given more study later. In September, 1908, a lot of Varichæta were placed in cold storage and kept there until January 18, when they were brought into the laboratory. From these puparia Vari- 
chæta adults issued from February 2 to February 14. Perilampus adults issued from the same lot April 1 to April 6, approximately two months later.

In this instance the puparia were not kept at an even temperature. During the night, especially, it was frequently cool. Another lot of puparia collected at about the same time but not placed in cold storage or exposed to frost produced Perilampus adults November 30 to January 30 and adult tachinids January 22 . Under these conditions the first Perilampus issued a month earlier than its host, as opposed to two months later when kept in cold storage until about the middle of January. It is apparent from the above that Perilampus adapts itself to changed conditions much more readily than does Varichæta. Indeed it is a necessity that it should be able to do this, being a parasite of other parasites which normally complete their development during either spring, summer, or fall, as the case may be.

EFFECT ON PARASITISM UPON HOST.

(Fig. 26.)

The Perilampus planidium, even before it begins to feed, exerts a very marked effect upon its host, especially in case the host is a tachinid. As mentioned on a preceding page, these planidia while living internally within the host larva do not seem to cause it the slightest inconvenience, and it is impossible to distinguish between a parasitized and an unparasitized larva before the planidium emerges, excepting, of course, where the secondary parasite itself is visible. Immediately pupation takes place in the host and the planidium becomes ectoparasitic, the effect of the parasitism becomes evident, especially after the host pupa has been subjected to warmth. Instead of responding to the increased temperature in the usual way - that is, instead of developing pigment in the imaginal eyes and bristles upon the body-it takes on a peculiar transparent appearance, principally in the cephalic and thoracic regions. The eyes and appendages develop very slightly and the imaginal head reaches scarcely one-half the size of that attained in the unparasitized pupa. These pupæ now present a very characteristic appearance (see fig. 26), and in opening a series of puparia one may recognize the parasitized individuals at a glance, even before Perilampus has begun to feed. This peculiar effect is noticeable to a considerably less extent where Limnerium acts as a host.

The pathological nature of this unusual condition of the parasitized pupæ has not been investigated as yet. It is apparently an arrested histogenesis, but in what manner this is brought about we can not say. Only a single case has come under observation where 
the host pupa developed the characters of the adult to any extent. During March, 1909, a puparium of Varichæta was dissected and found to contain a very small pupa of Perilampus, only about threefourths natural size but fully developed and apparently healthy in every way. The astonishing thing in this instance was the fact that the tachinid pupa had developed to a stage where it had taken on the characters of the adult. Even the bristles were well formerl. This is the only case out of several hundred puparia examined where development had not ceased soon after the formation of the pupa and is rather difficult to explain. It is possible that for some reason the planidium did not respond to the usual stimulus, histolysis, and remained internal within the pupa, giving the tachinid an opportunity to develop considerably further than normally before the secondary parasite changed its mode of life to external feeding. There were many other puparia subject to the same conditions and they all responded in the usual way, so that the above case must be considered as abuormal.

The retardation of development in the parasitized hosts is of course brought about by the presence of the planidium, but whether indirectly or directly has not been ascertained. That it may be due to a glandular secretion is not impossible, but this hardly seems to be an adequate explanation, as nothing resembling glands of this kind have been found, although a careful study of the planidium has been marle with the oil-emersion objective. In the opinion of many zoologists an insect during the process of pupation is in a very critical condition and is more susceptible to injury at this time than during any other period of its life. It does not seem improbable that in this supposition lies the explanation of the condition brought about in its host by Perilampus. The larva or maggot is able by reason of its great vigor to withstand the presence of the secondary parasite, but immediately histolysis and histogenesis begin to take place the weakened condition of the host makes itself apparent in the form of a céssation of development of pupal or imaginal organs and appendages and occasionally in certain instances death ensues. 'The development of Limnerium invariably ceases soon after the exit of Perilampus, although the latter does not emerge until the host larva has discharged its meconium and the formation of the pupa has begun. In one instance the planidium was observed located in the imaginal eye of its host, which becomes visible as a darker spot some time before the larval skin is discarded.

PERCENTAGE OF PARASITISM.

The percentage of parasitism of Varichæta and Limnerium by Perilampus in 1908 was not very high. Large numbers of the cocoons and puparia were opened, or reared through in the laboratory, 
but accurate counts were kept in only a single instance, in which 35 out of a lot of 164 puparia, or 21.4 per cent, were found to be parasitized by Perilampus. This is known to be above the average, taking the material which was reared or studied as a whole.

The results of several counts given in Table $I$ are indicative of parasitism in 1909 .

Table I.-Percentage of parasitism of Varichrta by Perilampus, 1909.

\begin{tabular}{|c|c|c|}
\hline $\begin{array}{l}\text { Number of } \\
\text { puparia. }\end{array}$ & $\begin{array}{l}\text { Number at- } \\
\text { tacked by } \\
\text { Perilampus. }\end{array}$ & $\begin{array}{l}\text { Per cent of } \\
\text { parasitism. }\end{array}$ \\
\hline $\begin{array}{r}29 \\
244 \\
57 \\
100 \\
100\end{array}$ & $\begin{array}{l}16 \\
58 \\
28 \\
54 \\
23\end{array}$ & $\begin{array}{r}55.0 \\
23.3 \\
49.1 \\
54.0 \\
23.0\end{array}$ \\
\hline $\begin{array}{l}\text { Total_........530 } \\
\text { A verage........ }\end{array}$ & 179 & 41.0 \\
\hline
\end{tabular}

The variation between the individual lots is due to their having been collected in different localities. Although it may be stated with assurance that the average was much higher than during the previous year, exact comparisons are impossible, since parasitism varies in different nests in the same locality, and in different localities. A long series of careful calculations would be required in order to secure accurate results.

As might be expected, the cocoons of Limnerium validum were parasitized to an approximately equal extent, and in these cocoons were found a few planidia of another species, which has been designated in the notes as "Species A." The summer-issuing Limnerium and Apanteles were not so heavily parasitized as a rule, probably because many of the planidia did not enter the caterpillars until a part of those afflicted by these parasites had died.

The percentage of healthy caterpillars of Hyphantria bearing the planidia, either internally or externally, ought to be, and apparently is, approximately the same as the percentage of Varichæta and Limnerium parasitized.

\section{SUPERPARASITISM.}

Perilampus versus Perilampus.

The extent to which Varichæta or Limnerium is parasitized by Perilampus may be easily determined by opening the puparia or cocoons before the planidia have begun to develop, and in this manner the prevalence of superparasitism may be easily calculated. Upon several occasions as many as five planidia have been found upon one host, and four, three, and two are of frequent occurrence. In not a 
single instance out of hundreds has more than one adult Perilampus issued from any cocoon or puparium under observation.

In a recent discussion of this phase of parasitisn by Mr. W. F. Fiske ${ }^{1}$ an attempt was made to classify its varied manifestations in accordance with the manner in which the parasites interested are ultimately affected. Superparasitism by Perilampus appears to fall in "I, b." of the scheme, i. e., one parasite lives and the other or others die, and the survivor brings about the destruction of the others by causing the premature death of the host. Several planidia may begin to feed at about the same time, but one invariably molts for the last time a little in advance of the others, and even though the difference is but a few hours it quickly devours the host, or else reduces it to such a condition as to render it unfit food for the next in succession. In no case has one larva been known to make a direct attack upon another.

In the article referred to above an attempt was made to indicate diagrammatically the probable amount of superparasitism accompanying a given amount of parasitism provided its prevalence was governed by chance alone. Whenever opportunity has permitted, the validity of the calculations which served as the basis for this diagram has been tested, and in nearly every instance, to date, the results have tended to confirm the contention at the time that "in the field * * * superparasitism would be distinctly more prevalent in proportion to the percentage of total parasitism" than these calculations demanded. This has proved to be true of Perilampus, as will be seen by Table II, which gives the results of a series of counts to determine the point.

TABLE II.-Prevalence of superparasitism of Perilampus on Varichæta, 1909.

\begin{tabular}{|c|c|c|c|}
\hline & Lot 1. & Lot 2. & Lot 3. \\
\hline 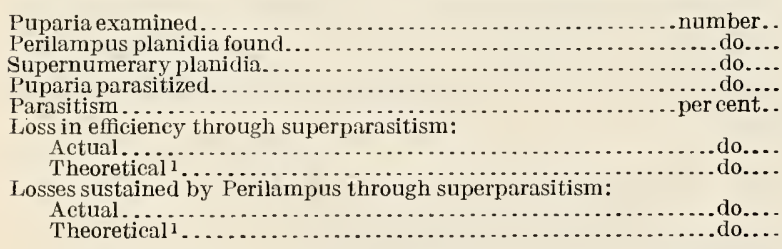 & $\begin{array}{r}100 \\
28 \\
5 \\
23 \\
23 \\
5 \\
3.3 \\
17.9 \\
11.8\end{array}$ & \begin{tabular}{l|}
100 \\
87 \\
33 \\
54 \\
54 \\
33 \\
28.8 \\
\\
37.9 \\
33.1
\end{tabular} & $\begin{array}{l}57 \\
47 \\
19 \\
28 \\
49 \\
33 \\
26.6 \\
40.2 \\
32.4\end{array}$ \\
\hline
\end{tabular}

${ }^{1}$ In accordance with calculations upon which the diagram published in the Journal of Economic Entomology (loc. eit.) was based.

It will be noted that in each instance the numerical loss sustained by Perilampus, and the decrease in its efficiency as a parasite, is greater than is theoretically called for. 
Perilampus versus Dibrachys.

Another exceedingly curious complication was observed in the winter of 1908-9 in an instance where a cocoon of Limnerium validum had been attacked by Perilampus and later by Dibrachys boucheanus Ratzeburg. The larvæ of the latter parasite fed externally and gregariously, and hibernated without transforming to pupæ. So soon as its original host was destroyed, the Perilampus planidium, not to be outwitted, calmly proceeded to take up a position internally in one of the Dibrachys larvæ. The particular larva bearing this planidium was killed and preserved, but in another instance a very small Perilampus adult issued from a puparium of Varichæta from which a number of Dibrachys adults had emerged some time before, and there is no doubt that it completed its transformations as a parasite on this host. With the exception of Melittobia, which from its very small size would likely prove unsuitable as an ultimate host, there is no known hymenopterous hyperparasite likely to attack the puparia of Varichæta or the cocoons of Limnerium which might not serve as well as Dibrachys as a host for Perilampus. The planidium is admirably fitted to triumph over adversity, and shows the part of wisdom in not causing the death of its host until it is ready to complete its transformations. If, for example, it had the habit of killing its host in the fall, and of hibernating as a full-fed larva, after the manner of Dibrachys, the latter might easily turn the tables and emerge victorious from the conflict.

\section{PERILAMPUS, "SPECIES A."}

(Figs. 30, 31.)

In the course of the investigations upon the genus Perilampus, two kinds of planidia have been found parasitic upon Limnerium validum, which, while belonging to the same general type, are quite different in structural detail and apparently represent different species. One of these, the commoner one, is Perilampus hyalinus, which has been treated rather fully in the preceding pages. The other species we have never succeeded in rearing through to the adult, so are unable to give it a specific name at this time. In length it is rather shorter than hyalinus, measuring on the average about $0.24 \mathrm{~mm}$., but is comparatively greater in diameter through the anterior segments. The color is usually somewhat darker than that of hyalinus. In $P$. hyalinus the head of the planidium is notched or emarginated and elevated posteriorly, but in this species the posterior margin is continuous. The mandibles are heavier and considerably less curved, and the recurved hooks on the top of the head are also considerably larger. The ambulatorial spines are very much less developed than 
in hyalinus and the ends of the chitinous bands which surround the body are simple, not terminating in long teeth or serrate as in the other species. The dorsal and ventral bristles, however, are stronger and more numerous, and somewhat differently arranged.

Considerable difference in habit in these two species has also been noted. P. hyalinus, we have reared from many different hosts, but the other species has been found only upon the larva of Limnerium validum. Instead of remaining internal within the Limnerium larva until it attempts to pupate in the spring as does $P$. hyalinus, this

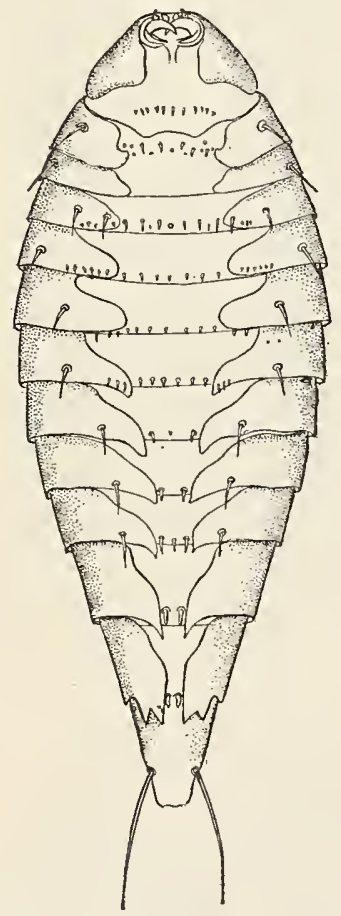

FIG. 30.-Perilampus, "species A:" Planidium, ventral view. Magnified about 400 diameters. (Original.)

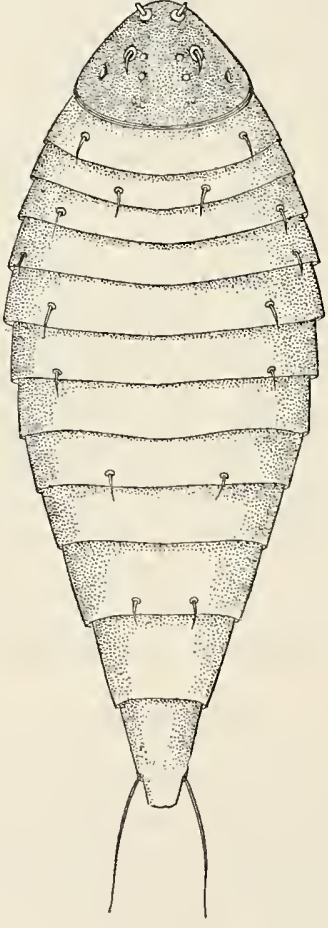

F1G. 31.-Perilampus, "species A:" Planidium, dorsal view. Magnified about 400 diameters. (Original.) species, if it ever feeds endoparasitically, must emerge from its host soon after the cocoon is spun, for it is found externally upon its host during the fall and winter before the Limnerium has any intention of pupating, and has never been found internally. In only one instance have we succeeded in getting this species to feed, and even that did not terminate satisfactorily. During the spring of 1909 a specimen of the planidium of this species was placed on a larva of Limnerium in a glass cell for observation. Six days later the planidium had not fed and was noted as being apparently dead, but on the next day it was seen to have been feeding, although its host was still alive and active. Five days later the planidium had molted its skin and had taken on the globular form of the second-stage larva but was apparently not in very good condition and died two or three days later. At no other time were we able to get this species to feed. There is a possibility that it is of purely accidental occurrence upon Limnerium, and this may account for our inability to rear the adults. This belief is strengthened by the fact that a large percentage of the specimens of this planidium are 
dead when found upon the Limnerium larvæ in the fall. Out of 11 specimens found during an examination of some 55 cocoons, 10 were dead and shrunken. These cocoons had been kept under perfectly natural conditions out of doors, so that it is obvious that there was something radically wrong between parasite and host. 'The fact that it has never been found upon Varichæta suggests the possibility of its being of ectoparasitic habits entirely, and that it attaches itself to the Limnerium larva after the latter emerges from the caterpillar, but prior to the spinning of its cocoon. This would of course preclude its being a parasite of a tachinid, as the formation of the puparium would naturally leave it outside of the hardened shell and death would inevitably result. The data on hand concerning this species, however, are too limited to warrant an attempt to draw any conchusions, and with the recording of the above facts we leave it until further investigations have thrown more light upon its habits.

\section{DEVELOPMENT OF ORASEMA.}

Dr. William Morton Wheeler, in the article referred to on page 35, gives an exceedingly interesting account of the life history and economy of the chalcidoid genus Orasema, of the family Eucharidæ. A comparison of the habits of representatives of the so-called families Eucharidæ and Perilampidæ is of unusual interest at this time and may assist in clearing up certain doubtful points in the economy of the former. Orasema is parasitic principally upon the harvesting ant Pheidole instabilis Emery, but also occurs not uncommonly upon representatives of other ant genera in the southwestern United States and Mexico. In view of the close relationship existing between the two genera and the general similarity of development so. far as is known in the two forms, it would seem permissible at this time to draw certain conclusions in regard to Orasema which have been suggested by the investigations upon Perilampus. In regard to the oviposition of Orasema Dr. Wheeler has the following to say:

I have not seen the eggs of $O$. viridis after oviposition, but only the very young larvæ. Dissection of the female shows that, as we should expect in a parasite, the eggs are extremely numerous and minute. The mother insect, when she comes to oviposit, exercises a very careful selection among the ant brood. In the first place she has nothing to do with the instabilis larvæ, but directs her attention to the pupæ. In the second place she selects, as a rule, only the pupæ of the soldiers, males and females. The small worker pupæ would not furnish sufficient food for her larvæ. In the third place she selects only pupæ at the very critical moment when they have been stripped of their larval skin by the workers and are, therefore, little more than semipupæ, for obviously at this moment the cuticle is thinner and will be more easily pierced by the young Orasema larvæ than during the preceding or succeeding stages; and in the fourth place she does not lay her eggs at random anywhere on the body of the semipupæ, but carefully selects one of four regions near the head. Usually she places the egg on the sternal surface just beneath the very short, incurving legs of the 
semipupa, but occasionally it is placed on the back of the neck between the head and the prothoracic segment or on the right or left side of the neck beneath the corresponding prothoracic leg. These regions would seem to be singularly appropriate, both because the cuticle is extremely thin aud readily punctured by the parasitic larva at these points, and also because the egg or resulting larva, especially when it is covered with the overlapping appendages of the semipupa, is not so readily brushed or licked off by the instabilis workers.

If we may judge from the habits of Perilampus, the explanation of Dr. Wheeler's failure to find the eggs of Orasema in the ant nest is possibly that they are not deposited there. It is possible that oviposition might take place outside the nest, perhaps upon flowers or other vegetation visited by both the Orasema adults and the worker ants; and that from the eggs deposited upon these plants the planidia hatch, in some manner attach themselves to the worker ants, and are in that way conveyed to the nest, where they leave their carrier and attack the larvæ. Several points in the economy of Orasema as noted by Dr. Wheeler tend to substantiate the belief that oviposition takes place outside the nest. In the first place the large number of eggs deposited by Orasema (Dr. Wheeler found by dissection of the adults that they were very numerous and minute) indicates that somewhere in its early life cycle there is prevalent a very great mortality. That this mortality actually takes place was observed by Dr. Wheeler, and he thought that it might be explained in the following manner:

I believe that the dauger of detaching the egg is very great, and this, together with the other special requirements enumerated above, may account for the fact that comparatively very few of the great number of Orasema eggs ever complete their development.

The number of eggs deposited by a single female Orasema, should they all become effective, would probably be sufficient to annihilate a whole colony of the Pheidole, and not one but many female Orasema are usually found in the infested nests. It would seem, therefore, that there would be little likelihood that such great mortality would occur if only the causes enumerated by Dr. Wheeler were operative. It is possible that the Orasema planidia attack the larvæ of Pheidole, not the pupæ, and that the seemingly sudden appearance of the young Orasema larvæ upon the pupæ of Pheidole immediately after the last larval ecdysis is similar to that which has been noted on a preceding page as occurring in Perilampus. In other words, the Orasema planidium may be endoparasitic within the Pheidole larvæ, making its exit to the exterior at the time of histolysis and feeding ectoparasitically thereafter. Dr. Wheeler's observation of the fact that the Orasema planidia appear upon the pupæ only at this critical time would tend to substantiate this theory.

It seems improbable that insects as highly positively phototropic as Dr. Wheeler has observed Orasema to be should return to the interior of an ant's nest to oviposit after having escaped and lived in the sunlight for a considerable time. 


\section{PLANIDIUM OF ORASEMA VIRIDIS ASHMEAD.}

Length about $0.16 \mathrm{~mm}$. General shape like that of Perilampus, but comparatively broader and much more simple in structural detail. Color dark, as in Perilampus. Head more elongate than that of $P$. hyalinus, the recurved hooks, if present, very small; there are two pairs of organs in a location similar to that of the hooks upon the head of Perilampus, but their extremely minute size makes the nature of these objects difficult to define even under the oil-immersion objective. Mouth parts indefinable, considerably retracted into head. Anterior margin of head much roughened. First dorsal segment short, with a pair of distinct bristles situated along the apical margin, the base of each within a transparent spot. Second segment broader, with two apical spines farther apart than on preceding. Next segment much like second, but broader, with similar spines. Remaining segments apparently without dorsal spines. Ventral ends of the chitinous plates simple, not ending in a serrate margin or with long teeth as in Perilampus. Seventh segment with a pair of spines ventrally. Last segment with a pair of stylets comparatively shorter and stronger than in Perilampus.

Dr. Wheeler's account of the effect of parasitism by Orasema upon Pheidole tallies very well with our observations upon parasites attacked by Peritampus; the same microcephalic characters are present in the host pupæ in both cases, with the peculiar transparent appearance, as noted upon a previous page of this article.

Other points in the economy of Orasema brought up by Dr. Wheeler and which at the time seemed very puzzling are apparently rather easy of explanation in the light of our present knowledge of Perilampus. It is hardly within the province of this bulletin, however, to take these up in detail, and it is merely suggested here that anyone desirous of doing further work upon the development of Orasema, and perhaps other members of the chalcidoid family Eucharidæ, would perhaps do well to bear in mind the similarity of the life cycle, so far as known, to that of Perilampus. ${ }^{1}$

\section{RELATIONSHIP OF EUCHARID必 AND PERILAMPID蚱.}

The great similarity of development in the genera Orasema and Perilampus can not fail to have considerable bearing upon the taxonomic relationship of the so-called families Euchariclæ and Perilampidæ. Francis Walker, in 1846, placed the two groups together under the family name Eucharidæ. Ten years later, however, the German hymenopterist, Arnold Förster, decided that the differences

1 During the winter of 1909-10 an extraordinary planidium was found on the hibernating larva of the larch sawfly (Nematus erichsonii Hartig), within the cocoon. This parasite was not reared, but was Perilampus in all probability. 
were sufficient to justify him in splitting the group into two distinct families. In this move he was later supported by Dr. William $\mathrm{H}$. Ashmead. It is of course impossible to come to any definite conclusions in a case of this kind until more has been learned concerning the larval development in the other genera of the two groups, and also in the related families. If it is found that this type of development is characteristic of these two groups and no others, it should certainly be an argument of considerable weight in support of Walker's views.

\section{RHIPIPHORUS AND O'THER COLEOPTEROUS PARASITES.}

Anyone at all familiar with the life histories of certain of the parasitic Coleoptera, Meloë, Sitaris, and more especially the hornet parasite Rhipiphorus, will be reminded of these genera by a perusal of the preceding pages. The similarity in development, life cycle, and habits even to certain minute details is so striking that one in reading the excellent description of the life history of Rhipiphorus paradoxus given by Dr. T. A. Chapman ${ }^{1}$ could scarcely tell whether it belonged to that insect or to Perilampus were the names omitted. A brief comparison of the two may be of interest.

So far as we know, the place of oviposition of Rhipiphorus paradoxus has not been observed, but other members of the family, notably Myodites, oviposit commonly upon flowers of various kinds. From the eggs hatch the triungulins which are not only analogous to the planidium of Perilampus and Orasema but, except for the legs and antennæ, are strikingly similar in anatomical details. The dark chitinous rings which encircle the triungulin for protective purposes during its adventurous search for its host, the backward-pointing spines with which these are provided, the pair of stylets on the last segment and the "comma"-shaped mandibles retracted into the buccal cavity all forcibly remind one of the planidium of Perilampus. The writer is aware that the resemblance is mainly a superficial one, but it is very unusual, superficial though it be. The similarity does not end here, however, but is carried out even to the details of the life cycle. It is more comparable to Orasema than to Perilampus inasmuch as the Perilampus is a secondary while the others are primary parasites. The Rhipiphorus triungulin, after gaining entrance to the nest of its host, conducts itself almost exactly as we have reason to suspect Orasema does; that is, it enters the young host larva, emerges at the time the host larva attempts to pupate, and feeds ectoparasitically thereafter. It differs, however, in the fact that the Rhipiphorus triungulin feeds and grows to 8 or 10 times its original length while within the host larva, while Orasema and Perilampus apparently do 
not grow at all until they emerge and begin feeding outside. This resemblance is not altogether lost in the later stages. Even the large dorsal tubercles or projections of Orasema and Perilampus are reproduced in the third-stage larva of Rhipiphorus. There is a slight difference in the method of pupation, the Rhipiphorus larva leaving the host to pupate while Orasema, when not interfered with by the worker ants, and Perilampus, transform in situ.

We have then in Perilampus and Orasema an instance of hypermetamorphism as defined by Packard, belonging to the same type as that occurring in the Rhipiphoridæ. The planidium exists as such because of the wandering and perilous life it is obliged to lead in its search for a host, but soon after that host is found, the protection of the chitinous plates or the use of the ambulatorial spines no longer being necessary, these accessory structures are discarded. As the parasite now has easy access to an abundance of rich nutritious food without the necessity of putting forth the slightest effort it becomes a mere grub-a perfect adaptation to the new mode of life.

\section{HOST RELATIONS OF THE GENUS PERILAMPUS.}

REARING RECORDS OF PERILAMPUS HYALINUS AT THE LABORATORY.

We have found the native species Perilampus hyalinus to attack the primary parasites of two species of Arctiidæ, Hyphantria textor Harris and Euchrtias egle Drury; a single notodontid, Melalopha inclusa Hübner; and a saturniid, Samia cecropia L.

The species hyalinus has shown an adaptability in the matter of food habits which is quite unusual in an insect with such a complicated life history. We have absolute records of this species from 10 different primary parasites belonging to 2 different orders and 6 or 7 different genera. A diversity of host relations as exhibited by hyalinus would not be considered at all remarkable in species of a great many chalcidoid genera, but when we consider the circumscribed method by which access to the host is gained, it seems, on first thought, to show a quite unusual versatility. When we come to analyze the habits of the parasite more closely, however, it is at once seen that the versatility is only apparent. The diversity of host relations is due more to a lack of discrimination than to any especial adaptability. Precisely the same efforts are put forth by the planidium on the occasion of its attack upon any and all of its hosts. The conditions under which it develops are somewhat variable, but even here the actual stimulus which causes the change from endoparasitism to ectoparasitism is the same, namely, that of histolysis in the host larva. 
We have reared $P$. hyalinus from the following hosts:

Parasites of Hyphantria textor Harris.

Tachinidæ:

Varichxta aldrichi Townsend.

Compsilura concinnata Meigen.

Ichneumonidæ:

Limnerium validum Cresson.

Limnerium fugitivum Say.

Limnerium pallipes Provancher.

Braconidæ:

Apanteles hyphantrix Riley.

Meteorus communis Cresson.

Pteromalidæ:

Dibrachys boucheanus Ratzeburg (on Varichæta).

Parasite of Euchetias egle Drury.

Tachinidæ:

Genus aud species undetermined.

Braconidæ:

Apanteles sp.

Parasite of Melalopha inclusa Hübner.

Ichneumonidæ:

Limnerium validum Cresson.

Parasite of Samia cecropia Linneus.

Tachinidæ:

Frontina frenchii Williston.

OTHER AMERICAN REARING RECORDS OF PERILAMPUS.

Through the courtesy of Dr. L. O. Howard the rearing records have been obtained from the collection and biological notes of the Bureau of Entomology. The species of Perilampus have not been determined. The hosts are all lepidopterous and are as follows:

Dasypyga alternosquamella Ragonot.

Acrobasis caryæ Grote.

Eucosma scudderiana Clemens.

Eucosma desertana Zeller.

Phlyctrnia extricalis Guenée.

Apatela haustulifera Smith and Abbot.

Harrisina americana Guerin-Méneville.

Retinia sp. (?)

Prof. C. V. Riley records ${ }^{1}$ Perilampus platygaster Say as a parasite of Harrisina americana in the State of Missouri.

A species of Perilampus was reared, according to the labels in the United States National Museum, by Mr. D. W. Coquillett from the cocoon of a Chrysopa at Los Angeles, Cal. Dr. Ashmead also reared

I Second Report on the Noxious and Beneficial Insects of Missouri, p. 87, 1870. 
a species from Chrysopa at Utica, Miss., this record being the one referred to in his Monograph of the Chalcidoidea.

In a paper entitled "A list of the parasites known to attack North American Rhynchophora," ${ }^{1} \mathrm{Mr}$. W. D. Pierce records Perilampus as a parasite of the cotton boll weevil (Anthonomus grandis Boheman) in cotton squares in Louisiana. Mr. Pierce in a recent letter regarding this record states that it is open to question. A cotton square from which a weevil had emerged forms an excellent retreat for another insect that might be inclined to secrete itself in this manner. It may be that in this case a Chrysopa larva parasitized by Perilampus crawled into the square to pupate and from this the Perilampus emerged later. That Chrysopa is prone to do just this thing is a well-known fact. Dr. Howard described the chalcidoid parasite Isodromus iceryæ as a parasite of the scale Icerya. He later found that Isodromus was instead a parasite of Chrysopa, which in this instance had crawled beneath the Icerya scale, through which the Isodromus later emerged.

In $1897 \mathrm{Mr}$. W. F. Fiske reared a single specimen of Perilampus hyatinus from the cocoon of Limnerium fugitivum Say as a parasite of Hyphantria. This fact was recorded in his paper on the parasites of the American tent caterpillar, ${ }^{2}$ and probably constitutes the first published record of Perilampus as a secondary parasite on Hymenoptera.

Quaintance and Brues in their study of the cotton bollworm ${ }^{3}$ found this species to be a rather uncommon parasite of Microplitis nigripennis Ashmead, a braconid parasite of Heliothis obsoleta Fabricius in Arkansas and Texas.

Dr. L. O. Howard, in a paper entitled "The biology of the hymenopterous insects of the family Chalcididæ," ${ }^{4}$ makes the statement that Perilampus has been reared from Tachinidæ, but none of the details of the rearing was given. Dr. Howard, in a recent letter in regard to this, says that he is unable to find any record upon which this statement was based, but that he is of the opinion that it was reared from tachinid puparia in the office of the Entomologist at Washington prior to 1892 . This is the first published record, so far as we are aware, of Perilampus as a parasite of Diptera.

Prof. M. H. Swenk ${ }^{5}$ records having reared Perilampus hyalinus from a sarcophagid which in turn was reared from Melanoplus bivitattus Say.

1 Journal of Economic Entomology, vol. 1, p. 383, 1908.

2 New Hampshire College Agricultural Experiment Station, Technical Bulletin 6, p. 206, 1903.

3 Bulletin 50, Bureau of Entomology, U. S. Department of Agriculture, p. 122, 1905.

4 Proceedings of the U. S. National Museum, vol. 14, p. 574, 1892.

5 Journal of Economic Entomology, vol. 4, p. 286, 1911. 


\section{EUROPEAN REARING RECORDS OF PERILAMPUS. ${ }^{1}$}

\section{Perilampus angustatus Nees.}

This species was reared by Rondani ${ }^{2}$ from the wood-boring larva of Anobium molle. Gaulle ${ }^{3}$ records angustatus as a parasite of Dryophilus pusillus.

Perilampus auratus Panzer.

According to Gaulle, ${ }^{3}$ this species has been reared from the crabronid wasps Solenius rubicola and $S$. vagus by Lichtenstein.

\section{Perilampus levifrons Dalman.}

Rondani ${ }^{2}$ has reared levifrons from the larvæ of the tortricid Coccyx buotiana and also from the codling moth (Carpocapsa pomonella L.). Gaulle ${ }^{3}$ gives an additional host in Exocentris punctipennis. Dour ${ }^{4}$ mentions the first two records, crediting the first to Gouraud.

Perilampus micans Dalman.

This parasite was reared by Rondani ${ }^{2}$ from the larvæ of Lyctus canaliculatus and Hister picipes.

\section{Perilampus ruficornis Fabricius.}

Gaulle ${ }^{3}$ records this insect as a parasite of Hylophila bicolorana. Rondani ${ }^{2}$ has reared it from the lepidopterous Halias quercona. Dalle Torre regards violaceus Fabricius as a synonym of this species. Ratzeburg ${ }^{5}$ refers to a Perilampus which he calls violaceus as follows: ${ }^{6}$

Herr Reissig was so fortunate as to rear a female of this species. The host was not determined definitely, but it was without doubt a forest insect. On an oak leaf he found the dried remains of a tortricid larva. The parasitic larva had come out of this and had hung itself by a spun thread. The cocoon has the compact form of those of Campoplex, is two lines long, transparent (but nevertheless of close texture), dark brown, with a somewhat lighter band. The large opening through which the Perilampus had gnawed its way is at one end and appears as au irregularly torn circle.

There seems to be little doubt that Ratzeburg was incorrect in his surmise that this species was primary upon the tortricid. Perilampus of course does not spin a cocoon, or even a thread. The cocoon which he describes was almost certainly that of Campoplex, which he says it resembles, and with which his description agrees.

\footnotetext{
1 The author is indebted to Dr. L.. O. Howard for examining literature which was inaccessible.

2 Bulletino della Società Entomologica 1taliana, vol. 4, pp. 57-58, 1872; vol. 8, pp. 241-242, 1876.

a Catalogue systematique et biologiques des Hyménoptères de France, in La Feuilles des Jeunes Naturalistes.

1 Catalogue synònimique des Hyménoplères de France, in Mémoires de Société Linnéene du Nord de la France.

- Ichneumonen der Forstinsekten, vol. 3, p. 221.

6 Translation by the author.
} 
This Campoplex was probably parasitic on the tortricid, and the Perilampus destroyed it as a secondary parasite.

There is almost certainly more than one species under the name ruficornis, as the records indicate that it has been reared from moths as a primary parasite, and from an ichneumonid as a secondary. That this would occur in a single species seems hardly probable in view of its highly specialized life cycle.

\section{Perilampus italicus Fabricius.}

Recorded by Gaulle ${ }^{1}$ as a parasite of the sawfly Athalia colibri.

Of course there is always the possibility that the specimens recorded from Lepidoptera really came from tachinids or ichneumonids which transform within their host. It is difficult to understand how the Perilampus larva, being an external feeder for the greater part of its life, could feed and develop externally upon the pupa of an ectophagous lepidopteron, taking for granted that the mode of development is similar in all the species of the genus. It might, however, be able to do so upon a lepidopterous host which feeds within stems or galls, the Perilampus in this case being protected from injury.

\section{EUROPEAN SPECIES OF PERILAMPUS REARED AT THE LABORATORY.}

\section{Perilampus cuprinus Förster.}

In 1906 several individuals of Perilampus cuprinus were reared by Mr. Titus from puparia of imported tachinids parasitic upon the gipsy moth and brown-tail moth. Occasionally a few more were secured under similar circumstances, but never in numbers sufficient to indicate that the species was of any particular importance as a secondary parasite. Neither were there any records which indicated that any species of the genus was of more than incidental interest in connection with lepidopterous hosts.

The tachinids acting as hosts were not identified in every instance, but among those species attacking the gipsy moth are Blepharipa scutellata Robineau Desvoidy, Compsilura concinnata Meigen, and Tricholyga grandis Zetterstedt, and among the brown-tail moth parasites are Pales pavida Rondani and Parexorista cheloniæ Rondani. It is practically certain that all of the tachinids and probably some of the ichneumonids and braconids preying upon this host are liable to attack by Perilampus. It is also possible, but not proven, that it is at times an enemy of sarcophagids which usually and probably always attack pupæ which have died from other causes.

In no instance has the planidium of this species been seen but there is hardly a doubt that this stage exists and that in its essential

\footnotetext{
1 Catalogue systematique et biologique des Hyménoptères de France, in La Feuilles des Jeunes Naturalistes.
} 
characteristics it resembles the planidium of $P$. hyalinus and others described in the preceding pages. It is also probable that the later larval development is analogous to that of $P$. hyalinus and that the beginning of development of the pupa is the signal which stirs the planidium into activity.

Varichata, as has been shown, hibernates as a pupa which has not begun to show the color or characteristics of the adult, and the Perilampus planidium remains dormant throughout the winter and feeds in the spring. Among the European tachinids known to act the part of host to P. cuprinus, Compsilura, Tricholyga, and Pales issue in the summer, much as do the summer-issuing hymenopterous parasites of the fall webworm, and $P$.cuprinus completes its transformations and hibernates as an adult without leaving the puparium. Blepharipa, unlike Varichrta, develops imaginal characters in the fall and is, so far as external evidences indicate, ready to emerge before winter. Perilampus as a parasite of Blepharipa acts exactly as it would had its host actually emerged in the fall, and hibernates as an adult within the puparium. Parexorista hibernates like Varichæta, and if the parallel between $P$. hyalinus and $P$. cuprinus is as close as is believed, the planidium hibernates as such and becomes active when its host begins to develop in the spring.

\section{Perilampus inimicus Crawford.}

A relatively small number of this species, recently described in Part II of this bulletin, was reared in 1908 from the cocoons of Apanteles fulvipes var. japonica Ashm., imported that year from Japan as a parasite of the gipsy moth. It has not been reared as a parasite of Japanese tachinids, but it may well be that it resembles $P$. cuprinus in habits, and that it will be reared when larger importations of tachinids from Japan have been made.

The specimens reared issued in the late summer, coincidently with the emergence of the other more common chalcidoid parasites of the same host.

\section{Perilampus sp.}

Another species of Perilampus, as yet undetermined, has been reared from the cocoons of a European Apanteles parasitic upon the young brown-tail moth caterpillars. The circumstances are interesting and suggestive but the incident will be discussed more at length in another connection.

\section{RÉSUMÉ OF HOST RELATIONS OF THE GENUS.}

Species of the genus Perilampus have been reared ${ }^{1}$ from insects belonging to five different orders, Hymenoptera, Diptera, Lepi-

1 This is according to the published records, although some of them are almost certainly incorrect. 
doptera, Coleoptera, and Neuroptera, in Europe, Japan, and America. Table III shows the number of each group from which Perilampus has been reared in those regions where the gipsy moth is found:

TABLE III.-Classification and distribution of the known hosts of the genus Perilampus.

\begin{tabular}{|c|c|c|c|c|}
\hline & America. & Europe. & Japan. & Total. \\
\hline 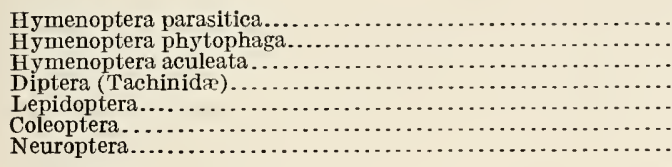 & \begin{tabular}{|l|}
8 \\
$\cdots$ \\
$\cdots$ \\
4 \\
8 \\
1 \\
1
\end{tabular} & $\begin{array}{r}2 \\
1 \\
2 \\
5 \\
5 \\
4 \\
-. . . \\
\end{array}$ & 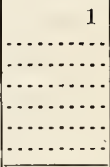 & $\begin{array}{r}11 \\
1 \\
2 \\
9 \\
13 \\
5 \\
1\end{array}$ \\
\hline Total.. & 22 & 19 & 1 & 42 \\
\hline
\end{tabular}

THE ECONOMIC ASPECTS.

In 1906 Mr. E. S. G. Titus, at that time in charge of the Gipsy Moth Parasite Laboratory, reared a few cocoons of Apanteles vimenetorum Wesmael ${ }^{1}$ from caterpillars of the brown-tail moth which had been imported in the hibernating nests. From them there emerged a very few specimens of a species of Mesochorus, different from any known American secondary upon Apanteles and apparently but not certainly European. The circumstances under which the A panteles were reared were not such as absolutely to protect them from the attack of the native hyperparasites, but there was good reason to believe that the Mesochorus, as well as the Apanteles, had attacked the very small caterpillars of the brown-tail moth in Europe the fall before. This was the first instance encountered in the course of the work of parasite introduction in which a secondary parasite was known or suspected to attack a primary parasite before the death of the primary host.

In 1907 this record was confirmed, and it was demonstrated beyond possibility of error that there were some secondary parasites which had this habit. The fact was of the greatest significance, since it was one of the fixed policies of the laboratory to introduce the primary parasites of the gipsy and brown-tail moths and to exclude the secondary. It had been supposed that this could be accomplished by importing the living caterpillars and pupæ of the gipsy and brown-tail moths and rearing the parasites. The fact that the primaries might be attacked before the death of their host altered the situation materially and made the strictest supervision of imported material necessary in order to meet the ideal which had been set.

That the relative importance of hyperparasitism has diminished rather than increased as a result of a better understanding of the 
subject affects the matter scarcely at all. We know now that the primary parasites of the gipsy and brown-tail moths, if they become established, will be subjected to the attack of native hyperparasites to a varying degree in accordance with the closeness of their resemblance in natural affinities and habits to American species, but there are among them a few which are so different from any American species as to make it probable that they will largely escape undue parasitism in America, much as the gipsy and brown-tail moths have themselves escaped. This does not lessen the force of the original contention at all materially. It has simply served to separate the secondary parasites into bad, worse, and worst, and has left them as a group with about the same degree of odium attached as before.

The separation of the several secondary parasites into groups in accordance with their capabilities for evil has not always been easy. As with the primary parasites, the importance of which can not be inferred from the numbers which chance to be reared from the imported material, the secondary parasites, which are the least frequently encountered, may easily be the most to be feared.

Perilampus has never been abundant as a parasite of tachinids in any of the imported material. So far as is directly indicated by our notes and breeding records there is nothing in its life or habits which would separate it from the minor and inconsequential secondary parasites, of which there are many species.

These opinions, formerly held, have been changed as a result of the investigations into the life and habits of the native Perilampus hyalinus. It was not known or suspected, in spite of the considerable study which the fall webworm has received at various times and by various entomologists, that this secondary was of any more interest or importance than any other', but it is now evident that species of this genus may become of the greatest importance as hyperparasites. It is further indicated as a direct result of these studies that the different species of Perilampus are likely to concentrate their attack upon the parasites of some particular primary host instead of scattering their attack upon all of the very numerous species of hymenopterous and dipterous parasites suitable in other respects. Thus Perilampus hyalinus appears to be particularly a parasite of the parasites of the fall webworm. It is possible that it will never attack the parasites of the gipsy moth or the brown-tail moth. Perilampus cuprinus, for all that is positively known to the contrary, may similarly concentrate its attack upon the parasites of the gipsy moth and the brown-tail moth and might become a factor of as much importance in the natural control of these insects as Perilampus hyalinus undoubtedly is in the control of Varichæta. 
It is not probable, but it is conceivable, that the establishment of $P$. cuprinus in America might make all the difference between success and failure of the whole work of parasite introduction, in so far as the gipsy moth is concerned, because, in the first place, Blepharipa scutellata is one of the most important parasites of the gipsy moth and the success or failure attending the attempts to introduce it into America might easily tip the scale one way or the other, and Perilampus, so far as known, is the most important parasite of Blepharipa and might in a similar manner determine whether or not its host reached the necessary state of efficiency.

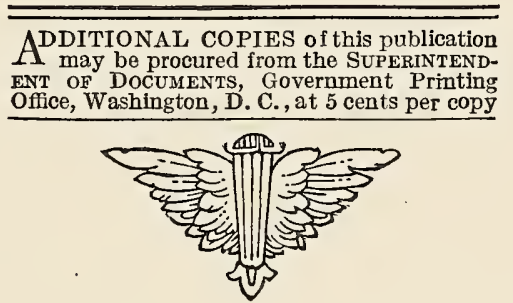









Technical Series No. 19, Part V.

U. S. DEPARTMENT OF_AGRICULTURE, BURFAU OF FITOMOLOGY.

L. O. HOWARD, Entomologist and Chief of Bureau.

\section{TECHNICAL RESULTS FROII THE GIPST IIOTH PARASITE LABORATORI.}

\section{EXPERIVIENTAL PARASITISII:}

A STUDY OF THE BIOLOGI OF LIMNERIUAI VALIDUII (CRESSON),

By P. H. TIMBERLAKE, A. M., Agent and Expert, Gipsy Moth Parasite Laboratory.

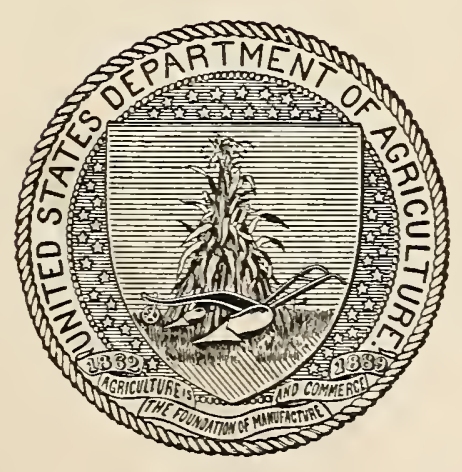

WASHINGTON:

GOVERNMENT PRINTING OFFICE. 


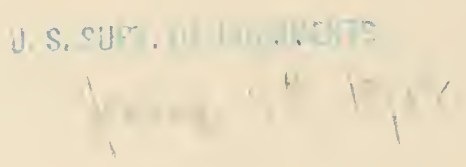

BUREAU OF ENTOHOLOGY.

L. O. HowARD, Entomologist and Chicf of Bureau.

C. L. Marlatt, Entomologist and Acling Chief in Absence of Chicf.

Ii. S. Clifton, Executive Assisiant.

W. F. Tastet, Chief Clerk.

F. H. Chittender, in charge of truel: erop and stored product insect intestigations.

A. D. Hopkrs, in charge of forest insect investigations.

W. D. HUNTER, in charge of southern field crop inseet investigations.

F. M. WeBster, in charge of cercal and forage insect investigations.

A. L. Quantance, in charge of deciduous fruit insect investigations.

E. F. Phillips, in charge of bee culture.

D. M. Rogers, in charge of preventing spread of moths, ficld work.

Rolla P. Currie, in charge of edlitorial work.

MABEL COLCORD, in charge of library.

\section{Preventing Spread of Moths.}

PARASITE LABORATORY.

W. F. Fiske, in charge; A. F. Burgess, Harry S. SMith, ${ }^{i}$ P. H. ThMlerlake, ${ }^{2}$ C. W. Collins, H. E. Smith, F. H. Mosher, J. N. Summers, Chas. W. МлотT, C. W. STOCKWELL, assistants.

FIELD WORK.

D. il. Iiogers, in charge; H. B. Dalton, II. W. Vinton, D. (;. Murphy, I. L. BAILEY, H. L. MICINTYRE, assistunts. 


\section{CONTENTS.}

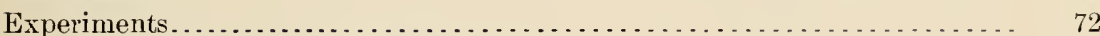

General metbods of experimentation.......................... $\quad 72$

Behavior of Limnerium validum (Cresson) in confinement............... . 73

Limnerium validum as a parasite of Euproctis chrysorrhoca (Linnaeus) ..... . $\quad 73$

First experiment........................................ 74

Second experiment.......................................... 74

Amœbocytosis as a protective reaction of the host................ 75

Adaptation of parasite to host........................... 76

Further experiments with Euproctis chrysorrhou.................. $\quad 77$

Limnerium validum as a parasite of Malacosoma americana (Fabricius).... $\quad 78$

Results of experiments as determined by dissection............. 78

Emergence of adults of Limnerium from reproduction.............. $\quad 79$

Length of the stages in the life history of Limnerium.............. 80

A possibly normal parasite of Malacosoma.................. 80

Limnerium validum as a parasite of Notolophus antiquus (Linnaeus) . . . . 81

Limnerium validum as a parasite of Porthetria dispar (Linnaeus) . . . . . . . . 82

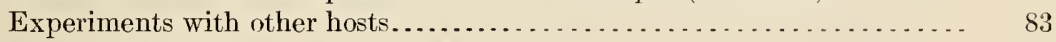

Notes on development and anatomy of the larva $\ldots \ldots \ldots \ldots \ldots \ldots \ldots \ldots \ldots . \ldots . \ldots 3$

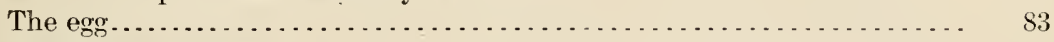

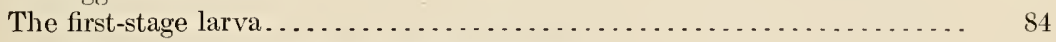

Description of the newly hatched larva..................... 84

Function of the tail appendage............................. 85

Appearance of older larvæ............................ 85

Notes on the anatomy of the larva......................... 86

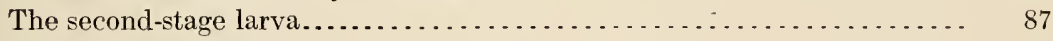

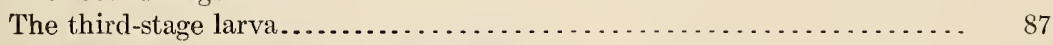

Description of the full-grown larva...................... 87

Feeding habits of the imprisoned larva...................... 88

Respiration of the larva in the third stage................. 89

The cocoon.............................................. 90

Results of the dissections of Hyphantria during the fall of $1910 \ldots \ldots \ldots \ldots . .90$

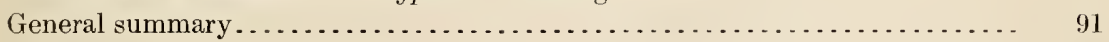

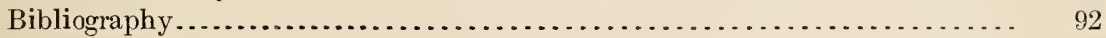




\section{ILLUSTRATIONS.}

Fig. 32. Limnerium validum: Adult female, abdomen of male, metascutum, cocoon .

Page.

33. Limnerium validum: Egg............................... 83

34. Limnerium validum: Eclosion of larva....................... 83

35. Limnerium validum: First-stage larva, newly hatched........... 84

36. Limnerium validum: First-stage larva of large size, showing silk glands

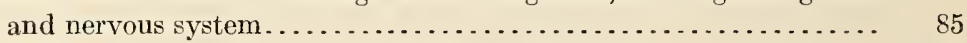

37. Limnerium validum: Mouthparts of first-stage larva............. 86

38. Limnerium validum: Second-stage larva...................... 87

39. Limnerium validum: Mouthparts of second-stage larva............ 87

40. Limnerium validum: Third-stage larva.................... 88

41. Limnerium validum: Anterior view of head of third-stage larva, show-

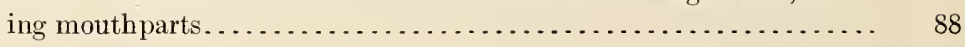
IV 


\section{TECHNIGAL RESULTS FROM TIIE GIISSY MOTII PARASITE LABORLTORY.}

\section{Experimental Parasitism: \\ A Study of the Biology of Limnerium Validum (Cresson).}

By P. H. Timberlake, A. M., Agent and Expert, Gipsy Ioth Parasite Laboratory.

INTRODUCTION.

The biology of none of our American parasitic Hymenoptera is too well known to demand an apology for the appearance of this article, and it is the hope of the anthor that the results of the studies here set forth will call to the attention of our professional and amateur entomologists this exceedingly rich but almost untonched field for investigation. A little of the ecology, especially of the host relationship, of many of our parasites has been recorded, but the various and interesting adaptations in the larval structure and habits of our different species are almost mnknown.

In connection with the practical work at the Gipsy Moth Parasite Laboratory of importing and liberating parasites of the gipsy and brown-tail moths, considerable attention is paid to the habits and biology not only of the imported parasites, but also of our native parasites of caterpillars that resemble the gipsy moth or brown-tail moth in habits or destructiveness. In this way considerable knowledge has accumulated which, besides its intrinsic and theoretical value, has been useful in perfecting the methods of handling the imported species and in showing which of our American species, if any, may be expected to become contributing factors in the control of these pests.

It was especially with this latter idea in mind that in the spring of 1910 a series of experiments was undertaken to work out the biology of our native Limnerium validum (Cresson) (fig. 32) and its behavior toward unusual hosts. The experiments grew out of a successful attempt to foster oviposition on small brown-tail moth caterpillars (Euproctis chrysorrhoea Linnaeus), which yielded such unexpected complications that the work was continued on other hosts as they became available in the course of the spring.

Limnerium validum proved to be an excellent subject for experimentation for several reasons, but chiefly on account of its docility in 
confinement and the readiness with which it attacks any suitable species of caterpillar and because the heavily chitinized chorion of the egg is remarkably durable. This last fact was an advantage in determining the number of eggs deposited in a caterpillar, even when considerable time had elapsed after the hatching of the larva. Foriunately for the success of the experiments an abundance of adults of this species was at hand, reared from cocoons obtained the preceding fall from its usual host, Hypantria cunea (Drury).

This Limnerium is one of the hymenopterous parasites affecting the fall webworm (Hyphantriacunea); and although not so important as Meteoms and Apanteles, it is frequently found. In the northern States it emerges from the fall webworm and spins its cocoon mostly during the month of September. Unlike Limnerium pilosulum (Provancher), another species common on IIyphantria, it hibernates in
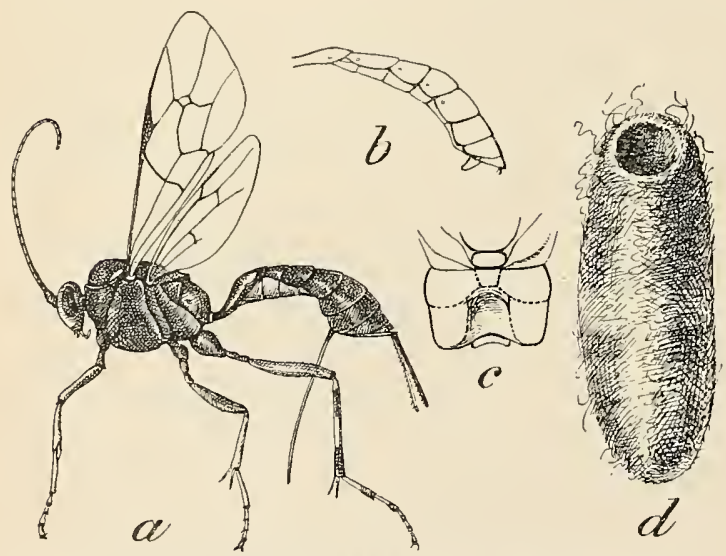

Frg. 32.-Limnerium ralirlum: $a$, Adult female, side view ; b. abdomen of male; $c$, metascutum from above; $d$, cocoon. Enlarged. ( $a, b, \|$, Redrawn from lloward; $c$, original.)

its cocoon until late the following spring or summer, and consequently it has been considered to have only a single generation a year. Farther south, howerer, as pointed out by Dr. L. O. Howard (1897) in his bulletin on the white - marked tussock-moth (Hemerocampa leucostigma Smith and Abbot), of which it is an unimportant parasite, it probably hibernates as an adult, as its empty cocoons were found associated with "spunup " larve of the IIemerocampu in the middle of December. Dr. Howard alco records rearing the adult as early as the middle of July, so that in the ricinity of Washington, D. C., tro generations, if not more, occur annually. Besides its farored host, Hyphantria cunea, and the II emerocampa, it probably attacks other caterpillars, but so far as the author is aware no other rearings have been recorded.

\section{EXPERIMENTS.}

GENERAL METHODS OF EXPERIMIENTATION.

In most of the experiments undertaken with Limnerium validum the parasites and caterpillar's were confined together in large glass cylinders covered at the top with cheesecloth, and resting on chothcovered frames. When it was desirable, howerer, to have a large 
number of caterpillars, a small, flat tray was used, wire screened on the bottom and covered with glass. A small hole in the side of the tray was found useful in introducing fresh foliage sprayed with sweetened water, as food for the caterpillars and parasites. In the first experiments several females of the Limnerium-were confined with a limited number of caterpillars, but later, when it was discovered how readily the parasites attacked the hosts, the number of the latter was proportionately increased. Dissection of the caterpillars was chiefly relied upon in working out the results of each experiment.

\section{BEHATIOR OF LIMNERIUM VALIDUM (CRESSON) IN CONFINEMENT.}

This species did not become overrestless in confinement, and hardly betrayed the excitement that some parasites are said to do when in proximity to their hosts. This tranquility may possibly be explained by the fact that the Limnerium was always confined with species of caterpillars that do not naturally serve it as hosts, and it might have been stimulated, perhaps, to greater activity by fall webworms. The females, however, readily oviposited in 4 of the 6 species of caterpillars with which they were confined. The posterodorsal part of the host was usually chosen as the most suitable point for attack, and there seems to be a more or less well-developed instinct in this as well as other parasites to keep a way from the head of the caterpillar in ovipositing. This instinct is not so necessary for large. strong parasites like Limnerium validum, but may be of great advantage to small, weak species like Meteorus or Apanteles. These frequently attack caterpillars that are many times their size, and might easily fall a victim to one vicious sweep of the host's head, or become so daubed up by juices exuding from the mouth of the excited caterpillar that they conld not escape. As circumstantial evidence of the existence of this instinct, comparatively few eggs were found near the head in dissected caterpillars, and by far the greater number was found in the posterior half of the body. A favored site for them was in the extreme tip of the postero-dorsal part of the body cavity just beneath the integument.

The males of Limnerium were slightly more active than the females in running about the cage, but they paid no attention to the caterpillars, and but little attention to the females. None was ever seen attempting to mate.

LIMNERIUM VALIDUM AS A PARASITE OF EUPROCTIS CHRYSORRHGA (LINNAEUS).

Three experiments were undertaken during February and March, 1910, to determine whether Limnerium validum would successfully attack brown-tail caterpillars, and to collect data, if possible, on the early stages. 
FIRST EXPERIMENT.

In the first experiment, on February 2, 5 females of Limnerium were confined in a small glass cylinder with 10 active brown-tail caterpillars about $8 \mathrm{~mm}$. long. The experiment was closed on February 15, at which time the last of the caterpillars died. Nine of the caterpillars were carefully dissected and a count made of the easily discovered eggs and larve of Limnerium. The largest number found in one caterpillar was 23 eggs and 11 larvæ with the empty eggshells, dissected from one that died on February 11. The smallest number was 4 eggs and 5 larvæ taken from a dead caterpillar on February 15. One hundred and forty-six eggs and 72 larvæ were found in all, making a total of 218 eggs deposited by the 5 females in the course of the 4 to 6 days that they remained alive, or an average of nearly $44 \mathrm{eggs}$ for each female, and about 24 to each caterpillar.

With this unusual number of eggs and larvæ present, it is no wonder that the caterpillars failed to survive. As the caterpillars in every case died before the larvæ had grown to any appreciable extent and even before all the eggs had hatched, it is not probable that they were killed by the feeding of the parasites. It is much more probable that they succumbed to the mechanical irritation produced by so many eggs and larvæ, which not only may have caused a violent disturbance or pathological condition of the body tissues, but also tended to keep them from feeding.

\section{SECOND EXPERIMENT.}

A second experiment was started on February 5, with 5 females and 13 active brown-tail caterpillars. By February 9, all the parasites were dead, and 3 caterpillars were found dead on the 11th and 5 more on the 19th. In the 8 dead caterpillars 61 unhatched and 5 hatched eggs were found, but only 1 larva, which had grown to be about five times the size of newly hatched larve, although still in the first stage. About 8 eggs, on an average, were thus found in each caterpillar, and they were undoubtedly at least a strong contributing factor in causing the death of the latter.

Three of the 5 living caterpillars were dissected on February 19 and the remaining two on March 4 . In these 5 caterpillars only 1 unhatched egg and 12 eggshells with only 4 larvæ were found. This, on an average, is only 2 or 3 to each caterpillar, for although 1 had been victimized 8 times, 1 had escaped altogether. Only 4 larvæ were found, and of these 3 had died shortly after hatching before growing to any extent, whereas 1 had managed to live and increase in size about five times. In the 13 caterpillars dissected, 72 unhatched eggs, 17 hatched eggs, and 5 larvæ were found, or nearly 7 to a caterpillar and 18 for each female Limnerium. 
AMabBocytosis AS A PROTECTIVE REACTION OF THE HOST.

The remarkable fact in the array of figures just given is the disparity between the number of eggshells or cast choria found andthe number of larvæ. The latter were large enough so that they could not have been overlooked, and the only explanation is that they had been killed by the host and absorbed by the blood tissues, or destroyed, in other words, by amøbocytosis. The chitinous choria, on the other hand, escaped unharmed. In the preceding experiment, in one of the dead caterpillars dissected on February 15 the dead larvæ and some of the eggs and eggshells were found inclosed in a firm, thick, homogeneous-appearing, transparent capsule of tissue. The significance of this was not realized at that time, but when on February 19 the same phenomenon was noticed in the dissection of living eaterpillars, the mystery of the missing larva was explained, for when the capsule was stained in methyl green and mounted in glycerin, it was resolved under the high power of the microscope into innumerable, densely packed, minute, roundish and spindleshaped cells. These were undoubtedly blood-tissue cells or amœbocytes, and whereas they were not true phagocytes, yet their function must have been to break down and absorb the tissues of the parasites, for within the capsules larvæ were found in several stages of dissolution.

Later experiments with the same and other hosts, such as Malacosoma and Notolophus, brought to light the fact that this amobocytic reaction takes place regularly when the Limnerium occurs in these hosts to which it seems to be unaccustomed and unadapted. In most cases it was found that the parasite was able to hatch from its egg, but that it perished generally soon afterwards before growing to any extent. Many times the larva was found to have disappeared entirely through the action of the amobocytes, yet the story of its death and dissolution was told by the encapsulated remains of the much more resistant eggshell. Whether the amobocytes gathered around and killed the living larvæ and eggs or attacked only parasites that had been killed by some other factor was not certainly determined; but the former supposition is probably correct, as unhatched eggs containing embryos in different stages of dissolution were found sometimes inclosed in sheaths of these cells. In one instance, also, a larva that had grown to be about six times the size of newly hatched larvæ, was found entirely inclosed except for its head in a characteristic sheath. This larva was probably living when its host was killed for dissection, or at least, judging from its fresh and uninjured condition, it could not have been dead for more than a few hours.

An extended series of dissections of Hyphantria cunea, on the other hand, made by J. D. Tothill during the fall of 1910, showed that the 
larvæ of Limnerium are free from the slightest trace of amobocytic attack when occurring in their natural host.

Other phases of this sozcalled "phagocytosis" have been studied by several European investigators, especially by Cuenot (18:)6), Janet $(1906,1907)$, and Pantel (1910). The latter author has given a summary of those cases of amœbocytosis that were known to him in his excellent "Recherches sur les Diptères a Larves Entomobies." He concludes that this defensive reaction of the host is aroused not only by bacterial infection but also by sick or dead parasitic larva and by molt skins, and states that free and healthy larvæ are regularly exempt.

The only cases of sick larvæ that Pantel seems to have observed are larvæ of Tachinidæ that have fallen accidentally from their breathing holes, generally during the molting of the host. Such larva do not affix themselves anew, but wander about in the body cavity of the host until overcome by suffocation. Pantel further observes that the anal sheaths of such larvæ begin to turn brown and become inclosed by a great number of amœbocytes, which finally almost completely cover the larva.

In the case of dead larvæ which have perished in the struggle for the possession of the host, Pantel observes that their bodies only exceptionally become incapsulated by amœbocytes. The molt skins, on the other hand, he furthermore states, are attacked, not always, but most frequently by amœbocytes.

The similar action of amobocytes in breaking down the wing muscles of queen ants has been described by Janet $(1906,1907)$. The muscles are not devoured in small fragments by phagocytes, but are disintegrated gradually and absorbed by amœbocytes, which creep in among the fibrillix in large numbers.

We have seemingly in this amœbocytic reaction a manifestation of the protective faculty of the host in guarding against the attack of entoparasites. As shown by Pantel (1910) and confirmed by our own observations of various species of parasitic Diptera and Hymenoptera, normal or adapted parasitic larve, when healthy, rarely if erer arouse this defensive reaction, or, in other possibly more correct words, they are able to repel the amobocytes by some curious adaptation. Unadapted parasites, on the contrary, being unable to repel the amœbocytes, may regularly succumb to their agency. The instinct of parasites under ordinary conditions well fits them for choosing their accustomed hosts, but in the millions of instances where this instinct comes into play, an egg may be placed occasionally in an unsuitable host. In such cases the resulting larva seems to be doomed to a lingering death, and its tissues are absorbed by the amœbocytes with no ultimate detriment to the host.

ADAPTATION OF PARASITE TO HOST.

The phenomenon of amcebocytosis, on the other hand, brings up the question, Why do not all parasites suffer the same fate, and what 
constitutes adaptation? We begin here to sink deep into the quagmire of speculation and doubt. We may say that the parasitic larva is so similar to the host in its effluvia or physical being, that its presence is not felt or resented, and that it bears much the same relation to the host that the fetus within the uterus does to the mammalian mother; or we may conclude that it secretes substances into the blood which paralyze the protective reactions of the host. We are more inclined to accept the latter view, for we have observed several phenomena in the course of other dissections which are difficult to explain except by a secretion hypothesis.

In dissecting various parasitized insects we have often noticed pathological changes in the borly tissues, and especially that the flaky fat bodies are often converted into a number of comparatively gigantic, globular cells which are unattached and float freely about in the blood of the insect. In dissecting brown-tail moth caterpillars imported from Europe we have seen small first-stage larve of Meteorus exert a strange and fatal influence over the larva of $Z$ ygobothia nidicola Fallen, when occurring together in the same host. The larve of Meteorus live free in the body cavity of the host at the extreme posterior end of the body on the dorsal side, whereas the maggot of Zygobothria is normally found encysted in the wall of the crop or œesophagus. In the few cases in which both were found in the same caterpillar, the maggot of $Z$ ygobothria had left its cyst in the crop, and was either wandering about in the body cavity of the host or had already died. How can we explain this strange and untimely reaction of the maggot, unless we consider that it had been stimulated to activity by some unusual substance in the blood tissues of the host, either secreted by the larvæ of Meteorus, or by the host itself in reaction thereto?

FURTHER EXPERIMENTS WITH EUPROCTIS CHRYSORRHCEA.

A third experiment was started on February 15 with about 100 brown-tail moth caterpillars that had been feeding for 20 days and were consequently about $10 \mathrm{~mm}$. long. These caterpillars were placed in a small tray, and 15 females of Limnerium were confined with them between the 15th and 27 th of February, fresh females being added as the first ones died.

Dissection of living caterpillars was undertaken on the 4 th of March and continued on the 14th. Thirty-four caterpillars in all were dissected and 15 were found to be parasitized by Limnerium. Not.more than 2 larvæ or eggs were found, on an average, in a single caterpillar, and the larvæ were in most cases dead. Only one larva, in fact, had obtained any size, and it was only about six times as large as the newly hatched larva. Although incrusted with a capsule of amobocytes it may have been still alive, but could not have survived 
much longer. All the other larvæ that were found were newly hatched, or had been killed soon after hatching, and were commonly inclosed in a sheath of amobocytes.

The rest of the caterpillars were kept alive as long as possible in the hope that one or two of the Limnerium might be able to pass through their transformations, but none was reared. 'The experiment therefore furnished data similar to those obtained in the preceding experiments, and conclusively confirmed the belief that Limnerium validum is unable to live as a parasite within brown-tail moth caterpillars.

\section{LIMNERIUM VALIDUM AS A PARASITE OF MALACOSONA AMERICANA} (FABRICIUS).

On April 20 an experiment was started with Limnerium validum as a parasite of the common tent caterpillar (Malacosoma americana Fabricius). Three females were confined in a large, flat, tanglefooted tray, with three nestfuls of caterpillars, mostly in the second stage, collected in the open at Melrose Highlands, Mass. A fourth nest was added on the 21st to insure an abundance of caterpillars for the Limnerium to attack. By the 26th the Limnerium had all died, but 2 more females were placed in the tray on the 28th. Many of the caterpillars at that time were passing into the third stage.

RESULTS OF EXPERIMENTS AS DETERMINED BY DISSECTION.

On May 3 dissections were made of 6 second-stage and 11 thirdstage caterpillars, of which all of the former and 9 of the latter were found to be parasitized. The results of the dissections are given in Table I.

TABLE I.-Results of dissections of caterpillars of Malacosoma americana parasitized by Limuerium validum.

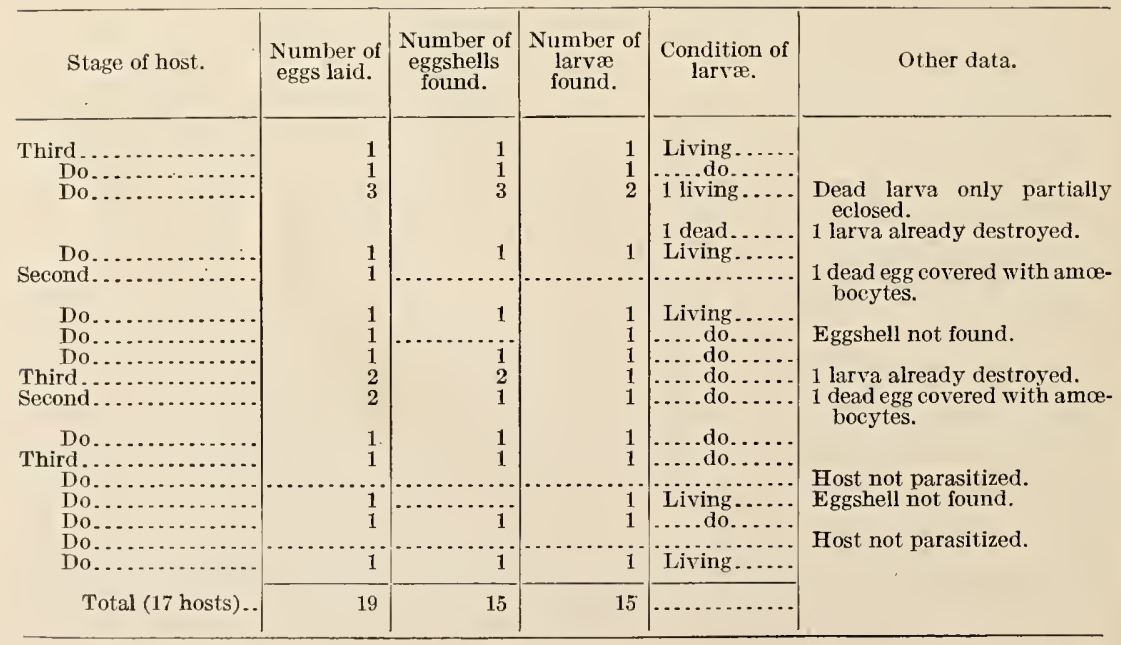


According to the dissections 19 eggs were deposited in the 17 caterpillars, distributed as follows: One caterpillar was parasitized three times, 2 twice, 12 once, and 2 escaped parasitism altogether. Of the 19 eggs deposited, 2 failed to hatch and became covered with amobocytes, as did also the eggshells except in one doubtful instance, and in case of a third the embryo or larva was killed during the process of eclosion, becoming also densely encapsulated with amœbocytes. Two other larvæ were killed after hatching, and were entirely destroyed by the action of the amobocytes, but their former presence was revealed by the empty eggshells. The remaining 14 larvæ were in a living and apparently healthy condition. Some were recently hatched, but other's had grown to an appreciable extent. They lay free in the body cavity of the host, generally in the posterior half of the body, either above or below the digestive tube, and with the head directed candad in respect to the host.

On the 7 th of May, 5 caterpillars in the fourth stage were dissected, and in 2 of them was found a living first-stage larva; on the 11 th, 10 more caterpillars were dissected, but none was parasitized; again on the 19th 2 caterpillars ont of 10 in the fourth and fifth stages were found to be parasitized. One contained a living, first-stage larva of Limnerium, the other a living larva in the second stage, each host being about $20 \mathrm{~mm}$. long.

EMERGENCE OF ADULTS OF LIMNERIUM FROM REPRODUCTION.

On the 21st of May, 2 unspun, full-grown larvæ of Limnerium were discovered in the tray, and between that time and the 1st of June, 29 in all were found, 6 of which died before spinning cocoons. The rest spun perfect cocoons, and 6 passed through their transformations to the imagos, in every case males, from June 7 to June 14 . The remaining 17 cocoons remained unissued up to December 13, when they were cut open and examined. All were found to contain dead larvæ, some perfectly dry and shriveled, although 4 seemed only recently dead, as they were still plump although much discolored.

In all cases in this experiment where remains of the host were found associated with the larva or cocoon, the Limnerium issued from half-grown caterpillars, which were mostly in the fourth stage, although a few appeared to be small and stunted specimens of the fifth stage. On May 28 the remains of a host were examined. This caterpillar was killed by the parasite when about $25 \mathrm{~mm}$. long, while still in the fourth stage. It had a large, round hole in the integument on the ventral side, just back of the head, through which the larva escaped, after destroying all of the internal organs. The integument inside was left perfectly dry and bare, except for a small amount of broken-down tissue at the extreme posterior tip of the body. 
LENGTH OF THE STAGES IN THE LIFE HISTORY OF LIMNERIUM.

From this and the preceding experiments we may estimate that the duration of the embryonic development of Limnerium validum, or the time from oviposition to the hatching of the egg, is about 6 to 8 days; that the larval developmental period lasts for about 24 to 33 days; and that the pupal period, or, more exactly, the time from the spinning of the cocoon to the eclosion of the adult, is about 13 to 22 days, or much longer. The length of the larval period within the cocoon before pupation was not determined, but, judging from the cocoons examined on December 13, it may be extended several months. The minimum time from egg to imago is thus about 7 weeks, or 50 days, whereas the maximum time to the eclosion of the adult may be many months, due to quiescence within the cocoon. This species hitherto has been considered to have a single generation a year, but this last experiment seems to indicate that under certain conditions at least it is able to pass throngh two generations annually. Under normal conditions, however, there is much doubt whether more than one generation actually occurs in the Northern States.

A POSSIBLY NORMAL PARASITE OF MALACOSOMA.

This experiment shows that Limnerium validum is a possibly normal parasite of the tent caterpillar, although it has never been found attacking that species in the field. The reason for this is obvious: The tent caterpillars hatch early in the spring, long before the Limnerium leaves its cocoon, and therefore are not in season for this parasite. From the fact, however, that nearly one-half of the caterpillars dissected in this experiment were found to be parasitized, and that comparatively few were killed by Limnerium, we may conclude that Limnerium validum is only partially adapted to this host. In the dissecting work only 5 dead larve or eggs were discovered, but many more without much doubt succumbed to the defensive reactions of the host. In the 42 caterpillars dissected, 23 eggs or larva were found, and 29 other larvæ were snccessful in passing throngh their larval development, making a total of only 52 parasites that came under observation. If the fo females used in this experiment oviposited as freely, however, as those in the preceding experiments, and there is no reason to believe otherwise, some 100 to 200 eggs or even more were probably laid. Taking 100 as a conservative estimate, and with due allowance for the destruction wrought by the dissections, we may thus figure on a mortality of at least about 37 per cent. The cast eggshells were almost invariably found thickly ensheathed with amobocytes, and the function of the latter was without doubt the same as in the case of the brown-tail moth caterpillars, to disintegrate if not to kill the young larvæ. In the present instance, 
however, a few of the larva were able to withstand the action of the amobocytes and reach maturity. This immunity of the few is of theoretical interest, as it would furnish a basis under proper conditions for the evolutionary development of complete host relationship. It is not difficult to conceive that this parasite in the course of not many generations might adapt itself so as to insure a minimum mortality, and thus become an effective enemy of the tent caterpillar.

I.IMNERIUM VALIDUM AS A PARASITE OF NOTOLOPHUS ANTIQUUS (IINNAEUS).

One of the most interesting of the experiments was started May 9,1910, with the rusty vaporer moth (Notolophus antiquus Linnaeus) as the host. One unfertilized female Limnerium was confined with 25 small, third-stage caterpillars. The female remained alive for 12 days and oviposited freely in the caterpillars.

Dissection work was commenced on June 17 and was continued at intervals until June 30 . In all, 10 caterpillars, 1 pupa, and 7 moths were dissected. In the 10 caterpillars, a total of 40 eggs and eggshells was found, and 8 larvæ which were all dead; in the 1 pupa, 1 eggshell was found; and in the 7 moths, a total of 16 dead eggs and eggshells was discovered, making a total of 57 eggs laid by the single female in only 18 of the hosts. The results of the dissections are given more in detail in Table II.

This experiment proved conclusively that this parasite is not at all adapted to live at the expense of Notolophus. The larvæ, even if they were able to hatch, were killed by the host soon afterward, and at least 6 of the eggs were unable to hatch. Two other eggs were found with the dead larva only partially out of the shell. The larvæ in most cases were entirely destroyed by the host, so that all trace of them was lost, except for the cast eggshell, yet a few resisted total disintegration for a long period. The body tissues of the latter, however, were broken down, so that nothing was left but the integument. The eggshells, or dead eggs with the embryo inside, resisted destruction, on the other hand, to a remarkable degree, and were found practically unharmed for a month or even longer after they were laid, not only in the body cavity of the caterpillar and pupa but even in that of the adult moth, and invariably well incased in a sheath of amobocytes. The eggshell in the single pupa dissected was found adhering to the ovarian tubules of the host; in the case of the moths, the eggs or shells were found many times just beneath the integument of the abdomen, or among the ovarian tubules. One female moth, which was in perfect condition and in no way inconvenienced, carried 6 of these eggshells. 
TABLE II.-Results of dissections of caterpillars and later stages of Notolophus antiquus parasitized by Limnerium validum.

\begin{tabular}{|c|c|c|c|c|c|c|}
\hline $\begin{array}{l}\text { Date of } \\
\text { dissec- } \\
\text { tion. }\end{array}$ & Stage and sex of host. & $\begin{array}{l}\text { Num- } \\
\text { ber of } \\
\text { eggs } \\
\text { laid. }\end{array}$ & $\begin{array}{l}\text { Number } \\
\text { of un- } \\
\text { hatched } \\
\text { eggs. }\end{array}$ & $\begin{array}{l}\text { Num- } \\
\text { ber of } \\
\text { egg- } \\
\text { shells. }\end{array}$ & $\begin{array}{l}\text { Num- } \\
\text { ber of } \\
\text { larvæ. }\end{array}$ & Remarks. \\
\hline May $17 \ldots$ & Fourth-stage caterpillar. & 2 & 2 & & & $\begin{array}{l}\text { Embryos not noticed within } \\
\text { eggs. }\end{array}$ \\
\hline Do...... & ...do do..................... & 5 & 5 & & & Do. \\
\hline May $30 \ldots$ & Fifth-stage caterpillar.. & $\begin{array}{l}3 \\
2\end{array}$ & & $\begin{array}{r}3 \\
2\end{array}$ & & $\begin{array}{l}\text { No trace of larvæ. } \\
\text { Larvæ much broken down. }\end{array}$ \\
\hline June $14 \ldots$ & Sixth-stage caterpillar. & 2 & & 2 & 1 & $\begin{array}{l}\text { Larva killed before complete } \\
\text { eclosion. }\end{array}$ \\
\hline Do.... & Male moth. & 1 & & 1 & & No trace of larva. \\
\hline $\begin{array}{l}\text { June } 15 . . \\
\text { Do.... }\end{array}$ & Femalo.... & 1 & 1 & & & Egg contained dead embryo. \\
\hline June $17 .$. & Sixth-stage caterpillar.... & $\frac{1}{7}$ & 2 & $\frac{1}{5}$ & i & $\begin{array}{l}\text { Shell among egg tubes of host. } \\
\text { Larva broken down. Host dead. }\end{array}$ \\
\hline June $18 . .$. & th............... & 1 & & 1 & & No trace of larva. \\
\hline $\begin{array}{r}\text { June } 20 \ldots \\
\text { Do..... }\end{array}$ & Fifth-stage caterpillar... & 8 & & 8 & 1 & $\begin{array}{l}\text { Larva killed before complete } \\
\text { eclosion, Host dead. }\end{array}$ \\
\hline & ….d & 6 & & 6 & 2 & $\begin{array}{l}\text { Larvæ broken down; killed soon } \\
\text { after eclosion. Host dead. }\end{array}$ \\
\hline $\begin{array}{l}\text { Do...... } \\
\text { June } 30 . .\end{array}$ & Female moth.. & 6 & 1 & 6 & & No trace of larvæ. \\
\hline & & 5 & $\begin{array}{l}1 \\
2\end{array}$ & 3 & & Two eggs contained dead em- \\
\hline \multirow{3}{*}{ Do..... } & Male moth .............. & 1 & & 1 & & No trace of larva. \\
\hline & \multirow{2}{*}{$\begin{array}{r}\text { Sixth-stage caterpillar... } \\
\text { Total............... }\end{array}$} & 5 & & 5 & 1 & \multirow{2}{*}{ Larva all destroyed except skin. } \\
\hline & & 57 & 13 & 44 & 8 & \\
\hline
\end{tabular}

LIMNERIUM VALIDUM AS A PARASITE OF PORTHETRIA DISPAR (IINNAEUS).

Two experiments were undertaken to determine whether this species of Limnerium can parasitize successfully the caterpillars of the gipsy math (Porthetria dispar Linnaeus). Both were, unfortunately, unsatisfactory in that the caterpillars were subject to disease and soon died in confinement. The second experiment only gave any results at all, and was started June 10, when 1 female Limnerium was confined with 20 caterpillars in the third and fourth stages, collected at Melrose Highlands, Mass.

On June 17 the female Limnerium was dead, and 19 of the caterpillars had succumbed to disease. These dead caterpillars were carefully dissected, and in 4 of them were found 18 eggs of Limnerium, occurring $2,3,5$, and 8 in number, respectively. The eggs were all unhatched, the embryos undeveloped, and in some of the eggs the contents appeared to be broken down, such eggs being undoubtedly dead. Whether they had died through contact with dead and diseased tissues of the caterpillars or had been killed previously by some reaction of the host is not clear. In experiments with browntail moth caterpillars earlier in the season, living eggs and even larvæ were found within dead hosts; but in that case the caterpillars had not died from disease, but were killed by superparasitism.

On the 21st of June, 6 more of the caterpillars had died. They were dissected, and in one 5 eggs of Limnerium were found still unhatched. By June 31 the remaining 5 caterpillars had succumbed 
to disease, and the experiment was closed without any conclusive evidence being gained, although the inference may be drawn that Limnerium validum is not adapted to the gipsy moth.

\section{EXPERIMENTS WITH OTHER HOSTS.}

Several experiments were also started with caterpillar's of the common tussock moth (Hemerocampa leucostigma Smith and Abbot) and of the mourning-cloak butterfly (Euvanessa antiopa Linnaeus), but for various reasons they furnish no satisfactory evidence to show whether these hosts can be parasitized successfully by Limnerium validum. It is rather unfortunate that the experiment with the Hemerocampa did not give any results on account of disease prev-

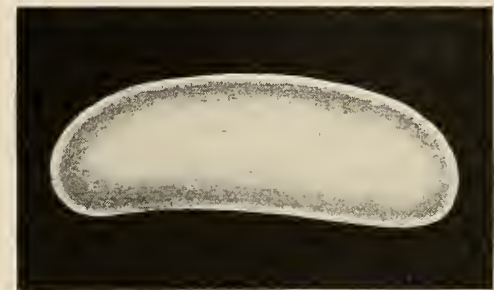

FIg. 33.—Limnerium validum: Egg. Enlarged about 120 times. (Original.) alent among the caterpillars, in view of the fact that this species of Limnerium has been reared by Dr. L. O. Howard from the tussock moth at Washington, D. C. In Massachusetts, however, it has never been surely reared from this host, although large numbers of the tussock moth have been collected in various parts of the State and carefully studied at the Gipsy Moth Parasite Laboratory. It seems likely, therefore, that the Limnerium, varies in habits in different parts of the country, or this apparent difference in host relationship

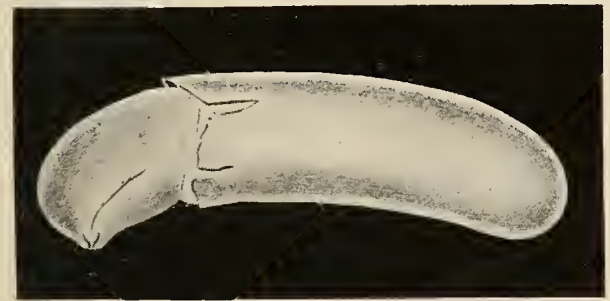

FIG. 34.-Limnerium validum: Eclosion of larva. Enlarged about 120 times. (Original.) may be ascribable merely to changes in its seasonal history brought about by a colder climate.

\section{NOTES ON DEVELOPIMENT AND ANATOMY OF THE IARVA.}

THE EGG.

The egg (figs. 33, 34) of Limnerium validum is elongate kidney-shaped or subcylindrical and rather convex on the dorsal side, slightly concave ventrally, with both poles bluntly rounded. The chorion is heavily chitinized, comparatively thick and resistant, and with a perfectly smooth surface. Its color is pale brown, or sometimes nearly white in the case of freshly deposited eggs, but not always, as fully colored eggs may be found in the oviducts of dissected females. In size the egg is about 0.35 to $0.41 \mathrm{~mm}$. long and 0.13 to $0.14 \mathrm{~mm}$. in transverse diameter. 
Adult females freshly issued from cocoons were dissected on several occasions, and fully dereloped eggs to the number of 15 to 20 were found in the oviducts ready for oviposition. The female of this species therefore may perpetuate its kind almost immediately after its eclosion from the cocoon (fig. 32). It may also be parthenogenetic at times, as eggs that were laid by unfertilized females in the preceding experiments hatched freely. Not enough evidence was gained to state positively whether unfertilized eggs always produce males, but this is probably true.

THE FIRST-STAGE LARVA.

DESCRIPTION OF THE NEWLY HATCHED LARVA.

The first stage of the larva of Limnerium is characterized by 13 segments, including the comparatively heavily chitinized head, and a long tapering ventral appendage of the last body segment. In the

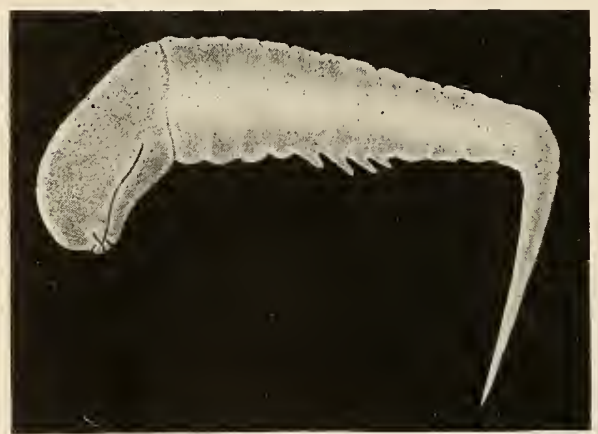

FIg. 35.-Limnerium validum: First-stage larva, newly hatched. Enlarged about 120 times. (Original.) case of newly hatched larvæ (fig. 35) the head is about one-half as long as the body, excluding the tail appendage, and is bent to the axis of the borly at an angle of about $45^{\circ}$. Its dorsal margin is strongly curved, especially anteriorly; the rentral margin is much shorter and only slightly curved. The integument of the head is rather heavily chitinized and is slightly pigmented with brown. It has a slight ridge on each side running backward from the insertion of the mandibles, and separating the gula from the cheeks. The gula seems to be but slightly hollowed out and is as heavily armored as the rest of the head.

The mouthparts (fig. 3i) consist of prominent, curved and sharply pointed mandibles, crossing each other at the tips, and projecting somewhat downward into the large mouth cavity. The aperture of the mouth is surrounded by a raised, chitinized, circular rim, about $0.037 \mathrm{~mm}$. in diameter, and with a broad inner margin. The posterior inner margin is a heavily chitinized plate, with two prominent teeth separated by an angular median indentation.

The body in the thoracic region is nearly as broad as the head but rapidly tapers posteriorly. The thin, delicate, transparent integument is thrown into folds on the dorsum and venter, but appar- 
ently not on the sides. Each fold on the venter represents a body segment, though some may be more or less double; the folds on the dorsum, however, are plainly double, as two occur on each segment. The body is thus found to be 12 -segmented, excluding the tail appendage which is plainly a ventral outgrowth of the last segment.

The appendage itself sometimes appears to be distinctly ringed, due undoubtedly to the folding of the integument. It is slender, tapering, and about four-fifths as long as the body. During embryonic development it is bent sharply forward and appressed to the venter; after eclosion it is bent to the axis of the body for a short period at an angle of abont $90^{\circ}$, though later in life it extends straight backward. Its color and that of the body is transparent whitish.

The total length of the newly hatehed larva is about $0.64 \mathrm{~mm}$.; without tail, only $0.41 \mathrm{~mm}$.; the width of the head is $0.11 \mathrm{~mm}$. and that of the thorax $0.10 \mathrm{~mm}$.

FUNCTION OF THE TAIL APPENDAGE.

In case of larvæ observed immediately after hatching, the tracheal system could be made out easily, and was filled with air without doubt, though necessarily of the closed or a p n e us t i c type. Only one fine trache a l branch could be dis-

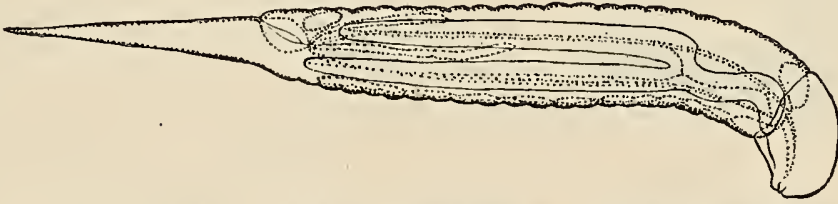

Fig. 36.-Limnerium validum: First-stage larva of large size, showing silk glands and nervous system. Enlarged 50 times. (Original.) tinguished in the tail, and it was clearly not important enough to indicate that the tail is a tracheal gill. The function of the tail, however, is probably respiratory, and the organ might properly be termed a blood gill. 'There is nothing in its structure to contradict this view, as it is a simple, hollow tube lined with hypodermal cells, and undoubtedly filled with blood a greater part of the time. Since the larva lies free in the body cavity of the host it is constantly bathed in blood and lymph fluids, from which the oxygen of its own blood must be derived through the delicate integument of the tail, or other parts of the body, especially while still small.

APPEARANCE OF OLDER LARV.

The larva makes its escape from the egg by bursting open the chorion irregularly at the anterior pole (fig. 34), possibly with the aid of the mandibles. After hatching it develops rapidly if located in a suitable host, and molts for the first time in probably about 7 to 10 
days. Before molting it attains a length of nearly if not quite 2 $\mathrm{mm}$., for some larvæ were found, evidently nearly full-sized, about $1.7 \mathrm{~mm}$. long. It now differs considerably in appearance from newly hatched larvæ, as a comparison of figures 35 and 36 will indicate. The head, being heavily chitinized, has remained the same size, but the body has grown until it is about five times as long as the head instead of only twice as long, as at first. The tail has also increased in size, but not proportionately to the growth of the body. Because of this rapid growth the folds of the integument so noticeable in newly hatched larvæ have largely disappeared, but are still discernible as slight creases, and afford the only means whereby the segments of the body may be distinguished.

NOTES ON THE ANATOMY OF THE LARVA.

The development of the viscera as made out in stained and mounted specimens is not without interest. Toward the end of the first instar

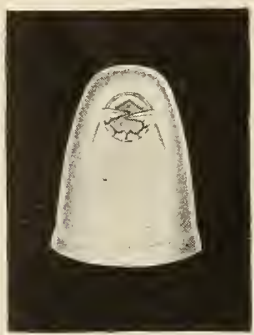

FIG. 37.-Limnerium validum: Mouthparts of first-stage larva. Enlarged about 250 times. (Original.) the sericteries become the most conspicuous organs in the body, thus forecasting the prime importance of the cocoon-spinning habit as a protection during the pupal period. There is a pair of these silk glands which seem to start blindly in the first body segment and extend backward after branching once to the eleventh or twelfth segment. In reality, however, they are connected anteriorly with a minute tube which runs forward to the mouth. 'The glands themselves are also tubular and composed of comparatively enormous cells, with large oval nuclei.

The proctodxum is also conspicuous and extends forward only to the anterior end of the twelfth body segment. It is a thick-walled, ovoid organ, and although contignous with the posterior end of the mesenteron, it does not communicate therewith. At the anterior end it gives rise to four large Malpighian tubules which extend forward into the ninth or even the eighth segment. The anus appears as a distinct opening at the end of the trelfth segment on the dorsal side, thus proving that the tail is a ventral outgrowth of the last segment. As the anus is distinctly open, there is no reason why the secretionis of the Malpighian tubules may not be passed off into the blood of the host.

The brain toward the end of the first instar is crowded partly out of the head and becomes a conspicuous organ of the first body segment. The same phenomenon takes place in regard to the infraœsophageal ganglion. Twelve ventral ganglia may be distinguished, of which the first 5 are closely united to each other and to the infraøsophageal ganglion, the following 5 being separated by commissures, but the last 2 are also conjoined. 
THE SECOND-STAGE LARVA.

The larva after the first molt differs conspicuously from the firststage larva in respect to the soft, unarmored head, and the much shorter tail appendage (fig. 38). The mouth and its parts are also considerably changed.

The head is still large and prominent and has much the same general shape as in the first stage, although considerably shorter. Its

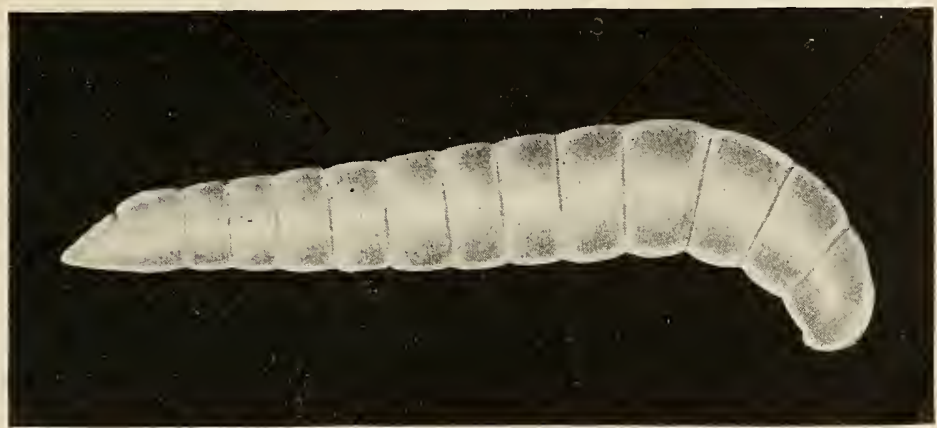

FIG. 38.-Limnerium validum: Second-stage larva. Enlarged about 30 times. (Original.)

integument is soft and pliable like that of the body. The mouthparts (fig. 39) consist of a slightly bilobed, simple labium, and two strong, curved mandibles, which project downward into the large funnel-shaped mouth cavity. The body is distinctly cylindrical and tapers but little behind. Twelve segments in the body may be easily distinguished, the last one of which is prolonged ventrally into a short, conical tail appendage.

Only a few larvæ in this stage were found, and they were all about $2.2 \mathrm{~mm}$. long. The duration of this stage is probably short, perhaps not more than from 5 to 7 days.

\section{THE THIRD-STAGE IARVA.}

DESCRIPTION OF THE FULL-GROWN LARVA.

When the larva has obtained its full size and leaves the host it is from 9 to $10 \mathrm{~mm}$. long, and

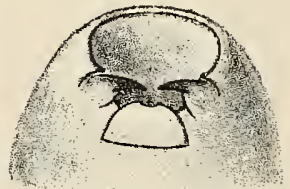

Fig. 39.-Limnerium validum: Mouthparts of second-stage larva. Enlarged about 100 times. (original.) pinkish white in color. It is like the usual hymenopterous type of larva (fig. 40), and the body is rather deeply twelve-segmented. The head is comparatively small and inconspicuous, and the tail appendage, so characteristic of the first stage and still persistent in the second stage, is now entirely lacking.

The mouth parts (fig. 41) are decidedly different from those in the preceding stages. They consist of strong mandibles, supported by two short, longitudinal, heavily chitinized ridges, and two long, transverse ridges that extend nearly to the lateral margins of the 
head. Below the mandibles is a more or less circular labium with heavily chitinized margins, supported by two short transverse ridges. The mouth opening is small and hardly distinguishable, but probably lies directly beneath the tips of the mandibles, toward which

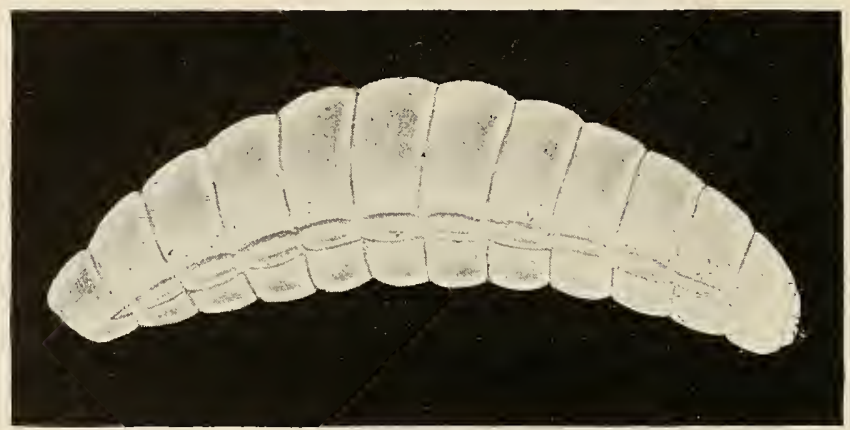

FiG. 40.-Limnerium validum: Third-stage larva. Enlarged about $S$ times. (Original.)

point there is a gentle declivity. Just in front of the deeply concave, anterior end of the labium, in fact at the bottom of this concavity, is located the external opening of the sericteries. Above the mandibles are two large, circular, slightly pigmented spots, which

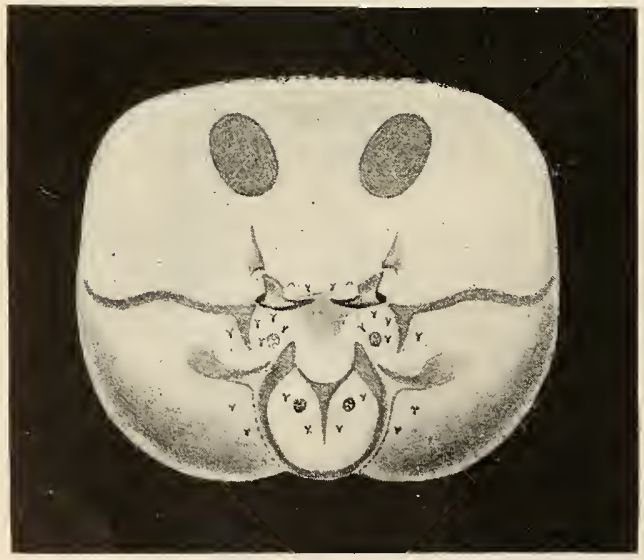

FIG. 41.-Limnerium validum: Anterior view of head of third-stage larva, showing mouthparts. Enlarged about 60 times. (Original.) undoubtedly mark the place where the compound eyes of the adult are beginning to derelop.

FEEDING HABITS OF THE IMPRISONED LARVA.

With a clear understanding of the month structures in the three stages, we may briefly consider the feeding habits of the imprisoned larva. The old accepted theory up to the time of Ratzeburg was that internal parasitic larvæ feed upon the fat-body of the host. Ratzeburg (1844), however, was forced to replace this theory with one that is probably more nearly correct. He concluded that such larvæ feed upon the lymph and blood of the host rather than upon any of the solid tissues. This riew seems especially applicable to the feeding habits of Apanteles and related genera, which often leave the host in a living though comatose condition, but as the mandibles are 
well developed in all three larval stages in the case of Limnerium, we hesitate to apply it in entirety to this species. We do not believe, however, that the larvæ of Limnerium while small actively attack and devour any of the solid tissues of the host including the fatbodies, but rather institute pathological changes whereby these tissues become available for food. The first tissues to be broken down are the fat-bodies, whereas the vital organs, including the digestive tube, resist dissolution until the last. The very apparent, early disappearance of the fat-body in parasitized caterpillars probably accounts for the old theory that the parasite consumes it directly. The parasite certainly does consume the fat-body, but only after it has been broken down. We have often noticed this condition of the fatbody in apparently healthy caterpillars that harbored the early stage of almost any hymenopterous parasite. In such cases the fat-bodies were broken down more or less completely into their component parts, and the blood of the host was filled with the perfectly globular fat cells of varying sizes, and sometimes of a truly enormous size for individual cells. These small, solid particles, we believe, are as readily eaten by the larvæ of Limnerium, at least, as the fluid medium in which they float about within the body of the host. The monthparts in the first and second stages of Limnerium are admirably adapted for this purpose, being in fact a sucking apparatus, with strong, pointed mandibles, so placed as to aid in swallowing small, solid particles. In the third stage the mouthparts are still essentially sucking, but as the mouth opening is surrounded by chitinized, supporting or possibly rasping ridges, there is some ground for believing that eren solid tissues may now be taken in, even before they have been wholly disintegrated. When the parasite reaches this stage, the host has become somewhat weakened, its fat-body having been almost entirely, and its body fluids greatly, depleted. Unlike the condition produced by some larve of tachinids at this stage in their development, the remaining tissues never dissolve into a putrid or semiputrid mass, but at all events remain clear and wholesome. To just what extent the tissues are broken down before being consumed has not been definitely determined, but we believe usually to a semiliquid condition in the case of Limnerium. A caterpillar forsaken by a larva of the Limnerium was closely examined, and a small amount of tissue was found at the posterior end of its body. This tissue was probably the remains of the muscles of that region, and appeared to be of a mucilaginous consistency.

RESPIRATION OF THE LARVA IN THE THIRD STAGE.

The shortening of the tail appendage in the second stage and its entire disappearance in the third stage must necessitate a gradual change in the respiratory habit of the larva, if, indeed, the tail is a 
truly respiratory organ, as we think it must be. This change is perhaps correlated with the more ravenous appetite of the parasite in the last two stages of its larval life, and also with the gradual disappearance of the blood and lymph of the host. With the disappearance of the fluids of the host, the tail as a blood gill must necessarily become useless, as it is fitted for life in a fluid medium only. Nor does it seem possible, for much the same reason, that the larva's whole supply of oxygen is gained by osmosis through the integument of the body itself, for as the larva grows older the integument becomes thicker and tougher, especially in the last stage. The only alternative left is to consider that the oxygen is derived from the comparatively enormous amount of food taken in during this period, and that it is absorbed by the blood of the larva through the walls of its digestive tube. In other words, if the larva stopped feeding it would not only starve but also suffocate. Toward the end of the third stage, however, when the host is nearly or possibly not entirely consumed the stigmata become open, and the larva is able to breathe air directly, as it certainly does after leaving the host to spin its cocooll.

THE COCOON.

The cocoon has been aptly described by Dr. L. O. Howard (1897) in his bulletin on the parasites of the white-marked tussock moth, and we take the liberty of transcribing his words here: "The cocoon is rather long ellipsoidal, averaging $7.5 \mathrm{~mm}$. in length by $2.8 \mathrm{~mm}$. in greatest diameter. It is composed of two distinct coverings, the outer one of weak, close-spun, crinkly, gray, or grayish-brown silk, readily peeling off in a sheet, and the inner one close, tough, parchmentlike, dark brown in color, with golden reflections, of the type common among the Ophioninæ."

\section{RESULTS OF THE DISSECTIONS OF HYPHANTRIA DURING THE FALL OF 1910.}

During the late summer and the fall of 1910 a large series of collections of the fall webworm (Hyphantria cunea Drury) was brought together at the Gipsy Moth Parasite Laboratory, and an extensive study made of its parasites by means of dissection and rearing work. Most of the work was conducted by Mr. J. D. Tothill, who kindly turned over to the writer, together with his notes, the series of larre of Limnerium that were found during the course of the dissections. Inasmuch as another species of Limnerium is found attacking the fall webworm in Massachusetts rather abundantly, the collection of larvæ may have included L. pilosulum as well as validum, but the most careful scrutiny of the larvæ, all of which were mounted in balsam and in the first stage, failed to reveal any characters to sepa- 
rate the series into the two species, so that some doubt remains whether $L$. pilosulum was actually represented.

The two most important lots of the larva were obtained respectively on August 18, from third-stage hosts collected the day previously at Reading Highlands, Mass., and on September 6 to 9, from mostly sixth-stage hosts collected near the laboratory at Melrose Highlands. The former lot may have been L. pilosulum, as this species spins its cocoon inside of the skin of small hosts and issnes therefrom throughout the month of September. The latter lot of larvæ seems to have been $L$. validum without any doubt, as they were in the first stage when $L$. pilosulum was already beginning to issue as imagos, and inasmuch as they were found in rather large sixthstage hosts. It seems reasonable to conclude, therefore, that the firststage larvæ of these two species are practically identical in structure and appearance.

The disposition of the larve in their natural host is not without interest. According to Mr. Tothill's notes, they were found free in the body cavity, between the walls of the body and the alimentary canal, either inferior or superior to the latter. No indication of amobocytosis was encountered during the course of the dissections.

\section{GENERAL SUIMIMARY.}

Limnerium validum (Cresson), a common parasite of the fall webworm (Hyphantria cunea Drury), readily attacks the caterpillars of the brown-tail moth, gipsy moth, and rusty vaporer moths, and also the tent caterpillar, "when placed in confinement with these hosts, but is able to complete its transformations in the last species only and even then in but a small percentage of cases. Its larvæ seem to be totally unadapted for life in the caterpillars of the three former species, and fail to survive the protective reactions of the host, which are visibly manifested by an accumulation of active blood cells or amobocytes around the larve, the cast eggshells, and even the eggs themselves. The amœbocytes presumably attack the living eggs and larvæ, or at least ultimately efface the latter entirely. The same reaction takes place in the case of the tent caterpillar, but a few of the larvæ are able to complete their transformations. Adaptation here is partially in evidence, and may be due to larval secretions which ward off the protective reactions of the host.

The egg of Limnerium has a thick, chitinized chorion, which resists decomposition in the body fluids of the host to a remarkable degree. The first-stage larva is characterized by a long, tapering tail appendage, evidently adapted for a respiratory function and acting as a blood gill. The second-stage larva has a much shorter appendage, and the third-stage larva has none, so that respiration very likely occurs through the walls of the digestive tube, oxygen 
being absorbed from the constantly ingested supply of fresh tissues of the host.

The larva while still small assumes a more or less definite positien in the body cavity of the host, and generally lies toward the posterior half of the body, either above or below the digestive tract and with its head directed caudad in respect to the host. During its whole life the larva feeds on blood and lymph and on small solid particles which result from the disintegration of the host's tissues, probably pathologically induced by some larval secretion. There is no evidence to show that such definite organs of the host as the digestive tube and muscular tissue can be consumed by the larva unless they are broken down, inasmuch as the mouthparts of the larva throughout life are essentially sucking.

Under artificial conditions the minimum time needed for the development of the insect from the egg to the adult was found to be about 50 days, but the maximum time may be extended many months. Under natural conditions in the Northern States as a parasite of Iyphantria, the females are probably active in parasitizing the caterpillars throughout the month of August and the first part of September. The larve issue from the caterpillars and spin their cocoons during September and the first part of October, but the cocoons always overwinter, and the adults emerge the following summer.

\section{BIBLIOGRAPHY.}

1864. Cresson, E. T.-Proc. Ent. Soc. Phila., vol. 3, p. 258.

1879. Provancher, L.-Nat. Canad., vol. 11, p. 174, fig. 9, a.

1883. Provancher, L.-Fauna Ent. Can. Hym., p. 367, fig. 44, a.

1890. Ashmead, W. H.-Proc. U. S. Nat. Mus., vol. 12, p. 429.

1844. Ratzeburg, F. T. C.-Die Forstinsecten.

1896. Cuenot, L.-Etudes physiologiques sur les Orthoptères. (Phigocytose.) Arch. Biol., vol. 14, pp. 315-325.

1897. How ard, L. O.-A study in insect parasitism. Tech. Ser. 5, Bur. Ent., U. S. Dept. Agr., p. 23, fig. 10.

1906. JANET, C.-Remplacement des muscles vibrateurs du vol par des colonnes d'Adipocytes, chez les fourmis après le vol nuptial. C. R. Acad. Sci., vol. 142 , pp. $1095-109$ S.

1907. JANET, C.-Histolyse sans phagocytose, des muscles vibrateurs du vol. chez des reines des fourmis. C. R. Acad. Sci., vol. 144, pp. 393-396.

1910. Pantel, J.-Recherches sur les Diptères a larves entomobies. (Manifestations éventuelles de la réaction défensive.) La Cellule, vol. 26, pp. 158-160.

$A_{\text {may be procured from the SUPERINTEND- }}^{\text {DIONAL }}$ 

a. 

BOSTON PUBLIC LIBRARY

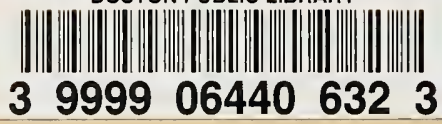


弲等 1201098 
